\title{
COMPLEXO PETÚNIA: REGISTRO DE MÚLTIPLOS ESTÁGIOS EVOLUTIVOS NA BORDA SUL DO CRÁTON DO SÃO FRANCISCO
}

\author{
Rafaela Machado Gengo \\ Orientador: Prof. Dr. Renato de Moraes
}

Tese de Doutorado

Programa de Pós-Graduação em Mineralogia e Petrologia 

UNIVERSIDADE DE SÃO PAULO

INSTITUTO DE GEOCIÊNCIAS

Complexo Petúnia: Registro de múltiplos estágios evolutivos na borda sul do Cráton do São Francisco

\section{RAFAELA MACHADO GENGO}

Tese apresentada ao Programa de Mineralogia e Petrologia para a obtenção do título de Doutor em Ciências

Área de concentração: Petrologia Ígnea e Metamórfica

Orientador: Prof. Dr. Renato de Moraes

SÃO PAULO 
Autorizo a reprodução e divulgação total ou parcial deste trabalho, por qualquer meio convencional ou eletrônico, para fins de estudo e pesquisa, desde que citada a fonte.

Serviço de Biblioteca e Documentação do IGc/USP

Ficha catalográfica gerada automaticamente com dados fornecidos pelo(a) autor(a) via programa desenvolvido pela Seção Técnica de Informática do ICMC/USP

Bibliotecários responsáveis pela estrutura de catalogação da publicação: Sonia Regina Yole Guerra - CRB-8/4208 | Anderson de Santana - CRB-8/6658

Gengo, Rafaela

Complexo Petúnia: Registro de múltiplos estágios evolutivos na borda sul do Cráton do São Francisco / Rafaela Gengo; orientador Renato de Moraes. -São Paulo, 2020 .

$189 \mathrm{p}$.

Tese (Doutorado - Programa de Pós-Graduação em Mineralogia e Petrologia) -- Instituto de Geociências, Universidade de São Paulo, 2020.

1. Cráton do São Francisco. 2. Orógeno Brasília Meridional. 3. Petrocronologia. 4. proveniência. 5. elementos traço em zircão. I. Moraes, Renato de, orient. II. Título. 


\section{UNIVERSIDADE DE SÃO PAULO INSTITUTO DE GEOCIÊNCIAS}

\section{Complexo Petúnia: registro de múltiplos estágios evolutivos na borda sul do Cráton do São Francisco}

\section{RAFAELA MACHADO GENGO}

Orientador: Prof. Dr. Renato de Moraes

Tese de Doutorado

$\mathbf{N}^{0} 627$

COMISSÃO JULGADORA

Dr. Renato de Moraes

Dra. Eliza Inez Nunes Peixoto

Dra. Glaucia Nascimento Queiroga

Dr. Claudio de Morisson Valeriano

Dr. Frederico Meira Faleiros

SÃO PAULO

2020 
Dedico esta tese aо теи irmão, por tudo o que eи posso fazer... 


\section{Agradecimentos}

À FAPESP (Fundação de Amparo à Pesquisa do Estado de São Paulo), por viabilizar o desenvolvimento deste trabalho, através do projeto 16/22627-3.

À CAPES (Coordenação de Aperfeiçoamento de Pessoal de Nível Superior), pela concessão da bolsa de doutorado. Resista!

Meus mais sinceros agradecimentos ao meu orientador, Prof. Renato de Moraes, por todo o apoio, incentivo, paciência e, principalmente, pela confiança que depositou em mim ao longo de toda minha trajetória na Geologia. Obrigada por sempre estar disposto a responder, mesmo minhas perguntas idiotas! Agora ficarão as dicas de aulas e músicas malucas.

Ao Prof. Gergely Andres Julio Szabó, nosso eterno guru, por tooooda a paciência, por estar sempre disposto a me ajudar e, principalmente, por confiar a mim desvendar os mistérios do Complexo Petúnia. Eu simplesmente amei ter trabalhado nessa região, apesar de parecer o plano de fundo do Windows XP. Você me proporcionará trabalho por um bom tempo, muito obrigada!

Ao Prof. Mario da Costa Campos Neto, pela ajuda com as seções, pelas discussões e pela motivação. Muito do que sou hoje como geóloga e pesquisadora, devo a você. Muito obrigada!

Ao Prof. Vinicius Hector Abud Louro, pelas valiosas dicas do mundo das publicações e por topar entrar nesse balaio de gatos que é o Complexo Petúnia. Bom, se alguém tem que fazer contas, que seja o geofísico!

Ao Prof. Marcos Egídio da Silva pela ajudinha com a estrutural e por proporcionar conversas sempre muito engraçadas!

Ao Dr. Caio Arthur Santos (Fóóófis), por TODA a força, por me acompanhar nos trabalhos de campo, por sua infinita ajuda com as pseudosseções, por ouvir minhas lamúrias diante dos percalços com a geocron e da MP-27. Muito obrigada!

À Msc. Laísa de Assis Batista pelas infinitas, produtivas e entusiasmantes discussões sobre petrocronologia (e outras coisas da vida), por estar sempre disposta a compartilhar todo o conhecimento e por finalmente ter se tornado uma amiga. Muito obrigada!

A todos os demais professores do IGc-USP, por todos esses anos de convívio, em especial os professores Kabong (Claudio), Silvio Vlach, Lucelene Martins, Miguel Basei, Oswaldo Siga Junior, Fábio Ramos. 
Ao Prof. George Luvizotto e ao Daniel pelo help com as análises na microssonda da UNESP. Ao Prof. Elton Dantas, por "salvar" a geocronologia da minha tese. Ao geólogo, Dr. Marco Aurélio Pinheiro por gentilmente ceder as imagens de geofísica.

A todos os funcionários do IGc-USP, em especial: Samuel (Samuca), grande Vasco Loios (CPGeo), Marcos Mansueto e Leandro Moraes (microssonda), Vinícius Martins (LAICP-MS), Solange Lucena (CPGeo), “Zé” Paulo (LTA), Henrique e Claudionor (gráfica), Renato (laminação).

Ao pessoal da sala B-09: Vanessa, Mariana, Eliana, Julio, Nicolas, Pedro (Prof. Porra), Lucas Tesser... E às agregadas, Grega e Garibaldo. Aos demais colegas da pós (...).

Ao grupo Bolsistas Capes, pela informação, divertimento, empatia e treta garantidas!

Ao Prof. Guintar, da Faculdade Oswaldo Cruz, pela compreensão e por sempre "dar um jeito" quando precisei fazer os trabalhos de campo.

Aos alunos e ex-alunos que, sem saberem (e por incrível que pareça) mantiveram minha mente sã. À Débora Alonso Lopes, minha fiél assecla, companheira do chopp depois da aula e confidente das madrugadas.

À Roberta de Brito, minha terapeuta, por ter me ajudado a segurar a barra durante a pós. Afinal, como manter a sanidade nesses tempos?

Por fim, ao Pedro Machado Simões, meu namorado, amigo e companheiro. Por todas as dicas construtivas para meu trabalho, pelo apoio e incentivo durante toda essa jornada. Muito Obrigada! 
Conhecer-se é dominar-se, dominar-se é triunfar Jigoro Kano 


\section{RESUMO}

O Complexo Petúnia corresponde a uma das faixas tectônicas englobadas pelo Cinturão de Cisalhamento Campo do Meio, de direção geral WNW - ESE, limitado por unidades do Orógeno Brasília, com a Nappe de Passos a norte, e pela Nappe Socorro Graxupé e por terrenos relacionados ao Sistema de Nappes Andrelândia ao sul.

A grande distinção entre os Complexos Petúnia e Campos Gerais reside no maior grau de deformação e maior recorrência de unidades supracrustais imbricadas por meio de um complexo arranjo de cavalgamentos e cisalhamentos no Complexo Petúnia e pela presença de rochas metaultramáficas de filiação komatiítica no Complexo Campos Gerais.

Trabalhos de mapeamento geológico combinados com modelos digitais de terreno e dados de gamaespectrometria e magnetrometria, permitiram individualizar com maior clareza os Complexos Petúnia e Campos Gerais. Neste trabalho o Complexo Petúnia foi redefinido e agora passa a corresponder apenas aos terrenos arqueanos-paleoproterozoicos, formados pela Unidade Petúnia, representada por gnaisses tonalíticos de 2,99 - 2,95 Ga, com intercalações de rochas máficas e metaultramáficas, bem como pelo Gnaisse Ribeirão da Conquista, de 2,83 Ga, e pelo Metagranito Bom Jesus da Penha, de 2,00 Ga. Junto ao Complexo Campos Gerais, o Complexo Petúnia constitui o arcabouço arqueano-paleoproterozoico da borda sul do Cráton do São Francisco, cuja evolução tectônica registra múltiplos estágios que remontam pelo menos desde o Paleoproterozoico até acomodações finais em resposta à consolidação do Orógeno Brasília Meridional, em torno de 574 Ma.

As unidades supracrustais são representadas pelas Unidades Serra do Ibituruna e Colônia. Na Unidade Serra do Ibituruna, metapsamítica, predominam cristais detríticos de zircão com texturas dos protólitos preservadas. A distribuição de idades ${ }^{207} \mathrm{~Pb} /{ }^{206} \mathrm{~Pb}$ define dois picos, um menor para idades do período Riaciano, com zircão proveniente predominantemente de granitoides do Cinturão Mineiro, outro pico, maior, com idades neo- a mesoarqueanas em grãos de zircão provenientes do embasamento cratônico da borda sul do Cráton do São Francisco. A idade máxima de deposição, em 2,08 Ga, o hiato no registro de fontes siderianas e a maior contribuição de fontes arqueanas sobre fontes paleoproterozoicas indica mudança no regime deposicional da bacia, que tem características de formação em ambiente colisional, tal como os Grupos Sabará e Itacolomi. A Unidade Serra do Ibituruna, portanto, pode registrar a ocorrência inédita desses grupos fora do Quadrilátero Ferrífero.

A Unidade Colônia é formada por metapelitos com intercalações de rochas metaultramáficas cuja filiação, embora ainda incerta, é distinta das rochas metaultramáficas 
do Complexo Campos Gerais. Os metapelitos registram trajetória horária de aquecimento, com fusão hidratada em presença de estaurolita durante o pico metamórfico, em $601 \mathrm{Ma}$, e durante o resfriamento e desenvolvimento da foliação milonítica, em $580 \mathrm{Ma}$, sob condições $P-T$ de 7,7 a 8,5 kbar e 680 a $690^{\circ} \mathrm{C}$. Relíquias de associações de alta pressão e temperatura, em conjunto com a distribuição de idades em zircão, ainda que heterogeneamente recristalizados durante o metamorfismo, guardam semelhanças com unidades do Orógeno Brasília. 


\begin{abstract}
The Petúnia Complex corresponds to one of the tectonic belts surrounded by the Campo do Meio Shearing Belt, of general direction WNW - ESE, and limited by units of Brasília Orogen, with the Passos Nappe, to the north, and Socorro Guaxupé Nappe and by terrains related to the Andrelândia Nappe System, to the south.

The great distinction between the Petúnia and Campos Gerais Complexes lies in the greater degree of deformation and the greater recurrence of supracrustal units imbricated through a complex arrangement of overthrusting and shearing in the first one and the presence of metaultramafic rocks of komatiitic affiliation in the last.

Geological mapping combined with digital terrain models and data from gammaspectrometry and magnetrometry, allowed a more clearly individualization of the Petunia and Campos Gerais Complexes. In this thesis, the Petúnia Complex was redefined and now shall correspond only to the Archean-Paleoproterozoic terrains, formed by the Petúnia Unit, represented by tonalitic gneisses of $2.99-2.95 \mathrm{Ga}$, with intercalations of mafic and metaultramafic rocks, as well as by the Ribeirão da Conquista Gneiss, of $2.83 \mathrm{Ga}$, and the Bom Jesus da Penha Metagranite, of $2.00 \mathrm{Ga}$. Next to the Campos Gerais Complex, the Petúnia Complex constitutes the archean-paleoproterozoic framework on the southern margin of the São Francisco Craton, whose tectonic evolution registers multiple stages that go back at least from the Paleoproterozoic until the final accommodations in response to the consolidation of the Meridional Brasília Orogen, in around 574 Ma.

The supracrustal units are represented by the Serra do Ibituruna and Colônia Units. At the Serra do Ibituruna Unit, which is metapsamitic, detrital zircon crystals with preserved protolith textures dominate. The ${ }^{207} \mathrm{~Pb} /{ }^{206} \mathrm{~Pb}$ age distribution defines two peaks, one smaller for ages from the Riaciano period, with zircon predominantly from granitoids of the Mineiro Belt, and another peak, larger, with neo- to mesoarchean ages in zircon grains from the cratonic basement of the south border of the São Francisco Craton. The maximum age of deposition, at $2.08 \mathrm{Ga}$, the gap in the registration of siderian sources and the greater contribution of archean sources over paleoproterozoic ones indicates a change in the depositional regime of the basin, which has characteristics of formation in a collisional setting, such as Sabará and Itacolomi Groups. The Serra do Ibituruna Unit, therefore, might record the unprecedented occurrence of these groups outside the Quadrilátero Ferrífero.

The Colony Unit is formed by metapelites with intercalations of metaultramafic rocks whose affiliation, although still uncertain, is distinct from the metaultramafic rocks of the
\end{abstract}


Campos Gerais Complex. The metapelites register a clockwise warming trajectory, with hydrated melting in the presence of staurolite during the metamorphic peak, at $601 \mathrm{Ma}$, and during the cooling and development of mylonitic foliation, at $580 \mathrm{Ma}$, under $P-T$ conditions of 7.7 to $8.5 \mathrm{kbar}$ and 680 to $690^{\circ} \mathrm{C}$. Relics of high pressure and temperature associations, along with the age distribution in zircon, although heterogeneously recrystallized during metamorphism, keep similarities with units of the Brasília Orogen. 


\section{SUMÁRIO}

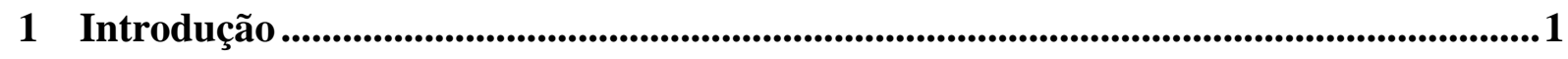

1.1 Objetivos e Justificativas ............................................................................................ 2

1.2 Localização da Área e Vias de Acesso ................................................................................ 2

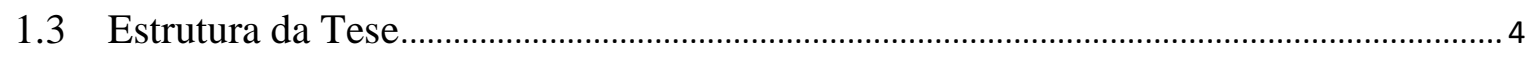

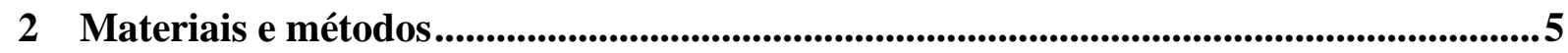

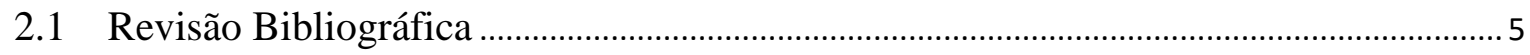

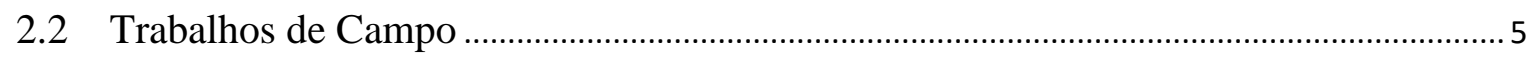

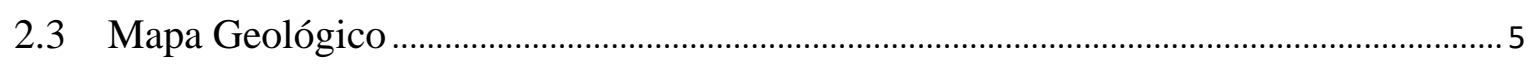

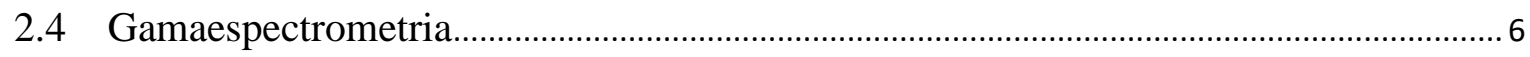

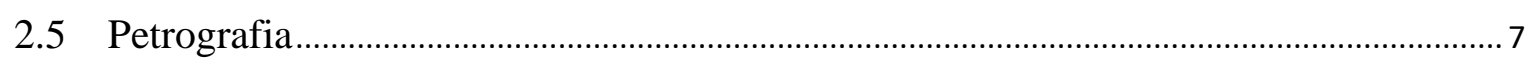

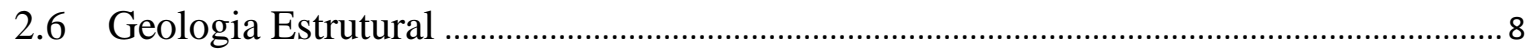

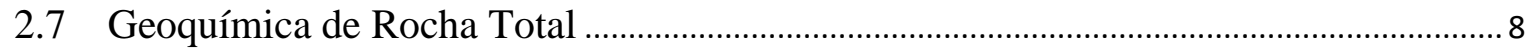

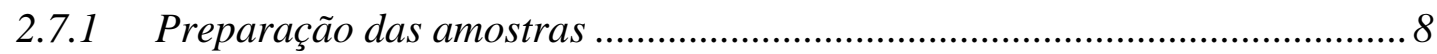

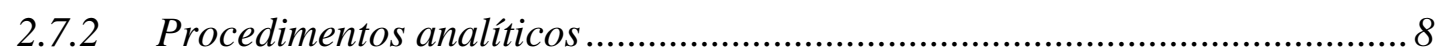

2.8 Química Mineral ...........................................................................................................

2.8.1 Procedimentos analíticos e tratamento dos dados....................................... 9

2.9 Pseudosseções e Geotermobarometria..............................................................................

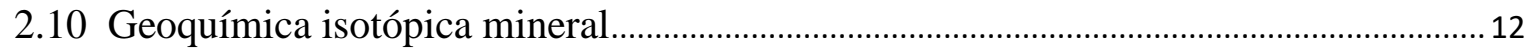

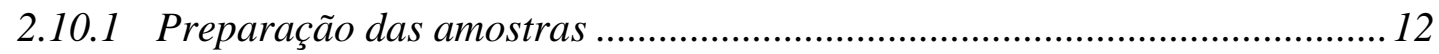

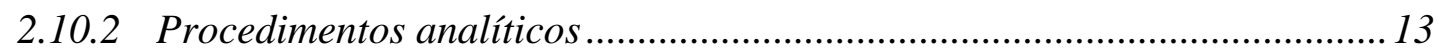

2.10.3 Tratamento dos dados ........................................................................... 14

2.11 Análise de Elementos Traço e Terras Raras em Zircão ....................................................... 17

2.11.1 Princípios e aplicações em estudo de proveniência .................................... 17

2.11.2 Procedimentos analíticos e tratamento dos dados....................................... 19

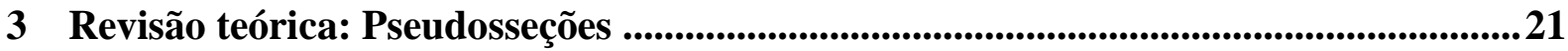

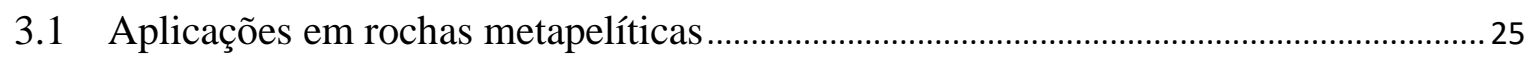

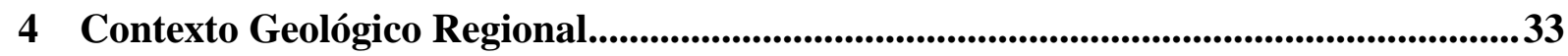

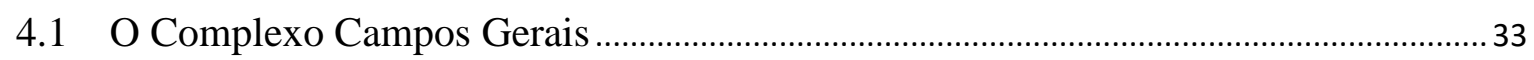

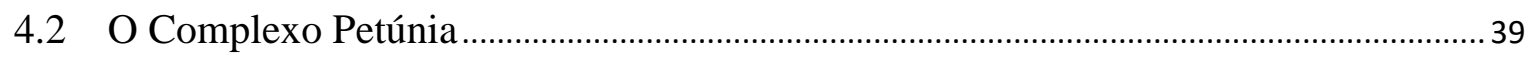

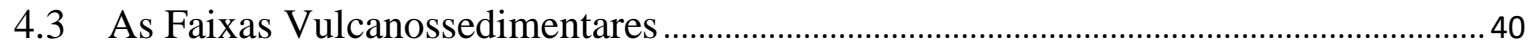

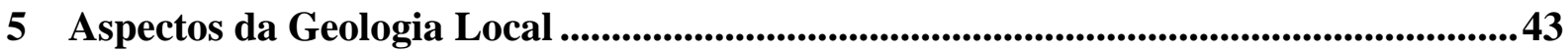




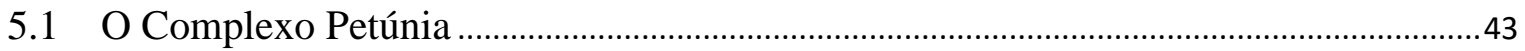

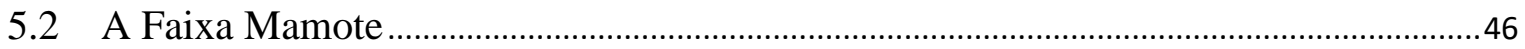

6 Redefinindo o Complexo Petúnia ............................................................................................... 49

7 Proveniência Sedimentar da Unidade Serra do Ibituruna.......................................... 51

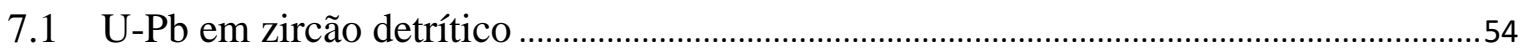

7.2 Assinatura de elementos traços e terras raras (ETR) em zircão detrítico ........................58

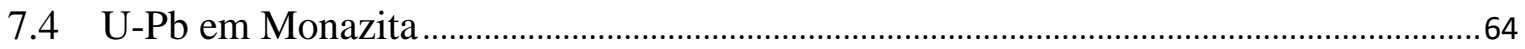

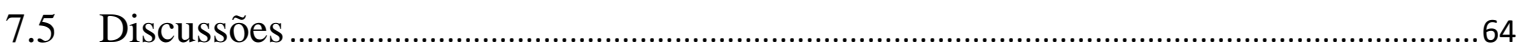

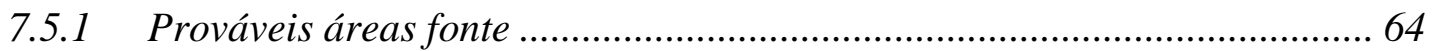

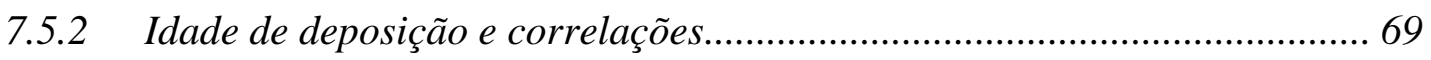

8 Metamorfismo da Unidade Colônia ...................................................................................... 77

8.1 Cianita - estaurolita - muscovita - granada - biotita xisto (CP-07) ................................77

8.2 Muscovita - cianita - plagioclásio - granada - biotita xisto (CP-333) ............................80

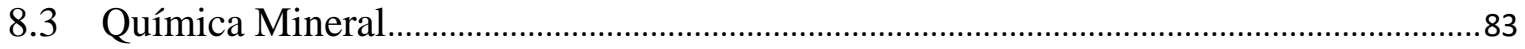

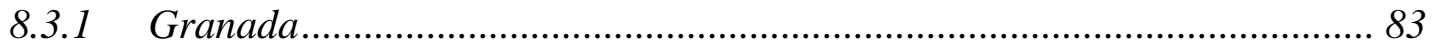

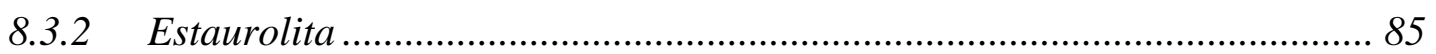

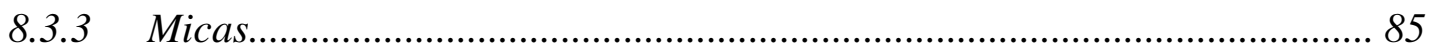

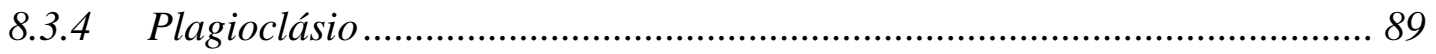

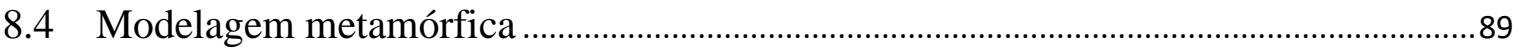

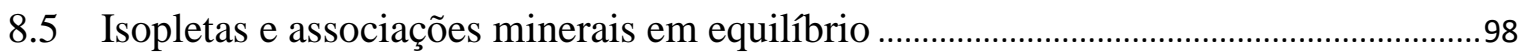

8.5.1 Cianita-estaurolita-muscovita-granada-biotita xisto (CP-07).................... 98

8.5.2 Muscovita-cianita-plagioclásio-granada-biotita xisto (CP-333).............. 103

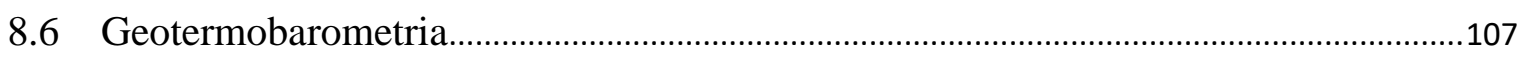

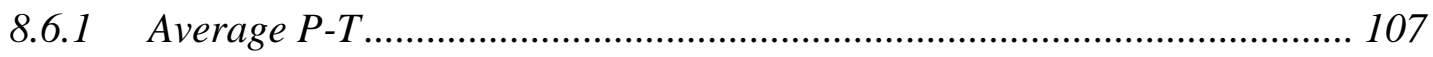

8.6.2 Geotermômetro Zr em rutilo.............................................................. 109

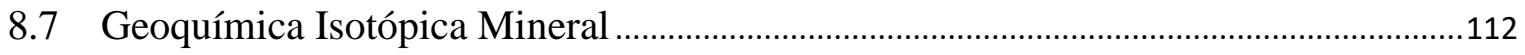

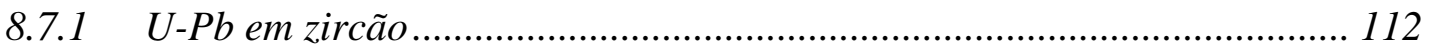

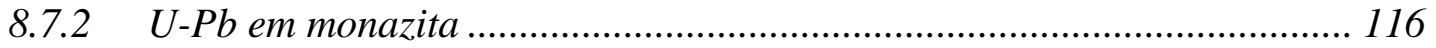

8.8 Assinatura de Elementos Traço e Terras Raras em Zircão .................................................116

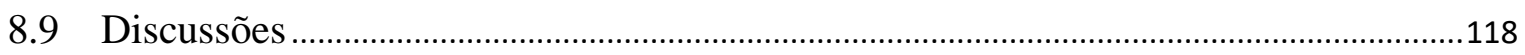

8.9.1 Paragêneses e reações de equilíbrio ........................................................ 118

8.9.2 Idades do equilíbrio de fases acessórias .................................................. 121

8.9.3 Reconstruindo as trajetórias $P$-T ..................................................... 124

9 As Rochas Metaultramáficas do Complexo Petúnia................................................... 129 


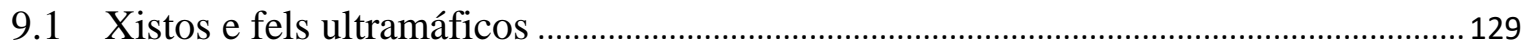

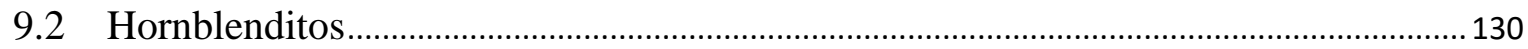

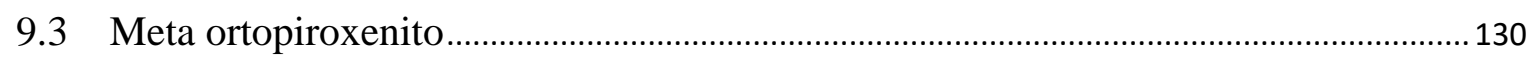

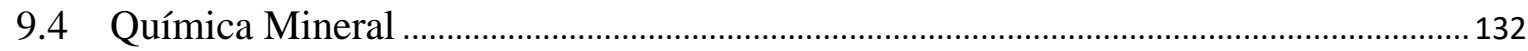

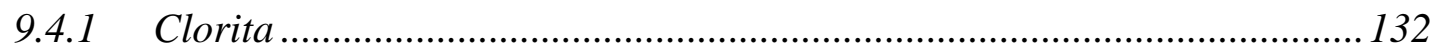

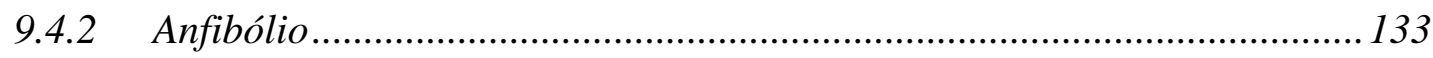

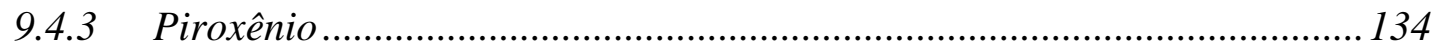

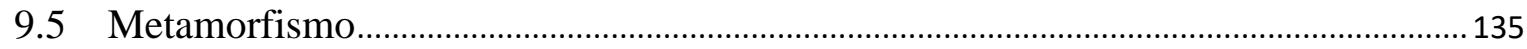

10 Modelo evolutivo do Complexo Petúnia ............................................................................137

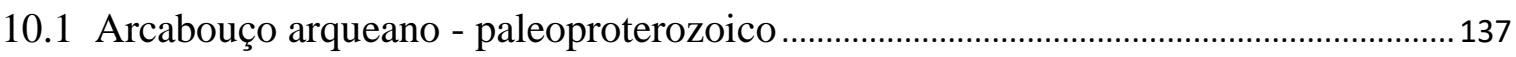

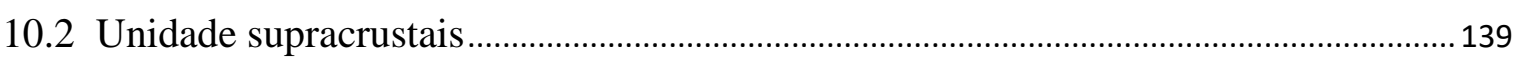

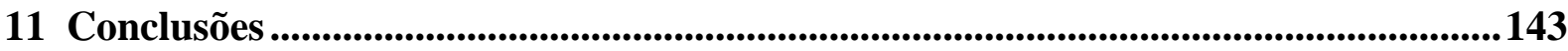

12 Referências Bibliográficas .................................................................................................. 145

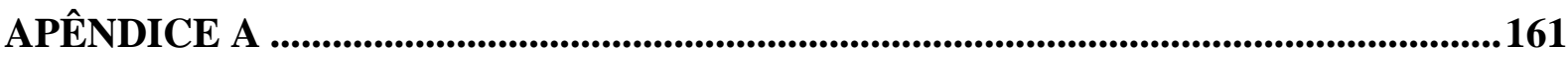

The Archean and Paleoproterozoic rocks of the Petunia Complex and its relationship with the Campos Gerais Complex as a basement window in the Brasília Orogen, Southeastern Minas Gerais, Brazil 161

\section{LISTA DE FIGURAS}

Figura 1.1: Localização da área de estudo (polígono sombreado) e principais vias de acesso. Simplificado dos mapas do DNIT (2013).

Figura 2.1: a) Diagrama de Distribuição Cumulativa "CDF" ou "CAD", úteis na visualização de várias amostras; b) Diferença estatística máxima (D) entre diferentes amostras. Extraído de Guynn \& Gehrels (2010).

Figura 3.1: Figuras esquemáticas mostrando a relação entre pontos invariantes e campos em uma pseudosseção. Em (a) o ganho da fase "c" e em (b) perda da fase "b"; (c) ilustra uma linha univariante para a reação $\mathrm{g}+\mathrm{chl}=\mathrm{bi}+\mathrm{st}$ e em (d) observamos que a linha é representada por um campo estreito. Extraído de Powell et al. (2009).

Figura 3.2: Grade petrogenética para o sistema KFMASH (linhas mais escuras) baseada nas grades KFASH (linhas finas) e KMASH (linhas tracejadas). Pontos representam pontos invariantes nos sistemas KFASH ou KMASH. Quadrados são pontos invariantes do sistema KFMASH. Extraído do site de Frank Spear, sendo versão levemente modificada de Spear \& Cheney (1989), com a mudança de um ponto invariante envolvendo a reação $\mathrm{Ctd}+\mathrm{Bt}=\mathrm{Grt}+\mathrm{Chl}$, para posição de baixa $P$.

Figura 3.3: Grade petrogenética construída para o Sistema KFMASH. Extraído de Powell \& Holland (1998). 
Figura 3.4: Pseudosseção P-T calculada no sistema KFMASH a partir do banco de dados internamente consistente de Holland e Powell (2011) para um metapelito com as seguintes composições, em \% molar: $\mathrm{SiO} 2$ (68.76); $\mathrm{Al} 2 \mathrm{O} 3$ (9.87); FeO (7.64); $\mathrm{MgO}$ (4.01); K2O (3.16); e H2O (6.56). Extraído de White et al (2014a)................................ 28

Figura 3.5: Pseudosseção calculada no sistema MnNCKFMASHTO. SiO2 (74.021), Al2O3 (9.452), $\mathrm{FeO}$ (7.530), $\mathrm{MgO}$ (3.844), $\mathrm{CaO}$ (0.296), $\mathrm{K} 2 \mathrm{O}$ (3.031), $\mathrm{Na} 2 \mathrm{O}$ (0.602), TiO2 (0.659), O (0.565) e MnO (0,1). Extraído de White et al., (2014b).....

Figura 4.1: Sistemas orogênicos da porção sudeste e central do Brasil. Modificado de Westin et al. (2016).

Figura 4.2: Mapa geológico esquemático de parte do Orógeno Brasília Meridional com os principais domínios tectônicos. Modificado e adaptado de Campos Neto et al. (2011) e Zanardo et al. (2006), com indicação da área de estudo. 34

Figura 4.3: Esboço tectônico com destaque para os domínios Campos Gerais e Petúnia. Extraído e modificado de Zanardo (1992). O polígono vermelho indica a área de estudo.

Figura 4.4: Mapa geológico simplificado com destaque para as faixas vulcanossedimentares associadas aos complexos Campos Gerais e Petúnia. A linha tracejada indica a divisão entre os domínios II e III do Complexo Campos Gerais, como proposto por Zanardo (1992), e o polígono vermelho indica a localização aproximada da área de estudo. A sequência ofiolítica equivale a Faixa Bom Jesus da Penha-Jacuí. Extraído e modificado de Feola (2004).

Figura 5.1: a) Cristas de muscovita - quartzo xisto da Unidade Serra do Ibituruna, ponto CP286; b) Hornblenda - biotita gnaisse granodiorítico da Unidade Petúnia, ponto CP-105; c) Exposição típica do gnaisse da Unidade Petúnia em talude de corte da estrada, ponto CP-54; d) Cristas de xistos ultramáficos in situ, do outro lado da estrada, ponto CP-54; e) Bloco de boudin de anfibolito da Unidade Petúnia, ponto CP-39. Notar núcleo maciço e bordas deformadas; f) Matacão de biotita gnaisse fresco - Gnaisse Ribeirão da Conquista, ponto CP-265. 45

Figura 5.2: Hornblenda-biotita metatexito estromático da Faixa Mamote, em (a) fresco, ponto CP-65 e em (b) saprolítico com estrutura preservada e foliação milonítica de alto ângulo, ponto CP-83; Biotita metatexito cinza rosado da Nappe Socorro - Guaxupé, em (c) blocos frescos em corte da rodovia BR-146, ponto CP-34 e em (d) matacão de rocha pouco alterada, ponto CP-77.

Figura 7.1: a) Rutilo-quartzo-muscovita-cianita fels, amostra CP-244; b) Foliação milonítica em muscovita-quartzo xisto, amostra CP-35 com aumento de 1,25x; Muscovita quartzito, amostra CP-98B - c) Com polarizadores cruzados e aumento de 1,25x. Notar domínios com extinção próxima; d) Com placa de gipso e aumento de 1,25x. Notar domínios com mesma orientação óptica, recristalizados por SGR (Subgrain Rotation Recrystallisation).

Figura 7.2: Imagens de catodoluminescência de cristais detríticos de zircão representativos das amostras da Unidade Serra do Ibituruna. Estão indicadas as idades $207 \mathrm{~Pb} / 206 \mathrm{~Pb} \mathrm{em}$ Ma. Os círculos verdes e vermelhos representam os locais onde foram feitas as datações, concordantes e discordantes, respectivamente. Os círculos azuis representam os locais onde foram feitas as análises de elementos traço e terras raras. 
Figura 7.3: Diagrama concórdia 207U/235Pb vs. 206U/238Pb para as amostras da Unidade Serra do Ibituruna. Elipses de cor cinza representam as datações com concordância fora do limite $100 \pm 10 \%$.

Figura 7.4: Diagramas Idade $207 \mathrm{~Pb} / 206 \mathrm{~Pb}$ vs. Probabilidade Relativa utilizando a estimativa de densidade de Kernel (KDE - Kernel Density Estimator) para as amostras da Unidade Serra do Ibituruna. (a), (b) e (c) representam as amostras de muscovita-quartzo xisto e (d) representa a amostra de muscovita quartzito. IMD: Idade Máxima de Deposição. ...56

Figura 7.5: a) Diagrama de Distribuição Cumulativa (CAD - Cumulative Age Distribution) para zircão detrítico das amostras da Unidade Serra do Ibituruna; b) Gráficos weighted average com as idades máximas de deposição obtidas a partir da média ponderada do grupo de idades mais jovem com 1ơ de incerteza. 56

Figura 7.6: Padrões de distribuição dos elementos terras raras (ETR) em zircão detrítico da Unidade Serra do Ibituruna normalizados pelo condrito de acordo com Sun \& McDonough (1989). Em (a) todo o conjunto, (b), (c) e (d) separados por Era. 59

Figura 7.7: Gráficos para avaliar o grau de modificações nos cristais de zircão. Para grau de metamictização e alteração - a) Gráfico Th+U vs. (La/Gd)N de Whitehouse \& Kamber (2002) e b) Th+U vs. EETR; Para zircão magmático e hidrotermal - c) Gráfico La vs. (Sm/La)N de Hoskin (2005) e d) Gráfico $(\mathrm{Tb} / \mathrm{Yb}) \mathrm{N}$ vs. ( $\mathrm{Sm} / \mathrm{Ce}) \mathrm{N}$, modificado de Toscano et al. (2014). Legenda dos símbolos na Figura a.

Figura 7.8: a) Gráfico da variação da razão Th/U em cristais de zircão da Unidade Serra do Ibituruna; b) Gráfico Y vs. U/Yb de Grimes et al., (2007) para diferenciação de zircão de rochas de crosta oceânica e continental; c) Gráfico Yb/Sm vs. Y de Belousova et al. (2002) para diferenciação de zircão de origem magmática. 1- Aplitos e Leucogranitos, 2 - Granitos, 3 - Granodioritos e Tonalitos, 4 - Nefelina sienitos e sienitos pegmatíticos; d) Gráfico Th vs. Nb de Nardi et al., (2013), também para diferenciação de zircão de origem ígnea; e) Gráfico Hf vs. Y de Pupin (2000) para identificação do ambiente tectônico de rochas ígneas. Os campos indicados, correspondem às rochas anorogênicas ( 1 e 2) e orogênicas (5 e 6), enquanto os campos 3 e 4 correspondem à um domínio intermediário, onde ocorrem rochas de ambas as origens. Para mais detalhes, ver o texto e Pupin (2000).

Figura 7.9: Diagramas Tera-Wasserburg para idade U-Pb em monazita das amostras da Unidade Serra do Ibituruna - a) Idade discórdia, amostra CP-27; b) Idade concórdia, amostra CP-35. 64

Figura 7.10: Diagrama Idade 207Pb/206Pb vs. Probabilidade Relativa utilizando a estimativa de densidade de Kernel (KDE - Kernel Density Estimator) para zircão detrítico da Unidade Serra do Ibituruna com a indicação das faixas etárias das rochas da porção meridional do Cráton do São Francisco: Orogenia Minas, 2,35-2,0 Ga (Teixeira et al., 2015); Evento Mamona II, 2,62-2,58 Ga e Mamona I, 2,75-2,70 Ga (Farina et al., 2015; Martínez Dopico et al., 2017); Evento Rio das Velhas II, 2,8-2,76 Ga, Rio das Velhas I, 2,93-2,85 Ga e Santa Bárbara, 3,22-3,20 Ga (Lana et al., 2013); Orogenia Campo Belo (Teixeira et al., 2017).

Figura 7.11: Gráfico comparativo mostrando os diagramas Idade vs. Probabilidade Relativa para a Unidade Serra do Ibituruna e unidades correlatas na literatura. Dados compilados 
de Falci et al., 2018, Rodrigues et al., 2010, Frugis et al., 2018 e Westin et al., 2016 e 2019.

Figura 7.12: Gráfico comparativo mostrando os diagramas Idade vs. Probabilidade Relativa para a Unidade Serra do Ibituruna e os Grupos Sabará e Itacolomi. Estão indicadas as idades máximas de deposição para cada unidade. Dados compilados de Dutra et al. (2019) e Duque, 2018. 73

Figura 7.13: Gráfico IC-ID (Idade de Cristalização - Idade de Deposição) vs. Probabilidade Cumulativa para inferências de regime deposicional segundo Cawood et al. (2012) das amostras da Unidade Serra do Ibituruna, as possíveis unidades correlatas e, comparativamente, unidades neoproterozoicas do Orógeno Brasília Meridional. Dados compilados de Westin et al. (2016, 2019), Duque et al., (2020) e Dutra et al. (2019)... 75

Figura 8.1: a-b) Cianita-estaurolita-muscovita-granada-biotita xisto, amostra MP-27; c-d) Muscovita-cianita-plagioclásio-granada-biotita xisto milonítico, amostra CP-333 ....... 78

Figura 8.2: Porfiroblastos de estaurolita - a) da primeira geração e b) da segunda geração; c) Porfiroblastos de granada, inter-cinemáticos e rotacionados pela foliação, amostra MP27; d) Textura inequigranular hipidiomórfica em lente quartzo-feldspática, amostra CP07; e) Cianita-estaurolita-muscovita-granada-biotita-quartzo xisto com intercalações lenticulares formadas por quartzo, plagioclásio e biotita; f) Esboço do cianita-estaurolitamuscovita-granada-biotita-quartzo xisto com as intercalações de lentes quartzofeldspáticas e destaque para os selvedges de biotita; g-h) Cristais de plagioclásio com quartzo intersticial e cristais de cianita, interpretada como peritética, amostra CP-07. .. 79

Figura 8.3: Muscovita-cianita-plagioclásio-granada-biotita-quartzo xisto milonítico (CP-333). a) Pods assimétrico de cianita com inclusões de quartzo, rutilo e granada da primeira geração (feição I). Notar granadas com coronas de granada da segunda geração no canto superior esquerdo; b) Detalhe para as bordas ameboides da cianita; c) Cristais de quartzo e plagioclásio ricos em inclusões de micas; d) Cristal de plagioclásio assimétrico e amoldado pela foliação. Notar microinclusões idioblásticas de estaurolita; e) Cristais de granada da segunda geração de crescimento (feição IV) com plagioclásio intersticial; e) Cianita com inclusão de cristal de ilmenita parcialmente substituído por rutilo. Círculos vermelhos representam os locais de análise química. 82

Figura 8.4: a) Porfiroblasto de granada tipo I da amostra CP-07, com a indicação do perfil composicional; b)Gráfico da distribuição da concentração dos membros finais almandina, piropo, grossulária e espessartita ao longo do perfil na granada tipo I; c-f) Mapas composicionais para concentrações de Fe, a Mg, Ca e Mn com indicação do perfil; g) Porfiroblasto de granada tipo II da amostra CP-07, com a indicação do perfil composicional; h) Gráfico da distribuição da concentração dos membros finais almandina, piropo, grossulária e espessartita ao longo do perfil na granada tipo II. ....... 84

Figura 8.5: Cristais de granada da amostra CP-333 - a) Granada idioblástica da primeira geração, preservada como inclusões em cianita; b) Granada da primeira geração com corona de granada da segunda geração; c) Granada da segunda geração com relíquias da granada anterior preservada; d) Granada da segunda geração, sem indícios de restos da granada anterior; e-h) Gráficos da distribuição das concentrações dos membros finais, respectivamente das granadas descritas de (a) a (d). 87 
Figura 8.6: Mapas composicionais para concentrações de Fe, $\mathrm{Mg}, \mathrm{Ca}$ e Mn. a-d) Granada da primeira geração de crescimento; e-h) Granada da primeira geração com corona de granada da segunda geração de crescimento; i-1) Granada da segunda geração com relíquias de granada da primeira geração de crescimento; m-p) Granada da segunda geração de crescimento, com maior grau de homogeneização.

Figura 8.7: Gráficos das variações composicionais em estaurolita, biotita e muscovita. (a) e (b) para vetores de substituição simples na estaurolita; substituição simples (c) e acopladas (d-f) na biotita; (g-i) para substituições acopladas na muscovita.

Figura 8.8: Cristal de plagioclásio subidiomórfico presente no leucossoma da amostra CP-07 e variação composicional dos cristais das amostras CP-07 e CP-333.....

Figura 8.9: Pseudosseção construída para a amostra CP-07 no sistema NCKFMASHTO. a) Detalhe para o intervalo de condições P-T onde a curva solidus ocorre no campo da estaurolita; b) Detalhe para as associações que ocorrem nas vizinhanças da associação em equilíbrio da amostra.

Figura 8.10: Pseudosseção construída para a amostra CP-333 no sistema NCKFMASHTO. a) Detalhe para o intervalo de condições P-T onde a curva solidus ocorre no campo da estaurolita; b) Detalhe para as associações que ocorrem nas vizinhanças da associação em equilíbrio da amostra.

Figura 8.11:Isopletas calculadas para a proporção modal de: estaurolita - (a) amostra CP-07 e (b) amostra CP-333; muscovita - (c) amostra CP-07 e (d) amostra CP-333; e fundido (e) amostra CP-07 e (f) amostra CP-333.

Figura 8.12: a) Variação composicional da biotita da amostra CP-07 plotada no diagrama AFM, modificado de Thompson (1957); Isopletas calculadas para parâmetros composicionais dos minerais da amostra $\mathrm{CP}-07$; b) $X \mathrm{Mg}$ da granada e da biotita; c) $X \mathrm{Ca}$ da granada e do plagioclásio; d) $X \mathrm{Mg}$ da estaurolita e $X \mathrm{Na}$ da muscovita; e) $X \mathrm{Ti}$ da biotita e da estaurolita; f) XAlVI das micas. A estrela indica cruzamento de isopletas composicionais.

Figura 8.13: a) Variação composicional da biotita da amostra CP-333 plotada no diagrama AFM, modificado de Thompson (1957); Isopletas calculadas para parâmetros composicionais dos minerais da amostra $\mathrm{CP}-333$; b) $X \mathrm{Mg}$ da granada e da biotita; c) $X \mathrm{Ca}$ da granada e do plagioclásio; d) $X \mathrm{Mg}$ da estaurolita e $X \mathrm{Na}$ da muscovita; e) $X \mathrm{Ti}$ da biotita e da estaurolita; f) XAIVI das micas. As estrelas indicam o cruzamento das isopletas de minerais em uma mesma associação em equilíbrio.

Figura 8.14: : Resultados dos cálculos por geotermobarometria otimizada para os conjuntos de associações em equilíbrio - a) amostra CP-07 e b) amostra CP-333. As estrelas indicam o cruzamento de isopletas minerais das associações em equilíbrio; Isopletas de Zr no rutilo - c) amostra CP-07 e d) amostra CP-333; e) Rutilo (Rt-1) na matriz, com corona parcial de ilmenita, amostra CP-07; f) Rutilo (Rt-2) na matriz, com corona de ilmenita bem desenvolvida e associada com magnetita, amostra CP-07; g) Rutilo (Rt-3) incluso em porfiroblasto de estaurolita; h) Cristais granulares de rutilo (Rt-6) homogêneo, associado com pouca ilmenita, inclusos na primeira geração de granada da amostra CP-333. 111

Figura 8.15: Imagens de catodoluminescência (CL) e de elétrons retroespalhados (BSE) de cristais de zircão (a) e monazita (b) representativos do cianita-estaurolita-muscovita- 
granada-biotita xisto (amostra CP-07) da Unidade Colônia. Estão indicadas as idades em Ma com 20 de incerteza, 207Pb/206Pb para idades $>1000$ e $206 \mathrm{~Pb} / 238 \mathrm{U}$ para idades $<$ 1000 . 113

Figura 8.16: a) Gráfico da variação da razão Th/U em cristais de zircão do cianita-estaurolitamuscovita-granada-biotita xisto (CP-07), b) Gráfico da variação da razão Th/U nos diferentes domínios texturais onde houve recristalização; c) Diagrama Idade vs. Probabilidade Relativa utilizando a estimativa de densidade de Kernel (KDE - Kernel Density Estimator); d) Diagrama com a curva concórdia de Tera-Wasserburg com os pontos plotados sem os erros; e) Diagrama com a curva concórdia de Tera-Wasserburg para os cristais de monazita; f) Diagrama com a curva concórdia de Tera-Wasserburg para as porções recristalizadas do zircão. 115

Figura 8.17: Padrões de distribuição dos elementos terras raras (ETR) em zircão do metapelito da Unidade Colônia, amostra CP-07. Em (a) para núcleos detríticos e zonas recristalizadas e homogêneas e em (b) para zonas com mistura de domínios. Valores normalizados pelo condrito de acordo com Sun \& McDonough (1989); c) gráfico Th+U vs. $\Sigma$ ETR; d) gráfico $\mathrm{Ca}+\mathrm{Al}+\mathrm{Fe}$ vs. U, adaptado de Rayner et al. (2005). 117

Figura 8.18: Detalhe para os campos de equilíbrio e as topologias que indicam as reações de fusão para os metapelitos da Unidade Colônia. Os pontos vermelhos indicam os pontos invariantes calculados - a) para a amostra CP-07; b) para a amostra CP-333.

Figura 8.19: a) Gráfico La vs. (Sm/La)N de Hoskin (2005); b) Diagrama concórdia para zircões. As elipses cinzas correspondem aos dados discordantes em mais de $5 \%$....... 123

Figura 8.20: a) Trajetórias horárias $P-T-t$ construída para a amostra CP-07 e $P-T$ para a amostra CP-333. 126

Figura 9.1: a) Aspecto textural do Antofilita-clorita-tremolita xisto do conjunto (i), amostra CP-16; b) Porfiroblastos de tremolita pós-S2 sobre foliação dada pela clorita, amostra CP-54A do conjunto $(i)$; c) Cristal de tremolita, pós-S2, com bordas de antofilitacummingtonita, amostra FAM-07A do conjunto (i); Talco-tremolita-cloritaortopiroxênio-clinopiroxênio fels porfiroblástico - d) Porfiroblasto de ortopiroxênio com geminação polissintética; e) Glomérulos máficos inclusos em ortopiroxênio; f) Glomeroporfiroblastos de anfibólio fibrorradiados sobre matriz formada por clorita e talco. .... 131

Figura 9.2: Gráficos das variações composicionais da clorita - a) Variação entre Fe e Mg; b) Variação entre AlVI e AlIV segundo critérios de Hey (1954); c) Variação composicional em termos da substituição tschermakítica. 134

Figura 9.3: Diagramas de classificação de anfibólios de acordo com Leake et al. (1997), em (a) para anfibólios cálcicos e em (b) para anfibólios de $\mathrm{Mg}-\mathrm{Fe}-\mathrm{Mn}-\mathrm{Li}$. 134

Figura 9.4: a) Gráfico da participação relativa das variações composicionais no anfibólio em função dos vetores das substituições edenítica (KAlIVロ-1Si-1) e tschermakítica (AlVIAlIVMg-1Si-1) mostrando a distribuição dos valores de AlIV no sítio T e $\mathrm{Na}+\mathrm{K}$ no sítio A; Variação composicional do anfibólio em termos da substituição tschermakítica (b) e titânio-tschermakítica (c)........................................................... 135

Figura 9.5: Grade petrogenética do sistema $\mathrm{SiO} 2-\mathrm{MgO}-\mathrm{H} 2 \mathrm{O}$ construída a partir do banco de dados de Berman (1988) com as curvas dos sistemas CMSH e CMASH indicadas em tracejado. O campo roxo representa as condições de equilíbrio dos xistos 
metaultramáficos das amostras CP-06 e CP-54a e em roxo escuro as condições estimadas para o pico térmico em $\sim 8$ kbar.

Figura 10.1: Diagrama Idade vs. Probabilidade Relativa para a Unidade Colônia utilizando apenas dados com concordância acima de $95 \%$ em núcleos detríticos e em zonas com mistura de domínios, i.e., relíquias de grão detrítico em meio às áreas parcialmente recristalizadas. São mostrados os espectros de distribuição de idades para a Unidade Serra do Ibituruna e para o Xisto Santo Antônio, com dados compilados de Frugis et al., 2018 .

\section{LiSTA DE TABELAS}

Tabela 2-1: Relação de amostras e minerais analisados por microssonda eletrônica. 9

Tabela 2-2: Configuração dos elementos químicos lidos em cada canal da microssonda. ....... 10 Tabela 2-3: elementos analisados e padrões utilizados nas análises de granada da amostra CP07 e minerais da amostra CP-333.

Tabela 2-4: Relação de amostras e análises de zircão pelo método U-Pb. Para finalidade, 1= proveniência, $2=$ metamorfirmo, $3=$ cristalização, $(*)$ amostra com dados $\mathrm{U}-\mathrm{Pb}$ em monazita.

Tabela 2-5: Condições analíticas do LA-ICP-MS

Tabela 4-1: Dados geocronológicos compilados para os Complexos Campos Gerais e Petúnia. Referências: 1-DNPM (1979); 2-Turbay (2010); 3-Lopes (2013), 4- Schrank \& Silva (1993), 5-Campos Neto et al., 2004; 6- Pinheiro (2013). 38

Tabela 7-1: Distribuição das populações de cristais de zircão nas amostras, com a quantidade de cristais datados por população e o número de análises válidas para a avaliação da proveniência sedimentar.

Tabela 7-2: Valores da probabilidade "P" obtidos no Teste K-S as idades na função de densidade cumulativa para as amostras da Unidade Serra do Ibituruna.

Tabela 7-3: Idades máximas de deposição determinadas para cada amostra da Unidade Serra do Ibituruna. Estão indicadas as idades $207 \mathrm{~Pb} / 206 \mathrm{~Pb}$ com 10 de incerteza.

Tabela 7-4: Distribuição das populações nos campos de ocorrência de rochas ígneas discriminadas com base no conteúdo de Hf e Y, de acordo com Pupin (2000).

Tabela 7-5: Histograma parcial da Figura 7.10 indicando as idades $207 \mathrm{~Pb} / 206 \mathrm{~Pb}$ neo- a mesoarqueanas obtidas em zircão detrítico da Unidade Serra do Ibituruna com os intervalos de idades $\mathrm{U}-\mathrm{Pb}$ em zircão disponíveis na literatura para as prováveis áreas fontes. Referências: 1-Turbay, 2010; 2-Campos Neto et al., 2004; 3-Gengo et al., (em preparação); 4-Teixeira et al., 1998; 5-Carvalho et al., 2017a; 6-Oliveira, 2004; 7Campos, 2004; 8-Quéméneur et al., 2003; 9-;Machado e Carneiro, 1992 10-Romano et al., 2013; 11-Farina et al., 2015; 12-Lana et al., 2013; 13-Cioffi et al., 2016b. *Idade Pb$\mathrm{Pb}$ em zircão e **Idade de cristalização do protólito do Gnaisse Engenheiro Correia....67

Tabela 7-6: Histograma parcial da Figura 7.10 indicando as idades $207 \mathrm{~Pb} / 206 \mathrm{~Pb}$ paleoproterozoicas obtidas em zircão detrítico da Unidade Serra do Ibituruna e os intervalos de idades U-Pb em zircão disponíveis na literatura para as prováveis áreas fontes. Referências: 1- Barbosa et al. 2015; 2- Seixas et al., 2013; 3- Teixeira et al., 
2014; 4-Ávila et al., 2006; 5- Teixeira et al., 2008; 6-Ávila et al., 2010; 7-Ávila et al., 2014; 8-Teixeira et al., 2015; 9-Seixas et al., 2012; 10-Oliveira, 2004; 11-Carvalho et al., 2017a; 12-Lopes, 2013; 13-Gengo et al. (em preparação); 14-(Cioffi et al., 2016a); 15Marinho (2014); 16-Medeiros Junior (2016). A linha tracejada em vermelho representa a idade máxima de deposição (IMD) determinada para a unidade. 68

Tabela 7-7: Valores da probabilidade "P" obtidos no Teste K-S usando os erros das idades em função de densidade cumulativa para as amostras da Unidade Serra do Ibituruna e amostras dos Grupos Sabará e Itacolomi. As idades 207Pb/206Pb utilizadas no teste foram extraídas de Duque (2018) e Dutra et al. (2019). 73

Tabela 8-1: Relações de crescimento mineral com as foliações nos metapelitos da Unidade Colônia. 80

Tabela 8-2: Associações minerais da amostra CP-333 e feições definidas para aplicação dos métodos geotermobarométricos. 103

Tabela 8-3: Dados calculados pelo average P-T. 108

Tabela 8-4: Concentração em ppm dos elementos traço em rutilo e resultado das temperaturas calculadas. 110

Tabela 8-5: Intervalos das concentrações em ppm de elementos terras raras leves, médios e pesados por domínio textural. Valores de referência para o padrão do zircão 91500 extraídos de http://georem.mpch-mainz.gwdg.de/ 117

\section{APÊNDICES:}

A - Artigo 1: The Archean and Paleoproterozoic rocks of the Petunia Complex and its relationship with the Campos Gerais Complex as a basement window in the Brasillia Orogen, Southeastern Minas Gerais, Brazil

B - Mapa de Pontos

C - Mapa Geológico

D - Resultados das análises de elementos maiores, menores e traços obtidos via FRX

$\mathrm{E}$ - Resultados das análises de química mineral obtidos via ME

F - Scripts do THERMOCALC

$\mathrm{G}$ - Resultados dos cálculos geotermobarométricos

$\mathrm{H}$ - Dados de U-Pb em zircão e monazita obtidos via LA-MC-ICP-MS

I - Resultados das análises in situ de elementos traços em zircão obtidas via LA-ICP-MS 


\section{LiSTA DE SIGLAS}

apfu: átomos por fórmula unitária

BIFs: banded iron formations

BLG: bulging recrystallization

BM: microscopia binocular

BSE: back scattered electron

CAD: cumulative age distribution

CAPES: Coordenação de Aperfeiçoamento de Pessoal de Nível Superior

CDF: cumulative distribution function

CL: catodoluminescência

CPGeo: Centro de Pesquisas em Geocronologia e Geoquímica Isotópica

CODEMIG: Companhia de Desenvolvimento Econômico de Minas Gerais

DNPM: Departamento Nacional de Produção Mineral

EDS: energy-dispersive system

EMPA: Electron Probe Micro Analyzer

ETR: elementos terras raras

FE: Field Emission

FRX: fluorescência de raios $\mathrm{X}$

Ga: bilhões de anos

GBM: Grain Boudary Migration

IBGE: Instituto Brasileiro de Geografia e Estatística

IC: idade de cristalização

ICP-MS: Inductively Coupled Plasma Mass Spectrometer

ID: idade de deposição

IMD: idade máxima de deposição

KDE: kernel density estimator

K-S: Kolmogorov-Smirnoff

LA-ICP-MS: Laser Ablation Inductively Coupled Plasma Mass Spectrometer

Ma: milhões de anos

MDT: Modelo Digital de Terreno

MEV: microscópio eletrônico de varredura

MORB: Middle ocean ridge basalt

MSWD: Mean Square Weighted Deviation 
NAP: Núcleo de Apoio à Pesquisa Geoanalítica-USP

ppm: partes por milhão

SGR: Subgrain Rotation Recrystallization

SIG: sistema de informação geográfica

TDM: idade-modelo calculada por depleted mantle

WDS: wavelenght-dispersive system

\section{LISTA DE UNIDADES E SÍMBOLOS}

Valores das razões minerais nas isopletas:

$X_{\mathrm{Mg}}=\frac{\mathrm{Mg}}{\mathrm{Fe}+\mathrm{Mg}}$ granada e estaurolita

$X_{\mathrm{Mg}}=\frac{2 * \mathrm{MgM} 1+\mathrm{MgM} 2}{2 * \mathrm{FeM} 1+\mathrm{FeM} 2+2 * \mathrm{MgM} 1+\mathrm{MgM} 2}$ biotita

$X_{\mathrm{Ca}}=\frac{\mathrm{Ca}}{\mathrm{Ca}+\mathrm{Fe}+\mathrm{Mg}}$ granada

$X_{\mathrm{Ca}}=\frac{\mathrm{Ca}}{\mathrm{Ca}+\mathrm{Na}+\mathrm{K}}$ plagioclásio

$X_{\mathrm{Ti}}=\frac{\mathrm{Ti}}{\mathrm{Ti}+\mathrm{Al}+\mathrm{Fe}^{3+}}$ estaurolita

$X_{\mathrm{Ti}}=\frac{\mathrm{Ti}}{\mathrm{FeM} 2+\mathrm{MgM} 2+\mathrm{Ti}+\mathrm{Al}+\mathrm{Fe}^{3+}}$

biotita

$X_{\mathrm{Al}}=\frac{\mathrm{Al}}{\mathrm{FeM} 2+\mathrm{MgM} 2+\mathrm{Ti}+\mathrm{Al}+\mathrm{Fe}^{3+}}$

$X_{\mathrm{Al}}=\frac{\mathrm{Al}}{\mathrm{Al}+\mathrm{FeM} 1+\mathrm{MgM} 1}$

$X_{\mathrm{Na}}=\frac{\mathrm{Na}}{\mathrm{Na}+\mathrm{K}+\mathrm{Ca}}$

muscovita

kbar = kilobar $=10^{3} \mathrm{bar}=10^{8} \mathrm{~Pa}$

${ }^{\circ} \mathrm{C}=$ graus Celsius 


$$
\begin{array}{ll}
\mathrm{km} & =\text { quilômetro }=10^{3} \mathrm{~m} \\
\mathrm{~m} & =\text { metro }=10^{1} \mathrm{~m} \\
\mathrm{~cm} & =\text { centímetro }=10^{-2} \mathrm{~m} \\
\mathrm{~mm} & =\text { milímetro }=10^{-3} \mathrm{~m} \\
\mu \mathrm{m} & =\text { micrômetro }=10^{-6} \mathrm{~m} \\
\mathrm{~kg} & =\text { quilograma } \\
\mathrm{g} & =\text { grama } \\
\mathrm{ppm} & =10^{-6} \mathrm{~kg} \\
\mathrm{~cm} & =\text { centímetro cúbico } \\
\mathrm{g} / \mathrm{cm} & =\text { gramas por centímetro cúbico } \\
\lambda & =\text { comprimento de onda } \\
\mathrm{s} & =\text { segundo } \\
\mathrm{kV} & =\text { voltagem } \\
\mathrm{kA} & =\text { quiloampère } \\
\mathrm{A} & =\text { ampère } \\
\mathrm{nA} & =\text { nanoampère } \\
\mathrm{Hz} & =\text { hertz } \\
\Delta \mathrm{G} & =\text { variação da energia livre de Gibbs } \\
\Delta \mathrm{S} & =\text { variação entropia } \\
\Delta \mathrm{V} & =\text { variação de volume } \\
\mathrm{mJ} & =\text { milijoule } \\
\mu \mathrm{m} / \mathrm{s} & =\text { micrometro por segundo } \\
\mathrm{J} / \mathrm{cm}{ }^{2} & =\text { joule por centímetro quadrado } \\
\mathrm{L} / \mathrm{min} & =\text { litros por minuto } \\
\sigma & =\text { desvio padrão } \\
&
\end{array}
$$





\section{INTRODUÇÃO}

Na região a sul de Passos, Minas Gerais, ocorre conjunto de rochas denominado Complexo Petúnia (Roig, 1993), que reúne gnaisses, rochas metapelíticas, metapsamíticas, metamáficas, metaultramáficas, além de gonditos e formações ferríferas bandadas, com disposição controlada pelas zonas de cisalhamento dúcteis - rúpteis do Cinturão de Cisalhamento de Campo do Meio (Morales et al., 1991; Morales, 1993), ativo durante a Colagem Orogênica Brasiliana (Brito Neves et al., 1999).

O Complexo Petúnia compõe o domínio alóctone do Complexo Campos Gerais (Roig, 1993; Szabó et al., 1993; Szabó, 1996) e suas rochas metaultramáficas, outrora relacionadas tanto com complexos estratiformes intensamente tectonizados (Roig, 1993), como com complexos ofiolíticos (Choudhuri et al., 1995), são distintas das já conhecidas rochas metaultramáficas de filiação komatiíca do Greenstone Belt Alpinópolis, presentes no domínio autóctone do Complexo Campos Gerais. Afinal, seria o Complexo Petúnia um conjunto deformado e metamorfizado contemporaneamente à consolidação do Orógeno Brasília Meridional, representada ali pelo Cinturão de Cisalhamento Campo do Meio? Ou trata-se de uma zona de sutura mais antiga que foi reativada em decorrência da instalação do Orógeno Brasília Meridional? Se o Complexo Petúnia é mesmo considerado uma zona de sutura, dada a presença de tais rochas ofiolíticas, a determinação das condições $P$ - T-t do metamorfismo na colisão é crucial para o entendimento do contexto geotectônico da porção noroeste do Orógeno Brasília Meridional.

As idades dos ciclos deposicionais e do metamorfismo das rochas do Complexo Petúnia também são desconhecidas, apesar disso, suas rochas pelíticas e psamíticas já foram correlacionadas às do Grupo Andrelândia (Trouw et al., 1984; Roig, 1993; Zanardo et al., 2006), Carrancas (Trouw et al., 1984; Campos Neto et al., 2004 e 2007) e Araxá (Machado Filho et al., 1983; Morales, 1993; Zanardo, 1992; Del Lama et al., 1994; Zanardo et al., 2006) não havendo, no entanto, continuidade física entre qualquer uma dessas unidades. A intensa tectônica transcorrente presente no Complexo Petúnia, por si só, dificulta sobremaneira as correlações litoestratigráficas de suas rochas e a ausência de dados geocronológicos limita a validade das correlações propostas. 


\subsection{Objetivos e Justificativas}

A definição do Complexo Petúnia como domínio alóctone do Complexo Campos Gerais necessita de refinamento, uma vez que este é formado por terrenos arqueanos e paleoproterozoicos enquanto aquele tem rochas metapelíticas e metapsamíticas correlacionadas com rochas neoproterozoicas. Assim, primeiramente, através de mapeamento geológico, aliado aos dados aerogeofísicos e geocronológicos será apresentada a extensão e redefinição do Complexo Petúnia.

As rochas do Complexo Petúnia carecem de informações a respeito das condições de metamorfismo e ambiente tectônico. Para o estudo do metamorfismo foram investigadas rochas metapelíticas e metaultramáficas da Unidade Colônia (Teixeira et al., 1987), usando diferentes métodos geotermobarométricos e pseudosseções, com o objetivo de estabelecer as trajetórias P-T e o gradiente metamórfico de campo, tornando possível comparar com informações da literatura e identificar se o seu ambiente tectônico e metamorfismo são os mesmos envolvidos na formação das demais rochas metamórficas do Orógeno Brasília Meridional, formadas em regimes de alta pressão, como nas rochas dos Grupos Araxá, Andrelândia e Carrancas (Simões, 1995; Luvizotto, 2003; Silva, 2010; Motta et al., 2010; Motta \& Moraes, 2017; Fumes et al., 2020).

Geograficamente as rochas do Complexo Petúnia ocupam localização chave para a possível conexão entre as rochas dos Grupos Araxá e Canastra, a norte, e Andrelândia e Carrancas, a sul, podendo ainda ser rochas depositadas e metamorfizadas em ambiente sem qualquer correlação cronológica com as rochas dos grupos citados. Assim, serão apresentados dados de $\mathrm{U}-\mathrm{Pb}$ em zircão e monazita de rochas metapelíticas da Unidade Colônia e metapsamíticas da Unidade Serra do Ibituruna (Teixeira et al., 1987), com o objetivo de determinar a proveniência sedimentar, as idades máximas de deposição e de metamorfismo, para então definir se as correlações existentes na literatura são pertinentes ou não.

A obtenção dessas informações virá a contribuir para o estabelecimento do quadro tectônico regional e para a readequação do Complexo Petúnia dentro do contexto do Orógeno Brasília Meridional.

\subsection{Localização da Área e Vias de Acesso}

A área de estudo localiza-se na mesorregião sul-sudoeste de Minas Gerais e abrange uma área de aproximadamente $920 \mathrm{~km}^{2}$, passando pelos municípios de Jacuí, Passos, Bom Jesus da Penha, São Pedro da União, Conceição da Aparecida e Nova Resende, incluindo o distrito de Petúnia (Figura 1.1). 
Os acessos para a região são abundantes, tanto em rodovias pavimentadas como estradas não pavimentadas. Partindo de São Paulo há várias opções de trajeto, entre elas seguir pela Rodovia dos Bandeirantes (SP-348) ou Anhanguera (SP-330) até Campinas, depois pela Rodovia Gov. Dr. Adhemar Pereira de Barros/Mario Beni (SP-340) até Casa Branca. De Casa Branca seguir pelas rodovias SP-350/MG-450 até Guaxupé e finalmente pela BR-146 até Bom Jesus da Penha, município mais próximo do ponto central da área.

Acessos para os demais municípios da área são feitos por rodovias federais e estaduais que nem sempre são pavimentadas, mas que no geral são bem sinalizadas e em boas condições de uso. Em virtude da ampla agricultura cafeeira que há na região, acessos secundários são amplos e bem distribuídos por toda a área.

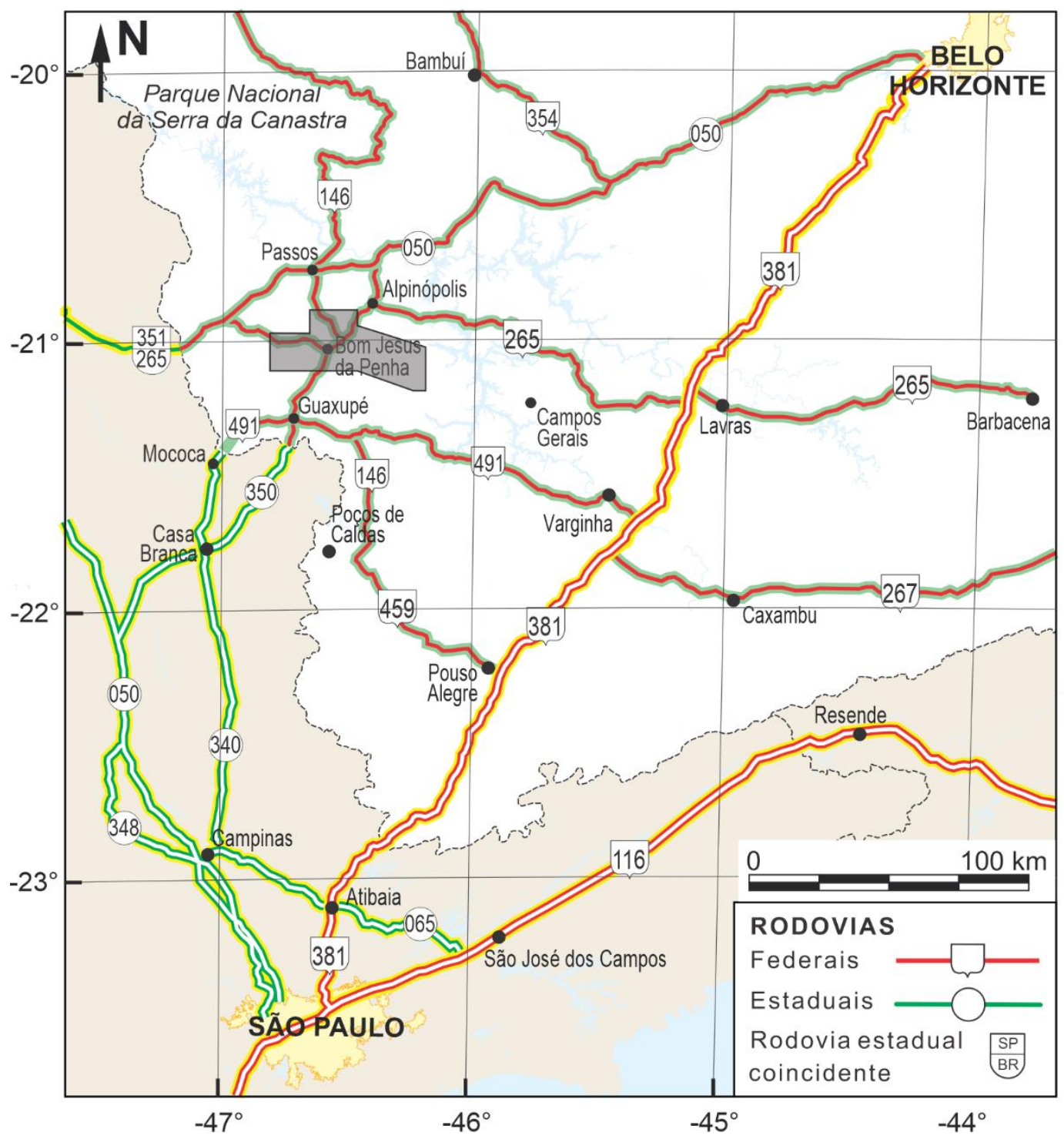

Figura 1.1: Localização da área de estudo (polígono sombreado) e principais vias de acesso. Simplificado dos mapas do DNIT (2013). 


\subsection{Estrutura da Tese}

Capítulo 1 - Introdução. Este capítulo apresenta o tema da Tese, os principais objetivos, e a localização da área de estudos.

* Capítulo 2-Materiais e Métodos. Neste capítulo são apresentados os métodos utilizados e os detalhes dos procedimentos analíticos adotados.

* Capítulo 3 - Revisão teórica. Este capítulo apresenta uma síntese bibliográfica sobre pseudosseções, suas principais variações e aplicações em rochas metapelíticas.

* Capítulo 4-Contexto Geológico Regional. Este capítulo apresenta a revisão bibliográfica do contexto geológico regional ao qual a área está inserida.

* Capítulo 5 - Aspectos da Geologia Local. Este capítulo apresenta uma breve descrição das unidades de mapeamento da área de estudo, já com a divisão litológica revisada, além das novas definições adotadas.

* Capítulo 6 - Redefinindo o Complexo Petúnia. O conteúdo deste capítulo é apresentado na forma de artigo científico disponível na íntegra no Apêndice A. Este artigo é resultado das revisões feitas nos capítulos 4 e 5 integrados com dados aerogeofísicos e dados de U-Pb em zircão para três unidades do Complexo Petúnia, duas delas definidas nesta Tese.

* Capítulo 7 - Proveniência sedimentar e metamorfismo da Unidade Serra do Ibituruna: Capítulo dedicado à apresentação das assinaturas de elementos traço e terras raras em zircão e da geoquímica isotópica (U-Pb) de zircão e monazita de amostras da Unidade Serra do Ibituruna.

* Capítulo 8-Os metapelitos da Unidade Colônia: Neste capítulo são apresentados os dados de química mineral e metamorfismo dos metapelitos da Unidade Colônia. também são apresentados dados de geoquímica isotópica em zircão e monazita.

- Capítulo 9 - As rochas metaultramáficas do Complexo Petúnia: Capítulo dedicado às rochas metaultramáficas da Unidade Colônia e das intercalações na Unidade Petúnia.

- Capítulo 10 - Integração dos dados. Neste capítulo são integrados e discutidos os dados apresentados ao longo da tese para então compor um modelo tectônico de evolução do Complexo Petúnia.

Capítulo 11 - Conclusões: sumário das conclusões obtidas na Tese.

Capítulo 12 - Referências Bibliográficas: sumário de todas as referências consultadas e citadas na tese. 


\section{MATERIAIS E MÉTODOS}

\subsection{Revisão Bibliográfica}

O levantamento bibliográfico foi feito ao longo de todo o trabalho e teve como principais bases para pesquisa o Portal de Periódicos CAPES, a biblioteca do Instituto de Geociências - USP e as plataformas de busca Scopus (https://www.scopus.com/) e Science Direct (https://www.sciencedirect.com/). Primeiramente contemplou-se a revisão dos conhecimentos sobre o contexto geológico regional, no qual os Complexos Petúnia e Campos Gerais estão inseridos e, no decorrer do trabalho, foram pesquisados trabalhos para a fundamentação de conceitos e técnicas utilizadas na tese.

\subsection{Trabalhos de Campo}

Como guia para os trabalhos de campo, foram utilizadas as seguintes folhas topográficas na escala 1:50.000 disponíveis no website do Instituto Brasileiro de Geografia e Estatística (IBGE - https://biblioteca.ibge.gov.br/pt/): Alpinópolis (SF-23-V-B-IV-3); Nova Resende (SF-23-V-D-I-1); Fortaleza de Minas (SF-23-V-A-VI-4); Jacuí (SF-23-V-C-III-2); São Sebastião do Paraíso (SF-23-V-A-VI-3); e, Monte Santo de Minas (SF-23-V-C-III-1).

Foram realizados 28 dias de campo, divididos em 5 etapas, totalizando 340 afloramentos visitados com o código CP. O acervo de afloramentos foi complementado com 63 pontos de Fayad (2013), com o código DCF, e 10 pontos de Moya \& Szabó (2000), com o código FAM, muitos dos quais foram visitados durante as etapas de campo e que possibilitaram refinar o mapa geológico. O mapa com a localização dos pontos, amostras coletadas e estudos realizados encontra-se disponível no Apêndice A.

Para a confecção do mapa de pontos, as drenagens, curvas de nível e estradas foram obtidas através da conversão de quilômetros $(\mathrm{km})$ para metros $(\mathrm{m})$ dos arquivos vetoriais (.dgn) das folhas topográficas na escala 1:50.000, também disponíveis no website do IBGE. Muitas estradas vicinais tiveram seu traçado modificado e, portanto, são apresentadas apenas aquelas representativas na escala 1:75.000, adotada neste trabalho, traçadas sobre o mosaico gerado com imagens de satélite do Google Earth Pro.

\subsection{Mapa Geológico}

O mapa geológico inicialmente foi elaborado através da compilação dos seguintes mapas existentes na região: Mapa geológico das folhas Jacuí, Fortaleza de Minas, Alpinópolis e Nova Resende, escala 1:200.000 (Morales et al., 1983); Mapa Geológico da região de 
Guaxupé - Passos - Delfinópolis em escala 1:180.000 (Zanardo, 1992); Mapa Geológico da região de Bom Jesus da Penha - Petúnia, MG, em escala 1:50.000 (Roig, 1993); Geologia do Complexo Campos Gerais (Domínio Norte) na região de sul a oeste de Alpinópolis em escala 1:50.000 (Szabó, 1996) e [Sem título] Fayad (2013). Os mapas geológicos das folhas Guaxupé e Nova Resende, apresentados pela CODEMIG (2015) não foram utilizados na compilação em virtude das inconsistências com os demais mapas já existentes.

O mapa geológico resultante da compilação e melhorado pelos dados coligidos está disponível no Apêndice B. Modificações foram feitas com base nos levantamentos de campo aliados a dados aerogeofísicos e de sensoriamento remoto. A integração da base de dados foi feita em ambiente SIG, utilizando o datum Sirgas 2000 UTM Zone 23S, onde foram analisados Modelos Digitais de Terreno (MDT), mapas gamaespectrométricos de composição ternária RGB e de concentrações de U, Th e K, e mapas magnéticos de Amplitude do Sinal Analítico (Roest et al., 1992), de Campo Magnético Total, e TILT Derivative (Miller \& Singh, 1994).

O Modelo Digital de Terreno foi gerado no software Quantum Gis 2.14.3 with Grass 7.0.4, utilizando como base as imagens S21W047.SRTMGL3S e S22W047.SRTMGL3S, ambas com resolução de 30 m, obtidas pelo Shuttle Radar Topography Mission da Nasa e disponíveis no website do U.S Geological Survey (http://earthexplorer.usgs.gov/).

\subsection{Gamaespectrometria}

A gamaespectrometria reflete as variações geoquímicas de $\mathrm{K}$, Th e $\mathrm{U}$ das rochas. Por

exemplo, "nas rochas ígneas há uma tendência de aumento no conteúdo de K, Th e U para composições mais félsicas" (Dickson e Scott, 1997). O metamorfismo não altera significativamente a concentração desses elementos, enquanto nas rochas sedimentares, a concentração pode ser maior em rochas derivadas de sedimentos imaturos ou menor em sedimentos maduros (Dickson e Scott, 1997).

Embora a gamaespectrometria seja uma ferramenta muito útil na cartografia geológica e estudos voltados para tectônica regional (exemplos em Monteiro et al., 2007, Ribeiro et al., 2013 e Araújo et al., 2019), sua interpretação deve ser feita com cautela, uma vez que se trata de técnica com baixo alcance em profundidade, cerca de $30 \mathrm{~cm}$ (Dickson e Scott, 1997; Minty, 1997), o que limita seu uso ao reconhecimento de contatos geológicos superficiais e afloramentos de rocha (Ribeiro et al., 2013). Além disso, os efeitos do intemperismo e a presença de colúvios, tálus, ou vegetação densa podem alterar ou mascarar 
as concentrações originais dos elementos, mudando a resposta da geologia, interferindo na posição dos contatos geológicos das unidades (International Atomic Energy Agency, 2003).

Segundo as diretrizes estabelecidas no guia do International Atomic Energy Agency (2003, p.120-121)

\footnotetext{
Em geral, uma estratégia útil para o mapeamento geológico, é primeiro delinear as principais unidades litológicas e, em seguida, aprimorar com os padrões de radioelementos nas unidades individuais.

[...]

A interpretação integrada com fotografia aérea, imagens de satélite e outros conjuntos de dados aerogeofísicos possibilita explorar informações geológicas complementares e permite que as distribuições dos radioelementos sejam estudadas em um contexto geológico e geomorfológico estrutural.
}

Exposições rochosas do Complexo Petúnia são escassas, sobretudo das Unidades Petúnia e Colônia (Capítulo 5). Os solos são jovens e residuais, com estruturas gnáissicas e xistosas muitas vezes preservadas, e a vegetação de grande porte é escassa, restrita ao longo dos canais de drenagem e ao topo das serras, e depósitos de colúvios e corpos de tálus ocorrem apenas ao longo das encostas das serras, assim, o uso da técnica torna-se viável e útil. Os dados aerogeofísicos utilizados foram cedidos pela Companhia de Desenvolvimento Econômico de Minas Gerais (CODEMIG), referentes ao Projeto Área 7. A descrição dos métodos de aquisição encontra-se no artigo disponível no Apêndice A.

\subsection{Petrografia}

Das amostras coletadas em campo, 89 foram selecionadas para a confecção de seções delgadas com $30 \mu \mathrm{m}$ de espessura. $\mathrm{O}$ acervo petrográfico foi complementado com a descrição de 32 seções delgadas de Fayad (2013) e 17 de Moya \& Szabó (2000), além de seções delgadas pertencentes ao acervo didático da disciplina GMG0332 - Petrologia Metamórfica do Instituto de Geociências (IGc -USP), totalizando aproximadamente 150 seções delgadas. A classificação dos litotipos foi feita através de estimativas visuais da proporção dos minerais. Contagem modal foi feita para uma amostra da Unidade Petúnia (CP-38) e uma amostra do Gnaisse Ribeirão da Conquista (CP-94).

As seções delgadas foram descritas utilizando os microscópios modelo Zeiss (Axioplan) e Olympus (BXP-50) do Laboratório de Óptica do IGc - USP. Feições mais significativas, tais como texturas, microestruturas deformacionais e associações minerais de pico metamórfico, texturas reacionais e de retrometamorfismo, foram registradas com fotomicrografias adquiridas através do software Zeiss Axiovision SE64 Rel. 4.9.1 com câmera Axiocam MRc acoplada ao microscópio Zeiss Axioimager pertencente também ao 
Laboratório de Microscopia Ótica do IGc - USP. As abreviações, quando utilizadas, estão de acordo com Whitney e Evans, 2010, exceto as abreviações utilizadas nas figuras dos trabalhos de Powell, Holland e White (Capítulo 5), que seguem padrão próprio.

\subsection{Geologia Estrutural}

A geologia estrutural inicialmente foi analisada por meio do arcabouço estrutural da área, com base em imagens de satélite do software Google Earth Pro e mapas de sombreamento gerados com diferentes direções de iluminação sobre o Modelo Digital de Terreno (MDT), a fim de identificar padrões de lineamentos morfoestruturais.

A visualização dos elementos estruturais foi feita através de perfis geológicos analisados em conjunto com os dados estruturais plotados em estereogramas. Os dados estruturais obtidos em campo foram compilados em diferentes arquivos .txt e plotados em estereogramas através do software OpenStereo 0.1.2 (Grohmann et al., 2010).

\subsection{Geoquímica de Rocha Total}

\subsubsection{Preparação das amostras}

Foram selecionadas 2 amostras para a construção de pseudosseções baseadas na composição química da rocha total, (CP-07 e CP-333). Para a amostra CP-07 foram preparadas uma amostra integral (CP-07) e uma derivada (CP-07melt), composta apenas pelo leucossoma da rocha.

Após a lavagem e retirada das porções alteradas, as amostras foram submetidas à limpeza e cominuição em prensa hidráulica manual. O material resultante foi quarteado e cerca de $100 \mathrm{~g}$ de cada amostra foi levado ao moinho de ágata tipo planetário para obtenção de frações com 200 mesh. As pastilhas fundidas, destinadas às análises dos elementos maiores e menores, foram produzidas misturando-se $1 \mathrm{~g}( \pm 0,001)$ de pó da amostra com $9 \mathrm{~g}( \pm 0,001)$ de metaborato e tetraborato de lítio como fundente. As pastilhas prensadas, destinadas às análises de elementos traço, foram feitas a partir da micronização das amostras e posterior homogeneização manual de $7 \mathrm{~g}$ de pó da amostra com $20 \%$ de parafina. A confecção das pastilhas foi feita através da prensagem em prensa hidráulica Herzog, especifica para este fim.

\subsubsection{Procedimentos analíticos}

As análises foram realizadas no Laboratório de Espectrometria de Fluorescência de Raios X do NAP GeoAnalítica - USP, utilizando-se o equipamento Philips, modelo PW2400. Os materiais de referências utilizados foram o basalto JB-1a e o granodiorito JG-1a e a 
metodologia das análises seguiu padrão estabelecido por Mori et al. (1999). Adicionalmente às análises de FRX, foram realizadas análises de perda ao fogo à $1000{ }^{\circ} \mathrm{C}$.

O conteúdo de $\mathrm{FeO}$ das amostras CP-07 e CP-333 foi obtido por análise de titrimetria de oxi-redução de acordo com o método de Andrade et al. (2002) utilizando como padrão de referência o basalto AQ-1. Os resultados das amostras e dos materiais de referência encontram-se disponíveis no Apêndice D.

\subsection{Química Mineral}

Foram selecionadas 10 amostras para análises quantitativas de química mineral. A relação das amostras, litotipos e minerais analisados está na Tabela 2-1. As seções foram preparadas no setor de laminação do Laboratório de Microssonda Eletrônica (EMPA) - NAP GeoAnalítica-USP e a metalização foi feita com cobertura de carbono espectrométrico. Para cada lâmina foram escolhidos de 3 a 5 cristais de diferentes domínios texturais para investigação das variações composicionais.

Tabela 2-1: Relação de amostras e minerais analisados por microssonda eletrônica.

\begin{tabular}{|c|c|c|c|c|}
\hline & Unidade & Amostra & Litotipo & Minerais \\
\hline \multirow{5}{*}{$\begin{array}{l}\text { Complexo } \\
\text { Petúnia }\end{array}$} & \multirow{4}{*}{ Colônia } & CP-07 & ky-st-ms-grt-bt xisto & grt, st, bt, ms, ru, pl \\
\hline & & CP-333 & ms-ky-grt-bt xisto c/ ru & grt, st, bt, ms, ru, pl \\
\hline & & CP-06 & ath-tr-chl xisto & ath, tr, chl \\
\hline & & DCF-22 & tlc-tr-chl-opx fels & opx, tr, chl, tlc \\
\hline & Petúnia & CP-54A & ath-tlc-tr-chl xisto & ath, tr, chl \\
\hline
\end{tabular}

\subsubsection{Procedimentos analíticos e tratamento dos dados}

As análises de química mineral foram feitas com a microssonda eletrônica JEOL, modelo JXA-FE-8530 com canhão eletrônico suportado por Field Emission Gun (FE) pertencente ao Laboratório de Microssonda Eletrônica (EMPA) - NAP GeoAnalítica-USP, no Instituto de Geociências (IGc-USP).

Para as análises quantitativas via WDS foi aplicada voltagem constante de $15 \mathrm{kV}$ ( $20 \mathrm{kV}$ para o rutilo) e $20 \mathrm{nA}$ de intensidade de corrente em feixe de $5 \mu \mathrm{m}$ diâmetro para todos os minerais, exceto feldspato $(10 \mu \mathrm{m})$. Adicionalmente foram feitas análises semiquantitativas via EDS apenas para identificação dos minerais opacos presentes. As rotinas foram construídas utilizando os padrões do Smithsonian National Museum of Natural History e da Geller e as correções foram feitas com base nos cálculos de Armstrong (1991). A 
distribuição dos elementos pelos cristais analisadores (TAP, LIF e PET), bem como o tempo de análise para cada elemento químico estão sumarizados na Tabela 2-2.

Granada e plagioclásio da amostra CP-07 e os minerais da amostra CP-333 foram analisados na microssonda eletrônica JEOL, modelo JXA-8230 Superprobe pertencente ao Laboratório de Microssonda Eletrônica da Universidade Estadual Paulista (UNESP), Campus Rio Claro. As condições analíticas foram de $15 \mathrm{kV}$ de voltagem constante (20 kV para rutilo), $20 \mathrm{nA}$ de intensidade de corrente ( $80 \mathrm{nA}$ para rutilo) e feixe com $5 \mu \mathrm{m}$ de diâmetro para as micas e $10 \mu \mathrm{m}$ no restante dos minerais. O tempo de contagem foi de $20 \mathrm{~s}$ ( $10 \mathrm{~s}$ no pico e $5 \mathrm{~s}$ de background) para os elementos maiores e $40 \mathrm{~s}$ ( $20 \mathrm{~s}$ no pico e $10 \mathrm{~s}$ de background) para os elementos menores. Os elementos analisados e os respectivos padrões utilizados são listados na Tabela 2-3.

Tabela 2-2: Configuração dos elementos químicos lidos em cada canal da microssonda da USP.

\begin{tabular}{|c|c|c|c|c|c|}
\hline Mineral & $\begin{array}{l}\text { CH-1 } \\
\text { TAP }\end{array}$ & $\begin{array}{l}\text { CH-2 } \\
\text { LIFL }\end{array}$ & $\begin{array}{l}\text { CH-3 } \\
\text { PETJ }\end{array}$ & $\begin{array}{l}\text { CH-4 } \\
\text { LIFL }\end{array}$ & $\begin{array}{l}\text { CH-5 } \\
\text { TAPH }\end{array}$ \\
\hline Granada & $\mathrm{Si}(10), \mathrm{Al}(40)$ & $\mathrm{Fe}(10), \mathrm{Mn}(40)$ & $\mathrm{Ca}(20)$ & $\mathrm{Cr}(60), \mathrm{Ti}(40)$ & $\operatorname{Mg}(30)$ \\
\hline Estaurolita & $\mathrm{Si}(10), \mathrm{Al}(40)$ & $\begin{array}{l}\mathrm{Fe}(20), \mathrm{Mn} \\
(100)\end{array}$ & $\mathrm{Ca}(20)$ & Ti (20), Zn (80) & $\operatorname{Mg}(20)$ \\
\hline Micas & $\mathrm{Si}(20), \mathrm{Al}(30)$ & $\begin{array}{l}\mathrm{Fe}(20), \mathrm{Mn}(40), \\
\mathrm{Zn}(60)\end{array}$ & $\begin{array}{l}\mathrm{Cl}(20), \mathrm{K}(20), \\
\mathrm{Ca}(20)\end{array}$ & Ti (20), Ba (60) & $\begin{array}{l}\mathrm{F}(20), \mathrm{Na}(20), \\
\mathrm{Mg}(20)\end{array}$ \\
\hline Feldspatos & $\mathrm{Si}(20), \mathrm{Al}(40)$ & $\mathrm{Fe}(20), \mathrm{Mn}(80)$ & $\begin{array}{l}\text { K (20), Ca (30), } \\
\operatorname{Sr}(80)\end{array}$ & $\mathrm{Ti}(20), \mathrm{Ba}(60)$ & $\begin{array}{l}\mathrm{Na}(20), \mathrm{Mg} \\
(20)\end{array}$ \\
\hline Anfibólio & $\mathrm{Si}(20), \mathrm{Al}(30)$ & $\mathrm{Fe}(20), \mathrm{Mn}(80)$ & $\begin{array}{l}\mathrm{Cl}(20), \mathrm{Ca} \\
(40), \mathrm{K}(20)\end{array}$ & $\operatorname{Ti}(20), \operatorname{Cr}(40)$ & $\begin{array}{l}\mathrm{F}(20), \mathrm{Na}(20), \\
\mathrm{Mg}(20)\end{array}$ \\
\hline Piroxênio & $\mathrm{Si}$ (20), Al (30) & $\mathrm{Fe}(20), \mathrm{Mn}(80)$ & $\mathrm{Ca}(40), \mathrm{K}(40)$ & $\mathrm{Ti}(20), \mathrm{Cr}(20)$ & $\begin{array}{l}\mathrm{Na}(20), \mathrm{Mg} \\
(20)\end{array}$ \\
\hline Rutilo & $\begin{array}{l}\mathrm{Al}(480) \\
\mathrm{Si}(120)\end{array}$ & $\begin{array}{l}\mathrm{Cr}(300), \mathrm{Fe} \\
(300)\end{array}$ & $\mathrm{Nb}(600)$ & Ti (25), V (520) & $\mathrm{Zr}(600)$ \\
\hline
\end{tabular}

Adicionalmente foram feitos mapas composicionais para $\mathrm{Fe}, \mathrm{Mg}, \mathrm{Ca}$ e $\mathrm{Mn}$ na granada dos metapelitos. Os elementos foram analisados por WDS no equipamento do Laboratório de Microssonda Eletrônica da Universidade Estadual Paulista (UNESP). As imagens foram processadas no software ImageJ (Schindelin et al., 2012; Rueden et al., 2017), de modo que os intervalos de contagens de k $\alpha$ apresentados fossem, na medida do possível, os mesmos para os cristais analisados. 
Tabela 2-3: elementos analisados e padrões utilizados na microssonda da UNESP para as análises de granada da amostra CP-07 e minerais da amostra CP-333.

Cristal

TAP

PET

LDE

\section{Elemento químico / padrão utilizado}

$\mathrm{Si} /$ ortoclásio, $\mathrm{Mg}$ / diopsídio, $\mathrm{Na} /$ albita

$\mathrm{Al} /$ almandina (granada), anortita nos demais minerais

$\mathrm{Ca} /$ Wolastonita, K / ortoclásio, Ti / Ilmenita, $\mathrm{Cr} /$ Cromita, $\mathrm{Cl} /$ sodalita, $\mathrm{Ba} / \mathrm{Barita}$

Os resultados das análises foram recalculados para a obtenção da distribuição catiônica nos sítios cristalográficos dos minerais. Todo o $\mathrm{Fe}$ foi calculado como $\mathrm{Fe}^{2+}$ e valores para $\mathrm{Fe}^{3+}$ foram obtidos pelo balanço de cargas. Com exceção de rutilo, anfibólio e clorita, foram utilizadas planilhas disponibilizadas no website Integrating Research and Education (https://serc.carleton.edu/researcheducation/equilibria/mineralformulaerecalculation.html).

Para a clorita, o cálculo da fórmula estrutural foi feito com base em 28 átomos de oxigênio, com determinação de $\mathrm{Fe}^{2+}, \mathrm{Fe}^{3+}$ e $\mathrm{OH}^{-}$assumindo ocupação total dos sítios. Enquanto para os anfibólios, as fórmulas estruturais foram calculadas com base em 23 átomos de oxigênios, através da média entre as estimativas máximas e mínimas de $\mathrm{Fe}^{3+}$ seguindo o Método de Schumacher (Leake et al., 1997; Schumacher, 2007). Os resultados das análises e os cátions recalculados são apresentados no Apêndice E.

$\mathrm{O}$ cálculo da fórmula estrutural dos minerais também foi feito no software AX (https://www.esc.cam.ac.uk/research/research-groups/research-projects/tim-hollandssoftware-pages/ax), que, além da distribuição catiônica, fornece os parâmetros das atividades dos membros finais dos minerais, necessários para a aplicação da geotermobarometria otimizada.

\subsection{Pseudosseções e Geotermobarometria}

A construção das pseudosseções foi feita no THERMOCALC (Powell \& Holland, 1988), versão 3.4, com o banco de dados internamente consistente ds62 (Holland e Powell, 2011; White et al., 2014a). Foi escolhido o sistema químico NCKFMASHTO ( $\mathrm{Na}_{2} \mathrm{O}-\mathrm{CaO}$ $\left.\mathrm{K}_{2} \mathrm{O}-\mathrm{FeO}_{\mathrm{t}}-\mathrm{MgO}-\mathrm{Al}_{2} \mathrm{O}_{3}-\mathrm{SiO}_{2}-\mathrm{H}_{2} \mathrm{O}-\mathrm{TiO}_{2}-\mathrm{O}_{2}\right)$, que contempla a maioria dos minerais observados na petrografia. Os scriptfiles utilizados estão disponíveis no Apêndice F. As isopletas das principais fases minerais foram obtidas no software TCInvestigator, versão 2.0, de Pearce et al. (2015). 
As condições P-T foram determinadas com o método de geotermobarometria otimizada de c utilizando o software THERMOCALC, versão 3.26, com o banco de dados ds55, através da linha de comando "average $P T$ " para diferentes associações minerais observadas na petrografia. O programa busca um conjunto de reações linearmente independentes a partir dos dados termodinâmicos dos membros finais e calcula as condições P-T com suas respectivas incertezas. Os arquivos de saída contendo apenas os cálculos obtidos com confiança maior ou igual a $95 \%$ estão disponíveis no Apêndice G. Adicionalmente foram feitos cálculos utilizando calibrações do termobarômetro de $\mathrm{Zr}$ em rutilo (Tomkins et al., 2007).

\subsection{Geoquímica isotópica mineral}

\subsubsection{Preparação das amostras}

A geoquímica isotópica foi feita por meio do método U-Pb em zircão e monazita. Foram selecionadas 8 amostras, três amostras para determinação das idades de cristalização e metamorfismo e 5 amostras para determinação da proveniência sedimentar e metamorfismo, dessas, 4 amostras foram preparadas também para monazita (Tabela 2-4).

Todo o processo de preparação das amostras foi feito no Laboratório de Separação e Preparação (LSP) do Centro de Pesquisas em Geocronologia e Geoquímica Isotópica (CPGeo) do Instituto de Geociências da USP. A obtenção dos concentrados de zircão e monazita foi feita a partir da trituração de aproximadamente 5 a $8 \mathrm{~kg}$ de cada amostra utilizando britador de mandíbulas. O material resultante, com fragmentos menores que $1 \mathrm{~cm}$, foi mecanicamente peneirado, e as frações maiores que $100 \mu \mathrm{m}$ foram moídas em moinho de disco para obtenção final de frações entre 100 e $250 \mu \mathrm{m}$ e menores que $250 \mu \mathrm{m}$, necessárias para lavagem e separação gravimétrica em mesa Wiffley.

Após a secagem do concentrado de minerais pesados, foram retirados cristais de magnetita com imã de mão comum. Os demais minerais magnéticos foram separados com o separador magnético Frantz, inicialmente a $0,3 \mathrm{~A}$, e o concentrado de minerais nãomagnéticos foi levado à capela de exaustão para separação gravimétrica usando líquidos densos. Minerais mais densos que $2,89 \mathrm{~g} / \mathrm{cm}^{3}$ (densidade do bromofórmio) foram passados pelo Frantz a 0,5 e 0,6 A, para reter cristais de monazita na fração magnética, e a 1,0 A para reter cristais de zircão da fração não magnética. Esse passou pelo iodeto de metileno $\left(3,32 \mathrm{~g} / \mathrm{cm}^{3}\right)$ para retenção dos cristais de zircão $\left(4,6-4,7 \mathrm{~g} / \mathrm{cm}^{3}\right)$. O concentrado final de minerais mais densos que $3,32 \mathrm{~g} / \mathrm{cm}^{3}$ foi submetido a ataque químico com ácido nítrico 
(50\%) para retirada de impregnações de óxidos e hidróxidos de ferro, seguido de última passagem pelo Frantz a 1,5A.

Tabela 2-4: Relação de amostras e análises de zircão pelo método U-Pb. Para finalidade, 1= proveniência, $2=$ metamorfismo, $3=$ cristalização, $(*)$ amostra com dados U-Pb em monazita.

\begin{tabular}{|c|c|c|c|c|c|c|}
\hline & Amostra & Litologia & $\begin{array}{l}\text { Finali- } \\
\text { dade }\end{array}$ & $\begin{array}{l}\text { Análises } \\
\text { registradas }\end{array}$ & $\begin{array}{c}\text { Pontos com } \\
\text { concordância } \\
100 \pm 10 \% \\
\end{array}$ & $\begin{array}{c}\text { Dados } \\
\text { usados para } \\
\text { proveniência }\end{array}$ \\
\hline \multirow{4}{*}{$\begin{array}{l}\text { Unidade } \\
\text { Serra do } \\
\text { Ibituruna }\end{array}$} & CP-05(*) & Ms-qtz xisto & $1-2$ & 92 & 90 & 68 \\
\hline & CP-27(*) & Ms-qtz xisto & $1-2$ & 111 & 75 & 39 \\
\hline & CP-35(*) & Ms-qtz xisto & $1-2$ & 111 & 47 & 33 \\
\hline & CP-98B & Ms-quartzito & $1-2$ & 116 & 61 & 49 \\
\hline \multirow{2}{*}{$\begin{array}{l}\text { Unidade } \\
\text { Colônia }\end{array}$} & CP-07*(IGc) & \multirow{2}{*}{$\begin{array}{l}\text { Ky-st-ms-grt- } \\
\text { bt xisto }\end{array}$} & \multirow{2}{*}{$1-2$} & 90 & 44 & 15 \\
\hline & CP-07(UnB) & & & 110 & 55 & 9 \\
\hline $\begin{array}{l}\text { Unidade } \\
\text { Petúnia }\end{array}$ & CP-38 & Bt gnaisse & $2-3$ & 40 & 9 & - \\
\hline $\begin{array}{l}\text { Gnaisse } \\
\text { Ribeirão da } \\
\text { Conquista }\end{array}$ & CP-94 & Bt gnaisse & $2-3$ & 49 & 24 & - \\
\hline $\begin{array}{l}\text { Metagranito } \\
\text { Bom Jesus } \\
\text { da Penha }\end{array}$ & CP-45 & $\begin{array}{l}\mathrm{Bt} \\
\text { metagranito }\end{array}$ & $2-3$ & 50 & 17 & - \\
\hline
\end{tabular}

Nas amostras destinadas ao estudo da proveniência sedimentar foi feita apenas a retirada manual de impurezas a fim de evitar que houvesse supervalorização de uma população de cristais de zircão sobre outra. Para as amostras destinadas à identificação das idades de cristalização, foi feita a catação manual dos cristais. Os cristais foram colados sobre fita adesiva e os mounts foram montados com resina epóxi, posteriormente polidas para expor o núcleo dos cristais.

\subsubsection{Procedimentos analíticos}

A escolha dos pontos de análise foi baseada na prévia descrição qualitativa dos cristais de zircão e monazita feita por meio de imagens obtidas por microscopia binocular (BM), catodoluminescência (CL) e elétrons retroespalhados (Back Scattered Eletron - BSE). As nomenclaturas utilizadas para texturas internas dos cristais estão de acordo com aquelas estabelecidas por (Corfu et al., 2003; Pidgeon, 1992; Hoskin e Black, 2000; Pidgeon et al., 2000; Schaltegger, 2007; Rubatto, 2017).

As medições das razões isotópicas U-Pb em zircão das amostras CP-05 e CP-07 e de monazita das amostras CP-05, CP-07, CP-27 e CP-35 foram feitas com o espectrômetro de 
massa multicoletor com plasma induzido Thermo Finnigan Neptune com laser ArF Excimer acoplado $(\lambda=193 \mathrm{~nm})$, pertencente ao Laboratório de LA-MC-ICP-MS, também no Centro de Pesquisas Geocronológicas (CPGeo). Durante as medições das razões dos isótopos de U e $\mathrm{Pb}$, as condições analíticas foram de $6 \mathrm{~Hz}$ de frequência, $7 \mathrm{~mJ}$ de energia e $40 \mathrm{~s}$ de tempo de ablação em spot com $32 \mu \mathrm{m}$ de diâmetro. Para os xistos foram feitas 8 planilhas com 13 análises pontuais por amostra e, para controle e correção de possíveis variações no equipamento, cada uma das planilhas foi iniciada com duas medições em branco, duas medições no padrão NIST-612 (Woodhead \& Hergt, 2001) e três no padrão GJ-01 (Elhlou et al., 2006), seguidas por treze análises da amostra, finalizando com duas medições em branco. Os resultados das análises reduzidos podem ser vistos no Apêndice $\mathbf{H}$.

Os cristais de zircão das demais amostras foram analisados com o espectrômetro de massa multicoletor com plasma induzido acoplado Thermo Finnigan Neptune com laser New Wave 213 acoplado pertencente ao Laboratório de Geocronologia do Instituto de Geociências (IG-UnB). Durante as medições das razões dos isótopos de $\mathrm{U}$ e $\mathrm{Pb}$, as condições analíticas foram de $10 \mathrm{~Hz}$ de frequência e $40 \mathrm{~s}$ de tempo de ablação em spot com $25 \mu \mathrm{m}$ de diâmetro. As demais condições analíticas do equipamento seguem o protocolo de Bühn et al. (2009).

\subsubsection{Tratamento dos dados}

$\mathrm{O}$ tratamento dos dados de $\mathrm{U}-\mathrm{Pb}$ foi feito na plataforma online do IsoplotR (Vermeesch, 2018), disponível em http://pieter-vermeesch.es.ucl.ac.uk/shiny/IsoplotR/. Em todas as amostras foram desconsideradas análises com mais de $3 \%$ de chumbo comum. Nas análises válidas o número de contagens de ${ }^{204} \mathrm{~Pb}$ é muito baixo, portanto, não foram feitas correções para este isótopo. As idades de cristalização foram obtidas usando a ferramenta "U$\mathrm{Pb}$ concórdia" de Wetherill com o cálculo da idade segundo o "modelo-1" de discórdia, segundo o método de (Ludwig, 1998), e foram usados dados com concordância $100 \pm 20 \%$.

Em estudos de proveniência é necessário que o número de grãos de zircão analisados seja estatisticamente adequado (Sircombe, 2000; Vermeesch, 2004; Andersen, 2005). Para estudos que envolvem a discussão de uma determinada população de cristais, Vermeesch (2004) recomenda que pelo menos 117 cristais sejam datados para que se tenha um nível de confiança de $95 \%$ nas populações presentes, mas se essa não for a abordagem principal, este número não deve ser inferior a 95 . Ao se fazer suposições sobre a natureza da distribuição das populações, a confiabilidade desse tipo de estimativa diminui (Andersen, 2005).

Usualmente são feitas de 60 a 120 análises de zircão detrítico por amostra, no entanto, o reconhecimento de grupos etários menores requer maior número de análises 
(Gehrels et al., 2012). "Para uma determinação mais robusta da distribuição das idades são necessárias 50 análises para cada faixa etária presente, gerando de 200 a 500 análises" (Gehrels, 2014), mas esse valor ainda não é praticado na maioria dos trabalhos voltados para proveniência sedimentar. Para as amostras detríticas deste trabalho foram consideradas apenas análises com concordância $100 \pm 10 \%$ e com isso um número reduzido de análises pôde ser utilizado (Tabela 2-3).

Estudos de proveniência sedimentar amplamente utilizam Gráficos de Densidade de Probabilidades (Hurford et al., 1984) ou de Distribuição de Densidade de Probabilidade (Sircombe, 2004), pois eles incorporam ao histograma comum as incertezas dos dados, gerando uma distribuição de probabilidade de toda a amostra variando de acordo com cada idade obtida (Fedo et al., 2003; Guynn e Gehrels, 2010), entretanto, eles carecem de base teórica (Vermeesch, 2012). Para avaliar os resultados obtidos em zircão detrítico foram construídos diagramas com estimativa de densidade Kernel (Kernel Density Estimator KDE) e de distribuição cumulativa (Cumulative Distribution Function - CDF). Diagramas com estimativa de densidade Kernel "KDE" fornecem uma aparência semelhante aos gráficos consagrados na literatura geocronológica, mas são baseados nos fundamentos teóricos de (Botev et al., 2010), "sendo uma alternativa estatisticamente mais robusta para o tratamento de dados de zircão detrítico" (Vermeesch, 2012).

Diagramas de distribuição cumulativa "CDF", ou "CAD" (Cumulative Age Distribution) servem para comparar de maneira mais direta os espectros de idades em um conjunto de amostras (Vermeesch, 2007) somando as probabilidades com o aumento da idade e com a possibilidade de levar em consideração as incertezas associadas (Figura 2.1a; Vermeesch, 2007; Guynn \& Gehrels, 2010). Outra maneira de comparar as distribuições de idades é através do Teste K-S (Kolmogorov-Smirnoff), que consiste em comparar os espectros de idades e determinar se existem diferenças estatisticamente significativas, que é representada pela diferença vertical "D" de probabilidade entre duas curvas (Figura 2.1b; Guynn \& Gehrels, 2010).

O Teste K-S “gera uma probabilidade P relacionada ao nível de significância de D” e está diretamente ligada ao nível de confiança ao testar a hipótese nula de que duas distribuições de idades tenham a mesma fonte (Guynn \& Gehrels, 2010). A relação entre P e $\mathrm{D}$ é recíproca, "maior $\mathrm{D}$ produz menor $\mathrm{P}$, sendo menos provável que $\mathrm{D}$ seja devido apenas aos erros de amostragem" (Guynn \& Gehrels, 2010). 

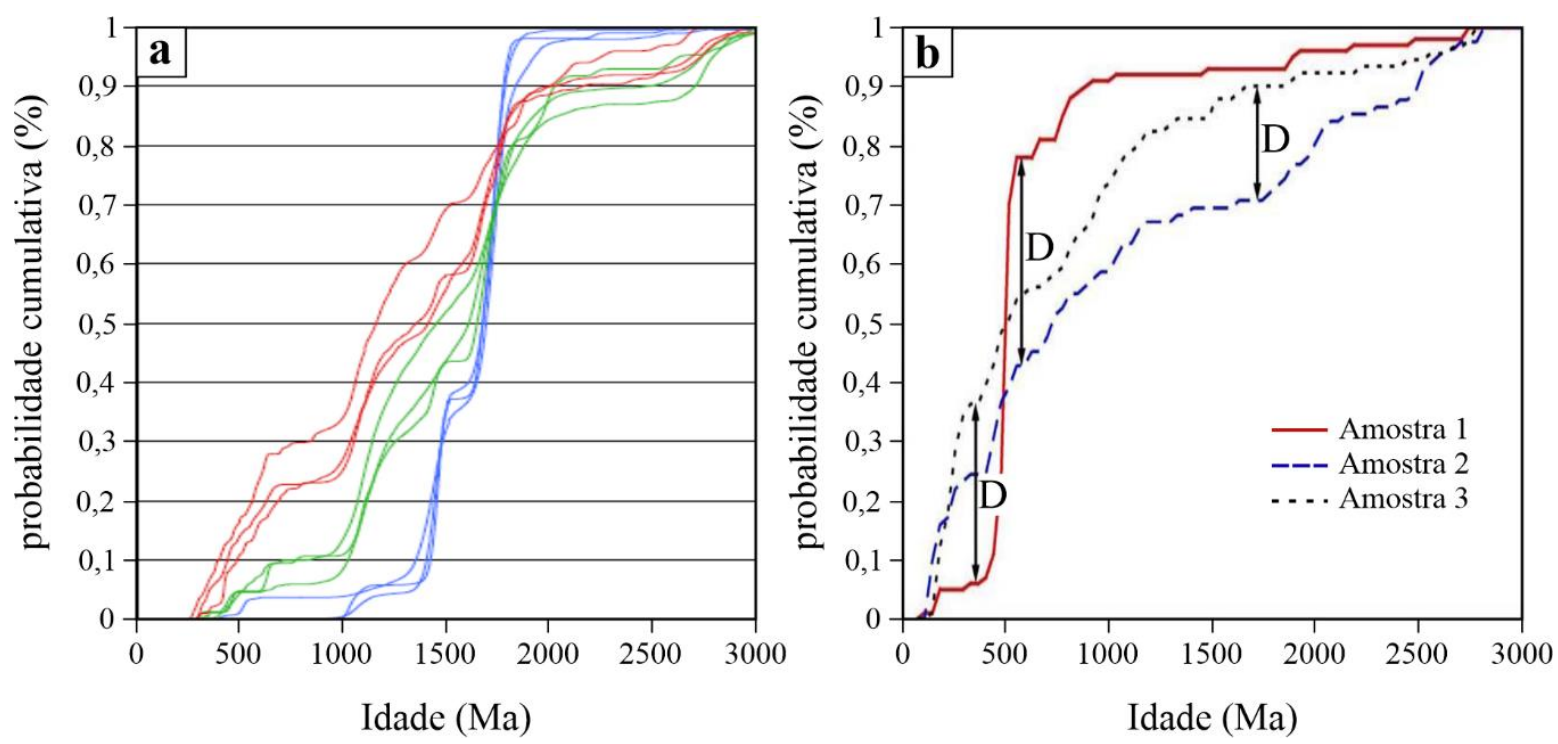

Figura 2.1: a) Diagrama de Distribuição Cumulativa "CDF" ou "CAD”, úteis na visualização de várias amostras; b) Diferença estatística máxima (D) entre diferentes amostras. Extraído de Guynn \& Gehrels (2010).

Idades máximas de deposição são amplamente utilizadas para correlações litoestratigráficas e comumente são indicadas pela idade do zircão detrítico mais jovem (Fedo et al., 2003), no entanto, "esse método trata de um dado isolado que, além de não ser reprodutível, pode estar incerto devido à perda de chumbo" (Dickinson e Gehrels, 2009). Além disso, "o tempo entre a geração do zircão na fonte e a idade da deposição final do sedimento gerado pela erosão dessa fonte não necessariamente tem conexão" (Andersen, 2005). O uso da idade do zircão detrítico mais jovem dentro de um conjunto como limite para a idade de deposição depende da distribuição das idades e do conhecimento geológico da região (Andersen, 2005).

Outros métodos para determinação das idades máximas de deposição incluem a "leitura direta no gráfico através do pico de idades mais jovens, idade a partir da média ponderada do grupo de idades mais jovem de 2 a 13 dados ( 3 em média) com 1ơ de incerteza ou de 3 a 24 dados (6 em média) com 20 de incerteza" (Dickinson \& Gehrels, 2009).

Para cristais de zircão que tiveram perda de $\mathrm{Pb}$, estatisticamente é mais confiável utilizar a média das idades do pico mais jovem obtido (Gehrels, 2013). Em virtude do reduzido número de cristais que compõem os grupos de idades das amostras, as idades máximas de deposição deste trabalho foram calculadas a partir da média ponderada de 3 ou 4 dados que compõem o grupo de idades mais jovem com lơ de incerteza. 


\subsection{Análise de Elementos Traço e Terras Raras em Zircão}

\subsubsection{Princípios e aplicações em estudo de proveniência}

A distribuição de elementos traços e terras raras (ETR) em zircão tem sido amplamente utilizada em estudos voltados para a proveniência sedimentar (exemplos em Xie et al., 2012; Zhou et al., 2012; Guo et al., 2017 e Frugis et al., 2018). Embora a abundância do zircão seja baixa nas rochas, ela é capaz de afetar o comportamento dos elementos traço e ETR, que são sensíveis à composição do magma e ao ambiente de cristalização (Belousova et al., 2002; Nardi et al., 2013), bem como a presença de outros minerais que também particionam ETR (Rubatto, 2017), fornecendo assim ferramentas potenciais na identificação da rocha fonte (Belousova et al., 2002; Hoskin e Schaltegger, 2003; Wang et al., 2012; Nardi et al., 2013; Grimes et al., 2007 e 2015; Rubatto, 2017).

A estrutura cristalina do zircão $\left(\mathrm{ZrSiO}_{4}\right)$ permite substituição simples de $\mathrm{Zr}^{4+}$ por $\mathrm{U}^{4+}$, $\mathrm{Th}^{4+}$ e $\mathrm{Hf}^{4+}$ como íons principais e substituições acopladas, só no sítio cúbico (1), ou envolvendo os sítios cúbicos e tetraédricos (2).

$$
\begin{aligned}
& 2 \mathrm{Zr}^{4+} \leftrightarrow(\mathrm{ETR}, \mathrm{Y})^{3+}+(\mathrm{Nb}, \mathrm{Ta})^{5+} \quad \text { (1) Hoskin \& Schaltegger (2003) } \\
& \mathrm{Zr}^{4+}+\mathrm{Si}^{4+} \leftrightarrow(\mathrm{ETR}, \mathrm{Y})^{3+}+\mathrm{P}^{5+} \quad \text { (2) Belousova et al. (2002) }
\end{aligned}
$$

Devido à sua maior carga e ao maior raio iônico, elementos terras raras são incompatíveis, apresentam taxas de difusão lentas e, sob a maioria das condições geológicas, são considerados imóveis (Cherniak et al., 1997a), sendo tardiamente incorporados na estrutura do zircão através das substituições catiônicas. A substituição que ocorre em (2) resulta em aumento no teor de ETR, Y e P, sugerindo que "o principal mecanismo de incorporação dos ETR e Y na estrutura do zircão é através da solução sólida com xenotímio" (Bea, 1996). ETR pesados e $\mathrm{Zr}^{4+}$ possuem raio iônico similar, o que resulta em padrões ETR em zircão semelhantes, tipicamente com anomalias positivas para $\mathrm{Ce}$ e negativas para $\mathrm{Eu}$, empobrecimento em ETR leves e enriquecimento em ETR pesados (Hoskin \& Schaltegger, 2003; Grimes et al., 2007).

Para que a composição química do zircão seja usada como traçador na identificação de áreas fonte, ela deve ser relacionada à composição química da rocha (Hoskin \& Schaltegger, 2003). "Existe tendência de aumento nas concentrações dos elementos ETR em zircão, partindo de kimberlitos, em direção às rochas máficas, granitoides e pegmatitos evoluídos” (Belousova, et al. 2002). No entanto, em zircão de diferentes rochas crustais, os 
padrões de distribuição dos ETR são semelhantes e, por si só, não são bons indicadores de proveniência (Hoskin e Ireland, 2000).

Apesar da ampla sobreposição observada nos padrões ETR em zircão das rochas crustais, o conteúdo de elementos traço combinados em diagramas discriminantes pode auxiliar no reconhecimento da rocha fonte, entretanto, para uma avaliação satisfatória, deve ser levado em consideração que a abundância dos elementos traço pode ser altamente variável, podendo ainda ser afetada pela presença de microinclusões, porções metamicticas, zoneamentos composicionais, entre outros fatores (Nardi et al., 2013; Zhoug et al., 2018).

Belousova et al., (2002) apresentam diversos diagramas discriminantes úteis para identificar zircão de diferentes fontes ígneas e Pupin (2000) utiliza amplamente diagramas de Hf $v s$. Y até na identificação do ambiente tectônico de geração de rochas ígneas diversas. Entre outros critérios de identificação que podem ser utilizados estão os diagramas U/Yb vs. Hf, Y ou P, que são capazes de distinguir zircão proveniente de rochas da crosta oceânica e continental (Grimes et al., 2007), razões $\mathrm{Th} / \mathrm{Pb},(\mathrm{Nb} / \mathrm{Pb})_{\mathrm{N}}$ e $\mathrm{Eu} / \mathrm{Eu}^{*}$, que tem potencial para diferenciar zircão de granitoides tipo I e S (Wang et al., 2012) e diagramas $\mathrm{Nb} v \boldsymbol{s}$. Th, $\mathrm{Eu} * / \mathrm{EuN} v s . \mathrm{Yb}$ e $(\mathrm{Y} / 200+\mathrm{Lu} / 10+\mathrm{Nb}) v s . \mathrm{Nb} / \mathrm{Ce}$ para discriminar zircão de granitoides tipo I, A e shoshoníticos (Nardi et al., 2013).

É importante ressaltar que esses critérios são úteis na identificação de zircão de origem magmática. Em zircão de rochas metamórficas e em rochas que passaram por processos hidrotermais, ou mesmo em zircão alterado e/ou metamictico, outras características químicas e texturais devem ser levadas em consideração. "Grãos metamórficos de zircão podem preservar ampla variedade de texturas, em parte porque podem crescer em amplo intervalo de condições $P$-T-x-stress" (Hoskin \& Schaltegger, 2003).

Não há consenso sobre como o metamorfismo afeta as assinaturas geoquímicas de elementos traço e terras raras no zircão, especialmente daqueles de rochas formadas sob condições de médio e baixo grau metamórfico. Para os termos descritivos de zircão metamórfico, Rubatto (2017) adota terminologia genérica baseada na alteração, substituição, recristalização e sobrecrescimento, que são processos comuns que podem ocorrer durante o metamorfismo.

De acordo com Rubatto (2017, p. 262 e 264)

Alteração é um processo que em parte sobrepõe e perturba o mineral, onde vestígios texturais e químicos são preservados. O termo alteração pode ser usado para núcleos antigos que perderam parcialmente suas assinaturas isotópicas e que podem apresentar zoneamento fantasma ou difuso.

A substituição é um processo in situ que altera a composição química de um domínio existente, ocorre em condições sub-sólidas e geralmente é auxiliada por 
fluidos. Recristalização é outro termo frequentemente usado para descrever esse processo. Os domínios de zircão substituídos/recristalizados mostram evidências de redefinição completa do sistema químico/isotópico, uma fronteira acentuada com os domínios herdados e carecem de texturas regulares de crescimento (forma ou zoneamento interno).

Sobrecrescimento indica um novo domínio de cristal que mostra limites nítidos com qualquer núcleo reliquiar existente e texturas regulares de crescimento (forma ou zoneamento interno). Esses domínios têm composições químicas e isotópicas distintas que geralmente são homogêneas dentro de um único domínio.

Quanto à composição química, se houver outras fases que particionam ETR, o zircão metamórfico poderá mostrar empobrecimento em ETR pesados, gerando padrões relativamente planos, quando em presença de granada e/ou ortopiroxênio, ou empobrecimento em ETR leves em associações contendo titanita, alanita e monazita (Rubatto et al., 2013; Rubatto, 2017). Anomalias positivas de Ce e negativas de Eu são mais pronunciadas no zircão cristalizado a partir de líquidos anatéticos, pois o $\mathrm{Ce}^{4+}$ substitui o $\mathrm{Zr}^{4+}$ (Schaltegger et al., 1999), enquanto todo o Eu é incorporado no feldspato peritético (Rubatto, 2017).

Durante o metamorfismo, "o zircão geralmente é menos reativo que a monazita" e "variações sistemáticas no teor de ETR pesados e nas anomalias negativas de Eu estão relacionadas respectivamente à variação na abundância da granada e do K-feldspato e, portanto, a reações metamórficas e estágios P-T” (Rubatto et al., 2013)

Cátions de elementos maiores, tais como $\mathrm{Al}^{3+}, \mathrm{Fe}^{3+}, \mathrm{Fe}^{2+}, \mathrm{Mg}^{2+}, \mathrm{Mn}^{2+}$, também podem entrar na estrutura do zircão, mas através de substituições intersticiais (Hoskin, 2000), e, em alguns casos, se houver enriquecimento também em $\mathrm{Ca}^{2+}$ e ETR leves, pode indicar zonas alteradas formadas durante a diagênese ou metamorfismo de baixo grau (Rayner et al., 2005; Rubatto, 2017). A própria metamictização, cujos danos causados pela radiação diminuem a estabilidade da estrutura do zircão, também facilita a entrada de ETR leves (Rayner et al., 2005; Cavosie et al., 2006). Outros fatores que também podem levar ao enriquecimento de ETR leves no zircão são a cristalização a partir de líquidos enriquecidos em ETR leves e a presença de microinclusões, em geral menores que $1 \mu \mathrm{m}$ (Zhong et al., 2018).

\subsubsection{Procedimentos analíticos e tratamento dos dados}

As análises de elementos traço e terras raras (ETR) foram obtidas no Laboratório de Química e ICP - NAP GeoAnalítica-USP, utilizando o espectrômetro do tipo quadrupolo Thermo Scientific, modelo iCAP Q ICP-MS com amostrador Laser Ablation New Wave, modelo UP-213 A/F acoplado. 
Nas amostras da Unidade Serra do Ibituruna, onde os cristais detríticos de zircão apresentam texturas dos protólitos claramente bem preservadas, foram escolhidos locais apenas junto aos pontos de análise U-Pb em cristais de todas as populações identificadas. Para a amostra CP-07, onde o zircão mostra texturas indicativas de processos de alteração, substituição e recristalização, além desse critério, foram escolhidos pontos adicionais a fim de verificar as possíveis variações composicionais nos diferentes domínios texturais. As análises estão disponíveis no Apêndice I.

A metodologia analítica seguiu o protocolo de Andrade et al., 2014, utilizando os padrões de referência NIST-610 (Jochum et al., 2011), GJ-01 (Elhlou et al., 2006) e Zr-91500 (Wiedenbeck et al., 2004). As condições analíticas durante as análises encontram-se na Tabela 2-6. Os dados foram reduzidos no software Glitter® (Griffin et al., 2008) partindo da composição estequiométrica de zircão $\left(\mathrm{ZrO}_{2}=67,2 \%\right)$ de acordo com Hoskin \& Schaltegger, (2003). Após a redução dos dados, análises com teor de $\mathrm{P} \geq 1000 \mathrm{ppm}$ foram descartadas, pois esse valor pode ser indicativo de presença de micro inclusões de fosfatos (Zhoug et al., 2018). Os diagramas multielementos (spidergrams) foram normalizados pelo condrito de acordo com Sun \& McDonough (1989).

Tabela 2-5: Condições analíticas do LA-ICP-MS.

\begin{tabular}{llll}
\hline Laser & \multicolumn{3}{l}{ Espectrômetro } \\
\hline Spot & $\mathrm{Zr}-30 \mu \mathrm{m}, \mathrm{Qtz}-80 \mu \mathrm{m}$ & Radiofrequência (Rf) & 1550 \\
\hline Raster $(\mathrm{Qtz})$ & $3 \mu \mathrm{m} / \mathrm{s}$ & Fluxo de gás: & \\
\hline Taxa de repetição & $20 \mathrm{~Hz}$ & $\mathrm{He}$ & $0,2 \mathrm{~L} / \mathrm{min}$ \\
\hline Fluência & $\mathrm{Zr}-2,25 \mathrm{~J} / \mathrm{cm}^{2}, \mathrm{Qtz}-1,76 \mathrm{~J} / \mathrm{cm}^{2}$ & $\mathrm{Ar}$ & $0,65 \mathrm{~L} / \mathrm{min}$ \\
\hline Potência & $90 \%$ & Ar auxiliar & $0,8 \mathrm{~L} / \mathrm{min}$ \\
\hline Tempo de análise & $70 \mathrm{~s}(30 \mathrm{~s}$ no branco, $40 \mathrm{~s}$ de ablação) & Ar do plasma & $14 \mathrm{~L} / \mathrm{min}$ \\
\hline
\end{tabular}




\section{REVISÃO TEÓRICA: PSEUDOSSEÇÕES}

No metamorfismo, as transformações químicas e mineralógicas são promovidas por recristalizações e/ou reações entre as fases que ocorrem em virtude das mudanças nas condições de temperatura e pressão no meio. Essas transformações são regidas pelas leis da Termodinâmica de Equilíbrio e ocorrem em sistema semiaberto ou aberto, pois há troca de calor e fluidos com o meio. Uma rocha pode ser vista como um sistema químico, onde minerais e fluidos representam as fases do sistema, enquanto os componentes, geralmente expressos em termos de óxidos, são escolhidos de forma coerente, a fim de idealmente descrever todas as fases do sistema, ou pelo menos aquelas que apresentem algum significado petrológico. A escolha dos componentes é fundamental para o tratamento de sistemas metamórficos, sejam eles teóricos ou construídos com base em composições reais.

As variáveis termodinâmicas são usadas para descrever o estado do sistema, incluindo variáveis intensivas, que independem da massa (pressão e temperatura, potencial químico), e extensivas, que dependem da massa do sistema (volume, energia interna, entropia, entalpia e energia livre de Gibbs). A entropia prediz o sentido da direção das reações, enquanto "a energia livre de Gibbs controla a viabilidade e direção da reação" (Philpotts e Ague, 2009).

O equilíbrio químico entre diferentes fases é alcançado quando a energia livre é mínima $(\Delta \mathrm{G}=0)$, que ocorre ao longo de curvas univariantes, ou de menor variância possível dado um sistema químico modelo, separando campos com associações distintas (Philpotts e Ague, 2009). Esse conceito é, portanto, usado para posicionar as curvas e retas nos diagramas $P-T$ sem, no entanto, determinar suas inclinações. Para determiná-las, aplicamos a equação de Clapeyron (1), que relaciona a inclinação das linhas de reação às propriedades termodinâmicas fundamentais (Perkins \& Mogk).

$$
\mathrm{dP} / \mathrm{dT}=\Delta S_{P, T} / \Delta V_{P, T}
$$

Por sua vez, a Regra das Fases de Gibbs, $\mathrm{P}+\mathrm{F}=\mathrm{C}+2$, fornece o fundamento teórico para analisar e interpretar sistemas geológicos, auxiliando na identificação de suas condições de equilíbrio e no reconhecimento das reações que são possíveis entre as fases do sistema (Mogk) e é, portanto, o ponto inicial para a construção de muitos diagramas de fases.

Grades petrogenéticas são diagramas de fases que, de acordo com Philpotts e Ague (2009) 
...são construídos considerando sistemas químicos teóricos e simplificados, que consistem em representações gráficas das relações de fases que podem ocorrer em um campo $P$-T. Com as mudanças nas condições de $T$ e $P$, alguns minerais podem estar envolvidos em mais de uma reação e suas curvas univariantes provavelmente terão diferentes inclinações, cruzando-se nos pontos invariantes.

Assim, a construção das grades petrogenéticas depende também das relações geométricas estabelecidas entre diferentes curvas univariantes. Essas regras foram determinadas por Zen (1966) sob a denominação Regras de Schreinemakers.

Uma das vantagens do uso de grades petrogenéticas é que, como importantes curvas de equilíbrio já foram determinadas experimentalmente, suas condições de pressão e temperatura são conhecidas e podem ser usadas para determinar condições $P-T$ do pico do metamorfismo da rocha, e quando uma série de texturas é examinada, até as trajetórias $P-T$ do metamorfismo podem ser inferidas (Spear, 1993). No entanto, a maior parte das grades petrogenéticas apresentam as curvas de equilíbrio com baixa variância, ou envolvendo composições fixas dos minerais (White et al., 2014a). Muitas das associações minerais observadas na natureza, geradas quando uma rocha passa por diferentes reações metamórficas em sua trajetória $P-T$, podem não ser facilmente entendidas ou representadas nas grades petrogenéticas, pois a composição química da rocha não é levada em consideração na construção das grades. Assim, muitas das associações minerais observadas podem apresentar variância maior que dois e não terem sido geradas por reações univariantes e estão atreladas às composições específicas das rochas. "À medida que aumenta o número de componentes considerados, há uma tendência à estabilização de equilíbrios de variância elevada, o que limita a utilidade das grades petrogenéticas" (White et al., 2014a).

A possibilidade de construir pseudosseções (Powell et al., 1998, Powell et al., 2005) com programas como PERPLEX (Connolly \& Kerrick, 1987) ou THERMOCALC (Powell e Holland, 1988), minimiza o problema, pois é possível usar a composição de uma amostra ou de um volume de equilíbrio (Stüwe, 1997) para calcular as reações e associações minerais compatíveis com a composição em qualquer sistema químico modelo desejado, incluindo os mais complexos, que representam da melhor maneira possível as variações composicionais das rochas na natureza (White et al., 2014b). A pseudosseção é um mapa de associações minerais no espaço $P-T$ em que somente as associações minerais permitidas pela composição da rocha podem ser calculadas. Os campos podem ser contornados para variáveis composicionais e de moda das fases, facilitando a inferência de condições e de trajetórias $P-T$, baseadas em variações texturais e composicionais das fases (Will, 1998; Powell et al., 2005). 
A construção de pseudosseções com o PERPLEX é feita via Método da Minimização de Energia Livre de Gibbs, que permite o reconhecimento das paragêneses em equilíbrio, ou seja, onde $\Delta \mathrm{G}=0$, localizando assim todos os campos de estabilidade entre as fases (Connolly \& Kerrick, 1987; Connolly, 1990). No entanto, apesar da construção direta do diagrama, o programa não permite a localização precisa dos limites dos campos e campos restritos geralmente se perdem (Powell et al., 2009).

O THERMOCALC usa um banco de dados internamente consistentes (Holland \& Powell, 1990, 1998 e 2011, o último revisado e atualizado), fornece as propriedades termodinâmicas das fases para os membros finais de soluções sólidas, relações de atividadecomposição (a-X) e a energia envolvida na mistura dos membros finais nas fases. Assim, o programa permite, através da resolução de equações não lineares, a construção de diagramas mais precisos e confiáveis, com os campos de estabilidade das associações minerais e seus limites, uma vez que a informação é obtida com o cálculo linha por linha e dos pontos que as conectam (Powell et al., 1998 e 2009).

A modelagem do equilíbrio de fases em rochas metamórficas pode ser inversa, quando observamos e identificamos a paragênese da rocha, obtemos a composição química dos minerais, levando-se em conta os zoneamentos composicionais, e aplicamos métodos tradicionais de termobarometria para determinar as condições $P-T$, ou modelagem direta, feita com base na composição química da rocha, ou seja, a rocha é o sistema em equilíbrio, permitindo considerações a respeito das condições de formação e processos envolvidos e calculando pseudosseções (Powell et al., 2009).

Claro que, mesmo sendo um método aplicado a uma composição específica de rocha, devemos ter cuidado na escolha da amostra ou determinação do volume de equilíbrio e do sistema químico modelo utilizado. Rochas com bandamento composicional, rochas que não foram completamente homogeneizadas durante o metamorfismo, ou seja, aquelas que preservam texturas ígneas, ou aquelas que após o pico metamórfico formaram uma série de texturas de desequilíbrio, tais como coronas e simplectitos, rochas que foram metamorfizadas em sistema aberto, como ocorre em zonas de cisalhamento, e rochas que sofreram fusão e tiveram extração de fundido, são casos em que o volume de equilíbrio deve ser considerado da melhor maneira possível.

Em uma pseudosseção todas as linhas marcam limites em que a moda de um mineral é zero, na qual o mineral aparece, ou é gerado, ou que desaparece, pelo seu consumo. Partindo de um ponto, em que duas modas são iguais a zero, há sempre quatro linhas separando quatro campos com diferentes variâncias. "Quando as linhas são sucessivamente cruzadas a variância 
muda de um, mas quando os vértices são cruzados, a variância muda de dois ou não muda" (Powell et al., 1998), como indicado na Figura 3.1a. A moda de determinada fase muda ao longo das linhas de acordo com as variações de $P$ e $T$, diminuindo até chegar a zero em um ponto, ou aumentando a partir do ponto. Na Figura 3.1 são representadas as linhas em que as modas das fases "b" e "c" são iguais à zero. Na Figura 3.1a está indicada a linha com o sentido da diminuição da fase " $b$ " decorrente do seu consumo para formar a fase "c" $(a+b=$ c) e a Figura 3.1b mostra o sentido da diminuição na moda da fase "b" em direção as linhas $\mathrm{a}(\mathrm{b})$ e $\mathrm{ac}(\mathrm{b})$, onde $\mathrm{b}=0$.
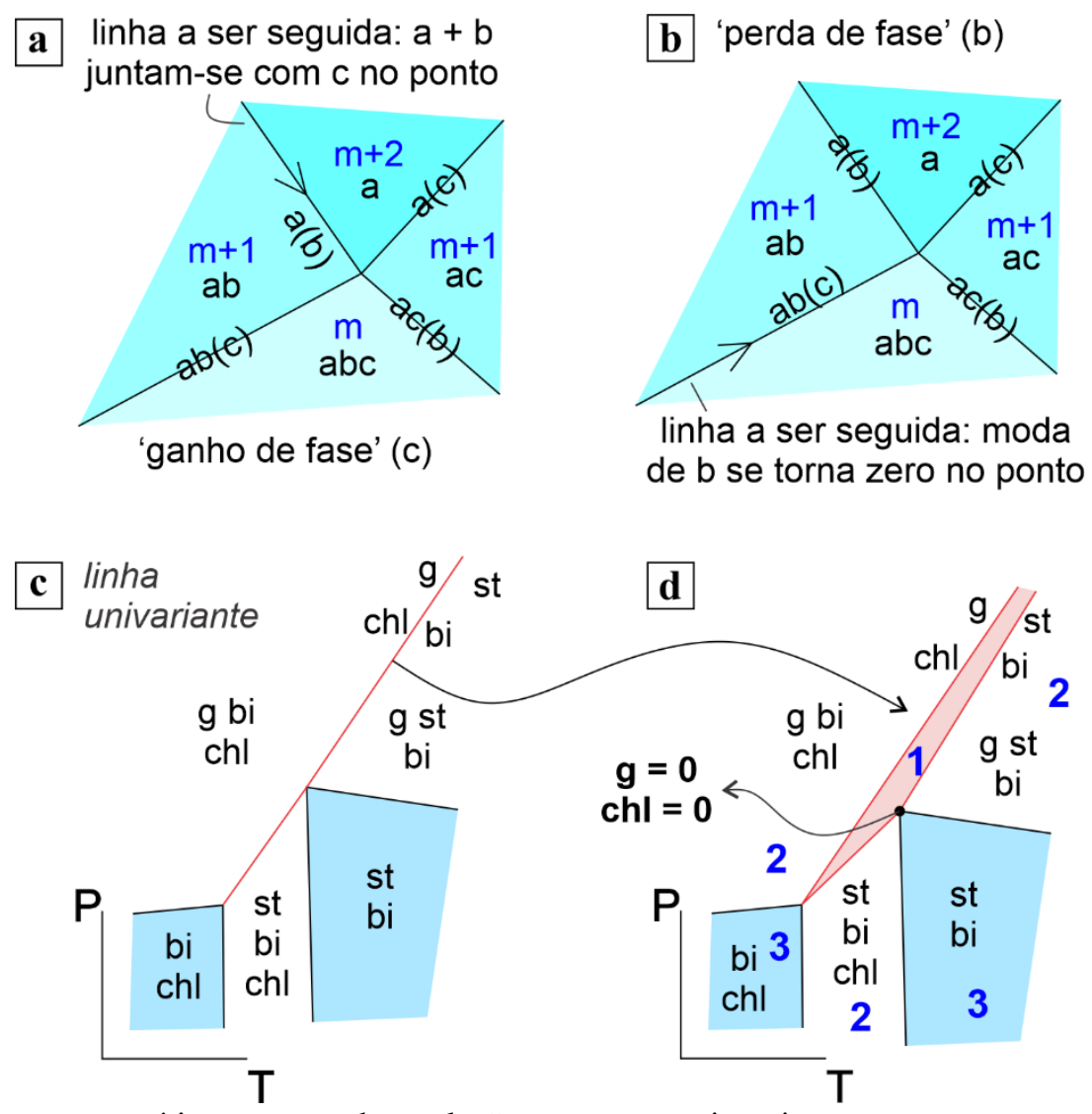

Figura 3.1: Figuras esquemáticas mostrando a relação entre pontos invariantes e campos em uma pseudosseção. Em (a) o ganho da fase "c" e em (b) perda da fase "b"; (c) ilustra uma linha univariante para a reação g + chl = bi + st e em (d) observamos que a linha é representada por um campo estreito. Extraído de Powell et al. (2009).

Moda zero pode representar o fim ou o primeiro aparecimento de determinada fase, isso pode ser visto nas linhas univariantes da pseudosseção. As linhas na pseudosseção não representam reações, a menos que esta seja uma curva univariante verdadeira, que é representada por campos estreitos. Na Figura 3.1c, a linha vermelha representa a linha univariante para a reação $g+c h l=b t+s t$, que, na Figura 3.1d, é mostrada como um campo estreito onde, à esquerda, a moda da estaurolita é zero $(s t=0)$, representa o primeiro aparecimento de estaurolita e, à direita, a moda da clorita é zero (chl =0), representa o 
desaparecimento/consumo de clorita, em pressões altas mais altas que o ponto em que clorita e granada têm moda igual a zero, em pressões mais baixas que esse ponto a granada é a fase consumida e que tem a moda igual a zero $(\mathrm{g}=0)$.

\subsection{Aplicações em rochas metapelíticas}

Rochas metapelíticas são derivadas do metamorfismo de rochas sedimentares ricas em argila e têm papel crucial no estudo de terrenos metamórficos, dada a facilidade com que desenvolvem associações minerais com as mudanças no campo $P-T$.

A grade petrogenética modelo mais utilizada para o estudo do metamorfismo de rochas pelíticas é a do sistema KFMASH $\left(\mathrm{SiO}_{2}-\mathrm{Al}_{2} \mathrm{O}_{3}-\mathrm{FeO}-\mathrm{MgO}-\mathrm{K}_{2} \mathrm{O}-\mathrm{H}_{2} \mathrm{O}\right)$, que compreende mais de $90 \%$ da composição de xistos pelíticos (Spear \& Cheney, 1989; Spear, 1993). A grade de Spear \& Cheney (1989) com o banco de dados de Berman (1988), leva em conta algumas premissas petrológicas e fixa a posição de alguns pontos invariantes e de reações univariantes para dar início aos cálculos. Uma versão levemente modificada foi publicada no site de Frank Spear e é aqui reproduzida na Figura 3.2. No entanto, o sistema modelo KFMASH não incorpora importantes componentes, tais como $\mathrm{CaO}, \mathrm{Na}_{2} \mathrm{O}, \mathrm{Fe}_{2} \mathrm{O}_{3}$, $\mathrm{TiO}_{2}$ e $\mathrm{MnO}$, sendo muitas vezes difícil remover o efeito de $\mathrm{Fe}_{2} \mathrm{O}_{3}, \mathrm{CaO}$ e $\mathrm{MnO}$ da rocha investigada (Powell \& Holland, 1990). O comportamento do $\mathrm{CaO}$ é avaliado no sistema CKNASH $\left(\mathrm{SiO}_{2}-\mathrm{Al}_{2} \mathrm{O}_{3}-\mathrm{CaO}-\mathrm{Na}_{2} \mathrm{O}-\mathrm{K}_{2} \mathrm{O}-\mathrm{H}_{2} \mathrm{O}\right)$, aplicado a gnaisses quartzofeldspáticos, migmatitos, xistos com Ca e outras rochas com composições de calcário (Spear, 1993). Mas esse sistema não considera $\mathrm{FeO}$ e $\mathrm{MgO}$, que são importantes componentes nas fases de sistemas metapelíticos, em especial naquelas que apresentam soluções sólidas entre Fe e $\mathrm{Mg}$ com as mudanças nas condições de $P$ e $T$, em fases como granada, biotita e clorita. Além dessas limitações, nos sistemas modelos existem partes da grade que podem não aparecer nas rochas devido à "deficiência" em um determinado componente, como por exemplo a presença de cloritóide, restrita apenas às rochas pelíticas muito ricas em $\mathrm{Al}_{2} \mathrm{O}_{3}$.

Powell \& Holland (1990) calcularam uma grade petrogenética no sistema KFMASH para rochas metapelíticas sob condições de fácies xisto verde a anfibolito (Figura 3.3), usando o banco de dados internamente consistente (Holland \& Powell, 1990) do THERMOCALC, considerando equilíbrios entre clorita, cloritoide, biotita, granada, estaurolita, cianita, sillimanita, andaluzita e cordierita, com muscovita, quartzo e água em excesso.

Ao comparar as grades petrogenéticas das Figuras 3.2 e 3.3 observamos que as topologias são praticamente as mesmas e que ambas foram determinadas com base em dados 
experimentais de reações dos subsistemas KFASH e KMASH, mas as diferenças estão no método de obtenção. Na grade da Figura 3.2, dos quatro pontos invariantes, apenas dois foram determinados experimentalmente (Spear, 1993), os demais foram fixados com base em observações de paragêneses naturais. Já para a grade da Figura 3.3, todos os pontos invariantes e curvas univariantes foram calculados com base em banco de dados internamente consistentes e, apesar da qualidade dos dados experimentais de equilíbrios minerais disponíveis na época, Powell \& Holland (1990) conseguiram calcular todas as curvas para equilíbrios em baixa pressão com as fases citadas acima.

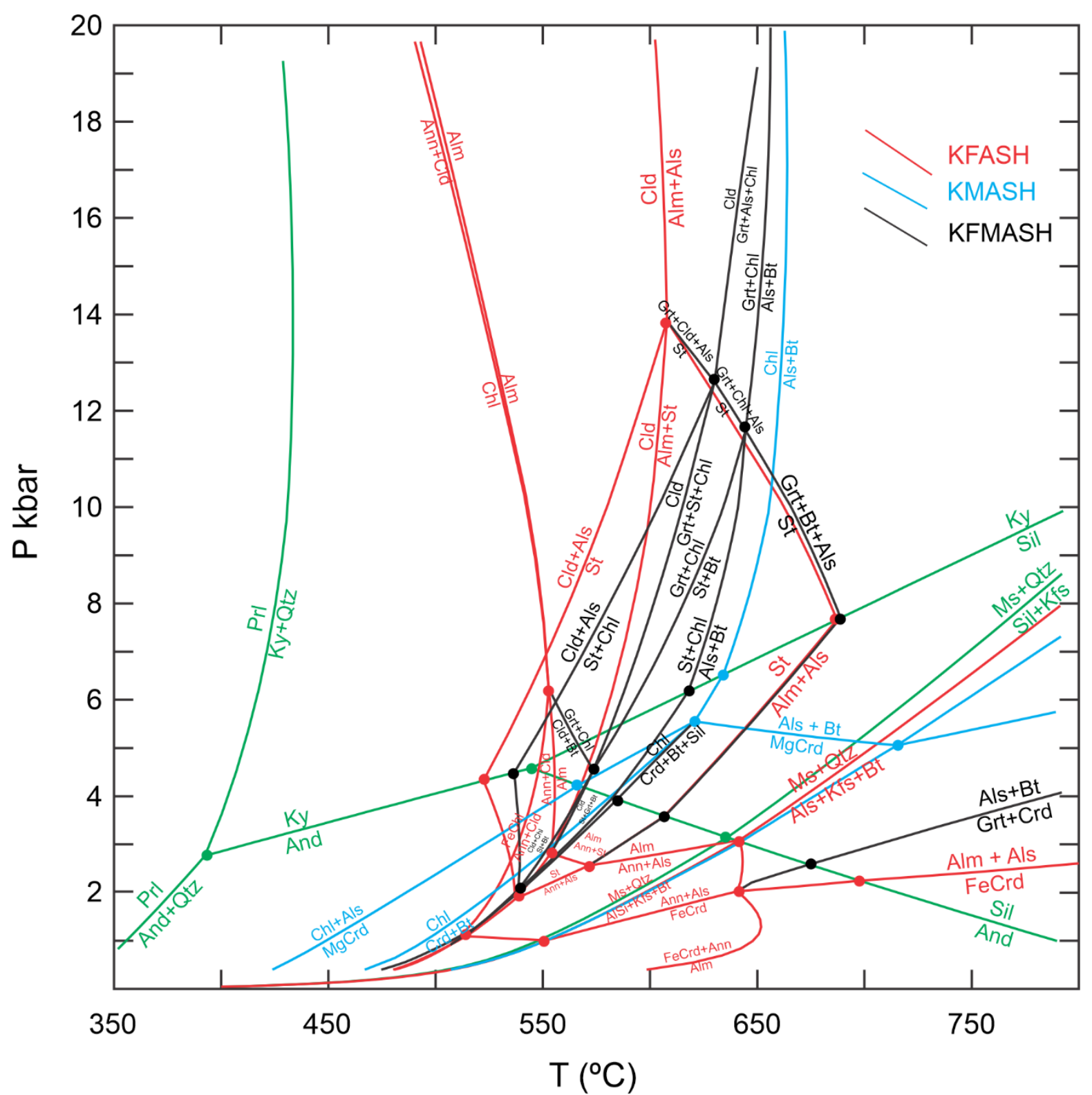

Figura 3.2: Grade petrogenética para o sistema KFMASH (linhas mais escuras) baseada nas grades KFASH (linhas finas) e KMASH (linhas tracejadas). Pontos representam pontos invariantes nos sistemas KFASH ou KMASH. Quadrados são pontos invariantes do sistema KFMASH. Extraído do site de Frank Spear, sendo versão levemente modificada de Spear \& Cheney (1989), com a mudança de um ponto invariante envolvendo a reação $\mathrm{Ctd}+\mathrm{Bt}=\mathrm{Grt}+\mathrm{Chl}$, para posição de baixa $P$. 


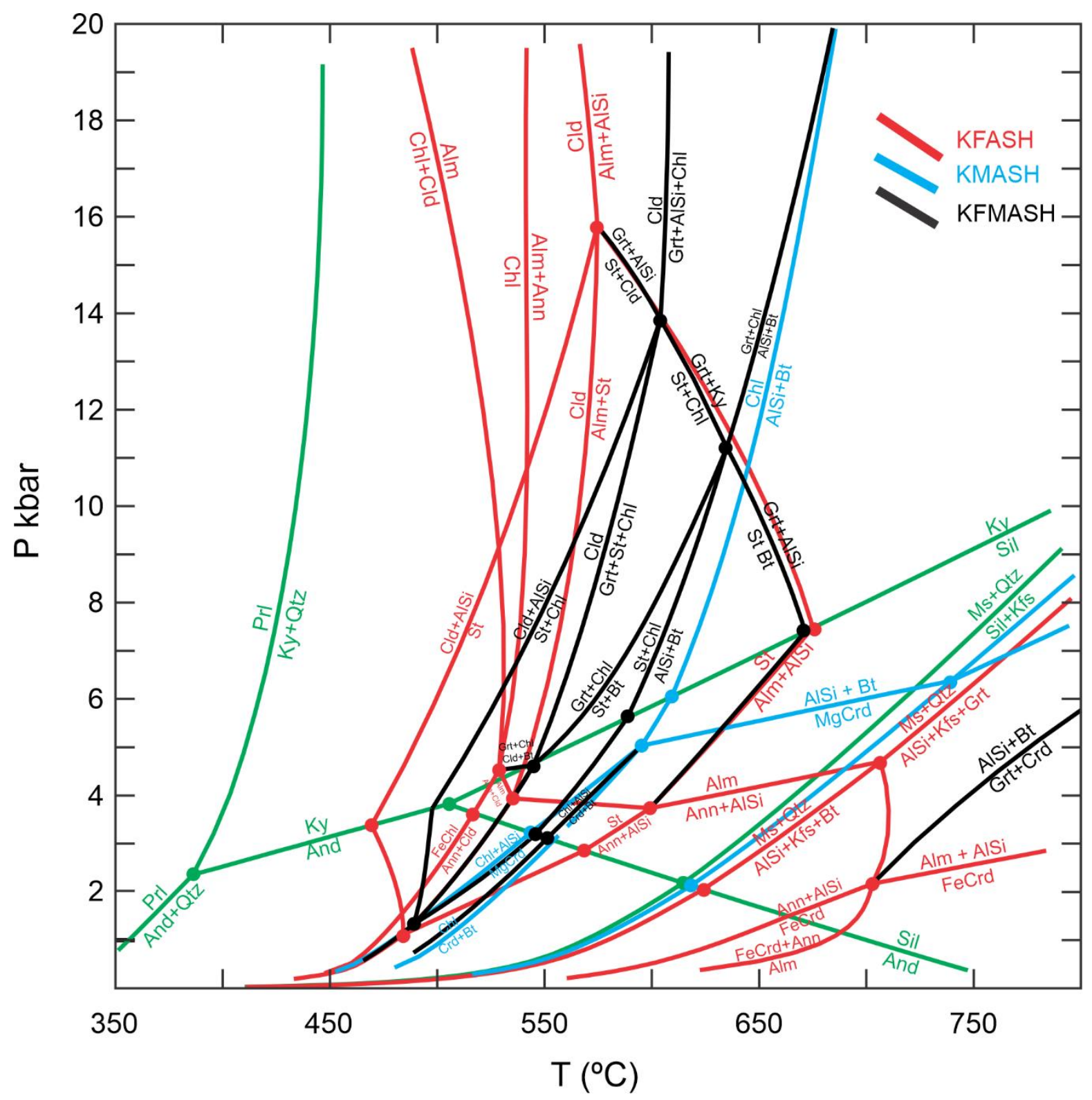

Figura 3.3: Grade petrogenética construída para o Sistema KFMASH. Extraído de Powell \& Holland (1998).

A Figura 3.4 apresenta uma pseudosseção calculada no sistema KFMASH para metapelito usando as relações de atividade-composição para membros finais a partir do banco de dados internamente consistentes de Holland \& Powell (2011), mas uma maior variedade de componentes deve ser incluída nos minerais para que a modelagem seja mais confiável e próxima da realidade (White et al., 2014a), uma vez que componentes "extras", não considerados no sistema KFMASH, podem ter efeitos significativos na formação e estabilidade das associações minerais das rochas metapelíticas. Além disso, "a ordemdesordem em minerais que apresentam troca $\mathrm{Fe}^{2+} \leftrightarrow \mathrm{Mg}^{2+}$ em mais de um sítio catiônico também deve ser levada em consideração nos modelos de atividade mais realistas" (White et al., 2014a). 


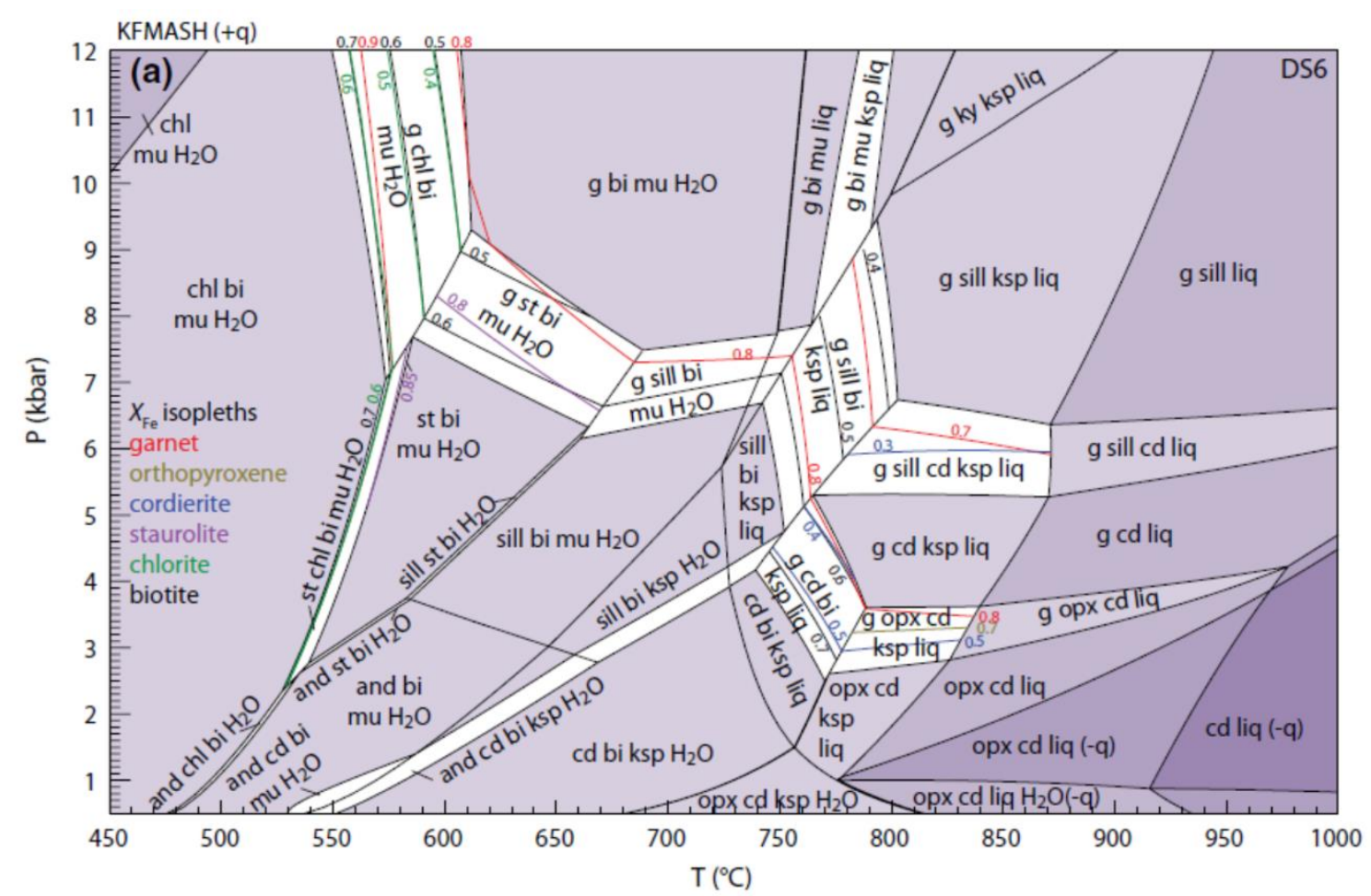

Figura 3.4: Pseudosseção P-T calculada no sistema KFMASH a partir do banco de dados internamente consistente de Holland e Powell (2011) para um metapelito com as seguintes composições, em \% molar: $\mathrm{SiO}_{2}$ (68.76); $\mathrm{Al}_{2} \mathrm{O}_{3}$ (9.87); $\mathrm{FeO}$ (7.64); $\mathrm{MgO}$ (4.01); $\mathrm{K}_{2} \mathrm{O}$ (3.16); e $\mathrm{H}_{2} \mathrm{O}$ (6.56). Extraído de White et al (2014a).

A inclusão de $\mathrm{Na}_{2} \mathrm{O}$ e $\mathrm{CaO}$ permite que fases como epidoto, plagioclásio e a solução sólida na mica branca (muscovita, margarita e paragonita) sejam consideradas nos cálculos, especialmente em equilíbrios estabelecidos sob condições de fácies xisto verde e anfibolito (White et al., 2014a). O CaO também pode particionar na granada, alterando sua estabilidade, entretanto, como ele também estabiliza outras fases, apenas muda um pouco a produção ou estabilidade da granada (Spear, 1993). No caso da margarita e paragonita, apesar das baixas proporções modais, aparecem em campos de estabilidade de tamanho relativamente moderados, o que pode refletir que as relações atividade-composição para minerais com $\mathrm{CaO}$ e $\mathrm{Na}_{2} \mathrm{O}$ ainda não sejam bem estabelecidas e, portanto, para que as comparações com associações naturais sejam válidas, são necessários mais estudos sobre equilíbrios envolvendo $\mathrm{Na}_{2} \mathrm{O}$ e $\mathrm{CaO}$ (White et al., 2014a).

Apesar dos silicatos de rochas metapelíticas apresentarem baixa concentração de $\mathrm{TiO}_{2}$ e $\mathrm{Fe}_{2} \mathrm{O}_{3}$, eles são componentes que podem influenciar no equilíbrio de algumas fases importantes e de algumas fases acessórias, que podem incluir membros das séries ilmenita hematita e ulvoespinélio - magnetita. Historicamente estes óxidos são ignorados na avaliação de equilíbrios metamórficos, ou porque os efeitos de pequenas quantidades não afetam grosseiramente a estabilidade de associações com silicatos (White et al., 2000), ou devido à 
dificuldade de determinar a proporção real de $\mathrm{Fe}_{2} \mathrm{O}_{3}$ nos minerais e nas rochas. É importante levar em consideração o teor real de $\mathrm{Fe}_{2} \mathrm{O}_{3}$, pois, ao ignorar seus efeitos no sistema químico, assumindo todo o Fe como divalente, ou não determinando seu teor de forma adequada, as pseudosseções podem não representar a realidade (White et al., 2014a).

$\mathrm{O} \mathrm{Fe}_{2} \mathrm{O}_{3}$ era considerado apenas como componente importante em granada, biotita, cloritóide e óxidos de Fe-Ti, apesar da sua importância em outros minerais, como clorita e estaurolita (White et al., 2014a). No caso da biotita, que é abundante em amplo intervalo $P-T$ dos metapelitos e, entre os silicatos, é geralmente a fase mais rica em $\mathrm{TiO}_{2}$ e $\mathrm{Fe}_{2} \mathrm{O}_{3}$ (White et al., 2000). Esses óxidos afetam sua estabilidade, permitindo sua presença em rochas em condições de temperatura mais alta (White et al., 2014b). Além da biotita, as demais fases minerais de rochas metapelíticas não incorporam grandes quantidades de $\mathrm{Fe}^{3+}$, assim, ilmenita está presente mesmo nas composições mais reduzidas e mudanças no teor de $\mathrm{Fe}^{3+}$ podem levar à introdução de magnetita ou hematita nas rochas (Diener e Powell, 2010).

White et al., (2000, 2007) e Diener \& Powell (2010) estudaram os efeitos do $\mathrm{TiO}_{2} \mathrm{e}$ $\mathrm{Fe}_{2} \mathrm{O}_{3}$ em associações minerais de metapelitos típicos, a partir de modelos termodinâmicos para soluções sólidas entre ilmenita-hematita e magnetita-ulvoespinélio, o que permitiu calcular a distribuição desses componentes não só nos óxidos, como também nos silicatos, demonstrando que quantidades baixas a moderadas de $\mathrm{TiO}_{2}$ e $\mathrm{Fe}_{2} \mathrm{O}_{3}$ têm pouco efeito nos equilíbrios entre silicatos formados sob condições de fácies xisto verde a anfibolito. Grandes quantidades de $\mathrm{TiO}_{2}$ também têm pouco efeito na estabilidade das fases envolvendo silicatos, por outro lado, rochas ricas em $\mathrm{Fe}_{2} \mathrm{O}_{3}$ apresentam sucessão mineral distinta das sequências barrovianas clássicas, com acentuada redução no campo de estabilidade de estaurolita e granada para pressões elevadas (White et al., 2000, 2007). A inclusão de $\mathrm{Fe}_{2} \mathrm{O}_{3}$ e $\mathrm{TiO}_{2}$ nos cálculos das pseudosseções pode ter efeito significativo na estabilidade de associações envolvendo silicatos nas rochas metapelíticas, possibilitando ainda a inclusão de novas fases minerais, antes não consideradas (White et al., 2000, 2007). Por exemplo, ao incluir esses componentes, a reação $\mathrm{g}+\mathrm{chl}=\mathrm{bi}+$ st passa a considerar ilmenita nos reagentes para a formação de magnetita ou rutilo, dependendo do estado de oxidação do equilíbrio e das condições de pressão em que a reação ocorre (Diener \& Powell, 2010).

Quando um maior número de componentes é considerado, mais fases minerais aparecem e, consequentemente, as pseudosseções geradas são mais complexas. Apesar disso, as relações e topologias de subsistemas mais simples se mantém (White et al., 2014a). A construção de diagramas no sistema NCKFMASHTO, por exemplo, sobrepõe três subsistemas mais "simples" para estabelecer as relações entre suas fases, KFMASH, e suas 
relações com $\mathrm{Fe}_{2} \mathrm{O}_{3}-\mathrm{FeO}-\mathrm{TiO}_{2}$ e $\mathrm{CaO}-\mathrm{Na}_{2} \mathrm{O}-\mathrm{K}_{2} \mathrm{O}$. As interdependências surgem quando minerais ferromagnesianos incorporam $\mathrm{Fe}_{2} \mathrm{O}_{3}$ e $\mathrm{TiO}_{2}$, estabelecendo a conexão entre os sistemas $\mathrm{AFM}$ e $\mathrm{Fe}_{2} \mathrm{O}_{3}-\mathrm{FeO}-\mathrm{TiO}_{2}$ ou quando a rocha tem plagioclásio o que também permite a entrada de $\mathrm{CaO}$ na granada e $\mathrm{Na}_{2} \mathrm{O}$ e $\mathrm{CaO}$ na mica branca (White et al., 2014a).

Apesar das vantagens da inclusão de $\mathrm{TiO}_{2}$ e $\mathrm{Fe}_{2} \mathrm{O}_{3}$ nos equilíbrios de rochas metapelíticas, devemos tratar com cautela equilíbrios envolvendo $\mathrm{FeO}, \mathrm{Fe}_{2} \mathrm{O}_{3}$ e $\mathrm{TiO}_{2}$, uma vez que a distribuição de $\mathrm{TiO}_{2}$ e $\mathrm{Fe}_{2} \mathrm{O}_{3}$ entre silicatos e óxidos ainda não é bem compreendida, em parte pela falta de conhecimento do comportamento do oxigênio durante o metamorfismo, o que dita o grau de oxidação do sistema (White et al., 2000, 2007).

Rochas metapelíticas apresentam baixos conteúdos de $\mathrm{MnO}$, no entanto é um óxido que pode ter efeitos significativos no equilíbrio das fases, em especial daqueles que envolvem granada, devido ao intenso particionamento de $\mathrm{MnO}$ que ocorre no mineral. A associação granada + biotita + clorita + quartzo $+\mathrm{H}_{2} \mathrm{O}$ é uma das mais comuns e importantes no metamorfismo de fácies xisto verde até, em algumas composições, anfibolito de pelitos, no entanto, observamos que seu campo de estabilidade é muito restrito no diagrama KFMASH (Figura 3.2). O que ocorre, na verdade, é que a simples adição de um componente extra muda os limites da reação, de modo que a granada incorpora a maior parte do $\mathrm{MnO}$ e terá seu campo de estabilidade expandido para temperaturas mais baixas, ampliando sobremaneira o campo de pressão e temperatura da referida associação (Spear, 1993).

O sistema MnNCKFMASHTO incorpora os efeitos de todos os componentes discutidos acima no cálculo de pseudosseções para rochas metapelíticas (White et al., 2014b), gerando a representação mais próxima de sistema natural, levando-se em consideração os modelos de atividade e os dados termodinâmicos atualmente disponíveis, considerando $0,1 \%$ de $\mathrm{MnO}$ (Figura 3.5). Os efeitos do $\mathrm{MnO}$ são mais expressivos para associações minerais formadas sob condições de fácies xisto verde a anfibolito, até a transição para a fácies granulito de baixa a média pressão, mas são menos intensos em condições de maior pressão e temperatura, já que granada é uma fase comum na maioria dos metapelitos formados nessas condições (White et al., 2014b).

Para mostrar os efeitos do $\mathrm{MnO}$ no sistema, na Figura 3.5 são mostradas as linhas para quantidades variáveis de $\mathrm{MnO}$. A adição de MnO, como apontada por Spear (1993), resulta na expansão dos campos de estabilidade da granada, em especial com relação à pressão, permanecendo estável para temperaturas desde a fácies xisto verde, até condições supra-sólidos, o que já observamos na natureza. Para temperaturas mais baixas, sob condições de fácies xisto verde, a adição de $\mathrm{MnO}$ expande o campo de estabilidade da granada para 
menores temperaturas, enquanto que, para condições de fácies anfibolito, as linhas são mais planas, de modo que a adição de $\mathrm{MnO}$ irá aumentar o campo de estabilidade da granada para pressões mais elevadas (White et al., 2014b).

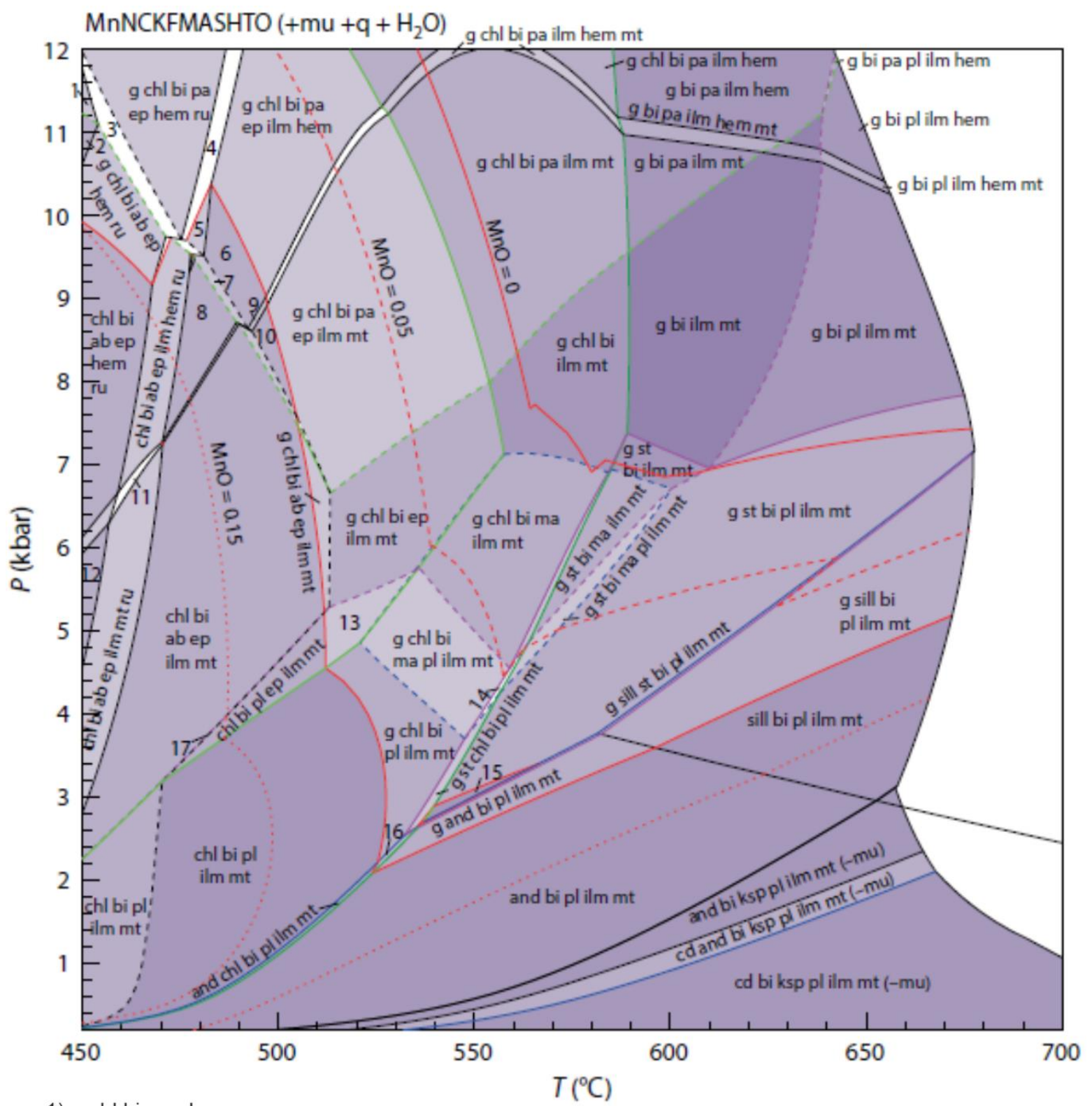

1) g chl bi pa ab ep ru

2) $\mathrm{g}$ chl bi ab ep ru

3) $\mathrm{g}$ chl bi pa ab ep hem ru

4) $\mathrm{g}$ chl bi pa ep ilm hem ru

5) chl bi pa ep ilm hem ru

6) chl bi pa ep ilm hem

7) chl bi pa ab ep ilm hem

8) chl bi ab ep ilm hem

9) chl bi pa ep ilm hem $\mathrm{mt}$

10) chl bi pa ep ilm mt

11) chl bi ab ep ilm hem mt ru

12) chl bi ab ep mt ru

13) $\mathrm{g}$ chl bi pl ep ilm mt

14) $\mathrm{g}$ st chl bi ma pl ilm mtr

15) st bi pl ilm mt

16) $\mathrm{g}$ and chl bi pl ilm mt

17) chl bi pl ab ep ilm mt
Moda zero

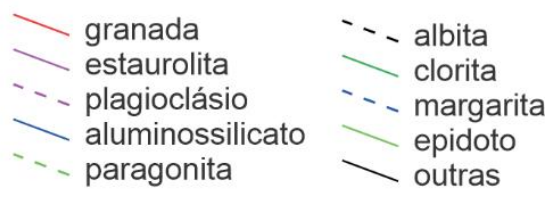

Figura 3.5: Pseudosseção calculada no sistema MnNCKFMASHTO. $\mathrm{SiO}_{2}$ (74.021), $\mathrm{Al}_{2} \mathrm{O}_{3}(9.452), \mathrm{FeO}$ (7.530), $\mathrm{MgO}$ (3.844), $\mathrm{CaO}$ (0.296), $\mathrm{K}_{2} \mathrm{O}$ (3.031), $\mathrm{Na}_{2} \mathrm{O}$ (0.602), $\mathrm{TiO}_{2}(0.659), \mathrm{O}(0.565)$ e $\mathrm{MnO}(0,1)$. Extraído de White et al., (2014b). 
Quando comparamos as pseudosseções para os sistemas KFMASH e MnKFMASH (Figuras 3.4 e 3.5) observamos que, embora $\mathrm{MnO}$ tenha efeito distinto no campo de estabilidade da granada, ele pouco influencia na estabilidade das demais fases, o que pode ser visto pelas topologias semelhantes entre os dois diagramas (White et al., 2014b), isso em parte pode ser porque a granada é a fase que mais absorve o $\mathrm{MnO}$ do sistema. 


\section{CONTEXTO GEOLÓGICO REGIONAL}

A área de estudo se insere ao longo de uma faixa de direção E-W/NW-SE geotectonicamente posicionada na borda sul do Cráton do São Francisco, onde predominam rochas com idades arqueanas e paleoproterozoicas reunidas em terrenos granito-greenstone atribuídos ao Complexo Campos Gerais (Kaefer et al., 1979), faixas de Greenstone Belts Morro do Ferro ou Fortaleza de Minas (Teixeira, 1978; Teixeira \& Danni, 1979), Bom Jesus da Penha-Jacuí (Teixeira et al., 1987) e Alpinópolis (Szabó, 1996), e unidades que em parte são embasamento da Faixa Brasília.

As rochas desses terrenos foram intensamente retrabalhadas no Neoproterozoico, durante a Colagem Orogênica Brasiliana (Figura 4.1, Brito Neves et al., 1999), e são considerados como representantes da zona de sutura entre a Paleoplaca São Francisco - Congo (margem passiva) e o Bloco Paranapanema, (margem ativa), caracterizada como Zona de Paleosutura de Alterosa (Figura 4.2; Zanardo et al., 2006), ou Zona de Cisalhamento Campo do Meio (Morales et al., 1991 e Morales, 1993), resultante da convergência durante o fechamento do paleo-oceano Goianides (Campos Neto \& Caby, 2000; Trouw et al., 2000).

\subsection{O Complexo Campos Gerais}

O Complexo Campos Gerais (CCG) foi definido durante mapeamentos regionais em escala 1:250.000 do Projeto Sapucaí, feito pelo Departamento Nacional de Produção Mineral (DNPM) e apresentado em 1979. Nele foi destacada a intensa compartimentação tectônica, com rochas caracteristicamente miloníticas e cataclásticas, além da presença de sequências vulcanossedimentares e diversos corpos metaultrabásicos.

O Complexo Campos Gerais constitui uma faixa de direção WNW-ESSE condicionada ao Cinturão de Cisalhamento Campo do Meio (Morales \& Hasui, 1993; Turbay et al., 2008; Turbay \& Valeriano, 2012). É, em parte, uma janela estrutural (Figura 4.2), onde, a norte e oeste cavalgam sequências metassedimentares psamo-pelíticas neoproterozoicas do Grupo Araxá - Canastra, a nordeste faz contato abrupto com cobertura cratônica carbonático-pelítica neoproterozoica do Grupo Bambuí, a leste não se distingue das rochas de outros complexos cratônicos e, ao sul é cavalgado por Nappes neoproterozoicas do sistema de nappes Andrelândia e parte do domínio norte da Nappe Socorro-Guaxupé (Campos Neto, et al. 2004 e 2010). 


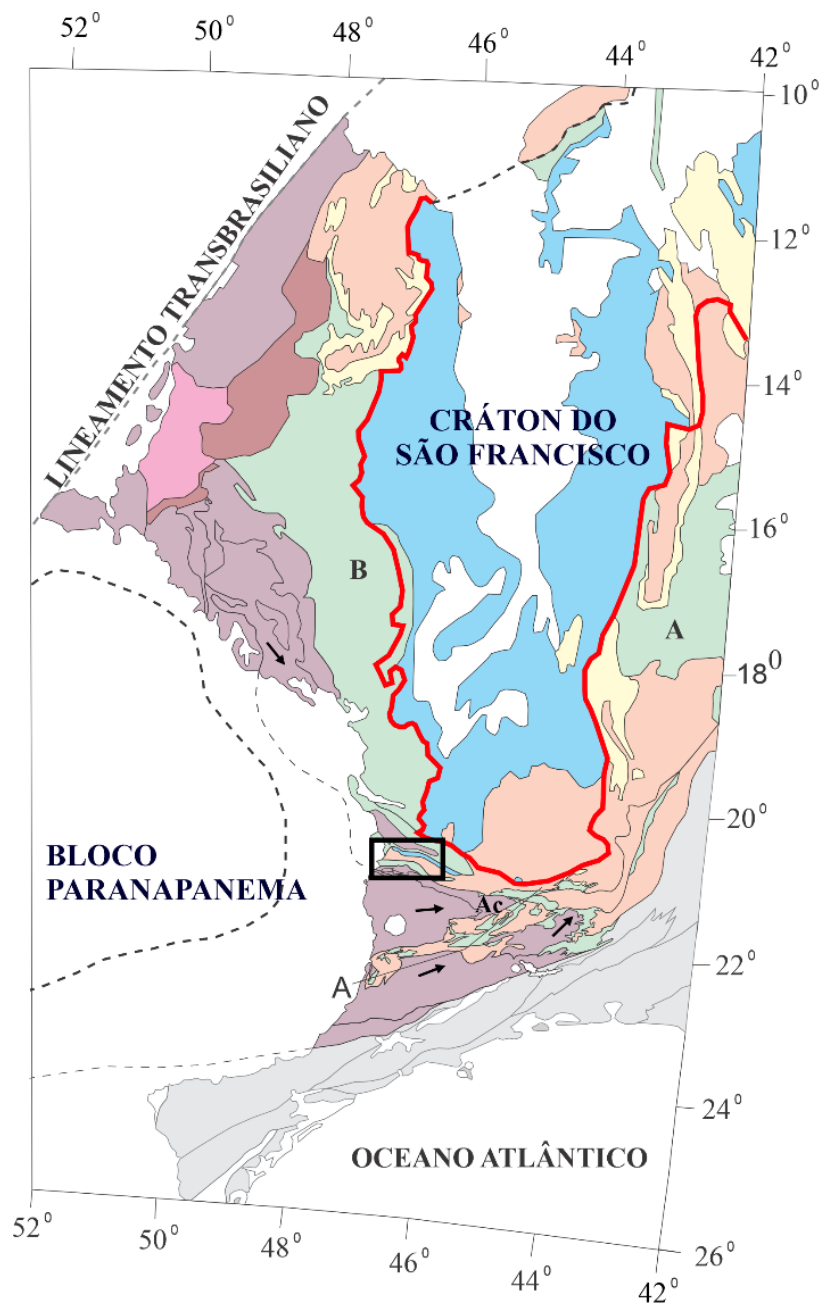

Terrenos do orógeno Ribeira

\section{BLOCOS PARANAPANEMA E GOIÁS CETRAL}

Domínio de margem ativa neoproterozoica

Sequência vulcano-sedimentar mesoproterozoica

Arqueano - Paleoproterozoico

\section{SÃO FRANCISCO PLATE}

Cobertura cratônica ediacarana

Sequências de margem continental passiva neoproterozoica

A) Orógeno Araçuai (B) Orógeno Brasília Sequências rift estateriana a esteniana

Arqueano - Paleoproterozoico

Y Main nappe kinematic

Borda cratônica

Figure 3.2

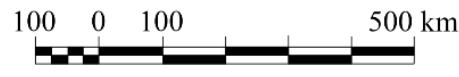

Figura 4.1: Sistemas orogênicos da porção sudeste e central do Brasil. Modificado de Westin et al. (2016).

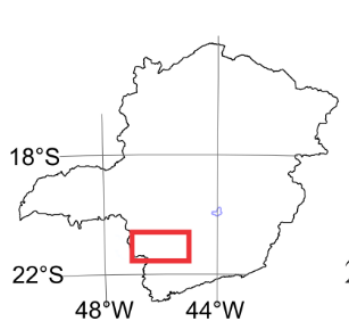

Cidades:

Guaxupé (Gx)

Passos (P)

Varginha (V)

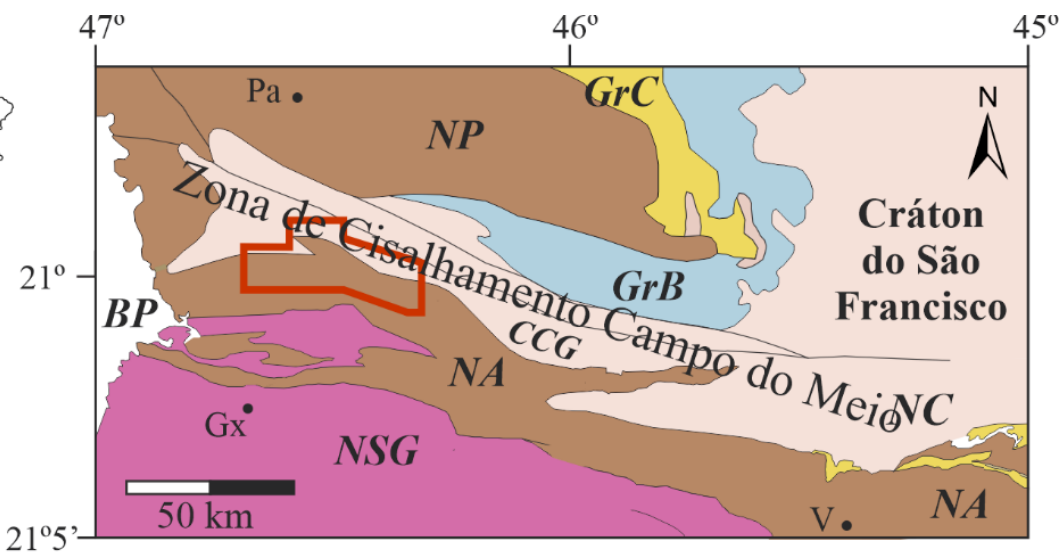

Arco magmático neoproterozoico: Nappe Socorro - Guaxupé (NSG) e granitoídes sin a pós colisionais.

Metassedimentos neoproterozoicos: Sistema de Nappes Andrelândia (NA) e Nappe de Passos $(N P)$

Sequências de margem continental passiva: Sistema de Nappes Carrancas $(N C)$ e Grupo Canastra $(G r C)$

Cobertura cratônica neoproterozoica: Grupo Bambuí $(\mathrm{GrB})$

Arqueano-Paleoproterozoico: Complexo Campos Gerais (CCG)

Figura 4.2: Mapa geológico esquemático de parte do Orógeno Brasília Meridional com os principais domínios tectônicos. Modificado e adaptado de Campos Neto et al. (2011) e Zanardo et al. (2006), com indicação da área de estudo. 
Embora o Complexo Campos Gerais ocupe posição chave no contexto geotectônico da geologia da região, ainda não há consenso para seu significado, compartimentação e extensão, em especial para leste e sul. Sua primeira compartimentação foi baseada em descontinuidades tectônicas e conjuntos litológicos delimitados por um ou mais litotipos característicos, resultando na correlação de seus gnaisses à Associação Barbacena, os xistos aos Grupos Andrelândia e os quartzitos e micaxistos ao Grupo São João Del Rei (Kaefer et al., 1979).

$\mathrm{Na}$ primeira tentativa de compartimentar o Complexo Campos Gerais foram definidos os Domínios Conceição de Aparecida, Jacuí e Nova Resende (Kaefer et al., 1979), mas considerados informais por Fonseca et al., 1979. Outra compartimentação proposta consistia nos Domínio Granito-Greenstone e migmatito, Domínio dos Gnaisses e Paragnaisses e Domínio dos Granitos Isolados (Crosta et al., 1986).

A compartimentação atual do CCG consiste em dois domínios (Schrank et al., 1993; Zanardo, 1992; Roig, 1993; Szábo et al., 1993; Szábo, 1996). Em trabalho de compilação litológica, estrutural, metamórfica, geofísica, geoquímica e geocronológica, a região de Guaxupé, Passos e Delfinópolis foi dividida em quatro grandes domínios delimitados por zonas de cisalhamento de alto e baixo ângulo de mergulho - Domínios Norte (I), Central (II e III) e Sul (IV) (Figura 4.3; Zanardo, 1992). Os domínios II e III correspondem, respectivamente, aos Domínios Alóctone (Sul) e Autóctone (Norte) do Complexo Campos Gerais (Roig, 1993; Szábo et al., 1993; Szábo, 1996).

Lentes de rochas metaultramáficas separam os Domínios II e III, configurando nítida descontinuidade. A norte (Domínio III), em contato com a Sinforme de Passos, ocorrem terrenos nitidamente mais antigos, compostos por gnaisse, granitoide e migmatito de afinidades geoquímicas tipo TTG, com enclaves tectônicos de sequências metavulcanossedimentares tipo greensone belt, e a sul (Domínio II), ao sul das Zonas de Cisalhamento de Riacho Fundo e Mumbuca, ocorrem rochas metassedimentares intercaladas aos corpos de ortognaisse (Zanardo, 1992).

O Domínio Autóctone é dividido em três unidades: Ortognaisse Campos Gerais, metatexito estromático tonalítico e monzogranítico; Ortognaisse Serra do Quilombo, com bandamento composicional irregular herdado da deformação de suíte de rochas tonalíticas e graníticas; e, Ortognaisse Mandembo, diatexito tonalítico e sienogranítico com estrutura schlieren a nebulítica (Turbay et al., 2008; Turbay \& Valeriano, 2012). O conjunto foi intrudido por corpos de tonalito, pelo granito Grão Mogol e leucogranitos Córrego do Sapateiro e Itapixé (Turbay \& Valeriano, 2012). 

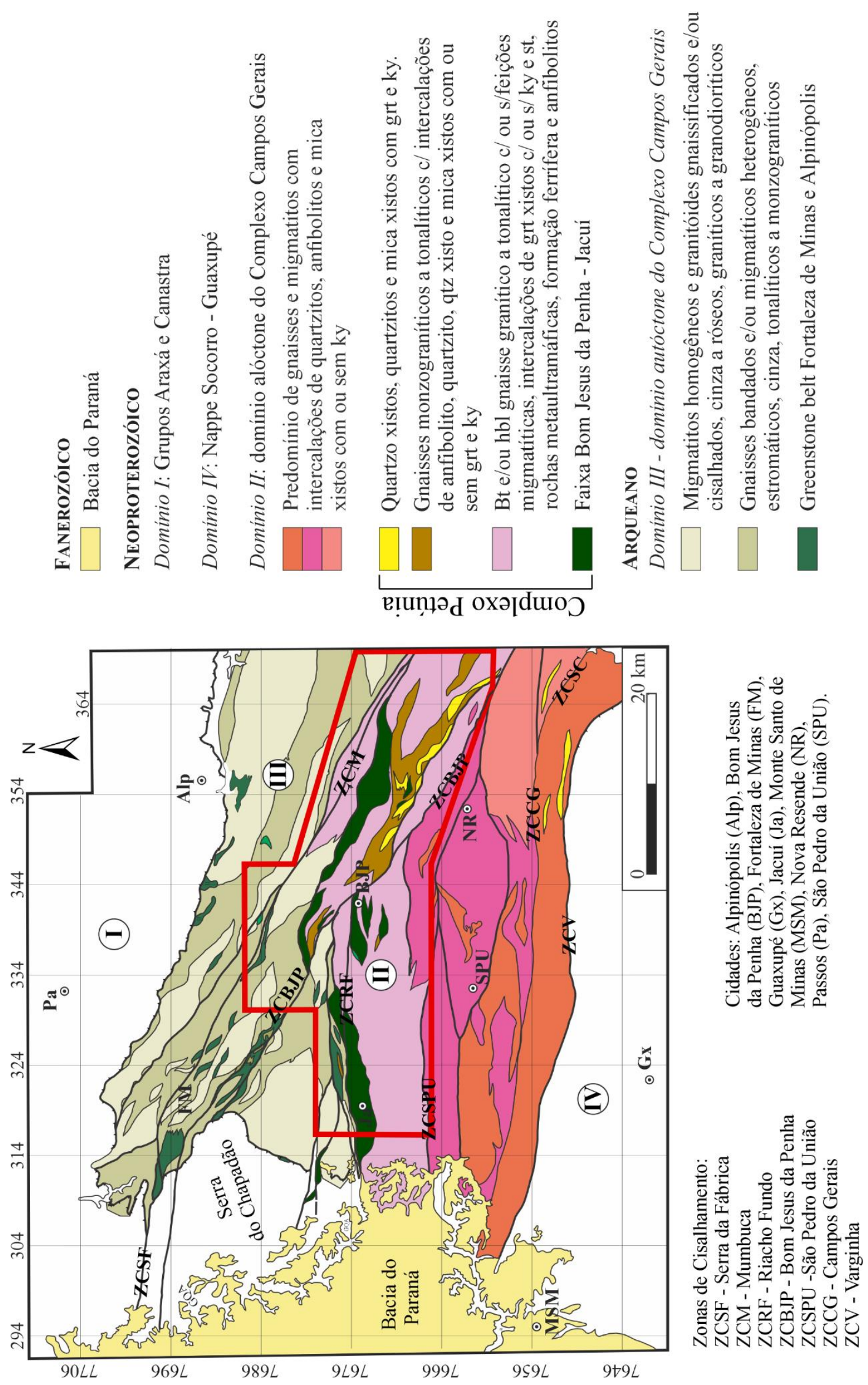

Figura 4.3: Esboço tectônico com destaque para os domínios Campos Gerais e Petúnia. Extraído e modificado de Zanardo (1992). O polígono vermelho indica a área de estudo. 
As rochas metaultramáficas e mineralizações associadas são característica distintiva entre os dois domínios. No Domínio Autóctone (norte) as rochas metaultramáficas apresentam filiação komatiítica, com textura spinifex localmente preservada, associadas a BIFs, anfibolito e mineralizações de Fe-Ni-Cu. Processo metassomático formou serpentinito e a presença de talco é restrita. Já no Domínio Alóctone (sul), BIFs são substituídas por formação ferrífero-manganesífera, com cromitito podiforme associado e nas rochas metaultramáficas predominam paragêneses com talco, clorita, tremolita, antofilita e hornblenda (Szábo, 1996).

Um dos problemas ao estabelecer o limite sul do Complexo Campos Gerais reside no fato de que as rochas pelíticas e psamíticas presentes no Domínio Alóctone (Sul) confundemse com as rochas metassedimentares neoproterozoicas e, inclusive, são correlacionadas aos Grupos Andrelândia (Roig, 1993), Carrancas (Campos Neto et al., 2004) e Araxá-Canastra (Morales, 1993). Unidades do sistema de Nappes Andrelândia ora são estendidas até a Bacia do Paraná, separando o CCG dos granulitos de Guaxupé (Vasconcelos, 1988), ora são interrompidas na região de Alfenas, e a partir daí, para oeste, o contato do CCG se dá diretamente com a nappe Socorro - Guaxupé (Hasui e Oliveira, 1984; Zanardo, 1992; Del Lama et al., 1994 e 2000).

Vários autores reconhecem a correlação entre o Complexo Campos Gerais e o Complexo Campos Belo (Turbay, 2010) ou Complexo Barbacena (e.g. Oliveira et al., 1983; Morales et al., 1983; Wernick e Artur, 1983; Artur e Wernick, 1984), ambos correspondem a terrenos granito-greenstone com diferenças litológicas pouco expressivas, mas que no Complexo Campos Gerais estão intensamente tectonizadas.

Uma compilação dos dados geocronológicos disponíveis para os Complexos Campos Gerais e Petúnia é apresentada na Tabela 4-1. As primeiras idades obtidas para o Complexo Campos Gerais foram determinadas a partir de isócronas $\mathrm{Rb}-\mathrm{Sr}$ em ortognaisse, com valores de cristalização dos protólitos a 2,8 Ga, e intrusões de granitoides a 2,1 e 1,9 Ga (Teixeira et al., 1989). No Domínio Autóctone (Sul), idades U-Pb em zircão usando ablação a laser e ICPMS indicam cristalização dos protólitos a 2,95 Ga para o Ortognaisse Campos Gerais, e 2,82 a 2,81 Ga, para o Ortognaisse Mandembo (Valeriano et al., 2006). Na região de Areado, ao sul de Alterosa, grãos de zircão do Ortognaisse Gaspar Lopes foram datados com ablação a laser e ICP-MS e fornecem idade de 2,07 Ga para a cristalização da rocha, mas não foi possível determinar a idade do metamorfismo (Lopes, 2013).

Quanto ao metamorfismo no CCG, gnaisses e migmatitos presentes no Domínio Alóctone (sul) exibem paragêneses indicativas de fácies granulito de alta pressão e o 
metamorfismo decresce para norte, chegando à fácies anfibolito de baixa pressão, caracterizada pela presença de sillimanita em rochas metassedimentares nos arredores de Alpinópolis. Reequilíbrio metamórfico para fácies xisto verde a anfibolito médio foi condicionado pela instalação das zonas de cisalhamento dúcteis/rúpteis de alto ângulo (Zanardo et al., 1990; Zanardo, 1992).

Rochas metassedimentares da Faixa Bom Jesus da Penha-Jacuí tiveram o pico metamórfico com temperaturas em torno de $650-700{ }^{\circ} \mathrm{C}$ e pressões de 6 a 7 kbar (Del Lama, 1993), enquanto granada anfibolito e granada-hornblenda gnaisse presentes na porção meridional do Domínio Alóctone (sul) alcançaram o pico metamórfico em condições entre 700 e $750{ }^{\circ} \mathrm{C}$ e pressões entre 10,5 e $13 \mathrm{kbar}$. Granada anfibolito, localizado a norte da Zona de Cisalhamento de Varginha, apresenta auge metamórfico em 830-900 ${ }^{\circ} \mathrm{C}$ de temperatura com 12,5-15 kbar de pressão, indicando ambiente de transição da fácies eclogito para granulito (Del Lama et al., 1994).

Tabela 4-1: Dados geocronológicos compilados para idades de cristalização de rochas dos Complexos Campos Gerais e Petúnia. Referências: 1-Kaefer et al. (1979); 2-Turbay (2010); 3-Lopes (2013), 4- Schrank \& Silva (1993), 5-Campos Neto et al., 2004; 6- Pinheiro (2013).

\begin{tabular}{llclc}
\multicolumn{1}{c}{ Método } & \multicolumn{1}{c}{ Rocha } & Idade (Ma) & \multicolumn{1}{c}{ Observações } & Ref. \\
\hline $\begin{array}{l}\text { Isócrona } \\
\mathrm{Rb} / \mathrm{Sr}\end{array}$ & Bt-hbl gnaisse & $1588 \pm 112$ & Próximo à Represa de Furnas & 1 \\
\hline $\mathrm{U}-\mathrm{Pb}(\mathrm{Zr})$ & $\begin{array}{l}\text { Ortognaisse } \\
\text { Campos Gerais }\end{array}$ & $2984 \pm 60$ & $\begin{array}{l}\text { Domínio Autóctone (Norte) } \\
\text { intercepto superior }\end{array}$ & 2 \\
\hline $\mathrm{U}-\mathrm{Pb}(\mathrm{Zr})$ & $\begin{array}{l}\text { Ortognaisse } \\
\text { Mandembo }\end{array}$ & $2812 \pm 15$ & $\begin{array}{l}\text { Domínio Autóctone (Norte) } \\
\text { intercepto superior }\end{array}$ & 2 \\
\hline $\mathrm{U}-\mathrm{Pb}(\mathrm{Zr})$ & $\begin{array}{l}\text { Ortognaisse } \\
\text { Mandembo }\end{array}$ & $587 \pm 20$ & $\begin{array}{l}\text { Domínio Autóctone (Norte) } \\
\text { intercepto inferior }\end{array}$ & 2 \\
\hline $\mathrm{U}-\mathrm{Pb}(\mathrm{Zr})$ & Metatonalito & $2775 \pm 13$ & $\begin{array}{l}\text { Domínio Autóctone (Norte) } \\
\text { intercepto superior }\end{array}$ & 2 \\
\hline $\mathrm{U}-\mathrm{Pb}(\mathrm{Tt})$ & Granito Itaxipé & $1976 \pm 29$ & $\begin{array}{l}\text { Domínio Autóctone (Norte) } \\
\text { intercepto superior }\end{array}$ & 2 \\
\hline $\mathrm{U}-\mathrm{Pb}(\mathrm{Zr})$ & Grt metagranito & $2073 \pm 7$ & $\begin{array}{l}\text { Domínio alóctone (Sul) } \\
\text { intercepto superior }\end{array}$ & 3 \\
\hline $\begin{array}{l}\mathrm{Isócrona} \\
\mathrm{Rb} / \mathrm{Sr}\end{array}$ & Gnaisse & $2900 \pm 110$ & Domínio Autóctone (Norte) & 4 \\
\hline $\mathrm{U}-\mathrm{Pb}(\mathrm{Zr})$ & $\begin{array}{l}\text { Hornblenda } \\
\text { gnaisse }\end{array}$ & $2947 \pm 80$ & $\begin{array}{l}\text { Complexo Petúnia } \\
\text { intercepto superior }\end{array}$ \\
\hline $\mathrm{Pb}-\mathrm{Pb}(\mathrm{Zr})$ & Metagabro & $2963 \pm 5,7$ & $\begin{array}{l}\text { Complexo Petúnia } \\
\text { concórdia age }\end{array}$ & 5 \\
\hline
\end{tabular}




\subsection{O Complexo Petúnia}

O Domínio Alóctone do CCG corresponde ao Complexo Petúnia, informalmente subdividido em três unidades: Unidade Gnáissica, formada por gnaisse fino com intercalações de metapelitos e anfibolito; Unidade Metassedimentar-Metaultramáfica, formada por metapelitos com proporções variáveis de granada e cianita, xisto com tremolita, clorita e antofilita, além de metadunito; e, Unidade Metapsamítica, formada por quartzitos e mica xistos (Figura 4.3; Roig, 1993).

Quatro fases deformacionais são reconhecidas no Complexo Petúnia. A fase $1\left(\mathrm{~F}_{1}\right)$ foi preservada como dobras isoclinais e intrafoliais $\mathrm{D}_{1}$ com foliação plano axial em biotita gnaisses e xistos pelíticos, arcos poligonais em biotitas e porfiroblastos de granada sin cinemática com foliação interna preservada. $\mathrm{F}_{2}$ formou a foliação principal, regional $\mathrm{S}_{2}$, e as zonas de cisalhamento dúcteis. $F_{3}$ desenvolveu dobras em chevron a isópacas e uma lineação de crenulação $\mathrm{Lcr}_{3}$, porem, sem desenvolver $S_{3}$, e a $F_{4}$ representa a fase rúptil, onde foram desenvolvidos os sistemas de Falhas de Mumbuca e Bom Jesus da Penha, ambas sub-verticais e de direção geral NW-SE (Roig, 1993).

Feições texturais preservadas da deformação nas rochas máfico-ultramáficas sugerem que elas correspondam a corpos diferenciados compatíveis tanto com complexos estratiformes intensamente tectonizados, como com complexos ofiolíticos (Roig, 1993), neste caso interpretados como prováveis restos de crosta oceânica neoproterozoica (Choudhuri et al., 1995). "O contato entre as unidades é marcado por descontinuidades tectônicas expressas geomorfologicamente por nítidas quebras de relevo" (Roig, 1993).

Granada anfibolito presente na Unidade Gnáissica é compatível com basaltos N, EMORB, até de arco vulcânico, sugerindo formação a partir de magmas de composições transicionais a partir de fonte mantélica fértil em ambientes dinâmicos associados a zonas de suprasubducção (Pinheiro, 2013).

Condições metamórficas para o Complexo Petúnia foram determinadas apenas para granada anfibolito, cujas condições são de 7,5-8 kbar de pressão e $635-675^{\circ} \mathrm{C}$ de temperatura estimada no par hornblenda-plagioclásio (Pinheiro, 2013). Nos metapelitos, paragêneses $\mathrm{Bt}+\mathrm{Qtz}+\mathrm{Pl}+\mathrm{Grt}+\mathrm{St}+\mathrm{Ky} \pm \mathrm{Ms}$, indicam condições metamórficas sob fácies anfibolito, atuante também nas rochas metaultramáficas, com formação de antofilita a partir de paragêneses mais antigas formadas por Ol + Opx + Spl (Roig, 1993). 


\subsection{As Faixas Vulcanossedimentares}

As sequências vulcanossedimentares (Figura 4.4) presentes no Complexo Campos Gerais foram inicialmente reunidas sob a denominação de Sequência Vulcanossedimentar Morro do Ferro - SVSMF (Teixeira \& Danni, 1979), posteriormente subdividida nas Faixas Fortaleza de Minas, Alpinópolis e Bom Jesus da Penha-Jacuí (Teixeira et al., 1987).

A Faixa Fortaleza de Minas, ou Greenstone Belt Fortaleza de Minas, ocorre encaixada no Complexo Campos Gerais, sua coluna estratigráfica é dividida em três unidades que compreendem rochas ultramáficas, máficas e metassedimentares com metamorfismo em fácies xisto verde a anfibolito (Teixeira \& Danni, 1979). Idades de 2,86 Ga foram determinadas através de isócrona $\mathrm{Sm}-\mathrm{Nd}$ em komatiitos da unidade basal da sequência, sendo comparável, ou marginalmente mais jovem que o Greenstone Belt Piumhí (ca. 2,9 - 3,1 Ga) (Pimentel \& Ferreira Filho, 2002).

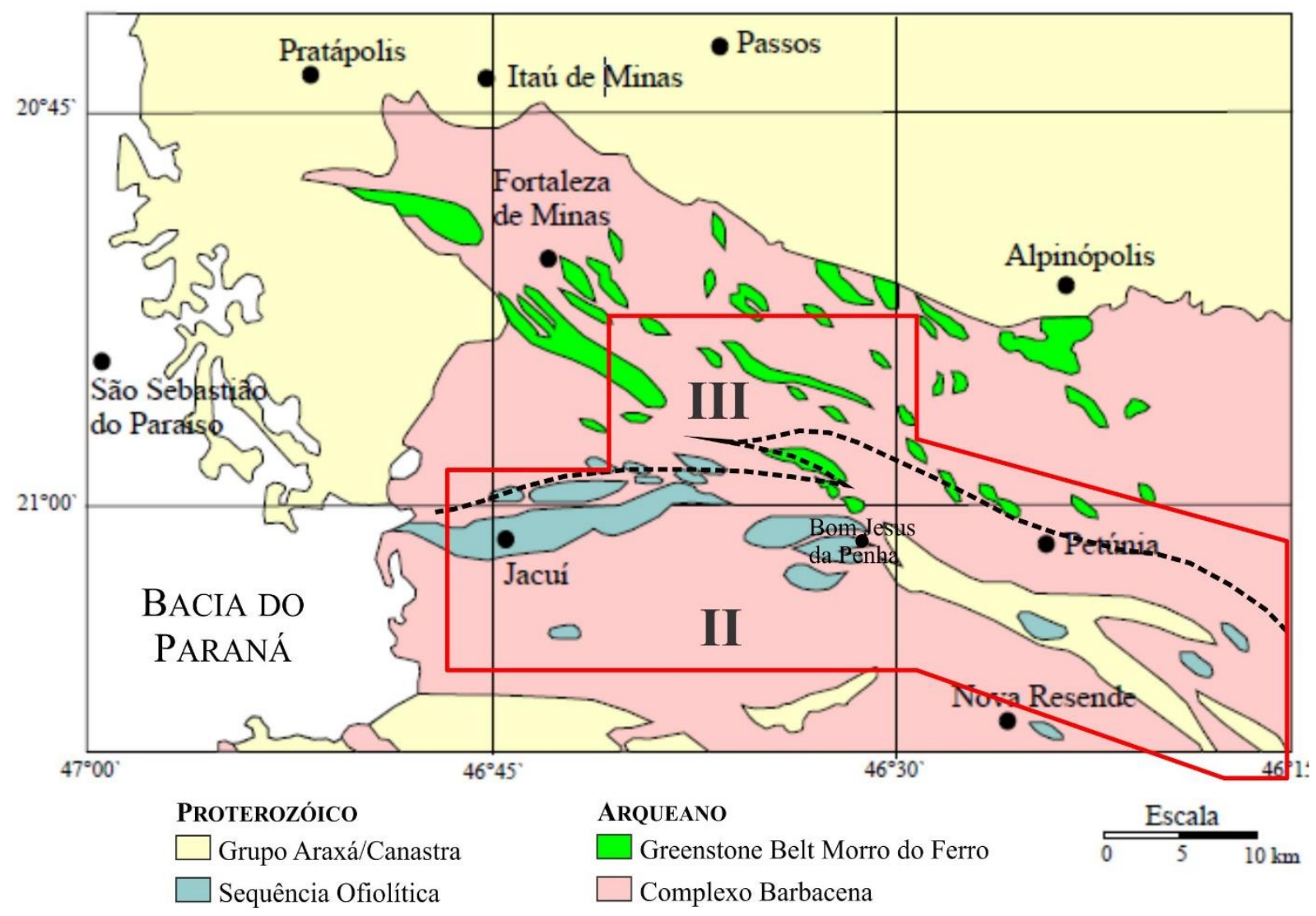

Figura 4.4: Mapa geológico simplificado com destaque para as faixas vulcanossedimentares associadas aos complexos Campos Gerais e Petúnia. A linha tracejada indica a divisão entre os domínios II e III do Complexo Campos Gerais, como proposto por Zanardo (1992), e o polígono vermelho indica a localização aproximada da área de estudo. A sequência ofiolítica equivale a Faixa Bom Jesus da Penha-Jacuí. Extraído e modificado de Feola (2004). 
A Sequência Vulcanossedimentar Alpinópolis, ou Greenstone Belts Alpinópolis (Szabó, 1989; Carvalho, 1990; Carvalho et al., 1993; Szabó, 1996), corresponde a Faixa Serra do Dondó, a norte, formada por rochas metaultramáficas de filiação komatiítica, com textura spinifex preservada, em meio a ortognaisses tonalíticos-granodioríticos cisalhados, mas com núcleos porfiríticos preservados (Szabó, 1996).

A Faixa Bom Jesus da Penha-Jacuí corresponde à faixa que ocorre ao sul da Faixa Fortaleza de Minas, onde as rochas metaultramáficas passam a estar associadas a rochas metavulcânicas básicas e metassedimentares aluminosas (Teixeira et al., 1987). A faixa é dividida em duas unidades: Colônia, formada por xisto magnesiano, anfibolito, metachert, gondito e granada-cianita micaxisto; e, Serra do Ibituruna, com o mesmo conteúdo litológico, mas diferindo nas proporções, com predomínio de rochas metassedimentares psamo-pelíticas (Szábo, 1996).

As rochas metaultramáficas da Faixa Bom Jesus da Penha-Jacuí podem corresponder à zona de sutura rotacionada pela ação de zonas de cisalhamento (Zanardo, 1992) com complexos de subducção resultantes da colisão oblíqua entre o Bloco Paraná e outras placas durante o Ciclo Brasiliano, seguida de convergência para E-NE, envolvendo zonas de cisalhamento dúctil, de cavalgamento e transcorrência, sob condições de alta pressão e temperatura, registrada nas rochas da Nappe Três Pontas-Varginha e posteriormente na direção E-W (Soares et al., 1990 e 1991). Neste contexto, rochas metaultramáficas do Domínio Alóctone do CCG, de caráter diferenciado, com cromitito podiforme e rocha metabásica com assinatura de basalto tipo MORB (Zanardo, 1992) estão associadas, o que sugere que correspondam à corpos diferenciados, compatíveis tanto com complexos estratiformes intensamente tectonizados, como com complexos ofiolíticos (Roig e Schrank, 1992; Roig, 1993), neste caso interpretados como prováveis restos de crosta oceânica neoproterozoica (Choudhuri et al., 1995). 


\section{ASPECTOS DA GEOLOGIA LOCAL}

\subsection{O Complexo Petúnia}

A compartimentação do Complexo Petúnia em unidades litoestratigráficas é dificultada pela presença das numerosas zonas de cisalhamento e falhas que ocorrem na região. A divisão litológica nas unidades Metapsamítica, Metapelítica - Metaultramáfica e dos Gnaisses "Indiferenciados”, apresentada por Roig (1993), tem caráter informal e foi revisada nesta tese.

Para as unidades Metapsamítica e Metapelítica - Metaultramáfica, foram adotadas as nomenclaturas originais propostas por Teixeira et al. (1987), Unidades Serra do Ibituruna e Colônia, respectivamente, e a Unidade dos Gnaisses "Indiferenciados" foi desmembrada nas Unidades Petúnia e Gnaisse Ribeirão da Conquista. A seguir será apresentada breve descrição das unidades de mapeamento da região.

A Unidade Serra do Ibituruna, é formada por muscovita quartzito branco a bege e muscovita - quartzo xisto, bege acinzentado (Figura 5.1a) que afloram em cristas que sustentam as serras da região, Serra do Estanho, Serra Pelada e Morro do Ibituruna, entre as mais expressivas, e que compõem alinhamento NW-SE, limitado a sul pela Falha/Zona de Cisalhamento Bom Jesus da Penha (Mapa Geológico - Apêndice C). Ao longo das encostas das serras é comum a presença de depósitos de tálus, com blocos e matacões subangulosos em meio a matriz areno-siltosa. As rochas da unidade apresentam variável grau de alteração, de baixo a alto, e afloram no chão, em canaletas e taludes de corte das estradas.

A foliação do muscovita - quartzo xisto exibe duas direções de crenulação superimpostas, definindo padrão de interferência em domos-e-bacias, no entanto, pouco foi preservado dessas estruturas, não sendo possível melhor caracterizar esses eventos deformacionais. Intercalações de lentes granoblásticas de espessura máxima de $2 \mathrm{~cm}$, descontínuas ou configurando dobras apertadas com espessamento de charneira e $S_{2}$ plano axial são comuns.

A Unidade Colônia é caracterizada por uma sub-unidade metapelítica dominante, formada por cianita-estaurolita-muscovita-granada-biotita xisto e muscovita-cianita-granadabiotita xisto com intercalações subordinadas de quartzito placoso, formação ferrífera, gonditos e muscovita-quartzo xisto e uma sub-unidade metaultramáfica associada, que pode ocorrer como intercalações centimétricas a decimétricas em meio aos metapelitos. Quando frescas, com exceção do talco xisto, que exibe cor branca, essas rochas exibem cor verde escuro a verde claro - amarelado. Já quando alteradas exibem cor amarelo ocre e desenvolvem solos 
residuais argilosos de cor marrom escuro, característica muitas vezes usada como critério de mapeamento.

Os xistos pelíticos raramente afloram em blocos e matacões com grau de alteração baixo a médio, o que impossibilitou separá-los no mapa geológico. $\mathrm{O}$ reconhecimento dos xistos pelíticos foi feito principalmente pelos solos residuais jovens, ou saprolíticos, que ocorrem em canaletas, taludes de corte e no próprio chão das estradas de terra. São solos siltoargilosos de cor avermelhada com estrutura xistosa preservada, onde muitas vezes é possível obter medidas estruturais de planos de foliação e lineações de estiramento e de crenulação. Na ausência de rocha sã, granada e cianita, quando presentes, ocorrem como fases primárias residuais e superficiais sobre o solo. Granada chega a ter $1 \mathrm{~cm}$ de diâmetro, enquanto cianita atinge até $2 \mathrm{~cm}$ ao longo do eixo c.

A Unidade Petúnia tem a maior distribuição em área e é formada por gnaisses tonalíticos a granodioríticos cinza, homogêneos (Figura 5.1b). Os litotipos são reconhecidos apenas em raros blocos e matacões de rocha com variável grau de alteração. Em sua área de ocorrência predominam solos residuais jovens, ou saprolíticos, onde o bandamento gnáissico foi preservado (Figura 5.1c) e intercala bandas avermelhadas, silto-arenosas, de espessura milimétrica a centimétricas, bandas de argila vermelho-arroxeada com até $1 \mathrm{~cm}$ de espessura, bandas centimétricas de argila branca (caulinita) e bandas centimétricas silto-argilosas de cor amarelo-ocre. Melhores exposições dos perfis de solo residual de gnaisse ocorrem em cicatrizes de escorregamento em taludes de corte das estradas e, eventualmente, em sulcos e ravinas nas canaletas das estradas.

Intercalações de rochas metaultramáficas e de corpos de metagabro e anfibolito são comuns na unidade e têm como diferencial o fato de apresentarem menor grau de alteração, preservando-se como cristas de rocha sã a pouco alterada, em meio ao solo residual de gnaisse (Figura 5.1d), o que pode, em muitas regiões, levar à superestimação das espessuras de suas camadas, como ocorre nos mapas existentes na região. Em regiões mais afetadas pelas zonas de cisalhamento, essas camadas de rochas metaultramáficas aparecem como boudins, onde é possível observar a passagem para clorititos formados durante o metassomatismo, resultando em zonas de blackwalls. Nessas regiões também é comum a presença veios de quartzo de espessura milimétrica a decimétrica. Metagabro e anfibolito ocorrem como corpos lenticulares ou arredondados que ressaltam na topografia na forma de morrotes formados por solo residual com blocos e matacões (Figura 5.1e). 

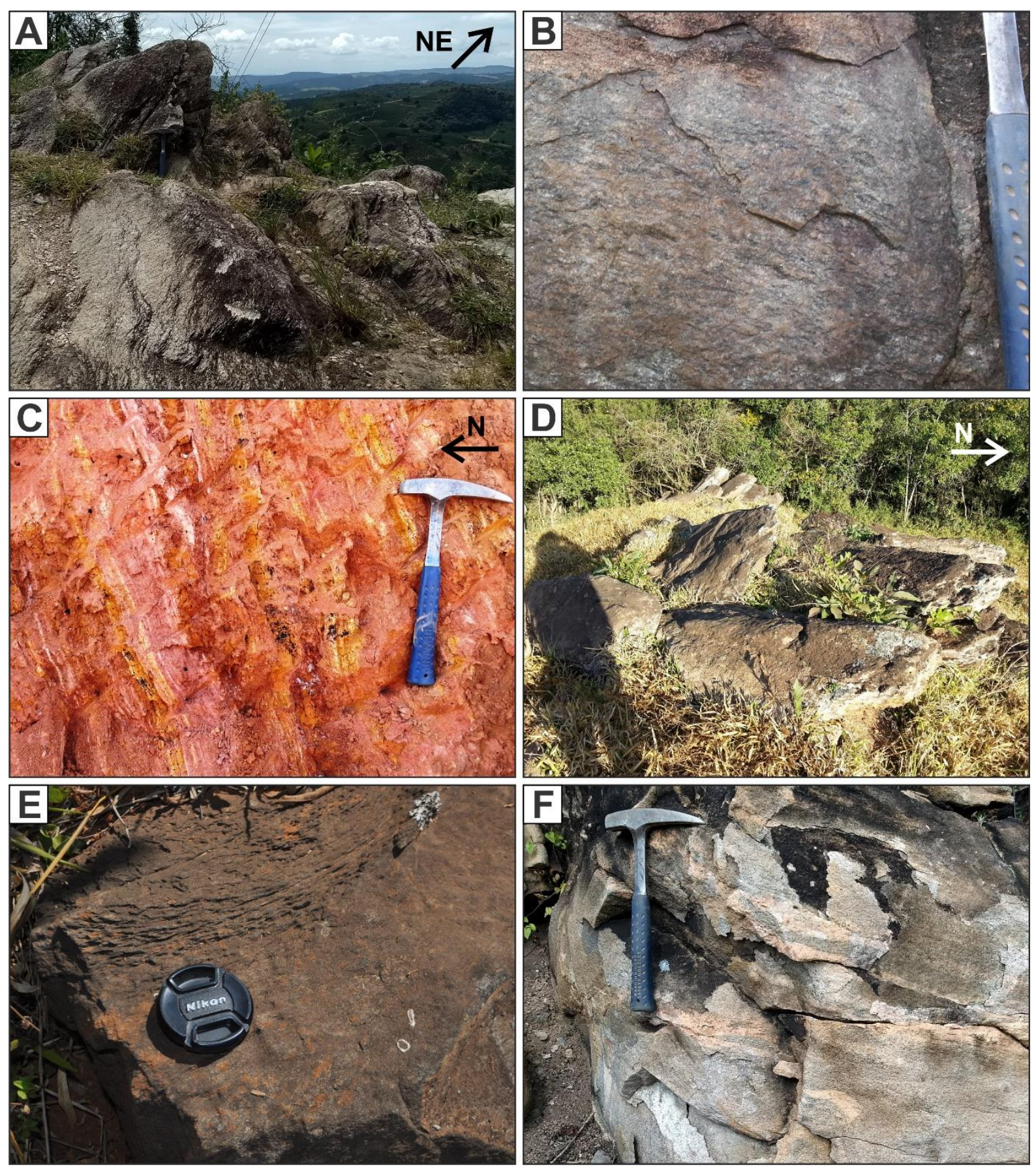

Figura 5.1: a) Cristas de muscovita - quartzo xisto da Unidade Serra do Ibituruna, ponto CP-286; b) Hornblenda - biotita gnaisse granodiorítico da Unidade Petúnia, ponto CP-105; c) Exposição típica do gnaisse da Unidade Petúnia em talude de corte da estrada, ponto CP-54; d) Cristas de xistos ultramáficos in situ, do outro lado da estrada, ponto CP-54; e) Bloco de boudin de anfibolito da Unidade Petúnia, ponto CP-39. Notar núcleo maciço e bordas deformadas; f) Matacão de biotita gnaisse fresco - Gnaisse Ribeirão da Conquista, ponto CP-265.

O Gnaisse Ribeirão da Conquista, ao contrário dos gnaisses da Unidade Petúnia, aflora em blocos e matacões de rocha pouco alterada ao longo das encostas (Figura 5.1f) e como cristas in situ no chão e nos taludes de corte das estradas. Consiste em biotita gnaisse cinza rosado com bandamento heterogêneo. Quando próximo às zonas de cisalhamento exibe foliação milonítica regular. 
Além destas quatro unidades, que já integravam o Complexo Petúnia, uma quinta unidade foi definida nesta tese. Trata-se do Metagranito Bom Jesus da Penha, que, assim como o Gnaisse Ribeirão da Conquista, aflora em blocos e matacões de rocha sã a pouco alterada. As relações de contato do Metagranito Bom Jesus da Penha com os gnaisses da Unidade Petúnia indicam que aquele trata-se de um corpo intrusivo, isotrópico, formado por biotita metagranito maciço, às vezes com foliação incipiente, de cor cinza médio (Figura $\mathbf{6 c}$ Apêndice A).

\subsection{A Faixa Mamote}

Os litotipos descritos a seguir, em conjunto com a Unidade Petúnia e o Gnaisse Ribeirão da Conquista, constituem o conjunto reunido por Zanardo (1992) como "Unidade GMA" (ou Gnaissic Unit - Figura 2 - Apêndice A), formada por gnaisses diversos, ou como Unidade São Vicente, predominantemente metassedimentar (CODEMIG, 2015). No entanto, ao sul das Zonas de Cisalhamento de Jacuí e Bom Jesus da Penha (Apêndice C) a frequência das intercalações de xistos pelíticos, formações ferríferas, anfibolitos e rochas metaultramáficas é muito baixa, ou mesmo ausente para alguns desses litotipos, em relação à disposição das rochas do Complexo Petúnia típico. Feições migmatíticas, tais como bolsões irregulares e bandas, dobradas ou não, formadas por leucossoma granítico, são quase sempre presentes, a frequência de afloramentos de rocha é maior e são distintos os padrões de deformação.

Ao sul da zona de cisalhamento de Jacuí ocorre uma faixa onde o litotipo dominante é hornblenda - biotita metatexito estromático cinza escuro, fino, com leucossoma branco. A essa faixa foi dado o nome de Faixa Mamote, em referência ao Ribeirão do Mamote, que atravessa a região. Intercalações de corpos lenticulares de anfibolito, quartzito e gondito são subordinadas e não mapeáveis na escala adotada. Hornblenda - biotita metatexito ocorre em blocos e matacões de rocha sã a pouco alterada (Figura 5.2a) e seu perfil de solo residual é observado apenas em taludes de corte das estradas e rodovias, onde é possível identificar a estrutura estromática preservada (Figura 5.2b). A Faixa Mamote é limitada a sul por biotita metatexito cinza-rosado, com leucossoma rosado, atribuído à Nappe Socorro-Guaxupé. Na área as rochas afloram ao longo da Serra do Zundum, em taludes de corte da rodovia BR-146 e em abundantes blocos e matacões com baixo grau de alteração (Figuras 5.2c e 5.2d). 

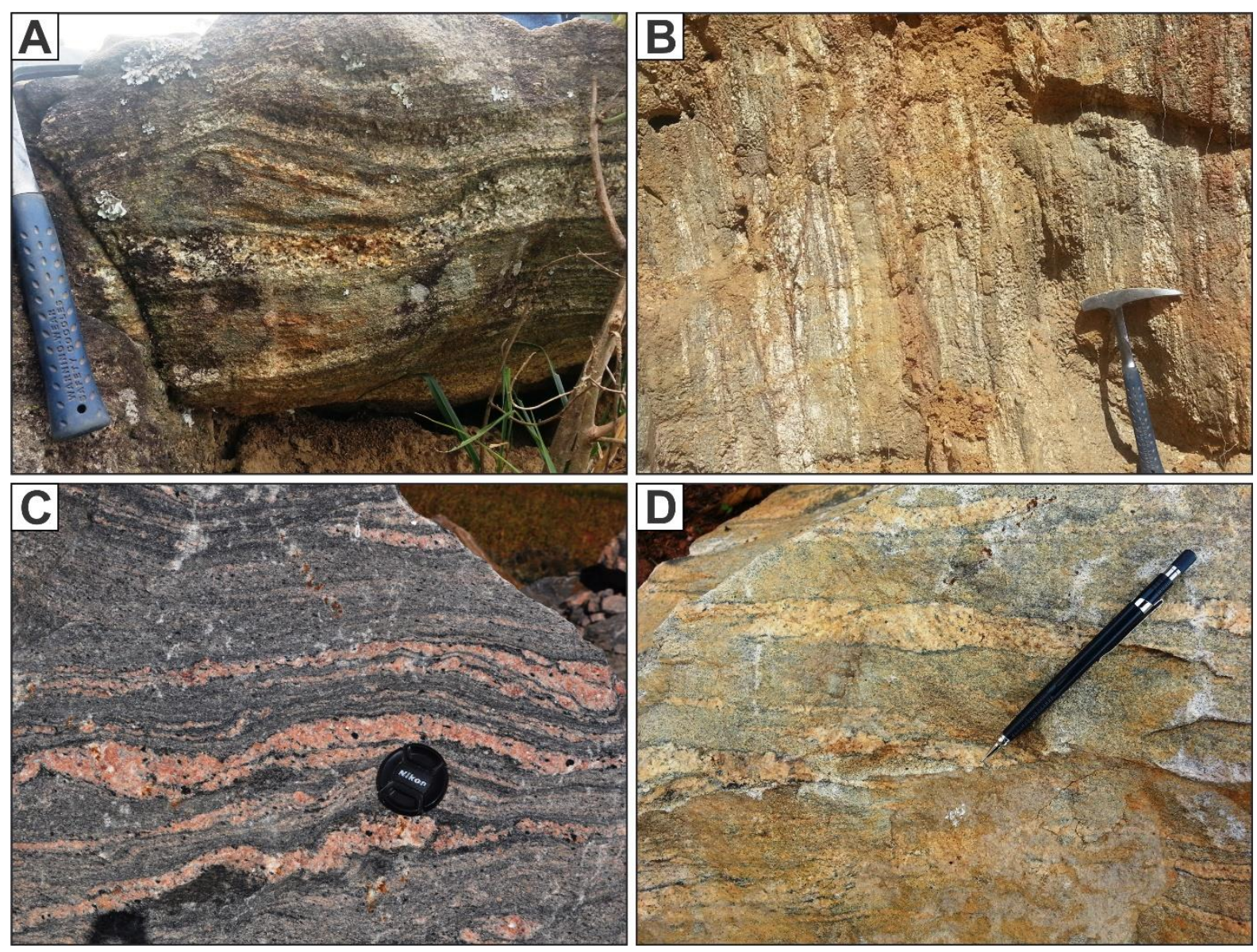

Figura 5.2: Hornblenda-biotita metatexito estromático da Faixa Mamote, em (a) fresco, ponto CP-65 e em (b) saprolítico com estrutura preservada e foliação milonítica de alto ângulo, ponto CP-83; Biotita metatexito cinza rosado da Nappe Socorro - Guaxupé, em (c) blocos frescos em corte da rodovia BR-146, ponto CP-34 e em (d) matacão de rocha pouco alterada, ponto CP-77. 


\title{
6 REDEFININDO O COMPLEXO PETÚNIA
}

Artigo a ser submetido ao periódico Journal of South American Earth Science. O conteúdo está disponível no Apêndice A.

The Archean and Paleoproterozoic rocks of the Petunia Complex and its relationship with the Campos Gerais Complex as a basement window in the Brasília Orogen, southeastern Minas Gerais, Brazil

Rafaela Machado Gengo (rafaela.gengo@usp.br)

Vinicius Hector Abud Louro (vilouro@usp.br)

Renato de Moraes (rmoraes@ usp.br)

Gergely Andres Julio Szabó (gajszabo@usp.br)

Elton Luiz Dantas (elton@unb.br)

Pedro Machado Simões (pedro.simoes@alumni.usp.br)

\begin{abstract}
On the southern margin of the São Francisco Craton, between Neoproterozoic nappes of the Southern Brasília Orogen, there is a structural window defined by elongated belts in the WNW-ESE direction, formed by fragments of rocks that were compartmentalized by a complex arrangement of overthrusts and high angle ductile-ruptile shear zones. We integrated field data with aerogeophysical surveys and U-Pb zircon dating to position the rocks of the Petunia Complex in the regional tectonic context of the evolution of the southern margin of the São Francisco Craton. The Petúnia Complex is characterized by the highest degree of deformation and the highest incidence of supracrustal units and tectonically imbricated metaultramafic rocks, so that they result in a radiometric signature characterized by low UTh-K counts.

In the Petúnia Complex two Archean units were identified: Petúnia Unit (2993 \pm 6 Ma) and Ribeirão da Conquista Gneiss (2835 $\pm 12 \mathrm{Ma}$ ). These units integrate, along with the orthogneisses of the Campos Gerais Complex, the reworked Archean infrastructure in the final stages of Minas Orogenesis, recorded in the Petúnia Complex through the Bom Jesus da Penha Metagranite (2004 \pm 5 Ma). Subsequently, through the reactivation of deep shear zones, the transport to NW along the Bom Jesus da Penha Shear Zone records the final tectonic accommodation, in response to the deformation from the transport to ENE of the Neoproterozoic nappes of the Southern Brasília Orogen.
\end{abstract}




\section{PROVENIÊNCIA SEDIMENTAR DA UNIDADE SERRA DO IBITURUNA}

A Unidade Serra do Ibituruna é formada por muscovita quartzito e muscovitaquartzo xisto milonítico (Figura 5.1a), cuja distribuição é estruturalmente controlada pelas Zonas de Cisalhamento de Riacho Fundo e de Bom Jesus da Penha. As rochas são formadas essencialmente por muscovita (10-40\%) e quartzo (60-90\%) e os minerais acessórios incluem cianita, zircão, monazita, rutilo, apatita e minerais opacos. Cianita é restrita aos leitos lepidoblásticos e pode compor intercalações de níveis decimétricos de rutilo-quartzomuscovita cianita fels (Figura 7.1a).

No muscovita-quartzo xisto milonítico, a muscovita está estirada ao longo das bandas de cisalhamento e localmente ocorre concentrada ao longo de C', conferindo textura lepidoblástica, às vezes com relíquias de crenulações anteriores à foliação milonítica (Figura 7.1b). Os cristais de muscovita também preservam superfícies dobradas $D_{1}$ com $S_{2}$ em posição plano axial, ou somente foram recristalizados na forma de peixe de mica. A textura granoblástica é dada por quartzo de granulação fina a média que define domínios com distintos registros de recristalização dinâmica, sugerindo superposição de deformações progressivamente em regimes de menor temperatura, incluindo contatos interlobados/ameboides formados por migração de borda (GBM - Grain Boudary Migration) em maior temperatura, domínios com cristais exibindo mesma orientação ótica, rotacionados durante a recristalização (SGR - Subgrain Rotation Recrystallization - Figura 7.1c-d), até recristalizações de baixa temperatura através de bulging (BLG-Bulging Recrystallization).

Todas as amostras investigadas, três de muscovita-quartzo xisto (CP-05, CP-27 e CP35) e uma de muscovita quartzito (CP-98B), possuem alta proporção de cristais de zircão, diferindo apenas na fração das populações presentes de uma amostra para outra (Tabela 7-1).

Tabela 7-1: Distribuição das populações de cristais de zircão nas amostras, com a quantidade de cristais datados por população e o número de análises válidas para a avaliação da proveniência sedimentar.

\begin{tabular}{|c|c|c|c|c|c|c|c|c|c|c|c|c|}
\hline \multirow{2}{*}{ População } & \multicolumn{3}{|c|}{ CP-05 } & \multicolumn{3}{|c|}{ CP-27 } & \multicolumn{3}{|c|}{ CP-35 } & \multicolumn{3}{|c|}{ CP-98B } \\
\hline & total & datado & válido & total & datado & válido & total & datado & válido & total & datado & válido \\
\hline 1 & 22 & 3 & 3 & 95 & 43 & 13 & 126 & 69 & 15 & 58 & 26 & 4 \\
\hline 2 & 97 & 52 & 34 & 63 & 35 & 15 & 47 & 24 & 13 & 70 & 45 & 29 \\
\hline 3 & 27 & 16 & 13 & 13 & 9 & 2 & 8 & 8 & 3 & 23 & 7 & 7 \\
\hline 4 & 54 & 21 & 18 & 51 & 24 & 6 & 49 & 10 & 3 & 60 & 38 & 9 \\
\hline Total & 200 & 92 & 68 & 222 & 111 & 39 & 230 & 111 & 35 & 211 & 116 & 49 \\
\hline
\end{tabular}



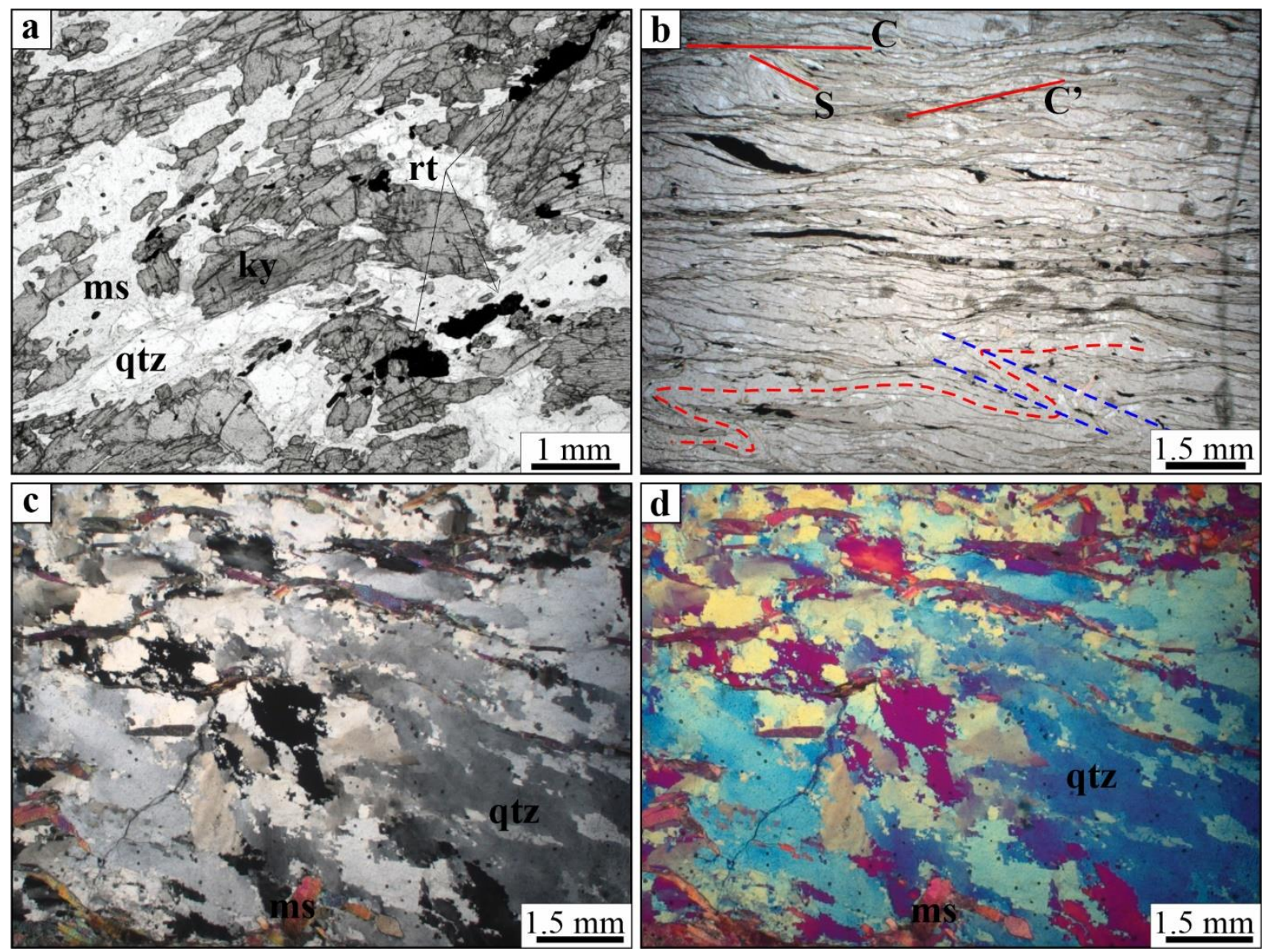

Figura 7.1: a) Rutilo-quartzo-muscovita-cianita fels, amostra CP-244; b) Foliação milonítica em muscovitaquartzo xisto, amostra CP-35 com aumento de 1,25x; c) Muscovita quartzito, amostra CP-98B, com polarizadores cruzados e aumento de 1,25x. Notar domínios com extinção próxima; d) Muscovita quartzito, amostra CP-98B, om placa de gipso e aumento de 1,25x. Notar domínios com mesma orientação óptica, recristalizados por SGR (Subgrain Rotation Recrystallisation).

Quatro populações de zircão foram distinguidas com base no hábito e cor dos cristais:

(i) População formada por cristais prismáticos de cor amarela, escurecida pela metamictização, com inclusões de minerais opacos e apatita. Os cristais possuem terminações subarredondadas, relações de comprimento/largura de 2:1 a 3:1 e ocorrem em duas frações, uma de 140-200 $\mu \mathrm{m}$, outra de 250-300 $\mu \mathrm{m}$. Internamente predominam texturas com zoneamento oscilatório concêntrico ou irregular e raros cristais com setores zonados, ambos exibindo média a baixa intensidade de luminescência (CL) e recristalização pontual. Parte desses cristais exibem zonas de recristalização progressiva que truncam o zoneamento oscilatório (cristais 23, CP-27 e 56, CP-98B, Figura 7.2). Nessa população também estão incluídos cristais de alta luminescência, geralmente aqueles com maior grau de metamictização, com ou sem núcleo herdado de baixa luminescência e fraturas radiais (cristais 90, CP-35 e 15, CP-98B, Figura 7.2); 


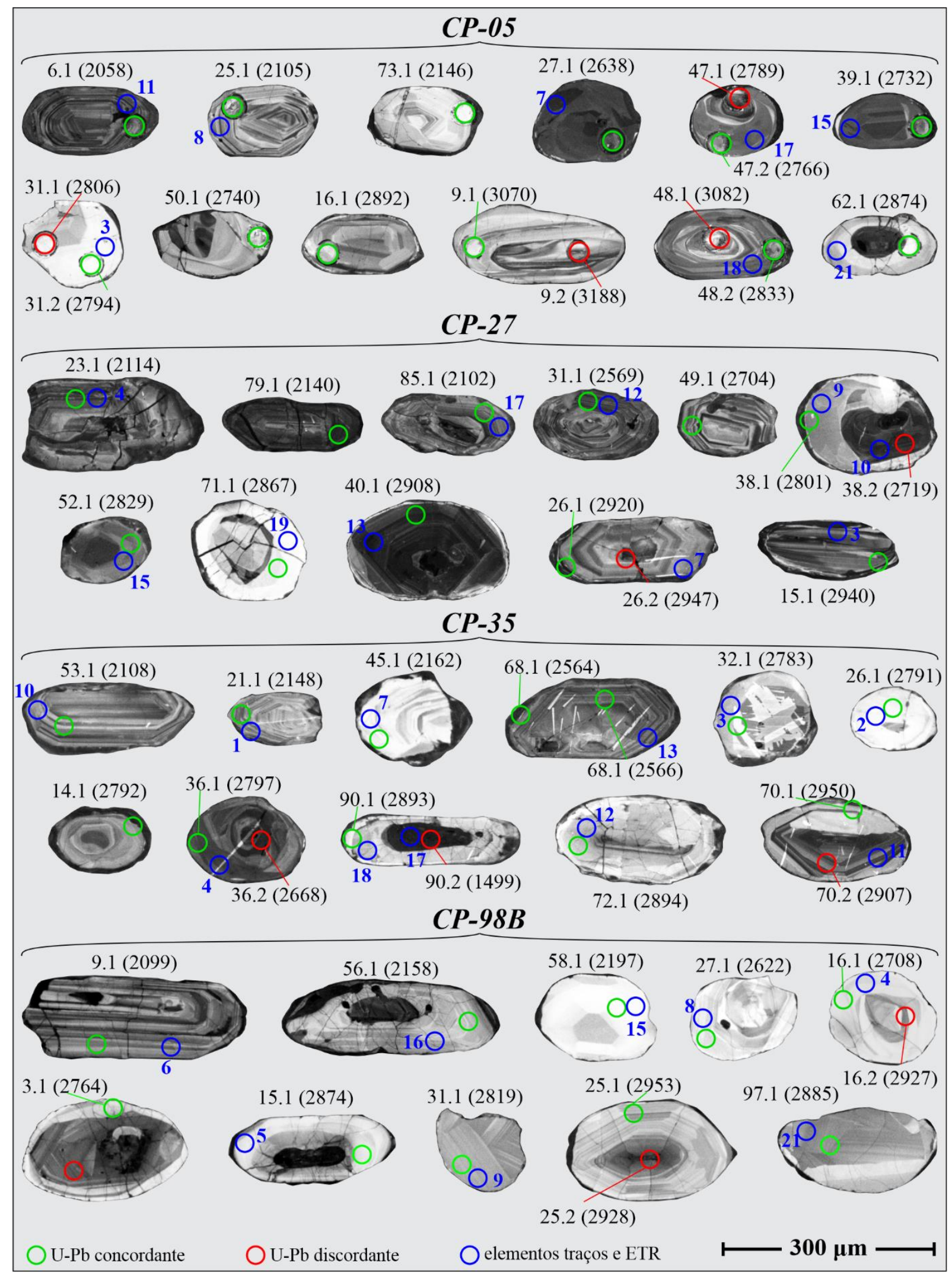

Figura 7.2: Imagens de catodoluminescência de cristais detríticos de zircão representativos das amostras da Unidade Serra do Ibituruna. Estão indicadas as idades ${ }^{207} \mathrm{~Pb} /{ }^{206} \mathrm{~Pb}$ em Ma. Os círculos verdes e vermelhos representam os locais onde foram feitas as datações, concordantes e discordantes, respectivamente. Os círculos azuis representam os locais onde foram feitas as análises de elementos traço e terras raras. 
(ii) População formada por cristais ovoides a arredondados, com tamanho entre $100 \mathrm{e}$ $230 \mu \mathrm{m}$, incolores a levemente amarelados, límpidos, às vezes com inclusões de apatita e de minerais opacos. Internamente predominam cristais homogêneos com luminescência muito alta com núcleo herdado preservado (31, CP-05 e 16, CP-98B, Figura 7.2) ou em variável grau de reabsorção (26, CP-35 e 58, CP-98B, Figura 7.2). Núcleos herdados exibem zoneamento oscilatório, irregular ou tipo fir-tree zoning (cristal 27, CP-05, Figura 7.2), sempre com luminescência média a alta. Nessa população também estão incluídos cristais com zoneamento oscilatório, luminescência média, sem núcleo herdado e bordas de sobrecrescimento metamórfico;

(iii) População formada por cristais prismáticos incolores, límpidos, com raras inclusões. Possuem terminações subarredondadas, tamanho entre 90 e $160 \mu \mathrm{m}$ e relação comprimento/largura de 2:1 a 3:1. Internamente predominam cristais com zoneamento oscilatório ou setores zonados, ambos com delgado sobrecrescimento metamórfico de alta luminescência. Cristais homogêneos com luminescência muito alta e resquícios de núcleos herdados são raros.

(iv) População formada por cristais ovoides de cor amarela, escurecidos pela metamictização, com tamanho entre 170 e $230 \mu \mathrm{m}$. Internamente exibem as mesmas texturas que os cristais da população (ii), mas com menor luminescência, com exceção dos cristais intensamente metamictizados, que exibem luminescência muito alta. Alguns núcleos herdados apresentam zoneamento convoluto.

\subsection{U-Pb em zircão detrítico}

Os dados com concordância dentro do limite $100 \pm 10 \%$ obtidos em zircão detrítico das amostras da Unidade Serra do Ibituruna mostram distribuição bimodal ao longo da concórdia (Figura 7.3) e datações ${ }^{207} \mathrm{~Pb} /{ }^{206} \mathrm{~Pb}$ similares nos diagramas de frequência e probabilidade relativa (Figura 7.4a-d), não havendo relações entre as idades obtidas com as populações de cristais identificadas.

A distribuição das idades compreende um pico menor para idades do período Riaciano, entre $2058 \pm 23$ e $2202 \pm 26 \mathrm{Ma}$, com 2 o entre 13 e $49 \mathrm{Ma}$, um hiato de registro no período Sideriano e um intervalo com picos maiores de idades neo a mesoarqueanas (Figura 7.4). Nas amostras CP-27 e CP-35 esse pico não está igualmente representado em virtude do menor número de análises concordantes (Tabela 2-3, Capítulo 2). Cristais com idades neo e mesoarqueanas correspondem respectivamente à 42 e $33 \%$ do conjunto e variam de $2521 \pm 18$ a $2799 \pm 29$ Ma e de $2800 \pm 42$ a $3070 \pm 22$ Ma, com 2 ơ entre 12 e 43 Ma. 


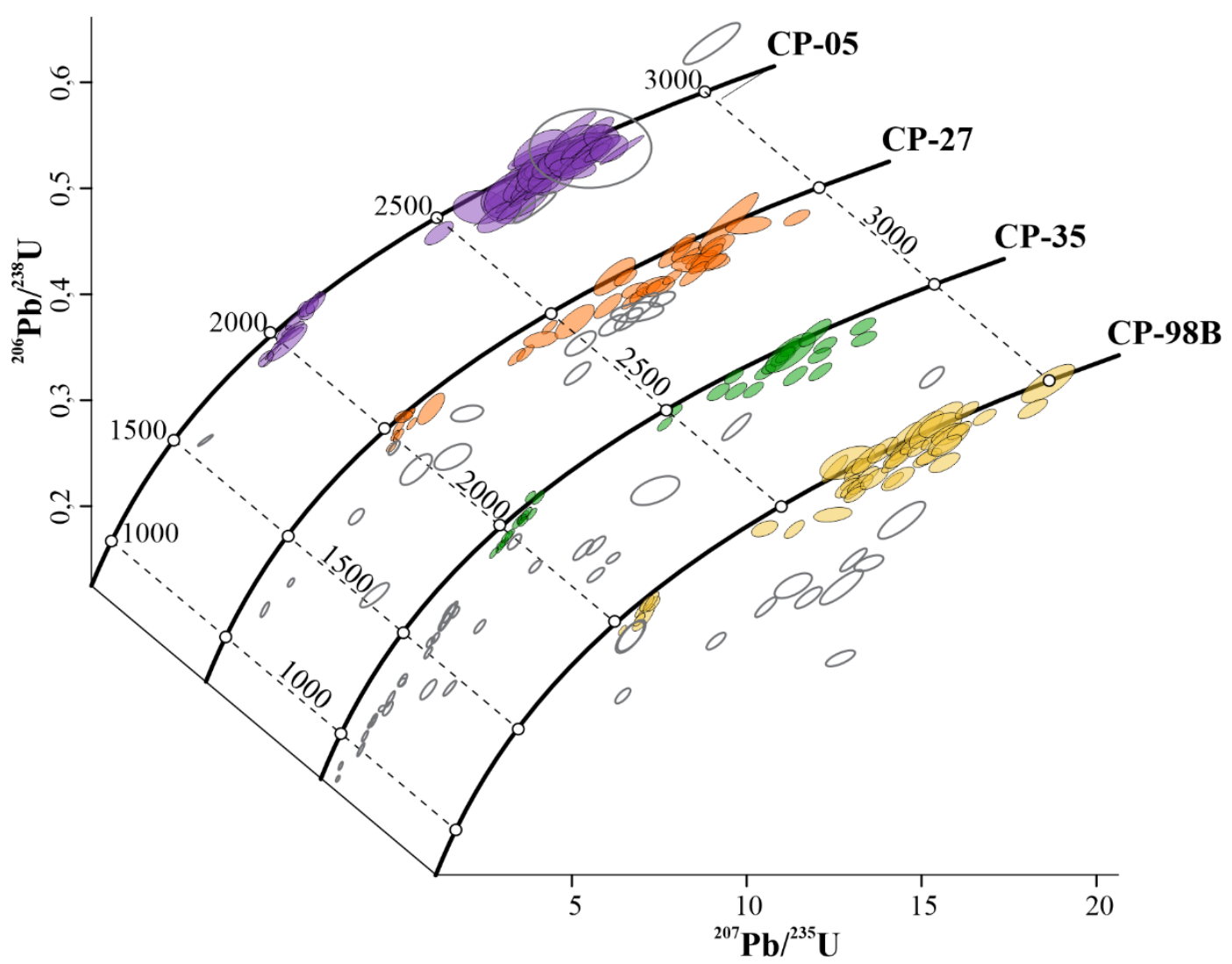

Figura 7.3: Diagrama concórdia ${ }^{207} \mathrm{U} /{ }^{235} \mathrm{~Pb} v s .{ }^{206} \mathrm{U} /{ }^{238} \mathrm{~Pb}$ para as amostras da Unidade Serra do Ibituruna. Elipses de cor cinza representam as datações com concordância fora do limite $100 \pm 10 \%$.

No diagrama de distribuição cumulativa é possível observar as variações nos espectros de idades. As amostras CP-05 e CP-27 exibem maior semelhança entre si, com $77 \%$ de probabilidade de as idades estarem entre o neoarqueano e mesoarqueano, enquanto na amostra CP-98B essa probabilidade aumenta para $85 \%$ e, para a amostra CP-35, diminui para $59 \%$ (Figura 7.5a). Tais diferenças podem ter sido causadas pelos dados que puderam ser considerados (Tabela 7-1), uma vez que, devido ao maior grau de metamictização nos cristais das populações 1 e 4, as datações apresentaram maiores índices de discordância, o que, proporcional e, especialmente nas amostras CP-35 e CP-98B, afetou a distribuição de idades obtidas.

Para validar as diferenças observadas na Figura 7.5a, o Teste K-S foi executado incorporando as idades ${ }^{207} \mathrm{~Pb} /{ }^{206} \mathrm{~Pb}$ com 20 de incerteza. As probabilidades "P" são apresentadas na Tabela 7-2.

Segundo Guynn e Gehrels (2010), para um nível de confiança de $95 \%$, P = 0,05 e duas hipóteses são avaliadas:

$\mathrm{P}>0,05$ : é improvável que as amostras sejam de fontes diferentes $\mathrm{P}<0,05$ : é provável que as amostras sejam de fontes diferentes 

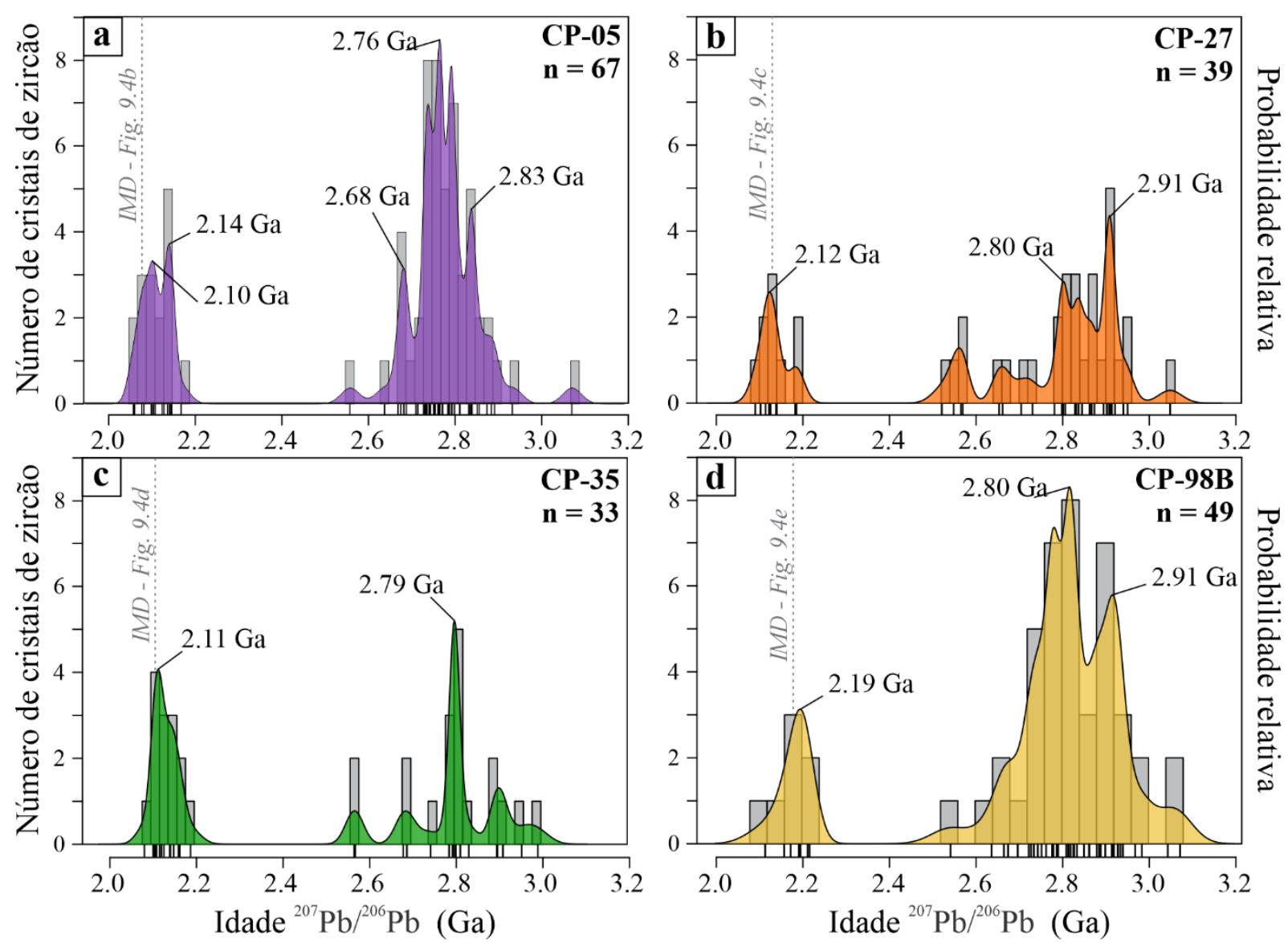

Figura 7.4: Diagramas Idade ${ }^{207} \mathrm{~Pb} /{ }^{206} \mathrm{~Pb}$ vs. Probabilidade Relativa utilizando a estimativa de densidade de Kernel (KDE - Kernel Density Estimator) para as amostras da Unidade Serra do Ibituruna. (a), (b) e (c) representam as amostras de muscovita-quartzo xisto e (d) representa a amostra de muscovita quartzito. IMD: Idade Máxima de Deposição.
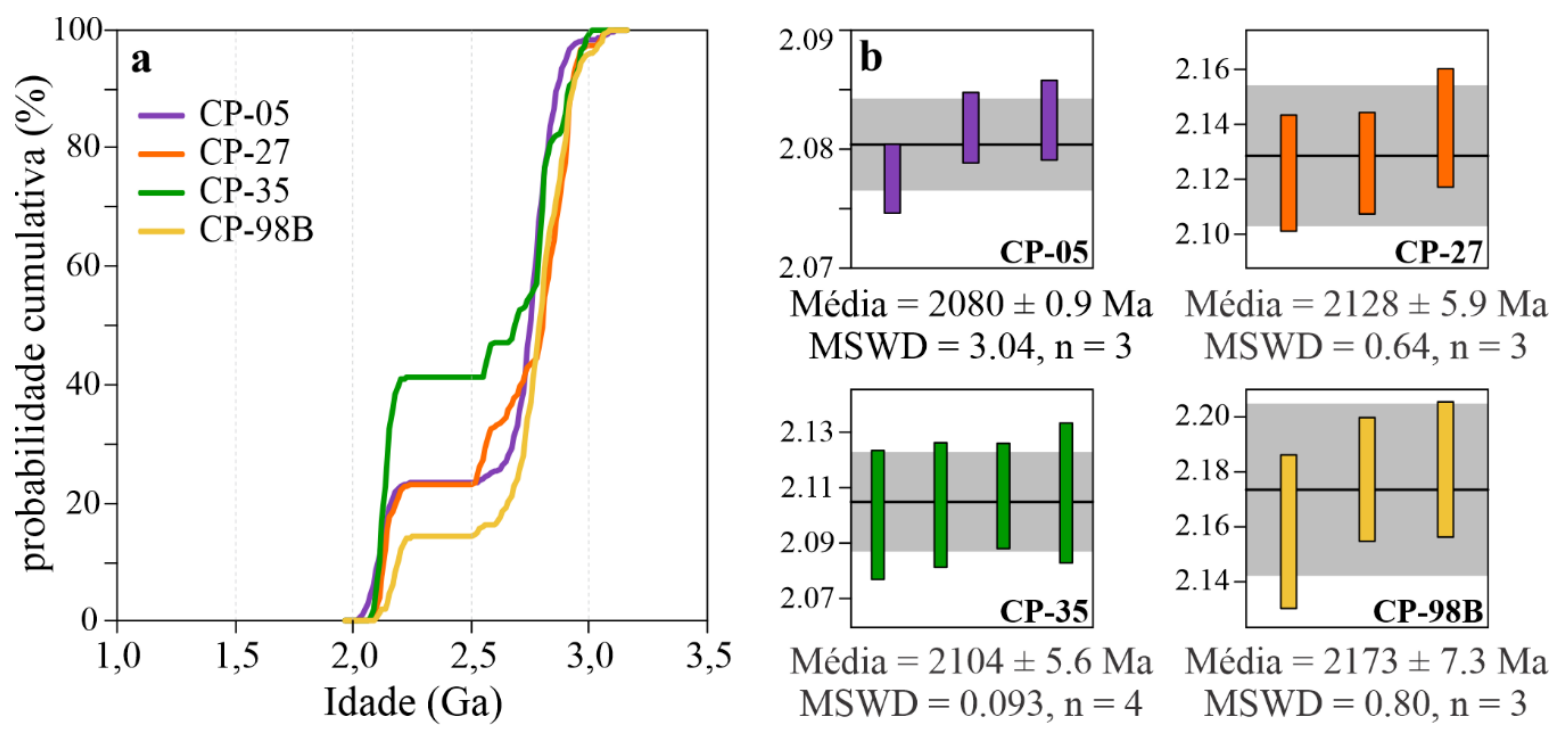

Figura 7.5: a) Diagrama de Distribuição Cumulativa (CAD - Cumulative Age Distribution) para zircão detrítico das amostras da Unidade Serra do Ibituruna; b) Gráficos weighted average com as idades máximas de deposição obtidas a partir da média ponderada do grupo de idades mais jovem com lơ de incerteza. 
Tabela 7-2: Valores da probabilidade "P" obtidos no Teste K-S as idades na função de densidade cumulativa para as amostras da Unidade Serra do Ibituruna.

K-S P-values using error in the CDF

\begin{tabular}{lcccc}
\hline & CP-05 & CP-27 & CP-35 & CP-98B \\
\hline CP-05 & & $\mathbf{0 . 1 7 9}$ & $\mathbf{0 . 1 8 8}$ & $\mathbf{0 . 3 0 0}$ \\
\hline CP-27 & $\mathbf{0 . 1 7 9}$ & & $\mathbf{0 . 3 2 4}$ & $\mathbf{0 . 6 2 7}$ \\
\hline CP-35 & $\mathbf{0 . 1 8 8}$ & $\mathbf{0 . 3 2 4}$ & & 0.039 \\
\hline CP-98B & $\mathbf{0 . 3 0 0}$ & $\mathbf{0 . 6 2 7}$ & 0.039 & \\
\hline
\end{tabular}

O teste K-S serve para mostrar que, mesmo com proporções de idades ligeiramente diferentes (Figura 7.4a-d) e o reduzido número de dados (Tabela 7-1), é possível inferir que as fontes são as mesmas nas quatro amostras. O par de amostras CP-35/CP-98B, possui $\mathrm{P}<0,05$, entretanto, uma vez que na amostra $\mathrm{CP}-27$, mesmo com um número reduzido de dados $(n=39)$, a semelhança com a amostra CP-98B é alta $(P=0.627)$, não se pode afirmar que a amostra CP-35 tenha fonte diferente. O teste K-S é sensível às proporções de idades similares nas amostras (Guynn \& Gehrels, 2010), portanto, essa diferença pode ser atribuída ao reduzido número de dados arqueanos na amostra CP-35 e não às fontes diferentes em si.

Para efeito de discussão, na Tabela 7-3 são mostradas as idades calculadas pela média ponderada dos dados mais jovens com 1ơ de incerteza (Figura 7.5b) e a idade individual do zircão mais jovem com lơ de incerteza. As idades máximas de deposição determinadas pelo zircão mais jovem exibem um intervalo de pelo menos $40 \mathrm{Ma}$ de anos (confiabilidade do método foi discutida no Capítulo 2). Pela média ponderada esse intervalo é de aproximadamente $100 \mathrm{Ma}$ e o melhor resultado obtido foi na amostra CP-35, que forneceu $2104 \pm 5,6 \mathrm{Ma}$ com MSDW = 0,093 (Tabela 7-3). No entanto, a amostra CP-35 é a que tem menos dados (Figura 7.4c) e, apesar de ter passado no teste K-S, a contribuição das idades arqueanas é menor, e isso não exclui a possibilidade de uma contribuição diferente também para as idades mais jovens.

Tabela 7-3: Idades máximas de deposição determinadas para cada amostra da Unidade Serra do Ibituruna. Estão indicadas as idades ${ }^{207} \mathrm{~Pb} /{ }^{206} \mathrm{~Pb}$ com 10 de incerteza.

\begin{tabular}{llcc}
\hline \multirow{2}{*}{ Litotipo } & Amostra & \multicolumn{2}{c}{ Idade máxima de deposição } \\
\cline { 3 - 4 } & & $\begin{array}{c}\text { Idade do zircão mais } \\
\text { jovem (Ma) }\end{array}$ & $\begin{array}{c}\text { Média ponderada do } \\
\text { grupo mais jovem (Ma) }\end{array}$ \\
\hline \multirow{2}{*}{$\begin{array}{l}\text { Muscovita }- \text { quartzo } \\
\text { xisto }\end{array}$} & $C P-05$ & $2060 \pm 0,02$ & $2080 \pm 0,9$ \\
& $C P-27$ & $2090 \pm 26,1$ & $2128 \pm 5,9$ \\
\hline Muscovita quartzito & $C P-98 B$ & $2080 \pm 8,8$ & $2104 \pm 5,6$ \\
\hline
\end{tabular}




\subsection{Assinatura de elementos traços e terras raras (ETR) em zircão detrítico}

Em todos os padrões de distribuição de ETR em zircão detrítico da Unidade Serra do Ibituruna (Figura 7.6a), observam-se as típicas anomalias positivas de $\mathrm{Ce}$, enquanto as anomalias de Eu podem ser negativas, com variável magnitude, ou ausente em alguns cristais. Algumas análises forneceram valores abaixo do limite de detecção para La, $\mathrm{Pr}, \mathrm{Nd}, \mathrm{Sm}$ e Eu, e por essa razão não são mostrados valores para $\mathrm{Ce} / \mathrm{Ce} *$ ou Eu/Eu* (Apêndice I).

Os cristais de zircão do Paleoproterozoico exibem zoneamento oscilatório regular e baixa a média intensidade de luminescência, indicando proveniência a partir de rochas ígneas. Cristais com sobrecrescimento de textura homogeneamente clara sobre núcleo herdado (spot U-Pb 45.1 - CP-35, Figura 7.2), típico de cristalização em ambiente metamórfico de alto grau (Corfu et al., 2003), são raros e ocorrem apenas na população 2.

A despeito do maior ou menor enriquecimento em ETR leves e da magnitude das anomalias de $\mathrm{Ce}\left(\mathrm{Ce} / \mathrm{Ce}^{*}\right.$ entre 2,7 e 38,2) e Eu (Eu/Eu* entre 0,9 e 4,9), os padrões ETR pesados para cristais paleoproterozoicos exibem inclinações semelhantes (Figura 7.6b) e as populações de cristais são visualmente indistinguíveis, portanto, com exceção dos cristais em que a textura é de zircão formado em ambiente metamórfico, os padrões não são bons traçadores de proveniência para os cristais paleoproterozoicos.

Padrões de enriquecimento em ETR pesados planos indicam que o zircão pode ser proveniente de kimberlitos e carbonatitos (Belousova et al., 2002), ou que cresceu em ambiente com granada e/ou ortopiroxênio (Rubatto, 2017). Pontos que mostram esse tipo de padrão tem $(\mathrm{Yb} / \mathrm{Sm})_{\mathrm{N}}$ baixo, variando de 0,9 a 5,3, e são observados apenas em zircão neo- e mesoarqueano (Figura 7.6c e 7.6d), em que, em todos os casos, as texturas são de zircão formado em rocha metamórfica de alto grau (i.e. fir tree zoning, zoneamento oscilatório irregular e amplos domínios homogêneos).

Nos cristais de zircão do neoarqueano há zoneamento magmático, mas predominam cristais com sobrecrescimento em volta de núcleo herdado, tal como as zonas de recristalização transgressiva, às vezes truncando zonas de crescimento magmático, em cristais da população 1, e, nas populações 2 e 4, cristais em que o novo crescimento exibe textura tipo fir tree zoning, spot U-Pb 27.1 - CP-05 (Figura 7.2), ou em domínios homogêneos (spot 26.1

- CP-35, Figura 7.2), indicando formação em ambiente metamórfico de alto grau.

Os padrões de ETR nos cristais neoarqueanos a magnitude das anomalias de Ce e Eu varia respectivamente de 1,8 a 34,2 e de 0 a 9,7 (Figura 7.6c), não havendo relações nem entre as populações reconhecidas, nem quanto à textura interna dos cristais. Excluindo os pontos que exibem padrões de ETR pesados planos, o fracionamento em ETR pesados 
também mostra inclinações semelhantes no conjunto, com $(\mathrm{Yb} / \mathrm{Sm})_{\mathrm{N}}$ entre 6 e 26 (Figura 7.6c), mas não há diferenças entre as populações. O enriquecimento em ETR leves observado em alguns pontos não é atribuído a presença de micro inclusões de fosfatos, pois o conteúdo de P é baixo, sendo característico do zircão nos pontos 7 (CP-05) e 4 (CP-98B) (Figura 7.2), e resultado de alterações no ponto 13 (CP-98B), onde há aumento na concentração de Ca e ETR leves.

Nos cristais de zircão do mesoarqueano também predominam texturas de zircão formado em metamorfismo de alto grau, tal como as descritas anteriormente, e a inclinação dos padrões ETR pesados também é semelhante, mas o grau de fracionamento é maior (Figura 7.6d), com $(\mathrm{Yb} / \mathrm{Sm})_{\mathrm{N}}$ entre 6 e 65. Dos pontos onde o padrão de enriquecimento em ETR pesados é plano, nos pontos 10 e 20 (amostra CP-98B) o padrão é característico do zircão, enquanto no ponto 14 (amostra CP-98B) ele é fruto da alteração, pois há também enriquecimento em Al, Mn, Li e ETR leves, em geral. A magnitude das anomalias de Ce $(3,2$ a 26,0) e Eu (0 a 4,8) também não mostram relações com as populações identificadas.
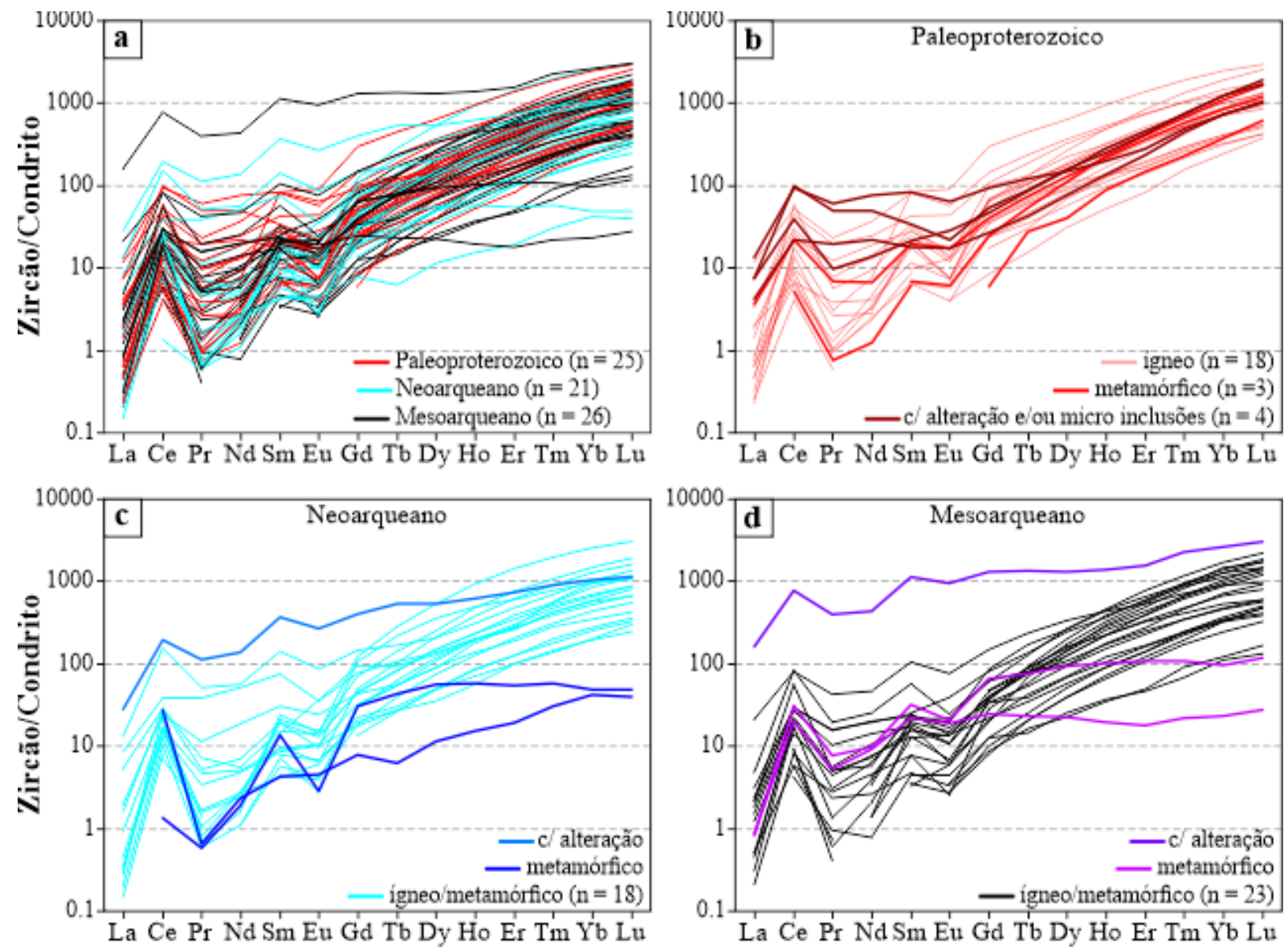

Figura 7.6: Padrões de distribuição dos elementos terras raras (ETR) em zircão detrítico da Unidade Serra do Ibituruna normalizados pelo condrito de acordo com Sun \& McDonough (1989). Em (a) todo o conjunto, (b), (c) e (d) separados por Era. 
Antes de identificar possíveis rochas fontes nos diagramas discriminantes, é necessário avaliar o grau de modificações pelas quais os cristais de zircão passaram durante ou após os processos de cristalização/recristalização, pois o conteúdo de elementos traço e ETR pode ser alterado, levando a interpretações dúbias.

Os danos causados pela radiação na estrutura cristalina do zircão podem ser indicados pelo maior conteúdo de ETR médios e leves (Whitehouse e Kamber, 2002). No gráfico Th+U vs. $(\mathrm{La} / \mathrm{Gd})_{\mathrm{N}}$ nota-se maior espalhamento para cristais das populações 1 e 4 , que têm maior grau de metamictização, mas não há nenhuma tendência (Figura 7.7a). Em zircão metamíctico, além da maior substituição de Zr por ETR, há maior teor de Th e U (Belousova et al., 2002), assim, deverá haver correlação positiva entre o conteúdo de ETR com Th e U. Os cristais das populações 1 e 4 apresentam maior grau de metamictização e, como esperado, mostram maior espalhamento no gráfico Th+U vs. $\mathrm{E} T \mathrm{TR}$, ancorados por pontos onde, além de maiores concentrações de Th e U, há maiores teores de Fe e Al (Figura 7.7b).
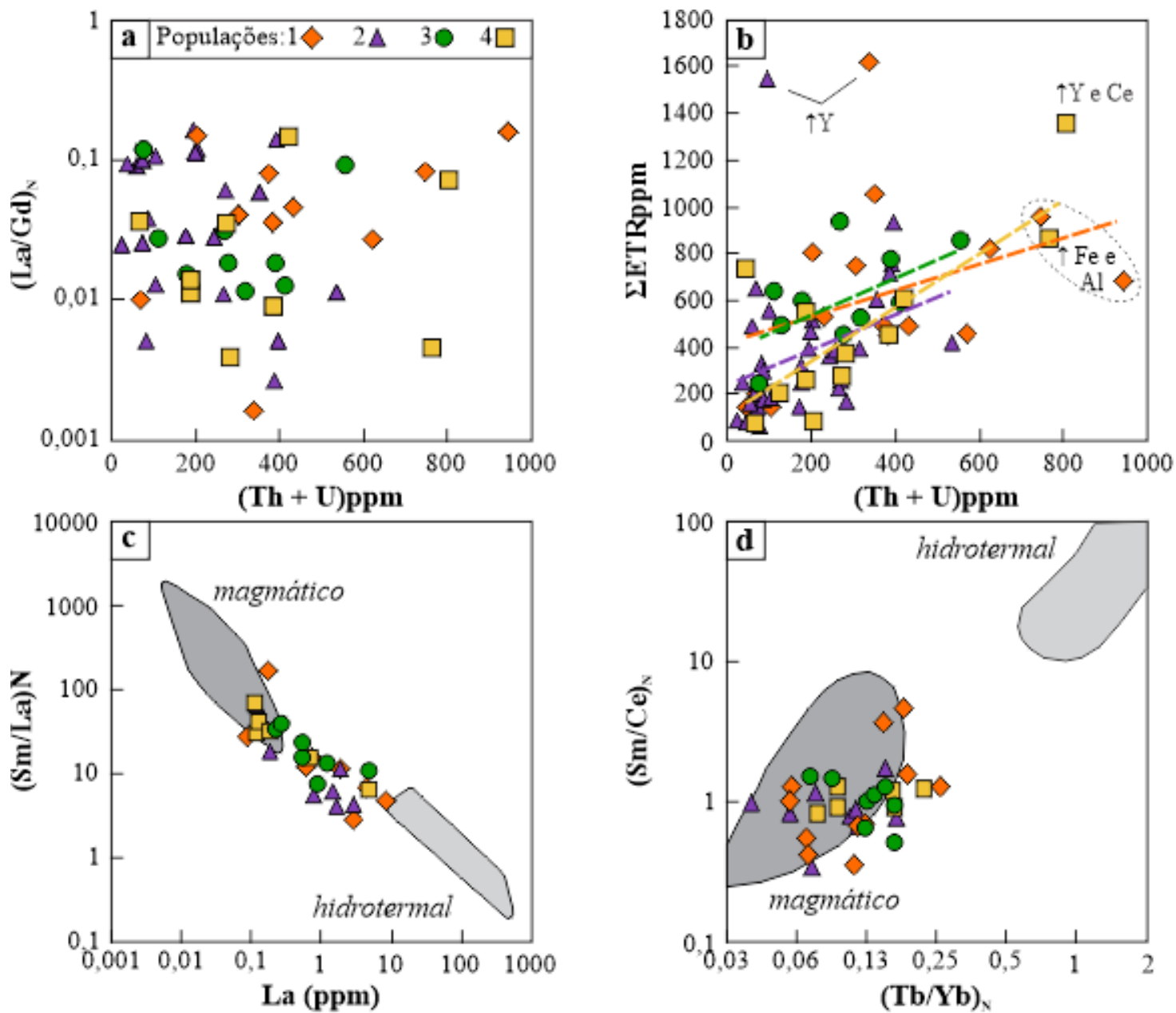

Figura 7.7: Gráficos para avaliar o grau de modificações nos cristais de zircão. Para grau de metamictização e alteração - a) Gráfico $\mathrm{Th}+\mathrm{U} v s$. $(\mathrm{La} / \mathrm{Gd})_{\mathrm{N}}$ de Whitehouse \& Kamber (2002) e b) $\mathrm{Th}+\mathrm{U} v s$. $\Sigma$ ETR; Para zircão magmático e hidrotermal - c) Gráfico La vs. $(\mathrm{Sm} / \mathrm{La})_{\mathrm{N}}$ de Hoskin $(2005)$ e d) Gráfico $(\mathrm{Tb} / \mathrm{Yb})_{\mathrm{N}} v s .(\mathrm{Sm} / \mathrm{Ce})_{\mathrm{N}}$, modificado de Toscano et al. (2014). Legenda dos símbolos na Figura a. 
Nos gráficos das Figuras 7.7c, 7.7d e 7.8c-e foram plotados apenas os pontos feitos em cristais com texturas de cristalização magmática, desconsiderando pontos indicativos de maior grau de alteração. No gráfico La vs. (Sm/La) $)_{N}$ de Hoskin, (2005) a maioria dos pontos situa-se entre os campos "magmático" e "hidrotermal" (Figura 7.7c). Isso se deve ao maior conteúdo de La em geral acompanhado de maiores teores de Y, $\mathrm{ETR}, \mathrm{Fe}$, Mn e Al. Já no gráfico $(\mathrm{Tb} / \mathrm{Yb})_{\mathrm{N}}$ vs. $(\mathrm{Sm} / \mathrm{Ce})_{\mathrm{N}}$ de Toscano et al. (2014), o caráter magmático dos cristais de zircão é melhor atestado (Figura 7.7d).

A identificação dos cristais de zircão metamórfico foi baseada essencialmente em critérios texturais, pois a distribuição de ETR só é distinta dos padrões de zircão ígneo quando ele coexiste com granada e/ou ortopiroxênio. Texturas como amplos domínios de alta intensidade de luminescência, zoneamento oscilatório irregular, caótico ou tipo fir tree e zonas de recristalização transgressiva são características de zircão de granulito, migmatitos e gnaisses de alto grau (Hoskin e Black, 2000; Corfu et al., 2003; Rubatto, 2017).

Razões Th/U tipicamente menores que 0,1 para zircão metamórfico (Rubatto e Gebauer, 2000) ocorrem em apenas 5 pontos de todas as análises de U-Pb. Zircão metamórfico pode ter razão $\mathrm{Th} / \mathrm{U}$ maior que $0,1 \mathrm{em}$ determinadas situações, entre elas, condições de metamorfismo de temperatura ultra alta, quando há perda de fusão, resultando em aumento da temperatura da solidus e, dependendo do tempo de cristalização, onde maior razão Th/U é favorecida pela resfriamento rápido e cristalização do fundido em ausência de monazita (Yakymchuk et al., 2018). As concentrações de Th, U e ETR leves no sistema também influenciam a razão Th/U no zircão, uma vez que ocorre particionamento de Th e ETR leves com monazita e apatita (Yakymchuk et al., 2018; Rubatto, 2017).

No gráfico Idade vs. razão Th/U estão plotados todos os pontos onde foi feita análise de U-Pb (Figura 7.8a). Nele é possível observar que os cristais das populações 1 e 4 estão distribuídos entre o Paleoproterozoico e o Neoarqueano, enquanto os cristais das populações 2 e 3 ocorrem no Paleoproterozoico, mas predominam entre o Neo- e Mesoarqueano. Além disso, observamos que as variações nas razões Th/U são mais amplas nos cristais das populações $2(0,05$ a 5,28) e $4(0,14$ a 2,48), onde predominam cristais com texturas de zircão metamórfico. Nos cristais das populações 1 e 3, com exceção de dois cristais com elevado grau de fraturamento e metamictização, a amplitude das variações na razão $\mathrm{Th} / \mathrm{U}$ é menor, de 0,11 a 0,78 na população 1 e de 0,06 a 1,44 na população 3 .

“Assinaturas $\mathrm{U} / \mathrm{Yb}$ e $\mathrm{Nb} / \mathrm{Yb}$ relativamente enriquecidas aparentemente podem se desenvolver por meio de uma infinidade de processos e fontes" (Grimes et al., 2015), limitando o uso desse critério, como pode ser visto na Figura 7.8b, no gráfico $\mathrm{Y}$ vs. U/Yb de 
Grimes et al. (2007). O gráfico fornece uma classificação geral para a origem do zircão, em que, com exceção de dois pontos, todos os demais plotam no campo de zircão de rochas de crosta continental. $\mathrm{O}$ ponto 2 da amostra CP-35, além do maior teor em $\mathrm{Y}$, há maior concentração de P e ETR, indicando que se trata da solução sólida com xenotímio através do vetor de substituição acoplada (ETR,Y)P Zr-Si. e não de uma origem a partir de rochas de crosta oceânica, o mesmo ocorre nos pontos que plotam na interface entre os campos de crosta oceânica e continental. O ponto que plota no campo dos kimberlitos possui baixo conteúdo em ETR (55 ppm) e menor fracionamento em ETR pesados, assim como em zircão de kimberlitos (Belousova et al., 1998), mas textural e morfologicamente diferem destes, além de mostrarem maior magnitude de anomalia de $\mathrm{Ce}^{*}(34,2)$. Zircão de kimberlitos, carbonatitos e granitoides tem menor amplitude de anomalias de $\mathrm{Ce}$, variando de 1 a 10 (Belousova et al., 2002).

O gráfico Yb/Sm vs. Y de Belousova et al. (2002) mostra que, independente da população de cristais, os pontos concentram-se na interface dos campos de granitos, granodioritos, tonalitos, sienitos pegmatíticos, rochas máficas, carbonatitos e lamproitos (Figura 7.8c). Já o gráfico Th vs. Nb de Nardi et al. (2013) mostra concentração dos pontos no campo dos monzonitos shoshoníticos, na interface com o campo dos granitos tipo I, sienitos e quartzo sienitos (Figura 7.8d).

Já no gráfico Hf vs. Y de Pupin (2000), os pontos plotam entre os campos de rochas anorogênicas, campos 1c, 1d e 1e, e anorogênicas/orogênicas, campos 5a e 5b (Figura 7.8e). A distribuição das populações de cristais de zircão com as prováveis rochas fontes de acordo com a classificação de Pupin (2000) está sintetizada na Tabela 7-4.

Tabela 7-4: Distribuição das populações nos campos de ocorrência de rochas ígneas discriminadas com base no conteúdo de Hf e Y, de acordo com Pupin (2000).

\begin{tabular}{|c|c|c|}
\hline População & Campos & Rochas \\
\hline 2 & $\begin{array}{l}1 \mathrm{c}, 1 \mathrm{~d}, 1 \mathrm{e}, \\
5 \mathrm{a}\end{array}$ & $\begin{array}{l}\text { álcali basaltos, álcali granitos/riolitos, sienitos/traquitos, gabros, dioritos, } \\
\text { tonalitos, quartzo dioritos, andesitos, dacitos, granitos/riolitos } \\
\text { subalcalinos, cálcio-alcalinos, cálcio-alcalinos de alto } \mathrm{K} \text { ou } \mathrm{Mg}-\mathrm{K}\end{array}$ \\
\hline 3 & $1 \mathrm{c}, 1 \mathrm{~d}$ & álcali basaltos, álcali granitos/riolitos, sienitos/traquitos \\
\hline 4 & $\begin{array}{l}1 \mathrm{c}, 1 \mathrm{~d}, 5 \mathrm{a}, \\
5 \mathrm{~b}\end{array}$ & $\begin{array}{l}\text { álcali basaltos, álcali granitos/riolitos, sienitos/traquitos, gabros, dioritos, } \\
\text { tonalitos, quartzo dioritos, andesitos, dacitos, granitos/riolitos } \\
\text { subalcalinos, cálcio-alcalinos, cálcio-alcalinos de alto } \mathrm{K} \text { ou Mg-K }\end{array}$ \\
\hline
\end{tabular}



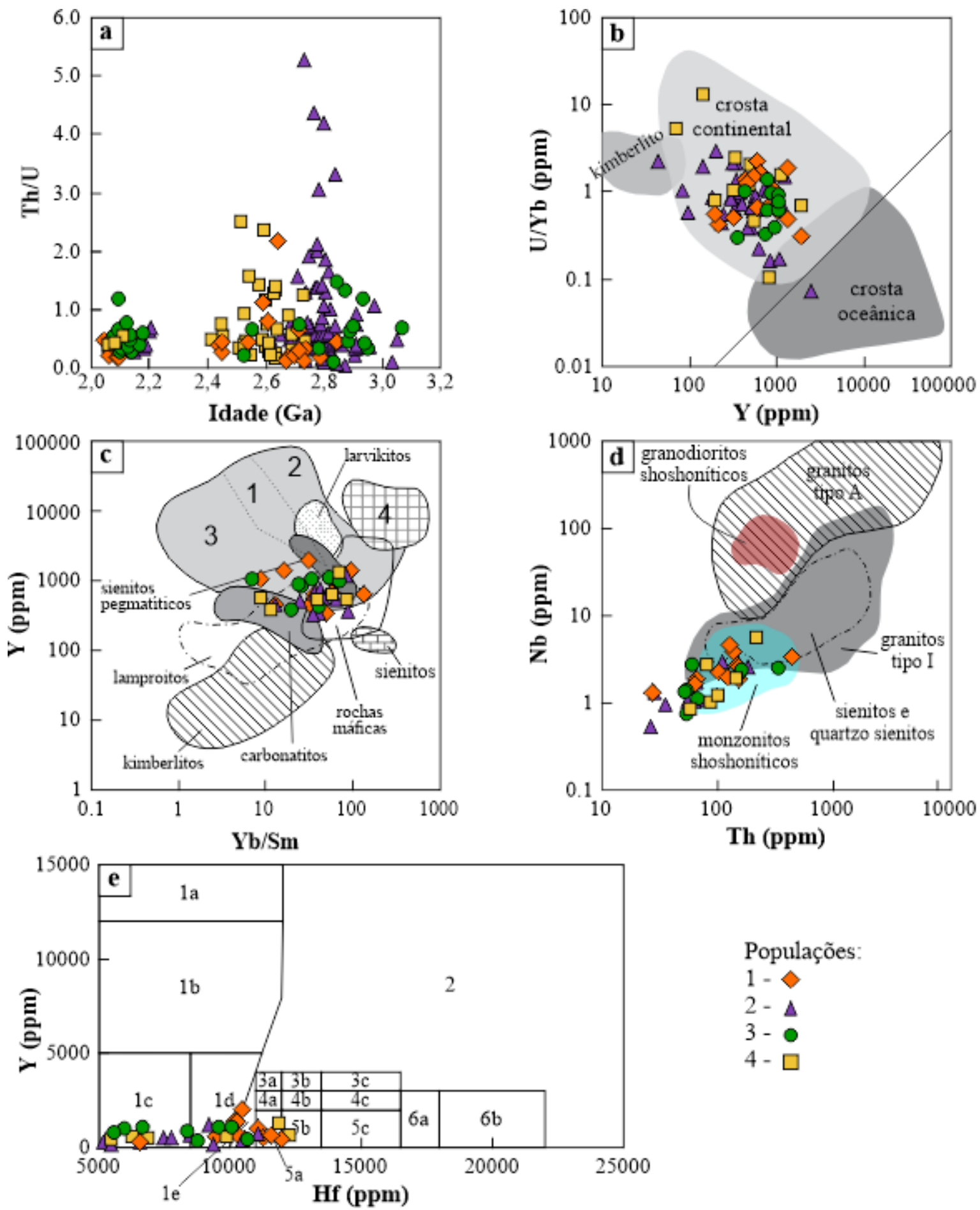

Populações:

$1-\diamond$

$2-\Delta$

$3-$ o

4 -

Figura 7.8: a) Gráfico da variação da razão Th/U em cristais de zircão da Unidade Serra do Ibituruna; b) Gráfico Y vs. U/Yb de Grimes et al., (2007) para diferenciação de zircão de rochas de crosta oceânica e continental; c) Gráfico Yb/Sm vs. Y de Belousova et al. (2002) para diferenciação de zircão de origem magmática. 1- Aplitos e Leucogranitos, 2 - Granitos, 3 - Granodioritos e Tonalitos, 4 - Nefelina sienitos e sienitos pegmatíticos; d) Gráfico Th $v s$. Nb de Nardi et al., (2013), também para diferenciação de zircão de origem ígnea; e) Gráfico Hf vs. Y de Pupin (2000) para identificação do ambiente tectônico de rochas ígneas. Os campos indicados, correspondem às rochas anorogênicas ( 1 e 2) e orogênicas (5 e 6), enquanto os campos 3 e 4 correspondem à um domínio intermediário, onde ocorrem rochas de ambas as origens. Para mais detalhes, ver o texto e Pupin (2000). 


\subsection{U-Pb em Monazita}

A monazita das amostras da Unidade Serra do Ibituruna ocorre como prismas com relação comprimento/largura de 2:1 e 100 a $230 \mu \mathrm{m}$ ao longo do eixo c ou como cristais equidimensionais com 80 a $170 \mu \mathrm{m}$. Em ambas morfologias as bordas são subangulosas a subarredondadas e as cores variam de amarelo pálido a acastanhado, às vezes com inclusões fluidas e de minerais opacos. Internamente os cristais menores são homogêneos, enquanto os cristais maiores exibem zoneamento oscilatório sutil ou são homogêneos.

Apenas as amostras CP-27 e CP-35 forneceram dados reproduzíveis (Apêndice $\mathbf{H}$ ). $\mathrm{Na}$ amostra $\mathrm{CP}-27$, vinte e quatro, das vinte e seis datações definem discórdia com idade de $574 \pm 11$ Ma, com MSWD de 0,69 (Figura 7.9a). Já a amostra CP-35 forneceu idade concórdia aplicada para todos os pontos analisados em $584 \pm 3 \mathrm{Ma}$, com MSWD de 0,51 (Figura 7.9b).
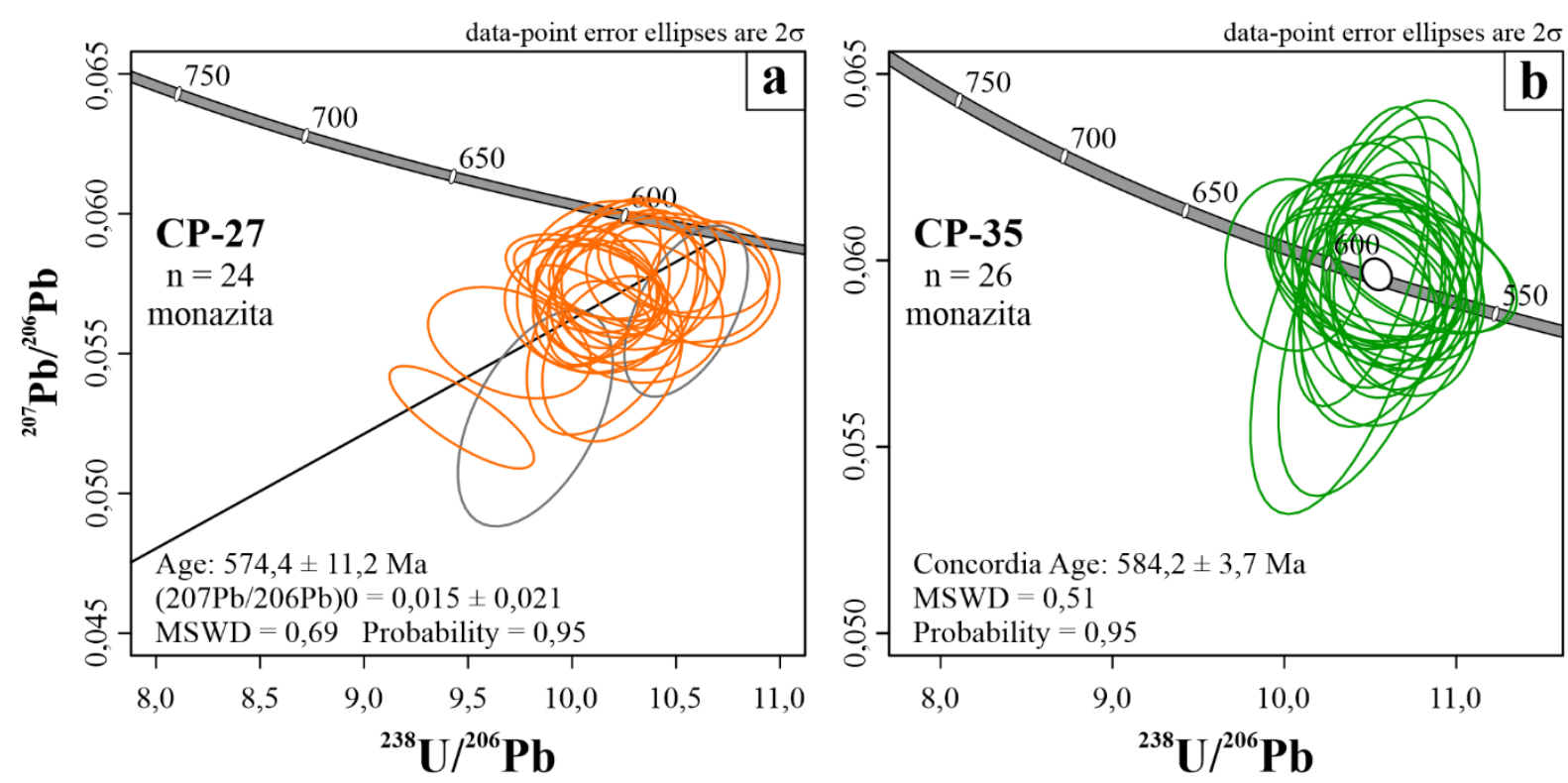

Figura 7.9: Diagramas Tera-Wasserburg para idade U-Pb em monazita das amostras da Unidade Serra do Ibituruna - a) Idade discórdia, amostra CP-27; b) Idade concórdia, amostra CP-35.

\subsection{Discussões}

\subsubsection{Prováveis áreas fonte}

Antes de iniciar a discussão sobre as prováveis áreas fonte é importante salientar que há dois fatores que podem acarretar inconsistências na identificação das áreas fonte baseada na assinatura de elementos traço de zircão, como visto nos diagramas classificatórios apresentados nas Figuras 7.8c-e. O primeiro é com relação ao conjunto amostral insuficiente, pois geralmente é utilizado um número muito menor de grãos de zircão para as análises 
químicas. A eficiência do método está ligada à boa base estatística e deve seguir a mesma abordagem adotada para a geocronologia de zircão detrítico (Grimes et al., 2015).

O segundo problema é com relação ao grau de modificações pós-magmáticas e metamórficas no zircão, que podem ser oriundas tanto das alterações causadas por hidrotermalismo e metamictização, como também pelo próprio grau de fracionamento. As taxas de difusão dos ETR são lentas, assim, esses elementos podem ser considerados imóveis (Cherniak et al., 1997b). Todavia, para rochas muito antigas, podem gerar diferenças significativas, pois "os processos que produzem as assinaturas geoquímicas provavelmente serão diferentes dos que atuam em ambientes magmáticos modernos" (Grimes et al., 2015). Assim, interpretações quanto ao tipo de ambiente tectônico baseado apenas na química de zircão cristalizado durante o arqueano pode levar a interpretações equivocadas.

A distribuição das idades obtidas nas amostras da Unidade Serra do Ibituruna mostra maior aporte sedimentar a partir de fontes neo- a mesoarqueanas, com contribuição secundária de fontes paleoproterozoicas do período Riaciano (Figura 7.10). Nos cristais de zircão neo- e mesoarqueanos predominam domínios com texturas metamórficas cujos intervalos de datações são compatíveis com os intervalos de datações em cristais com texturas de cristalização magmática, podendo assim refletir eventos metamórficos das áreas fontes em si. Além disso, a ausência de sobrecrescimento metamórfico na maioria dos cristais sugere que não houve formação expressiva de zircão no evento metamórfico que afetou as rochas da Unidade Serra do Ibituruna, conforme será discutido no tópico 7.4.3.

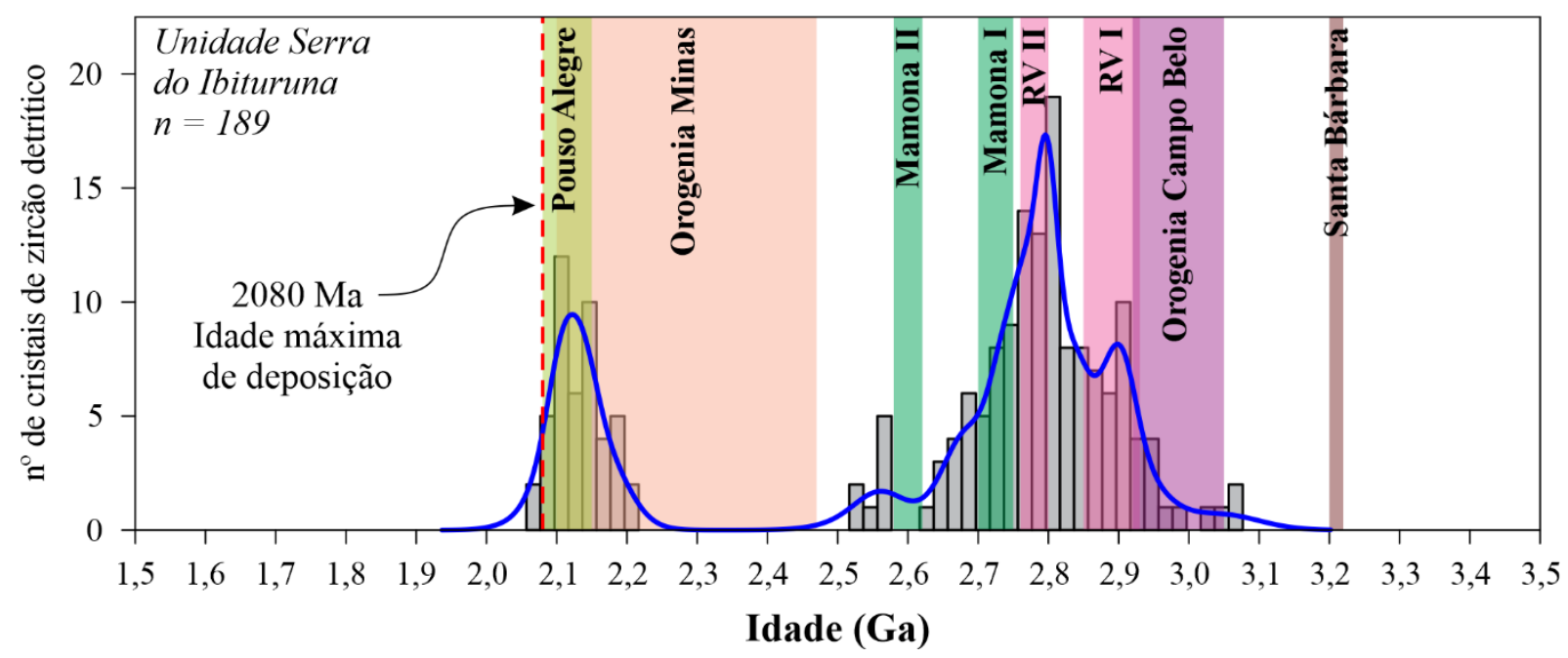

Figura 7.10: Diagrama Idade ${ }^{207} \mathrm{~Pb} /{ }^{206} \mathrm{~Pb}$ vs. Probabilidade Relativa utilizando a estimativa de densidade de Kernel (KDE - Kernel Density Estimator) para zircão detrítico da Unidade Serra do Ibituruna com a indicação das faixas etárias das rochas da porção meridional do Cráton do São Francisco: Orogenia Minas, 2,35-2,0 Ga (Teixeira et al., 2015); Evento Mamona II, 2,62-2,58 Ga e Mamona I, 2,75-2,70 Ga (Farina et al., 2015; Martínez Dopico et al., 2017); Evento Rio das Velhas II, 2,8-2,76 Ga, Rio das Velhas I, 2,93-2,85 Ga e Santa Bárbara, 3,22-3,20 Ga (Lana et al., 2013); Orogenia Campo Belo (Teixeira et al., 2017). 
As idades neo- e mesoarqueanas podem ser encontradas nos complexos gnáissicograníticos e migmatíticos da porção sul do Cráton do São Francisco e no embasamento do Orógeno Brasília Meridional. Os complexos gnáissico-graníticos foram formados durante os eventos Rio das Velhas II (2800 - 2760 Ma, Lana et al., 2013) e Mamona I (2750 - $2700 \mathrm{Ma}$ e II, 2620 - 2580 Ma, Farina et al., 2015; Dopico et al., 2017), enquanto os complexos gnáissico-migmatíticos foram formados durante o evento Rio das Velhas I (2930 - 2850 Ma, Lana et al., 2013) e na orogênese Campo Belo (3200 - 2900 Ma, Teixeira et al., 2017).

Cristais detríticos de zircão com texturas de cristalização magmática, datados do neoarqueano, podem ser provenientes de granitoides cálcio-alcalinos do Complexo Passa Tempo (Granitoide Rio do Amparo, Morro do Ferro e Bom Sucesso), do metatonalito do Complexo Campos Gerais e do leucogranito do Batólito Mamona. Já os cristais com texturas metamórficas podem ser encontrados nos ortognaisses migmatíticos do Complexo Campo Belo (Gnaisse Fernão Dias, Gnaisse Candeias, Migmatito Kinawa), nos ortognaisses monzoníticos a quartzo-sieníticos do Complexo Passa Tempo, no Gnaisse Alberto Flores do Complexo Bonfim e nos domos gnáissico-migmatíticos Bação e Santa Bárbara (Tabela 7-5).

Nos cristais detríticos de zircão datados do mesoarqueano, apenas três cristais da amostra CP-27 exibem textura de cristalização magmática e idades que podem ser encontradas no ortognaisse granodiorítico do Complexo Serra Negra e nos ortognaisses trondjemíticos dos Complexos Bação e Heliodora-Minduri. Os cristais com texturas metamórficas podem ser encontrados nos ortognaisses Mandembo e Campos Gerais, no Complexo Campos Gerais e no Gnaisse Fernão Dias, no Complexo Campo Belo.

Os cristais detríticos de zircão que datam do Paleoproterozoico predominantemente indicam proveniência a partir de granitoides, com prováveis áreas fontes de idades entre 2057 e 2217 Ma pertencentes ao Cinturão Mineiro, formado durante a Orogenia Minas (Teixeira et al., 2015) e detalhadas na Tabela 7-6. Outras possíveis áreas fontes estão no embasamento do Orógeno Brasília Meridional (Ortognaisse Gaspar Lopes e granito porfiroclástico do Complexo Pouso Alegre) e no próprio embasamento cratônico, na forma de leucossoma dos complexos migmatíticos, tal como no Migmatito Kinawa (Carvalho et al., 2017a). Já os raros cristais de zircão formados em ambiente metamórfico de alto grau podem ser encontrados em granitoides afetados pelo metamorfismo paleoproterozoico no Cinturão Mineiro, entre 2250 e 2170 Ma (Ávila et al., 2008) - granodiorito da Suíte Serrinha, ortognaisse granítico do Pluton Represa de Camargos e granodiorítico do Batólito Morro do Resende -, nos granulitos do Complexo Mantiqueira - Granulito Pedra Dourada e Acaiaca - e nos metatexitos do Complexo Pouso Alegre. 
Tabela 7-5: Histograma parcial da Figura 7.10 indicando as idades ${ }^{207} \mathrm{~Pb} /{ }^{206} \mathrm{~Pb}$ neo- a mesoarqueanas obtidas em zircão detrítico da Unidade Serra do Ibituruna com os intervalos de idades U-Pb em zircão disponíveis na literatura para as prováveis áreas fontes. Referências: 1-Turbay, 2010; 2-Campos Neto et al., 2004; 3-Gengo et al., (em preparação); 4-Teixeira et al., 1998; 5-Carvalho et al., 2017a; 6-Oliveira, 2004; 7-Campos, 2004; 8Quéméneur et al., 2003; 9-;Machado e Carneiro, 1992 10-Romano et al., 2013; 11-Farina et al., 2015; 12-Lana et al., 2013; 13-Cioffi et al., 2016b. *Idade Pb-Pb em zircão e **Idade de cristalização do protólito do Gnaisse Engenheiro Correia.

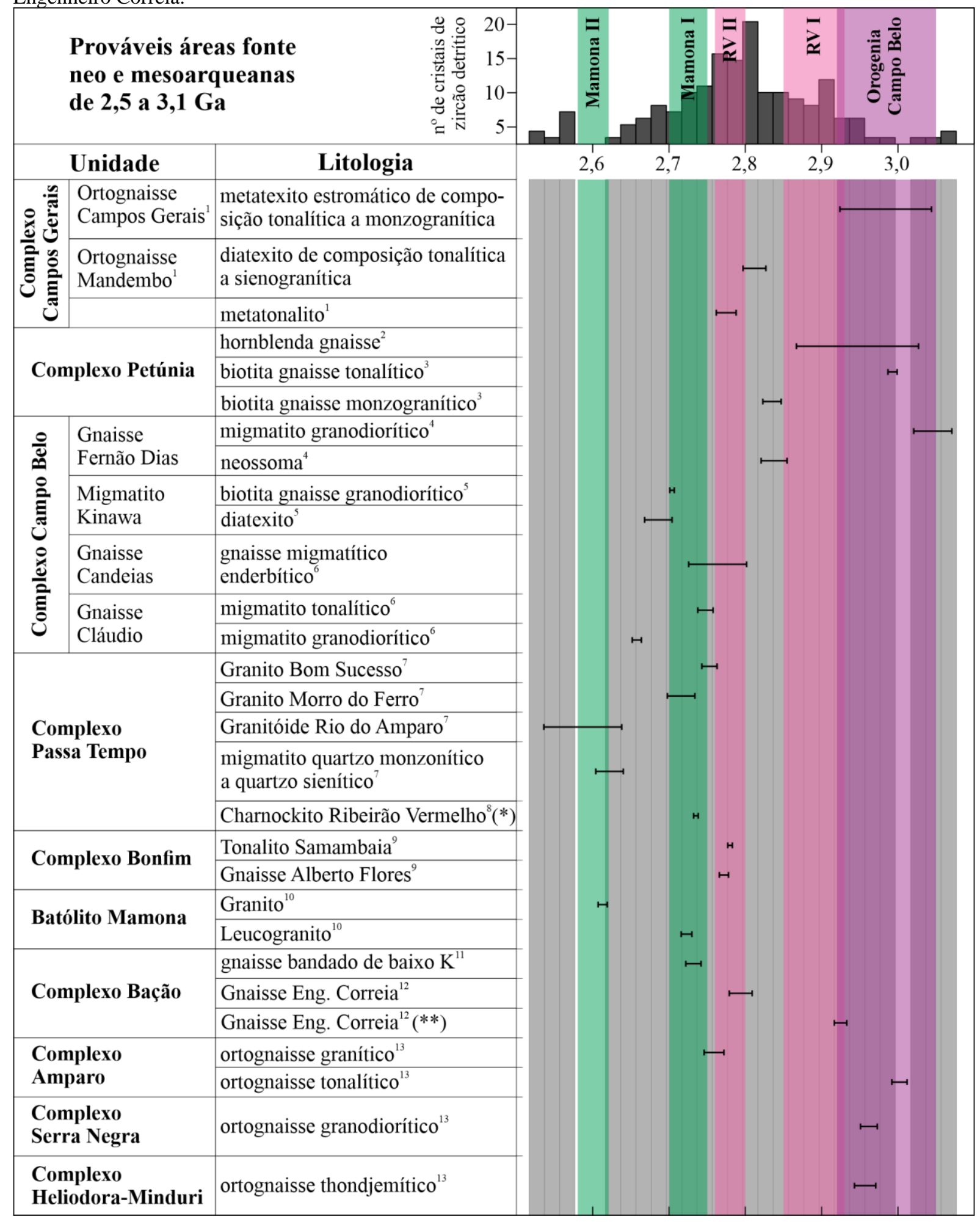


Tabela 7-6: Histograma parcial da Figura 7.10 indicando as idades ${ }^{207} \mathrm{~Pb} /{ }^{206} \mathrm{~Pb}$ paleoproterozoicas obtidas em zircão detrítico da Unidade Serra do Ibituruna e os intervalos de idades U-Pb em zircão disponíveis na literatura para as prováveis áreas fontes. Referências: 1- Barbosa et al. 2015; 2- Seixas et al., 2013; 3- Teixeira et al., 2014; 4-Ávila et al., 2006; 5- Teixeira et al., 2008; 6-Ávila et al., 2010; 7-Ávila et al., 2014; 8-Teixeira et al., 2015; 9Seixas et al., 2012; 10-Oliveira, 2004; 11-Carvalho et al., 2017a; 12-Lopes, 2013; 13-Gengo et al. (em preparação); 14-(Cioffi et al., 2016a); 15-Marinho (2014); 16-Medeiros Junior (2016). A linha tracejada em vermelho representa a idade máxima de deposição (IMD) determinada para a unidade.

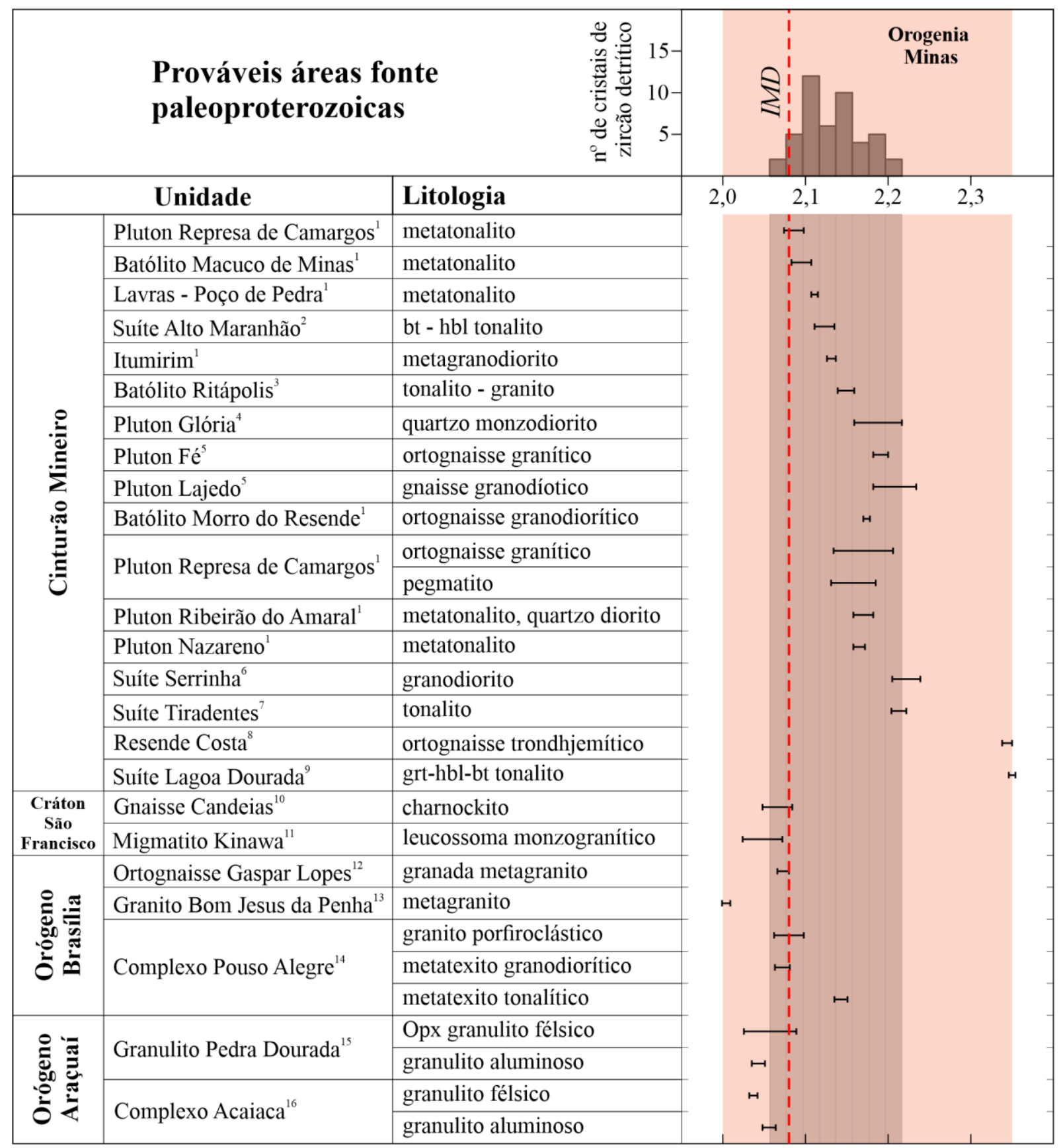

Quimicamente foi possível caracterizar apenas os cristais com texturas de cristalização magmática e cristais metamórficos coexistentes com granada e/ou piroxênio. $\mathrm{O}$ gráfico Yb/Sm vs. Y de Belousova et al., (2002) (Figura 7.8c), apesar da ampla sobreposição dos campos, foi o que apresentou de forma mais satisfatória a identificação das prováveis 
áreas fontes, com cristais de zircão arqueanos provavelmente pertencentes à leucogranitos (Batólito Mamona), sienogranitos (Granito Bom Sucesso), monzogranitos (Granitoide Rio do Amparo), granodioritos (Granito Morro do Ferro) e tonalitos (Tonalito Samambaia), além de ortognaisses dos Complexos Bação, Serra Negra e Heliodora-Minduri. Essas composições para zircão também aparecem no gráfico de Pupin (2000), porém, de forma mais conturbada (Tabela 7-4 e Figura 7.8e).

Os padrões de enriquecimento em ETR planos observados em cristais de zircão neoarqueano podem ser compatíveis com zircão do Gnaisse Candeias, que tem composição enderbítica (Oliveira, 2004), do ortopiroxênio - biotita granodiorito Santo Antônio do Amparo (Campos, 2004), ambos do Complexo Passa Tempo, e de schollens em meio ao migmatitos Kinawa, que podem apresentar clinopiroxênio + hornblenda + plagioclásio (Carvalho et al., 2017b).

Para os cristais de zircão magmático do paleoproterozoico, as prováveis áreas fontes seriam sienitos pegmatíticos, granitos, granodioritos, tonalitos e rochas máficas (Figura 7.8c). Nesses cristais o maior grau de fracionamento em ETR pesados pode ser usado para distinguir pegmatitos e rochas ígneas evoluídas (Belousova et al., 2002) ou, se associado com forte esgotamento em ETR leves, pode ser indicativo de coexistência com titanita, alanita e monazita (Rubatto, 2017). Entre as áreas fontes menos evoluídas estão os (meta)tonalitos de Represa de Camargos, Macuco de Minas, Lavras - Poço da Pedra, Alto Maranhão, Ritápolis, Ribeirão do Amaral, Nazareno e Tiradentes, quartzo diorito do Pluton Ribeirão do Amaral e quartzo monzodiorito do Pluton Glória. Áreas fontes intermediárias são representadas pelos granodioritos e ortognaisses granodioríticos de Itumirim, Lajedo, Morro do Resende e da Suíte Serrinha. Finalmente, as áreas fontes mais evoluídas podem ser representadas por granitos e ortognaisses graníticos dos Plutons Fé e Represa de Camargos, metagranito Gaspar Lopes, pegmatito da Represa de Camargos e granito porfiroblástico do Complexo Pouso Alegre.

\subsubsection{Idade de deposição e correlações}

$\mathrm{Na}$ Unidade Serra do Ibituruna não é possível reconstituir qualquer posição litoestratigráfica em virtude do grau de deformação atingido ao longo do Cinturão de Cisalhamento de Campo do Meio, uma vez que a unidade está restrita às zonas de cisalhamento ou como lascas isoladas em meio ao embasamento. Além disso, na unidade não foram reconhecidas intercalações de rochas associadas ao magmatismo sin-deposicional, o que dificulta a determinação de idades mínimas de deposição. 
Apesar das diferenças observadas nas proporções da contribuição das diferentes populações de zircão e dos dados concordantes que puderam ser considerados (Tabela 7-1), o teste K-S (Tabela 7-2) e os valores calculados para a idade máxima de deposição (Tabela 73) mostram que as quatro amostras são correlatas entre si e isso dá um certo grau de liberdade na escolha da amostra cuja idade melhor representa a máxima deposição da unidade.

Segundo Spencer et al. (2016) a idade máxima de deposição não deve ser definida com base no pico de idades mais jovens ou da média ponderada de múltiplos grãos pois estes métodos pressupõem um único evento de crescimento de zircão. "A média ponderada só pode ser usada quando se lida com análises de uma única população, por exemplo, uma erupção vulcânica ou um pluton rapidamente colocado" (Spencer et at., 2016). Os sistemas magmáticos costumam ser caracterizados por eventos prolongados (Spencer et at., 2016), como é o caso do arco magmático da Orogenia Minas (2,35 - 2,0 Ga, Teixeira et al., 2015). A idade máxima de deposição da Unidade Serra do Ibituruna estaria representada com maior exatidão se houvesse mais grãos com idades entre 2,1 e 2,0 Ga, entretanto, se a geologia do terreno de origem foi tal que a fonte mais nova produziu significativamente menos grãos de zircão do que outras fontes, ou porque esses grãos não foram depositados na bacia sedimentar precursora, essa população pode ter passado despercebida (Andersen, 2005).

A idade de $2080 \pm 0,9$ Ma obtida na amostra CP-05 (Tabela 7-3) foi escolhida para representar a idade máxima de deposição por se tratar da amostra que melhor contempla o intervalo de idades encontradas nos grãos detríticos de zircão da unidade, além disso, é a idade mais jovem obtida pela média ponderada dentro do intervalo de duração do arco magmático da Orogenia Minas (2,35 - 2,0 Ga, Teixeira et al., 2015).

A Figura 7.11 mostra gráfico comparativo da distribuição das idades U-Pb obtidas em cristais de zircão detrítico para a unidade Serra do Ibituruna e unidades pertencentes aos Grupos Canastra (Rodrigues et al., 2010), Araxá (Falci et al., 2018), Carrancas (Westin et al., 2019), Andrelândia (Frugis et al., 2018) e ao Complexo São Vicente (Westin et al., 2016). Apesar do Complexo Petúnia estar localizado em posição geográfica favorável à correlação entre as rochas do Grupo Canastra, a norte, e Carrancas, a sul, os dados U-Pb obtidos em cristais detríticos de zircão da Unidade Serra do Ibituruna revelam ausência de qualquer registro do Neoproterozoico, ou mesmo do Mesoproterozoico.

Mapeamentos realizados em 2015 nas Folhas Guaxupé e Nova Resende caracterizaram as rochas da Unidade Serra do Ibituruna como pertencentes à Unidade São Vicente, formada por xistos e quartzitos intercalados com paragnaisses de sequências autóctones e para-autóctones (Trouw et al., 2013; CODEMIG, 2015). O pico de idades em 
torno de 2,16 e 2,1 Ga representado por cristais de zircão provenientes das áreas-fonte secundárias da Unidade Serra do Ibituruna poderia ser correlacionado ao Complexo São Vicente (Figura 7.11), que tem picos de idades entre 2,17 e 2,13 (Westin et al., 2016), entretanto, no Complexo São Vicente, a contribuição de fontes arqueanas é insignificante e sua sucessão litológica, formada por uma fácies de paragnaisse e outra por intercalação de paragnaisse com quartzitos, xistos, rochas calciossilicáticas, anfibolitos e metaultramáficas (Westin et al., 2016), é distinta do que é observado no Complexo Petúnia (Gengo et al., em preparação).

Espectros de idades U-Pb em zircão detrítico similares aos da Unidade Serra do Ibituruna podem ser encontrados nos Grupos Sabará e Itacolomi (Figura 7.12). O Grupo Sabará é formado por metapelitos e metagrauvacas com lentes e camadas de metadiamectitos, metaconglomerados, metarenitos, metavulcanoclásticas e metatufitos que caracterizam sequência turbidítica correspondente à unidade mais jovem do Supergrupo Minas, separado das demais sequências por inconformidades regionais (Dorr, 1969; Alkmim e Marshak, 1998; Reis et al., 2002; Alkmin \& Noce, 2006). Já o Grupo Itacolomi é formado por sucessão de metarenitos e metaconglomerados com estruturas sedimentares primárias preservadas, depositados em ambientes de leques aluviais, além de metapelitos subordinados, separados das unidades do Supergrupo Minas por discordâncias angulares, sendo restrito à porção sul do Quadrilátero Ferrífero (Dorr, 1969; Alkmim \& Noce, 2006; Alkmim et al., 2014; Duque et al., 2020).

Para atestar a similaridade entre a Unidade Serra do Ibituruna e os Grupos Sabará e Itacolomi, o teste K-S foi executado para idades ${ }^{207} \mathrm{~Pb} /{ }^{206} \mathrm{~Pb}$ com 20 de incerteza, adotando um nível de confiança de $95 \%$, onde $\mathrm{P}=0,05$. Os resultados são apresentados na Tabela 7-8.

De acordo com Guynn \& Gehrels (2010), as duas hipóteses do teste K-S serão:

$$
\begin{gathered}
\text { P > 0,05: é improvável que as amostras sejam de fontes diferentes; } \\
\text { P < 0,05: é provável que as amostras sejam de fontes diferentes. }
\end{gathered}
$$

O teste K-S mostra que, com exceção da amostra CP-98B, as demais amostras da Unidade Serra do Ibituruna provavelmente tiveram as mesmas áreas fontes que as rochas do Grupo Itacolomi, com maior probabilidade de fonte comum entre os pares de amostras CP27/TR-312 e CP-35/TR-315 (Tabela 7-8). Já com o Grupo Sabará, apenas a amostra CP-35 mostra similaridade, inclusive com a maior probabilidade obtida no teste $(\mathrm{P}=0,642)$. 


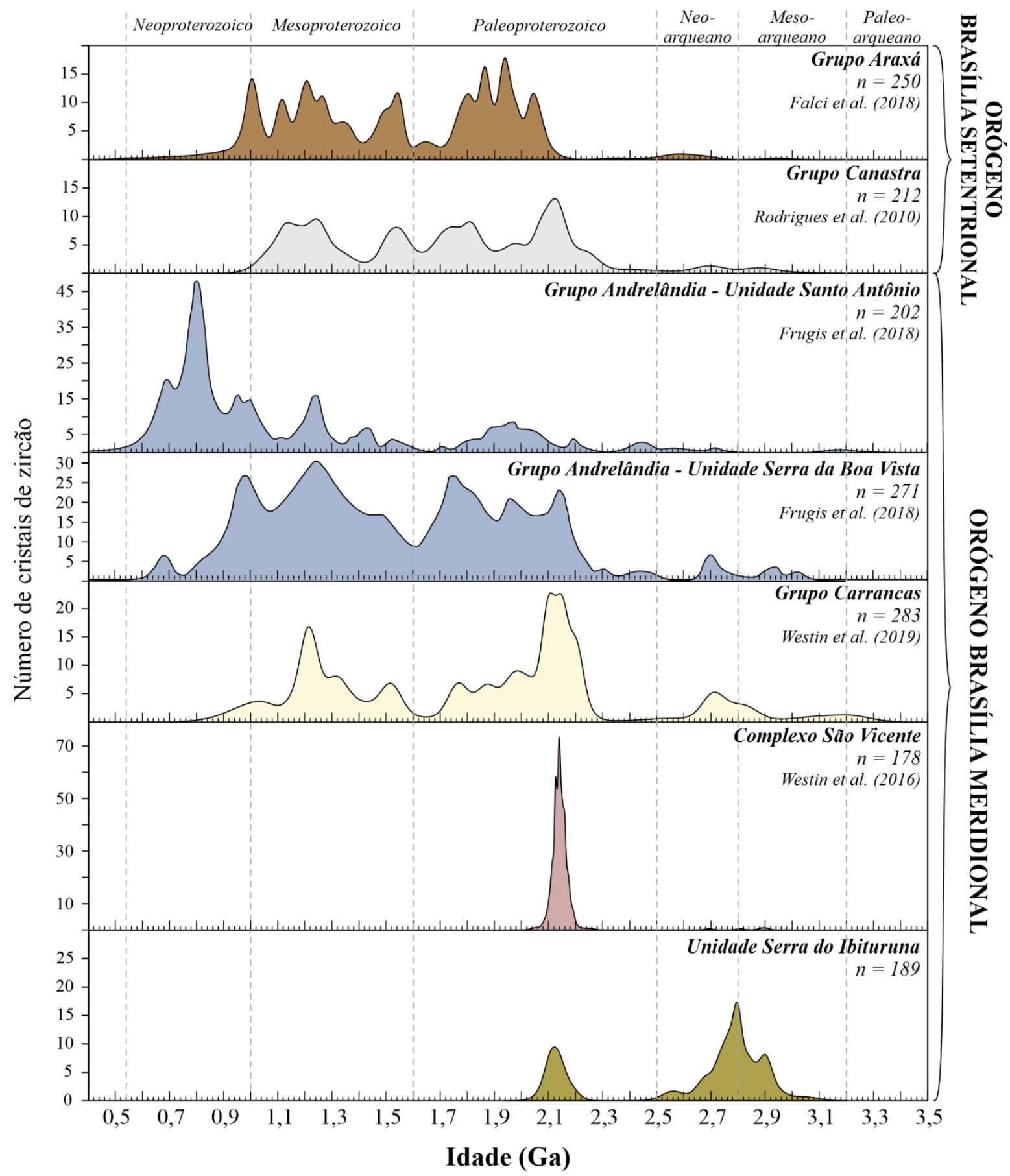

Figura 7.11: Gráfico comparativo mostrando os diagramas Idade vs. Probabilidade Relativa para a Unidade Serra do Ibituruna e unidades correlatas na literatura. Dados compilados de Falci et al., 2018, Rodrigues et al., 2010, Frugis et al., 2018 e Westin et al., 2016 e 2019.

Existem dois problemas com esse tipo de correlação, o primeiro porque a amostra CP-35 é àquela com o menor número de dados concordantes (n=33, Figura 7.4c), levando à possibilidade de contribuições errôneas de todas as suas áreas fontes, ou porque de fato ela teve menor contribuição de fontes arqueanas. Se a segunda possibilidade for verdadeira, podemos admitir que existe correlação entre a Unidade Serra do Ibituruna e os Grupos Sabará ou Itacolomi. 


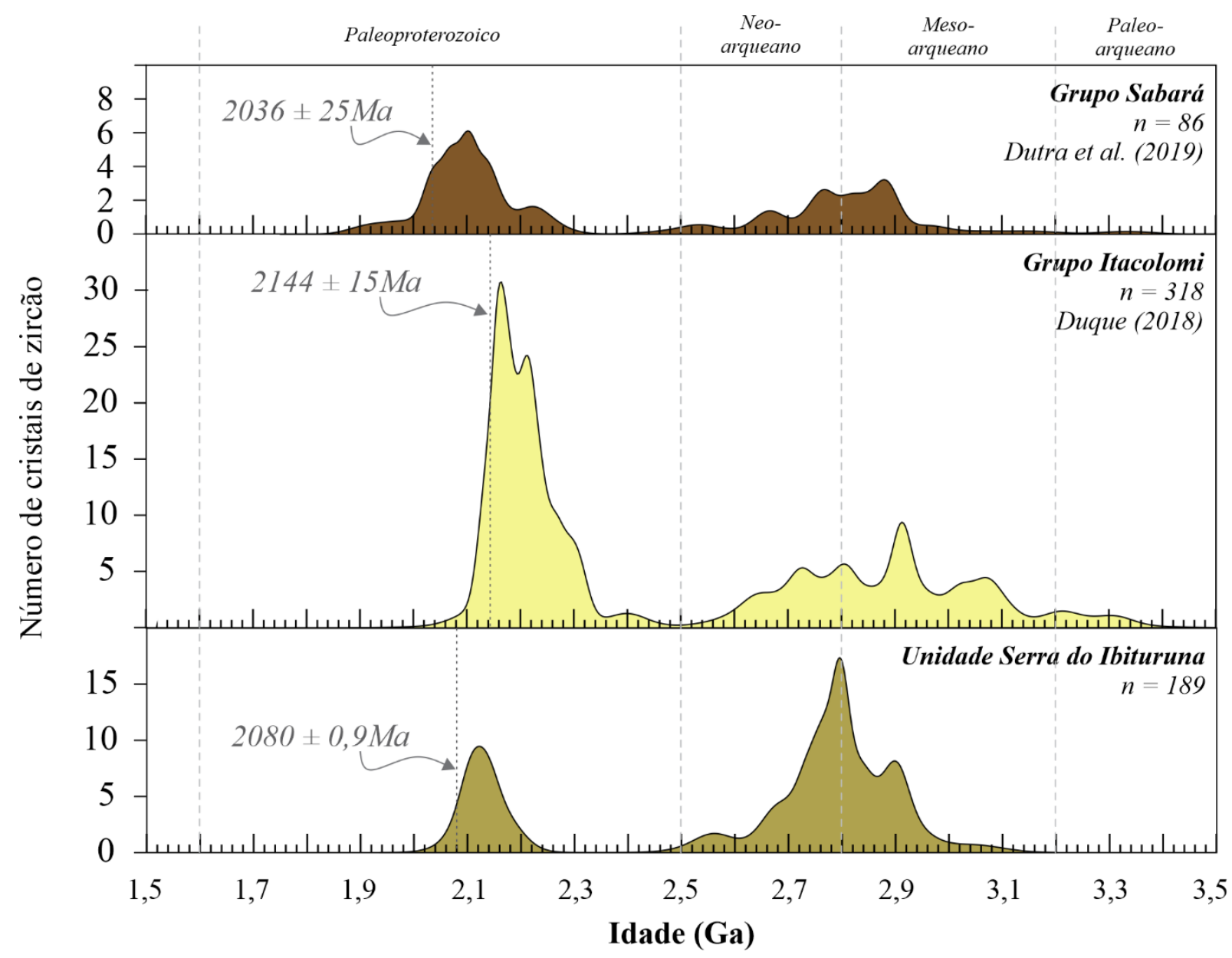

Figura 7.12: Gráfico comparativo mostrando os diagramas Idade vs. Probabilidade Relativa para a Unidade Serra do Ibituruna e os Grupos Sabará e Itacolomi. Estão indicadas as idades máximas de deposição para cada unidade. Dados compilados de Dutra et al. (2019) e Duque, 2018.

Tabela 7-7: Valores da probabilidade "P" obtidos no Teste K-S usando os erros das idades em função de densidade cumulativa para as amostras da Unidade Serra do Ibituruna e amostras dos Grupos Sabará e Itacolomi. As idades ${ }^{207} \mathrm{~Pb} /{ }^{206} \mathrm{~Pb}$ utilizadas no teste foram extraídas de Duque (2018) e Dutra et al. (2019).

\begin{tabular}{|c|c|c|c|c|c|c|c|c|c|c|}
\hline \multicolumn{11}{|c|}{ K-S P-values using error in the CDF } \\
\hline \multirow{2}{*}{ Amostra } & \multicolumn{4}{|c|}{ Unidade Serra do Ibituruna } & \multirow{2}{*}{$\begin{array}{l}\text { Grupo } \\
\text { Sabará } \\
\text { GD-05 }\end{array}$} & \multicolumn{5}{|c|}{ Grupo Itacolomi } \\
\hline & CP-05 & CP-27 & CP-35 & CP-98B & & TR-310 & TR-312 & TR-314 & TR-315 & TR-316 \\
\hline $\mathrm{CP}-05$ & & 0.179 & 0.188 & 0.300 & 0.000 & 0.033 & 0.074 & 0.000 & 0.001 & 0.000 \\
\hline $\mathrm{CP}-27$ & 0.179 & & 0.324 & 0.627 & 0.005 & 0.089 & 0.378 & 0.000 & 0.004 & 0.000 \\
\hline $\mathrm{CP}-35$ & 0.188 & 0.324 & & 0.039 & 0.642 & 0.278 & 0.099 & 0.027 & 0.395 & 0.068 \\
\hline CP-98B & 0.300 & 0.627 & 0.039 & & 0.000 & 0.003 & 0.012 & 0.000 & 0.000 & 0.000 \\
\hline GD-05 & 0.000 & 0.005 & 0.642 & 0.000 & & 0.010 & 0.001 & 0.016 & 0.012 & 0.001 \\
\hline TR-310 & 0.033 & 0.089 & 0.278 & 0.003 & 0.010 & & 0.967 & 0.014 & 0.221 & 0.029 \\
\hline TR-312 & 0.074 & 0.378 & 0.099 & 0.012 & 0.001 & 0.967 & & 0.003 & 0.132 & 0.007 \\
\hline TR-314 & 0.000 & 0.000 & 0.027 & 0.000 & 0.016 & 0.014 & 0.003 & & 0.296 & $\mathbf{0 . 7 8 8}$ \\
\hline TR-315 & 0.001 & 0.004 & 0.395 & 0.000 & 0.012 & 0.221 & 0.132 & 0.296 & & 0.497 \\
\hline TR-316 & 0.000 & 0.000 & 0.068 & 0.000 & 0.001 & 0.029 & 0.007 & 0.788 & 0.497 & \\
\hline
\end{tabular}


Apesar de ser mais improvável que as rochas da Unidade Serra do Ibituruna e do Grupo Itacolomi tenham tido áreas fontes diferentes, a idade máxima de deposição da Unidade Serra do Ibituruna, de $2080 \pm$ 0,9 Ma, é mais próxima da idade máxima de deposição do Grupo Sabará $(2036 \pm 25 \mathrm{Ma}$, Dutra et al., 2019) do que a do Grupo Itacolomi (2129 \pm 11 Ma, Duque et al., 2020). Além disso, o Grupo Sabará também mostra hiato no registro de áreas fontes siderianas, entre 2,40 - 2,35 Ga, assim como a Unidade Serra do Ibituruna (Figuras 7.3 e 7.11).

Inferências quanto ao regime deposicional das bacias paleoproterozoicas precursoras da Unidade Serra do Ibituruna são limitadas devido à ausência de dados geoquímicos e isotópicos. Outra maneira de inferir o contexto geotectônico das bacias sedimentares é a partir da forma das curvas de distribuição cumulativa "CAD" obtidas pela diferença entre as idades de cristalização/metamorfismo da área fonte dos cristais detríticos de zircão e a idade máxima de deposição (IC-ID, Cawood et al., 2012).

De acordo com Cawood et al. (2012, p. 876)

A interação entre tectônica, tipo de bacia e de sedimentos indica que o registro do zircão detrítico é a somatória de duas variáveis principais: (1) da presença ou ausência de atividade magmática sin-sedimentar, e (2) da propagação geral e proporção de diferentes idades registradas. O impacto dessas variáveis pode ser representado graficamente.

Devido à ausência de idades mínimas de deposição para a Unidade Serra do Ibituruna, para o gráfico da Figura 7.12 foram utilizadas as idades máximas de deposição, inclusive para os Grupos Sabará e Itacolomi. No caso destes últimos a escolha da idade máxima de deposição é devida à relativa proximidade ao pico de idades mais jovens (Figura 7.12), o que já descaracteriza deposição em ambiente extensional, onde há predomínio de idades de zircão detrítico muito mais antigas que o tempo de acumulação dos sedimentos (Cawood et al., 2012).

No conjunto de dados concordantes da Unidade Serra do Ibituruna $(\mathrm{n}=189), 21,2 \%$ tem IC-ID < $100 \mathrm{Ma}$ e curvas de densidade cumulativa que plotam no campo de bacias depositadas em ambiente colisional (Figura 7.13), tal como os Grupos Sabará e Itacolomi (Duque et al., 2020; Dutra et al., 2019). Para explicitar a diferença, no Complexo São Vicente, “cerca de $90 \%$ de todas as idades detríticas de zircão estão dentro de $50 \mathrm{Ma}$ da idade estimada de deposição de sedimentos" (Westin et al., 2016), implicando em ambiente deposicional em margem ativa (Cawood et al., 2012). 


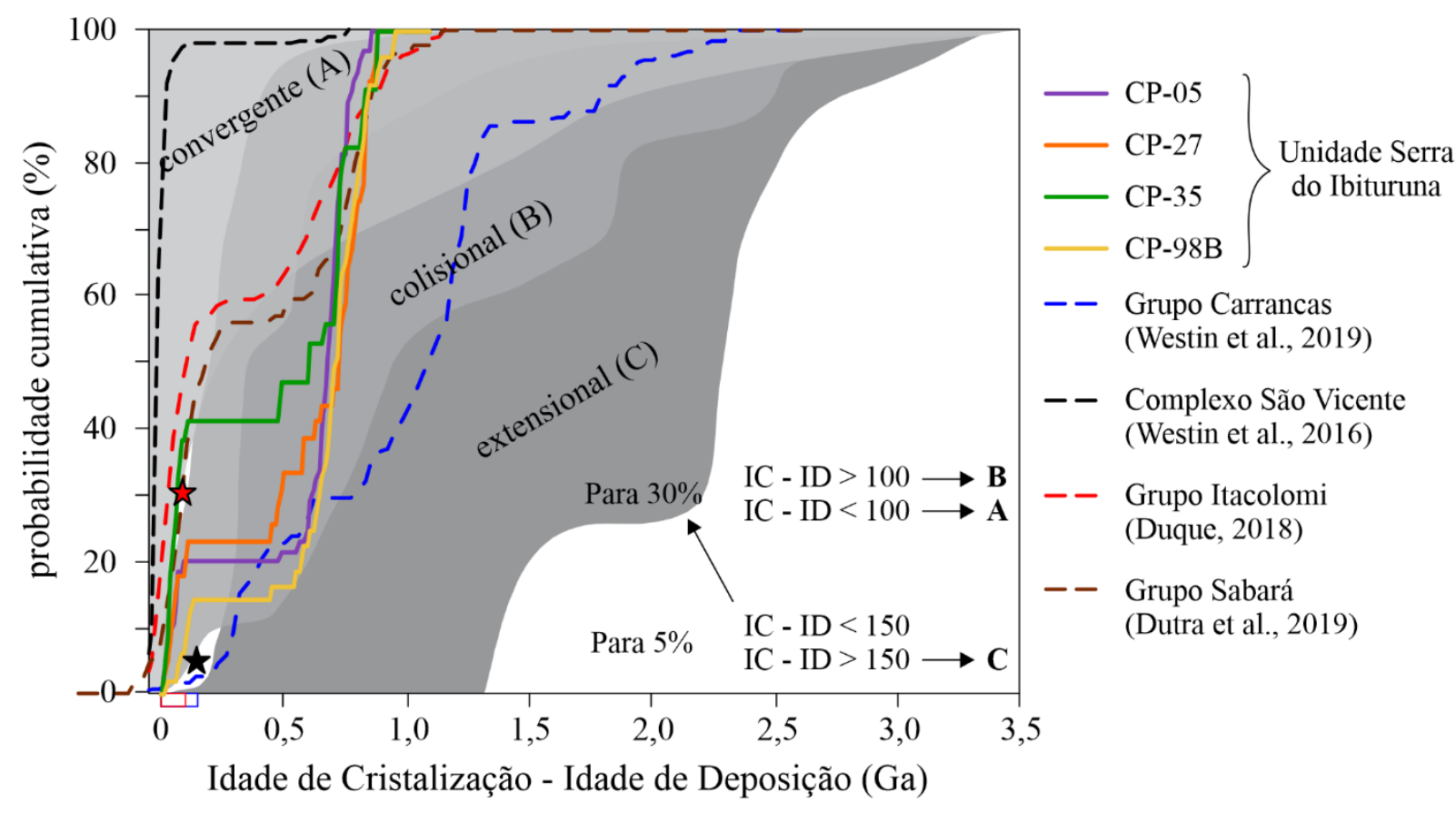

Figura 7.13: Gráfico IC-ID (Idade de Cristalização - Idade de Deposição) vs. Probabilidade Cumulativa para inferências de regime deposicional segundo Cawood et al. (2012) das amostras da Unidade Serra do Ibituruna, as possíveis unidades correlatas e, comparativamente, unidades neoproterozoicas do Orógeno Brasília Meridional. Dados compilados de Westin et al. (2016, 2019), Duque et al., (2020) e Dutra et al. (2019). 


\section{METAMORFISMO DA UNIDADE COLÔNIA}

Os metapelitos da Unidade Colônia foram escolhidos para avaliar com precisão as condições $P-T$ - $t$ do metamorfismo que atuou no Complexo Petúnia através da construção de pseudosseções e de cálculos geotermobarométricos. Duas amostras foram investigadas, um cianita-estaurolita-muscovita-granada-biotita xisto (CP-07) e um muscovita-cianitaplagioclásio-granada-biotita xisto (CP-333). As idades de metamorfismo foram abordadas através das assinaturas geoquímicas em zircão e dos dados U-Pb obtidos em zircão e monazita da amostra CP-07.

\subsection{Cianita - estaurolita - muscovita - granada - biotita xisto (CP-07)}

A rocha apresenta matriz xistosa formada por biotita e muscovita em textura lepidoblástica fina a média, com cianita e estaurolita associadas. Intercalações de leitos descontínuos de composição quartzo-feldspáticas são abundantes. Essas intercalações têm espessura submilimétrica a centimétrica e forma lenticular a ovoide, assimétrica, com eixo maior paralelo à foliação principal $S_{2}$ (Figura 8.1a).

Cianita ocorre como cristais subidioblásticos a idioblásticos, muitas vezes como porfiroblastos $\sin -\mathrm{S}_{2}$, orientados segundo a foliação principal (Figura 8.1b), podendo apresentar extinção ondulante, resultante da deformação interna por kink bands. Duas gerações de estaurolita podem ser reconhecidas, a primeira caracterizada por cristais subidioblásticos $\sin -\mathrm{S}_{2}$, orientados segundo a foliação principal, com bordas irregulares, sugerindo consumo parcial, e a segunda caracterizada por cristais idioblásticos, pós- $\mathrm{S}_{2}$, que cresceram sobre a foliação principal (Figuras 8.2a e 8.2b). Ambas as gerações podem conter inclusões de quartzo, rutilo, ilmenita e biotita. Biotita e muscovita raramente preservaram arcos poligonais da $\mathrm{S}_{1}$ e os poucos cristais discordantes da foliação principal são retrometamórficos. Quando associados à clorita, biotita e muscovita são produtos do retrometamorfismo, substituindo a granada.

Granada ocorre como porfiroblastos com diâmetro variado entre 2 e $5 \mathrm{~mm}$ em dois tipos distintos (Figuras 8.1a e 8.1b), ambos amoldados pela foliação principal, um com foliação interna mal definida e zonas ricas em inclusões de minerais opacos e mica muito fina separadas de zonas pobres em inclusões (granada tipo I, Figura 8.4a) e outro rico em inclusões de quartzo com foliação interna bem marcada (granada tipo II). As foliações internas são discordantes da foliação externa, indicando que os porfiroblastos são intercinemáticos, e são também discordantes entre si, sugerindo que os porfiroblastos foram 
rotacionados de maneira heterogênea durante o desenvolvimento da foliação milonítica, regional, $\mathrm{S}_{2}$ (Figura 8.2c).

Plagioclásio raramente ocorre na matriz compondo domínios de textura granoblástica ou como cristais subidioblásticos isolados em meio às micas. Fases acessórias incluem zircão, monazita, rutilo, ilmenita, apatita, turmalina, magnetita e clorita.

As lentes quartzo-feldspáticas com dimensões centimétricas possuem películas ricas em biotita (Figuras 8.2e e 8.2f) e internamente são maciças, com textura inequigranular hipidiomórfica recristalizada (Figura 8.2d) e com pouca deformação, registrada apenas pelo quartzo através dos contatos interlobados a poligonizados. O plagioclásio é subidiomórfico e exibe zoneamento composicional visível através da forte extinção concêntrica. A biotita ocorre entre os cristais de plagioclásio, sem definir foliação, e como inclusões no plagioclásio. As inclusões são idiomórficas ou tem bordas arredondadas e difusas, sugerindo borda reacional.
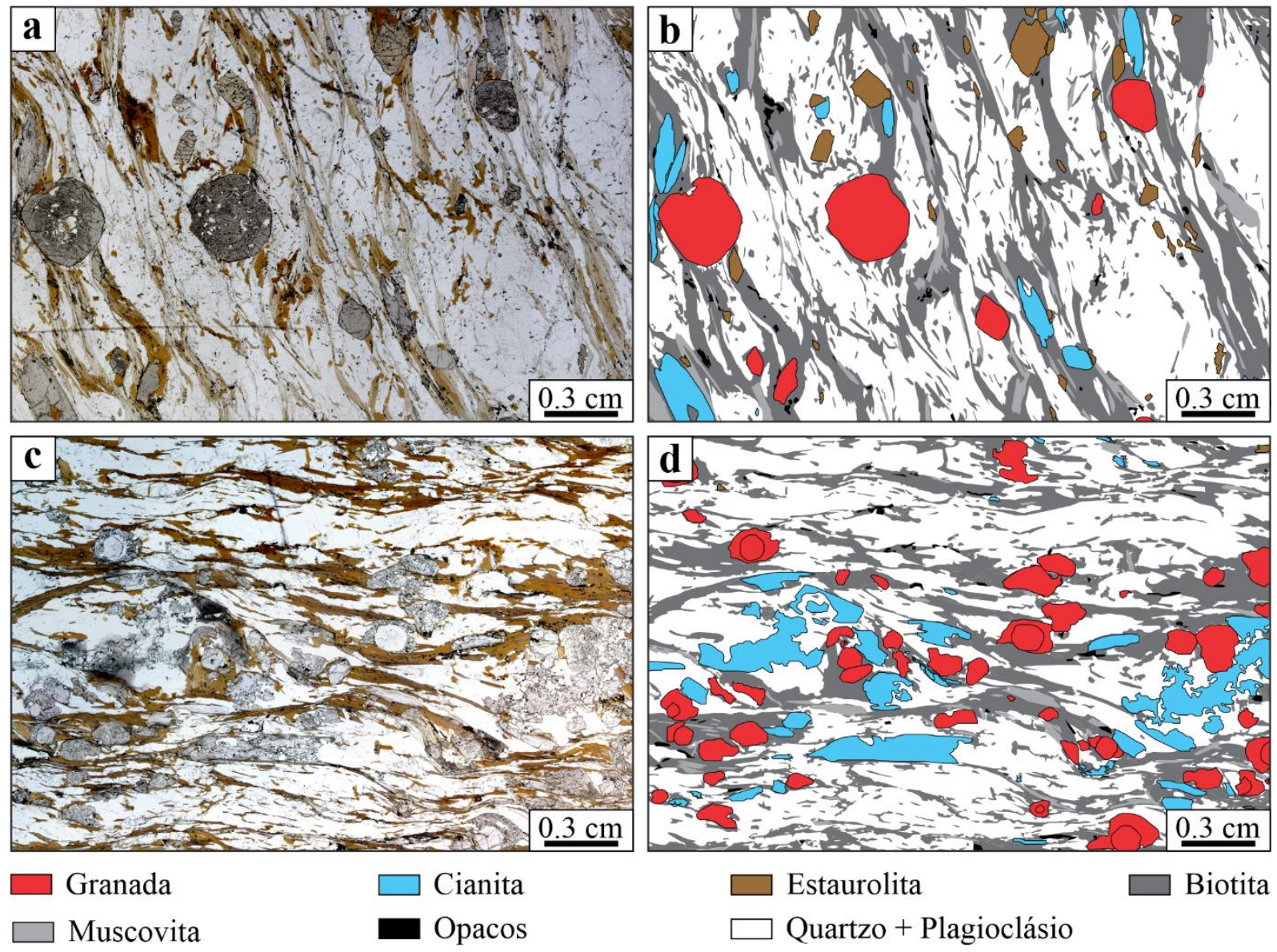

Granada

Muscovita $\square$ Cianita

Opacos

Figura 8.1: a-b) Cianita-estaurolita-muscovita-granada-biotita xisto, amostra MP-27; c-d) Muscovita-cianitaplagioclásio-granada-biotita xisto milonítico, amostra CP-333. 

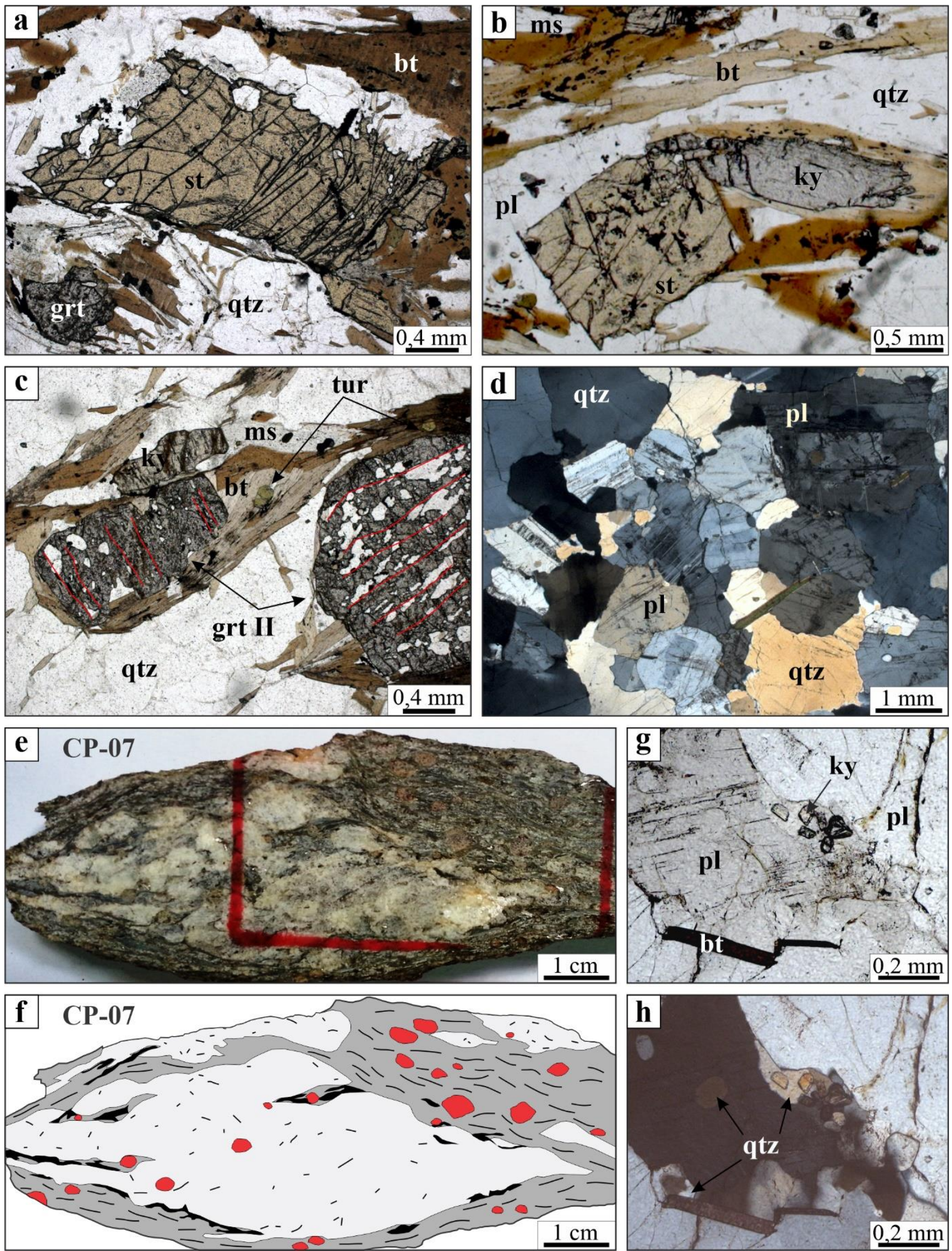

Figura 8.2: Porfiroblastos de estaurolita - a) da primeira geração e b) da segunda geração; c) Porfiroblastos de granada, inter-cinemáticos e rotacionados pela foliação, amostra MP-27; d) Textura inequigranular hipidiomórfica em lente quartzo-feldspática, amostra CP-07; e) Cianita-estaurolita-muscovita-granada-biotitaquartzo xisto com intercalações lenticulares formadas por quartzo, plagioclásio e biotita; f) Esboço do cianitaestaurolita-muscovita-granada-biotita-quartzo xisto com as intercalações de lentes quartzo-feldspáticas e destaque para os selvedges de biotita; g-h) Cristais de plagioclásio com quartzo intersticial e cristais de cianita, interpretada como peritética, amostra CP-07. 
Quartzo também ocorre nos interstícios entre cristais de plagioclásio, onde engloba cristais idioblásticos muito finos de estaurolita e cianita (Figuras 8.2g e 8.2h). As relações de cristalização/recristalização dos minerais com as foliações podem ser vistas na Tabela 8-1.

As lentes quartzo-feldspáticas intercaladas com o xisto podem corresponder à heterogeneidades composicionais originais do protólito, no entanto, levando em consideração que a Unidade Colônia tem disposição geral controlada por zonas de cisalhamento dúcteisrúpteis (Gengo et al. - em preparação), seria esperado encontrar feições com maior grau de deformação. A forma assimétrica das lentes quartzo-feldspáticas, os cristais subidiomórficos de plagioclásio com filmes de quartzo, com ou sem cristais de cianita e estaurolita interpretados como peritéticos e os selvedges de biotita no contato com o xisto sugerem que essas lentes tenham sido originadas por fusão parcial do cianita-estaurolita-muscovitagranada-biotita xisto. Este será o ponto de partida para a modelagem metamórfica que será abordada no item 8.4.

Tabela 8-1: Relações de crescimento mineral com as foliações nos metapelitos da Unidade Colônia.

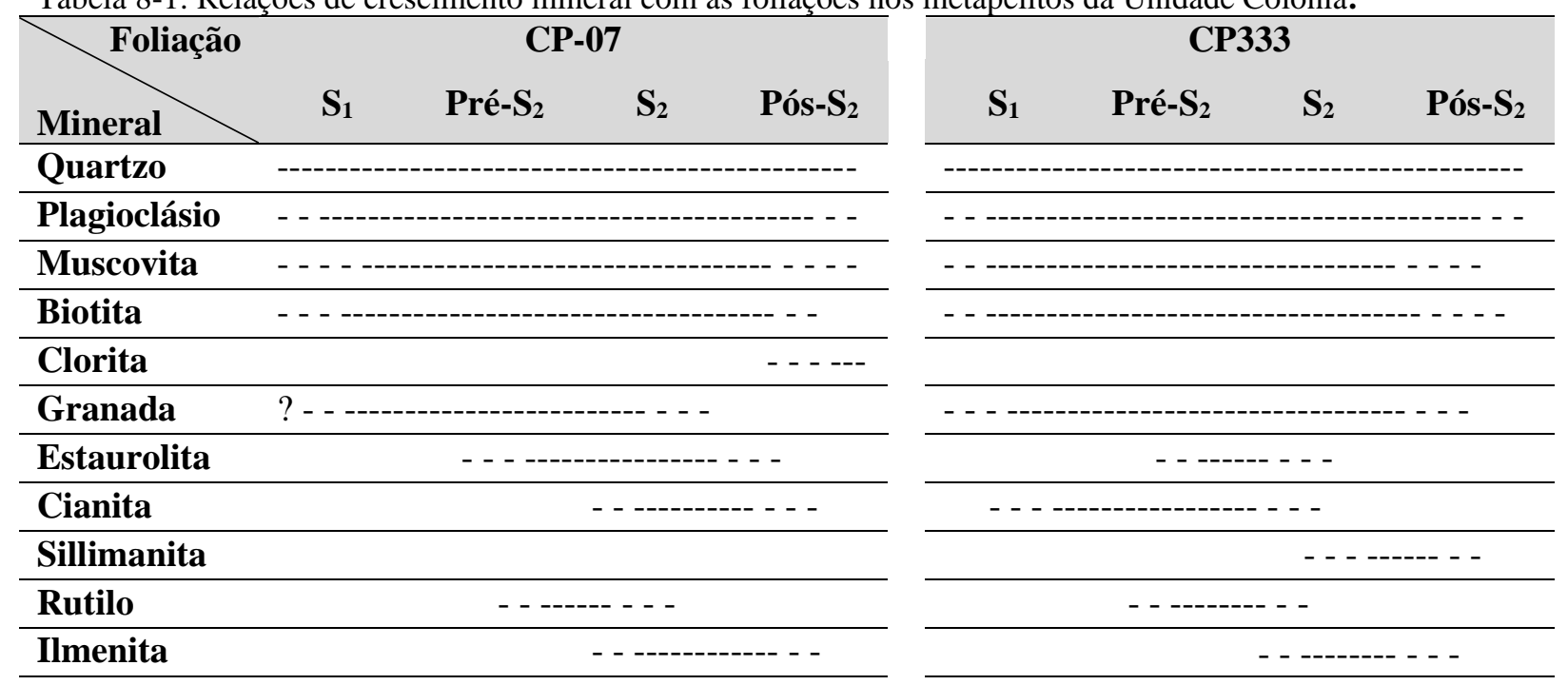

\subsection{Muscovita - cianita - plagioclásio - granada - biotita xisto (CP-333)}

A rocha é xistosa, tem granulação fina a média e foliação marcada por intercalações irregulares de bandas granoblásticas de granulação média, quartzo - feldspáticas, e bandas lepidoblásticas, formadas por biotita e muscovita, com esparsos pods assimétricos ricos em cianita, quartzo, plagioclásio e rutilo (Figuras 8.1c e 8.1d). Fases acessórias incluem estaurolita, sillimanita, ilmenita, magnetita, clorita, turmalina, zircão, monazita e apatita. 
Cianita ocorre em duas formas distintas, uma como porfiroblastos subidioblásticos a idioblásticos orientados segundo $\mathrm{S}_{2}$ e outra, nos pods, como cristais xenoblásticos que englobam granada idioblástica (Figura 8.3a). Esta cianita possui bordas ameboides (Figura 8.3b), e é associada a quartzo e plagioclásio ricos em inclusões de biotita e muscovita (Figura 8.3c). Plagioclásio ocorre como cristais subidioblásticos orientados segundo a foliação principal, às vezes assimétricos, ou como cristais xenoblásticos, em interstícios entre cristais de granada e nos pods assimétricos (Figuras 8.3d e 8.3e). A granada exibe quatro feições cujas relações texturais permitem identificar pelo menos duas gerações de crescimento:

I) Cristais idioblásticos de granada inclusos na cianita dos pods assimétricos (Figuras 8.3a e 8.5a). Possuem inclusões muito finas de quartzo, plagioclásio, muscovita, apatita e ilmenita que definem foliação interna $\left(S_{1}\right)$ discordante da foliação principal $\left(\mathrm{S}_{2} / / \mathrm{S}_{3}\right)$, e representam a primeira geração de crescimento. Esta geração de granada raramente mostra contato com os minerais da matriz;

II) Cristais idioblásticos como os da feição em (I), com coronas de granada e reduzido número de inclusões (Figuras 8.5b). A granada da corona é poiquiloblástica, rica em inclusões de quartzo, minerais opacos, biotita e, às vezes, estaurolita e rutilo. A foliação interna nem sempre está presente. Essa feição é predominante e a granada da corona representa a segunda geração de crescimento;

III) Cristais poiquiloblásticos da segunda geração com relíquias de cristais da primeira geração (Figura 8.5c). O contato entre as duas gerações de granada é difuso e irregular, muitas vezes acompanhado de maior quantidade de inclusões de quartzo;

IV) Granada poiquiloblástica da segunda geração de crescimento. Comumente possuem forma alongada com eixo maior paralelo à foliação, ou são assimétricas (Figura 8.5d).

Rutilo é xenoblástico, ocorre como inclusões na granada da primeira geração, mas predomina como inclusões nas duas gerações de cianita e, neste caso está intimamente associado com ilmenita (Figura 8.3d). Ilmenita também ocorre como cristais subidioblásticos a xenoblásticos orientados segundo a foliação principal ou em regiões associadas com clorita, muscovita e biotita tardias. Estaurolita é fase acessória e ocorre como cristais idioblásticos orientados segundo a foliação principal, como cristais xenoblásticos inclusos na granada da segunda geração, ou como cristais idioblásticos inclusos no plagioclásio, em feição similar à da Figura 8.2e. As relações de cristalização/recristalização dos minerais com as foliações podem ser vistas na Tabela 8-1. 

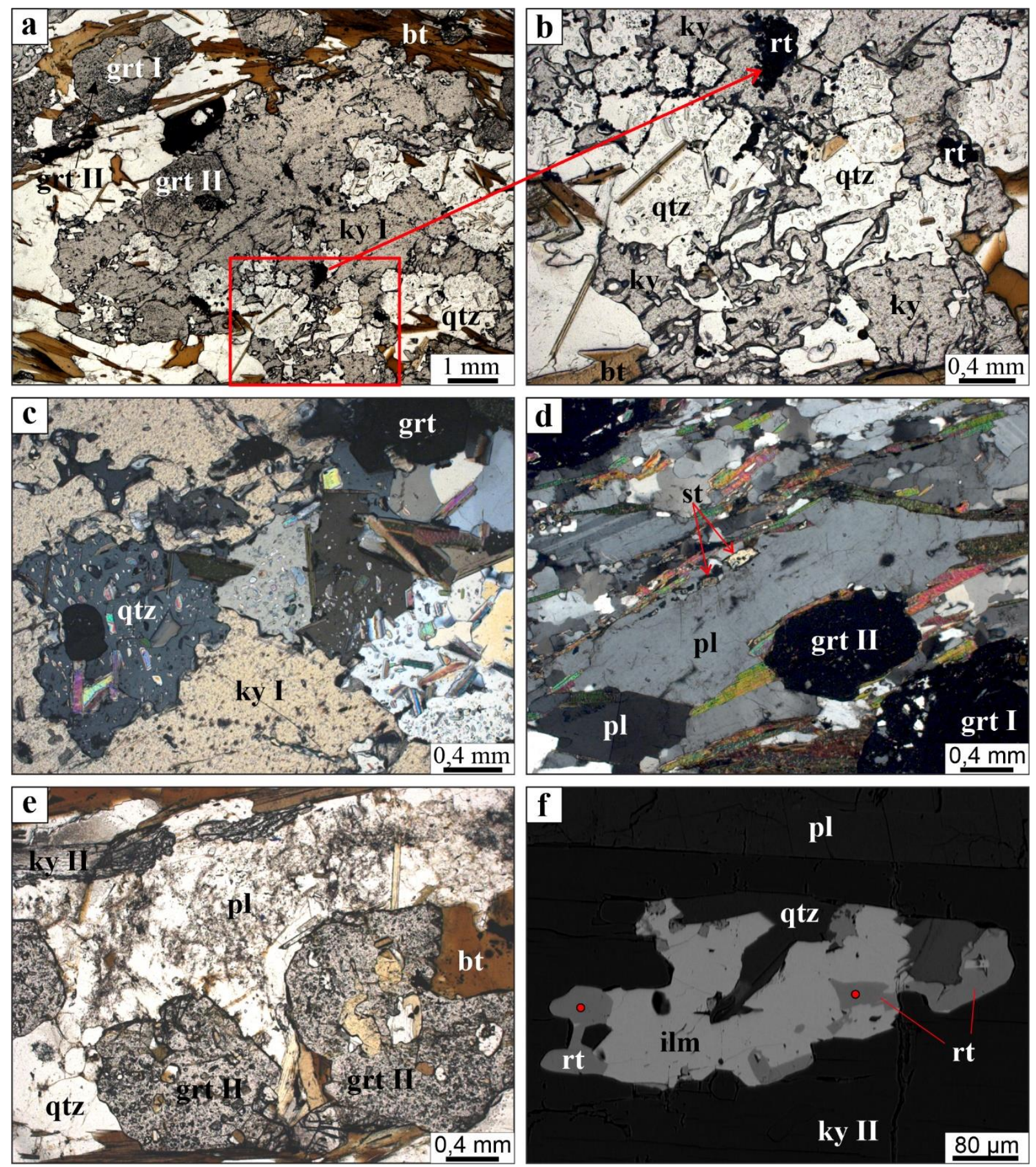

Figura 8.3: Muscovita-cianita-plagioclásio-granada-biotita-quartzo xisto milonítico (CP-333). a) Pods assimétrico de cianita com inclusões de quartzo, rutilo e granada da primeira geração (feição I). Notar granadas com coronas de granada da segunda geração no canto superior esquerdo; b) Detalhe para as bordas ameboides da cianita; c) Cristais de quartzo e plagioclásio ricos em inclusões de micas; d) Cristal de plagioclásio assimétrico e amoldado pela foliação. Notar microinclusões idioblásticas de estaurolita; e) Cristais de granada da segunda geração de crescimento (feição IV) com plagioclásio intersticial; e) Cianita com inclusão de cristal de ilmenita parcialmente substituído por rutilo. Círculos vermelhos representam os locais de análise química. 


\subsection{Química Mineral}

\subsubsection{Granada}

$\mathrm{Na}$ amostra CP-07 o comportamento das variações composicionais é distinto nos dois tipos de porfiroblastos de granada, mas ambos têm a almandina como molécula dominante. Nos porfiroblastos com zonas ricas em inclusões (granada tipo I - Figura 8.4a), as concentrações de Fe e Mg decrescem em direção ao núcleo (Figuras 8.4b-d), com alm73,9-77,8 nas bordas e alm64,7-72,2 no núcleo. Ca tem comportamento inverso, aumentando em direção ao núcleo (Figuras 8.4b e 8.4e), com grs4,7-10,8 nas bordas e grs $12,4-18,3$ no núcleo. Mn ocorre em menores concentrações, com aumento das bordas $\left(\operatorname{sps}_{0,3-3,8}\right)$ para o núcleo $\left(\operatorname{sps}_{8,2-12,6}\right)$, no entanto, no mapa composicional é possível verificar que ocorre fina película enriquecida em Mn, praticamente imperceptível em perfil (Figuras 8.4b e 8.4f).

Nos porfiroblastos ricos em inclusões de quartzo (tipo II - Figura 8.4g), as variações composicionais são sutis (Figura 8.4h). A concentração de Fe é similar à da borda da granada tipo I, com alm73,6-76,7 e ligeiro aumento nas bordas, porem acompanhado por diminuição de $\mathrm{Mg}$, com prp14,2-16,9. A concentração de Ca e Mn é praticamente constante, com grs4,3-5,5 e sps4-4,6, respectivamente.

Na granada da amostra CP-333 a molécula dominante também é a almandina. Apesar de texturalmente distintas, as duas gerações de crescimento mostram perfis com comportamento similar dos membros finais almandina, piropo, grossulária e espessartita (Figuras 8.5e e 8.5h). As concentrações de $\mathrm{Mg}, \mathrm{Ca}$ e $\mathrm{Mn}$ definem patamares planos e contínuos, com mudanças restritas às bordas, onde há diminuição de $\mathrm{Mg}$ e $\mathrm{Ca}$ (prp p̧,3-9,2 /grs 11,3-7,5 e prp 17,4-13,6/grs 10,3-6,9, respectivamente nas granadas da $1^{\mathrm{a}}$ e $2^{\mathrm{a}}$ geração) e aumento de $M n$ ( $\operatorname{sps}_{0,93-2,7}$ e $\operatorname{sps}_{1,4-2,81}$ respectivamente nas granadas da $1^{\text {a }}$ e $2^{\text {a }}$ geração), que é acompanhado por aumento da concentração de $\mathrm{Fe}$, com variações mais expressivas ao longo dos cristais, alm $70,9-80,7$ na granada da $1^{\text {a }}$ geração e alm $71,4-77,0$ na granada da $2^{\text {a }}$ geração.

Nos mapas composicionais é possível observar melhor o contraste entre as duas gerações de granada. A granada da $1^{a}$ geração mostra variação composicional concêntrica para $\mathrm{Fe}, \mathrm{Mg}, \mathrm{Ca}$ e $\mathrm{Mn}$, perturbada apenas na região rica em inclusões de quartzo (Figuras 8.6a-d), enquanto a granada da $2^{\mathrm{a}}$ geração mostra distribuição de Fe praticamente uniforme e similar à das bordas da granada da $1^{a}$ geração e variações heterogêneas para Ca e Mn (Figuras 8.6m, o-p). Já a concentração de $\mathrm{Mg}$ diminui quando a granada da $2^{\mathrm{a}}$ geração faz contato com as micas e a estaurolita na matriz (Figuras 8.5d e 8.6n). 

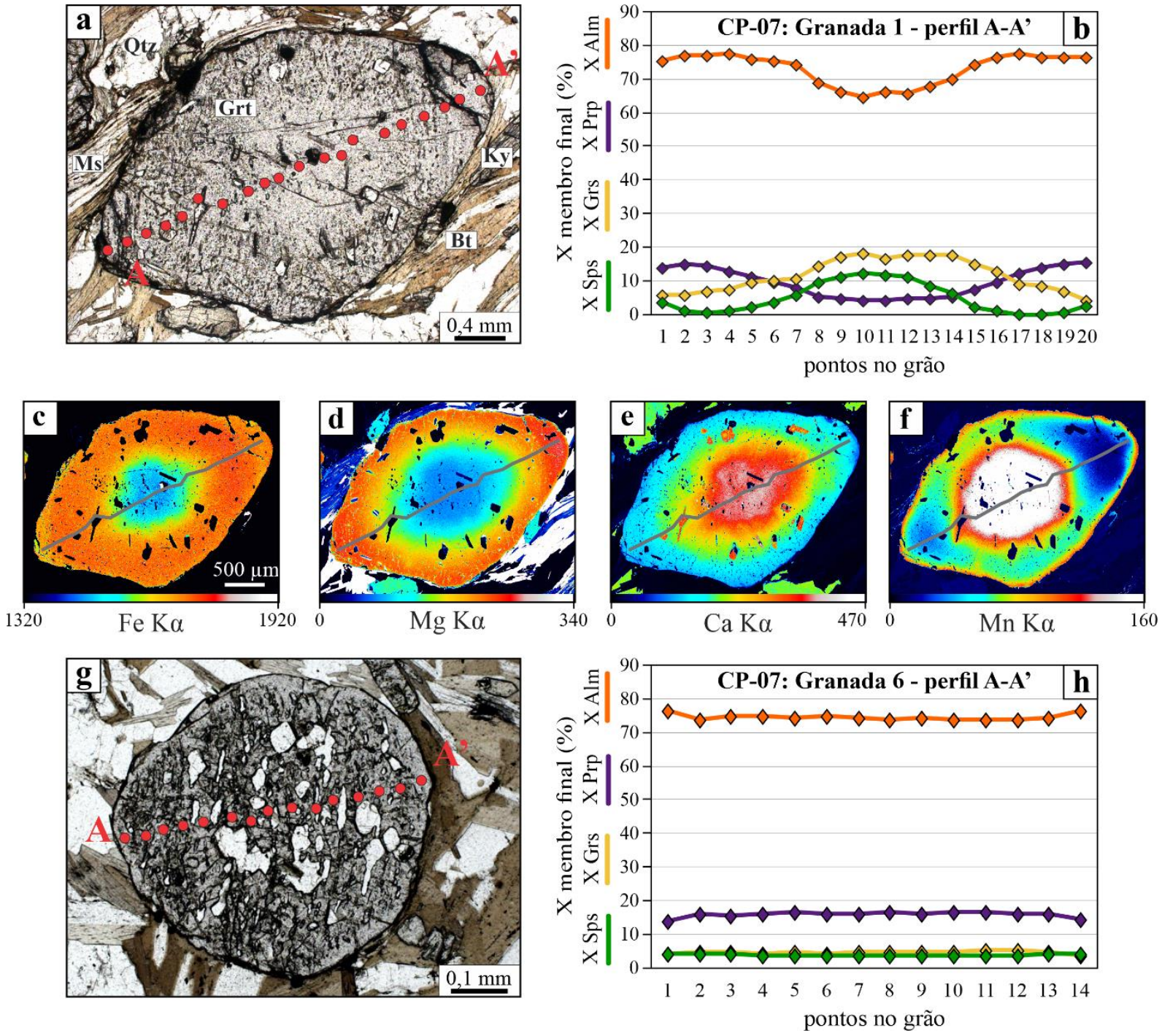

Figura 8.4: a) Porfiroblasto de granada tipo I da amostra CP-07, com a indicação do perfil composicional; b)Gráfico da distribuição da concentração dos membros finais almandina, piropo, grossulária e espessartita ao longo do perfil na granada tipo I; c-f) Mapas composicionais para concentrações de $\mathrm{Fe}$, a $\mathrm{Mg}$, $\mathrm{Ca}$ e $\mathrm{Mn}$ com indicação do perfil; g) Porfiroblasto de granada tipo II da amostra CP-07, com a indicação do perfil composicional; h) Gráfico da distribuição da concentração dos membros finais almandina, piropo, grossulária e espessartita ao longo do perfil na granada tipo II.

Na granada da $1^{a}$ geração com coronas de granada da $2^{a}$ geração há nítido contraste composicional (feição ii, Figura 8.5b). Há maior concentração de Fe nas bordas da granada da $2^{\mathrm{a}}$ geração (alm74,8-79,1), que diminui em direção à borda da granada da $1^{\mathrm{a}}$ geração, de onde passa a diminuir abruptamente, com alm $\operatorname{alm}_{7,2}$ a alm 69,1 (Figura 8.5f). No mapa de contagens de Fe é possível observar que a concentração de Fe na granada da $1^{a}$ geração torna-se menor em presença das coronas da $2^{\text {a }}$ geração de granada (Figuras 8.6a e 8.6e).

A concentração de $\mathrm{Mg}$ aumenta ao longo da granada da $2^{\mathrm{a}}$ geração $\left(\operatorname{prp}_{11,8-15,3}\right)$ e permanece constante na granada da $1^{a}$ geração, com prp16-17,5 (Figura 8.5f), no entanto, no mapa de contagens de $\mathrm{Mg}$ há sutil diminuição no núcleo da granada da $1^{\text {a }}$ geração 
(Figura 8.6f). Para o $\mathrm{Ca}$ as variações mais são sutis. Na granada da $1^{a}$ geração a concentração do Ca é constante, com grs5.7-6.7, e similar a das bordas da granada inclusa na cianita (feição i, Figuras 8.5a, 8.6c e 8.6g), enquanto a granada da corona mostra variações heterogêneas, com grs6,1-8,2, e similares à da granada na feição iv (Figura 8.5d). A distribuição do Mn é inversa à do Fe (Figura 8.5f), com pouca variação ao longo da granada da $2^{a}$ geração, com sps $2,53-3,12$, aumentando na granada da $1^{\text {a }}$ geração, com $\operatorname{sps}_{4,4-9,2}$. Tal comportamento é distinto ao observado na granada da feição i, sugerindo que a cianita agiu como isolante para as trocas catiônicas envolvendo $\mathrm{Mn}^{2+}$.

A granada da feição iii mostra distribuições irregulares para $\mathrm{Fe}$ e $\mathrm{Ca}$ ao longo do perfil, com $\operatorname{alm}_{72,5-75,9}$ e grs5,9-10,3 (Figura 8.5g). Mn não mostra variação significativa (sps 1,9 $3,2)$ e, para $\mathrm{Mg}$, a variação é menor na granada da $2^{\mathrm{a}}$ geração (prp $\left.13,5-15,3\right)$ e maior na granada da $1^{\text {a }}$ geração (prp $\left.14,1-18,1\right)$. Tais irregularidades para $\mathrm{Fe}, \mathrm{Ca}$ e altos de $\mathrm{Mg}$ são compatíveis com relíquias da granada da $1^{\text {a }}$ geração (Figuras 8.6i-k). A variação no conteúdo de Mn é dependente da posição relativa da granada da $1^{\text {a }}$ geração, quando está no núcleo da granada da $2^{\mathrm{a}}$ geração, a concentração de Mn é maior e a variação é tal como ocorre na feição ii (Figuras 8.6h e 8.6l) e, quando exibe contatos mal definidos com a granada da $2^{\mathrm{a}}$ geração, as concentrações são menores e a concentração do Mn aumenta do núcleo em direção às bordas (Figura 8.61).

\subsubsection{Estaurolita}

Na estaurolita, $X_{\mathrm{Mg}}$, é constante em cristais da amostra CP-07, com 4,0-4,16, e não foram verificadas variações sistemáticas núcleo-borda, porém, embora as variações composicionais sejam restritas, há correlação positiva entre $\mathrm{Fe}^{2+}$ e $\mathrm{Mg}^{2+}$ na estaurolita da amostra CP-333 (Figura 8.7a). Esta correlação é reflexo da maior variação no valor de $X_{\mathrm{Mg}}$, de 3.68 a 4.0. Na amostra CP-07 o conteúdo de Zn na estaurolita é constante, de 0.08 0.09 a.p.f.u., mas na estaurolita da amostra CP-333 há correlação negativa entre $\mathrm{Fe}^{2+}$ e $\mathrm{Zn}^{2+}$ indicando a presença do vetor $\mathrm{Fe}^{2+} \mathrm{Zn}_{-1}$, que controla a variação composicional (Figura 8.7b).

\subsubsection{Micas}

Para as micas foram analisados cristais de biotita e muscovita da matriz das amostras CP-07 e CP-333, de inclusões em granada na amostra CP-333 e cristais de biotita do leucossoma da amostra CP-07. Há pouca variação composicional intra-amostra, sendo mais expressivas as variações interamostras (Figuras 8.7c-8.7i). 

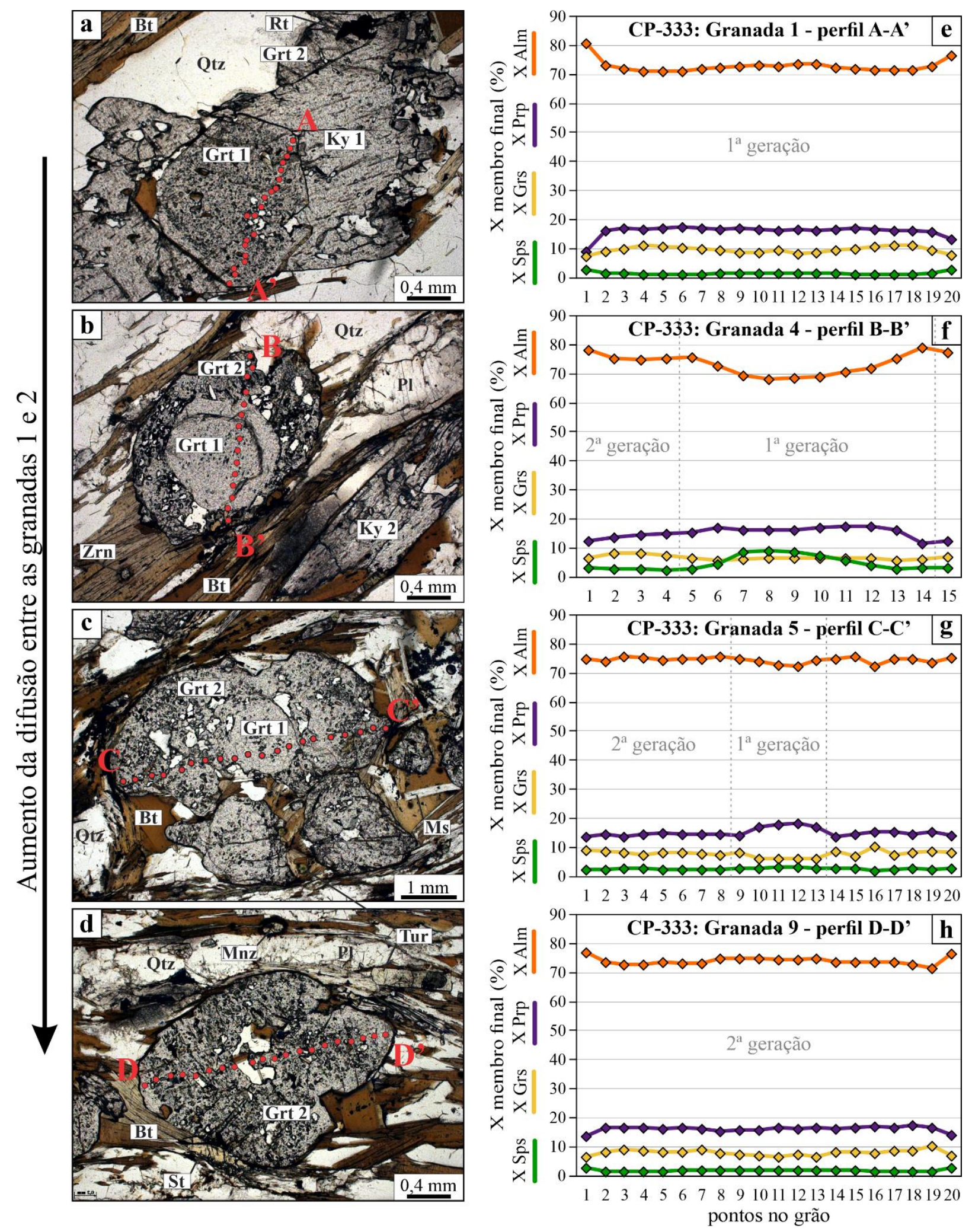

Figura 8.5: Cristais de granada da amostra CP-333 - a) Granada idioblástica da primeira geração, preservada como inulusões em ciania, b) Granada da primeira geraçăo com corona de granada da segunda geração, c) Granada da segunda geração com relíquias da granada anterior preservada; d) Granada da segunda geração, sem indícios de restos da granada anterior; e-h) Gráficos da distribuição das concentrações dos membros finais, respectivamente das granadas descritas de (a) a (d).
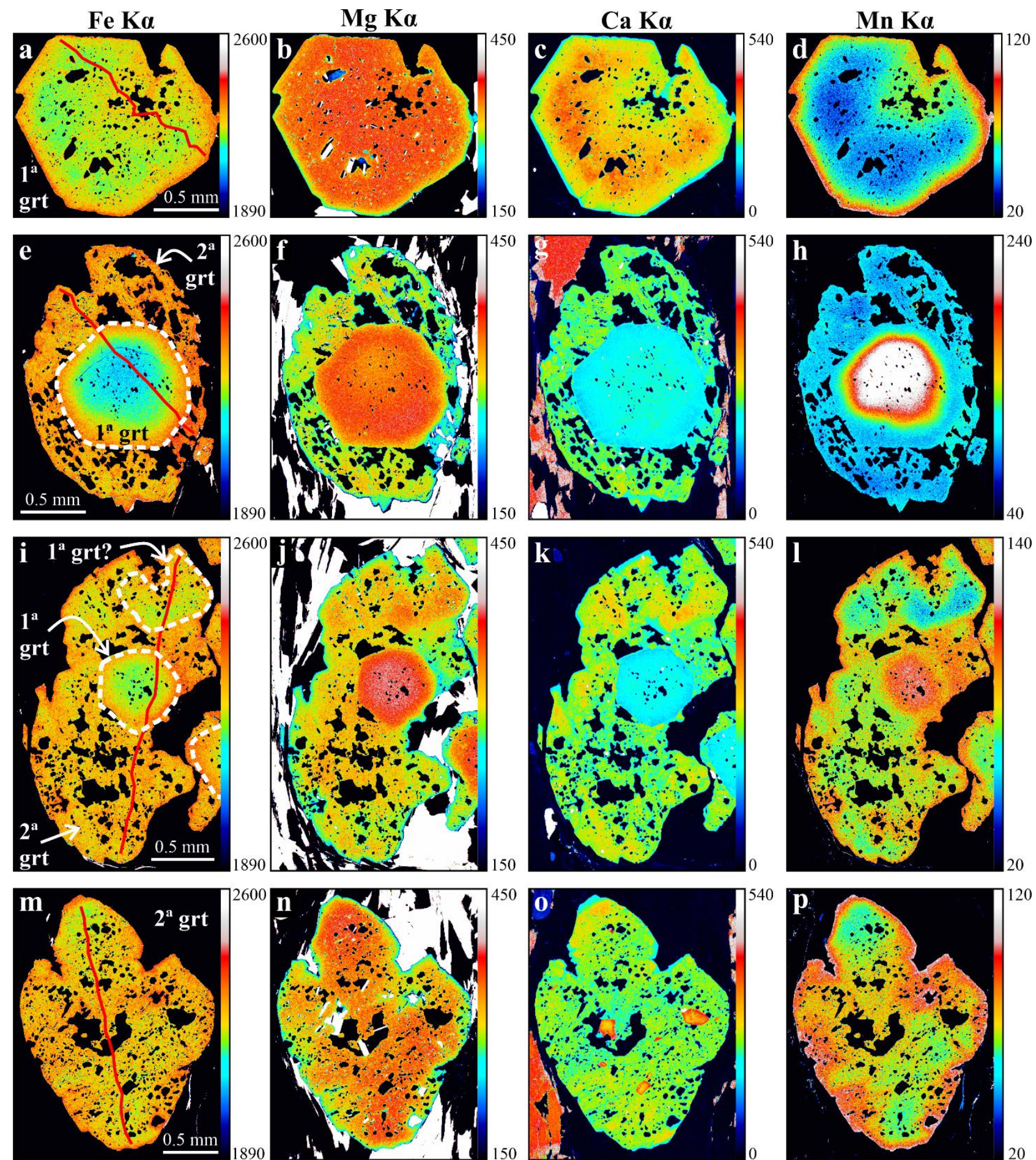

Figura 8.6: Mapas composicionais para concentrações de $\mathrm{Fe}, \mathrm{Mg}, \mathrm{Ca}$ e $\mathrm{Mn}$. a-d) Granada da primeira geração de crescimento; e-h) Granada da primeira geração com corona de granada da segunda geração de crescimento; i-l) Granada da segunda geração com relíquias de granada da primeira geração de crescimento; m-p) Granada da segunda geração de crescimento, com maior grau de homogeneização. 
A biotita da matriz de ambas as amostras apresenta pouca variação no valor de $X_{\mathrm{Mg}}$, de 0,5 a 0,55, e conteúdo de Al total entre 1,68-1,81 a.p.f.u., o que sugere pouca substituição tschermakítica ( $\mathrm{Al}^{\mathrm{VI}} \mathrm{Al}^{\mathrm{IV}} \mathrm{Mg}_{-1} \mathrm{Si}_{-1}$ ), sendo que na amostra $\mathrm{CP} 07$, cristais da matriz e do leucossoma apresentam diferenças mais pronunciadas entre si (Figura 8.7d). Biotita da matriz na amostra $\mathrm{CP}-07$, teve maior substituição $\mathrm{Fe}^{2+} \mathrm{Mg}_{-1}$ em relação à biotita do leucossoma e à biotita da matriz da amostra CP-333 (Figura 8.7c), enquanto a biotita inclusa na granada da amostra CP-333 tem maior $X_{\mathrm{Mg}}(0,57-0,63)$ e, consequentemente, mostra que houve maior substituição via $\mathrm{Fe}^{2+} \mathrm{Mg}_{-1}$ em relação à biotita da matriz. Já o comportamento das substituições edenítica $\mathrm{KAl}^{\mathrm{IV}}{ }_{\square-1} \mathrm{Si}_{-1}$ e $\mathrm{TiAl}^{\mathrm{IV}} \mathrm{Al}^{\mathrm{VI}}{ }_{-1} \mathrm{Si}_{-1}$ é semelhante, com maiores substituições na biotita da amostra CP07 (Figuras 8.7e-f).

A substituição tschermakítica na muscovita da amostra CP-333 é a única que exibe maior variação intra-amostra, com substituição mais expressiva na muscovita da amostra CP07 (Figura 8.7g). Na muscovita da amostra CP-07 e das inclusões em granada da amostra CP-333 a substituição edenítica $\left(\mathrm{NaAl}^{\mathrm{IV}} \square_{-1} \mathrm{Si}_{-1}\right)$ foi mais expressiva (Figura 8.7h), em consequência do conteúdo de $\mathrm{Na}^{+}(0,21$ a 0,24 a.p.f.u.) ligeiramente superior ao da muscovita da matriz da amostra CP-333 (0,14 a 0,2 a.p.f.u.). O conteúdo de Ti é muito baixo $(0,02$ a 0,04 a.p.f.u.), mas o suficiente para causar substituições $\mathrm{TiAl}^{\mathrm{IV}} \mathrm{Al}^{\mathrm{VI}}{ }_{-1} \mathrm{Si}_{-1}$, maiores também na muscovita da amostra CP-07 e das inclusões em granada da amostra CP-333 (Figura 8.7i).

\subsubsection{Plagioclásio}

Foram analisados cristais de plagioclásio da matriz e cristais subidiomórficos do leucossoma da amostra CP-07, sendo todos os cristais classificados como oligoclásio. Na matriz da amostra CP-07 a variação composicional não é significativa, $\mathrm{An}_{15,9-18,7}$, enquanto na matriz da amostra CP-333, o teor de anortita apresenta maior variação, An 16,9-28,6, embora não haja padrão de zoneamento (Figura 8.8). O plagioclásio do leucossoma da amostra $\mathrm{CP}-07$ exibe padrão de zoneamento composicional bem definido (Figura 8.8), com borda sódicas, similares à composição dos cristais da matriz $\left(\mathrm{An}_{14,8}-17,7\right)$, e ampla variação no teor de anortita no núcleo $\left(\mathrm{An}_{17,3-26,7}\right)$.

\subsection{Modelagem metamórfica}

A modelagem metamórfica foi feita de forma direta, através da construção de pseudosseções no sistema químico NCKFMASHTO, pois este contempla todas as fases presentes nas associações observadas na petrografia dos metapelitos. A exclusão do MnO, que é importante apenas para equilíbrios envolvendo granada (Capítulo 3), não afeta a estabilidade 
das demais fases de interesse, nem da granada dentro da janela $P-T$ investigada. Os cálculos foram feitos dentro do intervalo de 550 a $800{ }^{\circ} \mathrm{C}$ de temperatura e de 3 a $12 \mathrm{kbar}$ de pressão, considerando quartzo como fase em excesso.
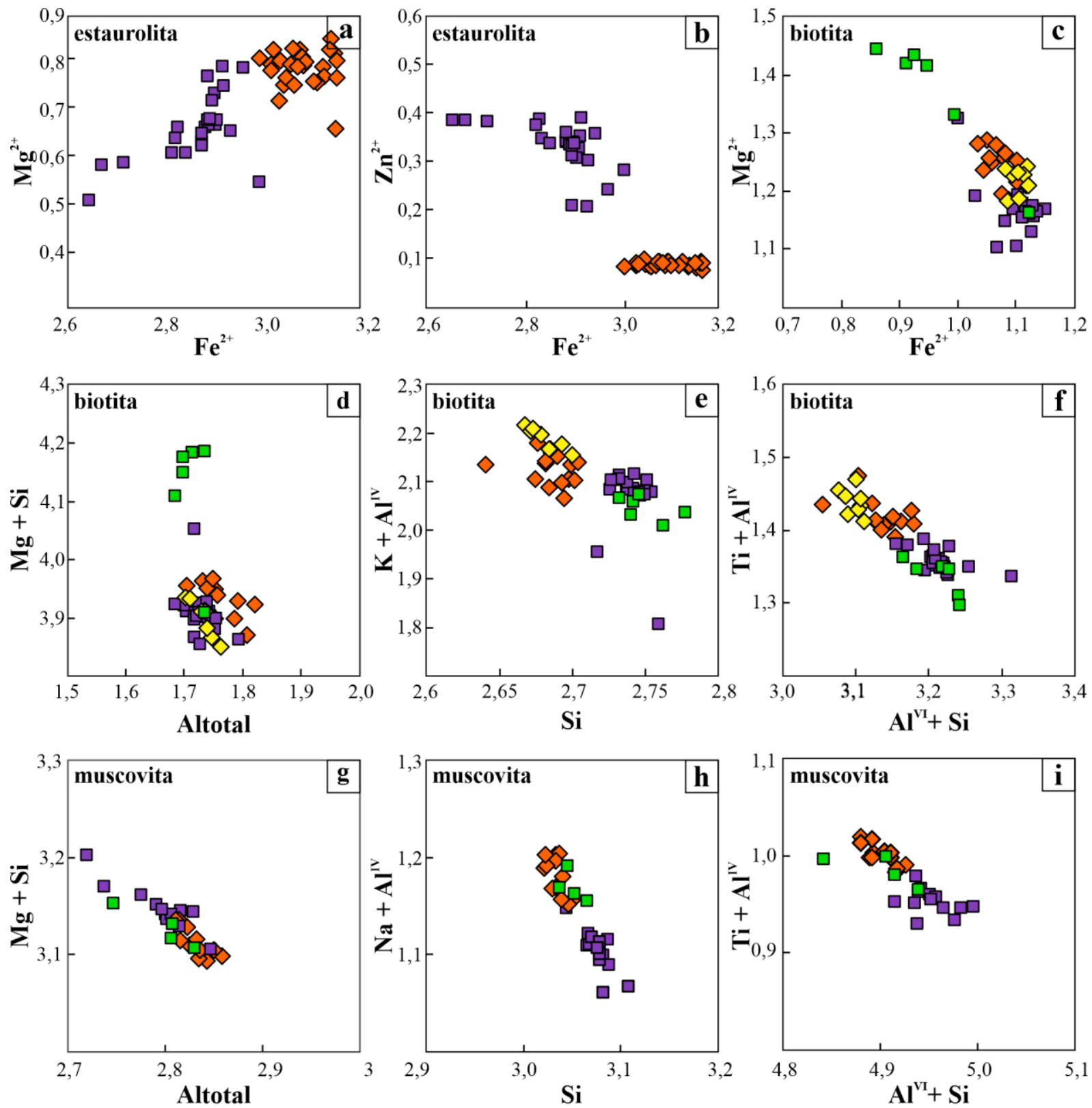

CP-07: ky-st-ms-grt-bt xisto

$\diamond$ estaurolita $(n=26)$, biotita $(n=14)$ e muscovita $(\mathrm{n}=12)$ na matriz

CP-333: ms-ky-grt-bt xisto c/st and ru

$\square$ estaurolita $(\mathrm{n}=25)$; biotita $(\mathrm{n}=22)$ e muscovita $(\mathrm{n}=14)$ na matriz

$>$ biotita no leucossoma $(\mathrm{n}=8)$

$\square$ biotita (n=6) e muscovita ( $n=4)$ inclusas na granada

Figura 8.7: Gráficos das variações composicionais em estaurolita, biotita e muscovita. (a) e (b) para vetores de substituição simples na estaurolita; substituição simples (c) e acopladas (d-f) na biotita; (g-i) para substituições acopladas na muscovita. 

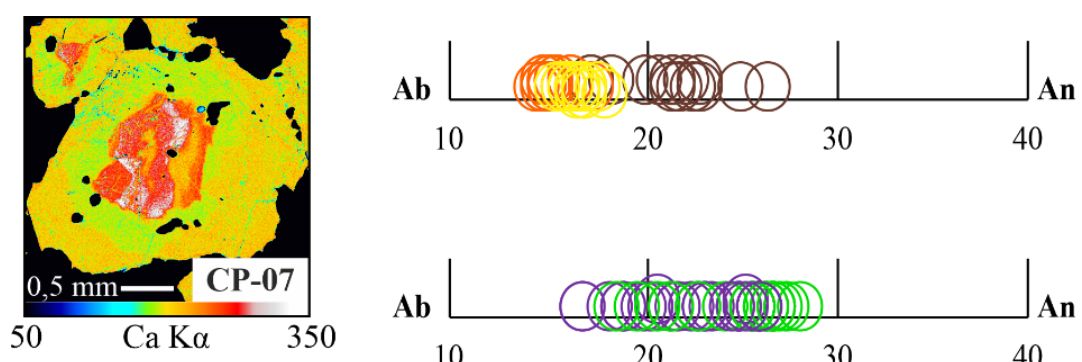

CP-07: Ky-St-Ms-Grt-Bt xisto plagioclásio do leucossoma: O núcleo $(\mathrm{n}=15)$

borda $(\mathrm{n}=30)$

plagioclásio na matriz $(\mathrm{n}=22)$

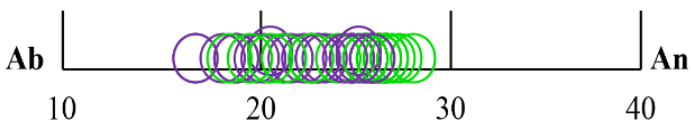

CP-333: Ms-Ky-Grt-Bt xisto

O núcleo $(\mathrm{n}=29)$

borda $(\mathrm{n}=16)$

Figura 8.8: Cristal de plagioclásio subidiomórfico presente no leucossoma da amostra CP-07 e variação composicional dos cristais das amostras CP-07 e CP-333.

A composição química dos metapelitos, amostras CP-07 e CP-333, é similar. Ambos são classificados como pelitos de baixo alumínio e, portanto, não são esperadas associações com cloritóide ou a ocorrência de cianita antes da fácies anfibolito. A quantidade de água foi considerada em excesso para equilíbrios subsolidus e, para equilíbrios suprasolidus, na amostra CP-07 foi usada a quantidade de água obtida pela análise de perda ao fogo, 4,9 \% (proporção molecular), que é a quantidade mínima de água presente na rocha. A quantidade média de água nas lamas sem interferência do intemperismo é de 2,7 \% (Nesbitt e Young, 1996) e, nas rochas metapelíticas de baixo grau, em torno de $4 \%$ (Shaw, 1956). Devido à ausência de feições de fusão na amostra CP-333, foi usado 7 \% de água para garantir total saturação em água em condições subsolidus.

A quantidade de ferro férrico foi escolhida de modo que equilíbrios com ilmenita e magnetita pudessem ser previstos pela pseudosseção. O conteúdo de $\mathrm{Fe}_{2} \mathrm{O}_{3}$ obtido através da titrimetria de oxirredução representa a quantidade máxima de $\mathrm{Fe}_{2} \mathrm{O}_{3}$ na rocha (Diener e Powell, 2010), com $X_{\mathrm{Fe}}{ }^{3+}$ de 0.21 e 0.16, respectivamente nas amostras CP-07 e CP-333. Valores muito elevados de $X_{\mathrm{Fe}}^{3+}$ estabilizam hematita, enquanto para valores de $X_{\mathrm{Fe}}{ }^{3+}$ inferiores a $~ 0,07$, o programa não consegue identificar equilíbrios com magnetita, que está presente nas amostras. Assim, foram utilizados valores de $X_{\mathrm{Fe}}{ }^{3+}$ de 0,075 (CP-07) e 0,08 (CP$333)$.

As pseudosseções construídas mostram topologias semelhantes, especialmente no domínio suprasolidus, com amplos campos de estabilidade tri- a pentavariantes e campos divariantes com menores dimensões (Figuras 8.9 e 8.10). As curvas univariantes tem dimensões restritas, ocorre apenas uma na amostra CP-07 (associação 16, Figura 8.9b) e três na amostra CP-333 (associações 21, 27 e 31, Figura 8.10a).

A granada ocorre em topologias similares entre as duas amostras e ao longo de todo o intervalo $P$ - $T$ calculado. Para condições de temperatura inferiores a $595^{\circ} \mathrm{C}$, a pressão na qual ocorre o aparecimento da granada varia aproximadamente de 3,6 a 7,0 kbar, enquanto, a 
partir dessa temperatura, até $715-725^{\circ} \mathrm{C}$, a granada aparece em pressão superior a $4 \mathrm{kbar}$ (Figuras 8.9 e 8.10). A curva de quebra da clorita ocorre a partir de $575{ }^{\circ} \mathrm{C}$, sendo controlada principalmente pela temperatura, e se estende até $605-615^{\circ} \mathrm{C}$, já em condições de fácies anfibolito médio nas pseudosseções construídas.

Grande parte da janela $P-T$ mostra associações com proporção modal de plagioclásio em torno de 17 a $21 \%$, que diminuem drasticamente apenas após cruzar a curva de entrada da paragonita. As curvas de quebra do plagioclásio e de entrada de paragonita são subparalelas. Na pseudosseção da amostra CP-07 a curva do plagioclásio aparece a partir de 7,5 kbar de pressão e a curva da paragonita já ocorre a partir de 3,4 kbar de pressão, definindo campos mais extensos de coexistência para essas fases. Já na pseudosseção da amostra CP-333 a curva de entrada da paragonita ocorre em pressão superior a $6 \mathrm{kbar}$, definindo campos mais estreitos para a coexistência de plagioclásio e paragonita (Figuras 8.9 e 8.10). Com a quebra do plagioclásio, maior conteúdo de sódio estabiliza associações com muscovita e paragonita.

A proporção modal de estaurolita, calculada através da pseudosseção, é similar nas amostras. As diferenças entre as topologias são mínimas, com deslocamento de 10 a $15{ }^{\circ} \mathrm{C}$ para maiores temperaturas na amostra CP-07 e alguns campos com associações sem plagioclásio na amostra CP-333. Para baixa pressão, onde não há estabilidade com granada, ocorre apenas quebra de clorita, formando associações com cordierita e estaurolita (Figuras 8.9 e 8.10). Com o aumento da temperatura há progressivo consumo da estaurolita até sua quebra, formando associações com granada, biotita e $\mathrm{Al}_{2} \mathrm{SiO}_{5}$. A partir de 7,8 kbar, esse consumo passa a ser condicionado pela pressão (Figuras 8.11a e 8.11b).

Ilmenita é estável em todo o intervalo de condições $P$ - $T$ calculado. Apesar do distinto estado de oxidação considerado em cada amostra, as topologias para associações com ilm + mag e ilm + rt são similares nas duas pseudosseções construídas. Magnetita aparece a partir de $570-575{ }^{\circ} \mathrm{C}$ de temperatura e não ultrapassa 5,1-5,2 kbar de pressão. A curva de entrada do rutilo aparece em pressão mínima de 9,7 e 10 kbar, respectivamente, nas amostras CP-333 e CP-07. Em condições subsolidus desta, o aparecimento do rutilo ocorre em pressões deslocadas para maiores condições de pressão (Figura 8.9).

A curva de quebra da biotita ocorre em temperaturas superiores à $800^{\circ} \mathrm{C}$, fazendo da biotita fase estável ao longo de todo o intervalo $P-T$ considerado. Já a muscovita é a fase que promove as diferenças mais significativas entre as pseudosseções construídas. Em condições suprasolidus, acima de $8 \mathrm{kbar}$, as pseudosseções mostram proporções modais de muscovita similares nas duas amostras e quebra para formar feldspato potássico a partir de 760 e $765^{\circ} \mathrm{C}$ de temperatura, respectivamente, nas amostras CP-07 e CP-333 (Figuras 8.11a e 8.11b). 
$\begin{array}{cccccccccc}\mathrm{H}_{2} \mathrm{O} & \mathrm{SiO}_{2} & \mathrm{Al}_{2} \mathrm{O}_{3} & \mathrm{CaO} & \mathrm{MgO} & \mathrm{FeO} & \mathrm{K}_{2} \mathrm{O} & \mathrm{Na}_{2} \mathrm{O} & \mathrm{TiO}_{2} & \mathrm{O} \\ 4,85 & 67,30 & 9,92 & 1,05 & 4,49 & 8,02 & 1,61 & 1,89 & 0,56 & 0,3\end{array}$

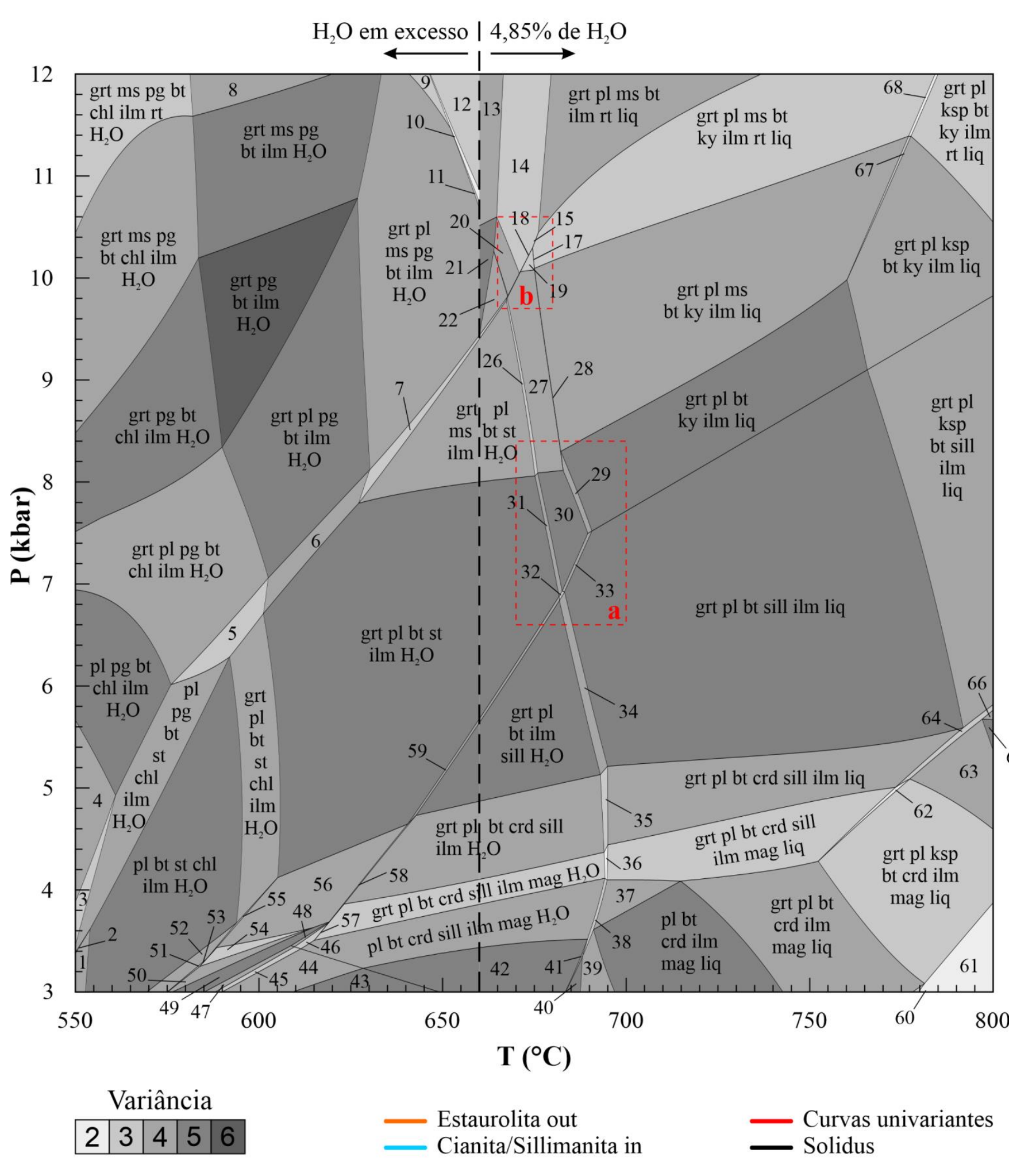

1. ab pl bt st chl ilm $\mathrm{H}_{2} \mathrm{O}$ 2. ab pl pq bt st chl ilm $\mathrm{H}_{2} \mathrm{O}$ 3. pl ms pg bt st chl ilm $\mathrm{H}_{2} \mathrm{O}$ 4. pl ms pg bt chl ilm $\mathrm{H}_{2} \mathrm{O}$ 5. grt pl pg bt st chl ilm $\mathrm{H}_{2} \mathrm{O}$ 6. grt pl pg bt st ilm $\mathrm{H}_{2} \mathrm{O}$ 7. grt pl ms pg bt st ilm $\mathrm{H}_{2} \mathrm{O}$ 8. grt ms pg bt ilm rt $\mathrm{H}_{2} \mathrm{O}$ 9. grt pl ms pg bt ilm rt $\mathrm{H}_{2} \mathrm{O}$ 10. grt pl ms pg bt ilm rt liq $\mathrm{H}_{2} \mathrm{O}$

11. grt pl ms pg bt ilm liq $\mathrm{H}_{2} \mathrm{O}$

12. grt ms pg bt ilm rt liq $\mathrm{H}_{2} \mathrm{O}$

13. grt pl ms pg bt ilm rt

14. grt pl ms pg bt ilm rt liq

15. grt pl ms pg bt ky ilm rt liq

16. grt pl ms pg bt st ky ilm rt liq

17. grt $\mathrm{pl} \mathrm{ms}$ bt st ky ilm rt liq

18. grt pl ms pg bt st ilm rt liq

19. grt pl ms bt st ilm rt liq

20. grt pl ms pg bt ilm liq

21. grt pl ms pg bt ilm

22. grt pl ms pg bt ilm $\mathrm{H}_{2} \mathrm{O}$

23. grt pl ms pg bt ilm liq $\mathrm{H}_{2} \mathrm{O}$
24. grt pl ms pg bt st ilm liq 25. grt pl ms pg bt st ilm liq $\mathrm{H}_{2} \mathrm{O}$

26. grt pl ms bt st ilm liq $\mathrm{H}_{2} \mathrm{O}$

27. grt pl ms bt st ilm liq

29. grt pl bt st ky ilm liq

30. grt pl bt st ilm liq

31. grt pl bt st ilm liq $\mathrm{H}_{2} \mathrm{O}$

32. grt pl bt st sill ilm liq $\mathrm{H}_{2} \mathrm{O}$

33. grt pl bt st sill ilm liq

34. grt pl bt sill ilm liq $\mathrm{H}_{2} \mathrm{O}$

35. grt pl bt crd sill ilm liq $\mathrm{H}_{2} \mathrm{O}$

36. grt pl bt crd sill ilm mag liq $\mathrm{H}_{2} \mathrm{O}$

37. $\mathrm{pl} \mathrm{bt} \mathrm{crd} \mathrm{sill} \mathrm{ilm} \mathrm{mag} \mathrm{liq}$

38. pl bt crd sill ilm mag liq $\mathrm{H}_{2} \mathrm{O}$

39. $\mathrm{pl} \mathrm{bt} \mathrm{crd} \mathrm{ilm} \mathrm{mag} \mathrm{liq} \mathrm{H}_{2} \mathrm{O}$

40. $\mathrm{pl} \mathrm{bt} \mathrm{crd} \mathrm{ilm} \mathrm{liq} \mathrm{H}_{2} \mathrm{O}$

41. $\mathrm{pl} \mathrm{bt} \mathrm{crd} \mathrm{sill} \mathrm{ilm} \mathrm{liq} \mathrm{H}_{2} \mathrm{O}$

42. pl bt crd sill ilm $\mathrm{H}_{2} \mathrm{O}$

43. $\mathrm{pl}$ bt crd and ilm $\mathrm{H}_{2} \mathrm{O}$

44. $\mathrm{pl} \mathrm{bt} \mathrm{crd} \mathrm{and} \mathrm{ilm} \mathrm{mag} \mathrm{H}_{2} \mathrm{O}$

45. pl bt st crd and ilm mag $\mathrm{H}_{2} \mathrm{O}$

46. pl bt st crd sill ilm mag $\mathrm{H}_{2} \mathrm{O}$
28. grt pl ms bt st ky ilm liq

47. $\mathrm{pl} \mathrm{bt} \mathrm{st} \mathrm{crd} \mathrm{and} \mathrm{ilm} \mathrm{H}_{2} \mathrm{O}$ 48. pl bt st crd sill ilm $\mathrm{H}_{2} \mathrm{O}$ 49. pl bt st crd ilm $\mathrm{H}_{2} \mathrm{O}$

50. pl bt st crd ilm mag $\mathrm{H}_{2} \mathrm{O}$

51. pl bt chl st crd ilm mag $\mathrm{H}_{2} \mathrm{O}$

52. pl bt chl st crd ilm $\mathrm{H}_{2} \mathrm{O}$

53. grt pl bt chl st crd ilm mag $\mathrm{H}_{2} \mathrm{O}$

54. grt pl bt st crd ilm mag $\mathrm{H}_{2} \mathrm{O}$

55. grt pl bt chl st crd ilm $\mathrm{H}_{2} \mathrm{O}$

56. grt pl bt st crd ilm $\mathrm{H}_{2} \mathrm{O}$

57. grt pl bt st crd sill ilm mag $\mathrm{H}_{2} \mathrm{O}$

58. grt $\mathrm{pl} \mathrm{bt} \mathrm{st} \mathrm{crd} \mathrm{sill} \mathrm{ilm} \mathrm{H}_{2} \mathrm{O}$

59. gtt pt st crd sill ilm $\mathrm{H}_{2} \mathrm{O}$

60. grt opx pl bt crd ilm mag liq

60. grt opx pl bt crd ilm mag liq
61. grt opx pl ksp bt crd ilm mag liq

61. grt opx pl ksp bt crd ilm mag liq
62p bt crd sill ilm mag liq

63. grt pl ksp bt crd ilm liq

64. grt pl ksp bt crd sill ilm liq

65. grt pl ksp crd ilm liq

66. grt pl ksp crd sill ilm liq

67. ort pl ksp ms bt ky ilm liq

68. grt pl ksp ms bt ky ilm rt liq

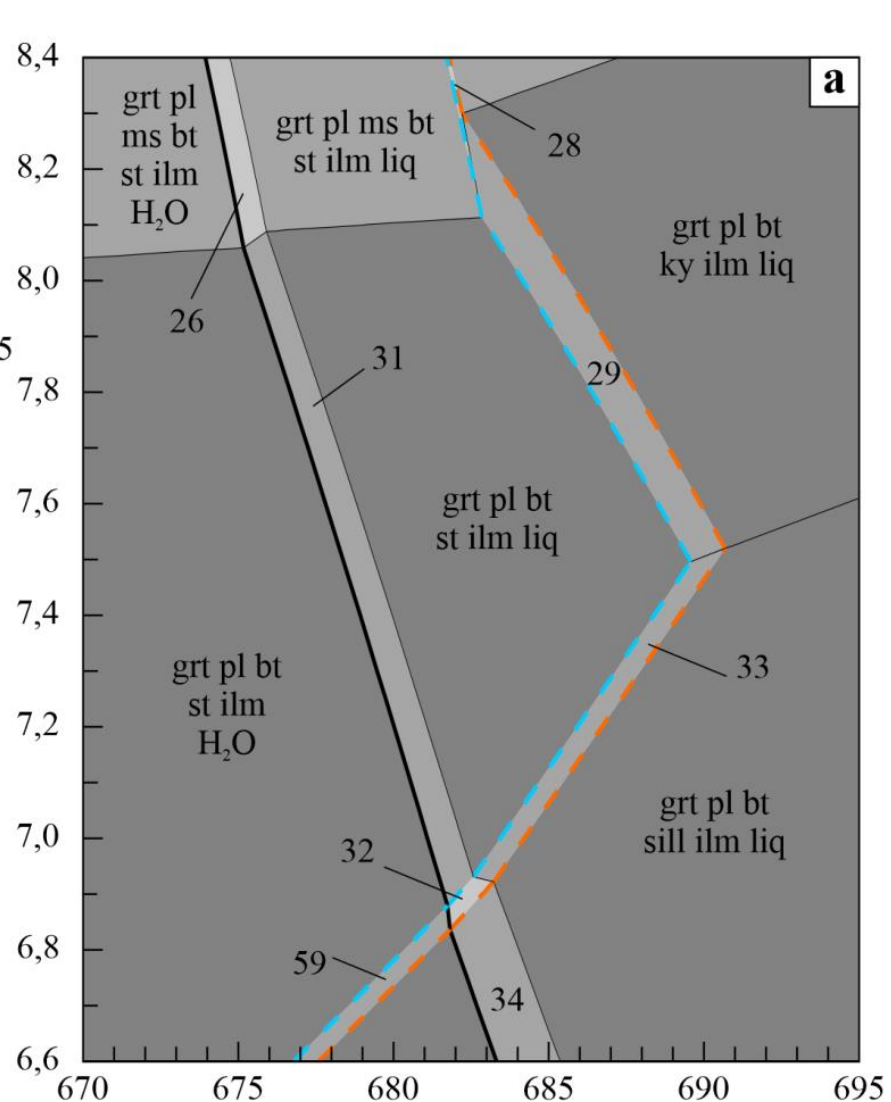

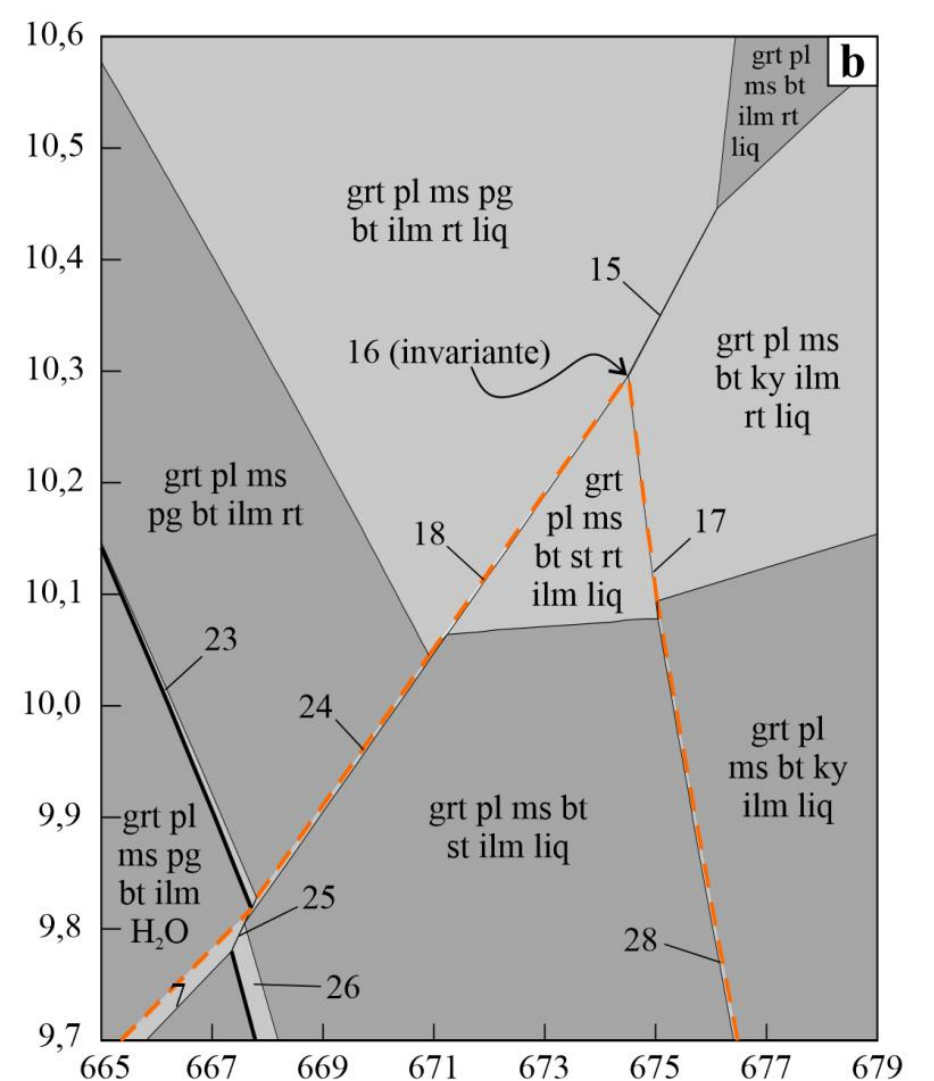

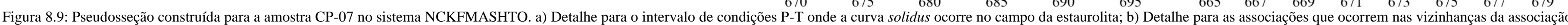
em equilíbrio da amostra. 
CP-333: ms-ky-grt-pl-bt xisto c/ st, ilm e rt

$\begin{array}{cccccccccc}\mathrm{H}_{2} \mathrm{O} & \mathrm{SiO}_{2} & \mathrm{Al}_{2} \mathrm{O}_{3} & \mathrm{CaO} & \mathrm{MgO} & \mathrm{FeO} & \mathrm{K}_{2} \mathrm{O} & \mathrm{Na}_{2} \mathrm{O} & \mathrm{TiO}_{2} & \mathrm{O} \\ 6,68 & 61,94 & 11,02 & 1,38 & 5,46 & 9,24 & 1,93 & 1,31 & 0,66 & 0,38\end{array}$

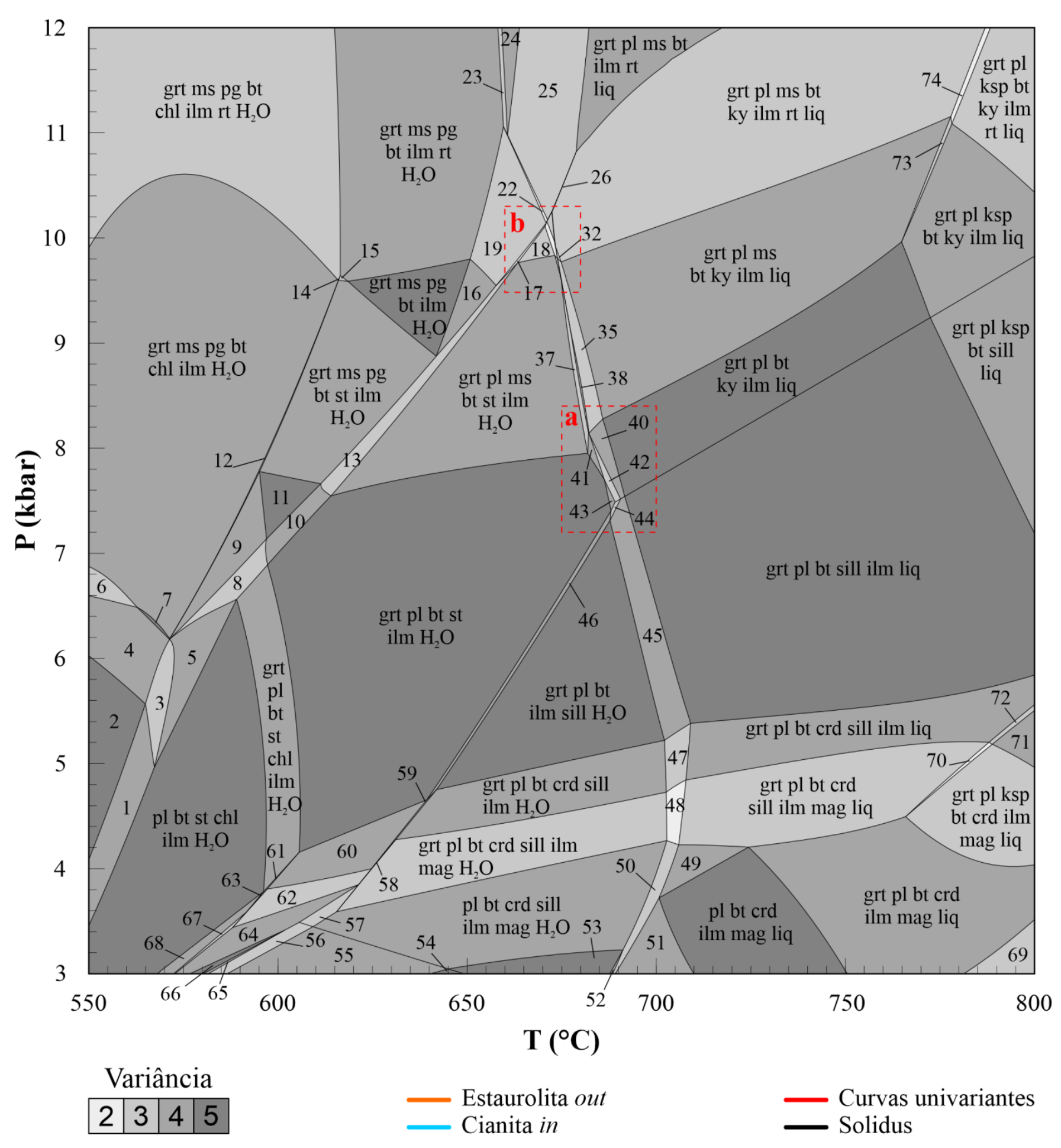

1. pl ms bt chl st ilm $\mathrm{H} 2 \mathrm{O}$

2. pl ms bt chl ilm $\mathrm{H} 2 \mathrm{O}$

3. pl ms pg bt chl st ilm $\mathrm{H} 2 \mathrm{O}$

4. pl ms pg bt chl ilm $\mathrm{H} 2 \mathrm{O}$

5. pl pg bt chl st ilm $\mathrm{H} 2 \mathrm{O}$

6. grt pl ms pg bt chl ilm $\mathrm{H} 2 \mathrm{O}$

. ms pg bt chl ilm $\mathrm{H} 2 \mathrm{O}$

8. grt pl pg bt chl st ilm $\mathrm{H} 2 \mathrm{O}$

9. grt pg bt chl st ilm $\mathrm{H} 2 \mathrm{O}$

10. grt pl pg bt st ilm $\mathrm{H} 2 \mathrm{O}$

11. grt pg bt st ilm $\mathrm{H} 2 \mathrm{O}$

12. grt ms pg bt chl st ilm $\mathrm{H} 2 \mathrm{O}$

13. grt pl ms pg bt st ilm $\mathrm{H} 2 \mathrm{O}$

14. grt ms pg bt chl st ilm rt $\mathrm{H} 2 \mathrm{O}$

15. grt ms pg bt st ilm rt $\mathrm{H} 2 \mathrm{O}$

16. grt ms pg bt st ilm $\mathrm{H} 2 \mathrm{O}$

17. grt pl ms pg bt st ilm rt $\mathrm{H} 2 \mathrm{O}$

18. grt pl ms bt st ilm rt $\mathrm{H} 2 \mathrm{O}$

19. ort $\mathrm{ms} \mathrm{pg} \mathrm{bt} \mathrm{st} \mathrm{ilm} \mathrm{rt} \mathrm{H} 2 \mathrm{O}$

20. grt pl ms bt st ilm rt liq

21. grt $\mathrm{pl} \mathrm{ms} \mathrm{pg} \mathrm{bt} \mathrm{st} \mathrm{ilm} \mathrm{rt} \mathrm{liq} \mathrm{H} 2 \mathrm{O}$

23. grt ms pg bt ilm rt liq $\mathrm{H} 2 \mathrm{O}$

24. grt ms pg bt ilm rt liq

25. grt pl ms pg bt ilm rt liq
22. grt $\mathrm{pl} \mathrm{ms} \mathrm{pg} \mathrm{bt} \mathrm{ilm} \mathrm{rt} \mathrm{liq} \mathrm{H} 2 \mathrm{O}$
26. grt pl ms pg bt ky ilm rt liq 28. grt pl ms pg bt st ilm rt liq 29. grt pl ms bt st ilm rt liq

30. grt pl ms bt st ky ilm rt liq

31. grt pl ms bt st ky ilm rt liq $\mathrm{H} 2 \mathrm{O}$

32. grt pl ms bt ky ilm rt liq $\mathrm{H} 2 \mathrm{O}$

33. grt $\mathrm{pl} \mathrm{ms} \mathrm{bt} \mathrm{st} \mathrm{ilm} \mathrm{liq} \mathrm{H} 2 \mathrm{O}$

34. grt $\mathrm{pl} \mathrm{ms} \mathrm{bt} \mathrm{st} \mathrm{ky} \mathrm{ilm} \mathrm{liq} \mathrm{H} 2 \mathrm{O}$

36. grt pl ms bt st ky ilm liq $\mathrm{H} 2 \mathrm{O}$

37. grt pl ms bt st ky ilm $\mathrm{H} 2 \mathrm{O}$

38. grt pl ms bt ky ilm $\mathrm{H} 2 \mathrm{O}$

38. grt $\mathrm{pl} \mathrm{ms} \mathrm{bt} \mathrm{ky} \mathrm{ilm} \mathrm{H} 2 \mathrm{O}$
39. grt $\mathrm{pl}$ bt ky ilm $\mathrm{H} 2 \mathrm{O}$

40. grt pl bt ky ilm liq $\mathrm{H} 2 \mathrm{O}$

41. grt pl bt st ky ilm $\mathrm{H} 2 \mathrm{O}$

42. grt pl bt st ky ilm liq $\mathrm{H} 2 \mathrm{O}$

43. grt pl bt st ilm liq $\mathrm{H} 2 \mathrm{O}$

44. grt pl bt st sill ilm liq $\mathrm{H} 2 \mathrm{O}$

45. grt pl bt sill ilm liq $\mathrm{H} 2 \mathrm{O}$

46. grt pl bt st sill ilm $\mathrm{H} 2 \mathrm{O}$

47. grt pl bt cd sill ilm liq $\mathrm{H} 2 \mathrm{O}$

49. $\mathrm{pl} \mathrm{bt} \mathrm{cd} \mathrm{sill} \mathrm{ilm} \mathrm{mag} \mathrm{liq}$

50. $\mathrm{pl} \mathrm{bt} \mathrm{cd} \mathrm{sill} \mathrm{ilm} \mathrm{mag} \mathrm{liq} \mathrm{H} 2 \mathrm{O}$ 27. grt pl ms pg bt st ky ilm rt liq

48. grt pl bt cd sill ilm mag liq $\mathrm{H} 2 \mathrm{O}$

51. pl bt cd ilm mag liq $\mathrm{H} 2 \mathrm{O}$

52. pl bt cd sill ilm liq $\mathrm{H} 2 \mathrm{O}$

53. pl bt cd sill ilm $\mathrm{H} 2 \mathrm{O}$

54. $\mathrm{pl} \mathrm{bt} \mathrm{cd} \mathrm{and} \mathrm{ilm} \mathrm{H} 2 \mathrm{O}$

55. $\mathrm{pl} \mathrm{bt} \mathrm{cd} \mathrm{and} \mathrm{ilm} \mathrm{mag} \mathrm{H} 2 \mathrm{O}$

.

7. pl bt st cd sill ilm mag $\mathrm{H} 2 \mathrm{O}$

58. grt pl bt st cd sill ilm mag $\mathrm{H} 2 \mathrm{O}$

59. grt pl bt cd sill ilm mag $\mathrm{H} 2 \mathrm{O}$

60. grt pl bt st cd ilm $\mathrm{H} 2 \mathrm{O}$

61. grt pl bt chl st cd ilm $\mathrm{H} 2 \mathrm{O}$

62. grt pl bt st cd ilm mag $\mathrm{H} 2 \mathrm{O}$

63. grt pl bt chl st cd ilm mag H2O

64. pl bt st cd ilm mag $\mathrm{H} 2 \mathrm{O}$

65. pl bt st cd and ilm $\mathrm{H} 2 \mathrm{O}$

66. pl bt st cd ilm $\mathrm{H} 2 \mathrm{O}$

67. pl bt st cd chl ilm mag $\mathrm{H} 2 \mathrm{O}$

68. pl bt st cd chl ilm $\mathrm{H} 2 \mathrm{O}$

69. grt liq opx pl bt cd mag ilm

70. grt pl ksp btcd sill ilm

71. grt

71. grt pl ksp be cd ilm liq

72. grt pl ksp bt cd sill ilm liq

73. grt pl ksp ms bt ky ilm liq

74. grt pl ksp ms bt ky ilm rt liq

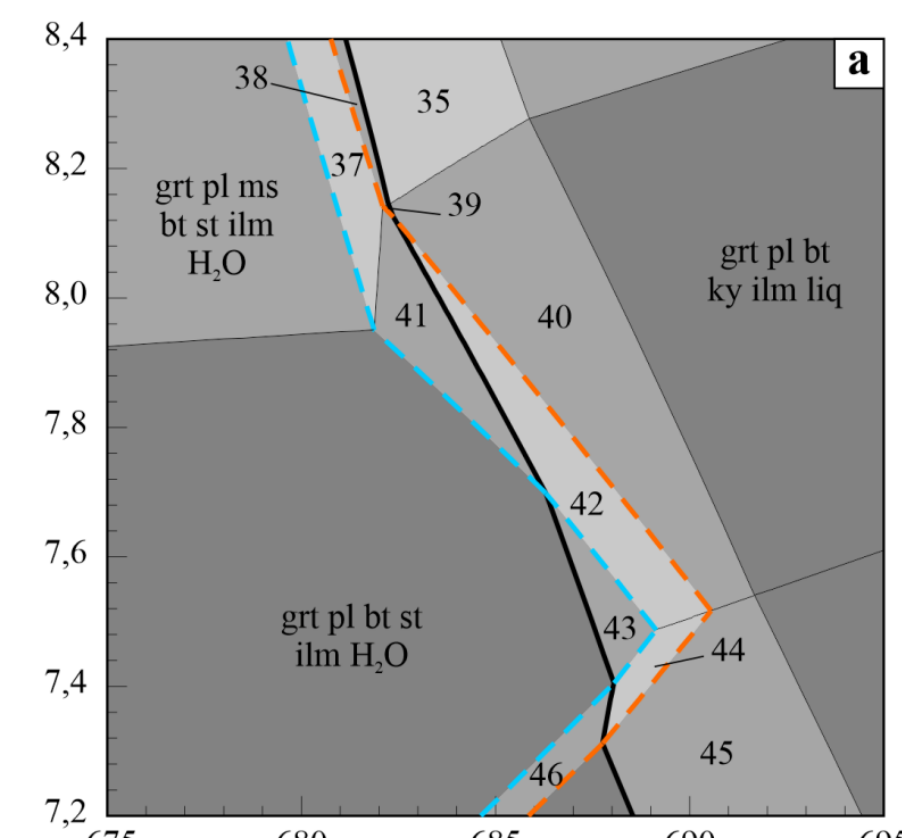

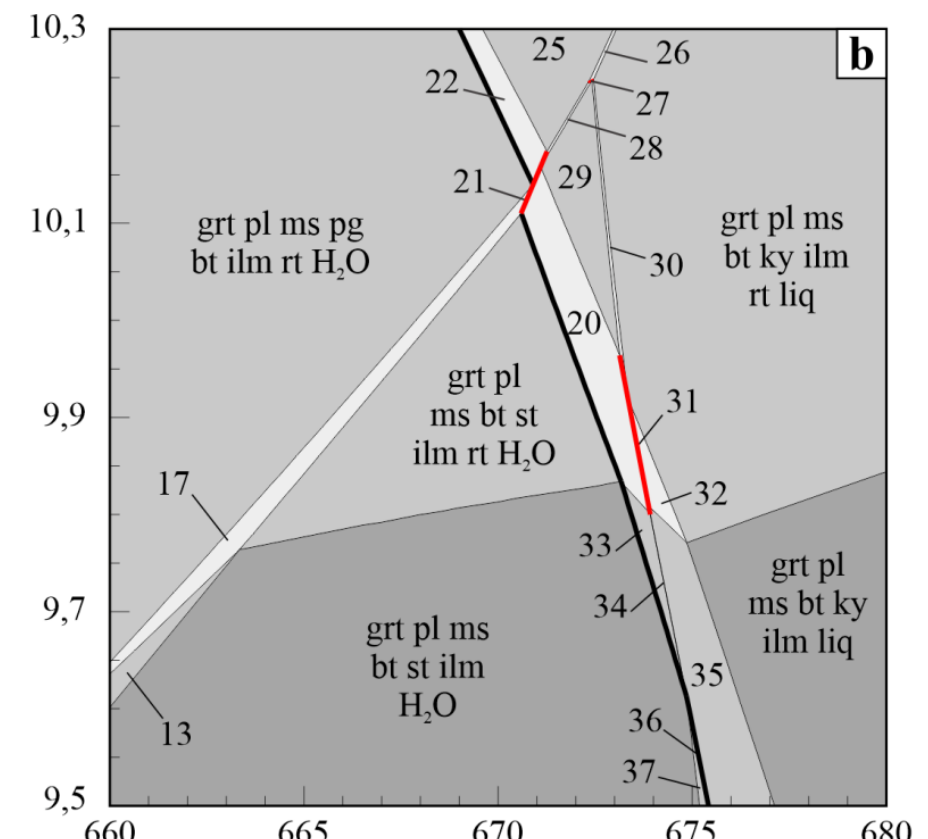

Figura 8.10: Pseudosseção construíd
associação em equilíbrio da amostra. 

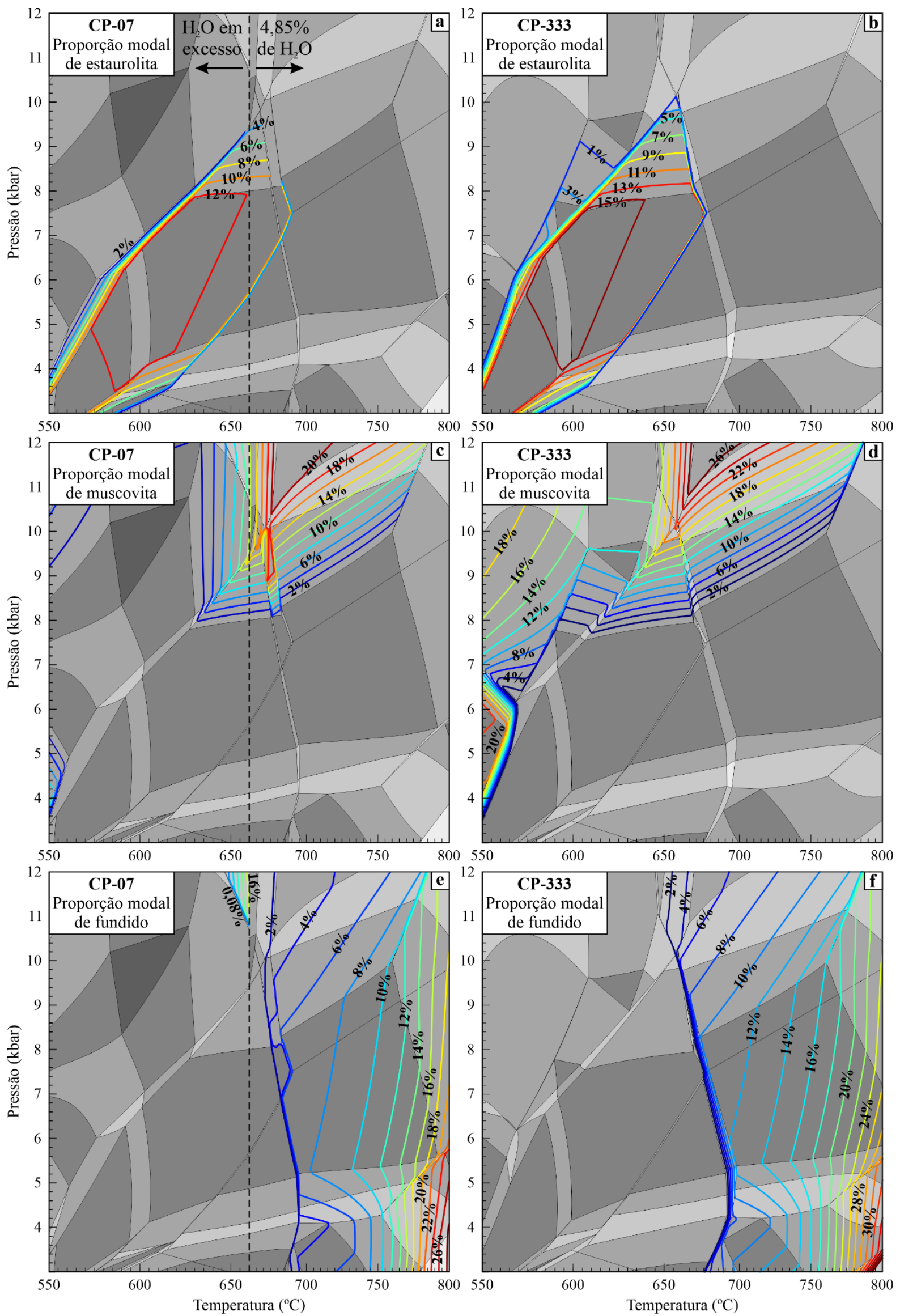

Figura 8.11:Isopletas calculadas para a proporção modal de: estaurolita - (a) amostra CP-07 e (b) amostra CP333; muscovita - (c) amostra CP-07 e (d) amostra CP-333; e fundido (e) amostra CP-07 e (f) amostra CP-333. 
Para condições subsolidus, em condições de alta pressão e baixa temperatura, a pseudosseção da amostra CP-07 mostra baixa proporção modal de muscovita em associações com paragonita, e aumento na proporção controlado pela temperatura a partir de $630{ }^{\circ} \mathrm{C}$. $\mathrm{Na}$ pseudosseção da amostra CP-333 a proporção modal de muscovita aumenta continuamente para condições de maior pressão e menor temperatura e há maior coexistência com paragonita (Figuras 8.11c e 8.11d).

A quebra da clorita e das micas brancas fornece água para o sistema, promovendo a geração do fundido ainda no campo da estaurolita em pressões intermediárias nas duas amostras (Figuras 8.9a e 8.10b). Com água em excesso e em condições de $12 \mathrm{kbar}$, a fusão na pseudosseção da amostra CP-07 já ocorre a partir de $644{ }^{\circ} \mathrm{C}$ e, com o mínimo de água para saturação do fundido, a curva solidus aparece entre 665 e $693{ }^{\circ} \mathrm{C}$. Na pseudosseção da amostra CP-333 a curva solidus aparece em maior intervalo de temperatura, entre 658 e $702{ }^{\circ} \mathrm{C}$ (Figuras 8.9 e 8.10).

Nas duas pseudosseções a proporção de fundido produzido no campo da estaurolita é inferior a $6 \%$ (Figuras 8.11e e 8.11f). O volume de fundido aumenta gradativamente com a temperatura, mas, à medida que a moda da biotita diminui, maior volume de fundido é gerado, chegando até $30 \%$, o que é esperado, já que a curva de quebra da biotita aparece acima de $800{ }^{\circ} \mathrm{C}$. Para o intervalo $P-T$ calculado, a pseudosseção prevê ocorrência de ortopiroxênio em condições de temperatura superior a $780{ }^{\circ} \mathrm{C}$ e pressão inferior a 3,5 kbar.

\subsection{Isopletas e associações minerais em equilíbrio}

\subsubsection{Cianita-estaurolita-muscovita-granada-biotita xisto (CP-07)}

No cianita-estaurolita-muscovita-granada-biotita xisto a associação mineral em equilíbrio consiste em $\mathrm{Ky}+\mathrm{St}+\mathrm{Grt}+\mathrm{Bt}+\mathrm{Ms}+\mathrm{Pl}+\mathrm{Qtz}+\mathrm{Ilm} \pm \mathrm{Rt}+\mathrm{Liq} . \quad \mathrm{Na}$ pseudosseção, essa associação ocorre em dois campos restritos, um divariante, outro trivariante (campos 17 e 28, Figura 8.9b). Clorita ocorre como fase retrometamórfica, substituindo biotita na matriz ou em zonas de sombra de pressão de poucos porfiroblastos de granada, porém, sem definir associação em equilíbrio. A magnetita também é fase retrometamórfica, de ocorrência restrita, associada com biotita e ilmenita na matriz.

A granada e a biotita, tem $X_{\mathrm{Mg}}$ praticamente constante, de 0,06 a 0,19 e de 0,52 a 0,55, respectivamente. No diagrama AFM, granada não mostra variação, enquanto a biotita, apesar do conteúdo de $\mathrm{Al}^{\text {total }}$ variar pouco, de 1,70 a 1,82 , mostra clara distinção entre a composição dos cristais do leucossoma e da matriz, estes exibem maior espalhamento no diagrama AFM (Figura 8.12a). As isopletas composicionais para $X_{\mathrm{Mg}}$ ao longo do intervalo 
$P-T$ calculado mostram distribuição semelhante para granada e biotita, ambas com valores crescentes em direção a condições de maior pressão e temperatura (Figura 8.12b).

Para condições de pressão superiores a 7,5 kbar a distribuição das isopletas de $X_{\mathrm{Ca}}$ na granada são controladas pela temperatura, com conteúdo de Ca diminuindo continuamente com o aumento da temperatura, até cerca de $585^{\circ} \mathrm{C}$. Ao entrar no campo de estabilidade do plagioclásio, as isopletas de $X_{\mathrm{Ca}}$ na granada passam a ser controladas também pela temperatura. Nessas condições, $X_{\mathrm{Ca}}$ na granada diminui rapidamente de 0,30 a 0,08 e, ao entrar no campo de estabilidade da estaurolita, as isopletas tornam-se mais espaçadas, com progressiva, diminuição de $X_{\mathrm{Ca}}$ até 0,03 , com a diminuição da pressão e aumento da temperatura (Figura 8.12c).

No plagioclásio há pouca variação composicional no conteúdo de Ca ao longo de grande parte do intervalo $P-T$ da pseudosseção. Em condições suprasolidus, $X_{\mathrm{Ca}}$ praticamente não varia $(0,20-0,28)$ até atingir pressão de aproximadamente $8 \mathrm{kbar}$, quando então $X_{\mathrm{Ca}}$ passa a diminuir continuamente com o aumento da pressão até atingir valores de 0,10. Em condições subsolidus, antes da curva de quebra da paragonita, a composição do plagioclásio é constante, com $X_{\mathrm{Ca}}$ entre 0,16 e 0,20. Com a formação de paragonita e ainda no campo de estabilidade da estaurolita o plagioclásio torna-se rapidamente mais cálcico, com $X_{\mathrm{Ca}}$ entre 0,16 e 0,36 . Já fora do campo de estabilidade da estaurolita as isopletas de $X_{\mathrm{Ca}}$ no plagioclásio passam a ser controladas prioritariamente pela pressão (Figura 8.12c).

As isopletas de $X_{\mathrm{Mg}}$ modeladas para a estaurolita mostram distribuição controlada pela temperatura sob condições de pressão inferior a $8 \mathrm{kbar}$, onde $X_{\mathrm{Mg}}$ varia de 0,14 a 0,24 . Acima desta pressão, $X_{\mathrm{Mg}}$ aumenta com o aumento da pressão (Figura 8.12d). Já o $X_{\mathrm{Ti}}$ é constante, em média 0,08 , mas as isopletas modeladas mostram valores inferiores a $0,06 . \mathrm{Na}$ biotita, as isopletas modeladas para $X_{\mathrm{Ti}}$ mostram que a concentração de Ti aumenta progressivamente com a temperatura (Figura 8.12e).

$\mathrm{Na}$ muscovita o conteúdo de $\mathrm{Na}$ aumenta com a diminuição da proporção modal de paragonita e as isopletas de $X_{\mathrm{Na}}$ mostram distribuição controlada igualmente pela pressão e pela temperatura. Após passar da curva de quebra da paragonita, $X_{\mathrm{Na}}$ passa a diminuir em direção a curva de quebra da muscovita para então formar o feldspato potássico, já em condições suprasolidus (Figura 8.12e). Para o conteúdo de $\mathrm{Al}^{\mathrm{VI}}$ na muscovita a pseudosseção fornece distinta distribuição de isopletas nos campos sub e suprasolidus e valores muito elevados para $X_{\text {Alvi }}$ em relação aos minerais analisados. Em presença de paragonita, as isopletas de $X_{\mathrm{AIVI}}$ aumentam em direção a curva de quebra da paragonita e, após a passagem por esta curva, $X_{\text {Alvi }}$ passa a ter diminuição controlada principalmente pela temperatura. Para 
a biotita as isopletas modeladas para $X_{\text {AIVI }}$ mostram valores muito inferiores aos valores reais obtidos, 0,28 a 0,36 (Figura 8.12f).

Com exceção do $X_{\mathrm{AlVI}}$ das micas e do $X_{\mathrm{Ti}}$ da estaurolita, a composição dos minerais pode ser refletida nas isopletas calculadas a partir da pseudosseção, porém nem sempre são compatíveis com os campos das associações em equilíbrio, como é o caso da granada. A granada tipo II e as bordas da granada tipo I possuem $X_{\mathrm{Mg}}$ equivalentes, entre 0,10 e 0,16, com $X_{\mathrm{Mg}}$ no núcleo da granada tipo I ainda mais baixo, entre 0,05 e 0,09. Ambos os intervalos não são compatíveis com as associações de equilíbrio da rocha. O mesmo padrão é observado para

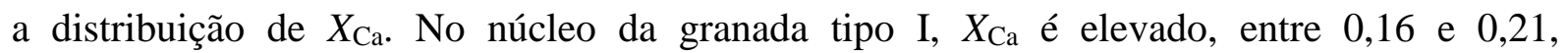
compatível com as isopletas fora do campo de estabilidade da estaurolita e cianita. Na granada tipo II e nas bordas da granada tipo I, $X_{\mathrm{Ca}}$ é menor, entre 0,04 e 0,10, com isopletas compatíveis com os campos das associações em equilíbrio.

Na biotita da matriz e do leucossoma, $X_{\mathrm{Mg}}$ é similar, entre 0,52 e 0,55 , e as isopletas deste intervalo passam pelo campo da associação em equilíbrio. Já $X_{\mathrm{Ti}}$ é muito baixo, de 0,07 a 0,09 na biotita da matriz e de 0,09 a 0,10 na biotita do leucossoma. Em ambas, as isopletas ocorrem em condições de temperatura inferiores as da associação em equilíbrio. Situação semelhante é observada para $X_{\mathrm{Mg}}$ da estaurolita, cujos valores de 0,17 a 0,21 ocorrem em isopletas já no campo de estabilidade da clorita (Figura 8.12d).

No plagioclásio da matriz e nas bordas do plagioclásio do leucossoma, $X_{\mathrm{Ca}}$ é similar, entre 0,15 e 0,17 , com isopletas compatíveis com a associação de equilíbrio, enquanto no núcleo do plagioclásio do leucossoma $X_{\mathrm{Ca}}$ é maior, entre 0,21 e 0,27.

Para testar a compatibilidade das isopletas calculadas com a composição química dos minerais analisados, foram definidos 3 conjuntos de minerais da associação em equilíbrio na rocha, diferenciados quanto ao tipo de porfiroblasto de granada presente no equilíbrio. Dois conjuntos, I-1 e I-2, são formados por Ky, St, Grt tipo I (Figura 8.4a), Bt, Ms, Pl e Qtz, e um conjunto, II-1, formado por Ky, St, Grt tipo II (Figura 8.4g), Bt, Ms, Pl e Qtz. De todas as isopletas apresentadas, apenas as de $X_{\mathrm{Ca}}$ na granada e no plagioclásio mostraram cruzamento nos conjuntos I-1 e I-2, que forneceram condições $P$ - $T$ de aproximadamente 8,9 kbar e $680{ }^{\circ} \mathrm{C}$, dentro do campo 28 (Figuras 8.9 e 8.12c). 


\section{a}
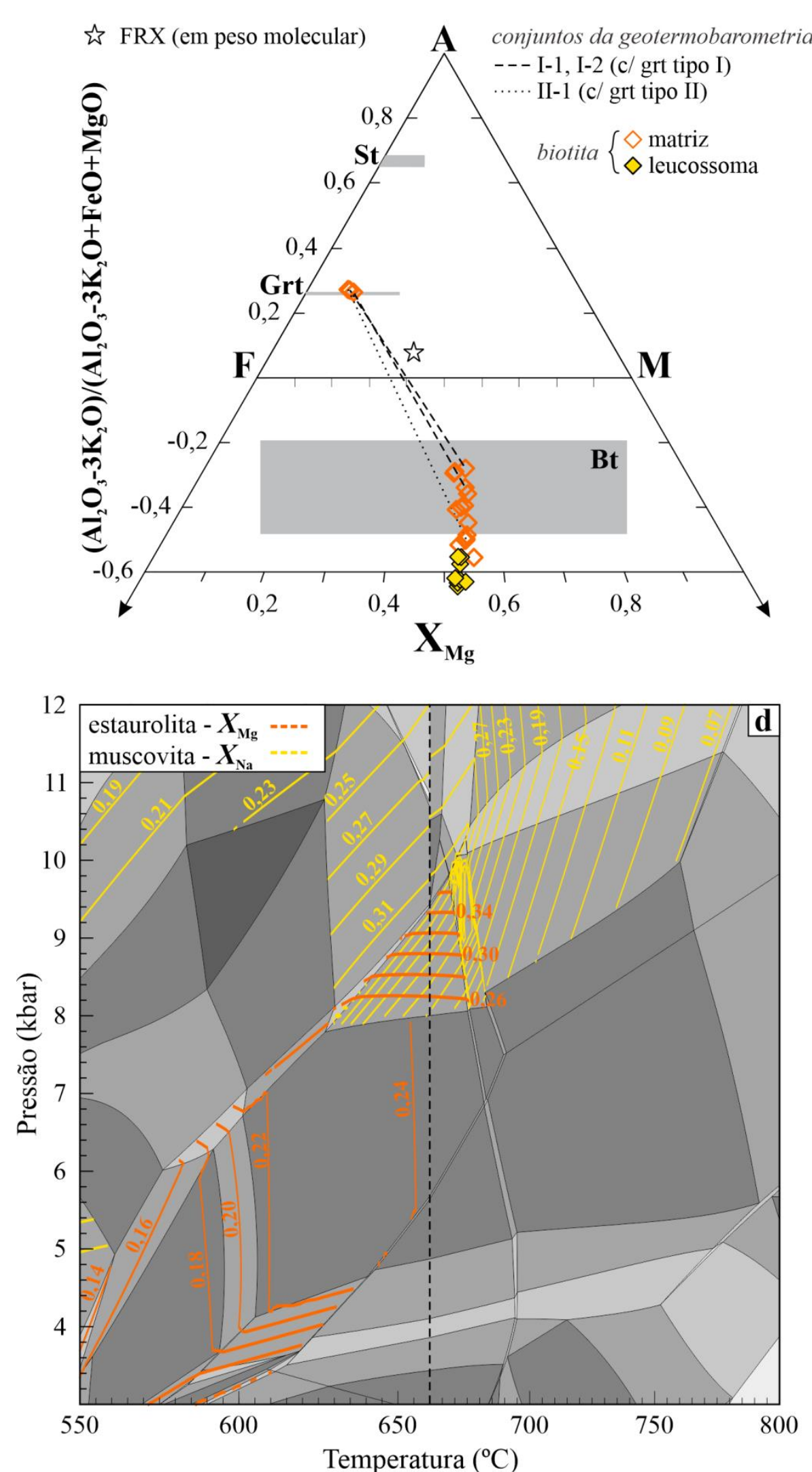
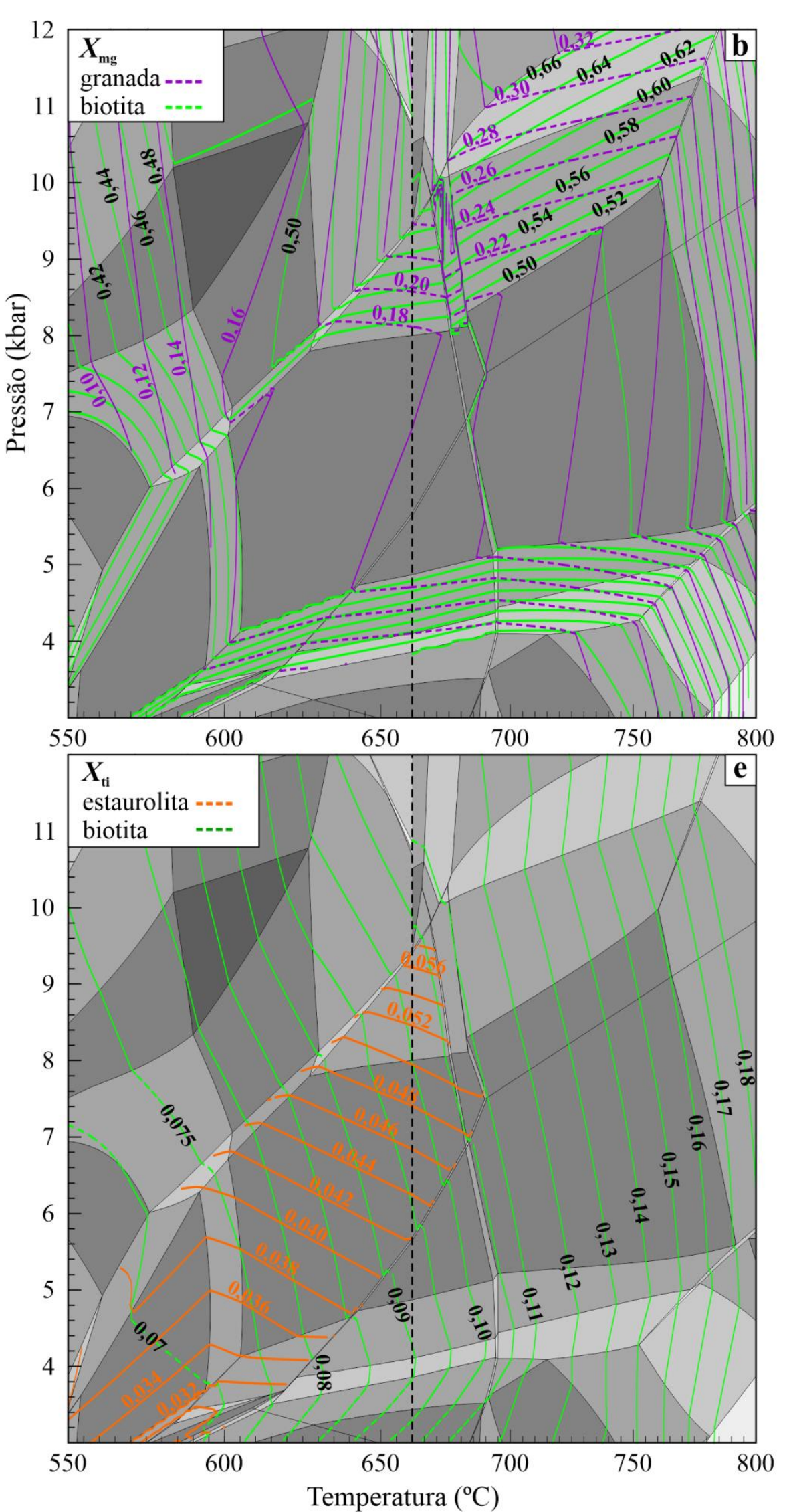
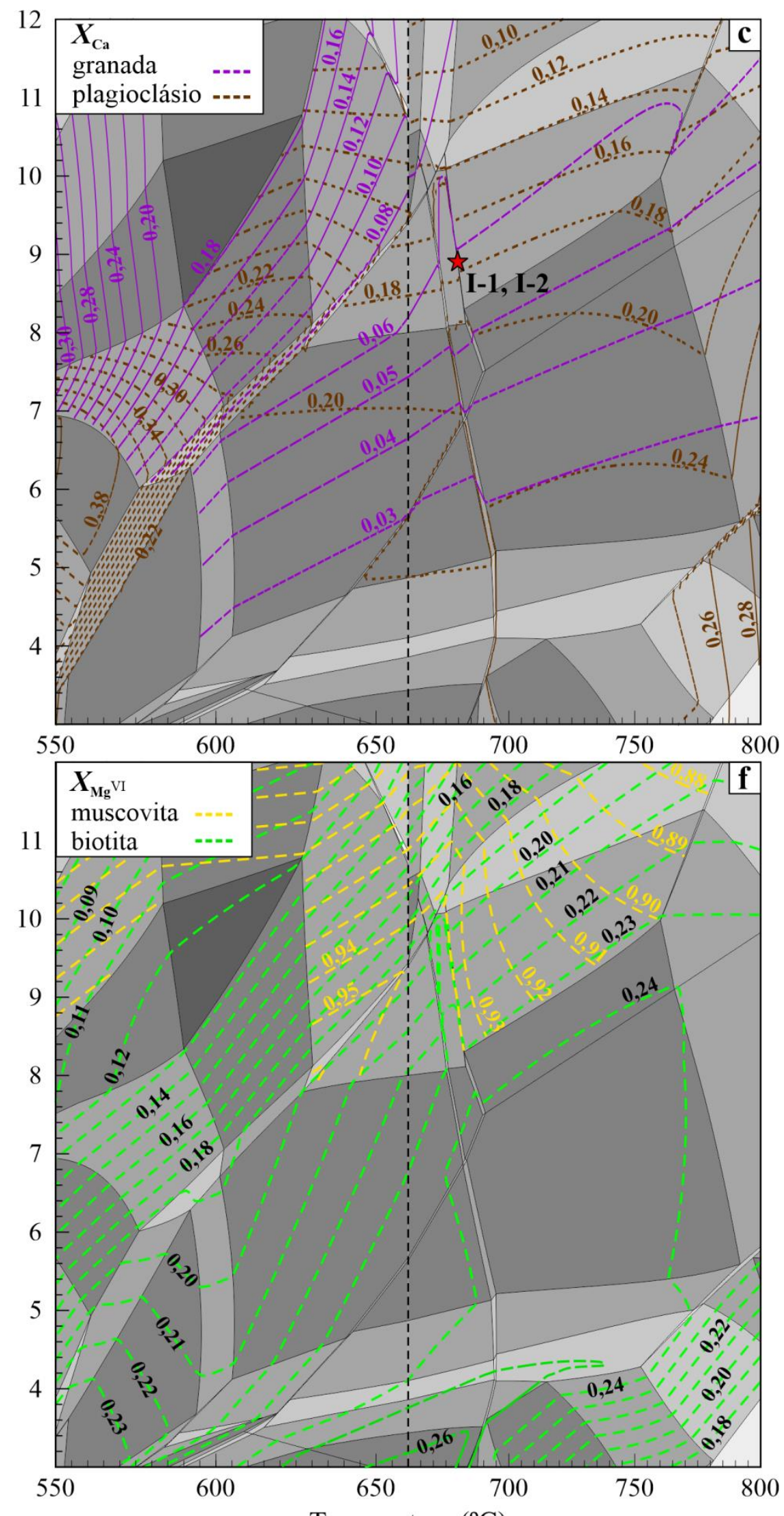

Temperatura $\left({ }^{\circ} \mathrm{C}\right)$

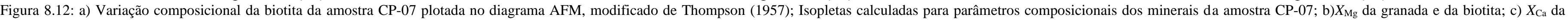
granada e do plagioclásio; d) $X_{\mathrm{Mg}}$ da estaurolita e $X_{\mathrm{Na}}$ da muscovita; e) $X_{\mathrm{Ti}}$ da biotita e da estaurolita; f) $X_{\mathrm{Al}}{ }^{\mathrm{V}}$ das micas. A estrela indica cruzamento de isopletas composicionais. 


\subsubsection{Muscovita-cianita-plagioclásio-granada-biotita xisto (CP-333)}

No muscovita-cianita-plagioclásio-granada-biotita xisto foram reconhecidas três associações minerais, "A", "B" e "C", divididas com base no contexto textural das duas gerações de granada e cianita (Tabela 8-2).

A associação "A" ocorre exclusivamente nos pods assimétricos amoldados pela foliação externa, mas internamente não estão deformados, podendo ser considerados relíquias do metamorfismo pré-deformacional. A associação mineral " $\mathrm{B}$ " representa a associação mineral em equilíbrio dominante na rocha. Nesta associação estão presentes as segundas gerações de cianita, sin- $S_{2}$, e granada, inter a sin-S $S_{2}$ (feições II, III e IV). A associação "C" ocorre localmente, e é marcada pelo equilíbrio de sillimanita tardia, sin- a pós-S $\mathbf{S}_{2}$. Esta associação, apesar de ter sillimanita, como visto na pseudosseção (Figura 8.14b), é de temperatura mais baixa. Clorita e magnetita ocorrem no mesmo contexto da amostra CP-07, sem definir associação em equilíbrio e são consideradas retrometamórficas.

Tabela 8-2: Associações minerais da amostra CP-333 e feições definidas para aplicação dos métodos geotermobarométricos.

\begin{tabular}{ll}
\multicolumn{1}{c}{ Associação mineral } & \multicolumn{1}{c}{$\begin{array}{c}\text { Associação - feição da granada - } \\
\text { conjunto }\end{array}$} \\
\hline $\mathrm{A} . \mathrm{ky}+\mathrm{grt}+\mathrm{bt}+\mathrm{ms}+\mathrm{pl}+\mathrm{qtz}+\mathrm{ru}+\mathrm{ilm}+\mathrm{liq}$ & A-I-1, A-I-2 e A-I-3 \\
\hline B. $\mathrm{ky} \pm \mathrm{st}+\mathrm{grt}+\mathrm{bt} \pm \mathrm{ms}+\mathrm{pl}+\mathrm{qtz}+\mathrm{ilm} \pm \mathrm{ru} \pm$ liq & B-II-1, B-IV-1 \\
\hline $\mathrm{C} . \mathrm{st}+\mathrm{grt}+\mathrm{bt}+\mathrm{ms}+\mathrm{pl}+\mathrm{qtz}+\mathrm{ilm} \pm \mathrm{mt} \pm \mathrm{sill}$ & ---- \\
\hline
\end{tabular}

A pseudosseção construída reflete os campos de equilíbrio das associações definidas na petrografia. A preservação da associação "A" é condicionada pela presença dos porfiroblastos de cianita. Essa associação pode ser encontrada em dois campos da pseudosseção, um amplo e trivalente, formado por grt $+\mathrm{pl}+\mathrm{ms}+\mathrm{bt}+\mathrm{ky}+\mathrm{ilm}+\mathrm{rt}+\mathrm{qtz}$ + liq, e outro divalente, com adição de $\mathrm{H}_{2} \mathrm{O}$ ao equilíbrio trivalente (campo 32, Figura 8.10b).

A associação "B”, em função da presença de estaurolita, muscovita, rutilo e líquido, aparece em onze campos distintos penta- a divariantes (campos 20, 31, 33 a 39, 41 e 42, Figuras 8.10a e 8.10b). A associação "C" pode ocorrer em três campos de equilíbrio em função da presença ou ausência de sillimanita e muscovita. Essa associação pode conter magnetita tardia, formada a partir da ilmenita e associada à biotita, no entanto, o modelo prevê a ocorrência de magnetita estável em associações com cordierita, fase que não ocorre na rocha. 
A granada mostra diminuição nos valores de $X_{\mathrm{Mg}}$ à medida que muda seu contexto textural. Na primeira geração de crescimento (feição I, Figura 8.5a), $X_{\mathrm{Mg}}$ é maior e varia de 0,18 a 0,20 , com abrupta diminuição nas bordas, onde $X_{\mathrm{Mg}}$ varia de 0,15 a 0,17 . A granada da segunda geração de crescimento tem bordas com menor $X_{\mathrm{Mg}}$, de 0,15 a 0,16 (feição IV, Figura 8.5d), e, ao longo dos cristais, $X_{\mathrm{Mg}}$ varia de 0,17 a 0,19 , mas os valores elevados podem ser compatíveis com relíquias de granada da primeira geração de crescimento.

Biotita inclusa no núcleo da primeira geração de granada possui valores de $X_{\mathrm{Mg}}$ mais elevados $(0,57$ a 0,63$)$ em relação à biotita da matriz, com $X_{\mathrm{Mg}}$ de 0,50 a 0,54 (Figura 8.13a). Com a aumento da temperatura a biotita se torna mais rica em $\mathrm{Mg}$ e sua composição varre o diagrama AFM (Spear, 1993), em virtude da substituição $\mathrm{Fe}^{2+} \leftrightarrow \mathrm{Mg}^{2+}$ que ocorre entre granada e biotita. No entanto, as isopletas calculadas para $X_{\mathrm{Mg}}$ na biotita mostram que as variações são controladas também pela pressão, efeito similar é observado para as isopletas de $X_{\mathrm{Mg}}$ na granada (Figura 8.13b).

A similaridade dos perfis composicionais das duas gerações de granada (Figuras 8.5e e 8.5h) também pode ser vista através dos valores de $X_{\mathrm{Mg}}$, com ambas mostrando intervalo de 0,15 a 0,17 , enquanto a granada das feições II e III mostram variação levemente superior, com $X_{\mathrm{Mg}}$ entre 0,13 a 0,19. Variações no conteúdo de $\mathrm{Ca}$ nas duas gerações de granada são heterogêneas e sutis, com $X_{\mathrm{Ca}}$ entre 0,06 e 0,12. As isopletas entre tais valores são espaçadas e controladas pela pressão e pela temperatura (Figura 8.13c).

A distribuição das isopletas de $X_{\mathrm{Ca}}$ no plagioclásio é distinta para condições $s u b$ - e suprasolidus. Em condições subsolidus, antes de coexistir com paragonita, entre 3 e 8 kbar e entre $550{ }^{\circ} \mathrm{C}$ e o início da fusão em 675 - $693{ }^{\circ} \mathrm{C}$, a composição do plagioclásio é praticamente constante, $\operatorname{com} X_{\mathrm{Ca}}$ de 0,30 a 0,36, e na pseudosseção as isopletas são espaçadas. Em associações com paragonita, $X_{\mathrm{Ca}}$ aumenta rapidamente até 0,50 , quando então o plagioclásio se torna instável. O mesmo efeito de mudança abrupta em sua composição ocorre assim que o fundido é gerado, sob pressão inferior a $8 \mathrm{kbar}$. O plagioclásio rapidamente se torna mais cálcico, com $X_{\mathrm{Ca}}$ de 0,32 a 0,38, enquanto ainda há $\mathrm{H}_{2} \mathrm{O}$. Quando a água é consumida, as isopletas de $X_{\mathrm{Ca}}$ se tornam mais espaçadas e o $\mathrm{Ca}$ vai diminuindo com o aumento da pressão (Figura 8.13c).

As isopletas modeladas para estaurolita, muscovita, $X_{\mathrm{Ti}}$ e $X_{\mathrm{AIVI}}$ na biotita mostram valores e distribuição similares às apresentadas para a amostra CP-07. Na estaurolita da amostra CP-333, $X_{\mathrm{Mg}}$ varia de 0,16 a 0,21 e $X_{\mathrm{Ti}}$ também é constante, em média 0,08 , superior aos valores das isopletas modeladas (Figuras 8.13d e 8.13e). 

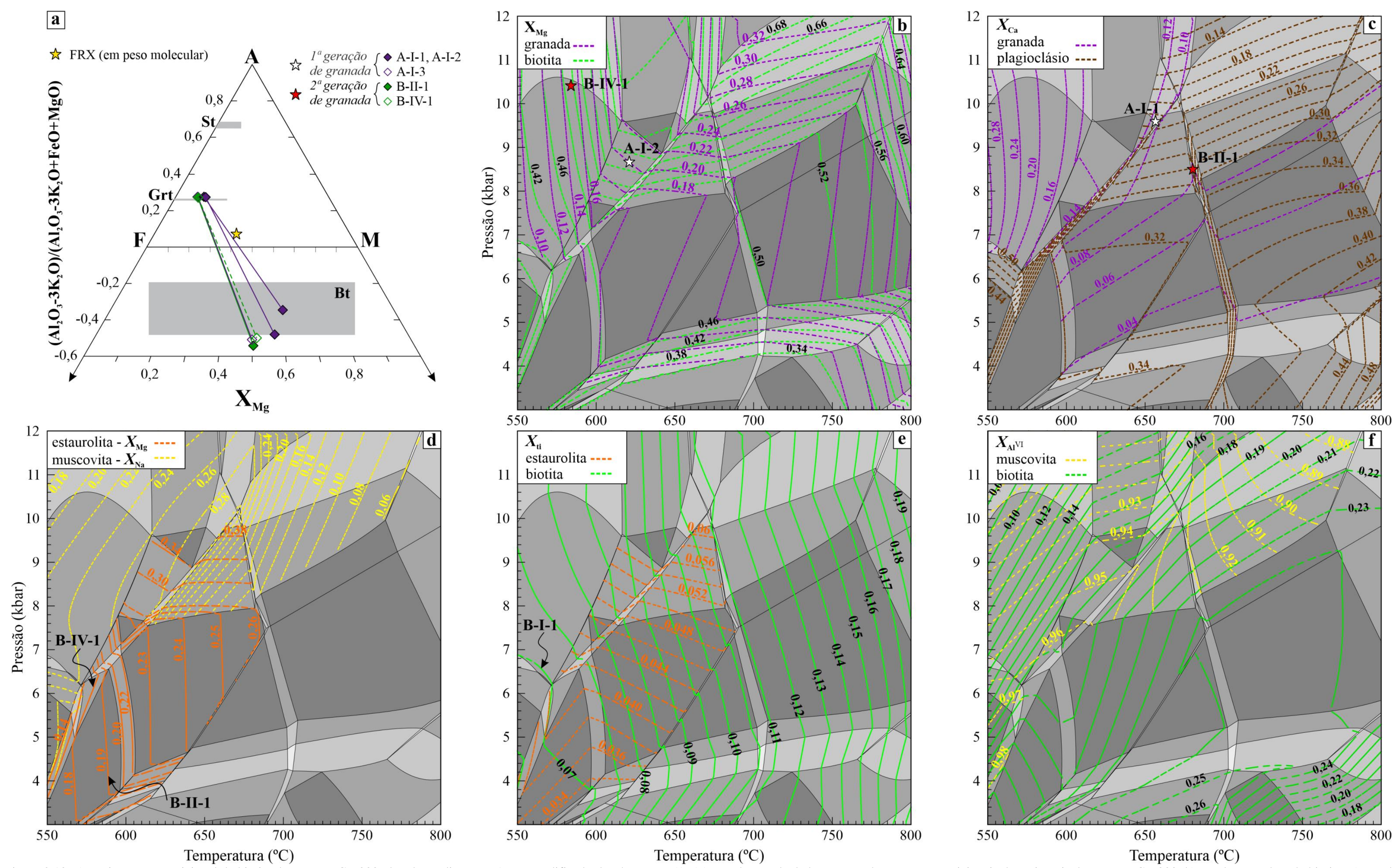

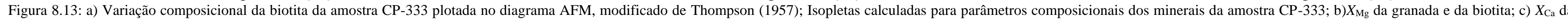
granada e do plagioclásio; d) $X_{\mathrm{Mg}}$ da estaurolita e $X_{\mathrm{Na}}$ da muscovita; e) $X_{\mathrm{Ti}}$ da biotita e da estaurolita; f) $X_{\mathrm{Al}}{ }^{\mathrm{V}}$ das micas. As estrelas indicam o cruzamento das isopletas de minerais em uma mesma associação em equilíbrio. 
Na biotita, os menores valores para $X_{\mathrm{Ti}}$ são encontrados nos cristais inclusos na primeira geração de granada, onde $X_{\mathrm{Ti}}$ varia entre 0,036 e 0,054. Mas estes valores ocorrem em temperaturas inferiores a $550{ }^{\circ} \mathrm{C}$ e não são mostrados na pseudosseção. A biotita inclusa na segunda geração de granada possui concentração de Ti ligeiramente superior, mas apenas dois cristais foram analisados, $\operatorname{com} X_{\mathrm{Ti}}$ de 0,061 e 0,066, não sendo coerente afirmar que há variação composicional. Na biotita da matriz a concentração de Ti é maior e mais variável, com $X_{\mathrm{Ti}}$ entre 0,06 e 0,09 . As isopletas modeladas para $X_{\text {AlVI }}$ na biotita também mostram valores muito inferiores aos valores reais obtidos, 0,37 a 0,41 (Figuras 8.13e e 8.13f).

Os valores para as isopletas modeladas, de maneira geral, ou passam em campos de equilíbrio distintos aos das associações minerais presentes na rocha, ou não aparecem para as condições $P-T$ apresentadas na pseudosseção. A granada das duas gerações tem composição química similar e, portanto, as isopletas calculadas mostram os mesmos intervalos, no entanto, nos cristais de granada que não foram reequilibrados, era esperado as isopletas fornecessem intervalos distintos, o que não é observado no modelo. Isopletas de $X_{\mathrm{Fe}}$ na granada compatíveis com a composição química analisada ocorrem em condições $P-T$ inferiores às das associações observadas. Já para $X_{\mathrm{Ca}}$ no plagioclásio, só há isopletas compatíveis para pressão superior a 8 kbar.

As composições para as isopletas de estaurolita, quando aparecem no intervalo $P-T$ definido, estão sempre associadas à equilíbrios com clorita, sugerindo forte reequilíbrio dessa fase durante o retrometamorfismo. Para a muscovita, $X_{\mathrm{Na}}$ mostra isopletas compatíveis com os campos onde ocorrem as associações $\mathrm{A}, \mathrm{B}$ e C, enquanto $X_{\mathrm{AlVI}}$, para condições de pressão superiores a 9 kbar, mostra valores compatíveis apenas com associação A.

Dos conjuntos de minerais definidos para as associações "A" e "B" (Tabela 8-2), em três foi possível cruzar isopletas na tentativa de identificar condições $P-T$. As isopletas de $X_{\mathrm{Mg}}$ para granada e biotita se cruzam em intervalo onde predominam equilíbrios contendo paragonita, fornecendo condições $P-T$ incompatíveis com as associações que caracteristicamente contem cianita estável (Figura 8.13b). O conjunto B-II-1 foi o que melhor se ajustou, através do cruzamento das isopletas de $X_{\mathrm{Ca}}$ na granada e no plagioclásio, fornecendo condições $P$ - $T$ de 8,5 kbar e $680,5{ }^{\circ} \mathrm{C}$ (Figuras 8.10b e 8.13c).

\subsection{Geotermobarometria}

\subsubsection{Average P-T}

Para os cálculos via geotermobarometria otimizada foram escolhidas composições químicas de minerais presentes em um mesmo domínio textural das associações em equilíbrio 
identificadas apresentadas na seção 8.5. Alguns dos conjuntos podem ser vistos nas figuras apresentadas na seção 8.3 (amostra CP-07, conjunto II-1, Figura 8.4g; amostra CP-333, conjunto B-IV-1, Figura 8.5d; conjuntos A-I-1 e A-I-3, Figura 8.5a). Os resultados obtidos estão sumarizados na Tabela 8-3 e as reações linearmente independentes definidas em cada conjunto são apresentadas no Apêndice G.

Tabela 8-3: Dados calculados pelo average P-T.

\begin{tabular}{ccccccc} 
Amostra & Conjunto & ${\mathbf{T ~}\left({ }^{\circ} \mathbf{C}\right)}^{*}$ & o & P (kbar) & o & correlação \\
\hline \multirow{2}{*}{ CP-07 } & I-1 & 651 & 11 & 8,2 & 0,6 & 0,67 \\
& I-2 & 682 & 17 & 8,6 & 0,8 & 0,71 \\
& II-1 & 658 & 13 & 7,7 & 0,9 & 0,74 \\
\hline \multirow{3}{*}{ CP-333 } & A-I-3 & 713 & 16 & 9,4 & 0,6 & 0,78 \\
& B-II-1 & 683 & 12 & 8,3 & 0,5 & 0,71 \\
& B-IV-1 & 689 & 15 & 8,5 & 0,6 & 0,71 \\
\hline
\end{tabular}

Na cianita-estaurolita-muscovita-granada-biotita xisto (CP-07) os conjuntos I-1 e II-1 forneceram condições $P-T$ dentro do campo da estaurolita, porém, fora do campo de estabilidade da cianita, enquanto o conjunto I-2, forneceu condições $P-T$ ligeiramente acima da curva de quebra da estaurolita, em $682{ }^{\circ} \mathrm{C}$ e $8,6 \mathrm{kbar}$, porém muito próximas das condições $P-T$ definidas através do cruzamento entre as isopletas de $X_{\mathrm{Ca}}$ na granada e no plagioclásio (Figuras 8.12c e 8.14a). Para o muscovita-cianita-plagioclásio-granada-biotita xisto (CP333), os conjuntos estabelecidos para a associação " $\mathrm{B}$ " forneceram condições $P-T$ que condizem, dentro das incertezas, com os campos de equilíbrio definidos na pseudosseção (Figura 8.14b).

Apesar de que o dataset utilizado para os cálculos das condições $P-T$ não contém fases com ferro férrico e titânio, os resultados obtidos para as duas composições de rocha nas associações minerais do equilíbrio dominante, $\mathrm{Ky}+\mathrm{St}+\mathrm{Grt}+\mathrm{Bt}+\mathrm{Ms}+\mathrm{Pl}+\mathrm{Qtz}+\mathrm{Ilm} \pm$ $\mathrm{Rt}+\mathrm{Liq}$, forneceram condições $P-T$ compatíveis, em torno de $683{ }^{\circ} \mathrm{C}$ e $8,3 \mathrm{kbar}$. As inconsistências dos resultados obtidos para as associações que envolvem a granada tipo I na amostra CP-07 podem ser oriundas de uma junção de fatores, entre eles o maior reequilíbrio das micas durante o retrometamorfismo e a persistência da cianita no campo da estaurolita.

Para os equilíbrios envolvendo a primeira geração de granada na amostra CP-333, os conjuntos A-I-1 e A-I-2 os cálculos forneceram número insuficiente de reações devido à ausência de análises de plagioclásio. Foram feitos cálculos de $\mathrm{P}$ e $\mathrm{T}$ separadamente, mas apenas a pressão pôde ser determinada, 9,9 \pm 1 e $8,6 \pm 0,9 \mathrm{kbar}$, respectivamente. Tais 
condições de pressão não possuem significado, pois além de não considerar o plagioclásio, a micas inclusas na granada não necessariamente estão em equilíbrio com a cianita. Além disso a difusão nas micas é mais rápida do que em outras fases e, para cristais muito finos, como é o caso das inclusões, é ainda mais rápida.

No conjunto A-I-3, onde a primeira geração de granada faz contato com a biotita da matriz, os cálculos forneceram condições $P-T$, em $713{ }^{\circ} \mathrm{C}$ e $9,4 \mathrm{kbar}$, porém fora do campo de estabilidade do rutilo. Isto pode estar relacionado ao reequilíbrio da granada com a matriz ou a escolha inadequada da quantidade de ferro férrico para a construção da pseudosseção, uma vez que, ao diminuir o conteúdo de $\mathrm{Fe}^{3+}$, a pressão na qual o rutilo aparece diminui.

\subsubsection{Geotermômetro $\mathrm{Zr}$ em rutilo}

Para o cálculo da temperatura com o termômetro Zr-in-rutilo foi utilizada a calibração de Tomkins et al., (2007), que, além da dependência da temperatura (Zack et al., 2004; Watson et al. 2006), insere a dependência da pressão na incorporação de $\mathrm{Zr}$ pelo rutilo (Tomkins et al., 2007). A pressão foi escolhida baseada na média dos resultados obtidos pela geotermobarometria otimizada (Tabela 8-3). Os resultados obtidos, bem como as concentrações dos elementos traço em ppm, acima do limite detecção são mostrados na Tabela 8-4. Outros dados referentes aos resultados estão disponíveis nos Apêndices E e G.

$\mathrm{Na}$ amostra CP-07, rutilo ocorre na matriz como cristais orientados segundo a foliação principal, associados ao quartzo e às micas, ou incluso na estaurolita. Os cristais são homogêneos, com finas lamelas de ilmenita, ou apresentam coronas de ilmenita, às vezes com magnetita associada (Figuras 8.15a-c).

As análises forneceram teores de Sn, Ta, Sb, W e Hf abaixo do limite de detecção e concentrações de Zr entre 252 e 614 ppm, independentemente da posição do cristal e da coexistência ou não com ilmenita (Figura 8.15e). O teor de Si é amplamente variável, de 75 a 1360 ppm, e, mesmo para os valores superiores a 300 ppm, não está associado com elevado teor de $\mathrm{Zr}$, descartando a possibilidade da presença de microinclusões de zircão (Luzivotto et al., 2009). Apesar do conteúdo de Fe não exercer influência na incorporação de $\mathrm{Zr}$ (Zack et al., 2004), análises com Fe>12000 ppm foram descartadas por suspeita de mistura com micro lamelas de ilmenita.

Cristais de rutilo com corona de ilmenita parcial, ou bem desenvolvida, forneceram temperaturas de $686 \pm 10$ a $694 \pm 11{ }^{\circ} \mathrm{C}$ nas bordas e $702 \pm 14{ }^{\circ} \mathrm{C}$ no núcleo (Figuras 8.15a e 8.15b). Um cristal de rutilo homogêneo, incluso na estaurolita, apresentou conteúdo uniforme de $\mathrm{Zr}$ (481 a $511 \mathrm{ppm}$ ) e temperaturas entre $680 \pm 9$ e $686 \pm 10{ }^{\circ} \mathrm{C}$ (Figura 8.15c), 
compatíveis com as temperaturas nas bordas dos cristais com corona de ilmenita. Já o cristal de rutilo homogêneo, na matriz e sem corona de ilmenita, apresenta a as menores concentrações de $\operatorname{Zr}(252$ a $437 \mathrm{ppm})$ e forneceu a temperatura mais baixa, $627 \pm 11^{\circ} \mathrm{C}$ na borda e $672 \pm 17{ }^{\circ} \mathrm{C}$ no núcleo (Tabela 8-4).

$\mathrm{Na}$ amostra CP-333, rutilo ocorre apenas como inclusões na cianita e na granada. Quando incluso na granada e na primeira geração de cianita, rutilo ocorre como agregados policristalinos irregulares, mas texturalmente homogêneos e com micro lamelas de ilmenita, ou como cristais granulares muito finos dispersos que mimetizaram os de ilmenita (Figura 8.15d). Quando incluso na segunda geração de cianita, rutilo ocorre de forma irregular e subordinada à ilmenita, que ainda preserva forma subidioblástica e alongada (Figura 8.3f). Esta feição é indicativa de crescimento de rutilo a partir da quebra da ilmenita durante o metamorfismo progressivo, tal como observado por Luzivotto et al. (2009).

Tabela 8-4: Concentração em ppm dos elementos traço em rutilo e resultado das temperaturas calculadas.

\begin{tabular}{|c|c|c|c|c|c|c|c|c|c|c|c|c|c|}
\hline & Ponto & Posição & $\mathbf{S i}$ & Al & $\mathbf{V}$ & Sn & $\mathrm{Cr}$ & $\mathbf{F e}$ & $\mathbf{Z r}$ & $\mathrm{Nb}$ & P (kbar) & $\mathbf{T}\left({ }^{\circ} \mathbf{C}\right)$ & o \\
\hline \multirow{13}{*}{$\begin{array}{l}\hat{\theta} \\
\hat{\theta} \\
\hat{\prime}\end{array}$} & 1.1 & borda & 131 & 85 & 4576 & - & 1505 & 5581 & 533 & 5655 & 8.0 & 689 & 3 \\
\hline & 1.2 & núcleo & 93 & 74 & 4680 & - & 1519 & 7190 & 614 & 7466 & 8.0 & 702 & 3 \\
\hline & 1.3 & borda & 439 & 619 & 4840 & - & 1587 & 3918 & 533 & 8535 & 8.0 & 689 & 3 \\
\hline & 2.1 & borda & 108 & 64 & 5135 & - & 2196 & 5262 & 511 & 10416 & 8.0 & 686 & 3 \\
\hline & 2.3 & borda & 98 & 26 & 4502 & - & 1594 & 2347 & 548 & 4551 & 8.0 & 692 & 3 \\
\hline & 3.1 & borda & 495 & 212 & 4521 & - & 1204 & 3117 & 481 & 9234 & 8.0 & 680 & 3 \\
\hline & 3.2 & núcleo & 126 & 127 & 4428 & - & 1669 & 7594 & 503 & 9661 & 8.0 & 684 & 3 \\
\hline & 3.3 & borda & 168 & 206 & 4459 & - & 1745 & 2930 & 511 & 9577 & 8.0 & 686 & 3 \\
\hline & 4.1 & núcleo & 79 & 164 & 5620 & - & 2135 & 6117 & 474 & 16707 & 8.0 & 679 & 3 \\
\hline & 5.1 & borda & 1360 & 1180 & 3139 & - & 363 & 1384 & 252 & 1852 & 8.0 & 627 & 3 \\
\hline & 5.2 & núcleo & 612 & 677 & 5276 & - & 1676 & 4757 & 437 & 13701 & 8.0 & 672 & 5 \\
\hline & 5.3 & borda & 238 & 196 & 2942 & - & 62 & 490 & 318 & 1824 & 8.0 & 646 & 4 \\
\hline & 6.3 & borda & 318 & 191 & 4459 & - & 2456 & 1718 & 563 & 5453 & 8.0 & 694 & 5 \\
\hline \multirow{16}{*}{ 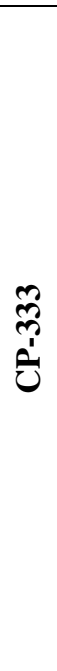 } & 1.1 & borda & - & 223 & - & 150 & 980 & 868 & 267 & 2057 & 8.4 & 634 & 9 \\
\hline & 1.2 & núcleo' & 596 & 257 & - & 145 & 987 & 739 & 186 & 1967 & 8.4 & 606 & 12 \\
\hline & 1.3 & núcleo' & - & 116 & - & 109 & 984 & 787 & 244 & 2039 & 8.4 & 627 & 9 \\
\hline & 1.4 & borda & - & 105 & - & 98 & 989 & 843 & 271 & 2003 & 8.4 & 635 & 9 \\
\hline & 2.1 & núcleo & 257 & 170 & - & 134 & 879 & 1268 & 315 & 4115 & 9.4 & 651 & 8 \\
\hline & 3.1 & núcleo & 342 & 181 & - & 174 & 843 & 1391 & 288 & 3745 & 9.4 & 644 & 8 \\
\hline & 4.1 & núcleo & 66 & 199 & - & 141 & 894 & 1353 & 309 & 3348 & 9.4 & 650 & 8 \\
\hline & 5.1 & borda & 40 & 154 & - & 116 & 1234 & 1677 & 345 & 4196 & 8.4 & 654 & 7 \\
\hline & 5.2 & núcleo & - & 112 & - & 142 & 1448 & 3380 & 274 & 4130 & 8.4 & 636 & 9 \\
\hline & 6.1 & borda & - & 159 & - & - & 829 & 6642 & 304 & 4879 & 9.4 & 648 & 8 \\
\hline & 6.2 & núcleo & - & 123 & - & 113 & 774 & 2403 & 205 & 2863 & 9.4 & 618 & 11 \\
\hline & 6.3 & núcleo & - & 66 & - & 132 & 794 & 2395 & 143 & 1766 & 9.4 & 591 & 15 \\
\hline & 6.4 & núcleo & 58 & 104 & - & 106 & 841 & 3648 & 201 & 3073 & 9.4 & 616 & 11 \\
\hline & 7.1 & borda & - & 116 & - & 128 & 813 & 1797 & 165 & 2923 & 8.4 & 597 & 13 \\
\hline & 7.2 & núcleo & - & 131 & - & 98 & 835 & 2708 & 209 & 3633 & 8.4 & 615 & 11 \\
\hline & 7.3 & núcleo & 619 & 180 & - & 159 & 965 & 3136 & 250 & 6353 & 8.4 & 629 & 9 \\
\hline
\end{tabular}



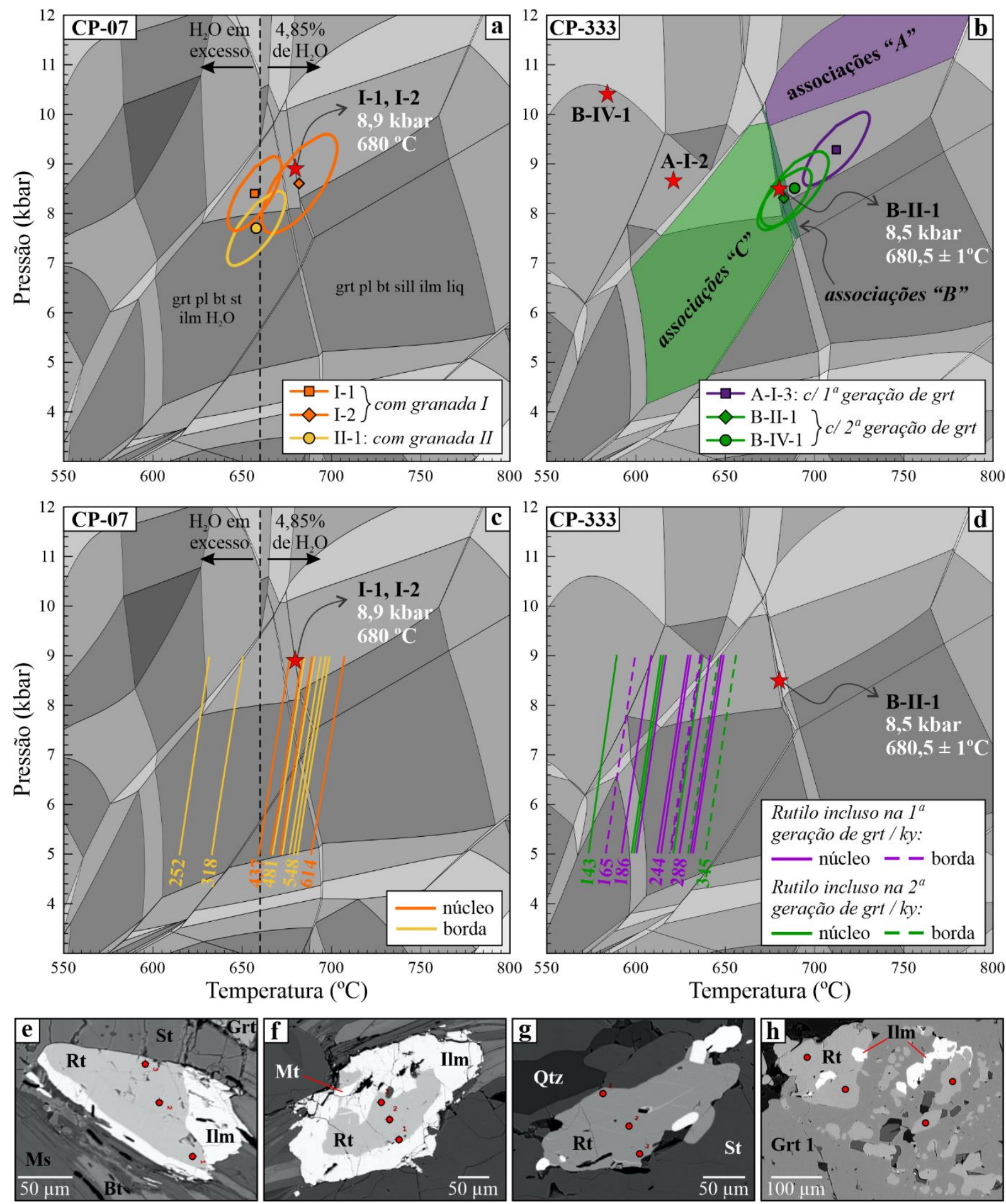

Figura 8.14: : Resultados dos cálculos por geotermobarometria otimizada para os conjuntos de associações em equilíbrio - a) amostra CP-07 e b) amostra CP-333. As estrelas indicam o cruzamento de isopletas minerais das associações em equilíbrio; Isopletas de $\mathrm{Zr}$ no rutilo - c) amostra CP-07 e d) amostra CP-333; e) Rutilo (Rt-1) na matriz, com corona parcial de ilmenita, amostra CP-07; f) Rutilo (Rt-2) na matriz, com corona de ilmenita bem desenvolvida e associada com magnetita, amostra CP-07; g) Rutilo (Rt-3) incluso em porfiroblasto de estaurolita; h) Cristais granulares de rutilo (Rt-6) homogêneo, associado com pouca ilmenita, inclusos na primeira geração de granada da amostra CP-333.

As análises forneceram teores de $\mathrm{V}, \mathrm{Sb}, \mathrm{W}$ e $\mathrm{Hf}$ abaixo do limite de detecção. Ao contrário da amostra CP-07, na amostra CP-333, rutilo possui teor de Sn baixo, entre 98 e 
174 ppm, Si nem sempre é detectável e concentrações de $\mathrm{Cr}$ e $\mathrm{Nb}$ mais baixas. O teor de $\mathrm{Zr}$ é menor, de 143 a 345 ppm, também varia independentemente da posição do cristal, e forneceu temperaturas são mais baixas, de $591 \pm 15$ a $654 \pm 7{ }^{\circ} \mathrm{C}$ (Figura 8.15f).

Mais do que a posição relativa do cristal, o teor de $\mathrm{Zr}$ e a temperatura estão relacionados ao contexto textural em que se encontra o rutilo. As maiores temperaturas foram registradas nos cristais granulares de rutilo inclusos na primeira geração de granada inclusa na cianita dos pods, de $644 \pm 9$ a $651 \pm 8{ }^{\circ} \mathrm{C}$, e na borda do rutilo incluso na segunda geração de cianita, $654 \pm 7{ }^{\circ} \mathrm{C}$. Conforme aumenta a interação entre granada e cianita dos pods com a matriz, o rutilo incluso nestas fases mostra diminuição do teor de $\mathrm{Zr}$ e, consequentemente, registra menores temperaturas, de $591 \pm 15$ a $635 \pm 8^{\circ} \mathrm{C}$.

\subsection{Geoquímica Isotópica Mineral}

\subsubsection{U-Pb em zircão}

$\mathrm{Na}$ amostra CP-07, cianita-estaurolita-muscovita-granada-biotita xisto, três populações de zircão foram reconhecidas e são descritas em ordem decrescente de abundância:

(i) População formada por cristais prismáticos bipiramidais, incolor a rosa pálido, com terminações subangulosas a subarredondadas, relações comprimento/largura de 3:1 a 4:1 e tamanho entre 75 e $130 \mu \mathrm{m}$ ao longo do eixo c. Internamente exibem baixa intensidade de luminescência e zoneamento oscilatório discreto (cristais 12 e 60, Figura 8.15a), muitas vezes acompanhado por zonas de alteração concêntrica (cristais 11 e 107, Figura 8.15a). Núcleo detríticos, quando presentes, mostram alta intensidade de luminescência e não preservaram a forma original do grão, apenas bordas irregulares, difusas, indicando reabsorção parcial (cristais 60 e 75, Figura 8.15a);

(ii) População formada por cristais prismáticos bipiramidais de cor amarela, com terminações subarredondadas, relações comprimento/largura de 2:1 a 3:1 e tamanho entre 150 e $250 \mu \mathrm{m}$ ao longo do eixo c. Os cristais possuem fraturamento e escurecimento causado pela metamictização e inclusões de minerais opacos. Internamente exibem baixa intensidade de luminescência, zoneamento oscilatório discreto, às vezes acompanhado por zonas de alteração concêntrica (cristal 120, Figura 8.15a) ou com domínios de recristalização penetrativa, invadindo núcleos detríticos (cristal 15, Figura 8.15a). Os núcleos detríticos exibem bordas regulares e/ou ameboides, maior intensidade de luminescência, zoneamento oscilatório ou em setor 
(cristais 24, 50 e 67), podendo ainda ser homogêneos, com intensidade de luminescência muito alta ou exibir textura esponjosa (cristais 71 e 120, Figura 8.15a); (iii) População formada por cristais ovoides de tamanho entre 150 e $200 \mu \mathrm{m}$. São incolores ou amarelados, fraturados e moderadamente metamictizados. Nesta população o sobrecrescimento é menos desenvolvido e não desenvolveu faces prismáticas. Internamente as bordas exibem baixa intensidade de luminescência e zonas de alteração concêntrica (cristais 168 e 171), ou são homogêneas, por vezes penetrativas (cristal 139, Figura 8.15a). Os núcleos detríticos são subarredondados ou têm bordas irregulares e internamente são homogêneos ou exibem zoneamento oscilatório, ambos com alta intensidade de luminescência (ou escuros ao BSE).

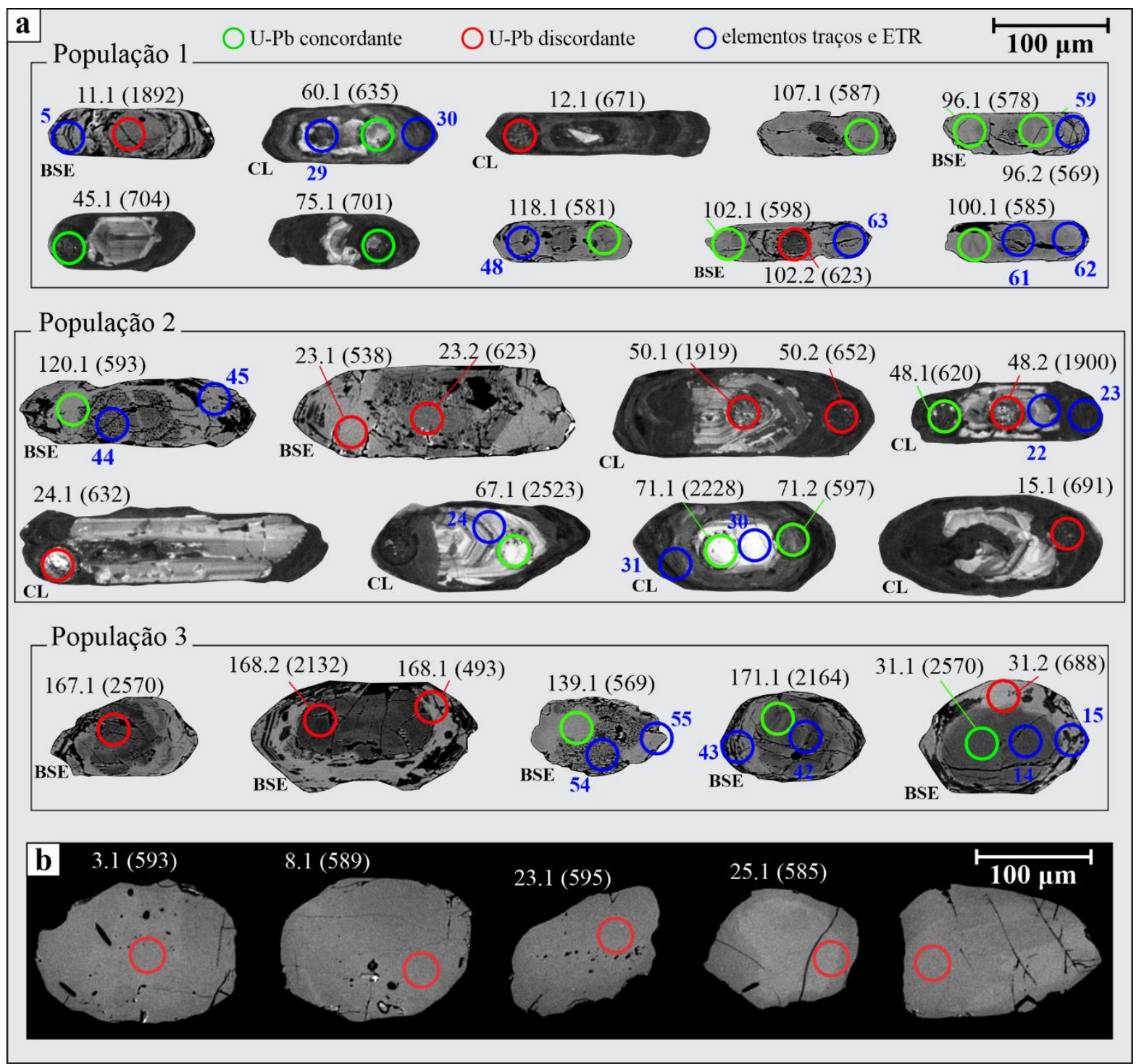

Figura 8.15: Imagens de catodoluminescência (CL) e de elétrons retroespalhados (BSE) de cristais de zircão (a) e monazita (b) representativos do cianita-estaurolita-muscovita-granada-biotita xisto (amostra CP-07) da Unidade Colônia. Estão indicadas as idades em Ma com 20 de incerteza, ${ }^{207} \mathrm{~Pb} /{ }^{206} \mathrm{~Pb}$ para idades $>1000$ e ${ }^{206} \mathrm{~Pb} /{ }^{238} \mathrm{U} \mathrm{para}$ idades $<1000$. 
Os cristais de zircão da amostra CP-07 apresentaram elevados índices de discordância na maioria das análises realizadas (Apêndice $\mathbf{H}$ ), causadas pelo alto teor de chumbo comum e pela presença de microporosidades nos núcleos detríticos. Além disso, devido à granulação muito fina nos cristais da população 1 , os cristais muitas vezes não suportaram todos os ciclos de contagem durante as análises e nem sempre foi possível isolar cada domínio textural. As relíquias de texturas primárias dentro de áreas recristalizadas observadas podem ser responsáveis por misturar as razões isotópicas (Corfu et al., 2003; Hoskin \& Black, 2000), resultando também em discordâncias elevadas. Por estas razões foi adotada outra abordagem para o tratamento dos dados de U-Pb em zircão, descrita a seguir.

As análises obtidas foram separadas em quatro domínios texturais independentes das populações identificadas: núcleo detrítico; zonas de substituição/recristalização; zonas com mistura de domínios na borda, e; zona com mistura de domínios no núcleo. Os domínios texturais com mistura referem-se às porções onde há relíquias de texturas primárias dentro de áreas recristalizadas. Já as zonas de recristalização correspondem às porções homogêneas ou com zoneamento oscilatório discreto e/ou irregular.

Nos núcleos detríticos preservados, a razão Th/U varia de 0,27 a 2,76 (Figura 8.16a), enquanto nos demais domínios texturais, mesmo naqueles com zoneamento oscilatório, ela é inferior à 0,1 , tal como em zircão de origem metamórfica (Rubatto et al., 1999; Hoskin \& Black, 2000), sendo praticamente constante nos domínios recristalizados e mais variável nas porções com mistura de domínios (Figura 8.16b).

Do total de análises, $63 \%$ dos dados têm concordância $100 \pm 10 \%$, mas essa porcentagem diminui quando desconsideramos análises em porções recristalizadas ou com mistura de domínios. O gráfico de distribuição de densidade de probabilidades das idades (Figura 8.16c) mostra predomínio de idades no período Riaciano, no entanto, como muitos cristais não puderam ser considerados, devido ao elevado grau de discordância e às misturas de domínios texturais, a identificação da proveniência e estimativas de idade máxima de deposição para a Unidade Colônia não são estatisticamente viáveis.

Para avaliar o grau de comprometimento das datações obtidas, na Figura 8.16d estão plotadas todas as análises em zonas de recristalização e com mistura de domínios que forneceram concordância de $100 \pm 5 \%$. Nas zonas com mistura de domínios no núcleo a perda de chumbo é mais significativa, enquanto nas bordas e nas zonas recristalizadas há variável grau de perda ou ganho de chumbo. As análises em zonas de mistura de domínios nas bordas dos cristais apresentam maior intervalo de datações, de 559 a 835 Ma, entretanto, sem significado geológico aparente. 

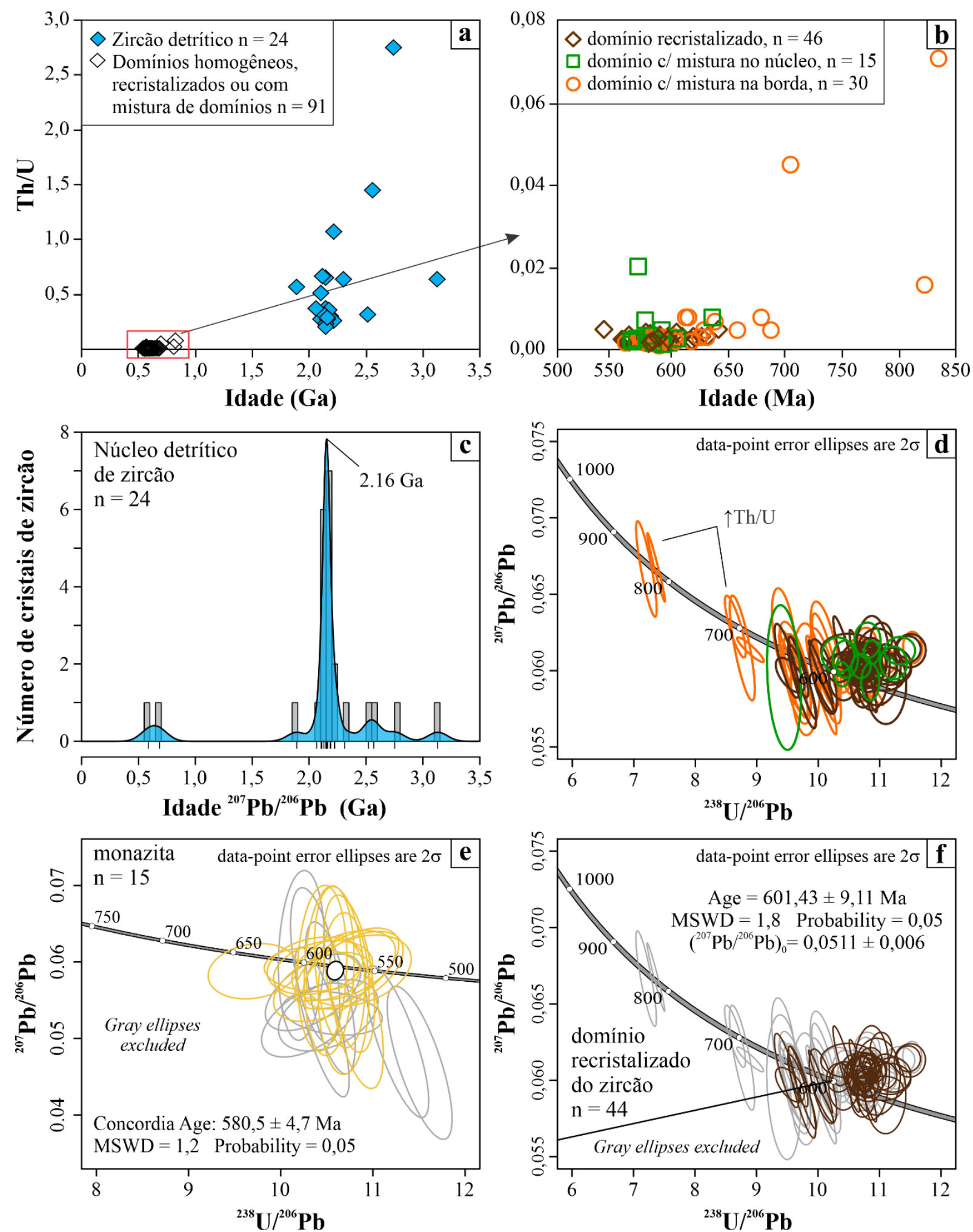

Figura 8.16: a) Gráfico da variação da razão Th/U em cristais de zircão do cianita-estaurolita-muscovitagranada-biotita xisto (CP-07), b) Gráfico da variação da razão Th/U nos diferentes domínios texturais onde houve recristalização; c) Diagrama Idade vs. Probabilidade Relativa utilizando a estimativa de densidade de Kernel (KDE - Kernel Density Estimator); d) Diagrama com a curva concórdia de Tera-Wasserburg com os pontos plotados sem os erros; e) Diagrama com a curva concórdia de Tera-Wasserburg para os cristais de monazita; f) Diagrama com a curva concórdia de Tera-Wasserburg para as porções recristalizadas do zircão. 
As zonas de recristalização observadas nos cristais de zircão da amostra CP-07 são estruturas secundárias que geralmente apresentam zoneamento irregular, catodoluminescência homogênea e química de elementos traços contrastantes (Hoskin \& Black, 2000; Rubatto, 2017). Quando o processo de recristalização do zircão é avançado, leva à extensas alterações, com total reabsorção dos núcleos detríticos e redefinição do sistema isotópico, "podendo gerar idades precisas e reproduzíveis" (Rubatto, 2017).

O grau de reabsorção dos núcleos detríticos foi maior nos cristais da população 1 e menor nos cristais das populações 2 e 3 , estando diretamente relacionado com o tamanho dos cristais (Figura 8.15a). Considerando apenas as análises em zonas recristalizadas, 44 datações forneceram curva discórdia com intercepto em $601 \pm 9$ Ma, com MSWD de 1,8 (Figura 8.16f).

\subsubsection{U-Pb em monazita}

Os cristais de monazita da amostra CP-07 exibem cor amarelo pálido, escurecido quando há maior número de inclusões e impregnações de minerais opacos. O tamanho dos cristais varia de 130 - $240 \mu \mathrm{m}$ e quanto à forma, não desenvolveram faces, podendo ser subarredondados a bem arredondados. Internamente predominam cristais homogêneos com raras relíquias de zonas difusas e irregulares (Figura 8.15b).

As análises nos cristais de monazita da amostra CP-07 forneceram elevados índices de discordância. Foram obtidos quinze pontos concordantes em cristais homogêneos que forneceram idade concórdia de $580 \pm 4$ Ma, com MSWD de 1,2 (Figura 8.16e).

\subsection{Assinatura de Elementos Traço e Terras Raras em Zircão}

As concentrações de elementos terras raras (ETR) em zircão do metapelito da Unidade Colônia são mais elevadas e não definem padrões de distribuição típicos para zircão (Tabela 8-5, Figuras 8.17a e b), tais como os padrões observados nos cristais de zircão da Unidade Serra do Ibituruna (Capítulo 7), mostrando diferenças em cada domínio textural, em geral como resultado do maior conteúdo de ETR (Tabela 8-5). Parte dos núcleos detríticos e das zonas recristalizadas preservaram parcialmente as formas típicas dos padrões de ETR em zircão, com anomalias bem definidas, positivas de Ce e negativas de Eu (Figura 8.17a), enquanto nas zonas com mistura de domínios nas bordas e nos núcleos os padrões mostram anomalias de Ce fracamente positivas, de baixa magnitude, $\mathrm{Ce} / \mathrm{Ce}^{*}$ entre 3,4 e 13,2, e anomalias de Eu fracamente negativas, também de baixa magnitude, Eu/Eu* entre 3,4 e 12,8 (Figura 8.17b). 
Tabela 8-5: Intervalos das concentrações em ppm de elementos terras raras leves, médios e pesados por domínio textural. Valores de referência para o padrão do zircão 91500 extraídos de http://georem.mpch-mainz.gwdg.de/

\begin{tabular}{lccc}
\hline Domínio textural & ETR leves & ETR médios & ETR pesados \\
\hline Núcleo detrítico & $28,1-192,9$ & $25,7-214,1$ & $347,6-1465,7$ \\
\hline Mistura no núcleo & $51,8-171,5$ & $94-279,8$ & $517,5-978,9$ \\
\hline Mistura na borda & $17,9-342,2$ & $31,11-479,1$ & $275,6-1144,3$ \\
\hline Zona recristalizada & $4,8-169,8$ & $9,6-243,6$ & $331,7-910,6$ \\
\hline Zircon 91500 & 2,63 & 3,18 & 136,56 \\
\hline
\end{tabular}
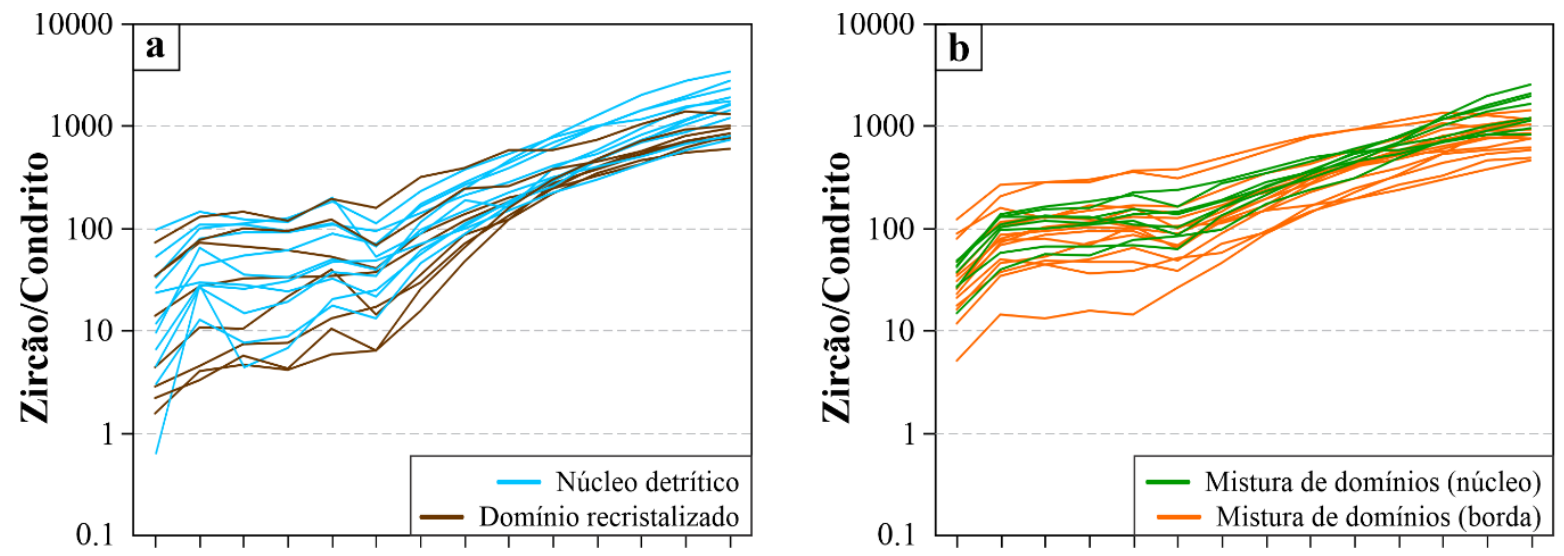

La Ce Pr Nd Sm Eu Gd Tb Dy Ho Er Tm Yb Lu La Ce Pr Nd Sm Eu Gd Tb Dy Ho Er Tm Yb Lu
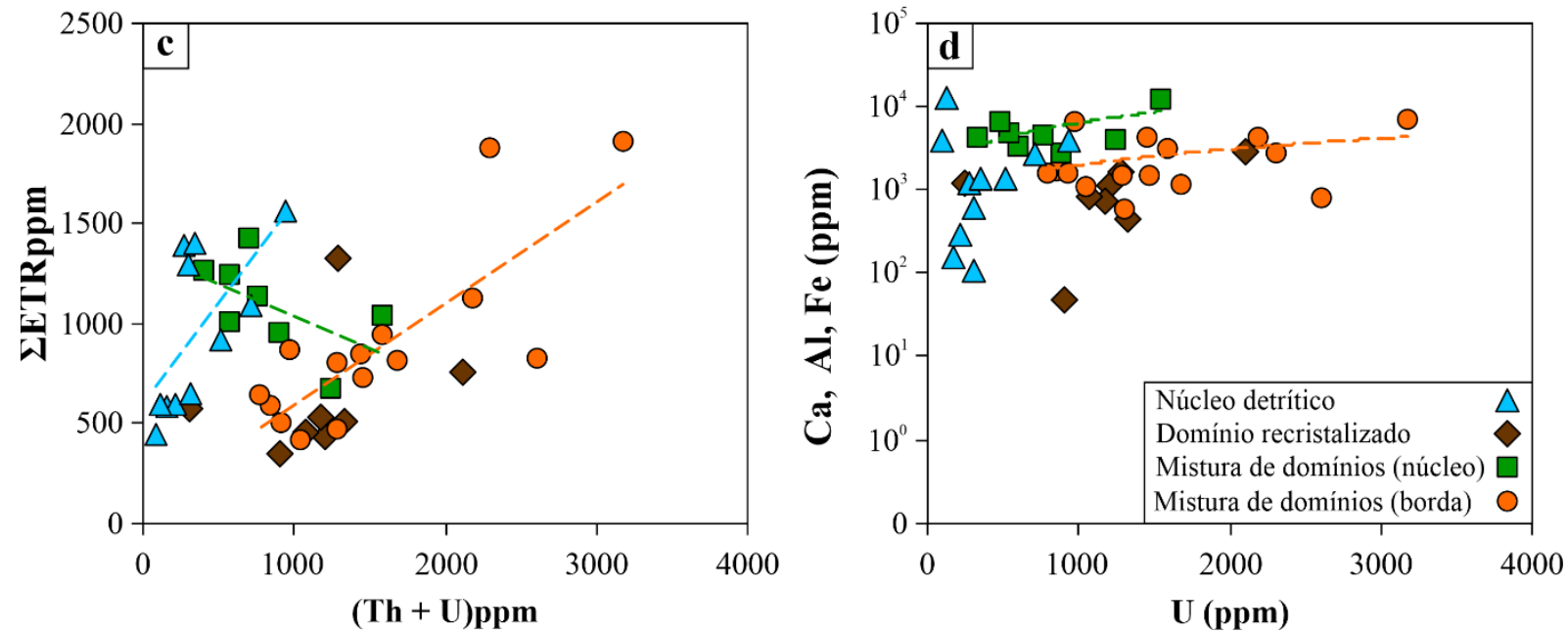

Figura 8.17: Padrões de distribuição dos elementos terras raras (ETR) em zircão do metapelito da Unidade Colônia, amostra CP-07. Em (a) para núcleos detríticos e zonas recristalizadas e homogêneas e em (b) para zonas com mistura de domínios. Valores normalizados pelo condrito de acordo com Sun \& McDonough (1989); c) gráfico Th+U vs. $\Sigma E T R ;$ d) gráfico Ca+Al+Fe vs. U, adaptado de Rayner et al. (2005).

O aumento do teor de ETR é acompanhado por aumento de Th + U nos núcleos detríticos e nas zonas com misturas de domínios nas bordas dos cristais (Figura 8.17c). Esta maior concentração de ETR pode ser resultado de soluções sólidas com xenotímio (Bea, 1996), uma vez que está acompanhada por maiores teores de Y e P, ou mesmo do maior teor também de ETR leves. Os danos causados pela metamictização também levam ao aumento no conteúdo Th, U e de ETR médios e leves (Whitehouse \& Kamber, 2002; Belousova et al., 
2002). Além da maior concentração de ETR, os cristais de zircão mostram maiores teores de $\mathrm{Ca}, \mathrm{Fe}$ e $\mathrm{Al}$, com as zonas com mistura de domínios no núcleo mais enriquecidas, de $2832 \mathrm{ppm}$ a $1,26 \%$, seguidas pelas bordas, com $579 \mathrm{ppm}$ a $0,66 \%$ e zonas recristalizadas com 45 ppm a $0,28 \%$ (Figura 8.17d).

\subsection{Discussões}

\subsubsection{Paragêneses e reações de equilíbrio}

As duas amostras da Unidade Colônia investigadas neste trabalho mostram grande similaridade composicional, todavia, apresentam contraste mineralógico e textural, apesar de ambas terem sido coletadas próximas à Zona de Cisalhamento Cássia - Fortaleza de Minas. Em linhas gerais, enquanto o cianita-estaurolita-muscovita-granada-biotita xisto (CP-07) exibe feições indicativas de fusão parcial (tópico 8.1), no muscovita-cianita-plagioclásiogranada-biotita xisto (CP-333) granada e cianita preservam texturas que registram diferentes etapas da evolução metamórfica da rocha.

$\mathrm{Na}$ amostra CP-333 as feições de fusão não são tão evidentes devido à maior taxa de deformação da rocha, ainda assim, localmente foram preservadas na forma de cristais de plagioclásio intersticial, com ou sem quartzo associado, mimetizando líquido silicático (Figura 8.e). Mesmo a forma alongada e subidioblástica de alguns cristais de plagioclásio sugere cristalização em condições inter a sin-deformacionais (Figura 8.3d). Em algumas intercalações de lentes com textura granoblástica, o plagioclásio ocorre como cristais subidioblásticos ao longo das bordas, enquanto o núcleo é formado por amplos cristais de quartzo com contatos interlobados, formados pelo resfriamento e cristalização das bordas em direção ao núcleo, sugerindo que a cristalização do fundido foi sin- $\mathrm{S}_{2}$.

Admitindo que os metapelitos da Unidade Colônia cruzaram a curva solidus, independente da proporção relativa entre os minerais e as texturas geradas, a associação em equilíbrio nas duas amostras consiste em (1):

$$
\mathrm{Ky}+\mathrm{St}+\mathrm{Grt}+\mathrm{Bt}+\mathrm{Ms}+\mathrm{Pl}+\mathrm{Qtz}+\mathrm{Ilm} \pm \mathrm{Rt}+\mathrm{Liq}
$$

Nas topologias das pseudosseções construídas para os metapelitos da Unidade Colônia, os pontos invariantes [ms, liq] e [st, liq] indicam, no sistema NCKFMASHTO, que as reações de fusão para as amostras CP-07 e CP-333 podem ser expressas, respectivamente, pelas reações (2) e (3). Já para condições de pressão inferior a 8 kbar, a geração de fundido fica restrita à desidratação e fusão envolvendo estaurolita, através das reações (4) e (5) 


$$
\begin{aligned}
& \mathrm{St}+\mathrm{Ms}+\mathrm{Pl}+\mathrm{Ilm}+\mathrm{H}_{2} \mathrm{O} \rightarrow \mathrm{Grt}+\mathrm{Bt}+\mathrm{Liq} \\
& \mathrm{St}+\mathrm{Ms}+\mathrm{Pl}+\mathrm{Ilm}+\mathrm{H}_{2} \mathrm{O} \rightarrow \mathrm{Grt}+\mathrm{Bt}+\mathrm{Ky}+\mathrm{Liq} \\
& \mathrm{St}+\mathrm{Pl}+\mathrm{Ilm} \rightarrow \mathrm{Grt}+\mathrm{Bt}+\mathrm{Al}_{2} \mathrm{SiO}_{5}+\mathrm{Liq} \\
& \mathrm{St}+\mathrm{Pl}+\mathrm{Ilm}+\mathrm{H}_{2} \mathrm{O} \rightarrow \mathrm{Grt}+\mathrm{Bt}+\mathrm{Al}_{2} \mathrm{SiO}_{5}+\mathrm{Liq}
\end{aligned}
$$

Nas pseudosseções, dois aspectos são notáveis nas reações que deram origem à associação em equilíbrio dessas rochas (1), o primeiro é com relação à formação da cianita. $\mathrm{Na}$ amostra $\mathrm{CP}-07$, cianita é formada após a fusão e o consumo de toda a água do sistema (Figura 8.18a). Já na amostra CP-333, a curva de entrada da cianita pode ocorrer antes ou depois da fusão, dependendo das condições de pressão (Figuras 8.10a, 8.10b e 8.18b). Essa diferença pode ser atribuída à maior quantidade de $\mathrm{H}_{2} \mathrm{O}$ utilizada para a construção da pseudosseção da amostra CP-333 e às diferenças na composição das rochas.

O segundo aspecto é com relação à proporção modal de muscovita prevista nas pseudosseções. Nas duas amostras essa proporção é a mesma antes de atingir os campos de estabilidade da paragonita, em condições subsolidus (Figuras 8.11c e 8.11d). Na amostra CP333 essa proporção é relativamente condizente com o que é observado na petrografia, enquanto na amostra $\mathrm{CP}-07$, a proporção calculada é muito mais baixa do que a proporção real de muscovita na rocha, e para a maioria dos campos de estabilidade com paragonita, muscovita é ausente (Figura 8.11c). Este efeito pode ter sido causado devido à impossibilidade de separar o leucossoma da amostra CP-07 para a análise química de rocha total, resultando em expansão do campo de estabilidade do plagioclásio e excesso de paragonita sendo estabilizada no lugar da muscovita (Figura 8.9).

As reações 2-5 geram de 2 a $8 \%$ de fundido (Figura 8.11e), que é uma quantidade muito pequena em relação a proporção de leucossoma presente na amostra CP-07, e, ao mesmo tempo, elevada quando comparada ao volume esperado de fundido gerado nessas condições de pressão e temperatura (Thompson e Connolly, 1995; Spear et al., 1999; GarcíaCasco et al., 2003). A água residual liberada pelas reações de desidratação das micas em condições subsolidus é capaz de produzir menos de 0,5\% de fundido na curva solidus em condições saturadas (Thompson e Connolly, 1995). A desidratação de outras fases, tais como talco, clorita, cloritóide e estaurolita, produzem proporções ainda menores de fundido (Thompson e Connolly, 1995). Estaurolita contém pouca $\mathrm{H}_{2} \mathrm{O}$, sendo necessário a quebra de $\sim 10 \%$ em proporção modal, em condições onde haja pelo menos $10 \%$ em peso de $\mathrm{H}_{2} \mathrm{O}$ no fundido, para produzir apenas $\sim 2 \%$ de fundido sob condições de temperatura $<700{ }^{\circ} \mathrm{C}$ e pressão superior a 6 kbar (Thompson e Connolly, 1995; Spear et al., 1999; García-Casco et 
al., 2003). Essa proporção de fundido é dificilmente detectável petrograficamente (Spear et al., 1999), o que não é o caso da amostra CP-07, que desenvolveu bolsões de leucossoma com dimensões milimétricas a centimétricas (Figuras 8.2d-h).

Trabalhos que reportam a ocorrência natural de estaurolita em alto grau são escassos. Ashworth (1975) descreve semipelitos sem muscovita e com estaurolita formada durante o retrometamorfismo precoce, pós migmatização, na zona da sillimanita/ feldspato potássico. $\mathrm{Na}$ ausência de muscovita, estaurolita pode ocorrer em condições de maior temperatura e formar associações com cordierita e sillimanita (Ashworth, 1975), tal como pode ser observado nas pseudosseções calculadas para os metapelitos da Unidade Colônia, mas para condições subsolidus, sem feldspato potássico (Figuras 8.9 e 8.10).

Outro ponto apresentado por Ashworth (1975) é com relação ao maior teor de zinco na estaurolita de alto grau, cujo papel é mais importante que o $\mathrm{Mg}$ na estabilidade da estaurolita para maiores temperaturas. No muscovita-cianita-plagioclásio-granada-biotita xisto (CP-333) a proporção de estaurolita é inferior a $3 \%$ e ela é caracteristicamente enriquecida em $\mathrm{Zn}$ através do vetor de substituição $\mathrm{ZnFe}_{-1}$ (Figura 8.8b), o que pode suportar que a estaurolita ocorre como fase metaestável para condições suprasolidus na amostra CP-333.
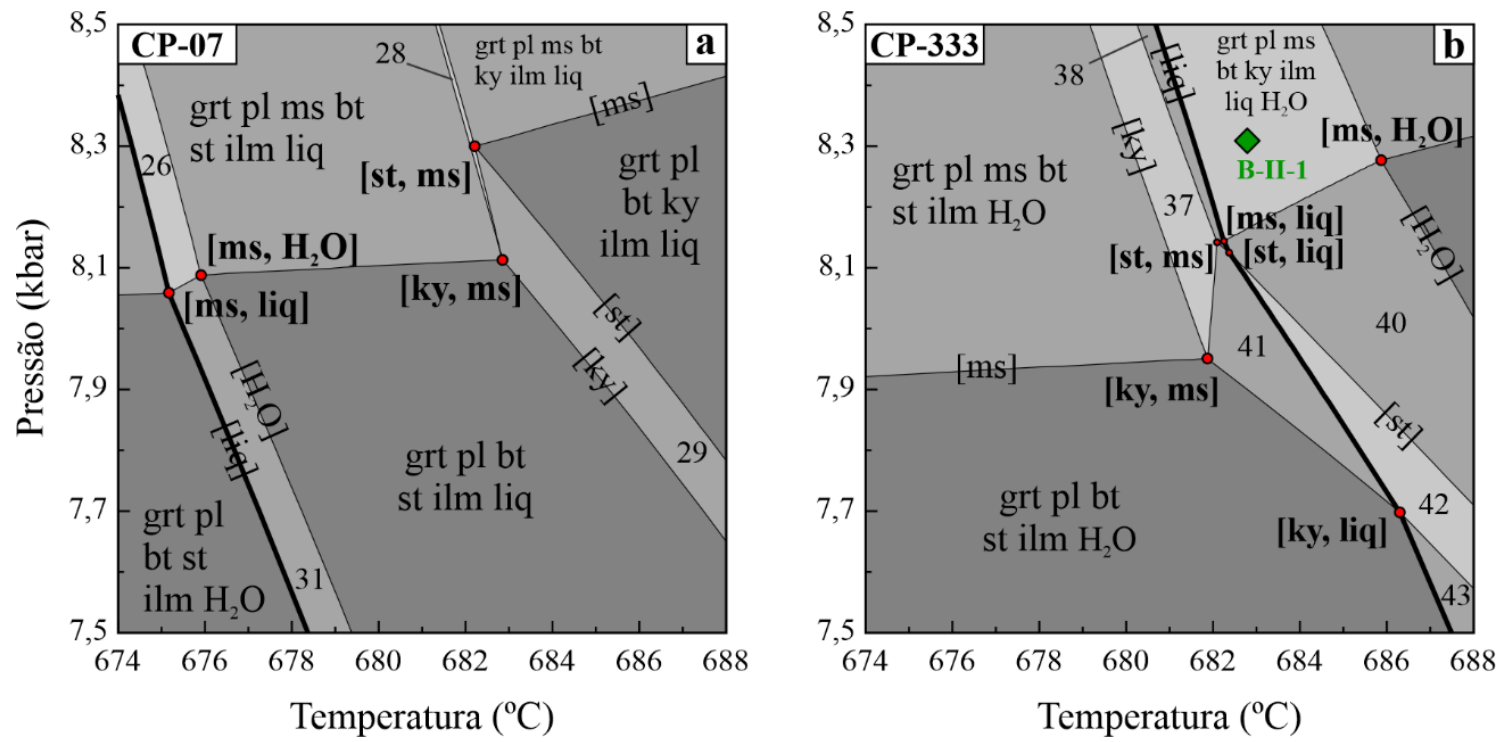

Figura 8.18: Detalhe para os campos de equilíbrio e as topologias que indicam as reações de fusão para os metapelitos da Unidade Colônia. Os pontos vermelhos indicam os pontos invariantes calculados - a) para a amostra CP-07; b) para a amostra CP-333.

García-Casco et al. (2003) sintetizaram estaurolita em condições de temperatura entre 675 e $700{ }^{\circ} \mathrm{C}$ e pressão entre 6 e $10 \mathrm{kbar}$, através da fusão em presença de fluidos a partir de amostras de metapelito. Além do maior teor de Zn, a estaurolita formada em equilíbrio com o fundido possui maiores teores de Mg e Ti (García-Casco et al., 2003). A 
ausência de variações composicionais sistemáticas na estaurolita da amostra CP-07 não permite distinguir as duas gerações observadas, mas as bordas irregulares observadas nos cristais da primeira geração sugerem que eles possam ter parcialmente resistido à fusão e se reestabilizado durante o resfriamento da rocha (Figuras 8.2a e 8.2b). Já os cristais idiomórficos de estaurolita que ocorrem junto ao leucossoma podem representar a geração de estaurolita em equilíbrio com o fundido, mas esses cristais são escassos e não puderam ser analisados. Deve-se salientar que a fusão em baixa temperatura pela quebra da estaurolita, como indicado por García-Casco et al. (2003) e aqui observado, não está em intervalo de temperatura muito abaixo que a quebra da muscovita em presença de água, havendo praticamente uma sobreposição destas condições.

A grade petrogenética no sistema NKFMASH, desenvolvida por García-Casco et al. (2001 e 2003) considera estaurolita estável com fundido e feldspato potássico em topologias com condições $P-T$ similares às obtidas nas pseudosseções construídas para os metapelitos da Unidade Colônia (Figuras 8.9a e 8.10a), entretanto, eles não possuem feldspato potássico em sua composição. O leucossoma gerado na fusão parcial do cianita-estaurolita-muscovitagranada-biotita xisto tem composição tonalítica e caráter levemente peraluminoso (Apêndice D). Mesmo tratando-se de um pelito pobre em alumínio, era esperado caráter mais aluminoso para o leucossoma da rocha.

Com relação a composição do fundido gerado, as isopletas calculadas indicam que próximo à curva solidus, em condições de maior pressão, a desidratação da paragonita e da muscovita resultam em fundido inicialmente mais rico em Na. Fora do campo de estabilidade da muscovita, a medida em que aumenta a temperatura, sob pressão constante, o fundido se torna mais rico em $\mathrm{K}$ e $\mathrm{Ca}$ e mais pobre em $\mathrm{Na}$, indicando que biotita e plagioclásio são os reagentes para a formação do fundido, resultando na associação "A" (Tabela 8.2) formada durante o pico metamórfico, representada pela reação (6)

$$
\mathrm{Bt}+\mathrm{Pl}+\mathrm{Grt}+\mathrm{Qtz} \pm \mathrm{H}_{2} \mathrm{O} \rightarrow \mathrm{Ky}+\mathrm{liq}
$$

\subsubsection{Idades do equilíbrio de fases acessórias}

As estruturas internas e a composição química do zircão dos metapelitos da Unidade Colônia apontam que o tratamento dos dados de U-Pb em zircão detrítico de rochas metamórficas deve ser feito de forma mais criteriosa. O zircão formado durante o metamorfismo pode gerar estruturas distintas de acordo com as condições $P-T$ (Rubatto, 2017), obliterando as estruturas do zircão pré-existentes. As texturas internas dos cristais de 
zircão dos metapelitos da Unidade Colônia registram o progresso dos processos de substituição/recristalização. A presença de cristais com variável grau de preservação do núcleo detrítico indica que tais processos ocorreram de forma heterogênea (Figura 8.15a), porém, afetando principalmente os cristais mais finos da população 1, e implicam na impossibilidade de interpretações quanto à proveniência sedimentar para os metapelitos da Unidade Colônia.

Durante os processos de substituição/recristalização, os elementos traço dos núcleos detríticos podem ser removidos e particionados com as frentes de recristalização (Hoskin \& Black, 2000) e, assim como as razões isotópicas, a abundância de elementos traço também pode ser afetada pela presença de relíquias de texturas primárias dentro de áreas recristalizadas se ela não for eficiente ou ocorrer em sistema aberto (Corfu et al., 2003; Hoskin \& Black, 2000).

Os cristais com núcleo detrítico total ou parcialmente preservados tendem a apresentar maior grau de metamictização e, consequentemente, mostram correlação positiva entre o conteúdo de ETR e Th + U. Os danos na estrutura cristalina são representados pelas microporosidades e fraturas concentradas nos núcleos detríticos. As bordas dos cristais são límpidas e aparentam homogeneidade, entretanto as imagens de elétrons retroespalhados (BSE) revelam zonas de alteração concêntrica enriquecidas em Ca, Fe, Al e ETR leves. Estes elementos não são compatíveis com a estrutura do zircão, mas podem penetrar em suas microporosidades e fraturas durante o metamorfismo de baixo grau com fluidos associados (Geisler et al., 2003a, 2007; Nasdala et al., 2010; Rubatto, 2017).

A recuperação de zircão metamictizado é lenta (Geisler et al., 2001a), mas pode ser aprimorada pelo aumento de temperatura e pela presença de fluidos (Geisler et al., 2001b), que facilitam o processo de recristalização e podem gerar zircão prismático (Geisler et al., 2003a; Corfu et al., 2003). O elevado grau de metassomatização das rochas metaultramáficas intercaladas aos metapelitos (Capítulo 10) e as mineralizações auríferas e de sulfetos de CuFe-Zn (Feola, 2004) presentes na Unidade Colônia são reflexo de atividade hidrotermal e podem responder pelas formas e texturas observadas nos cristais de zircão das populações $1 \mathrm{e}$ 2. O gráfico La vs. $(\mathrm{Sm} / \mathrm{La})_{\mathrm{N}}$ mostra que, mesmo os núcleos detríticos que forneceram datações concordantes (Apêndice H) tiveram a distribuição de elementos traço comprometida, resultando em características de zircão hidrotermal (Figura 8.19a).

Além da atuação de fase fluida, a fusão nos metapelitos da Unidade Colônia também pode ter tido importante papel durante a recuperação do zircão. Geisler et al. (2007) apontam dois mecanismos de reequilíbrio no zircão, (i) por reações de difusão no estado sólido em 
presença de fluidos, a partir de estruturas metamicticas, e (ii) por dissolução e reprecipitação em presença de fluidos ou fundido, a partir de uma solução sólida de zircão. Estes mecanismos podem ser distinguidos quimicamente, com maiores concentrações de elementos exóticos à estrutura cristalina do zircão, tais como $\mathrm{Ca}, \mathrm{Fe}, \mathrm{Mn}$ e $\mathrm{Al}$, em (i) e menores concentrações de elementos traço em (ii) (Geisler et al., 2003b, 2007; Rubatto, 2017).

$\mathrm{O}$ enriquecimento em $\mathrm{Ca}$, Fe e $\mathrm{Al}$ é acompanhado por perdas de $\mathrm{Zr}, \mathrm{Si}$, U, Th, Hf, ETR e $\mathrm{Pb}$ radiogênico, resultando em realce na intensidade de luminescência e dados discordantes (Geisler et al., 2007; Nasdala et al., 2010). No entanto, as zonas recristalizadas ou com mistura de domínios exibem altos teores de U e ETR, gerando caracteristicamente baixa intensidade de luminescência, podendo mostrar tanto perda, como ganho de $\mathrm{Pb}$ radiogênico, e dados com mais de $95 \%$ de concordância (Figura 8.19b), sugerindo reequilíbrio das razões isotópicas. Assim, os cristais de zircão da Unidade Colônia registram tanto o reequilíbrio por processos de dissolução-reprecipitação gerados pela interação com o fundido, como também por processos de difusão no estado sólido através da interação com fluidos tardios.

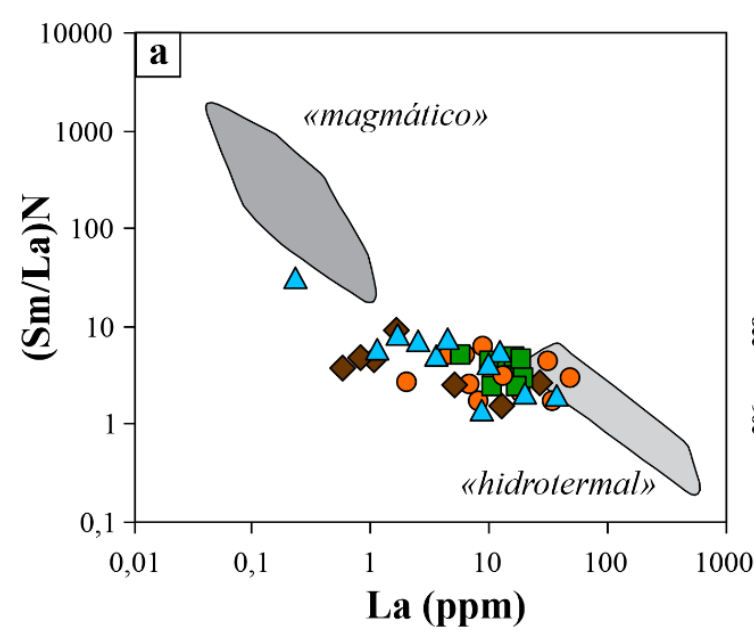

Núcleo detrítico Domínio recristalizado

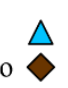

Mistura de domínios (núcleo) $\square$ Mistura de domínios (borda)

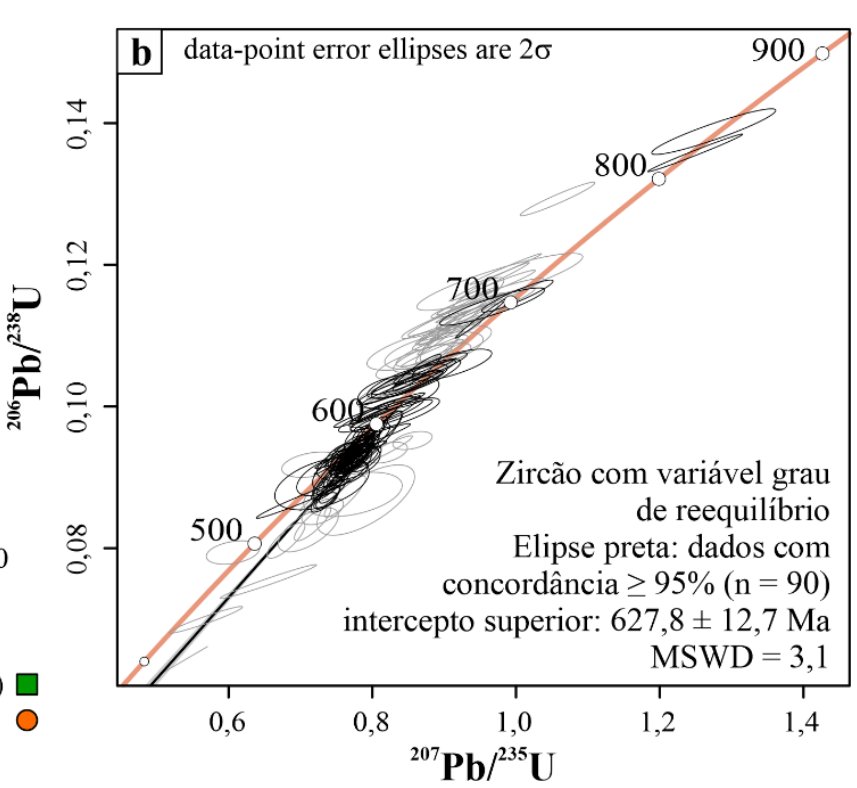

Figura 8.19: a) Gráfico La vs. (Sm/La) $)_{\mathrm{N}}$ de Hoskin (2005); b) Diagrama concórdia para zircões. As elipses cinzas correspondem aos dados discordantes em mais de $5 \%$.

A idade de $601 \pm 9 \mathrm{Ma}$ obtida nas zonas recristalizadas homogêneas, ou com zoneamento oscilatório, representa o completo reequilíbrio dos cristais de zircão detríticos com o zircão reprecipitado durante o pico metamórfico (Figura 8.20a). A baixa amplitude das anomalias de Eu observadas nos padrões ETR (Figuras 8.17a e 8.17b) implica que a reprecipitação de zircão durante o pico metamórfico ocorreu antes da cristalização do 
plagioclásio no leucossoma, do contrário, o zircão competiria pelo Eu com o feldspato, gerando as anomalias mais pronunciadas (Rubatto, 2002). Com relação ao enriquecimento em ETR pesados, o maior fracionamento indica cristalização de zircão em ausência de granada (Rubatto, 2017), portanto, antes da formação da segunda geração de granada.

O desenvolvimento da foliação milonítica durante o retrometamorfismo contribuiu com o aporte de fluidos para o reequilíbrio do zircão por difusão no estado sólido, responsável pelo enriquecimento em elementos traço. Além da ação hidrotermal, o enriquecimento em ETR leves pode ser ligado também à cristalização a partir de fundido enriquecidos em ETR leves (Whitehouse e Kamber, 2002). O reequilíbrio secundário do zircão com enriquecimento em ETR leves persistiu até atingir as condições $P-T$ de formação da monazita, cuja idade concórdia de $580 \pm 4 \mathrm{Ma}$ corresponde à idade de retrometamorfismo da Unidade (Figura 8.20a).

\subsubsection{Reconstruindo as trajetórias $P-T$}

Utilizando a modelagem direta, feita através da construção de pseudosseções, foi possível estimar as condições $P-T$ da associação em equilíbrio nos metapelitos da Unidade Colônia (1), com intervalos de $674-682{ }^{\circ} \mathrm{C}$ e 8,3 - 10,3 kbar na amostra CP-07 e de 672 $682{ }^{\circ} \mathrm{C}$ e 7,9 - 10,2 kbar na amostra CP-333 (Figuras 8.9 e 8.10). Ainda que não tenha sido considerado o mesmo conteúdo de $\mathrm{H}_{2} \mathrm{O}$ e $\mathrm{Fe}_{2} \mathrm{O}_{3}$, as condições $P$-T obtidas nas duas amostras são similares, indicando que os resultados são confiáveis. Esse resultado é validado pelas condições $P-T$ obtidas através do cruzamento das isopletas de $X_{\mathrm{Ca}}$ na granada e no plagioclásio, que forneceram condições $P-T$ muito próximas para as duas amostras (Figuras 8.14a e 8.14b).

$\mathrm{Na}$ amostra CP-333, a pseudosseção forneceu diversos campos possíveis para a associação em equilíbrio. Muitos deles, embora teoricamente possíveis, são muito restritos, sendo improvável que a rocha realmente tenha se equilibrado em todos eles. O mais provável é que uma ou mais fases tenham localmente se mantido como metaestáveis nesse curto intervalo de condições $P-T$ determinado (Figura 8.10b).

Parte das isopletas calculadas mostraram condições $P-T$ inconsistentes com os campos das associações em equilíbrio (1) e com as condições $P-T$ obtidas através da modelagem inversa (Figuras 8.12, 8.13, 8.14b). Essas inconsistências podem ser relacionadas à diversos fatores, entre eles o volume de equilíbrio, a existência de heterogeneidades na composição química da rocha, ao zoneamento composicional observado na granada, às reações retrógadas de troca Fe-Mg entre granada e biotita (Kohn e Spear, 2000) e às próprias 
taxas de difusão nas fases em equilíbrio, que podem ser mais rápidas nas micas, especialmente de rochas com matriz de granulação mais fina (Carlson e Gordon, 2004), e em rochas com maiores taxas de deformação.

Com relação ao zoneamento composicional na granada, as características contrastantes observadas entre as amostras, contribuíram para melhor posicionar as trajetórias $P-T$. Na amostra CP-07 a granada tipo I exibe zoneamento típico de metamorfismo progressivo, nas zonas da estaurolita e da cianita, com aumento de $\mathrm{Fe}$ e $\mathrm{Mg}$ e diminuição de Ca e Mn em direção às bordas dos cristais (Figura 8.4b), formados por growth zoning (Spear, 1993), pois há preservação da composição química dos núcleos (Figuras 8.4c-f). O ligeiro enriquecimento em Mn nas bordas mais externas da granada tipo I (Figura 8.4f) é resultante da dissolução da granada através de net transfer reactions, com troca de Fe-Mg entre granada e biotita. No processo, o Mn, que não tem afinidade com a estrutura da biotita, ou outros minerais da matriz é reabsorvido pela granada (Kohn e Spear, 2000).

$\mathrm{Na}$ granada tipo II da amostra CP-07 a maior homogeneidade poderia ter sido atingida através de processos de difusão. A difusão é favorecida pelo aumento de temperatura, assim, granada de alto grau é mais homogênea (Spear, 1993), embora condições hidratadas contribuam para maior extensão da difusão na granada (Zhang et al., 2019). A granada tipo II forneceu condições $P-T$ ligeiramente mais baixas que a granada tipo I (Figura 8.14a), e, se tivesse ocorrido difusão, a granada tipo I também deveria mostrar maior grau de homogeneidade. Assim, a homogeneidade da composição da granada tipo II indica que a taxa de resfriamento da rocha foi mais rápida do que a modificação do zoneamento por difusão, já em condições de retrometamorfismo.

As texturas observadas entre as duas gerações de granada da amostra CP-333 indicam que o crescimento da segunda geração de granada foi rápido, sem que houvesse tempo para desenvolver zoneamento por crescimento contínuo (Figuras 8.6e-h). A primeira geração de granada é mais homogênea e os perfis de distribuição dos membros finais diferem dos perfis esperados para granada formada em condições de fácies xisto verde a anfibolito. Seu zoneamento é significativo apenas nas bordas, quando em contato com a biotita da matriz, indicando a participação da troca Fe-Mg.

Ainda que os resultados obtidos para os conjuntos A-I-1 e A-I-2 não sejam confiáveis, as condições $P$-T determinadas nestes conjuntos são compatíveis com o campo de estabilidade previsto na pseudosseção (Figuras 8.10 e 8.14b). Além disso, os maiores valores para $X_{\mathrm{Mg}}$ na primeira geração de granada e na biotita inclusa (Figura 8.13a), aliado ao contexto textural da associação A (Figuras 8.3a e 8.3b), permitem condicionar a formação 
desta associação em pressão entre 10 e 12 kbar (Figura 8.20b). No conjunto A-I-3, onde a primeira geração de granada foi reequilibrada com a biotita da matriz, as condições de $713{ }^{\circ} \mathrm{C}$ e 9,4 kbar representam a melhor aproximação das condições $P-T$ para o pico metamórfico da amostra CP-333. A ocorrência de relíquias de associação metaestáveis reflete o incompleto reequilíbrio da amostra CP-333 frente às novas condições metamórficas, já na zona da estaurolita.

A segunda geração de granada não mostra zoneamento regular como o que é desenvolvido por zoneamento de crescimento. Os perfis para as variações dos membros finais são relativamente homogêneos e mostram zoneamento regular apenas nas bordas mais externas (Figura 8.5d), assim como os da primeira geração da granada. O crescimento da segunda geração de granada, além de ter sido rápido, aproveitou parcialmente os núcleos da granada pré-existente e, tal como na granada tipo II da amostra CP-07, a taxa de resfriamento foi mais rápida do que a taxa de difusão, indicando que a segunda geração de granada da amostra CP-333 também foi gerada durante o retrometamorfismo.

\section{Estender}

As particularidades observadas durante o crescimento da granada sugerem evolução $P-T$ para os metapelitos da Unidade Colônia através de trajetória horária de aquecimento, com pico metamórfico atingido antes do desenvolvimento da foliação principal, $S_{2}$, seguido por descompressão e consequente fusão parcial das rochas (Figura 8.20b). A presença de sillimanita tardia, sin- $\mathrm{S}_{2}$, na amostra $\mathrm{CP}-333$ indica que a descompressão persistiu para condições subsolidus.
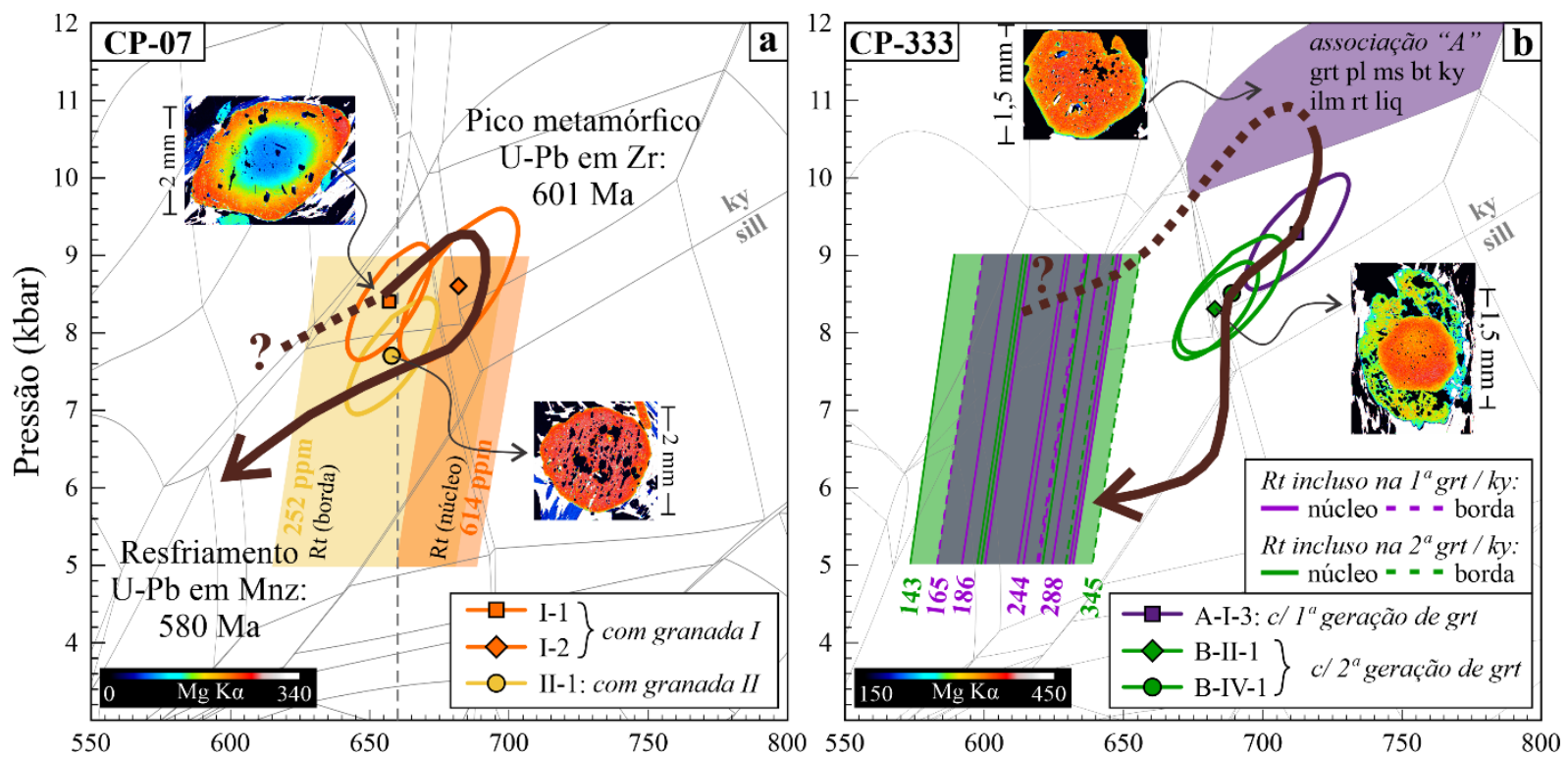

Figura 8.20: a) Trajetórias horárias $P-T$ - $t$ construída para a amostra CP-07 e $P-T$ para a amostra CP-333. 
As temperaturas atingidas para a fusão são relativamente baixas, mas possíveis em ambientes onde há influxo de água. García-Casco et al. (2001) sugerem que a descompressão contribui para a fusão hidratada, gerando fundidos trondhjemíticos a pressões acima de 45 kbar.

A origem das diferentes direções de discordância entre a foliação interna dos porfiroblastos de granada da amostra CP-07 com foliação externa está relacionada à rotação da granada durante o desenvolvimento da foliação milonítica, facilitada pela presença do fundido ainda em cristalização, uma vez que no leucossoma não são observadas feições de deformação. A presença de fundido, mesmo em baixa proporção, pode facilitar o processo.

$\mathrm{O}$ reequilíbrio de $X_{\mathrm{Ti}}$ na biotita e de $X_{\mathrm{Mg}}$ na estaurolita para temperaturas inferiores à $600{ }^{\circ} \mathrm{C}$, a presença de clorita e magnetita retrometamórficas e as temperaturas obtidas pelo geotermômetro de $\mathrm{Zr}$ em rutilo indicam que a trajetória de resfriamento persistiu até condições em torno de $600{ }^{\circ} \mathrm{C}$ de temperatura e de 6 a 7 kbar de pressão (Figuras 8.14c-d e 8.20). 


\section{AS ROCHAS METAULTRAMÁFICAS DO COMPLEXO PETÚNIA}

As rochas metaultramáficas do Complexo Petúnia ocorrem como intercalações nos metapelitos da Unidade Colônia, parte da Faixa Bom Jesus da Penha-Jacuí, e nos gnaisses da Unidade Petúnia, não sendo possível distinguir litotipos metaultramáficos específicos de uma unidade para outra. Três conjuntos foram reconhecidos, um formado por xistos ultramáficos diversos, um formado por hornblenditos e outro com rochas cuja mineralogia foi preservada aos processos metassomáticos, sendo que este só ocorre na Unidade Colônia.

\subsection{Xistos e fels ultramáficos}

No conjunto dos xistos ultramáficos, os litotipos variam desde xistos com proporções variáveis entre talco, clorita, antofilita e tremolita, até clorititos e talco xistos. Devido à essas extensas e heterogêneas variações mineralógicas, não serão dados nomes específicos aos xistos metaultramáficos com talco, clorita, antofilita e tremolita, mas texturalmente essas rochas podem ser divididas em três subconjuntos:

i) Xistos com xistosidade de granulação fina definida por textura lepidoblástica a nematoblástica, dependendo da proporção relativa na paragênese antofilita + tremolita + clorita \pm talco, podendo também definir bandamento, intercalando bandas ricas em clorita e bandas ricas em anfibólio (Figura 9.1a). O desenvolvimento de foliação milonítica é sutil e ocorre em rochas com proporção similar entre clorita e anfibólio. Porfiroblastos pós-cinemáticos de antofilita e/ou tremolita que truncam a foliação são comuns (Figura 9.1b);

ii) Xistos com foliação anastomosada com domínios em que a textura lepidoblástica a nematoblástica, definida por antofilita + tremolita + clorita de granulação fina a média, foi preservada em meio a textura decussada, que é mais comum e tem granulação muito fina, dada por talco;

iii) Fels com textura decussada fina a grossa formada por antofilita + tremolita + clorita \pm talco. Localmente ocorre granulação muito grossa composta por cristais de antofilita fibrorradiados com até $6 \mathrm{~cm}$ ao longo do eixo maior.

A relação de crescimento mineral com as foliações é apresentada na Tabela 9-1. Antofilita e tremolita são subidioblásticas a idioblásticas e definem a foliação principal. Em rochas com foliação anastomosada, antofilita ocorre como aglomerados pseudomórficos de até $1 \mathrm{~cm}$, ou como cristais pós-cinemáticos rompidos e/ou geminados, ambos sobre a foliação. 
Tremolita às vezes apresenta fraturas ortogonais à direção de maior elongação do cristal, formadas em resposta ao cisalhamento rúptil, e cristais com lamelas de exsolução muito finas, não distinguíveis ao microscópio. É comum a presença de antofilita e/ou cummingtonita nas bordas de tremolita, sobretudo em rochas com maior proporção de clorita (Figura 9.1c).

Talco e clorita são placóides e subidioblásticos, quando em maiores proporções, substituíram completamente tremolita e antofilita, formando clorititos e talco xistos. Em menores proporções, talco é muito fino e xenoblástico e, junto à clorita define esparsas intercalações submilimétricas com textura lepidoblástica.

Tabela 9-1: Relações de crescimento mineral com as foliações para os xistos ultramáficos.

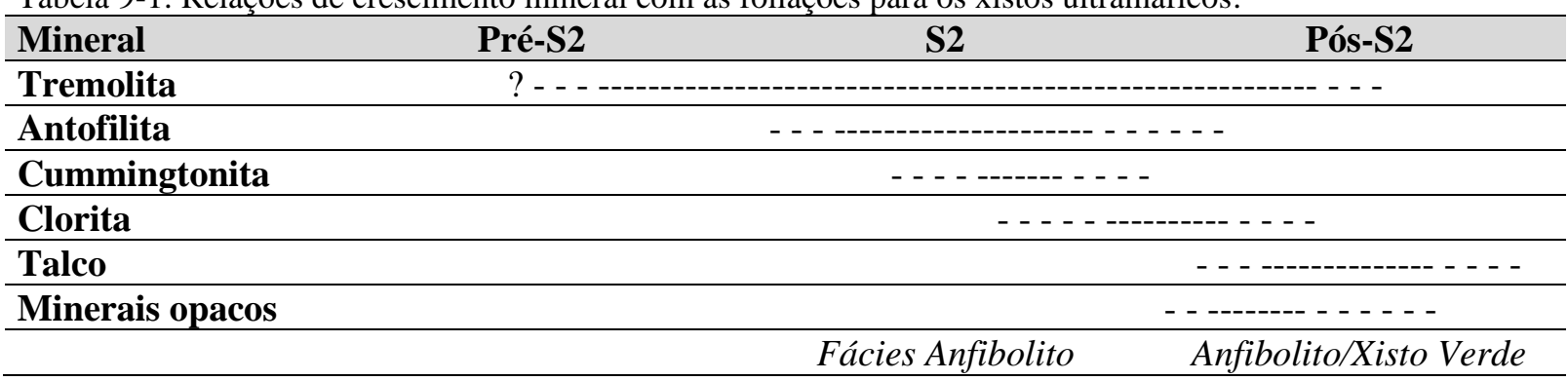

\subsection{Hornblenditos}

Rocha foliada com textura nematoblástica poligonizada de granulação fina a média, marcada por hornblenda subidioblástica a idioblástica. Cristais de granulação média exibem microlamelas de exsolução de cummingtonita, ou zoneamento composicional, com bordas límpidas e núcleo rico em inclusões muito finas de minerais opacos e que, muitas vezes, acompanham seus planos de clivagem.

Antofilita e tremolita, são subidioblásticas a idioblásticas e ocorrem associadas, com antofilita nas bordas de tremolita. Ambas são incolores e orientadas segundo a foliação principal. Minerais acessórios incluem zircão, titanita, rutilo, clorita, talco e minerais opacos.

\subsection{Meta ortopiroxenito}

Rocha maciça, com textura decussada grossa a muito grossa definida por porfiroblastos de ortopiroxênio sobre matriz decussada fina a média. $\mathrm{O}$ ortopiroxênio ( 55\%) ocorre como cristais de no mínimo $2 \mathrm{~cm}$ ao longo do eixo c, com bordas irregulares, extinção ondulante e geminação polissintética (Figura 9.1d) e inúmeras inclusões de clorita, olivina reliquiar e minerais opacos finos a muito finos, muitas vezes distribuídos na forma de glomérulos que foram incorporados pelo cristal durante a cristalização (Figura 9.1e). 

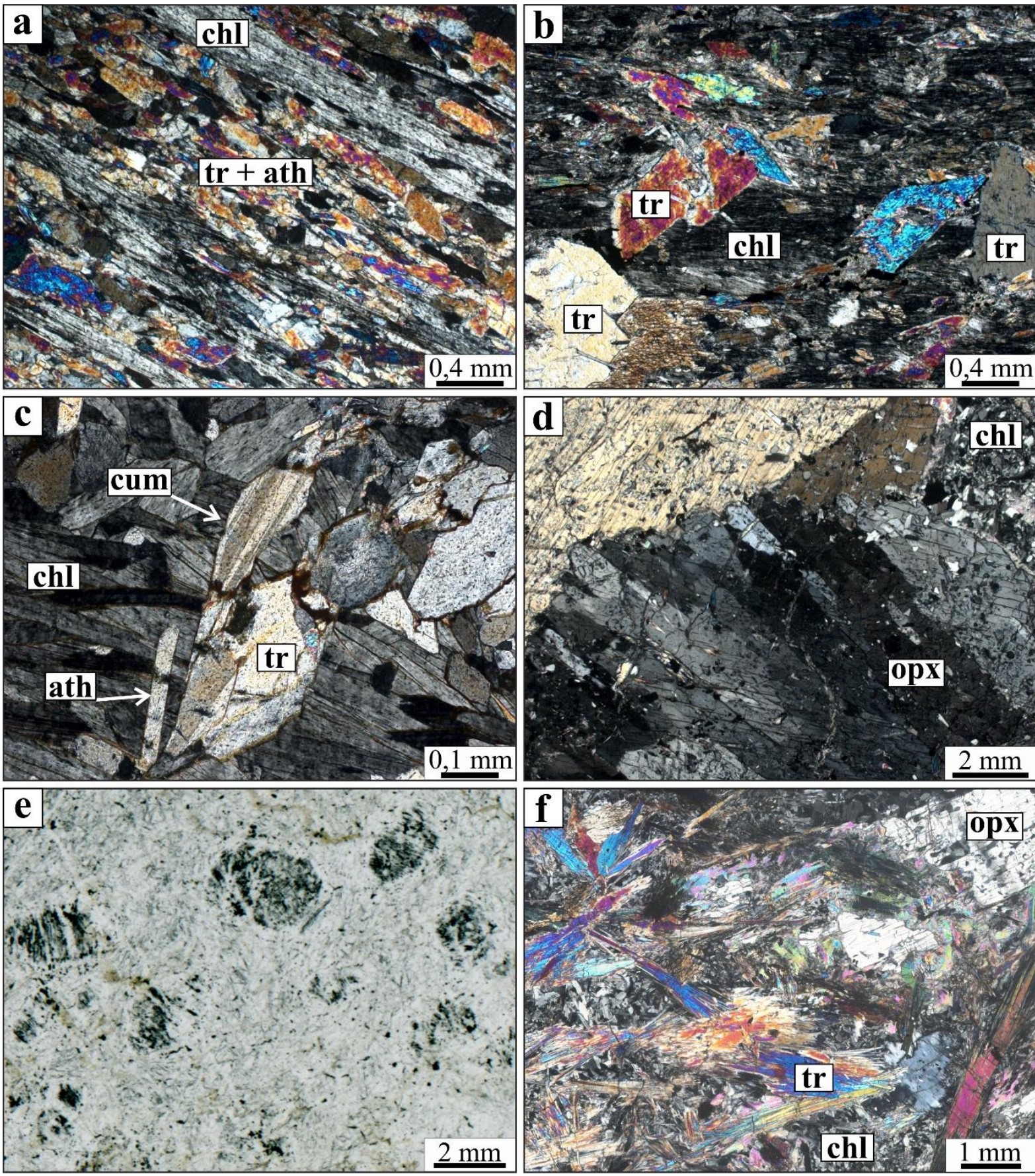

Figura 9.1: a) Aspecto textural do Antofilita-clorita-tremolita xisto do conjunto (i), amostra CP-16; b) Porfiroblastos de tremolita pós-S2 sobre foliação dada pela clorita, amostra CP-54A do conjunto (i); c) Cristal de tremolita, pós-S2, com bordas de antofilita-cummingtonita, amostra FAM-07A do conjunto ( $i$ ); Talco-tremolitaclorita-ortopiroxênio-clinopiroxênio fels porfiroblástico - d) Porfiroblasto de ortopiroxênio com geminação polissintética; e) Glomérulos máficos inclusos em ortopiroxênio; f) Glomero-porfiroblastos de anfibólio fibrorradiados sobre matriz formada por clorita e talco.

A matriz tem granulação fina formada por clorita $(30 \%)$ e talco $(5 \%)$, que muitas vezes substituem ortopiroxênio ao longo de suas fraturas e planos de clivagem. Na matriz também ocorrem glomero-porfiroblastos de tremolita e cummingtonita fibrorradiados, subidioblásticos a idioblásticos (Figura 9.1f), às vezes substituindo bordas do ortopiroxênio. 
Minerais acessórios são restritos à minerais opacos subidioblásticos a idioblásticos, heterogeneamente disseminados, representados por magnetita e ilmenita ricos em exsoluções. Outros minerais acessórios incluem zircão e serpentina. As relações de contemporaneidade podem ser vistas na Tabela 9-2.

Outras rochas metaultramáficas com associações minerais preservadas dos processos metassomáticos são raras no Complexo Petúnia e, além do meta-ortopiroxenito, ocorrem metagabro, metadunito, olivina-ortopiroxenito e derivados metamórficos descritos por Pinheiro (2013).

Tabela 9-2: Relações de contemporaneidade entre os minerais que compõem o talco-tremolita-cloritaortopiroxênio fels porfiroblástico (amostra DCF-22).

\begin{tabular}{|c|c|c|}
\hline Mineral & Metamórfico & Retrometamórfico \\
\hline Olivina & - - - - - --------------- & \\
\hline Enstatita & - - - ------------------- - - - - & \\
\hline Minerais opacos & -------------------------------- & \\
\hline Cummingtonita & 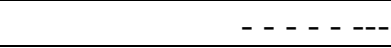 & \\
\hline Clorita & & --------- - - - - - \\
\hline Tremolita & & \\
\hline Antofilita & --- & \\
\hline Talco & & 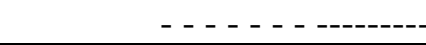 \\
\hline \multicolumn{3}{|l|}{ Serpentina } \\
\hline & Anfibolito & Xisto Verde \\
\hline
\end{tabular}

\subsection{Química Mineral}

\subsubsection{Clorita}

Nas amostras CP-06 e CP-54A, a clorita é classificada como clinocloro, enquanto no talco-tremolita-clorita-ortopiroxênio fels, amostra DCF-22, há clinocloro, mas predomina penninita (Apêndice E). O conteúdo de Al total varia pouco, de 4,21 a 4,48 a.p.f.u. no clinocloro dos xistos ultramáficos é de 3,34 a 3,68 a.p.f.u. em clinocloro e penninita da amostra DCF-22.

A clorita não mostra variações composicionais intra-amostras significativas, com exceção da substituição simples $\left(\mathrm{FeMg}_{-1}\right)$ que define tendência positiva nos cristais da amostra CP-06 (Figura 9.2a). Por outro lado, as variações interamostras definem tendências negativas para as substituições simples $\left(\mathrm{FeMg}_{-1}\right)$ e tschermakítica $\left(\mathrm{Al}^{\mathrm{VI}} \mathrm{Al}^{\mathrm{IV}} \mathrm{Mg}_{-1} \mathrm{Si}_{-1}\right)$. Clorita do talco-tremolita-clorita-ortopiroxênio fels tem maior $X_{\mathrm{Mg}} 0,94$ e, consequentemente, teve maior substituição de $\mathrm{Fe}$ por $\mathrm{Mg}$ nas folhas octaédricas (Figura 9.2a). O teor de $\mathrm{Al}^{\text {total }}$ é menor e varia pouco, de 3,34 a 3,68 a.p.f.u., ainda assim há tendência com correlação 
negativa mostrando a variação ao longo do vetor de substituição tschermakítica (Figura 9.2c). Já nos xistos ultramáficos a clorita exibe maior teor de $\mathrm{Al}^{\text {total }}$, de 4,21 a 4,48, e o grau de substituição tschermakítica foi maior na amostra CP-06 em relação à amostra CP-54A (Figura 9.2c).

Os elevados teores de $\mathrm{Al}$ são próximos ao conteúdo máximo de $\mathrm{Al}$ na clorita, como sugerido por Frost (1975) e experimentalmente obtido por Jenkins \& Chernosky (1986) para o limite da estabilidade de clorita magnesiana durante o metamorfismo progressivo, quando então ela quebra para formar paragêneses com espinélio como fase aluminosa dominante. Apesar do talco-tremolita-clorita-ortopiroxênio fels ter paragênese indicativa de fácies anfibolito superior a granulito, o teor de Al total na clorita mais baixo pode indicar que se trata de clorita retrometamórfica.

\subsubsection{Anfibólio}

Nos xistos ultramáficos o anfibólio foi analisado em porfiroblastos e em cristais que compõem a matriz. No antofilita-tremolita-clorita xisto (CP-06) os porfiroblastos são constituídos por núcleos de tremolita e bordas de antofilita (Apêndice E), enquanto na matriz os cristais têm núcleos de antofilita e bordas de tremolita (Figura 9.3a). O teor de alumínio total $\left(\mathrm{Al}^{\mathrm{VI}+\mathrm{IV}}\right)$ varia pouco, entre 0.018 e 0.162 a.p.f.u. nos porfiroblastos, mas é superior nos cristais da matriz, entre 0.023 e 0.272 a.p.f.u.

No antofilita-talco-tremolita-clorita xisto (CP-54A), porfiroblastos e cristais da matriz podem ter núcleo de antofilita com bordas de tremolita e vice-versa. O teor de alumínio total apresenta maior variação, entre 0.025 e 0.459 a.p.f.u. No talco-tremolitaclorita-ortopiroxênio fels (DCF-22), além da tremolita, há também cristais de cummingtonita (Figura 9.3b), e ambos não apresentam variações composicionais entre núcleo e borda (Figuras 9.4b e 9.4c).

As variações composicionais em função dos vetores das substituições edenítica $\left(\mathrm{KAl}^{\mathrm{IV}} \square_{-1} \mathrm{Si}_{-1}\right)$ e tschermakítica $\left(\mathrm{Al}^{\mathrm{VI}} \mathrm{Al}^{\mathrm{IV}} \mathrm{Mg}_{-1} \mathrm{Si}_{-1}\right)$ mostram distribuição dos valores de $\mathrm{Al}^{\mathrm{IV}} \mathrm{e}$ $\mathrm{Na}+\mathrm{K}$ no sítio A definindo tendência com predomínio da substituição tschermakítica e pequena participação da substituição edenítica (Figura 9.4a). A variação composicional ao longo do vetor da substituição tschermakítica $\left(\mathrm{Al}^{\mathrm{VI}} \mathrm{Al}^{\mathrm{IV}} \mathrm{Mg}_{-1} \mathrm{Si}_{-1}\right)$ é mais significativa na antofilita, da matriz da amostra CP-54A, nos porfiroblastos da amostra CP-06, na tremolita da matriz da amostra CP-06 e nos porfiroblastos da amostra CP-54A (Figura 9.4b). Não há variações significativas intra-amostras em termos do vetor de substituição titânio- 
tschermakítica $\left(\mathrm{TiAl}_{2}{ }^{\mathrm{VI}} \mathrm{Mg}_{-1} \mathrm{Si}_{-2}\right)$, entretanto, tremolita da matriz da amostra $\mathrm{CP}-06$ e dos porfiroblastos da amostra CP-54A apresentam maior grau dessa substituição (Figura 9.4c).

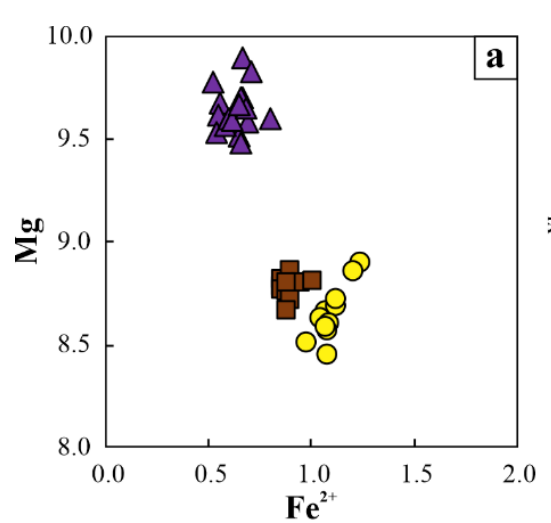

CP-06: Ath-tr-chl xisto

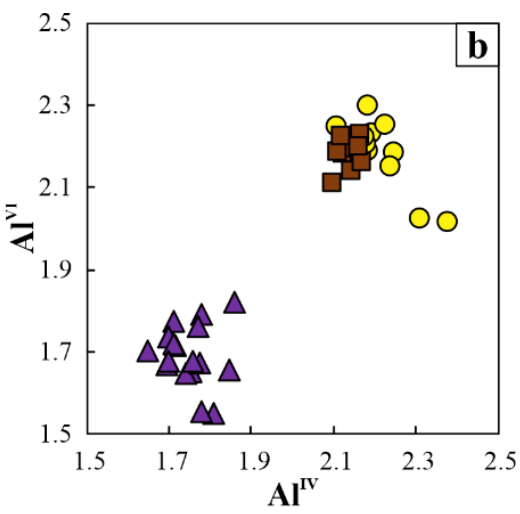

CP-54A: Ath-tlc-tr-chl xisto

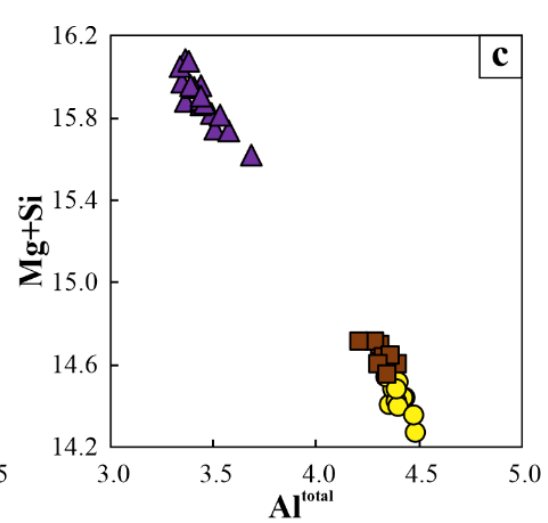

$\triangle$ DCF-22: meta ortopiroxenito

Figura 9.2: Gráficos das variações composicionais da clorita - a) Variação entre $\mathrm{Fe}$ e $\mathrm{Mg}$; b) Variação entre $\mathrm{Al}^{\mathrm{VI}}$ e $\mathrm{Al}^{\mathrm{IV}}$ segundo critérios de Hey (1954); c) Variação composicional em termos da substituição tschermakítica.
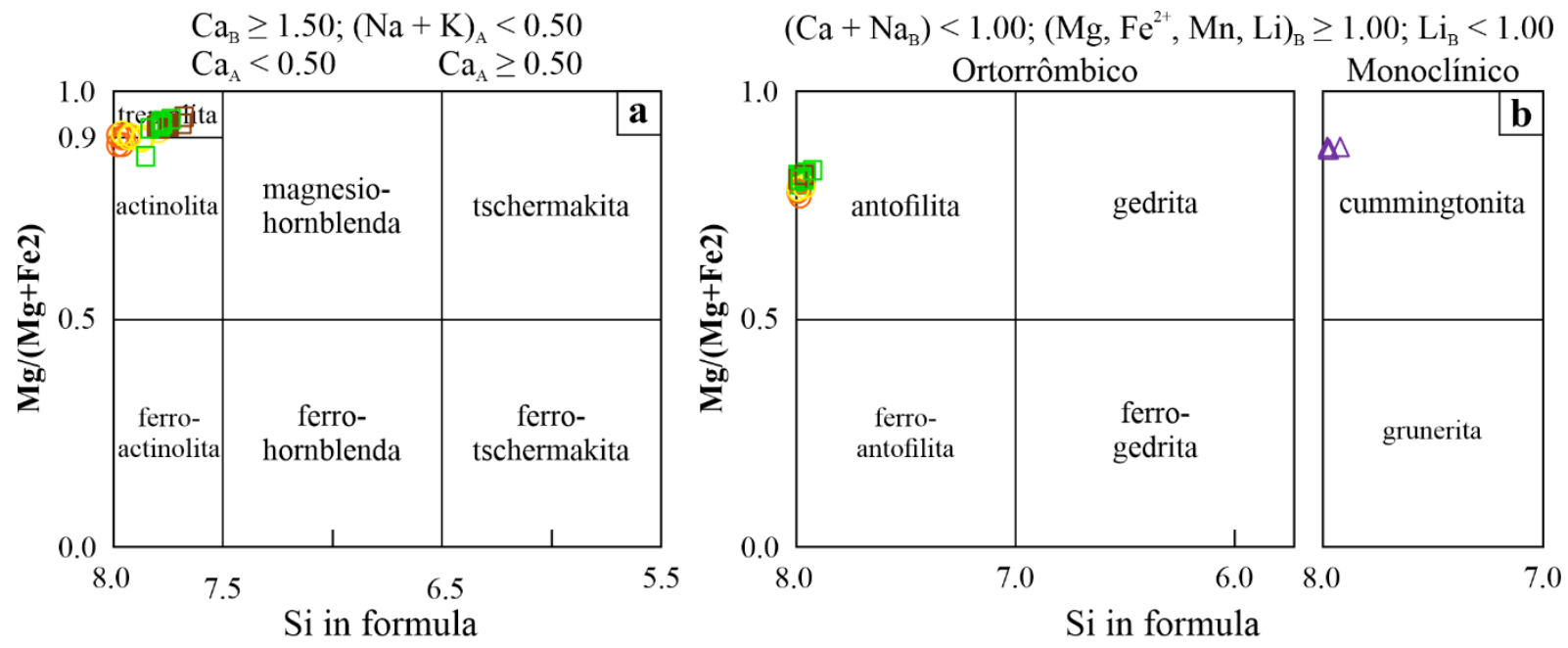

CP-06: Ath-tr-chl xisto porfiroblastos matriz
CP-54A: Ath-tlc-tr-chl xisto
$\square$ porfiroblastos
$\square$ matriz

DCF-22: Meta ortopiroxenito $\triangle$ micro porfiroblastos

Figura 9.3: Diagramas de classificação de anfibólios de acordo com Leake et al. (1997), em (a) para anfibólios cálcicos e em (b) para anfibólios de $\mathrm{Mg}-\mathrm{Fe}-\mathrm{Mn}-\mathrm{Li}$.

\subsubsection{Piroxênio}

A molécula dominante no ortopiroxênio é a enstatita (En89,1-91,2). Os teores de Ca e $\mathrm{Al}$ são desprezíveis, inferior 0,005 a.p.f.u. para Ca e entre 0,001 e 0,007 a.p.f.u para o Al. 

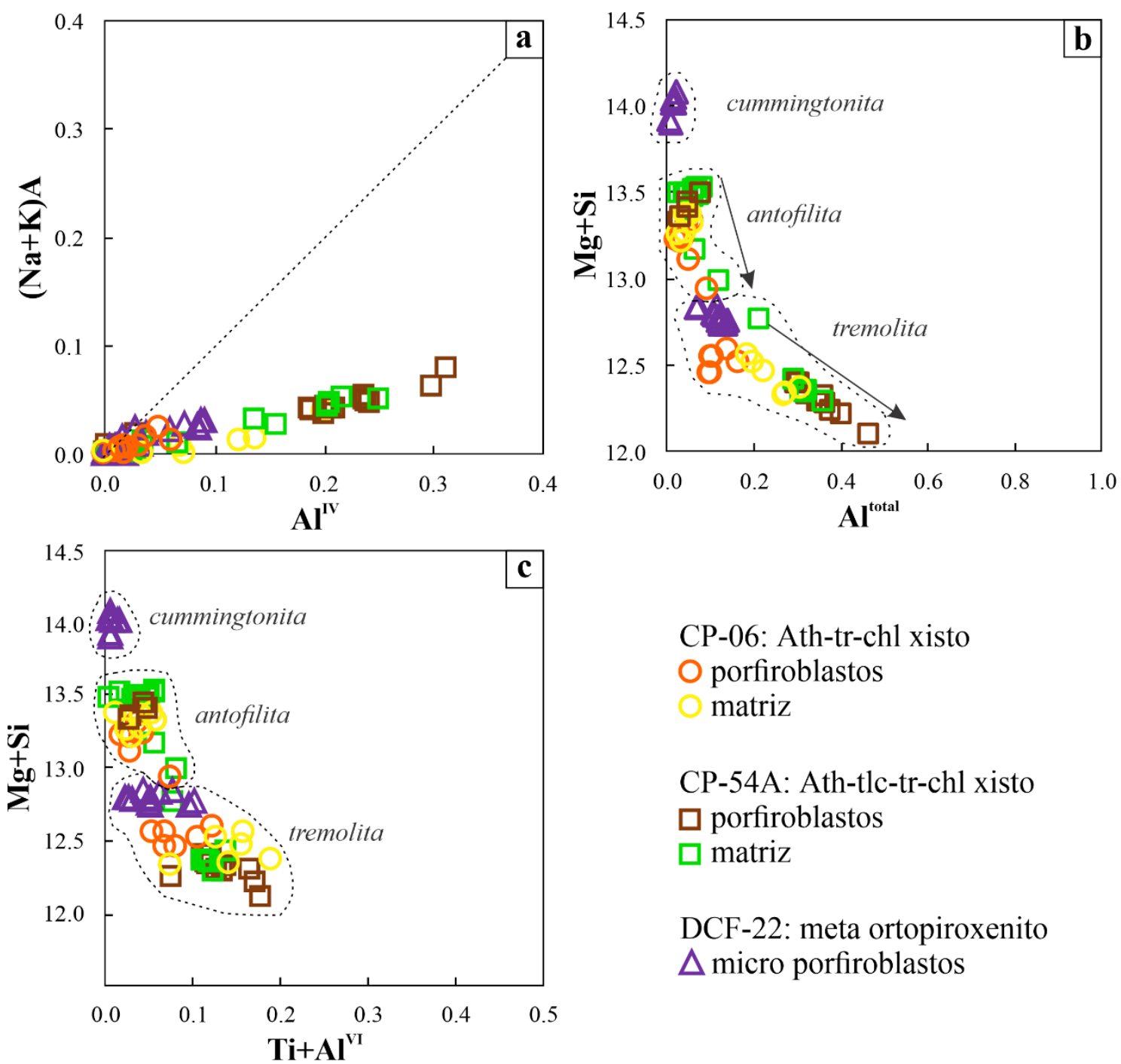

CP-06: Ath-tr-chl xisto
porfiroblastos
matriz

CP-54A: Ath-tlc-tr-chl xisto $\square$ porfiroblastos $\square$ matriz

DCF-22: meta ortopiroxenito $\triangle$ micro porfiroblastos

Figura 9.4: a) Gráfico da participação relativa das variações composicionais no anfibólio em função dos vetores das substituições edenítica ( $\left.\mathrm{KAl}^{\mathrm{IV}} \square_{-1} \mathrm{Si}_{-1}\right)$ e tschermakítica $\left(\mathrm{Al}^{\mathrm{VI}} \mathrm{Al}^{\mathrm{IV}} \mathrm{Mg}_{-1} \mathrm{Si}_{-1}\right)$ mostrando a distribuição dos valores de $\mathrm{Al}^{\mathrm{IV}}$ no sítio $\mathrm{T}$ e $\mathrm{Na}+\mathrm{K}$ no sítio $\mathrm{A}$; Variação composicional do anfibólio em termos da substituição tschermakítica (b) e titânio-tschermakítica (c).

\subsection{Metamorfismo}

As disparidades observadas nas composições e variações composicionais na clorita dos xistos ultramáficos e no meta-ortopiroxenito podem não corresponder apenas ao distinto grau metamórfico das rochas. Tais disparidades podem ser reflexo também das variações químicas que ocorreram durante o metassomatismo generalizado dos xistos ultramáficos, com aumento no teor de Al culminando com a cloritização generalizada que formou os clorititos.

Durante o desenvolvimento da foliação $S_{2}$, o metassomatismo atuou na formação de clorita, através da cloritização, que ocorre quando é cessado o transporte de $\mathrm{Al}$, localmente formando bandas milimétricas a decimétricas de clorititos. Concomitante a esse processo, e após o pico deformacional, fases fluidas ricas em sílica $+\mathrm{H}_{2} \mathrm{O}$ foram responsáveis pela 
talcificação, que ocorreu em muitos locais de forma generalizada, formando camadas de espessura decimétrica a métrica de talco xisto. Nessa fase foram formados os minerais opacos com o ferro extraído da antofilita e da cummingtonita. A formação de antofilita fels pode ser atribuída a processos metassomáticos tardios e pós-deformacionais que distribuíram de maneira heterogênea os fluidos ricos em sílica.

A formação de paragêneses com antofilita + cummingtonita + tremolita marca condições de pico metamórfico em fácies anfibolito durante o desenvolvimento da foliação principal $S_{2}$ (Figura 9.5). Admitindo equilíbrio entre os metapelitos e xistos ultramáficos, para condições de $\sim 8$ kbar, o intervalo de temperatura durante o pico metamórfico nos xistos ultramáficos varia de 710 a $775^{\circ} \mathrm{C}$. A presença de cristais de tremolita e antofilita pós-S $\mathrm{S}_{2}$ indica que tais condições persistiram após o pico deformacional.

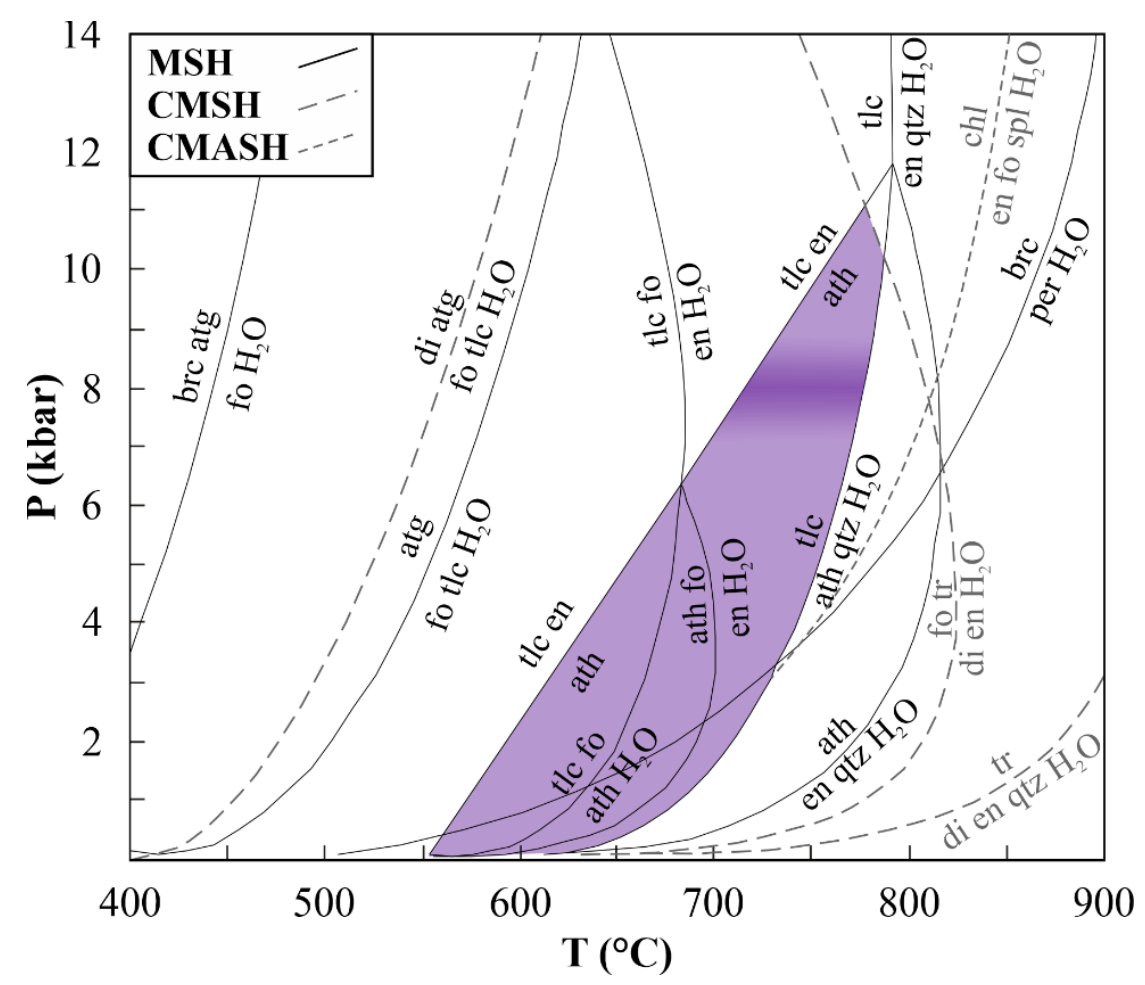

Figura 9.5: Grade petrogenética do sistema $\mathrm{SiO}_{2}-\mathrm{MgO}-\mathrm{H}_{2} \mathrm{O}$ construída a partir do banco de dados de Berman (1988) com as curvas dos sistemas CMSH e CMASH indicadas em tracejado. O campo roxo representa as condições de equilíbrio dos xistos metaultramáficos das amostras CP-06 e CP-54a e em roxo escuro as condições estimadas para o pico térmico em $\sim 8$ kbar. 


\section{MODELO EVOLUTIVO DO COMPLEXO PETÚNIA}

Antes de redefinir o contexto tectônico do Complexo Petúnia, o primeiro passo foi determinar a disposição geral de suas unidades para além dos limites definidos por Roig (1993), ou seja, o que de fato pertence ao Complexo Petúnia, e quais suas relações com o Complexo Campos Gerais. Esta tarefa agrega dificuldades inerentes ao amplo caráter tectônico das unidades e às deformações decorrentes da colocação das nappes durante a orogenia Brasiliana.

Até o momento, o Complexo Petúnia era interpretado como domínio alóctone do Complexo Campos Gerais, com rochas metapelíticas e metapsamíticas correlacionadas com unidades do Orógeno Brasília, porém, sem qualquer critério cronoestratigráfico. A origem a partir de sequências ofiolíticas atribuída para as rochas metamáficas e metaultramáficas do Complexo Petúnia (Soares et al., 1990; Roig e Schrank, 1992; Roig, 1993; Zanardo et al., 1996) levou o Cinturão de Cisalhamento Campo do Meio ao status de paleosutura (Zona de Paleosutura de Alterosa, Zanardo et al., 2006), o que, por si só, leva ao questionamento sobre a relevância da colocação do Complexo Petúnia como domínio alóctone do Complexo Campos Gerais e não como um domínio independente, pois a presença das sequências ofiolíticas remete à subducção entre estes complexos.

O mapeamento geológico em maior escala, agregado às informações extraídas dos levantamentos aerogeofísicos permitiram dividir o Complexo Petúnia em três unidades de infraestrutura, Unidade Petúnia, Gnaisse Ribeirão da Conquista e Metagranito Bom Jesus da Penha, e duas unidades supracrustais, Unidades Colônia e Serra do Ibituruna.

\subsection{Arcabouço arqueano - paleoproterozoico}

A similaridade entre os Complexos Petúnia e Campos Gerais reside apenas na infraestrutura, que é formada por terrenos arqueanos a paleoproterozoicos heterogeneamente deformados pela tectônica transcorrente dúctil-rúptil sinistral. No Complexo Petúnia esses terrenos são representados pelos gnaisses tonalíticos da Unidade Petúnia (2993 \pm 6 Ma), Gnaisse Ribeirão da Conquista $(2877 \pm 5 \mathrm{Ma})$ e pelo Metagranito Bom Jesus da Penha (2004 $\pm 5 \mathrm{Ma}$ ). O alto contraste observado na distribuição de U-Th-K é reflexo do grau de deformação, menor no Complexo Campos Gerais, na medida em que se caminha em direção aos núcleos entre as zonas de cisalhamento anastomosadas, onde estão preservadas as estruturas migmatíticas, e maior no Complexo Petúnia, em que, além da maior extensão da 
deformação, ocorre intensa e complexa justaposição de unidades supracrustais e rochas metaultramáficas.

Considerando apenas os terrenos arqueanos, as Unidades Petúnia e o Gnaisse Ribeirão da Conquista poderiam ser parte tanto do próprio Complexo Campos Gerais, como também de outras unidades da borda sul do Cráton São Francisco (Tabela 7-5). O ortognaisse tonalítico da Unidade Petúnia (2,99 Ga) e o Ortognaisse Campos Gerais (2,98 Ga - Turbay, 2010) poderiam, inclusive, junto aos Complexos Amparo, Serra Negra e Heliodiora-Minduri compor crosta mesoarqueana formada na lacuna de atividade magmática da borda sul do Cráton do São Francisco (Cioffi et al.,2016a). Entretanto, a rara ocorrência de idades mesoarqueanas, entre 3,20 e 2,93 Ga, na borda sul do Cráton do São Francisco não implica em interpretar esses ortognaisses como terrenos exóticos à borda sul do Cráton do São Francisco, pois o conhecimento geocronológico da infraestrutura arqueana-paleoproterozoica ao longo do Cinturão de Cisalhamento de Campo do Meio ainda é escasso, porém, já é estabelecido que o Complexo Campos Gerais corresponde à extensão do Complexo Campo Belo para oeste, como concluído anteriormente (Capítulo 4).

O Metagranito Bom Jesus da Penha $(2004 \pm 5 \mathrm{Ma})$, intrusivo nos gnaisses da Unidade Petúnia, os granitos Itapixé (1976 \pm 29 Ma, Turbay, 2010) e Porto Mendes (1978 $\pm 25 \mathrm{Ma}$, Paciullo et al., 2008), intrusivos no Complexo Campos Gerais, e o Ortognaisse Gaspar Lopes, como lascas em meio às unidades neoproterozoicas do Orógeno Brasília Meridional (Ribeiro et al., 2010) correspondem à extensão do Cinturão Mineiro para oeste e incluem as idades mais jovens reportadas para a Orogenia Minas.

As rochas do arcabouço do Cinturão de Cisalhamento Campo do Meio registraram de forma heterogênea os efeitos do evento deformacional relacionado a Orogenia Brasiliana. O gnaisse da Unidade Petúnia e o Gnaisse Ribeirão da Conquista possuem idades de intercepto inferior em 845 e $959 \mathrm{Ma}$, respectivamente, indicando distúrbios no sistema isotópico tardios em relação a Orogenia Minas, enquanto os ortognaisses do Complexo Campos Gerais mostram idades de intercepto inferior entre 651 e 507 Ma (Turbay, 2010), compatíveis com distúrbios proporcionados pela deformação relacionada à colisão durante a Orogenia Brasiliana, proveniente do transporte da nappe de Passos sobre o embasamento cratônico. Se as rochas da infraestrutura do Complexo Petúnia, que mostram evidências de deformação mais intensa que as rochas do Complexo Campos Gerais registram idades de metamorfismo neoproterozoico, permanece como uma das questões em aberto para futuros trabalhos na região. 


\subsection{Unidade supracrustais}

Se considerarmos as Unidades Serra do Ibituruna e Colônia como parte de um mesmo ciclo deposicional, o pico de idades meso- a neoarqueanas, que têm destaque nos cristais de zircão da Unidade Serra do Ibituruna (Figura 7.4), pode não estar tão bem registrado nos cristais de zircão da Unidade Colônia devido às diferentes energias envolvidas no transporte sedimentar dos protólitos. Cristais de zircão da Unidade Serra do Ibituruna possuem maior granulometria, entre 200 e $400 \mu \mathrm{m}$, e alto grau de arredondamento e esfericidade, evidenciando maior energia e tempo de retrabalhamento durante o transporte. Já na Unidade Colônia predominam cristais de menor granulometria, entre 75 e $130 \mu \mathrm{m}$, o que reflete que houve menor energia para transporte, uma vez que a primeira unidade é psamítica e a última pelítica.

A despeito das considerações acima, deve-se levar em conta que a intensa deformação ao longo do Cinturão de Cisalhamento Campos do Meio torna inviável reconstruir a litoestratigrafia das unidades supracrustais do Complexo Petúnia. Além disso, mais do que morfologia dos grãos, as assinaturas geoquímicas e as texturas internas dos cristais de zircão trazem um fator agravante relacionado ao grau de preservação dos cristais detríticos de zircão frente ao metamorfismo neoproterozoico.

Enquanto os cristais detríticos de zircão da Unidade Serra do Ibituruna preservam texturas e assinaturas geoquímicas condizentes com os protólitos, sejam eles ígneos ou metamórficos, e ausência de sobrecrescimentos de idade neoproterozoica, os cristais de zircão da Unidade Colônia mostram variável grau de modificações texturais causadas por processos de substituição e recristalização relacionadas aos diferentes estágios da trajetória $P-T$ durante o metamorfismo (seção 8.10.2), resultando no reequilíbrio das assinaturas geoquímicas e consequente distúrbio das razões isotópicas causado pela sobreposição metamórfica durante o Neoproterozoico.

A ausência de registros de proveniência a partir de áreas fontes meso- a neoproterozoicas descarta a conexão entre os Grupos Carrancas e Canastra através das rochas da Unidade Serra do Ibituruna e seus espectros de idades abrem a possibilidade para estabelecer correlações com os Grupos Sabará e Itacolomi (Figura 7.12). O Grupo Sabará tem idades modelo $\mathrm{T}_{\mathrm{DM}}$ de $2,3 \mathrm{Ga}$ e pequeno $\varepsilon N d$ negativo (-1), indicando que as áreas fontes paleoproterozoicas tiveram curto tempo de permanência na crosta (Brueckner et al., 2000; Alkmin \& Teixeira, 2017), como reflexo da mudança de um regime precursor de bacia de margem passiva para sistema ativo, representado por bacias de antepaís sin-orogênicas relacionadas à Orogenia Minas, com deposição até o final do Riaciano (Renger et al., 1994; 
Machado et al., 1996; Reis et al., 2002; Alkmim \& Teixeira, 1998; Alkmin \& Teixeira, 2017; Dutra et al., 2019). Este processo de inversão culminou com a deposição do Grupo Itacolomi, que é associado à deposição em ambientes fluviais em bacias intermontanas pós-Orogenia Minas, (Machado et al., 1996; Alkmim e Marshak, 1998; Alkmim \& Noce, 2006; Alkmim \& Teixeira, 2017; Duque et al., 2020).

Neste contexto, a Unidade Serra do Ibituruna pode ter tido menor contribuição de sedimentos de áreas fontes paleoproterozoicas devido a menor proximidade do arco magmático que originou o Cinturão Mineiro. A idade máxima de deposição em 2080 Ma e o hiato no registro de fontes siderianas revelam maior similaridade entre a Unidade Serra do Ibituruna e o Grupo Sabará. Trabalhos futuros que contemplem a geoquímica elemental e isotópica dessas rochas podem contribuir para melhor fundamentar esta nova proposta.

A configuração litológica do Complexo Petúnia envolvendo um arcabouço arqueano com intrusões paleoproterozoicas e sucessões metassedimentares com idade máxima de deposição no período Riaciano reforçam a interpretação da extensão do Cinturão Mineiro para oeste e indicam que o Cinturão de Cisalhamento Campo do Meio, aqui como Paleosutura de Alterosa (Zanardo et al., 2006), registra evolução policíclica, pelo menos desde a Orogenia Minas, durante o Paleoproterozoico, até estágios finais da Orogenia Brasiliana, o que será discutido a seguir.

Na Unidade Colônia os dados obtidos para o zircão não suportam interpretações relacionadas à proveniência sedimentar em virtude do variável grau de reabsorção dos núcleos detríticos. Considerando a lenta recuperação geoquímica, textural e isotópica do zircão, ao utilizar apenas os dados com concordância acima de $95 \%$, excluindo aqueles que atingiram total reequilíbrio durante o metamorfismo, a distribuição de idades obtidas guarda semelhanças com a distribuição de idades do Xisto Santo Antônio (Figura 10.1).

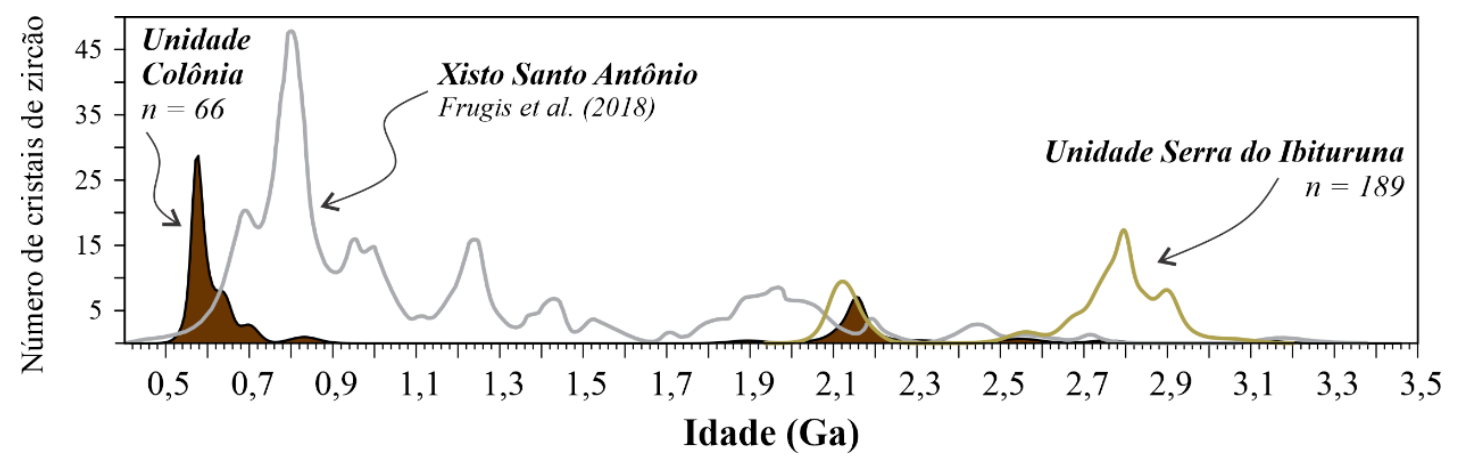

Figura 10.1: Diagrama Idade vs. Probabilidade Relativa para a Unidade Colônia utilizando apenas dados com concordância acima de $95 \%$ em núcleos detríticos e em zonas com mistura de domínios, i.e., relíquias de grão detrítico em meio às áreas parcialmente recristalizadas. São mostrados os espectros de distribuição de idades para a Unidade Serra do Ibituruna e para o Xisto Santo Antônio, com dados compilados de Frugis et al., 2018. 
Os espectros de idade mostrados na Figura 10.1 evidenciam que as Unidades Serra do Ibituruna e Colônia não podem ser parte de um mesmo ciclo deposicional. No entanto, a Unidade Colônia poderia estar relacionada com algumas das unidades metapelíticas do Orógeno Brasília, principalmente dos Grupos Carrancas, Andrelândia ou Araxá, mas os dados de zircão aqui levantados, ainda não permitem fazer essa correlação com total segurança e, talvez, ela nem seja possível. Além disso, a distribuição de idades da Unidade Colônia mostra pico em torno de 580 Ma e essa idade, como será exposto adiante, representa a idade de retrometamorfismo no Complexo Petúnia.

Nas zonas recristalizadas, embora tenha ocorrido enriquecimento em elementos traço no zircão, associados às zonas de alteração, i.e. $\mathrm{Ca}, \mathrm{Al}, \mathrm{Fe}$ e $\mathrm{Pb}$, as razões isotópicas do zircão não foram novamente afetadas e o reequilíbrio atingido durante o metamorfismo foi eficiente ao ponto de fornecer dados com concordância acima de $95 \%$. A idade de $601 \pm 9 \mathrm{Ma}$ corresponde à recuperação do zircão durante o pico metamórfico, concomitante com a fusão dos metapelitos. Fusão parcial de metapelitos no campo da estaurolita é rara na natureza, mas pode ocorrer em ambientes com influxo de fluidos, tal como em extensos cinturões de cisalhamento. A estaurolita formada em equilíbrio com o fundido sugere que sua estabilidade pode ultrapassar a curva solidus em presença de fluidos, caracterizando migmatização de "baixa” temperatura (García-Casco et al., 2003), a qual ocorre conjuntamente ou algo antes da quebra da muscovita, por fusão em presença de água. A metassomatização generalizada das rochas metaultramáficas do Complexo Petúnia corrobora com o caráter hidratado dessa fusão.

O volume de fundido é baixo, com segregação incipiente, e a foliação de cisalhamento gerada durante o retrometamorfismo mascara as feições indicativas de fusão. As condições $P-T$ determinadas para a associação em equilíbrio formada durante o desenvolvimento da foliação milonítica, em 7,7 a 8,5 kbar de pressão e de 680 a $690{ }^{\circ} \mathrm{C}$ de temperatura são compatíveis com as condições $P$ - $T$ obtidas por Pinheiro (2013) em granada anfibolito da Unidade Petúnia. Na Unidade Serra do Ibituruna, a associação mineral formada por rutilo + cianita + muscovita + quartzo, desenvolvida em leitos mais aluminosos (Figura 7.1a) indicam condições de pico metamórfico também em fácies anfibolito, porém, com temperaturas insuficientes para afetar os cristais de zircão detrítico da unidade, uma vez que estes não registraram recristalização neoproterozoica.

A associação "A", formada pelas primeiras gerações de granada e cianita (reação 6, tópico 8.9.1) no muscovita-cianita-plagioclásio-granada-biotita xisto remete à uma composição mais residual, com menos fundido gerado, e preserva paragênese de pico de alta pressão (Kriegsman, 2001). As feições preservadas nos pods, tais como cianita esquelética 
com rutilo parcialmente transformado em ilmenita, ausência de zoneamento composicional no plagioclásio e quartzo rico em inclusões de micas, sugerem texturas de desequilíbrio formadas por descompressão e resfriamento rápido do fundido gerado, antes do desenvolvimento da foliação milonítica. Indícios de rápido resfriamento também são observados na segunda geração de granada, que forma coronas em torno de núcleos pré-existentes. As condições $P-T$ aproximadas para a associação de pico bárico, de $713{ }^{\circ} \mathrm{C}$ de temperatura e 9,4 kbar de pressão para granada reequilibrada com a biotita da matriz, indicam formação em ambiente de alta pressão, tal como o de unidades do Sistema de Nappes Andrelândia (Campos Neto et al., 2007; Motta et al., 2017) e do Grupo Araxá, na Nappe de Passos (Fumes et al., 2020), mas certamente a história metamórfica dos metapelitos da Unidade Colônia pode ser ainda mais complexa, como sugerido pela trajetória na Figura 8.20b.

A idade de $580 \pm 4$ Ma obtida nos cristais de monazita da Unidade Colônia representam a idade de retrometamorfismo, compatível com a idade concórdia de $584 \pm 3 \mathrm{Ma}$, obtida para os cristais de monazita da amostra CP-35 da Unidade Serra do Ibituruna e também com o retrometamorfismo do Xisto Santo Antônio (Motta et al., 2017). A trajetória horária com intervalo de 20 Ma entre a fusão e a cristalização do fundido, sin- $S_{2}$, corrobora para a interpretação de uma trajetória de descompressão e resfriamento rápidos, compatíveis com orógenos colisionais (Jamieson et al.,2004).

As idades obtidas através da monazita permitem estabelecer a cronologia de importantes zonas de cisalhamento dentro do Cinturão de Cinturão de Cisalhamento Campo do Meio. A idade da amostra CP-35 representa a idade da deformação (reativação?) ao longo da Zona de Cisalhamento de Riacho Fundo, enquanto a idade de $574 \pm 11 \mathrm{Ma}$, obtida na amostra CP-27, data a transporte tectônico para NW ao longo da Zona de Cisalhamento de Bom Jesus da Penha, resultante da acomodação final na Paleosutura de Alterosa. O intervalo de idades entre 600 e 575 Ma, obtidas respectivamente em zircão metamórfico e monazita, correspondem ao período onde metamorfismo e deformação foram controlados pela colisão frontal e migração das nappes para ENE no Neoproterozoico (Campos Neto et al., 2004). 


\section{CONCLUSÕES}

- Os dados obtidos ao longo desta tese permitiram redefinir o Complexo Petúnia, que agora, assim como o Complexo Campos Gerais, está restrito ao arcabouço formado por rochas arqueanas a paleoproterozoicas, representadas por gnaisses da Unidade Petúnia (2993 $\pm 6 \mathrm{Ma}$ ), pelo Gnaisse Ribeirão da Conquista $(2835 \pm 12 \mathrm{Ma}$ ), e pelo Metagranito Bom Jesus da Penha $(2004 \pm 5 \mathrm{Ma})$, sendo as duas últimas unidades definidas neste trabalho;

- A Unidade Serra do Ibituruna, com idade máxima de deposição em $2080 \pm 0,9$ Ma e características de bacia de ambientes colisionais, pode a ser correlacionada com os Grupos Sabará ou Itacolomi, representando a ocorrência inédita dessas unidades fora do Quadrilátero Ferrífero;

- O Metagranito Bom Jesus da Penha representa a idade mais jovem para granitoides formados durante a Orogenia Minas e, em conjunto com as unidades arqueanas e a Unidade Serra do Ibituruna, podem corresponder a extensão do Cinturão Mineiro para oeste, em direção à Nappe de Passos;

- Os metapelitos da Unidade Colônia revelaram duas problemáticas no estudo voltado para a determinação da proveniência sedimentar e das condições de pico metamórfico em zonas de cisalhamento: (i) a presença de água diminui a temperatura da solidus, então, em condições com alta atividade de fluidos, que é o que se espera ao longo de cinturões de cisalhamento, pode haver fusão em baixa temperatura, caracterizando "migmatitos de baixo temperatura" e, (ii) nesses ambientes tectônicos, processos de substituição/recristalização do zircão detrítico são comuns e favorecidos pela presença de fases fluidas e/ou fundido, podendo resultar em reequilíbro total ou parcial das assinaturas isotópicas e geoquímicas do zircão, tornando inviável a identificação das áreas fonte.

- As associações de equilíbrio das fases principais e as texturas de equilíbrio das fases acessórias, aliados aos dados de U-Pb em zircão e monazita permitiram reconstruir a trajetória $P-T$ - $t$ do cianita-estaurolita-muscovita-granada-biotita xisto (CP-07) da Unidade Colônia. A evolução petrocronológica da rocha define trajetória horária de aquecimento até a fusão, durante o pico metamórfico em $601 \mathrm{Ma}$, sob condições de $680^{\circ} \mathrm{C}$ de temperatura e 8,9 kbar de pressão, seguido de resfriamento para condições de temperatura inferiores a $620^{\circ} \mathrm{C}$, em $580 \mathrm{Ma}$. 
- Na Unidade Serra do Ibituruna, as condições P-T-fluidos, durante o metamorfismo neoproterozoico, não foram capazes de reequilibrar/recristalizar os cristais detríticos de zircão, enquanto a monazita registrou a idade da deformação associada ao transporte tectônico ao longo do Cinturão de Cisalhamento Campo do Meio. Em $584 \mathrm{Ma}$, o transporte para $\mathrm{W}$ ocorreu ao longo da Zona de Cisalhamento Riacho Fundo e, em $574 \mathrm{Ma}$, o transporte para NW ocorreu ao longo da Falha/Zona de Cisalhamento de Bom Jesus da Penha, como resultado da consolidação do Orógeno Brasília Meridional. 


\section{REFERÊNCIAS BIBLIOGRÁFICAS}

Alkmim, F.F., Teixeira, W., 2017, The Paleoproterozoic Mineiro Belt and the Quadrilátero Ferrífero, in Heilbron, M., Cordani, U.G., Alkmim, F.F., eds., São Francisco Craton, Eastern Brazil: Tectonic Genealogy of a Miniature Continent: Springer International Publishing, New York, Regional Geology Reviews, p. 71-94, doi:10.1007/978-3-319-01715-0_5.

Alkmim, F.F., Lana, C., Duque, T.R.F., 2014, Zircões detríticos do Grupo Itacolomi e o registro do soerguimento do Cinturão Mineiro, in Congresso Brasileiro de Geologia, 47, Salvador. Anais, p. 1802.

Alkmim, F.F. e Noce, C.M., 2006, Outline of the geology of the Quadrilátero Ferrífero, in Alkmim, F.F. e Noce, C.M., eds., The Paleoproterozoic Record of the Sao Francisco Craton: IGCP 509 Field workshop, Bahia and Minas Gerais, Brazil, Field Guide \& Abstracts, $114 \mathrm{p}$.

Alkmim, F.F., e Marshak, S., 1998, Transamazonian Orogeny in the Southern São Francisco Craton Region, Minas Gerais, Brazil: Evidence for Paleoproterozoic collision and collapse in the Quadrilátero Ferrífero: Precambrian Research, v. 90, p. 29-58, doi:10.1016/s03019268(98)00032-1.

Andersen, T., 2005, Detrital zircons as tracers of sedimentary provenance: Limiting conditions from statistics and numerical simulation: Chemical Geology, v. 216, p. 249270, doi:10.1016/j.chemgeo.2004.11.013.

Andrade, S., Ulbrich, H.H., Gomes, C.B., e Martins, L., 2014, Methodology for the Determination of Trace and Minor Elements in Minerals and Fused Rock Glasses with Laser Ablation Associated with Quadrupole Inductively Coupled Plasma Mass Spectrometry (LA-Q-ICPMS): American Journal of Analytical Chemistry, v. 05, p. 701721, doi:10.4236/ajac.2014.511079.

Andrade, S., Hypolito R., Ulbrich H.H., Silva M.L., 2002, Iron (II) oxide determination in rocks and minerals: Chemical Geology, v. 182, p. 85-89, doi:10.1016/S00092541(01)00274-1.

Araújo, A.J.D., Bongiolo, E.M., e Ávila, C.A., 2019, The southern São Francisco Craton puzzle: Insights from aerogeophysical and geological data: Journal of South American Earth Sciences, v. 94, p. 102203, doi:10.1016/j.jsames.2019.05.019.

Armstrong, J.T., 1991, Quantitative Elemental Analysis of Individual Microparticles with Electron Beam Instruments, in Heinrich K.F.J., Newbury D.E., eds., Electron Probe Quantitation. Springer, Boston, MA. doi:10.1007/978-1-4899-2617-3 15

Artur, A.C., Wernick, E., 1984, Terrenos Policíclicos e Estágios de Evolução Crustal, in Congresso Brasileiro de Geologia, 33, Rio de Janeiro, v. 7, p. 3081-3090.

Ashworth, J.R., 1975, Staurolite at anomalously high grade: Contributions to Mineralogy and Petrology, v. 53, p. 281-291, doi:10.1007/BF00382444

Ávila, C.A., Teixeira, W., Bongiolo, E.M., Dussin, I.A., e Vieira, T.A.T., 2014, Rhyacian evolution of subvolcanic and metasedimentary rocks of the southern segment of the Mineiro belt, São Francisco Craton, Brazil: Precambrian Research, v. 243, p. 221-251, doi:10.1016/j.precamres.2013.12.028.

Ávila, C.A., Teixeira, W., Cordani, U.G., Barrueto, H.R., Pereira, R.M., Martins, V.T.S., e Dunyi, L., 2006, The Glória quartz-monzodiorite: Isotopic and chemical evidence of arcrelated magmatism in the central part of the paleoproterozoic Mineiro belt, Minas Gerais State, Brazil: Anais da Academia Brasileira de Ciencias, v. 78, p. 543-556, doi:10.1590/s0001-37652006000300013.

Ávila, C.A., Teixeira, W., Cordani, U.G., Moura, C.A.V., e Pereira, R.M., 2010, Rhyacian 
(2.23-2.20 Ga) juvenile accretion in the southern São Francisco craton, Brazil: Geochemical and isotopic evidence from the Serrinha magmatic suite, Mineiro belt: Journal of South American Earth Sciences, v. 29, p. 464-482, doi:10.1016/j.jsames.2009.07.009.

Ávila, C.A., Cherman, A.F., Valença, J.G., 2008, Dioritos Brumado e Rio Grande: geologia e relação com o metamorfismo paleoproterozoico do Cinturão Mineiro, borda meridional do Cráton São Francisco, Minas Gerais: Arquivos do Museu Nacional, 67, 248-277.

Barbosa, N.S., Teixeira, W., Ávila, C.A., Montecinos, P.M., e Bongiolo, E.M., 2015, 2.172.10Ga plutonic episodes in the Mineiro belt, São Francisco Craton, Brazil: U-Pb ages, geochemical constraints and tectonics: Precambrian Research, v. 270, p. 204-225, doi:10.1016/j.precamres.2015.09.010.

Bea, F., 1996, Residence of REE, Y5 Th and U in Granites and Crustal Protoliths; Implications for the Chemistry of Crustal Melts: Journal of Petrology, v. 37, p. 521-552, doi:10.1093/petrology/37.3.521.

Belousova, E.A., Griffin, W.L., O’Reilly, S.Y., e Fisher, N.I., 2002, Igneous zircon: Trace element composition as an indicator of source rock type: Contributions to Mineralogy and Petrology, v. 143, p. 602-622, doi:10.1007/s00410-002-0364-7.

Belousova, E.A., Griffin, W.L., e Pearson, N.J., 1998, Trace element composition and cathodoluminescence properties of southern African kimberlitic zircons: Mineralogical Magazine, v. 62, p. 355-366, doi:10.1180/002646198547747.

Berman, R.G., 1988, Internally-Consistent Thermodynamic Data for Minerals in the System $\mathrm{Na}_{2} \mathrm{O}-\mathrm{K}_{2} \mathrm{O}-\mathrm{CaO}-\mathrm{MgO}-\mathrm{FeO}-\mathrm{Fe}_{2} \mathrm{O}_{3}-\mathrm{Al}_{2} \mathrm{O}_{3}-\mathrm{SiO}_{2}-\mathrm{TiO}_{2}-\mathrm{H}_{2} \mathrm{O}-\mathrm{CO}_{2}$ : Journal of Petrology, v. 29, p. 445-522, doi:10.1093/petrology/29.2.445.

Botev, Z.I., Grotowski, J.F., e Kroese, D.P., 2010, Kernel density estimation via diffusion: Annals of Statistics, v. 38, p. 2916-2957, doi:10.1214/10-AOS799.

Brito Neves, B.B., Campos Neto, M.C., Fuck, R.A., 1999, From Rodinia to Western Gondwana: an approach to the Brasiliano-Pan African Cycle and orogenic collage. Episodes v.22, no.3, p. 155-166. doi:10.18814/epiiugs/1999/v22i3/002.

Brueckner, H.K., Cunningham, D., Alkmin, F.F., Marshak, S., 2000, Tectonic implications of Precambrian Sm-Nd dates from the southern São Francisco craton and adjacent Araçuaí and Ribeira belts, Brazil: Precambrian Research, v. 99, p. 255-269, doi:10.1016/S0301-9268(99)00065-0.

Bühn, B., Pimentel, M.M., Matteini, M., Dantas, E.L., 2009, High spatial resolution analysis of $\mathrm{Pb}$ and $\mathrm{U}$ isotopes for geochronology by laser ablation multi-collector inductively coupled plasma mass spectrometry (LA-MC-ICP-MS): Anais da Academia Brasileira de Ciências, v. 81, p. 99-114, doi: 10.1590/S0001-37652009000100011

Campos, J.C.S., 2004, O Lineamento Jeceaba-Bom Sucesso como Limite dos Terrenos Arqueanos e Paleoproterozoicos do Cráton São Francisco Meridional: Evidências Geológicas, Geoquímicas (Rocha Total) e Geocronológicas (U-Pb) [Tese de Doutorado]: Ouro Preto, Universidade Federal de Ouro Preto, 191 p.

Campos Neto, M.C., Basei, M.A.S., Janasi, V.A., Moraes, R., 2011, Orogen migration and tectonic setting of the Andrelândia Nappe system: an Ediacaran western Gondwana collage, south of São Francisco craton: Journal of South American Earth Science, v. 32, p. 393-406, doi:10.1016/j.jsames.2011.02.006.

Campos Neto, M.C., Cioffi, C.R., Moraes, R., et al., 2010, Structural and metamorphic control on the exhumation of high-P granulites: the Carvalhos Klippe example, from the oriental Andrelândia Nappe system, southern portion of the Brasília Orogen, Brazil: Precambrian Research, v. 180, p. 125-142, doi:10.1016/j.precamres.2010.05.010 
Campos Neto, M.C.; Caby, R., 2000, Terrane accretion and upward extrusion of highpressure granulites in the Neoproterozoic nappes of southeast Brazil: petrologic and structural constraints: Tectonics, v.19, p. 669-687, doi: 10.1029/1999TC900065

Campos Neto, M.C., Janasi, V.A., Basei, M.A.S., e Siga Jr, O., 2007, Sistema de nappes Andrelândia, setor oriental: litoestratigrafia e posição estratigráfica: Revista Brasileira de Geociências, v. 37, p. 47-60, doi:10.25249/0375-7536.200737s44760.

Campos Neto, M.C., Basei, M.A.S., Vlach, S.R.F., Caby, R., Szabó, G.A.J., Vasconcelos, P., 2004, Migração de orógenos e superposição de orogêneses: um esboço da colagem brasiliana no sul do Cráton do São Francisco, SE - Brasil. Revista do Instituto de Geociências - USP. São Paulo, v.4, p. 13-40, doi:10.5327/S1519-874X2004000100002

Carlson, W.D., Gordon, C.L., 2004, Effects of matrix grain size on the kinetics of intergranular diffusion: Journal of Metamorphic Geology, v. 22, p.733-742, doi: doi:10.1111/j.1525-1314.2004.00545.x

Carvalho, B.B., Janasi, V.A., e Sawyer, E.W., 2017a, Evidence for Paleoproterozoic anatexis and crustal reworking of Archean crust in the São Francisco Craton, Brazil: A dating and isotopic study of the Kinawa migmatite: Precambrian Research, v. 291, p. 98-118, doi:10.1016/j.precamres.2017.01.019.

Carvalho, B.B., Sawyer, E.W., e Janasi, V.A., 2017b, Enhancing maficity of granitic magma during anatexis: Entrainment of infertile mafic lithologies: Journal of Petrology, v. 58, p. 1333-1362, doi:10.1093/petrology/egx056.

Carvalho, S.G., Soares, P.C., Antonio, M.C., Zanardo, A., Oliveira, M.A.F., 1993, Geologia da Sequência Vulcano-Sedimentar de Alpinópolis (MG): Revista Brasileira de Geociências, v. 23, p. 38-51, doi:10.25249/0375-7536.19932313851.

Carvalho, S.G., 1990, Geologia, petrografia e metalogenia da sequência vulcanossedimentar de Alpinópolis, Minas Gerais [Tese de Doutorado]: São Paulo, Universidade de São Paulo, $216 \mathrm{p}$.

Cavosie, A.J., Valley, J.W., Wilde, S.A., 2006, Correlated microanalysis of zircon: Trace element, $\delta 18 \mathrm{O}$, and $\mathrm{U}-\mathrm{Th}-\mathrm{Pb}$ isotopic constraints on the igneous origin of complex $>3900 \mathrm{Ma}$ detrital grains: Geochimica et Cosmochimica Acta, v. 70, p. 5601-5616, doi:10.1016/j.gca.2006.08.011.

Cawood, P.A., Hawkesworth, C.J., e Dhuime, B., 2012, Detrital zircon record and tectonic setting: Geology, v. 40, p. 875-878, doi:10.1130/G32945.1.

Cherniak, D.J., Hanchar, J.M., e Watson, E.B., 1997a, Diffusion of tetravalent cations in zircon: Contributions to Mineralogy and Petrology, v. 127, p. 383-390, doi: $10.1007 / \mathrm{s} 004100050287$.

Cherniak, D.J., Hanchar, J.M., e Watson, E.B., 1997b, Rare-earth diffusion in zircon: Chemical Geology, v. 134, p. 289-301, doi: 10.1016/S0009-2541(96)00098-8.

Choudhuri, A., Schrank, A., Roig, H.L., Szabó, G.A.J., 1995, Negative Ce anomaly in mafic rocks of a possible Late Proterozoic ophiolite from SW Minas Gerais, Brazil, in Srivastava, R.K., Chandra, R., eds., Magmatism in relation to diverse tectonic settings. Oxford: IBH Publishing Co., p. 283-290.

Cioffi, C.R., Campos Neto, M. da C., Möller, A., e Rocha, B.C., 2016a, Paleoproterozoic continental crust generation events at 2.15 and $2.08 \mathrm{Ga}$ in the basement of the southern Brasília Orogen, SE Brazil: Precambrian Research, v. 275, p. 176-196, doi:10.1016/j.precamres.2016.01.007.

Cioffi, C.R., Campos Neto, M. da C., Möller, A., e Rocha, B.C., 2016b, Tectonic significance of the Meso- to Neoarchean complexes in the basement of the southern Brasília Orogen: Precambrian Research, v. 287, p. 91-107, doi:10.1016/j.precamres.2016.10.009.

Companhia de Desenvolvimento Econômico de Minas Gerais, 2015, Projeto Fronteiras de Minas Gerais - Folha Nova Resende, SF.23-V-D-I, escala 1:100.000, Por Antônio Carlos 
Pedrosa Soares e outros. Minas Gerais, CODEMIG/UFMG.

Connolly, J.A.D., 1990, Multivariable phase-diagrams-an algorithm based on generalized thermodynamics: American Journal of Science, v. 290, p. 666-718, doi:10.2475/ajs.290.6.666.

Connolly, J.A.D., Kerrick D.M., 1987, An algorithm and computer program for calculating composition phase diagrams, disponível em http://www.perplex.ethz.ch/perplex/tutorial/Marks_C2C_workshop_Sevilla/distributed\%2 0files/papers/ (acesso em junho de 2017).

Corfu, F., Hanchar, J.M., Hoskin, P.W.O., e Kinny, P., 2003, Atlas of zircon textures: Zircon, in Reviews in Mineralogy and Geochemistry. Ed. Mineralogical Society of America, p. 469-500, doi:10.2113/0530469.

Crosta, A.P., Choudhuri, A., Szabó, G.A.J., Schrank, A., 1986, Relações entre tipos litológicos e suas estruturas regionais nos terrenos arqueanos e paleoproterozoicos do sudoeste de Minas Gerais, in Congresso Brasileiro de Geologia, 34, Goiânia, Goiás, p. 720-721.

Del Lama, E.A., Zanardo, A., Oliveira, M.A.F., Morales, N., 2000, Exhumation of highpressure granulites of the Guaxupé complex, southeastern Brazil: Geological Journal, v. 35, p. 231-249, doi: 10.1002/gj.859.

Del Lama, E.A., Oliveira, M.A.F., Zanardo, A., 1994, Geotermobarometria em rochas do Complexo Campos Gerais ao norte da Zona de Cisalhamento de Varginha. Revista Brasileira de Geociências. v. 24, p. 233-239, doi:10.25249/0375-7536.1994233239.

Del Lama, E.A., 1993, Petrologia das rochas metamórficas de alto grau do Complexo Campos Gerais e correlação com as do Complexo Varginha-Guaxupé: estudos termobarométricos [Dissertação de Mestrado]: Rio Claro, Universidade Estadual Paulista, 132 p.

Dickinson, W.R., e Gehrels, G.E., 2009, Use of U-Pb ages of detrital zircons to infer maximum depositional ages of strata: A test against a Colorado Plateau Mesozoic database: Earth and Planetary Science Letters, v. 288, p. 115-125, doi:10.1016/j.epsl.2009.09.013

Dickson, B.L., e Scott, K.M., 1997, Interpretation of aerial gamma-ray surveys - adding the geochemical factors: AGSO Journal of Australian Geology and Geophysics, v. 17, p. 187200, doi: http://pid.geoscience.gov.au/dataset/ga/81502.

Diener, J.F.A., e Powell, R., 2010, Influence of ferric iron on the stability of mineral assemblages: Journal of Metamorphic Geology, v. 28, p. 599-613, doi:10.1111/j.15251314.2010.00880.x.

Dorr II, J.V.N., 1969, Physiographic, stratigraphic, and structural development of the Quadrilatero Ferrifero, Minas Gerais, Brazil: U.S. Geology Survey Professional Paper, v. 641-A, p. 1-110, doi:10.3133/pp641A.

DPP, CGPLAN, IPR/DNIT, 2013, Mapa Multimodal, Minas Gerais: Departamento Nacional de Infraestrutura de Transportes, escala 1:1.580.000.

Infraestrutura de Transportes, escala 1:1.580.000.

Duque, T.R.F., 2018, O Grupo Itacolomi em sua área tipo: estratigrafia, estrutura e significado tectônico [Dissertação de Mestrado]: Ouro Preto, Universidade Federal de Ouro Preto, $101 \mathrm{p}$.

Duque, T.R.F. Alkmim, F.F., Lana, C.C., 2020, Grão detríticos de zircão do grupo Itacolomi em sua área tipo, Quadrilátero Ferrífero, Minas Gerais: idades, proveniência e significado tectônico: Geologia USP, Série Científica, v. 20, p. 101-123, doi:10.11606/issn.23169095.v20-151397

Dutra, L.F., Martins, M., e Lana, C., 2019, Sedimentary and U-Pb detrital zircons provenance of the Paleoproterozoic Piracicaba and Sabará groups, Quadrilátero Ferrífero, Southern São 
Francisco craton, Brazil: Brazilian Journal of Geology, v. 49, doi:10.1590/23174889201920180095.

Elhlou, S., Belousova, E., Griffin, W.L., Pearson, N.J., O’reilly, S.Y., 2006, Trace element and isotopic composition of GJ-red zircon standard by laser ablation, in Geochimica et Cosmochimica Acta: http://hdl.handle.net/1959.14/1245004 (acesso em setembro de 2019).

Falci, A., Caxito, F. de A., Seer, H.J., Valeriano, C. de M., Dias, P.H.A., e Pedrosa-Soares, A.C., 2018, Provenance shift from a continental margin to a syn-orogenic basin in the Neoproterozoic Araxá nappe system, southern Brasília belt, Brazil: Precambrian Research, v. 306, p. 209-219, doi:10.1016/j.precamres.2018.01.004.

Farina, F., Albert, C., e Lana, C., 2015, The Neoarchean transition between medium-and highK granitoids: Clues from the Southern São Francisco Craton (Brazil): Precambrian Research, v. 266, p. 375-394, doi:10.1016/j.precamres.2015.05.038.

Fayad, D.A.C., 2013, Cromititos dos Complexos Campos Gerais e Petúnia (Faixa Brasília Meridional) na região de Alpinópolis e Nova Resende (MG): Geologia, petrografia, química mineral e ambientação tectono-magmática [Dissertação de Mestrado]: São Paulo, Universidade de São Paulo, 99 p.

Fedo, C.M., Sircombe, K.N., e Rainbird, R.H., 2003, Detrital zircon analysis of the sedimentary record: Zircon, in Reviews in Mineralogy and Geochemistry. Ed. Mineralogical Society of America, p. 277-303, doi:10.2113/0530277.

Feola, J.L., 2004, Mineralizações auríferas hospedadas na Faixa Metavulcanossedimentar Jacuí-Bom Jesus da Penha - sudoeste de Minas Gerais [Tese de Doutorado]: Rio Claro, Universidade Estadual Paulista, 211 p.

Frost, B.R., 1975, Contact Metamorphism of Serpentinite, Chloritic Blackwall and Rodingite at Paddy-Go-Easy Pass, Central Cascades, Washington: Journal of Petrology, v. 16, p. 272 313, doi:10.1093/petrology/16.1.272

Frugis, G.L., Campos Neto, M. da C., e Lima, R.B., 2018, Eastern Paranapanema and southern São Francisco orogenic margins: Records of enduring Neoproterozoic oceanic convergence and collision in the southern Brasília Orogen: Precambrian Research, v. 308, p. 35-57, doi:10.1016/j.precamres.2018.02.005.

Fu, B., Page, F.Z., Cavosie, A.J., Fournelle, J., Kita, N.T., Lackey, J.S., Wilde, S.A., e Valley, J.W., 2008, Ti-in-zircon thermometry: Applications and limitations: Contributions to Mineralogy and Petrology, v. 156, p. 197-215, doi:10.1007/s00410-008-0281-5.

Fumes, R.A., Luvizotto, G., Moraes, R., Lanari, P., Valeriano, C., Zack, T., Caddick, M., Simões, L.S., 2020, P-T-t path of high-pressure granulite facies rocks from Southern Brasília Orogen, SE Brazil: combining quantitative compositional mapping, single-element thermometery and geochronology: Journal of Metamorphic Geology (submetido)

García-Casco, A., Haissen, F.,Castro, A., El-Hmidi, H., Torres-Roldán, R.L., Millán, G., 2003, Synthesis of Staurolite in Melting Experiments of a Natural Metapelite: Consequences for the Phase Relations in Low-Temperature Pelitic Migmatites: Journal of Petrology, v. 44, p. 1727-1757, doi:10.1093/petrology/egg056

García-Casco, A., Torres-Roldán, R. L., Millán, G., Monié, P., Haissen, F., 2001, High-grade metamorphism and hydrous melting of metapelites in the Pinos terrane (W Cuba): evidence for crustal thickening and extension in the northern Caribbean collisional belt: Journal of Metamorphic Geology, v. 19, p. 699-715, doi:10.1046/j.02634929.2001.00343.x

Gehrels, G., 2014, Detrital Zircon U-Pb Geochronology Applied to Tectonics: Annual Review of Earth and Planetary Sciences, v. 42, p. 127-149, doi:10.1146/annurev-earth050212-124012.

Gehrels, G., 2013, Determining Max Depositional Ages, disponível em: 
https://sites.google.com/a/laserchron.org/laserchron/home. (acesso em janeiro de 2017).

Gehrels, G., Giesler, D., Pecha, M., 2012, Detrital zircon geochronology with $\mathrm{n}=1000$. Geological Society of America Abstracts with Programs, v. 44, p. 71, https://gsa.confex.com/gsa/2012AM/webprogram/Paper211517.html. (acesso em agosto de 2019).

Geisler, T., Pidgeon, R.T., Kurtz, R., van Bronswijk, W., Schleicher, H., 2003a, Experimental hydrothermal alteration of partially metamict zircon: American Mineralogist, v. 88, p. 1496-1543, doi:10.2138/am-2003-1013

Geisler, T., Rashwan, A.A., Rahn, M.K.W., Poller, U., Zwingmann, H., Pidgeon, R.T., Schleicher, H., Tomaschek, F., 2003b, Low-temperature hydrothermal alteration of natural metamict zircons from the Eastern Desert, Egypt: Mineralogical Magazine, v. 67, p. 485508, doi: 10.1180/0026461036730112

Geisler, T., Pidgeon, R.T., van Bronswijk, W., Pleysier, R., 2001a, Kinetics of thermal recovery and recrystallization of partially metamict zircon: a Raman spectroscopic study: European Journal of Mineralogy, v. 13, p. 1163-1176, doi: 10.1127/0935-1221/2001/00131163

Geisler, T., Ulonska, M., Schleicher, H., Pidgeon, R.T., van Bronswijk, W., 2001b, Leaching and differential recrystallization of metamict zircon under experimental hydrothermal conditions: Contributions to Mineralogy and Petrology, v. 141, p. 53-65, doi: $10.1007 / \mathrm{s} 004100000202$

Geisler, T., Schaltegger, Urs, Tomaschek, F., 2007, Re-equilibration of Zircon in Aqueous Fluids and Melts: Elements, v. 3, p. 43-50, doi:10.2113/gselements.3.1.43 https://archiveouverte.unige.ch/unige: 28473

Griffin, E. L., Powell, W.J., Pearson, N. J., O’Reilly, S. Y., 2008, GLITTER: Data reduction software for laser ablation ICP-MS, in Sylvester, P., ed., Laser Ablation ICP-MS in the Earth Sciences: current practices and outstanding issues. Vancouver: Mineralogical Association of Canada Short Course Series, p- 307-311.

Grimes, C.B., Wooden, J.L., Cheadle, M.J., John, B.E., 2015, "Fingerprinting" tectono-magmatic provenance using trace elements in igneous zircon: Contributions of Mineralogy and Petrology, v. 170, p. 1-26, doi:10.1007/s00410-015-1199-3.

Grimes, C.B., John, B.E., Kelemen, P.B., Mazdab, F.K., Wooden, J.L., Cheadle, M.J., Hanghøj, K., e Schwartz, J.J., 2007, Trace element chemistry of zircons from oceanic crust: A method for distinguishing detrital zircon provenance: Geology, v. 35, p. 643-646, doi:10.1130/G23603A.1.

Grimes, C.B., Wooden, J.L., Cheadle, M.J., e John, B.E., 2015, "Fingerprinting” tectonomagmatic provenance using trace elements in igneous zircon: Contributions to Mineralogy and Petrology, v. 170, p. 1-26, doi:10.1007/s00410-015-1199-3.

Grohmann, C.H., Campanha, G.A.C., Soares Junior, A.V., 2011, OPENSTEREO: Um programa livre e multiplataforma para análise de dados estruturais, in Simpósio Nacional De Estudos Tectônicos, 13, Campinas, São Paulo.

Guo, L., Zhang, H.F., Harris, N., Xu, W.C., e Pan, F. Bin, 2017, Detrital zircon U-Pb geochronology, trace-element and Hf isotope geochemistry of the metasedimentary rocks in the Eastern Himalayan syntaxis: Tectonic and paleogeographic implications: Gondwana Research, v. 41, p. 207-221, doi:10.1016/j.gr.2015.07.013.

Guynn, J., e Gehrels, G., 2010, Comparison of Detrital Zircon Age Distributions Using the K$S$ Test Visualization and representation of age-distribution data Histograms, https://sites.google.com/a/laserchron.org/laserchron/home (acesso em maio de 2017).

Hasui Y., Oliveira, M.A.F., 1984, Província Mantiqueira - Setor Central. O Pré-cambriano do Brasil, Edgard Blücher, São Paulo, p. 308-344.

Hey, M., 1954, A new review of the chlorites: Mineralogical Magazine and Journal of the 
Mineralogical Society, v. 30(224), p. 277-292, doi:10.1180/minmag.1954.030.224.01

Holland, T.J.B., e Powell, R., 2011, An improved and extended internally consistent thermodynamic dataset for phases of petrological interest, involving a new equation of state for solids: Journal of Metamorphic Geology, v. 29, p. 333-383, doi:10.1111/j.15251314.2010.00923.x.

Holland, T.J.B., Powell, R., 1998, An internally consistent thermodynamic dataset for phases of petrological interest: Journal of Metamorphic Geology, v. 16, p. 309-344, doi:10.1111/j.1525-1314.1998.00140.x.

Holland, T. J. B., Powell, R., 1990, An internally-consistent thermodynamic dataset with uncertainties and correlations: the system $\mathrm{Na}_{2} \mathrm{O}-\mathrm{K}_{2} \mathrm{O}-\mathrm{CaO}-\mathrm{MgO}-\mathrm{MnO}-\mathrm{FeO}-\mathrm{Fe}_{2} \mathrm{O}_{3}-$ $\mathrm{Al}_{2} \mathrm{O}_{3}-\mathrm{SiO}_{2}-\mathrm{TiO}_{2}-\mathrm{C}-\mathrm{H}_{2}-\mathrm{O}_{2}$ : Journal of Metamorphic Geology, v. 8, p. 89-124, doi: 10.1111/j.1525-1314.1990.tb00458.x

Hoskin, P.W.O., 2005, Trace-element composition of hydrothermal zircon and the alteration of Hadean zircon from the Jack Hills, Australia: Geochimica et Cosmochimica Acta, v. 69, p. 637-648, doi:10.1016/j.gca.2004.07.006.

Hoskin, P.W.O., e Schaltegger, U., 2003, The composition of zircon and igneous and metamorphic petrogenesis: Zircon, Reviews in Mineralogy and Geochemistry. Ed. Mineralogical Society of America, p. 27-62, doi:10.2113/0530027.

Hoskin, P.W.O., 2000, Patterns of chaos: Fractal statistics and the oscillatory chemistry of zircon: Geochimica et Cosmochimica Acta, v. 64, p. 1905-1923, doi:10.1016/S00167037(00)00330-6.

Hoskin, P.W.O., e Black, L.P., 2000, Metamorphic zircon formation by solid-state recrystallization of protolith igneous zircon: Journal of Metamorphic Geology, v. 18, p. 423-439, doi:10.1046/j.1525-1314.2000.00266.x.

Hoskin, P.W.O., e Ireland, T.R., 2000, Rare earth element chemistry of zircon and its use as a provenance indicator: Geology, v. 28, p. 627-630, doi:10.1130/00917613(2000)028<0627:REECOZ>2.3.CO;2.

Hurford, A., Fitch, F., Clarke, A., 1984, Resolution of the age structure of the detrital zircon populations of two Lower Cretaceous sandstones from the Weald of England by fission track dating: Geological Magazine, v. 121, p. 269-396.

International Atomic Energy Agency, 2003, Mapping Using Gamma Ray: Encyclopedia of Atmospheric Sciences, v. 4, p. 1549-1555., disponível em: http://cdiac.esd.ornl.gov/oceans/GLODAP/glodap_pdfs/Thermohaline.web.pdf.

Jamieson, R.A., Beaumont, C., Medvedev, S., Nguyen, M.H., 2004, Crustal channel flows: 2. Numerical models with implications for metamorphism in the Himalayan-Tibetan orogen. Journal of Geophysical Research, v. 109, p. 1-24, doi:10.1029/2003JB002811

Jenkins, D.M., Chernosky J.V., 1986, Phase equilibria and crystallochemical properties of Mg-chlorite: American Mineralogist, v. 71, p. 924-936, disponível em: http://www.minsocam.org/ammin/AM71/AM71_924.pdf, acesso em junho de 2017.

Jochum, K.P., Weis, U., Stoll, B., et al., 2011, Determination of Reference Values for NIST SRM 610-617 Glasses Following ISO Guidelines: Geostandards and Geoanalytical Research, v. 35, p. 397-429, doi:10.1111/j.1751-908X.2011.00120.x.

Kaefer, L.Q. et al., 1979, Projeto Sapucaí, estados de São Paulo, Rio de Janeiro e Minas Gerais. Relatório final de geologia. Departamento Nacional de Produção Mineral, Brasília, Superintendência Regional de São Paulo, 299 p.

Kohn, M.J., Spear, F., 2000, Retrograde net transfer reaction insurance for pressuretemperature estimates: Geology, v. 28, p. 1127-1130, doi:10.1130/00917613(2000)28<1127:RNTRIF>2.0.CO;2

Kriegsman, L.M., 2001, Partial melting, partial melt extraction and partial back reaction in anatectic migmatites: Lithos, v.56, p. 75-96, doi:10.1016/S0024-4937(00)00060-8 
Lana, C., Alkmim, F.F., Armstrong, R., Scholz, R., Romano, R., e Nalini, H.A., 2013, The ancestry and magmatic evolution of Archaean TTG rocks of the Quadrilátero Ferrífero province, southeast Brazil: Precambrian Research, v. 231, p. 157-173, doi:10.1016/j.precamres.2013.03.008.

Leake, B.E., Woolley, A.R., Arps, C.E.S., et al., 1997, Nomenclature of amphiboles: Report of the subcommittee on amphiboles of the International Mineralogical Association, Commission on New Minerals and Mineral Names: Canadian Mineralogist, v. 35, p. 219246.

Lopes, L.B.L., 2013, Granitogênese e metamorfismo da fácies granulito da porção sul da Faixa Brasília, Areado, Minas Gerais [Monografia de Conclusão de Curso]: São Paulo, Universidade de São Paulo, 52 p.

Ludwig, K.R., 1998, On the treatment of concordant uranium-lead ages: Geochimica et Cosmochimica Acta, v. 62, p. 665-676, doi:10.1016/S0016-7037(98)00059-3.

Luvizotto, G.L., Zack, T., Triebold, S., von Eynatten, H., 2009, Rutile occurrence and trace element behavior in medium-grade metasedimentary rocks: example from the Erzgebirge, Germany: Mineralogy and Petrology, v. 97, p. 233-249, doi: 10.1007/s00710-009-0092-z.

Luvizotto G., 2003, Caracterização metamórfica das rochas do Grupo Araxá na região de São Sebastião do Paraíso, sudoeste de Minas Gerais [Dissertação de Mestrado]: Rio Claro, Universidade Estadual Paulista, 152 p.

Machado Filho, L., Ribeiro, M.W., Gonzalez, S.R., et al. 1983, Geologia, in Departamento Nacional de Produção Mineral, Folhas SF. 23/24, Rio de Janeiro/Vitoria: geologia, geomorfologia, pedologia, vegetação, uso potencial da terra/ Projeto RADAM Brasil, Levantamento de Recursos Naturais, 32, Rio de Janeiro, 780 p.

Machado, N., e Carneiro, M., 1992, U-Pb evidence of late Archean tectono-thermal activity in the southern Sao Francisco shield, Brazil: Canadian Journal of Earth Sciences, v. 29, p. 2341-2346, doi:10.1139/e92-182.

Machado, N., Schrank, A., Noce, C.M., e Gauthier, G., 1996, Ages of detrital zircon from archean - Paleoproterozoic sequences: Implications for greenstone belt setting and evolution of a transamazonian foreland basin in Quadrilátero Ferrífero, southeast Brazil: Earth and Planetary Science Letters, v. 141, p. 259-276, doi:10.1016/0012$821 \times(96) 00054-4$.

Marinho, K.S.M., 2014, Petrogênese do Granulito Pedra Dourada [Dissertação de Mestrado]: Ouro Preto, Universidade Federal de Ouro Preto, 115 p.

Martínez Dopico, C.I., Lana, C., Moreira, H.S., Cassino, L.F., e Alkmim, F.F., 2017, U-Pb ages and Hf-isotope data of detrital zircons from the late Neoarchean-Paleoproterozoic Minas Basin, SE Brazil: Precambrian Research, v. 291, p. 143-161, doi:10.1016/j.precamres.2017.01.026.

Medeiros-Junior, E.B., 2016, Evolução petrogenéticade terrenos granulíticos nos estados de Minas Gerais e Espírito Santo [Tese de Doutorado]: Ouro Preto, Universidade Federal de Ouro Preto, 165 p.

Miller, H.G. e Singh, V., 1994, Potential Field Tilt a New Concept for Location of Potential Field Sources: Journal of Applied Geophysics, v. 32, p. 213-217, doi:10.1016/09269851(94)90022-1.

Minty, B.R.S., 1997, Fundamentals of airborne gamma-ray spectrometry: Journal of Australian Geology \& Geophysics, v. 17, p. 39-50.

Mogk, D., Gibbs' Phase Rule: Where it all Begins, disponível em: http://serc.carleton.edu/research_education/equilibria/phaserule.html. Acesso junho de 2017.

Monteiro, C.F., Marques, G.C., de Oliveira, C.G., Silva, A.M., Dantas, E.L., 2007, Análise e Interpretação de Dados Aerogeofísicos Aplicados ao Mapeamento Geológico no Arco 
Magmático de Mara Rosa, Goiás, Brasil Central, in International Congresso of the Brazilian Geophysical Society, 10, p. 1028-1033, doi:10.1190/sbgf2007-197.

Morales N., 1993, Evolução Tectônica do Cinturão de Cisalhamento Campo do Meio na sua porção ocidental [Tese de Doutorado]: Rio Claro, Universidade Estadual Paulista, 270 p.

Morales, N., Carvalho, S.G., Choudhuri, A., Fiori, A.P., Oliveira, M.A.F., Rodrigues, M.F.B., Soares, P.C., Zanardo, A., 1983, Geologia das folhas de Fortaleza de Minas, Alpinópolis, Jacuí e Nova Resende, MG, in Simpósio de Geologia de Minas Gerais, 2, Belo Horizonte, Minas Gerais, p. 411-422.

Morales, N., Hasui, Y., 1993, Evolução tectônica da porção ocidental do Cinturão de Cisalhamento Campo do Meio, in Simpósio Nacional de Estudos Tectônicos, 4, Belo Horizonte, Minas Gerais, p. 292-296.

Morales, N., Zanardo, A., Simões, L.S.A., Godoy, A.M., 1991, A zona de cisalhamento Campo do Meio na região entre Fortaleza de Minas e Alpinópolis, sul de Minas Gerais. in Simpósio Nacional De Estudos Tectônicos, 3, UNESP, Rio Claro, p. 34-60

Mori, P.E., Reeves, S., Correia, C.T., Haukka, M., 1999, Development of a fused glass disc XRF facility and comparison with the pressed powder pellet technique at Instituto de Geociências, Universidade de São Paulo: Revista Brasileira de Geociências, v. 29, p. 441446.

Motta, R.G., Moraes, R., 2017, Pseudo- and real-inverted metamorphism caused by the superposition and extrusion of a stack of nappes: a case study of the Southern Brasília Orogen, Brazil. International Journal Earth Science, v. 106, p. 24072427,doi:10.1007/s00531-016-1436-7.

Motta, R.G., De Moraes, R., Trouw, R.A.J., e Da Costa Campos Neto, M., 2010, Reconstrução e comparação de trajetórias P-T no sistema de nappes andrelândia, sul da faixa brasília, MG: Geologia USP - Serie Cientifica, v. 10, p. 79-96.

Moya, F.A., Szabó, G.A.J., 2000, Implicações das variações composicionais e texturais de cloritas e anfibólios em rochas metaultramáficas de domínios tectono-estratigráficos distintos do Complexo Campos Gerais (sudoeste de Minas Gerais). Resumo SIICUSP.

Nardi, L.V.S., Formoso, M.L.L., Müller, I.F., Fontana, E., Jarvis, K., e Lamarão, C., 2013, Zircon/rock partition coefficients of REEs, Y, Th, U, Nb, and Ta in granitic rocks: Uses for provenance and mineral exploration purposes: Chemical Geology, v. 335, p. 1-7, doi:10.1016/j.chemgeo.2012.10.043.

Nasdala, L., Hanchar, J.M., Rhede, D., Kennedy, A.K., Váczi, T., 2010, Retention of uranium in complexly altered zircon: An example from Bancroft, Ontario: Chemical Geology, v. 269, p. 290-300, doi:10.1016/j.chemgeo.2009.10.004.

Nesbitt, H.W. and Young, G.M., 1996, Petrogenesis of sediments in the absence of chemical weathering: effects of abrasion and sorting on bulk composition and mineralogy: Sedimentology, v. 43, p. 341-358, doi:10.1046/j.1365-3091.1996.d01-12.x

Oliveira, A.H., 2004, Evolução tectônica de um fragmento do Cráton São Francisco Meridional com base em aspectos estruturais, geoquímicos (rocha total) e geocronológicos ( $\mathrm{Rb}-\mathrm{Sr}, \mathrm{Sm}-\mathrm{Nd}, \mathrm{Ar}-\mathrm{Ar}, \mathrm{U}-\mathrm{Pb}$ ) [Tese de Doutorado]: Ouro Preto, Universidade Federal de Ouro Preto, 196 p.

Oliveira, M.A.F., Carvalho, S.G., Morales, N., Rodrigues, M.F.B., Zanardo, A., 1983, Geologia das quadrículas de Cássia e São Sebastião do Paraíso, MG, in Simpósio de Geologia de Minas Gerais, 2, Belo Horizonte, Minas Gerais, p. 432-439.

Paciullo, F.V.P., Ribeiro, A., Cherman, A., Chrispim, S., Maciel, R.R., 2008, Programa Geologia do Brasil: Folha Nepomuceno, SF-23-V-D-III, escala 1:100.000. Nota explicativa, Brasília: CPRM, 92 p.

Pearce, M.A., White, A.J.R., e Gazley, M.F., 2015, TCInvestigator: Automated calculation of mineral mode and composition contours for thermocalc pseudosections: Journal of 
Metamorphic Geology, v. 33, p. 413-425, doi:10.1111/jmg.12126.

Perkins, D., Mogk, D., Method of Schreinemakers - A Geometric Approach to Constructing

Phase

Diagrams.

Disponível

em:

https://serc.carleton.edu/research_education/equilibria/schreinemakers.html. Acesso em junho de 2017.

Pidgeon, R.T., 1992, Recrystallisation of oscillatory zoned zircon: some geochronological and petrological implications: Contributions to Mineralogy and Petrology, v. 110, p. 463-472, doi:10.1007/BF00344081.

Pidgeon, R.T., Nemchin, A.A., e Kinny, P.D., 2000, Fir-Tree and Nebulously Zoned Zircons from Granulite Facies Rocks: Evidence for Zircon Growth and Interaction with Metamorphic Fluids: Journal of Conference Abstracts, v. 5, p. 798.

Philpotts, A.R., Ague, J.J., 2009, Principles of Igneous and Metamorphic Geology: New York, Cambridge University Press, 667 p.

Pimentel, M.M., Ferreira Filho, M.F., 2002, Idades Sm-Nd de komatiitos do greenstone belt do Morro do Ferro, Fortaleza de Minas (MG): Revista Brasileira de Geociências, v. 32, p. 147-148.

Pinheiro, M.A.P., 2013, Geologia e petrogênese de corpos máfico-ultramáficos da Faixa Brasília Sul, borda sul do Cráton São Francisco - Minas Gerais [Tese de Doutorado]: Ouro Preto, Universidade Federal de Ouro Preto, 248 p.

Powell, R., Guiraud, M., White, R.W., 2005, Truth and beauty in metamorphic phaseequilibria: Conjugate variables and phase diagrams: Canadian Mineralogist, v. 43, p. 2133, doi:10.2113/gscanmin.43.1.21.

Powell, R., Holland, T.J.B., White, R., 2009, Thermocalc Short Course. Praga, República Checa. Disponível em: http://www.metamorph.geo.uni-mainz.de/thermocalc/. Acesso em maio de 2017.

Powell, R., Holland, T.J.B., Worley, B., 1998, Calculating phase diagrams involving solid solutions via nonlinear equations, with examples using THERMOCALC: Journal of Metamorphic Geology, v. 16, p. 577-588, doi: 10.1111/j.1525-1314.1998.00157.x.

Powell, R., e Holland, T., 1994, Optimal geothermometry and geobarometry: American Mineralogist, v. 79, p. 120-133, doi:10.1007/1-4020-4496-8_148.

Powell, R., Holland, T.J.B., 1990, Calculated mineral equilibria in the pelite system. KFMASH (K2O-FeO-MgO-Al2O3-SiO2-H2O): American Mineralogist, v. 75, p. 367380.

Powell, R., Holland, T.J.B., 1988, An internally consistent thermodynamic dataset with uncertainties and correlations: application methods, worked examples and a computer program: Journal of Metamorphic Geology, v. 6, p. 173-204, doi:10.1111/j.15251314.1988.tb00415.x.

Pupin, J.P., 2000, Granite genesis related to geodynamics from Hf-Y in zircon: Special Paper of the Geological Society of America, v. 350, p. 245-256, doi:10.1130/0-8137-2350-7.245.

Quéméneur, J.J.G., Ribeiro, A., Trouw, R.A.J., Paciullo, F.V.P., Heilbron, M., 2003, Geologia da Folha Lavras: Geologia e Recursos Minerais do Sudeste Mineiro, Projeto Sul de Minas - Etapa I, relatório final, v. 1, p. 259-319.

Rayner, N., Stern, R.A., e Carr, S.D., 2005, Grain-scale variations in trace element composition of fluid-altered zircon, Acasta Gneiss Complex, northwestern Canada: Contributions to Mineralogy and Petrology, v. 148, p. 721-734, doi:10.1007/s00410-0040633-8.

Reis, L.A., Martins-neto, M.A., Gomes, N.S., Endo, I., e Jordt-Evangelista, H., 2002, a Bacia De Antepaís Paleoproterozóica Sabará, Quadrilátero: Revista Brasileira de Geociências, v. 32, p. 27-42.

Renger, F.E., Noce, C.M., Romano, A.W., e Machado, N., 1994, Evolução Sedimentar do 
Supergrupo Minas: 500 Ma. de registro geológico no Quadrilátero Ferrífero, Minas Gerais, Brasil: Geonomos, doi:10.18285/geonomos.v2i1.227.

Ribeiro, A., Campos, M.T., Paciullo, F.V.P., Carvalho, M.V., Valeriano, C., Nascimento, D., 2010, Programa Geologia do Brasil: Folha Alfenas, SF-23-V-D-III, Brasília: CPRM, escala $1: 100.000$.

Ribeiro, V.B., Mantovani, M., e Louro, V.H.A., 2013, Aerogamaespectrometria e suas aplicações no mapeamento geológico: Terrae Didatica, v. 10, p. 29, doi:10.20396/td.v10i1.8637386.

Rodrigues, J.B., Pimentel, M.M., Dardenne, M.A., e Armstrong, R.A., 2010, Age, provenance and tectonic setting of the Canastra and Ibiá Groups (Brasília Belt, Brazil): Implications for the age of a Neoproterozoic glacial event in central Brazil: Journal of South American Earth Sciences, v. 29, p. 512-521, doi:10.1016/j.jsames.2009.08.008.

Roest, W.R., Verhoef, J. and Pilkington, M., 1992. Magnetic interpretation using the 3-D analytic signal. Geophysics, v. 57, p. 116-125, doi:10.1190/1.1443174.

Roig, H.L., 1993, Caracterização da "Zona de Sutura" Jacuí-Conceição da Aparecida, MG limite norte do Cinturão Alto Rio Grande: implicações geotectônicas e metalogenéticas [Dissertação de Mestrado]: Campinas, Universidade Estadual de Campinas, 136 p.

Roig, H.L., Schrank, A., 1992, Caracterização da zona de sutura Jacuí-Conceição da Aparecida - limite norte do complexo de nappes de Guaxupé, in Congresso Brasileiro de Geologia, 37, São paulo, SP, p.283-285

Romano, R., Lana, C., Alkmim, F.F., Stevens, G., e Armstrong, R., 2013, Stabilization of the southern portion of the São Francisco craton, SE Brazil, through a long-lived period of potassic magmatism: Precambrian Research, v. 224, p. 143-159, doi:10.1016/j.precamres.2012.09.002.

Rubatto, D., 2017, Zircon: The Metamorphic Mineral: v. 83, 261-295 p., doi:10.2138/rmg.2017.83.09.

Rubatto, D., 2002, Zircon trace element geochemistry: partitioning with garnet and the link between U-Pb ages and metamorphism: Chemical Geology, v. 184, p. 123-138, doi:10.1016/S0009-2541(01)00355-2.

Rubatto, D., Chakraborty, S., e Dasgupta, S., 2013, Timescales of crustal melting in the Higher Himalayan Crystallines (Sikkim, Eastern Himalaya) inferred from trace elementconstrained monazite and zircon chronology: Contributions to Mineralogy and Petrology, v. 165, p. 349-372, doi:10.1007/s00410-012-0812-y.

Rubatto, D., Gebauer, D., 2000, Use of cathodoluminescence for U-Pb zircon dating by ion microprobe: some examples from the Western Alps, in Pagel, M., Barbin, V., Blanc, P., Ohnenstetter, D., eds., Cathodoluminescence in geosciences: Springer, Berlin Heidelberg New York, p. 373-400.

Rubatto, D., Gebauer, D., Compagnoni, R., 1999, Dating of eclogite-facies zircons: the age of Alpine metamorphism in the Sesia-Lanzo Zone (Western Alps): Earth and Planetary Science Letters, v. 167, p. 141-158, doi:10.1016/S0012-821X(99)00031-X.

Rueden, C. T., Schindelin, J., Hiner, M. C., DeZonia, B. E., Walter, A. E., Arena, E. T., \& Eliceiri, K. W., 2017, ImageJ2: ImageJ for the next generation of scientific image data. BMC Bioinformatics, v. 18:529, doi:10.1186/s12859-017-1934-z.

Schaltegger, U., 2007, Hydrothermal zircon: Elements, v. 3, doi:10.2113/gselements.3.1.51.

Schaltegger, U., Fanning, C.M., Günther, D., Maurin, J.C., Schulmann, K., e Gebauer, D., 1999, Growth, annealing and recrystallization of zircon and preservation of monazite in high-grade metamorphism: Conventional and in-situ U-Pb isotope, cathodoluminescence and microchemical evidence: Contributions to Mineralogy and Petrology, v. 134, p. 186201, doi:10.1007/s004100050478.

Schindelin, J., Arganda-Carreras, I., Frise, E., Kaynig, V., Longair, M., Pietzsch, T., ... 
Cardona, A., 2012, Fiji: an open-source platform for biological-image analysis: Nature Methods, v. 9(7), p. 676-682, doi:10.1038/nmeth.2019.

Schrank A., Silva M.G., 1993, Greenstone belt do Cráton do São Francisco, Brasil, in Dominguez, J.M.L., Misi, A., eds, O Cráton do São Francisco: SBG/SGM/CNPq, Salvador, p.85-118.

Schumacher, J.C., 2007, Metamorphic Amphiboles: Composition and Coexistence: Reviews in Mineralogy and Geochemistry, v. 67, p. 359-416, doi:10.2138/rmg.2007.67.10

Seixas, L.A.Ô.R., Bardintzeff, J.M., Stevenson, R., Bonin, B., 2013, Petrology of the high-Mg tonalites and dioritic enclaves of the ca. 2130 Ma Alto Maranhão suite: Evidence for a major juvenile crustal addition event during the Rhyacian orogenesis, Mineiro Belt, southeast Brazil: Precambrian Research, v. 238, p. 18-41, doi:10.1016/j.precamres.2013.09.015.

Seixas, L.A.R., David, J., e Stevenson, R., 2012, Geochemistry, Nd isotopes and U-Pb geochronology of a 2350Ma TTG suite, Minas Gerais, Brazil: Implications for the crustal evolution of the southern São Francisco craton: Precambrian Research, v. 196-197, p. 6180, doi:10.1016/j.precamres.2011.11.002.

Shaw, D.M., 1956, Geochemistry of pelitic rocks. Part III: major elements and general geochemistry: Bulletin of Geological Society of America, v. 67, p. 919-934, doi: 10.1130/0016-7606(1956)67[919:GOPRPI]2.0.CO;2

Sircombe, K.N., 2004, AgeDisplay: An EXCEL workbook to evaluate and display univariate geochronological data using binned frequency histograms and probability density distributions: Computers and Geosciences, v. 30, p. 21-31, doi:10.1016/j.cageo.2003.09.006.

Sircombe, K.N., 2000, The usefulness and limitations of binned frequency histograms and probability density distributions for displaying absolute age data. Radiogenic age and isotopic studies, Report 13, Geological Survey of Canada, Current Research 2000-F2, $11 \mathrm{pp}$.

Silva, M., 2010, Modelamento metamórfico de rochas das fácies xisto-verde e anfibolito com o uso de pseudosseções: exemplo das rochas da Klippe Carrancas, sul de Minas Gerais [Dissertação de Mestrado]: São Paulo, Universidade de São Paulo, 138 p.

Simões, L.S.A., 1995, Evolução tectono-metamórfica da nappe de Passos, sudoeste de Minas Gerais [Tese de Doutorado]: São Paulo, Universidade de São Paulo, 149 p.

Soares, P.C., Carvalho, S.G., Fiori, A.P., 1991, Evolução tectônica dos terrenos máficoultramáficos na margem sul do Cráton do São Francisco, in Simpósio Nacional de Estudos Tectônicos, 3, Rio Claro, São Paulo, p. 66-68.

Soares, P.C., Fiori, A.P., 1990, Tectônica Colisional Oblíqua entre o Bloco Paraná e a margem sul do Cráton do São Francisco, no Maciço de Guaxupé, in Congresso Brasileiro de Geologia, 36, Natal, Rio Grande do Norte, p. 2723-2734.

Spear, F.S., Cheney, J.T., 1989, A petrogenetic grid for politic schists in the system $\mathrm{SiO}_{2}-$ $\mathrm{Al}_{2} \mathrm{O}_{3}-\mathrm{FeO}-\mathrm{MgO}-\mathrm{K}_{2} \mathrm{O}-\mathrm{H}_{2} \mathrm{O}$ : Contributions to Mineralogy and Petrology, v. 101, p. 149164, doi:10.1007/BF00375302.

Spear, F., Kohn, M., Cheney, J., 1999, $P-T$ paths from anatectic pelites: Contributions to Mineralogy and Petrology, v. 134, p. 17-32, doi:10.1007/s004100050466.

Spear, F.S., 1993, Metamorphic Phase Equilibria and Pressure-Temperature-Time Paths. Mineralogical Society of America, Washington, D. C., 799 p.

Spencer, C.J., Kirkland, C.L., e Taylor, R.J.M., 2016, Strategies towards statistically robust interpretations of in situ U-Pb zircon geochronology: Geoscience Frontiers, v. 7, p. 581589, doi:10.1016/j.gsf.2015.11.006.

Sun, S.S., Mcdonough, W.F., 1989. Chemical and isotopic systematics of oceanic basalts: implications for mantle composition and processes. Geological. Society, London, Special 
Publications, v. 42, p. 313-345, doi:10.1144/GSL.SP.1989.042.01.19.

Stüwe, K., 1997, Effective bulk composition changes due to cooling: a model predicting complexities in retrograde reaction textures: Contributions to Mineralogy and Petrology, v. 129, p. 43-52, doi:10.1007/s004100050322.

Szabó, G.A.J., Rolo, H.L., Schrank, A., Choudhuri, A., 1993, Duas faixas litoestruturais distintas e o limite das Províncias Tocantins e Mantiqueira, entre Alpinópolis e Nova Resende (MG), in Simpósio sobre o Cráton do São Francisco, Salvador, BA, p. 272-274.

Szabó, G.A.J., 1996, Petrologia da Suíte Metaultramáfica da Sequência Vulcano-Sedimentar Morro do Ferro na Região de sul a oeste de Alpinópolis, MG (Domínio Norte do Complexo Campos Gerais) [Tese de Doutorado]: São Paulo, Universidade de São Paulo, $354 \mathrm{p}$.

Szabó, J.A.G., 1989, Contexto Geológico e Petrologia das Rochas Metaultramáficas de Alpinópolis, Minas Gerais [Dissertação de Mestrado]: São Paulo, Universidade de São Paulo, 203 p.

Teixeira, N.A., 1978, Geologia, petrologia e prospecção geoquímica da sequência vulcanossedimentar Morro do Ferro, Fortaleza de Minas (MG) [Dissertação de Mestrado]: Brasília, Universidade de Brasília.

Teixeira, N.A., Danni, J.C.M., 1979, Geologia da raiz de um greenstone belt na região de Fortaleza de Minas, MG: Revista Brasileira de Geociências, v. 9, p. 17-26.

Teixeira, N.A., Gaspar, J.C., Brenner, T.L., Cheney, J.T., Marchetto, C.M.L., 1987, Geologia e implicações geotectônicas do Greenstone Belt Morro do Ferro (Fortaleza de Minas-MG). Revista Brasileira de Geociências, São Paulo, v. 17, p. 209-220.

Teixeira W., Oliveira E.P., Marques L.S. 2017. Nature and Evolution of the Archean Crust of the Sao Francisco Craton, in Heilbron, M., Cordani, U.G., Alkmim, F.F., eds., São Francisco Craton, Eastern Brazil: Tectonic Genealogy of a Miniature Continent: Springer International Publishing, New York, Regional Geology Reviews, p. 29-56, doi:10.1007/978-3-319-01715-0_3

Teixeira, W., Ávila, C.A., Dussin, I.A., Corrêa Neto, A. V., Bongiolo, E.M., Santos, J.O., e Barbosa, N.S., 2015, A juvenile accretion episode (2.35-2.32Ga) in the Mineiro belt and its role to the Minas accretionary orogeny: Zircon U-Pb-Hf and geochemical evidences: Precambrian Research, v. 256, p. 148-169, doi:10.1016/j.precamres.2014.11.009.

Teixeira, W., Ávila, C.A., Bongiolo, E.M., Hollanda, M.H.B., Barbosa, N.S., 2014, Age and tectonic significance of the Ritápolis batholith, Mineiro belt (Southern São Francisco Craton): U-Pb LA-ICPMS, Nd isotopes and geochemical evidence, in South American Symposium on Isotope Geology, $9^{\text {th }}$, p. 2014.

Teixeira, W., Ávila, C.A., e Nunes, L.C., 2008, Nd-Sr Isotopic geochemistry and U-Pb geochronology of the Fé granitic gneiss and Lajedo granodiorite: Implications for paleoproterozoic evolution of the Mineiro Belt, Southern São Francisco Craton, Brazil: Geologia USP - Serie Cientifica, v. 8, p. 53-74, doi:10.5327/Z1519-874X2008000100005.

Teixeira, W., Cordani, U.G., Nutman, A.P., Sato, K., 1998, Polyphase archean evolution in the Campo Belo metamorphic complex, Southern São Francisco Craton, Brazil: SHRIMP U-Pb zircon evidence: Journal of South American Earth Sciences, v. 11, p. 279-289, doi:10.1016/S0895-9811(98)00011-X.

Teixeira, W., Akimoto, H., Siga Jr., O., Sato, K., 1989, A evolução geocronológica dos terrenos granítico-gnáissico migmatíticos ao sul da Faixa Canastra, sudoeste de Minas Gerais, in Simpósio de Geologia de Minas Gerais, 5, Belo Horizonte, Minas Gerais, p. 243-246.

Thompson, A.B., Connolly, J.A.D., 1995, Melting of the continental crust: some thermal and petrological constraints on anatexis in continental collision zones and other tectonic settings: Journal of Geophysical Research, v. 100, p. 15565-15579, doi: 


\subsection{9/95JB00191}

Thompson Jr., J.B., 1957, The graphical analysis of mineral assemblages in pelitic schists: American Mineralogist, v. 42, p. 842-858, disponível em: http://www.minsocam.org/ammin/AM42/AM42_842.pdf, acesso em março de 2020.

Tomkins, H.S., Powell, R., e Ellis, D.J., 2007, The pressure dependence of the zirconium-inrutile thermometer: Journal of Metamorphic Geology, v. 25, p. 703-713, doi:10.1111/j.1525-1314.2007.00724.x.

Toscano, M., Pascual, E., Nesbitt, R.W., Almodóvar, G.R., Sáez, R., e Donaire, T., 2014, Geochemical discrimination of hydrothermal and igneous zircon in the Iberian Pyrite Belt, Spain: Ore Geology Reviews, v. 56, p. 301-311, doi:10.1016/j.oregeorev.2013.06.007.

Trouw, R.A.J., Peternel, R., Ribeiro, A., Heilbron, M., Vinagre, R., Duffles, P., Trouw, C.C., Fontainha, M., e Kussama, H.H., 2013, A new interpretation for the interference zone between the southern Brasília belt and the central Ribeira belt, SE Brazil: Journal of South American Earth Sciences, v. 48, p. 43-57, doi:10.1016/j.jsames.2013.07.012.

Trouw, R.A.J., Heilbron, M., Ribeiro, A., Paciullo, F., Valeriano, C.M., Almeida, J.C.H., Tupinambá, M., Andreis, R.R., 2000. The central segment of Ribeira belt, in Cordani, U.G., Milani, E.J., Thomaz Filho, A., Campos, D.A., eds., Tectonic Evolution of South America, International Geological Congress, 31th, Rio de Janeiro, Brazil, p. 287-310.

Trouw, R.A.J., Ribeiro, A., Paciullo, F.V.P., Heilbron, M.L., 1984, Os grupos São João Del Rei, Carrancas e Andrelândia, interpretados como a continuação dos grupos Araxá e Canastra, in Congresso Brasileiro de Geologia, 33, Rio de Janeiro, RJ, p. 3227-3240.

Turbay C.V.G., Valeriano C.M., Rossi A., Rocha E Silva V.G.M., 2008, Geologia do Complexo Campos Gerais ao sul de Alpinópolis, sudoeste de Minas Gerais: Geonomos, v. 16, p. 79-90, doi:10.18285/geonomos.v16i2.86.

Turbay C.V.G., Valeriano C.M., 2012, Litogeoquímica do Complexo Campos Gerais e granitoides intrusivos, Arqueano/Paleoproterozoico, Brasil: Revista Brasileira de Geociências, v. 42, p. 663-689, doi:10.5327/Z0375-75362012000400003.

Turbay, C.V.G., 2010, Caracterização petrológica e geocronológica do Complexo Campos Gerais (Arqueano/Paleoproterozóico), Minas Gerais, Brasil [Tese de Doutorado]: Rio de Janeiro, Universidade do Estado do Rio de Janeiro, 176 p.

Valeriano C.M., Simonetti A., Turbay C., Rossi A., Nogueira J.R., 2006, U-Pb zircon ages by LA-MCICPMS from orthogneisses south of Alpinópolis (Minas Gerais, SE-Brazil): reconstructing Paleoproterozoic cratons on the southwestern margin of the São Francisco paleocontinent, in Annual Meeting of Geological Association of Canada, Montreal, Canada.

Vasconcelos, A.C.B.C., 1988, O Grupo Andrelândia na região norte de Ouro Fino, MG [Dissertação de Mestrado]: São Paulo, Universidade de São Paulo, 199 p.

Vermeesch, P., 2018, IsoplotR: a free and open toolbox for geochronology: Geoscience Frontiers, v. 9, p. 1479-1493, doi:10.1016/j.gsf.2018.04.001.

Vermeesch, P., 2012, On the visualisation of detrital age distributions: Chemical Geology, v. 312-313, p. 190-194, doi:10.1016/j.chemgeo.2012.04.021.

Vermeesch, P., 2007, Quantitative geomorphology of the White Mountains (California) using detrital apatite fission track thermochronology: Journal of Geophysical Research: Earth Surface, v. 112, p. 1-11, doi:10.1029/2006JF000671.

Vermeesch, P., 2004, How many grains are needed for a provenance study? Earth and Planetary Science Letters, v. 224, p. 441-451, doi:10.1016/j.eps1.2004.05.037.

Wang, Q., Zhu, D.C., Zhao, Z.D., Guan, Q., Zhang, X.Q., Sui, Q.L., Hu, Z.C., e Mo, X.X., 2012, Magmatic zircons from I-, S- and A-type granitoids in Tibet: Trace element characteristics and their application to detrital zircon provenance study: Journal of Asian Earth Sciences, v. 53, p. 59-66, doi:10.1016/j.jseaes.2011.07.027. 
Wernick, E., Artur, A.C., 1983, Regenerações Sucessivas de Terrenos Arqueanos no Leste do Estado de São Paulo e Sul de Minas Gerais, in Simpósio Regional Geologia, 4, São Paulo, São Paulo, p. 17-31.

Westin, A., Campos Neto, M.C., Cawood, P.A., Hawkesworth, C.J., Dhuime, B., e Delavault, H., 2019, The Neoproterozoic southern passive margin of the São Francisco craton: Insights on the pre-amalgamation of West Gondwana from U-Pb and Hf-Nd isotopes: Precambrian Research, v. 320, p. 454-471, doi:10.1016/j.precamres.2018.11.018.

Westin, A., Campos Neto, M.C., Hawkesworth, C.J., Cawood, P.A., Dhuime, B., e Delavault, H., 2016, A paleoproterozoic intra-arc basin associated with a juvenile source in the Southern Brasilia Orogen: Application of $\mathrm{U}-\mathrm{Pb}$ and $\mathrm{Hf}-\mathrm{Nd}$ isotopic analyses to provenance studies of complex areas: Precambrian Research, v. 276, p. 178-193, doi:10.1016/j.precamres.2016.02.004.

White, R.W., Powell, R., Holland, T.J.B., Johnson, T.E., e Green, E.C.R., 2014a, New mineral activity-composition relations for thermodynamic calculations in metapelitic systems: Journal of Metamorphic Geology, v. 32, p. 261-286, doi:10.1111/jmg.12071.

White, R.W., Powell, R., e Johnson, T.E., 2014b, The effect of Mn on mineral stability in metapelites revisited: New a-X relations for manganese-bearing minerals: Journal of Metamorphic Geology, v. 32, p. 809-828, doi:10.1111/jmg.12095.

White, R.W., Powell, R., e Holland, T.J.B., 2007, Progress relating to calculation of partial melting equilibria for metapelites: Journal of Metamorphic Geology, v. 25, p. 511-527, doi:10.1111/j.1525-1314.2007.00711.x.

White, Powell, Holland, e Worley, 2000, The effect of $\mathrm{TiO} 2$ and Fe2O3 on metapelitic assemblages at greenschist and amphibolite facies conditions: Mineral equilibria calculations in the system $\mathrm{K} 2 \mathrm{O}-\mathrm{FeO}-\mathrm{MgO}-\mathrm{Al} 2 \mathrm{O} 3-\mathrm{SiO} 2-\mathrm{H} 2 \mathrm{O}-\mathrm{TiO} 2-\mathrm{Fe} 2 \mathrm{O} 3$ : Journal of Metamorphic Geology, v. 18, p. 497-511, doi:10.1046/j.1525-1314.2000.00269.x.

Whitehouse, M.J., e Kamber, B.S., 2002, On the overabundance of light rare earth elements in terrestrial zircons and its implication for Earth's earliest magmatic differentiation: Earth and Planetary Science Letters, v. 204, p. 333-346, doi:10.1016/S0012-821X(02)01000-2.

Whitney, D.L., e Evans, B.W., 2010, Abbreviations for names of rock-forming minerals: American Mineralogist, v. 95, p. 185-187, doi:10.2138/am.2010.3371.

Wiedenbeck, M., Hanchar, J.M., Peck, W.H., et al., 2004, Further characterization of the 91500 zircon crystal. Geostandards and Geoanalytical Research, v. 28, p. 9-39, doi: 10.1111/j.1751-908X.2004.tb01041.x

Will, T.M., 1998, Phase Equilibria in Metamorphic Rocks: Thermodynamic Background and Petrological Applications: Springer-Verlag, v. 71, 315 p, doi: 10.1007/BFb0117723

Woodhead, J.D., Hergt, J.M., 2001, Strontium, neodymium, and lead isotope analyses of NIST glass certified reference materials SRM 610, 612 and 614. Geostandards Newsletter, v. 25, p. 261-266, doi:10.1111/j.1751-908X.2001.tb00601.x.

Xie, S., Wu, Y., Zhang, Z., Qin, Y., Liu, X., Wang, H., Qin, Z., Liu, Q., e Yang, S., 2012, U$\mathrm{Pb}$ ages and trace elements of detrital zircons from Early Cretaceous sedimentary rocks in the Jiaolai Basin, north margin of the Sulu UHP terrane: Provenances and tectonic implications: Lithos, v. 154, p. 346-360, doi:10.1016/j.lithos.2012.08.002.

Yakymchuk, C, Kirkland, C.L., Clark, C., 2018, Th/U ratios in metamorphic zircon: Journal of Metamorphic Geology, v. 36, p. 715-737, doi:10.1111/jmg.12307.

Zack, T., Moraes, R. \& Kronz, A., 2004, Temperature dependence of Zr in rutile: empirical calibration of a rutile thermometer: Contributions to Mineralogy and Petrology, v. 148, p. 471-488, doi:10.1007/s00410-004-0617-8.

Zanardo A., 1992, Análise petrográfica, estratigráfica e microestrutural da região de GuaxupéPassos-Delfinópolis (MG) [Tese de Doutorado] Rio Claro, Universidade Estadual Paulista, $288 \mathrm{p}$. 
Zanardo, A., Morales, N., Oliveira, M.A.F., Del Lama, E.A., 2006, Tectono-Lithologic Associations of the Alterosa Paleo Suture Zone - Southeastern Brazil Associação TectonoLitológica da Paleozona de Sutura, Revista Geociências UNG, v. 5, p. 103-117.

Zanardo, A., Morales, N., Carvalho, S., Simões, L., Oliveira, M.A.F., 1990, Evolução Metamórfica da Porção Sul do Craton Paramirim, in Congresso Brasileiro de Geologia, 36, Natal, RN, p. 1945-1955.

Zanardo, A., Oliveira, M.A.F., Del Lama, E.A., 1996, Rochas máficas e ultramáficas da Faixa Jacuí-Bom Jesus da Penha-Conceição da Aparecida (MG): Geociências, v. 15, p. 279-297.

Zen, E-an, 1966, Construction of pressure temperature diagrams for multicomponent systems after the method of Schreinemakers - a geometric approach: United States Geological Survey Bulletin, v. 1225, 68 p, disponível em https://pubs.usgs.gov/bul/1225/report.pdf.

Zhang, B., Li, B., Zhao, C., Yang, X., 2019, Large effect of water on Fe-Mg interdiffusion in garnet: Earth and Planetary Science Letters, v. 505, p. 20-29, doi: 10.1016/j.epsl.2018.10.015.

Zhong, S., Feng, C., Seltmann, R., Li, D., e Qu, H., 2018, Can magmatic zircon be distinguished from hydrothermal zircon by trace element composition? The effect of mineral inclusions on zircon trace element composition: Lithos, v. 314-315, p. 646-657, doi:10.1016/j.lithos.2018.06.029.

Zhou, J.B., Wilde, S.A., Liu, F.L., e Han, J., 2012, Zircon U-Pb and Lu-Hf isotope study of the Neoproterozoic Haizhou Group in the Sulu orogen: Provenance and tectonic implications: Lithos, v. 136-139, p. 261-281, doi:10.1016/j.lithos.2011.01.015. 


\title{
APÊNDICE A
}

Artigo a ser submetido ao periódico Journal of South American Earth Science.

\section{The Archean and Paleoproterozoic rocks of the Petunia Complex and its relationship with the Campos Gerais Complex as a basement window in the Brasília Orogen, Southeastern Minas Gerais, Brazil}

\author{
Rafaela Machado Gengo (rafaela.gengo@usp.br) \\ Vinicius Hector Abud Louro (vilouro@usp.br) \\ Renato de Moraes (rmoraes@usp.br) \\ Gergely Andres Julio Szabó (gajszabo@usp.br) \\ Elton Luiz Dantas (elton@unb.br) \\ Pedro Machado Simões (pedro.simoes@ alumni.usp.br)
}

\begin{abstract}
In the southern margin of the São Francisco Craton, between Neoproterozoic nappes of the Southern Brasília Orogen, there is a structural window defined by elongated belts in the WNW-ESE direction, formed by fragments of rocks that were compartmentalized by a complex arrangement of overthrusts and high angle ductile-ruptile shear zones. We integrated field data with aerogeophysical surveys and U-Pb zircon dating to position the rocks of the Petúnia Complex in the regional tectonic context of the evolution of the southern margin of the São Francisco Craton. The Petúnia Complex is characterized by the highest degree of deformation and the highest incidence of supracrustal units tectonically imbricated and metaultramafic rocks, so that they result in a radiometric signature characterized by low UTh-K counts.

In the Petúnia Complex two Archean units were identified: Petúnia Unit (2993 $\pm 6 \mathrm{Ma}$ ) and Ribeirão da Conquista Gneiss (2835 $\pm 12 \mathrm{Ma}$ ). These units integrate, along with the orthogneisses of the Campos Gerais Complex, the reworked Archean infrastructure in the final stages of Minas Orogenesis, recorded in the Petúnia Complex through the Bom Jesus da Penha Metagranite (2004 $\pm 5 \mathrm{Ma}$ ). Subsequently, through the reactivation of deep shear zones, the transport to NW along the Bom Jesus da Penha Shear Zone records the final tectonic accommodation, in response to the deformation with the transport to ENE of the Neoproterozoic nappes of the Southern Brasília Orogen.
\end{abstract}




\section{Introduction}

In the Southern Brasília Orogen (Fuck et al., 1994; Dardenne, 2000; Fig. 1), Paleoproterozoic and Archean rocks emerge in a structural window between the Neoproterozoic Passos Nappe and part of the set of Socorro-Guaxupé Nappe and Andrelândia Nappe Systems (Campos Neto \& Caby, 1999; Campos Neto et al., 2010; 2011). In this region, gravimetric anomalies (Haralyi \& Hasui, 1982; Malagutti et al., 1996), indicate the presence of marginal suture between crustal blocks (Hasui et al., 1993), which are related to the intense transcurrent tectonics present in the Campo do Meio Shear Belt (Morales \& Hasui, 1993).

The Campo do Meio Shear Belt is a transpressive belt (Hasui, 2010), developed along the southwestern edge of the São Francisco Craton and affect rocks attributed to the Petúnia (Roig, 1993) and Campos Gerais complexes (Kaefer et al., 1979). The Campos Gerais Complex corresponds to the Archean to Paleoproterozoic terrane of the Southern Brasília Orogen basement (Valeriano et al., 2004), while the Petúnia Complex corresponds to its allochthonous portion (Roig, 1993; Szabó et al., 1993) with metapelitic and metapsammitic rocks correlated to Neoproterozoic units of the orogen (Trouw et al., 1984; Zanardo, 1992; Roig, 1993; Zanardo et al., 2006; Campos Neto et al., 2004) and meta-ultramafic rocks related to ophiolitic complexes (Choudhuri et al., 1995).

With such lithological content, it cannot be said that Petunia and Campos Gerais Complexes have the same genesis or record the same evolutionary stage. Thus, in this paper, we present a review of the Petunia Complex, which proposes a new lithological compartmentalization based on field surveys and aerogeophysical data, updating the cartographic knowledge of the region. Additionally, we present geochronological data that will contribute to the positioning of the Petunia Complex in the regional context.

\section{Geological Setting}

The Campo do Meio Shear Belt, with directions WNW-ESSE, contains rocks from Petúnia and Campos Gerais Complexes, migmatites correlated to the Andrelândia Group (CPRM, 2003), or São Vicente Complex (CODEMIG, 2015) and Paleoproterozoic intrusive granitoids (Lopes, 2013). These terranes were intensely reworked during the Brasiliano-pan African cycle and orogenic collage (Brito Neves et al., 1999) and are considered part of the suture zone between the Paleoplate São Francisco - Congo and Paranapanema Block. (Trouw et al., 2000; Campos Neto et al., 2004, 2010 e 2011; Fig. 1). 


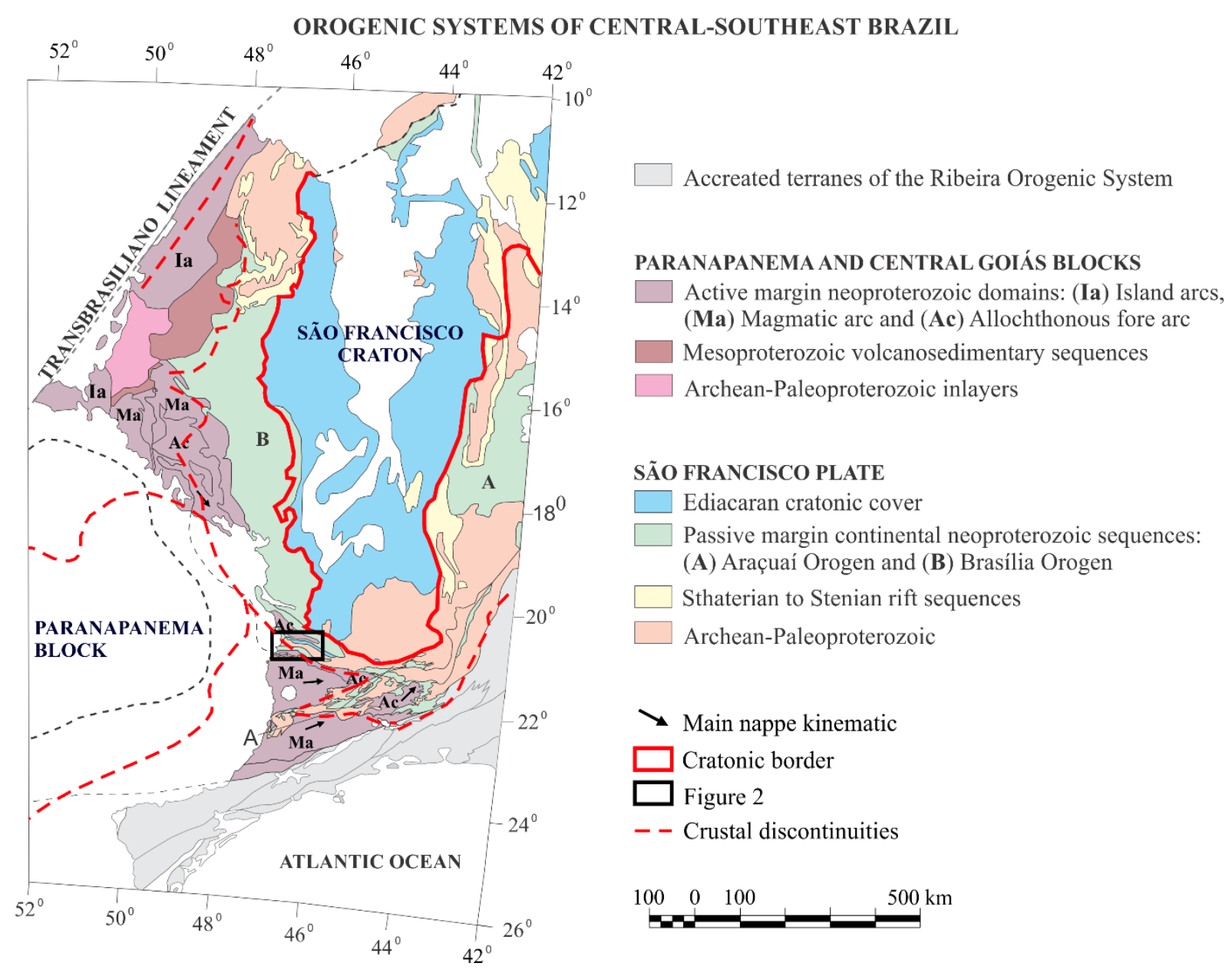

Fig. 1: Tectonic map showing the Brasília Orogen between São Francisco Craton and Paranapanema Block. The polygonal area is focused in this work. Modified from Westin et al., 2016) with crustal discontinuities pointed out by gravimetry are in accordance with Hasui et al. (1993).

The Campos Gerais Complex stands out for its tectonic compartmentalization, with mylonitic and cataclastic rocks correlated to the São Francisco Craton units (Kaefer et al., 1979; Morales et al., 1983; Wernick and Arthur, 1983). The classical division of the Campos Gerais Complex consists of two domains (Schrank et al., 1993; Zanardo, 1992; Szabó et al., 1993), with one Autochthon in the north and the other Allochthon in the south (Roig, 1993; Szabó et al., 1993; Szabó, 1996; Fig. 2), separated by the Bom Jesus da Penha-Jacuí Belt.

There are three sub-areas with NW-SE direction in the Autochthonous Domain: the Mumbuca, Córrego das Almas and Serra do Dondó sub-areas (Szabó, 1996), which are separated by high-angle transcurrent shear zones. The sub-areas are mainly formed by Meso to Neoarchean gneisses, Paleoproterozoic intrusive granites (Turbay \& Valeriano, 2012) and the Fortaleza de Minas (Teixeira \& Danni, 1979) and Alpinópolis Greenstone Belts, with meta ultramafic rocks of komatiitic affiliation (Szabó, 1996; Pimentel \& Ferreira Filho, 2002), serpentinized and associated with BIFs, amphibolites and platinoid mineralizations (Marchetto, 1986) and Fe-Ni-Cu-Co sulfides (Carvalho \& Batista, 1983; Lima, 2017). 


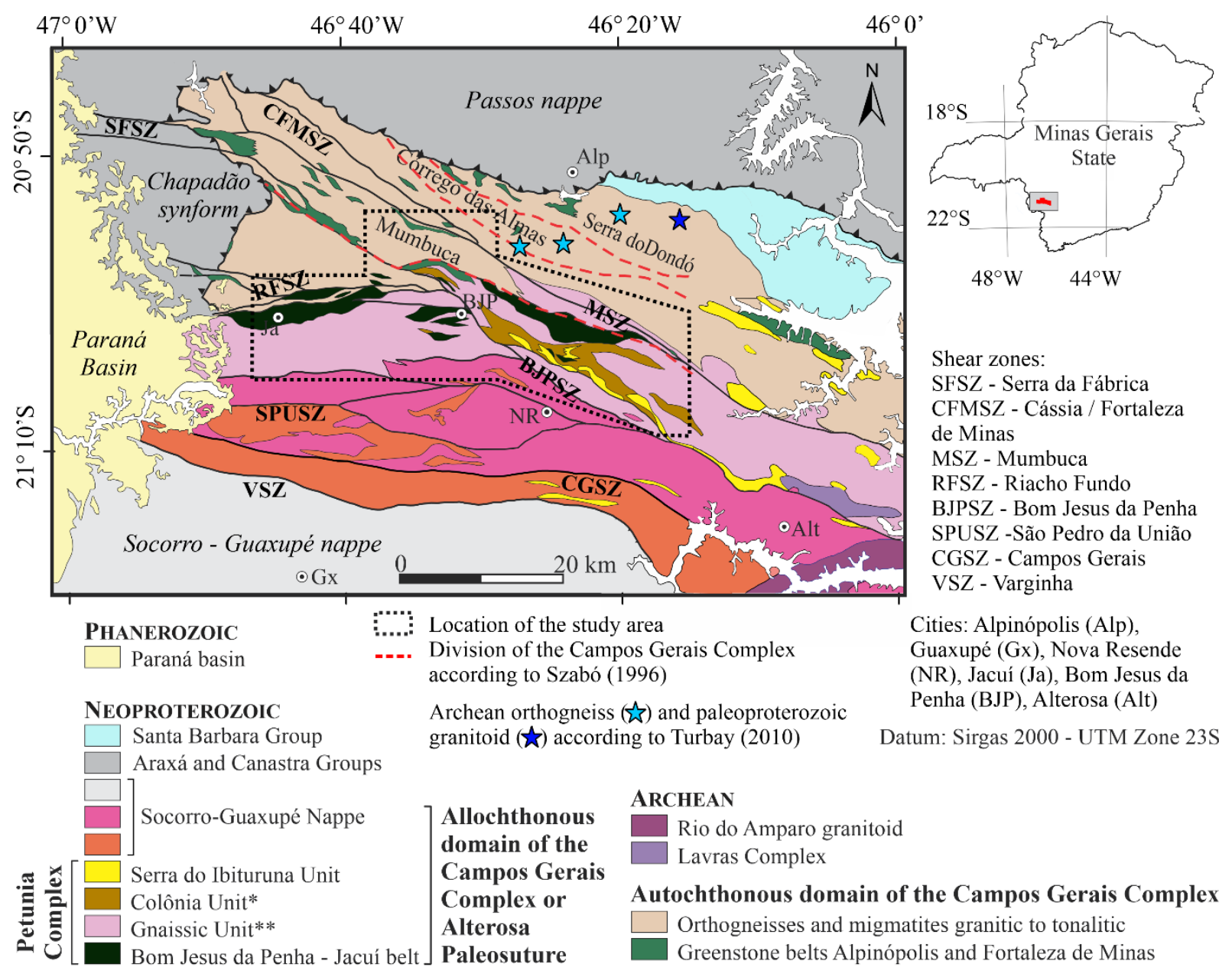

(*) Schists and quartzites like a São Vicente Unit (CODEMIG, 2015)

(**) Gneisses and migmatites correlated with Andrelandia Group (CPRM, 2003) or like a São Vicente Complex (CODEMIG, 2015)

Fig. 2: Campo do Meio Shear Belt and the division of the Campos Gerais Complex into autochthonous and allochthonous domains. Modified from Zanardo (1992) and CODEMIG (2015).

The Bom Jesus da Penha-Jacuí Belt was previously considered greenstone belt (Teixeira \& Danni, 1979), formed by Colônia and Serra do Ibituruna units (Teixeira et al., 1987), incorporated into the Petúnia Complex (Roig, 1993), and corresponds to the Allochthonous Domain of the Campos Gerais Complex (Roig, 1993; Szabó et al., 1993). Zanardo et al. (2006) present the allochthonous domain of the Campos Gerais Complex as Alterosa Paleosuture Zone, which involves these rocks in the area between the Varginha (VSZ), Riacho Fundo (RFSZ) and Mumbuca (MSZ) shear zones (Fig. 2).

In the metaultramafic rocks of the Petúnia Complex mineral assemblages resulting from intense metasomatism, predominate talc, chlorite, tremolite, anthophyllite, hornblende, and replacing the BIFs, manganese-ferriferous formations associated with podiform chromite (Szabó, 1996; Fayad, 2013). Preserved textural features suggest correspondence to differentiated bodies compatible with stratiform complexes intensely tectonized or ophiolitic 
complexes (Soares et al., 1990; Roig and Schrank, 1992; Zanardo et al., 1996), interpreted as probable remnants of Neoproterozoic oceanic crust (Choudhuri et al., 1995). Auriferous and $\mathrm{Cu}-\mathrm{Fe}-\mathrm{Zn}$ sulfide mineralizations hosted in the rocks of the Colônia unit and are distribute according to the main shear zones of the region, showing the tectonic control associated with the hydrothermal action, especially silicification (Feola, 2004).

\section{Methodology}

The update of the conception of the Petunia Complex was the result of the compilation of published geological data and included new field surveys integrated with the aerogeophysical database. The geological contacts have been adjusted Along with the use of Digital Terrain Models observation, constructed from the Shuttle Radar Topography Mission (SRTM) data with $30 \mathrm{~m}$ resolution and aerogeophysical data.

The aerogeophysical data were provided by the Minas Gerais Economic Development Company (CODEMIG) for the Area 7 Project. This project performed magnetometric and gamma-spectrometric aerial surveys at a nominal height of $100 \mathrm{~m}$, on North-South lines which were $400 \mathrm{~m}$ spaced and with east-west controlled lines $8000 \mathrm{~m}$ spaced. The aircraft used maintained an average speed of about $280 \mathrm{~km} / \mathrm{h}$, with magnetic data collected every $0.1 \mathrm{~s}$ and gamma spectrometry every $1 \mathrm{~s}$, resulting in measurements at approximately $7.8 \mathrm{~m}$ and $78 \mathrm{~m}$, respectively. These acquisitions took place between the years of 2006 and 2007, in which the geomagnetic field remained with slope averages of $-31.3^{\circ}$, declination $339.6^{\circ}$ and intensity of $23218 \mathrm{nT}$.

$\mathrm{U}-\mathrm{Pb}$ in situ analysis were performed on zircon crystals of three gneisses of the Petunia Complex (Table 1 - supplementary material). These samples, which were prepared at the Separation Laboratory of the Geochronological Research Center (CPGEO), in the Geosciences Institute of the University of São Paulo (IGc-USP), followed ground to 100-250 and $<250 \mu \mathrm{m}$ fractions. The concentrated of zircon crystals was separated with by using heavy-mineral separation Wilfley table, Frantz magnetic separator and dense liquids (bromoform and methylene iodide). The zircon crystals of interest were manually separated and placed on adhesive tape, later covered with epoxy resin. The mounts were polished to expose the crystal core, and the cathodoluminescence (CL) images were obtained by scanning electron microscope (SEM) with cathodoluminescence detector.

The analysis were performed at the Geochronology Laboratory of the Institute of Geosciences of the University of Brasília, using Thermo Finnigan Neptune com laser New Wave 213 coupled. Laser ablation operated 40 cycles with $10 \mathrm{~Hz}$ frequency at $25 \mu \mathrm{m}$ spot 
size. Fractionation and possible variations in calibration were corrected by measurements in the reference material GJ-1 (Jackson et al., 2004) and 91500 (Wiedenbeck et al., 2004). Valid analyzes showed common $\mathrm{Pb}$ below the detection limit and, therefore, no corrections were made. Diagrams were constructed on IsoplotR (Vermmesch, 2018) and discordia lines were calculated according to the method of Ludwig (1998).

\section{The Petunia Complex}

The Petunia Complex comprises five lithodemic units: Serra do Ibituruna, Colônia, Petúnia, Ribeirão da Conquista Gneiss and Bom Jesus da Penha Metagranite. With the exception of the Metagranite, the contact between the units is marked by shear zones subordinated to the larger shear zones, with intense imbricating of lithotypes, especially near the BJPSZ, where there is a higher incidence of breccias, cataclasites and of quartz veins centimeter-to-metric sizes.

The Bom Jesus da Penha Shear Zone divides the Petunia Complex into two belts: the first one with NW-SE direction, in concordance with the Mumbuca and Córrego das Almas Belts; and the second one with EW direction (Fig. 2), limited to the north by the Riacho Fundo Shear Zone (RFSZ), and overlapped to the south by the Mamote Belt metatexites. The Mamote Belt is limited to the south by stromatic metatexites attributed to the SocorroGuaxupé Nappe, which is also in contact with the Petunia Complex to the east, through the Bom Jesus da Penha Shear Zone.

\section{Serra do Ibituruna Unit}

The Serra do Ibituruna Unit consists of muscovite-quartz schist and muscovite quartzite. The muscovite-quartz schist (Fig. 3a) presents fine to medium lepidoblastic texture with sparse intercalations of discontinuous granoblastic texture lenses and, when deformed, it presents mylonitic texture with well-developed S-C fabric. Quartz and muscovite compose the essential mineralogy, having as accessory minerals kyanite, zircon, monazite, tourmaline, rutile, apatite, ilmenite, and magnetite. In muscovite quartzite the deformation formed incipient S-C fabrics and there are feldspar relics.

The rocks of the unit sustain high topographic areas, with often outcropping rock, which shows that the variations of the contents of $\mathrm{K}$, Th and $\mathrm{U}$, in relation to the other areas of the unit, are primarily lithological. The gamma-spectrometric signature differs from adjacent units, with a predominance of $\mathrm{K}$ over intermediate values of $\mathrm{Th}$ and, in a lesser extent, U (Fig. 4a-d). The pervasive development of the S-C fabric, together with the 
predominance of potassium over thorium, reflects the hydrothermal character behavior by the Bom Jesus da Penha Shear Zone (BJPSZ, Zanardo et al., 2006), which may have resulted in rocks with higher muscovite proportions. The presence of accessory minerals such as monazite, rutile and zircon guarantee $\mathrm{Th}$ and $\mathrm{U}$ counts, although they are less expressive. Superficially this unit has no characteristic magnetic signature, being confused with the magnetic lineament of the Bom Jesus da Penha Shear Zone (Fig. 5a).

\section{Colônia Unit}

The Colônia Unit is formed by metapelites with intercalations of lenses of decimetric to metric thickness of meta-ultramafic rocks, placous quartzite, graphite schist, gondites and, subordinately, muscovite-quartz schist, iron-manganese formations and podiform chromitites. The metapelites are represented by kyanite-staurolite-muscovite-garnet-biotite schist with fine to medium grained feldspar and muscovite-kyanite-garnet-biotite schist with fine-grained feldspar. In both, the texture is lepidoblastic, with pre to inter-kinematic garnet porphyroblasts, shaped by external foliation, and millimeter-to-centimeter discontinuous lenses, formed by quartz and plagioclase, sometimes folded with an axial plane parallel to the main foliation. Accessory minerals include zircon, monazite, rutile, apatite, tourmaline, ilmenite, magnetite, and chlorite.

Meta-ultramafic rocks have anastomosed mylonitic foliation and include chloritite, talc schist, hornblende schist and meta- ultramafic schists with variable proportions of talc, chlorite, anthophyllite and tremolite. Massive rocks with preserved mineral associations from the metasomatic processes are rare and include metadunite, olivine-orthopyroxene and metamorphic derivatives (Pinheiro, 2013) such as anthophyllite fels and talc-anthophyllitetremolite-chlorite-orthopyroxene fels.

The gamma-spectrometric signature shows a predominance of $\mathrm{K}$ and $\mathrm{U}$ throughout the whole unit, except in the high topographic regions, where high Th contents predominate (Fig. 4b and 4d). This behavior occurs due to the lower mobility of Th in relation to $\mathrm{K}$ and $\mathrm{U}$, which are removed from the source rock by grain transport. Much of the unit, however, has low counts of the three elements attached to the meta-ultramafic rocks present in its extension (Figure 4e). Ultramafic rocks typically have low U, Th and K counts (Dickson \& Scott, 1997), which remain at their metamorphic equivalents.

The northern boundary of the Colônia Unit is marked by the Cassia-Fortaleza de Minas Shear Zone, which is well defined by magnetic data, which shows magnetic lineaments following the NW-SE regional trend (Fig. 5a, 5c and 5d). On the southern boundary, where it 
is overlapped by the Petunia Unit gneisses, it has distinct lineament, possibly associated with the magnetic susceptibility contrast between the Ribeirão da Conquista Gneiss (with lower susceptibility) and the Petunia Unit granodiorite gneisses (with higher susceptibility; Gleizes et al., 2006). The unit includes several meta-ultramafic bodies that extend and align in the same direction, generating a lineament of magnetic anomalies of normal polarity, with no direct evidence of remaining magnetization (Fig. 5a).

\section{Petúnia Unit}

The Petunia Unit consists of epidote-biotite and hornblende-biotite tonalitic gneiss and tonalitic to granodioritic gray-colored biotite gneiss, homogeneous and finely banded to mylonitic (Fig. 3b), with formation of fish minerals in ductile deformation (Fig. 3c). Near the shear zones there are sub millimetric to decimetric cataclastic bands, rich in epidote and quartz (Fig. 3d). The rocks are constituted by oligoclase, quartz, microcline, biotite, hornblende and epidote. In mylonites, muscovite and chlorite set the essential mineralogy, replacing biotite and epidote. Accessory minerals include zircon, apatite, titanite, allanite, opaque minerals and interstitial carbonate, as secondary alteration product.

Intersections of meta-ultramafic rocks and amphibolites are common and abundant, occur as centimetric to metric intersections, not always mappable, and are like those occurring in the Colônia Unit. The amphibolite bodies are lenticular and zoned, with metagabbro in the core of the boudins, where there is preservation of the igneous texture in areas of low deformation and hydration, and edges formed by garnet mylonitic amphibolite.

The radiometric features of the unit are distinct in the two belts of the Petunia Complex. In the NW-SE belt, north of the Cassia-Fortaleza de Minas Shear Zone, from east to west occur high-K intercalations and U- and Th-rich zones (Fig. 4e), consistent with heterogeneities in the unit gneisses. In the south of the Colônia Unit, the counts are medium to low for the three elements, with predominance of $\mathrm{U}$ and $\mathrm{K}$. This behavior may be related to the $\mathrm{U}$ and $\mathrm{K}$ remobilization of the Colônia Unit pelitic schists and meta-ultramafic rocks that are intercalated with the gneisses, which are structurally limited by the Bom Jesus da Penha Shear Zone. The E-W belt presents inverse behavior, with Th predominating over U and K (Fig. 4b and 4d). The close relationship of meta-ultramafic rocks with the Bom Jesus da Penha and Riacho Fundo Shear Zones, as well as the absence of topographic elements that mechanically remobilize sediments from these rocks to distal areas, preserve the high signature of $\mathrm{Th}$. 

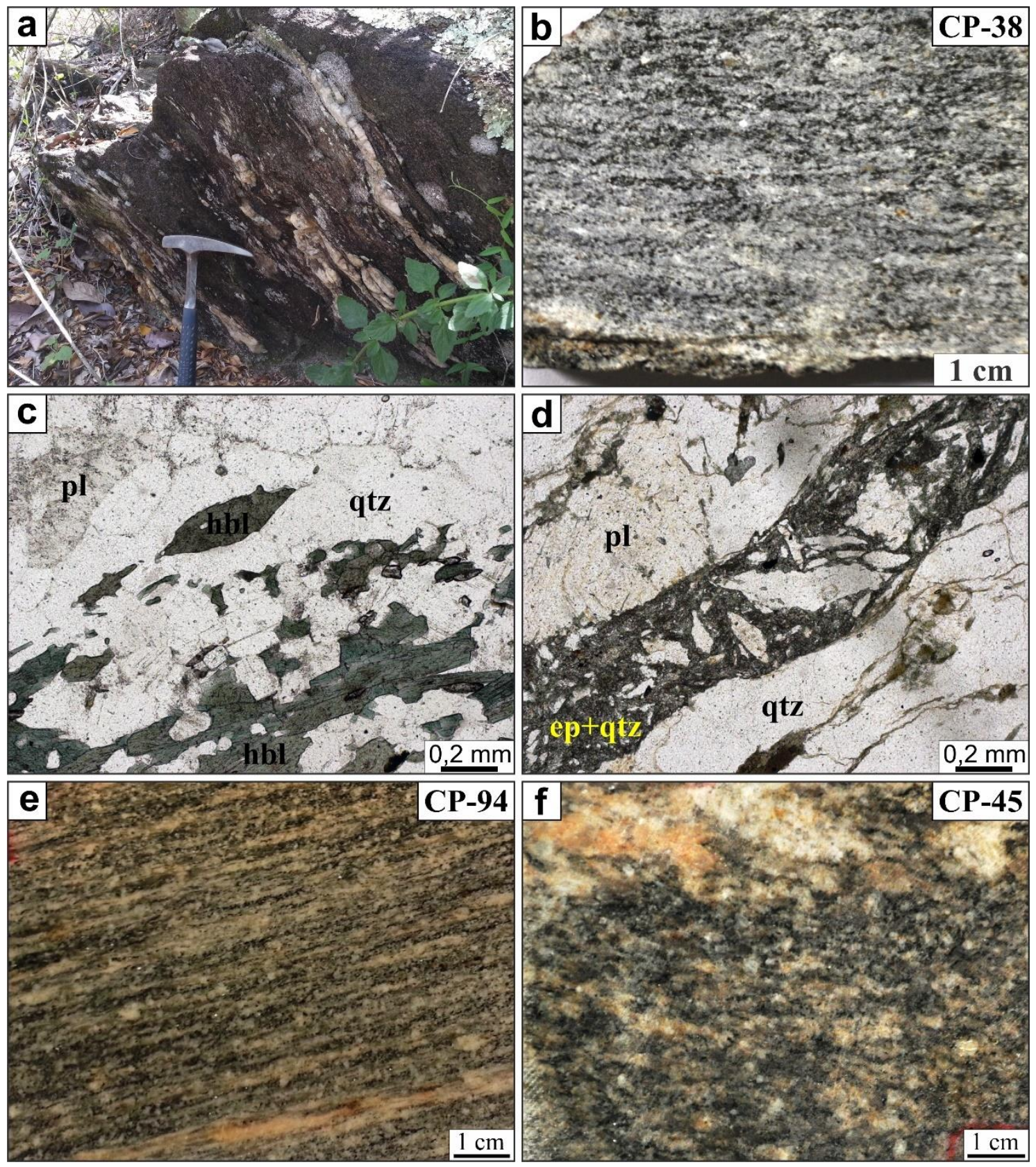

Fig. 3: a) Muscovite-quartz schist from the Serra do Ibituruna Unit; b) Biotite gneiss tonalitic from the Petunia Unit, sample CP-38; Microscopic aspect of the biotite gneiss tonalitic from the Petunia Unit, in c) Foliation marked by crystals of hornblende and hornblende fish, formed in ductile regime and, in d) Intercalations of cataclastic bands formed in brittle regime; e) Biotite gneiss monzogranitic, Ribeirão da Conquista Gneiss, sample CP-94; f) Bom Jesus da Penha Metagranite, sample CP-45.

The magnetic signature behavior is repeated for the meta-ultramafic rocks of the Colônia and Petunia Units. The high content of paramagnetic minerals such as tremolite and anthophyllite and ferromagnetic minerals such as ilmenite and magnetite reflect in magnetic anomalies of normal polarization to the southern hemisphere (Fig. 5b). In these rocks, the magnetizations are dominated by the induced component or, in a different hypothesis, with possible magnetizations remaining parallel to the magnetic field at the time of the survey. 
Short wavelength magnetic lineaments follow the structuring of the area, with direction ENEWSW in the western portion of the unit and south of the RFSZ, and NE-SE in the north BJPSZ. These lineaments may be associated with small structures subordinate to the main shear zones of the region.

\section{Ribeirão da Conquista Gneiss}

The Ribeirão da Conquista Gneiss is present in the southeast of the area and overlaps the other units of the Petúnia Complex. It consists of pinkish gray biotite monzogranitic gneiss, with mylonitic foliation marked by heterogeneous banding, defined by plagioclase bands, microcline bands and millimeter-sized quartz ribbons (Fig. 3e). The rock has simple mineralogy, formed by microcline, oligoclase, quartz and biotite. Accessory minerals include muscovite, zircon, opaque minerals, apatite, epidote and allanite. Rocks with less intense deformation have less quartz and preserve sub-idiomorphic to idiomorphic feldspar, while deformation was followed by enrichment in silica, changing the original mineralogical proportions. Mafic minerals are restricted to sparse biotite crystals and fine opaque minerals.

The gamma-spectrometric signature shows a predominance of Th over the other elements, characteristic of gneisses and monzogranites, grading to low counts of the three elements as it approaches towards contact with the Serra do Ibituruna Unit (Fig. 4b and 4e). There are no characteristic magnetic features in the unit, except for a magnetic lineament at the southern limit, possibly associated with the Bom Jesus da Penha Shear Zone.

\section{Bom Jesus da Penha Metagranite}

The Bom Jesus da Penha metagranite is massive rock, with granoblastic matrix formed essentially by plagioclase, microcline and quartz (Fig. 3f). Foliation is incipient and given by the orientation of sparse agglomerations formed by quartz and microcline. Biotite $(\sim 10 \%)$ is the dominant mafic mineral and has a homogeneous distribution and occurs as idiomorphic crystals, sometimes included in plagioclase. Accessory minerals include zircon, apatite, epidote, allanite, chlorite and fine opaque minerals. Plagioclase ( $35 \%)$ occurs as early crystals, sub-idiomorphic and with concentric extinction indicating compositional zoning. Microcline ( 30\%) occurs as xenomorphic and interstitial crystals, indicating late crystallization. In the bands where the plagioclase predominates, the contacts are interlobate to polygonized and in the agglomerations, next to the quartz, it occurs as sub-idiomorphic to idiomorphic crystals. Quartz $(\sim 25 \%)$ in the matrix exhibits polygonized contacts, but predominates in the bands, next to the microcline, where it shows curved contacts and 
moderate wavy extinction. Mineralogy does not favor sufficient magnetization contrast to generate a magnetic anomaly. Biotite can be interpreted as the source of $\mathrm{K}$ enrichment over the other components (Fig. $\mathbf{4 a}$ and $\mathbf{4 d}$ ).

\section{Mamote belt}

In the Mamote Belt, a hornblende-biotite stromatic metatexite predominates with or without garnet and epidote-hornblende gneiss. Amphibolite, quartzite and gondite garnet occur as subordinate lenticular intercalations. Epidote-hornblende gneiss has millimeter banding, medium granulation and mineralogy formed by plagioclase, quartz, hornblende, and epidote. Accessory minerals include clinopyroxene, apatite, zircon, and opaque minerals.
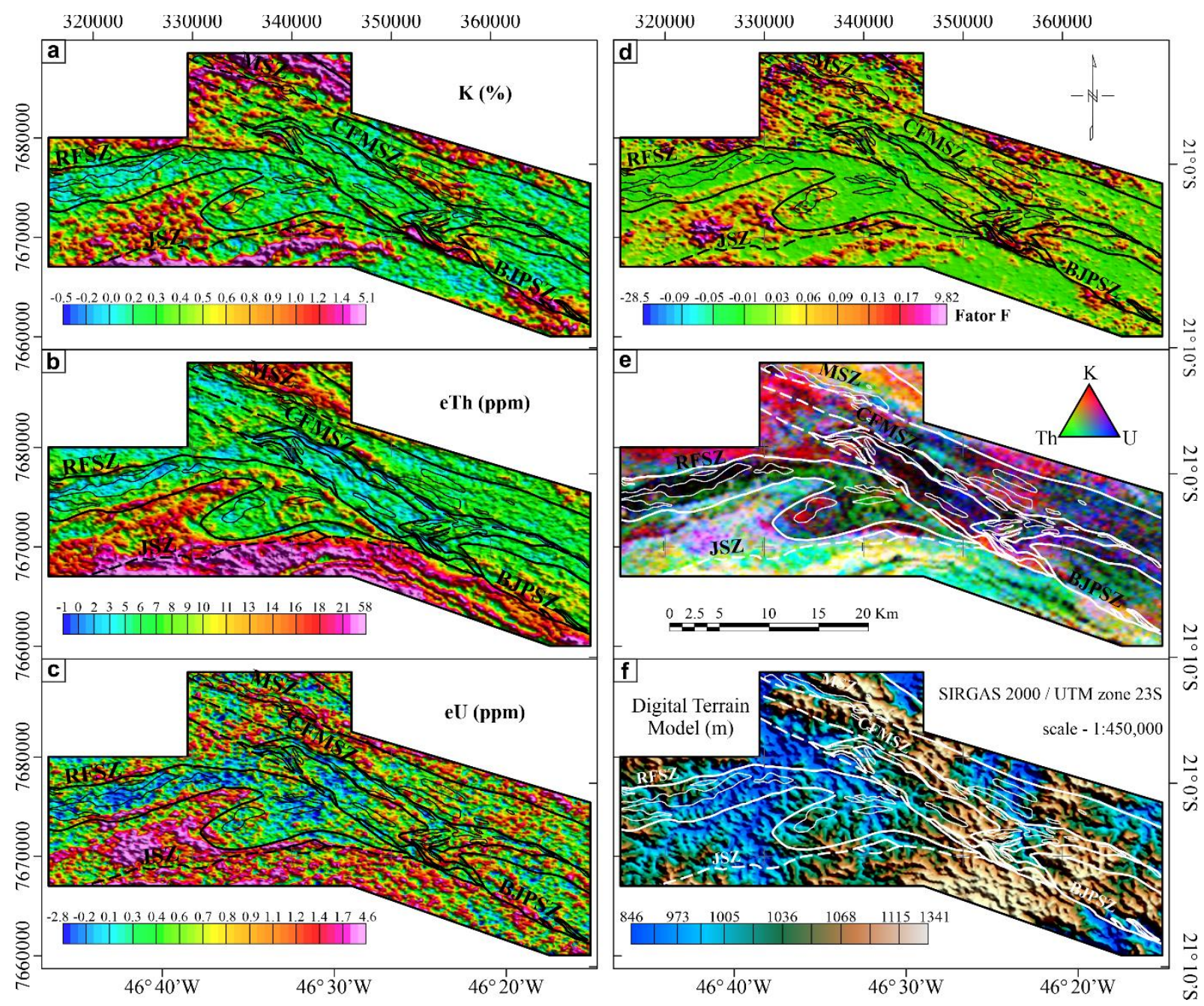

Fig. 4: Gamma-spectrometric maps showing the radiometric concentrations of $K(a)$, Th (b) and $U$ (c) with the structural contacts of the geological map; d) F-factor map showing areas with $\mathrm{K}$ and $\mathrm{U}$ enrichment in relation to Th; e) RGB ternary map; f) Digital elevation model. 

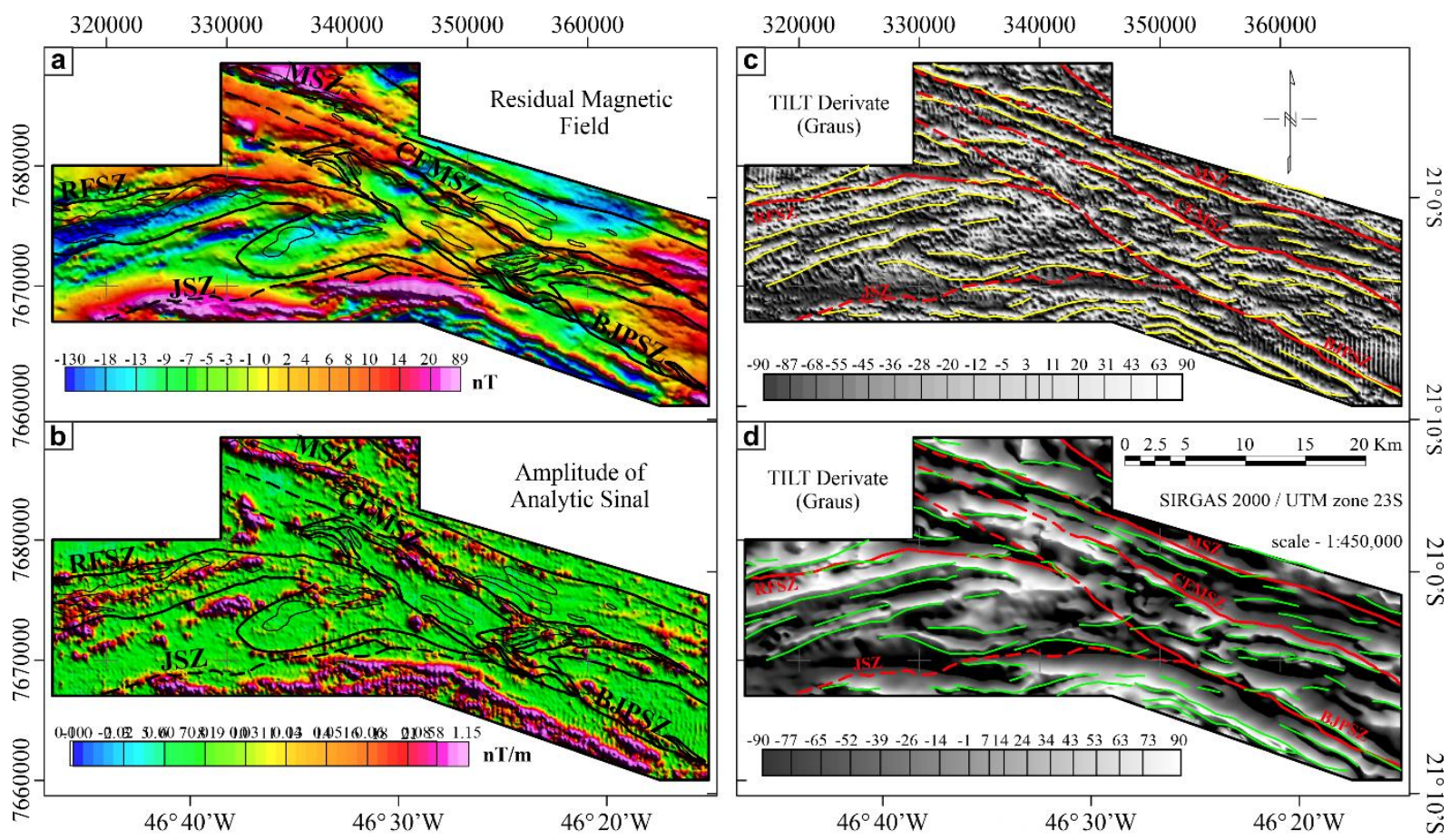

Fig. 5: Residual magnetic field maps (a) and Analytical Signal Amplitude (ASA, b) with the indicated structural contacts; c-d) Maps built by calculating the TDR (Tilt Derivative).

Hornblende-biotite metatexite stromatic has a dark and fine gray residue, formed by plagioclase, microcline, quartz, biotite, hornblende, and garnet (Fig. 6a). Accessory minerals include epidote, titanite, allanite, apatite, zircon, opaque minerals, and late interstitial carbonate. The leucosome has medium to coarse granulation and composes aggregates or intercalations of millimetric to centimetric thickness, sometimes folded, with an axial plane parallel to the foliation. It has mineralogy like that of the residue, but with a higher proportion of microcline.

The northwestern portion of the Mamote Belt presents a calm magnetic domain, with lower frequency of magnetic anomalies than the anomalies in the Petunia and Campos Gerais Complexes (Fig. 5a). Despite this behavior, it is a region marked by long-wavelength magnetic lineament in the ENE direction (Fig. 5a-b), also visible in radiometric data (Fig. 4ac). Gamma emissions separate the rocks of Socorro-Guaxupé Nappe, rich in U, Th and K, to the south, from the lithologies of the E-W belt of the Petunia Complex (Fig. 4e). Magnetic anomalies of normal polarization, elongated in the same direction as ENE, mark this lineament and are possibly associated with the structurally controlled intrusion of the granite body (Fig. 5a).

Still in the NW portion of the Mamote Belt, an anomaly rich in $\mathrm{K}$ and $\mathrm{U}$ is observed, with low Th counts (Fig.4a-c). In the Factor F map (Gnojek \& Prichystal, 1985), this behavior is evidenced and is commonly associated with hydrothermal alteration (Fig. 4d). 
The absence of outcrops, topographic elements and a discrete magnetic anomaly, added to the geological scenario and its association with a magnetic lineament, suggests that the source of this anomaly is a low content of ferromagnetic minerals body intruded close to the surface. Towards Socorro-Guaxupé Nappe, the metatexites of the Mamote Belt show an enrichment of Th typical of evolved rocks, with occasional variations in the K count, high for residues rich in biotite and low for amphibolites and meta-ultramafic rocks.

\section{Socorro - Guaxupé Nappe}

The Socorro-Guaxupé Nappe has the highest topographic expression in the region, being represented by biotite metatexito stromatic, granodioritic, with syenogranitic leucosome (Fig. 6b) and amphibolite intercalations. Magnetic lineaments of high magnitude in the WNW-ESSE direction, smoothly folded and with a north direction axis (Fig. 5a and 5b), reflect the presence of ferromagnetic minerals, such as biotite, hornblende, titanite and opaque minerals that mark the foliation of the rock. Their normal polarizations follow the regional pattern, where induced magnetization predominates. The gamma-spectrometric signature is marked by high counts of $\mathrm{K}$, Th and $\mathrm{U}$, with a predominance of Th, and the described fold is observed as an arc with intercalations of high and low counts of U, Th and K (Fig. 4e).

\section{Campos Gerais Complex}

The contact between the Petúnia and Campos Gerais Complexes occurs through the Mumbuca and Riacho Fundo shear zones (Fig. 2). In the studied area, at north of the Riacho Fundo shear zone, the Campos Gerais Complex is represented by mylonitic granitoid rocks. In this area, the radiometric features occur with a predominance of $\mathrm{K}$ over the other elements to the north and an abrupt E-W contrast for zones of predominance of $U$ (Fig $\mathbf{4 a}$ and $\mathbf{4 c}$ ). This contrast is typical of lithological changes, although not observed in the field. In the northern areas with a predominance of $\mathrm{K}$, there are still subareas with low Th counts and intermediate U counts, indicating the occurrence of possible hydrothermal processes. Its limits are marked by well-defined shear zones in magnetic lineaments to the south (RFSZ) and to the northeast, in a continuation of the BJPSZ without superficial expression. Adjacent to the shear zones, magnetic anomalies of normal polarization occur that may represent bodies structurally controlled by these zones.

The Mumbuca Belt is formed by gray to pink orthogneiss, granodioritic to granitic, sheared and locally with preserved migmatitic features. This belt has a strong influence of the Mumbuca Shear Zone (MSZ), observed on the surface and in magnetic lineaments parallel to 
the high amplitude MSZ (Fig. 5a, e). The high amplitudes can be associated with the presence of ferromagnetic minerals common in the constitution of granodiorites. The Mumbuca Belt is marked by three different radiometric domains: (1) High K domain; (2) High U domain; and (3) High $\mathrm{K}$ and Th domains (Fig. 4a-c). The high $\mathrm{U}$ and high $\mathrm{K}$ domains follow the trend observed in the portion of the Campos Gerais Complex to the north of the RFSZ, intercalating in the same direction as the lineaments. These intercalations are common in areas dominated by gneisses, showing a more regional variation of metamorphized compositions. The high $\mathrm{K}$ and Th domain extends across the northern limit of the study area, from the magnetic lineaments that define the northern limit of domains (1) and (2) and the southern of the domain (3). In the Córrego das Almas Belt, gray granodioritic orthogneisses, mylonitic, predominate, with intercalations of biotite metatonalite. This belt appears in a limited way in the studied area (Fig. 2), being characterized by a high magnetic gradient when compared to the Mumbuca Belt (Fig. 5b). High K values predominate in the belt, possibly linked to the mylonitic structures that tend to accumulate this element during their formation (Fig 4a, 4e).
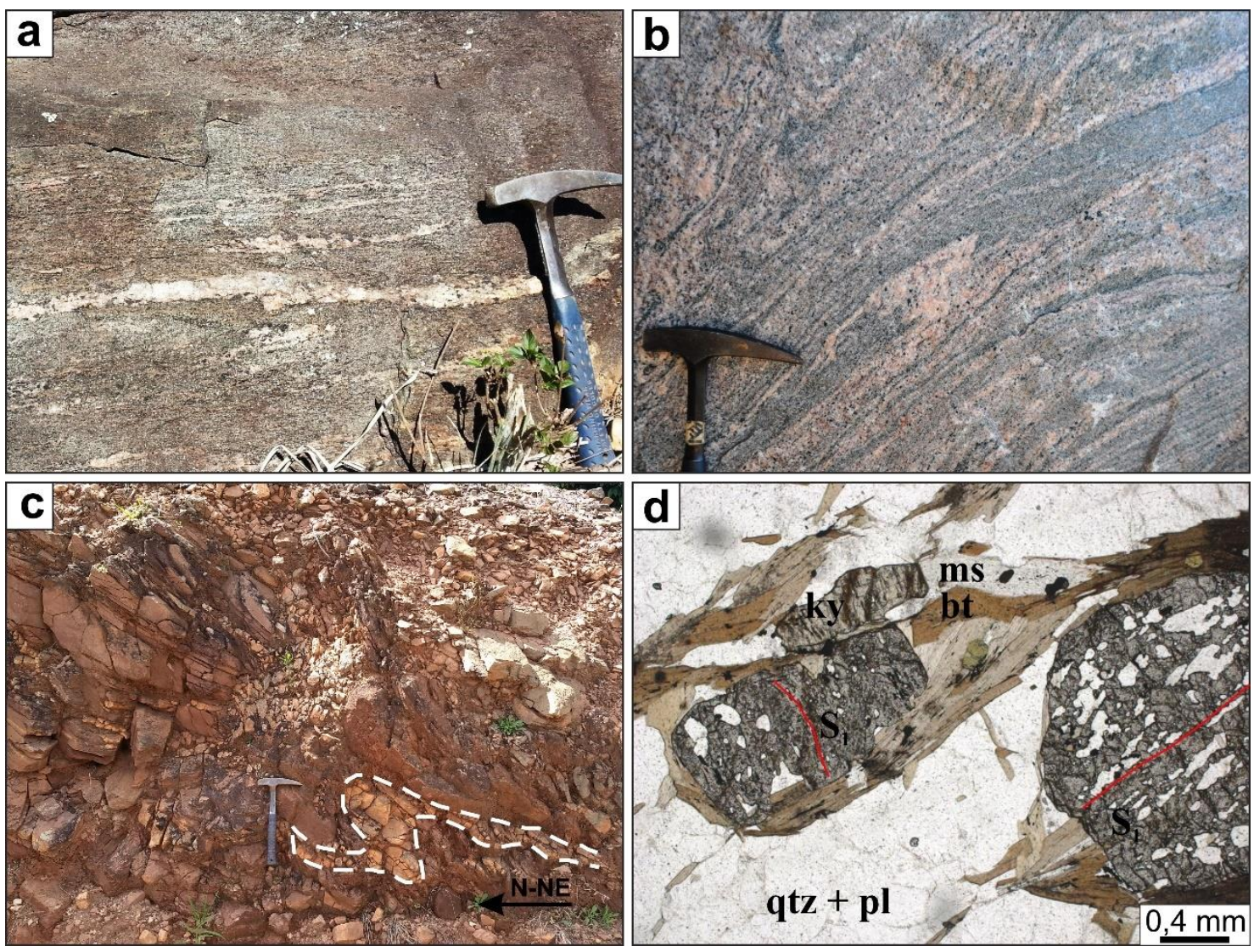

Fig. 6: a) Hornblende-biotite stromatic metathexite predominant in the Mamote Belt; b) Socorro Guaxupé Nappe biotite stromatic metathexite; c) Outcrop of the Colônia Unit with parasitic folds of $\mathrm{D}_{2}$ developed in the most competent beds; d) Garnet porphyroblasts with inclusion trails marking internal foliations discordant with each other, in kyanite-staurolite-muscovite-garnet-biotite schist of the Colonia Unit. 


\section{Structural Geology}

Morphostructural lineaments present in the Petúnia and Campos Gerais Complexes have a broad geomorphological expression, demarcate clear relief breaks and are associated with regional shear zones (Fig. 4f). These lines are compatible with extensive magnetic lineaments identified on the maps of Total Magnetic Field, Analytical Signal Amplitude (Roest et al., 1992) and TILT Derivative (Miller \& Singh, 1994; Fig. 5c-d). The Mumbuca and Córrego das Almas Belts and the NW-SE domains of the Petunia Complex are marked by a high frequency of NW-SE directional magnetic lineaments, subordinated to long wavelength lineaments, usually associated with deep structures and concomitant with shear zones that delimit these belts. In the E-W belt of the Petúnia Complex, in the Mamote Belt and in Socorro-Guaxupé Nappe, there are subparallel high-intensity magnetic lineaments of E-W direction (Fig. 5d), which even extend under sedimentary units in the Paraná Basin.

In the NW-SE belt of the Petúnia Complex, three deformational phases are recognized. The first one developed a $S_{1}$ foliation, preserved in rare biotite polygonal arcs and in inclusion trails in inter-kinematic garnet porphyroblasts in the metapelites of the Colônia Unit. The second one developed a $S_{2}$ foliation, and in the most competent beds, $\mathrm{D}_{2}$ folds, formed by granoblastic quartz lenses in the middle of the schists, configuring millimeter to centimeter isoclinal folds, intrafolial, with an $S_{2}$ axial plane, and rare decimetric parasitic folds preserved (Fig. 6c). The $\mathrm{D}_{2}$ folds have a 265/33 constructed axis (Fig. 7a stereogram 2). Registers of deformations superimposed on $S_{2}$ are rare, as the structures were obliterated by the mylonitization/cataclasis. They are characterized as two crenulation directions superimposed on $\mathrm{D}_{2}$, defining an interference pattern in dome-and-basin structures, however, little has been preserved from these structures, and it is not possible to better characterize these deformational events.

Garnet porphyroblasts with internal foliations that are discordant with each other (Fig. 6d) suggest that $S_{2}$ admits a rotational component related to the installation of the Bom Jesus da Penha, Mumbuca and Cássia-Fortaleza de Minas transcurrent shear zones. These shear zones were also responsible for the transposition of $S_{2}$, forming the regional foliation $S_{3}$ (Fig. 7a - stereogram 2). The shear zones have ductile-brittle characteristics, are sub-vertical, and have a general NW-SE direction, with stretching lineation L $_{3}$ 200/10 (Fig. 7a stereogram 3) and kinematic indicators of sinistral movement. The $S_{3}$ foliation is mylonitic, with C-S pairs and that generated $\mathrm{S}$ tectonites, with dipping foliation predominantly to 150/65. This structural pattern is repeated in the Mumbuca Belt (Fig. 7a - stereogram 1) and 
is also pointed out in the Campos Gerais Orthogneiss (Turbay, 2010), in the Serra do Dondó Belt (Fig. 2).

In the E-W belt of the Petúnia Complex the foliations are subvertical, with dips from $70^{\circ}$ to $80^{\circ}$ to the south, controlled by the RFSZ (Fig. $7 \mathbf{b}$ - stereogram 4). In the Mamote Belt, the stretch lineations, with a medium direction 270/20, are related to the transcurrent tectonics (Fig. 7b - stereogram 6), but their rocks still exhibit past medium dipping foliations and preserved large folds (Fig. 7b - stereogram 5).

\section{$\mathrm{U}-\mathrm{Pb}$ results}

From the Petúnia Unit, a sample of epidote - biotite tonalitic gneiss (CP-38) was collected, which is the dominant rock type in the unit. The zircon crystals are prismatic, with rounded terminations and 80-220 $\mu \mathrm{m}$ along the c axis. They are yellow colored, with opaque mineral inclusions, fracturing and varying degrees of metamictization. The luminescence is varied, and typical textures of igneous crystallization predominate internally, such as concentric oscillatory zoning and zoned sectors, both at the edges and in the inherited core, when they are present (Fig. 8a). Thin, homogeneous edges and sparse resorption points, both with high luminescence, which indicate low $\mathrm{U}$ content, are interpreted as metamorphic recrystallization products. More metamictization reflects a greater abundance of these recrystallization points and, together with the constant loss of $\mathrm{Pb}$, is one of the causes of the observed discrepancies (Fig. 9c).

Intermediate portions and core inherited from the crystals were analyzed. Due to its limited size, the outer edges were not analyzed. Fifteen out of forty analyzes were selected to calculate the age, most of which were discordant. Regardless of the degree of discordance, the Th / U ratio varies from 0.13 to 0.57 , and the data show dispersion aligned in a discord whose superior intercept at $2993 \pm 6 \mathrm{Ma}(\mathrm{MSWD}=0.65)$ is interpreted as the age of crystallization of the igneous protolith (Fig. 9c). The lower intercept at $845 \pm 17$ Ma reflects loss of lead and mixture of domains, suggesting a Neoproterozoic overlap.

In the Ribeirão da Conquista Gneiss, sample CP-94, two populations of zircon crystals are recognized: the first one formed by prismatic crystals with 120 to $180 \mu \mathrm{m}$ along the $c$ axis and proportions of $4: 1$; and the second on is formed by prismatic crystals to ovoids with 180 to $360 \mu \mathrm{m}$ along the c axis and proportions of 3:1. In both crystals they are colorless or yellowish, with variable degree of fracturing and metamictization, systematically more intense at the edges (Fig. 8b). 
The crystals of both populations have the same internal textures. The edges of the crystals are dark, exhibit oscillatory zoning, sometimes with convoluted domains, and provided highly discordant results due to loss of $\mathrm{Pb}$. Only six out of twenty-five edge analyzes (Table 3 - supplementary material) define a discord line with the superior intercept at $2835 \pm 12 \mathrm{Ma}(\mathrm{MSWD}=3.1)$ and Th / U ratio from 0.025 to 0.19 (Fig. 9a).

Inherited cores exhibit zoned sectors or concentric oscillatory zoning, both with higher luminescence, indicating lower $\mathrm{U}$ content, or lower luminescence convoluted zoning, and higher $\mathrm{U}$ content, and may also exhibit a combination of these textures, suggesting multiple stages of crystallization. Two sets of inherited cores provided discordant lines, one of them formed by eleven crystals with greater variation in the Th / U ratio, from 0.09 to 0.85 , and upper intercept at $2877 \pm 5 \mathrm{Ma}(\mathrm{MSWD}=0.57)$, and another on formed by seven crystals with less variation in the Th / U ratio, 0.09 to 0.38, and older ages (points 5.2, 19.1 and 30.1 Fig. 8b), with the upper intercept at $3027 \pm 8 \mathrm{Ma}(\mathrm{MSWD}=0.95)$ (Fig. 9b).

A sample (CP-45) of Bom Jesus da Penha metagranite was collected, from which were separated prismatic, euhedral and bipyramidal zircon crystals, with 100-200 $\mu \mathrm{m}$ along the $\mathrm{c}$ axis. Two populations are distinguishable: the first one formed by colorless crystals with rare inclusions of opaque minerals and low or absent fracturing, and the second one predominantly formed by light yellow crystals, rich in inclusions and impregnations of opaque minerals, where fracturing is always present and followed by metamictization.

Internally there are no textural differences between the two populations and the crystals exhibit low luminescence. In both crystals they have inherited core with oscillatory zoning or zoned sectors and homogeneous dark edges (Fig. 8c), locally with visible oscillatory zoning, but always with less luminescence, indicating a higher U content. Punctual recrystallization and thin overgrowth of metamorphic edges with higher luminescence and lower $U$ content are not always present and have too small dimensions to analyze. The data show a variable degree of discordia due to loss of $\mathrm{Pb}$ and mixture of domains. Eleven out of nineteen analysis on the inner edges, with $\mathrm{Th} / \mathrm{U}$ from 0.021 to 0.281 , define a discordia line with the upper intercept at $2004 \pm 5 \mathrm{Ma}(\mathrm{MSWD}=0.5)$, interpreted as the age of crystallization of the igneous protolith (Fig. 9d). Inherited core record ages from the Archean to the Rhyacian period, but the degree of discordance is variable, and the data do not define any noteworthy discord curves. 


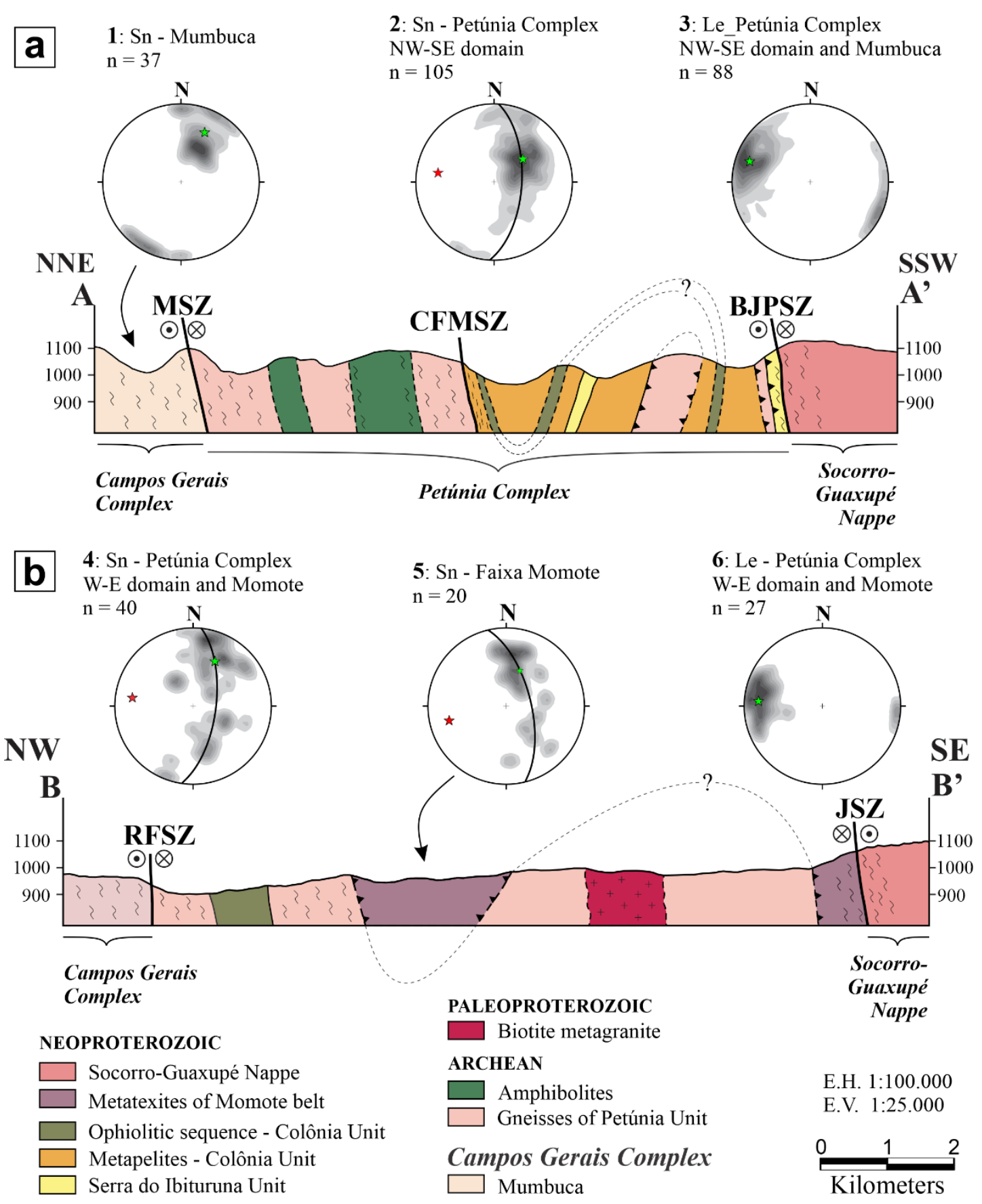

Fig. 7: Geological sections of the Petunia Complex (a) and of the Mamote Belt (b). 


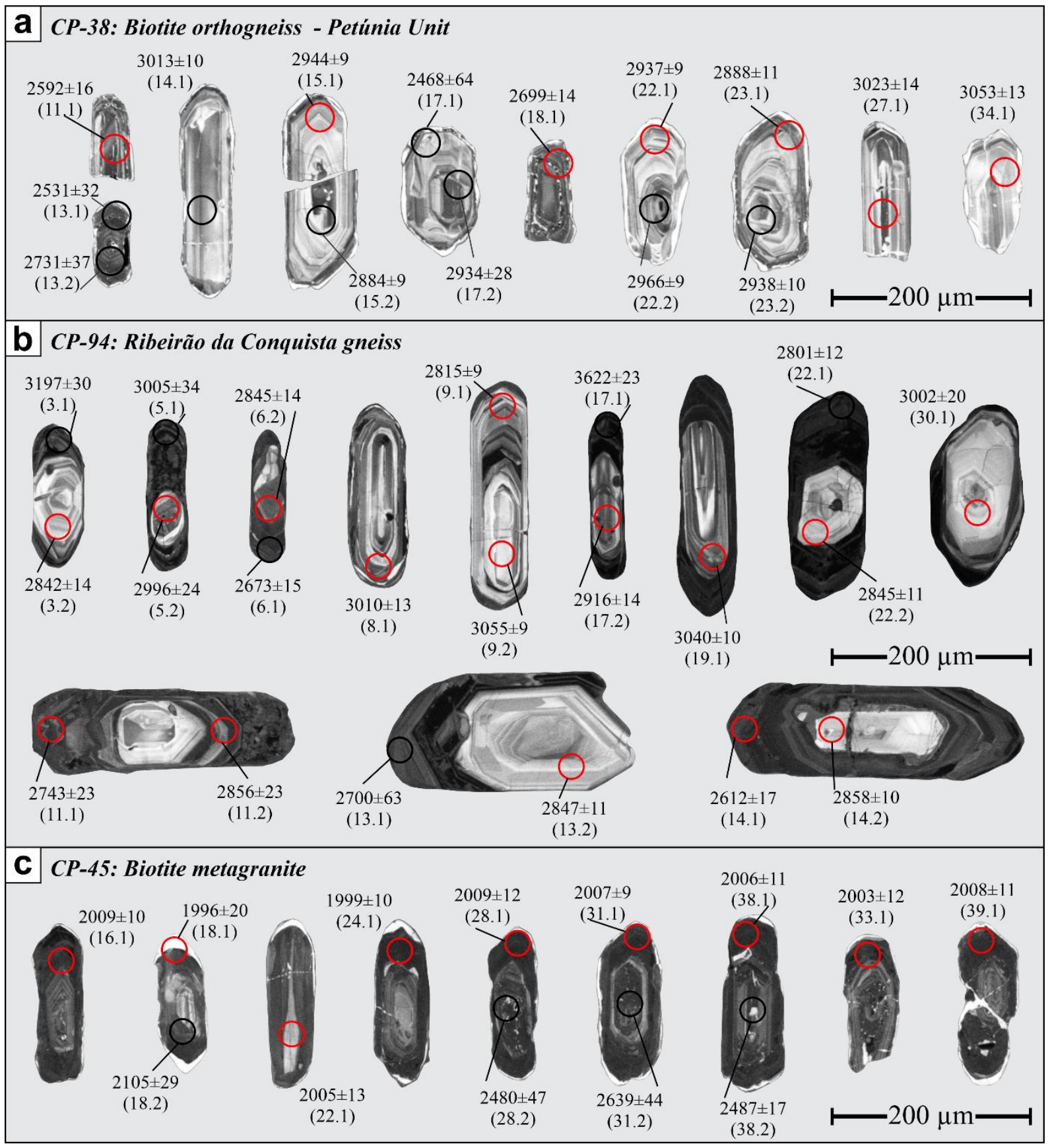

Figure 8: Catodoluminescence images of zircon crystals representative of the samples, placed on the same scale for comparison. a) Petunia Unit, sample CP-38; b) Ribeirão da Conquista Gneiss, sample CP-94; c) Bom Jesus da Penha Metagranite, sample CP-45. The ${ }^{207} \mathrm{~Pb} /{ }^{206} \mathrm{~Pb}$ ages, with 20 error, are indicated in red circles for concordant ages and black for discordant ages. 

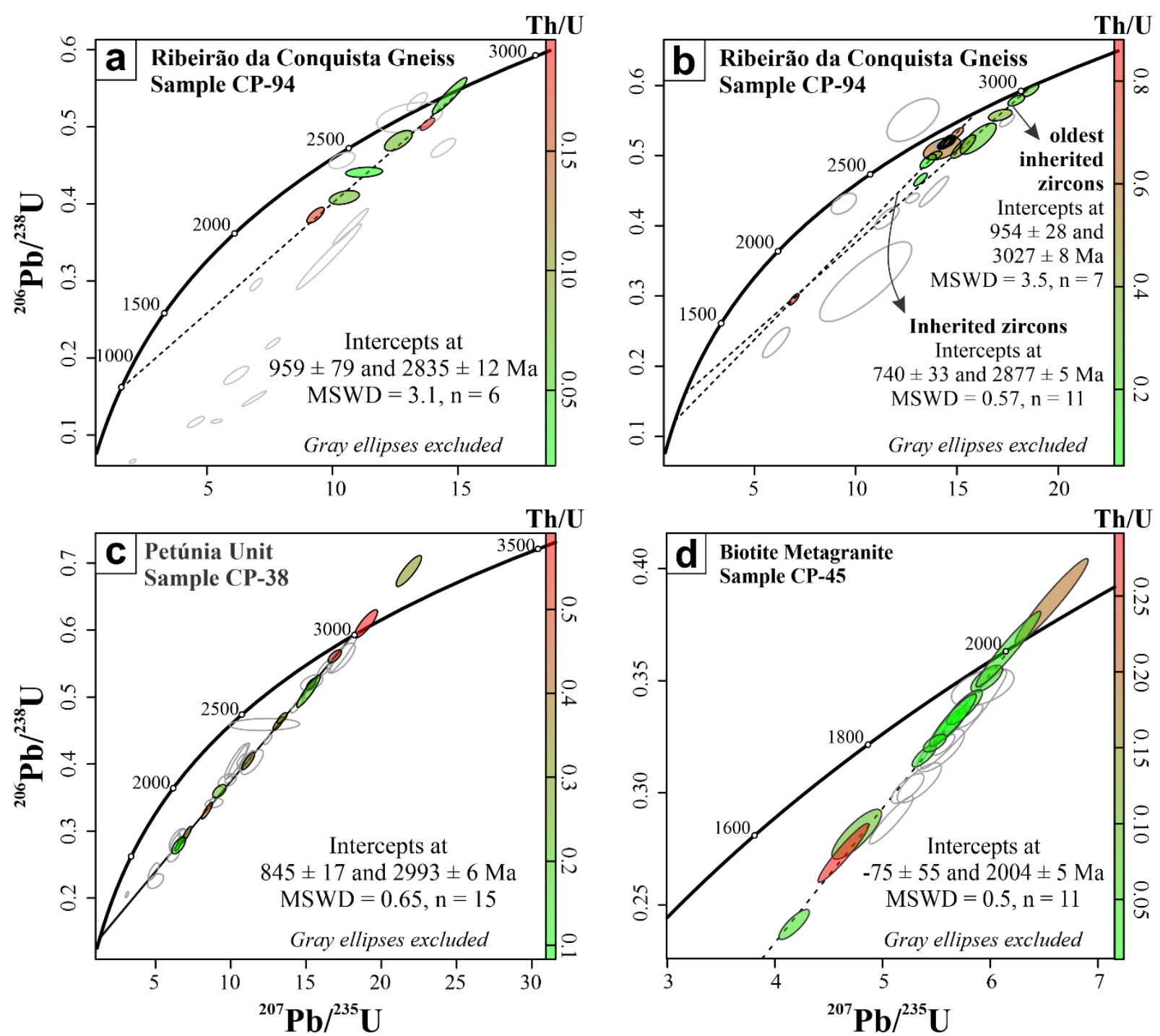

Figure 9: Concordia diagrams for zircon U-Pb LA-ICP-MS. Crystallization age of the Ribeirão da Conquista Gneiss - a) for protolith, sample CP-94; b) for inheritances; c) Crystallization age of the biotite gneiss tonalitic from the Petunia Unit, sample CP-38; d) Crystallization age for Bom Jesus da Penha Metagranite, sample CP-45. Error ellipses are 2o.

\section{Discussions}

The Campos Gerais Complex, in its stricto sensu conception (Kaefer et al., 1979), corresponds to a TTG type Archean terrane (Turbay \& Valeriano, 2012) with Greenstone Belts that compose part of the southwest edge of the São Francisco Craton reworked by the Campo do Meio Shear Belt, developed during the consolidation of the Brasília Meridional Orogen. Despite the intense reworking along the Campo do Meio Shear Belt, the Campos Gerais Complex preserves less deformed Archean nuclei with intrusions of Paleoproterozoic granitoids, which is one of the characteristics that led to the status of an autochthonous domain. 


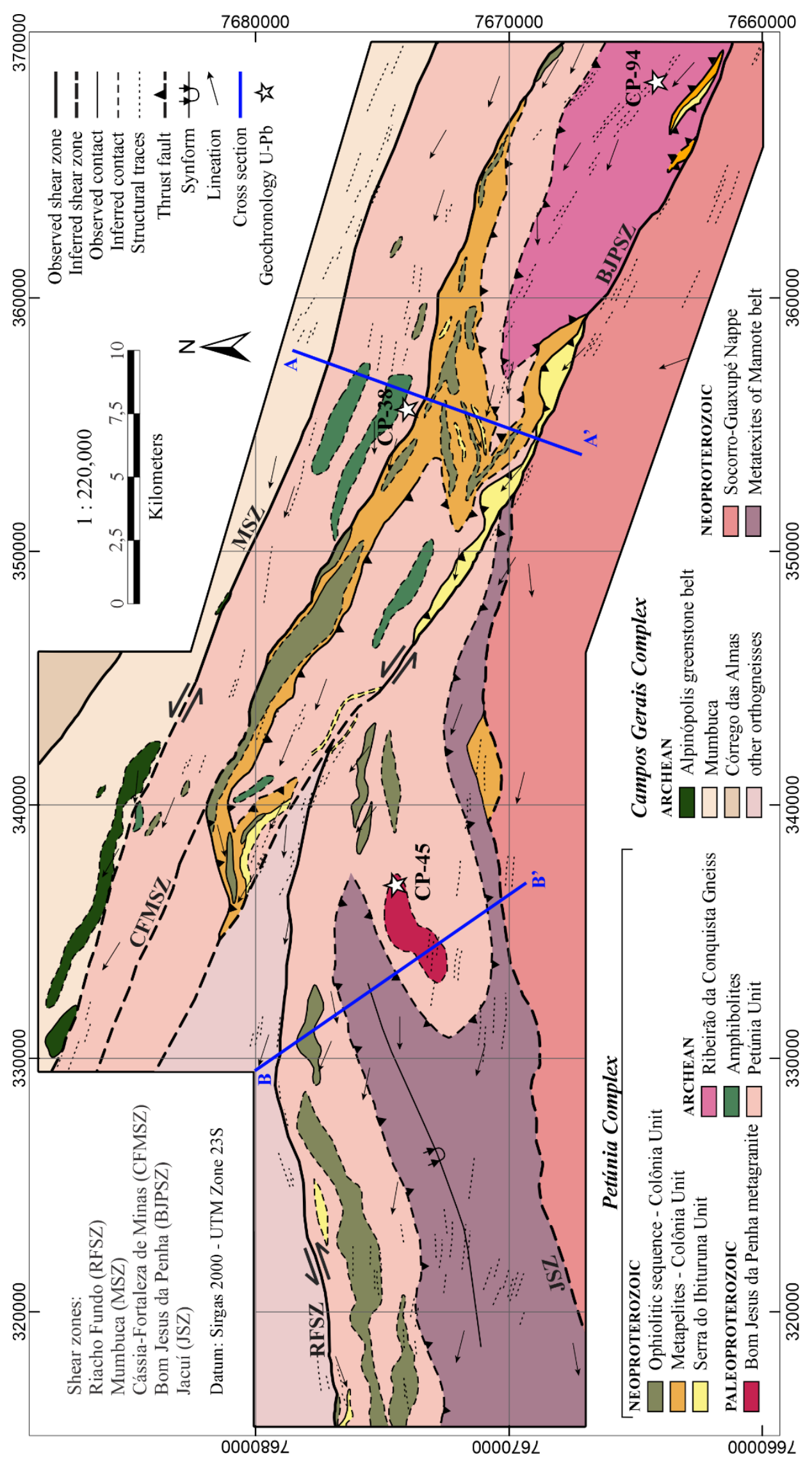

Fig. 10: Geologic Map for Petúnia Complex. 
The intense hydrothermal activity associated with the transcurrent shear zones was also responsible for the widespread metasomatization observed in the meta-ultramafic rocks of the Petunia and Colônia Units and in the gneisses of the Petunia Unit, forming intercalations of silicified muscovite-quartz schist. Despite the absence of geochemical data in the literature these intercalations led to the interpretation of a paraderivative origin for the gneisses of the Petunia Unit (Crosta et al., 1986; Zanardo, 1992; Roig, 1993), reinforcing the idea of allochthonous domain of the Campos Gerais Complex. However, the formation of these schists results from the substitution of feldspars for muscovite, catalyzed by hydration associated with the shear zones, which also justifies the low U-Th and $\mathrm{K}$ airborn gammaspectrometric counts observed in the Petunia Unit (Fig. 4a-c).

The structural pattern of the Petunia and Campos Gerais Complexes is similar, and both have a structural framework formed by a sinistral transcurrent zone framework, with brittle-ductile characteristics and distribution in an anastomosed pattern, with mineral stretch lineations and kinematic indicators registering tectonic transport for WNW (Fig. 10). Several groups of magnetic lineaments appear parallel to the main shear zones in the region, showing the effects of tectonism within both complexes.

The Mumbuca Belt presents typical metasedimentary sequences of the Petunia Complex and its meta-ultramafic rocks do not have spinifex relict textures such as those present in the Alpinópolis Greenstone Belt (Szabó, 1996), but this is only due to the tectonic mixture that occurs in the contact between these complexes. The distribution of radioelements, with high counts in the Campos Gerais Complex and low counts in the Petúnia Complex (Fig. 4a-c) corroborates that the southern limit of the Campos Gerais Complex is established by the shear zones of Mumbuca and Riacho Fundo, which were responsible for the juxtaposition of the Petunia Complex at south of them (Fig. 10). Both magnetic anomalies and radiometric signatures show that the meta-ultramafic rocks respect the limits observed on the surface, following the Riacho Fundo, Bom Jesus da Penha, Cássia-Fortaleza de Minas and Mumbuca Shear Zones (Fig. 3), suggesting that they facilitated tectonic transport along them. The separation of the complexes, although hardly visible in the field outcrops, is clearly defined in the geophysical data (Fig.4 and Fig.5).

The structural framework of the EW portion of the Petunia Complex and the Mamote Belt is controlled by the Riacho Fundo and Jacuí Shear Zones. However, there are two less deformed domains between these shear zones, with the first one represented by past folds in the Mamote Belt, related to the convergence between the paleoplates São Francisco-Congo and Paranapanema, and another one represented by the metagranite body whose contact 
relations were interpreted as being of an intrusive nature due to its low degree of deformation in relation to the enclosing rocks.

The Paleoproterozoic age obtained for this metagranite (2004 $\pm 5 \mathrm{Ma})$ may represent the extension of the Mineiro Belt to the west along the edge of the São Francisco Craton, which registers plutonism, metamorphism and deformations that occurred in the interval between 2.2-1.9 Ga due to the Transamazonic Cycle (Alkmim \& Teixeira, 2017).

Until now, two occurrences of Archean rocks in the Petúnia Complex were known, a biotite gneiss of $2.95 \mathrm{Ga}$ (Campos Neto, et al., 2004) and a metagabbro of $2.96 \mathrm{Ga}$ (Pinheiro, 2013), both from the Petúnia Unit. The crystallization ages of the gneiss protolith of the Petunia Unit, at $2.99 \mathrm{Ga}$, and for the Ribeirão da Conquista Gneiss, at $2.83 \mathrm{Ga}$, obtained in this study reveal that, like the Campos Gerais Complex, the Petunia Complex framework can also be correlated with units from the southern portion of the São Francisco Craton, despite this, in the Petúnia Complex, the presence of splinters of tectonically embedded Neoproterozoic units (ie Colônia and Serra do Ibituruna units) and meta-ultramafic rocks interpreted as remnants of the Neoproterozoic oceanic crust (Choudhuri et al., 1995), allows the interpretation that the Petunia Complex is a terrane independent from the Campos Gerais Complex, restricted to Archean and Paleoproterozoic terrains.

The ages of the Petunia Unit (2.99 Ga) and the Campos Gerais Orthogneiss (2.98 Ga) may represent registers of early stages of pre-cratonization magmatic activity during the Mesoarchean and which peaked during the Rio das Velhas I event, 2.92 - 2.85 Ga ( Lana et al., 2013; Farina et al., 2015) or, in another approach, which considers that the ages obtained are located during the magmatic activity gap, between 3.20 and $2.93 \mathrm{Ga}$, in the southern portion of the São Francisco Craton (Cioffi et al., 2016), the Petúnia and Campos Gerais Complexes may represent amalgamated terranes before the Mesoproterozoic magmatic activity. Data from element and isotope geochemistry analysis may contribute to the understanding of the relationship between the Petunia and Campos Gerais Complexes with the construction of the southern portion of the São Francisco Craton.

\section{Conclusions}

- The Petúnia Complex is formed by a Mesoarchean framework, correlated with units of the São Francisco Craton, and tectonically embedded neoproterozoic units, while the Campos

Gerais Complex is restricted to TTG meso to neoarchean terranes with greenstone belts. The set was juxtaposed due to the installation of the Campo do Meio Shear Belt and in 
this sense the terms allochthonous and autochthonous for the Campos Gerais Complex lose their meaning;

- The presence of gneisses whose protoliths were granitoids with crystallization ages between 2.07 and $1.98 \mathrm{Ga}$, ie Metagranite and Itaxipé Granite respectively intrusive in the Petunia and Campos Gerais Complexes, besides representing the extension of the Mineiro Belt to the west, indicate a polycyclic evolution for the Campo do Meio Shear Belt, with the oldest reworking in the Transamazonic Cycle, during the Paleoproterozoic, followed by the reworking in the Brasiliano Cycle, when it served as a suture zone between the São Francisco and Paranapanema paleoplates, nowadays registered by the remains of Neoproterozoic oceanic crust;

- While the tectonic transport of the Neoproterozoic nappes of the orogen has a general ENE direction (Campos Neto et al., 2004), in the Campo do Meio Shear Belt the tectonic transport to WNW represents the final stages of consolidation and, when already in a brittle regime, reactivated old basement faults, such as the Bom Jesus da Penha Fault.

\section{Bibliographic references}

Alkmim, F.F., Teixeira, W., 2017, The Paleoproterozoic Mineiro Belt and the Quadrilátero Ferrífero, in Heilbron, M., Cordani, U.G., Alkmim, F.F., eds., São Francisco Craton, Eastern Brazil: Tectonic Genealogy of a Miniature Continent: Springer International Publishing, New York, Regional Geology Reviews, p. 71-94, doi:10.1007/978-3-319-01715-0_5.

Brito Neves, B.B., Campos Neto, M.C., Fuck, R.A., 1999, From Rodinia to Western Gondwana: an approach to the Brasiliano-Pan African Cycle and orogenic collage. Episodes v.22, no.3, p. 155-166. doi:10.18814/epiiugs/1999/v22i3/002.

Campos Neto, M.C., Basei, M.A.S., Janasi, V.A., Moraes, R., 2011, Orogen migration and tectonic setting of the Andrelândia Nappe system: an Ediacaran western Gondwana collage, south of São Francisco craton: Journal of South American Earth Science, v. 32, p. 393-406, doi:10.1016/j.jsames.2011.02.006.

Campos Neto, M.C., Cioffi, C.R., Moraes, R., et al., 2010, Structural and metamorphic control on the exhumation of high-P granulites: the Carvalhos Klippe example, from the oriental Andrelândia Nappe system, southern portion of the Brasília Orogen, Brazil: Precambrian Research, v. 180, p. 125-142, doi:10.1016/j.precamres.2010.05.010

Campos Neto, M.C., Basei, M.A.S., Vlach, S.R.F., Caby, R., Szabó, G.A.J., Vasconcelos, P., 
2004, Migração de orógenos e superposição de orogêneses: um esboço da colagem brasiliana no sul do Cráton do São Francisco, SE - Brasil. Revista do Instituto de Geociências - USP. São Paulo, v.4, p. 13-40, doi:10.5327/S1519-874X2004000100002

Campos Neto, M.C.; Caby, R., 1999, Neoproterozoic high-pressure metamorphism and tectonic constraint from the nappe system south of the São Francisco Craton, Southeast Brazil: Precambrian Research, v. 97, p. 3-26, doi:10.1016/S0301-9268(99)00010-8

Choudhuri, A., Schrank, A., Roig, H.L., Szabó, G.A.J., 1995, Negative Ce anomaly in mafic rocks of a possible Late Proterozoic ophiolite from SW Minas Gerais, Brazil, in Srivastava, R.K., Chandra, R., eds., Magmatism in relation to diverse tectonic settings. Oxford: IBH Publishing Co., p. 283-290.

Cioffi, C.R., Campos Neto, M. da C., Möller, A., e Rocha, B.C., 2016a, Paleoproterozoic continental crust generation events at 2.15 and $2.08 \mathrm{Ga}$ in the basement of the southern Brasília Orogen, SE Brazil: Precambrian Research, v. 275, p. 176-196, doi:10.1016/j.precamres.2016.01.007.

Companhia de Desenvolvimento Econômico de Minas Gerais, 2015, Projeto Fronteiras de Minas Gerais - Folha Nova Resende, SF.23-V-D-I, escala 1:100.000, Por Antônio Carlos Pedrosa Soares e outros. Minas Gerais, CODEMIG/UFMG.

Commission for the Geologial Map of the World, 2001. Geological Map of South America.

Crosta, A.P., Choudhuri, A., Szabó, G.A.J., Schrank, A., 1986, Relações entre tipos litológicos e suas estruturas regionais nos terrenos arqueanos e paleoproterozoicos do sudoeste de Minas Gerais, in Congresso Brasileiro de Geologia, 34, Goiânia, Goiás, p. 720-721.

Dardenne, M.A., 2000, The Brasília fold belt, in Cordani, U.G., Milani, E.J., Thomaz Filho, A., Campos, D.A., eds., Tectonic Evolution of South America, 31th International Geological Congress, Rio de Janeiro, Brazil, p. 231-257.

Dickson, B.L., e Scott, K.M., 1997, Interpretation of aerial gamma-ray surveys - adding the geochemical factors: AGSO Journal of Australian Geology and Geophysics, v. 17, p. 187200, doi: http://pid.geoscience.gov.au/dataset/ga/81502.

Farina, F., Albert, C., e Lana, C., 2015, The Neoarchean transition between medium-and highK granitoids: Clues from the Southern São Francisco Craton (Brazil): Precambrian Research, v. 266, p. 375-394, doi:10.1016/j.precamres.2015.05.038.

Fayad, D.A.C., 2013, Cromititos dos Complexos Campos Gerais e Petúnia (Faixa Brasília Meridional) na região de Alpinópolis e Nova Resende (MG): Geologia, petrografia, 
química mineral e ambientação tectono-magmática [Dissertação de Mestrado]: São Paulo, Universidade de São Paulo, 99 p.

Feola, J.L., 2004, Mineralizações auríferas hospedadas na Faixa Metavulcanossedimentar Jacuí-Bom Jesus da Penha - sudoeste de Minas Gerais [Tese de Doutorado]: Rio Claro, Universidade Estadual Paulista, 211 p.

Fuck, R.A., Pimentel, M.M., Del Rey Silva, L.J.H., 1994, Compartimentação tectônica da porção oriental da província Tocantins: Congresso Brasileiro de Geologia, 38th, Camboriu, SC, Anais, p. 215-216.

Gleizes, G., Crevon, G., Asrat, A., Barbey, P., 2006, Structure, age and mode of emplacement of the Hercynian Bordères-Louron pluton (Central Pyrenees, France): International Journal of Earth Sciences (Geol Rundsch), v. 95, p. 1039-1052, doi:10.1007/s00531-006-0088-4

Gnojek I., Prichystal A., 1985, A new zinc mineralization detected by airborne gamma-ray spectrometry in northern Moravia (Czechoslovakia): Geoexploration, v. 23, p. 491-502, doi:10.1016/0016-7142(85)90076-6

Haralyi, N.L.E., Hasui, Y., 1982. The gravimetric information and the archean-proterozoic structural framework of eastern Brazil: Revista Brasileira de Geociências, v.12, p. 160-166.

Hasui, Y.A., 2010, A grande colisão pré-cambriana do sudeste brasileiro e a estruturação regional. Geociências, v. 29, p. 141-169.

Hasui, Y., Haralyi, N.L.E., Costa, J.B.S., 1993, Megaestruturação pré-cambriana do território brasileiro baseada em dados geofísicos e geológicos. Geociências, v. 12, p. 7-31.

Jackson, S.E., Pearson, N.J., Griffin, W.L., Belousova, E.A., 2004, The application of laser ablation-inductively coupled plasma-mass spectrometry to in-situ $\mathrm{U}-\mathrm{Pb}$ zircon geochronology: Chemical Geology, v. 211, p. 47-69, doi: 10.1016/j.chemgeo.2004.06.017

Kaefer, L.Q. et al., 1979, Projeto Sapucaí, estados de São Paulo, Rio de Janeiro e Minas Gerais. Relatório final de geologia. Departamento Nacional de Produção Mineral, Brasília, Superintendência Regional de São Paulo, 299 p.

Lana, C., Alkmim, F.F., Armstrong, R., Scholz, R., Romano, R., e Nalini, H.A., 2013, The ancestry and magmatic evolution of Archaean TTG rocks of the Quadrilátero Ferrífero province, southeast Brazil: Precambrian Research, v. 231, p. 157-173, doi:10.1016/j.precamres.2013.03.008.

Lopes, L.B.L., 2013, Granitogênese e metamorfismo da fácies granulito da porção sul da Faixa Brasília, Areado, Minas Gerais [Monografia de Conclusão de Curso]: São Paulo, Universidade de São Paulo, 52 p.

Ludwig, K.R., 1998, On the treatment of concordant uranium-lead ages: Geochimica et 
Cosmochimica Acta, v. 62, p. 665-676, doi:10.1016/S0016-7037(98)00059-3.

Malagutti Filho, W., Ebert, H.D., Hasui, Y., Haralyi, N.L.E., Hackspacher, P.C., Sturaro, J.R., Souza, C.A., Almeida, S.H.S., 1996, Gravimetria e compartimentação crustal do sul de Minas Gerais: Geociências, v. 15, p. 199-217.

Miller, H.G. e Singh, V., 1994, Potential Field Tilt a New Concept for Location of Potential Field Sources: Journal of Applied Geophysics, v. 32, p. 213-217, doi:10.1016/09269851(94)90022-1.

Morales, N., Hasui, Y.A., 1993, Evolução tectônica da porção ocidental do Cinturão de Cisalhamento Campo do Meio, in Simpósio Nacional de Estudos Tectônicos, $4^{\circ}$, Belo Horizonte, MG, p. 292-296.

Morales, N., Carvalho, S.G., Choudhuri, A., Fiori, A.P., Oliveira, M.A.F., Rodrigues, M.F.B., Soares, P.C., Zanardo, A., 1983, Geologia das folhas de Fortaleza de Minas, Alpinópolis, Jacuí e Nova Resende, MG, in Simpósio de Geologia de Minas Gerais, 2, Belo Horizonte, Minas Gerais, p. 411-422.

Paciullo, F.V.P., Ribeiro, A., Cherman, A., Chrispim, S., Maciel, R.R., 2008, Programa Geologia do Brasil: Folha Nepomuceno, SF-23-V-D-III, escala 1:100.000. Nota explicativa, Brasília: CPRM, 92 p.

Pimentel, M.M., Ferreira Filho, M.F., 2002, Idades Sm-Nd de komatiitos do greenstone belt do Morro do Ferro, Fortaleza de Minas (MG): Revista Brasileira de Geociências, v. 32, p. 147-148.

Pinheiro, M.A.P., 2013, Geologia e petrogênese de corpos máfico-ultramáficos da Faixa Brasília Sul, borda sul do Cráton São Francisco - Minas Gerais [Tese de Doutorado]: Ouro Preto, Universidade Federal de Ouro Preto, 248 p.

Roest, W.R., Verhoef, J. and Pilkington, M., 1992. Magnetic interpretation using the 3-D analytic signal. Geophysics, v. 57, p. 116-125, doi:10.1190/1.1443174.

Roig, H.L., 1993, Caracterização da "Zona de Sutura" Jacuí-Conceição da Aparecida, MG limite norte do Cinturão Alto Rio Grande: implicações geotectônicas e metalogenéticas [Dissertação de Mestrado]: Campinas, Universidade Estadual de Campinas, 136 p.

Roig, H.L., Schrank, A., 1992, Caracterização da zona de sutura Jacuí-Conceição da Aparecida - limite norte do complexo de nappes de Guaxupé, in Congresso Brasileiro de Geologia, 37, São paulo, SP, p.283-285

Schrank, A., Abreu, F.R., Roig, H.L., Choudhuri, A., Carvalho, E.D.R., 1990, Determinação dos vetores de transporte tectônico na borda sudoeste do Cráton do São Francisco, in Congresso Brasileiro de Geologia, 36, Natal, RN, p. 2276-2283. 
Soares, P.C., Fiori, A.P., 1990, Tectônica Colisional Oblíqua entre o Bloco Paraná e a margem sul do Cráton do São Francisco, no Maciço de Guaxupé, in Congresso Brasileiro de Geologia, 36, Natal, Rio Grande do Norte, p. 2723-2734.

Szabó, G.A.J., 1996, Petrologia da Suíte Metaultramáfica da Sequência Vulcano-Sedimentar Morro do Ferro na Região de sul a oeste de Alpinópolis, MG (Domínio Norte do Complexo Campos Gerais) [Tese de Doutorado]: São Paulo, Universidade de São Paulo, $354 \mathrm{p}$.

Szabó, G.A.J., Rolo, H.L., Schrank, A., Choudhuri, A., 1993, Duas faixas litoestruturais distintas e o limite das Províncias Tocantins e Mantiqueira, entre Alpinópolis e Nova Resende (MG), in Simpósio sobre o Cráton do São Francisco, Salvador, BA, p. 272-274.

Teixeira, N.A., Gaspar, J.C., Brenner, T.L., Cheney, J.T., Marchetto, C.M.L., 1987, Geologia e implicações geotectônicas do Greenstone Belt Morro do Ferro (Fortaleza de Minas-MG). Revista Brasileira de Geociências, São Paulo, v. 17, p. 209-220.

Teixeira, N.A., Danni, J.C.M., 1979, Geologia da raiz de um greenstone belt na região de Fortaleza de Minas, MG: Revista Brasileira de Geociências, v. 9, p. 17-26.

Teixeira, W., Cordani, U.G., Nutman, A.P., Sato, K., 1998, Polyphase archean evolution in the Campo Belo metamorphic complex, Southern São Francisco Craton, Brazil: SHRIMP $\mathrm{U}-\mathrm{Pb}$ zircon evidence: Journal of South American Earth Sciences, v. 11, p. 279-289, doi:10.1016/S0895-9811(98)00011-X.

Trouw, R.A.J., Heilbron, M., Ribeiro, A., Paciullo, F., Valeriano, C.M., Almeida, J.C.H., Tupinambá, M., Andreis, R.R., 2000. The central segment of Ribeira belt, in Cordani, U.G., Milani, E.J., Thomaz Filho, A., Campos, D.A., eds., Tectonic Evolution of South America, International Geological Congress, 31th, Rio de Janeiro, Brazil, p. 287-310.

Trouw, R.A.J., Ribeiro, A., Paciullo, F.V.P., Heilbron, M.L., 1984, Os grupos São João Del Rei, Carrancas e Andrelândia, interpretados como a continuação dos grupos Araxá e Canastra, in Congresso Brasileiro de Geologia, 33, Rio de Janeiro, RJ, p. 3227-3240.

Turbay C.V.G., Valeriano C.M., 2012, Litogeoquímica do Complexo Campos Gerais e granitoides intrusivos, Arqueano/Paleoproterozoico, Brasil: Revista Brasileira de Geociências, v. 42, p. 663-689, doi:10.5327/Z0375-75362012000400003.

Turbay, C.V.G., 2010, Caracterização petrológica e geocronológica do Complexo Campos Gerais (Arqueano/Paleoproterozóico), Minas Gerais, Brasil [Tese de Doutorado]: Rio de Janeiro, Universidade do Estado do Rio de Janeiro, 176 p.

Valeriano, C.M., Dardenne, M.A., Fonseca, M.A., Simões, L.S.A., Seer, H.J., 2004, A evolução tectônica da faixa Brasília, in Mantesso Neto, V., BartorellI, A., Carneiro C.D.R., 
Brito-Neves, B.B., eds., Geologia do continente sul-americano: Evolução da obra de Fernando Flávio Marques de Almeida. São Paulo, Beca, p. 575-592.

Vermeesch, P., 2018, IsoplotR: a free and open toolbox for geochronology: Geoscience Frontiers, v. 9, p. 1479-1493, doi:10.1016/j.gsf.2018.04.001.

Wernick, E., Artur, A.C., 1983, Regenerações Sucessivas de Terrenos Arqueanos no Leste do Estado de São Paulo e Sul de Minas Gerais, in Simpósio Regional Geologia, 4, São Paulo, São Paulo, p. 17-31.

Westin, A., Campos Neto, M.C., Hawkesworth, C.J., Cawood, P.A., Dhuime, B., e Delavault, H., 2016, A paleoproterozoic intra-arc basin associated with a juvenile source in the Southern Brasilia Orogen: Application of $\mathrm{U}-\mathrm{Pb}$ and $\mathrm{Hf}-\mathrm{Nd}$ isotopic analyses to provenance studies of complex areas: Precambrian Research, v. 276, p. 178-193, doi:10.1016/j.precamres.2016.02.004.

Wiedenbeck, M., Hanchar, J.M., Peck, W.H., et al., 2004, Further characterization of the 91500 zircon crystal. Geostandards and Geoanalytical Research, v. 28, p. 9-39, doi: 10.1111/j.1751-908X.2004.tb01041.X

Zanardo, A., Morales, N., Oliveira, M.A.F., Del Lama, E.A., 2006, Tectono-Lithologic Associations of the Alterosa Paleo Suture Zone - Southeastern Brazil Associação TectonoLitológica da Paleozona de Sutura, Revista Geociências, v. 5, p. 103-117.

Zanardo, A., Oliveira, M.A.F., Del Lama, E.A., 1996, Rochas máficas e ultramáficas da Faixa Jacuí-Bom Jesus da Penha-Conceição da Aparecida (MG): Geociências, v. 15, p. 279-297.

Zanardo A., 1992, Análise petrográfica, estratigráfica e microestrutural da região de GuaxupéPassos-Delfinópolis (MG) [Tese de Doutorado] Rio Claro, Universidade Estadual Paulista, 288 p. 


\section{APÊNDICE B}

Mapa de Pontos 
Apêndice B: Mapa de Pontos Complexo Petúnia e áreas adjacentes

$$
\text { Escala - 1:75.000 }
$$

UNIVERSIDADE DE SÃO PAULO

Programa de Pós-Grituduaçăa em Mineraralogia e Petrologia Complexo Petúnia: Registros de múltiplos estágios evolutivos Rafaela Machado Gengo

Orientador: Prof. Dr. Renato de Moraes TESE DE DOUTORAMENTO
Programa de Pós-Graduacão m Mineralogia e Petrologia
São Paulo, 2020
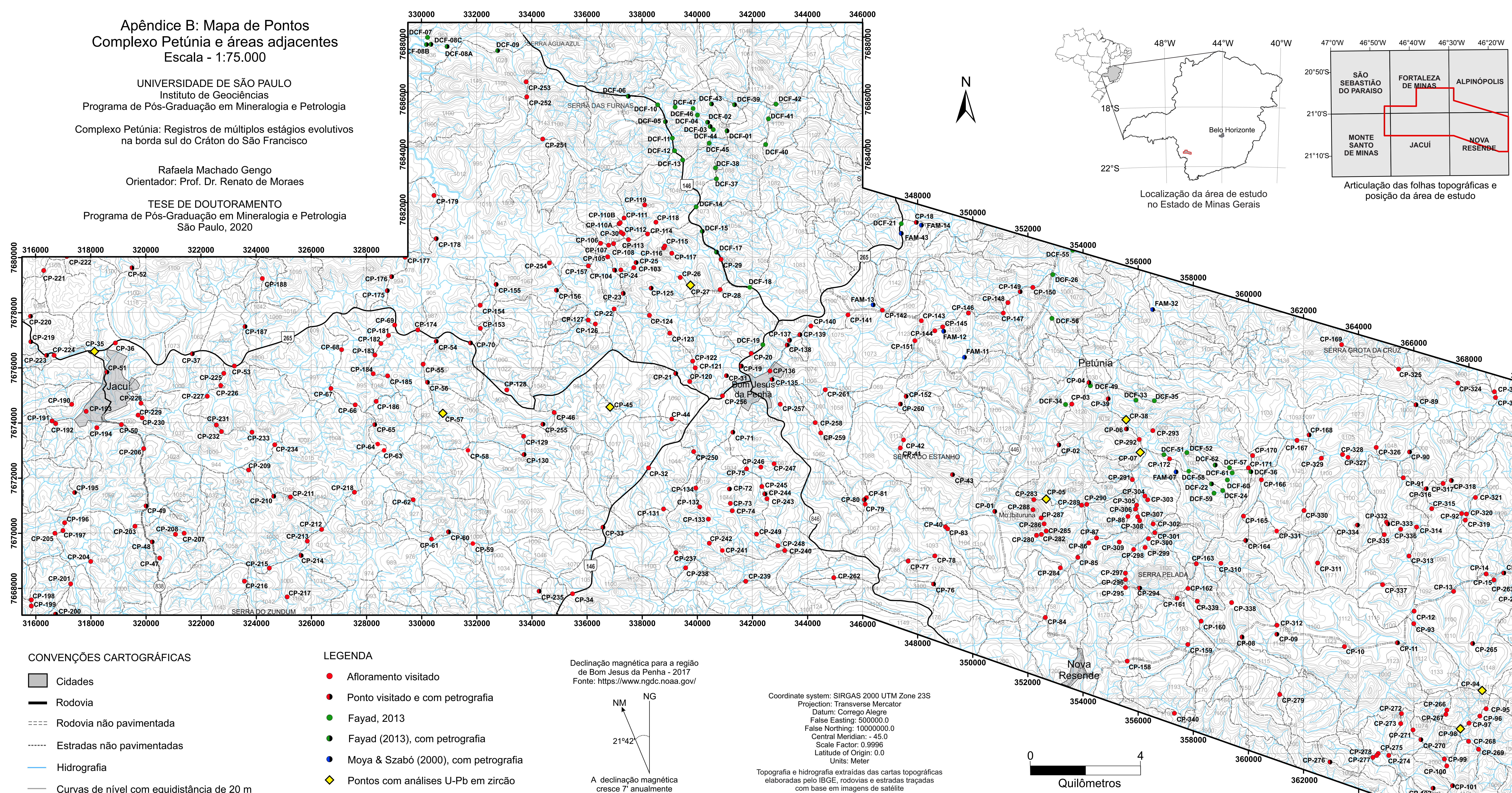

Aticulaçãa das folhas topográificas
posiçăo da área de estudo
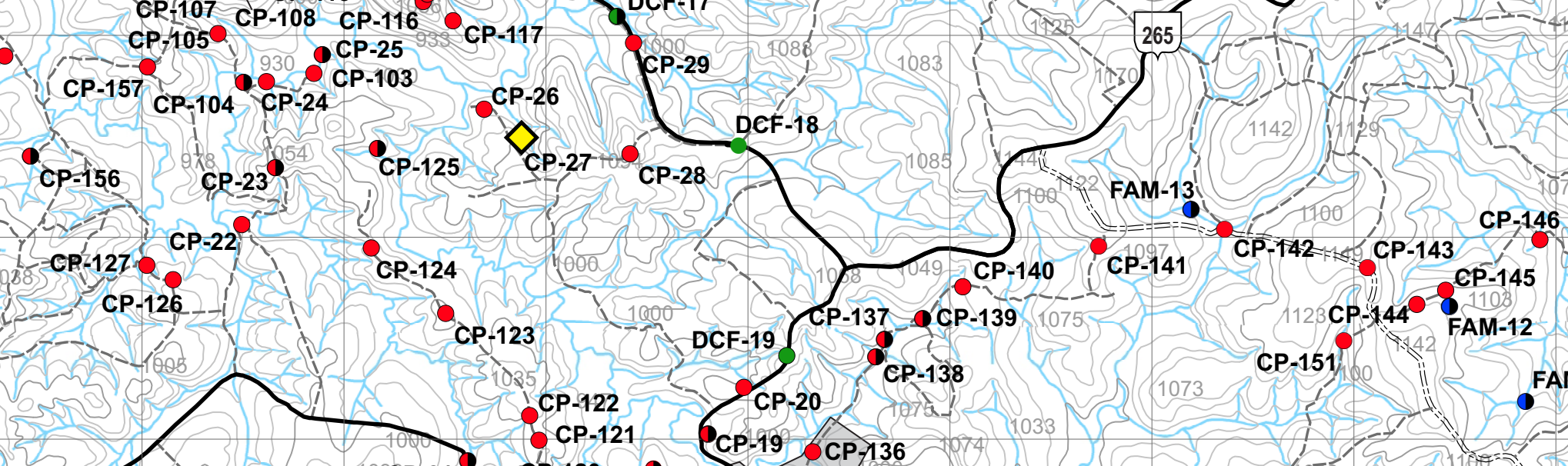

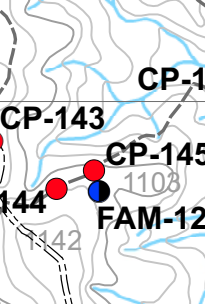

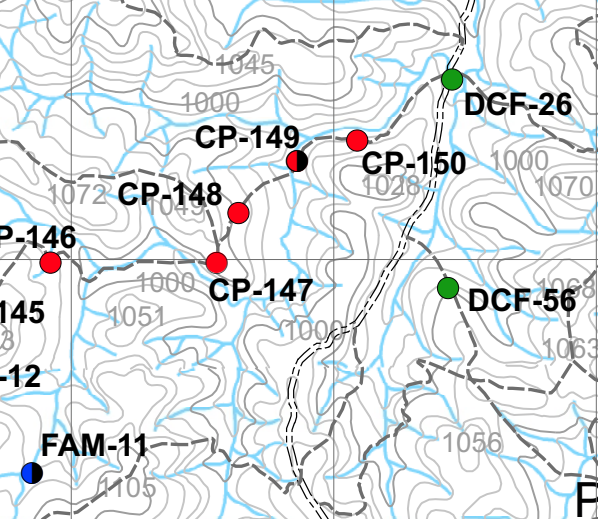

$\overbrace{0 \mathrm{c}-26}^{26}$<smiles>C=CCC</smiles>

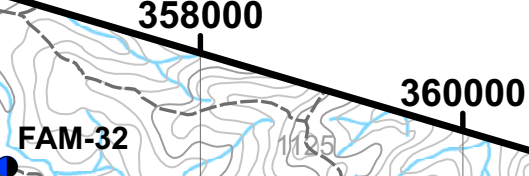

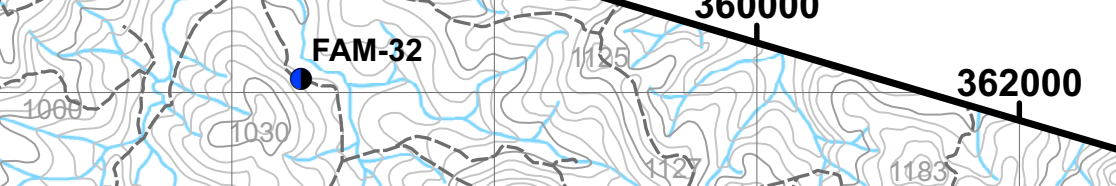

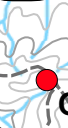

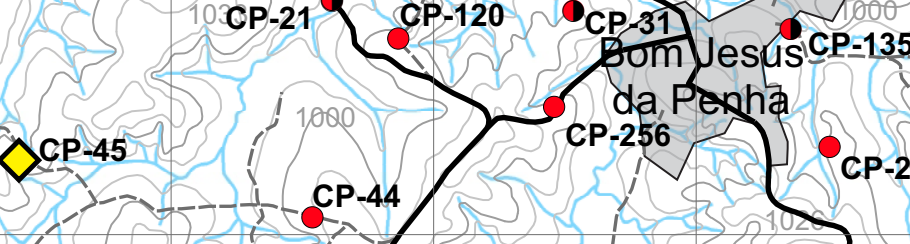

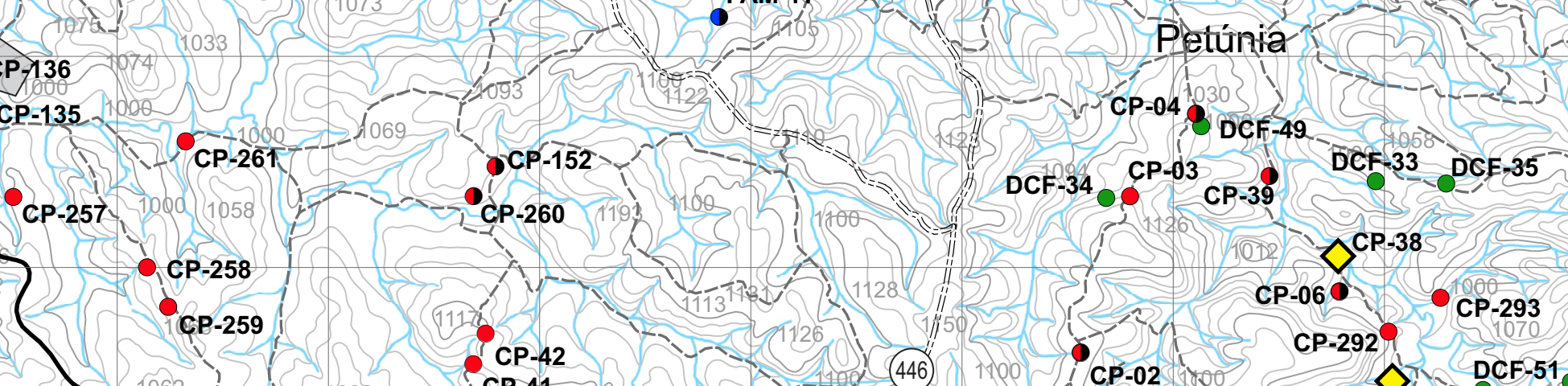

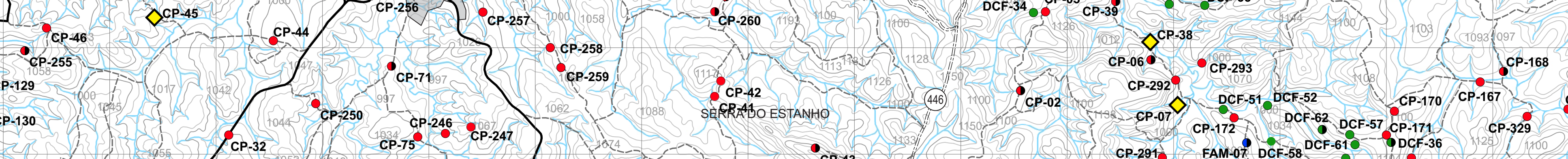

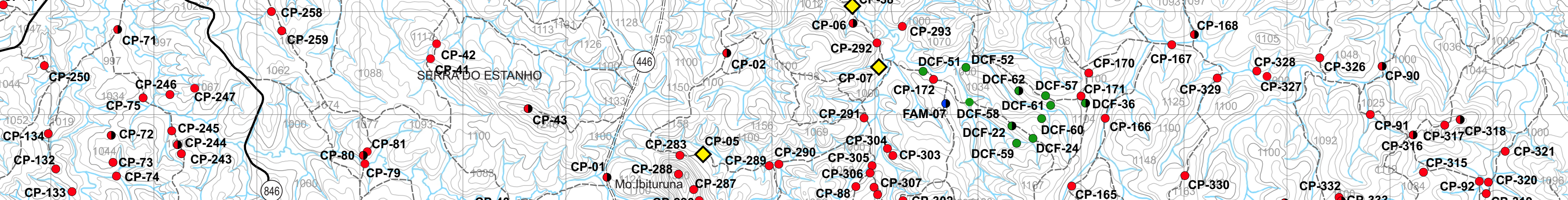

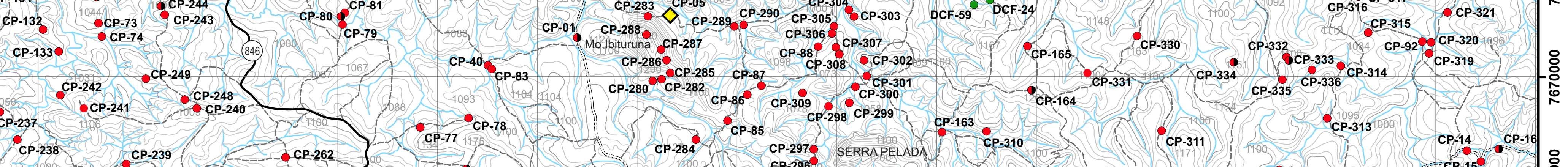

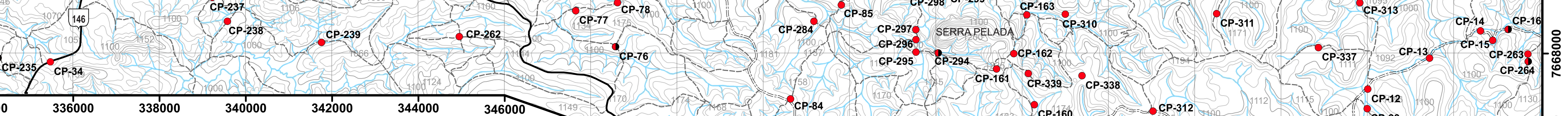

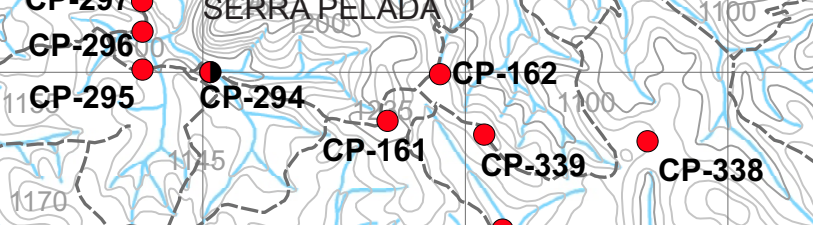

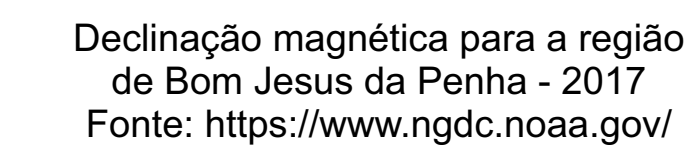

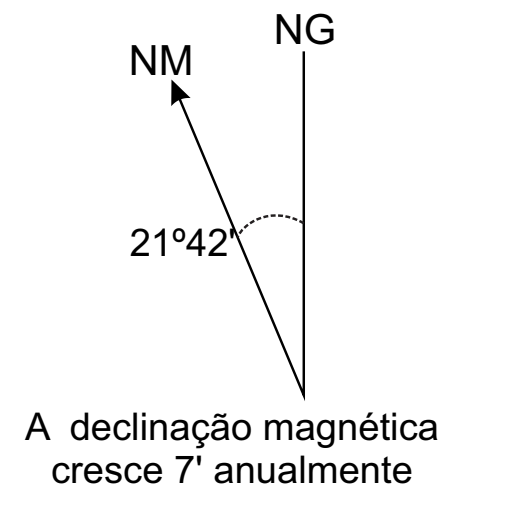

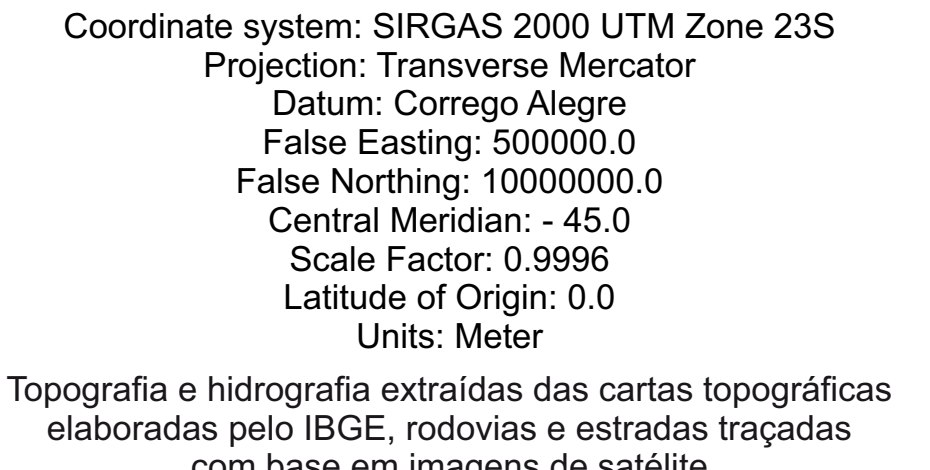

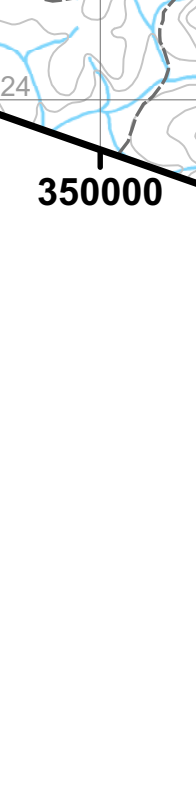
- ocesit2

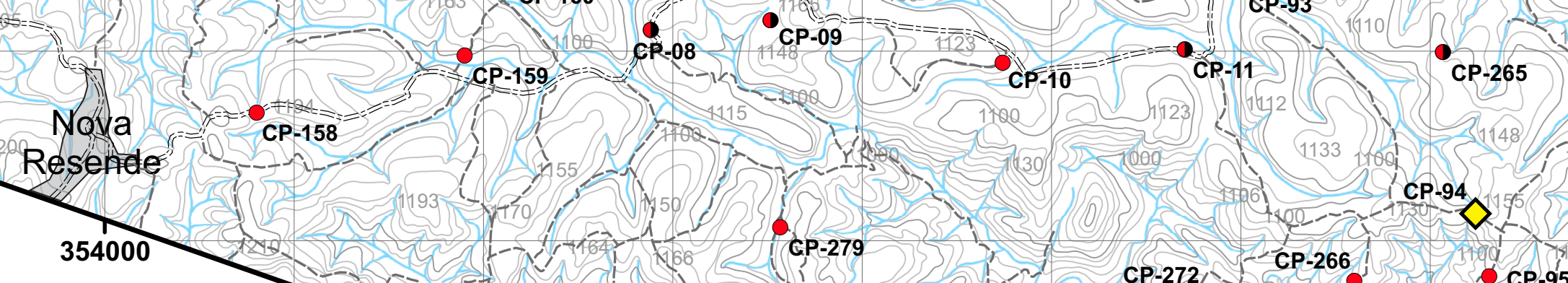

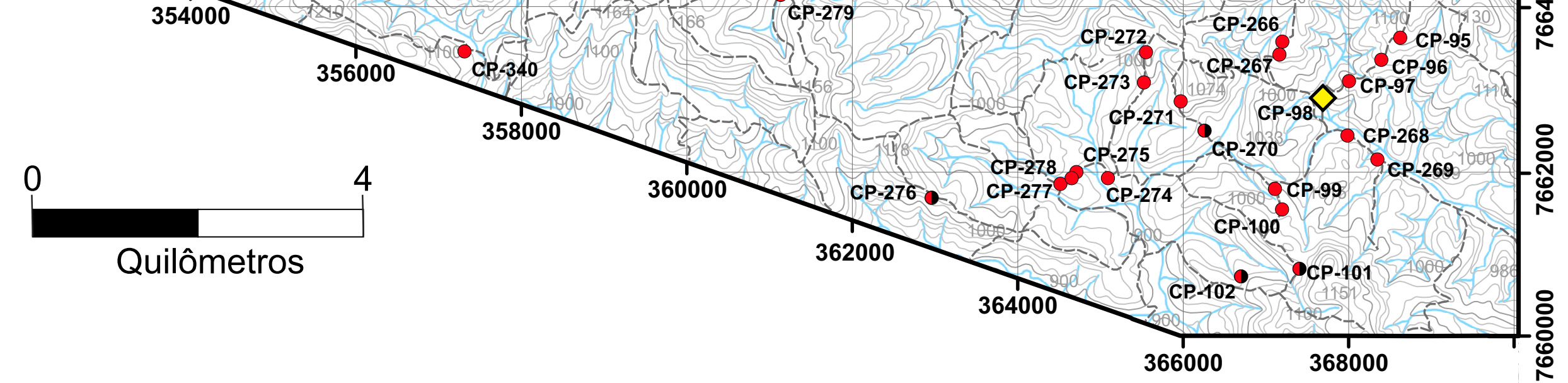




\section{APÊNDICE C}

Mapa Geológico do Complexo Petúnia e áreas adjacentes 


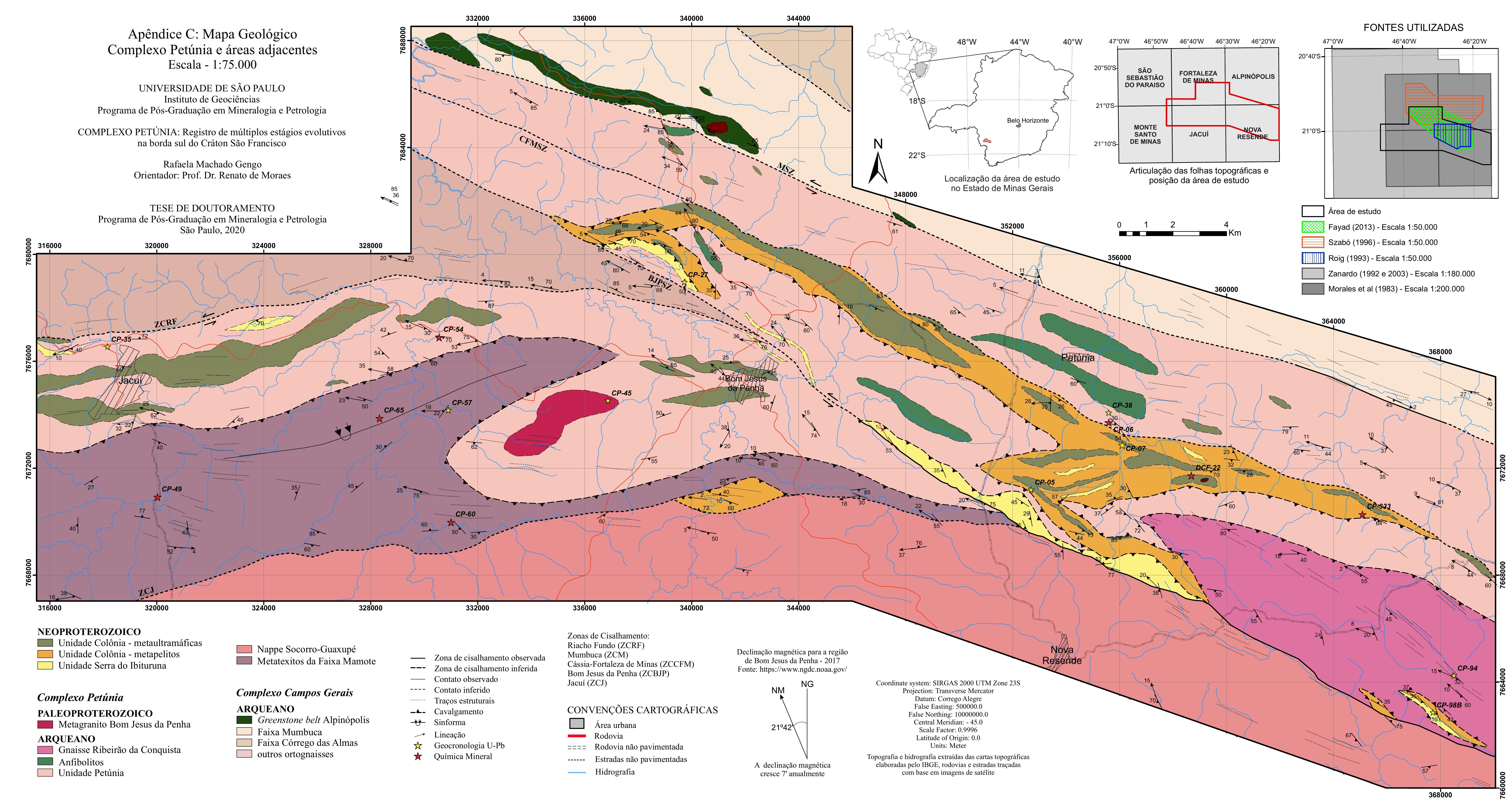




\section{APÊNDICE D}

Resultados das análises de elementos maiores, menores e traços obtidos via FRX

\begin{tabular}{|l|c|c|c|c|c|}
\hline Padrão & \multicolumn{2}{|c|}{ JB 1a } & \multicolumn{2}{c|}{ JG 1a } & LD \\
\hline & Obtida & Recomendada & Obtida & Recomendada & \\
\hline $\mathbf{S i O}_{2}$ & 52.6 & 52.16 & 71.72 & 72.19 & 0.03 \\
\hline $\mathbf{T i O}_{\mathbf{2}}$ & 1.279 & 1.3 & 0.229 & 0.25 & 0.003 \\
\hline $\mathbf{A l}_{\mathbf{2}} \mathbf{O}_{\mathbf{3}}$ & 14.6 & 14.51 & 14.05 & 14.22 & 0.02 \\
\hline $\mathbf{F e}_{\mathbf{2}} \mathbf{O}_{\mathbf{3}}$ & 9.03 & 9.1 & 2.00 & 2.05 & 0.01 \\
\hline $\mathbf{M n O}$ & 0.147 & 0.15 & 0.06 & 0.06 & 0.002 \\
\hline $\mathbf{M g O}$ & 7.78 & 7.75 & 0.67 & 0.69 & 0.01 \\
\hline $\mathbf{C a O}$ & 9.33 & 9.23 & 2.12 & 2.13 & 0.01 \\
\hline $\mathbf{N a} \mathbf{a}_{\mathbf{2}}$ & 2.74 & 2.74 & 3.27 & 3.41 & 0.02 \\
\hline $\mathbf{K}_{\mathbf{2}} \mathbf{O}$ & 1.39 & 1.42 & 3.96 & 4.01 & 0.01 \\
\hline $\mathbf{P}_{\mathbf{2}} \mathbf{O}_{\mathbf{5}}$ & 0.259 & 0.26 & 0.079 & 0.08 & 0.003 \\
\hline $\mathbf{L o I}$ & 1.1 & 1.1 & 0.59 & 0.59 & 0.01 \\
\hline $\mathbf{T o t a l}$ & $\mathbf{1 0 0 . 2 6}$ & $\mathbf{9 9 . 7 2}$ & $\mathbf{9 8 . 7 5}$ & $\mathbf{9 9 . 6 8}$ & \\
\hline $\mathbf{B a}$ & 510 & 497 & 459 & 458 & 37 \\
\hline $\mathbf{C e}$ & 57 & 66.1 & 42 & 45.2 & 35 \\
\hline $\mathbf{C o}$ & 39 & 39.5 & $<6$ & 5.7 & 6 \\
\hline $\mathbf{C r}$ & 400 & 415 & 28 & 18.6 & 13 \\
\hline $\mathbf{C u}$ & 56 & 55.5 & $<5$ & 1.3 & 5 \\
\hline $\mathbf{G a}$ & 18 & 18 & 16 & 17 & 9 \\
\hline $\mathbf{L a}$ & 43 & 38.1 & $<28$ & 21.8 & 28 \\
\hline $\mathbf{N b}$ & 26 & 27 & 10 & 12 & 9 \\
\hline $\mathbf{N d}$ & 24 & 25.5 & 19 & 21 & 14 \\
\hline $\mathbf{N i}$ & 140 & 140 & $<5$ & 6.4 & 5 \\
\hline $\mathbf{P b}$ & $<$ & 7.2 & 12 & 27 & 4 \\
\hline $\mathbf{R b}$ & 40 & 41 & 178 & 180 & 3 \\
\hline $\mathbf{S c}$ & 24 & 27.9 & $<14$ & 6.31 & 14 \\
\hline $\mathbf{S r}$ & 440 & 443 & 181 & 185 & 2 \\
\hline $\mathbf{T h}$ & 7 & 8.8 & $<7$ & 12.1 & 7 \\
\hline $\mathbf{U}$ & 5 & 1.6 & 5 & 4.7 & 3 \\
\hline $\mathbf{V}$ & 203 & 220 & 21 & 23 & 9 \\
\hline $\mathbf{Y}$ & 23 & 24 & 30 & 31.6 & 2 \\
\hline $\mathbf{Z n}$ & 81 & 82 & 39 & 38.8 & 2 \\
\hline $\mathbf{Z r}$ & 136 & 146 & 118 & 121 & 2 \\
\hline $\mathbf{F}$ & 493 & 170 & 628 & & 50 \\
\hline $\mathbf{C l}$ & $<500$ & 385 & $<500$ & 450 & 500 \\
\hline $\mathbf{S}$ & $<550$ & 9 & $<550$ & 10 & 550 \\
\hline & & & & & \\
\hline
\end{tabular}

\begin{tabular}{|c|c|c|}
\hline & AQ-1 obtido & AQ-1 recom. \\
\hline FeO & 9,91 & $10,03 \pm 0,33$ \\
\hline
\end{tabular}




\begin{tabular}{|c|c|c|c|c|c|}
\hline & CP-07 & CP-07melt & CP-333 & CP-06 & CP-54a \\
\hline $\mathrm{SiO}_{2}$ & 64.80 & 82.94 & 60.52 & 45.66 & 48.15 \\
\hline $\mathrm{TiO}_{2}$ & 0.727 & 0.065 & 0.861 & 0.154 & 0.135 \\
\hline $\mathrm{Al}_{2} \mathrm{O}_{3}$ & 16.21 & 9.52 & 18.27 & 8.21 & 6.18 \\
\hline $\mathrm{Fe}_{2} \mathrm{O}_{3}$ & 8.10 & 1.03 & 9.96 & 8.53 & 8.63 \\
\hline $\mathrm{FeO}$ & 5.35 & - & 7.13 & - & - \\
\hline MnO & 0.150 & 0.022 & 0.129 & 0.143 & 0.084 \\
\hline MgO & 2.90 & 0.33 & 3.58 & 26.30 & 26.16 \\
\hline $\mathrm{CaO}$ & 0.94 & 1.40 & 1.25 & 4.53 & 4.02 \\
\hline $\mathrm{Na}_{2} \mathrm{O}$ & 1.88 & 3.57 & 1.32 & $<0.02$ & 0.02 \\
\hline $\mathrm{K}_{2} \mathrm{O}$ & 2.44 & 0.30 & 2.95 & $<0.01$ & 0.01 \\
\hline $\mathrm{P}_{2} \mathrm{O}_{5}$ & 0.117 & 0.097 & 0.150 & 0.009 & 0.003 \\
\hline LoI & 1.40 & 0.26 & 0.95 & 5.94 & 5.42 \\
\hline Total & 99.66 & 99.53 & 99.94 & 99.48 & 98.81 \\
\hline Ba & 500 & 84 & 540 & $<37$ & $<37$ \\
\hline $\mathrm{Ce}$ & 39 & $<35$ & 44 & $<35$ & $<35$ \\
\hline Co & 26 & $<6$ & 33 & 86 & 99 \\
\hline $\mathrm{Cr}$ & 231 & 14 & 263 & 3233 & 2424 \\
\hline $\mathrm{Cu}$ & 45 & 6 & 59 & $<5$ & $<5$ \\
\hline Ga & 21 & 8 & 23 & $<9$ & 9 \\
\hline La & $<28$ & $<28$ & $<28$ & $<28$ & 29 \\
\hline $\mathbf{N b}$ & 9 & $<9$ & 10 & $<9$ & $<9$ \\
\hline Nd & 20 & $<14$ & 20 & $<14$ & $<14$ \\
\hline $\mathrm{Ni}$ & 109 & 5 & 139 & 1343 & 1738 \\
\hline $\mathbf{P b}$ & 14 & 16 & 12 & $<4$ & $<4$ \\
\hline $\mathbf{R b}$ & 112 & 15 & 134 & $<3$ & $<3$ \\
\hline Sc & $<14$ & $<14$ & 17 & 17 & 18 \\
\hline $\mathbf{S r}$ & 88 & 156 & 95 & 9 & 6 \\
\hline Th & $<7$ & $<7$ & 14 & $<7$ & $<7$ \\
\hline $\mathbf{U}$ & 5 & 4 & 7 & 5 & 5 \\
\hline $\mathbf{V}$ & 130 & 14 & 164 & 100 & 75 \\
\hline $\mathbf{Y}$ & 23 & 8 & 21 & 7 & 8 \\
\hline $\mathbf{Z n}$ & 100 & 8 & 123 & 56 & 112 \\
\hline $\mathbf{Z r}$ & 153 & 24 & 143 & 16 & 21 \\
\hline $\mathbf{F}$ & 408 & 84 & 318 & $<50$ & 319 \\
\hline Cl & $<500$ & $<500$ & $<500$ & $<500$ & $<500$ \\
\hline$S$ & $<550$ & $<550$ & $<550$ & $<550$ & $<550$ \\
\hline
\end{tabular}




\section{APÊNDICE E}

Resultados das análises de química mineral obtidos via Microssonda Eletrônica 


\section{ESTAUROLITA - amostra CP-07}

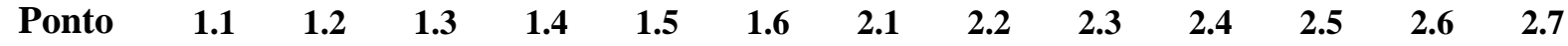

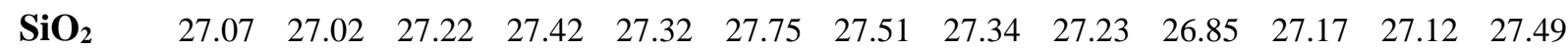

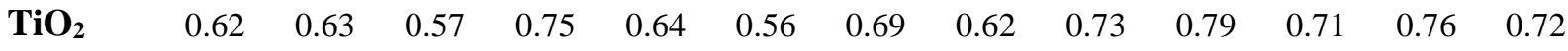

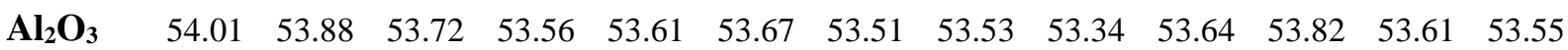

$\begin{array}{llllllllllllll}\text { FeO } & 13.06 & 13.41 & 13.51 & 13.25 & 12.95 & 13.01 & 13.06 & 13.42 & 13.20 & 13.31 & 13.35 & 13.05 & 13.03\end{array}$

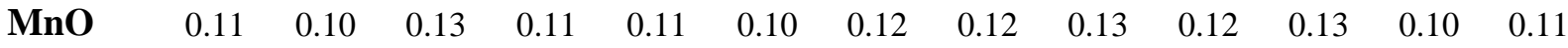

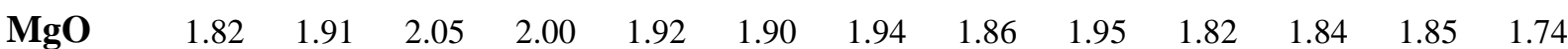

$\begin{array}{llllllllllllll}\text { ZnO } & 0.41 & 0.40 & 0.39 & 0.42 & 0.41 & 0.44 & 0.42 & 0.42 & 0.45 & 0.45 & 0.42 & 0.40 & 0.48\end{array}$

$\begin{array}{llllllllllllll}\mathrm{CaO} & 0.01 & 0.00 & 0.04 & 0.00 & 0.04 & 0.00 & 0.00 & 0.04 & 0.03 & 0.00 & 0.04 & 0.00 & 0.01\end{array}$

$\begin{array}{llllllllllllll}\text { Total } & 97.11 & 97.35 & 97.63 & 97.51 & 97.01 & 97.43 & 97.25 & 97.34 & 97.05 & 96.97 & 97.47 & 96.90 & 97.12\end{array}$

$\begin{array}{lrrrrrrrrrrrrr}\text { Si } & 7.57 & 7.55 & 7.59 & 7.64 & 7.64 & 7.72 & 7.67 & 7.64 & 7.63 & 7.53 & 7.58 & 7.60 & 7.68 \\ \text { Ti } & 0.13 & 0.13 & 0.12 & 0.16 & 0.14 & 0.12 & 0.14 & 0.13 & 0.15 & 0.17 & 0.15 & 0.16 & 0.15 \\ \text { Al } & 17.79 & 17.74 & 17.64 & 17.58 & 17.67 & 17.60 & 17.59 & 17.62 & 17.60 & 17.73 & 17.69 & 17.70 & 17.63 \\ \text { Fe }^{2+} & 3.05 & 3.13 & 3.15 & 3.09 & 3.03 & 3.03 & 3.05 & 3.13 & 3.09 & 3.12 & 3.11 & 3.06 & 3.04 \\ \text { Mn } & 0.02 & 0.02 & 0.03 & 0.03 & 0.03 & 0.02 & 0.03 & 0.03 & 0.03 & 0.03 & 0.03 & 0.02 & 0.03 \\ \text { Mg } & 0.76 & 0.80 & 0.85 & 0.83 & 0.80 & 0.79 & 0.81 & 0.77 & 0.81 & 0.76 & 0.77 & 0.77 & 0.72 \\ \text { Zn } & 0.09 & 0.08 & 0.08 & 0.09 & 0.08 & 0.09 & 0.09 & 0.09 & 0.09 & 0.09 & 0.09 & 0.08 & 0.10 \\ \text { Ca } & 0.00 & 0.00 & 0.01 & 0.00 & 0.01 & 0.00 & 0.00 & 0.01 & 0.01 & 0.00 & 0.01 & 0.00 & 0.00\end{array}$

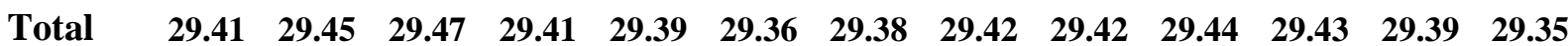

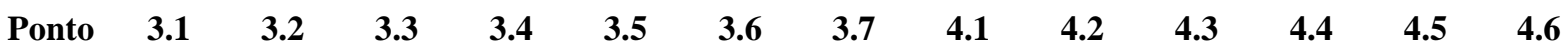

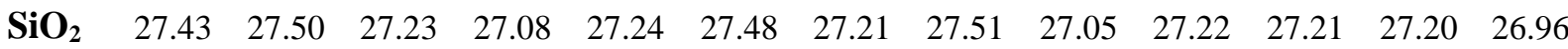

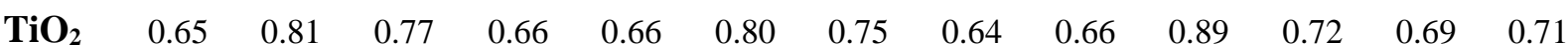

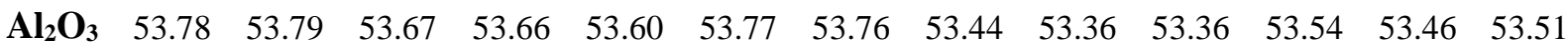

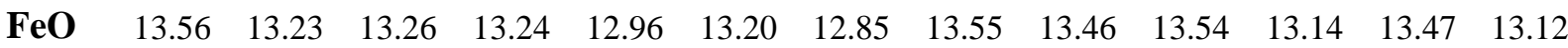

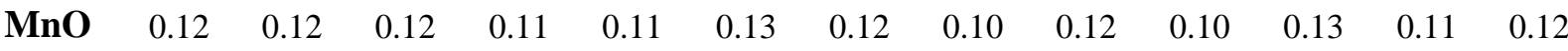

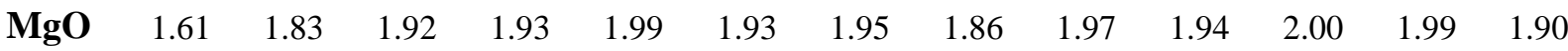

$\begin{array}{llllllllllllll}\text { ZnO } & 0.45 & 0.45 & 0.45 & 0.41 & 0.42 & 0.41 & 0.41 & 0.37 & 0.43 & 0.43 & 0.45 & 0.43 & 0.44\end{array}$

$\begin{array}{llllllllllllll}\mathbf{C a O} & 0.01 & 0.00 & 0.02 & 0.01 & 0.03 & 0.02 & 0.00 & 0.00 & 0.00 & 0.03 & 0.00 & 0.00 & 0.00\end{array}$

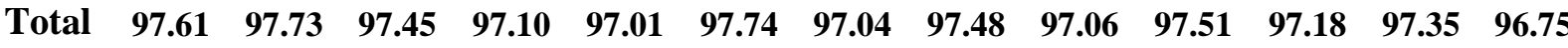

$\begin{array}{lrrrrrrrrrrrrr}\text { Si } & 7.64 & 7.64 & 7.60 & 7.58 & 7.62 & 7.63 & 7.60 & 7.67 & 7.59 & 7.60 & 7.61 & 7.60 & 7.57 \\ \mathbf{T i} & 0.14 & 0.17 & 0.16 & 0.14 & 0.14 & 0.17 & 0.16 & 0.14 & 0.14 & 0.19 & 0.15 & 0.15 & 0.15 \\ \mathbf{A l} & 17.66 & 17.62 & 17.64 & 17.70 & 17.67 & 17.61 & 17.70 & 17.57 & 17.63 & 17.56 & 17.64 & 17.61 & 17.71 \\ \mathbf{F e}^{2+} & 3.16 & 3.07 & 3.09 & 3.10 & 3.03 & 3.07 & 3.00 & 3.16 & 3.16 & 3.16 & 3.07 & 3.15 & 3.08 \\ \mathbf{M n} & 0.03 & 0.03 & 0.03 & 0.03 & 0.03 & 0.03 & 0.03 & 0.02 & 0.03 & 0.02 & 0.03 & 0.03 & 0.03 \\ \mathbf{M g} & 0.67 & 0.76 & 0.80 & 0.81 & 0.83 & 0.80 & 0.81 & 0.77 & 0.82 & 0.81 & 0.83 & 0.83 & 0.80 \\ \mathbf{Z n} & 0.09 & 0.09 & 0.09 & 0.08 & 0.09 & 0.08 & 0.08 & 0.08 & 0.09 & 0.09 & 0.09 & 0.09 & 0.09 \\ \mathbf{C a} & 0.00 & 0.00 & 0.01 & 0.00 & 0.01 & 0.01 & 0.00 & 0.00 & 0.00 & 0.01 & 0.00 & 0.00 & 0.00\end{array}$

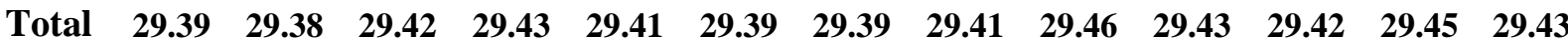


ESTAUROLITA - amostra CP-333

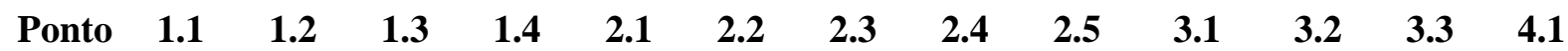

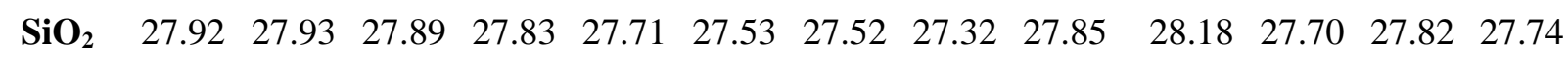

$\begin{array}{llllllllllllll}\mathrm{TiO}_{2} & 0.62 & 0.67 & 0.66 & 0.66 & 0.63 & 0.70 & 0.69 & 0.72 & 0.59 & 0.62 & 0.70 & 0.58 & 0.66\end{array}$

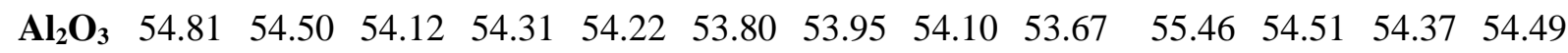

$\begin{array}{lrrrrrrrrrrrrr}\text { FeO } & 12.59 & 12.33 & 12.49 & 12.79 & 12.62 & 12.54 & 12.64 & 12.52 & 12.49 & 12.56 & 12.56 & 12.58 & 12.29\end{array}$

$\begin{array}{lllllllllllllll}\text { MnO } & 0.07 & 0.10 & 0.06 & 0.06 & 0.07 & 0.07 & 0.07 & 0.07 & 0.05 & 0.07 & 0.09 & 0.06 & 0.07\end{array}$

$\begin{array}{llllllllllllll}\text { MgO } & 1.57 & 1.63 & 1.54 & 1.61 & 1.64 & 1.79 & 1.83 & 1.75 & 1.87 & 1.52 & 1.63 & 1.64 & 1.57\end{array}$

$\begin{array}{lllllllllllllll}\text { ZnO } & 1.67 & 1.71 & 1.67 & 1.75 & 1.72 & 1.60 & 1.47 & 1.49 & 1.52 & 1.68 & 1.64 & 1.67 & 1.90\end{array}$

$\begin{array}{lllllllllllllll}\mathbf{C a O} & 0.00 & 0.00 & 0.00 & 0.00 & 0.00 & 0.01 & 0.00 & 0.00 & 0.00 & 0.00 & 0.00 & 0.00 & 0.00\end{array}$

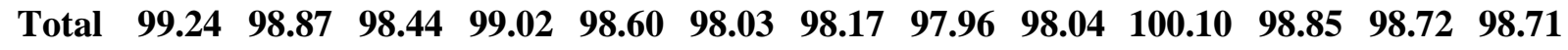

$\begin{array}{lrrrrrrrrrrrrr}\mathbf{S i} & 7.65 & 7.68 & 7.71 & 7.66 & 7.65 & 7.65 & 7.63 & 7.59 & 7.72 & 7.65 & 7.63 & 7.67 & 7.65 \\ \mathbf{T i} & 0.13 & 0.14 & 0.14 & 0.14 & 0.13 & 0.15 & 0.14 & 0.15 & 0.12 & 0.13 & 0.15 & 0.12 & 0.14 \\ \mathbf{A l} & 17.71 & 17.66 & 17.62 & 17.62 & 17.65 & 17.61 & 17.63 & 17.71 & 17.54 & 17.75 & 17.69 & 17.66 & 17.70 \\ \mathbf{F e}^{2+} & 2.89 & 2.84 & 2.89 & 2.94 & 2.91 & 2.91 & 2.93 & 2.91 & 2.90 & 2.85 & 2.89 & 2.90 & 2.83 \\ \mathbf{M n} & 0.02 & 0.02 & 0.01 & 0.01 & 0.02 & 0.02 & 0.02 & 0.02 & 0.01 & 0.02 & 0.02 & 0.01 & 0.02 \\ \mathbf{M g} & 0.64 & 0.67 & 0.63 & 0.66 & 0.67 & 0.74 & 0.76 & 0.72 & 0.77 & 0.62 & 0.67 & 0.67 & 0.65 \\ \mathbf{Z n} & 0.34 & 0.35 & 0.34 & 0.36 & 0.35 & 0.33 & 0.30 & 0.31 & 0.31 & 0.34 & 0.33 & 0.34 & 0.39 \\ \text { Ca } & 0.00 & 0.00 & 0.00 & 0.00 & 0.00 & 0.00 & 0.00 & 0.00 & 0.00 & 0.00 & 0.00 & 0.00 & 0.00 \\ \text { Total } & \mathbf{2 9 . 3 7} & \mathbf{2 9 . 3 5} & \mathbf{2 9 . 3 4} & \mathbf{2 9 . 3 9} & \mathbf{2 9 . 3 9} & \mathbf{2 9 . 4 0} & \mathbf{2 9 . 4 1} & \mathbf{2 9 . 4 0} & \mathbf{2 9 . 3 8} & \mathbf{2 9 . 3 5} & \mathbf{2 9 . 3 8} & \mathbf{2 9 . 3 8} & \mathbf{2 9 . 3 7}\end{array}$

$\begin{array}{lllllllllllll}\text { Ponto } & 4.2 & 4.3 & 5.1 & 5.2 & 5.3 & 5.4 & 6.1 & 6.2 & 7.1 & 7.2 & 8.1 & 8.2\end{array}$

$\begin{array}{lllllllllllll}\mathrm{SiO}_{2} & 27.74 & 27.80 & 28.21 & 27.97 & 27.77 & 27.60 & 28.02 & 28.08 & 27.62 & 27.78 & 27.66 & 27.60\end{array}$

$\begin{array}{lllllllllllll}\mathbf{T i O}_{2} & 0.62 & 0.66 & 0.70 & 0.67 & 0.71 & 0.63 & 0.64 & 0.65 & 0.69 & 0.65 & 0.65 & 0.67\end{array}$

$\begin{array}{lllllllllllll}\mathbf{A l}_{2} \mathbf{O}_{3} & 53.87 & 54.01 & 54.99 & 54.74 & 54.71 & 54.39 & 54.37 & 54.43 & 54.81 & 54.41 & 54.17 & 54.24\end{array}$

$\begin{array}{lrrrrrrrrrrrr}\text { FeO } & 12.43 & 12.63 & 11.57 & 11.85 & 12.28 & 11.54 & 12.59 & 12.77 & 13.06 & 12.92 & 12.52 & 12.55\end{array}$

$\begin{array}{lllllllllllll}\text { MnO } & 0.09 & 0.06 & 0.05 & 0.07 & 0.07 & 0.07 & 0.04 & 0.05 & 0.08 & 0.04 & 0.09 & 0.05\end{array}$

$\begin{array}{lllllllllllll}\text { MgO } & 1.59 & 1.66 & 1.27 & 1.46 & 1.51 & 1.43 & 1.89 & 1.94 & 1.36 & 1.93 & 1.66 & 1.67\end{array}$

$\begin{array}{lllllllllllll}\text { ZnO } & 1.76 & 1.91 & 1.90 & 1.88 & 1.85 & 1.87 & 1.03 & 1.02 & 1.39 & 1.18 & 1.62 & 1.65\end{array}$

$\begin{array}{lllllllllllll}\mathbf{C a O} & 0.00 & 0.01 & 0.00 & 0.00 & 0.00 & 0.00 & 0.00 & 0.00 & 0.00 & 0.00 & 0.00 & 0.00\end{array}$

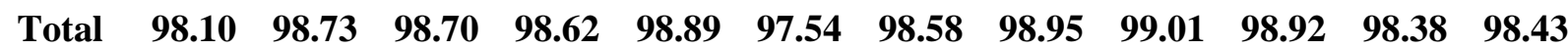

$\begin{array}{lrrrrrrrrrrrr}\mathbf{S i} & 7.70 & 7.68 & 7.74 & 7.69 & 7.64 & 7.67 & 7.71 & 7.70 & 7.60 & 7.64 & 7.65 & 7.63 \\ \mathbf{T i} & 0.13 & 0.14 & 0.14 & 0.14 & 0.15 & 0.13 & 0.13 & 0.13 & 0.14 & 0.14 & 0.13 & 0.14 \\ \mathbf{A l} & 17.62 & 17.58 & 17.78 & 17.75 & 17.73 & 17.81 & 17.62 & 17.59 & 17.77 & 17.63 & 17.66 & 17.68 \\ \mathbf{F e}^{2+} & 2.88 & 2.92 & 2.65 & 2.73 & 2.82 & 2.68 & 2.90 & 2.93 & 3.00 & 2.97 & 2.90 & 2.90 \\ \mathbf{M n} & 0.02 & 0.01 & 0.01 & 0.02 & 0.02 & 0.02 & 0.01 & 0.01 & 0.02 & 0.01 & 0.02 & 0.01 \\ \mathbf{M g} & 0.66 & 0.69 & 0.52 & 0.60 & 0.62 & 0.59 & 0.78 & 0.80 & 0.56 & 0.79 & 0.68 & 0.69 \\ \mathbf{Z n} & 0.36 & 0.39 & 0.39 & 0.38 & 0.38 & 0.38 & 0.21 & 0.21 & 0.28 & 0.24 & 0.33 & 0.34 \\ \mathbf{C a} & 0.00 & 0.00 & 0.00 & 0.00 & 0.00 & 0.00 & 0.00 & 0.00 & 0.00 & 0.00 & 0.00 & 0.00 \\ \text { Total } & \mathbf{2 9 . 3 7} & \mathbf{2 9 . 4 0} & \mathbf{2 9 . 2 3} & \mathbf{2 9 . 3 0} & \mathbf{2 9 . 3 5} & \mathbf{2 9 . 2 9} & \mathbf{2 9 . 3 5} & \mathbf{2 9 . 3 7} & \mathbf{2 9 . 3 7} & \mathbf{2 9 . 4 1} & \mathbf{2 9 . 3 8} & \mathbf{2 9 . 3 9}\end{array}$


GRANADA - Amostra CP-07

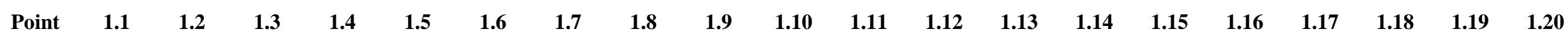

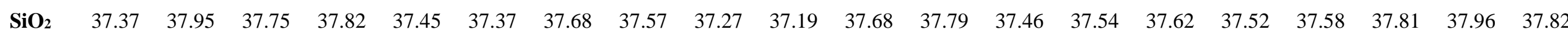

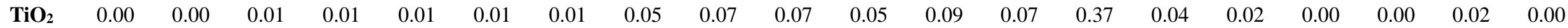

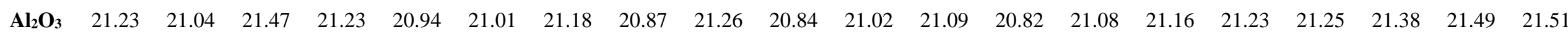

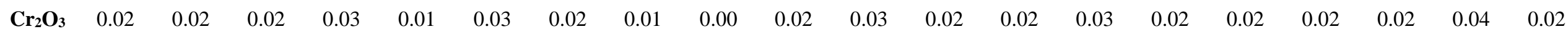

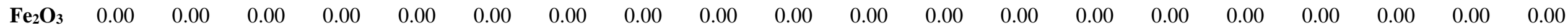

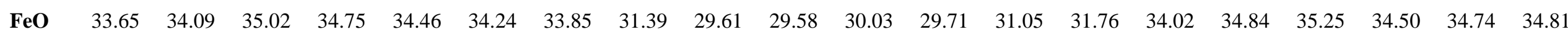

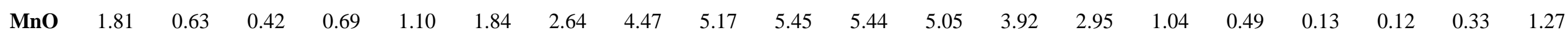

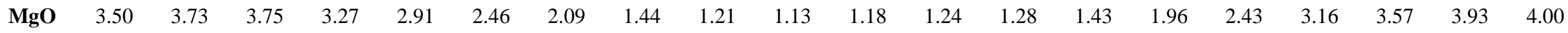

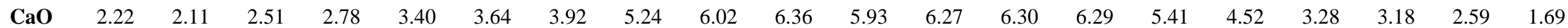

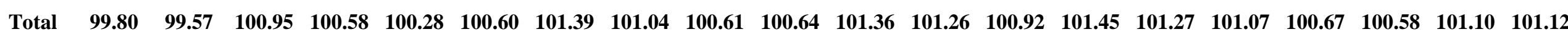

\begin{tabular}{|c|c|c|c|c|c|c|c|c|c|c|c|c|c|c|c|c|c|c|c|c|}
\hline $\mathbf{S i}$ & 2.998 & 3.036 & 2.990 & 3.011 & 2.999 & 2.992 & 2.998 & 3.005 & 2.988 & 2.984 & 3.004 & 3.009 & 2.996 & 2.985 & 2.990 & 2.984 & 2.993 & 3.002 & 2.998 & 2.991 \\
\hline $\mathbf{T i}$ & 0.000 & 0.000 & 0.001 & 0.001 & 0.001 & 0.001 & 0.001 & 0.003 & 0.004 & 0.004 & 0.003 & 0.005 & 0.004 & 0.022 & 0.002 & 0.001 & 0.000 & 0.000 & 0.001 & 0.000 \\
\hline Al & 2.008 & 1.984 & 2.005 & 1.993 & 1.977 & 1.983 & 1.987 & 1.968 & 2.009 & 1.971 & 1.975 & 1.980 & 1.963 & 1.976 & 1.983 & 1.990 & 1.995 & 2.001 & 2.001 & 2.006 \\
\hline $\mathrm{Cr}$ & 0.001 & 0.001 & 0.001 & 0.002 & 0.001 & 0.002 & 0.001 & 0.001 & 0.000 & 0.001 & 0.002 & 0.001 & 0.001 & 0.002 & 0.001 & 0.001 & 0.001 & 0.001 & 0.002 & 0.001 \\
\hline $\mathrm{Fe}^{3+}$ & 0.000 & 0.000 & 0.013 & 0.000 & 0.024 & 0.031 & 0.016 & 0.015 & 0.006 & 0.053 & 0.009 & 0.000 & 0.035 & 0.009 & 0.032 & 0.038 & 0.019 & 0.000 & 0.000 & 0.011 \\
\hline $\mathrm{Fe}^{2+}$ & 2.258 & 2.281 & 2.307 & 2.314 & 2.284 & 2.262 & 2.237 & 2.084 & 1.979 & 1.932 & 1.993 & 1.978 & 2.042 & 2.103 & 2.229 & 2.279 & 2.329 & 2.291 & 2.294 & 2.291 \\
\hline Mn & 0.123 & 0.043 & 0.028 & 0.047 & 0.075 & 0.125 & 0.178 & 0.303 & 0.351 & 0.370 & 0.367 & 0.341 & 0.266 & 0.199 & 0.070 & 0.033 & 0.009 & 0.008 & 0.022 & 0.085 \\
\hline Mg & 0.418 & 0.445 & 0.443 & 0.388 & 0.347 & 0.293 & 0.248 & 0.172 & 0.145 & 0.135 & 0.140 & 0.147 & 0.153 & 0.169 & 0.232 & 0.288 & 0.375 & 0.422 & 0.462 & 0.471 \\
\hline $\mathrm{Ca}$ & 0.191 & 0.181 & 0.213 & 0.237 & 0.292 & 0.312 & 0.334 & 0.449 & 0.517 & 0.547 & 0.507 & 0.535 & 0.540 & 0.536 & 0.461 & 0.385 & 0.280 & 0.271 & 0.219 & 0.143 \\
\hline Total & 8.00 & 7.97 & 8.00 & 7.99 & 8.00 & 8.00 & 8.00 & 8.00 & 8.00 & 8.00 & 8.00 & 8.00 & 8.00 & 8.00 & 8.00 & 8.00 & 8.00 & 8.00 & 8.00 & 8.00 \\
\hline Alm & 0.755 & 0.773 & 0.771 & 0.775 & 0.762 & 0.756 & 0.746 & 0.693 & 0.661 & 0.647 & 0.663 & 0.659 & 0.680 & 0.699 & 0.745 & 0.763 & 0.778 & 0.766 & 0.765 & 0.766 \\
\hline $\mathbf{P y}$ & 0.140 & 0.151 & 0.148 & 0.130 & 0.116 & 0.098 & 0.083 & 0.057 & 0.048 & 0.045 & 0.047 & 0.049 & 0.051 & 0.056 & 0.078 & 0.096 & 0.125 & 0.141 & 0.154 & 0.158 \\
\hline Gr & 0.064 & 0.061 & 0.071 & 0.079 & 0.097 & 0.104 & 0.111 & 0.149 & 0.173 & 0.183 & 0.169 & 0.178 & 0.180 & 0.178 & 0.154 & 0.129 & 0.094 & 0.091 & 0.073 & 0.048 \\
\hline Sps & 0.041 & 0.015 & 0.009 & 0.016 & 0.025 & 0.042 & 0.059 & 0.101 & 0.117 & 0.124 & 0.122 & 0.114 & 0.089 & 0.066 & 0.023 & 0.011 & 0.003 & 0.003 & 0.007 & 0.028 \\
\hline
\end{tabular}


GRANADA - Amostra CP-07 (continuação)

\begin{tabular}{|c|c|c|c|c|c|c|c|c|c|c|c|c|c|c|c|c|c|c|c|c|}
\hline Point & 2.1 & 2.2 & 2.3 & 2.4 & 2.5 & 2.6 & 2.7 & 2.8 & 2.9 & 2.10 & 2.11 & 2.12 & 2.13 & 2.14 & 2.15 & 2.16 & 2.17 & 2.18 & 2.19 & 2.20 \\
\hline $\mathrm{SiO}_{2}$ & 38.24 & 37.82 & 37.59 & 37.52 & 37.32 & 37.72 & 37.64 & 35.66 & 37.24 & 37.54 & 37.38 & 33.96 & 36.95 & 37.21 & 37.59 & 37.67 & 37.69 & 37.56 & 37.93 & 37.61 \\
\hline $\mathrm{TiO}_{2}$ & 0.00 & 0.00 & 0.00 & 0.00 & 0.00 & 0.02 & 0.03 & 1.67 & 0.05 & 0.07 & 0.02 & 2.13 & 0.06 & 0.04 & 0.03 & 0.01 & 0.00 & 0.01 & 0.00 & 0.00 \\
\hline $\mathrm{Al}_{2} \mathrm{O}_{3}$ & 21.75 & 21.42 & 21.20 & 21.07 & 21.17 & 20.98 & 21.08 & 20.35 & 21.17 & 20.85 & 20.95 & 24.09 & 20.78 & 21.15 & 21.14 & 21.19 & 21.23 & 21.41 & 21.63 & 21.32 \\
\hline $\mathrm{Cr}_{2} \mathrm{O}_{3}$ & 0.05 & 0.04 & 0.02 & 0.04 & 0.02 & 0.02 & 0.03 & 0.01 & 0.03 & 0.02 & 0.04 & 0.02 & 0.03 & 0.04 & 0.06 & 0.05 & 0.03 & 0.05 & 0.02 & 0.05 \\
\hline $\mathrm{Fe}_{2} \mathrm{O}_{3}$ & 0.00 & 0.00 & 0.00 & 0.00 & 0.00 & 0.00 & 0.00 & 0.00 & 0.00 & 0.00 & 0.00 & 0.00 & 0.00 & 0.00 & 0.00 & 0.00 & 0.00 & 0.00 & 0.00 & 0.00 \\
\hline $\mathrm{FeO}$ & 34.47 & 34.63 & 35.10 & 35.24 & 34.94 & 34.18 & 32.68 & 30.89 & 29.83 & 29.77 & 31.62 & 29.61 & 31.45 & 32.56 & 33.59 & 34.38 & 34.48 & 34.60 & 34.12 & 34.08 \\
\hline MnO & 1.68 & 0.50 & 0.39 & 0.51 & 1.08 & 1.58 & 2.88 & 4.07 & 5.15 & 5.58 & 4.63 & 3.59 & 3.58 & 2.38 & 1.45 & 0.68 & 0.46 & 0.41 & 0.44 & 1.08 \\
\hline MgO & 3.82 & 4.10 & 3.53 & 3.20 & 2.50 & 2.22 & 1.79 & 1.39 & 1.21 & 1.23 & 1.74 & 1.67 & 1.45 & 1.51 & 1.72 & 2.54 & 3.25 & 3.63 & 3.90 & 4.02 \\
\hline $\mathrm{CaO}$ & 1.64 & 2.35 & 2.86 & 3.16 & 3.76 & 4.07 & 5.02 & 5.35 & 5.97 & 5.79 & 4.58 & 4.00 & 5.50 & 5.92 & 5.62 & 4.29 & 3.57 & 2.90 & 2.67 & 2.13 \\
\hline
\end{tabular}

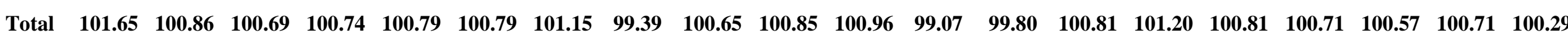

\begin{tabular}{|c|c|c|c|c|c|c|c|c|c|c|c|c|c|c|c|c|c|c|c|c|}
\hline $\mathbf{S i}$ & 3.005 & 2.992 & 2.989 & 2.988 & 2.980 & 3.014 & 3.001 & 2.911 & 2.986 & 3.008 & 2.991 & 2.747 & 2.989 & 2.975 & 2.993 & 3.001 & 2.996 & 2.985 & 3.000 & 2.994 \\
\hline $\mathbf{T i}$ & 0.000 & 0.000 & 0.000 & 0.000 & 0.000 & 0.001 & 0.002 & 0.103 & 0.003 & 0.004 & 0.001 & 0.130 & 0.004 & 0.002 & 0.002 & 0.001 & 0.000 & 0.001 & 0.000 & 0.000 \\
\hline Al & 2.015 & 1.998 & 1.987 & 1.978 & 1.993 & 1.976 & 1.981 & 1.958 & 2.001 & 1.969 & 1.976 & 2.297 & 1.982 & 1.994 & 1.984 & 1.990 & 1.990 & 2.006 & 2.017 & 2.001 \\
\hline $\mathrm{Cr}$ & 0.003 & 0.003 & 0.001 & 0.003 & 0.001 & 0.001 & 0.002 & 0.001 & 0.002 & 0.001 & 0.003 & 0.001 & 0.002 & 0.003 & 0.004 & 0.003 & 0.002 & 0.003 & 0.001 & 0.003 \\
\hline $\mathbf{F e}^{3+}$ & 0.000 & 0.015 & 0.033 & 0.043 & 0.046 & 0.000 & 0.012 & 0.016 & 0.019 & 0.005 & 0.038 & 0.000 & 0.032 & 0.050 & 0.023 & 0.003 & 0.016 & 0.019 & 0.000 & 0.008 \\
\hline $\mathrm{Fe}^{2+}$ & 2.265 & 2.276 & 2.301 & 2.304 & 2.288 & 2.284 & 2.166 & 2.093 & 1.982 & 1.989 & 2.078 & 2.003 & 2.096 & 2.127 & 2.213 & 2.288 & 2.276 & 2.281 & 2.257 & 2.261 \\
\hline Mn & 0.112 & 0.034 & 0.026 & 0.034 & 0.073 & 0.107 & 0.194 & 0.281 & 0.350 & 0.379 & 0.314 & 0.246 & 0.245 & 0.161 & 0.098 & 0.046 & 0.031 & 0.028 & 0.029 & 0.073 \\
\hline Mg & 0.447 & 0.483 & 0.418 & 0.380 & 0.298 & 0.264 & 0.213 & 0.169 & 0.145 & 0.147 & 0.207 & 0.201 & 0.175 & 0.180 & 0.204 & 0.302 & 0.385 & 0.430 & 0.460 & 0.477 \\
\hline $\mathrm{Ca}$ & 0.138 & 0.199 & 0.244 & 0.270 & 0.322 & 0.348 & 0.429 & 0.468 & 0.513 & 0.497 & 0.393 & 0.347 & 0.477 & 0.507 & 0.479 & 0.366 & 0.304 & 0.247 & 0.226 & 0.182 \\
\hline Total & 7.99 & 8.00 & 8.00 & 8.00 & 8.00 & 8.00 & 8.00 & 8.00 & 8.00 & 8.00 & 8.00 & 7.97 & 8.00 & 8.00 & 8.00 & 8.00 & 8.00 & 8.00 & 7.99 & 8.00 \\
\hline Alm & 0.765 & 0.761 & 0.770 & 0.771 & 0.768 & 0.761 & 0.722 & 0.695 & 0.663 & 0.660 & 0.695 & 0.716 & 0.700 & 0.715 & 0.739 & 0.762 & 0.760 & 0.764 & 0.759 & 0.755 \\
\hline Py & 0.151 & 0.161 & 0.140 & 0.127 & 0.100 & 0.088 & 0.071 & 0.056 & 0.048 & 0.049 & 0.069 & 0.072 & 0.058 & 0.061 & 0.068 & 0.101 & 0.129 & 0.144 & 0.155 & 0.159 \\
\hline Gr & 0.047 & 0.067 & 0.082 & 0.090 & 0.108 & 0.116 & 0.143 & 0.155 & 0.172 & 0.165 & 0.131 & 0.124 & 0.159 & 0.170 & 0.160 & 0.122 & 0.101 & 0.083 & 0.076 & 0.061 \\
\hline Sps & 0.038 & 0.011 & 0.009 & 0.011 & 0.024 & 0.036 & 0.065 & 0.093 & 0.117 & 0.126 & 0.105 & 0.088 & 0.082 & 0.054 & 0.033 & 0.015 & 0.010 & 0.009 & 0.010 & 0.024 \\
\hline
\end{tabular}


GRANADA - Amostra CP-07 (continuação)

\begin{tabular}{|c|c|c|c|c|c|c|c|c|c|c|c|c|c|c|}
\hline Point & 6.1 & 6.2 & 6.3 & 6.4 & 6.5 & 6.6 & 6.7 & 6.9 & 6.10 & 6.11 & 6.12 & 6.13 & 6.14 & 6.15 \\
\hline $\mathrm{SiO}_{2}$ & 37.65 & 37.74 & 37.86 & 36.64 & 37.58 & 38.09 & 37.94 & 37.94 & 38.01 & 37.89 & 37.84 & 37.81 & 37.83 & 37.61 \\
\hline $\mathrm{TiO}_{2}$ & 0.00 & 0.01 & 0.00 & 0.00 & 0.00 & 0.00 & 0.00 & 0.01 & 0.00 & 0.01 & 0.00 & 0.00 & 0.00 & 0.00 \\
\hline $\mathrm{Al}_{2} \mathrm{O}_{3}$ & 21.41 & 21.54 & 21.53 & 20.84 & 21.62 & 21.56 & 21.60 & 21.66 & 21.57 & 21.57 & 21.61 & 21.52 & 21.47 & 21.40 \\
\hline $\mathrm{Cr}_{2} \mathrm{O}_{3}$ & 0.00 & 0.02 & 0.00 & 0.00 & 0.01 & 0.01 & 0.00 & 0.02 & 0.01 & 0.00 & 0.03 & 0.00 & 0.01 & 0.01 \\
\hline $\mathrm{Fe}_{2} \mathrm{O}_{3}$ & 0.00 & 0.00 & 0.00 & 0.00 & 0.00 & 0.00 & 0.00 & 0.00 & 0.00 & 0.00 & 0.00 & 0.00 & 0.00 & 0.00 \\
\hline $\mathrm{FeO}$ & 34.22 & 33.62 & 33.82 & 32.25 & 33.77 & 34.16 & 33.45 & 33.59 & 33.70 & 33.40 & 33.55 & 33.48 & 33.74 & 34.26 \\
\hline MnO & 1.97 & 1.93 & 2.04 & 1.80 & 1.81 & 1.84 & 1.86 & 1.79 & 1.83 & 1.79 & 1.86 & 1.85 & 1.91 & 1.92 \\
\hline MgO & 3.56 & 4.19 & 4.04 & 3.91 & 4.23 & 4.14 & 4.19 & 4.32 & 4.23 & 4.23 & 4.27 & 4.14 & 4.12 & 3.76 \\
\hline $\mathrm{CaO}$ & 1.62 & 1.88 & 1.71 & 1.57 & 1.72 & 1.62 & 1.78 & 1.80 & 1.75 & 1.83 & 1.90 & 1.92 & 1.85 & 1.49 \\
\hline Total & 100.43 & 100.93 & 101.00 & 97.01 & 100.74 & 101.42 & 100.82 & 101.13 & 101.10 & 100.72 & 101.06 & 100.72 & 100.93 & 100.45 \\
\hline $\mathbf{S i}$ & 3.002 & 2.984 & 2.996 & 3.009 & 2.977 & 3.000 & 3.000 & 2.991 & 2.999 & 2.998 & 2.986 & 2.995 & 2.993 & 2.998 \\
\hline $\mathbf{T i}$ & 0.000 & 0.001 & 0.000 & 0.000 & 0.000 & 0.000 & 0.000 & 0.001 & 0.000 & 0.001 & 0.000 & 0.000 & 0.000 & 0.000 \\
\hline Al & 2.013 & 2.008 & 2.008 & 2.017 & 2.019 & 2.002 & 2.013 & 2.013 & 2.006 & 2.012 & 2.011 & 2.010 & 2.003 & 2.011 \\
\hline $\mathrm{Cr}$ & 0.000 & 0.001 & 0.000 & 0.000 & 0.001 & 0.001 & 0.000 & 0.001 & 0.001 & 0.000 & 0.002 & 0.000 & 0.001 & 0.001 \\
\hline $\mathbf{F e}^{3+}$ & 0.000 & 0.021 & 0.000 & 0.000 & 0.027 & 0.000 & 0.000 & 0.002 & 0.000 & 0.000 & 0.015 & 0.001 & 0.010 & 0.000 \\
\hline $\mathrm{Fe}^{2+}$ & 2.282 & 2.203 & 2.238 & 2.215 & 2.210 & 2.250 & 2.212 & 2.213 & 2.224 & 2.210 & 2.199 & 2.217 & 2.223 & 2.284 \\
\hline Mn & 0.133 & 0.129 & 0.137 & 0.125 & 0.121 & 0.123 & 0.125 & 0.120 & 0.122 & 0.120 & 0.124 & 0.124 & 0.128 & 0.130 \\
\hline Mg & 0.423 & 0.494 & 0.476 & 0.478 & 0.499 & 0.486 & 0.494 & 0.508 & 0.497 & 0.499 & 0.502 & 0.489 & 0.486 & 0.447 \\
\hline $\mathrm{Ca}$ & 0.138 & 0.159 & 0.145 & 0.138 & 0.146 & 0.137 & 0.151 & 0.152 & 0.148 & 0.155 & 0.161 & 0.163 & 0.157 & 0.127 \\
\hline Total & 7.99 & 8.00 & 8.00 & 7.98 & 8.00 & 8.00 & 8.00 & 8.00 & 8.00 & 8.00 & 8.00 & 8.00 & 8.00 & 8.00 \\
\hline Alm & 0.767 & 0.738 & 0.747 & 0.749 & 0.743 & 0.751 & 0.742 & 0.739 & 0.744 & 0.741 & 0.736 & 0.741 & 0.742 & 0.764 \\
\hline Py & 0.142 & 0.165 & 0.159 & 0.162 & 0.168 & 0.162 & 0.166 & 0.170 & 0.166 & 0.167 & 0.168 & 0.163 & 0.162 & 0.150 \\
\hline $\mathbf{G r}$ & 0.046 & 0.053 & 0.048 & 0.047 & 0.049 & 0.046 & 0.051 & 0.051 & 0.049 & 0.052 & 0.054 & 0.054 & 0.052 & 0.043 \\
\hline Sps & 0.045 & 0.043 & 0.046 & 0.042 & 0.041 & 0.041 & 0.042 & 0.040 & 0.041 & 0.040 & 0.042 & 0.041 & 0.043 & 0.044 \\
\hline
\end{tabular}


GRANADA - Amostra CP-07 (continuação)

\begin{tabular}{|c|c|c|c|c|c|c|c|c|c|c|c|c|c|c|c|c|c|c|c|c|}
\hline Point & 7.1 & 7.2 & 7.3 & 7.4 & 7.5 & 7.6 & 7.7 & 7.8 & 7.9 & 7.1 & 7.11 & 7.12 & 7.13 & 7.14 & 7.15 & 7.16 & 7.17 & 7.18 & 7.19 & 7.20 \\
\hline $\mathrm{SiO}_{2}$ & 38.01 & 38.19 & 37.82 & 37.97 & 37.85 & 37.99 & 37.76 & 37.54 & 37.80 & 37.48 & 37.74 & 37.73 & 37.99 & 37.89 & 37.79 & 37.83 & 37.99 & 37.68 & 37.86 & 37.78 \\
\hline $\mathrm{TiO}_{2}$ & 0.01 & 0.00 & 0.00 & 0.02 & 0.00 & 0.00 & 0.01 & 0.00 & 0.01 & 0.00 & 0.61 & 0.02 & 0.01 & 0.01 & 0.01 & 0.00 & 0.00 & 0.00 & 0.01 & 0.00 \\
\hline $\mathrm{Al}_{2} \mathrm{O}_{3}$ & 21.65 & 21.65 & 21.61 & 21.27 & 21.39 & 21.32 & 21.35 & 21.36 & 21.39 & 21.28 & 21.33 & 21.44 & 21.27 & 21.47 & 21.46 & 21.65 & 21.46 & 21.51 & 21.63 & 21.62 \\
\hline $\mathrm{Cr}_{2} \mathrm{O}_{3}$ & 0.06 & 0.01 & 0.02 & 0.04 & 0.02 & 0.02 & 0.00 & 0.00 & 0.02 & 0.03 & 0.02 & 0.04 & 0.01 & 0.03 & 0.02 & 0.04 & 0.01 & 0.06 & 0.03 & 0.04 \\
\hline $\mathrm{Fe}_{2} \mathrm{O}_{3}$ & 0.00 & 0.00 & 0.00 & 0.00 & 0.00 & 0.00 & 0.00 & 0.00 & 0.00 & 0.00 & 0.00 & 0.00 & 0.00 & 0.00 & 0.00 & 0.00 & 0.00 & 0.00 & 0.00 & 0.00 \\
\hline $\mathrm{FeO}$ & 34.50 & 34.69 & 34.47 & 34.29 & 34.27 & 34.27 & 34.03 & 34.00 & 33.57 & 33.80 & 33.86 & 33.55 & 33.87 & 33.71 & 34.11 & 34.61 & 34.45 & 34.07 & 34.50 & 34.89 \\
\hline MnO & 1.64 & 0.89 & 0.76 & 0.71 & 0.93 & 1.06 & 1.37 & 1.44 & 1.76 & 1.87 & 1.87 & 1.98 & 1.87 & 1.73 & 1.51 & 1.13 & 0.88 & 0.66 & 0.53 & 0.99 \\
\hline MgO & 4.02 & 4.45 & 4.34 & 4.24 & 4.22 & 4.08 & 4.09 & 4.05 & 4.04 & 4.08 & 4.15 & 4.05 & 4.01 & 3.98 & 3.93 & 3.92 & 4.17 & 4.21 & 4.41 & 4.26 \\
\hline $\mathrm{CaO}$ & 1.28 & 1.43 & 1.80 & 2.04 & 2.09 & 2.11 & 2.00 & 1.89 & 1.77 & 1.71 & 1.67 & 1.67 & 1.76 & 2.01 & 2.19 & 2.06 & 2.02 & 2.17 & 1.63 & 1.39 \\
\hline
\end{tabular}

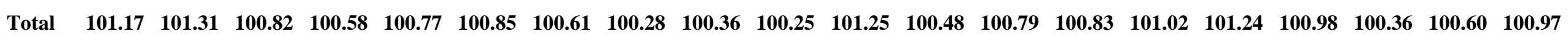

\begin{tabular}{|c|c|c|c|c|c|c|c|c|c|c|c|c|c|c|c|c|c|c|c|c|}
\hline $\mathbf{S i}$ & 3.001 & 3.003 & 2.990 & 3.009 & 2.996 & 3.007 & 2.997 & 2.990 & 3.005 & 2.988 & 2.979 & 2.998 & 3.011 & 3.000 & 2.990 & 2.986 & 3.002 & 2.992 & 2.996 & 2.988 \\
\hline $\mathbf{T i}$ & 0.001 & 0.000 & 0.000 & 0.001 & 0.000 & 0.000 & 0.001 & 0.000 & 0.001 & 0.000 & 0.036 & 0.001 & 0.001 & 0.001 & 0.001 & 0.000 & 0.000 & 0.000 & 0.001 & 0.000 \\
\hline Al & 2.015 & 2.007 & 2.014 & 1.987 & 1.996 & 1.989 & 1.998 & 2.006 & 2.005 & 2.000 & 1.985 & 2.009 & 1.988 & 2.004 & 2.002 & 2.015 & 1.999 & 2.014 & 2.018 & 2.016 \\
\hline $\mathrm{Cr}$ & 0.004 & 0.001 & 0.001 & 0.003 & 0.001 & 0.001 & 0.000 & 0.000 & 0.001 & 0.002 & 0.001 & 0.003 & 0.001 & 0.002 & 0.001 & 0.002 & 0.001 & 0.004 & 0.002 & 0.003 \\
\hline $\mathrm{Fe}^{3+}$ & 0.000 & 0.000 & 0.006 & 0.000 & 0.010 & 0.000 & 0.007 & 0.016 & 0.000 & 0.023 & 0.000 & 0.000 & 0.000 & 0.000 & 0.017 & 0.010 & 0.000 & 0.000 & 0.000 & 0.006 \\
\hline $\mathrm{Fe}^{2+}$ & 2.278 & 2.281 & 2.273 & 2.273 & 2.259 & 2.269 & 2.252 & 2.249 & 2.232 & 2.231 & 2.235 & 2.230 & 2.245 & 2.232 & 2.240 & 2.275 & 2.276 & 2.263 & 2.283 & 2.302 \\
\hline Mn & 0.110 & 0.059 & 0.051 & 0.048 & 0.062 & 0.071 & 0.092 & 0.097 & 0.119 & 0.126 & 0.125 & 0.133 & 0.126 & 0.116 & 0.101 & 0.076 & 0.059 & 0.044 & 0.036 & 0.066 \\
\hline Mg & 0.473 & 0.521 & 0.511 & 0.501 & 0.498 & 0.481 & 0.484 & 0.481 & 0.479 & 0.485 & 0.488 & 0.480 & 0.474 & 0.470 & 0.463 & 0.461 & 0.491 & 0.498 & 0.520 & 0.502 \\
\hline $\mathrm{Ca}$ & 0.108 & 0.120 & 0.152 & 0.173 & 0.177 & 0.179 & 0.170 & 0.161 & 0.151 & 0.146 & 0.141 & 0.142 & 0.149 & 0.171 & 0.186 & 0.174 & 0.171 & 0.185 & 0.138 & 0.118 \\
\hline Total & 7.99 & 7.99 & 8.00 & 8.00 & 8.00 & 8.00 & 8.00 & 8.00 & 7.99 & 8.00 & 7.99 & 8.00 & 8.00 & 8.00 & 8.00 & 8.00 & 8.00 & 8.00 & 7.99 & 8.00 \\
\hline Alm & 0.767 & 0.765 & 0.761 & 0.759 & 0.754 & 0.756 & 0.751 & 0.753 & 0.749 & 0.747 & 0.748 & 0.747 & 0.750 & 0.747 & 0.749 & 0.762 & 0.759 & 0.757 & 0.767 & 0.770 \\
\hline $\mathbf{P y}$ & 0.159 & 0.175 & 0.171 & 0.167 & 0.166 & 0.160 & 0.161 & 0.161 & 0.161 & 0.162 & 0.163 & 0.161 & 0.158 & 0.157 & 0.155 & 0.154 & 0.164 & 0.167 & 0.175 & 0.168 \\
\hline Gr & 0.036 & 0.040 & 0.051 & 0.058 & 0.059 & 0.060 & 0.057 & 0.054 & 0.051 & 0.049 & 0.047 & 0.048 & 0.050 & 0.057 & 0.062 & 0.058 & 0.057 & 0.062 & 0.046 & 0.039 \\
\hline Sps & 0.037 & 0.020 & 0.017 & 0.016 & 0.021 & 0.024 & 0.031 & 0.032 & 0.040 & 0.042 & 0.042 & 0.045 & 0.042 & 0.039 & 0.034 & 0.025 & 0.020 & 0.015 & 0.012 & 0.022 \\
\hline
\end{tabular}




\section{GRANADA - Amostra CP-333}

Granada tipo 1, anterior, sem corona, inclusa na ky

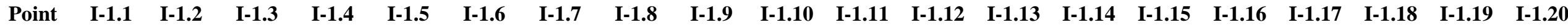

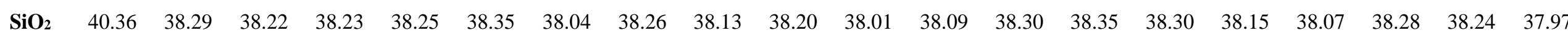

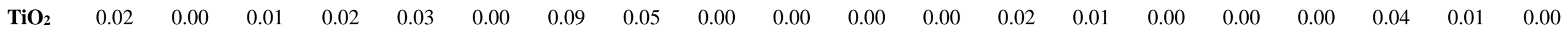

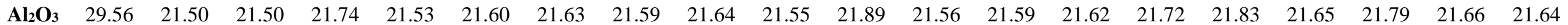

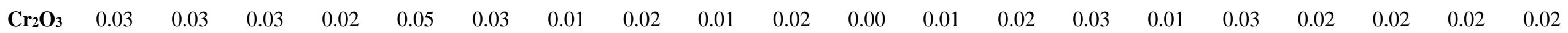

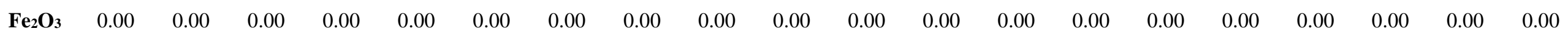

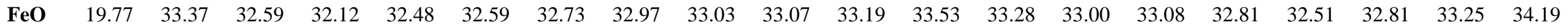

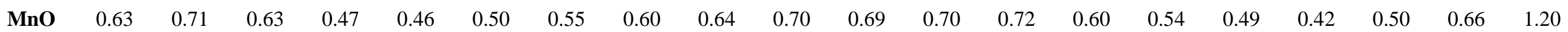

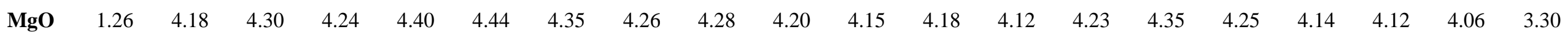

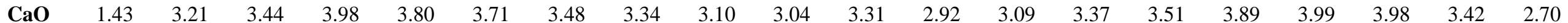

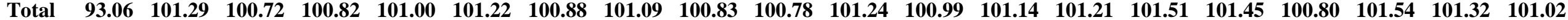

\begin{tabular}{|c|c|c|c|c|c|c|c|c|c|c|c|c|c|c|c|c|c|c|c|c|}
\hline $\mathbf{S i}$ & 3.154 & 3.007 & 3.010 & 3.002 & 3.003 & 3.004 & 2.993 & 3.005 & 3.002 & 3.010 & 2.984 & 3.001 & 3.009 & 3.008 & 2.996 & 2.984 & 2.997 & 2.994 & 3.001 & 3.004 \\
\hline $\mathbf{T i}$ & 0.001 & 0.000 & 0.001 & 0.001 & 0.002 & 0.000 & 0.005 & 0.003 & 0.000 & 0.000 & 0.000 & 0.000 & 0.001 & 0.001 & 0.000 & 0.000 & 0.000 & 0.002 & 0.001 & 0.000 \\
\hline Al & 2.724 & 1.990 & 1.996 & 2.013 & 1.993 & 1.995 & 2.006 & 1.999 & 2.009 & 2.002 & 2.026 & 2.003 & 2.000 & 1.999 & 2.003 & 2.013 & 2.009 & 2.009 & 2.004 & 2.019 \\
\hline $\mathrm{Cr}$ & 0.002 & 0.002 & 0.002 & 0.001 & 0.003 & 0.002 & 0.001 & 0.001 & 0.001 & 0.001 & 0.000 & 0.001 & 0.001 & 0.002 & 0.001 & 0.002 & 0.001 & 0.001 & 0.001 & 0.001 \\
\hline $\mathrm{Fe}^{3+}$ & 0.000 & 0.000 & 0.000 & 0.000 & 0.000 & 0.000 & 0.000 & 0.000 & 0.000 & 0.000 & 0.005 & 0.000 & 0.000 & 0.000 & 0.005 & 0.016 & 0.000 & 0.000 & 0.000 & 0.000 \\
\hline $\mathrm{Fe}^{2+}$ & 1.292 & 2.192 & 2.146 & 2.110 & 2.132 & 2.135 & 2.154 & 2.165 & 2.175 & 2.179 & 2.174 & 2.209 & 2.187 & 2.165 & 2.159 & 2.130 & 2.140 & 2.146 & 2.182 & 2.263 \\
\hline Mn & 0.042 & 0.047 & 0.042 & 0.031 & 0.031 & 0.033 & 0.037 & 0.040 & 0.043 & 0.047 & 0.046 & 0.047 & 0.048 & 0.040 & 0.036 & 0.032 & 0.028 & 0.033 & 0.044 & 0.080 \\
\hline Mg & 0.147 & 0.489 & 0.505 & 0.496 & 0.515 & 0.518 & 0.510 & 0.499 & 0.502 & 0.493 & 0.486 & 0.491 & 0.482 & 0.494 & 0.507 & 0.495 & 0.486 & 0.480 & 0.475 & 0.389 \\
\hline $\mathrm{Ca}$ & 0.120 & 0.270 & 0.290 & 0.335 & 0.320 & 0.311 & 0.293 & 0.281 & 0.262 & 0.257 & 0.278 & 0.247 & 0.260 & 0.283 & 0.294 & 0.326 & 0.337 & 0.334 & 0.288 & 0.229 \\
\hline Total & 7.5 & 8.0 & 8.0 & 8.0 & 8.0 & 8.0 & 8.0 & 8.0 & 8.0 & 8.0 & 8.0 & 8.0 & 8.0 & 8.0 & 8.0 & 8.0 & 8.0 & 8.0 & 8.0 & 8.0 \\
\hline Alm & 0.807 & 0.731 & 0.719 & 0.710 & 0.711 & 0.712 & 0.719 & 0.725 & 0.729 & 0.732 & 0.729 & 0.738 & 0.735 & 0.726 & 0.721 & 0.714 & 0.715 & 0.717 & 0.730 & 0.764 \\
\hline & 0.092 & 0.163 & 0.169 & 0.167 & 0.172 & 0.173 & 0.170 & 0.167 & 0.168 & 0.166 & 0.163 & 0.164 & 0.162 & 0.166 & 0.169 & 0.166 & 0.162 & 0.160 & 0.159 & 0.131 \\
\hline & 0.075 & 0.090 & 0.097 & 0.113 & 0.107 & 0.104 & 0.098 & 0.094 & 0.088 & 0.086 & 0.093 & 0.082 & 0.087 & 0.095 & 0.098 & 0.109 & 0.113 & 0.112 & 0.096 & 0.077 \\
\hline Sps & 0.026 & 0.016 & 0.014 & 0.010 & 0.010 & 0.011 & 0.012 & 0.013 & 0.014 & 0.016 & 0.015 & 0.016 & 0.016 & 0.013 & 0.012 & 0.011 & 0.009 & 0.011 & 0.015 & 0.027 \\
\hline
\end{tabular}


GRANADA - Amostra CP-333

Granada tipo 1, anterior, sem corona, inclusa na ky

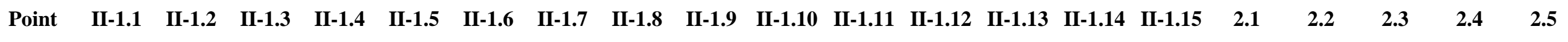

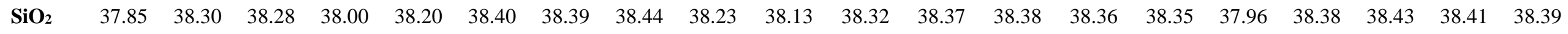

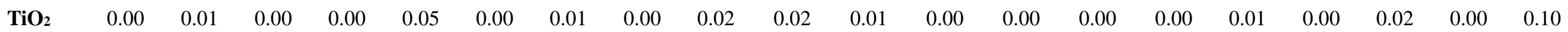

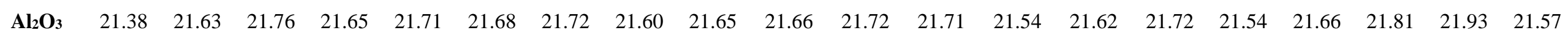

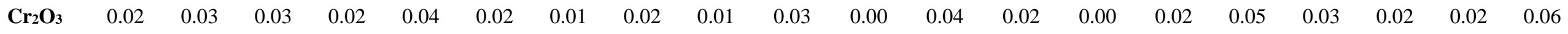

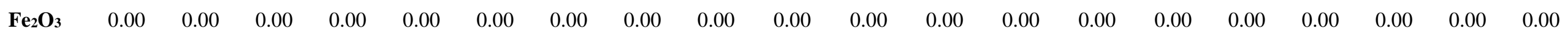

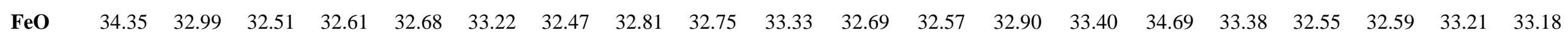

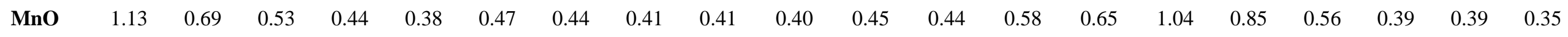

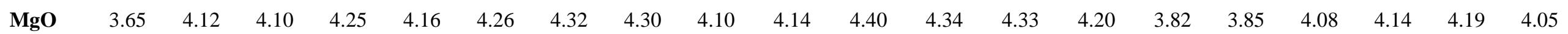

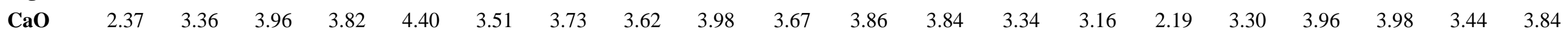

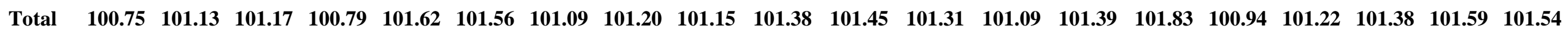

\begin{tabular}{|c|c|c|c|c|c|c|c|c|c|c|c|c|c|c|c|c|c|c|c|c|}
\hline $\mathbf{S i}$ & 3.004 & .008 & 3.001 & 2.992 & .983 & 3.003 & 3.007 & .011 & 3.000 & 2.990 & 2.995 & 3.002 & & 3.007 & 3.007 & 2.997 & 3.008 & 3.004 & 3.000 & 3.004 \\
\hline $\mathbf{T i}$ & 0.000 & 0.001 & 0.000 & 0.000 & 0.003 & 0.000 & 0.001 & 0.000 & 0.001 & 0.001 & 0.001 & 0.000 & 0.000 & 0.000 & 0.000 & 0.001 & 0.000 & 0.001 & 0.000 & 0.006 \\
\hline Al & 2.000 & 2.002 & 2.011 & 2.010 & 1.999 & 1.999 & 2.006 & 1.995 & 2.003 & 2.002 & 2.002 & 2.003 & 1.993 & 1.998 & 2.007 & 2.005 & 2.001 & 2.010 & 2.019 & 1.990 \\
\hline $\mathrm{Cr}$ & .001 & .002 & 0.002 & 0.001 & 0.002 & 0.001 & 0.001 & 0.001 & 0.001 & 0.002 & 0.000 & 0.002 & 0.001 & 0.000 & 0.001 & 0.003 & 0.002 & 0.001 & 0.001 & 0.004 \\
\hline $\mathrm{Fe}^{-1}$ & .000 & .000 & 0.000 & 0.006 & 0.026 & 0.000 & 0.000 & 0.000 & 0.000 & 0.013 & 0.007 & 0.000 & 0.000 & 0.000 & 0.000 & 0.000 & 0.000 & 0.000 & 0.000 & 0.000 \\
\hline $\mathrm{Fe}^{2+}$ & 2.280 & 2.167 & 2.132 & 2.142 & 2.109 & 2.173 & 2.127 & 2.150 & 2.150 & 2.172 & 2.130 & 2.131 & 2.159 & 2.190 & 2.274 & 2.204 & 2.133 & 2.131 & 2.169 & 2.172 \\
\hline Mn & 0.076 & 0.046 & 0.035 & 0.029 & 0.025 & 0.031 & 0.029 & 0.027 & 0.027 & 0.027 & 0.030 & 0.029 & 0.039 & 0.043 & 0.069 & 0.057 & 0.037 & 0.026 & 0.026 & 0.023 \\
\hline Mg & 0.432 & 0.482 & 0.479 & 0.499 & 0.484 & 0.496 & 0.504 & 0.502 & 0.480 & 0.484 & 0.513 & 0.506 & 0.506 & 0.491 & 0.446 & 0.453 & 0.477 & 0.482 & 0.488 & 0.472 \\
\hline $\mathrm{Ca}$ & 0.202 & 0.283 & 0.333 & 0.322 & 0.368 & 0.294 & 0.313 & 0.304 & 0.335 & 0.308 & 0.323 & 0.322 & 0.281 & 0.265 & 0.184 & 0.279 & 0.333 & 0.333 & 0.288 & 0.322 \\
\hline Total & 8.0 & 8.0 & 8.0 & 8.0 & 8.0 & 8.0 & 8.0 & 8.0 & 8.0 & 8.0 & 8.0 & 8.0 & 8.0 & 8.0 & 8.0 & 8.0 & 8.0 & 8.0 & 8.0 & 8.0 \\
\hline Alm & 0.763 & 0.728 & 0.716 & 0.716 & 0.706 & 0.726 & 0.715 & 0.721 & 0.719 & 0.726 & 0.711 & 0.713 & 0.723 & 0.733 & 0.765 & 0.736 & 0.716 & 0.717 & 0.730 & 0.727 \\
\hline Py & 0.144 & 0.162 & 0.161 & 0.167 & 0.162 & 0.166 & 0.170 & 0.168 & 0.160 & 0.162 & 0.171 & 0.169 & 0.170 & 0.164 & 0.150 & 0.151 & 0.160 & 0.162 & 0.164 & 0.158 \\
\hline $\mathbf{G r}$ & 0.068 & 0.095 & 0.112 & 0.108 & 0.123 & 0.098 & 0.105 & 0.102 & 0.112 & 0.103 & 0.108 & 0.108 & 0.094 & 0.089 & 0.062 & 0.093 & 0.112 & 0.112 & 0.097 & 0.108 \\
\hline Sps & 0.025 & 0.015 & 0.012 & 0.010 & 0.008 & 0.010 & 0.010 & 0.009 & 0.009 & 0.009 & 0.010 & 0.010 & 0.013 & 0.014 & 0.023 & 0.019 & 0.012 & 0.009 & 0.009 & 0.008 \\
\hline
\end{tabular}


GRANADA - Amostra CP-333

Granada tipo 1, anterior, sem corona, inclusa na ky

\begin{tabular}{|c|c|c|c|c|c|c|c|c|c|c|c|c|c|c|c|c|c|c|c|c|}
\hline Point & 2.6 & 2.7 & 2.8 & 2.9 & 2.10 & 3.1 & 3.2 & 3.3 & 3.4 & 3.5 & 3.6 & 3.7 & 3.8 & 3.9 & 3.10 & 3.11 & 3.12 & 3.13 & 3.14 & 3.15 \\
\hline $\mathrm{SiO}_{2}$ & 38.50 & 38.20 & 38.29 & 38.13 & 37.69 & 37.79 & 38.30 & 38.09 & 38.58 & 38.40 & 38.48 & 37.99 & 38.29 & 38.56 & 37.72 & 38.67 & 38.30 & 38.29 & 38.18 & 38.31 \\
\hline $\mathrm{TiO}_{2}$ & 0.01 & 0.03 & 0.00 & 0.00 & 0.00 & 0.00 & 0.00 & 0.00 & 0.00 & 0.00 & 0.00 & 0.00 & 0.00 & 0.00 & 0.03 & 0.05 & 0.00 & 0.28 & 0.00 & 0.00 \\
\hline $\mathrm{Al}_{2} \mathrm{O}_{3}$ & 21.69 & 21.48 & 21.60 & 21.71 & 21.59 & 21.51 & 21.46 & 21.75 & 21.56 & 21.66 & 21.78 & 21.51 & 21.64 & 21.73 & 21.32 & 21.68 & 21.64 & 21.50 & 21.56 & 21.92 \\
\hline 1203 & 0.02 & 0.03 & 0.04 & 0.02 & 0.02 & 0.03 & 0.02 & 0.02 & 0.02 & 0.01 & 0.03 & 0.02 & 0.01 & 0.03 & 0.03 & 0.04 & 0.02 & 0.03 & 0.02 & 0.03 \\
\hline $\mathbf{e}_{2} \mathbf{O}_{3}$ & 0.00 & 0.00 & 0.00 & 0.00 & 0.00 & 0.00 & 0.00 & 0.00 & 0.00 & 0.00 & 0.00 & 0.00 & 0.00 & 0.00 & 0.00 & 0.00 & 0.00 & 0.00 & 0.00 & 0.00 \\
\hline $\mathrm{FeO}$ & 33.03 & 33.04 & 32.44 & 32.75 & 34.44 & 33.44 & 32.89 & 32.55 & 33.03 & 33.01 & 33.40 & 33.36 & 33.34 & 33.38 & 33.63 & 33.16 & 33.08 & 33.09 & 33.53 & 33.52 \\
\hline MnO & 0.31 & 0.28 & 0.32 & 0.54 & 1.08 & 0.94 & 0.59 & 0.51 & 0.57 & 0.63 & 0.80 & 0.80 & 0.79 & 0.77 & 0.85 & 0.68 & 0.62 & 0.61 & 0.92 & 0.96 \\
\hline MgO & 4.08 & 4.14 & 4.13 & 4.12 & 3.38 & 3.81 & 4.43 & 4.49 & 4.36 & 4.25 & 4.15 & 4.08 & 4.10 & 4.11 & 3.86 & 4.23 & 4.34 & 4.36 & 3.89 & 3.82 \\
\hline $\mathrm{CaO}$ & 3.97 & 3.89 & 3.86 & 4.07 & 2.41 & 3.22 & 3.41 & 3.30 & 3.35 & 3.38 & 3.01 & 2.75 & 3.09 & 3.25 & 2.68 & 3.26 & 3.27 & 3.08 & 3.13 & 3.00 \\
\hline
\end{tabular}

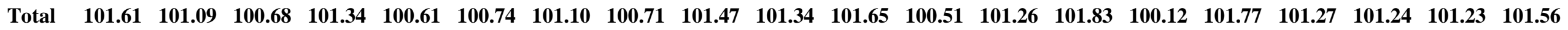

\begin{tabular}{|c|c|c|c|c|c|c|c|c|c|c|c|c|c|c|c|c|c|c|c|c|}
\hline $\mathbf{S i}$ & 3.007 & 3.002 & 3.013 & 2.988 & 2.997 & 2.991 & 3.007 & 2.996 & 3.016 & 3.008 & 3.008 & 3.006 & 3.006 & 3.009 & 3.004 & 3.015 & 3.003 & 3.002 & 3.005 & 3.001 \\
\hline $\mathbf{T i}$ & 0.001 & 0.002 & 0.000 & 0.000 & 0.000 & 0.000 & 0.000 & 0.000 & 0.000 & 0.000 & 0.000 & 0.000 & 0.000 & 0.000 & 0.002 & 0.003 & 0.000 & 0.017 & 0.000 & 0.000 \\
\hline Al & 1.998 & 1.990 & 2.004 & 2.006 & 2.024 & 2.007 & 1.986 & 2.017 & 1.987 & 2.000 & 2.007 & 2.007 & 2.003 & 1.999 & 2.002 & 1.993 & 2.000 & 1.987 & 2.000 & 2.025 \\
\hline $\mathrm{Cr}$ & 0.001 & 0.002 & 0.002 & .001 & 0.001 & 0.002 & 0.001 & .001 & 0.001 & 0.001 & 0.002 & 0.001 & .001 & 0.002 & 0.002 & 0.002 & .001 & 0.002 & .001 & 0.002 \\
\hline & 0.000 & 0.000 & 0.000 & .017 & 0.000 & 0.008 & 0.000 & 0.000 & 0.000 & 0.000 & 0.000 & 0.000 & 0.000 & 0.000 & 0.000 & 0.000 & 0.000 & 0.000 & 0.000 & 0.000 \\
\hline $\mathrm{Fe}^{2+}$ & 2.158 & 2.172 & 2.135 & 2.129 & 2.290 & 2.206 & 2.160 & 2.141 & 2.159 & 2.162 & 2.183 & 2.208 & 2.189 & 2.179 & 2.240 & 2.162 & 2.169 & 2.170 & 2.207 & 2.196 \\
\hline $\mathbf{M n}$ & 0.021 & 0.019 & 0.021 & 0.036 & 0.073 & 0.063 & 0.039 & 0034 & 0.038 & & 0.053 & 0.054 & & & & 0.045 & .041 & 0.041 & & 0.064 \\
\hline Mg & 0.475 & 0.485 & 0.484 & 0.481 & 0.401 & 0.449 & 0.518 & 0.526 & 0.508 & 0.496 & 0.483 & 0.481 & 0.480 & 0.478 & 0.458 & 0.492 & .507 & 0.509 & 0.456 & 0.446 \\
\hline $\mathrm{Ca}$ & 0.332 & 0.328 & 0.325 & 0.342 & 0.205 & 0.273 & 0.287 & 0.278 & 0.281 & 0.284 & 0.252 & 0.233 & 0.260 & 0.272 & 0.229 & 0.272 & 0.275 & 0.259 & 0.264 & 0.252 \\
\hline . & 7.993 & 8.000 & 7.984 & 8.000 & 7.991 & 8.000 & 7.999 & 7.995 & 7.990 & 7.992 & 7.988 & 7.990 & 7.992 & 7.990 & 7.993 & 7.984 & 7.997 & 7.987 & 7.995 & 7.986 \\
\hline Alm & 0.723 & 0.723 & 0.720 & 0.713 & 0.771 & 0.738 & 0.719 & 0.719 & 0.723 & 0.725 & 0.735 & 0.742 & 0.734 & 0.731 & 0.751 & 0.728 & 0.725 & 0.728 & 0.739 & 0.742 \\
\hline $\mathbf{P}_{\mathbf{y}}$ & 0.159 & 0.161 & 0.163 & 0.161 & 0.135 & 0.150 & 0.172 & 0.177 & 0.170 & 0.166 & 0.163 & 0.162 & 0.161 & 0.160 & 0.153 & 0.166 & 0.169 & 0.171 & 0.153 & 0.151 \\
\hline $\mathbf{C}$ & 0.111 & 0.109 & 0.110 & 0.114 & 0.069 & 0.091 & 0.096 & 0.093 & 0.094 & 0.095 & 0.085 & 0.078 & 0.087 & 0.091 & 0.077 & 0.092 & 0.092 & 0.087 & 0.088 & 0.085 \\
\hline & 0.007 & 0.006 & 0.007 & 0.012 & 0.025 & 0.021 & 0.013 & 0.011 & 0.013 & 0.014 & 0.018 & 0.018 & 0.018 & 0.017 & 0.019 & 0.015 & 0.014 & 0.014 & 0.020 & 0.022 \\
\hline
\end{tabular}


GRANADA - Amostra CP-333

Granada tipo 2, reliquiar com corona de granada

\begin{tabular}{|c|c|c|c|c|c|c|c|c|c|c|c|c|c|c|c|c|c|c|c|c|}
\hline Point & 4.1 & 4.2 & 4.3 & 4.4 & 4.5 & 4.6 & 4.7 & 4.8 & 4.9 & 4.10 & 4.11 & 4.12 & 4.13 & 4.14 & 4.15 & 5.1 & 5.2 & 5.3 & 5.4 & 5.5 \\
\hline $\mathrm{SiO}_{2}$ & 38.05 & 38.34 & 38.22 & 38.24 & 38.11 & 38.37 & 38.33 & 38.32 & 38.25 & 38.21 & 38.35 & 38.44 & 38.13 & 37.73 & 37.71 & 38.12 & 38.12 & 37.88 & 37.95 & 38.12 \\
\hline $\mathrm{TiO}_{2}$ & 0.00 & 0.00 & 0.02 & 0.32 & 0.00 & 0.01 & 0.01 & 0.00 & 0.00 & 0.01 & 0.01 & 0.01 & 0.00 & 0.00 & 0.00 & 0.01 & 0.00 & 0.00 & 0.00 & 0.00 \\
\hline $\mathrm{Al}_{2} \mathrm{O}_{3}$ & 21.71 & 21.47 & 21.66 & 21.43 & 21.58 & 21.80 & 21.68 & 21.79 & 21.67 & 21.67 & 21.85 & 21.85 & 21.73 & 21.31 & 21.49 & 21.75 & 21.63 & 21.41 & 21.46 & 21.26 \\
\hline $\mathrm{Cr}_{2} \mathrm{O}_{3}$ & 0.01 & 0.08 & 0.06 & 0.08 & 0.03 & 0.00 & 0.02 & 0.02 & 0.03 & 0.02 & 0.02 & 0.01 & 0.01 & 0.04 & 0.00 & 0.01 & 0.02 & 0.02 & 0.02 & 0.02 \\
\hline $\mathrm{Fe}_{2} \mathrm{O}_{3}$ & 0.00 & 0.00 & 0.00 & 0.00 & 0.00 & 0.00 & 0.00 & 0.00 & 0.00 & 0.00 & 0.00 & 0.00 & 0.00 & 0.00 & 0.00 & 0.00 & 0.00 & 0.00 & 0.00 & 0.00 \\
\hline $\mathrm{FeO}$ & 34.91 & 33.98 & 33.54 & 33.97 & 34.25 & 32.93 & 31.41 & 30.74 & 30.71 & 31.06 & 32.17 & 32.41 & 34.21 & 35.53 & 34.83 & 33.99 & 33.81 & 33.94 & 34.04 & 33.77 \\
\hline MnO & 1.37 & 1.21 & 1.16 & 1.12 & 1.21 & 1.96 & 3.78 & 4.11 & 3.74 & 3.28 & 2.47 & 1.77 & 1.21 & 1.35 & 1.37 & 1.06 & 1.11 & 1.26 & 1.17 & 1.06 \\
\hline MgO & 3.07 & 3.48 & 3.63 & 3.76 & 3.90 & 4.30 & 4.11 & 4.06 & 4.09 & 4.24 & 4.43 & 4.42 & 4.18 & 2.97 & 3.12 & 3.46 & 3.75 & 3.41 & 3.70 & 3.75 \\
\hline $\mathrm{CaO}$ & 2.25 & 2.84 & 2.87 & 2.64 & 2.25 & 2.07 & 2.17 & 2.30 & 2.23 & 2.35 & 2.36 & 2.29 & 2.02 & 2.15 & 2.51 & 3.25 & 3.06 & 2.82 & 2.67 & 2.88 \\
\hline
\end{tabular}

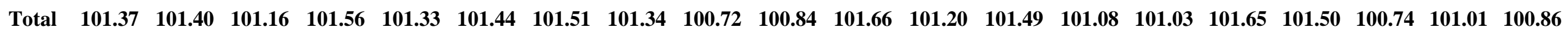

\begin{tabular}{|c|c|c|c|c|c|c|c|c|c|c|c|c|c|c|c|c|c|c|c|c|}
\hline Si & 3.007 & 3.019 & 3.010 & .004 & .003 & .007 & 3.007 & .007 & & 3.009 & .998 & & .996 & .003 & 2.996 & 2.996 & 2.998 & 3.006 & 02 & 3.016 \\
\hline Ti & 0.000 & 0.000 & 0.001 & 0.019 & 0.000 & 0.001 & 0.001 & 0.000 & 0.000 & 0.001 & 0.001 & 0.001 & 0.000 & 0.000 & 0.000 & 0.001 & 0.000 & 0.000 & 0.000 & 0.000 \\
\hline & 2.023 & 1.993 & 2.011 & 1.985 & 2.004 & 2.014 & 2.005 & 2.016 & 2.014 & 2.012 & 2.014 & 2.018 & 2.013 & 1.999 & 2.013 & 2.015 & 2.005 & 2.003 & 2.001 & 1.983 \\
\hline & .001 & 0.005 & .004 & 005 & .002 & .000 & 0.001 & 0.001 & 0.002 & 0.001 & 0.001 & 0.001 & 0.001 & .003 & 0.000 & 0.001 & 0.001 & 0.001 & 0.001 & 0.001 \\
\hline 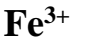 & .000 & 0.000 & 0.000 & .000 & .000 & .000 & 0.000 & 0.000 & 0.000 & 0.000 & 0.000 & 0.000 & 0.000 & 0.000 & 0.000 & 0.000 & 0.000 & 0.000 & 0.000 & 0.000 \\
\hline re & 2.307 & 2.237 & 2.209 & 2.232 & 2.257 & 2.158 & 2.061 & 2.018 & 2.025 & 2.046 & 2.103 & 2.123 & 2.248 & 2.365 & 2.314 & 2.234 & 2.224 & 2.253 & 2.252 & 2.234 \\
\hline In & 0.092 & 0.081 & 0.077 & 0.075 & 0.081 & 0.130 & 0.251 & 0.273 & 0.250 & 0.219 & 0.164 & .117 & 0.081 & .091 & 0.092 & 0.071 & 0.074 & 0.085 & 0.078 & 0.071 \\
\hline Ig & 0.362 & 0.408 & 0.426 & 0.440 & 0.458 & 0.502 & 0.481 & 0.475 & 0.481 & 0.498 & 0.516 & 0.516 & 0.489 & 0.352 & 0.369 & 0.405 & 0.439 & 0.403 & 0.436 & 0.442 \\
\hline Ca & 0.191 & 0.240 & 0.242 & 0.222 & 0.190 & 0.174 & 0.182 & 0.193 & 0.188 & 0.198 & 0.198 & 0.192 & 0.170 & 0.183 & 0.214 & 0.274 & 0.258 & 0.240 & 0.226 & 0.244 \\
\hline Total & 8.0 & 8.0 & 8.0 & 8.0 & 8.0 & 8.0 & 8.0 & 8.0 & 8.0 & 8.0 & 8.0 & 8.0 & 8.0 & 8.0 & 8.0 & 8.0 & 8.0 & 8.0 & 8.0 & 8.0 \\
\hline Alm & 0.782 & 0.754 & 0.748 & 0.752 & 0.756 & 0.728 & 0.693 & 0.682 & 0.688 & 0.691 & 0.705 & 0.720 & 0.752 & 0.791 & 0.774 & 0.749 & 0.743 & 0.756 & 0.753 & 0.747 \\
\hline Py & 0.123 & 0.138 & 0.144 & 0.148 & 0.153 & 0.169 & 0.162 & 0.161 & 0.163 & 0.168 & 0.173 & 0.175 & 0.164 & 0.118 & 0.123 & 0.136 & 0.147 & 0.135 & 0.146 & 0.148 \\
\hline Gr & 0.065 & 0.081 & 0.082 & 0.075 & 0.064 & 0.059 & 0.061 & 0.065 & 0.064 & 0.067 & 0.066 & 0.065 & 0.057 & 0.061 & 0.072 & 0.092 & 0.086 & 0.081 & 0.076 & 0.082 \\
\hline Sps & 0.031 & 0.027 & 0.026 & 0.025 & 0.027 & 0.044 & 0.084 & 0.092 & 0.085 & 0.074 & 0.055 & 0.040 & 0.027 & 0.030 & 0.031 & 0.024 & 0.025 & 0.029 & 0.026 & 0.024 \\
\hline
\end{tabular}


GRANADA - Amostra CP-333

\begin{tabular}{|c|c|c|c|c|c|c|c|c|c|c|c|c|c|c|c|c|c|c|c|c|}
\hline \multicolumn{21}{|c|}{ Granada tipo 2, reliquiar com corona de granada } \\
\hline Point & 5.6 & 5.7 & 5.8 & 5.9 & 5.10 & 5.11 & 5.12 & 5.13 & 5.14 & 5.15 & 5.16 & 5.17 & 5.18 & 5.19 & 5.20 & 6.1 & 6.2 & 6.3 & 6.4 & 6.5 \\
\hline $\mathrm{SiO}_{2}$ & 37.95 & 38.17 & 37.92 & 38.10 & 38.15 & 38.17 & 38.13 & 37.92 & 38.07 & 38.02 & 38.44 & 37.78 & 37.76 & 38.05 & 37.81 & 37.95 & 37.89 & 38.22 & 38.36 & 38.11 \\
\hline $\mathrm{TiO}_{2}$ & 0.00 & 0.00 & 0.00 & 0.00 & 0.00 & 0.00 & 0.00 & 0.01 & 0.00 & 0.00 & 0.00 & 0.02 & 0.00 & 0.00 & 0.00 & 0.13 & 0.00 & 0.00 & 0.00 & 0.00 \\
\hline $\mathrm{Al}_{2} \mathrm{O}_{3}$ & 21.60 & 21.52 & 21.30 & 21.51 & 21.72 & 21.74 & 21.70 & 21.60 & 21.61 & 21.65 & 21.33 & 21.32 & 21.45 & 21.58 & 21.36 & 21.20 & 21.45 & 21.55 & 21.65 & 21.86 \\
\hline $\mathrm{Cr}_{2} \mathrm{O}_{3}$ & 0.04 & 0.01 & 0.02 & 0.02 & 0.04 & 0.04 & 0.04 & 0.00 & 0.02 & 0.02 & 0.03 & 0.00 & 0.01 & 0.02 & 0.04 & 0.06 & 0.03 & 0.00 & 0.01 & 0.01 \\
\hline $\mathrm{Fe}_{2} \mathrm{O}_{3}$ & 0.00 & 0.00 & 0.00 & 0.00 & 0.00 & 0.00 & 0.00 & 0.00 & 0.00 & 0.00 & 0.00 & 0.00 & 0.00 & 0.00 & 0.00 & 0.00 & 0.00 & 0.00 & 0.00 & 0.00 \\
\hline $\mathrm{FeO}$ & 34.02 & 33.90 & 34.28 & 33.83 & 33.47 & 32.88 & 32.68 & 33.81 & 33.71 & 34.19 & 32.77 & 34.16 & 34.46 & 33.61 & 34.15 & 34.53 & 32.93 & 32.32 & 32.07 & 31.50 \\
\hline MnO & 1.11 & 1.08 & 1.13 & 1.16 & 1.21 & 1.46 & 1.36 & 1.23 & 1.28 & 1.20 & 0.86 & 1.01 & 1.15 & 1.00 & 1.15 & 1.29 & 1.41 & 1.80 & 2.19 & 2.53 \\
\hline MgO & 3.67 & 3.69 & 3.69 & 3.58 & 4.37 & 4.53 & 4.58 & 4.29 & 3.46 & 3.67 & 3.87 & 3.89 & 3.67 & 3.92 & 3.58 & 3.11 & 4.22 & 4.47 & 4.49 & 4.62 \\
\hline $\mathrm{CaO}$ & 2.91 & 2.79 & 2.62 & 2.96 & 2.09 & 2.21 & 2.18 & 2.14 & 2.98 & 2.42 & 3.65 & 2.64 & 2.86 & 3.06 & 2.85 & 2.69 & 2.40 & 2.22 & 2.40 & 2.19 \\
\hline
\end{tabular}

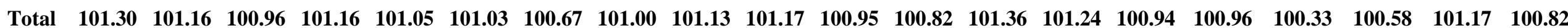

\begin{tabular}{|c|c|c|c|c|c|c|c|c|c|c|c|c|c|c|c|c|c|c|c|c|}
\hline $\mathbf{S i}$ & 2.993 & 3.010 & 3.004 & 3.007 & 3.001 & 3.000 & 3.004 & 2.992 & 3.005 & 3.001 & 3.026 & 2.993 & 2.980 & 2.997 & 2.996 & 3.013 & 3.004 & 3.015 & 3.009 & 2.997 \\
\hline $\mathbf{T i}$ & 0.000 & 0.000 & 0.000 & 0.000 & 0.000 & 0.000 & 0.000 & 0.001 & 0.000 & 0.000 & 0.000 & 0.001 & 0.000 & 0.000 & 0.000 & 0.008 & 0.000 & 0.000 & 0.000 & 0.000 \\
\hline Al & 2.009 & 2.001 & 1.989 & 2.001 & 2.015 & 2.014 & 2.015 & 2.009 & 2.011 & 2.015 & 1.979 & 1.991 & 1.995 & 2.004 & 1.996 & 1.984 & 2.005 & 2.004 & 2.002 & 2.026 \\
\hline $\mathrm{Cr}$ & 0.002 & 0.001 & 0.001 & 0.001 & 0.002 & 0.002 & 0.002 & 0.000 & 0.001 & 0.001 & 0.002 & 0.000 & 0.001 & 0.001 & 0.003 & 0.004 & 0.002 & 0.000 & 0.001 & 0.001 \\
\hline $\mathrm{Fe}^{3+}$ & 0.002 & 0.000 & 0.001 & 0.000 & 0.000 & 0.000 & 0.000 & 0.006 & 0.000 & 0.000 & 0.000 & 0.020 & 0.045 & 0.002 & 0.009 & 0.000 & 0.000 & 0.000 & 0.000 & 0.000 \\
\hline $\mathrm{Fe}^{2+}$ & 2.242 & 2.236 & 2.270 & 2.233 & 2.202 & 2.161 & 2.153 & 2.225 & 2.226 & 2.257 & 2.157 & 2.243 & 2.229 & 2.212 & 2.254 & 2.293 & 2.184 & 2.132 & 2.104 & 2.072 \\
\hline Mn & 0.074 & 0.072 & 0.076 & 0.078 & 0.081 & 0.097 & 0.091 & 0.082 & 0.086 & 0.080 & 0.057 & 0.068 & 0.077 & 0.067 & 0.077 & 0.087 & 0.095 & 0.120 & 0.146 & 0.169 \\
\hline Mg & 0.431 & 0.434 & 0.436 & 0.421 & 0.512 & 0.531 & 0.538 & 0.504 & 0.407 & 0.432 & 0.454 & 0.459 & 0.432 & 0.460 & 0.423 & 0.368 & 0.499 & 0.525 & 0.525 & 0.541 \\
\hline $\mathrm{Ca}$ & 0.246 & 0.236 & 0.222 & 0.250 & 0.176 & 0.186 & 0.184 & 0.181 & 0.252 & 0.205 & 0.308 & 0.224 & 0.242 & 0.258 & 0.242 & 0.229 & 0.204 & 0.188 & 0.202 & 0.185 \\
\hline Total & 8.0 & 8.0 & 8.0 & 8.0 & 8.0 & 8.0 & 8.0 & 8.0 & 8.0 & 8.0 & 8.0 & 8.0 & 8.0 & 8.0 & 8.0 & 7.985 & 7.992 & 7.984 & 7.989 & 7.990 \\
\hline Alm & 0.749 & 0.751 & 0.756 & 0.749 & 0.741 & 0.726 & 0.726 & 0.744 & 0.749 & 0.759 & 0.725 & 0.749 & 0.748 & 0.738 & 0.752 & 0.770 & 0.732 & 0.719 & 0.707 & 0.698 \\
\hline Py & 0.144 & 0.146 & 0.145 & 0.141 & 0.172 & 0.178 & 0.181 & 0.168 & 0.137 & 0.145 & 0.153 & 0.153 & 0.145 & 0.153 & 0.141 & 0.124 & 0.167 & 0.177 & 0.176 & 0.182 \\
\hline Gr & 0.082 & 0.079 & 0.074 & 0.084 & 0.059 & 0.063 & 0.062 & 0.060 & 0.085 & 0.069 & 0.103 & 0.075 & 0.081 & 0.086 & 0.081 & 0.077 & 0.068 & 0.063 & 0.068 & 0.062 \\
\hline Sps & 0.025 & 0.024 & 0.025 & 0.026 & 0.027 & 0.033 & 0.031 & 0.027 & 0.029 & 0.027 & 0.019 & 0.023 & 0.026 & 0.022 & 0.026 & 0.029 & 0.032 & 0.040 & 0.049 & 0.057 \\
\hline
\end{tabular}


GRANADA - Amostra CP-333

\begin{tabular}{|c|c|c|c|c|c|c|c|c|c|c|c|c|c|c|c|c|c|}
\hline \multicolumn{18}{|c|}{ Granada tipo 2 , reliquiar com corona de granada } \\
\hline Point & 6.6 & 6.7 & 6.8 & 6.9 & 6.10 & 6.11 & 8.1 & 8.2 & 8.3 & 8.4 & 8.5 & 8.6 & 8.7 & 8.8 & 8.9 & 8.10 & 8.12 \\
\hline $\mathrm{SiO}_{2}$ & 38.33 & 38.00 & 38.12 & 37.88 & 38.12 & 38.06 & 37.91 & 38.04 & 38.15 & 38.41 & 38.18 & 38.09 & 37.92 & 38.10 & 38.00 & 38.20 & 38.22 \\
\hline $\mathrm{TiO}_{2}$ & 0.01 & 0.00 & 0.00 & 0.00 & 0.02 & 0.12 & 0.01 & 0.01 & 0.00 & 0.00 & 0.00 & 0.00 & 0.00 & 0.00 & 0.00 & 0.00 & 0.01 \\
\hline $\mathrm{Al}_{2} \mathrm{O}_{3}$ & 21.69 & 21.47 & 21.26 & 21.35 & 21.58 & 21.52 & 21.55 & 21.62 & 21.44 & 21.46 & 21.40 & 21.59 & 21.53 & 21.44 & 21.41 & 21.44 & 21.27 \\
\hline $\mathrm{Cr}_{2} \mathrm{O}_{3}$ & 0.02 & 0.03 & 0.09 & 0.05 & 0.05 & 0.07 & 0.01 & 0.02 & 0.01 & 0.02 & 0.01 & 0.02 & 0.00 & 0.03 & 0.03 & 0.02 & 0.04 \\
\hline $\mathrm{Fe}_{2} \mathrm{O}_{3}$ & 0.00 & 0.00 & 0.00 & 0.00 & 0.00 & 0.00 & 0.00 & 0.00 & 0.00 & 0.00 & 0.00 & 0.00 & 0.00 & 0.00 & 0.00 & 0.00 & 0.00 \\
\hline $\mathrm{FeO}$ & 31.63 & 34.41 & 33.72 & 34.34 & 33.71 & 33.97 & 33.91 & 33.38 & 33.63 & 33.85 & 34.06 & 33.76 & 34.69 & 34.14 & 34.50 & 34.11 & 33.33 \\
\hline MnO & 2.32 & 1.32 & 1.11 & 1.17 & 1.00 & 1.04 & 0.99 & 0.80 & 0.92 & 1.04 & 1.10 & 0.90 & 1.20 & 1.28 & 1.29 & 1.08 & 1.19 \\
\hline MgO & 4.45 & 3.72 & 3.64 & 3.50 & 3.83 & 3.80 & 3.35 & 3.89 & 3.81 & 3.71 & 3.91 & 4.18 & 3.65 & 3.32 & 3.41 & 3.50 & 3.34 \\
\hline $\mathrm{CaO}$ & 2.26 & 2.14 & 3.07 & 2.70 & 2.77 & 2.77 & 3.56 & 3.53 & 3.16 & 2.90 & 2.50 & 2.29 & 2.08 & 2.72 & 2.42 & 2.85 & 3.33 \\
\hline Total & 100.71 & 101.09 & 101.01 & 100.99 & 101.08 & 101.35 & 101.29 & 101.29 & 101.12 & 101.39 & 101.16 & 100.83 & 101.07 & 101.03 & 101.06 & 101.20 & 100.73 \\
\hline Si & 3.016 & 3.005 & 3.013 & 3.002 & 3.005 & 2.998 & 2.993 & 2.992 & 3.008 & 3.020 & 3.011 & 3.006 & 3.001 & 3.015 & 3.010 & 3.015 & 3.026 \\
\hline $\mathbf{T i}$ & 0.001 & 0.000 & 0.000 & 0.000 & 0.001 & 0.007 & 0.001 & 0.001 & 0.000 & 0.000 & 0.000 & 0.000 & 0.000 & 0.000 & 0.000 & 0.000 & 0.001 \\
\hline Al & 2.012 & 2.002 & 1.981 & 1.995 & 2.006 & 1.998 & 2.006 & 2.004 & 1.993 & 1.989 & 1.990 & 2.009 & 2.009 & 2.000 & 1.999 & 1.995 & 1.986 \\
\hline $\mathrm{Cr}$ & 0.001 & 0.002 & 0.006 & 0.003 & 0.003 & 0.004 & 0.001 & 0.001 & 0.001 & 0.001 & 0.001 & 0.001 & 0.000 & 0.002 & 0.002 & 0.001 & 0.003 \\
\hline $\mathrm{Fe}^{3+}$ & 0.000 & 0.000 & 0.000 & 0.000 & 0.000 & 0.000 & 0.007 & 0.010 & 0.000 & 0.000 & 0.000 & 0.000 & 0.000 & 0.000 & 0.000 & 0.000 & 0.000 \\
\hline $\mathrm{Fe}^{2+}$ & 2.081 & 2.276 & 2.229 & 2.276 & 2.223 & 2.238 & 2.232 & 2.185 & 2.218 & 2.226 & 2.247 & 2.228 & 2.296 & 2.259 & 2.285 & 2.251 & 2.207 \\
\hline Mn & 0.155 & 0.088 & 0.074 & 0.079 & 0.067 & 0.069 & 0.066 & 0.053 & 0.061 & 0.069 & 0.073 & 0.060 & 0.080 & 0.086 & 0.087 & 0.072 & 0.080 \\
\hline Mg & 0.522 & 0.438 & 0.429 & 0.413 & 0.450 & 0.446 & 0.394 & 0.456 & 0.448 & 0.435 & 0.460 & 0.492 & 0.431 & 0.392 & 0.402 & 0.412 & 0.394 \\
\hline $\mathrm{Ca}$ & 0.191 & 0.181 & 0.260 & 0.229 & 0.234 & 0.234 & 0.301 & 0.297 & 0.267 & 0.244 & 0.211 & 0.194 & 0.176 & 0.231 & 0.205 & 0.241 & 0.283 \\
\hline Total & 7.977 & 7.993 & 7.993 & 7.998 & 7.989 & 7.994 & 8.000 & 8.000 & 7.995 & 7.985 & 7.993 & 7.989 & 7.994 & 7.984 & 7.990 & 7.987 & 7.979 \\
\hline Alm & 0.706 & 0.763 & 0.745 & 0.759 & 0.747 & 0.749 & 0.746 & 0.731 & 0.741 & 0.748 & 0.751 & 0.749 & 0.770 & 0.761 & 0.767 & 0.756 & 0.745 \\
\hline Py & 0.177 & 0.147 & 0.143 & 0.138 & 0.151 & 0.149 & 0.132 & 0.152 & 0.150 & 0.146 & 0.154 & 0.165 & 0.144 & 0.132 & 0.135 & 0.138 & 0.133 \\
\hline $\mathbf{G r}$ & 0.065 & 0.061 & 0.087 & 0.076 & 0.079 & 0.078 & 0.101 & 0.099 & 0.089 & 0.082 & 0.071 & 0.065 & 0.059 & 0.078 & 0.069 & 0.081 & 0.095 \\
\hline Sps & 0.053 & 0.030 & 0.025 & 0.026 & .023 & 0.023 & 0.022 & 0.018 & 0.020 & 0.023 & 0.024 & 0.020 & 0.027 & 0.029 & 0.029 & 0.024 & 0.027 \\
\hline
\end{tabular}


GRANADA - Amostra CP-333

Granada tipo 2, reliquiar com corona de granada

\begin{tabular}{|c|c|c|c|c|c|c|c|c|c|c|c|c|c|c|c|c|c|c|c|c|}
\hline Point & 7.1 & 7.2 & 7.3 & 7.4 & 7.5 & 7.6 & 7.7 & 7.8 & 7.9 & 7.10 & 7.11 & 7.12 & 7.13 & 7.14 & 7.15 & 7.16 & 7.17 & 7.18 & 7.19 & 7.20 \\
\hline $\mathrm{SiO}_{2}$ & 37.99 & 38.28 & 38.30 & 38.13 & 38.06 & 37.84 & 37.83 & 38.15 & 37.80 & 38.03 & 37.94 & 38.16 & 38.25 & 38.04 & 37.86 & 38.32 & 37.95 & 38.29 & 38.15 & 38.06 \\
\hline $\mathrm{TiO}_{2}$ & 0.00 & 0.00 & 0.01 & 0.00 & 0.01 & 0.01 & 0.00 & 0.00 & 0.01 & 0.00 & 0.00 & 0.01 & 0.00 & 0.00 & 0.01 & 0.00 & 0.00 & 0.00 & 0.00 & 0.00 \\
\hline $\mathrm{Al}_{2} \mathrm{O}_{3}$ & 21.72 & 21.89 & 21.54 & 21.79 & 21.48 & 21.57 & 21.31 & 21.63 & 21.57 & 21.69 & 21.70 & 21.68 & 21.57 & 21.69 & 21.43 & 21.56 & 21.51 & 21.48 & 21.56 & 21.37 \\
\hline $\mathrm{Cr}_{2} \mathrm{O}_{3}$ & 0.04 & 0.00 & 0.04 & 0.00 & 0.01 & 0.02 & 0.01 & 0.03 & 0.01 & 0.03 & 0.04 & 0.02 & 0.04 & 0.02 & 0.02 & 0.01 & 0.01 & 0.01 & 0.03 & 0.03 \\
\hline $\mathrm{Fe}_{2} \mathrm{O}_{3}$ & 0.00 & 0.00 & 0.00 & 0.00 & 0.00 & 0.00 & 0.00 & 0.00 & 0.00 & 0.00 & 0.00 & 0.00 & 0.00 & 0.00 & 0.00 & 0.00 & 0.00 & 0.00 & 0.00 & 0.00 \\
\hline $\mathrm{FeO}$ & 33.92 & 33.34 & 33.72 & 33.46 & 33.49 & 33.85 & 34.04 & 34.67 & 34.75 & 33.91 & 33.40 & 33.56 & 33.87 & 33.11 & 33.82 & 33.62 & 33.87 & 33.71 & 33.20 & 33.84 \\
\hline MnO & 1.04 & 0.67 & 0.74 & 0.81 & 0.87 & 0.92 & 1.00 & 1.02 & 0.95 & 0.86 & 0.79 & 0.76 & 0.75 & 0.75 & 0.74 & 0.74 & 0.84 & 0.80 & 0.74 & 1.08 \\
\hline MgO & 3.69 & 4.21 & 4.05 & 3.89 & 3.83 & 3.75 & 3.49 & 3.83 & 4.03 & 4.19 & 4.25 & 4.33 & 4.52 & 4.55 & 4.59 & 4.42 & 3.85 & 3.93 & 3.88 & 3.53 \\
\hline $\mathrm{CaO}$ & 2.68 & 3.27 & 3.17 & 3.37 & 3.25 & 3.16 & 3.03 & 2.15 & 2.08 & 2.40 & 2.62 & 2.43 & 2.38 & 2.38 & 2.40 & 2.50 & 3.05 & 3.15 & 3.68 & 3.3 \\
\hline
\end{tabular}

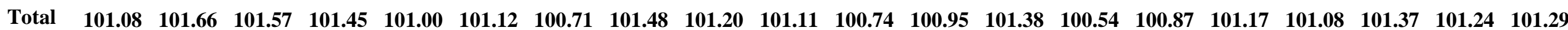

\begin{tabular}{|c|c|c|c|c|c|c|c|c|c|c|c|c|c|c|c|c|c|c|c|c|}
\hline Si & 2.998 & 2.993 & 3.004 & 2.993 & 3.003 & 2.987 & 3.004 & 3.003 & 2.984 & 2.995 & 2.994 & 3.003 & 3.001 & 3.001 & 2.985 & 3.010 & 2.995 & 3.009 & 3.000 & 3.003 \\
\hline $\mathbf{T i}$ & 0.000 & 0.000 & 0.001 & 0.000 & 0.001 & 0.001 & 0.000 & 0.000 & 0.001 & 0.000 & 0.000 & 0.001 & 0.000 & 0.000 & 0.001 & 0.000 & 0.000 & 0.000 & .000 & .000 \\
\hline Al & 2.021 & 2.017 & 1.992 & 2.017 & 1.998 & 2.007 & 1.995 & 2.007 & 2.007 & 2.014 & 2.019 & 2.012 & 1.995 & 2.017 & 1.992 & 1.996 & 2.001 & 1.990 & 1.999 & 1.988 \\
\hline $\mathrm{Cr}$ & 0.002 & 0.000 & 0.002 & .000 & 0.001 & 0.001 & 0.001 & .002 & .001 & 0.002 & .002 & .001 & 002 & 001 & 001 & .001 & .001 & .001 & .002 & .002 \\
\hline $\mathrm{Fe}^{3+}$ & 0.000 & 0.000 & 0.000 & 0.000 & 0.000 & 0.017 & 0.000 & 0.000 & 0.023 & 0.000 & 0.000 & 0.000 & 0.000 & 0.000 & 0.036 & 0.000 & 0.007 & 0.000 & 0.000 & 0.003 \\
\hline $\mathrm{Fe}^{2+}$ & 2.239 & 2.180 & 2.212 & 2.197 & 2.210 & 2.217 & 2.261 & 2.282 & 2.271 & 2.234 & 2.205 & 2.209 & 2.223 & 2.184 & 2.194 & 2.208 & 2.228 & 2.216 & 2.184 & 2.230 \\
\hline Mn & 0.070 & 0.044 & 0.049 & 0.054 & 0.058 & 0.062 & 0.067 & 0.068 & 0.064 & 0.057 & 0.053 & 0.051 & 0.050 & 0.050 & 0.049 & 0.049 & 056 & .053 & .049 & 0.072 \\
\hline Mo & 0.434 & 0.491 & 0.473 & 0.455 & & & & & & & 0.500 & 0.508 & 0.529 & & & & .453 & 0.460 & 0.455 & 0.415 \\
\hline Ca & 0.227 & 0.274 & 0.266 & 0.283 & 0.275 & 0.267 & 0.258 & 0.181 & & 0.203 & 0.222 & 0.205 & 0.200 & 0.201 & 0.203 & 0.210 & 0.258 & 0.265 & 0.310 & 0.286 \\
\hline . & 7.990 & 7.999 & 7.999 & 7.999 & 7.997 & 8.000 & 7.998 & 7.993 & 8.000 & 7.997 & 7.995 & 7.990 & 8.000 & 7.990 & 8.000 & 7.992 & 3.000 & 7.995 & 7.999 & 8.000 \\
\hline & 0.754 & 0.729 & 0.737 & 0.735 & 0.738 & 0.742 & 0.754 & 0.766 & 0.761 & 0.748 & 0.740 & 0.743 & 0.741 & 0.735 & 0.735 & 0.740 & 0.744 & 0.740 & 0.728 & 0.743 \\
\hline $\mathbf{P y}$ & 0.146 & 0.164 & 0.158 & 0.152 & 0.150 & 0.148 & 0.138 & 0.151 & 0.159 & 0.165 & 0.168 & 0.171 & 0.176 & 0.180 & 0.181 & 0.173 & 0.151 & 0.154 & 0.152 & 0.138 \\
\hline $\mathbf{G r}$ & 0.076 & 0.092 & 0.089 & 0.095 & 0.092 & 0.089 & 0.086 & 0.061 & 0.059 & 0.068 & 0.074 & 0.069 & 0.067 & 0.068 & 0.068 & 0.070 & 0.086 & 0.089 & 0.103 & 0.095 \\
\hline Sns & 0.024 & 0.015 & 0.016 & 0.018 & 0.019 & 0.021 & 0.022 & 0.023 & 0.021 & 0.019 & 0.018 & 0.017 & 0.017 & 0.017 & 0.016 & 0.016 & 0.019 & 0.018 & 0.016 & 0.024 \\
\hline
\end{tabular}


GRANADA - Amostra CP-333

\begin{tabular}{|c|c|c|c|c|c|c|c|c|c|c|c|c|c|c|c|c|c|c|c|c|}
\hline \multicolumn{21}{|c|}{ Granada tipo 3, posterior } \\
\hline Point & 9.1 & 9.2 & 9.3 & 9.4 & 9.5 & 9.6 & 9.7 & 9.8 & 9.9 & 9.10 & 9.11 & 9.12 & 9.13 & 9.14 & 9.15 & 9.16 & 9.17 & 9.18 & 9.19 & 9.20 \\
\hline $\mathrm{SiO}_{2}$ & 37.47 & 38.17 & 38.13 & 37.90 & 38.01 & 38.19 & 38.13 & 38.26 & 38.01 & 38.03 & 38.21 & 37.89 & 38.18 & 40.77 & 37.32 & 38.26 & 38.04 & 38.11 & 38.28 & 38.57 \\
\hline $\mathrm{TiO}_{2}$ & 0.00 & 0.00 & 0.00 & 0.02 & 0.00 & 0.01 & 0.01 & 0.04 & 0.00 & 0.01 & 0.00 & 0.00 & 0.00 & 0.00 & 0.00 & 0.00 & 0.00 & 0.00 & 0.01 & 0.00 \\
\hline $\mathrm{Al}_{2} \mathrm{O}_{3}$ & 21.51 & 21.69 & 21.79 & 21.67 & 21.40 & 21.52 & 21.43 & 21.81 & 21.48 & 21.67 & 21.67 & 21.58 & 21.54 & 20.62 & 21.03 & 21.60 & 21.46 & 21.65 & 21.64 & 21.79 \\
\hline $\mathrm{Cr}_{2} \mathrm{O}_{3}$ & 0.03 & 0.01 & 0.08 & 0.08 & 0.05 & 0.10 & 0.06 & 0.04 & 0.02 & 0.01 & 0.02 & 0.02 & 0.01 & 0.00 & 0.03 & 0.04 & 0.09 & 0.04 & 0.03 & 0.00 \\
\hline $\mathrm{Fe}_{2} \mathrm{O}_{3}$ & 0.00 & 0.00 & 0.00 & 0.00 & 0.00 & 0.00 & 0.00 & 0.00 & 0.00 & 0.00 & 0.00 & 0.00 & 0.00 & 0.00 & 0.00 & 0.00 & 0.00 & 0.00 & 0.00 & 0.00 \\
\hline $\mathrm{FeO}$ & 34.73 & 33.54 & 33.24 & 33.03 & 33.37 & 33.29 & 33.12 & 33.92 & 33.83 & 34.01 & 33.83 & 33.99 & 33.83 & 32.01 & 33.54 & 33.55 & 33.63 & 33.12 & 32.64 & 34.54 \\
\hline MnO & 1.24 & 0.70 & 0.66 & 0.72 & 0.75 & 0.79 & 0.79 & 0.83 & 0.88 & 0.89 & 0.87 & 0.85 & 0.90 & 0.83 & 0.81 & 0.77 & 0.65 & 0.63 & 0.65 & 1.15 \\
\hline MgO & 3.41 & 4.30 & 4.28 & 4.27 & 4.16 & 4.23 & 4.11 & 3.89 & 3.97 & 4.03 & 4.26 & 4.14 & 4.19 & 3.92 & 4.11 & 4.32 & 4.20 & 4.45 & 4.28 & 3.54 \\
\hline $\mathrm{CaO}$ & 2.33 & 2.91 & 3.15 & 3.13 & 2.98 & 2.91 & 3.17 & 2.78 & 2.57 & 2.51 & 2.36 & 2.62 & 2.36 & 2.74 & 2.82 & 2.71 & 3.04 & 3.03 & 3.67 & 2.37 \\
\hline otal & 100.72 & 101.32 & 101.33 & 100.82 & 100.72 & 101.04 & 100.82 & 101.57 & 100.76 & 101.16 & 101.22 & 101.09 & 101.01 & 100.89 & 99.66 & 101.25 & 101.11 & 101.03 & 101.20 & 101.96 \\
\hline
\end{tabular}

\begin{tabular}{|c|c|c|c|c|c|c|c|c|c|c|c|c|c|c|c|c|c|c|c|c|}
\hline $\mathbf{S i}$ & 2.982 & 2.996 & 2.991 & 2.988 & 3.004 & 3.005 & 3.008 & 3.000 & 3.006 & 2.996 & 3.003 & 2.987 & 3.008 & 172 & 2.985 & 3.004 & 2.995 & 2.996 & 3.002 & 3.018 \\
\hline $\mathbf{T i}$ & 0.000 & 0.000 & 0.000 & 0.001 & 0.000 & 0.001 & 0.001 & 0.002 & 0.000 & 0.001 & 0.000 & 0.000 & 0.000 & 0.000 & 0.000 & 0.000 & 0.000 & 0.000 & 0.001 & 0.000 \\
\hline Al & 2.018 & 2.007 & 2.015 & 2.014 & 1.994 & 1.996 & 1.993 & 2.016 & 2.003 & 2.013 & 2.008 & 2.006 & 2.001 & 1.891 & 1.983 & 2.000 & 1.992 & 2.006 & 2.000 & 2.010 \\
\hline $\mathrm{Cr}$ & 0.002 & 0.001 & 0.005 & 0.005 & 0.003 & 0.006 & 0.004 & 0.002 & 0.001 & 0.001 & 0.001 & 0.001 & 0.001 & 0.000 & 0.002 & 0.002 & 0.006 & 0.002 & 0.002 & 0.000 \\
\hline & 0.016 & 0.000 & 0.000 & 0.003 & 0.000 & 0.000 & 0.000 & 0.000 & 0.000 & 0.000 & 0.000 & 0.018 & 0.000 & 0.000 & 0.045 & 0.000 & 0.012 & 0.000 & 0.000 & 0.000 \\
\hline $\mathrm{Fe}^{2+}$ & 2.295 & 2.202 & 2.180 & 2.175 & 2.205 & 2.191 & 2.185 & 2.224 & 2.238 & 2.241 & 2.224 & 2.223 & 2.229 & 2.083 & 2.199 & 2.203 & 2.202 & 2.177 & 2.140 & 2.260 \\
\hline Mn & 0.084 & 0.047 & 0.044 & 0.048 & 0.050 & 0.053 & 0.053 & 0.055 & 0.059 & 0.059 & 0.058 & 0.057 & 0.060 & 0.055 & 0.055 & 0.051 & 0.043 & 0.042 & 0.043 & 0.076 \\
\hline Mg & 0.404 & 0.503 & 0.500 & 0.502 & 0.490 & 0.496 & 0.483 & 0.455 & 0.468 & 0.473 & 0.499 & 0.486 & 0.492 & 0.454 & 0.490 & 0.506 & 0.493 & 0.521 & 0.500 & 0.413 \\
\hline $\mathbf{C a}$ & 0.199 & 0.245 & 0.265 & 0.264 & 0.252 & 0.245 & 0.268 & 0.234 & 0.218 & 0.212 & 0.199 & 0.221 & 0.199 & 0.228 & 0.242 & 0.228 & 0.256 & 0.255 & 0.308 & 0.199 \\
\hline Total & 8.0 & 8.0 & 8.0 & 8.0 & 8.0 & 8.0 & 8.0 & 8.0 & 8.0 & 8.0 & 8.0 & 8.0 & 8.0 & 7.9 & 8.0 & 8.0 & 8.0 & 8.0 & 8.0 & 8.0 \\
\hline Alm & 0.770 & 0.735 & 0.729 & 0.728 & 0.736 & 0.734 & 0.731 & 0.749 & 0.750 & 0.751 & 0.746 & 0.744 & 0.748 & 0.739 & 0.736 & 0.737 & 0.735 & 0.727 & 0.715 & 0.767 \\
\hline Py & 0.135 & 0.168 & 0.167 & 0.168 & 0.163 & 0.166 & 0.162 & 0.153 & 0.157 & 0.158 & 0.167 & 0.163 & 0.165 & 0.161 & 0.164 & 0.169 & 0.165 & 0.174 & 0.167 & 0.140 \\
\hline Gr & 0.067 & 0.082 & 0.089 & 0.088 & 0.084 & 0.082 & 0.090 & 0.079 & 0.073 & 0.071 & 0.067 & 0.074 & 0.067 & 0.081 & 0.081 & 0.076 & 0.086 & 0.085 & 0.103 & 0.068 \\
\hline Sps & 0.028 & 0.016 & 0.015 & 0.016 & 0.017 & 0.018 & 0.018 & 0.019 & 0.020 & 0.020 & 0.019 & 0.019 & 0.020 & 0.020 & 0.018 & 0.017 & 0.014 & 0.014 & 0.014 & 0.026 \\
\hline
\end{tabular}




\section{GRANADA - Amostra CP-333}

\section{Granada tipo 3, posterior}

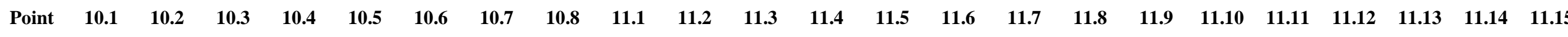

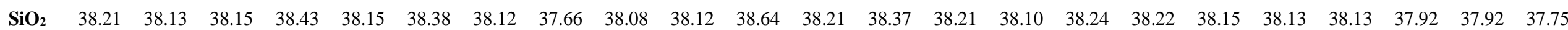

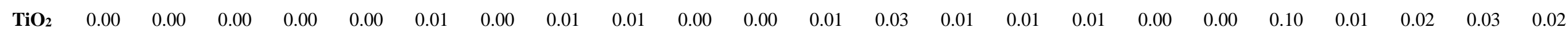

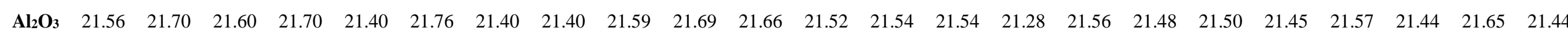

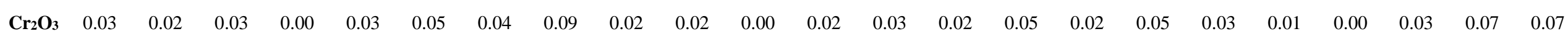

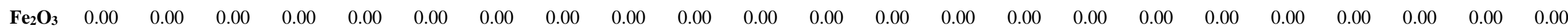

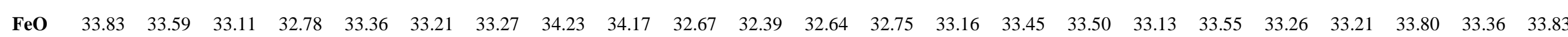

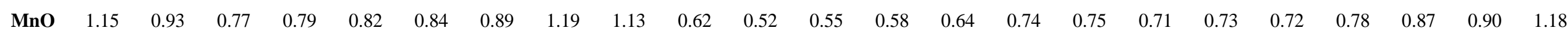

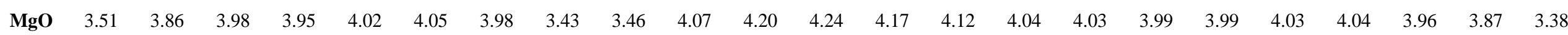

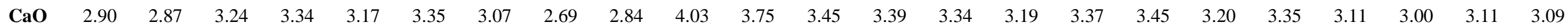

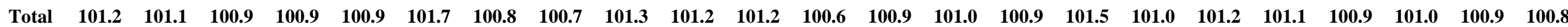

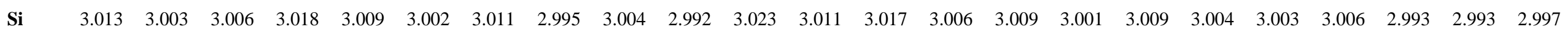

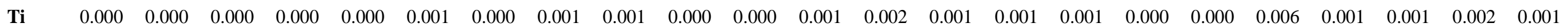

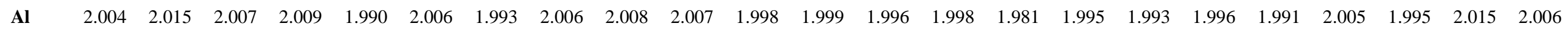

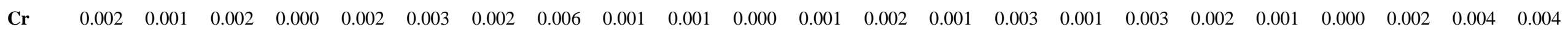

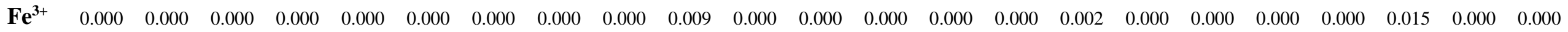

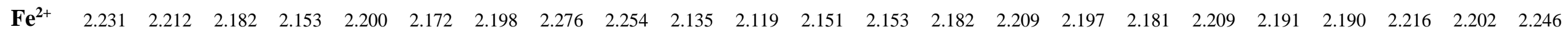

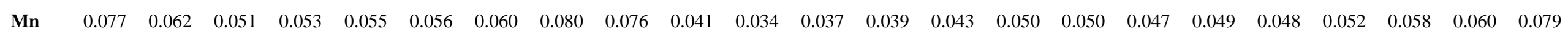

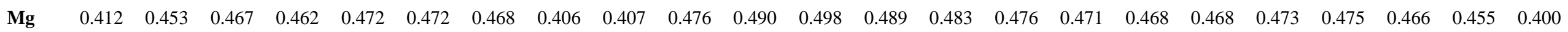

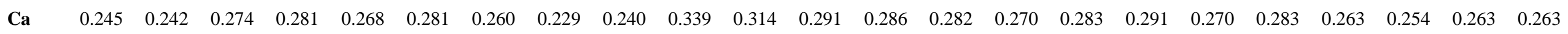

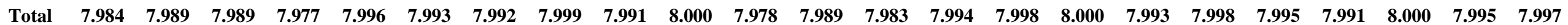

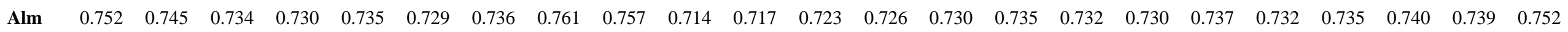

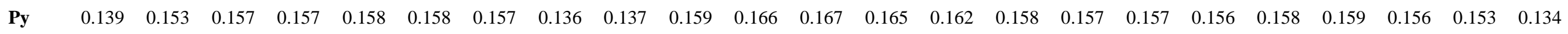

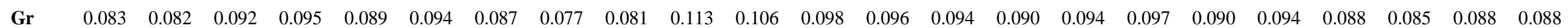

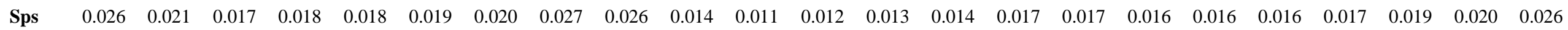


GRANADA - amostra CP-60

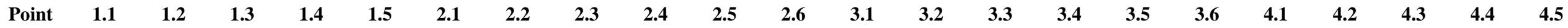

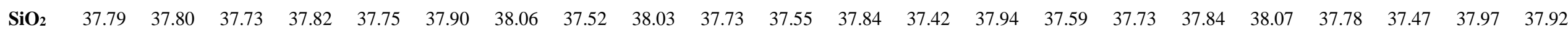

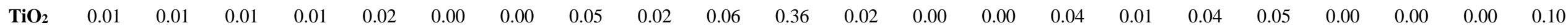

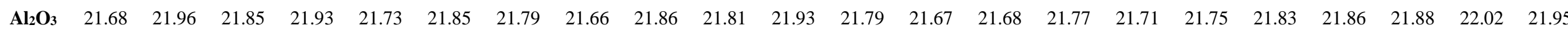

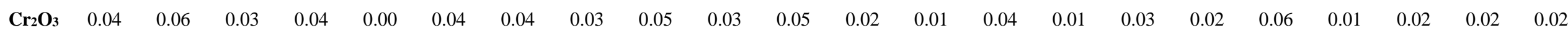

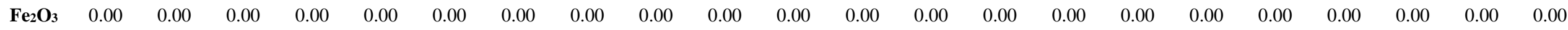

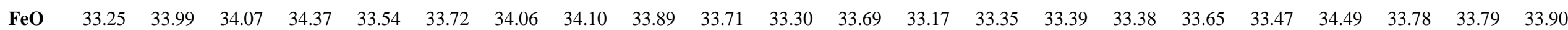

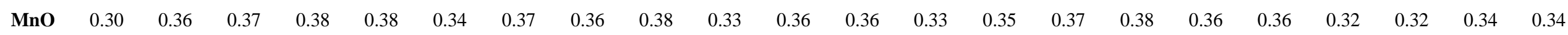

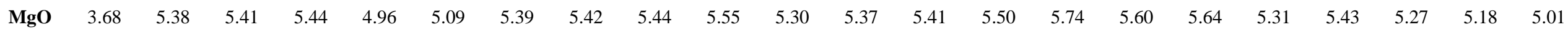

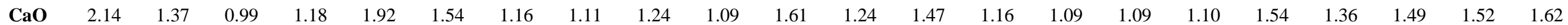

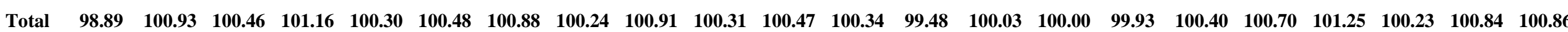

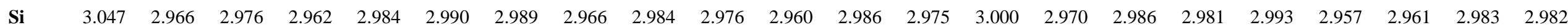

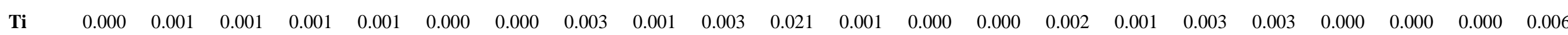

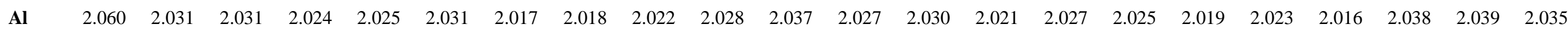

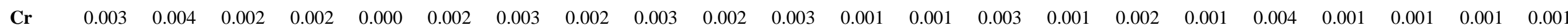

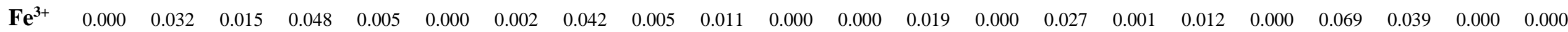

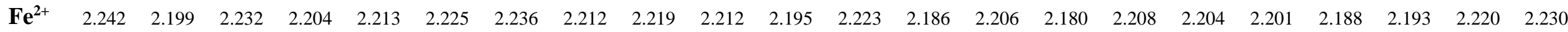

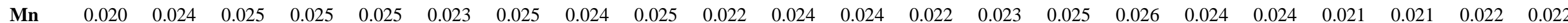

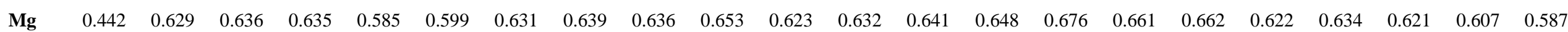

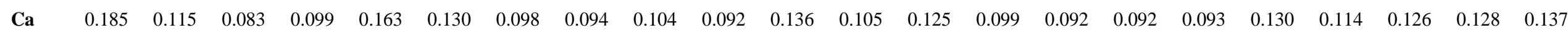

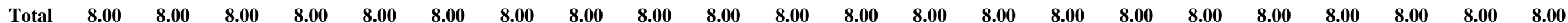

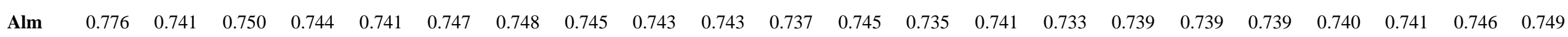

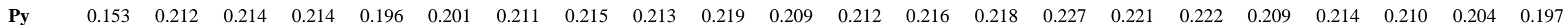

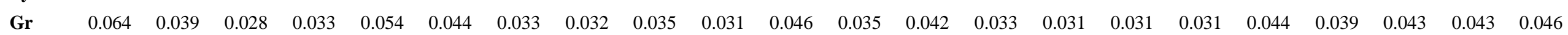

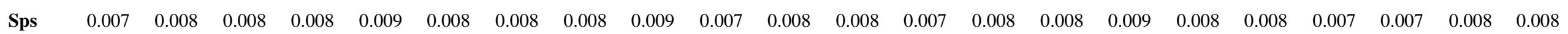


GRANADA - amostra CP-65A

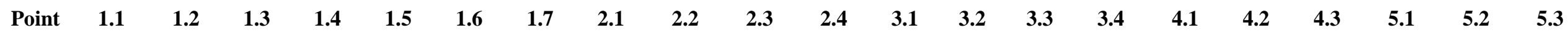

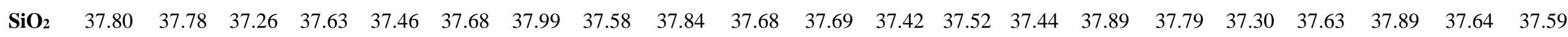

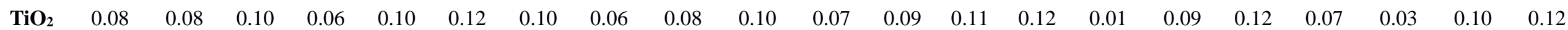

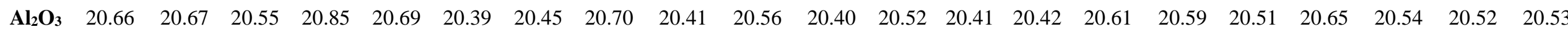

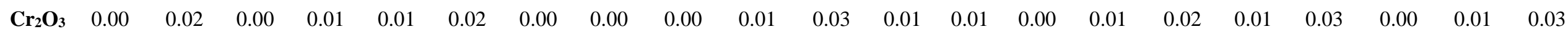

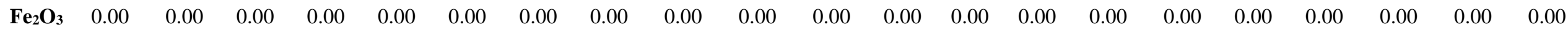

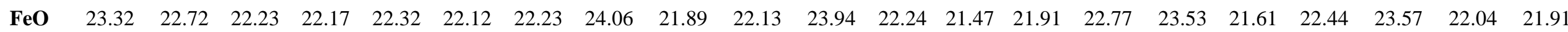

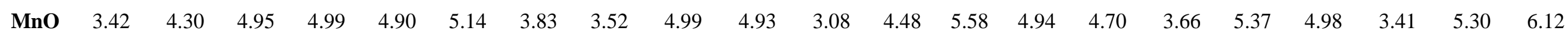

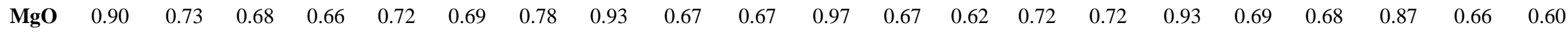

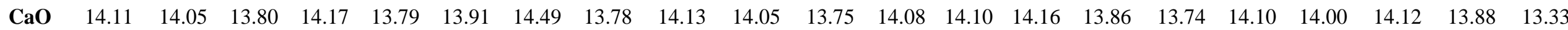

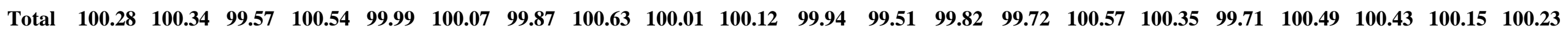

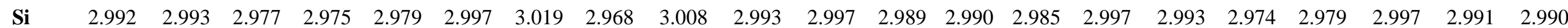

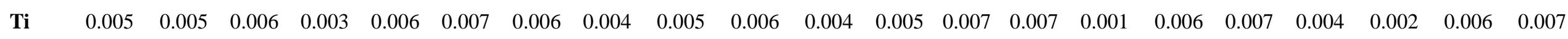

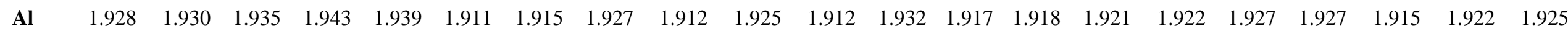

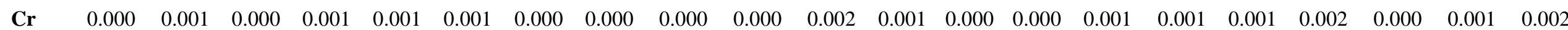

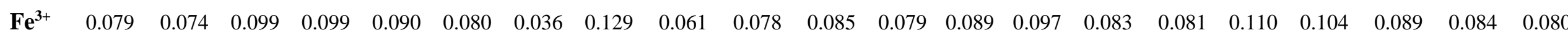

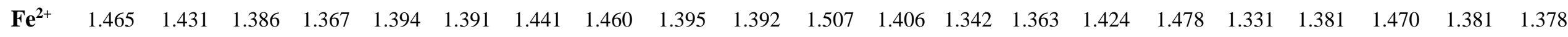

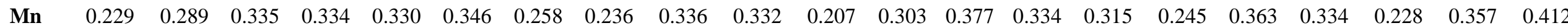

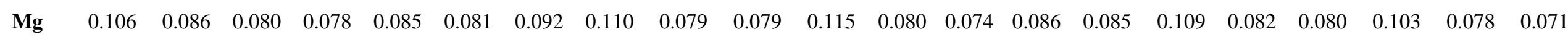

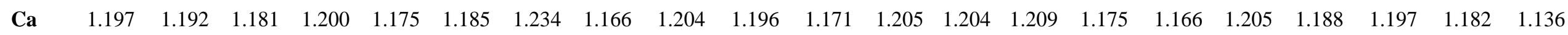

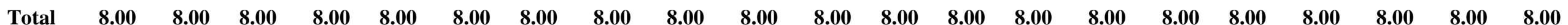

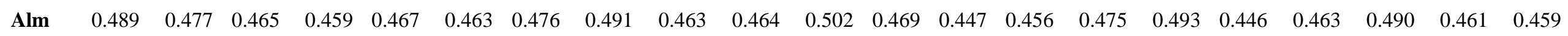

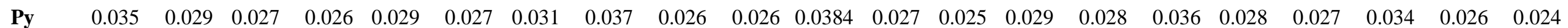

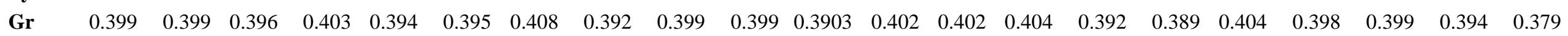

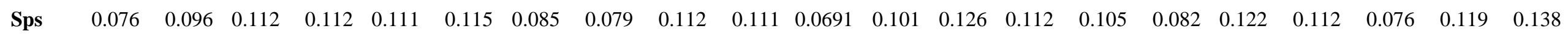




\section{GRANADA}

\section{amostra CP-65A}

$\begin{array}{lllll}\text { Point } & 6.1 & 6.2 & 6.3 & 6.4\end{array}$

$\begin{array}{lllll}\mathrm{SiO}_{2} & 37.85 & 37.62 & 37.85 & 37.53\end{array}$

$\begin{array}{lllll}\mathbf{T i O}_{2} & 0.03 & 0.04 & 0.04 & 0.08\end{array}$

$\begin{array}{lllll}\mathbf{A l}_{2} \mathbf{O}_{3} & 20.75 & 20.90 & 20.79 & 20.71\end{array}$

$\begin{array}{lllll}\mathrm{Cr}_{2} \mathrm{O}_{3} & 0.00 & 0.00 & 0.00 & 0.02\end{array}$

$\begin{array}{lllll}\mathrm{Fe}_{2} \mathrm{O}_{3} & 0.00 & 0.00 & 0.00 & 0.00\end{array}$

$\begin{array}{lllll}\text { FeO } & 23.98 & 22.01 & 22.16 & 21.99\end{array}$

$\begin{array}{lllll}\text { MnO } & 3.44 & 6.55 & 5.47 & 5.96\end{array}$

$\begin{array}{lllll}\text { MgO } & 0.98 & 0.69 & 0.69 & 0.80\end{array}$

$\begin{array}{lllll}\mathbf{C a O} & 13.68 & 12.74 & 13.54 & 12.74\end{array}$

$\begin{array}{lllll}\text { Total } & 100.7 & 100.5 & 100.5 & 99.8\end{array}$

$\begin{array}{lllll}\text { Si } & 2.986 & 2.983 & 2.996 & 2.994\end{array}$

$\begin{array}{lllll}\text { Ti } & 0.002 & 0.002 & 0.002 & 0.005\end{array}$

$\begin{array}{lllll}\text { Al } & 1.929 & 1.953 & 1.939 & 1.947\end{array}$

$\begin{array}{lllll}\text { Cr } & 0.000 & 0.000 & 0.000 & 0.001\end{array}$

$\begin{array}{lllll}\mathbf{F e}^{3+} & 0.095 & 0.078 & 0.064 & 0.055\end{array}$

$\begin{array}{lllll}\mathbf{F e}^{2+} & 1.487 & 1.382 & 1.402 & 1.412\end{array}$

$\begin{array}{lllll}\text { Mn } & 0.230 & 0.440 & 0.367 & 0.403\end{array}$

$\begin{array}{lllll}\text { Mg } & 0.115 & 0.081 & 0.081 & 0.095\end{array}$

$\begin{array}{lllll}\text { Ca } & 1.156 & 1.082 & 1.148 & 1.089\end{array}$

$\begin{array}{lllll}\text { Total } & 8.00 & \mathbf{8 . 0 0} & \mathbf{8 . 0 0} & \mathbf{8}\end{array}$

$\begin{array}{lllll}\text { Py } & 0.038 & 0.027 & 0.027 & 0.032\end{array}$

\section{amostra CP-65B}

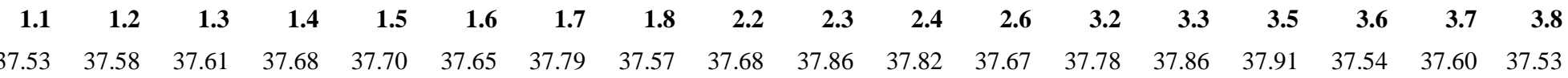

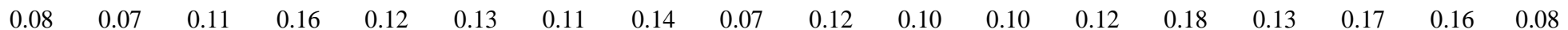

$\begin{array}{lllllllllllllllllll}20.72 & 20.56 & 20.72 & 20.52 & 20.43 & 20.44 & 20.53 & 20.47 & 20.49 & 20.69 & 20.60 & 20.50 & 20.54 & 20.37 & 20.66 & 20.27 & 20.37 & 20.43\end{array}$

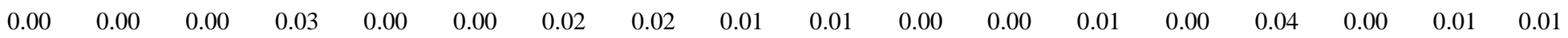

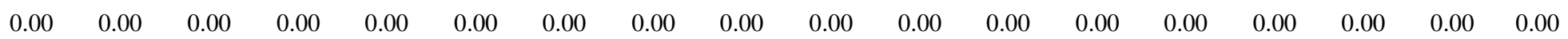

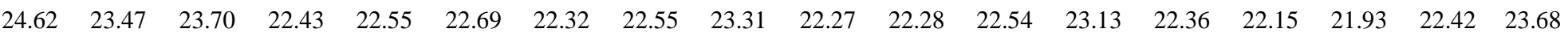

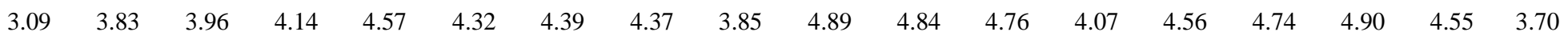

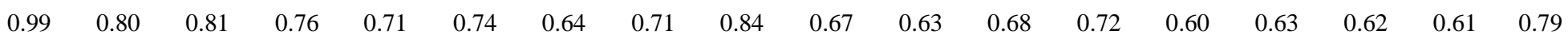

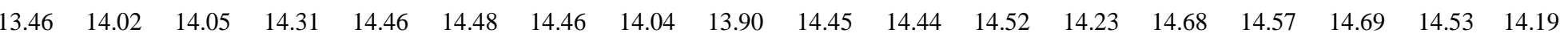

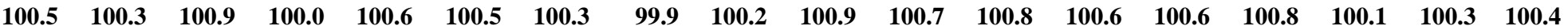

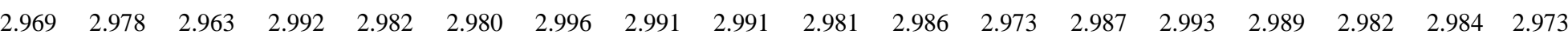

$\begin{array}{lllllllllllllllllll}0.005 & 0.004 & 0.006 & 0.010 & 0.007 & 0.008 & 0.007 & 0.008 & 0.004 & 0.007 & 0.006 & 0.006 & 0.007 & 0.011 & 0.007 & 0.010 & 0.009 & 0.005\end{array}$

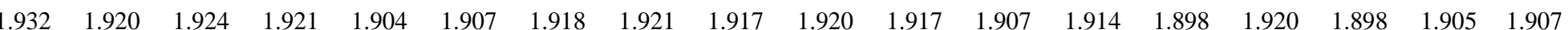

$\begin{array}{lllllllllllllllllll}0.000 & 0.000 & 0.000 & 0.002 & 0.000 & 0.000 & 0.001 & 0.001 & 0.001 & 0.000 & 0.000 & 0.000 & 0.000 & 0.000 & 0.002 & 0.000 & 0.001 & 0.000\end{array}$

$\begin{array}{lllllllllllllllll}0.115 & 0.138 & 0.074 & 0.118 & 0.119 & 0.076 & 0.079 & 0.092 & 0.103 & 0.098 & 0.135 & 0.098 & 0.095 & 0.086 & 0.118 & 0.108 & 0.138\end{array}$

$\begin{array}{llllllllllllllllll}0.307 & 0.257 & 0.264 & 0.278 & 0.306 & 0.290 & 0.295 & 0.295 & 0.259 & 0.326 & 0.324 & 0.318 & 0.273 & 0.305 & 0.317 & 0.330 & 0.306 & 0.248\end{array}$

$\begin{array}{lllllllllllllllllllll}0.117 & 0.095 & 0.095 & 0.090 & 0.084 & 0.087 & 0.076 & 0.085 & 0.099 & 0.079 & 0.074 & 0.080 & 0.085 & 0.071 & 0.074 & 0.073 & 0.072 & 0.094\end{array}$

$\begin{array}{lllllllllllllllllll}1.141 & 1.190 & 1.186 & 1.218 & 1.225 & 1.228 & 1.228 & 1.198 & 1.182 & 1.219 & 1.222 & 1.228 & 1.205 & 1.243 & 1.231 & 1.250 & 1.235 & 1.204\end{array}$

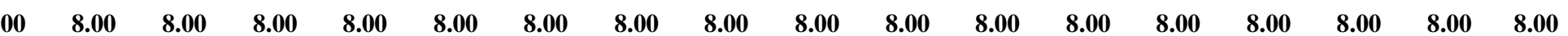

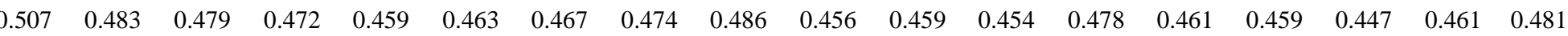

$\begin{array}{lllllllllllllllllll}0.384 & 0.399 & 0.399 & 0.405 & 0.409 & 0.411 & 0.409 & 0.399 & 0.394 & 0.408 & 0.408 & 0.412 & 0.403 & 0.414 & 0.411 & 0.418 & 0.413 & 0.404\end{array}$

$\begin{array}{llllllllllllllllll}.089 & 0.093 & 0.102 & 0.097 & 0.098 & 0.098 & 0.086 & 0.109 & 0.1081 & 0.107 & 0.091 & 0.101 & 0.106 & 0.110 & 0.102 & 0.083\end{array}$ 
GRANADA - amostra CP-49C

\begin{tabular}{|c|c|c|c|c|c|c|c|c|c|c|c|c|c|c|c|c|}
\hline Ponto & 1.1 & 1.2 & 1.3 & 1.4 & 1.5 & 2.1 & 2.2 & 2.3 & 2.4 & 2.5 & 3.1 & 3.2 & 3.3 & 3.4 & 3.5 & 3.6 \\
\hline $\mathrm{SiO}_{2}$ & 37.46 & 37.48 & 37.83 & 37.63 & 37.72 & 37.52 & 37.27 & 37.54 & 36.99 & 37.48 & 37.86 & 37.38 & 37.74 & 37.57 & 37.38 & 37.62 \\
\hline $\mathrm{TiO}_{2}$ & 0.07 & 0.04 & 0.01 & 0.04 & 0.03 & 0.01 & 0.03 & 0.04 & 0.07 & 0.03 & 0.03 & 0.06 & 0.05 & 0.07 & 0.04 & 0.03 \\
\hline $\mathrm{Al}_{2} \mathrm{O}_{3}$ & 21.28 & 21.42 & 21.27 & 21.05 & 21.33 & 21.12 & 21.34 & 21.12 & 21.11 & 21.32 & 21.29 & 21.32 & 21.27 & 21.43 & 21.17 & 21.13 \\
\hline $\mathrm{Cr}_{2} \mathrm{O}_{3}$ & 0 & 0 & 0 & 0.01 & 0 & 0 & 0 & 0.02 & 0 & 0 & 0.01 & 0 & 0 & 0 & 0 & 0.01 \\
\hline $\mathrm{Fe}_{2} \mathrm{O}_{3}$ & 1.28 & 0.65 & 0 & 0.63 & 0.27 & 0.45 & 0.5 & 1.03 & 1.79 & 1.03 & 0.6 & 0.79 & 0.53 & 0.2 & 1.18 & 0.47 \\
\hline $\mathrm{FeO}$ & 26.19 & 28.02 & 28.63 & 29.68 & 27.73 & 28.75 & 29.23 & 29.4 & 27.85 & 26.45 & 26.81 & 25.98 & 27.38 & 27.88 & 28.32 & 26.88 \\
\hline MnO & 1.1 & 1.27 & 1.33 & 1.56 & 1.49 & 1.54 & 1.39 & 1.32 & 1.22 & 1.16 & 1.22 & 1.12 & 1 & 0.99 & 1.42 & 1.36 \\
\hline MgO & 1.99 & 2.44 & 2.52 & 2.68 & 2.38 & 2.43 & 2.27 & 2.04 & 2.1 & 2 & 2.37 & 2.28 & 1.97 & 2.4 & 2.88 & 2.55 \\
\hline $\mathrm{CaO}$ & 10.92 & 8.73 & 8.19 & 6.98 & 9.08 & 7.98 & 7.72 & 8.16 & 8.94 & 10.64 & 10.14 & 10.58 & 10.34 & 9.22 & 7.67 & 9.51 \\
\hline Total & 100.29 & 100.06 & 99.78 & 100.27 & 100.02 & 99.8 & 99.75 & 100.68 & 100.07 & 100.12 & 100.34 & 99.51 & 100.28 & 99.76 & 100.05 & 99.56 \\
\hline $\mathbf{S i}$ & 965 & 2.976 & 3.008 & 2.993 & 2.993 & 2.993 & 2.979 & 2.98 & 2.95 & 2.971 & 2.99 & 2.974 & 2.989 & 2.986 & 2.971 & 2.993 \\
\hline $\mathbf{T i}$ & 0.004 & 0.003 & 0.001 & 0.002 & 0.002 & 0.001 & 0.002 & 0.002 & 0.004 & 0.002 & 0.002 & 0.004 & 0.003 & 0.004 & 0.002 & 0.002 \\
\hline Al & 1.986 & 2.005 & 1.994 & 1.974 & 1.995 & 1.986 & 2.011 & 1.976 & 1.985 & 1.9925 & 1.982 & 2 & 1.986 & 2.008 & 1.984 & 1.982 \\
\hline $\mathrm{Cr}$ & 0 & 0 & 0 & 0.001 & 0 & 0 & 0 & 0.001 & 0 & 0 & 0.001 & 0 & 0 & 0 & 0 & 0 \\
\hline $\mathrm{Fe}^{3+}$ & 0.075 & 0.038 & 0 & 0.038 & 0.015 & 0.026 & 0.029 & 0.061 & 0.107 & 0.061 & 0.036 & 0.046 & 0.031 & 0.011 & 0.07 & 0.028 \\
\hline $\mathrm{Fe}^{2+}$ & 1.735 & 1.862 & 1.904 & 1.974 & 1.841 & 1.919 & 1.955 & 1.952 & 1.858 & 1.754 & 1.77 & 1.73 & 1.815 & 1.854 & 1.883 & 1.789 \\
\hline Mn & 0.074 & 0.085 & 0.09 & 0.105 & 0.1 & 0.104 & 0.094 & 0.089 & 0.082 & 0.078 & 0.082 & 0.075 & 0.067 & 0.067 & 0.096 & 0.092 \\
\hline Mg & 0.235 & 0.289 & 0.299 & 0.318 & 0.281 & 0.289 & 0.27 & 0.241 & 0.25 & 0.236 & 0.279 & 0.27 & 0.233 & 0.284 & 0.341 & 0.302 \\
\hline $\mathbf{C a}$ & 0.926 & 0.743 & 0.698 & 0.595 & 0.772 & 0.682 & 0.661 & 0.694 & 0.764 & 0.904 & 0.858 & 0.902 & 0.877 & 0.785 & 0.653 & 0.811 \\
\hline Total & 8.00 & 8.00 & 7.99 & 8.00 & 8.00 & 8.00 & 8.00 & 8.00 & 8.00 & 8.00 & 8.00 & 8.00 & 8.00 & 8.00 & 8.00 & 8.00 \\
\hline Alm & 842 & 0.625 & 6366 & 0.6598 & 0.6149 & 0.6409 & 0.656 & 0.6559 & 0.629 & 0.5902 & 0.5922 & 0.5811 & 0.6066 & 0.6201 & 0.6334 & 0.5975 \\
\hline Py & 0.0791 & 0.097 & 0.1 & 0.1063 & 0.0939 & 0.0965 & 0.0906 & 0.081 & 0.0846 & 0.0794 & 0.0933 & 0.0907 & 0.0779 & 0.095 & 0.1147 & 0.1009 \\
\hline Gr & 0.3118 & 0.2494 & 0.2334 & 0.1989 & 0.2578 & 0.2278 & 0.2218 & 0.2332 & 0.2586 & 0.3042 & 0.2871 & 0.303 & 0.2931 & 0.2625 & 0.2196 & 0.2709 \\
\hline Sps & 0.0249 & 0.0285 & 0.0301 & 0.0351 & 0.0334 & 0.0347 & 0.0315 & 0.0299 & 0.0278 & 0.0262 & 0.0274 & 0.0252 & 0.0224 & 0.0224 & 0.0323 & 0.0307 \\
\hline
\end{tabular}


GRANADA - amostra CP-49C (continuação)

\begin{tabular}{|c|c|c|c|c|c|c|c|c|c|c|c|c|c|c|c|c|}
\hline Ponto & 4.1 & 4.2 & 4.3 & 4.4 & 4.5 & 4.6 & 5.1 & 5.2 & 5.3 & 5.4 & 5.5 & 6.1 & 6.2 & 6.3 & 6.4 & 6.5 \\
\hline $\mathrm{SiO}_{2}$ & 37.82 & 38 & 37.85 & 37.43 & 37.3 & 37.72 & 38.22 & 38.1 & 37.55 & 37.81 & 37.97 & 38.18 & 38.09 & 38.06 & 38 & 37.71 \\
\hline $\mathrm{TiO}_{2}$ & 0.03 & 0.06 & 0.02 & 0.04 & 0.02 & 0.09 & 0.02 & 0.04 & 0.03 & 0 & 0 & 0.02 & 0.04 & 0.03 & 0.08 & 0.01 \\
\hline $\mathrm{Al}_{2} \mathbf{O}_{3}$ & 21.17 & 21.31 & 21.24 & 21.34 & 21.28 & 20.95 & 21.49 & 21.57 & 21.91 & 21.84 & 21.54 & 21.71 & 21.45 & 21.68 & 21.51 & 21.6 \\
\hline $\mathrm{Cr}_{2} \mathrm{O}_{3}$ & 0 & 0.01 & 0.02 & 0 & 0 & 0.02 & 0 & 0 & 0 & 0.01 & 0 & 0.02 & 0.02 & 0.01 & 0 & 0 \\
\hline $\mathrm{Fe}_{2} \mathrm{O}_{3}$ & 0.4 & 0.16 & 0 & 1.55 & 0.98 & 0.35 & 0.08 & 0.19 & 0.57 & 0.55 & 0.7 & 0.15 & 0 & 0 & 0.52 & 1.18 \\
\hline $\mathrm{FeO}$ & 26.92 & 26.89 & 26.23 & 26.13 & 26.33 & 28.05 & 24.91 & 25.26 & 26.47 & 25.35 & 23.73 & 26.2 & 25.57 & 25.96 & 26 & 26.28 \\
\hline MnO & 1.41 & 1.13 & 1.27 & 1.12 & 1.52 & 1.59 & 0.96 & 1.08 & 1.22 & 1.09 & 1.02 & 0.93 & 1.02 & 0.85 & 0.89 & 1.19 \\
\hline MgO & 2.31 & 2.12 & 2.29 & 2.09 & 2.47 & 2.52 & 2.87 & 2.99 & 3.3 & 2.99 & 2.72 & 3.05 & 2.83 & 2.74 & 2.88 & 3 \\
\hline $\mathrm{CaO}$ & 9.97 & 10.63 & 10.46 & 10.76 & 9.63 & 8.54 & 11.48 & 10.85 & 8.84 & 10.45 & 12.31 & 10.15 & 10.7 & 10.7 & 10.51 & 9.57 \\
\hline Total & 100.04 & 100.32 & 99.41 & 100.45 & 99.53 & 99.84 & 100.03 & 100.08 & 99.88 & 100.09 & 99.99 & 100.42 & 99.74 & 100.04 & 100.39 & 100.54 \\
\hline $\mathbf{S i}$ & 997 & 3.001 & 3.008 & 2.958 & 2.971 & 3.002 & 3.002 & 2.993 & 2.963 & 2.972 & 2.983 & 2.992 & 3.004 & 2.995 & 2.984 & 2.964 \\
\hline $\mathbf{T i}$ & 0.002 & 0.003 & 0.001 & 0.002 & 0.001 & 0.005 & 0.001 & 0.002 & 0.002 & 0 & 0 & 0.001 & 0.002 & 0.002 & 0.005 & 0.001 \\
\hline Al & 1.978 & 1.984 & 1.99 & 1.988 & 1.998 & 1.966 & 1.99 & 1.998 & 2.038 & 2.024 & 1.995 & 2.006 & 1.995 & 2.011 & 1.992 & 2.002 \\
\hline $\mathrm{Cr}$ & 0 & 0.001 & 0.001 & 0 & 0 & 0.001 & 0 & 0 & 0 & 0.001 & 0 & 0.001 & 0.001 & 0.001 & 0 & 0 \\
\hline $\mathbf{F e}^{3+}$ & 024 & 0.009 & 0 & 0.091 & 0.058 & 0.021 & 0.004 & 0.01 & 0.033 & 0.032 & 0.04 & 0.009 & 0 & 0 & 0.03 & 0.069 \\
\hline $\mathrm{Fe}^{2+}$ & 1.784 & 1.776 & 1.744 & 1.728 & 1.754 & 1.867 & 1.637 & 1.66 & 1.747 & 1.666 & 1.56 & 1.717 & 1.687 & 1.708 & 1.709 & 1.728 \\
\hline Mn & .095 & 0.076 & 0.086 & 0.075 & 0.103 & 0.107 & 0.064 & 0.072 & 0.082 & 0.073 & 0.068 & 0.062 & 0.068 & 0.057 & 0.059 & 0.079 \\
\hline Mg & 0.273 & 0.249 & 0.271 & 0.246 & 0.293 & 0.299 & 0.336 & 0.35 & 0.388 & 0.35 & 0.318 & 0.356 & 0.333 & 0.321 & 0.337 & 0.351 \\
\hline $\mathrm{Ca}$ & 0.847 & 0.899 & 0.891 & 0.911 & 0.822 & 0.728 & 0.966 & 0.913 & 0.747 & 0.88 & 1.036 & 0.852 & 0.904 & 0.902 & 0.884 & 0.806 \\
\hline Total & 8.00 & 8.00 & 7.99 & 8.00 & 8.00 & 8.00 & 8.00 & 8.00 & 8.00 & 8.00 & 8.00 & 8.00 & 7.99 & 8.00 & 8.00 & 8.00 \\
\hline & 949 & 592 & 5829 & & 5902 & .6221 & & 5543 & & & 0.5231 & & 0.5638 & 0.5716 & 0.5718 & 0.583 \\
\hline Py & 0.091 & 0.083 & 0.0906 & 0.0831 & 0.0986 & 0.0996 & 0.1119 & 0.1169 & 0.1309 & 0.1179 & 0.1066 & 0.1192 & 0.1113 & 0.1074 & 0.1127 & 0.1184 \\
\hline Gr & 0.2824 & 0.2997 & 0.2978 & 0.3078 & 0.2766 & 0.2426 & 0.3217 & 0.3048 & 0.252 & 0.2964 & 0.3474 & 0.2852 & 0.3021 & 0.3019 & 0.2958 & 0.2719 \\
\hline Sps & 0.0317 & 0.0253 & 0.0287 & 0.0253 & 0.0347 & 0.0357 & 0.0213 & 0.024 & 0.0277 & 0.0246 & 0.0228 & 0.0208 & 0.0227 & 0.0191 & 0.0197 & 0.0267 \\
\hline
\end{tabular}


ORTOPIROXÊNIO - amostra DCF-22

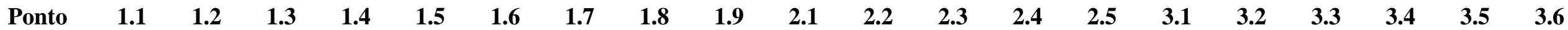

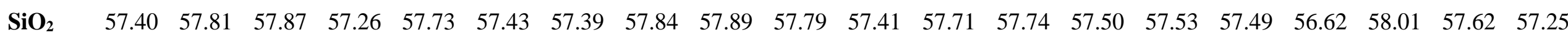

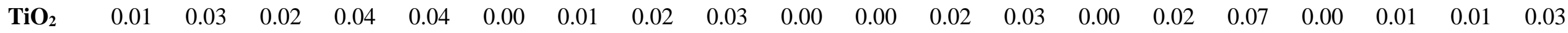

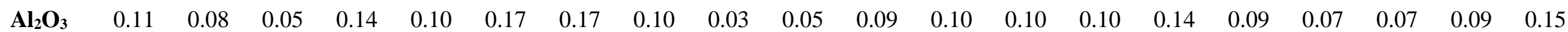

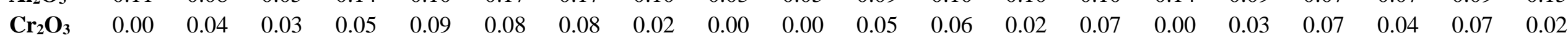

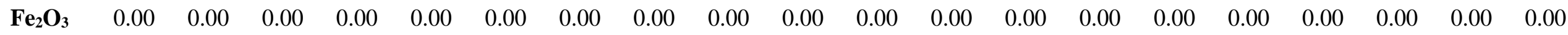

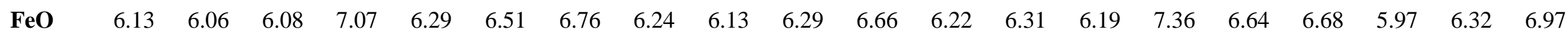

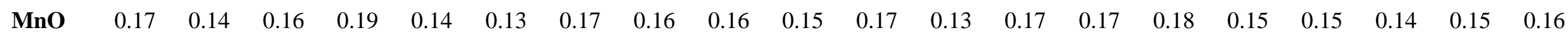

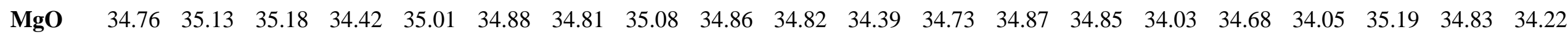

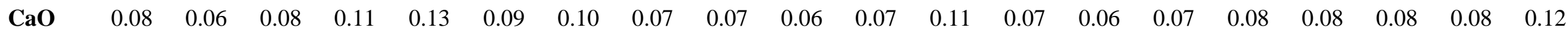

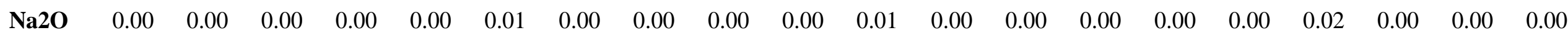

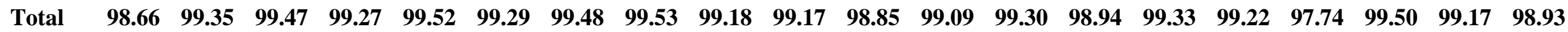

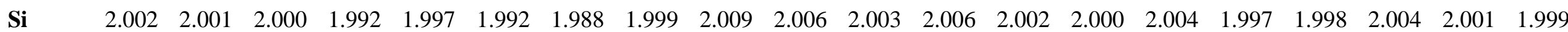

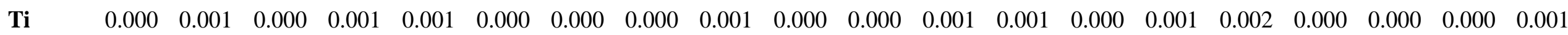

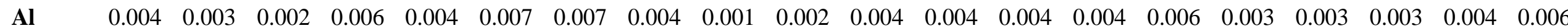

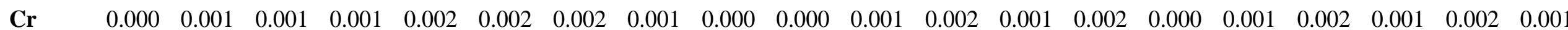

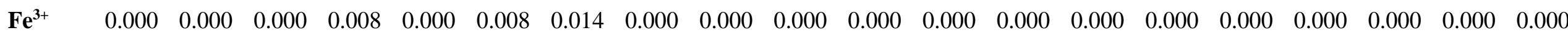

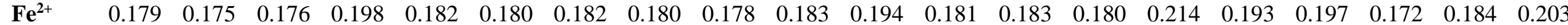

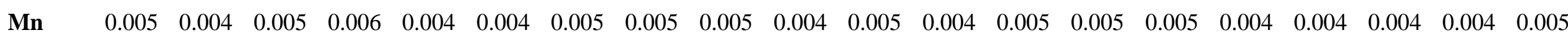

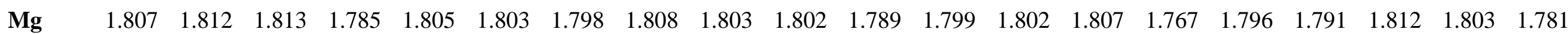

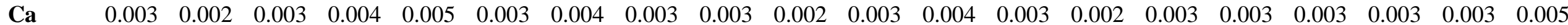

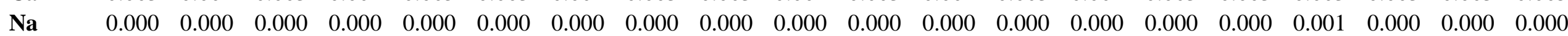

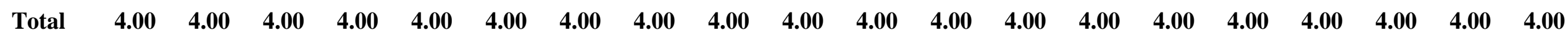

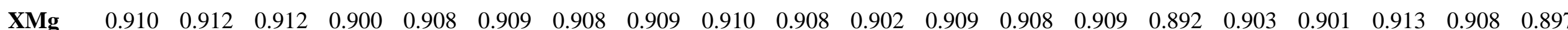


CLINOPIROXÊNIO - amostra CP-49C

\begin{tabular}{|c|c|c|c|c|c|c|c|c|c|c|c|c|c|c|c|c|}
\hline Ponto & 1.1 & 1.2 & 1.3 & 1.4 & 1.5 & 2.1 & 2.2 & 2.3 & 3.1 & 3.2 & 3.3 & 4.1 & 4.2 & 5.1 & 5.2 & 5.3 \\
\hline $\mathrm{SiO}_{2}$ & 51.20 & 52.33 & 51.90 & 49.59 & 52.11 & 50.84 & 49.80 & 52.01 & 49.92 & 51.06 & 52.02 & 52.41 & 52.40 & 52.37 & 52.07 & 52.14 \\
\hline $\mathrm{TiO}_{2}$ & 0.28 & 0.09 & 0.22 & 0.37 & 0.10 & 0.39 & 0.48 & 0.10 & 0.37 & 0.23 & 0.12 & 0.09 & 0.09 & 0.07 & 0.06 & 0.10 \\
\hline $\mathrm{Al}_{2} \mathrm{O}_{3}$ & 2.33 & 1.03 & 1.76 & 4.20 & 0.86 & 3.71 & 3.96 & 1.02 & 3.96 & 2.37 & 1.52 & 1.09 & 1.29 & 1.04 & 1.13 & 1.21 \\
\hline $\mathrm{Cr}_{2} \mathrm{O}_{3}$ & 0.02 & 0.04 & 0.01 & 0.01 & 0.00 & 0.00 & 0.03 & 0.00 & 0.02 & 0.01 & 0.06 & 0.00 & 0.00 & 0.02 & 0.03 & 0.11 \\
\hline $\mathrm{Fe}_{2} \mathrm{O}_{3}$ & 0.00 & 0.00 & 0.00 & 0.00 & 0.00 & 0.00 & 0.00 & 0.00 & 0.00 & 0.00 & 0.00 & 0.00 & 0.00 & 0.00 & 0.00 & 0.00 \\
\hline $\mathrm{FeO}$ & 13.00 & 12.37 & 12.78 & 14.68 & 11.84 & 16.93 & 14.31 & 12.04 & 14.53 & 13.06 & 12.13 & 12.27 & 12.58 & 11.86 & 12.17 & 12.78 \\
\hline MnO & 0.14 & 0.16 & 0.13 & 0.12 & 0.17 & 0.12 & 0.12 & 0.18 & 0.12 & 0.15 & 0.15 & 0.13 & 0.16 & 0.18 & 0.14 & 0.15 \\
\hline MgO & 10.96 & 10.94 & 10.83 & 10.61 & 11.13 & 12.35 & 10.56 & 11.19 & 10.83 & 10.94 & 11.10 & 11.14 & 10.67 & 11.14 & 11.08 & 10.55 \\
\hline $\mathrm{CaO}$ & 21.18 & 23.01 & 21.71 & 17.81 & 23.25 & 12.10 & 18.20 & 22.85 & 18.10 & 20.94 & 22.21 & 22.83 & 22.01 & 22.79 & 22.63 & 22.01 \\
\hline $\mathrm{Na} 2 \mathrm{O}$ & 0.50 & 0.50 & 0.50 & 0.69 & 0.39 & 0.56 & 0.69 & 0.44 & 0.68 & 0.55 & 0.43 & 0.66 & 0.93 & 0.58 & 0.67 & 1.01 \\
\hline Total & 99.60 & 100.47 & 99.85 & 98.08 & 99.85 & 96.99 & 98.15 & 99.82 & 98.53 & 99.32 & 99.73 & 100.62 & 100.13 & 100.05 & 99.97 & 100.06 \\
\hline Si & 1.948 & 1.974 & 1.971 & 1.918 & 1.976 & 1.989 & 1.925 & 1.972 & 1.920 & 1.947 & 1.974 & 1.969 & 1.979 & 1.978 & 1.968 & 1.971 \\
\hline $\mathbf{T i}$ & 0.008 & 0.003 & 0.006 & 0.011 & 0.003 & 0.012 & 0.014 & 0.003 & 0.011 & 0.007 & 0.003 & 0.003 & 0.003 & 0.002 & 0.002 & 0.003 \\
\hline Al & 0.104 & 0.046 & 0.079 & 0.191 & 0.038 & 0.171 & 0.180 & 0.045 & 0.180 & 0.107 & 0.068 & 0.048 & 0.058 & 0.046 & 0.050 & 0.054 \\
\hline $\mathrm{Cr}$ & 0.000 & 0.001 & 0.000 & 0.000 & 0.000 & 0.000 & 0.001 & 0.000 & 0.000 & 0.000 & 0.002 & 0.000 & 0.000 & 0.000 & 0.001 & 0.003 \\
\hline $\mathrm{Fe}^{3+}$ & 0.021 & 0.036 & 0.003 & 0.004 & 0.033 & 0.000 & 0.000 & 0.037 & 0.008 & 0.027 & 0.007 & 0.056 & 0.048 & 0.035 & 0.058 & 0.069 \\
\hline $\mathrm{Fe}^{2+}$ & 0.393 & 0.354 & 0.403 & 0.471 & 0.342 & 0.554 & 0.463 & 0.344 & 0.459 & 0.389 & 0.378 & 0.329 & 0.350 & 0.340 & 0.327 & 0.335 \\
\hline Mn & 0.004 & 0.005 & 0.004 & 0.004 & 0.005 & 0.004 & 0.004 & 0.006 & 0.004 & 0.005 & 0.005 & 0.004 & 0.005 & 0.006 & 0.004 & 0.005 \\
\hline Mg & 0.621 & 0.615 & 0.613 & 0.612 & 0.629 & 0.720 & 0.608 & 0.632 & 0.621 & 0.622 & 0.628 & 0.624 & 0.601 & 0.627 & 0.624 & 0.595 \\
\hline $\mathbf{C a}$ & 0.863 & 0.930 & 0.883 & 0.738 & 0.944 & 0.507 & 0.754 & 0.928 & 0.746 & 0.855 & 0.903 & 0.919 & 0.890 & 0.922 & 0.917 & 0.891 \\
\hline $\mathbf{N a}$ & 0.037 & 0.036 & 0.037 & 0.052 & 0.029 & 0.042 & 0.052 & 0.032 & 0.051 & 0.041 & 0.032 & 0.048 & 0.068 & 0.043 & 0.049 & 0.074 \\
\hline Total & 4.000 & 4.000 & 4.000 & 4.000 & 4.000 & 4.000 & 4.000 & 4.000 & 4.000 & 4.000 & 4.000 & 4.000 & 4.000 & 4.000 & 4.000 & 4.000 \\
\hline XMg & 0.613 & 0.635 & 0.604 & 0.565 & 0.648 & 0.565 & 0.568 & 0.647 & 0.575 & 0.615 & 0.624 & 0.655 & 0.632 & 0.649 & 0.656 & 0.639 \\
\hline
\end{tabular}


ANFIBÓLIO - amostra CP-06

\begin{tabular}{|c|c|c|c|c|c|c|c|c|c|c|c|c|c|c|}
\hline \multirow[b]{3}{*}{ Ponto } & \multicolumn{4}{|c|}{ porfiroblasto } & \multicolumn{3}{|c|}{ matriz } & \multicolumn{4}{|c|}{ porfiroblasto } & \multicolumn{3}{|c|}{ matriz } \\
\hline & borda & borda-núcleo & núcleo & borda & borda & núcleo & borda & borda & núcleo & núcleo & borda & borda & núcleo & borda \\
\hline & 1.1 & 1.2 & 1.3 & 1.4 & 2.1 & 2.2 & 2.3 & 3.1 & 3.2 & 3.3 & 3.4 & 4.1 & 4.2 & 4.3 \\
\hline $\mathrm{SiO}_{2}$ & 57.58 & 57.77 & 57.66 & 57.26 & 58.20 & 57.90 & 57.58 & 57.79 & 57.37 & 57.57 & 56.89 & 57.17 & 57.53 & 57.58 \\
\hline $\mathrm{TiO}_{2}$ & 0.06 & 0.01 & 0.03 & 0.02 & 0.01 & 0.02 & 0.05 & 0.00 & 0.07 & 0.03 & 0.00 & 0.06 & 0.02 & 0.08 \\
\hline $\mathrm{Al}_{2} \mathrm{O}_{3}$ & 0.22 & 0.62 & 0.63 & 0.27 & 0.35 & 0.29 & 0.26 & 0.35 & 0.57 & 0.62 & 0.29 & 1.36 & 0.23 & 1.12 \\
\hline $\mathrm{Cr}_{2} \mathrm{O}_{3}$ & 0.03 & 0.10 & 0.09 & 0.05 & 0.06 & 0.04 & 0.04 & 0.07 & 0.09 & 0.10 & 0.05 & 0.12 & 0.03 & 0.13 \\
\hline $\mathrm{FeO}$ & 12.99 & 5.09 & 4.62 & 12.94 & 12.39 & 12.59 & 12.60 & 12.58 & 5.08 & 4.52 & 13.14 & 4.35 & 12.97 & 4.09 \\
\hline MnO & 0.36 & 0.21 & 0.16 & 0.34 & 0.33 & 0.34 & 0.36 & 0.34 & 0.22 & 0.16 & 0.38 & 0.10 & 0.37 & 0.12 \\
\hline MgO & 25.19 & 21.75 & 22.32 & 25.63 & 25.59 & 26.15 & 26.24 & 25.74 & 21.70 & 22.37 & 24.56 & 21.99 & 25.31 & 22.28 \\
\hline $\mathrm{CaO}$ & 0.89 & 12.06 & 11.87 & 0.47 & 0.47 & 0.50 & 0.48 & 0.50 & 12.05 & 12.08 & 1.64 & 11.50 & 0.70 & 11.24 \\
\hline $\mathrm{Na}_{2} \mathrm{O}$ & 0.05 & 0.11 & 0.12 & 0.02 & 0.03 & 0.01 & 0.02 & 0.02 & 0.07 & 0.09 & 0.02 & 0.22 & 0.01 & 0.21 \\
\hline $\mathbf{K}_{2} \mathbf{O}$ & 0.00 & 0.03 & 0.03 & 0.01 & 0.02 & 0.01 & 0.00 & 0.00 & 0.04 & 0.02 & 0.01 & 0.00 & 0.00 & 0.00 \\
\hline Total & 97.38 & 97.74 & 97.51 & 97.01 & 97.45 & 97.84 & 97.62 & 97.38 & 97.25 & 97.54 & 96.98 & 96.88 & 97.17 & 96.84 \\
\hline $\mathbf{S i}$ & 8.012 & 7.979 & 7.962 & 7.990 & 8.048 & 7.993 & 7.965 & 8.012 & 7.968 & 7.950 & 7.981 & 7.926 & 8.016 & 7.966 \\
\hline $\mathbf{T i}$ & 0.006 & 0.001 & 0.003 & 0.002 & 0.001 & 0.002 & 0.006 & 0.000 & 0.007 & 0.003 & 0.000 & 0.007 & 0.002 & 0.008 \\
\hline Al & 0.037 & 0.101 & 0.102 & 0.044 & 0.057 & 0.047 & 0.042 & 0.057 & 0.094 & 0.100 & 0.047 & 0.223 & 0.038 & 0.183 \\
\hline $\mathrm{Cr}$ & 0.004 & 0.010 & 0.010 & 0.006 & 0.006 & 0.004 & 0.004 & 0.008 & 0.009 & 0.011 & 0.006 & 0.013 & 0.003 & 0.014 \\
\hline $\mathrm{Fe}^{3+}$ & 0.000 & 0.000 & 0.000 & 0.000 & 0.000 & 0.000 & 0.013 & 0.000 & 0.000 & 0.000 & 0.000 & 0.000 & 0.000 & 0.000 \\
\hline $\mathrm{Fe}^{2+}$ & 1.512 & 0.588 & 0.534 & 1.510 & 1.433 & 1.453 & 1.444 & 1.459 & 0.590 & 0.522 & 1.542 & 0.504 & 1.511 & 0.473 \\
\hline Mn & 0.043 & 0.024 & 0.019 & 0.040 & 0.038 & 0.039 & 0.042 & 0.039 & 0.026 & 0.018 & 0.045 & 0.012 & 0.044 & 0.014 \\
\hline Mg & 5.225 & 4.478 & 4.595 & 5.332 & 5.275 & 5.381 & 5.411 & 5.320 & 4.493 & 4.605 & 5.137 & 4.545 & 5.257 & 4.595 \\
\hline Ca & 0.133 & 1.785 & 1.756 & 0.070 & 0.070 & 0.074 & 0.071 & 0.074 & 1.793 & 1.787 & 0.247 & 1.708 & 0.105 & 1.666 \\
\hline $\mathbf{N a}$ & 0.013 & 0.029 & 0.031 & 0.006 & 0.009 & 0.003 & 0.005 & 0.005 & 0.018 & 0.024 & 0.005 & 0.059 & 0.002 & 0.055 \\
\hline K & 0.000 & 0.006 & 0.005 & 0.001 & 0.003 & 0.001 & 0.000 & 0.000 & 0.007 & 0.003 & 0.002 & 0.000 & 0.000 & 0.000 \\
\hline Total & 14.98 & 15.00 & 15.02 & 15.00 & 14.94 & 15.00 & 15.00 & 14.97 & 15.00 & 15.02 & 15.01 & 15.00 & 14.98 & 14.97 \\
\hline XMg & 0.776 & 0.884 & 0.896 & 0.779 & 0.786 & 0.787 & 0.789 & 0.785 & 0.884 & 0.898 & 0.769 & 0.900 & 0.777 & 0.907 \\
\hline
\end{tabular}


ANFIBÓLIO - amostra CP-06 (continuação)

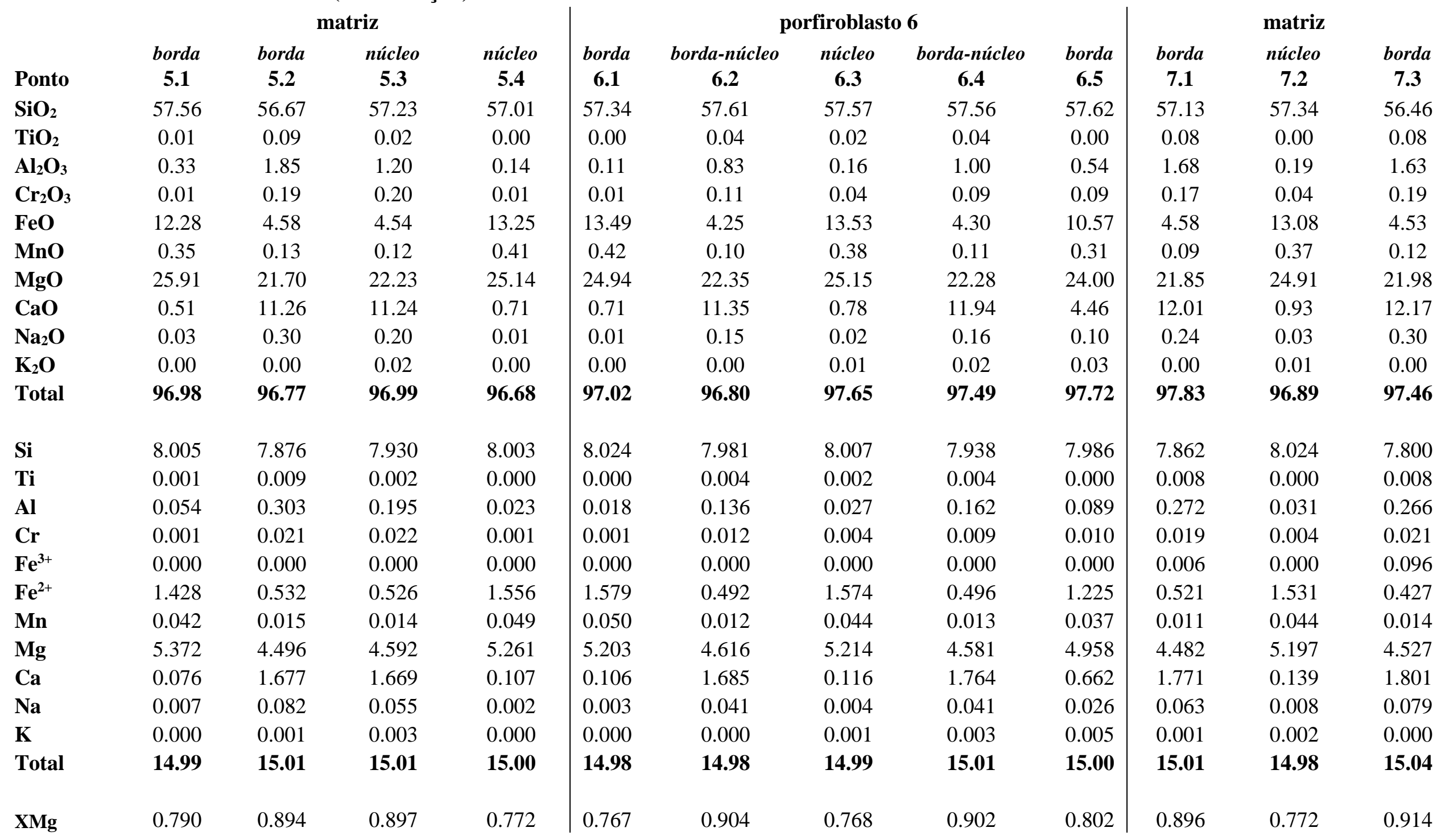




\section{Porfiroblasto}

\begin{tabular}{lllllll} 
Ponto & 1.1 & 1.2 & 1.3 & 1.4 & 1.5 \\
\hline
\end{tabular}

$\mathrm{TiO}_{2} \quad 0.15$

$\mathrm{Al}_{2} \mathrm{O}_{3} \quad 2.82$

$\mathrm{Cr}_{2} \mathrm{O}_{3} \quad 0.26$

$\mathrm{FeO} \quad 4.34$

MnO 0.07

MgO 21.39

CaO 11.89

Na2O 0.62

K2O 0.05

Total $\quad 97.28$

Ti $\quad 0.02-0.00$

$\begin{array}{lll}\mathrm{Cr} & 0.03 \quad 0.00\end{array}$

$\mathrm{Fe}^{3+} \quad 0.13 \quad 0.00$

$\mathrm{Fe}^{2+} \quad 0.37 \quad 1.42$

$\begin{array}{lll}\text { Mn } & 0.01 \quad 0.02\end{array}$

Mg 4.41

Ca $\quad 1.76$

$\begin{array}{lll}\mathrm{Na} & 0.17 \quad 0.01\end{array}$

$\begin{array}{lll}\text { K } & 0.01 \quad 0.00\end{array}$

Total $\mathbf{1 5 . 0 6}$

$\begin{array}{lllll}15.06 & 14.99 & 15.05 & 15.02 & 15.04\end{array}$

$\begin{array}{lll}0.02 & 0.00 \quad 0.02\end{array}$

$0.10 \quad 0.00$

$0.37 \quad 1.31$

$$
\begin{array}{r}
0.02 \\
5.53
\end{array}
$$

0.08

\begin{abstract}
$\begin{array}{lllll}\text { XMg } & 0.922 & 0.790 & 0.925 & 0.80\end{array}$
\end{abstract}
Porfiroblasto

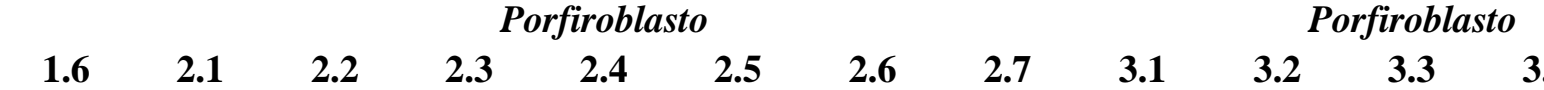

$\begin{array}{lllllllllllll}56.36 & 56.35 & 56.10 & 56.19 & 56.18 & 55.27 & 57.60 & 57.81 & 56.57 & 57.43 & 56.22 & 56.13 & 56.23\end{array}$

$\begin{array}{lllllllllllll}0.11 & 0.14 & 0.07 & 0.10 & 0.05 & 0.13 & 0.02 & 0.01 & 0.12 & 0.01 & 0.18 & 0.10 & 0.08\end{array}$

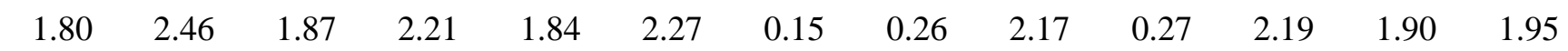

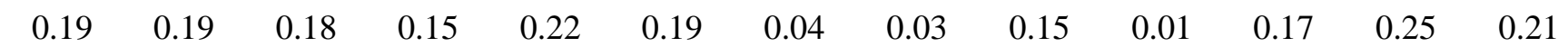

$\begin{array}{lll}3.93 & 4.26 & 4.23\end{array}$

4.11

$3.94 \quad 4.24$

$12.37 \quad 11.74$

4.20

0.01
11.55

0.17

$4.35 \quad 3.77$

$0.06 \quad 0.06$

$\begin{array}{ll}22.26 & 21.76 \\ 11.66 & 11.84\end{array}$

22.04

$\begin{array}{lll}0.05 & 0.05 \quad 0.06\end{array}$

$0.21 \quad 0.19$

$\begin{array}{ll}25.55 & 26.46 \\ 0.88 & 0.68\end{array}$

0.07

0.23

0.08

$11.61 \quad 11.89 \quad 0.88$

0.68

11.79

0.93

22.18
11.41

0.0

$0.04 \quad 0.04$

$0.38-0.49$

$0.06-0.05$

0.00

0.06

0.42

0.01

97.29

97.44

(1)

$\begin{array}{lll}0.36 & 0.31 & 0.32\end{array}$

0.02

0.07

0.02

0.02
0.09

$0.40 \quad 0.41$

$0.02 \quad 0.02$

$0.30 \quad 0.37$

0.02
0.00

0.00

0.00

0.00

0.06

0.19
0.30

1.44

1.36

0.02

$0.05 \quad 0.00$

$0.43 \quad 1.35$

0.02

0.09

$0.08-0.09$

0.01

0.01

4.60

4.56

5.31

5.46

0.01

0.03

$\begin{array}{lll}0.41 & 0.43 & 0.35\end{array}$

$\begin{array}{lll}4.60 & 4.47 & 4.57\end{array}$

$1.74 \quad 1.75$

$1.73 \quad 1.77$

5.31
0.13

0.10

4.50
1.74

5.4

4.57

0.01

4.57

0.01

$\begin{array}{llll}0.11 & 0.14 & 0.10 & 0.13\end{array}$

$0.10 \quad 0.14$

0.01

0.01

0.11

0.01

$\begin{array}{lll}1.69 & 1.71 \quad 1.80\end{array}$

$0.01 \quad 0.01$

$0.01 \quad 0.01$

$0.01 \quad 0.01$

0.0

$0.01 \quad 0.00$

0.12

$0.11 \quad 0.11$

$\begin{array}{lllllllllllllll}0.919 & 0.923 & 0.917 & 0.918 & 0.925 & 0.920 & 0.938 & 0.786 & 0.801 & 0.912 & 0.801 & 0.917 & 0.915 & 0.929\end{array}$ 


\section{ANFIBÓLIO - amostra CP-54 (continuação)}

\begin{tabular}{|c|c|c|c|c|c|c|c|c|c|c|c|c|c|c|c|c|c|c|c|c|}
\hline \multirow[b]{2}{*}{ Ponto } & \multicolumn{20}{|c|}{ Matriz } \\
\hline & 4.1 & 4.2 & 4.3 & 4.4 & 4.5 & 4.6 & 4.7 & 4.8 & 5.1 & 5.2 & 5.3 & 5.4 & 6.1 & 6.2 & 6.3 & 7.1 & 7.2 & 7.3 & 8.1 & 8.2 \\
\hline $\mathrm{SiO}_{2}$ & 58.47 & 57.70 & 56.68 & 56.03 & 57.35 & 56.47 & 56.65 & 57.41 & 57.70 & 57.74 & 57.97 & 57.80 & 58.45 & 57.74 & 57.49 & 57.87 & 56.99 & 56.43 & 57.65 & 56.14 \\
\hline $\mathrm{TiO}_{2}$ & 0.03 & 0.00 & 0.07 & 0.17 & 0.01 & 0.11 & 0.05 & 0.01 & 0.02 & 0.00 & 0.01 & 0.05 & 0.00 & 0.00 & 0.06 & 0.06 & 0.02 & 0.10 & 0.05 & 0.06 \\
\hline $\mathrm{dl}_{2} \mathrm{O}_{3}$ & 0.27 & 0.36 & 1.76 & 2.18 & 0.38 & 1.88 & 1.26 & 0.71 & 0.28 & 0.16 & 0.44 & 0.26 & 0.39 & 0.35 & 0.48 & 0.35 & 0.03 & 1.92 & 0.23 & 1.95 \\
\hline $\mathrm{Cr}_{2} \mathrm{O}_{3}$ & 0.04 & 0.05 & 0.11 & 0.12 & 0.02 & 0.14 & 0.05 & 0.03 & 0.05 & 0.01 & 0.01 & 0.00 & 0.02 & 0.01 & 0.03 & 0.05 & 0.03 & 0.09 & 0.04 & 0.01 \\
\hline $\mathrm{FeO}$ & 11.36 & 11.70 & 4.10 & 3.90 & 11.81 & 3.84 & 7.84 & 9.64 & 11.48 & 12.21 & 11.48 & 11.94 & 11.19 & 11.23 & 11.04 & 11.53 & 8.62 & 4.21 & 11.67 & 4.18 \\
\hline MnO & 0.21 & 0.21 & 0.07 & 0.07 & 0.23 & 0.06 & 0.16 & 0.15 & 0.21 & 0.22 & 0.18 & 0.23 & 0.18 & 0.19 & 0.18 & 0.18 & 0.29 & 0.06 & 0.18 & 0.07 \\
\hline $\mathrm{MgO}$ & 26.70 & 26.75 & 22.24 & 22.06 & 24.97 & 22.20 & 23.74 & 24.35 & 26.62 & 26.82 & 27.01 & 26.34 & 27.22 & 26.77 & 27.22 & 26.87 & 18.87 & 22.14 & 26.70 & 22.16 \\
\hline $\mathrm{CaO}$ & 0.49 & 0.49 & 11.59 & 12.08 & 2.26 & 12.07 & 6.93 & 4.81 & 0.47 & 0.41 & 0.54 & 0.90 & 0.51 & 0.48 & 0.52 & 0.50 & 12.34 & 11.82 & 0.45 & 11.83 \\
\hline $\mathrm{Na2O}$ & 0.06 & 0.04 & 0.33 & 0.43 & 0.06 & 0.39 & 0.30 & 0.12 & 0.05 & 0.01 & 0.08 & 0.03 & 0.07 & 0.06 & 0.08 & 0.06 & 0.02 & 0.42 & 0.02 & 0.40 \\
\hline K2O & 0.00 & 0.00 & 0.02 & 0.01 & 0.01 & 0.03 & 0.00 & 0.03 & 0.00 & 0.00 & 0.02 & 0.00 & 0.02 & 0.00 & 0.00 & 0.00 & 0.00 & 0.03 & 0.01 & 0.03 \\
\hline Total & 97.63 & 97.30 & 96.95 & 97.06 & 97.09 & 97.20 & 96.97 & 97.25 & 96.89 & 97.57 & 97.73 & 97.55 & 98.05 & 96.83 & 97.08 & 97.48 & 97.20 & 97.22 & 96.99 & 96.83 \\
\hline $\mathbf{S i}$ & 8.03 & 7.97 & 7.84 & 7.75 & 7.99 & 7.80 & 7.86 & 7.96 & 8.00 & 7.98 & 7.96 & 7.98 & 7.99 & 8.00 & 7.93 & 7.98 & 8.05 & 7.79 & 7.99 & 7.78 \\
\hline $\mathbf{T i}$ & 0.00 & 0.00 & 0.01 & 0.02 & 0.00 & 0.01 & 0.01 & 0.00 & 0.00 & 0.00 & 0.00 & 0.00 & 0.00 & 0.00 & 0.01 & 0.01 & 0.00 & 0.01 & 0.01 & 0.01 \\
\hline Al & 0.04 & 0.06 & 0.29 & 0.36 & 0.06 & 0.31 & 0.21 & 0.12 & 0.05 & 0.03 & 0.07 & 0.04 & 0.06 & 0.06 & 0.08 & 0.06 & 0.01 & 0.31 & 0.04 & 0.32 \\
\hline $\mathrm{Cr}$ & 0.00 & 0.01 & 0.01 & 0.01 & 0.00 & 0.01 & 0.01 & 0.00 & 0.01 & 0.00 & 0.00 & 0.00 & 0.00 & 0.00 & 0.00 & 0.01 & 0.00 & 0.01 & 0.00 & 0.00 \\
\hline $\mathrm{Fe}^{3+}$ & 0.00 & -0.01 & 0.04 & 0.11 & 0.00 & 0.08 & 0.07 & -0.03 & 0.00 & 0.00 & 0.00 & -0.02 & 0.00 & 0.00 & 0.04 & -0.02 & 0.00 & 0.09 & -0.03 & 0.11 \\
\hline $\mathrm{Fe}^{2+}$ & 1.30 & 1.36 & 0.44 & 0.34 & 1.38 & 0.36 & 0.84 & 1.15 & 1.33 & 1.41 & 1.32 & 1.40 & 1.28 & 1.30 & 1.23 & 1.35 & 1.02 & 0.40 & 1.38 & 0.38 \\
\hline Mn & 0.02 & 0.02 & 0.01 & 0.01 & 0.03 & 0.01 & 0.02 & 0.02 & 0.02 & 0.03 & 0.02 & 0.03 & 0.02 & 0.02 & 0.02 & 0.02 & 0.03 & 0.01 & 0.02 & 0.01 \\
\hline Mg & 5.47 & 5.51 & 4.59 & 4.55 & 5.19 & 4.57 & 4.91 & 5.04 & 5.50 & 5.52 & 5.53 & 5.42 & 5.55 & 5.53 & 5.60 & 5.52 & 3.97 & 4.56 & 5.52 & 4.58 \\
\hline $\mathrm{Ca}$ & 0.07 & 0.07 & 1.72 & 1.79 & 0.34 & 1.79 & 1.03 & 0.71 & 0.07 & 0.06 & 0.08 & 0.13 & 0.07 & 0.07 & 0.08 & 0.07 & 1.87 & 1.75 & 0.07 & 1.76 \\
\hline $\mathrm{Na}$ & 0.01 & 0.01 & 0.09 & 0.12 & 0.01 & 0.11 & 0.08 & 0.03 & 0.01 & 0.00 & 0.02 & 0.01 & 0.02 & 0.02 & 0.02 & 0.02 & 0.01 & 0.11 & 0.01 & 0.11 \\
\hline $\mathbf{\alpha}$ & 0.00 & 0.00 & 0.00 & 0.00 & 0.00 & 0.01 & 0.00 & 0.00 & 0.00 & 0.00 & 0.00 & 0.00 & 0.00 & 0.00 & 0.00 & 0.00 & 0.00 & 0.01 & 0.00 & 0.01 \\
\hline Total & 14.96 & 15.00 & 15.03 & 15.05 & 14.99 & 15.04 & 15.03 & 15.01 & 14.99 & 15.03 & 15.01 & 15.00 & 15.00 & 14.99 & 15.01 & 15.00 & 14.96 & 15.05 & 15.00 & 15.05 \\
\hline
\end{tabular}

$\begin{array}{lllllllllllllllllllll}\text { XMg } & 0.81 & 0.80 & 0.91 & 0.93 & 0.79 & 0.93 & 0.85 & 0.81 & 0.81 & 0.80 & 0.81 & 0.79 & 0.81 & 0.81 & 0.82 & 0.80 & 0.80 & 0.92 & 0.80 & 0.92\end{array}$ 


\section{ANFIBÓLIO - amostra DCF-22}

borda núcleo núcleo núcleo borda borda núcleo borda

borda núcleo borda

borda núcleo borda borda núcleo borda

$\begin{array}{lllllllllllllllllllll}\text { Ponto } & 1.1 & 1.2 & 1.3 & 1.4 & 1.5 & 2.1 & 2.2 & 2.3 & 3.1 & 4.1 & 4.2 & 4.3 & 5.1 & 5.2 & 6.1 & 6.2 & 6.3 & 7.1 & 7.2 & 7.3\end{array}$

$\begin{array}{lllllllllllllllllllll}\mathrm{SiO}_{2} & 57.48 & 57.58 & 57.42 & 57.37 & 57.85 & 57.39 & 58.27 & 58.05 & 57.60 & 57.62 & 57.79 & 58.20 & 58.87 & 58.23 & 58.77 & 58.63 & 58.96 & 58.46 & 59.30 & 60.69\end{array}$

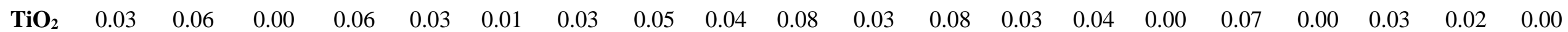

$\begin{array}{llllllllllllllllllllll}\mathbf{A l}_{2} \mathbf{O}_{3} & 0.68 & 0.81 & 0.76 & 0.83 & 0.72 & 0.66 & 0.39 & 0.72 & 0.66 & 0.64 & 0.42 & 0.74 & 0.08 & 0.11 & 0.08 & 0.08 & 0.11 & 0.07 & 0.02 & 0.04\end{array}$

$\begin{array}{lllllllllllllllllllllll}\mathrm{Cr}_{2} \mathrm{O}_{3} & 0.07 & 0.08 & 0.04 & 0.05 & 0.03 & 0.07 & 0.01 & 0.04 & 0.05 & 0.05 & 0.02 & 0.05 & 0.00 & 0.00 & 0.04 & 0.02 & 0.03 & 0.02 & 0.00 & 0.00\end{array}$

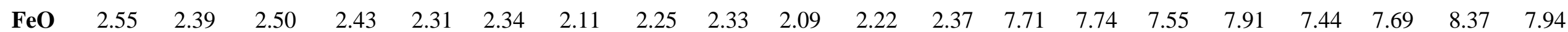

$\begin{array}{lllllllllllllllllllllll}\text { MnO } & 0.07 & 0.07 & 0.10 & 0.11 & 0.08 & 0.06 & 0.09 & 0.08 & 0.07 & 0.09 & 0.09 & 0.06 & 0.27 & 0.28 & 0.27 & 0.25 & 0.25 & 0.27 & 0.29 & 0.32\end{array}$

$\begin{array}{lllllllllllllllllllllll}\text { MgO } & 23.67 & 23.58 & 23.63 & 23.63 & 23.92 & 23.76 & 23.70 & 23.36 & 23.82 & 23.67 & 23.74 & 23.42 & 29.66 & 30.37 & 29.52 & 29.86 & 30.01 & 29.77 & 29.10 & 28.96\end{array}$

$\begin{array}{lllllllllllllllllllll}\mathbf{C a O} & 11.41 & 12.16 & 11.88 & 11.94 & 12.23 & 12.07 & 12.30 & 12.14 & 12.16 & 12.15 & 12.19 & 12.25 & 0.36 & 0.35 & 0.35 & 0.35 & 0.39 & 0.36 & 0.30 & 0.30\end{array}$

$\begin{array}{lllllllllllllllllllllll}\mathrm{Na2O} & 0.17 & 0.21 & 0.16 & 0.21 & 0.18 & 0.19 & 0.13 & 0.17 & 0.18 & 0.19 & 0.10 & 0.19 & 0.02 & 0.04 & 0.02 & 0.03 & 0.03 & 0.02 & 0.02 & 0.03\end{array}$

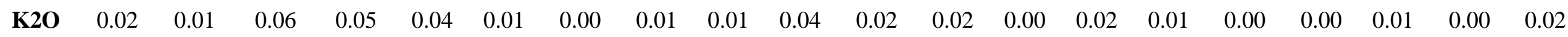

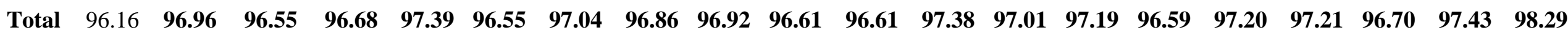

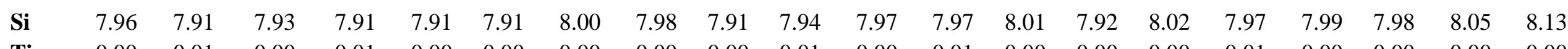

$\begin{array}{llllllllllllllllllllll}\text { Ti } & 0.00 & 0.01 & 0.00 & 0.01 & 0.00 & 0.00 & 0.00 & 0.00 & 0.00 & 0.01 & 0.00 & 0.01 & 0.00 & 0.00 & 0.00 & 0.01 & 0.00 & 0.00 & 0.00 & 0.00\end{array}$

$\begin{array}{lllllllllllllllllllllll}\text { Al } & 0.11 & 0.13 & 0.12 & 0.14 & 0.12 & 0.11 & 0.06 & 0.12 & 0.11 & 0.10 & 0.07 & 0.12 & 0.01 & 0.02 & 0.01 & 0.01 & 0.02 & 0.01 & 0.00 & 0.01\end{array}$

$\begin{array}{lllllllllllllllllllllll}\text { Cr } & 0.01 & 0.01 & 0.00 & 0.01 & 0.00 & 0.01 & 0.00 & 0.00 & 0.01 & 0.01 & 0.00 & 0.01 & 0.00 & 0.00 & 0.00 & 0.00 & 0.00 & 0.00 & 0.00 & 0.00\end{array}$

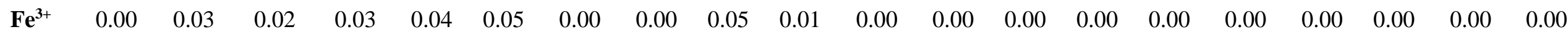

$\begin{array}{lllllllllllllllllllll}\mathbf{F e}^{2+} & 0.30 & 0.25 & 0.27 & 0.25 & 0.22 & 0.22 & 0.24 & 0.26 & 0.22 & 0.23 & 0.26 & 0.27 & 0.88 & 0.88 & 0.86 & 0.90 & 0.84 & 0.88 & 0.95 & 0.89\end{array}$

$\begin{array}{llllllllllllllllllllll}\text { Mn } & 0.01 & 0.01 & 0.01 & 0.01 & 0.01 & 0.01 & 0.01 & 0.01 & 0.01 & 0.01 & 0.01 & 0.01 & 0.03 & 0.03 & 0.03 & 0.03 & 0.03 & 0.03 & 0.03 & 0.04\end{array}$

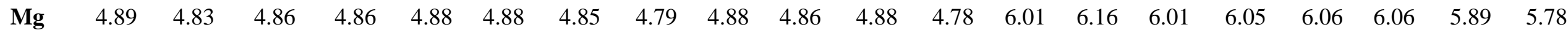

$\begin{array}{llllllllllllllllllllll}\mathbf{C a} & 1.69 & 1.79 & 1.76 & 1.76 & 1.79 & 1.78 & 1.81 & 1.79 & 1.79 & 1.79 & 1.80 & 1.80 & 0.05 & 0.05 & 0.05 & 0.05 & 0.06 & 0.05 & 0.04 & 0.04\end{array}$

$\begin{array}{lllllllllllllllllllllll}\mathrm{Na} & 0.04 & 0.06 & 0.04 & 0.06 & 0.05 & 0.05 & 0.04 & 0.05 & 0.05 & 0.05 & 0.03 & 0.05 & 0.01 & 0.01 & 0.01 & 0.01 & 0.01 & 0.00 & 0.01 & 0.01\end{array}$

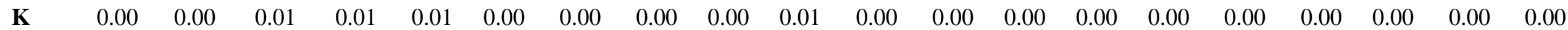

$\begin{array}{llllllllllllllllllllllll}\text { Total } & 15.02 & 15.02 & 15.03 & 15.03 & 15.03 & 15.03 & 15.01 & 15.00 & 15.03 & 15.02 & 15.02 & 15.01 & 15.00 & 15.08 & 14.99 & 15.03 & 15.00 & 15.02 & 14.97 & 14.89\end{array}$

$\begin{array}{lllllllllllllllllllll}\text { XMg } & 0.94 & 0.95 & 0.95 & 0.95 & 0.96 & 0.96 & 0.95 & 0.95 & 0.96 & 0.95 & 0.95 & 0.95 & 0.87 & 0.87 & 0.87 & 0.87 & 0.88 & 0.87 & 0.86 & 0.87\end{array}$ 


\section{ANFIBÓLIO - amostra CP-49C}

borda núcleo borda borda núcleo borda borda núcleo borda borda núcleo borda borda núcleo núcleo núcleo borda

\begin{tabular}{|c|c|c|c|c|c|c|c|c|c|c|c|c|c|c|c|c|c|}
\hline Ponto & 1.1 & 1.2 & 1.3 & 2.1 & 2.2 & 2.3 & 3.1 & 3.2 & 3.3 & 4.1 & 4.2 & 4.3 & 5.1 & 5.2 & 5.3 & 5.4 & 5.5 \\
\hline $\mathrm{SiO}_{2}$ & 43.03 & 43.98 & 43.36 & 44.22 & 44.45 & 44.93 & 45.52 & 45.21 & 44.59 & 43.38 & 44.06 & 43.24 & 45.02 & 44.26 & 43.90 & 43.92 & 45.01 \\
\hline $\mathrm{TiO}_{2}$ & 1.20 & 1.07 & 1.27 & 1.02 & 1.10 & 1.04 & 0.93 & 0.93 & 0.97 & 0.69 & 0.65 & 0.78 & 0.86 & 1.00 & 0.97 & 0.94 & 0.82 \\
\hline $\mathrm{Al} 2 \mathrm{O3}$ & 11.07 & 10.46 & 10.69 & 9.74 & 9.52 & 8.92 & 9.69 & 10.17 & 10.67 & 12.18 & 11.56 & 12.65 & 10.74 & 11.63 & 11.59 & 11.51 & 10.47 \\
\hline $\mathrm{Cr} 2 \mathrm{O} 3$ & 0.04 & 0.00 & 0.01 & 0.02 & 0.01 & 0.02 & 0.00 & 0.00 & 0.05 & 0.01 & 0.00 & 0.00 & 0.00 & 0.05 & 0.01 & 0.01 & 0.00 \\
\hline $\mathrm{FeO}$ & 18.45 & 18.57 & 19.12 & 18.57 & 18.76 & 18.09 & 15.70 & 16.23 & 16.56 & 16.48 & 16.34 & 16.18 & 16.61 & 16.37 & 16.77 & 16.61 & 16.43 \\
\hline MnO & 0.11 & 0.14 & 0.14 & 0.13 & 0.11 & 0.13 & 0.11 & 0.12 & 0.13 & 0.12 & 0.11 & 0.11 & 0.11 & 0.13 & 0.11 & 0.10 & 0.12 \\
\hline MgO & 8.98 & 9.41 & 9.08 & 9.55 & 9.57 & 9.91 & 11.50 & 11.38 & 10.54 & 10.25 & 10.79 & 10.22 & 10.66 & 10.17 & 10.19 & 10.23 & 10.78 \\
\hline $\mathrm{CaO}$ & 10.73 & 10.73 & 10.92 & 10.97 & 10.61 & 10.84 & 10.83 & 10.85 & 11.03 & 10.72 & 10.72 & 10.91 & 10.85 & 10.81 & 10.93 & 10.94 & 10.95 \\
\hline $\mathrm{Na} 2 \mathrm{O}$ & 1.61 & 1.56 & 1.53 & 1.41 & 1.45 & 1.41 & 1.43 & 1.45 & 1.52 & 1.69 & 1.58 & 1.64 & 1.45 & 1.56 & 1.54 & 1.56 & 1.44 \\
\hline $\mathrm{K}_{2} \mathrm{O}$ & 0.85 & 0.84 & 0.83 & 0.74 & 0.74 & 0.72 & 0.63 & 0.63 & 0.74 & 0.79 & 0.75 & 0.77 & 0.68 & 0.75 & 0.79 & 0.75 & 0.68 \\
\hline Total & 96.08 & 96.75 & 96.96 & 96.38 & 96.32 & 96.01 & 96.34 & 96.97 & 96.80 & 96.31 & 96.56 & 96.49 & 96.99 & 96.73 & 96.80 & 96.57 & 96.71 \\
\hline $\mathbf{S i}$ & 6.556 & 6.639 & 6.561 & 6.705 & 6.732 & 6.817 & 6.778 & 6.700 & 6.662 & 6.506 & 6.570 & 6.468 & 6.689 & 6.605 & 6.564 & 6.578 & 6.708 \\
\hline Ti & 0.138 & 0.121 & 0.145 & 0.117 & 0.125 & 0.119 & 0.104 & 0.103 & 0.109 & 0.078 & 0.073 & 0.087 & 0.096 & 0.112 & 0.109 & 0.106 & 0.092 \\
\hline Al & 1.988 & 1.861 & 1.907 & 1.740 & 1.699 & 1.595 & 1.701 & 1.776 & 1.879 & 2.153 & 2.032 & 2.230 & 1.881 & 2.045 & 2.042 & 2.032 & 1.839 \\
\hline $\mathrm{Cr}$ & 0.005 & 0.000 & 0.002 & 0.003 & 0.001 & 0.003 & 0.000 & 0.000 & 0.006 & 0.001 & 0.000 & 0.000 & 0.000 & 0.006 & 0.001 & 0.002 & 0.000 \\
\hline $\mathrm{Fe}^{3+}$ & 0.294 & 0.327 & 0.327 & 0.304 & 0.354 & 0.278 & 0.338 & 0.394 & 0.284 & 0.365 & 0.408 & 0.334 & 0.339 & 0.286 & 0.317 & 0.304 & 0.319 \\
\hline $\mathrm{Fe}^{2+}$ & 2.057 & 2.017 & 2.093 & 2.050 & 2.022 & 2.018 & 1.617 & 1.618 & 1.785 & 1.702 & 1.630 & 1.690 & 1.725 & 1.757 & 1.780 & 1.776 & 1.729 \\
\hline Mn & 0.014 & 0.017 & 0.018 & 0.017 & 0.014 & 0.016 & 0.014 & 0.015 & 0.017 & 0.015 & 0.013 & 0.014 & 0.014 & 0.016 & 0.014 & 0.013 & 0.016 \\
\hline Mg & 2.040 & 2.118 & 2.048 & 2.159 & 2.161 & 2.242 & 2.553 & 2.514 & 2.347 & 2.292 & 2.399 & 2.279 & 2.361 & 2.262 & 2.271 & 2.284 & 2.395 \\
\hline $\mathrm{Ca}$ & 1.752 & 1.735 & 1.771 & 1.782 & 1.722 & 1.762 & 1.728 & 1.723 & 1.766 & 1.723 & 1.713 & 1.749 & 1.727 & 1.728 & 1.751 & 1.756 & 1.749 \\
\hline $\mathbf{N a}$ & 0.476 & 0.457 & 0.449 & 0.414 & 0.426 & 0.415 & 0.413 & 0.417 & 0.440 & 0.491 & 0.457 & 0.476 & 0.418 & 0.451 & 0.446 & 0.453 & 0.416 \\
\hline $\mathbf{K}$ & 0.165 & 0.162 & 0.161 & 0.143 & 0.144 & 0.140 & 0.119 & 0.119 & 0.141 & 0.152 & 0.142 & 0.146 & 0.129 & 0.144 & 0.151 & 0.142 & 0.130 \\
\hline Total & 15.48 & 15.45 & 15.48 & 15.43 & 15.40 & 15.40 & 15.36 & 15.38 & 15.44 & 15.48 & 15.44 & 15.47 & 15.38 & 15.41 & 15.45 & 15.45 & 15.39 \\
\hline XMg & 0.498 & 0.512 & 0.495 & 0.513 & 0.517 & 0.526 & 0.612 & 0.608 & 0.568 & 0.574 & 0.595 & 0.574 & 0.578 & 0.563 & 0.561 & 0.562 & 0.581 \\
\hline
\end{tabular}




\section{ANFIBÓLIO}

\begin{tabular}{|c|c|c|c|c|c|c|c|c|c|c|c|c|c|c|c|c|c|c|c|c|}
\hline \multirow[b]{3}{*}{ Ponto } & \multicolumn{10}{|c|}{ CP-49C (continuação) } & \multicolumn{10}{|c|}{ CP-65A } \\
\hline & borda & núcleo & núcleo & núcleo & borda & borda & núcleo & núcleo & núcleo & borda & & & & & & & & & & \\
\hline & 6.1 & 6.2 & 6.3 & 6.4 & 6.5 & 7.1 & 7.2 & 7.3 & 7.4 & 7.5 & 1.1 & 1.2 & 2.1 & 2.2 & 3.1 & 3.2 & 4.1 & 4.2 & 5.1 & 5.2 \\
\hline $\mathrm{SiO}_{2}$ & 43.33 & 44.22 & 43.62 & 43.71 & 44.20 & 43.56 & 44.66 & 43.90 & 43.58 & 43.51 & 38.99 & 38.99 & 39.14 & 39.18 & 39.07 & 39.33 & 39.06 & 39.01 & 39.12 & 39.12 \\
\hline $\mathrm{TiO}_{2}$ & 92 & .95 & 1.05 & 1.09 & 0.95 & 0.97 & 0.90 & 0.99 & 0.85 & 1.00 & .45 & 1.35 & 1.36 & 1.21 & 1.04 & 1.38 & 1.04 & 1.41 & 1.14 & 1.25 \\
\hline $\mathrm{Al}_{2} \mathrm{O} 3$ & .62 & 1.13 & 12.01 & 11.76 & 1.17 & 11.07 & 10.25 & 10.72 & 10.66 & 10.68 & 12.86 & 12.87 & 12.68 & 12.90 & 12.77 & 12.96 & 12.85 & 12.80 & 12.79 & 12.71 \\
\hline $\mathrm{Cr}_{2} \mathrm{O}_{3}$ & .11 & & 0.33 & 0.27 & 0.28 & 0.00 & 0.01 & 0.00 & 0.00 & 0.00 & 0.02 & 0.02 & 0.01 & 0.01 & 0.02 & 0.02 & 0.00 & 0.03 & 0.04 & 0.03 \\
\hline $\mathbf{F e O}$ & 5.3 & 5.14 & 16.04 & 16.23 & 16.43 & 18.13 & 18.03 & 18.22 & 18.56 & 18.75 & 24.47 & 24.08 & 24.79 & 24.39 & 24.33 & 24.01 & 24.49 & 24.53 & 24.67 & 24.43 \\
\hline MnO & $0 S$ & 12 & 0.11 & 0.12 & 0.13 & 0.11 & 0.12 & & 0.13 & 0.12 & 0.48 & 0.54 & 0.48 & 0.43 & 0.42 & 0.43 & 0.42 & 0.42 & 0.46 & 0.45 \\
\hline $\mathrm{MgO}$ & .14 & .28 & 9.95 & 0.10 & .52 & & 9.80 & 33 & 9.49 & 9.35 & 5.01 & 4.92 & 4.98 & 5.18 & 5.03 & 5.28 & 4.85 & 5.02 & 4.76 & 4.98 \\
\hline $\mathrm{CaO}$ & .06 & 1.09 & 10.97 & 11.00 & 11.01 & 11.00 & 11.03 & 10.90 & 10.88 & 11.04 & 10.78 & 10.78 & 10.84 & 10.79 & 10.78 & 10.77 & 10.84 & 10.87 & 10.74 & 10.76 \\
\hline $\mathrm{Na} 2 \mathrm{O}$ & 1.5 & 43 & 1.51 & 1.49 & 1.52 & 1.50 & 1.43 & 1.52 & 1.45 & 1.41 & 1.50 & 1.53 & 1.59 & 1.48 & 1.53 & 1.48 & 1.49 & 1.53 & 1.52 & 1.54 \\
\hline $\mathrm{K}_{2} \mathrm{O}$ & 0.78 & 76 & 0.76 & 0.74 & .72 & 0.78 & 0.65 & 0.74 & 0.75 & 0.70 & 2.09 & 1.99 & 1.88 & 1.98 & 1.83 & 1.99 & 1.80 & 1.94 & 1.85 & 1.90 \\
\hline Total & 96.00 & 96.27 & 96.34 & 96.51 & 96.93 & 96.26 & 96.87 & 96.44 & 96.35 & 96.56 & 97.64 & 97.07 & 97.74 & 97.54 & 96.82 & 97.65 & 96.84 & 97.56 & 97.08 & 97.16 \\
\hline Si & & & 6 & & & & 6.705 & & 6.600 & .583 & 6.106 & 6.138 & 6.121 & 6.122 & 6.150 & 6.133 & 6.151 & 6.109 & 6.155 & 6.147 \\
\hline $\mathbf{T i}$ & & & 118 & & & & 0.101 & 0.113 & 0.097 & 0.114 & 0.170 & 0.160 & 0.160 & 0.142 & 0.123 & 0.162 & 0.123 & 0.166 & 0.135 & 0.147 \\
\hline Al & 067 & 969 & 2.124 & 2.077 & 1.963 & 1.979 & 1.814 & 1.911 & 1.903 & 1.904 & 2.373 & 2.388 & 2.337 & 2.376 & 2.369 & 2.382 & 2.385 & 2.363 & 2.371 & 2.354 \\
\hline $\mathrm{Cr}$ & 013 & .018 & 0.039 & 0.032 & 0.033 & 0.000 & 0.001 & 0.000 & 0.000 & 0.000 & 0.002 & 0.002 & 0.001 & 0.001 & 0.003 & 0.003 & 0.000 & 0.004 & 0.004 & 0.003 \\
\hline $\mathrm{Fe}^{3+}$ & 270 & .240 & 0.246 & 0.272 & 0.317 & 0.256 & 0.298 & 0.284 & 0.382 & 0.376 & 0.402 & 0.340 & 0.438 & 0.458 & 0.440 & 0.397 & 0.432 & 0.419 & 0.412 & 0.405 \\
\hline $\mathrm{Fe}^{2+}$ & 707 & & 1.766 & & & 2.044 & 1.966 & & 1.969 & 1.997 & 2.802 & 2.830 & 2.805 & 2.729 & 2.763 & 2.734 & 2.794 & 2.794 & 2.834 & 2.805 \\
\hline Mn & 011 & 016 & 0.014 & 0.016 & 0.017 & 0.014 & 0.015 & 0.016 & 0.016 & 0.015 & 0.063 & 0.072 & 0.063 & 0.056 & 0.056 & 0.057 & 0.056 & 0.056 & 0.061 & 0.060 \\
\hline Mg & 282 & 2.301 & 2.226 & 2.256 & 2.339 & 2.069 & 2.193 & 2.104 & 2.143 & 2.109 & 1.170 & 1.155 & 1.161 & 1.207 & 1.180 & 1.227 & 1.139 & 1.172 & 1.116 & 1.167 \\
\hline $\mathrm{Ca}$ & 780 & 1.784 & 1.764 & & 1.759 & 1.788 & 1.774 & 1.767 & 1.765 & 1.790 & 1.809 & 1.818 & 1.816 & 1.806 & 1.818 & 1.799 & 1.829 & 1.824 & 1.810 & 1.812 \\
\hline $\mathrm{Na}$ & & & & & & & 0.416 & & & 0.414 & 0.455 & 0.467 & 0.482 & 0.448 & 0.467 & 0.447 & 0.455 & 0.465 & 0.464 & 0.469 \\
\hline $\mathbf{K}$ & 0.150 & 0.145 & 0.145 & 0.141 & 0.138 & 0.150 & 0.125 & 0.143 & 0.144 & 0.135 & 0.418 & 0.400 & 0.375 & 0.395 & 0.368 & 0.396 & 0.362 & 0.388 & 0.371 & 0.381 \\
\hline Total & 15.49 & 15.42 & 15.43 & 15.43 & 15.43 & 15.46 & 15.41 & 15.44 & 15.45 & 15.44 & 15.77 & 15.77 & 15.76 & 15.74 & 15.74 & 15.74 & 15.73 & 15.76 & 15.73 & 15.75 \\
\hline & 0.559 & 0.563 & 0.558 & 0.562 & 0.575 & 0.503 & 0.527 & 0.510 & 0.521 & 0.514 & 0.294 & 0.290 & 0.293 & 0.307 & 0.299 & 0.310 & 0.290 & 0.295 & 0.283 & 0.294 \\
\hline
\end{tabular}


ANFIBÓLIO - amostra CP-65B

\begin{tabular}{|c|c|c|c|c|c|c|c|c|c|c|c|c|c|}
\hline Ponto & 1.1 & 1.2 & 1.3 & 2.1 & 2.2 & 2.3 & 3.1 & 3.2 & 4.1 & 4.2 & 5.1 & 5.2 & 5.3 \\
\hline $\mathrm{SiO}_{2}$ & 39.33 & 39.51 & 39.10 & 39.18 & 39.19 & 39.44 & 38.80 & 39.00 & 39.01 & 39.24 & 39.81 & 39.52 & 39.23 \\
\hline $\mathrm{TiO}_{2}$ & 1.36 & 1.24 & 1.23 & 0.91 & 1.33 & 1.13 & 1.64 & 1.21 & 1.25 & 1.25 & 1.13 & 1.41 & 1.29 \\
\hline $\mathrm{Al}_{2} \mathrm{O} 3$ & 12.30 & 12.89 & 12.90 & 13.90 & 13.24 & 13.08 & 12.32 & 13.11 & 12.45 & 13.31 & 12.46 & 13.07 & 12.78 \\
\hline $\mathrm{Cr} 2 \mathrm{O} 3$ & 0.00 & 0.01 & 0.03 & 0.00 & 0.00 & 0.03 & 0.01 & 0.00 & 0.00 & 0.00 & 0.00 & 0.00 & 0.02 \\
\hline $\mathrm{FeO}$ & 24.75 & 24.30 & 24.10 & 23.61 & 23.69 & 24.30 & 24.52 & 24.43 & 24.74 & 24.22 & 24.87 & 24.26 & 24.72 \\
\hline MnO & 0.35 & 0.36 & 0.37 & 0.32 & 0.36 & 0.37 & 0.32 & 0.35 & 0.48 & 0.42 & 0.39 & 0.40 & 0.46 \\
\hline MgO & 4.82 & 4.96 & 4.91 & 4.51 & 4.97 & 4.98 & 4.98 & 4.82 & 4.81 & 4.86 & 4.73 & 4.86 & 4.67 \\
\hline $\mathrm{CaO}$ & 10.75 & 10.51 & 10.49 & 9.78 & 10.63 & 10.44 & 10.74 & 10.52 & 10.69 & 10.49 & 10.66 & 10.50 & 10.58 \\
\hline $\mathrm{Na} 2 \mathrm{O}$ & 1.57 & 1.72 & 1.66 & 1.37 & 1.66 & 1.71 & 1.56 & 1.62 & 1.56 & 1.69 & 1.62 & 1.52 & 1.60 \\
\hline $\mathrm{K}_{2} \mathrm{O}$ & 1.89 & 2.00 & 2.00 & 1.57 & 1.89 & 2.07 & 1.96 & 2.12 & 1.90 & 2.12 & 1.91 & 2.10 & 2.00 \\
\hline Total & 97.12 & 97.50 & 96.78 & 95.15 & 96.97 & 97.55 & 96.86 & 97.19 & 96.89 & 97.60 & 97.58 & 97.63 & 97.34 \\
\hline $\mathbf{S i}$ & 6.199 & 6.185 & 6.168 & 6.203 & 6.155 & 6.168 & 6.134 & 6.136 & 6.160 & 6.139 & 6.241 & 6.174 & 6.170 \\
\hline $\mathbf{T i}$ & 0.161 & 0.146 & 0.145 & 0.108 & 0.157 & 0.133 & 0.196 & 0.144 & 0.149 & 0.147 & 0.134 & 0.165 & 0.152 \\
\hline Al & 2.285 & 2.378 & 2.398 & 2.593 & 2.451 & 2.411 & 2.295 & 2.431 & 2.317 & 2.454 & 2.302 & 2.406 & 2.369 \\
\hline $\mathrm{Cr}$ & 0.000 & 0.001 & 0.004 & 0.000 & 0.000 & 0.004 & 0.001 & 0.000 & 0.000 & 0.000 & 0.000 & 0.000 & 0.002 \\
\hline $\mathrm{Fe}^{3+}$ & 0.332 & 0.318 & 0.321 & 0.456 & 0.286 & 0.344 & 0.364 & 0.338 & 0.408 & 0.324 & 0.307 & 0.325 & 0.330 \\
\hline $\mathrm{Fe}^{2+}$ & 2.930 & 2.864 & 2.858 & 2.670 & 2.825 & 2.834 & 2.878 & 2.876 & 2.859 & 2.845 & 2.953 & 2.844 & 2.921 \\
\hline Mn & 0.047 & 0.047 & 0.049 & 0.043 & 0.048 & 0.049 & 0.043 & 0.047 & 0.064 & 0.055 & 0.052 & 0.053 & 0.061 \\
\hline Mg & 1.133 & 1.158 & 1.155 & 1.064 & 1.164 & 1.161 & 1.174 & 1.131 & 1.132 & 1.133 & 1.105 & 1.132 & 1.095 \\
\hline Ca & 1.815 & 1.763 & 1.773 & 1.659 & 1.789 & 1.749 & 1.819 & 1.773 & 1.809 & 1.758 & 1.790 & 1.757 & 1.783 \\
\hline $\mathrm{Na}$ & 0.480 & 0.522 & 0.508 & 0.420 & 0.505 & 0.518 & 0.478 & 0.494 & 0.478 & 0.513 & 0.492 & 0.460 & 0.488 \\
\hline K & 0.380 & 0.399 & 0.402 & 0.317 & 0.379 & 0.413 & 0.395 & 0.426 & 0.383 & 0.423 & 0.382 & 0.418 & 0.401 \\
\hline Total & 15.76 & 15.78 & 15.78 & 15.53 & 15.76 & 15.79 & 15.78 & 15.80 & 15.76 & 15.79 & 15.76 & 15.74 & 15.77 \\
\hline XMg & 0.279 & 0.288 & 0.288 & 0.285 & 0.292 & 0.291 & 0.290 & 0.282 & 0.284 & 0.285 & 0.272 & 0.285 & 0.273 \\
\hline
\end{tabular}


MUSCOVITA - amostra CP-07

\begin{tabular}{|c|c|c|c|c|c|c|c|c|c|c|c|c|}
\hline Ponto & 1.1 & 1.2 & 1.3 & 2.1 & 2.2 & 2.3 & 3.1 & 3.2 & 3.3 & 4.1 & 4.2 & 4.3 \\
\hline $\mathrm{SiO}_{2}$ & 44.77 & 44.71 & 44.81 & 44.41 & 44.64 & 44.58 & 42.51 & 44.56 & 44.63 & 44.76 & 44.75 & 44.36 \\
\hline $\mathrm{TiO}_{2}$ & 0.81 & 0.83 & 0.73 & 0.72 & 0.71 & 0.49 & 0.70 & 0.65 & 0.74 & 0.77 & 0.67 & 0.66 \\
\hline $\mathrm{Al}_{2} \mathrm{O3}$ & 35.71 & 35.59 & 35.42 & 35.08 & 35.09 & 35.62 & 33.80 & 34.86 & 35.01 & 35.49 & 35.17 & 35.40 \\
\hline FeO & 0.89 & 0.88 & 0.95 & 0.84 & 0.85 & 0.76 & 0.94 & 0.85 & 0.91 & 0.89 & 0.89 & 0.89 \\
\hline MnO & 0.00 & 0.00 & 0.00 & 0.00 & 0.00 & 0.00 & 0.00 & 0.00 & 0.00 & 0.01 & 0.03 & 0.00 \\
\hline MgO & 0.71 & 0.81 & 0.77 & 0.75 & 0.77 & 0.64 & 0.70 & 0.84 & 0.94 & 0.71 & 0.81 & 0.74 \\
\hline $\mathrm{CaO}$ & 0.00 & 0.00 & 0.01 & 0.00 & 0.00 & 0.00 & 0.06 & 0.02 & 0.03 & 0.04 & 0.01 & 0.03 \\
\hline $\mathrm{Na} 2 \mathrm{O}$ & 1.65 & 1.62 & 1.49 & 1.79 & 1.83 & 1.75 & 1.64 & 1.57 & 1.67 & 1.55 & 1.51 & 1.50 \\
\hline $\mathrm{K}_{2} \mathrm{O}$ & 8.72 & 8.79 & 8.51 & 8.66 & 8.85 & 8.58 & 8.43 & 8.44 & 8.44 & 8.62 & 8.48 & 8.48 \\
\hline Cl & 0.00 & 0.02 & 0.00 & 0.02 & 0.00 & 0.01 & 0.02 & 0.01 & 0.03 & 0.01 & 0.01 & 0.00 \\
\hline $\mathbf{F}$ & 0.00 & 0.00 & 0.02 & 0.00 & 0.02 & 0.00 & 0.01 & 0.01 & 0.01 & 0.01 & 0.01 & 0.00 \\
\hline Total & 93.26 & 93.24 & 92.68 & 92.25 & 92.74 & 92.42 & 88.77 & 91.80 & 92.38 & 92.83 & 92.32 & 92.06 \\
\hline Si & 3.024 & 3.022 & 3.039 & 3.034 & 3.037 & 3.034 & 3.023 & 3.051 & 3.040 & 3.034 & 3.047 & 3.030 \\
\hline $\mathbf{T i}$ & 0.041 & 0.042 & 0.037 & 0.037 & 0.036 & 0.025 & 0.037 & 0.034 & 0.038 & 0.039 & 0.034 & 0.034 \\
\hline Al total & 2.843 & 2.836 & 2.832 & 2.825 & 2.815 & 2.858 & 2.834 & 2.814 & 2.811 & 2.836 & 2.823 & 2.850 \\
\hline AlIV & 0.976 & 0.978 & 0.961 & 0.966 & 0.963 & 0.966 & 0.977 & 0.949 & 0.960 & 0.966 & 0.953 & 0.970 \\
\hline AlVI & 1.867 & 1.858 & 1.871 & 1.859 & 1.852 & 1.892 & 1.857 & 1.865 & 1.851 & 1.870 & 1.870 & 1.880 \\
\hline $\mathrm{Fe}^{3+}$ & 0.000 & 0.000 & 0.000 & 0.000 & 0.000 & 0.000 & 0.000 & 0.000 & 0.000 & 0.000 & 0.000 & 0.000 \\
\hline $\mathrm{Fe}^{2+}$ & 0.050 & 0.050 & 0.054 & 0.048 & 0.048 & 0.043 & 0.056 & 0.049 & 0.052 & 0.050 & 0.051 & 0.051 \\
\hline Mn & 0.000 & 0.000 & 0.000 & 0.000 & 0.000 & 0.000 & 0.000 & 0.000 & 0.000 & 0.000 & 0.002 & 0.000 \\
\hline Mg & 0.071 & 0.082 & 0.078 & 0.076 & 0.078 & 0.065 & 0.074 & 0.086 & 0.096 & 0.072 & 0.082 & 0.075 \\
\hline $\mathbf{C a}$ & 0.000 & 0.000 & 0.000 & 0.000 & 0.000 & 0.000 & 0.004 & 0.001 & 0.002 & 0.003 & 0.000 & 0.002 \\
\hline $\mathbf{N a}$ & 0.216 & 0.212 & 0.196 & 0.237 & 0.241 & 0.231 & 0.226 & 0.208 & 0.221 & 0.204 & 0.199 & 0.199 \\
\hline $\mathbf{K}$ & 0.751 & 0.758 & 0.736 & 0.755 & 0.768 & 0.745 & 0.765 & 0.737 & 0.733 & 0.745 & 0.737 & 0.739 \\
\hline Total & 6.998 & 7.003 & 6.974 & 7.013 & 7.025 & 7.001 & 7.019 & 6.981 & 6.994 & 6.984 & 6.976 & 6.980 \\
\hline
\end{tabular}


MUSCOVITA - amostra CP-333

\begin{tabular}{|c|c|c|c|c|c|c|c|c|c|c|c|c|c|c|c|c|c|c|}
\hline Point & 1.1 & 2.1 & 3.1 & 4.1 & 5.1 & 5.2 & 5.3 & 6.1 & 7.1 & 8.1 & 8.2 & 8.3 & 9.1 & 9.2 & 10.1 & 10.2 & 10.3 & 11.1 \\
\hline $\mathrm{SiO}_{2}$ & 46.57 & 46.49 & 45.24 & 45.56 & 46.34 & 45.64 & 45.96 & 46.85 & 46.58 & 46.24 & 46.22 & 47.16 & 45.92 & 46.21 & 46.35 & 46.01 & 46.63 & 46.88 \\
\hline $\mathrm{TiO}_{2}$ & 0.60 & 0.87 & 0.72 & 0.45 & 0.71 & 0.66 & 0.55 & 0.70 & 0.42 & 0.62 & 0.62 & 0.77 & 0.55 & 0.50 & 0.62 & 0.58 & 0.60 & 0.83 \\
\hline $\mathrm{Al} 2 \mathrm{O3}$ & 36.18 & 35.57 & 35.76 & 36.13 & 35.63 & 35.46 & 35.75 & 36.53 & 35.84 & 35.35 & 35.79 & 35.00 & 35.74 & 35.74 & 35.75 & 35.66 & 36.31 & 35.25 \\
\hline eO & 1.45 & 1.92 & 1.22 & 1.35 & 0.95 & 1.01 & 0.94 & 1.59 & 1.14 & 1.21 & 1.08 & 1.18 & 0.95 & 0.96 & 0.92 & 0.88 & 0.95 & 1.70 \\
\hline $\mathrm{MnO}$ & 0.01 & 0.01 & 0.02 & 0.01 & 0.01 & 0.00 & 0.00 & 0.02 & 0.01 & 0.00 & 0.00 & 0.00 & 0.00 & 0.02 & 0.00 & 0.00 & 0.00 & 0.01 \\
\hline MgO & 0.67 & 1.09 & 0.69 & 0.60 & 0.72 & 0.64 & 0.61 & 0.65 & 0.54 & 0.82 & 0.68 & 0.95 & 0.61 & 0.62 & 0.70 & 0.62 & 0.62 & 0.82 \\
\hline $\mathrm{CaO}$ & 0.00 & 0.00 & 0.00 & 0.00 & 0.00 & 0.00 & 0.00 & 0.00 & 0.00 & 0.00 & 0.00 & 0.00 & 0.00 & 0.00 & 0.00 & 0.00 & 0.00 & 0.00 \\
\hline $\mathbf{a} 20$ & 1.73 & 1.87 & 1.59 & 1.49 & 1.35 & 1.35 & 1.46 & 1.71 & 1.58 & 1.40 & 1.39 & 1.38 & 1.47 & 1.49 & 1.43 & 1.40 & 1.12 & 1.40 \\
\hline $\mathrm{K}_{2} \mathrm{O}$ & 8.13 & 8.21 & 8.49 & 8.09 & 8.75 & 8.79 & 8.71 & 8.54 & 8.56 & 8.78 & 9.00 & 9.02 & 8.83 & 8.68 & 8.84 & 8.11 & 7.73 & 8.79 \\
\hline Cl & 0.01 & 0.00 & 0.00 & 0.01 & 0.00 & 0.00 & 0.00 & 0.00 & 0.00 & 0.00 & 0.00 & 0.00 & 0.00 & 0.00 & 0.00 & 0.00 & 0.00 & 0.00 \\
\hline Total & 95.55 & 96.18 & 93.82 & 94.14 & 94.88 & 93.98 & 94.40 & 96.73 & 95.05 & 94.51 & 94.86 & 95.72 & 94.46 & 94.69 & 95.03 & 93.65 & 94.34 & 96.03 \\
\hline ii & 066 & 3.047 & 3.038 & & 3.080 & 3.067 & 071 & 3.054 & 3.088 & & 3.069 & 3.109 & & 3.079 & 3.077 & 3.083 & 3.083 & 3.089 \\
\hline $\mathbf{T i}$ & 0.030 & 0.043 & 0.036 & 0.023 & 0.035 & 0.033 & 0.028 & 0.034 & 0.021 & 0.031 & 0.031 & 0.038 & 0.028 & 0.025 & 0.031 & 0.029 & 0.030 & 0.041 \\
\hline Al total & 2.808 & 2.748 & 2.831 & 2.847 & 2.792 & 2.809 & 2.816 & 2.807 & 2.801 & 2.776 & 2.802 & 2.720 & 2.815 & 2.807 & 2.798 & 2.817 & 2.830 & 2.738 \\
\hline IIV & 0.934 & 0.953 & 0.962 & 0.955 & 0.920 & 0.933 & 0.929 & 0.946 & 0.912 & 0.920 & 0.931 & 0.891 & 0.932 & 0.921 & 0.923 & 0.917 & 0.917 & 0.911 \\
\hline IVI & 1.874 & 1.795 & 1.869 & 1.892 & 1.872 & 1.876 & 1.887 & 1.861 & 1.889 & 1.856 & 1.871 & 1.829 & 1.883 & 1.886 & 1.875 & 1.900 & 1.913 & .827 \\
\hline $\mathrm{Fe}^{3+}$ & 0.000 & 0.049 & 0.000 & 0.035 & 0.000 & 0.000 & 0.000 & 0.000 & 0.000 & 0.000 & 0.000 & 0.000 & 0.000 & 0.000 & 0.000 & 0.000 & 0.037 & 0.000 \\
\hline $\mathrm{Fe}^{2+}$ & 0.080 & 0.057 & 0.069 & 0.040 & 0.053 & 0.057 & 0.053 & 0.087 & 0.063 & 0.067 & 0.060 & 0.065 & 0.053 & 0.053 & 0.051 & 0.049 & 0.016 & 0.094 \\
\hline Mn & 0.001 & 0.001 & 0.001 & & 0.001 & 0.000 & 0.000 & 0.001 & 0.001 & 0.000 & 0.000 & 0.000 & 0.000 & 0.001 & 0.000 & 0.000 & 0.000 & 0.001 \\
\hline Mg & 0.066 & 0.106 & 0.069 & 0.060 & 0.071 & 0.064 & 0.061 & 0.063 & 0.053 & 0.081 & 0.067 & 0.093 & 0.061 & 0.062 & 0.069 & 0.062 & 0.061 & 0.081 \\
\hline $\mathrm{Ca}$ & 0.000 & 0.000 & 0.000 & 0.000 & 0.000 & 0.000 & 0.000 & 0.000 & 0.000 & 0.000 & 0.000 & 0.000 & 0.000 & 0.000 & 0.000 & 0.000 & 0.000 & 0.000 \\
\hline $\mathrm{Na}$ & 0.221 & 0.238 & 0.207 & 0.193 & 0.174 & 0.176 & 0.189 & 0.216 & 0.203 & 0.181 & 0.179 & 0.176 & 0.190 & 0.192 & 0.184 & 0.182 & 0.144 & 0.179 \\
\hline 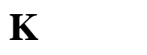 & 0.683 & 0.686 & 0.727 & & 0.742 & 0.754 & 0.742 & 0.710 & 0.724 & 0.746 & 0.762 & & & 0.738 & 0.749 & 0.693 & 0.652 & 0.739 \\
\hline Total & 6.953 & 6.975 & 6.978 & 6.934 & 6.948 & 6.960 & 6.960 & 6.972 & 6.955 & 6.964 & 6.971 & 6.961 & 6.969 & 6.958 & 6.960 & 6.917 & 6.852 & 6.961 \\
\hline
\end{tabular}


BIOTITA - amostra CP-07

borda Grt 1

\begin{tabular}{|c|c|c|c|c|c|c|c|c|c|c|c|c|c|c|}
\hline \multirow[b]{2}{*}{ Ponto } & \multirow{2}{*}{\multicolumn{3}{|c|}{12}} & & & \\
\hline & & & 1.3 & 2.1 & 2.2 & 2.3 & 3.1 & 3.2 & $\mathbf{3 . 3}$ & 4.1 & 4.2 & 4.3 & 5.1 & 5.2 \\
\hline $\mathrm{SiO}_{2}$ & 35.03 & 34.84 & 35.46 & 34.48 & 33.57 & 33.67 & 34.97 & 35.12 & 34.31 & 34.80 & 34.89 & 34.86 & 34.41 & 34.28 \\
\hline $\mathrm{TiO}_{2}$ & 2.12 & 1.86 & 2.03 & 1.73 & 1.86 & 1.97 & 1.69 & 1.80 & 1.71 & 2.06 & 1.71 & 1.61 & 1.73 & 1.90 \\
\hline $\mathrm{Al}_{2} \mathrm{O} 3$ & 19.23 & 19.15 & 19.51 & 18.96 & 18.14 & 19.70 & 19.37 & 19.33 & 19.38 & 19.34 & 19.08 & 19.15 & 19.42 & 19.59 \\
\hline FeO & 16.45 & 16.34 & 16.88 & 17.10 & 16.01 & 15.78 & 16.84 & 16.84 & 16.86 & 16.37 & 17.05 & 16.67 & 15.95 & 16.60 \\
\hline MnO & 0.03 & 0.02 & 0.03 & 0.03 & 0.05 & 0.04 & 0.04 & 0.03 & 0.03 & 0.06 & 0.00 & 0.03 & 0.03 & 0.04 \\
\hline MgO & 11.31 & 10.83 & 10.52 & 10.40 & 10.78 & 10.97 & 11.04 & 11.01 & 10.45 & 10.95 & 10.87 & 10.96 & 10.61 & 10.16 \\
\hline $\mathrm{CaO}$ & 0.07 & 0.03 & 0.04 & 0.15 & 0.14 & 0.15 & 0.05 & 0.05 & 0.08 & 0.09 & 0.13 & 0.08 & 0.23 & 0.15 \\
\hline $\mathrm{Na} 2 \mathrm{O}$ & 0.44 & 0.44 & 0.42 & 0.33 & 0.39 & 0.40 & 0.39 & 0.40 & 0.26 & 0.35 & 0.39 & 0.31 & 0.36 & 0.28 \\
\hline $\mathrm{K}_{2} \mathrm{O}$ & 8.78 & 8.44 & 8.67 & 7.62 & 7.67 & 7.76 & 8.63 & 8.63 & 8.21 & 8.38 & 8.15 & 8.14 & 7.91 & 7.73 \\
\hline $\mathrm{BaO}$ & 0.23 & 0.14 & 0.06 & 0.14 & 0.13 & 0.12 & 0.15 & 0.07 & 0.07 & 0.09 & 0.09 & 0.15 & 0.16 & 0.13 \\
\hline Cl & 0.00 & 0.00 & 0.00 & 0.01 & 0.03 & 0.01 & 0.02 & 0.00 & 0.01 & 0.00 & 0.01 & 0.00 & 0.00 & 0.01 \\
\hline Total & 93.46 & 91.95 & 93.55 & 91.23 & 89.59 & 90.47 & 93.01 & 93.21 & 91.29 & 92.39 & 92.27 & 91.82 & 90.64 & 90.73 \\
\hline $\mathbf{S i}$ & 2.676 & 2.699 & 2.704 & 2.695 & 2.675 & 2.641 & 2.686 & 2.690 & 2.682 & 2.682 & 2.698 & 2.702 & 2.693 & 2.684 \\
\hline $\mathbf{T i}$ & 0.122 & 0.108 & 0.116 & 0.102 & 0.111 & 0.116 & 0.098 & 0.104 & 0.101 & 0.119 & 0.099 & 0.094 & 0.102 & 0.112 \\
\hline Al total & 1.732 & 1.749 & 1.754 & 1.747 & 1.704 & 1.821 & 1.754 & 1.746 & 1.786 & 1.757 & 1.739 & 1.750 & 1.792 & 1.808 \\
\hline AlIV & 1.324 & 1.301 & 1.296 & 1.305 & 1.325 & 1.359 & 1.314 & 1.310 & 1.318 & 1.318 & 1.302 & 1.298 & 1.307 & 1.316 \\
\hline AlVI & 0.408 & 0.448 & 0.458 & 0.442 & 0.379 & 0.462 & 0.440 & 0.436 & 0.468 & 0.439 & 0.437 & 0.452 & 0.485 & 0.492 \\
\hline $\mathbf{F e}^{3+}$ & 0.000 & 0.000 & 0.000 & 0.026 & 0.060 & 0.003 & 0.000 & 0.000 & 0.000 & 0.000 & 0.000 & 0.000 & 0.000 & 0.000 \\
\hline $\mathrm{Fe}^{2+}$ & 1.051 & 1.059 & 1.076 & 1.117 & 1.066 & 1.034 & 1.082 & 1.079 & 1.102 & 1.055 & 1.102 & 1.081 & 1.044 & 1.087 \\
\hline Mn & 0.002 & 0.001 & 0.002 & 0.002 & 0.003 & 0.003 & 0.002 & 0.002 & 0.002 & 0.004 & 0.000 & 0.002 & 0.002 & 0.003 \\
\hline Mg & 1.288 & 1.250 & 1.195 & 1.211 & 1.280 & 1.282 & 1.264 & 1.257 & 1.217 & 1.258 & 1.253 & 1.266 & 1.237 & 1.186 \\
\hline $\mathbf{C a}$ & 0.005 & 0.002 & 0.003 & 0.012 & 0.012 & 0.013 & 0.004 & 0.004 & 0.007 & 0.007 & 0.011 & 0.007 & 0.019 & 0.012 \\
\hline $\mathrm{Na}$ & 0.065 & 0.066 & 0.062 & 0.049 & 0.060 & 0.060 & 0.058 & 0.059 & 0.040 & 0.052 & 0.058 & 0.046 & 0.054 & 0.043 \\
\hline $\mathbf{K}$ & 0.856 & 0.834 & 0.843 & 0.760 & 0.780 & 0.776 & 0.846 & 0.843 & 0.819 & 0.824 & 0.804 & 0.805 & 0.790 & 0.772 \\
\hline Total & 7.797 & 7.768 & 7.755 & 7.721 & 7.751 & 7.749 & 7.794 & 7.784 & 7.756 & 7.758 & 7.764 & 7.753 & 7.733 & 7.707 \\
\hline
\end{tabular}




\section{BIOTITA}

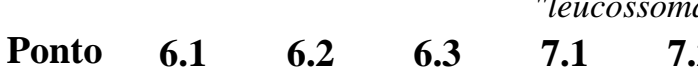

$\begin{array}{lllllllll}\mathbf{S i O} & 34.74 & 35.00 & 35.04 & 34.51 & 34.81 & 34.38 & 34.63 & 34.74\end{array}$

$\begin{array}{llllll}\text { Al2O3 } & 18.63 & 19.18 & 19.21 & 19.34 & 19.26\end{array}$

$\begin{array}{llllllll}\text { MgO } & 10.76 & 10.74 & 10.76 & 10.27 & 10.36 & 10.70 & 10.52\end{array}$

$\begin{array}{llllllll}\mathbf{C a O} & 0.02 & 0.05 & 0.02 & 0.04 & 0.02 & 0.07 & 0.00\end{array}$

$\begin{array}{llllllll}\mathrm{Na2O} & 0.38 & 0.49 & 0.41 & 0.32 & 0.48 & 0.47 & 0.43\end{array}$

$\begin{array}{llllllll}\text { K2O } & 8.80 & 8.72 & 8.72 & 8.96 & 8.91 & 8.84 & 8.95\end{array}$

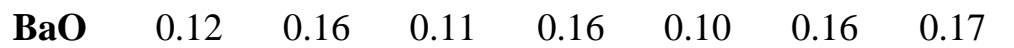

$\begin{array}{llllllll}\text { Cl } & 0.01 & 0.00 & 0.00 & 0.00 & 0.01 & 0.00 & 0.01\end{array}$

$\begin{array}{lllllllll}\text { Total } & 92.62 & 93.31 & 93.56 & 92.66 & 93.20 & 92.25 & 93.12 & 92.18\end{array}$

$\begin{array}{lllllllll}\text { Si } & 2.693 & 2.685 & 2.684 & 2.668 & 2.679 & 2.672 & 2.673 & 2.700\end{array}$

$\begin{array}{lllllllll}\text { Ti } & 0.115 & 0.119 & 0.114 & 0.138 & 0.123 & 0.128 & 0.120 & 0.113\end{array}$

$\begin{array}{llllllll}0.091 & 0.125 & 0.128 & 0.043 & 0.076 & 0.037\end{array}$

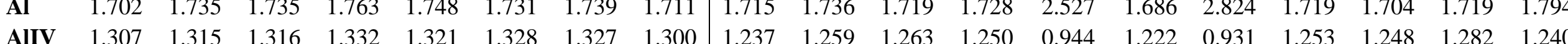

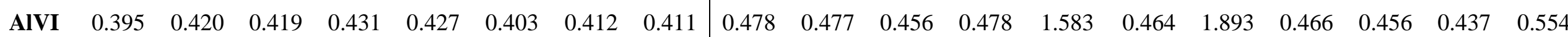

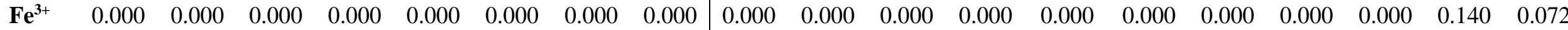

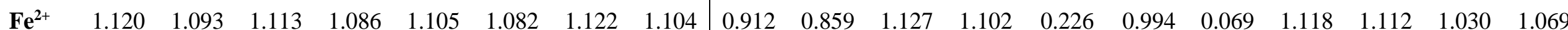

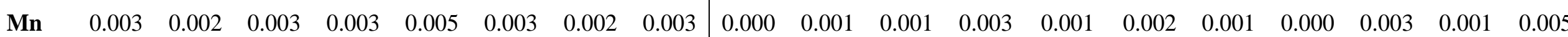

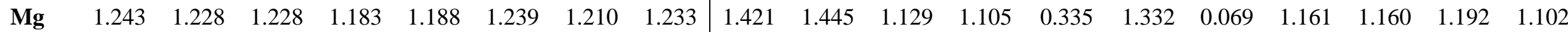

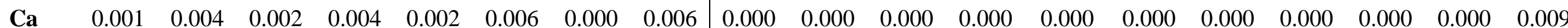

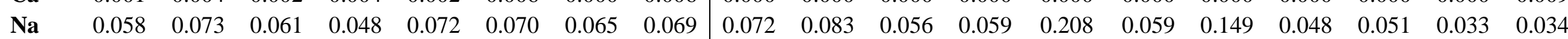

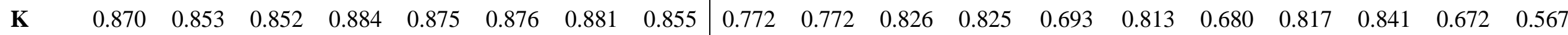

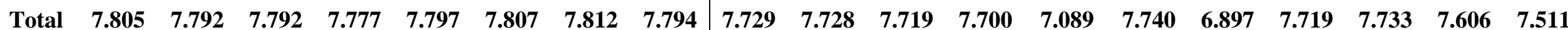


BIOTITA - amostra CP-333

\section{borda Grt 6 in Grt 7}

8

$\begin{array}{llll}\text { SiO2 } & 36.11 & 36.03 & 36.11\end{array}$

$\begin{array}{llll}\mathbf{T i O} 2 & 1.82 & 1.86 & 1.75\end{array}$

$\begin{array}{llll}\mathbf{A l 2 O} & 18.94 & 19.15 & 18.74\end{array}$

$\begin{array}{llll}\text { FeO } & 17.51 & 17.79 & 18.05\end{array}$

$\begin{array}{llll}\text { MnO } & 0.01 & 0.03 & 0.02\end{array}$

$\begin{array}{llll}\text { MgO } & 10.30 & 10.19 & 10.28\end{array}$

$\begin{array}{llll}\mathrm{CaO} & 0.00 & 0.00 & 0.00\end{array}$

$\begin{array}{llll}\mathrm{Na} 2 \mathrm{O} & 0.31 & 0.31 & 0.32\end{array}$

$\begin{array}{llll}\mathbf{K 2 O} & 8.78 & 8.52 & 8.57\end{array}$

$\begin{array}{llll}\text { BaO } & 0.16 & 0.22 & 0.12\end{array}$

$\begin{array}{llll}\text { Cl } & 0.02 & 0.02 & 0.01\end{array}$

Total $93.96 \quad 94.12 \quad 93.97$

$\begin{array}{llll}\text { Si } & 2.752 & 2.742 & 2.755\end{array}$

$\begin{array}{llll}\text { Ti } & 0.104 & 0.106 & 0.100\end{array}$

$\begin{array}{llll}\text { Al } & 1.701 & 1.718 & 1.685\end{array}$

AlIV $\quad 1.248 \quad 1.258 \quad 1.245$

$\begin{array}{llll}\text { AIVI } & 0.453 & 0.460 & 0.440\end{array}$

$\begin{array}{llll}\mathbf{F e}^{3+} & 0.000 & 0.000 & 0.000\end{array}$

$\begin{array}{llll}\mathbf{F e}^{2+} & 1.116 & 1.132 & 1.152\end{array}$

$\begin{array}{llll}\text { Mn } & 0.001 & 0.002 & 0.001\end{array}$

$\begin{array}{llll}\text { Mg } & 1.170 & 1.156 & 1.169\end{array}$

$\begin{array}{llll}\text { Ca } & 0.000 & 0.000 & 0.000\end{array}$

$\begin{array}{lllll}\mathbf{N a} & 0.046 & 0.046 & 0.047\end{array}$

$\begin{array}{llll}\text { K } & 0.854 & 0.827 & 0.834\end{array}$

$\begin{array}{llll}\text { Total } & \mathbf{7 . 7 4} & \mathbf{7 . 7 3} & \mathbf{7 . 7 4}\end{array}$

0.43

8.42

0.16

0.02

94.52

0.000

0.000

0.062

0.800

7.75 $\begin{array}{lllll} & 10.2 & 10.3 & 10.4 & 11.1\end{array}$

$\begin{array}{lllll}36.21 & 36.27 & 36.43 & 35.93 & 36.47\end{array}$ $\begin{array}{llllll}1.54 & 1.56 & 1.56 & 1.50 & 1.89\end{array}$

$\begin{array}{llllll}19.35 & 19.58 & 19.32 & 19.50 & 19.36 & 19.49\end{array}$

$\begin{array}{lllllll}14.85 & 17.86 & 17.63 & 17.94 & 17.86 & 16.01\end{array}$

$\begin{array}{lllllll}0.00 & 0.01 & 0.01 & 0.02 & 0.01 & 0.01\end{array}$

$\begin{array}{llllll}12.92 & 10.35 & 10.40 & 10.36 & 10.25 & 11.90\end{array}$

$\begin{array}{llllll}0.00 & 0.00 & 0.00 & 0.00 & 0.00 & 0.00\end{array}$

2.742

0.088

1.699

1.258

0.441

0.000

0.925

1.434 $\begin{array}{lllll}0.33 & 0.33 & 0.33 & 0.33 & 0.37\end{array}$

$\begin{array}{lllll}0.13 & 0.15 & 0.14 & 0.17 & 0.15\end{array}$

$\begin{array}{lllll}0.02 & 0.02 & 0.02 & 0.02 & 0.02\end{array}$

$\begin{array}{lllll}94.55 & 94.28 & 94.88 & 94.00 & 94.80\end{array}$

$\begin{array}{llllll}2.738 & 2.750 & 2.746 & 2.738 & 2.726 & 2.746\end{array}$ $\begin{array}{lllllll}0.088 & 0.089 & 0.088 & 0.086 & 0.106 & 0.092\end{array}$ $\begin{array}{llllll}1.745 & 1.727 & 1.733 & 1.739 & 1.718 & 1.736\end{array}$ $\begin{array}{llllll}1.262 & 1.250 & 1.254 & 1.262 & 1.274 & 1.254\end{array}$ $\begin{array}{lllllll}0.483 & 0.477 & 0.479 & 0.477 & 0.444 & 0.482\end{array}$ $\begin{array}{lllllll}0.000 & 0.000 & 0.000 & 0.000 & 0.000 & 0.000\end{array}$ $\begin{array}{llllll}1.129 & 1.118 & 1.131 & 1.138 & 1.001 & 1.123\end{array}$ $\begin{array}{lllllll}0.001 & 0.001 & 0.001 & 0.001 & 0.001 & 0.002\end{array}$ $\begin{array}{llllll}1.166 & 1.175 & 1.164 & 1.164 & 1.326 & 1.163\end{array}$ $\begin{array}{lllllll}0.000 & 0.000 & 0.000 & 0.000 & 0.000 & 0.000\end{array}$ $\begin{array}{lllllll}0.048 & 0.049 & 0.048 & 0.049 & 0.054 & 0.047\end{array}$ $\begin{array}{lllllll}0.821 & 0.830 & 0.824 & 0.835 & 0.810 & 0.818\end{array}$ $\begin{array}{lllllll}\mathbf{7 . 7 4} & \mathbf{7 . 7 4} & \mathbf{7 . 7 4} & \mathbf{7 . 7 5} & \mathbf{7 . 7 4} & \mathbf{7 . 7 3}\end{array}$ $\begin{array}{lllll}8.51 & 8.58 & 8.57 & 8.59 & 8.49\end{array}$
Grt 9
12.1

36.03

1.61
19.32

17.62

10.24

0.00

0.32

8.41

0.18
0.02

93.79

46
.092
.736
.254
.82
.000
23
.002
163
.000
.047
.818
.73

\begin{tabular}{|c|c|c|c|c|}
\hline da grt9 & \multicolumn{3}{|c|}{ borda Grt 10} & in Grt \\
\hline 13.1 & 14.1 & 14.2 & 14.3 & 15.1 \\
\hline 36.01 & 35.82 & 35.85 & 35.53 & 36.51 \\
\hline 1.68 & 1.55 & 1.54 & 1.69 & 1.71 \\
\hline 19.50 & 19.33 & 19.35 & 19.05 & 19.25 \\
\hline 17.53 & 17.30 & 17.71 & 16.96 & 15.12 \\
\hline 0.02 & 0.04 & 0.02 & 0.00 & 0.00 \\
\hline 10.44 & 10.50 & 10.35 & 10.15 & 12.70 \\
\hline 0.00 & 0.00 & 0.00 & 0.00 & 0.00 \\
\hline 0.30 & 0.32 & 0.31 & 0.33 & 0.42 \\
\hline 8.63 & 8.69 & 8.63 & 8.70 & 8.36 \\
\hline 0.16 & 0.14 & 0.10 & 0.16 & 0.16 \\
\hline 0.03 & 0.02 & 0.02 & 0.02 & 0.02 \\
\hline 94.30 & 93.71 & 93.89 & 92.60 & 94.24 \\
\hline 2.731 & 2.733 & 2.733 & 2.743 & 2.733 \\
\hline 0.096 & 0.089 & 0.088 & 0.098 & 0.096 \\
\hline 1.743 & 1.739 & 1.739 & 1.734 & 1.699 \\
\hline 1.269 & 1.267 & 1.267 & 1.257 & 1.267 \\
\hline 0.474 & 0.472 & 0.472 & 0.477 & 0.432 \\
\hline 0.000 & 0.000 & 0.000 & 0.000 & 0.000 \\
\hline 1.112 & 1.104 & 1.129 & 1.095 & 0.947 \\
\hline 0.001 & 0.003 & 0.001 & 0.000 & 0.000 \\
\hline 1.180 & 1.194 & 1.176 & 1.168 & 1.417 \\
\hline 0.000 & 0.000 & 0.000 & 0.000 & 0.000 \\
\hline 0.044 & 0.047 & 0.046 & 0.049 & 0.061 \\
\hline 0.835 & 0.846 & 0.839 & 0.857 & 0.798 \\
\hline 7.74 & 7.76 & 7.75 & 7.75 & 7.75 \\
\hline
\end{tabular}

\section{borda Grt 11}

$\begin{array}{llll}16.1 & 16.2 & 16.3 & 16.4\end{array}$

$\begin{array}{llll}36.53 & 36.04 & 35.99 & 36.35\end{array}$

$\begin{array}{llll}1.78 & 1.81 & 1.78 & 1.76\end{array}$

$\begin{array}{llll}19.49 & 19.21 & 19.63 & 19.67\end{array}$

$\begin{array}{llll}17.77 & 17.65 & 17.54 & 17.10\end{array}$

$\begin{array}{lllll}0.01 & 0.02 & 0.04 & 0.02\end{array}$

$\begin{array}{llll}10.40 & 10.24 & 10.23 & 10.19\end{array}$

$\begin{array}{lllll}0.00 & 0.00 & 0.00 & 0.00\end{array}$

$\begin{array}{lllll}0.37 & 0.36 & 0.37 & 0.32\end{array}$

$\begin{array}{lllll}8.53 & 8.44 & 8.59 & 8.53\end{array}$

$\begin{array}{llll}0.21 & 0.16 & 0.22 & 0.10\end{array}$

$\begin{array}{lllll}0.01 & 0.01 & 0.02 & 0.03\end{array}$

$\begin{array}{llll}95.12 & 93.94 & 94.40 & 94.06\end{array}$

$\begin{array}{llll}2.745 & 2.743 & 2.727 & 2.750\end{array}$ $\begin{array}{lllll}0.101 & 0.104 & 0.101 & 0.100\end{array}$ $\begin{array}{llll}1.727 & 1.723 & 1.754 & 1.755\end{array}$ $\begin{array}{lllll}1.255 & 1.257 & 1.273 & 1.250\end{array}$ $\begin{array}{lllll}0.472 & 0.466 & 0.481 & 0.505\end{array}$ $\begin{array}{lllll}0.000 & 0.000 & 0.000 & 0.000\end{array}$ $\begin{array}{llll}1.117 & 1.123 & 1.112 & 1.082\end{array}$ $\begin{array}{llll}0.001 & 0.001 & 0.003 & 0.001\end{array}$ $\begin{array}{llll}1.165 & 1.161 & 1.155 & 1.149\end{array}$ $\begin{array}{lllll}0.000 & 0.000 & 0.000 & 0.000\end{array}$ $\begin{array}{lllll}0.054 & 0.053 & 0.054 & 0.047\end{array}$ $\begin{array}{lllll}0.818 & 0.819 & 0.830 & 0.823\end{array}$ $\begin{array}{llll}\mathbf{7 . 7 3} & \mathbf{7 . 7 3} & \mathbf{7 . 7 4} & \mathbf{7 . 7 1}\end{array}$ 
BIOTITA - amostra CP-60

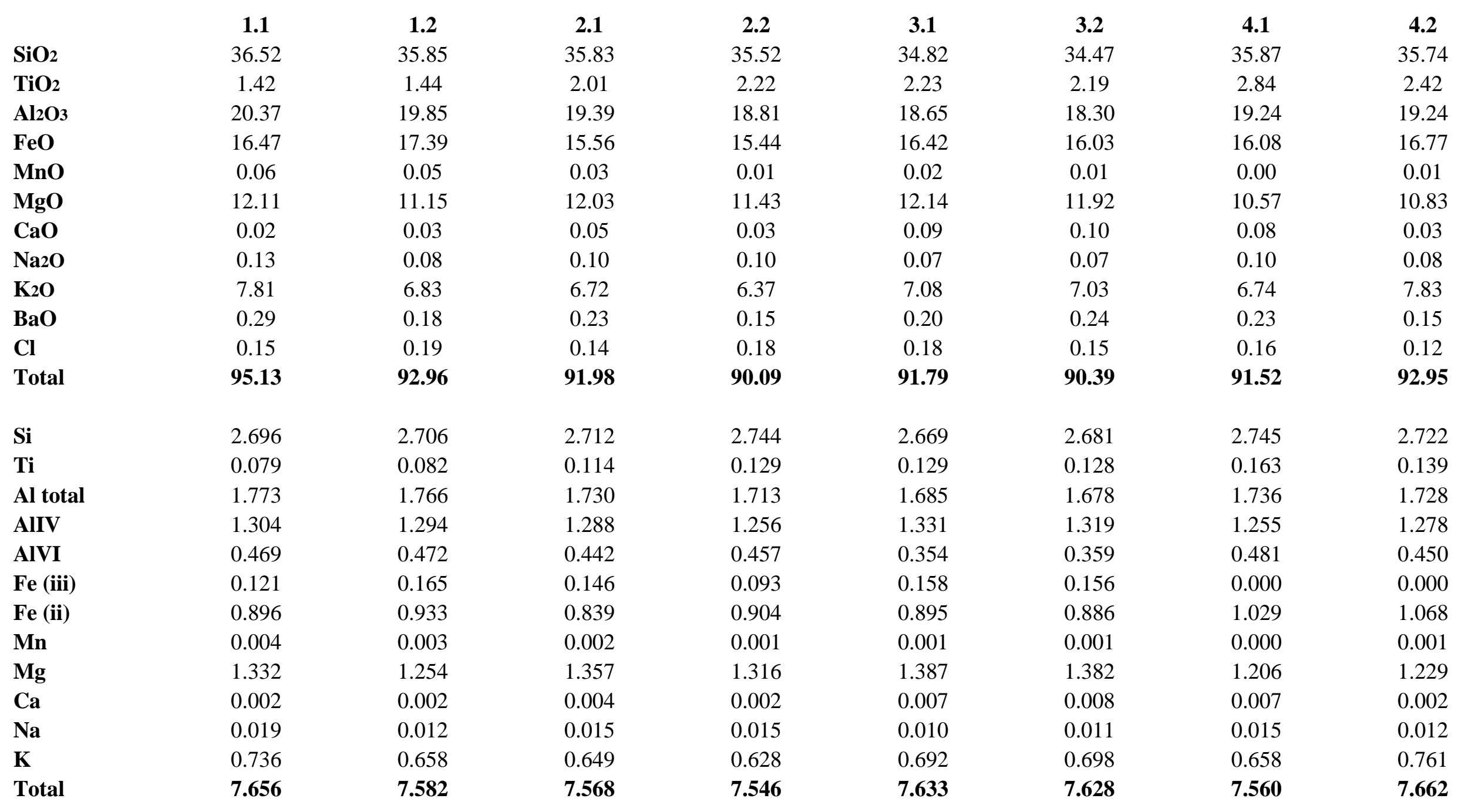


BIOTITA - amostra CP-65

\begin{tabular}{|c|c|c|c|c|c|c|c|c|c|c|c|c|c|c|}
\hline & & & & & & & & & & & & & & \\
\hline & 1.1 & 2.1 & 3.1 & 4.1 & 5.1 & 6.1 & 1.1 & 1.2 & 2.1 & 3.1 & 4.1 & 5.1 & 5.2 & 6.1-inclu \\
\hline $\mathrm{SiO} 2$ & 33.34 & 33.65 & 34.16 & 34.09 & 34.02 & 34.05 & 34.12 & 33.85 & 34.19 & 34.00 & 34.45 & 34.72 & 34.11 & 34.12 \\
\hline TiO2 & 2.29 & 2.54 & 2.80 & 3.02 & 2.71 & 2.28 & 2.77 & 2.66 & 1.99 & 2.41 & 2.70 & 2.89 & 2.77 & 3.66 \\
\hline Al2O3 & 14.88 & 14.88 & 15.40 & 15.08 & 15.22 & 15.15 & 15.48 & 15.39 & 15.53 & 15.21 & 15.32 & 15.57 & 15.49 & 15.04 \\
\hline $\mathrm{FeO}$ & 26.15 & 26.32 & 25.68 & 26.14 & 25.85 & 25.80 & 26.84 & 27.27 & 27.32 & 27.88 & 27.05 & 26.00 & 26.44 & 26.67 \\
\hline MnO & 0.30 & 0.35 & 0.40 & 0.42 & 0.38 & 0.38 & 0.48 & 0.48 & 0.36 & 0.42 & 0.26 & 0.26 & 0.28 & 0.27 \\
\hline $\mathrm{MgO}$ & 6.98 & 6.88 & 6.35 & 6.50 & 6.69 & 6.67 & 5.76 & 5.87 & 6.04 & 5.71 & 6.15 & 6.15 & 6.30 & 5.85 \\
\hline $\mathrm{CaO}$ & 0.06 & 0.03 & 0.02 & 0.03 & 0.31 & 0.04 & 0.02 & 0.00 & 0.02 & 0.00 & 0.02 & 0.02 & 0.04 & 0.01 \\
\hline $\mathrm{Na} 2 \mathrm{O}$ & 0.13 & 0.06 & 0.10 & 0.12 & 0.06 & 0.06 & 0.05 & 0.07 & 0.07 & 0.07 & 0.04 & 0.10 & 0.06 & 0.07 \\
\hline K2O & 9.50 & 9.75 & 9.72 & 9.74 & 9.26 & 9.59 & 9.85 & 9.71 & 9.83 & 9.70 & 9.76 & 9.73 & 9.88 & 9.76 \\
\hline $\mathbf{B a O}$ & 0.34 & 0.28 & 0.26 & 0.37 & 0.29 & 0.31 & 0.25 & 0.31 & 0.29 & 0.30 & 0.26 & 0.29 & 0.25 & 0.22 \\
\hline $\mathrm{Cl}$ & 0.00 & 0.00 & 0.00 & 0.00 & 0.02 & 0.01 & 0.00 & 0.01 & 0.00 & 0.01 & 0.00 & 0.00 & 0.01 & 0.01 \\
\hline Total & 93.77 & 94.53 & 94.63 & 95.14 & 94.5 & 94.02 & 95.37 & 95.3 & 95.38 & 95.4 & 95.75 & 95.44 & 95.37 & 95.45 \\
\hline $\mathbf{S i}$ & 2.702 & 2.710 & 2.736 & 2.724 & 2.727 & 2.746 & 2.728 & 2.715 & 2.738 & 2.730 & 2.739 & 2.752 & 2.720 & 2.722 \\
\hline $\mathbf{T i}$ & 0.140 & 0.154 & 0.169 & 0.181 & 0.163 & 0.138 & 0.167 & 0.160 & 0.120 & 0.146 & 0.161 & 0.172 & 0.166 & 0.220 \\
\hline Al & 1.422 & 1.413 & 1.454 & 1.421 & 1.438 & 1.441 & 1.459 & 1.455 & 1.466 & 1.440 & 1.436 & 1.455 & 1.456 & 1.414 \\
\hline AlIV & 1.298 & 1.290 & 1.264 & 1.276 & 1.273 & 1.254 & 1.272 & 1.285 & 1.262 & 1.270 & 1.261 & 1.248 & 1.280 & 1.278 \\
\hline AIVI & 0.124 & 0.123 & 0.190 & 0.145 & 0.165 & 0.187 & 0.187 & 0.170 & 0.204 & 0.170 & 0.175 & 0.207 & 0.176 & 0.136 \\
\hline $\mathrm{Fe} 3$ & 0.081 & 0.041 & 0.000 & 0.000 & 0.000 & 0.000 & 0.000 & 0.000 & 0.000 & 0.004 & 0.000 & 0.000 & 0.000 & 0.000 \\
\hline $\mathrm{Fe} 2$ & 1.692 & 1.732 & 1.720 & 1.747 & 1.733 & 1.740 & 1.795 & 1.829 & 1.830 & 1.869 & 1.799 & 1.724 & 1.764 & 1.779 \\
\hline Mn & 0.021 & 0.024 & 0.027 & 0.029 & 0.026 & 0.026 & 0.033 & 0.033 & 0.024 & 0.029 & 0.018 & 0.017 & 0.019 & 0.018 \\
\hline Mg & 0.843 & 0.826 & 0.758 & 0.774 & 0.799 & 0.802 & 0.686 & 0.702 & 0.721 & 0.683 & 0.729 & 0.726 & 0.749 & 0.695 \\
\hline $\mathrm{Ca}$ & 0.005 & 0.003 & 0.002 & 0.002 & 0.026 & 0.003 & 0.002 & 0.000 & 0.002 & 0.000 & 0.002 & 0.002 & 0.003 & 0.001 \\
\hline $\mathbf{N a}$ & 0.021 & 0.010 & 0.015 & 0.018 & 0.009 & 0.009 & 0.008 & 0.011 & 0.011 & 0.011 & 0.006 & 0.015 & 0.009 & 0.011 \\
\hline $\mathbf{K}$ & 0.982 & 1.002 & 0.993 & 0.993 & 0.947 & 0.987 & 1.005 & 0.994 & 1.004 & 0.994 & 0.990 & 0.984 & 1.005 & 0.993 \\
\hline Total & 7.91 & 7.915 & 7.874 & 7.89 & 7.869 & 7.894 & 7.883 & 7.9 & 7.917 & 7.906 & 7.88 & 7.848 & 7.893 & 7.854 \\
\hline
\end{tabular}


Reformatted oxide percentages based on 28 oxygens (with $\mathrm{Fe} 2+/ \mathrm{Fe} 3+$ and $\mathrm{OH}$ calculated assuming full site occupancy)

\begin{tabular}{|c|c|c|c|c|c|c|c|c|c|c|c|c|c|c|c|c|c|c|c|}
\hline \multirow[b]{2}{*}{ Ponto } & \multicolumn{11}{|c|}{ CP-06 } & \multicolumn{8}{|c|}{ CP-54A } \\
\hline & 1.1 & 1.2 & 2.1 & 2.2 & 3.1 & 3.2 & 4.1 & 4.2 & 5.1 & 6.1 & 6.2 & 1.1 & 1.2 & 1.3 & 2.1 & 2.2 & 3.1 & 3.2 & 3.3 \\
\hline $\mathrm{SiO}_{2}$ & 29.66 & 29.46 & 28.85 & 28.28 & 29.43 & 29.47 & 29.34 & 29.44 & 29.05 & 28.48 & 29.03 & 29.74 & 29.71 & 29.56 & 29.49 & 29.49 & 29.43 & 29.52 & 29.45 \\
\hline $\mathrm{TiO}_{2}$ & 0.08 & 0.08 & 0.07 & 0.11 & 0.06 & 0.12 & 0.01 & 0.06 & 0.09 & 0.17 & 0.07 & 0.06 & 0.09 & 0.07 & 0.11 & 0.11 & 0.08 & 0.06 & 0.05 \\
\hline $\mathrm{Al}_{2} \mathrm{O}_{3}$ & 18.58 & 18.82 & 18.86 & 18.69 & 19.02 & 18.86 & 19.16 & 18.86 & 19.12 & 18.37 & 18.76 & 18.64 & 18.47 & 18.87 & 18.29 & 18.48 & 18.52 & 18.69 & 17.82 \\
\hline $\mathrm{Fe}_{2} \mathrm{O}_{3}$ & 0.64 & 0.09 & 0.00 & 0.00 & 0.21 & 0.22 & 0.42 & 0.22 & 0.18 & 0.00 & 0.00 & 0.39 & 0.34 & 0.35 & 0.13 & 0.36 & 0.14 & 0.24 & 0.10 \\
\hline $\mathrm{FeO}$ & 5.92 & 6.54 & 6.67 & 6.66 & 6.37 & 6.59 & 6.51 & 6.55 & 6.45 & 6.67 & 6.59 & 5.19 & 5.17 & 5.20 & 5.40 & 5.29 & 5.71 & 5.32 & 6.02 \\
\hline MnO & 0.02 & 0.02 & 0.02 & 0.03 & 0.02 & 0.02 & 0.01 & 0.02 & 0.05 & 0.04 & 0.05 & 0.03 & 0.02 & 0.03 & 0.01 & 0.03 & 0.01 & 0.01 & 0.02 \\
\hline MgO & 28.74 & 29.45 & 29.23 & 30.04 & 29.34 & 29.23 & 28.60 & 29.07 & 28.98 & 29.74 & 29.49 & 29.90 & 29.93 & 29.80 & 29.93 & 29.55 & 29.80 & 29.85 & 29.50 \\
\hline $\mathrm{ZnO}$ & 0.04 & 0.00 & 0.01 & 0.03 & 0.01 & 0.00 & 0.00 & 0.01 & 0.00 & 0.01 & 0.00 & 0.04 & 0.02 & 0.03 & 0.05 & 0.02 & 0.00 & 0.03 & 0.00 \\
\hline $\mathrm{CaO}$ & 0.07 & 0.05 & 0.02 & 0.03 & 0.00 & 0.02 & 0.06 & 0.10 & 0.01 & 0.06 & 0.05 & 0.00 & 0.00 & 0.00 & 0.04 & 0.03 & 0.04 & 0.05 & 0.04 \\
\hline $\mathrm{Na}_{2} \mathrm{O}$ & 0.00 & 0.01 & 0.01 & 0.00 & 0.00 & 0.00 & 0.01 & 0.01 & 0.00 & 0.00 & 0.01 & 0.00 & 0.00 & 0.00 & 0.01 & 0.01 & 0.01 & 0.01 & 0.01 \\
\hline $\mathbf{K}_{2} \mathbf{O}$ & 0.00 & 0.01 & 0.00 & 0.01 & 0.01 & 0.01 & 0.01 & 0.01 & 0.02 & 0.00 & 0.01 & 0.00 & 0.0 & 0.00 & 0.03 & 0.00 & 0.00 & 0.00 & 0.02 \\
\hline $\mathrm{BaO}$ & 0.02 & 0.00 & 0.00 & 0.00 & 0.00 & 0.01 & 0.00 & 0.00 & 0.01 & 0.0 & 0.09 & 0.02 & 0.0 & 0.00 & 0.03 & 0.00 & 0.05 & 0.00 & 0.00 \\
\hline $\mathbf{F}$ & 0.01 & 0.00 & 0.01 & 0.00 & 0.00 & 0.00 & 0.00 & 0.00 & 0.00 & 0.00 & 0.00 & 0.03 & 0.00 & 0.01 & 0.01 & 0.01 & 0.02 & 0.01 & 0.00 \\
\hline Cl & 0.01 & 0.00 & 0.02 & 0.02 & 0.00 & 0.00 & 0.00 & 0.00 & 0.01 & 0.01 & 0.00 & 0.00 & 0.00 & 0.00 & 0.01 & 0.00 & 0.01 & 0.00 & 0.00 \\
\hline H2O* & 12.04 & 12.15 & 12.01 & 12.00 & 12.15 & 12.14 & 12.08 & 12.12 & 12.06 & 11. & 12.07 & 12.12 & 12.11 & 12.13 & 12.05 & 12.04 & 12.06 & 12.10 & 11.96 \\
\hline Total & 95.82 & 96.69 & 95.75 & 95.88 & 96.62 & 96.68 & 96.23 & 96.48 & 96.02 & 95.55 & 96.23 & 96.14 & 95.84 & 96.04 & 95.58 & 95.40 & 95.88 & 95.88 & 94.98 \\
\hline $\mathbf{S i}$ & 5.891 & 5.813 & 5.750 & 5.619 & 5.806 & 5.817 & 5.816 & & 5.772 & 5.687 & 5.759 & 5.863 & 5.877 & 5.836 & 5.858 & 5.864 & & & 5.903 \\
\hline Al iv & 2.109 & 2.187 & 2.250 & 2.381 & 2.194 & 2.183 & 2.184 & 2.177 & 2.228 & 2.313 & 2.241 & 2.137 & 2.123 & 2.164 & 2.142 & 2.136 & 2.167 & 2.159 & 2.097 \\
\hline Al vi & 2.249 & 2.192 & 2.185 & 2.018 & 2.232 & 2.208 & 2.299 & 2.223 & 2.253 & 2.026 & 2.152 & 2.200 & 2.187 & 2.231 & 2.143 & 2.201 & 2.163 & 2.203 & 2.114 \\
\hline $\mathbf{T i}$ & 0.011 & 0.012 & 0.010 & 0.016 & 0.008 & 0.018 & 0.002 & 0.009 & 0.013 & 0.026 & 0.011 & 0.0 & 0.013 & 0.011 & 0.017 & 0.01 & 0.0 & 0.009 & 0.008 \\
\hline $\mathrm{Fe}^{3+}$ & 0.096 & 0.014 & 0.000 & 0.000 & 0.031 & 0.033 & 0.063 & 0.033 & 0.027 & 0.000 & 0.000 & 0.058 & 0.050 & 0.053 & 0.020 & 0.054 & 0.021 & 0.035 & 0.015 \\
\hline $\mathrm{Fe}^{2+}$ & 0.984 & 1.079 & 1.126 & 1.241 & 1.051 & 1.088 & 1.079 & 1.083 & 1.071 & 1.211 & 1.124 & 0.856 & 0.855 & 0.859 & 0.897 & 0.879 & 0.947 & 0.880 & 1.009 \\
\hline Mn & 0.003 & 0.004 & 0.003 & 0.004 & 0.004 & 0.003 & 0.002 & 0.004 & 0.009 & 0.007 & 0.008 & 0.006 & 0.003 & 0.005 & 0.002 & 0.005 & 0.002 & 0.001 & 0.003 \\
\hline Mg & 8.510 & 8.663 & 8.685 & 8.898 & 8.629 & 8.601 & 8.452 & 8.571 & 8.584 & 8.852 & 8.722 & 8.787 & 8.825 & 8.770 & 8.862 & 8.760 & & 8.804 & 8.814 \\
\hline $\mathbf{Z n}$ & 0.005 & 0.000 & 0.001 & 0.004 & 0.002 & 0.000 & 0.000 & 0.001 & 0.000 & 0.001 & 0.000 & 0.005 & 0.002 & 0.004 & 0.007 & 0.002 & 0.001 & 0.005 & 0.000 \\
\hline Ca & 0.016 & 0.011 & 0.004 & 0.005 & 0.000 & 0.004 & 0.014 & 0.022 & 0.003 & 0.013 & 0.010 & 0.000 & 0.000 & 0.000 & 0.009 & 0.007 & 0.008 & 0.010 & 0.008 \\
\hline $\mathbf{N a}$ & 0.000 & 0.006 & 0.005 & 0.000 & 0.000 & 0.000 & 0.011 & 0.010 & 0.000 & 0.000 & 0.010 & 0.000 & 0.000 & 0.000 & 0.008 & 0.011 & 0.010 & 0.009 & 0.005 \\
\hline $\mathbf{K}$ & 0.000 & 0.007 & 0.000 & 0.007 & 0.003 & 0.005 & 0.004 & 0.005 & 0.008 & 0.001 & 0.006 & 0.000 & 0.001 & 0.001 & 0.014 & 0.000 & 0.000 & 0.000 & 0.010 \\
\hline $\mathbf{B a}$ & 0.003 & 0.000 & 0.000 & 0.000 & 0.000 & 0.001 & 0.000 & 0.000 & 0.001 & 0.005 & 0.014 & 0.003 & 0.000 & 0.000 & 0.004 & 0.000 & 0.007 & 0.000 & 0.000 \\
\hline $\mathbf{F}$ & 0.010 & 0.000 & 0.010 & 0.004 & 0.000 & 0.000 & 0.000 & 0.000 & 0.000 & 0.000 & 0.000 & 0.036 & 0.001 & 0.011 & 0.011 & 0.006 & 0.029 & 0.008 & 0.000 \\
\hline Cl & 0.005 & 0.000 & 0.012 & 0.013 & 0.002 & 0.001 & 0.000 & 0.000 & 0.003 & 0.004 & 0.000 & 0.000 & 0.000 & 0.000 & 0.005 & 0.000 & 0.005 & 0.001 & 0.000 \\
\hline OH* & 15.98 & 16.00 & 15.98 & 15.98 & 16.00 & 16.00 & 16.00 & 16.00 & 16.00 & 16.00 & 16.00 & 15.96 & 16.00 & 15.99 & 15.98 & 15.99 & 15.97 & 15.99 & 16.00 \\
\hline Total & 35.88 & 35.99 & 36.02 & 36.19 & 35.96 & 35.96 & 35.92 & 35.96 & 35.97 & 36.14 & 36.06 & 35.92 & 35.94 & 35.93 & 35.98 & 35.93 & 35.98 & 35.96 & 35.99 \\
\hline
\end{tabular}


CLORITA

Reformatted oxide percentages based on 28 oxygens (with $\mathrm{Fe}^{2+} / \mathrm{Fe}^{3+}$ and $\mathrm{OH}^{-}$calculated assuming full site occupancy)

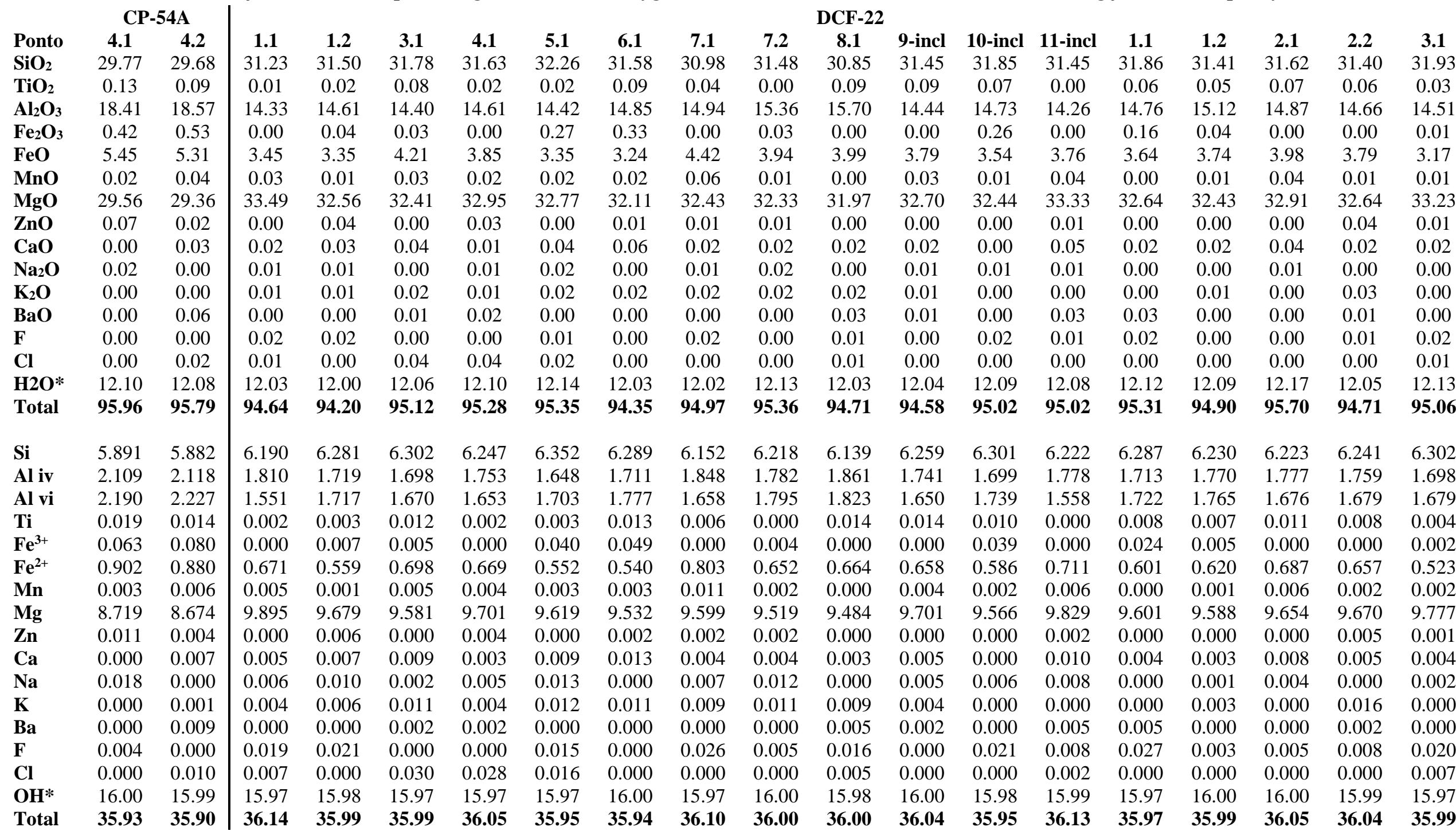




\section{PLAGIOCLÁSIO - amostra CP-07}

\begin{tabular}{|c|c|c|c|c|c|c|c|c|c|c|c|c|c|c|c|c|c|c|c|c|}
\hline Ponto & 1.1 & 1.2 & 1.3 & 1.4 & 1.5 & 1.6 & 1.7 & 1.8 & 1.9 & 1.10 & 1.11 & 1.12 & 1.13 & 1.14 & 1.15 & 1.16 & 1.17 & 1.18 & 1.19 & 1.20 \\
\hline $\mathrm{SiO}_{2}$ & 63.43 & 63.74 & 64.21 & 64.33 & 63.71 & 62.05 & 62.72 & 63.81 & 62.61 & 62.27 & 61.67 & 63.90 & 62.83 & 64.40 & 64.70 & 63.74 & 63.92 & 64.51 & 64.16 & 63.25 \\
\hline $\mathrm{TiO}_{2}$ & 0.00 & 0.00 & 0.00 & 0.00 & 0.00 & 0.00 & 0.00 & 0.00 & 0.00 & 0.00 & 0.00 & 0.00 & 0.00 & 0.00 & 0.00 & 0.00 & 0.00 & 0.00 & 0.00 & 0.00 \\
\hline $\mathrm{Al}_{2} \mathrm{O}_{3}$ & 22.64 & 22.76 & 22.73 & 22.46 & 22.92 & 23.79 & 23.79 & 22.97 & 23.66 & 23.66 & 24.68 & 23.00 & 23.54 & 22.51 & 22.52 & 22.55 & 22.68 & 22.81 & 22.64 & 22.47 \\
\hline $\mathrm{Cr}_{2} \mathrm{O}_{3}$ & 0.00 & 0.00 & 0.00 & 0.00 & 0.00 & 0.00 & 0.00 & 0.00 & 0.00 & 0.00 & 0.00 & 0.00 & 0.00 & 0.00 & 0.00 & 0.00 & 0.00 & 0.00 & 0.00 & 0.00 \\
\hline $\mathrm{Fe}_{2} \mathrm{O}_{3}$ & 0.01 & 0.01 & 0.00 & 0.03 & 0.01 & 0.02 & 0.00 & 0.00 & 0.01 & 0.00 & 0.02 & 0.00 & 0.02 & 0.00 & 0.00 & 0.00 & 0.03 & 0.00 & 0.01 & 0.01 \\
\hline $\mathrm{FeO}$ & 0.00 & 0.00 & 0.00 & 0.00 & 0.00 & 0.00 & 0.00 & 0.00 & 0.00 & 0.00 & 0.00 & 0.00 & 0.00 & 0.00 & 0.00 & 0.00 & 0.00 & 0.00 & 0.00 & 0.00 \\
\hline MnO & 0.00 & 0.00 & 0.00 & 0.00 & 0.00 & 0.00 & 0.00 & 0.00 & 0.00 & 0.00 & 0.00 & 0.00 & 0.00 & 0.00 & 0.00 & 0.00 & 0.00 & 0.00 & 0.00 & 0.00 \\
\hline MgO & 0.00 & 0.00 & 0.00 & 0.00 & 0.00 & 0.00 & 0.00 & 0.00 & 0.00 & 0.00 & 0.00 & 0.00 & 0.00 & 0.00 & 0.00 & 0.00 & 0.00 & 0.00 & 0.00 & 0.00 \\
\hline $\mathrm{CaO}$ & 3.56 & 3.43 & 3.44 & 3.22 & 3.82 & 4.76 & 4.47 & 3.60 & 4.48 & 4.59 & 5.58 & 3.61 & 4.43 & 3.24 & 3.15 & 3.39 & 3.43 & 3.41 & 3.33 & 3.46 \\
\hline $\mathrm{Na}_{2} \mathrm{O}$ & 9.66 & 9.75 & 9.61 & 9.73 & 9.32 & 8.80 & 8.85 & 9.38 & 8.88 & 8.92 & 8.38 & 9.38 & 9.10 & 9.77 & 9.67 & 9.54 & 9.49 & 9.44 & 9.74 & 9.60 \\
\hline $\mathrm{K}_{2} \mathrm{O}$ & 0.06 & 0.10 & 0.11 & 0.12 & 0.12 & 0.11 & 0.11 & 0.12 & 0.12 & 0.11 & 0.11 & 0.14 & 0.13 & 0.15 & 0.14 & 0.14 & 0.12 & 0.11 & 0.12 & 0.09 \\
\hline
\end{tabular}

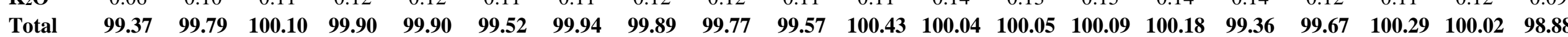

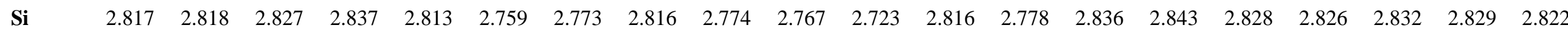

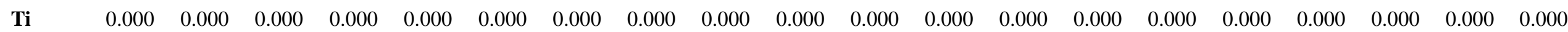

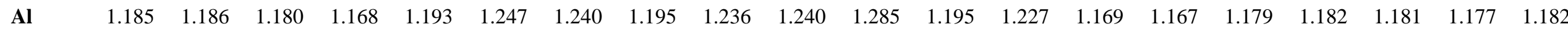

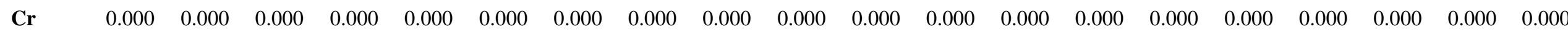

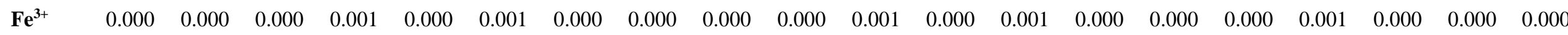

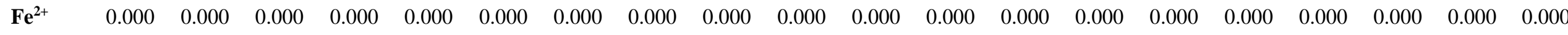

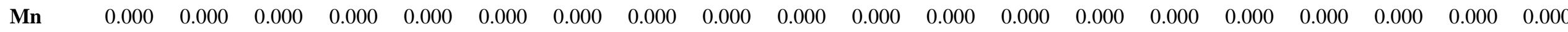

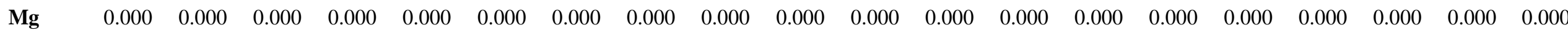

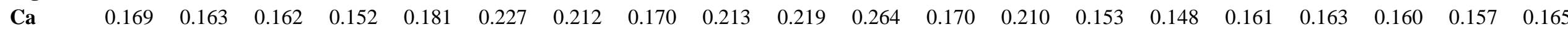

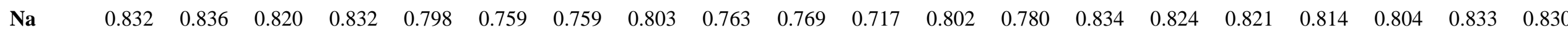

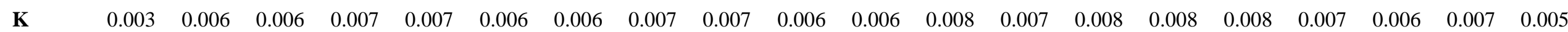

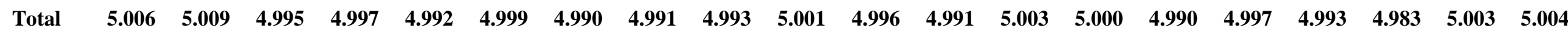

\begin{tabular}{|c|c|c|c|c|c|c|c|c|c|c|c|c|c|c|c|c|c|c|c|}
\hline \multirow[t]{2}{*}{ An } & 0.17 & 0.16 & 0.16 & 0.15 & 0.18 & 0.23 & 0.22 & 0.17 & 0.22 & 0.22 & 0.27 & 0.17 & 0.21 & 0.15 & 0.15 & 0.16 & 0.17 & 0.16 & 0.16 \\
\hline & 0.83 & 0.83 & 0.83 & 0.84 & 0.81 & 0.77 & 0.78 & 0.82 & 0.78 & 0.77 & 0.73 & 0.82 & 0.78 & 0.84 & 0.84 & 0.83 & 0.83 & 0.83 & 0.84 \\
\hline 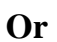 & 0.00 & 0.01 & 0.01 & 0.01 & 0.01 & 0.01 & 0.01 & 0.01 & 0.01 & 0.01 & 0.01 & 0.01 & 0.01 & 0.01 & 0.01 & 0.01 & 0.01 & 0.01 & 0.01 \\
\hline
\end{tabular}


PLAGIOCLÁSIO - amostra CP-07 (continuação)

\begin{tabular}{|c|c|c|c|c|c|c|c|c|c|c|c|c|c|c|c|c|c|c|c|c|}
\hline Ponto & 2.1 & 2.2 & 2.3 & 2.4 & 2.5 & 2.6 & 2.7 & 2.8 & 3.1 & 3.2 & 3.3 & 3.4 & 3.5 & 3.6 & 3.7 & 3.8 & 4.1 & 4.2 & 4.3 & 4.4 \\
\hline $\mathrm{SiO}_{2}$ & 64.78 & 64.05 & 64.22 & 63.99 & 64.19 & 64.38 & 64.03 & 63.92 & 63.64 & 63.86 & 64.01 & 63.45 & 64.03 & 64.55 & 63.82 & 63.68 & 64.56 & 64.03 & 64.02 & 64.37 \\
\hline $\mathrm{TiO}_{2}$ & 0.00 & 0.00 & 0.00 & 0.00 & 0.00 & 0.00 & 0.00 & 0.00 & 0.00 & 0.00 & 0.00 & 0.00 & 0.00 & 0.00 & 0.00 & 0.00 & 0.00 & 0.00 & 0.00 & 0.00 \\
\hline $\mathrm{Al}_{2} \mathrm{O}_{3}$ & 23.25 & 22.89 & 22.66 & 22.39 & 22.59 & 22.66 & 22.62 & 22.85 & 23.04 & 22.68 & 22.96 & 22.87 & 22.70 & 22.91 & 22.78 & 22.73 & 22.83 & 22.74 & 22.79 & 23.00 \\
\hline $\mathrm{Cr}_{2} \mathrm{O}_{3}$ & 0.00 & 0.00 & 0.00 & 0.00 & 0.00 & 0.00 & 0.00 & 0.00 & 0.00 & 0.00 & 0.00 & 0.00 & 0.00 & 0.00 & 0.00 & 0.00 & 0.00 & 0.00 & 0.00 & 0.00 \\
\hline $\mathrm{Fe}_{2} \mathrm{O}_{3}$ & 0.00 & 0.00 & 0.01 & 0.03 & 0.03 & 0.02 & 0.02 & 0.00 & 0.00 & 0.00 & 0.00 & 0.03 & 0.02 & 0.00 & 0.02 & 0.03 & 0.13 & 0.02 & 0.00 & 0.00 \\
\hline $\mathrm{FeO}$ & 0.00 & 0.00 & 0.00 & 0.00 & 0.00 & 0.00 & 0.00 & 0.00 & 0.00 & 0.00 & 0.00 & 0.00 & 0.00 & 0.00 & 0.00 & 0.00 & 0.00 & 0.00 & 0.00 & 0.00 \\
\hline MnO & 0.00 & 0.00 & 0.00 & 0.00 & 0.00 & 0.00 & 0.00 & 0.00 & 0.00 & 0.00 & 0.00 & 0.00 & 0.00 & 0.00 & 0.00 & 0.00 & 0.00 & 0.00 & 0.00 & 0.00 \\
\hline MgO & 0.00 & 0.00 & 0.00 & 0.00 & 0.00 & 0.00 & 0.00 & 0.00 & 0.00 & 0.00 & 0.00 & 0.00 & 0.00 & 0.00 & 0.00 & 0.00 & 0.00 & 0.00 & 0.00 & 0.00 \\
\hline $\mathrm{CaO}$ & 3.53 & 3.57 & 3.38 & 3.35 & 3.30 & 3.38 & 3.46 & 3.62 & 3.51 & 3.50 & 3.54 & 3.81 & 3.48 & 3.51 & 3.45 & 3.68 & 3.76 & 3.52 & 3.56 & 3.60 \\
\hline $\mathrm{Na}_{2} \mathrm{O}$ & 9.70 & 9.54 & 9.47 & 9.59 & 9.57 & 9.68 & 9.64 & 9.50 & 9.51 & 9.41 & 9.45 & 9.41 & 9.67 & 9.56 & 9.52 & 9.56 & 9.41 & 9.44 & 9.36 & 9.45 \\
\hline $\mathrm{K}_{2} \mathrm{O}$ & 0.06 & 0.06 & 0.08 & 0.07 & 0.07 & 0.07 & 0.06 & 0.03 & 0.04 & 0.05 & 0.07 & 0.04 & 0.07 & 0.07 & 0.07 & 0.04 & 0.05 & 0.06 & 0.07 & 0.08 \\
\hline
\end{tabular}

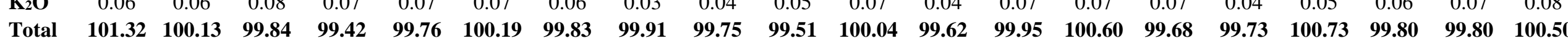

\begin{tabular}{|c|c|c|c|c|c|c|c|c|c|c|c|c|c|c|c|c|c|c|c|c|}
\hline $\mathbf{S i}$ & 2.818 & 2.820 & 2.833 & 2.835 & 2.834 & 2.831 & 2.827 & 2.820 & 2.812 & 2.827 & 2.819 & 2.811 & 2.824 & 2.827 & 2.822 & 2.817 & 2.825 & 2.826 & 2.825 & 2.822 \\
\hline $\mathbf{T i}$ & 0.000 & 0.000 & 0.000 & 0.000 & 0.000 & 0.000 & 0.000 & 0.000 & 0.000 & 0.000 & 0.000 & 0.000 & 0.000 & 0.000 & 0.000 & 0.000 & 0.000 & 0.000 & 0.000 & 0.000 \\
\hline Al & .192 & 1.188 & 1.178 & 1.170 & 1.176 & 1.175 & 1.178 & 1.188 & 1.200 & 1.184 & 1.192 & 1.194 & 1.180 & 1.183 & 1.188 & 1.186 & 1.178 & 1.183 & 1.186 & .189 \\
\hline $\mathrm{Cr}$ & 0.000 & 0.000 & 0.000 & 0.000 & 0.000 & 0.000 & 0.000 & 0.000 & 0.000 & 0.000 & 0.000 & 0.000 & 0.000 & 0.000 & 0.000 & 0.000 & 0.000 & 0.000 & 0.000 & 0.000 \\
\hline $\mathrm{Fe}^{3+}$ & 0.000 & 0.000 & 0.000 & 0.001 & 0.001 & 0.001 & 0.001 & 0.000 & 0.000 & 0.000 & 0.000 & 0.001 & 0.001 & 0.000 & 0.001 & 0.001 & 0.004 & 0.001 & 0.000 & 0.000 \\
\hline $\mathrm{Fe}^{2+}$ & 0.000 & 0.000 & 0.000 & 0.000 & 0.000 & 0.000 & 0.000 & 0.000 & 0.000 & 0.000 & 0.000 & 0.000 & 0.000 & 0.000 & 0.000 & 0.000 & 0.000 & 0.000 & 0.000 & .000 \\
\hline Mn & 0.000 & 0.000 & 0.000 & 0.000 & 0.000 & 0.000 & 0.000 & 0.000 & 0.000 & 0.000 & 0.000 & 0.000 & 0.000 & 0.000 & 0.000 & 0.000 & 0.000 & 0.000 & 0.000 & 0.000 \\
\hline Mg & 0.000 & 0.000 & 0.000 & 0.000 & 0.000 & 0.000 & 0.000 & 0.000 & 0.000 & 0.000 & 0.000 & 0.000 & 0.000 & 0.000 & 0.000 & 0.000 & 0.000 & 0.000 & 0.000 & 0.000 \\
\hline $\mathbf{C a}$ & 0.165 & 0.168 & 0.160 & 0.159 & 0.156 & 0.159 & 0.164 & 0.171 & 0.166 & 0.166 & 0.167 & 0.181 & 0.164 & 0.165 & 0.163 & 0.174 & 0.176 & 0.166 & 0.168 & 0.169 \\
\hline $\mathrm{Na}$ & 0.818 & 0.814 & 0.810 & 0.824 & 0.819 & 0.825 & 0.825 & 0.813 & 0.815 & 0.808 & 0.807 & 0.808 & 0.827 & 0.812 & 0.816 & 0.820 & 0.798 & 0.808 & 0.801 & 0.803 \\
\hline $\mathbf{K}$ & 0.003 & 0.003 & 0.005 & 0.004 & 0.004 & 0.004 & 0.003 & 0.002 & 0.002 & 0.003 & 0.004 & 0.002 & 0.004 & 0.004 & 0.004 & 0.002 & 0.003 & 0.003 & 0.004 & 0.004 \\
\hline Total & 4.996 & 4.993 & 4.986 & 4.993 & 4.990 & 4.995 & 4.998 & 4.994 & 4.995 & 4.988 & 4.989 & 4.997 & 5.000 & 4.991 & 4.994 & 5.000 & 4.984 & 4.987 & 4.984 & 4.987 \\
\hline & 0.17 & 0.17 & 0.16 & 0.16 & 0.16 & 0.16 & 0.17 & 0.17 & 0.17 & 0.17 & 0.17 & 0.18 & 0.16 & 0.17 & 0.17 & 0.17 & 0.18 & 0.17 & 0.17 & 0.17 \\
\hline $\mathbf{A b}$ & 0.83 & 0.83 & 0.83 & 0.83 & 0.84 & 0.84 & 0.83 & 0.82 & 0.83 & 0.83 & 0.83 & 0.82 & 0.83 & 0.83 & 0.83 & 0.82 & 0.82 & 0.83 & 0.82 & 0.82 \\
\hline Or & 0.00 & 0.00 & 0.01 & 0.00 & 0.00 & 0.00 & 0.00 & 0.00 & 0.00 & 0.00 & 0.00 & 0.00 & 0.00 & 0.00 & 0.00 & 0.00 & 0.00 & 0.00 & 0.00 & 0.00 \\
\hline
\end{tabular}


PLAGIOCLÁSIO - amostra CP-07 (continuação)

\begin{tabular}{|c|c|c|c|c|c|c|c|c|c|c|c|c|c|c|c|c|c|c|c|c|}
\hline Ponto & 4.5 & 4.6 & 5.1 & 5.2 & 5.3 & 5.4 & 5.5 & 5.6 & 5.7 & 5.8 & 5.9 & 5.10 & 5.11 & 5.12 & 5.13 & 5.14 & 5.15 & 6.1 & 6.2 & 6.3 \\
\hline $\mathrm{SiO}_{2}$ & 64.39 & 64.22 & 64.82 & 63.05 & 64.47 & 64.66 & 64.54 & 62.54 & 62.90 & 63.63 & 62.98 & 62.16 & 62.76 & 64.73 & 64.29 & 64.79 & 63.92 & 64.30 & 64.35 & 64.18 \\
\hline $\mathrm{TiO}_{2}$ & 0.00 & 0.00 & 0.00 & 0.00 & 0.00 & 0.00 & 0.00 & 0.00 & 0.00 & 0.00 & 0.00 & 0.00 & 0.00 & 0.00 & 0.00 & 0.00 & 0.00 & 0.00 & 0.00 & 0.00 \\
\hline $\mathrm{Al}_{2} \mathrm{O}_{3}$ & 22.80 & 22.87 & 23.28 & 22.38 & 22.63 & 22.55 & 22.48 & 23.80 & 24.09 & 23.41 & 23.69 & 24.29 & 24.07 & 22.44 & 22.90 & 22.99 & 22.72 & 22.70 & 22.65 & 22.71 \\
\hline $\mathrm{Cr}_{2} \mathrm{O}_{3}$ & 0.00 & 0.00 & 0.00 & 0.00 & 0.00 & 0.00 & 0.00 & 0.00 & 0.00 & 0.00 & 0.00 & 0.00 & 0.00 & 0.00 & 0.00 & 0.00 & 0.00 & 0.00 & 0.00 & 0.00 \\
\hline $\mathrm{Fe}_{2} \mathrm{O}_{3}$ & 0.02 & 0.00 & 0.07 & 0.01 & 0.04 & 0.02 & 0.01 & 0.00 & 0.00 & 0.00 & 0.00 & 0.01 & 0.01 & 0.01 & 0.02 & 0.01 & 0.06 & 0.01 & 0.00 & 0.00 \\
\hline $\mathrm{FeO}$ & 0.00 & 0.00 & 0.00 & 0.00 & 0.00 & 0.00 & 0.00 & 0.00 & 0.00 & 0.00 & 0.00 & 0.00 & 0.00 & 0.00 & 0.00 & 0.00 & 0.00 & 0.00 & 0.00 & 0.00 \\
\hline MnO & 0.00 & 0.00 & 0.00 & 0.00 & 0.00 & 0.00 & 0.00 & 0.00 & 0.00 & 0.00 & 0.00 & 0.00 & 0.00 & 0.00 & 0.00 & 0.00 & 0.00 & 0.00 & 0.00 & 0.00 \\
\hline MgO & 0.00 & 0.00 & 0.00 & 0.00 & 0.00 & 0.00 & 0.00 & 0.00 & 0.00 & 0.00 & 0.00 & 0.00 & 0.00 & 0.00 & 0.00 & 0.00 & 0.00 & 0.00 & 0.00 & 0.00 \\
\hline $\mathrm{CaO}$ & 3.61 & 3.60 & 3.62 & 3.53 & 3.24 & 3.14 & 3.18 & 4.64 & 4.76 & 4.22 & 4.50 & 5.35 & 4.81 & 3.15 & 3.53 & 3.42 & 3.57 & 3.51 & 3.60 & 3.49 \\
\hline $\mathrm{Na}_{2} \mathrm{O}$ & 9.47 & 9.67 & 9.67 & 9.05 & 9.79 & 9.75 & 9.67 & 8.76 & 8.76 & 9.08 & 8.98 & 8.65 & 8.82 & 9.91 & 9.66 & 9.65 & 9.49 & 9.52 & 9.57 & 9.43 \\
\hline $\mathrm{K}_{2} \mathrm{O}$ & 0.07 & 0.05 & 0.07 & 0.10 & 0.11 & 0.13 & 0.14 & 0.12 & 0.12 & 0.13 & 0.12 & 0.10 & 0.11 & 0.11 & 0.08 & 0.07 & 0.07 & 0.07 & 0.10 & 0.11 \\
\hline
\end{tabular}

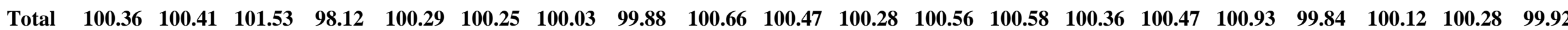

\begin{tabular}{|c|c|c|c|c|c|c|c|c|c|c|c|c|c|c|c|c|c|c|c|c|}
\hline $\mathbf{S i}$ & 2.827 & 2.821 & 2.815 & 2.829 & 2.833 & 2.840 & 2.841 & 2.769 & 2.764 & 2.796 & 2.777 & 2.740 & 2.761 & 2.842 & 2.821 & 2.828 & 2.823 & 2.830 & 2.829 & 2.829 \\
\hline $\mathbf{T i}$ & 0.000 & 0.000 & 0.000 & 0.000 & 0.000 & 0.000 & 0.000 & 0.000 & 0.000 & 0.000 & 0.000 & 0.000 & 0.000 & 0.000 & 0.000 & 0.000 & 0.000 & 0.000 & 0.000 & 0.000 \\
\hline Al & 1.180 & 1.184 & 1.192 & 1.184 & 1.172 & 1.168 & 1.167 & 1.242 & 1.248 & 1.213 & 1.231 & 1.262 & 1.248 & 1.162 & 1.185 & 1.183 & 1.183 & 1.178 & 1.174 & 1.180 \\
\hline $\mathrm{Cr}$ & 0.000 & 0.000 & 0.000 & 0.000 & 0.000 & 0.000 & 0.000 & 0.000 & 0.000 & 0.000 & 0.000 & 0.000 & 0.000 & 0.000 & 0.000 & 0.000 & 0.000 & 0.000 & 0.000 & 0.000 \\
\hline $\mathrm{Fe}^{3+}$ & 0.001 & 0.000 & 0.002 & 0.000 & 0.001 & 0.001 & 0.000 & 0.000 & 0.000 & 0.000 & 0.000 & 0.000 & 0.000 & 0.000 & 0.001 & 0.000 & 0.002 & 0.000 & 0.000 & 0.000 \\
\hline $\mathrm{Fe}^{2+}$ & 0.000 & 0.000 & 0.000 & 0.000 & 0.000 & 0.000 & 0.000 & 0.000 & 0.000 & 0.000 & 0.000 & 0.000 & 0.000 & 0.000 & 0.000 & 0.000 & 0.000 & 0.000 & 0.000 & 0.000 \\
\hline Mn & 0.000 & 0.000 & 0.000 & 0.000 & 0.000 & 0.000 & 0.000 & 0.000 & 0.000 & 0.000 & 0.000 & 0.000 & 0.000 & 0.000 & 0.000 & 00 & 00 & 0.000 & 0.000 & 0.000 \\
\hline Mg & 0.000 & 0.000 & 0.000 & 0.000 & 0.000 & 0.000 & 0.000 & 0.000 & 0.000 & 0.000 & 0.000 & 0.000 & 0.000 & 0.000 & 0.000 & 0.000 & 0.000 & 0.000 & 0.000 & 0.000 \\
\hline $\mathrm{Ca}$ & 0.170 & 0.169 & 0.168 & 0.170 & 0.153 & 0.148 & 0.150 & 0.220 & 0.224 & 0.199 & 0.213 & 0.253 & 0.227 & 0.148 & 0.166 & 0.160 & 0.169 & 0.166 & 0.170 & 0.165 \\
\hline $\mathbf{N a}$ & 0.806 & 0.824 & 0.814 & 0.787 & 0.834 & 0.830 & 0.825 & 0.752 & 0.746 & 0.774 & 0.768 & 0.739 & 0.752 & 0.844 & 0.822 & 0.817 & 0.813 & 0.812 & 0.816 & 0.806 \\
\hline $\mathbf{K}$ & 0.004 & 0.003 & 0.004 & 0.006 & 0.006 & 0.007 & 0.008 & 0.007 & 0.007 & 0.007 & 0.007 & 0.006 & 0.006 & 0.006 & 0.004 & 0.004 & 0.004 & 0.004 & 0.006 & 0.006 \\
\hline Total & 4.988 & 5.001 & 4.995 & 4.976 & 4.999 & 4.994 & 4.991 & 4.990 & 4.989 & 4.989 & 4.996 & 5.000 & 4.994 & 5.002 & 4.999 & 4.992 & 4.994 & 4.990 & 4.995 & 4.986 \\
\hline & 0.17 & 0.17 & 0.17 & 0.18 & 0.15 & 0.15 & 0.15 & 0.22 & 0.23 & 0.20 & 0.22 & 0.25 & 0.23 & 0.15 & 0.17 & 0.16 & 0.17 & 0.17 & 0.17 & 0.17 \\
\hline $\mathbf{A b}$ & 0.82 & 0.83 & 0.83 & 0.82 & 0.84 & 0.84 & 0.84 & 0.77 & 0.76 & 0.79 & 0.78 & 0.74 & 0.76 & 0.85 & 0.83 & 0.83 & 0.82 & 0.83 & 0.82 & 0.82 \\
\hline Or & 0.00 & 0.00 & 0.00 & 0.01 & 0.01 & 0.01 & 0.01 & 0.01 & 0.01 & 0.01 & 0.01 & 0.01 & 0.01 & 0.01 & 0.00 & 0.00 & 0.00 & 0.00 & 0.01 & 0.01 \\
\hline
\end{tabular}




\section{PLAGIOCLÁSIO}

\begin{tabular}{|c|c|c|c|c|c|c|c|c|c|c|c|c|c|c|c|c|c|c|c|c|}
\hline \multirow[b]{2}{*}{ Ponto } & \multicolumn{7}{|c|}{ CP-07 (continuação) } & \multicolumn{13}{|c|}{ CP-333 } \\
\hline & 6.4 & 6.5 & 6.6 & 6.7 & 6.8 & 6.9 & 6.1 & 1.1 & 1.2 & 1.3 & 1.4 & 1.5 & 1.6 & 1.7 & 1.8 & 1.9 & 1.10 & 2.1 & 2.2 & 2.3 \\
\hline $\mathrm{SiO}_{2}$ & 64.47 & 64.38 & 64.73 & 64.76 & 65.02 & 64.75 & 64.67 & 61.22 & 63.66 & 63.80 & 63.67 & 64.08 & 64.27 & 64.42 & 63.25 & 63.57 & 63.84 & 61.85 & 62.01 & 62.23 \\
\hline $\mathrm{TiO}_{2}$ & 0.00 & 0.00 & 0.00 & 0.00 & 0.00 & 0.00 & 0.00 & 0.00 & 0.00 & 0.00 & 0.00 & 0.00 & 0.00 & 0.00 & 0.00 & 0.00 & 0.00 & 0.00 & 0.00 & 0.00 \\
\hline $\mathrm{Al}_{2} \mathrm{O}_{3}$ & 22.59 & 22.67 & 22.56 & 22.53 & 22.69 & 22.48 & 22.58 & 24.79 & 23.40 & 23.11 & 23.06 & 23.03 & 22.75 & 22.74 & 23.26 & 23.20 & 23.36 & 24.59 & 24.67 & 24.24 \\
\hline $\mathrm{Cr}_{2} \mathrm{O}_{3}$ & 0.00 & 0.00 & 0.00 & 0.00 & 0.00 & 0.00 & 0.00 & 0.00 & 0.00 & 0.00 & 0.00 & 0.00 & 0.00 & 0.00 & 0.00 & 0.00 & 0.00 & 0.00 & 0.00 & 0.00 \\
\hline $\mathrm{Fe}_{2} \mathrm{O}_{3}$ & 0.00 & 0.01 & 0.01 & 0.02 & 0.00 & 0.00 & 0.04 & 0.16 & 0.02 & 0.00 & 0.00 & 0.00 & 0.01 & 0.02 & 0.02 & 0.03 & 0.03 & 0.02 & 0.00 & 0.02 \\
\hline $\mathrm{FeO}$ & 0.00 & 0.00 & 0.00 & 0.00 & 0.00 & 0.00 & 0.00 & 0.00 & 0.00 & 0.00 & 0.00 & 0.00 & 0.00 & 0.00 & 0.00 & 0.00 & 0.00 & 0.00 & 0.00 & 0.00 \\
\hline $\mathrm{MnO}$ & 0.00 & 0.00 & 0.00 & 0.00 & 0.00 & 0.00 & 0.00 & 0.00 & 0.00 & 0.00 & 0.00 & 0.00 & 0.00 & 0.00 & 0.00 & 0.00 & 0.00 & 0.00 & 0.00 & 0.00 \\
\hline MgO & 0.00 & 0.00 & 0.00 & 0.00 & 0.00 & 0.00 & 0.00 & 0.00 & 0.00 & 0.00 & 0.00 & 0.00 & 0.00 & 0.00 & 0.00 & 0.00 & 0.00 & 0.00 & 0.00 & 0.00 \\
\hline $\mathrm{CaO}$ & 3.40 & 3.55 & 3.31 & 3.16 & 3.21 & 3.24 & 3.45 & 5.69 & 4.26 & 3.94 & 3.80 & 3.81 & 3.52 & 3.53 & 4.17 & 4.01 & 3.85 & 5.63 & 5.20 & 5.31 \\
\hline $\mathrm{Na}_{2} \mathrm{O}$ & 9.35 & 9.58 & 9.77 & 9.72 & 9.82 & 9.71 & 9.65 & 8.24 & 8.99 & 9.27 & 9.27 & 9.04 & 9.49 & 9.47 & 9.18 & 9.07 & 9.35 & 8.45 & 8.62 & 8.64 \\
\hline $\mathbf{K}_{2} \mathbf{O}$ & 0.09 & 0.07 & 0.12 & 0.10 & 0.10 & 0.09 & 0.06 & 0.07 & 0.08 & 0.07 & 0.09 & 0.10 & 0.10 & 0.08 & 0.08 & 0.09 & 0.07 & 0.06 & 0.10 & 0.12 \\
\hline Total & 99.90 & 100.27 & 100.50 & 100.29 & 100.83 & 100.27 & 100.44 & 100.17 & 100.42 & 100.19 & 99.89 & 100.07 & 100.13 & 100.26 & 99.95 & 99.97 & 100.48 & 100.60 & 100.61 & 100.55 \\
\hline $\mathbf{S i}$ & 839 & 2.830 & 2.838 & 2.843 & 2.839 & 2.843 & 2.836 & 2.708 & 2.793 & 2.805 & 2.806 & 2.816 & 2.824 & 2.826 & 2.790 & 2.800 & 2.798 & 2.722 & 2.727 & 2.739 \\
\hline $\mathbf{T i}$ & 0.000 & 0.000 & 0.000 & 0.000 & 0.000 & 0.000 & 0.000 & 0.000 & 0.000 & 0.000 & 0.000 & 0.000 & 0.000 & 0.000 & 0.000 & 0.000 & 0.000 & 0.000 & 0.000 & 0.000 \\
\hline Al & 1.173 & 1.175 & 1.166 & 1.166 & 1.168 & 1.164 & 1.168 & 1.299 & 1.216 & 1.203 & 1.204 & 1.199 & 1.184 & 1.182 & 1.216 & 1.211 & 1.213 & 1.282 & 1.285 & 1.264 \\
\hline $\mathrm{Cr}$ & 0.000 & 0.000 & 0.000 & 0.000 & 0.000 & 0.000 & 0.000 & 0.000 & 0.000 & 0.000 & 0.000 & 0.000 & 0.000 & 0.000 & 0.000 & 0.000 & 0.000 & 0.000 & 0.000 & 0.000 \\
\hline $\mathrm{Fe}^{3+}$ & 0.000 & 0.000 & 0.000 & 0.001 & 0.000 & 0.000 & 0.001 & 0.005 & 0.001 & 0.000 & 0.000 & 0.000 & 0.000 & 0.001 & 0.001 & 0.001 & 0.001 & 0.001 & 0.000 & 0.001 \\
\hline $\mathrm{Fe}^{2+}$ & 0.000 & 0.000 & 0.000 & 0.000 & 0.000 & 0.000 & 0.000 & 0.000 & 0.000 & 0.000 & 0.000 & 0.000 & 0.000 & 0.000 & 0.000 & 0.000 & 0.000 & 0.000 & 0.000 & 0.000 \\
\hline Mn & 0.000 & 0.000 & 0.000 & 0.000 & 0.000 & 0.000 & 0.000 & 0.000 & 0.000 & 0.000 & 0.000 & 0.000 & 0.000 & 0.000 & 0.000 & 0.000 & 0.000 & 0.000 & 0.000 & 0.000 \\
\hline Mg & 0.000 & 0.000 & 0.000 & 0.000 & 0.000 & & 0.000 & 0.000 & 0.000 & 0.000 & 0.000 & 0.000 & 0.000 & 0.000 & 0.000 & 0.000 & 0.000 & 0.000 & 0.000 & 0.000 \\
\hline $\mathrm{Ca}$ & 0.160 & 0.167 & 0.156 & 0.149 & 0.150 & 0.152 & 0.162 & 0.271 & 0.201 & 0.186 & 0.180 & 0.180 & 0.167 & 0.167 & 0.198 & 0.190 & 0.182 & 0.267 & 0.246 & 0.252 \\
\hline $\mathrm{Na}$ & 0.798 & 0.817 & 0.831 & 0.827 & 0.832 & 0.827 & 0.821 & 0.710 & 0.769 & 0.794 & 0.796 & 0.774 & 0.812 & 0.809 & 0.789 & 0.778 & 0.798 & 0.725 & 0.739 & 0.741 \\
\hline $\mathbf{K}$ & 0.005 & 0.004 & 0.007 & 0.006 & 0.006 & 0.005 & 0.003 & 0.004 & 0.004 & 0.004 & 0.005 & 0.006 & 0.006 & 0.004 & 0.005 & 0.005 & 0.004 & 0.003 & 0.006 & 0.007 \\
\hline Total & 4.975 & 4.993 & 4.998 & 4.992 & 4.995 & 4.991 & 4.991 & 4.992 & 4.980 & 4.992 & 4.992 & 4.974 & 4.988 & 4.984 & 4.994 & 4.981 & 4.991 & 4.995 & 5.002 & 4.998 \\
\hline AII & 0.17 & 0.17 & 0.16 & 0.15 & 0.15 & 0.15 & 0.16 & 0.28 & 0.21 & 0.19 & 0.18 & 0.19 & 0.17 & 0.17 & 0.20 & 0.20 & 0.18 & 0.27 & 0.25 & 0.25 \\
\hline Ab & 0.83 & 0.83 & 0.84 & 0.84 & 0.84 & 0.84 & 0.83 & 0.72 & 0.79 & 0.81 & 0.81 & 0.81 & 0.82 & 0.83 & 0.80 & 0.80 & 0.81 & 0.73 & 0.75 & 0.74 \\
\hline Or & 0.01 & 0.00 & 0.01 & 0.01 & 0.01 & 0.01 & 0.00 & 0.00 & 0.00 & 0.00 & 0.01 & 0.01 & 0.01 & 0.00 & 0.01 & 0.01 & 0.00 & 0.00 & 0.01 & 0.01 \\
\hline
\end{tabular}


PLAGIOCLÁSIO - amostra CP-333 (continuação)

\begin{tabular}{|c|c|c|c|c|c|c|c|c|c|c|c|c|c|c|c|c|c|c|c|c|}
\hline Ponto & 2.4 & 2.5 & 2.6 & 2.7 & 2.8 & 3.1 & 3.2 & 3.3 & 3.4 & 3.5 & 3.6 & 3.7 & 3.8 & 4.1 & 4.2 & 4.3 & 4.4 & 4.5 & 4.6 & 4.7 \\
\hline $\mathrm{SiO}_{2}$ & 61.73 & 61.80 & 61.90 & 62.38 & 61.50 & 61.84 & 61.48 & 61.68 & 62.08 & 61.68 & 62.17 & 61.48 & 61.39 & 60.91 & 61.86 & 62.59 & 59.13 & 63.05 & 63.35 & 63.51 \\
\hline $\mathrm{TiO}_{2}$ & 0.00 & 0.00 & 0.00 & 0.00 & 0.00 & 0.00 & 0.00 & 0.00 & 0.00 & 0.00 & 0.00 & 0.00 & 0.00 & 0.00 & 0.00 & 0.00 & 0.00 & 0.00 & 0.00 & 0.00 \\
\hline $\mathrm{Al}_{2} \mathrm{O}_{3}$ & 24.38 & 24.64 & 24.65 & 24.20 & 24.67 & 24.51 & 24.41 & 24.42 & 24.50 & 24.31 & 24.30 & 24.32 & 24.55 & 24.26 & 24.15 & 23.51 & 22.34 & 23.54 & 23.38 & 23.76 \\
\hline $\mathrm{Cr}_{2} \mathrm{O}_{3}$ & 0.00 & 0.00 & 0.00 & 0.00 & 0.00 & 0.00 & 0.00 & 0.00 & 0.00 & 0.00 & 0.00 & 0.00 & 0.00 & 0.00 & 0.00 & 0.00 & 0.00 & 0.00 & 0.00 & 0.00 \\
\hline $\mathrm{Fe}_{2} \mathrm{O}_{3}$ & 0.02 & 0.00 & 0.00 & 0.02 & 0.06 & 0.03 & 0.03 & 0.01 & 0.02 & 0.00 & 0.02 & 0.03 & 0.02 & 0.07 & 0.01 & 0.01 & 0.07 & 0.03 & 0.05 & 0.16 \\
\hline $\mathrm{FeO}$ & 0.00 & 0.00 & 0.00 & 0.00 & 0.00 & 0.00 & 0.00 & 0.00 & 0.00 & 0.00 & 0.00 & 0.00 & 0.00 & 0.00 & 0.00 & 0.00 & 0.00 & 0.00 & 0.00 & 0.00 \\
\hline MnO & 0.00 & 0.00 & 0.00 & 0.00 & 0.00 & 0.00 & 0.00 & 0.00 & 0.00 & 0.00 & 0.00 & 0.00 & 0.00 & 0.00 & 0.00 & 0.00 & 0.00 & 0.00 & 0.00 & 0.00 \\
\hline MgO & 0.00 & 0.00 & 0.00 & 0.00 & 0.00 & 0.00 & 0.00 & 0.00 & 0.00 & 0.00 & 0.00 & 0.00 & 0.00 & 0.00 & 0.00 & 0.00 & 0.00 & 0.00 & 0.00 & 0.00 \\
\hline $\mathrm{CaO}$ & 5.48 & 5.35 & 5.41 & 5.27 & 5.66 & 5.52 & 5.45 & 5.34 & 5.28 & 5.11 & 5.26 & 5.31 & 5.52 & 5.27 & 5.22 & 4.48 & 4.12 & 4.49 & 4.28 & 4.50 \\
\hline $\mathrm{Na}_{2} \mathrm{O}$ & 8.47 & 8.35 & 8.43 & 8.37 & 8.43 & 8.36 & 8.39 & 8.45 & 8.47 & 8.53 & 8.56 & 8.39 & 8.24 & 8.39 & 8.67 & 8.96 & 8.67 & 9.01 & 9.18 & 9.07 \\
\hline $\mathbf{K}_{2} \mathbf{O}$ & 0.09 & 0.07 & 0.08 & 0.11 & 0.07 & 0.05 & 0.06 & 0.06 & 0.06 & 0.08 & 0.10 & 0.10 & 0.07 & 0.05 & 0.05 & 0.10 & 0.11 & 0.11 & 0.11 & 0.07 \\
\hline
\end{tabular}

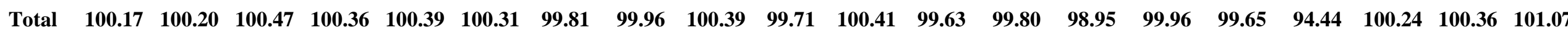

\begin{tabular}{|c|c|c|c|c|c|c|c|c|c|c|c|c|c|c|c|c|c|c|c|c|}
\hline $\mathbf{S i}$ & 2.728 & 2.727 & 2.726 & 2.747 & 2.714 & 2.728 & 2.726 & 2.729 & 2.734 & 2.735 & 2.739 & 2.730 & 2.722 & 2.724 & 2.738 & 2.773 & 2.767 & 2.776 & 2.786 & 2.774 \\
\hline $\mathbf{T i}$ & 0.000 & 0.000 & 0.000 & 0.000 & 0.000 & 0.000 & 0.000 & 0.000 & 0.000 & 0.000 & 0.000 & 0.000 & 0.000 & 0.000 & 0.000 & 0.000 & 0.000 & 0.000 & 0.000 & 0.000 \\
\hline Al & 1.276 & 1.288 & 1.286 & 1.263 & 1.290 & 1.280 & 1.282 & 1.280 & 1.278 & 1.277 & 1.268 & 1.279 & 1.289 & 1.285 & 1.267 & 1.234 & 1.238 & 1.229 & 1.218 & 1.229 \\
\hline $\mathrm{Cr}$ & 0.000 & 0.000 & 0.000 & 0.000 & 0.000 & 0.000 & 0.000 & 0.000 & 0.000 & 0.000 & 0.000 & 0.000 & 0.000 & 0.000 & 0.000 & 0.000 & 0.000 & 0.000 & 0.000 & 0.000 \\
\hline $\mathrm{Fe}^{3+}$ & 0.001 & 0.000 & 0.000 & 0.001 & 0.002 & 0.001 & 0.001 & 0.000 & 0.001 & 0.000 & 0.001 & 0.001 & 0.001 & 0.002 & 0.000 & 0.000 & 0.002 & 0.001 & 0.002 & 0.005 \\
\hline $\mathrm{Fe}^{2+}$ & 0.000 & 0.000 & 0.000 & 0.000 & 0.000 & 0.000 & 0.000 & 0.000 & 0.000 & 0.000 & 0.000 & 0.000 & 0.000 & 0.000 & 0.000 & 0.000 & 0.000 & 0.000 & 0.000 & 0.000 \\
\hline Mn & 0.000 & 0.000 & 0.000 & 0.000 & 0.000 & 0.000 & 0.000 & 0.000 & 0.000 & 0.000 & 0.000 & 0.000 & 0.000 & 0.000 & 0.000 & .000 & 0.000 & 000 & 0.000 & 0.000 \\
\hline Mg & 0.000 & 0.000 & 0.000 & 0.000 & 0.000 & 0.000 & 0.000 & 0.000 & 0.000 & 0.000 & 0.000 & 0.000 & 0.000 & 0.000 & 0.000 & 0.000 & 0.000 & 0.000 & 0.000 & 0.000 \\
\hline $\mathrm{Ca}$ & 0.261 & 0.254 & 0.256 & 0.250 & 0.269 & 0.262 & 0.260 & 0.254 & 0.250 & 0.244 & 0.249 & 0.254 & 0.263 & 0.254 & 0.249 & 0.214 & 0.208 & 0.213 & 0.203 & 0.212 \\
\hline $\mathbf{N a}$ & 0.729 & 0.718 & 0.723 & 0.718 & 0.725 & 0.718 & 0.725 & 0.729 & 0.726 & 0.737 & 0.735 & 0.726 & 0.712 & 0.731 & 0.748 & 0.773 & 0.790 & 0.773 & 0.786 & 0.772 \\
\hline $\mathbf{K}$ & 0.005 & 0.004 & 0.005 & 0.006 & 0.004 & 0.003 & 0.003 & 0.003 & 0.003 & 0.005 & 0.006 & 0.006 & 0.004 & 0.003 & 0.003 & 0.006 & 0.007 & 0.006 & 0.006 & 0.004 \\
\hline Total & 4.996 & 4.990 & 4.995 & 4.979 & 4.999 & 4.987 & 4.992 & 4.992 & 4.987 & 4.997 & 4.992 & 4.991 & 4.986 & 4.994 & 4.999 & 4.995 & 5.007 & 4.994 & 4.996 & 4.991 \\
\hline III & 0.26 & 0.26 & 0.26 & 0.26 & 0.27 & 0.27 & 0.26 & 0.26 & 0.26 & 0.25 & 0.25 & 0.26 & 0.27 & 0.26 & 0.25 & 0.22 & 0.21 & 0.21 & 0.20 & 0.21 \\
\hline $\mathbf{A b}$ & 0.73 & 0.74 & 0.73 & 0.74 & 0.73 & 0.73 & 0.73 & 0.74 & 0.74 & 0.75 & 0.74 & 0.74 & 0.73 & 0.74 & 0.75 & 0.78 & 0.79 & 0.78 & 0.79 & 0.78 \\
\hline Or & 0.01 & 0.00 & 0.01 & 0.01 & 0.00 & 0.00 & 0.00 & 0.00 & 0.00 & 0.01 & 0.01 & 0.01 & 0.00 & 0.00 & 0.00 & 0.01 & 0.01 & 0.01 & 0.01 & 0.00 \\
\hline
\end{tabular}


PLAGIOCLÁSIO - amostra CP-333 (continuação)

\begin{tabular}{|c|c|c|c|c|c|c|c|c|c|c|c|c|}
\hline Ponto & 5.1 & 5.2 & 5.3 & 5.4 & 5.5 & 5.6 & 6.1 & 6.2 & 6.3 & 6.4 & 6.5 & 6.6 \\
\hline $\mathrm{SiO}_{2}$ & 61.88 & 62.52 & 62.83 & 62.97 & 62.70 & 63.03 & 61.82 & 61.76 & 62.36 & 62.51 & 61.66 & 60.89 \\
\hline $\mathrm{TiO}_{2}$ & 0.00 & 0.00 & 0.00 & 0.00 & 0.00 & 0.00 & 0.00 & 0.00 & 0.00 & 0.00 & 0.00 & 0.00 \\
\hline $\mathrm{Al}_{2} \mathrm{O}_{3}$ & 24.34 & 23.82 & 23.93 & 23.89 & 24.08 & 24.07 & 24.66 & 24.64 & 24.12 & 24.14 & 24.62 & 24.89 \\
\hline $\mathrm{Cr}_{2} \mathrm{O}_{3}$ & 0.00 & 0.00 & 0.00 & 0.00 & 0.00 & 0.00 & 0.00 & 0.00 & 0.00 & 0.00 & 0.00 & 0.00 \\
\hline $\mathrm{Fe}_{2} \mathrm{O}_{3}$ & 0.02 & 0.01 & 0.00 & 0.03 & 0.00 & 0.08 & 0.01 & 0.00 & 0.01 & 0.01 & 0.01 & 0.00 \\
\hline $\mathrm{FeO}$ & 0.00 & 0.00 & 0.00 & 0.00 & 0.00 & 0.00 & 0.00 & 0.00 & 0.00 & 0.00 & 0.00 & 0.00 \\
\hline $\mathrm{MnO}$ & 0.00 & 0.00 & 0.00 & 0.00 & 0.00 & 0.00 & 0.00 & 0.00 & 0.00 & 0.00 & 0.00 & 0.00 \\
\hline MgO & 0.00 & 0.00 & 0.00 & 0.00 & 0.00 & 0.00 & 0.00 & 0.00 & 0.00 & 0.00 & 0.00 & 0.00 \\
\hline $\mathrm{CaO}$ & 5.15 & 4.84 & 4.81 & 4.72 & 4.74 & 4.79 & 5.45 & 5.60 & 5.03 & 4.92 & 5.42 & 5.77 \\
\hline $\mathrm{Na}_{2} \mathrm{O}$ & 8.86 & 8.79 & 8.79 & 8.78 & 8.98 & 8.85 & 8.30 & 8.43 & 8.55 & 8.76 & 8.52 & 8.07 \\
\hline $\mathbf{K}_{2} \mathbf{O}$ & 0.06 & 0.09 & 0.09 & 0.08 & 0.10 & 0.08 & 0.05 & 0.06 & 0.07 & 0.10 & 0.09 & 0.05 \\
\hline Total & 100.30 & 100.06 & 100.45 & 100.46 & 100.60 & 100.91 & 100.28 & 100.48 & 100.14 & 100.42 & 100.32 & 99.67 \\
\hline $\mathbf{S i}$ & 2.731 & 2.760 & 2.762 & 2.766 & 2.754 & 2.759 & 2.725 & 2.721 & 2.750 & 2.750 & 2.721 & 2.705 \\
\hline $\mathbf{T i}$ & 0.000 & 0.000 & 0.000 & 0.000 & 0.000 & 0.000 & 0.000 & 0.000 & 0.000 & 0.000 & 0.000 & 0.000 \\
\hline Al & 1.273 & 1.246 & 1.247 & 1.243 & 1.253 & 1.249 & 1.288 & 1.286 & 1.260 & 1.258 & 1.287 & 1.310 \\
\hline $\mathrm{Cr}$ & 0.000 & 0.000 & 0.000 & 0.000 & 0.000 & 0.000 & 0.000 & 0.000 & 0.000 & 0.000 & 0.000 & 0.000 \\
\hline $\mathrm{Fe}^{3+}$ & 0.001 & 0.000 & 0.000 & 0.001 & 0.000 & 0.003 & 0.000 & 0.000 & 0.000 & 0.000 & 0.000 & 0.000 \\
\hline $\mathrm{Fe}^{2+}$ & 0.000 & 0.000 & 0.000 & 0.000 & 0.000 & 0.000 & 0.000 & 0.000 & 0.000 & 0.000 & 0.000 & 0.000 \\
\hline Mn & 0.000 & 0.000 & 0.000 & 0.000 & 0.000 & 0.000 & 0.000 & 0.000 & 0.000 & 0.000 & 0.000 & 0.000 \\
\hline Mg & 0.000 & 0.000 & 0.000 & 0.000 & 0.000 & 0.000 & 0.000 & 0.000 & 0.000 & 0.000 & 0.000 & 0.000 \\
\hline $\mathrm{Ca}$ & 0.245 & 0.230 & 0.228 & 0.223 & 0.224 & 0.226 & 0.259 & 0.266 & 0.239 & 0.233 & 0.258 & 0.276 \\
\hline $\mathrm{Na}$ & 0.762 & 0.756 & 0.753 & 0.751 & 0.769 & 0.755 & 0.713 & 0.723 & 0.735 & 0.751 & 0.733 & 0.698 \\
\hline $\mathbf{K}$ & 0.003 & 0.005 & 0.005 & 0.005 & 0.006 & 0.004 & 0.003 & 0.003 & 0.004 & 0.006 & 0.005 & 0.003 \\
\hline Total & 5.010 & 4.993 & 4.994 & 4.985 & 5.006 & 4.990 & 4.983 & 4.999 & 4.984 & 4.994 & 4.999 & 4.991 \\
\hline An & 0.24 & 0.23 & 0.23 & 0.23 & 0.22 & 0.23 & 0.27 & 0.27 & 0.24 & 0.24 & 0.26 & 0.28 \\
\hline $\mathbf{A b}$ & 0.75 & 0.76 & 0.76 & 0.77 & 0.77 & 0.77 & 0.73 & 0.73 & 0.75 & 0.76 & 0.74 & 0.71 \\
\hline Or & 0.00 & 0.01 & 0.01 & 0.01 & 0.01 & 0.00 & 0.00 & 0.00 & 0.00 & 0.01 & 0.01 & 0.00 \\
\hline
\end{tabular}




\section{PLAGIOCLÁSIO}

$\begin{array}{lccccc}\text { Point } & \mathbf{1 . 1} & \mathbf{1 . 2} & \mathbf{1 . 3} & \mathbf{2 . 1} & \\ \mathrm{SiO}_{2} & 62.44 & 62.60 & 62.34 & 63.09 & 64 .\end{array}$

$\begin{array}{lllllll}\mathrm{TiO}_{2} & 0.02 & 0.03 & 0.00 & 0.00 & 0.00 & 0.00\end{array}$

$\begin{array}{lllllll}\mathbf{A l}_{2} \mathrm{O}_{3} & 23.31 & 23.75 & 23.59 & 23.94 & 22.74 & 23.21\end{array}$

$\begin{array}{lllllll}\mathrm{Cr}_{2} \mathrm{O}_{3} & 0.00 & 0.00 & 0.00 & 0.00 & 0.00 & 0.00\end{array}$

$\begin{array}{lllllll}\mathrm{Fe}_{2} \mathrm{O}_{3} & 0.19 & 0.07 & 0.10 & 0.12 & 0.09 & 0.11\end{array}$

$\begin{array}{lllll}\mathrm{FeO} & 0.00 & 0.00 & 0.00 & 0.00\end{array}$

MnO $0.01-0.01-0.00$

$\begin{array}{llll}\text { MgO } & 0.00 & 0.00 & 0.00\end{array}$

$\mathrm{BaO}$

$\mathrm{Na}_{2} \mathrm{O}$

$\begin{array}{lll}4.43 & 4.73 & 4.79\end{array}$

$\begin{array}{lll}0.02 & 0.00 \quad 0.05\end{array}$

$\begin{array}{lll}9.01 & 8.85 & 8.79\end{array}$

$\mathrm{K}_{2} \mathrm{O}$

$\begin{array}{lll}0.26 & 0.10 & 0.25\end{array}$

$99.69 \quad 100.13 \quad 99.91$

$\begin{array}{llll}2.775 & 2.767 & 2.766 & 2.771\end{array}$

$\begin{array}{lllll}0.001 & 0.001 & 0.000 & 0.000\end{array}$

$\begin{array}{llll}1.221 & 1.237 & 1.233 & 1.239\end{array}$

$\begin{array}{llll}0.000 & 0.000 & 0.000 & 0.000\end{array}$

$\begin{array}{llll}0.006 & 0.002 & 0.003 & 0.004\end{array}$

$\begin{array}{llll}0.000 & 0.000 & 0.000 & 0.000\end{array}$

$\begin{array}{llll}0.000 & 0.000 & 0.000 & 0.000\end{array}$

$\begin{array}{llll}0.000 & 0.000 & 0.000 & 0.000\end{array}$

$\begin{array}{llll}0.211 & 0.224 & 0.228 & 0.219\end{array}$

$\begin{array}{llll}0.000 & 0.000 & 0.001 & 0.000\end{array}$

$\begin{array}{llll}0.776 & 0.758 & 0.756 & 0.743\end{array}$

$\begin{array}{llll}0.015 & 0.005 & 0.014 & 0.006\end{array}$

$\begin{array}{llll}5.006 & 4.995 & 5.001 & 4.982\end{array}$

$\begin{array}{llll}0.21 & 0.23 & 0.23 & 0.23 \\ 0.77 & 0.77 & 0.76 & 0.77\end{array}$

$\begin{array}{llll}0.01 & 0.01 & 0.01 & 0.01\end{array}$
CP-65A (resíduo)

CP-65B (leucossoma)

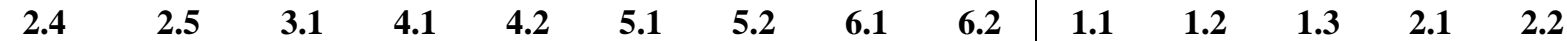
$\begin{array}{lllllllllllllll}67.31 & 63.21 & 63.54 & 63.30 & 63.90 & 63.40 & 64.53 & 62.89 & 64.12 & 63.55 & 64.58 & 64.24 & 63.95 & 64.52\end{array}$ $\begin{array}{llllllllllllll}0.02 & 0.00 & 0.05 & 0.00 & 0.00 & 0.06 & 0.07 & 0.00 & 0.00 & 0.03 & 0.01 & 0.03 & 0.00 & 0.01\end{array}$

$\begin{array}{llllllllllllll}19.88 & 23.67 & 22.74 & 22.81 & 22.67 & 22.91 & 22.20 & 23.28 & 22.52 & 23.24 & 22.21 & 22.69 & 23.05 & 22.53\end{array}$

$\begin{array}{llllllllllllll}0.00 & 0.00 & 0.00 & 0.00 & 0.00 & 0.00 & 0.00 & 0.00 & 0.00 & 0.00 & 0.00 & 0.00 & 0.00 & 0.00\end{array}$

$\begin{array}{llllllllllllll}0.08 & 0.12 & 0.05 & 0.14 & 0.03 & 0.05 & 0.15 & 0.07 & 0.11 & 0.09 & 0.08 & 0.09 & 0.21 & 0.10\end{array}$

$\begin{array}{llllllllllllll}0.00 & 0.00 & 0.00 & 0.00 & 0.00 & 0.00 & 0.00 & 0.00 & 0.00 & 0.00 & 0.00 & 0.00 & 0.00 & 0.00\end{array}$

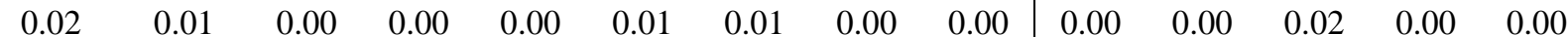

$\begin{array}{llllllllllllll}0.01 & 0.00 & 0.00 & 0.00 & 0.00 & 0.00 & 0.00 & 0.00 & 0.00 & 0.00 & 0.00 & 0.00 & 0.00 & 0.00\end{array}$

$\begin{array}{llllllllllllll}0.43 & 4.63 & 3.75 & 3.82 & 3.64 & 4.00 & 3.10 & 4.39 & 3.48 & 3.90 & 3.09 & 3.61 & 2.54 & 3.35\end{array}$

$\begin{array}{llllllllllllll}0.16 & 0.03 & 0.00 & 0.06 & 0.02 & 0.00 & 0.00 & 0.01 & 0.00 & 0.01 & 0.06 & 0.00 & 0.04 & 0.00\end{array}$

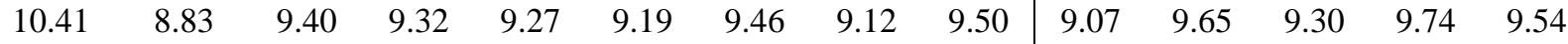

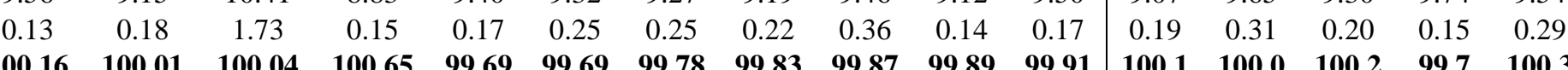

$\begin{array}{llllllllllllllll}2.822 & 2.796 & 2.965 & 2.778 & 2.814 & 2.807 & 2.825 & 2.806 & 2.847 & 2.785 & 2.830 & 2.802 & 2.848 & 2.827 & 2.824 & 2.836\end{array}$

$\begin{array}{llllllllllllllll}0.000 & 0.000 & 0.001 & 0.000 & 0.002 & 0.000 & 0.000 & 0.002 & 0.002 & 0.000 & 0.000 & 0.001 & 0.000 & 0.001 & 0.000 & 0.000\end{array}$

$\begin{array}{lllllllllllllllll}1.181 & 1.209 & 1.032 & 1.226 & 1.187 & 1.192 & 1.181 & 1.195 & 1.155 & 1.215 & 1.172 & 1.208 & 1.154 & 1.177 & 1.200 & 1.167\end{array}$

$\begin{array}{llllllllllllllll}0.000 & 0.000 & 0.000 & 0.000 & 0.000 & 0.000 & 0.000 & 0.000 & 0.000 & 0.000 & 0.000 & 0.000 & 0.000 & 0.000 & 0.000 & 0.000\end{array}$

$\begin{array}{llllllllllllllll}0.003 & 0.004 & 0.003 & 0.004 & 0.001 & 0.005 & 0.001 & 0.001 & 0.005 & 0.002 & 0.004 & 0.003 & 0.003 & 0.003 & 0.007 & 0.003\end{array}$

$\begin{array}{lllllllllllllllllll}0.000 & 0.000 & 0.000 & 0.000 & 0.000 & 0.000 & 0.000 & 0.000 & 0.000 & 0.000 & 0.000 & 0.000 & 0.000 & 0.000 & 0.000 & 0.000\end{array}$

$\begin{array}{llllllllllllllllll}0.000 & 0.001 & 0.001 & 0.000 & 0.000 & 0.000 & 0.000 & 0.000 & 0.000 & 0.000 & 0.000 & 0.000 & 0.000 & 0.001 & 0.000 & 0.000\end{array}$

$\begin{array}{llllllllllllllllll}0.000 & 0.000 & 0.000 & 0.000 & 0.000 & 0.000 & 0.000 & 0.000 & 0.000 & 0.000 & 0.000 & 0.000 & 0.000 & 0.000 & 0.000 & 0.000\end{array}$

$\begin{array}{llllllllllllllllll}0.168 & 0.190 & 0.020 & 0.218 & 0.178 & 0.182 & 0.172 & 0.190 & 0.147 & 0.208 & 0.165 & 0.184 & 0.146 & 0.170 & 0.120 & 0.158\end{array}$

$\begin{array}{lllllllllllllllllll}0.001 & 0.001 & 0.003 & 0.001 & 0.000 & 0.001 & 0.000 & 0.000 & 0.000 & 0.000 & 0.000 & 0.000 & 0.001 & 0.000 & 0.001 & 0.000\end{array}$

$\begin{array}{lllllllllllllllll}0.817 & 0.784 & 0.889 & 0.752 & 0.807 & 0.801 & 0.795 & 0.788 & 0.809 & 0.783 & 0.813 & 0.775 & 0.825 & 0.794 & 0.834 & 0.813\end{array}$

$\begin{array}{llllllllllllllllll}0.007 & 0.010 & 0.097 & 0.008 & 0.010 & 0.014 & 0.014 & 0.012 & 0.020 & 0.008 & 0.010 & 0.010 & 0.018 & 0.011 & 0.008 & 0.016\end{array}$

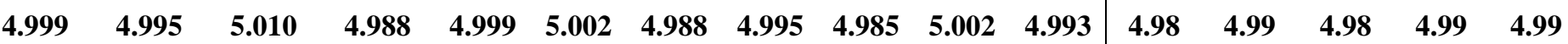

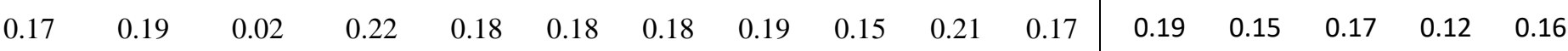

$\begin{array}{llllllllllllllll}0.82 & 0.80 & 0.88 & 0.77 & 0.81 & 0.80 & 0.81 & 0.80 & 0.83 & 0.78 & 0.82 & 0.80 & 0.83 & 0.81 & 0.87 & 0.82\end{array}$

$\begin{array}{llllllllllllllll}0.01 & 0.01 & 0.10 & 0.01 & 0.01 & 0.01 & 0.01 & 0.01 & 0.02 & 0.01 & 0.01 & 0.01 & 0.02 & 0.01 & 0.01 & 0.02\end{array}$ 
PLAGIOCLÁSIO - amostra CP-65B (continuação)

\begin{tabular}{|c|c|c|c|c|c|c|c|c|c|c|c|c|c|c|c|c|c|c|c|c|}
\hline Point & 2.3 & 3.1 & 3.2 & 3.3 & 3.4 & 3.5 & 4.1 & 4.2 & 4.3 & 4.4 & 5.1 & 5.2 & 5.3 & 5.4 & 5.5 & 7.1 & 7.2 & 7.3 & 7.4 & 7.5 \\
\hline $\mathrm{SiO}_{2}$ & 63.70 & 64.10 & 64.58 & 64.71 & 64.42 & 63.28 & 64.41 & 64.90 & 64.37 & 64.28 & 61.62 & 64.37 & 63.79 & 64.52 & 63.56 & 63.41 & 64.36 & 64.13 & 64.37 & 64.24 \\
\hline $\mathrm{TiO}_{2}$ & 0.02 & 0.04 & 0.06 & 0.01 & 0.02 & 0.02 & 0.00 & 0.00 & 0.00 & 0.02 & 0.05 & 0.03 & 0.02 & 0.00 & 0.03 & 0.01 & 0.00 & 0.00 & 0.03 & 0.04 \\
\hline $\mathrm{Al}_{2} \mathrm{O}_{3}$ & 22.92 & 22.37 & 22.27 & 22.35 & 22.36 & 22.78 & 18.81 & 18.97 & 18.95 & 18.72 & 22.34 & 22.47 & 22.96 & 22.48 & 22.93 & 23.31 & 22.64 & 22.79 & 22.23 & 22.67 \\
\hline $\mathrm{Cr}_{2} \mathrm{O}_{3}$ & 0.00 & 0.00 & 0.00 & 0.00 & 0.00 & 0.00 & 0.00 & 0.00 & 0.00 & 0.00 & 0.00 & 0.00 & 0.00 & 0.00 & 0.00 & 0.00 & 0.00 & 0.00 & 0.00 & 0.00 \\
\hline $\mathrm{Fe}_{2} \mathrm{O}_{3}$ & 0.06 & 0.18 & 0.09 & 0.04 & 0.06 & 0.12 & 0.04 & 0.01 & 0.07 & 0.02 & 2.10 & 0.10 & 0.04 & 0.05 & 0.06 & 0.14 & 0.06 & 0.07 & 0.05 & 0.04 \\
\hline $\mathrm{FeO}$ & 0.00 & 0.00 & 0.00 & 0.00 & 0.00 & 0.00 & 0.00 & 0.00 & 0.00 & 0.00 & 0.00 & 0.00 & 0.00 & 0.00 & 0.00 & 0.00 & 0.00 & 0.00 & 0.00 & 0.00 \\
\hline MnO & 0.00 & 0.00 & 0.00 & 0.00 & 0.00 & 0.00 & 0.01 & 0.00 & 0.00 & 0.01 & 0.04 & 0.01 & 0.01 & 0.00 & 0.01 & 0.00 & 0.01 & 0.00 & 0.01 & 0.00 \\
\hline MgO & 0.00 & 0.00 & 0.00 & 0.00 & 0.00 & 0.00 & 0.00 & 0.00 & 0.00 & 0.00 & 0.29 & 0.00 & 0.00 & 0.00 & 0.00 & 0.00 & 0.00 & 0.00 & 0.00 & 0.00 \\
\hline $\mathrm{CaO}$ & 3.63 & 3.57 & 3.16 & 3.20 & 3.26 & 4.00 & 0.00 & 0.01 & 0.06 & 0.00 & 4.60 & 3.33 & 3.84 & 3.27 & 3.92 & 4.17 & 3.48 & 3.48 & 3.43 & 3.38 \\
\hline $\mathrm{BaO}$ & 0.00 & 0.01 & 0.04 & 0.00 & 0.01 & 0.04 & 1.16 & 0.90 & 0.86 & 0.83 & 0.06 & 0.01 & 0.00 & 0.10 & 0.00 & 0.04 & 0.00 & 0.01 & 0.06 & 0.00 \\
\hline $\mathrm{Na}_{2} \mathrm{O}$ & 9.37 & 9.44 & 9.70 & 9.71 & 9.63 & 9.17 & 0.38 & 1.29 & 1.45 & 1.18 & 8.57 & 9.70 & 9.40 & 9.64 & 9.21 & 9.21 & 9.63 & 9.56 & 9.55 & 9.62 \\
\hline $\mathbf{K}_{2} \mathbf{O}$ & 0.24 & 0.20 & 0.23 & 0.15 & 0.23 & 0.25 & 15.83 & 14.44 & 14.26 & 14.67 & 0.47 & 0.17 & 0.20 & 0.17 & 0.14 & 0.12 & 0.16 & 0.18 & 0.20 & 0.21 \\
\hline Total & 99.9 & 99.9 & 100.1 & 100.2 & 100.0 & 99.7 & 100.6 & 100.5 & 100.0 & 99.7 & 100.1 & 100.2 & 100.3 & 100.2 & 99.9 & 100.4 & 100.3 & 100.2 & 99.9 & 100.2 \\
\hline Si & 813 & 2.831 & 2.844 & 2.846 & 2.840 & 2.807 & 2.978 & 2.981 & 2.973 & 2.980 & 2.751 & 2.834 & 2.810 & 2.839 & 2.809 & 2.792 & 2.829 & 2.823 & 2.842 & 2.828 \\
\hline $\mathbf{T i}$ & 0.001 & 0.001 & 0.002 & 0.000 & 0.001 & 0.001 & 0.000 & 0.000 & 0.000 & 0.001 & 0.002 & 0.001 & 0.001 & 0.000 & 0.001 & 0.000 & 0.000 & 0.000 & 0.001 & 0.001 \\
\hline Al & 1.193 & 1.164 & 1.156 & 1.158 & 1.162 & 1.191 & & 1.027 & 1.031 & 1.023 & & 1.166 & 1.192 & 1.166 & 1.195 & 1.210 & 1.173 & 1.182 & 1.157 & 1.176 \\
\hline $\mathrm{Cr}$ & 0.000 & 0.000 & 0.000 & 0.000 & 0.000 & 0.000 & 0.000 & 0.000 & 0.000 & 0.000 & 0.000 & 0.000 & 0.000 & 0.000 & 0.000 & 0.000 & 0.000 & 0.000 & 0.000 & 0.000 \\
\hline $\mathrm{Fe}^{3+}$ & 0.002 & 0.006 & 0.003 & 0.001 & 0.002 & 0.004 & 0.001 & 0.000 & 0.003 & 0.001 & 0.071 & 0.003 & 0.001 & 0.002 & 0.002 & 0.005 & 0.002 & 0.002 & 0.002 & 0.001 \\
\hline $\mathrm{Fe}^{2+}$ & 0.000 & 0.000 & 0.000 & 0.000 & 0.000 & 0.000 & 0.000 & 0.000 & 0.000 & 0.000 & 0.000 & 0.000 & 0.000 & 0.000 & 0.000 & 0.000 & 0.000 & 0.000 & 0.000 & 0.000 \\
\hline Mn & 0.000 & 0.000 & 0.000 & 0.000 & 0.000 & 0.000 & 0.000 & 0.000 & 0.000 & 0.000 & 0.001 & 0.000 & 0.000 & 0.000 & 0.000 & 0.000 & 0.000 & 0.000 & 0.000 & 0.000 \\
\hline Mg & 0.000 & 0.000 & 0.000 & 0.000 & 0.000 & 0.000 & 0.000 & 0.000 & 0.000 & 0.000 & 0.019 & 0.000 & 0.000 & 0.000 & 0.000 & 0.000 & 0.000 & 0.000 & 0.000 & 0.000 \\
\hline $\mathbf{C a}$ & 0.172 & 0.169 & 0.149 & 0.151 & 0.154 & 0.190 & 0.000 & 0.000 & 0.003 & 0.000 & 0.220 & 0.157 & 0.181 & 0.154 & 0.186 & 0.197 & 0.164 & 0.164 & 0.162 & 0.159 \\
\hline $\mathbf{B a}$ & 0.000 & 0.000 & 0.001 & 0.000 & 0.000 & 0.001 & 0.021 & 0.016 & 0.016 & 0.015 & 0.001 & 0.000 & 0.000 & 0.002 & 0.000 & 0.001 & 0.000 & 0.000 & 0.001 & 0.000 \\
\hline $\mathbf{N a}$ & 0.802 & 0.808 & 0.828 & 0.828 & 0.823 & 0.789 & 0.034 & 0.115 & 0.130 & 0.106 & 0.742 & 0.828 & 0.803 & 0.822 & 0.789 & 0.786 & 0.821 & 0.816 & 0.817 & 0.821 \\
\hline $\mathbf{K}$ & 0.013 & 0.011 & 0.013 & 0.008 & 0.013 & 0.014 & 0.934 & 0.846 & 0.840 & 0.868 & 0.027 & 0.009 & 0.011 & 0.009 & 0.008 & 0.007 & 0.009 & 0.010 & 0.011 & 0.012 \\
\hline Total & 5.00 & 4.99 & 5.00 & 4.99 & 5.00 & 5.00 & 4.99 & 4.99 & 5.00 & 4.99 & 5.01 & 5.00 & 5.00 & 4.99 & 4.99 & 5.00 & 5.00 & 5.00 & 4.99 & 5.00 \\
\hline An & 0.17 & 0.17 & 0.15 & 0.15 & 0.16 & 0.19 & 0.00 & 0.00 & 0.00 & 0.00 & 0.22 & 0.16 & 0.18 & 0.16 & 0.19 & 0.20 & 0.16 & 0.17 & 0.16 & 0.16 \\
\hline Ab & 0.81 & 0.82 & 0.84 & 0.84 & 0.83 & 0.79 & 0.03 & 0.12 & 0.13 & 0.11 & 0.75 & 0.83 & 0.81 & 0.83 & 0.80 & 0.79 & 0.83 & 0.82 & 0.83 & 0.83 \\
\hline Or & 0.01 & 0.01 & 0.01 & 0.01 & 0.01 & 0.01 & 0.97 & 0.88 & 0.86 & 0.89 & 0.03 & 0.01 & 0.01 & 0.01 & 0.01 & 0.01 & 0.01 & 0.01 & 0.01 & 0.01 \\
\hline
\end{tabular}


FELDSPATO ALCALINO - amostra CP-65B

\begin{tabular}{|c|c|c|c|c|c|c|c|c|c|c|c|c|c|c|c|}
\hline Point & 1.1 & 1.2 & 1.3 & 1.4 & 1.5 & 1.6 & 2.1 & 2.2 & 2.3 & 3.1 & 3.2 & 3.3 & 3.4 & 3.5 & 3.6 \\
\hline $\mathrm{SiO}_{2}$ & 64.22 & 64.11 & 68.35 & 64.76 & 64.36 & 64.65 & 64.37 & 64.35 & 64.58 & 64.15 & 64.51 & 65.17 & 64.43 & 64.44 & 64.17 \\
\hline $\mathrm{TiO}_{2}$ & 0.00 & 0.00 & 0.00 & 0.00 & 0.03 & 0.00 & 0.02 & 0.00 & 0.00 & 0.00 & 0.01 & 0.00 & 0.00 & 0.03 & 0.00 \\
\hline $\mathrm{Al}_{2} \mathrm{O}_{3}$ & 18.94 & 18.68 & 19.88 & 18.87 & 18.81 & 18.88 & 18.82 & 18.77 & 18.77 & 18.70 & 18.89 & 19.13 & 18.88 & 18.83 & 18.72 \\
\hline $\mathrm{Cr}_{2} \mathrm{O}_{3}$ & 0.00 & 0.00 & 0.00 & 0.00 & 0.00 & 0.00 & 0.00 & 0.00 & 0.00 & 0.00 & 0.00 & 0.00 & 0.00 & 0.00 & 0.00 \\
\hline $\mathrm{Fe}_{2} \mathrm{O}_{3}$ & 0.00 & 0.06 & 0.00 & 0.05 & 0.08 & 0.08 & 0.09 & 0.03 & 0.00 & 0.00 & 0.08 & 0.01 & 0.06 & 0.05 & 0.05 \\
\hline FeO & 0.00 & 0.00 & 0.00 & 0.00 & 0.00 & 0.00 & 0.00 & 0.00 & 0.00 & 0.00 & 0.00 & 0.00 & 0.00 & 0.00 & 0.00 \\
\hline MnO & 0.01 & 0.00 & 0.01 & 0.00 & 0.00 & 0.01 & 0.00 & 0.01 & 0.00 & 0.02 & 0.00 & 0.00 & 0.00 & 0.00 & 0.00 \\
\hline MgO & 0.00 & 0.01 & 0.00 & 0.00 & 0.00 & 0.01 & 0.00 & 0.00 & 0.00 & 0.00 & 0.00 & 0.01 & 0.00 & 0.00 & 0.00 \\
\hline $\mathrm{CaO}$ & 0.03 & 0.05 & 0.39 & 0.06 & 0.04 & 0.01 & 0.00 & 0.01 & 0.01 & 0.01 & 0.05 & 0.07 & 0.05 & 0.02 & 0.01 \\
\hline $\mathbf{B a O}$ & 1.18 & 0.80 & 0.04 & 0.80 & 0.84 & 0.93 & 0.99 & 0.87 & 0.88 & 1.06 & 0.84 & 0.94 & 0.75 & 0.83 & 0.98 \\
\hline $\mathrm{Na}_{2} \mathrm{O}$ & 1.45 & 0.63 & 11.28 & 0.80 & 0.96 & 0.49 & 0.92 & 1.04 & 1.21 & 0.78 & 1.06 & 3.64 & 1.16 & 1.01 & 0.74 \\
\hline $\mathbf{K}_{2} \mathbf{O}$ & 13.98 & 15.45 & 0.13 & 15.10 & 14.94 & 15.64 & 14.97 & 14.82 & 14.52 & 15.14 & 15.05 & 11.34 & 14.47 & 14.86 & 15.00 \\
\hline Total & 99.82 & 99.79 & 100.08 & 100.44 & 100.06 & 100.70 & 100.19 & 99.89 & 99.97 & 99.86 & 100.49 & 100.32 & 99.79 & 100.07 & 99.67 \\
\hline $\mathbf{S i}$ & 2.974 & 2.979 & 2.991 & 2.982 & 2.977 & 2.979 & 2.977 & 2.980 & 2.992 & 2.985 & 2.974 & 2.972 & 2.980 & 2.979 & 2.982 \\
\hline $\mathbf{T i}$ & 0.000 & 0.000 & 0.000 & 0.000 & 0.001 & 0.000 & 0.001 & 0.000 & 0.000 & 0.000 & 0.000 & 0.000 & 0.000 & 0.001 & 0.000 \\
\hline Al & 1.034 & 1.023 & 1.025 & 1.024 & 1.026 & 1.025 & 1.026 & 1.025 & 1.025 & 1.025 & 1.026 & 1.028 & 1.029 & 1.026 & 1.025 \\
\hline $\mathrm{Cr}$ & 0.000 & 0.000 & 0.000 & 0.000 & 0.000 & 0.000 & 0.000 & 0.000 & 0.000 & 0.000 & 0.000 & 0.000 & 0.000 & 0.000 & 0.000 \\
\hline $\mathrm{Fe}^{3+}$ & 0.000 & 0.002 & 0.000 & 0.002 & 0.003 & 0.003 & 0.003 & 0.001 & 0.000 & 0.000 & 0.003 & 0.000 & 0.002 & 0.002 & 0.002 \\
\hline $\mathrm{Fe}^{2+}$ & 0.000 & 0.000 & 0.000 & 0.000 & 0.000 & 0.000 & 0.000 & 0.000 & 0.000 & 0.000 & 0.000 & 0.000 & 0.000 & 0.000 & 0.000 \\
\hline Mn & 0.001 & 0.000 & 0.000 & 0.000 & 0.000 & 0.000 & 0.000 & 0.000 & 0.000 & 0.001 & 0.000 & 0.000 & 0.000 & 0.000 & 0.000 \\
\hline Mg & 0.000 & 0.001 & 0.000 & 0.000 & 0.000 & 0.001 & 0.000 & 0.000 & 0.000 & 0.000 & 0.000 & 0.001 & 0.000 & 0.000 & 0.000 \\
\hline $\mathbf{C a}$ & 0.002 & 0.002 & 0.018 & 0.003 & 0.002 & 0.001 & 0.000 & 0.000 & 0.001 & 0.001 & 0.003 & 0.003 & 0.002 & 0.001 & 0.000 \\
\hline $\mathbf{B a}$ & 0.021 & 0.015 & 0.001 & 0.014 & 0.015 & 0.017 & 0.018 & 0.016 & 0.016 & 0.019 & 0.015 & 0.017 & 0.014 & 0.015 & 0.018 \\
\hline $\mathrm{Na}$ & 0.130 & 0.057 & 0.957 & 0.071 & 0.086 & 0.044 & 0.083 & 0.094 & 0.109 & 0.070 & 0.094 & 0.322 & 0.104 & 0.091 & 0.067 \\
\hline $\mathbf{K}$ & 0.826 & 0.916 & 0.007 & 0.887 & 0.882 & 0.919 & 0.883 & 0.876 & 0.858 & 0.899 & 0.885 & 0.660 & 0.854 & 0.876 & 0.889 \\
\hline Total & 4.987 & 4.995 & 5.000 & 4.984 & 4.992 & 4.989 & 4.991 & 4.991 & 5.000 & 5.000 & 5.001 & 5.004 & 4.984 & 4.990 & 4.983 \\
\hline An & 0.00 & 0.00 & 0.02 & 0.00 & 0.00 & 0.00 & 0.00 & 0.00 & 0.00 & 0.00 & 0.00 & 0.00 & 0.00 & 0.00 & 0.00 \\
\hline $\mathbf{A b}$ & 0.14 & 0.06 & 0.97 & 0.07 & 0.09 & 0.05 & 0.09 & 0.10 & 0.11 & 0.07 & 0.10 & 0.33 & 0.11 & 0.09 & 0.07 \\
\hline Or & 0.86 & 0.94 & 0.01 & 0.92 & 0.91 & 0.95 & 0.91 & 0.90 & 0.89 & 0.93 & 0.90 & 0.67 & 0.89 & 0.91 & 0.93 \\
\hline
\end{tabular}


PLAGIOCLÁSIO - amostra CP-60

\begin{tabular}{|c|c|c|c|c|c|c|c|c|c|c|c|c|c|c|c|c|c|}
\hline Point & 1.1 & 1.2 & 1.3 & 2.1 & 2.2 & 2.3 & 3.1 & 3.2 & 3.3 & 3.4 & 3.5 & 4.1 & 4.2 & 4.3 & 5.1 & 5.2 & 5.3 \\
\hline $\mathrm{SiO}_{2}$ & 63.60 & 64.27 & 63.90 & 63.38 & 63.32 & 63.82 & 63.95 & 63.72 & 63.97 & 63.83 & 63.79 & 62.31 & 63.82 & 63.56 & 62.63 & 62.24 & 62.33 \\
\hline $\mathrm{TiO}_{2}$ & 0.00 & 0.00 & 0.00 & 0.00 & 0.05 & 0.00 & 0.02 & 0.03 & 0.00 & 0.03 & 0.01 & 0.01 & 0.01 & 0.03 & 0.05 & 0.00 & 0.00 \\
\hline $\mathrm{Al}_{2} \mathrm{O}_{3}$ & 23.16 & 22.83 & 22.84 & 22.87 & 23.18 & 22.81 & 22.63 & 22.74 & 23.05 & 22.84 & 22.80 & 23.45 & 22.92 & 23.24 & 23.28 & 23.40 & 23.21 \\
\hline $\mathrm{Cr}_{2} \mathrm{O}_{3}$ & 0.00 & 0.00 & 0.00 & 0.00 & 0.00 & 0.00 & 0.00 & 0.00 & 0.00 & 0.00 & 0.00 & 0.00 & 0.00 & 0.00 & 0.00 & 0.00 & 0.00 \\
\hline $\mathrm{Fe}_{2} \mathrm{O}_{3}$ & 0.08 & 0.00 & 0.00 & 0.07 & 0.08 & 0.13 & 0.05 & 0.02 & 0.01 & 0.00 & 0.02 & 0.16 & 0.03 & 0.05 & 0.15 & 0.04 & 0.20 \\
\hline $\mathrm{FeO}$ & 0.00 & 0.00 & 0.00 & 0.00 & 0.00 & 0.00 & 0.00 & 0.00 & 0.00 & 0.00 & 0.00 & 0.00 & 0.00 & 0.00 & 0.00 & 0.00 & 0.00 \\
\hline MnO & 0.01 & 0.00 & 0.00 & 0.00 & 0.01 & 0.01 & 0.01 & 0.00 & 0.00 & 0.00 & 0.02 & 0.01 & 0.00 & 0.01 & 0.00 & 0.01 & 0.00 \\
\hline MgO & 0.00 & 0.00 & 0.00 & 0.00 & 0.00 & 0.00 & 0.00 & 0.00 & 0.00 & 0.00 & 0.00 & 0.00 & 0.00 & 0.00 & 0.00 & 0.00 & 0.00 \\
\hline $\mathrm{CaO}$ & 3.79 & 3.48 & 3.75 & 3.81 & 3.94 & 3.48 & 3.38 & 3.36 & 3.61 & 3.47 & 3.42 & 4.36 & 3.55 & 3.69 & 4.09 & 4.21 & 4.21 \\
\hline $\mathbf{B a O}$ & 0.05 & 0.04 & 0.04 & 0.00 & 0.07 & 0.02 & 0.00 & 0.04 & 0.05 & 0.02 & 0.08 & 0.02 & 0.00 & 0.00 & 0.00 & 0.00 & 0.00 \\
\hline $\mathrm{Na}_{2} \mathrm{O}$ & 9.20 & 9.41 & 9.27 & 9.12 & 9.15 & 9.27 & 9.41 & 9.26 & 9.20 & 9.20 & 9.33 & 8.71 & 9.14 & 9.25 & 8.76 & 8.81 & 8.92 \\
\hline $\mathrm{K}_{2} \mathrm{O}$ & 0.12 & 0.15 & 0.16 & 0.09 & 0.11 & 0.06 & 0.15 & 0.13 & 0.16 & 0.15 & 0.15 & 0.15 & 0.14 & 0.10 & 0.12 & 0.17 & 0.11 \\
\hline Total & 100.01 & 100.18 & 99.96 & 99.35 & 99.90 & 99.60 & 99.60 & 99.30 & 100.04 & 99.54 & 99.62 & 99.17 & 99.62 & 99.92 & 99.08 & 98.88 & 98.97 \\
\hline Si & 2.806 & 2.835 & 2.827 & 2.813 & 2.799 & 2.823 & 2.829 & 2.826 & 2.818 & 2.836 & 2.823 & 2.777 & 2.821 & 2.805 & 2.790 & 2.781 & 2.784 \\
\hline $\mathbf{T i}$ & 0.000 & 0.000 & 0.000 & 0.000 & 0.002 & 0.000 & 0.001 & 0.001 & 0.000 & 0.001 & 0.000 & 0.000 & 0.000 & 0.001 & 0.002 & 0.000 & 0.000 \\
\hline Al & 1.204 & 1.187 & 1.191 & 1.196 & 1.208 & 1.189 & 1.180 & 1.189 & 1.197 & 1.196 & 1.189 & 1.232 & 1.194 & 1.209 & 1.222 & 1.232 & 1.222 \\
\hline $\mathrm{Cr}$ & 0.000 & 0.000 & 0.000 & 0.000 & 0.000 & 0.000 & 0.000 & 0.000 & 0.000 & 0.000 & 0.000 & 0.000 & 0.000 & 0.000 & 0.000 & 0.000 & 0.000 \\
\hline $\mathrm{Fe}^{3+}$ & 0.002 & 0.000 & 0.000 & 0.002 & 0.003 & 0.004 & 0.001 & 0.001 & 0.000 & 0.000 & 0.001 & 0.005 & 0.001 & 0.002 & 0.005 & 0.001 & 0.007 \\
\hline $\mathrm{Fe}^{2+}$ & 0.000 & 0.000 & 0.000 & 0.000 & 0.000 & 0.000 & 0.000 & 0.000 & 0.000 & 0.000 & 0.000 & 0.000 & 0.000 & 0.000 & 0.000 & 0.000 & 0.000 \\
\hline Mn & 0.000 & 0.000 & 0.000 & 0.000 & 0.000 & 0.000 & 0.000 & 0.000 & 0.000 & 0.000 & 0.001 & 0.000 & 0.000 & 0.000 & 0.000 & 0.000 & 0.000 \\
\hline Mg & 0.000 & 0.000 & 0.000 & 0.000 & 0.000 & 0.000 & 0.000 & 0.000 & 0.000 & 0.000 & 0.000 & 0.000 & 0.000 & 0.000 & 0.000 & 0.000 & 0.000 \\
\hline $\mathbf{C a}$ & 0.179 & 0.164 & 0.178 & 0.181 & 0.187 & 0.165 & 0.160 & 0.160 & 0.170 & 0.165 & 0.162 & 0.208 & 0.168 & 0.174 & 0.195 & 0.202 & 0.201 \\
\hline $\mathbf{B a}$ & 0.001 & 0.001 & 0.001 & 0.000 & 0.001 & 0.000 & 0.000 & 0.001 & 0.001 & 0.000 & 0.001 & 0.000 & 0.000 & 0.000 & 0.000 & 0.000 & 0.000 \\
\hline $\mathrm{Na}$ & 0.787 & 0.805 & 0.795 & 0.785 & 0.784 & 0.795 & 0.807 & 0.796 & 0.786 & 0.793 & 0.801 & 0.753 & 0.783 & 0.791 & 0.757 & 0.763 & 0.772 \\
\hline $\mathbf{K}$ & 0.007 & 0.008 & 0.009 & 0.005 & 0.006 & 0.003 & 0.009 & 0.007 & 0.009 & 0.008 & 0.008 & 0.009 & 0.008 & 0.006 & 0.007 & 0.009 & 0.006 \\
\hline Total & 4.987 & 5.000 & 5.000 & 4.983 & 4.989 & 4.980 & 4.987 & 4.980 & 4.981 & 5.000 & 4.986 & 4.985 & 4.976 & 4.988 & 4.977 & 4.989 & 4.992 \\
\hline An & 0.18 & 0.17 & 0.18 & 0.19 & 0.19 & 0.17 & 0.16 & 0.17 & 0.18 & 0.17 & 0.17 & 0.21 & 0.18 & 0.18 & 0.20 & 0.21 & 0.21 \\
\hline $\mathbf{A b}$ & 0.81 & 0.82 & 0.81 & 0.81 & 0.80 & 0.83 & 0.83 & 0.83 & 0.81 & 0.82 & 0.82 & 0.78 & 0.82 & 0.81 & 0.79 & 0.78 & 0.79 \\
\hline Or & 0.01 & 0.01 & 0.01 & 0.01 & 0.01 & 0.00 & 0.01 & 0.01 & 0.01 & 0.01 & 0.01 & 0.01 & 0.01 & 0.01 & 0.01 & 0.01 & 0.01 \\
\hline
\end{tabular}




\section{RUTILO - amostra CP-07}

\begin{tabular}{|c|c|c|c|c|c|c|c|c|c|c|c|c|c|c|c|c|}
\hline & 1.1 & 1.2 & 1.3 & 2.1 & 2.2 & 2.3 & 3.1 & 3.2 & 3.3 & 4.1 & 5.1 & 5.2 & 5.3 & 6.1 & 6.2 & 6.3 \\
\hline $\mathrm{TiO}_{2}$ & 97.88 & 97.12 & 96.82 & 96.22 & 95.93 & 97.38 & 96.18 & 95.38 & 96.91 & 95.51 & 97.15 & 94.48 & 97.76 & 75.94 & 87.97 & 96.16 \\
\hline $\mathrm{Cr}_{2} \mathrm{O}_{3}$ & 0.22 & 0.22 & 0.23 & 0.32 & 0.22 & 0.23 & 0.18 & 0.24 & 0.26 & 0.31 & 0.05 & 0.25 & 0.01 & 0.61 & 0.29 & 0.36 \\
\hline $\mathbf{A l}_{2} \mathbf{O}_{3}$ & 0.02 & 0.01 & 0.12 & 0.01 & 0.01 & 0.01 & 0.04 & 0.02 & 0.04 & 0.03 & 0.22 & 0.13 & 0.04 & 11.73 & 0.02 & 0.04 \\
\hline $\mathrm{Nb}_{2} \mathrm{O}_{5}$ & 0.81 & 1.07 & 1.22 & 1.49 & 0.60 & 0.65 & 1.32 & 1.38 & 1.37 & 2.39 & 0.27 & 1.96 & 0.26 & 2.19 & 0.85 & 0.78 \\
\hline $\mathrm{FeO}$ & 0.72 & 0.93 & 0.50 & 0.68 & 1.78 & 0.30 & 0.40 & 0.98 & 0.38 & 0.79 & 0.18 & 0.61 & 0.06 & 3.03 & 11.06 & 0.22 \\
\hline $\mathrm{V}^{2} \mathrm{O}_{3}$ & 0.75 & 0.76 & 0.79 & 0.84 & 0.72 & 0.73 & 0.74 & 0.72 & 0.73 & 0.92 & 0.51 & 0.86 & 0.48 & 0.73 & 0.64 & 0.73 \\
\hline $\mathrm{ZrO}_{2}$ & 0.07 & 0.08 & 0.07 & 0.07 & 0.08 & 0.07 & 0.07 & 0.07 & 0.07 & 0.06 & 0.03 & 0.06 & 0.04 & 0.05 & 0.07 & 0.08 \\
\hline $\mathrm{SiO}_{2}$ & 0.03 & 0.02 & 0.09 & 0.02 & 0.02 & 0.02 & 0.11 & 0.03 & 0.04 & 0.02 & 0.29 & 0.13 & 0.05 & 4.74 & 0.03 & 0.07 \\
\hline Total & 100.49 & 100.22 & 99.85 & 99.65 & 99.34 & 99.40 & 99.03 & 98.82 & 99.78 & 100.03 & 98.70 & 98.47 & 98.70 & 99.02 & 100.93 & 98.43 \\
\hline Ti & 0.981 & 0.978 & 0.977 & 0.975 & 0.977 & 0.985 & 0.978 & 0.975 & 0.978 & 0.966 & 0.986 & 0.969 & 0.992 & 0.756 & 0.920 & 0.982 \\
\hline $\mathrm{Cr}$ & 0.002 & 0.002 & 0.002 & 0.003 & 0.002 & 0.002 & 0.002 & 0.003 & 0.003 & 0.003 & 0.001 & 0.003 & 0.000 & 0.006 & 0.003 & 0.004 \\
\hline Al & 0.000 & 0.000 & 0.002 & 0.000 & 0.000 & 0.000 & 0.001 & 0.000 & 0.001 & 0.000 & 0.004 & 0.002 & 0.001 & 0.183 & 0.000 & 0.001 \\
\hline Nb & 0.005 & 0.006 & 0.007 & 0.009 & 0.004 & 0.004 & 0.008 & 0.008 & 0.008 & 0.015 & 0.002 & 0.012 & 0.002 & 0.013 & 0.005 & 0.005 \\
\hline $\mathrm{Fe}$ & 0.008 & 0.010 & 0.006 & 0.008 & 0.020 & 0.003 & 0.005 & 0.011 & 0.004 & 0.009 & 0.002 & 0.007 & 0.001 & 0.034 & 0.129 & 0.003 \\
\hline $\mathbf{V}$ & 0.008 & 0.008 & 0.008 & 0.009 & 0.008 & 0.008 & 0.008 & 0.008 & 0.008 & 0.010 & 0.006 & 0.009 & 0.005 & 0.008 & 0.007 & 0.008 \\
\hline $\mathbf{Z r}$ & 0.000 & 0.001 & 0.000 & 0.000 & 0.000 & 0.000 & 0.000 & 0.000 & 0.000 & 0.000 & 0.000 & 0.000 & 0.000 & 0.000 & 0.000 & 0.001 \\
\hline $\mathbf{S i}$ & 0.000 & 0.000 & 0.001 & 0.000 & 0.000 & 0.000 & 0.001 & 0.000 & 0.000 & 0.000 & 0.004 & 0.002 & 0.001 & 0.063 & 0.000 & 0.001 \\
\hline Total & 1.005 & 1.006 & 1.004 & 1.005 & 1.012 & 1.003 & 1.003 & 1.006 & 1.003 & 1.004 & 1.003 & 1.004 & 1.001 & 1.063 & 1.066 & 1.003 \\
\hline
\end{tabular}




\section{RUTILO - amostra CP-333}

\begin{tabular}{|c|c|c|c|c|c|c|c|c|c|c|c|c|c|c|c|c|}
\hline & 1.1 & 1.2 & 1.3 & 1.4 & 2 & 3 & 4 & 5.1 & 5.2 & 6.1 & 6.2 & 6.3 & 6.4 & 7.1 & 7.2 & 7.3 \\
\hline $\mathrm{TiO}_{2}$ & 99.45 & 99.33 & 99.56 & 99.63 & 99.15 & 99.25 & 99.43 & 99.21 & 99.25 & 98.88 & 99.76 & 100.09 & 99.60 & 99.84 & 99.78 & 99.23 \\
\hline $\mathrm{Cr}_{2} \mathrm{O}_{3}$ & 0.14 & 0.14 & 0.14 & 0.14 & 0.13 & 0.12 & 0.13 & 0.18 & 0.21 & 0.12 & 0.11 & 0.12 & 0.12 & 0.12 & 0.12 & 0.14 \\
\hline $\mathrm{Al}_{2} \mathrm{O}_{3}$ & 0.04 & 0.05 & 0.02 & 0.02 & 0.03 & 0.03 & 0.04 & 0.03 & 0.02 & 0.03 & 0.02 & 0.01 & 0.02 & 0.02 & 0.02 & 0.03 \\
\hline $\mathrm{Nb}_{2} \mathrm{O}_{5}$ & 0.29 & 0.28 & 0.29 & 0.29 & 0.59 & 0.54 & 0.48 & 0.60 & 0.59 & 0.70 & 0.41 & 0.25 & 0.44 & 0.42 & 0.52 & 0.91 \\
\hline $\mathrm{FeO}$ & 0.11 & 0.10 & 0.10 & 0.11 & 0.16 & 0.18 & 0.17 & 0.22 & 0.43 & 0.85 & 0.31 & 0.31 & 0.47 & 0.23 & 0.35 & 0.40 \\
\hline $\mathrm{ZrO}_{2}$ & 0.04 & 0.03 & 0.03 & 0.04 & 0.04 & 0.04 & 0.04 & 0.05 & 0.04 & 0.04 & 0.03 & 0.02 & 0.03 & 0.02 & 0.03 & 0.03 \\
\hline $\mathrm{Ta}_{2} \mathrm{O}_{5}$ & 0.01 & 0.01 & 0.01 & 0.02 & 0.01 & 0.00 & 0.01 & 0.01 & 0.01 & 0.00 & 0.00 & 0.00 & 0.00 & 0.00 & 0.01 & 0.04 \\
\hline $\mathrm{SnO}_{2}$ & 0.02 & 0.02 & 0.01 & 0.01 & 0.02 & 0.02 & 0.02 & 0.01 & 0.02 & 0.01 & 0.01 & 0.02 & 0.01 & 0.02 & 0.01 & 0.02 \\
\hline $\mathrm{SiO}_{2}$ & 0.00 & 0.13 & 0.00 & 0.00 & 0.06 & 0.07 & 0.01 & 0.01 & 0.00 & 0.00 & 0.00 & 0.00 & 0.01 & 0.01 & 0.00 & 0.13 \\
\hline Total & 100.11 & 100.08 & 100.17 & 100.25 & 100.19 & 100.26 & 100.34 & 100.31 & 100.58 & 100.64 & 100.66 & 100.81 & 100.71 & 100.68 & 100.85 & 100.94 \\
\hline $\mathbf{T i}$ & 0.995 & 0.994 & 0.996 & 0.995 & 0.992 & 0.992 & 0.993 & 0.992 & 0.991 & 0.988 & 0.994 & 0.995 & 0.992 & 0.994 & 0.993 & 0.987 \\
\hline $\mathrm{Cr}$ & 0.002 & 0.002 & 0.002 & 0.002 & 0.001 & 0.001 & 0.001 & 0.002 & 0.002 & 0.001 & 0.001 & 0.001 & 0.001 & 0.001 & 0.001 & 0.001 \\
\hline Al & 0.001 & 0.001 & 0.000 & 0.000 & 0.001 & 0.001 & 0.001 & 0.000 & 0.000 & 0.000 & 0.000 & 0.000 & 0.000 & 0.000 & 0.000 & 0.001 \\
\hline Nb & 0.002 & 0.002 & 0.002 & 0.002 & 0.004 & 0.003 & 0.003 & 0.004 & 0.004 & 0.004 & 0.002 & 0.002 & 0.003 & 0.003 & 0.003 & 0.005 \\
\hline $\mathbf{F e}$ & 0.001 & 0.001 & 0.001 & 0.001 & 0.002 & 0.002 & 0.002 & 0.002 & 0.005 & 0.009 & 0.003 & 0.003 & 0.005 & 0.003 & 0.004 & 0.004 \\
\hline $\mathbf{Z r}$ & 0.000 & 0.000 & 0.000 & 0.000 & 0.001 & 0.001 & 0.001 & 0.001 & 0.000 & 0.001 & 0.000 & 0.000 & 0.000 & 0.000 & 0.000 & 0.000 \\
\hline Ta & 0.000 & 0.000 & 0.000 & 0.000 & 0.000 & 0.000 & 0.000 & 0.000 & 0.000 & 0.000 & 0.000 & 0.000 & 0.000 & 0.000 & 0.000 & 0.000 \\
\hline Sn & 0.000 & 0.000 & 0.000 & 0.000 & 0.000 & 0.000 & 0.000 & 0.000 & 0.000 & 0.000 & 0.000 & 0.000 & 0.000 & 0.000 & 0.000 & 0.000 \\
\hline $\mathbf{S i}$ & 0.000 & 0.002 & 0.000 & 0.000 & 0.001 & 0.001 & 0.000 & 0.000 & 0.000 & 0.000 & 0.000 & 0.000 & 0.000 & 0.000 & 0.000 & 0.002 \\
\hline Total & 1.001 & 1.001 & 1.001 & 1.001 & 1.001 & 1.001 & 1.001 & 1.001 & 1.002 & 1.004 & 1.002 & 1.002 & 1.003 & 1.001 & 1.002 & 1.002 \\
\hline
\end{tabular}




\section{RUTILO - amostra CP-60}

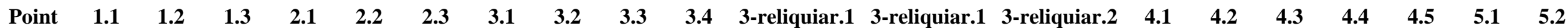

$\begin{array}{lllllllllll}\text { TiO2 } & 98.43 & 98.31 & 97.73 & 96.85 & 97.22 & 97.17 & 97.96 & 97.55 & 97.16 & 68.33\end{array}$

$\begin{array}{lllllllllll}\text { Cr2O3 } & 0.08 & 0.08 & 0.08 & 0.08 & 0.08 & 0.08 & 0.13 & 0.13 & 0.13 & 0.12\end{array}$

$\begin{array}{lllllllllll}\mathbf{V 2 O 3} & 0.84 & 0.82 & 0.82 & 0.93 & 0.90 & 0.92 & 1.09 & 1.10 & 1.10 & 0.87\end{array}$

$\begin{array}{lllllllllll}\mathbf{A} 203 & 0.01 & 0.01 & 0.03 & 0.01 & 0.01 & 0.01 & 0.01 & 0.01 & 0.05 & 5.10\end{array}$

$\begin{array}{llllllllllll}\text { Nb2O5 } & 0.52 & 0.40 & 0.36 & 0.60 & 0.40 & 0.49 & 0.64 & 0.66 & 0.64 & 0.72\end{array}$

$\begin{array}{llllllllllll}\text { FeO } & 0.10 & 0.12 & 0.22 & 0.14 & 0.12 & 0.23 & 0.14 & 0.09 & 0.15 & 9.00\end{array}$

$\begin{array}{lllllllllll}\text { ZrO2 } & 0.08 & 0.08 & 0.09 & 0.08 & 0.08 & 0.08 & 0.09 & 0.10 & 0.07 & 0.07\end{array}$

$\begin{array}{llllllllllll}\text { SiO2 } & 0.03 & 0.03 & 0.12 & 0.11 & 0.03 & 0.03 & 0.07 & 0.04 & 0.05 & 5.98\end{array}$

$\begin{array}{lllllllllll}\text { Total } & 0.73 & 0.64 & 0.81 & 0.95 & 0.62 & 0.84 & 0.94 & 0.90 & 0.95 & 20.88\end{array}$

\subsection{7}

0.13

1.07

0.20

0.65

0.48

0.10

0.52

1.97
61.87

0.06

0.59

0.00

0.31

22.63

0.07

0.04

23.05
57.10

0.04

0.51

0.08

0.20

33.44

0.06

0.20

33.99 $\begin{array}{lllllll}98.21 & 98.06 & 98.14 & 98.21 & 98.42 & 97.03 & 98.36\end{array}$

$\begin{array}{lllllll}0.08 & 0.08 & 0.08 & 0.08 & 0.07 & 0.15 & 0.15\end{array}$

$\begin{array}{lllllll}0.89 & 0.88 & 0.89 & 0.90 & 0.90 & 0.92 & 0.90\end{array}$

$\begin{array}{llllllll}0.02 & 0.01 & 0.01 & 0.01 & 0.02 & 0.02 & 0.01\end{array}$

$\begin{array}{llllllll}0.36 & 0.35 & 0.33 & 0.33 & 0.32 & 0.45 & 0.57\end{array}$

$\begin{array}{llllllll}0.24 & 0.15 & 0.14 & 0.16 & 0.31 & 0.37 & 0.22\end{array}$

$\begin{array}{lllllll}0.06 & 0.06 & 0.06 & 0.05 & 0.06 & 0.11 & 0.10\end{array}$

$\begin{array}{llllllll}0.06 & 0.02 & 0.02 & 0.01 & 0.04 & 0.18 & 0.08\end{array}$ 


\section{Apêndice $\mathbf{F}$}

\section{Scriptfiles das Pseudosseções}

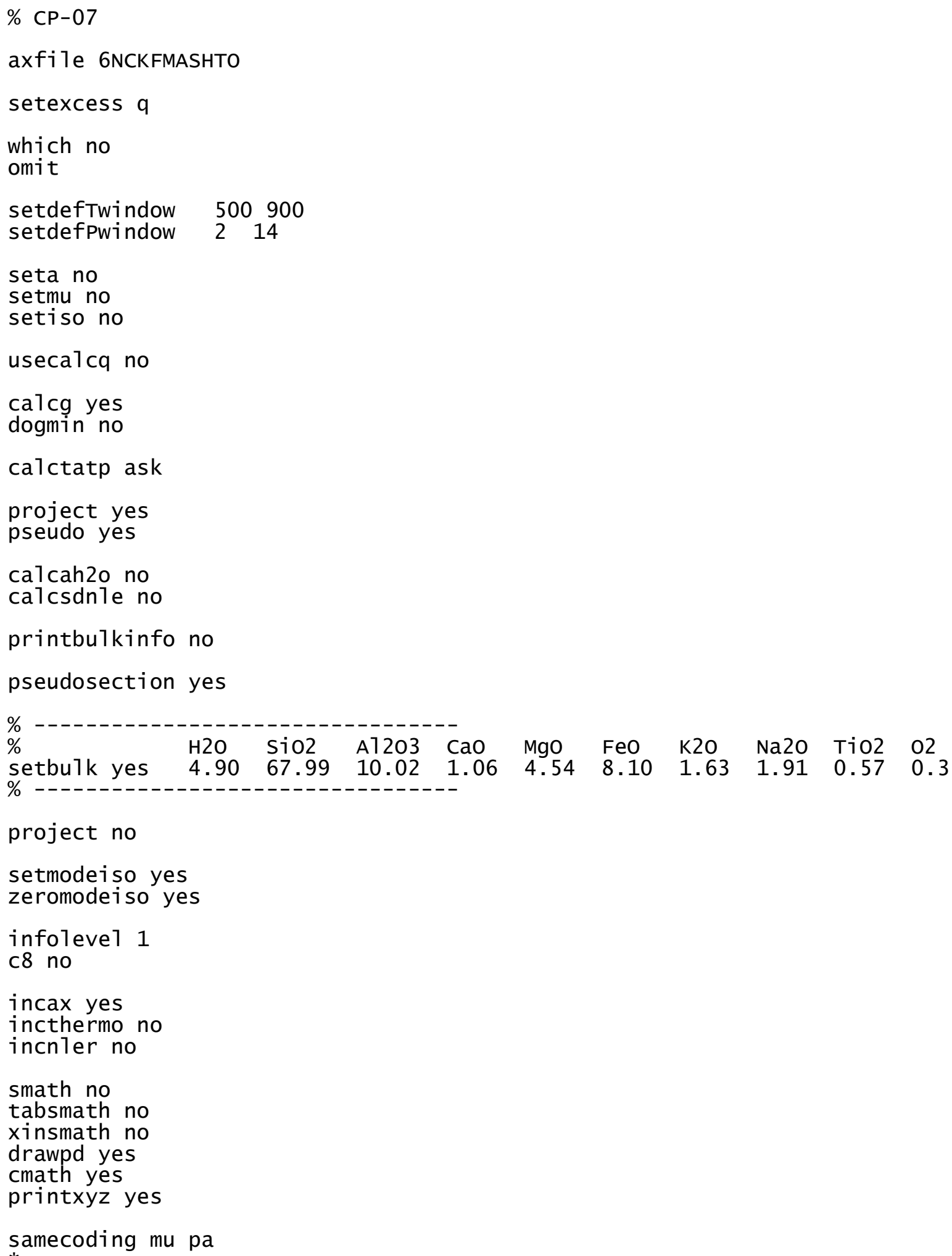


$\% \quad \mathrm{CP}-333$

axfi1e 6NCKFMASHTO

setexcess q

which no

omit

setdefTwindow 500900

setdefPwindow 214

seta no

setmu no

setiso no

usecalcq no

calcg yes

dogmin no

calctatp ask

project yes

pseudo yes

calcah2o no

calcsdnle no

printbulkinfo no

pseudosection yes

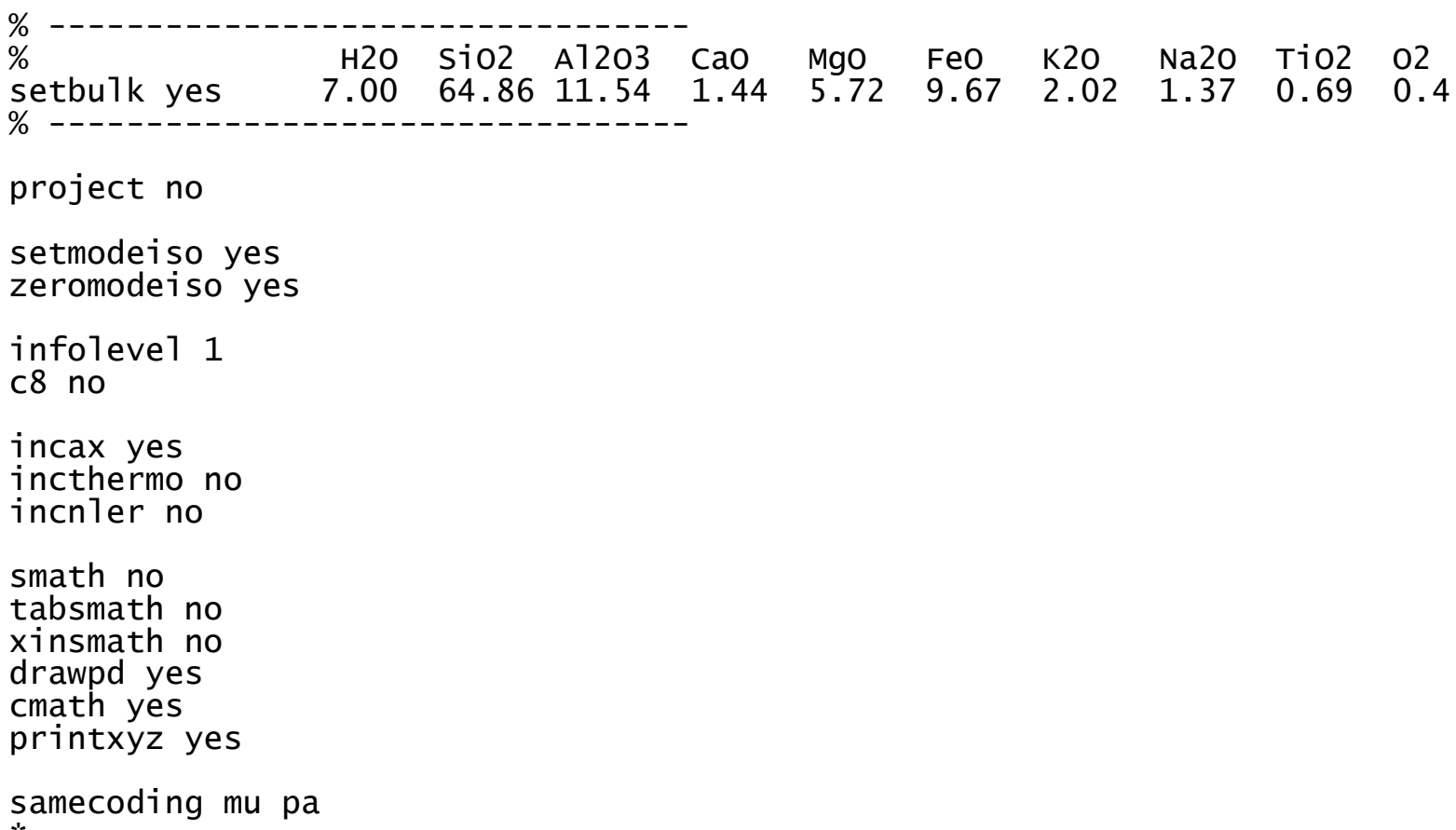




\section{Apêndice G}

Resultados dos cálculos geotermobarométricos

Average PT (for $x(\mathrm{H} 2 \mathrm{O})=1.0)$

Single end-member diagnostic information

avp, avT, sd's, cor, fit are result of doubling the uncertainty on $1 \mathrm{n}$ a:

a $1 n$ a suspect if any are $v$ different from 1 sq values.

$\mathrm{e}^{*}$ are $1 \mathrm{n}$ a residuals normalised to $1 \mathrm{n}$ a uncertainties:

large absolute values, say $>2.5$, point to suspect info.

\section{CP-07-I-1}

Activities and their uncertainties

$\begin{array}{lrrrrrrr} & \text { py } & \text { gr } & \text { a7m } & \text { ph1 } & \text { ann } & \text { east } & \text { mu } \\ \text { a } & 0.00540 & 0.000360 & 0.410 & 0.0550 & 0.0290 & 0.0630 & 0.650 \\ \mathrm{sd}(\mathrm{a}) / \mathrm{a} & 0.20397 & 0.42172 & 0.15000 & 0.11719 & 0.15000 & 0.11220 & 0.10000 \\ & & & & & & & \\ & \mathrm{ce} 1 & \mathrm{fce} 1 & \mathrm{pa} & \mathrm{mst} & \mathrm{fst} & \text { an } & \mathrm{ab} \\ \mathrm{a} & 0.0319 & 0.0201 & 0.760 & 0.00160 & 0.410 & 0.300 & 0.830 \\ \mathrm{sd}(\mathrm{a}) / \mathrm{a} & 0.31348 & 0.49751 & 0.05000 & 0.25600 & 0.20000 & 0.05000 & 0.05000\end{array}$

$\begin{array}{lrrr} & \mathrm{q} & \mathrm{H} 2 \mathrm{O} & \mathrm{ky} \\ \mathrm{a} & 1.00 & 1.00 & 1.00 \\ \mathrm{sd}(\mathrm{a}) / \mathrm{a} & 0 & & 0\end{array}$

Independent set of reactions

1) $g r+q+2 k y=3 a n$

2) $23 g r+6 f s t+48 q=8 a 7 m+69 a n+12 H 2 O$

3) $\mathrm{gr}+2 \mathrm{pa}+3 \mathrm{q}=3 \mathrm{an}+2 \mathrm{ab}+2 \mathrm{H} 2 \mathrm{O}$

4) $a n n+3 a n=g r+a 7 m+m u$

Calculations for the independent set of reactions (for $x(H 2 O)=1.0$ )

$\begin{array}{rrrrrrrr}\mathrm{P}(\mathrm{T}) & \mathrm{Sd}(\mathrm{P}) & \mathrm{a} & \mathrm{sd}(\mathrm{a}) & \mathrm{b} & \mathrm{C} & 1 \mathrm{n} \_\mathrm{K} & \mathrm{sd}\left(1 \mathrm{ln} \_\mathrm{K}\right) \\ 8.4 & 0.55 & 42.01 & 0.57 & -0.13943 & 6.383 & 4.317 & 0.448 \\ 8.4 & 0.57 & 1511.79 & 14.01 & -3.74093 & 141.875 & 97.519 & 10.434 \\ 8.2 & 0.46 & 141.47 & 0.69 & -0.26194 & 7.998 & 4.494 & 0.469 \\ 8.7 & 0.55 & -35.61 & 1.15 & 0.12483 & -7.328 & -2.099 & 0.505\end{array}$

hat are the diagonal elements of the hat matrix:

large values, say $>0.38$, point to influential data.

For $95 \%$ confidence, fit $(=\operatorname{sd}(f i t))<1.73$ 


$\begin{array}{rrrrrrr} & \text { avp } & \text { sd } & \text { avT } & \text { sd } & \text { cor } & \text { fit } \\ 1 \text { sq } & 8.4 & 0.6 & 657 & 12 & 0.715 & 0.99\end{array}$

$\begin{array}{rrrrrrrrr} & \mathrm{P} & \mathrm{sd}(\mathrm{P}) & \mathrm{T} & \mathrm{sd}(\mathrm{T}) & \text { cor } & \text { fit } & \mathrm{e}^{*} & \text { hat } \\ \mathrm{gr} & 8.27 & 0.88 & 655 & 14 & 0.778 & 0.98 & 0.15 & 0.66 \\ \mathrm{a} 7 \mathrm{~m} & 8.37 & 0.66 & 656 & 13 & 0.764 & 0.98 & 0.12 & 0.17 \\ \mathrm{ann} & 8.38 & 0.60 & 657 & 12 & 0.712 & 0.75 & -0.75 & 0.01 \\ \mathrm{mu} & 8.39 & 0.60 & 657 & 12 & 0.713 & 0.85 & 0.50 & 0.00 \\ \mathrm{pa} & 8.40 & 0.60 & 653 & 15 & 0.617 & 0.94 & -0.28 & 0.36 \\ \mathrm{fst} & 8.60 & 0.65 & 662 & 14 & 0.763 & 0.82 & 0.63 & 0.18 \\ \text { an } & 8.38 & 0.66 & 656 & 12 & 0.728 & 0.98 & -0.05 & 0.08 \\ \mathrm{ab} & 8.40 & 0.60 & 653 & 15 & 0.617 & 0.94 & 0.28 & 0.36 \\ \mathrm{q} & 8.41 & 0.60 & 657 & 12 & 0.715 & 0.99 & 0 & 0 \\ \mathrm{H} 2 \mathrm{O} & 8.41 & 0.60 & 657 & 12 & 0.715 & 0.99 & 0 & 0 \\ \mathrm{ky} & 8.41 & 0.60 & 657 & 12 & 0.715 & 0.99 & 0 & 0\end{array}$

$\mathrm{T}=657 ; \mathrm{C}, \quad \mathrm{sd}=12$,

$P=8.4$ kbars, $s d=0.6$, cor $=0.715$, sigfit $=0.99$

\section{CP-07-I-2}

Activities and their uncertainties

$\begin{array}{lrrrrrr} & \text { gr } & \text { alm } & \text { ph1 } & \text { ann } & \text { east } & \text { mu } \\ \text { a } & 0.000400 & 0.410 & 0.0630 & 0.0300 & 0.0660 & 0.670 \\ \mathrm{sd}(\mathrm{a}) / \mathrm{a} & 0.40716 & 0.15000 & 0.11220 & 0.15000 & 0.11044 & 0.10000\end{array}$

$\begin{array}{lrrrrrr} & \text { ce1 } & \text { fce1 } & \text { pa } & \text { fst } & \text { an } & \text { ab } \\ \text { a } & 0.0212 & 0.0150 & 0.620 & 0.390 & 0.290 & 0.830 \\ \mathrm{sd}(\mathrm{a}) / \mathrm{a} & 0.47170 & 0.66667 & 0.05000 & 0.20000 & 0.05041 & 0.05000\end{array}$

$\begin{array}{lrrr} & \mathrm{q} & \mathrm{H} 20 & \mathrm{ky} \\ \mathrm{a} & 1.00 & 1.00 & 1.00 \\ \mathrm{sd}(\mathrm{a}) / \mathrm{a} & 0 & & 0\end{array}$

Independent set of reactions
1) $g r+q+2 k y=3 a n$
2) $23 g r+6 f s t+48 q=8 a 7 m+69 a n+12 \mathrm{H} 20$
3) $\mathrm{gr}+2 \mathrm{pa}+3 \mathrm{q}=3 \mathrm{an}+2 \mathrm{ab}+2 \mathrm{H} 2 \mathrm{O}$
4) $\mathrm{ph} 1+\mathrm{cel}+2 \mathrm{ky}=2$ east $+5 q$
5) $2 \mathrm{cel}+2 \mathrm{ky}=$ east $+\mathrm{mu}+5 \mathrm{q}$
6) $a n n+3 a n=g r+a 7 m+m u$
7) $2 \mathrm{ph} 1+4 a n n+9 a n=3 g r+3 a 1 m+3$ east $+3 f c e 1$

Calculations for the independent set of reactions (for $x(H 2 O)=1.0$ )

$\begin{array}{rrrrrrrrr} & \mathrm{P}(\mathrm{T}) & \mathrm{sd}(\mathrm{P}) & \mathrm{a} & \mathrm{sd}(\mathrm{a}) & \mathrm{b} & \mathrm{c} & \text { 1n_K } & \mathrm{sd}\left(1 \mathrm{ln} \_\mathrm{K}\right) \\ 1 & 7.8 & 0.50 & 42.05 & 0.57 & -0.13973 & 6.410 & 4.110 & 0.434 \\ 2 & 7.6 & 0.53 & 1527.71 & 14.01 & -3.76279 & 142.313 & 93.057 & 10.133\end{array}$




$\begin{array}{rrrrrrrrr}3 & 6.7 & 0.42 & 142.29 & 0.69 & -0.26336 & 8.051 & 4.694 & 0.457 \\ 4 & 7.3 & 1.29 & 13.18 & 0.95 & -0.05055 & 3.080 & 1.182 & 0.533 \\ 5 & 9.1 & 2.08 & -9.31 & 0.90 & -0.06250 & 3.362 & 4.589 & 0.955 \\ 6 & 8.1 & 0.51 & -36.23 & 1.15 & 0.12578 & -7.355 & -1.896 & 0.494 \\ 7 & 9.0 & 0.82 & -14.87 & 4.49 & 0.38816 & -23.039 & -16.204 & 2.534\end{array}$

hat are the diagonal elements of the hat matrix:

large values, say $>0.47$, point to influential data.

For $95 \%$ confidence, fit $(=\operatorname{sd}(f i t))<1.49$

$\begin{array}{rrrrrrrrrr} & \text { avP } & \text { sd } & \text { avT } & \text { sd } & \text { cor } & \text { fit } & & \\ \text { 1sq } & 8.6 & 0.8 & 682 & 17 & 0.713 & 1.35 & & & \\ & & & & & & & & & \\ \text { gr } & 7.98 & 0.93 & 676 & 17 & 0.752 & 1.24 & 0.97 & 0.56 \\ \text { a1m } & 8.67 & 0.81 & 684 & 18 & 0.755 & 1.34 & -0.30 & 0.15 \\ \text { ph1 } & 8.72 & 0.71 & 683 & 16 & 0.712 & 1.24 & -0.89 & 0.03 \\ \text { ann } & 8.57 & 0.69 & 683 & 15 & 0.711 & 1.23 & -1.06 & 0.01 \\ \text { east } & 8.79 & 0.70 & 684 & 15 & 0.712 & 1.21 & 1.24 & 0.07 \\ \text { mu } & 8.59 & 0.76 & 682 & 17 & 0.709 & 1.35 & 0.19 & 0.01 \\ \text { ce1 } & 8.54 & 0.75 & 681 & 17 & 0.718 & 1.32 & 0.69 & 0.04 \\ \text { fce1 } & 8.57 & 0.76 & 682 & 17 & 0.717 & 1.34 & 0.33 & 0.02 \\ \text { pa } & 8.55 & 0.74 & 675 & 20 & 0.635 & 1.30 & -0.52 & 0.36 \\ \text { fst } & 8.96 & 0.69 & 692 & 16 & 0.757 & 1.14 & 1.34 & 0.17 \\ \text { an } & 8.45 & 0.81 & 681 & 17 & 0.722 & 1.32 & -0.36 & 0.08 \\ \text { ab } & 8.55 & 0.74 & 675 & 20 & 0.635 & 1.30 & 0.52 & 0.36 \\ \text { q } & 8.60 & 0.76 & 682 & 17 & 0.713 & 1.35 & 0 & 0 \\ \text { H20 } & 8.60 & 0.76 & 682 & 17 & 0.713 & 1.35 & 0 & 0 \\ \text { ky } & 8.60 & 0.76 & 682 & 17 & 0.713 & 1.35 & 0 & 0\end{array}$

$\mathrm{T}=682 \mathrm{iC}, \mathrm{sd}=17$,

$P=8.6$ kbars, $s d=0.8$, cor $=0.713$, sigfit $=1.35$

\section{CP-07-II-1}

Activities and their uncertainties

$\begin{array}{lrrrrrrr} & \text { py } & \text { gr } & \text { alm } & \text { ph1 } & \text { ann } & \text { east } & \text { mu } \\ \text { a } & 0.00450 & 0.000180 & 0.430 & 0.0630 & 0.0340 & 0.0640 & 0.650 \\ \mathrm{sd}(\mathrm{a}) / \mathrm{a} & 0.20912 & 0.53133 & 0.15000 & 0.11220 & 0.15000 & 0.11161 & 0.10000\end{array}$

$\begin{array}{lrrrrrrr} & \text { ce1 } & \text { fce1 } & \text { pa } & \text { mst } & \text { fst } & \text { an } & \text { ab } \\ \text { a } & 0.0277 & 0.0210 & 0.720 & 0.00210 & 0.380 & 0.280 & 0.830 \\ \mathrm{sd}(\mathrm{a}) / \mathrm{a} & 0.36101 & 0.47619 & 0.05000 & 0.24707 & 0.20000 & 0.05184 & 0.05000\end{array}$

$\begin{array}{lrrr} & \mathrm{q} & \mathrm{H} 20 & \mathrm{ky} \\ \mathrm{a} & 1.00 & 1.00 & 1.00 \\ \mathrm{sd}(\mathrm{a}) / \mathrm{a} & 0 & & 0\end{array}$


Independent set of reactions

1) $g r+q+2 k y=3 a n$

2) $23 g r+6 f s t+48 q=8 a 7 m+69 a n+12 H 2 O$

3) $\mathrm{gr}+2 \mathrm{pa}+3 \mathrm{q}=3 \mathrm{an}+2 \mathrm{ab}+2 \mathrm{H} 2 \mathrm{O}$

4) $2 \mathrm{ph} 1+\mathrm{mu}+2 \mathrm{ky}=3$ east $+5 \mathrm{q}$

5) $a n n+3 a n=g r+a 7 m+m u$

Calculations for the independent set of reactions (for $x(H 2 O)=1.0$ )

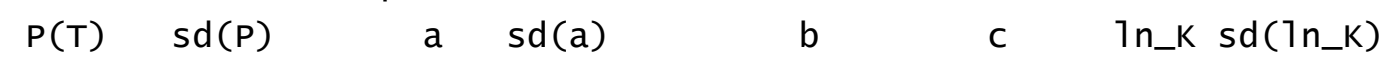

$\begin{array}{rrrrrrrrr}1 & 7.8 & 0.67 & 41.48 & 0.57 & -0.13905 & 6.405 & 4.804 & 0.554 \\ 2 & 7.8 & 0.70 & 1511.92 & 14.01 & -3.75339 & 143.259 & 109.538 & 12.846 \\ 3 & 7.7 & 0.54 & 141.75 & 0.69 & -0.26394 & 8.189 & 5.088 & 0.571 \\ 4 & 6.3 & 1.19 & 35.85 & 1.10 & -0.03911 & 2.834 & -2.287 & 0.415 \\ 5 & 8.0 & 0.65 & -35.16 & 1.15 & 0.12463 & -7.359 & -2.697 & 0.601\end{array}$

hat are the diagonal elements of the hat matrix :

large values, say $>0.38$, point to influential data.

For $95 \%$ confidence, fit $(=s d(f i t))<1.61$

$\begin{array}{rrrrrrrrrr} & \text { avP } & \text { sd } & \text { avT } & \text { sd } & \text { cor fit } & & \\ \text { 1sq } & 7.7 & 0.6 & 658 & 13 & 0.742 & 0.87 & & & \\ & & & & & & & & & \\ \text { gr } & 7.51 & 0.84 & 656 & 14 & 0.789 & 0.84 & 0.31 & 0.53 \\ \text { a1m } & 7.55 & 0.71 & 655 & 14 & 0.790 & 0.81 & 0.45 & 0.19 \\ \text { ph1 } & 7.83 & 0.66 & 659 & 13 & 0.744 & 0.74 & -0.59 & 0.04 \\ \text { ann } & 7.69 & 0.64 & 658 & 13 & 0.740 & 0.76 & -0.61 & 0.01 \\ \text { east } & 7.90 & 0.67 & 660 & 13 & 0.745 & 0.66 & 0.88 & 0.09 \\ \text { mu } & 7.69 & 0.65 & 658 & 13 & 0.738 & 0.86 & 0.14 & 0.02 \\ \text { pa } & 7.71 & 0.64 & 658 & 15 & 0.635 & 0.87 & 0.02 & 0.36 \\ \text { fst } & 7.76 & 0.70 & 659 & 15 & 0.791 & 0.86 & 0.15 & 0.20 \\ \text { an } & 7.68 & 0.68 & 658 & 13 & 0.751 & 0.86 & -0.09 & 0.05 \\ \text { ab } & 7.71 & 0.64 & 658 & 15 & 0.635 & 0.87 & -0.02 & 0.36 \\ \text { q } & 7.71 & 0.64 & 658 & 13 & 0.742 & 0.87 & 0 & 0 \\ \text { H20 } & 7.71 & 0.64 & 658 & 13 & 0.742 & 0.87 & 0 & 0 \\ \text { ky } & 7.71 & 0.64 & 658 & 13 & 0.742 & 0.87 & 0 & 0\end{array}$

$\mathrm{T}=658 \mathrm{iC}, \mathrm{sd}=13$,

$P=7.7$ kbars, $s d=0.6$, cor $=0.742$, sigfit $=0.87$

\section{CP-333}




\section{Apêndice H}

Dados de U-Pb em zircão obtidos via LA-MC-ICP-MS

Legenda para a descrição das características texturais do ponto analisado (segunda coluna da planilha de dados analíticos de acordo com as populações descritas no texto).

\begin{tabular}{|c|c|c|}
\hline $\begin{array}{c}\text { SITE } \\
\text { (posição do spot) }\end{array}$ & $\begin{array}{c}\text { HABIT } \\
\text { (forma do grão) }\end{array}$ & $\begin{array}{c}\text { CL/BSE PETROGRAPHY } \\
\text { (estrutura interna) }\end{array}$ \\
\hline $\mathrm{m}=$ middle & $\mathrm{p}=$ prism (comprimento/largura $>2$ & osc $=$ oscillatory zoning \\
\hline $\mathrm{e}=$ end or edge & rd = round & $\mathrm{sz}=$ sector zoning \\
\hline $\mathrm{c}=$ core & ov = ovoid & $\mathrm{ic}=$ inherited core \\
\hline & $\mathrm{eq}=$ equant & $\mathrm{r}=$ rim/overgrowth \\
\hline & $\mathrm{fr}=$ fragment & $\mathrm{hb}=$ homogeneous bright \\
\hline & $\mathrm{anh}-$ anhedral & $\mathrm{hd}=$ homogeneous dark \\
\hline & & $\mathrm{rx}=$ recrystallization \\
\hline
\end{tabular}

Observações para as planilhas:

- Valores de 1 e 2 o em \%;

- Pontos destacados em cinza não foram utilizados;

- Zircão com análise química de traços e ETR estão destacados em verde;

- pop. = população de cristais com mesmas características. 
Unidade Petúnia: amostra CP-38

\begin{tabular}{|c|c|c|c|c|c|c|c|c|c|c|c|c|c|c|c|c|c|c|c|c|c|c|}
\hline spot & site & habit & CL & $206 *(\%)$ & ${ }^{204} \mathrm{~Pb} \mathrm{cps}$ & $\mathrm{Th} / \mathrm{U}$ & ${ }^{206} \mathrm{~Pb} /{ }^{204} \mathrm{~Pb}$ & 10 & ${ }^{207} \mathrm{~Pb} /{ }^{206} \mathrm{~Pb}$ & 10 & ${ }^{207} \mathbf{P b} /{ }^{235} \mathrm{U}$ & 10 & ${ }^{206} \mathrm{~Pb} /{ }^{238} \mathrm{U}$ & 10 & Rho & t.76 & 20 & t.68 & 20 & t.75 & $20^{\circ}$ & concordância \\
\hline 1 & $\mathrm{c}$ & $\mathrm{p}$ & $\mathrm{ic} / \mathrm{rx}$ & 0.0465 & 32 & 0.151 & 33016 & 49.08 & 0.16215 & 2.50 & 6.443 & 3.38 & 0.2881 & 2.25 & 0.67 & 2478.7 & 84.6 & 1632 & 64.8 & 2038.2 & 59.4 & 65.8 \\
\hline 2 & $\mathrm{e}$ & $\mathrm{p}$ & osc/ic & 2026 & 128 & 0.251 & 7505 & 11.69 & 0.18649 & 1.60 & 9.246 & 1.98 & 0.3596 & 1.11 & 0.56 & 2711.4 & 54.2 & 1980.3 & 37.8 & 2362.7 & 36.2 & 73.0 \\
\hline 3 & $\mathrm{c}$ & $\mathrm{p}$ & osc /ic & 0.0190 & 44 & 0.307 & 76482 & 34.86 & 0.22521 & 1.40 & 17.331 & 2.19 & 0.5581 & 1.64 & 0.75 & 3018.4 & 46.4 & 2858.8 & 75.8 & 2953.3 & 42 & 94.7 \\
\hline 4 & $\mathrm{c}$ & $\mathrm{p}$ & $\mathrm{ic} / \mathrm{rx}$ & 0.0734 & 55 & 0.285 & 20546 & 41.93 & 0.18585 & 1.30 & 10.355 & 2.99 & 0.4041 & 2.66 & 0.89 & 2705.8 & 45 & 2187.9 & 98.8 & 2467 & 55.4 & 80.9 \\
\hline 5 & $\mathrm{c}$ & $\mathrm{fr}$ & ic & 0.0666 & 95 & 0.211 & 23060 & 36.69 & 0.17068 & 1.20 & 6.732 & 1.48 & 0.2860 & 0.79 & 0.53 & 2564.7 & 42 & 1621.5 & 23 & 2076.8 & 26.2 & 63.2 \\
\hline 6 & $\mathrm{~m}$ & $\mathrm{fr}$ & $\mathrm{rx}$ & 0.0139 & 53 & 0.364 & 107521 & 56.68 & 0.20720 & 0.51 & 13.160 & 1.11 & 0.4606 & 0.91 & 0.82 & 2883.9 & 20.6 & 2442.2 & 36.6 & 2691.2 & 21 & 84.7 \\
\hline 7 & $\mathrm{c}$ & $\mathrm{p}$ & sz/ic & 0.0810 & 50 & 0.258 & 18619 & 40.20 & 0.18809 & 0.86 & 10.528 & 2.76 & 0.4059 & 2.59 & 0.94 & 2725.8 & 31 & 2196.1 & 96.4 & 2482.4 & 51.2 & 80.6 \\
\hline 8 & $\mathrm{c}$ & $\mathrm{p}$ & ic/osc/rx & 0.3697 & 53 & 0.151 & 4171 & 26.62 & 0.14720 & 2.03 & 4.862 & 3.02 & 0.2396 & 2.21 & 0.73 & 2313.3 & 70.8 & 1384.6 & 55 & 1795.7 & 50.8 & 59.9 \\
\hline 9 & $\mathrm{e}$ & ov & osc/rx & 0.4660 & 399 & 0.232 & 3302 & 6.14 & 0.17083 & 2.07 & 6.196 & 2.54 & 0.2631 & 1.43 & 0.56 & 2565.5 & 70.4 & 1505.7 & 38.4 & 2003.9 & 44.4 & 58.7 \\
\hline 10 & $\mathrm{e}$ & $\mathrm{p}$ & $\mathrm{rx}$ & 0.5920 & 182 & 0.388 & 2575 & 17.03 & 0.18865 & 2.54 & 8.892 & 2.70 & 0.3418 & 0.84 & 0.31 & 2730.7 & 84.6 & 1895.3 & 28 & 2327 & 49.2 & 69.4 \\
\hline 11 & $\mathrm{c}$ & $\mathrm{fr}$ & $\mathrm{sz}$ & 0.0443 & 68 & 0.365 & 34619 & 70.11 & 0.17351 & 0.88 & 7.064 & 1.88 & 0.2952 & 1.62 & 0.86 & 2592.2 & 32 & 1667.5 & 47.6 & 2119.5 & 33.4 & 64.3 \\
\hline 12 & $\mathrm{c}$ & $\mathrm{p}$ & $\mathrm{sz}$ & 0.0726 & 64 & 0.354 & 20774 & 30.12 & 0.20011 & 0.81 & 11.165 & 1.57 & 0.4046 & 1.30 & 0.82 & 2827.3 & 29.4 & 2190.2 & 48.2 & 2537 & 29.2 & 77.5 \\
\hline 13.1 & $\mathrm{e}$ & $\mathrm{p}$ & osc & 0.0126 & 108 & 0.292 & 121274 & 54.24 & 0.16722 & 1.85 & 6.852 & 2.05 & 0.2971 & 0.81 & 0.40 & 2530.5 & 63 & 1676.9 & 23.6 & 2092.5 & 36.4 & 66.3 \\
\hline 13.2 & $\mathrm{c}$ & $\mathrm{p}$ & osc & 0.0702 & 70 & 0.451 & 21617 & 34.93 & 0.18873 & 2.23 & 9.766 & 2.52 & 0.3753 & 1.11 & 0.44 & 2731.1 & 74.6 & 2054.3 & 39 & 2412.9 & 46.4 & 75.2 \\
\hline 14 & $\mathrm{c}$ & $\mathrm{p}$ & $\mathrm{sz}$ & 0.0064 & 41 & 0.565 & 225757 & 47.63 & 0.22445 & 0.51 & 17.527 & 2.24 & 0.5663 & 2.15 & 0.96 & 3013 & 20.2 & 2892.6 & 100.2 & 2964.1 & 43 & 96.0 \\
\hline 15.1 & $\mathrm{~m}$ & $\mathrm{p}$ & osc & 0.0088 & 25 & 0.386 & 166321 & 33.69 & 0.21509 & 0.43 & 15.342 & 0.84 & 0.5173 & 0.62 & 0.74 & 2944.36 & 18.5 & 2687.7 & 26.4 & 2836.71 & 16.2 & 91.3 \\
\hline 15.2 & c & $\mathrm{p}$ & ic/rx & 0.0083 & 26 & 0.538 & 180946 & 29.44 & 0.20725 & 0.39 & 12.473 & 0.86 & 0.4365 & 0.68 & 0.78 & 2884.13 & 17.32 & 2335 & 27.4 & 2640.69 & 15.98 & 81.0 \\
\hline 16 & $\mathrm{e}$ & $\mathrm{p}$ & osc & 0.1127 & 90 & 0.436 & 13550 & 50.51 & 0.18508 & 0.73 & 8.434 & 1.75 & 0.3305 & 1.54 & 0.88 & 2698.9 & 27.4 & 1840.8 & 49.4 & 2278.8 & 31.8 & 68.2 \\
\hline 17.1 & $\mathrm{e}$ & ov & osc/rx & 0.0550 & 76 & 0.102 & 28101 & 67.68 & 0.16119 & 3.79 & 5.007 & 4.29 & 0.2253 & 1.97 & 0.46 & 2468.1 & 128.6 & 1309.8 & 46.8 & 1820.5 & 72.6 & 53.1 \\
\hline 17.2 & $\mathrm{c}$ & ov & ic & 0.2892 & 258 & 0.440 & 5078 & 16.19 & 0.21372 & 1.72 & 15.376 & 1.97 & 0.5217 & 0.90 & 0.46 & 2934.3 & 56.6 & 2706.4 & 39.8 & 2838.8 & 37.6 & 92.2 \\
\hline 18 & $\mathrm{e}$ & $\mathrm{p}$ & osc/rx & 0.0943 & 76 & 0.368 & 16293 & 24.11 & 0.16982 & 0.76 & 6.583 & 1.84 & 0.2811 & 1.63 & 0.89 & 2556.2 & 28 & 1596.9 & 46.2 & 2057.1 & 32.4 & 62.5 \\
\hline 19 & $\mathrm{e}$ & $\mathrm{fr}$ & $\mathrm{osc} / \mathrm{hb}$ & 0.2342 & 50 & 0.248 & 6555 & 36.91 & 0.16148 & 1.18 & 6.306 & 2.28 & 0.2832 & 1.91 & 0.84 & 2471.4 & 41.8 & 1607.5 & 54.4 & 2019.3 & 40 & 65.0 \\
\hline 20 & $\mathrm{c}$ & $\mathrm{p}$ & $\mathrm{rx}$ & 0.1505 & 221 & 0.491 & 10278 & 5.80 & 0.10969 & 0.94 & 3.101 & 1.35 & 0.2050 & 0.89 & 0.66 & 1794.6 & 37 & 1202.12 & 19.74 & 1432.9 & 20.8 & 67.0 \\
\hline 21 & $\mathrm{e}$ & $\mathrm{p}$ & $\mathrm{sz}$ & 0.3816 & 153 & 0.129 & 4026 & 19.26 & 0.17036 & 2.13 & 6.537 & 2.83 & 0.2783 & 1.82 & 0.64 & 2561.2 & 72.8 & 1582.8 & 51 & 2050.9 & 49.8 & 61.8 \\
\hline 22.1 & $\mathrm{e}$ & $\mathrm{p}$ & osc & 0.0155 & 49 & 0.324 & 94643 & 75.82 & 0.21406 & 0.45 & 15.340 & 0.85 & 0.5197 & 0.63 & 0.73 & 2936.67 & 18.8 & 2697.9 & 28.6 & 2836.59 & 16.2 & 91.9 \\
\hline 22.2 & $\mathrm{c}$ & $\mathrm{p}$ & osc & 0.0118 & 62 & 0.457 & 124664 & 52.07 & 0.21800 & 0.46 & 15.224 & 0.91 & 0.5065 & 0.69 & 0.76 & 2965.95 & 18.86 & 2641.7 & 30.4 & 2829.36 & 17.16 & 89.1 \\
\hline 23.1 & $\mathrm{e}$ & $\mathrm{p}$ & osc & 0.0047 & 36 & 0.325 & 318559 & 26.40 & 0.20766 & 0.58 & 13.422 & 0.99 & 0.4687 & 0.72 & 0.72 & 2887.6 & 22.6 & 2477.9 & 28.8 & 2709.81 & 18.9 & 85.8 \\
\hline 23.2 & $\mathrm{c}$ & $p$ & ic & 0.0083 & 56 & 0.541 & 177623 & 33.88 & 0.21424 & 0.52 & 14.402 & 1.14 & 0.4875 & 0.95 & 0.83 & 2938.1 & 20.6 & 2559.9 & 40.2 & 2776.6 & 21.6 & 87.1 \\
\hline 24 & $\mathrm{~m}$ & $\mathrm{p}$ & $\mathrm{osc} / \mathrm{hb}$ & 0.0061 & 29 & 0.483 & 238017 & 28.18 & 0.21861 & 0.70 & 16.904 & 1.07 & 0.5608 & 0.71 & 0.67 & 2970.5 & 25.6 & 2869.9 & 32.4 & 2929.4 & 20.6 & 96.6 \\
\hline 25 & $\mathrm{~m}$ & fr & $\mathrm{ic} / \mathrm{rx}$ & 0.0078 & 58 & 0.496 & 192368 & 62.74 & 0.19175 & 0.79 & 10.743 & 1.26 & 0.4063 & 0.91 & 0.72 & 2757.4 & 28.8 & 2198 & 33.6 & 2501.1 & 23.4 & 79.7 \\
\hline 26 & $\mathrm{c}$ & $\mathrm{p}$ & $\mathrm{sz}$ & 0.0179 & 101 & 0.397 & 83233 & 63.77 & 0.19341 & 7.76 & 12.243 & 7.81 & 0.4590 & 0.79 & 0.10 & 2772 & 254 & 2435.1 & 32.4 & 2623.2 & 146.4 & 87.8 \\
\hline
\end{tabular}


Unidade Petúnia: amostra CP-38 (continuação)

\begin{tabular}{|c|c|c|c|c|c|c|c|c|c|c|c|c|c|c|c|c|c|c|c|c|c|c|}
\hline spot & site & habit & CL & $206 *(\%)$ & ${ }^{204} \mathrm{~Pb}$ cps & $T h / U$ & ${ }^{206} \mathrm{~Pb} /{ }^{204} \mathrm{~Pb}$ & $10^{\circ}$ & ${ }^{207} \mathrm{~Pb} /{ }^{206} \mathrm{~Pb}$ & $10^{\circ}$ & ${ }^{207} \mathbf{P b} /{ }^{235} \mathbf{U}$ & $10^{\circ}$ & ${ }^{206} \mathrm{~Pb} /{ }^{238} \mathrm{U}$ & $10^{\circ}$ & Rho & t.76 & $20^{\circ}$ & t.68 & $20^{\circ}$ & t.75 & $20^{\circ}$ & concordância \\
\hline 27 & $\mathrm{c}$ & $\mathrm{p}$ & $\mathrm{sz}$ & 0.0085 & 32 & 0.572 & 166781 & 35.40 & 0.22582 & 0.81 & 18.972 & 1.67 & 0.6093 & 1.41 & 0.85 & 3022.7 & 28.2 & 3067.2 & 68.8 & 3040.4 & 32.2 & 101.5 \\
\hline 28 & $\mathrm{c}$ & $\mathrm{p}$ & $\mathrm{ic} / \mathrm{rx}$ & 0.0215 & 72 & 0.419 & 70166 & 47.37 & 0.19773 & 0.77 & 10.835 & 1.17 & 0.3974 & 0.80 & 0.68 & 2807.7 & 28 & 2157.1 & 29.4 & 2509.1 & 21.8 & 76.8 \\
\hline 29.1 & $\mathrm{e}$ & $\mathrm{p}$ & $\mathrm{osc} / \mathrm{hb}$ & 0.0711 & 114 & 0.304 & 21423 & 12.29 & 0.18399 & 0.45 & 8.786 & 0.86 & 0.3463 & 0.63 & 0.73 & 2689.33 & 19.22 & 1916.9 & 21.6 & 2316.04 & 15.5 & 71.3 \\
\hline 29.2 & $\mathrm{c}$ & $\mathrm{p}$ & $\mathrm{sz}$ & 0.0070 & 41 & 0.485 & 215741 & 29.61 & 0.19823 & 0.77 & 11.072 & 1.76 & 0.4051 & 1.53 & 0.87 & 2811.7 & 28.4 & 2192.5 & 56.8 & 2529.2 & 32.8 & 78.0 \\
\hline 30 & $\mathrm{c}$ & ov & ic/osc & 0.0193 & 46 & 0.396 & 75461 & 56.00 & 0.21703 & 0.65 & 16.254 & 1.22 & 0.5431 & 0.96 & 0.79 & 2959 & 24.2 & 2796.4 & 43.2 & 2891.9 & 23.4 & 94.5 \\
\hline 31 & $\mathrm{~m}$ & $\mathrm{p}$ & hd & 0.0075 & 42 & 0.202 & 197500 & 52.20 & 0.21619 & 0.76 & 15.170 & 2.12 & 0.5089 & 1.94 & 0.92 & 2952.6 & 26.8 & 2651.9 & 84.4 & 2826 & 40.4 & 89.8 \\
\hline 32 & $\mathrm{c}$ & $\mathrm{p}$ & $\mathrm{ic/rx}$ & 0.5047 & 464 & 0.290 & 991 & 15.67 & 0.20556 & 1.77 & 11.422 & 2.61 & 0.4030 & 1.88 & 0.72 & 2870.8 & 58.8 & 2182.8 & 69.6 & 2558.2 & 48.8 & 76.0 \\
\hline 33 & $\mathrm{c}$ & $\mathrm{p}$ & osc & 0.0969 & 289 & 0.505 & 15649 & 16.69 & 0.18960 & 0.65 & 9.866 & 0.98 & 0.3774 & 0.64 & 0.65 & 2738.7 & 25 & 2064.1 & 23 & 2422.34 & 18.44 & 75.4 \\
\hline 34 & $\mathrm{~m}$ & $\mathrm{p}$ & osc & 0.0225 & 64 & 0.330 & 61043 & 66.69 & 0.23006 & 0.71 & 21.830 & 1.58 & 0.6882 & 1.37 & 0.86 & 3052.5 & 25.8 & 3375.7 & 72 & 3176.2 & 30.6 & 110.6 \\
\hline
\end{tabular}

\section{Gnaisse Ribeirão da Conquista: amostra CP-94}

\begin{tabular}{|c|c|c|c|c|c|c|c|c|c|c|c|c|c|c|c|c|c|c|c|c|c|c|}
\hline spot & site & habit & CL & $206 *(\%)$ & ${ }^{204} \mathrm{~Pb} \mathrm{cps}$ & $\mathbf{T h} / \mathrm{U}$ & ${ }^{206} \mathrm{~Pb} /{ }^{204} \mathrm{~Pb}$ & 10 & ${ }^{207} \mathrm{~Pb} /{ }^{206} \mathrm{~Pb}$ & 10 & ${ }^{207} \mathrm{~Pb} /{ }^{235} \mathrm{U}$ & 10 & ${ }^{206} \mathrm{~Pb} /{ }^{238} \mathrm{U}$ & 10 & Rho & t.76 & 20 & t.68 & 20 & t.75 & 20 & concordância \\
\hline 1 & $\mathrm{c}$ & $\mathrm{p}$ & sz & 1.5653 & 185 & 0.225 & 930 & 7.75 & 0.16890 & 3.38 & 12.831 & 4.09 & 0.5509 & 2.27 & 0.56 & 2547 & 113.6 & 2828.9 & 104 & 2667.3 & 77 & 111.1 \\
\hline 2 & $\mathrm{c}$ & $\mathrm{p}$ & $\mathrm{sz}$ & 0.0051 & 248 & 0.589 & 288957 & 64.18 & 0.20293 & 2.29 & 14.277 & 2.66 & 0.5102 & 1.30 & 0.49 & 2850 & 75.6 & 2657.5 & 56.6 & 2768.3 & 50.4 & 93.2 \\
\hline 3.1 & $\mathrm{e}$ & $\mathrm{p}$ & osc & 2.8871 & 5043 & 0.182 & 537 & 11.77 & 0.25183 & 1.87 & 6.164 & 3.31 & 0.1775 & 2.71 & 0.82 & 3197 & 60 & 1053.3 & 52.6 & 1999.4 & 57.8 & 33.0 \\
\hline 3.2 & $\mathrm{c}$ & $\mathrm{p}$ & ic & 0.0204 & 57 & 0.300 & 72358 & 44.06 & 0.20195 & 0.75 & 13.925 & 0.98 & 0.5001 & 0.50 & 0.51 & 2842 & 28 & 2614.2 & 21.4 & 2744.62 & 18.94 & 92.0 \\
\hline 4 & $\mathrm{e}$ & $\mathrm{p}$ & osc & n.a. & 6243 & 0.175 & 193 & 5.78 & 0.34341 & 3.40 & -2.713 & 12.23 & -0.0573 & 11.74 & 0.96 & & 0 & & 0 & & 0 & \\
\hline 5.1 & $\mathrm{e}$ & $\mathrm{p}$ & osc & 9.6851 & 6514 & 0.018 & 161 & 1.34 & 0.22333 & 2.08 & 2.035 & 2.64 & 0.0661 & 1.58 & 0.60 & 3005 & 67.8 & 412.62 & 12.64 & 1127.3 & 36 & 13.7 \\
\hline 5.2 & $\mathrm{c}$ & $\mathrm{p}$ & ic & 2.0527 & 7162 & 0.247 & 715 & 24.73 & 0.22212 & 1.43 & 16.056 & 2.27 & 0.5242 & 1.73 & 0.76 & 2996 & 47.4 & 2717 & 76.8 & 2880.1 & 43.4 & 90.7 \\
\hline 6.1 & $\mathrm{e}$ & $\mathrm{p}$ & osc & 0.0072 & 363 & 0.530 & 203434 & 18.89 & 0.18218 & 0.78 & 13.375 & 1.26 & 0.5324 & 0.91 & 0.72 & 2673 & 29 & 2751.6 & 40.4 & 2706.5 & 23.8 & 102.9 \\
\hline 6.2 & $\mathrm{c}$ & $\mathrm{p}$ & ic/hd & 0.0102 & 65 & 0.546 & 144185 & 58.61 & 0.20223 & 0.76 & 14.395 & 1.02 & 0.5162 & 0.56 & 0.55 & 2845 & 27.8 & 2683 & 24.2 & 2776.1 & 19.36 & 94.3 \\
\hline 7 & $\mathrm{e}$ & $\mathrm{p}$ & osc/hd & 0.7237 & 2511 & 0.013 & 2063 & 18.42 & 0.16502 & 1.75 & 10.384 & 2.04 & 0.4564 & 0.97 & 0.48 & 2508 & 60.2 & 2423.6 & 38.4 & 2469.6 & 37.8 & 96.6 \\
\hline 8 & $\mathrm{e}$ & $\mathrm{p}$ & osc & 0.7391 & 1182 & 0.312 & 2024 & 6.12 & 0.22398 & 0.69 & 13.862 & 2.14 & 0.4488 & 1.99 & 0.93 & 3010 & 25.2 & 2389.9 & 79.4 & 2740.3 & 40.6 & 79.4 \\
\hline 9.1 & $\mathrm{e}$ & $\mathrm{p}$ & osc & 0.1158 & 144 & 0.190 & 12742 & 9.45 & 0.19868 & 0.43 & 13.791 & 0.86 & 0.5034 & 0.64 & 0.75 & 2815 & 18.38 & 2628.4 & 28 & 2735.46 & 16.1 & 93.4 \\
\hline 9.2 & $\mathrm{c}$ & $\mathrm{p}$ & ic & 0.1969 & 215 & 0.614 & 7393 & 8.30 & 0.23048 & 0.41 & 17.478 & 0.83 & 0.5500 & 0.63 & 0.75 & 3055 & 18 & 2825.2 & 29.8 & 2961.45 & 16.32 & 92.5 \\
\hline 10.1 & $\mathrm{e}$ & $\mathrm{p}$ & hd & 0.4637 & 1452 & 0.076 & 3252 & 7.57 & 0.18608 & 2.13 & 10.473 & 2.34 & 0.4082 & 0.90 & 0.38 & 2708 & 71.4 & 2206.7 & 33.6 & 2477.5 & 43.4 & 81.5 \\
\hline 10.2 & $\mathrm{c}$ & $\mathrm{p}$ & $\mathrm{rx} / \mathrm{hd}$ & 0.0996 & 653 & 0.082 & 15486 & 17.54 & 0.18847 & 2.39 & 6.073 & 4.49 & 0.2337 & 3.78 & 0.84 & 2729 & 80.2 & 1353.9 & 92.4 & 1986.4 & 78.2 & 49.6 \\
\hline 11.1 & $\mathrm{e}$ & $\mathrm{p}$ & $\mathrm{rx}$ & 0.0149 & 870 & 0.077 & 99869 & 95.92 & 0.19008 & 1.35 & 12.633 & 1.80 & 0.4820 & 1.13 & 0.63 & 2743 & 46 & 2536 & 47.4 & 2652.7 & 33.8 & 92.5 \\
\hline 11.2 & $\mathrm{~m}$ & $\mathrm{p}$ & ic/osc & 0.8871 & 2508 & 0.115 & 1699 & 5.69 & 0.20372 & 1.39 & 11.545 & 2.12 & 0.4110 & 1.56 & 0.74 & 2856 & 46.4 & 2219.5 & 58.6 & 2568.2 & 39.6 & 77.7 \\
\hline 12.1 & $\mathrm{e}$ & $\mathrm{p}$ & osc/rx & 0.4018 & 3594 & 0.162 & 3799 & 30.13 & 0.21564 & 1.13 & 9.855 & 5.36 & 0.3314 & 5.23 & 0.98 & 2949 & 34.4 & 1845.2 & 168.4 & 2421.3 & 98.6 & 62.6 \\
\hline 12.2 & $\mathrm{c}$ & $\mathrm{p}$ & ic & 0.3633 & 680 & 0.087 & 4101 & 6.04 & 0.20547 & 0.51 & 13.206 & 1.03 & 0.4661 & 0.81 & 0.79 & 2870 & 20.6 & 2466.4 & 32.8 & 2694.49 & 19.44 & 85.9 \\
\hline
\end{tabular}


Gnaisse Ribeirão da Conquista: amostra CP-94 (continuação)

\begin{tabular}{|c|c|c|c|c|c|c|c|c|c|c|c|c|c|c|c|c|c|c|c|c|c|c|}
\hline spot & site & habit & $\mathbf{C L}$ & $206 *(\%)$ & ${ }^{204} \mathrm{~Pb}$ cps & $\mathbf{T h} / \mathrm{U}$ & ${ }^{206} \mathrm{~Pb} /{ }^{204} \mathrm{~Pb}$ & 10 & ${ }^{207} \mathrm{~Pb} /{ }^{206} \mathrm{~Pb}$ & 10 & ${ }^{207} \mathrm{~Pb} /{ }^{235} \mathrm{U}$ & 10 & ${ }^{206} \mathrm{~Pb} /{ }^{238} \mathrm{U}$ & 10 & Rho & t.76 & $20^{\circ}$ & t.68 & $20^{\circ}$ & t.75 & 20 & concordância \\
\hline 13.1 & $\mathrm{e}$ & $\mathrm{p}$ & osc & 3.6542 & 9444 & 0.056 & 403 & 20.09 & 0.18515 & 3.76 & 13.075 & 4.09 & 0.5121 & 1.56 & 0.38 & 2700 & 125 & 2665.6 & 68.2 & 2685.1 & 77.2 & 98.7 \\
\hline 13.2 & $\mathrm{~m}$ & $\mathrm{p}$ & osc/hb & 0.3790 & 252 & 0.458 & 3876 & 8.01 & 0.20255 & 0.54 & 14.529 & 0.91 & 0.5202 & 0.62 & 0.69 & 2847 & 21.2 & 2700 & 26.4 & 2784.9 & 17.1 & 94.8 \\
\hline 14.1 & $\mathrm{e}$ & $\mathrm{p}$ & osc & 0.0055 & 1 & 0.164 & 273972 & 23.78 & 0.17564 & 0.98 & 9.328 & 1.51 & 0.3852 & 1.09 & 0.72 & 2612 & 34.8 & 2100.5 & 39 & 2370.8 & 27.6 & 80.4 \\
\hline 14.2 & $\mathrm{c}$ & $\mathrm{p}$ & $\mathrm{ic} / \mathrm{sz}$ & 0.0201 & 62 & 0.117 & 72989 & 53.07 & 0.20393 & 0.48 & 14.624 & 0.89 & 0.5200 & 0.65 & 0.73 & 2858 & 20 & 2699.2 & 28.6 & 2791.09 & 17.1 & 94.4 \\
\hline 15.1 & $\mathrm{e}$ & $\mathrm{p}$ & osc/rx & 12.3363 & 13883 & 0.109 & 126 & 3.84 & 0.33938 & 0.78 & 6.884 & 2.91 & 0.1471 & 2.78 & 0.96 & 3660 & 25 & 884.7 & 46 & 2096.6 & 51.6 & 24.2 \\
\hline 15.2 & $\mathrm{c}$ & $\mathrm{p}$ & osc/rx & 0.0128 & 51 & 0.850 & 114934 & 49.26 & 0.20470 & 0.44 & 14.655 & 0.79 & 0.5192 & 0.55 & 0.69 & 2864 & 18.84 & 2695.8 & 24.2 & 2793.11 & 15.2 & 94.1 \\
\hline 16.1 & $\mathrm{e}$ & $\mathrm{p}$ & hd & 0.1777 & 693 & 0.025 & 8429 & 11.16 & 0.18524 & 2.58 & 11.265 & 2.67 & 0.4410 & 0.59 & 0.22 & 2701 & 86 & 2355.1 & 23.6 & 2545.3 & 49.8 & 87.2 \\
\hline 16.2 & $\mathrm{c}$ & $\mathrm{p}$ & ic & 0.0169 & 80 & 0.797 & 90637 & 67.60 & 0.17086 & 0.80 & 6.957 & 1.44 & 0.2953 & 1.13 & 0.79 & 2566 & 29.6 & 1668 & 33.2 & 2106 & 25.6 & 65.0 \\
\hline 17.1 & $\mathrm{e}$ & $\mathrm{p}$ & $\mathrm{rx} / \mathrm{hd}$ & 25.3799 & 13535 & 0.016 & 61 & 1.90 & 0.33103 & 1.44 & 5.381 & 1.72 & 0.1179 & 0.87 & 0.50 & 3622 & 45.6 & 718.47 & 11.56 & 1881.8 & 29.4 & 19.8 \\
\hline 17.2 & $\mathrm{c}$ & $\mathrm{p}$ & ic/sz & 1.1247 & 870 & 0.472 & 1332 & 4.42 & 0.21139 & 0.77 & 12.804 & 1.08 & 0.4393 & 0.66 & 0.61 & 2916 & 27.8 & 2347.5 & 25.6 & 2665.3 & 20.4 & 80.5 \\
\hline 18.1 & $\mathrm{e}$ & $\mathrm{p}$ & osc & 13.9507 & 18024 & 0.018 & 112 & 2.87 & 0.28276 & 1.75 & 4.553 & 3.06 & 0.1168 & 2.48 & 0.81 & 3378 & 56 & 712.1 & 33.4 & 1740.7 & 51 & 21.1 \\
\hline 18.2 & $\mathrm{c}$ & $\mathrm{p}$ & $\mathrm{ic} / \mathrm{rx}$ & 14.9126 & 21868 & 0.034 & 104 & 1.98 & 0.28201 & 1.22 & 5.256 & 1.55 & 0.1352 & 0.88 & 0.57 & 3374 & 39.8 & 817.46 & 13.82 & 1861.7 & 26.4 & 24.2 \\
\hline 19 & $\mathrm{~m}$ & $\mathrm{p}$ & ic/osc & 0.0071 & 34 & 0.276 & 202104 & 34.71 & 0.22823 & 0.48 & 18.656 & 0.87 & 0.5928 & 0.62 & 0.71 & 3040 & 19.18 & 3000.8 & 28.8 & 3024.2 & 16.38 & 98.7 \\
\hline 20.1 & $\mathrm{e}$ & $\mathrm{p}$ & osc & 0.7792 & 2539 & 0.491 & 1997 & 18.94 & 0.28407 & 2.17 & 4.320 & 18.66 & 0.1103 & 18.53 & 0.99 & 3385 & 82 & 674 & 238 & 1697 & 308 & 19.9 \\
\hline 20.2 & $\mathrm{c}$ & $\mathrm{p}$ & ic/osc & 0.0093 & 43 & 0.641 & 157327 & 32.48 & 0.20473 & 0.48 & 15.016 & 0.84 & 0.5319 & 0.58 & 0.69 & 2864 & 20 & 2749.5 & 26.8 & 2816.25 & 16.18 & 96.0 \\
\hline 21.1 & $\mathrm{e}$ & $\mathrm{p}$ & hd & 1.2871 & 1975 & 0.204 & 1179 & 7.88 & 0.21003 & 0.56 & 10.725 & 2.72 & 0.3703 & 2.63 & 0.97 & 2906 & 21.4 & 2030.8 & 91.6 & 2499.6 & 50.6 & 69.9 \\
\hline 21.2 & $\mathrm{c}$ & $\mathrm{p}$ & $\mathrm{rx} / \mathrm{hd}$ & 1.8864 & 4153 & 0.035 & 819 & 8.19 & 0.20633 & 0.63 & 6.216 & 1.58 & 0.2185 & 1.40 & 0.89 & 2877 & 23.4 & 1273.9 & 32.4 & 2006.7 & 27.6 & 44.3 \\
\hline 22.1 & $\mathrm{e}$ & $\mathrm{p}$ & hd & 0.9537 & 3920 & 0.052 & 1531 & 9.90 & 0.19692 & 0.62 & 14.670 & 1.93 & 0.5402 & 1.79 & 0.93 & 2801 & 23.2 & 2784.3 & 81 & 2794.1 & 36.6 & 99.4 \\
\hline 22.2 & $\mathrm{c}$ & $\mathrm{p}$ & ic & 0.0294 & 37 & 0.455 & 50044 & 35.37 & 0.20233 & 0.54 & 14.441 & 0.93 & 0.5176 & 0.66 & 0.71 & 2845 & 21.8 & 2689 & 28.6 & 2779.13 & 18.04 & 94.5 \\
\hline 23 & $\mathrm{e}$ & ov & osc & 0.0167 & 41 & 0.228 & 86459 & 32.13 & 0.22479 & 0.69 & 17.938 & 0.97 & 0.5787 & 0.57 & 0.59 & 3016 & 24.6 & 2943.4 & 26 & 2986.41 & 18.28 & 97.6 \\
\hline 24.1 & $\mathrm{e}$ & $p$ & osc & 0.0976 & 456 & 0.098 & 15198 & 52.71 & 0.12515 & 14.93 & 8.389 & 15.68 & 0.4861 & 4.77 & 0.30 & 2031 & 530 & 2554 & 202 & 2274 & 284 & 125.8 \\
\hline 24.2 & $\mathrm{c}$ & $\mathrm{p}$ & ic/hd & 18.3866 & 19878 & 0.029 & 85 & 4.35 & 0.43176 & 1.74 & 3.951 & 2.97 & 0.0664 & 2.37 & 0.80 & 4023 & 53.2 & 414.43 & 19.02 & 1624.2 & 48.2 & 10.3 \\
\hline 25.1 & $\mathrm{e}$ & $\mathrm{p}$ & osc & 2.4368 & 970 & 0.220 & 610 & 1.57 & 0.22123 & 0.83 & 14.420 & 1.39 & 0.4727 & 1.06 & 0.76 & 2990 & 29 & 2495.4 & 43.8 & 2777.7 & 26.4 & 83.5 \\
\hline 25.2 & $\mathrm{c}$ & $\mathrm{p}$ & ic/hd & 3.8259 & 6294 & 0.274 & 400 & 3.09 & 0.23773 & 5.05 & 10.499 & 8.86 & 0.3203 & 7.26 & 0.82 & 3105 & 161.4 & 1791 & 226 & 2479.8 & 164 & 57.7 \\
\hline 26.1 & $\mathrm{e}$ & $\mathrm{p}$ & osc & 5.1661 & 8435 & 0.120 & 299 & 5.42 & 0.25255 & 0.69 & 7.623 & 1.58 & 0.2189 & 1.37 & 0.87 & 3201 & 24.6 & 1276.1 & 31.8 & 2187.6 & 28.4 & 39.9 \\
\hline 26.2 & $\mathrm{c}$ & $\mathrm{p}$ & ic/osc & 0.2678 & 116 & 0.288 & 5486 & 5.83 & 0.20157 & 0.43 & 14.466 & 0.91 & 0.5205 & 0.71 & 0.78 & 2839 & 18.36 & 2701.3 & 30.8 & 2780.77 & 17.1 & 95.2 \\
\hline 27.2 & $\mathrm{c}$ & $\mathrm{p}$ & ic/osc & 0.0073 & 22 & 0.443 & 202258 & 25.20 & 0.19948 & 0.41 & 14.207 & 0.87 & 0.5165 & 0.67 & 0.77 & 2822 & 17.72 & 2684.3 & 28.6 & 2763.62 & 16.12 & 95.1 \\
\hline 28 & $\mathrm{c}$ & ov & ic & 3.6869 & 4052 & 0.367 & 407 & 17.78 & 0.15825 & 2.29 & 9.417 & 2.71 & 0.4315 & 1.40 & 0.51 & 2437 & 79 & 2312.5 & 54.4 & 2379.5 & 49.8 & 94.9 \\
\hline 29.1 & $\mathrm{e}$ & $\mathrm{p}$ & $\mathrm{hb}$ & 0.0286 & 26 & 0.375 & 51544 & 29.06 & 0.21665 & 0.86 & 15.320 & 1.62 & 0.5128 & 1.32 & 0.82 & 2956 & 30 & 2668.6 & 57.6 & 2835.3 & 30.8 & 90.3 \\
\hline 29.2 & $\mathrm{c}$ & $\mathrm{p}$ & ic & 0.0095 & 28 & 0.088 & 155136 & 30.51 & 0.20014 & 0.78 & 13.577 & 1.20 & 0.4920 & 0.84 & 0.70 & 2827 & 28 & 2579.3 & 36.2 & 2720.7 & 22.6 & 91.2 \\
\hline 30 & c & ov & ic/osc & 0.1113 & 163 & 0.356 & 13046 & 17.19 & 0.22292 & 1.19 & 17.144 & 1.39 & 0.5577 & 0.61 & 0.44 & 3002 & 40.2 & 2857.1 & 27.6 & 2942.9 & 26.6 & 95.2 \\
\hline
\end{tabular}


Metagranito Bom Jesus da Penha: amostra CP-45

\begin{tabular}{|c|c|c|c|c|c|c|c|c|c|c|c|c|c|c|c|c|c|c|c|c|c|c|}
\hline spot & site & habit & CL & $206 *(\%)$ & ${ }^{204} \mathrm{~Pb}$ cps & $\mathrm{Th} / \mathrm{U}$ & ${ }^{206} \mathrm{~Pb} /{ }^{204} \mathrm{~Pb}$ & 10 & ${ }^{207} \mathrm{~Pb} /{ }^{206} \mathrm{~Pb}$ & 10 & ${ }^{207} \mathrm{~Pb} /{ }^{235} \mathrm{U}$ & 10 & ${ }^{206} \mathrm{~Pb} /{ }^{238} \mathrm{U}$ & 10 & Rho & t.76 & $20^{\circ}$ & t.68 & 20 & t.75 & 20 & concordância \\
\hline 1 & $\mathrm{e}$ & $\mathrm{p}$ & hd & 0.1499 & 106 & 0.045 & 10098 & 50.41 & 0.12124 & 1.16 & 6.465 & 2.20 & 0.3867 & 1.83 & 0.83 & 1974.7 & 21.9 & 2107.5 & 32.9 & 2041.1 & 19.3 & 106.7 \\
\hline 2 & $\mathrm{c}$ & $\mathrm{p}$ & $\mathrm{sz}$ & 0.0711 & 86 & 0.091 & 21178 & 59.10 & 0.11879 & 3.47 & 6.782 & 4.02 & 0.4141 & 1.99 & 0.49 & 1938 & 62.7 & 2233.6 & 37.6 & 2083.4 & 35.6 & 115.3 \\
\hline 3 & $\mathrm{e}$ & $\mathrm{p}$ & hd & 0.7230 & 157 & 0.960 & 2087 & 12.12 & 0.11071 & 1.65 & 6.162 & 3.21 & 0.4036 & 2.73 & 0.85 & 1811.4 & 30.7 & 2185.6 & 50.6 & 1999.1 & 28 & 120.7 \\
\hline 4 & $\mathrm{~m}$ & $\mathrm{p}$ & osc & 0.0521 & 733 & 0.081 & 29396 & 83.74 & 0.15983 & 1.73 & 6.626 & 1.95 & 0.3006 & 0.82 & 0.42 & 2454.3 & 29.9 & 1694.3 & 11.9 & 2062.8 & 17.2 & 69.0 \\
\hline 5.1 & $\mathrm{e}$ & $\mathrm{p}$ & hd & 0.2424 & 473 & 0.107 & 6305 & 8.15 & 0.12556 & 0.41 & 5.562 & 0.82 & 0.3213 & 0.60 & 0.74 & 2036.58 & 9.52 & 1796.07 & 9.41 & 1910.24 & 6.89 & 88.2 \\
\hline 5.2 & $\mathrm{c}$ & $\mathrm{p}$ & ic & 0.0127 & 150 & 0.045 & 116938 & 85.17 & 0.17494 & 6.01 & 11.310 & 6.56 & 0.4689 & 2.60 & 0.40 & 2605 & 100 & 2478.7 & 53.5 & 2549 & 61.1 & 95.2 \\
\hline 6 & $\mathrm{e}$ & $\mathrm{p}$ & osc & 0.2791 & 304 & 0.112 & 5400 & 18.78 & 0.18115 & 3.39 & 10.253 & 3.55 & 0.4105 & 0.98 & 0.28 & 2663.4 & 56.5 & 2217.2 & 18.8 & 2457.9 & 32.8 & 83.2 \\
\hline 7 & $\mathrm{c}$ & $\mathrm{p}$ & ic & 0.2263 & 260 & 0.079 & 6709 & 4.89 & 0.15259 & 1.82 & 7.721 & 2.10 & 0.3670 & 0.98 & 0.47 & 2375.1 & 31.6 & 2015.3 & 17.3 & 2199 & 18.9 & 84.9 \\
\hline 8 & $\mathrm{~m}$ & $\mathrm{p}$ & hd & 0.2296 & 407 & 0.041 & 6672 & 7.35 & 0.12573 & 0.71 & 5.233 & 1.19 & 0.3018 & 0.88 & 0.74 & 2039.5 & 14.2 & 1700.2 & 13.5 & 1858 & 10.1 & 83.4 \\
\hline 9 & $\mathrm{~m}$ & $\mathrm{p}$ & ic & 0.2727 & 661 & 0.145 & 5625 & 3.63 & 0.15057 & 1.42 & 6.066 & 1.87 & 0.2922 & 1.17 & 0.62 & 2352.3 & 25.1 & 1652.5 & 17.1 & 1985.4 & 16.3 & 70.3 \\
\hline 10 & $\mathrm{~m}$ & $\mathrm{p}$ & osc & 0.1429 & 272 & 0.056 & 10661 & 11.59 & 0.12395 & 1.69 & 5.930 & 2.00 & 0.3469 & 1.00 & 0.50 & 2014.3 & 30.7 & 1919.8 & 16.6 & 1965.6 & 17.4 & 95.3 \\
\hline 11 & $\mathrm{c}$ & $\mathrm{p}$ & hd & 0.4619 & 792 & 0.072 & 3294 & 41.64 & 0.13991 & 0.91 & 6.839 & 1.34 & 0.3545 & 0.92 & 0.68 & 2226.2 & 17 & 1956.1 & 15.2 & 2090.8 & 11.9 & 87.9 \\
\hline 12 & $\mathrm{~m}$ & $\mathrm{p}$ & hd & 0.0782 & 367 & 0.042 & 19529 & 26.14 & 0.12367 & 0.47 & 5.628 & 1.11 & 0.3300 & 0.94 & 0.84 & 2010.1 & 10.7 & 1838.4 & 15.2 & 1920.4 & 9.57 & 91.5 \\
\hline 13 & $\mathrm{c}$ & $\mathrm{p}$ & sz/ic & 0.0825 & 259 & 0.100 & 18605 & 6.71 & 0.13746 & 1.52 & 5.463 & 1.75 & 0.2882 & 0.78 & 0.44 & 2195.7 & 27.3 & 1632.5 & 11.5 & 1894.8 & 15 & 74.3 \\
\hline 14 & $\mathrm{~m}$ & $\mathrm{p}$ & osc & 0.0270 & 136 & 0.132 & 55223 & 80.31 & 0.17692 & 1.57 & 11.385 & 1.77 & 0.4667 & 0.72 & 0.40 & 2624.3 & 27 & 2469.1 & 14.4 & 2555.2 & 16.5 & 94.1 \\
\hline 15 & e & $\mathrm{p}$ & hd & 0.0475 & 259 & 0.032 & 32155 & 20.06 & 0.12589 & 0.45 & 5.802 & 0.89 & 0.3342 & 0.67 & 0.75 & 2041.7 & 10.5 & 1858.7 & 10.5 & 1946.71 & 7.79 & 91.0 \\
\hline 16 & $\mathrm{~m}$ & $\mathrm{p}$ & hd & 0.1363 & 178 & 0.191 & 11111 & 8.37 & 0.12364 & 0.48 & 6.570 & 2.11 & 0.3854 & 2.02 & 0.96 & 2009.4 & 10.5 & 2101.5 & 36.2 & 2055.3 & 18.6 & 104.6 \\
\hline 17 & $\mathrm{e}$ & $\mathrm{p}$ & osc & 0.1713 & 422 & 0.127 & 8887 & 6.04 & 0.16219 & 0.64 & 7.847 & 1.11 & 0.3509 & 0.83 & 0.75 & 2478.6 & 12.4 & 1938.9 & 14.2 & 2213.61 & 10 & 78.2 \\
\hline 18.1 & $\mathrm{e}$ & $\mathrm{p}$ & $\mathrm{hd} / \mathrm{hb}$ & 0.3882 & 83 & 0.099 & 3957 & 47.06 & 0.12270 & 1.08 & 4.760 & 1.98 & 0.2813 & 1.62 & 0.82 & 1996.2 & 20.1 & 1597.9 & 22.9 & 1777.9 & 16.6 & 80.0 \\
\hline 18.2 & $\mathrm{~m}$ & $\mathrm{p}$ & hd & 0.0533 & 85 & 0.070 & 28510 & 15.94 & 0.13052 & 1.63 & 6.631 & 2.16 & 0.3684 & 1.37 & 0.63 & 2105.3 & 29.4 & 2021.9 & 23.8 & 2063.5 & 19.1 & 96.0 \\
\hline 19 & $\mathrm{e}$ & $\mathrm{p}$ & osc & 0.1403 & 255 & 0.110 & 10861 & 9.69 & 0.14977 & 1.05 & 7.098 & 1.37 & 0.3437 & 0.80 & 0.59 & 2343.4 & 18.9 & 1904.4 & 13.2 & 2123.8 & 12.2 & 81.3 \\
\hline 20 & $\mathrm{e}$ & $\mathrm{p}$ & hd & 0.2223 & 610 & 0.064 & 6815 & 10.91 & 0.14108 & 0.97 & 7.426 & 1.66 & 0.3818 & 1.29 & 0.78 & 2240.3 & 18 & 2084.7 & 23 & 2164.1 & 14.9 & 93.1 \\
\hline 21 & e & $\mathrm{p}$ & hd & 0.4728 & 554 & 0.078 & 3240 & 44.57 & 0.12732 & 0.95 & 5.341 & 1.57 & 0.3043 & 1.20 & 0.76 & 2061 & 18 & 1712.6 & 18 & 1875.4 & 13.4 & 83.1 \\
\hline 22 & $\mathrm{c}$ & $\mathrm{p}$ & $\mathrm{sz}$ & 0.0550 & 123 & 0.052 & 27693 & 29.94 & 0.12337 & 0.63 & 5.967 & 1.01 & 0.3508 & 0.70 & 0.69 & 2005.5 & 13 & 1938.4 & 11.7 & 1971.05 & 8.78 & 96.7 \\
\hline 23 & $\mathrm{e}$ & $\mathrm{p}$ & osc/hd & 0.2113 & 298 & 0.082 & 7228 & 9.15 & 0.13228 & 0.54 & 5.983 & 1.15 & 0.3280 & 0.95 & 0.82 & 2128.7 & 11.5 & 1828.7 & 15.1 & 1973.4 & 10 & 85.9 \\
\hline 24 & $\mathrm{e}$ & $\mathrm{p}$ & hd & 0.0836 & 359 & 0.055 & 18172 & 22.18 & 0.12292 & 0.43 & 6.169 & 1.99 & 0.3640 & 1.90 & 0.96 & 1998.99 & 9.9 & 2001.1 & 32.7 & 2000.1 & 17.4 & 100.1 \\
\hline 25 & $\mathrm{e}$ & $\mathrm{p}$ & hd & 0.1922 & 130 & 0.032 & 7929 & 29.20 & 0.11779 & 0.73 & 5.582 & 1.67 & 0.3437 & 1.45 & 0.87 & 1923 & 14.8 & 1904.4 & 23.9 & 1913.3 & 14.4 & 99.0 \\
\hline 26.1 & $\mathrm{e}$ & $\mathrm{p}$ & osc & 0.2184 & 319 & 0.077 & 6984 & 7.35 & 0.14410 & 1.19 & 6.722 & 1.64 & 0.3383 & 1.07 & 0.65 & 2277.2 & 21.5 & 1878.5 & 17.4 & 2075.5 & 14.5 & 82.5 \\
\hline 26.2 & $\mathrm{c}$ & $\mathrm{p}$ & ic/osc & 0.3156 & 442 & 0.117 & 4830 & 3.60 & 0.17301 & 1.65 & 8.179 & 1.89 & 0.3428 & 0.86 & 0.45 & 2587.3 & 28.2 & 1900.1 & 14 & 2251 & 17.1 & 73.4 \\
\hline 27 & $\mathrm{e}$ & $p$ & $\mathrm{hd} / \mathrm{rx}$ & 1.5700 & 850 & 0.040 & 983 & 14.51 & 0.13089 & 1.76 & 4.250 & 2.63 & 0.2355 & 1.91 & 0.73 & 2109.9 & 31.5 & 1363.3 & 23.5 & 1683.7 & 21.6 & 64.6 \\
\hline 28.1 & e & $\mathrm{p}$ & hd & 0.2215 & 424 & 0.040 & 6884 & 14.05 & 0.12361 & 0.55 & 5.762 & 1.17 & 0.3380 & 0.97 & 0.82 & 2009.4 & 11.9 & 1877 & 15.5 & 1940.7 & 10.1 & 93.4 \\
\hline
\end{tabular}


Metagranito Bom Jesus da Penha: amostra CP-45 (continuação)

\begin{tabular}{|c|c|c|c|c|c|c|c|c|c|c|c|c|c|c|c|c|c|c|c|c|c|c|}
\hline spot & site & habit & CL & $206 *(\%)$ & ${ }^{204} \mathrm{~Pb}$ cps & Th/U & ${ }^{206} \mathrm{~Pb} /{ }^{204} \mathrm{~Pb}$ & 10 & ${ }^{207} \mathrm{~Pb} /{ }^{206} \mathrm{~Pb}$ & 10 & ${ }^{207} \mathrm{~Pb} /{ }^{235} \mathrm{U}$ & 10 & ${ }^{206} \mathrm{~Pb} /{ }^{238} \mathrm{U}$ & 10 & Rho & t.76 & $20^{\circ}$ & t.68 & 20 & t.75 & 20 & concordância \\
\hline 28.2 & $\mathrm{c}$ & $\mathrm{p}$ & $\mathrm{ic} / \mathrm{rx}$ & 0.2335 & 275 & 0.059 & 6520 & 11.68 & 0.16233 & 2.74 & 7.817 & 2.97 & 0.3492 & 1.07 & 0.36 & 2480.3 & 46.7 & 1930.8 & 17.9 & 2210.2 & 26.7 & 77.8 \\
\hline 29 & $\mathrm{e}$ & $\mathrm{p}$ & osc/hd & 0.2880 & 572 & 0.048 & 5324 & 10.14 & 0.13148 & 0.46 & 5.367 & 1.25 & 0.2960 & 1.11 & 0.88 & 2118.1 & 10.4 & 1671.4 & 16.3 & 1879.6 & 10.7 & 78.9 \\
\hline 30 & $\mathrm{e}$ & $\mathrm{p}$ & osc & 0.0247 & 41 & 0.118 & 60694 & 24.82 & 0.16384 & 1.78 & 9.812 & 2.04 & 0.4343 & 0.94 & 0.46 & 2495.9 & 30.5 & 2325.1 & 18.5 & 2417.3 & 18.8 & 93.2 \\
\hline 31.1 & $\mathrm{e}$ & $\mathrm{p}$ & hd & 0.0994 & 340 & 0.037 & 15382 & 7.76 & 0.12346 & 0.38 & 5.387 & 0.85 & 0.3164 & 0.66 & 0.78 & 2007.16 & 9.44 & 1772.1 & 10.1 & 1882.79 & 7.28 & 88.3 \\
\hline 31.2 & $\mathrm{c}$ & $\mathrm{p}$ & ic & 0.0256 & 471 & 0.130 & 59567 & 87.99 & 0.17850 & 2.59 & 8.153 & 2.80 & 0.3312 & 0.98 & 0.35 & 2639.3 & 43.6 & 1844.2 & 16 & 2248.1 & 25.3 & 69.9 \\
\hline 32 & $\mathrm{c}$ & $\mathrm{p}$ & ic & 0.0233 & 346 & 0.159 & 64183 & 83.01 & 0.19446 & 2.48 & 12.145 & 2.84 & 0.4529 & 1.34 & 0.47 & 2780.5 & 41.1 & 2408.1 & 26.9 & 2615.7 & 26.6 & 86.6 \\
\hline 33 & $\mathrm{e}$ & $\mathrm{p}$ & osc & 0.7160 & 595 & 0.281 & 2147 & 9.93 & 0.12318 & 0.55 & 4.637 & 2.08 & 0.2730 & 1.97 & 0.95 & 2002.9 & 11.5 & 1556 & 27.2 & 1756 & 17.4 & 77.7 \\
\hline 34.1 & $\mathrm{e}$ & $p$ & hd & 0.7498 & 1133 & 0.158 & 2047 & 13.83 & 0.12810 & 0.49 & 5.081 & 1.64 & 0.2876 & 1.52 & 0.93 & 2072.5 & 10.6 & 1629.5 & 21.9 & 1832.9 & 13.9 & 78.6 \\
\hline 34.2 & $\mathrm{~m}$ & $\mathrm{p}$ & ic & 0.0535 & 116 & 0.219 & 28298 & 3.79 & 0.16991 & 0.50 & 9.152 & 0.89 & 0.3906 & 0.64 & 0.72 & 2557 & 10.5 & 2125.6 & 11.8 & 2353.32 & 8.24 & 83.1 \\
\hline 35 & $\mathrm{c}$ & $\mathrm{p}$ & ic & 0.0484 & 919 & 0.100 & 31640 & 88.48 & 0.13497 & 3.29 & 5.794 & 3.52 & 0.3113 & 1.19 & 0.34 & 2163.9 & 57.7 & 1747.1 & 18.2 & 1945.5 & 30.5 & 80.7 \\
\hline 36.1 & $\mathrm{e}$ & $\mathrm{p}$ & hd & 0.6925 & 472 & 0.054 & 2204 & 6.26 & 0.12550 & 0.71 & 5.754 & 2.83 & 0.3325 & 2.71 & 0.96 & 2036 & 14 & 1850.5 & 43.6 & 1939.5 & 24.5 & 90.9 \\
\hline 36.2 & $\mathrm{c}$ & $\mathrm{p}$ & $\mathrm{ic} / \mathrm{rx}$ & 0.0577 & 133 & 0.188 & 26133 & 18.26 & 0.18545 & 0.44 & 10.446 & 0.90 & 0.4085 & 0.70 & 0.77 & 2702.34 & 9.48 & 2208.1 & 13.1 & 2475.14 & 8.34 & 81.7 \\
\hline 37 & $\mathrm{e}$ & $\mathrm{p}$ & hd & 0.5493 & 359 & 0.054 & 2808 & 8.65 & 0.12573 & 0.69 & 4.179 & 1.38 & 0.2410 & 1.14 & 0.82 & 2039.6 & 14 & 1391.9 & 14.3 & 1669.9 & 11.3 & 68.2 \\
\hline 38.1 & $\mathrm{e}$ & $\mathrm{p}$ & hd & 0.0176 & 181 & 0.021 & 86706 & 19.93 & 0.12341 & 0.47 & 5.653 & 1.57 & 0.3322 & 1.45 & 0.92 & 2006.2 & 10.9 & 1849 & 23.3 & 1924.2 & 13.5 & 92.2 \\
\hline 38.2 & $\mathrm{c}$ & $\mathrm{p}$ & $\mathrm{ic} / \mathrm{rx}$ & 0.1842 & 277 & 0.180 & 8319 & 8.30 & 0.16297 & 0.96 & 6.738 & 1.47 & 0.2998 & 1.05 & 0.71 & 2487.1 & 17.4 & 1690.3 & 15.6 & 2077.6 & 13 & 68.0 \\
\hline 39 & $\mathrm{e}$ & $\mathrm{p}$ & hd & 0.4047 & 640 & 0.042 & 3776 & 11.04 & 0.12354 & 0.49 & 5.485 & 0.79 & 0.3220 & 0.50 & 0.63 & 2008 & 11 & 1799.49 & 7.85 & 1898.25 & 6.87 & 89.6 \\
\hline 40 & $\mathrm{c}$ & $\mathrm{p}$ & ic & 0.3267 & 404 & 0.072 & 4680 & 5.67 & 0.15623 & 1.76 & 6.888 & 2.32 & 0.3197 & 1.48 & 0.63 & 2415.6 & 30.6 & 1788.3 & 23.1 & 2097.1 & 20.6 & 74.0 \\
\hline 41 & $\mathrm{~m}$ & $\mathrm{p}$ & ic/hd & 0.0019 & 74 & 0.426 & 768324 & 95.61 & 0.21082 & 1.54 & 15.458 & 1.99 & 0.5318 & 1.20 & 0.60 & 2911.8 & 25.8 & 2749 & 26.9 & 2843.9 & 19 & 94.4 \\
\hline 42 & $\mathrm{e}$ & $\mathrm{p}$ & hd & 0.0382 & 70 & 0.047 & 40018 & 26.84 & 0.12608 & 1.00 & 5.540 & 1.62 & 0.3187 & 1.22 & 0.75 & 2043.9 & 18.9 & 1783.4 & 19 & 1906.8 & 13.9 & 87.3 \\
\hline
\end{tabular}

\section{Unidade Serra do Ibituruna: amostra CP-05}

\begin{tabular}{|c|c|c|c|c|c|c|c|c|c|c|c|c|c|c|c|c|c|c|c|c|c|c|c|}
\hline spot & pop. & site & habit & CL & ${ }^{207} \mathbf{P b} /{ }^{235} \mathbf{U}$ & 10 & ${ }^{206} \mathrm{~Pb} /{ }^{238} \mathrm{U}$ & 10 & Rho & ${ }^{207} \mathrm{~Pb} /{ }^{206} \mathrm{~Pb}$ & 10 & $208 / 206$ & $10^{\circ}$ & Pb total & Pb rad & $\mathbf{T h} / \mathbf{U}$ & t.68 & 10 & t.75 & $10^{\circ}$ & t.76 & 10 & concordância \\
\hline 1.1 & 1 & $\mathrm{e}$ & $\mathrm{p}$ & $\mathrm{hb}$ & 12.3950 & 0.2480 & 0.4731 & 0.0062 & 0.69 & 0.1900 & 0.0038 & 0.3662 & 0.0103 & 0.29 & 29 & 1.12 & 2497 & 27 & 2635 & 19 & 2742 & 32 & 95 \\
\hline 2.1 & 4 & $\mathrm{e}$ & $\mathrm{rd}$ & osc & 7.1266 & 0.1089 & 0.3878 & 0.0038 & 0.65 & 0.1333 & 0.0019 & 0.1718 & 0.0028 & 0.08 & 76 & 0.52 & 2113 & 18 & 2127 & 14 & 2142 & 26 & 99 \\
\hline 3.1 & 2 & $\mathrm{~m}$ & ov & ic & 14.5548 & 0.2193 & 0.5268 & 0.0053 & 0.30 & 0.2004 & 0.0028 & 0.0611 & 0.0031 & 0.11 & 58 & 0.20 & 2728 & 22 & 2787 & 14 & 2829 & 23 & 98 \\
\hline 4.1 & 2 & $\mathrm{~m}$ & $\mathrm{rd}$ & osc & 6.7351 & 0.1034 & 0.3751 & 0.0036 & 0.80 & 0.1302 & 0.0019 & 0.1000 & 0.0043 & 0.08 & 73 & 0.34 & 2054 & 17 & 2077 & 14 & 2101 & 26 & 99 \\
\hline 5.1 & 4 & $\mathrm{c}$ & $\mathrm{p}$ & ic & 7.3912 & 0.1447 & 0.3906 & 0.0046 & 0.77 & 0.1372 & 0.0027 & 0.3447 & 0.0060 & 0.80 & 28 & 1.11 & 2126 & 21 & 2160 & 18 & 2193 & 35 & 98 \\
\hline 6.1 & 2 & $\mathrm{e}$ & ov & osc & 5.9398 & 0.0853 & 0.3390 & 0.0031 & 0.55 & 0.1271 & 0.0017 & 0.0951 & 0.0026 & 0.00 & 103 & 0.29 & 1882 & 15 & 1967 & 12 & 2058 & 23 & 96 \\
\hline 7.1 & 2 & $\mathrm{e}$ & $\mathrm{rd}$ & $\mathrm{hb}$ & 13.6943 & 0.3262 & 0.5134 & 0.0080 & 0.17 & 0.1934 & 0.0046 & 0.5467 & 0.0126 & 0.61 & 16 & 1.98 & 2671 & 34 & 2729 & 22 & 2772 & 40 & 98 \\
\hline 8.1 & 3 & $\mathrm{~m}$ & $\mathrm{p}$ & hd & 13.6509 & 0.1908 & 0.5070 & 0.0048 & 0.38 & 0.1953 & 0.0026 & 0.0974 & 0.0055 & 0.00 & 56 & 0.30 & 2644 & 20 & 2726 & 14 & 2787 & 22 & 97 \\
\hline
\end{tabular}


Unidade Serra do Ibituruna: amostra CP-05 (continuação)

\begin{tabular}{|c|c|c|c|c|c|c|c|c|c|c|c|c|c|c|c|c|c|c|c|c|c|c|c|}
\hline spot & pop. & site & habit & CL & ${ }^{207} \mathrm{~Pb} /{ }^{235} \mathrm{U}$ & 10 & ${ }^{206} \mathrm{~Pb} /{ }^{238} \mathrm{U}$ & 10 & Rho & ${ }^{207} \mathrm{~Pb} /{ }^{206} \mathrm{~Pb}$ & 10 & $208 / 206$ & 10 & Pb total & Pb rad & $\mathbf{T h} / \mathrm{U}$ & t.68 & 10 & t.75 & $10^{\circ}$ & t.76 & 10 & concordância \\
\hline 9.1 & 3 & $\mathrm{e}$ & $\mathrm{p}$ & hb & 19.2077 & 0.2690 & 0.5988 & 0.0058 & 1.00 & 0.2327 & 0.0032 & 0.1573 & 0.0208 & 0.13 & 54 & 0.64 & 3025 & 23 & 3052 & 14 & 3070 & 22 & 99 \\
\hline 9.2 & 3 & $\mathrm{~m}$ & $\mathrm{p}$ & ic & 21.3639 & 0.4136 & 0.6187 & 0.0088 & 0.41 & 0.2505 & 0.0051 & 0.2081 & 0.0311 & 0.16 & 22 & 0.65 & 3105 & 36 & 3155 & 20 & 3188 & 32 & 98 \\
\hline 10.1 & 3 & $\mathrm{c}$ & $\mathrm{p}$ & hd & 10.7274 & 0.1619 & 0.4576 & 0.0045 & 0.69 & 0.1700 & 0.0025 & 0.1958 & 0.0018 & 0.09 & 65 & 0.62 & 2429 & 20 & 2500 & 14 & 2558 & 24 & 97 \\
\hline 11.1 & 2 & $\mathrm{e}$ & $\mathrm{rd}$ & $\mathrm{hb}$ & 6.5032 & 0.0958 & 0.3606 & 0.0034 & 0.91 & 0.1308 & 0.0018 & 0.2397 & 0.0128 & 1.65 & 138 & 0.67 & 1985 & 16 & 2046 & 12 & 2109 & 23 & 97 \\
\hline 12.1 & 2 & $\mathrm{~m}$ & ov & hd & 7.0470 & 0.0970 & 0.3845 & 0.0036 & 0.16 & 0.1329 & 0.0019 & 0.1623 & 0.0047 & 0.11 & 138 & 0.53 & 2097 & 17 & 2117 & 12 & 2137 & 25 & 99 \\
\hline 13.1 & 2 & $\mathrm{~m}$ & $\mathrm{rd}$ & ic & 14.1182 & 0.1922 & 0.5201 & 0.0051 & 0.61 & 0.1969 & 0.0028 & 0.3736 & 0.0168 & 0.21 & 63 & 1.48 & 2700 & 22 & 2758 & 13 & 2800 & 24 & 98 \\
\hline 14.1 & 2 & $\mathrm{e}$ & eq & $\mathrm{hb}$ & 14.6549 & 0.2278 & 0.5363 & 0.0061 & 0.62 & 0.1982 & 0.0033 & 0.1132 & 0.0053 & 0.11 & 45 & 0.42 & 2768 & 25 & 2793 & 15 & 2811 & 27 & 99 \\
\hline 15.1 & 2 & $\mathrm{~m}$ & rd & ic & 13.7557 & 0.1884 & 0.5079 & 0.0050 & 0.45 & 0.1964 & 0.0028 & 0.0768 & 0.0034 & 0.08 & 28 & 0.29 & 2647 & 21 & 2733 & 13 & 2797 & 23 & 97 \\
\hline 16.1 & 3 & $\mathrm{~m}$ & $\mathrm{p}$ & osc & 15.4335 & 0.2144 & 0.5375 & 0.0053 & 0.32 & 0.2082 & 0.0030 & 0.1434 & 0.0144 & 0.12 & 68 & 0.59 & 2773 & 22 & 2842 & 13 & 2892 & 23 & 98 \\
\hline 17.1 & 4 & $\mathrm{e}$ & $\mathrm{rd}$ & $\mathrm{hb}$ & 6.4417 & 0.0879 & 0.3627 & 0.0033 & 0.65 & 0.1288 & 0.0019 & 0.1183 & 0.0046 & 0.00 & 118 & 0.39 & 1995 & 16 & 2038 & 12 & 2082 & 25 & 98 \\
\hline 18.1 & 3 & $\mathrm{e}$ & $\mathrm{p}$ & $\mathrm{sz}$ & 7.1658 & 0.1116 & 0.3928 & 0.0041 & 0.98 & 0.1323 & 0.0022 & 0.1303 & 0.0097 & 0.37 & 45 & 0.33 & 2136 & 19 & 2132 & 14 & 2129 & 29 & 100 \\
\hline 19.1 & 2 & $\mathrm{c}$ & eq & ic & 12.8463 & 0.1838 & 0.5048 & 0.0051 & 0.01 & 0.1846 & 0.0028 & 0.2275 & 0.0232 & 0.14 & 70 & 0.96 & 2634 & 22 & 2668 & 13 & 2694 & 25 & 99 \\
\hline 19.2 & 2 & $\mathrm{e}$ & eq & $\mathrm{hb}$ & 14.4074 & 0.2746 & 0.5538 & 0.0077 & 0.94 & 0.1887 & 0.0042 & 1.3190 & 0.1029 & 0.18 & 46 & 5.28 & 2841 & 32 & 2777 & 18 & 2731 & 36 & 102 \\
\hline 20.1 & 2 & $\mathrm{c}$ & eq & $\mathrm{hb}$ & 14.8363 & 0.2952 & 0.5469 & 0.0083 & 0.88 & 0.1968 & 0.0048 & 0.3754 & 0.0956 & 0.19 & 20 & 1.29 & 2812 & 35 & 2805 & 20 & 2800 & 42 & 100 \\
\hline 21.1 & 2 & $\mathrm{~m}$ & ov & hd & 13.1843 & 0.1891 & 0.5004 & 0.0051 & 0.76 & 0.1911 & 0.0029 & 0.1992 & 0.0187 & 0.08 & 69 & 0.70 & 2615 & 22 & 2693 & 14 & 2752 & 25 & 97 \\
\hline 22.1 & 2 & $\mathrm{e}$ & $\mathrm{rd}$ & hd & 12.4591 & 0.1732 & 0.4932 & 0.0049 & 0.25 & 0.1832 & 0.0027 & 0.1390 & 0.0230 & 0.04 & 77 & 0.61 & 2585 & 21 & 2640 & 13 & 2682 & 24 & 98 \\
\hline 23.1 & 2 & $\mathrm{c}$ & $\mathrm{rd}$ & ic & 16.6603 & 0.3510 & 0.5717 & 0.0060 & 0.95 & 0.2113 & 0.0049 & 0.3077 & 0.0293 & 0.27 & 39 & 1.16 & 2915 & 25 & 2915 & 20 & 2916 & 37 & 100 \\
\hline 24.1 & 3 & $\mathrm{c}$ & $\mathrm{p}$ & hd & 6.2006 & 0.0995 & 0.3490 & 0.0024 & 1.00 & 0.1289 & 0.0026 & 0.1013 & 0.0338 & 0.55 & 94 & 0.49 & 1930 & 12 & 2005 & 17 & 2083 & 38 & 96 \\
\hline 25.1 & 4 & $\mathrm{e}$ & $\mathrm{rd}$ & osc & 6.4635 & 0.1205 & 0.3592 & 0.0028 & 0.99 & 0.1305 & 0.0028 & 0.1304 & 0.0092 & 0.00 & 76 & 0.40 & 1978 & 13 & 2041 & 17 & 2105 & 38 & 97 \\
\hline 26.1 & 3 & $\mathrm{e}$ & $\mathrm{p}$ & osc/rx & 6.6506 & 0.1326 & 0.3614 & 0.0031 & 0.91 & 0.1335 & 0.0029 & 0.1040 & 0.0350 & 0.22 & 57 & 0.24 & 1989 & 15 & 2066 & 18 & 2144 & 38 & 96 \\
\hline 27.1 & 4 & $\mathrm{~m}$ & ov & hd & 11.8619 & 0.3052 & 0.4822 & 0.0064 & 0.01 & 0.1784 & 0.0054 & 0.1438 & 0.0173 & 0.76 & 12 & 0.33 & 2537 & 28 & 2594 & 25 & 2638 & 51 & 98 \\
\hline 28.1 & 2 & $\mathrm{~m}$ & $\mathrm{rd}$ & hd & 13.8411 & 0.3076 & 0.5220 & 0.0057 & 0.57 & 0.1923 & 0.0048 & 1.4269 & 0.0167 & 0.10 & 67 & 4.37 & 2708 & 24 & 2739 & 21 & 2762 & 41 & 99 \\
\hline 29.1 & 2 & $\mathrm{~m}$ & eq & hd & 13.3749 & 0.3036 & 0.5316 & 0.0058 & 0.84 & 0.1825 & 0.0047 & 0.0785 & 0.0659 & 0.17 & 31 & 0.47 & 2748 & 25 & 2706 & 22 & 2676 & 43 & 102 \\
\hline 30.1 & 2 & $\mathrm{~m}$ & $\mathrm{p}$ & $\mathrm{sz}$ & 14.4275 & 0.2643 & 0.5188 & 0.0040 & 0.01 & 0.2017 & 0.0040 & 0.1147 & 0.0158 & 0.41 & 18 & 0.46 & 2694 & 17 & 2778 & 17 & 2840 & 30 & 97 \\
\hline 31.1 & 2 & $\mathrm{e}$ & $\mathrm{fr}$ & ic & 14.6524 & 0.2895 & 0.5380 & 0.0051 & 0.92 & 0.1975 & 0.0044 & 0.3976 & 0.0134 & 0.18 & 58 & 1.39 & 2775 & 22 & 2793 & 19 & 2806 & 36 & 99 \\
\hline 31.2 & 4 & $\mathrm{~m}$ & $\mathrm{fr}$ & $\mathrm{hb}$ & 14.2736 & 0.3965 & 0.5280 & 0.0079 & 0.69 & 0.1961 & 0.0064 & 0.3839 & 0.0095 & 0.23 & 21 & 1.33 & 2733 & 33 & 2768 & 26 & 2794 & 52 & 99 \\
\hline 32.1 & 4 & $\mathrm{e}$ & $\mathrm{rd}$ & hd & 13.6229 & 0.2545 & 0.5160 & 0.0038 & 0.35 & 0.1915 & 0.0037 & 0.0820 & 0.0088 & 0.07 & 97 & 0.36 & 2682 & 16 & 2724 & 16 & 2755 & 30 & 98 \\
\hline 33.1 & 2 & $\mathrm{e}$ & ov & $\mathrm{hb}$ & 14.9174 & 0.6891 & 0.5376 & 0.0152 & 0.02 & 0.2013 & 0.0113 & 0.2138 & 0.0226 & 1.56 & 9 & 0.69 & 2773 & 64 & 2810 & 44 & 2836 & 91 & 99 \\
\hline 34.1 & 4 & $\mathrm{c}$ & eq & ic & 12.0539 & 0.2448 & 0.5189 & 0.0046 & 0.53 & 0.1685 & 0.0035 & 0.0782 & 0.0083 & 0.67 & 8 & 0.25 & 2695 & 19 & 2609 & 18 & 2543 & 32 & 103 \\
\hline 35.1 & 2 & $\mathrm{c}$ & $\mathrm{p}$ & ic & 15.1269 & 0.2721 & 0.5373 & 0.0045 & 0.82 & 0.2042 & 0.0038 & 0.1966 & 0.0070 & 0.06 & 67 & 0.62 & 2772 & 19 & 2823 & 17 & 2860 & 30 & 98 \\
\hline 35.2 & 2 & $\mathrm{e}$ & $\mathrm{p}$ & $\mathrm{hb}$ & 14.2966 & 0.2692 & 0.5308 & 0.0047 & 0.91 & 0.1953 & 0.0038 & 0.2051 & 0.0035 & 0.06 & 83 & 0.85 & 2745 & 20 & 2770 & 18 & 2788 & 32 & 99 \\
\hline
\end{tabular}


Unidade Serra do Ibituruna: amostra CP-05 (continuação)

\begin{tabular}{|c|c|c|c|c|c|c|c|c|c|c|c|c|c|c|c|c|c|c|c|c|c|c|c|}
\hline spot & pop. & site & habit & CL & ${ }^{207} \mathrm{~Pb} /{ }^{235} \mathrm{U}$ & 10 & ${ }^{206} \mathrm{~Pb} /{ }^{238} \mathrm{U}$ & 10 & Rho & ${ }^{207} \mathrm{~Pb} /{ }^{206} \mathrm{~Pb}$ & 10 & $208 / 206$ & 10 & Pb total & Pb rad & $\mathbf{T h} / \mathbf{U}$ & t.68 & $10^{\circ}$ & t.75 & 10 & t.76 & 10 & concordância \\
\hline 36.1 & 4 & $\mathrm{e}$ & ov & $\mathrm{hd} / \mathrm{rx}$ & 13.2870 & 0.2226 & 0.5302 & 0.0038 & 0.89 & 0.1818 & 0.0032 & 0.0873 & 0.0058 & 0.20 & 147 & 0.44 & 2742 & 16 & 2700 & 16 & 2669 & 28 & 102 \\
\hline 37.1 & 2 & $\mathrm{e}$ & rd & $\mathrm{hb}$ & 14.1553 & 0.2815 & 0.5235 & 0.0050 & 0.18 & 0.1961 & 0.0041 & 0.3046 & 0.0112 & 0.14 & 49 & 1.05 & 2714 & 21 & 2760 & 19 & 2794 & 34 & 98 \\
\hline 38.1 & 2 & $\mathrm{c}$ & anh & sz & 13.1870 & 0.2616 & 0.5132 & 0.0048 & 0.46 & 0.1864 & 0.0039 & 0.2135 & 0.0037 & 0.11 & 48 & 0.68 & 2670 & 20 & 2693 & 19 & 2710 & 34 & 99 \\
\hline 39.1 & 2 & $\mathrm{e}$ & ov & $\mathrm{hd} / \mathrm{rx}$ & 13.4591 & 0.2367 & 0.5168 & 0.0041 & 0.74 & 0.1889 & 0.0034 & 0.2030 & 0.0156 & 0.10 & 92 & 0.69 & 2686 & 18 & 2712 & 17 & 2732 & 30 & 99 \\
\hline 40.1 & 2 & $\mathrm{~m}$ & eq & $\mathrm{osc} / \mathrm{hb}$ & 14.6039 & 0.3905 & 0.5344 & 0.0075 & 0.50 & 0.1982 & 0.0057 & 0.2014 & 0.0151 & 0.26 & 18 & 0.58 & 2760 & 32 & 2790 & 25 & 2811 & 47 & 99 \\
\hline 41.1 & 3 & $\mathrm{~m}$ & $\mathrm{p}$ & hd & 6.6863 & 0.1262 & 0.3674 & 0.0029 & 0.86 & 0.1320 & 0.0026 & 0.1159 & 0.0047 & 2.22 & 66 & 0.73 & 2017 & 14 & 2071 & 16 & 2125 & 34 & 97 \\
\hline 42.1 & 2 & $\mathrm{c}$ & $\mathrm{rd}$ & ic & 13.5865 & 0.3018 & 0.5119 & 0.0054 & 0.83 & 0.1925 & 0.0043 & 0.1226 & 0.0516 & 0.09 & 56 & 0.11 & 2665 & 23 & 2721 & 20 & 2764 & 36 & 98 \\
\hline 43.1 & 3 & $\mathrm{e}$ & $\mathrm{p}$ & $\mathrm{hb}$ & 12.2687 & 0.2411 & 0.4762 & 0.0048 & 1.00 & 0.1868 & 0.0043 & 0.0935 & 0.0143 & 0.99 & 58 & 0.72 & 2511 & 22 & 2625 & 20 & 2715 & 38 & 96 \\
\hline 44.1 & 3 & $\mathrm{e}$ & $\mathrm{p}$ & $\mathrm{sz}$ & 4.2646 & 0.0841 & 0.2621 & 0.0021 & 0.95 & 0.1180 & 0.0022 & 0.0876 & 0.0149 & 1.03 & 116 & 0.33 & 1501 & 11 & 1687 & 15 & 1926 & 33 & 89 \\
\hline 45.1 & 2 & $\mathrm{e}$ & eq & ic/osc & 13.7193 & 0.2054 & 0.5209 & 0.0050 & 0.67 & 0.1910 & 0.0030 & 0.2629 & 0.0051 & 0.11 & 55 & 0.92 & 2703 & 21 & 2731 & 14 & 2751 & 26 & 99 \\
\hline 46.1 & 4 & $\mathrm{~m}$ & rd & ic & 15.6043 & 0.3213 & 0.5516 & 0.0073 & 0.29 & 0.2052 & 0.0044 & 0.2007 & 0.0064 & 0.37 & 25 & 0.68 & 2832 & 30 & 2853 & 19 & 2868 & 35 & 99 \\
\hline 47.1 & 2 & $\mathrm{~m}$ & $\mathrm{eq}$ & ic & 14.3436 & 0.1893 & 0.5321 & 0.0044 & 0.37 & 0.1955 & 0.0026 & 0.0585 & 0.0071 & 0.06 & 91 & 0.25 & 2750 & 19 & 2773 & 12 & 2789 & 21 & 99 \\
\hline 47.2 & 2 & $\mathrm{e}$ & eq & $\mathrm{hd} / \mathrm{rx}$ & 13.9068 & 0.1913 & 0.5233 & 0.0047 & 0.61 & 0.1927 & 0.0027 & 0.3227 & 0.0193 & 0.19 & 74 & 1.36 & 2713 & 20 & 2743 & 13 & 2766 & 24 & 99 \\
\hline 48.1 & 3 & $\mathrm{c}$ & $\mathrm{p}$ & ic & 19.1558 & 0.2553 & 0.5927 & 0.0052 & 0.35 & 0.2344 & 0.0032 & 0.0146 & 0.0026 & 0.43 & 16 & 0.10 & 3000 & 21 & 3050 & 12 & 3082 & 21 & 98 \\
\hline 48.2 & 3 & $\mathrm{e}$ & $\mathrm{p}$ & osc & 14.5396 & 0.1917 & 0.5250 & 0.0046 & 0.78 & 0.2008 & 0.0027 & 0.0149 & 0.0021 & 0.12 & 85 & 0.06 & 2720 & 19 & 2786 & 12 & 2833 & 22 & 98 \\
\hline 49.1 & 4 & $\mathrm{e}$ & $\mathrm{rd}$ & $\mathrm{rx} / \mathrm{hb}$ & 13.5001 & 0.2656 & 0.5121 & 0.0063 & 0.74 & 0.1912 & 0.0040 & 0.2500 & 0.0082 & 2.35 & 31 & 1.15 & 2666 & 27 & 2715 & 19 & 2752 & 34 & 98 \\
\hline 50.1 & 2 & $\mathrm{e}$ & $\mathrm{rd}$ & $\mathrm{hb}$ & 13.4391 & 0.2162 & 0.5136 & 0.0053 & 0.16 & 0.1898 & 0.0032 & 0.0956 & 0.0066 & 0.10 & 36 & 0.45 & 2672 & 22 & 2711 & 15 & 2740 & 28 & 99 \\
\hline 51.1 & 2 & $\mathrm{e}$ & $\mathrm{rd}$ & hd/osz & 13.1169 & 0.1646 & 0.4941 & 0.0041 & 0.97 & 0.1925 & 0.0026 & 0.1597 & 0.0160 & 0.03 & 88 & 0.55 & 2588 & 18 & 2688 & 12 & 2764 & 22 & 96 \\
\hline 52.1 & 1 & $\mathrm{e}$ & $\mathrm{p}$ & $\mathrm{hb}$ & 6.0495 & 0.1118 & 0.3447 & 0.0034 & 1.00 & 0.1273 & 0.0028 & 0.1281 & 0.0136 & 0.95 & 50 & 0.47 & 1909 & 17 & 1983 & 18 & 2061 & 39 & 96 \\
\hline 53.1 & 3 & $\mathrm{~m}$ & $\mathrm{p}$ & $\mathrm{hb}$ & 15.7894 & 0.2497 & 0.5362 & 0.0056 & 0.97 & 0.2135 & 0.0035 & 0.3807 & 0.0154 & 0.26 & 46 & 1.16 & 2768 & 23 & 2864 & 15 & 2933 & 26 & 97 \\
\hline 54.1 & 2 & $\mathrm{e}$ & eq & $r x$ & 12.3897 & 0.1793 & 0.4903 & 0.0046 & 0.86 & 0.1833 & 0.0027 & 0.1690 & 0.0312 & 0.20 & 53 & 0.76 & 2572 & 20 & 2634 & 13 & 2683 & 25 & 98 \\
\hline 55.1 & 2 & $\mathrm{c}$ & eq & ic & 13.5289 & 0.3417 & 0.5208 & 0.0091 & 0.77 & 0.1884 & 0.0059 & 0.9093 & 0.0902 & 0.11 & 32 & 2.45 & 2702 & 38 & 2717 & 24 & 2728 & 51 & 99 \\
\hline 55.2 & 2 & $\mathrm{e}$ & eq & $\mathrm{hb}$ & 13.7138 & 0.2043 & 0.5143 & 0.0053 & 0.65 & 0.1934 & 0.0032 & 0.5376 & 0.0060 & 0.07 & 68 & 2.11 & 2675 & 23 & 2730 & 14 & 2771 & 28 & 98 \\
\hline 56.1 & 4 & $\mathrm{e}$ & $\mathrm{eq}$ & $\mathrm{hb}$ & 12.7466 & 0.1839 & 0.4885 & 0.0049 & 0.96 & 0.1893 & 0.0030 & 0.0946 & 0.0207 & 0.26 & 48 & 0.46 & 2564 & 21 & 2661 & 13 & 2736 & 26 & 96 \\
\hline 57.1 & 4 & $\mathrm{e}$ & fr & $\mathrm{hb}$ & 14.1204 & 0.2062 & 0.5252 & 0.0053 & 0.93 & 0.1950 & 0.0032 & 0.3702 & 0.0106 & 0.11 & 72 & 1.26 & 2721 & 23 & 2758 & 14 & 2785 & 27 & 99 \\
\hline 58.1 & 2 & $\mathrm{~m}$ & rd & $\mathrm{hb}$ & 13.3787 & 0.2387 & 0.4820 & 0.0060 & 0.93 & 0.2013 & 0.0043 & 0.1337 & 0.0056 & 0.18 & 28 & 0.39 & 2536 & 26 & 2707 & 17 & 2837 & 35 & 94 \\
\hline 59.1 & 4 & $\mathrm{e}$ & $\mathrm{rd}$ & $\mathrm{rx}$ & 6.1337 & 0.0871 & 0.3462 & 0.0032 & 0.98 & 0.1285 & 0.0020 & 0.0705 & 0.0082 & 0.07 & 71 & 0.34 & 1916 & 15 & 1995 & 12 & 2078 & 28 & 96 \\
\hline 60.1 & 4 & $\mathrm{e}$ & $\mathrm{rd}$ & $\mathrm{hb}$ & 13.3689 & 0.3536 & 0.5097 & 0.0094 & 0.76 & 0.1902 & 0.0062 & 0.7069 & 0.0161 & 0.48 & 21 & 2.36 & 2655 & 40 & 2706 & 25 & 2744 & 54 & 98 \\
\hline 61.1 & 4 & $\mathrm{~m}$ & eq & $\mathrm{hb}$ & 13.5596 & 0.3134 & 0.5348 & 0.0084 & 0.50 & 0.1839 & 0.0054 & 0.0605 & 0.0102 & 0.26 & 15 & 0.20 & 2762 & 36 & 2719 & 22 & 2688 & 48 & 102 \\
\hline 62.1 & 1 & $\mathrm{~m}$ & $\mathrm{p}$ & $\mathrm{hb}$ & 15.2496 & 0.2062 & 0.5369 & 0.0050 & 0.89 & 0.2060 & 0.0031 & 0.0796 & 0.0060 & 0.05 & 61 & 0.25 & 2770 & 21 & 2831 & 13 & 2874 & 24 & 98 \\
\hline 63.1 & 2 & $\mathrm{e}$ & $\mathrm{rd}$ & $\mathrm{osc} / \mathrm{hb}$ & 15.2269 & 0.1993 & 0.5479 & 0.0050 & 0.01 & 0.2016 & 0.0029 & 0.0152 & 0.0038 & 0.04 & 83 & 0.06 & 2816 & 21 & 2830 & 12 & 2839 & 24 & 100 \\
\hline
\end{tabular}


Unidade Serra do Ibituruna: amostra CP-05 (continuação)

\begin{tabular}{|c|c|c|c|c|c|c|c|c|c|c|c|c|c|c|c|c|c|c|c|c|c|c|c|}
\hline spot & pop. & site & habit & CL & ${ }^{207} \mathbf{P b} /{ }^{235} \mathbf{U}$ & 10 & ${ }^{206} \mathrm{~Pb} /{ }^{238} \mathrm{U}$ & 10 & Rho & ${ }^{207} \mathrm{~Pb} /{ }^{206} \mathrm{~Pb}$ & 10 & $208 / 206$ & 10 & Pb total & Pb rad & $\mathrm{Th} / \mathrm{U}$ & t.68 & 10 & t.75 & $10^{\circ}$ & t.76 & 10 & concordância \\
\hline 64.1 & 2 & $\mathrm{~m}$ & ov & hd & 14.6267 & 0.2153 & 0.5350 & 0.0055 & 0.70 & 0.1983 & 0.0033 & 0.1222 & 0.0046 & 0.11 & 56 & 0.40 & 2762 & 23 & 2791 & 14 & 2812 & 27 & 99 \\
\hline 65.1 & 2 & $\mathrm{c}$ & eq & ic & 14.0700 & 0.1826 & 0.5212 & 0.0047 & 0.20 & 0.1958 & 0.0028 & 0.1025 & 0.0450 & 0.20 & 60 & 0.39 & 2704 & 20 & 2754 & 12 & 2791 & 23 & 98 \\
\hline 66.1 & 3 & $\mathrm{~m}$ & $\mathrm{p}$ & $\mathrm{sz}$ & 6.1130 & 0.0972 & 0.3408 & 0.0035 & 1.00 & 0.1301 & 0.0020 & 0.2423 & 0.0312 & 0.70 & 107 & 1.16 & 1891 & 17 & 1992 & 15 & 2099 & 27 & 95 \\
\hline 67.1 & 2 & $\mathrm{~m}$ & $\mathrm{rd}$ & ic & 16.1831 & 0.4073 & 0.5458 & 0.0104 & 0.72 & 0.2151 & 0.0058 & 0.3512 & 0.0150 & 0.34 & 21 & 1.01 & 2808 & 44 & 2888 & 25 & 2944 & 44 & 97 \\
\hline 68.1 & 4 & $\mathrm{e}$ & $\mathrm{rd}$ & $\mathrm{hb}$ & 18.2739 & 0.3188 & 0.6393 & 0.0080 & 0.87 & 0.2073 & 0.0033 & 0.0564 & 0.0055 & 0.23 & 57 & 0.20 & 3186 & 32 & 3004 & 17 & 2885 & 26 & 106 \\
\hline 69.1 & 2 & $\mathrm{e}$ & $\mathrm{rd}$ & $\mathrm{hb}$ & 14.4929 & 0.2523 & 0.5432 & 0.0067 & 0.52 & 0.1935 & 0.0030 & 0.1108 & 0.0070 & 0.16 & 58 & 0.34 & 2797 & 28 & 2783 & 17 & 2772 & 26 & 101 \\
\hline 70.1 & 2 & $\mathrm{~m}$ & eq & $\mathrm{hb}$ & 14.1749 & 0.2857 & 0.5274 & 0.0076 & 0.60 & 0.1949 & 0.0038 & 0.2454 & 0.0067 & 0.19 & 33 & 0.74 & 2731 & 32 & 2761 & 19 & 2784 & 32 & 99 \\
\hline 71.1 & 2 & $\mathrm{e}$ & ov & $\mathrm{rx}$ & 14.5158 & 0.3332 & 0.5373 & 0.0090 & 0.95 & 0.1959 & 0.0047 & 0.4229 & 0.0106 & 0.16 & 26 & 1.42 & 2772 & 38 & 2784 & 22 & 2793 & 40 & 100 \\
\hline 72.1 & 2 & $\mathrm{e}$ & ov & $\mathrm{hb}$ & 14.7506 & 0.2771 & 0.5250 & 0.0071 & 0.88 & 0.2038 & 0.0036 & 0.0897 & 0.0053 & 0.29 & 33 & 0.37 & 2720 & 30 & 2799 & 18 & 2857 & 29 & 97 \\
\hline 73.1 & 2 & $\mathrm{e}$ & ov & $\mathrm{hb}$ & 6.5306 & 0.2242 & 0.3544 & 0.0072 & 0.85 & 0.1336 & 0.0050 & 0.1715 & 0.0200 & 1.92 & 15 & 0.45 & 1956 & 34 & 2050 & 30 & 2146 & 65 & 95 \\
\hline 74.1 & 4 & $\mathrm{~m}$ & $\mathrm{rd}$ & $\mathrm{hb}$ & 12.6482 & 0.3079 & 0.4871 & 0.0084 & 0.01 & 0.1883 & 0.0047 & 0.4582 & 0.0233 & 2.90 & 28 & 1.41 & 2558 & 37 & 2654 & 23 & 2728 & 41 & 96 \\
\hline 75.1 & 2 & $\mathrm{~m}$ & $\mathrm{rd}$ & ic & 13.9143 & 0.6768 & 0.5302 & 0.0188 & 0.80 & 0.1903 & 0.0109 & 0.1475 & 0.0172 & 0.57 & 6 & 0.54 & 2742 & 80 & 2744 & 47 & 2745 & 94 & 100 \\
\hline 76.1 & 2 & $\mathrm{~m}$ & ov & $\mathrm{hb}$ & 13.7220 & 0.2591 & 0.5058 & 0.0068 & 0.96 & 0.1967 & 0.0035 & 0.1673 & 0.0082 & 0.32 & 39 & 0.56 & 2639 & 29 & 2731 & 18 & 2799 & 29 & 97 \\
\hline 77.1 & 2 & $\mathrm{~m}$ & eq & ic & 14.2241 & 0.2354 & 0.5267 & 0.0060 & 0.55 & 0.1959 & 0.0028 & 0.0747 & 0.0160 & 0.08 & 52 & 0.36 & 2727 & 25 & 2765 & 15 & 2792 & 23 & 99 \\
\hline 78.1 & 2 & $\mathrm{~m}$ & eq & ic & 14.8804 & 0.2134 & 0.5336 & 0.0064 & 0.75 & 0.2023 & 0.0024 & 0.2077 & 0.0094 & 0.07 & 76 & 0.59 & 2757 & 27 & 2808 & 14 & 2845 & 19 & 98 \\
\hline 79.1 & 2 & $\mathrm{c}$ & rd & ic & 12.7783 & 0.2054 & 0.4945 & 0.0065 & 0.28 & 0.1874 & 0.0026 & 0.1503 & 0.0106 & 0.13 & 44 & 0.47 & 2590 & 28 & 2663 & 15 & 2720 & 23 & 97 \\
\hline 80.1 & 2 & $\mathrm{~m}$ & ov & $\mathrm{rx} / \mathrm{hb}$ & 14.8184 & 0.2190 & 0.5354 & 0.0061 & 0.93 & 0.2007 & 0.0025 & 0.1762 & 0.0267 & 0.12 & 37 & 0.53 & 2764 & 26 & 2804 & 15 & 2832 & 20 & 99 \\
\hline 81.1 & 2 & $\mathrm{c}$ & $\mathrm{rd}$ & $\mathrm{hb}$ & 12.9069 & 0.3791 & 0.4952 & 0.0098 & 0.39 & 0.1890 & 0.0051 & 0.0430 & 0.0165 & 0.52 & 6 & 0.11 & 2593 & 42 & 2673 & 28 & 2734 & 44 & 97 \\
\hline 82.1 & 4 & $\mathrm{e}$ & $\mathrm{p}$ & $\mathrm{hb} / \mathrm{rx}$ & 13.1591 & 0.1988 & 0.4965 & 0.0057 & 0.91 & 0.1922 & 0.0024 & 0.2072 & 0.0084 & 0.08 & 43 & 0.73 & 2599 & 24 & 2691 & 14 & 2761 & 21 & 97 \\
\hline 83.1 & 4 & $\mathrm{~m}$ & ov & $\mathrm{hb} / \mathrm{rx}$ & 14.9461 & 0.2276 & 0.5335 & 0.0062 & 0.78 & 0.2032 & 0.0026 & 0.3008 & 0.0119 & 0.19 & 35 & 0.88 & 2756 & 26 & 2812 & 15 & 2852 & 21 & 98 \\
\hline 84.1 & 3 & $\mathrm{e}$ & $\mathrm{p}$ & osc & 7.3126 & 0.1111 & 0.3919 & 0.0043 & 0.73 & 0.1353 & 0.0017 & 0.1001 & 0.0039 & 0.13 & 42 & 0.36 & 2132 & 20 & 2150 & 14 & 2168 & 22 & 99 \\
\hline 85.1 & 4 & $\mathrm{e}$ & $\mathrm{rd}$ & $\mathrm{hb}$ & 12.8452 & 0.2063 & 0.4834 & 0.0058 & 0.93 & 0.1927 & 0.0026 & 0.0778 & 0.0047 & 0.45 & 27 & 0.25 & 2542 & 25 & 2668 & 15 & 2766 & 23 & 95 \\
\hline
\end{tabular}

Unidade Serra do Ibituruna: amostra CP-27

\begin{tabular}{|c|c|c|c|c|c|c|c|c|c|c|c|c|c|c|c|c|c|c|c|c|c|c|c|}
\hline spot & pop. & site & habit & CL & $206 *(\%)$ & ${ }^{204} \mathrm{~Pb} \mathrm{cps}$ & $\mathbf{T h} / \mathbf{U}$ & ${ }^{206} \mathrm{~Pb} /{ }^{204} \mathrm{~Pb}$ & 10 & ${ }^{207} \mathrm{~Pb} /{ }^{206} \mathrm{~Pb}$ & 10 & ${ }^{207} \mathrm{~Pb} /{ }^{235} \mathrm{U}$ & 10 & ${ }^{206} \mathrm{~Pb} /{ }^{238} \mathrm{U}$ & 10 & Rho & t.76 & 20 & t.68 & 20 & t.75 & 20 & concordância \\
\hline 1 & 2 & $\mathrm{~m}$ & fr & $\mathrm{rx}$ & 0.3996 & 102 & 0.327 & 3701 & 6.06 & 0.19755 & 0.37 & 13.492 & 0.81 & 0.4953 & 0.63 & 0.77 & 2806 & 8 & 2594 & 14 & 2715 & 8 & 92 \\
\hline 2 & 2 & $\mathrm{~m}$ & eq & hd & 0.1244 & 122 & 0.438 & 11749 & 7.87 & 0.20067 & 0.80 & 14.845 & 1.16 & 0.5365 & 0.76 & 0.65 & 2832 & 14 & 2769 & 17 & 2805 & 11 & 98 \\
\hline 3 & 4 & e & ov & hb/osc & 0.8470 & 472 & 0.162 & 1836 & 2.88 & 0.19111 & 1.71 & 3.209 & 4.99 & 0.1218 & 4.67 & 0.94 & 2752 & 28 & 741 & 33 & 1459 & 39 & 27 \\
\hline 4 & 2 & $\mathrm{~m}$ & fr & osc & 0.3004 & 137 & 0.299 & 4938 & 9.91 & 0.20357 & 0.72 & 13.611 & 1.32 & 0.4849 & 1.04 & 0.79 & 2855 & 13 & 2549 & 22 & 2723 & 13 & 89 \\
\hline 5.1 & 3 & $\mathrm{e}$ & $\mathrm{fr}$ & $\mathrm{hb}$ & 1.3833 & 140 & 0.117 & 1090 & 8.40 & 0.20306 & 1.32 & 11.433 & 3.19 & 0.4083 & 2.88 & 0.90 & 2851 & 23 & 2207 & 54 & 2559 & 30 & 77 \\
\hline 5.2 & 3 & $\mathrm{c}$ & fr & ic/hd & 0.1375 & 116 & 0.073 & 10778 & 6.93 & 0.19593 & 0.38 & 13.157 & 0.77 & 0.4870 & 0.55 & 0.72 & 2793 & 9 & 2558 & 12 & 2691 & 7 & 92 \\
\hline
\end{tabular}


Unidade Serra do Ibituruna: amostra CP-27 (continuação)

\begin{tabular}{|c|c|c|c|c|c|c|c|c|c|c|c|c|c|c|c|c|c|c|c|c|c|c|c|}
\hline spot & pop. & site & habit & CL & $206 *(\%)$ & ${ }^{204} \mathrm{~Pb}$ cps & $\mathrm{Th} / \mathrm{U}$ & ${ }^{206} \mathrm{~Pb} /{ }^{204} \mathrm{~Pb}$ & 10 & ${ }^{207} \mathbf{P b} /{ }^{206} \mathbf{P b}$ & 10 & ${ }^{207} \mathbf{P b} /{ }^{235} \mathbf{U}$ & 10 & ${ }^{206} \mathrm{~Pb} /{ }^{238} \mathrm{U}$ & 10 & Rho & t.76 & 20 & t.68 & 20 & t.75 & 20 & concordância \\
\hline 6.1 & 3 & $\mathrm{e}$ & $\mathrm{p}$ & $\mathrm{hb}$ & 0.6373 & 133 & 0.487 & 2335 & 11.14 & 0.20275 & 0.72 & 13.198 & 1.23 & 0.4721 & 0.93 & 0.75 & 2849 & 13 & 2493 & 20 & 2694 & 12 & 88 \\
\hline 6.2 & 3 & $\mathrm{~m}$ & $\mathrm{p}$ & hd & 0.0538 & 271 & 0.047 & 28492 & 75.19 & 0.20509 & 2.76 & 8.272 & 2.93 & 0.2925 & 0.92 & 0.31 & 2867 & 45 & 1654 & 13 & 2261 & 27 & 58 \\
\hline 7 & 1 & $\mathrm{~m}$ & $\mathrm{p}$ & $\mathrm{hb} / \mathrm{rx}$ & 0.2049 & 194 & 0.341 & 7226 & 3.56 & 0.20912 & 0.78 & 14.163 & 1.05 & 0.4912 & 0.60 & 0.57 & 2899 & 14 & 2576 & 13 & 2761 & 10 & 89 \\
\hline 8 & 2 & $\mathrm{~m}$ & ov & ic & 0.3422 & 103 & 0.428 & 4327 & 12.32 & 0.18604 & 0.55 & 12.600 & 0.87 & 0.4912 & 0.57 & 0.65 & 2708 & 11 & 2576 & 12 & 2650 & 8 & 95 \\
\hline 9 & 2 & $\mathrm{~m}$ & $\mathrm{rd}$ & osc & 0.0861 & 85 & 0.477 & 16804 & 16.99 & 0.22946 & 0.52 & 18.008 & 0.85 & 0.5692 & 0.55 & 0.65 & 3048 & 10 & 2905 & 13 & 2990 & 8 & 95 \\
\hline 10 & 1 & $\mathrm{~m}$ & $\mathrm{p}$ & ic/osc & 0.0747 & 91 & 0.582 & 19756 & 60.06 & 0.20479 & 1.11 & 14.241 & 1.69 & 0.5043 & 1.22 & 0.72 & 2865 & 19 & 2632 & 26 & 2766 & 16 & 92 \\
\hline 11 & 1 & $\mathrm{~m}$ & $\mathrm{p}$ & $\mathrm{ic} / \mathrm{hd}$ & 0.1196 & 110 & 0.381 & 12139 & 12.00 & 0.22324 & 1.69 & 17.187 & 1.82 & 0.5584 & 0.59 & 0.32 & 3004 & 28 & 2860 & 14 & 2945 & 18 & 95 \\
\hline 12 & 1 & $\mathrm{e}$ & $\mathrm{p}$ & $\mathrm{hd} / \mathrm{rx}$ & 0.0399 & 98 & 0.308 & 36624 & 62.29 & 0.20952 & 0.53 & 15.589 & 1.00 & 0.5396 & 0.77 & 0.76 & 2902 & 11 & 2782 & 17 & 2852 & 10 & 96 \\
\hline 13.1 & 1 & e & $\mathrm{p}$ & osc & 0.2204 & 472 & 0.281 & 6911 & 15.15 & 0.12940 & 3.52 & 6.186 & 3.59 & 0.3467 & 0.60 & 0.17 & 2090 & 62 & 1919 & 10 & 2003 & 31 & 92 \\
\hline 13.2 & 1 & $\mathrm{c}$ & $\mathrm{p}$ & ic & 0.2163 & 262 & 0.287 & 7081 & 5.75 & 0.12827 & 0.51 & 5.388 & 1.41 & 0.3046 & 1.27 & 0.90 & 2075 & 11 & 1714 & 19 & 1883 & 12 & 83 \\
\hline 14.1 & 2 & $\mathrm{e}$ & ov & hd & 0.1026 & 75 & 3.042 & 14394 & 52.95 & 0.19452 & 0.96 & 13.396 & 1.20 & 0.4994 & 0.61 & 0.51 & 2781 & 17 & 2611 & 13 & 2708 & 11 & 94 \\
\hline 14.2 & 2 & $\mathrm{c}$ & ov & $\mathrm{ic} / \mathrm{sz}$ & 0.1104 & 84 & 3.026 & 13330 & 58.69 & 0.20268 & 0.46 & 14.400 & 0.80 & 0.5153 & 0.54 & 0.68 & 2848 & 10 & 2679 & 12 & 2776 & 8 & 94 \\
\hline 15 & 3 & $\mathrm{e}$ & $\mathrm{p}$ & $\mathrm{sz}$ & 0.0261 & 78 & 0.378 & 55562 & 65.64 & 0.21453 & 1.45 & 16.622 & 1.61 & 0.5619 & 0.60 & 0.37 & 2940 & 24 & 2875 & 14 & 2913 & 15 & 98 \\
\hline 16 & 2 & $\mathrm{c}$ & $\mathrm{rd}$ & ic & 0.0232 & 77 & 0.056 & 62846 & 67.96 & 0.20827 & 0.55 & 15.499 & 1.17 & 0.5397 & 0.96 & 0.83 & 2892 & 11 & 2782 & 22 & 2846 & 11 & 96 \\
\hline 17 & 3 & $\mathrm{e}$ & $\mathrm{p}$ & $\mathrm{sz}$ & 0.1304 & 84 & 0.293 & 11241 & 10.18 & 0.21585 & 0.45 & 15.700 & 0.83 & 0.5275 & 0.59 & 0.71 & 2950 & 10 & 2731 & 13 & 2859 & 8 & 93 \\
\hline 18 & 2 & $\mathrm{~m}$ & $\mathrm{fr}$ & osc & 0.1318 & 72 & 0.326 & 11513 & 14.41 & 0.13644 & 0.40 & 6.998 & 0.84 & 0.3720 & 0.64 & 0.76 & 2182 & 10 & 2039 & 11 & 2111 & 8 & 93 \\
\hline 19 & 2 & $\mathrm{c}$ & $\mathrm{rd}$ & ic & 0.0487 & 70 & 0.457 & 30315 & 47.13 & 0.20140 & 0.72 & 13.963 & 1.02 & 0.5028 & 0.63 & 0.62 & 2838 & 13 & 2626 & 14 & 2747 & 10 & 93 \\
\hline 20 & 1 & $\mathrm{e}$ & $\mathrm{p}$ & osc & 0.1549 & 118 & 0.371 & 9676 & 10.15 & 0.16907 & 0.50 & 10.248 & 0.97 & 0.4396 & 0.74 & 0.77 & 2549 & 10 & 2349 & 15 & 2457 & 9 & 92 \\
\hline 21 & 1 & $\mathrm{~m}$ & $\mathrm{p}$ & sz/ic & 0.4409 & 314 & 0.149 & 3512 & 4.72 & 0.12735 & 0.48 & 3.368 & 1.80 & 0.1918 & 1.69 & 0.94 & 2062 & 11 & 1131 & 18 & 1497 & 14 & 55 \\
\hline 22 & 4 & $\mathrm{~m}$ & ov & ic/osc & 0.0643 & 79 & 0.368 & 22927 & 56.40 & 0.19840 & 0.52 & 13.826 & 1.01 & 0.5054 & 0.78 & 0.77 & 2813 & 11 & 2637 & 17 & 2738 & 10 & 94 \\
\hline 23 & 1 & $\mathrm{~m}$ & $\mathrm{p}$ & osc & 0.2359 & 125 & 0.319 & 6443 & 6.91 & 0.13117 & 0.40 & 6.525 & 0.79 & 0.3607 & 0.57 & 0.72 & 2114 & 10 & 1985 & 9 & 2049 & 7 & 94 \\
\hline 24 & 1 & $\mathrm{~m}$ & $\mathrm{p}$ & hd & 0.0565 & 115 & 0.188 & 26118 & 9.89 & 0.20224 & 0.69 & 14.049 & 1.00 & 0.5038 & 0.62 & 0.62 & 2844 & 13 & 2630 & 13 & 2753 & 9 & 92 \\
\hline 25 & 2 & $\mathrm{c}$ & $\mathrm{rd}$ & $\mathrm{hb} / \mathrm{rx}$ & 0.0720 & 68 & 0.924 & 20353 & 38.56 & 0.21017 & 0.63 & 15.354 & 0.97 & 0.5298 & 0.64 & 0.66 & 2907 & 12 & 2741 & 15 & 2837 & 9 & 94 \\
\hline 26.1 & 1 & $\mathrm{e}$ & $\mathrm{p}$ & osc & 0.1202 & 105 & 0.315 & 12241 & 11.60 & 0.21195 & 0.52 & 15.072 & 1.13 & 0.5157 & 0.94 & 0.83 & 2921 & 10 & 2681 & 21 & 2820 & 11 & 92 \\
\hline 26.2 & 1 & $\mathrm{c}$ & $\mathrm{p}$ & ic & 0.9826 & 430 & 0.532 & 1505 & 5.87 & 0.21550 & 1.35 & 14.755 & 1.71 & 0.4966 & 0.97 & 0.57 & 2947 & 23 & 2599 & 20 & 2800 & 16 & 88 \\
\hline 27 & 3 & $\mathrm{c}$ & ov & $\mathrm{ic} / \mathrm{hb}$ & 0.9880 & 98 & 0.366 & 1463 & 12.08 & 0.21158 & 0.96 & 16.659 & 1.45 & 0.5710 & 1.01 & 0.70 & 2918 & 17 & 2912 & 24 & 2915 & 14 & 100 \\
\hline 28.1 & 4 & $\mathrm{e}$ & $\mathrm{rd}$ & $\mathrm{hb}$ & 0.2076 & 96 & 0.398 & 7091 & 74.67 & 0.18090 & 1.22 & 12.795 & 1.91 & 0.5129 & 1.43 & 0.75 & 2661 & 21 & 2669 & 31 & 2665 & 18 & 100 \\
\hline 28.2 & 4 & $\mathrm{c}$ & $\mathrm{rd}$ & ic & 0.0011 & 95 & 0.304 & 1310196 & 98.52 & 0.20140 & 1.51 & 15.160 & 1.69 & 0.5459 & 0.67 & 0.40 & 2838 & 25 & 2808 & 15 & 2825 & 16 & 99 \\
\hline 29.1 & 1 & $\mathrm{e}$ & $\mathrm{p}$ & $\mathrm{hb}$ & 0.8318 & 148 & 0.893 & 1809 & 12.05 & 0.20258 & 0.65 & 11.734 & 1.29 & 0.4201 & 1.05 & 0.81 & 2847 & 12 & 2261 & 20 & 2583 & 12 & 79 \\
\hline 29.2 & 1 & $\mathrm{c}$ & $\mathrm{p}$ & ic & 4.4283 & 2553 & 0.307 & 352 & 3.08 & 0.16765 & 1.03 & 1.495 & 2.06 & 0.0647 & 1.74 & 0.84 & 2534 & 19 & 404 & 7 & 928 & 13 & 16 \\
\hline 30 & 2 & $\mathrm{e}$ & ov & $\mathrm{hb}$ & 1.0541 & 142 & 0.721 & 1384 & 10.09 & 0.21046 & 0.89 & 15.748 & 1.25 & 0.5426 & 0.80 & 0.64 & 2909 & 16 & 2794 & 18 & 2862 & 12 & 96 \\
\hline
\end{tabular}


Unidade Serra do Ibituruna: amostra CP-27 (continuação)

\begin{tabular}{|c|c|c|c|c|c|c|c|c|c|c|c|c|c|c|c|c|c|c|c|c|c|c|c|}
\hline spot & pop. & site & habit & CL & $206 *(\%)$ & ${ }^{204} \mathrm{~Pb}$ cps & $\mathbf{T h} / \mathbf{U}$ & ${ }^{206} \mathrm{~Pb} /{ }^{204} \mathrm{~Pb}$ & 10 & ${ }^{207} \mathrm{~Pb} /{ }^{206} \mathrm{~Pb}$ & 10 & ${ }^{207} \mathrm{~Pb} /{ }^{235} \mathrm{U}$ & 10 & ${ }^{206} \mathrm{~Pb} /{ }^{238} \mathrm{U}$ & 10 & Rho & t.76 & 20 & t.68 & 20 & t.75 & $20^{\circ}$ & concordância \\
\hline 31 & 4 & $\mathrm{e}$ & ov & osc & 0.2316 & 193 & 0.519 & 6451 & 5.70 & 0.17118 & 1.71 & 10.682 & 1.88 & 0.4525 & 0.70 & 0.37 & 2570 & 29 & 2406 & 14 & 2496 & 18 & 94 \\
\hline 32 & 1 & $\mathrm{~m}$ & $\mathrm{p}$ & sz & 0.1046 & 156 & 0.351 & 14366 & 19.27 & 0.20896 & 0.52 & 12.305 & 1.89 & 0.4271 & 1.78 & 0.94 & 2898 & 11 & 2293 & 34 & 2628 & 18 & 79 \\
\hline 33 & 1 & $\mathrm{c}$ & ov & ic/osc & 2.1572 & 903 & 0.172 & 719 & 2.55 & 0.17551 & 0.59 & 3.819 & 1.67 & 0.1578 & 1.51 & 0.91 & 2611 & 12 & 945 & 13 & 1597 & 13 & 36 \\
\hline 34 & 2 & $\mathrm{c}$ & ov & ic & 0.0440 & 82 & 0.080 & 33561 & 47.16 & 0.20447 & 0.60 & 14.150 & 0.99 & 0.5019 & 0.70 & 0.70 & 2862 & 12 & 2622 & 15 & 2760 & 9 & 92 \\
\hline 35 & 3 & $\mathrm{~m}$ & ov & $\mathrm{hb}$ & 0.9759 & 189 & 0.337 & 1525 & 5.87 & 0.19207 & 2.43 & 12.492 & 4.96 & 0.4717 & 4.30 & 0.87 & 2760 & 40 & 2491 & 89 & 2642 & 47 & 90 \\
\hline 36.1 & 4 & $\mathrm{e}$ & ov & osc & 0.3601 & 463 & 0.459 & 4165 & 13.92 & 0.16632 & 0.53 & 9.995 & 0.99 & 0.4358 & 0.75 & 0.76 & 2521 & 11 & 2332 & 15 & 2434 & 9 & 92 \\
\hline 36.2 & 4 & $\mathrm{c}$ & ov & ic & 0.4221 & 496 & 0.448 & 3618 & 7.21 & 0.16021 & 0.39 & 7.214 & 1.22 & 0.3266 & 1.10 & 0.90 & 2458 & 9 & 1822 & 18 & 2138 & 11 & 74 \\
\hline 37 & 2 & $\mathrm{e}$ & $\mathrm{rd}$ & osc & 0.0791 & 98 & 0.691 & 18759 & 71.44 & 0.18861 & 0.74 & 12.606 & 1.29 & 0.4847 & 0.99 & 0.77 & 2730 & 14 & 2548 & 21 & 2651 & 12 & 93 \\
\hline 38.1 & 2 & $\mathrm{e}$ & $\mathrm{rd}$ & $\mathrm{hb} / \mathrm{rx}$ & 0.0609 & 66 & 1.844 & 23940 & 47.43 & 0.19696 & 0.47 & 14.803 & 0.89 & 0.5450 & 0.66 & 0.74 & 2801 & 10 & 2804 & 15 & 2803 & 9 & 100 \\
\hline 38.2 & 2 & $\mathrm{~m}$ & $\mathrm{rd}$ & $\mathrm{ic} / \mathrm{sz}$ & 0.0271 & 118 & 0.151 & 55909 & 58.69 & 0.18729 & 2.90 & 10.047 & 3.29 & 0.3890 & 1.52 & 0.46 & 2719 & 48 & 2118 & 27 & 2439 & 30 & 78 \\
\hline 39 & 1 & $\mathrm{~m}$ & $\mathrm{p}$ & $\mathrm{sz}$ & 0.2427 & 86 & 0.507 & 6243 & 12.78 & 0.13181 & 0.51 & 6.928 & 0.87 & 0.3812 & 0.60 & 0.69 & 2122 & 11 & 2082 & 11 & 2102 & 8 & 98 \\
\hline 40 & 2 & $\mathrm{e}$ & ov & osc & 0.0309 & 121 & 0.312 & 47492 & 66.35 & 0.21032 & 2.11 & 15.262 & 2.25 & 0.5263 & 0.71 & 0.32 & 2908 & 35 & 2726 & 16 & 2832 & 21 & 94 \\
\hline 41 & 2 & $\mathrm{~m}$ & ov & ic/osc & 0.6795 & 138 & 0.424 & 2174 & 8.04 & 0.18655 & 0.79 & 12.873 & 1.13 & 0.5004 & 0.73 & 0.64 & 2712 & 14 & 2616 & 16 & 2670 & 11 & 96 \\
\hline 42 & 1 & $\mathrm{e}$ & ov & $\mathrm{hb} / \mathrm{rx}$ & 1.2294 & 162 & 2.156 & 1189 & 10.63 & 0.19679 & 0.74 & 14.542 & 1.38 & 0.5359 & 1.10 & 0.80 & 2800 & 14 & 2766 & 25 & 2786 & 13 & 99 \\
\hline 43 & 4 & $\mathrm{c}$ & $\mathrm{rd}$ & ic & 0.5167 & 149 & 0.388 & 2858 & 7.78 & 0.19425 & 0.70 & 13.415 & 1.01 & 0.5008 & 0.63 & 0.63 & 2779 & 13 & 2617 & 14 & 2709 & 10 & 94 \\
\hline 44 & 1 & $\mathrm{~m}$ & fr & osc & 0.0516 & 125 & 0.564 & 29386 & 64.03 & 0.16304 & 2.00 & 8.581 & 2.19 & 0.3817 & 0.82 & 0.38 & 2488 & 34 & 2084 & 14 & 2295 & 20 & 84 \\
\hline 45 & 2 & $\mathrm{c}$ & fr & $\mathrm{ic} / \mathrm{sz}$ & 0.2775 & 95 & 1.519 & 5219 & 11.33 & 0.19734 & 0.50 & 15.391 & 0.94 & 0.5656 & 0.71 & 0.75 & 2805 & 10 & 2890 & 16 & 2840 & 9 & 103 \\
\hline 46 & 1 & $\mathrm{e}$ & $\mathrm{p}$ & hd & 0.0202 & 113 & 0.129 & 73095 & 64.58 & 0.20127 & 1.35 & 13.966 & 1.61 & 0.5032 & 0.80 & 0.50 & 2837 & 23 & 2628 & 17 & 2747 & 15 & 93 \\
\hline 47 & 1 & $\mathrm{e}$ & $\mathrm{p}$ & $\mathrm{hd} / \mathrm{rx}$ & 0.2820 & 173 & 0.199 & 5136 & 8.29 & 0.20588 & 0.74 & 16.055 & 2.17 & 0.5655 & 2.00 & 0.92 & 2874 & 14 & 2889 & 47 & 2880 & 21 & 101 \\
\hline 48 & 2 & $\mathrm{c}$ & ov & $\mathrm{ic} / \mathrm{sz}$ & 0.0943 & 93 & 0.752 & 15441 & 29.53 & 0.20645 & 0.67 & 15.603 & 0.99 & 0.5481 & 0.64 & 0.64 & 2878 & 13 & 2817 & 15 & 2853 & 10 & 98 \\
\hline 49 & 2 & $\mathrm{e}$ & ov & osc & 0.2240 & 95 & 0.370 & 6572 & 11.38 & 0.18567 & 0.66 & 13.109 & 1.00 & 0.5120 & 0.65 & 0.65 & 2704 & 13 & 2665 & 14 & 2688 & 9 & 99 \\
\hline 50 & 1 & e & $\mathrm{p}$ & osc & 1.6895 & 3022 & 0.614 & 872 & 16.93 & 0.19554 & 2.60 & 13.734 & 2.79 & 0.5094 & 0.93 & 0.34 & 2789 & 43 & 2654 & 21 & 2732 & 26 & 95 \\
\hline 51 & 4 & $\mathrm{~m}$ & ov & hd & 0.1147 & 246 & 0.169 & 12992 & 8.27 & 0.19837 & 0.85 & 12.757 & 1.29 & 0.4664 & 0.89 & 0.70 & 2813 & 15 & 2468 & 19 & 2662 & 12 & 88 \\
\hline 52 & 2 & $\mathrm{~m}$ & ov & osc & 0.1166 & 100 & 0.169 & 12666 & 20.15 & 0.20029 & 0.42 & 13.868 & 0.78 & 0.5022 & 0.54 & 0.70 & 2828 & 9 & 2623 & 12 & 2741 & 8 & 93 \\
\hline 53 & 4 & $\mathrm{e}$ & $\mathrm{p}$ & osc & 0.2880 & 200 & 0.722 & 5175 & 6.40 & 0.17075 & 0.39 & 10.937 & 0.79 & 0.4645 & 0.58 & 0.74 & 2565 & 9 & 2459 & 12 & 2518 & 7 & 96 \\
\hline 54 & 1 & $\mathrm{e}$ & $\mathrm{p}$ & $\mathrm{hb} / \mathrm{osc}$ & 0.8902 & 161 & 0.276 & 1711 & 7.53 & 0.13503 & 0.56 & 6.492 & 1.03 & 0.3487 & 0.78 & 0.76 & 2164 & 12 & 1928 & 13 & 2045 & 9 & 89 \\
\hline 55.1 & 1 & $\mathrm{e}$ & $\mathrm{p}$ & hd & 0.5776 & 832 & 0.171 & 2675 & 6.43 & 0.11690 & 0.64 & 3.543 & 1.06 & 0.2198 & 0.76 & 0.72 & 1910 & 13 & 1281 & 9 & 1537 & 8 & 67 \\
\hline 55.2 & 1 & $\mathrm{c}$ & $\mathrm{p}$ & hd & 0.6802 & 567 & 0.205 & 2276 & 2.23 & 0.10468 & 0.90 & 2.797 & 1.79 & 0.1938 & 1.50 & 0.84 & 1709 & 18 & 1142 & 16 & 1355 & 13 & 67 \\
\hline 56 & 4 & $\mathrm{~m}$ & ov & osc & 0.3145 & 110 & 0.564 & 4681 & 7.26 & 0.20446 & 0.36 & 14.453 & 0.78 & 0.5126 & 0.59 & 0.75 & 2862 & 9 & 2668 & 13 & 2780 & 8 & 93 \\
\hline 57 & 4 & $\mathrm{~m}$ & $\mathrm{fr}$ & $\mathrm{hb}$ & 1.1648 & 98 & 0.632 & 1284 & 9.86 & 0.19105 & 1.03 & 11.823 & 1.52 & 0.4488 & 1.06 & 0.70 & 2751 & 18 & 2390 & 21 & 2591 & 14 & 87 \\
\hline 58 & 2 & $\mathrm{e}$ & ov & $\mathrm{hb}$ & 0.5731 & 108 & 0.392 & 2639 & 71.79 & 0.13663 & 1.43 & 7.367 & 2.15 & 0.3910 & 1.57 & 0.73 & 2185 & 26 & 2128 & 28 & 2157 & 19 & 97 \\
\hline
\end{tabular}


Unidade Serra do Ibituruna: amostra CP-27 (continuação)

\begin{tabular}{|c|c|c|c|c|c|c|c|c|c|c|c|c|c|c|c|c|c|c|c|c|c|c|c|}
\hline spot & pop. & site & habit & CL & $206 *(\%)$ & ${ }^{204} \mathrm{~Pb}$ cps & $\mathbf{T h} / \mathbf{U}$ & ${ }^{206} \mathrm{~Pb} /{ }^{204} \mathrm{~Pb}$ & 10 & ${ }^{207} \mathrm{~Pb} /{ }^{206} \mathrm{~Pb}$ & 10 & ${ }^{207} \mathrm{~Pb} /{ }^{235} \mathrm{U}$ & 10 & ${ }^{206} \mathrm{~Pb} /{ }^{238} \mathrm{U}$ & 10 & Rho & t.76 & 20 & t.68 & 20 & t.75 & 20 & concordância \\
\hline 59 & 4 & $\mathrm{c}$ & $\mathrm{p}$ & ic/sz & 0.2614 & 267 & 0.462 & 5833 & 4.53 & 0.22807 & 0.60 & 10.710 & 1.57 & 0.3406 & 1.40 & 0.89 & 3039 & 12 & 1890 & 23 & 2498 & 15 & 62 \\
\hline 60 & 1 & $\mathrm{c}$ & $\mathrm{p}$ & ic/osc & 0.1793 & 187 & 0.272 & 8016 & 10.80 & 0.24080 & 1.02 & 19.487 & 1.37 & 0.5869 & 0.83 & 0.61 & 3125 & 17 & 2977 & 20 & 3066 & 13 & 95 \\
\hline 61 & 4 & $\mathrm{c}$ & ov & $\mathrm{hb}$ & 0.7437 & 93 & 0.777 & 2022 & 23.49 & 0.13417 & 1.10 & 7.809 & 1.60 & 0.4221 & 1.10 & 0.69 & 2153 & 20 & 2270 & 21 & 2209 & 14 & 105 \\
\hline 62 & 4 & $\mathrm{~m}$ & ov & osc & 0.2042 & 106 & 0.362 & 7158 & 10.51 & 0.20755 & 0.50 & 15.368 & 0.88 & 0.5370 & 0.62 & 0.70 & 2887 & 10 & 2771 & 14 & 2838 & 9 & 96 \\
\hline 63 & 1 & $\mathrm{~m}$ & ov & ic & 0.9745 & 769 & 0.176 & 1583 & 12.59 & 0.12801 & 1.06 & 4.177 & 4.27 & 0.2367 & 4.12 & 0.96 & 2071 & 21 & 1370 & 51 & 1670 & 35 & 66 \\
\hline 64 & 2 & $\mathrm{c}$ & $\mathrm{rd}$ & ic & 0.1911 & 115 & 0.470 & 7687 & 8.66 & 0.20179 & 0.35 & 14.502 & 0.72 & 0.5212 & 0.51 & 0.71 & 2841 & 8 & 2704 & 11 & 2783 & 7 & 95 \\
\hline 65 & 1 & $\mathrm{~m}$ & $\mathrm{p}$ & osc & 0.3161 & 227 & 0.203 & 4857 & 8.39 & 0.12651 & 0.46 & 4.975 & 1.23 & 0.2852 & 1.08 & 0.88 & 2050 & 10 & 1618 & 15 & 1815 & 10 & 79 \\
\hline 66 & 2 & $\mathrm{e}$ & $\mathrm{p}$ & $\mathrm{hb}$ & 2.0358 & 180 & 1.418 & 760 & 8.48 & 0.20723 & 1.59 & 5.934 & 2.83 & 0.2077 & 2.31 & 0.82 & 2884 & 26 & 1217 & 26 & 1966 & 25 & 42 \\
\hline 67 & 1 & $\mathrm{c}$ & $\mathrm{p}$ & ic & 7.8495 & 1974 & 0.399 & 199 & 1.47 & 0.16225 & 1.79 & 0.730 & 2.86 & 0.0326 & 2.19 & 0.77 & 2481 & 31 & 207 & 4 & 557 & 12 & 8 \\
\hline 68 & 1 & $\mathrm{c}$ & $\mathrm{p}$ & $\mathrm{sz}$ & 0.5109 & 688 & 0.224 & 2972 & 17.40 & 0.12115 & 2.33 & 6.118 & 2.54 & 0.3662 & 0.93 & 0.37 & 1974 & 42 & 2012 & 16 & 1993 & 22 & 102 \\
\hline 69.1 & 1 & $\mathrm{e}$ & $\mathrm{p}$ & osc & 0.8959 & 554 & 0.430 & 1705 & 12.89 & 0.15740 & 1.79 & 7.122 & 2.59 & 0.3281 & 1.84 & 0.71 & 2428 & 31 & 1829 & 29 & 2127 & 23 & 75 \\
\hline 69.2 & 1 & $\mathrm{c}$ & $\mathrm{p}$ & osc & 0.8295 & 695 & 0.620 & 1859 & 7.45 & 0.15947 & 0.67 & 5.334 & 1.74 & 0.2426 & 1.56 & 0.90 & 2450 & 13 & 1400 & 20 & 1874 & 15 & 57 \\
\hline 70 & 2 & $\mathrm{~m}$ & $\mathrm{p}$ & $\mathrm{sz}$ & 0.1478 & 110 & 0.973 & 9649 & 46.74 & 0.21667 & 0.74 & 18.162 & 1.64 & 0.6079 & 1.41 & 0.86 & 2956 & 14 & 3062 & 34 & 2998 & 16 & 104 \\
\hline 71 & 2 & $\mathrm{~m}$ & $\mathrm{rd}$ & $\mathrm{hb}$ & 0.0687 & 77 & 0.048 & 21316 & 56.10 & 0.20504 & 0.64 & 15.073 & 0.96 & 0.5331 & 0.61 & 0.64 & 2867 & 12 & 2755 & 13 & 2820 & 9 & 96 \\
\hline 72 & 2 & $\mathrm{e}$ & ov & $\mathrm{hb}$ & 0.0158 & 77 & 0.545 & 96458 & 94.05 & 0.17422 & 2.14 & 8.170 & 2.64 & 0.3401 & 1.49 & 0.56 & 2599 & 37 & 1887 & 24 & 2250 & 24 & 73 \\
\hline 73 & 1 & $\mathrm{e}$ & $\mathrm{p}$ & osc & 0.1894 & 249 & 0.113 & 7734 & 24.26 & 0.21105 & 0.58 & 15.414 & 1.29 & 0.5297 & 1.10 & 0.85 & 2914 & 11 & 2740 & 25 & 2841 & 12 & 94 \\
\hline 74 & 2 & $\mathrm{~m}$ & $\mathrm{fr}$ & hd & 0.0270 & 82 & 0.166 & 54383 & 57.73 & 0.20410 & 1.79 & 14.759 & 1.91 & 0.5244 & 0.54 & 0.29 & 2860 & 30 & 2718 & 12 & 2800 & 18 & 95 \\
\hline 75 & 1 & $\mathrm{c}$ & $\mathrm{p}$ & hd & 0.0672 & 79 & 0.452 & 22541 & 25.93 & 0.13206 & 0.40 & 6.955 & 0.81 & 0.3819 & 0.60 & 0.74 & 2126 & 9 & 2085 & 11 & 2106 & 7 & 98 \\
\hline 76 & 4 & $\mathrm{c}$ & $\mathrm{fr}$ & ic & 0.5576 & 376 & 0.386 & 2767 & 3.10 & 0.12430 & 0.87 & 4.059 & 1.86 & 0.2368 & 1.60 & 0.86 & 2019 & 17 & 1370 & 20 & 1646 & 15 & 68 \\
\hline 77 & 1 & $\mathrm{~m}$ & $\mathrm{p}$ & $\mathrm{hb} / \mathrm{ic}$ & 0.0328 & 316 & 0.604 & 44597 & 88.28 & 0.20340 & 2.51 & 15.096 & 2.93 & 0.5382 & 1.46 & 0.50 & 2854 & 41 & 2776 & 33 & 2821 & 28 & 97 \\
\hline 78 & 3 & $\mathrm{c}$ & $\mathrm{p}$ & osc & 0.0427 & 85 & 0.451 & 35556 & 71.10 & 0.13303 & 0.50 & 6.621 & 0.94 & 0.3609 & 0.70 & 0.75 & 2139 & 11 & 1986 & 12 & 2062 & 8 & 93 \\
\hline 79 & 1 & $\mathrm{~m}$ & $\mathrm{p}$ & hd/osc & 0.1396 & 144 & 0.334 & 10903 & 10.45 & 0.13314 & 0.55 & 6.413 & 0.88 & 0.3493 & 0.57 & 0.65 & 2140 & 12 & 1931 & 9 & 2034 & 8 & 90 \\
\hline 80 & 2 & $\mathrm{c}$ & ov & $\mathrm{rx} / \mathrm{ic}$ & 0.0976 & 88 & 0.491 & 15380 & 13.00 & 0.17223 & 0.43 & 10.228 & 0.91 & 0.4307 & 0.71 & 0.78 & 2579 & 9 & 2309 & 14 & 2456 & 8 & 90 \\
\hline 81 & 1 & $\mathrm{c}$ & $\mathrm{p}$ & $\mathrm{rx} / \mathrm{ic}$ & 0.0198 & 73 & 0.260 & 74419 & 57.37 & 0.20458 & 0.45 & 14.176 & 0.89 & 0.5025 & 0.67 & 0.75 & 2863 & 10 & 2625 & 14 & 2762 & 9 & 92 \\
\hline 82 & 2 & $\mathrm{~m}$ & $\mathrm{fr}$ & $\mathrm{hb}$ & 0.0202 & 84 & 0.497 & 72886 & 48.06 & 0.19898 & 0.42 & 14.246 & 0.91 & 0.5192 & 0.71 & 0.78 & 2818 & 9 & 2696 & 15 & 2766 & 9 & 96 \\
\hline 83 & 4 & $\mathrm{~m}$ & $\mathrm{p}$ & osc & 0.0655 & 654 & 0.177 & 23099 & 79.54 & 0.12397 & 1.87 & 6.728 & 3.24 & 0.3936 & 2.62 & 0.81 & 2014 & 34 & 2140 & 48 & 2076 & 29 & 106 \\
\hline 84 & 4 & $\mathrm{~m}$ & ov & osc & 0.2227 & 234 & 0.194 & 6815 & 19.29 & 0.13285 & 0.41 & 6.808 & 2.40 & 0.3716 & 2.33 & 0.97 & 2136 & 10 & 2037 & 41 & 2087 & 21 & 95 \\
\hline 85 & 1 & $\mathrm{e}$ & $\mathrm{p}$ & osc & 0.0375 & 163 & 0.420 & 40475 & 80.62 & 0.13033 & 0.52 & 6.628 & 1.07 & 0.3688 & 0.86 & 0.80 & 2103 & 11 & 2024 & 15 & 2063 & 9 & 96 \\
\hline 86 & 4 & $\mathrm{e}$ & $\mathrm{p}$ & osc & 0.0277 & 83 & 0.244 & 53425 & 61.17 & 0.19661 & 0.42 & 13.283 & 0.89 & 0.4900 & 0.69 & 0.78 & 2798 & 9 & 2571 & 15 & 2700 & 9 & 92 \\
\hline 87 & 4 & $\mathrm{c}$ & $\mathrm{p}$ & osc/ic & 1.2833 & 1029 & 0.104 & 1186 & 14.81 & 0.19138 & 5.49 & 9.288 & 6.23 & 0.3520 & 2.93 & 0.47 & 2754 & 91 & 1944 & 49 & 2367 & 57 & 71 \\
\hline 88 & 1 & $\mathrm{e}$ & $\mathrm{p}$ & osc & 0.7450 & 422 & 0.533 & 2061 & 3.14 & 0.13877 & 1.13 & 5.414 & 1.61 & 0.2829 & 1.09 & 0.68 & 2212 & 21 & 1606 & 16 & 1887 & 14 & 73 \\
\hline
\end{tabular}


Unidade Serra do Ibituruna: amostra CP-27 (continuação)

\begin{tabular}{|c|c|c|c|c|c|c|c|c|c|c|c|c|c|c|c|c|c|c|c|c|c|c|c|}
\hline spot & pop. & site & habit & CL & $206 *(\%)$ & ${ }^{204} \mathrm{~Pb}$ cps & $\mathrm{Th} / \mathrm{U}$ & ${ }^{206} \mathrm{~Pb} /{ }^{204} \mathrm{~Pb}$ & 10 & ${ }^{207} \mathrm{~Pb} /{ }^{206} \mathrm{~Pb}$ & 10 & ${ }^{207} \mathrm{~Pb} /{ }^{235} \mathrm{U}$ & 10 & ${ }^{206} \mathrm{~Pb} /{ }^{238} \mathrm{U}$ & 10 & Rho & t.76 & 20 & t.68 & $20^{\circ}$ & t.75 & 20 & concordância \\
\hline 89 & 1 & $\mathrm{~m}$ & $\mathrm{p}$ & $\mathrm{hb}$ & 0.0356 & 85 & 0.291 & 41127 & 49.42 & 0.20856 & 0.57 & 15.168 & 0.91 & 0.5274 & 0.61 & 0.67 & 2895 & 11 & 2731 & 13 & 2826 & 9 & 94 \\
\hline 90 & 2 & $\mathrm{c}$ & rd & $\mathrm{rx} / \mathrm{ic}$ & 0.0088 & 52 & 0.069 & 165305 & 28.94 & 0.21920 & 0.77 & 16.633 & 1.10 & 0.5503 & 0.70 & 0.63 & 2975 & 14 & 2826 & 16 & 2914 & 11 & 95 \\
\hline 91 & 1 & $\mathrm{e}$ & $\mathrm{p}$ & $\mathrm{hb} / \mathrm{rx}$ & 0.0281 & 163 & 0.508 & 53984 & 46.31 & 0.12942 & 1.44 & 6.760 & 1.61 & 0.3788 & 0.63 & 0.39 & 2090 & 26 & 2071 & 12 & 2081 & 14 & 99 \\
\hline 92 & 2 & $\mathrm{c}$ & rd & ic & 0.0434 & 69 & 0.438 & 34030 & 42.62 & 0.20037 & 0.49 & 13.931 & 1.03 & 0.5042 & 0.83 & 0.80 & 2829 & 10 & 2632 & 18 & 2745 & 10 & 93 \\
\hline 93 & 4 & $\mathrm{~m}$ & $\mathrm{fr}$ & ic & 0.0461 & 72 & 0.449 & 32910 & 44.59 & 0.13101 & 0.55 & 6.685 & 0.90 & 0.3701 & 0.61 & 0.68 & 2112 & 12 & 2030 & 10 & 2071 & 8 & 96 \\
\hline 94 & 1 & $\mathrm{c}$ & $\mathrm{p}$ & $\mathrm{sz}$ & 1.0927 & 685 & 1.204 & 1341 & 10.67 & 0.20419 & 0.57 & 14.921 & 0.99 & 0.5299 & 0.71 & 0.72 & 2860 & 11 & 2741 & 16 & 2810 & 10 & 96 \\
\hline 95 & 1 & $\mathrm{~m}$ & $\mathrm{p}$ & osc & 0.8426 & 591 & 0.177 & 1825 & 7.63 & 0.13006 & 0.62 & 4.817 & 3.31 & 0.2686 & 3.23 & 0.98 & 2099 & 12 & 1534 & 44 & 1788 & 28 & 73 \\
\hline 96 & 4 & $\mathrm{c}$ & $\mathrm{rd}$ & $\mathrm{hb} / \mathrm{ic}$ & 0.0353 & 71 & 0.616 & 41435 & 47.12 & 0.20395 & 0.40 & 14.950 & 0.80 & 0.5316 & 0.59 & 0.73 & 2858 & 9 & 2748 & 13 & 2812 & 8 & 96 \\
\hline 97 & 4 & $\mathrm{e}$ & $\mathrm{rd}$ & osc/hd & 0.0628 & 104 & 0.539 & 23659 & 62.15 & 0.20357 & 2.11 & 13.441 & 2.29 & 0.4788 & 0.80 & 0.35 & 2855 & 35 & 2522 & 17 & 2711 & 22 & 88 \\
\hline 98 & 2 & $\mathrm{e}$ & ov & $\mathrm{hb}$ & 0.2060 & 62 & 0.564 & 7225 & 60.28 & 0.18002 & 1.31 & 11.660 & 1.98 & 0.4697 & 1.43 & 0.73 & 2653 & 22 & 2482 & 30 & 2578 & 19 & 94 \\
\hline 99 & 4 & $\mathrm{c}$ & ov & sz/ic & 0.1606 & 176 & 0.447 & 9517 & 27.78 & 0.18184 & 0.61 & 8.061 & 1.24 & 0.3215 & 1.01 & 0.82 & 2670 & 12 & 1797 & 16 & 2238 & 11 & 67 \\
\hline 100 & 2 & $\mathrm{c}$ & $\mathrm{rd}$ & $\mathrm{rx} / \mathrm{ic}$ & 0.0129 & 60 & 0.081 & 113493 & 37.29 & 0.20582 & 0.51 & 15.060 & 0.90 & 0.5306 & 0.64 & 0.71 & 2873 & 10 & 2744 & 15 & 2819 & 9 & 96 \\
\hline
\end{tabular}

Unidade Serra do Ibituruna: amostra CP-35

\begin{tabular}{|c|c|c|c|c|c|c|c|c|c|c|c|c|c|c|c|c|c|c|c|c|c|c|c|}
\hline spot & pop. & site & habit & CL & $206 *(\%)$ & ${ }^{204} \mathrm{~Pb}$ cps & Th/U & ${ }^{206} \mathrm{~Pb} /{ }^{204} \mathrm{~Pb}$ & 10 & ${ }^{207} \mathrm{~Pb} /{ }^{206} \mathrm{~Pb}$ & 10 & ${ }^{207} \mathbf{P b} /{ }^{235} \mathbf{U}$ & 10 & ${ }^{206} \mathrm{~Pb} /{ }^{338} \mathrm{U}$ & 10 & Rho & t.76 & 20 & t.68 & 20 & t.75 & 20 & concordância \\
\hline 1.1 & 1 & $\mathrm{e}$ & $\mathrm{p}$ & $\mathrm{hb}$ & 0.4967 & 320 & 0.196 & 2726 & 9.68 & 0.22734 & 1.69 & 22.366 & 2.05 & 0.7135 & 1.09 & 0.53 & 3034 & 28 & 3472 & 29 & 3200 & 20 & 114 \\
\hline 1.2 & 1 & $\mathrm{c}$ & $\mathrm{p}$ & sz/ic & 0.1546 & 118 & 0.480 & 9687 & 38.06 & 0.19788 & 0.88 & 12.085 & 1.36 & 0.4429 & 0.98 & 0.72 & 2809 & 15 & 2364 & 20 & 2611 & 13 & 84 \\
\hline 2 & 1 & $\mathrm{c}$ & ov & ic & 0.3689 & 328 & 0.089 & 4206 & 5.06 & 0.13167 & 0.57 & 2.906 & 0.94 & 0.1601 & 0.65 & 0.69 & 2120 & 12 & 957 & 6 & 1383 & 7 & 45 \\
\hline 3 & 1 & $\mathrm{~m}$ & $\mathrm{p}$ & osc & 0.8936 & 1052 & 0.205 & 1738 & 12.46 & 0.08251 & 3.85 & 1.688 & 3.96 & 0.1483 & 0.81 & 0.21 & 1259 & 76 & 891 & 7 & 1004 & 25 & 71 \\
\hline 4 & 3 & $\mathrm{~m}$ & $\mathrm{p}$ & osc/ic & 0.1143 & 123 & 0.559 & 12713 & 12.48 & 0.20831 & 0.44 & 15.951 & 0.80 & 0.5553 & 0.56 & 0.70 & 2893 & 9 & 2847 & 13 & 2874 & 8 & 98 \\
\hline 5.1 & 3 & $\mathrm{e}$ & $\mathrm{p}$ & osc & 0.1552 & 88 & 0.341 & 9922 & 15.23 & 0.12022 & 0.65 & 4.245 & 1.07 & 0.2560 & 0.77 & 0.72 & 1960 & 13 & 1469 & 10 & 1683 & 9 & 75 \\
\hline 5.2 & 3 & $\mathrm{c}$ & $\mathrm{p}$ & ic & 0.5355 & 287 & 0.471 & 2878 & 4.33 & 0.12253 & 0.67 & 4.222 & 1.54 & 0.2499 & 1.34 & 0.87 & 1993 & 14 & 1438 & 17 & 1678 & 13 & 72 \\
\hline 6 & 2 & $\mathrm{~m}$ & ov & $\mathrm{hb}$ & 1.7132 & 92 & 0.621 & 903 & 9.69 & 0.17777 & 2.17 & 4.962 & 9.83 & 0.2024 & 9.58 & 0.97 & 2633 & 40 & 1188 & 104 & 1813 & 83 & 45 \\
\hline 7 & 4 & $\mathrm{c}$ & $\mathrm{fr}$ & $\mathrm{ic} / \mathrm{rx}$ & 0.0233 & 68 & 0.594 & 65614 & 73.25 & 0.12676 & 0.60 & 5.514 & 2.72 & 0.3155 & 2.63 & 0.97 & 2054 & 12 & 1768 & 41 & 1903 & 23 & 86 \\
\hline 8 & 4 & $\mathrm{~m}$ & $\mathrm{p}$ & $\mathrm{sz}$ & 0.0774 & 64 & 1.550 & 19033 & 56.05 & 0.18354 & 0.52 & 12.924 & 0.86 & 0.5106 & 0.57 & 0.66 & 2685 & 11 & 2659 & 12 & 2674 & 8 & 99 \\
\hline 9 & 1 & $\mathrm{~m}$ & $\mathrm{p}$ & hd & 0.8931 & 439 & 0.217 & 1741 & 3.11 & 0.12436 & 1.06 & 2.148 & 2.10 & 0.1253 & 1.78 & 0.85 & 2019 & 20 & 761 & 13 & 1164 & 15 & 38 \\
\hline 10 & 4 & $\mathrm{~m}$ & $\mathrm{rd}$ & $\mathrm{hb}$ & 0.4039 & 81 & 0.143 & 3627 & 17.41 & 0.19640 & 0.61 & 14.345 & 1.03 & 0.5297 & 0.74 & 0.72 & 2797 & 12 & 2740 & 17 & 2773 & 10 & 98 \\
\hline 11 & 1 & $\mathrm{c}$ & $\mathrm{p}$ & ic & 0.5459 & 539 & 0.050 & 2844 & 3.43 & 0.12583 & 3.00 & 2.659 & 3.57 & 0.1532 & 1.89 & 0.53 & 2041 & 54 & 919 & 16 & 1317 & 26 & 45 \\
\hline 12 & 1 & $\mathrm{~m}$ & $\mathrm{p}$ & $\mathrm{rx}$ & 0.4326 & 73 & 0.445 & 3419 & 21.27 & 0.18264 & 0.69 & 12.479 & 1.04 & 0.4955 & 0.68 & 0.66 & 2677 & 13 & 2594 & 15 & 2641 & 10 & 97 \\
\hline 13 & 2 & $\mathrm{c}$ & $\mathrm{rd}$ & $\mathrm{ic} / \mathrm{hb}$ & 0.1380 & 78 & 1.047 & 10638 & 71.54 & 0.19397 & 0.62 & 13.943 & 1.07 & 0.5213 & 0.79 & 0.74 & 2776 & 12 & 2705 & 18 & 2746 & 10 & 97 \\
\hline 14 & 2 & $\mathrm{e}$ & $\mathrm{rd}$ & osc & 0.0221 & 70 & 0.144 & 65963 & 41.13 & 0.19582 & 0.42 & 14.560 & 0.83 & 0.5392 & 0.61 & 0.73 & 2792 & 10 & 2780 & 14 & 2787 & 8 & 100 \\
\hline
\end{tabular}


Unidade Serra do Ibituruna: amostra CP-35 (continuação)

\begin{tabular}{|c|c|c|c|c|c|c|c|c|c|c|c|c|c|c|c|c|c|c|c|c|c|c|c|}
\hline spot & pop. & site & habit & CL & 206* $(\%)$ & ${ }^{204} \mathrm{~Pb} \mathrm{cps}$ & $\mathbf{T h} / \mathbf{U}$ & ${ }^{206} \mathrm{~Pb} /{ }^{204} \mathrm{~Pb}$ & 10 & ${ }^{207} \mathrm{~Pb} /{ }^{206} \mathrm{~Pb}$ & 10 & ${ }^{207} \mathrm{~Pb} /{ }^{335} \mathrm{U}$ & 10 & ${ }^{206} \mathrm{~Pb} /{ }^{238} \mathrm{U}$ & 10 & Rho & t.76 & $20^{\circ}$ & t.68 & $20^{\circ}$ & t.75 & 20 & concordância \\
\hline 15 & 1 & $\mathrm{c}$ & $\mathrm{p}$ & sz/ic & 0.3862 & 155 & 0.037 & 4012 & 6.33 & 0.14875 & 1.87 & 3.770 & 3.89 & 0.1838 & 3.39 & 0.87 & 2332 & 33 & 1088 & 34 & 1586 & 31 & 47 \\
\hline 16 & 1 & $\mathrm{c}$ & ov & ic & 0.1292 & 91 & 0.320 & 11802 & 34.25 & 0.17266 & 0.94 & 8.059 & 3.65 & 0.3385 & 3.51 & 0.96 & 2584 & 17 & 1879 & 57 & 2238 & 33 & 73 \\
\hline 17 & 3 & $\mathrm{~m}$ & ov & osc & 0.2915 & 180 & 0.107 & 5314 & 34.51 & 0.16563 & 2.86 & 4.233 & 12.60 & 0.1853 & 12.27 & 0.97 & 2515 & 52 & 1096 & 124 & 1680 & 103 & 44 \\
\hline 18 & 1 & $\mathrm{c}$ & $\mathrm{p}$ & ic & 0.0758 & 91 & 0.581 & 19254 & 14.21 & 0.22022 & 2.06 & 16.412 & 2.19 & 0.5405 & 0.65 & 0.30 & 2982 & 34 & 2786 & 15 & 2901 & 21 & 93 \\
\hline 19 & 2 & $\mathrm{e}$ & $\mathrm{rd}$ & $\mathrm{hb}$ & 0.7045 & 106 & 0.758 & 2099 & 8.46 & 0.18973 & 0.59 & 12.985 & 0.97 & 0.4963 & 0.67 & 0.69 & 2740 & 11 & 2598 & 14 & 2679 & 9 & 95 \\
\hline 20 & 1 & $\mathrm{~m}$ & $\mathrm{p}$ & osc & 0.9312 & 740 & 0.291 & 1665 & 13.63 & 0.11022 & 5.13 & 2.666 & 5.74 & 0.1754 & 2.55 & 0.44 & 1803 & 94 & 1042 & 25 & 1319 & 43 & 58 \\
\hline 21 & 2 & $\mathrm{~m}$ & ov & osc & 0.0443 & 84 & 0.282 & 34232 & 57.03 & 0.13374 & 0.48 & 6.989 & 0.91 & 0.3790 & 0.68 & 0.75 & 2148 & 10 & 2072 & 12 & 2110 & 8 & 96 \\
\hline 22 & 1 & $\mathrm{~m}$ & $\mathrm{p}$ & osc & 0.0270 & 124 & 0.153 & 57508 & 64.45 & 0.10696 & 0.70 & 2.256 & 1.88 & 0.1530 & 1.71 & 0.91 & 1748 & 14 & 918 & 15 & 1199 & 13 & 52 \\
\hline 23 & 1 & $\mathrm{e}$ & $\mathrm{p}$ & osc & 0.2408 & 182 & 0.161 & 6418 & 9.49 & 0.11450 & 1.06 & 3.433 & 1.35 & 0.2174 & 0.76 & 0.56 & 1873 & 20 & 1268 & 9 & 1512 & 11 & 68 \\
\hline 24 & 1 & $\mathrm{e}$ & $\mathrm{p}$ & $\mathrm{rx}$ & 0.5217 & 416 & 0.813 & 2963 & 5.51 & 0.16439 & 0.59 & 4.800 & 1.57 & 0.2118 & 1.41 & 0.90 & 2501 & 12 & 1238 & 16 & 1785 & 13 & 50 \\
\hline 25 & 1 & $\mathrm{~m}$ & $p$ & $\mathrm{rx}$ & 0.4240 & 330 & 0.244 & 3597 & 6.60 & 0.20466 & 1.17 & 9.566 & 3.57 & 0.3390 & 3.35 & 0.94 & 2864 & 20 & 1882 & 55 & 2394 & 33 & 66 \\
\hline 26 & 2 & $\mathrm{~m}$ & $\mathrm{rd}$ & $\mathrm{hb}$ & 0.0347 & 82 & 0.349 & 42273 & 48.48 & 0.19570 & 0.70 & 14.112 & 1.12 & 0.5230 & 0.80 & 0.71 & 2791 & 13 & 2712 & 18 & 2757 & 11 & 97 \\
\hline 27.1 & 1 & $\mathrm{e}$ & $p$ & osc & 0.2564 & 226 & 0.155 & 6066 & 5.96 & 0.09259 & 0.95 & 1.597 & 1.41 & 0.1251 & 0.97 & 0.69 & 1479 & 19 & 760 & 7 & 969 & 9 & 51 \\
\hline 27.2 & 1 & $\mathrm{~m}$ & $\mathrm{p}$ & $\mathrm{rx} / \mathrm{hd}$ & 0.2018 & 147 & 0.201 & 7615 & 9.19 & 0.12224 & 0.69 & 4.640 & 1.46 & 0.2753 & 1.24 & 0.85 & 1989 & 14 & 1568 & 17 & 1757 & 12 & 79 \\
\hline 28.1 & 1 & $\mathrm{e}$ & $\mathrm{p}$ & $\mathrm{osc} / \mathrm{rx}$ & 1.2025 & 1592 & 0.047 & 1290 & 0.97 & 0.12365 & 0.68 & 2.927 & 0.99 & 0.1716 & 0.61 & 0.62 & 2010 & 14 & 1021 & 6 & 1389 & 8 & 51 \\
\hline 28.2 & 1 & $\mathrm{~m}$ & $\mathrm{p}$ & osc & 0.1909 & 158 & 0.328 & 8101 & 7.92 & 0.14426 & 1.26 & 4.187 & 2.26 & 0.2105 & 1.84 & 0.81 & 2279 & 23 & 1232 & 21 & 1672 & 19 & 54 \\
\hline 29 & 1 & $\mathrm{c}$ & $\mathrm{p}$ & ic & 0.6888 & 269 & 0.093 & 2258 & 5.63 & 0.11720 & 4.41 & 1.979 & 11.15 & 0.1225 & 10.23 & 0.92 & 1914 & 78 & 745 & 72 & 1108 & 75 & 39 \\
\hline 30 & 4 & $\mathrm{~m}$ & ov & osc & 0.1167 & 75 & 1.368 & 12545 & 26.16 & 0.19651 & 0.37 & 14.385 & 0.78 & 0.5309 & 0.58 & 0.74 & 2797 & 9 & 2745 & 13 & 2775 & 8 & 98 \\
\hline 31 & 1 & $\mathrm{c}$ & $\mathrm{p}$ & ic & 0.0788 & 72 & 0.398 & 18588 & 30.34 & 0.21444 & 0.43 & 15.628 & 0.74 & 0.5285 & 0.48 & 0.65 & 2940 & 9 & 2735 & 11 & 2854 & 7 & 93 \\
\hline 32 & 2 & $\mathrm{~m}$ & $\mathrm{rd}$ & $\mathrm{rx}$ & 0.2585 & 95 & 0.561 & 5692 & 6.90 & 0.19475 & 0.56 & 13.824 & 0.89 & 0.5148 & 0.59 & 0.66 & 2783 & 11 & 2677 & 13 & 2738 & 9 & 96 \\
\hline 33 & 1 & $\mathrm{~m}$ & $\mathrm{p}$ & osc & 0.2893 & 191 & 0.381 & 5349 & 13.23 & 0.11157 & 0.70 & 3.100 & 1.72 & 0.2015 & 1.53 & 0.89 & 1825 & 14 & 1183 & 17 & 1433 & 13 & 65 \\
\hline 34 & 4 & $\mathrm{c}$ & $\mathrm{p}$ & $\mathrm{ic} / \mathrm{sz}$ & 0.1234 & 170 & 0.193 & 11944 & 14.78 & 0.21826 & 0.93 & 15.270 & 1.86 & 0.5074 & 1.56 & 0.84 & 2968 & 16 & 2646 & 34 & 2832 & 18 & 89 \\
\hline 35 & 1 & $\mathrm{~m}$ & $\mathrm{fr}$ & osc & 0.2603 & 183 & 0.213 & 5959 & 6.11 & 0.10380 & 0.74 & 2.374 & 1.52 & 0.1659 & 1.27 & 0.84 & 1693 & 15 & 990 & 12 & 1235 & 11 & 58 \\
\hline 36.1 & 2 & $\mathrm{e}$ & $\mathrm{rd}$ & osc & 0.0220 & 68 & 0.091 & 66553 & 41.92 & 0.19642 & 0.54 & 14.545 & 0.86 & 0.5370 & 0.56 & 0.65 & 2797 & 11 & 2771 & 12 & 2786 & 8 & 99 \\
\hline 36.2 & 2 & $\mathrm{c}$ & $\mathrm{rd}$ & osc & 0.1774 & 142 & 0.123 & 8589 & 6.54 & 0.18160 & 0.65 & 8.620 & 1.37 & 0.3442 & 1.15 & 0.84 & 2668 & 12 & 1907 & 19 & 2299 & 13 & 71 \\
\hline 37 & 2 & $\mathrm{c}$ & ov & ic & 0.0566 & 70 & 0.542 & 25443 & 60.20 & 0.21135 & 0.52 & 16.986 & 0.98 & 0.5829 & 0.75 & 0.76 & 2916 & 11 & 2961 & 18 & 2934 & 10 & 102 \\
\hline 38 & 1 & $\mathrm{~m}$ & $\mathrm{p}$ & osc & 0.2041 & 128 & 0.370 & 7586 & 8.74 & 0.11413 & 1.21 & 3.028 & 1.91 & 0.1924 & 1.43 & 0.75 & 1866 & 23 & 1134 & 15 & 1415 & 15 & 61 \\
\hline 39.1 & 1 & $\mathrm{~m}$ & $\mathrm{fr}$ & osc & 0.0345 & 95 & 0.542 & 44181 & 72.18 & 0.18682 & 0.58 & 8.977 & 1.24 & 0.3485 & 1.03 & 0.83 & 2714 & 11 & 1927 & 17 & 2336 & 11 & 71 \\
\hline 39.2 & 1 & $\mathrm{c}$ & $\mathrm{fr}$ & ic & 0.0608 & 139 & 0.573 & 24960 & 75.26 & 0.18225 & 2.50 & 9.329 & 7.76 & 0.3712 & 7.33 & 0.95 & 2674 & 40 & 2035 & 128 & 2371 & 71 & 76 \\
\hline 40 & 1 & $\mathrm{~m}$ & $\mathrm{p}$ & $\mathrm{hb}$ & 0.0933 & 72 & 0.343 & 16031 & 38.02 & 0.20901 & 0.64 & 12.860 & 1.44 & 0.4462 & 1.23 & 0.86 & 2898 & 12 & 2378 & 25 & 2669 & 14 & 82 \\
\hline 41 & 3 & $\mathrm{~m}$ & $\mathrm{fr}$ & $\mathrm{rx} / \mathrm{hd}$ & 0.0387 & 71 & 0.226 & 39049 & 59.25 & 0.13041 & 0.54 & 7.107 & 0.86 & 0.3952 & 0.55 & 0.64 & 2104 & 12 & 2147 & 10 & 2125 & 8 & 102 \\
\hline
\end{tabular}


Unidade Serra do Ibituruna: amostra CP-35 (continuação)

\begin{tabular}{|c|c|c|c|c|c|c|c|c|c|c|c|c|c|c|c|c|c|c|c|c|c|c|c|}
\hline spot & pop. & site & habit & CL & $206 *(\%)$ & ${ }^{204} \mathrm{~Pb} \mathrm{cps}$ & Th/U & ${ }^{206} \mathrm{~Pb} /{ }^{204} \mathrm{~Pb}$ & 10 & ${ }^{207} \mathrm{~Pb} /{ }^{206} \mathrm{~Pb}$ & 10 & ${ }^{207} \mathrm{~Pb} /{ }^{235} \mathrm{U}$ & 10 & ${ }^{206} \mathrm{~Pb} /{ }^{238} \mathrm{U}$ & 10 & Rho & t.76 & 20 & t.68 & $20^{\circ}$ & t.75 & 20 & concordância \\
\hline 42 & 2 & $\mathrm{~m}$ & $\mathrm{p}$ & osc & 0.0547 & 56 & 0.562 & 26619 & 41.77 & 0.20022 & 0.65 & 15.246 & 1.23 & 0.5522 & 0.98 & 0.79 & 2828 & 12 & 2834 & 23 & 2831 & 12 & 100 \\
\hline 43 & 2 & $\mathrm{c}$ & eq & ic & 0.0734 & 62 & 0.425 & 20001 & 46.21 & 0.19599 & 0.92 & 14.117 & 1.19 & 0.5224 & 0.65 & 0.55 & 2793 & 16 & 2709 & 14 & 2758 & 11 & 97 \\
\hline 44 & 1 & $\mathrm{~m}$ & $\mathrm{p}$ & osc/hd & 0.0656 & 154 & 0.155 & 23628 & 80.91 & 0.10471 & 0.80 & 2.635 & 1.38 & 0.1825 & 1.07 & 0.77 & 1709 & 16 & 1081 & 11 & 1311 & 10 & 63 \\
\hline 45 & 2 & $\mathrm{e}$ & $\mathrm{rd}$ & $\mathrm{osc} / \mathrm{hb}$ & 0.3284 & 101 & 0.481 & 4603 & 39.80 & 0.13481 & 0.60 & 7.335 & 1.00 & 0.3946 & 0.71 & 0.71 & 2162 & 12 & 2144 & 13 & 2153 & 9 & 99 \\
\hline 46 & 2 & $\mathrm{e}$ & ov & $\mathrm{hb}$ & 0.0291 & 82 & 0.473 & 53313 & 70.21 & 0.14433 & 1.23 & 2.999 & 5.80 & 0.1507 & 5.65 & 0.98 & 2280 & 20 & 905 & 48 & 1407 & 44 & 40 \\
\hline 47 & 1 & $\mathrm{e}$ & $\mathrm{p}$ & osc & 0.3766 & 331 & 0.081 & 4126 & 6.79 & 0.12384 & 1.86 & 2.415 & 4.85 & 0.1414 & 4.46 & 0.92 & 2013 & 34 & 853 & 36 & 1247 & 35 & 42 \\
\hline 48 & 1 & $\mathrm{~m}$ & $\mathrm{p}$ & osc & 0.1418 & 98 & 0.213 & 10749 & 16.57 & 0.12868 & 0.36 & 6.060 & 0.82 & 0.3415 & 0.64 & 0.78 & 2080 & 9 & 1894 & 11 & 1985 & 7 & 91 \\
\hline 49 & 1 & $\mathrm{e}$ & ov & hd/osc & 0.8914 & 645 & 0.174 & 1743 & 2.25 & 0.08856 & 0.88 & 1.678 & 1.50 & 0.1374 & 1.16 & 0.77 & 1395 & 18 & 830 & 9 & 1000 & 10 & 60 \\
\hline 50 & 1 & $\mathrm{~m}$ & $\mathrm{p}$ & osc & 0.2246 & 119 & 0.242 & 6756 & 18.93 & 0.13201 & 0.58 & 6.756 & 1.01 & 0.3711 & 0.74 & 0.73 & 2125 & 12 & 2035 & 13 & 2080 & 9 & 96 \\
\hline 51 & 1 & $\mathrm{e}$ & $\mathrm{p}$ & hd & 0.3732 & 178 & 0.179 & 4153 & 5.68 & 0.10328 & 0.55 & 2.519 & 0.98 & 0.1769 & 0.72 & 0.73 & 1684 & 13 & 1050 & 7 & 1278 & 7 & 62 \\
\hline 52 & 3 & $\mathrm{e}$ & $\mathrm{p}$ & $\mathrm{sz}$ & 0.2632 & 93 & 0.525 & 5761 & 19.88 & 0.13306 & 0.57 & 6.889 & 0.99 & 0.3755 & 0.72 & 0.72 & 2139 & 12 & 2055 & 12 & 2097 & 9 & 96 \\
\hline 53 & 1 & $\mathrm{~m}$ & $\mathrm{p}$ & osc & 0.1745 & 80 & 0.411 & 8717 & 11.94 & 0.13073 & 0.62 & 6.436 & 0.99 & 0.3570 & 0.67 & 0.68 & 2108 & 13 & 1968 & 11 & 2037 & 9 & 93 \\
\hline 54.1 & 4 & $\mathrm{e}$ & ov & $\mathrm{hb}$ & 2.3009 & 2278 & 0.307 & 661 & 15.01 & 0.19516 & 2.78 & 9.636 & 3.06 & 0.3581 & 1.23 & 0.40 & 2786 & 46 & 1973 & 21 & 2401 & 28 & 71 \\
\hline 54.2 & 4 & $\mathrm{~m}$ & ov & ic & 1.8531 & 74 & 0.187 & 775 & 10.44 & 0.21520 & 1.30 & 17.498 & 1.82 & 0.5897 & 1.23 & 0.67 & 2945 & 22 & 2988 & 29 & 2963 & 18 & 101 \\
\hline 55 & 1 & $\mathrm{~m}$ & ov & osc & 0.4109 & 272 & 0.173 & 3772 & 5.44 & 0.10525 & 0.62 & 2.609 & 1.32 & 0.1798 & 1.10 & 0.84 & 1719 & 13 & 1066 & 11 & 1303 & 10 & 62 \\
\hline 56 & 1 & $\mathrm{c}$ & ov & ic/hd & 0.2450 & 185 & 0.157 & 6330 & 9.88 & 0.10680 & 1.18 & 2.476 & 4.81 & 0.1681 & 4.64 & 0.97 & 1746 & 21 & 1002 & 43 & 1265 & 35 & 57 \\
\hline 57 & 4 & $\mathrm{c}$ & ov & ic & 0.1788 & 67 & 0.773 & 8211 & 27.89 & 0.19083 & 0.62 & 13.738 & 0.96 & 0.5221 & 0.63 & 0.66 & 2749 & 12 & 2708 & 14 & 2732 & 9 & 99 \\
\hline 58 & 1 & $\mathrm{~m}$ & $\mathrm{p}$ & osc/ic & 0.0593 & 143 & 0.066 & 25702 & 69.40 & 0.19269 & 1.28 & 9.134 & 1.75 & 0.3438 & 1.14 & 0.65 & 2765 & 22 & 1905 & 19 & 2352 & 16 & 69 \\
\hline 59 & 1 & $\mathrm{e}$ & $\mathrm{fr}$ & $\mathrm{hb} / \mathrm{ic}$ & 0.0349 & 76 & 0.278 & 42212 & 48.48 & 0.21685 & 0.42 & 15.399 & 0.88 & 0.5150 & 0.68 & 0.77 & 2958 & 9 & 2678 & 15 & 2840 & 9 & 91 \\
\hline 60 & 2 & $\mathrm{~m}$ & ov & $\mathrm{hb}$ & 0.2883 & 98 & 1.080 & 5196 & 12.29 & 0.19235 & 0.52 & 11.707 & 0.89 & 0.4414 & 0.61 & 0.69 & 2762 & 11 & 2357 & 12 & 2581 & 8 & 85 \\
\hline 61 & 2 & $\mathrm{~m}$ & ov & $\mathrm{hb}$ & 0.3041 & 74 & 0.319 & 4812 & 53.36 & 0.19780 & 1.33 & 14.547 & 2.01 & 0.5333 & 1.45 & 0.72 & 2808 & 23 & 2755 & 33 & 2786 & 19 & 98 \\
\hline 62 & 3 & $\mathrm{c}$ & $\mathrm{p}$ & ic & 0.2705 & 119 & 0.404 & 5610 & 10.52 & 0.13187 & 0.61 & 6.732 & 1.05 & 0.3702 & 0.77 & 0.73 & 2123 & 13 & 2030 & 13 & 2077 & 9 & 96 \\
\hline 63 & 2 & $\mathrm{~m}$ & $\mathrm{fr}$ & ic & 0.4991 & 88 & 0.368 & 3034 & 17.91 & 0.13499 & 0.72 & 7.142 & 1.07 & 0.3837 & 0.70 & 0.66 & 2164 & 14 & 2094 & 13 & 2129 & 10 & 97 \\
\hline 64 & 1 & $\mathrm{e}$ & $\mathrm{p}$ & osc & 0.2572 & 152 & 0.303 & 6019 & 5.94 & 0.10772 & 1.06 & 2.857 & 1.29 & 0.1923 & 0.63 & 0.49 & 1762 & 21 & 1134 & 7 & 1371 & 10 & 64 \\
\hline 65.1 & 1 & $\mathrm{e}$ & $\mathrm{p}$ & osc & 1.5515 & 1987 & 0.225 & 973 & 16.42 & 0.19303 & 2.20 & 10.676 & 2.64 & 0.4011 & 1.41 & 0.53 & 2768 & 37 & 2174 & 26 & 2495 & 25 & 79 \\
\hline 65.2 & 1 & $\mathrm{c}$ & $\mathrm{p}$ & ic/hd & 0.4829 & 292 & 0.284 & 3218 & 6.46 & 0.10449 & 0.89 & 1.997 & 2.85 & 0.1386 & 2.68 & 0.94 & 1706 & 18 & 837 & 21 & 1115 & 19 & 49 \\
\hline 66 & 1 & $\mathrm{e}$ & $\mathrm{p}$ & osc & 0.2327 & 134 & 0.356 & 6599 & 14.48 & 0.12624 & 0.50 & 4.952 & 0.97 & 0.2845 & 0.75 & 0.77 & 2046 & 11 & 1614 & 11 & 1811 & 8 & 79 \\
\hline 67 & 4 & $\mathrm{e}$ & oc & $\mathrm{hb}$ & 0.3256 & 145 & 0.383 & 4580 & 9.62 & 0.20393 & 0.46 & 12.998 & 1.28 & 0.4622 & 1.14 & 0.89 & 2858 & 10 & 2449 & 23 & 2680 & 12 & 86 \\
\hline 68.1 & 1 & $\mathrm{e}$ & $\mathrm{p}$ & osc & 0.1689 & 103 & 0.269 & 8798 & 18.37 & 0.17062 & 0.44 & 11.242 & 0.76 & 0.4779 & 0.49 & 0.64 & 2564 & 10 & 2518 & 10 & 2543 & 7 & 98 \\
\hline 68.2 & 1 & $\mathrm{~m}$ & $\mathrm{p}$ & osc & 0.2370 & 127 & 0.451 & 6288 & 7.75 & 0.17083 & 0.39 & 10.949 & 0.79 & 0.4648 & 0.57 & 0.73 & 2566 & 9 & 2461 & 11 & 2519 & 7 & 96 \\
\hline 69 & 1 & $\mathrm{e}$ & $\mathrm{p}$ & osc/hd & 0.1317 & 106 & 0.136 & 11666 & 13.13 & 0.12312 & 0.64 & 4.768 & 2.18 & 0.2809 & 2.05 & 0.94 & 2002 & 13 & 1596 & 29 & 1779 & 18 & 80 \\
\hline
\end{tabular}


Unidade Serra do Ibituruna: amostra CP-35 (continuação)

\begin{tabular}{|c|c|c|c|c|c|c|c|c|c|c|c|c|c|c|c|c|c|c|c|c|c|c|c|}
\hline spot & pop. & site & habit & CL & $206 *(\%)$ & ${ }^{204} \mathrm{~Pb} \mathrm{cps}$ & Th/U & ${ }^{206} \mathrm{~Pb} /{ }^{204} \mathrm{~Pb}$ & 10 & ${ }^{207} \mathrm{~Pb} /{ }^{206} \mathrm{~Pb}$ & 10 & ${ }^{207} \mathrm{~Pb} /{ }^{235} \mathrm{U}$ & 10 & ${ }^{206} \mathrm{~Pb} /{ }^{238} \mathrm{U}$ & 10 & Rho & t.76 & 20 & t.68 & 20 & t.75 & 20 & concordância \\
\hline 70.1 & 2 & $\mathrm{e}$ & ov & $\mathrm{hb}$ & 0.0607 & 101 & 0.355 & 23929 & 74.56 & 0.21584 & 0.56 & 16.616 & 0.90 & 0.5583 & 0.61 & 0.67 & 2950 & 11 & 2860 & 14 & 2913 & 9 & 97 \\
\hline 70.2 & 2 & $\mathrm{~m}$ & ov & osc & 0.0762 & 87 & 0.376 & 19225 & 31.63 & 0.21014 & 0.56 & 15.375 & 0.88 & 0.5306 & 0.57 & 0.64 & 2907 & 11 & 2744 & 12 & 2839 & 9 & 94 \\
\hline 71 & 1 & $\mathrm{~m}$ & $\mathrm{p}$ & osc/ic & 0.2929 & 215 & 0.356 & 5284 & 4.30 & 0.11059 & 0.81 & 2.978 & 1.95 & 0.1953 & 1.74 & 0.89 & 1809 & 16 & 1150 & 18 & 1402 & 15 & 64 \\
\hline 72 & 1 & $\mathrm{~m}$ & ov & $\mathrm{hb}$ & 0.4844 & 107 & 0.706 & 3015 & 7.61 & 0.20856 & 0.53 & 15.540 & 0.87 & 0.5404 & 0.59 & 0.67 & 2894 & 10 & 2785 & 14 & 2849 & 8 & 96 \\
\hline 73 & 2 & $\mathrm{~m}$ & ov & sz/osc & 0.0961 & 99 & 0.413 & 15778 & 67.06 & 0.13319 & 0.44 & 6.866 & 0.78 & 0.3739 & 0.52 & 0.67 & 2140 & 10 & 2048 & 9 & 2094 & 7 & 96 \\
\hline 74 & 1 & $\mathrm{~m}$ & ov & hd & 0.0738 & 99 & 0.011 & 19537 & 13.47 & 0.25379 & 1.44 & 20.226 & 1.64 & 0.5780 & 0.69 & 0.42 & 3209 & 24 & 2941 & 17 & 3102 & 16 & 92 \\
\hline 75 & 1 & $\mathrm{c}$ & $\mathrm{p}$ & $\mathrm{hb} / \mathrm{osc}$ & 0.0238 & 77 & 0.333 & 63673 & 62.02 & 0.13462 & 0.50 & 6.901 & 0.83 & 0.3718 & 0.54 & 0.66 & 2159 & 11 & 2038 & 10 & 2099 & 8 & 94 \\
\hline 76 & 1 & $\mathrm{~m}$ & $\mathrm{p}$ & $\mathrm{ic} / \mathrm{rx}$ & 0.0318 & 57 & 0.351 & 47926 & 46.11 & 0.13135 & 0.37 & 6.150 & 0.77 & 0.3395 & 0.56 & 0.73 & 2117 & 9 & 1884 & 9 & 1997 & 7 & 89 \\
\hline 77 & 1 & $\mathrm{~m}$ & ov & hd & 0.2683 & 218 & 0.473 & 5685 & 4.47 & 0.20412 & 0.39 & 9.471 & 0.82 & 0.3365 & 0.62 & 0.76 & 2860 & 8 & 1870 & 10 & 2385 & 7 & 65 \\
\hline 78 & 1 & $\mathrm{c}$ & $\mathrm{fr}$ & hd & 0.1588 & 85 & 0.182 & 9588 & 13.26 & 0.13128 & 0.40 & 6.359 & 0.78 & 0.3513 & 0.55 & 0.71 & 2115 & 10 & 1941 & 9 & 2027 & 7 & 92 \\
\hline 79 & 1 & $\mathrm{e}$ & $\mathrm{p}$ & $\mathrm{sz}$ & 0.1917 & 105 & 0.174 & 7932 & 14.00 & 0.13163 & 0.50 & 6.515 & 0.87 & 0.3590 & 0.61 & 0.70 & 2120 & 11 & 1977 & 10 & 2048 & 7 & 93 \\
\hline 80 & 1 & $\mathrm{~m}$ & $\mathrm{p}$ & osc & 0.2629 & 206 & 0.289 & 5848 & 4.77 & 0.15144 & 0.53 & 5.657 & 1.17 & 0.2709 & 0.97 & 0.83 & 2362 & 11 & 1545 & 13 & 1925 & 10 & 65 \\
\hline 81 & 1 & $\mathrm{e}$ & $\mathrm{p}$ & osc & 0.0398 & 110 & 0.239 & 38696 & 60.19 & 0.12341 & 0.49 & 4.182 & 1.10 & 0.2458 & 0.91 & 0.83 & 2006 & 11 & 1417 & 11 & 1671 & 9 & 71 \\
\hline 82 & 1 & $\mathrm{e}$ & $\mathrm{fr}$ & osc & 0.1646 & 90 & 0.500 & 9207 & 17.02 & 0.13676 & 0.40 & 7.141 & 0.82 & 0.3787 & 0.62 & 0.75 & 2187 & 9 & 2070 & 11 & 2129 & 7 & 95 \\
\hline 83 & 2 & $\mathrm{~m}$ & $\mathrm{rd}$ & osc & 0.0394 & 79 & 0.570 & 37491 & 63.03 & 0.19651 & 0.51 & 13.482 & 0.88 & 0.4975 & 0.62 & 0.70 & 2798 & 11 & 2603 & 13 & 2714 & 9 & 93 \\
\hline 84 & 2 & $\mathrm{c}$ & rd & ic & 0.7856 & 614 & 0.200 & 1981 & 2.79 & 0.12814 & 0.89 & 1.958 & 1.83 & 0.1108 & 1.55 & 0.85 & 2073 & 17 & 677 & 10 & 1101 & 12 & 33 \\
\hline 85 & 1 & $\mathrm{e}$ & $\mathrm{p}$ & osc & 0.5363 & 579 & 0.462 & 2851 & 2.43 & 0.20316 & 0.53 & 8.974 & 1.10 & 0.3203 & 0.89 & 0.81 & 2852 & 11 & 1791 & 14 & 2335 & 10 & 63 \\
\hline 86 & 1 & $\mathrm{e}$ & $\mathrm{p}$ & osc/hd & 0.3577 & 252 & 0.201 & 4348 & 8.95 & 0.09468 & 2.01 & 1.645 & 6.97 & 0.1260 & 6.67 & 0.96 & 1522 & 37 & 765 & 48 & 988 & 44 & 50 \\
\hline 87 & 1 & $\mathrm{e}$ & $\mathrm{p}$ & osc & 0.0279 & 94 & 0.218 & 55072 & 78.64 & 0.12203 & 0.88 & 4.771 & 1.61 & 0.2835 & 1.30 & 0.81 & 1987 & 17 & 1609 & 19 & 1780 & 14 & 81 \\
\hline 88 & 4 & $\mathrm{c}$ & $\mathrm{p}$ & ic/hd & 0.6990 & 736 & 0.301 & 2219 & 4.06 & 0.13220 & 0.51 & 3.028 & 0.99 & 0.1661 & 0.76 & 0.77 & 2128 & 11 & 991 & 7 & 1415 & 8 & 47 \\
\hline 89 & 1 & $\mathrm{e}$ & $\mathrm{p}$ & osc & 0.1518 & 110 & 0.331 & 10059 & 9.16 & 0.16003 & 0.49 & 7.244 & 0.97 & 0.3283 & 0.74 & 0.77 & 2456 & 10 & 1830 & 12 & 2142 & 8 & 75 \\
\hline 90.1 & 1 & $\mathrm{e}$ & $\mathrm{p}$ & $\mathrm{hb}$ & 0.2223 & 97 & 0.633 & 6627 & 30.45 & 0.20832 & 0.50 & 14.679 & 0.97 & 0.5110 & 0.74 & 0.76 & 2893 & 10 & 2661 & 16 & 2795 & 9 & 92 \\
\hline 90.2 & 1 & $\mathrm{c}$ & $\mathrm{p}$ & ic & 0.2900 & 271 & 0.054 & 5367 & 7.40 & 0.09353 & 0.67 & 1.397 & 1.05 & 0.1083 & 0.72 & 0.68 & 1499 & 15 & 663 & 4 & 888 & 6 & 44 \\
\hline 91 & 2 & $\mathrm{c}$ & $\mathrm{rd}$ & ic & 0.0992 & 91 & 0.365 & 14853 & 60.51 & 0.19696 & 0.43 & 13.805 & 0.87 & 0.5083 & 0.66 & 0.76 & 2801 & 9 & 2649 & 14 & 2736 & 8 & 95 \\
\hline 92 & 3 & $\mathrm{~m}$ & $\mathrm{p}$ & hd & 0.1690 & 96 & 0.297 & 9011 & 9.48 & 0.13066 & 0.40 & 6.259 & 0.90 & 0.3474 & 0.72 & 0.79 & 2107 & 10 & 1922 & 12 & 2013 & 8 & 91 \\
\hline 93 & 1 & $\mathrm{c}$ & $\mathrm{p}$ & ic/osc & 0.3110 & 91 & 0.151 & 4969 & 12.02 & 0.11737 & 0.51 & 3.480 & 1.11 & 0.2150 & 0.91 & 0.82 & 1917 & 11 & 1255 & 10 & 1523 & 9 & 66 \\
\hline 94 & 1 & $\mathrm{~m}$ & $\mathrm{p}$ & hd & 0.0999 & 89 & 0.172 & 14596 & 10.11 & 0.22087 & 0.60 & 16.645 & 0.90 & 0.5465 & 0.55 & 0.62 & 2987 & 11 & 2811 & 13 & 2915 & 9 & 94 \\
\hline 95 & 1 & $\mathrm{c}$ & $\mathrm{p}$ & ic & 0.6086 & 399 & 0.229 & 2554 & 4.13 & 0.09736 & 0.61 & 1.826 & 3.15 & 0.1360 & 3.07 & 0.97 & 1575 & 14 & 822 & 24 & 1055 & 21 & 52 \\
\hline 96 & 1 & $\mathrm{~m}$ & $\mathrm{p}$ & osc & 0.2717 & 158 & \begin{tabular}{|l|l|}
0.372 \\
\end{tabular} & 5665 & 14.34 & 0.12249 & 0.55 & 4.389 & 1.05 & 0.2599 & 0.81 & 0.77 & 1993 & 12 & 1489 & 11 & 1710 & 9 & 75 \\
\hline 97 & 1 & $\mathrm{e}$ & ov & osc & 0.2520 & 185 & 0.218 & 6041 & 15.92 & 0.13700 & 0.74 & 6.651 & 1.19 & 0.3521 & 0.85 & 0.71 & 2190 & 15 & 1945 & 14 & 2066 & 11 & 89 \\
\hline 98 & 1 & $\mathrm{e}$ & $\mathrm{p}$ & hd & 0.0532 & 132 & 0.195 & 29047 & 61.72 & 0.11418 & 0.86 & 3.459 & 1.42 & 0.2197 & 1.07 & 0.75 & 1867 & 17 & 1280 & 12 & 1518 & 11 & 69 \\
\hline
\end{tabular}


Unidade Serra do Ibituruna: amostra CP-35 (continuação)

\begin{tabular}{|c|c|c|c|c|c|c|c|c|c|c|c|c|c|c|c|c|c|c|c|c|c|c|c|}
\hline spot & pop. & site & habit & CL & $206 *(\%)$ & ${ }^{204} \mathrm{~Pb} \mathrm{cps}$ & $T h / U$ & ${ }^{206} \mathrm{~Pb} /{ }^{204} \mathrm{~Pb}$ & 10 & ${ }^{207} \mathrm{~Pb} /{ }^{206} \mathrm{~Pb}$ & $10^{\circ}$ & ${ }^{207} \mathrm{~Pb} /{ }^{235} \mathrm{U}$ & 10 & ${ }^{206} \mathrm{~Pb} /{ }^{238} \mathrm{U}$ & $10^{\circ}$ & Rho & t.76 & 20 & t.68 & 20 & t.75 & $20^{\circ}$ & concordância \\
\hline 99 & 2 & $\mathrm{c}$ & rd & ic/hd & 0.1183 & 119 & 0.191 & 12457 & 17.83 & 0.20443 & 0.62 & 14.381 & 1.32 & 0.5102 & 1.11 & 0.84 & 2862 & 12 & 2658 & 24 & 2775 & 13 & 93 \\
\hline 100 & 1 & $\mathrm{c}$ & $p$ & osc & 0.1443 & 89 & 0.369 & 10556 & 12.70 & 0.13017 & 0.54 & 6.267 & 0.88 & 0.3492 & 0.58 & 0.66 & 2100 & 12 & 1931 & 10 & 2014 & 8 & 92 \\
\hline
\end{tabular}

\section{Unidade Serra do Ibituruna: amostra CP-98B}

\begin{tabular}{|c|c|c|c|c|c|c|c|c|c|c|c|c|c|c|c|c|c|c|c|c|c|c|c|}
\hline spot & pop. & site & habit & CL & $206 *(\%)$ & 204Pb cps & Th/U & $206 \mathrm{~Pb} / 204 \mathrm{~Pb}$ & 10 & $207 \mathrm{~Pb} / 206 \mathrm{~Pb}$ & 10 & $207 \mathrm{~Pb} / 235 \mathrm{U}$ & 10 & $206 \mathrm{~Pb} / 238 \mathrm{U}$ & 10 & Rho & t.76 & $20^{\circ}$ & t.68 & $20^{\circ}$ & t.75 & $20^{\circ}$ & concordância \\
\hline 1 & 4 & $\mathrm{~m}$ & ov & osc & 7.8108 & 4343 & 1.654 & 192 & 1.51 & 0.23100 & 0.95 & 13.499 & 1.26 & 0.4238 & 0.74 & 0.59 & 3059 & 16 & 2278 & 14 & 2715 & 12 & 74 \\
\hline 2 & 1 & $\mathrm{~m}$ & $\mathrm{p}$ & osc & 3.5468 & 1479 & 0.324 & 437 & 1.94 & 0.12321 & 0.51 & 2.840 & 0.89 & 0.1672 & 0.63 & 0.71 & 2003 & 11 & 997 & 6 & 1366 & 7 & 50 \\
\hline 3.1 & 4 & $\mathrm{e}$ & ov & $\mathrm{hb}$ & 9.8644 & 2339 & 3.103 & 156 & 4.56 & 0.32284 & 0.73 & 11.214 & 8.31 & 0.2519 & 8.26 & 1.00 & & & & & & & 40 \\
\hline 3.2 & 4 & $\mathrm{~m}$ & ov & $\mathrm{sz}$ & 0.1944 & 200 & 0.420 & 7612 & 9.14 & 0.19256 & 0.31 & 13.095 & 0.82 & 0.4932 & 0.66 & 0.81 & 2764 & 8 & 2585 & 14 & 2687 & 8 & 93 \\
\hline 4 & 4 & $\mathrm{~m}$ & ov & $\mathrm{sz}$ & 5.7615 & 3763 & 0.658 & 265 & 3.60 & 0.24379 & 2.04 & 11.416 & 2.99 & 0.3396 & 2.16 & 0.72 & 3145 & 33 & 1885 & 35 & 2558 & 28 & 60 \\
\hline 5.1 & 2 & $\mathrm{e}$ & $\mathrm{rd}$ & $\mathrm{hb}$ & 0.0075 & 49 & 0.620 & 195542 & 76.92 & 0.18667 & 0.85 & 13.482 & 1.46 & 0.5238 & 1.12 & 0.77 & 2713 & 15 & 2715 & 25 & 2714 & 14 & 100 \\
\hline 5.2 & 2 & $\mathrm{c}$ & rd & $\mathrm{hb}$ & 0.0185 & 52 & 1.378 & 78678 & 39.18 & 0.19349 & 0.65 & 14.499 & 1.41 & 0.5434 & 1.20 & 0.85 & 2772 & 12 & 2798 & 27 & 2783 & 13 & 101 \\
\hline 6 & 1 & $\mathrm{~m}$ & $\mathrm{p}$ & $\mathrm{sz}$ & 3.3625 & 2237 & 0.591 & 458 & 7.48 & 0.17247 & 0.83 & 6.006 & 3.04 & 0.2526 & 2.90 & 0.95 & 2582 & 16 & 1452 & 38 & 1977 & 27 & 56 \\
\hline 7.1 & 1 & $\mathrm{e}$ & $\mathrm{p}$ & $\mathrm{hb}$ & 0.4377 & 135 & 0.441 & 3302 & 11.43 & 0.23063 & 0.55 & 18.186 & 0.95 & 0.5718 & 0.68 & 0.72 & 3057 & 11 & 2915 & 16 & 3000 & 9 & 95 \\
\hline 7.2 & 1 & $\mathrm{~m}$ & $\mathrm{p}$ & osc & 0.9107 & 1516 & 0.783 & 1634 & 17.32 & 0.19228 & 1.65 & 12.472 & 1.80 & 0.4704 & 0.61 & 0.34 & 2762 & 28 & 2485 & 12 & 2641 & 17 & 90 \\
\hline 8 & 2 & $\mathrm{e}$ & ov & $\mathrm{hb}$ & 0.0054 & 37 & 0.286 & 274306 & 81.52 & 0.18321 & 0.44 & 13.071 & 0.81 & 0.5174 & 0.57 & 0.71 & 2682 & 9 & 2688 & 12 & 2685 & 8 & 100 \\
\hline 9 & 3 & $\mathrm{e}$ & $\mathrm{p}$ & $\mathrm{sz}$ & 0.0251 & 54 & 0.615 & 60471 & 48.28 & 0.13010 & 0.33 & 6.452 & 0.74 & 0.3596 & 0.56 & 0.75 & 2100 & 9 & 1980 & 9 & 2039 & 7 & 94 \\
\hline 10.1 & 1 & $\mathrm{e}$ & $\mathrm{p}$ & osc & 25.7520 & 14750 & 0.328 & 60 & 0.75 & 0.36315 & 1.22 & 8.166 & 2.14 & 0.1631 & 1.72 & 0.80 & 3763 & 20 & 974 & 16 & 2250 & 19 & 26 \\
\hline 10.2 & 1 & $\mathrm{~m}$ & $\mathrm{p}$ & osc & 39.7973 & 45828 & 0.846 & 39 & 0.91 & 0.49263 & 0.44 & 10.375 & 1.65 & 0.1527 & 1.54 & 0.94 & 4220 & 8 & 916 & 13 & 2469 & 15 & 22 \\
\hline 11 & 2 & $\mathrm{~m}$ & ov & $\mathrm{hb}$ & 0.1002 & 33 & 0.068 & 15179 & 30.29 & 0.13732 & 1.71 & 6.713 & 2.45 & 0.3545 & 1.72 & 0.70 & 2194 & 30 & 1956 & 29 & 2074 & 22 & 89 \\
\hline 12 & 4 & $\mathrm{~m}$ & ov & $\mathrm{sz}$ & 0.0376 & 52 & 0.200 & 39393 & 45.46 & 0.19392 & 0.62 & 13.098 & 0.97 & 0.4899 & 0.65 & 0.67 & 2776 & 12 & 2570 & 14 & 2687 & 9 & 93 \\
\hline 13 & 1 & $\mathrm{~m}$ & $\mathrm{p}$ & osc & 22.6233 & 13418 & 1.489 & 68 & 4.93 & 0.37876 & 4.42 & 17.019 & 4.62 & 0.3259 & 1.29 & 0.28 & 3827 & 67 & 1819 & 20 & 2936 & 44 & 48 \\
\hline 14 & 3 & $\mathrm{~m}$ & $\mathrm{p}$ & $\mathrm{hb}$ & 0.0645 & 128 & 1.444 & 22534 & 37.40 & 0.20263 & 1.31 & 15.542 & 1.62 & 0.5562 & 0.88 & 0.54 & 2848 & 22 & 2851 & 21 & 2849 & 16 & 100 \\
\hline 15 & 3 & $\mathrm{~m}$ & $\mathrm{p}$ & $\mathrm{hb}$ & 0.1254 & 42 & 1.290 & 11762 & 38.71 & 0.20592 & 0.88 & 14.330 & 1.33 & 0.5047 & 0.93 & 0.70 & 2874 & 15 & 2634 & 21 & 2772 & 13 & 92 \\
\hline 16.1 & 2 & $\mathrm{e}$ & $\mathrm{rd}$ & $\mathrm{hb}$ & 0.0538 & 38 & 1.562 & 27359 & 29.66 & 0.18610 & 0.66 & 13.181 & 1.19 & 0.5137 & 0.91 & 0.77 & 2708 & 13 & 2672 & 20 & 2693 & 11 & 99 \\
\hline 16.2 & 2 & $\mathrm{~m}$ & $\mathrm{rd}$ & osc & 0.0743 & 64 & 1.039 & 19616 & 48.70 & 0.21283 & 0.49 & 15.975 & 1.10 & 0.5443 & 0.92 & 0.83 & 2927 & 10 & 2801 & 20 & 2875 & 11 & 96 \\
\hline 17 & 2 & $\mathrm{e}$ & rd & $\mathrm{sz}$ & 0.0273 & 46 & 0.940 & 52281 & 38.23 & 0.18440 & 0.47 & 15.302 & 0.92 & 0.6018 & 0.69 & 0.76 & 2693 & 10 & 3037 & 17 & 2834 & 9 & 113 \\
\hline 18 & 4 & $\mathrm{e}$ & ov & osc & 13.7057 & 10637 & 0.672 & 113 & 9.00 & 0.20229 & 6.62 & 5.685 & 6.67 & 0.2038 & 0.66 & 0.10 & & & & & & & 42 \\
\hline 19.1 & 4 & $\mathrm{e}$ & $\mathrm{rd}$ & $\mathrm{hb}$ & 32.2750 & 6550 & 3.827 & 48 & 1.06 & 0.48756 & 1.32 & 15.970 & 3.66 & 0.2375 & 3.39 & 0.93 & 4204 & 20 & 1374 & 42 & 2875 & 35 & 33 \\
\hline 19.2 & 4 & $\mathrm{~m}$ & $\mathrm{rd}$ & hd & 11.0187 & 5109 & 0.362 & 141 & 1.89 & 0.20131 & 1.73 & 3.530 & 1.94 & 0.1272 & 0.80 & 0.41 & 2837 & 29 & 772 & 6 & 1534 & 15 & 27 \\
\hline 20 & 3 & $\mathrm{~m}$ & $\mathrm{p}$ & osc & 0.0313 & 64 & 0.185 & 47772 & 48.67 & 0.16695 & 1.24 & 10.517 & 1.47 & 0.4569 & 0.69 & 0.47 & 2527 & 22 & 2426 & 14 & 2481 & 14 & 96 \\
\hline 21.1 & 1 & $\mathrm{e}$ & $\mathrm{p}$ & osc & 14.9175 & 7532 & 2.511 & 103 & 3.69 & 0.30219 & 3.48 & 12.968 & 3.74 & 0.3112 & 1.32 & 0.35 & 3482 & 54 & 1747 & 20 & 2677 & 35 & 50 \\
\hline 21.2 & 1 & $\mathrm{c}$ & $\mathrm{p}$ & ic & 33.2580 & 9231 & 2.134 & 46 & 9.48 & 0.49977 & 3.09 & 16.150 & 4.02 & 0.2344 & 2.54 & 0.63 & 4240 & 46 & 1358 & 31 & 2886 & 38 & 32 \\
\hline 22 & 2 & $\mathrm{c}$ & ov & $\mathrm{hb}$ & 0.0542 & 56 & 0.676 & 27928 & 40.23 & 0.13795 & 0.74 & 7.324 & 1.13 & 0.3850 & 0.77 & 0.68 & 2202 & 14 & 2100 & 13 & 2152 & 10 & 95 \\
\hline
\end{tabular}


Unidade Serra do Ibituruna: amostra CP-98B (continuação)

\begin{tabular}{|c|c|c|c|c|c|c|c|c|c|c|c|c|c|c|c|c|c|c|c|c|c|c|c|}
\hline spot & pop. & site & habit & CL & $206 *(\%)$ & $204 \mathrm{~Pb}$ cps & Th/U & $206 \mathrm{~Pb} / 204 \mathrm{~Pb}$ & 10 & $207 \mathrm{~Pb} / 206 \mathrm{~Pb}$ & 10 & $207 \mathrm{~Pb} / 235 \mathrm{U}$ & 10 & $206 \mathrm{~Pb} / 238 \mathrm{U}$ & $10^{\circ}$ & Rho & t.76 & 20 & t.68 & 20 & t.75 & 20 & concordância \\
\hline 23 & 2 & $\mathrm{~m}$ & ov & $\mathrm{hb}$ & 0.0367 & 21 & 1.641 & 39938 & 22.47 & 0.19832 & 0.63 & 14.350 & 1.07 & 0.5247 & 0.78 & 0.73 & 2813 & 12 & 2719 & 18 & 2773 & 10 & 97 \\
\hline 24 & 2 & $\mathrm{~m}$ & ov & osc & 2.7514 & 1773 & 0.440 & 538 & 18.84 & 0.26543 & 2.95 & 18.058 & 3.77 & 0.4934 & 2.32 & 0.62 & 3279 & 47 & 2585 & 49 & 2993 & 36 & 79 \\
\hline 25.1 & 2 & $\mathrm{e}$ & ov & osc & 0.0129 & 30 & 0.357 & 112346 & 25.85 & 0.21624 & 0.45 & 16.808 & 0.81 & 0.5637 & 0.56 & 0.69 & 2953 & 9 & 2882 & 13 & 2924 & 8 & 98 \\
\hline 25.2 & 2 & $\mathrm{c}$ & ov & ic & 0.3028 & 137 & 0.771 & 4849 & 5.55 & 0.21295 & 0.37 & 15.344 & 0.79 & 0.5226 & 0.59 & 0.75 & 2928 & 9 & 2710 & 13 & 2837 & 8 & 93 \\
\hline 26 & 1 & $\mathrm{~m}$ & $\mathrm{p}$ & osc & 0.3050 & 149 & 0.435 & 4970 & 9.53 & 0.13339 & 0.38 & 6.971 & 0.94 & 0.3790 & 0.77 & 0.83 & 2143 & 9 & 2072 & 13 & 2108 & 8 & 97 \\
\hline 27 & 2 & $\mathrm{e}$ & $\mathrm{rd}$ & $\mathrm{hb}$ & 0.0240 & 56 & 0.389 & 61290 & 41.93 & 0.17664 & 0.48 & 12.528 & 1.21 & 0.5143 & 1.05 & 0.87 & 2622 & 10 & 2675 & 23 & 2645 & 11 & 102 \\
\hline 28 & 4 & $\mathrm{~m}$ & eq & osc & 3.7125 & 3028 & 2.099 & 416 & 12.92 & 0.30129 & 2.15 & 9.384 & 2.52 & 0.2259 & 1.27 & 0.50 & 3477 & 34 & 1313 & 15 & 2376 & 23 & 38 \\
\hline 29 & 2 & $\mathrm{~m}$ & ov & $\mathrm{hb}$ & 0.1428 & 62 & 1.911 & 10357 & 51.73 & 0.19060 & 0.56 & 13.013 & 0.99 & 0.4951 & 0.72 & 0.73 & 2748 & 11 & 2593 & 15 & 2681 & 9 & 94 \\
\hline 30 & 2 & $\mathrm{~m}$ & $\mathrm{rd}$ & $\mathrm{hb}$ & 0.4478 & 61 & 3.311 & 3245 & 64.18 & 0.20105 & 1.16 & 15.420 & 2.04 & 0.5562 & 1.64 & 0.80 & 2835 & 20 & 2851 & 38 & 2842 & 20 & 101 \\
\hline 31 & 2 & $\mathrm{e}$ & $\mathrm{rd}$ & $\mathrm{sz}$ & 0.0416 & 52 & 0.988 & 35137 & 44.43 & 0.19910 & 0.58 & 14.766 & 1.02 & 0.5378 & \begin{tabular}{|l|}
0.75 \\
\end{tabular} & \begin{tabular}{|l|}
0.74 \\
\end{tabular} & 2819 & 11 & 2774 & 17 & 2800 & 10 & 98 \\
\hline 32 & 2 & $\mathrm{c}$ & $\mathrm{rd}$ & $\mathrm{hb}$ & 0.0369 & 50 & 0.222 & 39734 & 39.26 & 0.20923 & 0.61 & 15.109 & 0.94 & 0.5237 & 0.62 & 0.66 & 2900 & 12 & 2715 & 13 & 2822 & 9 & 94 \\
\hline 33 & 4 & $\mathrm{~m}$ & $\mathrm{rd}$ & $\mathrm{hb}$ & 0.0501 & 38 & 0.439 & 29170 & 33.88 & 0.21249 & 0.71 & 15.724 & 1.12 & 0.5366 & 0.79 & \begin{tabular}{|l|}
0.70 \\
\end{tabular} & 2925 & 13 & 2769 & 18 & 2860 & 11 & 95 \\
\hline 34 & 2 & $\mathrm{~m}$ & $\mathrm{rd}$ & $\mathrm{hb}$ & 0.1090 & 46 & 0.313 & 13362 & 38.21 & 0.20927 & 0.98 & 15.798 & 1.31 & 0.5475 & 0.79 & \begin{tabular}{|l|}
0.60 \\
\end{tabular} & 2900 & 17 & 2815 & 18 & 2865 & 13 & 97 \\
\hline 35 & 1 & $\mathrm{~m}$ & $\mathrm{p}$ & osc & 8.6729 & 4789 & 0.438 & 178 & 10.08 & 0.33141 & 4.14 & 8.895 & 4.66 & 0.1946 & 2.11 & 0.45 & 3624 & 64 & 1146 & 22 & 2327 & 43 & 32 \\
\hline 36 & 1 & $\mathrm{~m}$ & $\mathrm{p}$ & $\mathrm{sz}$ & 2.7567 & 3507 & 0.835 & 529 & 18.99 & 0.14603 & 5.86 & 11.002 & 6.07 & 0.5464 & 1.55 & \begin{tabular}{|l|}
0.26 \\
\end{tabular} & & & & & & & 122 \\
\hline 37 & 1 & $\mathrm{~m}$ & $\mathrm{p}$ & ic & 0.0128 & 45 & 0.181 & 103977 & 37.01 & 0.35640 & 0.37 & 36.542 & 0.80 & 0.7436 & 0.60 & 0.76 & 3735 & 8 & 3584 & 17 & 3681 & 8 & 96 \\
\hline 38 & 4 & $\mathrm{~m}$ & ov & osc & 0.1642 & 421 & 0.433 & 9225 & 81.47 & 0.20048 & 0.48 & 10.555 & 1.19 & 0.3818 & 1.02 & 0.86 & 2830 & 10 & 2085 & 18 & 2485 & 11 & 74 \\
\hline 39 & 1 & $\mathrm{c}$ & $\mathrm{p}$ & ic & 1.1610 & 466 & 0.440 & 1320 & 9.77 & 0.14643 & 1.38 & 6.076 & 1.70 & 0.3009 & 0.93 & 0.54 & 2305 & 25 & 1696 & 14 & 1987 & 15 & 74 \\
\hline 40 & 4 & $\mathrm{c}$ & rd & ic & 5.7166 & 1310 & 2.069 & 266 & 2.96 & 0.25186 & 1.16 & 12.348 & 1.61 & 0.3555 & \begin{tabular}{|l|}
1.06 \\
\end{tabular} & 0.65 & 3197 & 19 & 1961 & 18 & 2631 & 15 & 61 \\
\hline 41.1 & 4 & $\mathrm{e}$ & $\mathrm{rd}$ & $\mathrm{hb}$ & 11.1052 & 336 & 7.567 & 138 & 3.40 & 0.26454 & 1.69 & 9.899 & 3.42 & 0.2714 & 2.95 & 0.86 & \begin{tabular}{|l|}
3274 \\
\end{tabular} & 27 & 1548 & 41 & 2425 & 32 & 47 \\
\hline 41.2 & 4 & $\mathrm{c}$ & $\mathrm{rd}$ & ic & 18.7649 & 9807 & 1.161 & 83 & 2.95 & 0.32319 & 1.69 & 6.710 & 2.13 & 0.1506 & 1.23 & \begin{tabular}{|l|} 
\\
\end{tabular} & 3585 & 27 & 904 & 10 & 2074 & 19 & 25 \\
\hline 42 & 1 & $\mathrm{e}$ & $\mathrm{p}$ & $\mathrm{sz}$ & 2.2168 & 744 & 1.254 & 684 & 5.14 & 0.25616 & 0.63 & 13.349 & 3.30 & 0.3779 & 3.22 & 0.98 & 3224 & 10 & 2067 & 57 & 2705 & 31 & 64 \\
\hline 43 & 2 & $\mathrm{c}$ & $\mathrm{fr}$ & $\mathrm{hb} / \mathrm{ic}$ & 0.0248 & 29 & 0.359 & 59733 & 30.44 & 0.18720 & 0.56 & 12.482 & 1.07 & 0.4836 & 0.84 & 0.78 & 2718 & 11 & 2543 & 18 & 2641 & 10 & 94 \\
\hline 44 & 2 & $\mathrm{~m}$ & ov & $\mathrm{hb}$ & 0.0240 & 34 & 0.331 & 61252 & 24.00 & 0.19811 & 0.52 & 14.255 & 1.11 & 0.5218 & 0.90 & \begin{tabular}{|l|}
0.82 \\
\end{tabular} & 2811 & 10 & 2707 & 20 & 2767 & 11 & 96 \\
\hline 45.1 & 2 & $\mathrm{e}$ & ov & $\mathrm{hb}$ & 0.0270 & 23 & 0.313 & 54706 & 27.99 & 0.19608 & 0.77 & 13.652 & 1.20 & 0.5049 & \begin{tabular}{|l|}
0.84 \\
\end{tabular} & \begin{tabular}{|l|}
0.70 \\
\end{tabular} & \begin{tabular}{|l|}
2794 \\
\end{tabular} & 14 & 2635 & 18 & 2726 & 11 & 94 \\
\hline 45.2 & 2 & $\mathrm{c}$ & ov & ic & 0.0171 & 22 & 0.251 & 85169 & 27.38 & 0.21819 & 0.43 & 16.590 & 0.82 & 0.5514 & \begin{tabular}{|l|}
0.60 \\
\end{tabular} & \begin{tabular}{|l|}
0.72 \\
\end{tabular} & 2968 & 9 & 2831 & 14 & 2911 & 8 & 95 \\
\hline 46.1 & 1 & $\mathrm{e}$ & $\mathrm{p}$ & osc & 1.9556 & 578 & 0.659 & 794 & 91.43 & 0.55419 & 3.49 & 12.186 & 7.12 & 0.1595 & \begin{tabular}{|l|}
6.19 \\
\end{tabular} & 0.87 & 4392 & 51 & 954 & 55 & 2619 & 67 & 22 \\
\hline 46.2 & 1 & $\mathrm{~m}$ & $\mathrm{p}$ & $\mathrm{hb}$ & 0.6499 & 78 & 1.119 & 2343 & 23.94 & 0.18957 & 0.69 & 9.130 & 1.22 & 0.3493 & \begin{tabular}{|l|}
0.94 \\
\end{tabular} & \begin{tabular}{|l|}
0.77 \\
\end{tabular} & 2738 & 13 & 1931 & 16 & 2351 & 11 & 71 \\
\hline 47 & 4 & $\mathrm{~m}$ & ov & osc & 4.4026 & 2352 & 1.562 & 349 & 8.57 & 0.21756 & 3.70 & 8.134 & 3.84 & 0.2711 & 0.97 & 0.25 & 2963 & 60 & 1546 & 13 & 2246 & 35 & 52 \\
\hline 48 & 2 & $\mathrm{c}$ & $\mathrm{rd}$ & $\mathrm{hb}$ & 0.0501 & 63 & 0.344 & 29497 & 41.20 & 0.19252 & 0.72 & 13.259 & 1.12 & 0.4995 & \begin{tabular}{|l|}
0.77 \\
\end{tabular} & \begin{tabular}{|l|}
0.69 \\
\end{tabular} & \begin{tabular}{|l|}
2764 \\
\end{tabular} & 13 & 2612 & 16 & 2698 & 11 & 94 \\
\hline 49 & 1 & $\mathrm{e}$ & $\mathrm{p}$ & osc & 1.6104 & 12649 & 1.455 & 937 & 46.31 & 0.09631 & 7.37 & 5.367 & 7.75 & 0.4042 & 2.36 & 0.30 & 1554 & 139 & 2188 & 44 & 1880 & 66 & 141 \\
\hline 50 & 3 & $\mathrm{~m}$ & ov & $\mathrm{sz}$ & 0.4292 & 71 & 0.555 & 3527 & 20.20 & 0.13630 & 0.61 & 7.268 & 1.26 & 0.3867 & 1.04 & \begin{tabular}{|l|}
0.82 \\
\end{tabular} & 2181 & 13 & 2108 & 19 & 2145 & 11 & 97 \\
\hline 51 & 2 & $\mathrm{~m}$ & ov & ic & 0.0344 & 50 & 0.661 & 42176 & 38.55 & 0.21383 & 0.49 & 16.518 & 0.96 & 0.5602 & \begin{tabular}{|l|}
0.74 \\
\end{tabular} & \begin{tabular}{|l|}
0.77 \\
\end{tabular} & 2935 & 10 & 2868 & 17 & 2907 & 9 & 98 \\
\hline 52.1 & 4 & $\mathrm{e}$ & ov & osc & 1.7411 & 877 & 0.396 & 863 & 3.54 & 0.22183 & 0.42 & 13.060 & 1.19 & 0.4270 & 1.05 & 0.88 & 2994 & 9 & 2292 & 20 & 2684 & 11 & 77 \\
\hline 52.2 & 4 & c & ov & ic & 19.1140 & 14600 & 0.734 & 81 & 4.62 & 0.35517 & 4.60 & 8.733 & 4.73 & 0.1783 & 1.07 & 0.23 & \begin{tabular}{|l|}
3730 \\
\end{tabular} & 70 & 1058 & 10 & 2311 & 43 & 28 \\
\hline
\end{tabular}


Unidade Serra do Ibituruna: amostra CP-98B (continuação)

\begin{tabular}{|c|c|c|c|c|c|c|c|c|c|c|c|c|c|c|c|c|c|c|c|c|c|c|c|}
\hline spot & pop. & site & habit & CL & 206* (\%) & 204Pb cps & $\mathbf{T h} / \mathrm{U}$ & $206 \mathrm{~Pb} / 204 \mathrm{~Pb}$ & 10 & $207 \mathrm{~Pb} / 206 \mathrm{~Pb}$ & 10 & $207 \mathrm{~Pb} / 235 \mathrm{U}$ & 10 & $206 \mathrm{~Pb} / 238 \mathrm{U}$ & 10 & Rho & t.76 & $20^{\circ}$ & t.68 & 20 & t.75 & $20^{\circ}$ & concordância \\
\hline 53 & 4 & $\mathrm{~m}$ & ov & osc & 0.0665 & 65 & 0.263 & 21956 & 58.05 & 0.20542 & 0.45 & 15.333 & 0.91 & 0.5413 & 0.69 & 0.77 & 2870 & 9 & 2789 & 16 & 2836 & 9 & 97 \\
\hline 54 & 1 & $\mathrm{e}$ & $\mathrm{p}$ & $\mathrm{sz}$ & 33.9258 & 23503 & 1.979 & 45 & 4.73 & 0.30189 & 26.64 & 15.131 & 27.01 & 0.3635 & 4.47 & 0.17 & & & & & & & 57 \\
\hline 55.1 & 2 & $\mathrm{e}$ & $\mathrm{rd}$ & osc & 0.0284 & 44 & 0.290 & 51656 & 32.80 & 0.19678 & 0.53 & 14.250 & 0.97 & 0.5252 & 0.72 & 0.75 & 2800 & 10 & 2721 & 16 & 2766 & 9 & 97 \\
\hline 55.2 & 2 & $\mathrm{~m}$ & $\mathrm{rd}$ & $\mathrm{hb} / \mathrm{ic}$ & 2.5418 & 577 & 1.234 & 585 & 3.14 & 0.24567 & 0.57 & 15.989 & 1.66 & 0.4720 & 1.51 & 0.91 & 3157 & 11 & 2492 & 31 & 2876 & 16 & 79 \\
\hline 56 & 1 & $\mathrm{~m}$ & $\mathrm{p}$ & osc & 0.1037 & 57 & 0.527 & 14602 & 52.35 & 0.13456 & 0.72 & 7.150 & 1.16 & 0.3854 & 0.82 & 0.71 & 2158 & 14 & 2102 & 14 & 2130 & 10 & 97 \\
\hline 57 & 1 & $\mathrm{e}$ & $\mathrm{p}$ & osc & 1.8051 & 772 & 0.995 & 836 & 6.61 & 0.20435 & 1.44 & 11.336 & 1.92 & 0.4023 & 1.21 & 0.63 & 2861 & 24 & 2180 & 22 & 2551 & 18 & 76 \\
\hline 58 & 2 & $\mathrm{~m}$ & $\mathrm{rd}$ & $\mathrm{hb}$ & 0.0793 & 42 & 0.624 & 19133 & 35.66 & 0.13760 & 1.08 & 7.055 & 1.84 & 0.3718 & 1.44 & 0.78 & 2198 & 20 & 2038 & 25 & 2118 & 16 & 93 \\
\hline 59 & 4 & $\mathrm{~m}$ & $\mathrm{rd}$ & $\mathrm{hb}$ & 0.0613 & 44 & 1.244 & 23814 & 36.47 & 0.21094 & 0.96 & 15.777 & 1.54 & 0.5424 & 1.14 & 0.74 & 2913 & 17 & 2794 & 26 & 2863 & 15 & 96 \\
\hline 60.1 & 2 & $\mathrm{e}$ & ov & $\mathrm{hb}$ & 0.1822 & 35 & 0.093 & 7870 & 59.32 & 0.21772 & 3.49 & 17.828 & 4.64 & 0.5939 & 3.03 & 0.65 & 2964 & 57 & 3005 & 73 & 2981 & 45 & 101 \\
\hline 60.2 & 2 & $\mathrm{c}$ & ov & ic & 3.4037 & 1470 & 0.571 & 455 & 5.12 & 0.21104 & 1.05 & 5.794 & 1.86 & 0.1991 & 1.49 & 0.80 & 2914 & 18 & 1171 & 16 & 1946 & 16 & 40 \\
\hline 61.1 & 4 & $\mathrm{e}$ & ov & osc & 14.7822 & 7317 & 0.358 & 105 & 5.16 & 0.30303 & 3.39 & 7.968 & 3.83 & 0.1907 & 1.75 & \begin{tabular}{|l|} 
\\
\end{tabular} & 3486 & 53 & 1125 & 18 & 2227 & 35 & 32 \\
\hline 61.2 & 4 & $\mathrm{~m}$ & ov & osc & 0.8232 & 427 & 1.106 & 1849 & 23.76 & 0.13687 & 1.69 & 6.665 & 2.47 & 0.3531 & 1.76 & 0.71 & 2188 & 30 & 1949 & 30 & 2068 & 22 & 89 \\
\hline 62 & 2 & $\mathrm{~m}$ & $\mathrm{rd}$ & hd & 0.4841 & 221 & 1.295 & 3024 & 27.23 & 0.18940 & 0.76 & 13.902 & 1.27 & 0.5323 & 0.95 & 0.75 & 2737 & 14 & 2751 & 21 & 2743 & 12 & 101 \\
\hline 63 & 4 & $\mathrm{~m}$ & $\mathrm{rd}$ & $\mathrm{hb}$ & 0.1133 & 91 & 2.482 & 12970 & 47.28 & 0.17969 & 2.13 & 12.885 & 2.50 & 0.5200 & 1.27 & \begin{tabular}{|l|}
0.51 \\
\end{tabular} & 2650 & 36 & 2699 & 28 & 2671 & 24 & 102 \\
\hline 64.1 & 2 & $\mathrm{e}$ & ov & $\mathrm{hb}$ & 2.2824 & 599 & 0.637 & 678 & 17.15 & 0.28343 & 3.39 & 8.076 & 7.14 & 0.2066 & 6.27 & 0.88 & 3382 & 53 & 1211 & 69 & 2240 & 65 & 36 \\
\hline 64.2 & 2 & $\mathrm{c}$ & ov & $\mathrm{hb} / \mathrm{ic}$ & 0.1180 & 60 & 0.641 & 12470 & 53.96 & 0.18578 & 1.26 & 13.165 & 1.97 & 0.5139 & 1.48 & 0.75 & 2705 & 22 & 2673 & 32 & 2692 & 19 & 99 \\
\hline 65 & 2 & $\mathrm{~m}$ & $\mathrm{fr}$ & osc & 0.0902 & 68 & 0.288 & 16221 & 64.44 & 0.19678 & 0.48 & 14.456 & 1.02 & 0.5328 & 0.82 & 0.80 & 2800 & 10 & 2753 & 18 & 2780 & 10 & 98 \\
\hline 66 & 2 & $\mathrm{~m}$ & ov & $\mathrm{hb}$ & 0.7899 & 91 & 0.093 & 1814 & 15.01 & 0.22667 & 1.02 & 18.624 & 1.67 & 0.5959 & 1.27 & 0.76 & 3029 & 17 & 3013 & 31 & 3023 & 16 & 99 \\
\hline 67 & 2 & $\mathrm{~m}$ & $\mathrm{rd}$ & $\mathrm{sz}$ & 0.0441 & 42 & 0.367 & 32989 & 52.10 & 0.21168 & 0.48 & 16.084 & 0.89 & 0.5510 & 0.65 & 0.73 & 2919 & 10 & 2829 & 15 & 2882 & 9 & 97 \\
\hline 68 & 4 & $\mathrm{~m}$ & ov & $\mathrm{hb}$ & 0.2225 & 30 & 0.312 & 6611 & 33.47 & 0.19317 & 3.45 & 13.739 & 5.17 & 0.5158 & 3.83 & 0.74 & 2770 & 57 & 2681 & 84 & 2732 & 49 & 97 \\
\hline 69 & 4 & $\mathrm{~m}$ & $\mathrm{rd}$ & $\mathrm{rx}$ & 2.8893 & 1734 & 0.332 & 524 & 3.81 & 0.21839 & 0.72 & 11.771 & 1.34 & 0.3909 & 1.06 & 0.80 & 2969 & 13 & 2127 & 19 & 2586 & 13 & 72 \\
\hline 70 & 1 & $\mathrm{~m}$ & $\mathrm{p}$ & osc & 18.7055 & 5546 & 0.581 & 83 & 1.74 & 0.28890 & 2.47 & 7.652 & 2.64 & 0.1921 & 0.85 & 0.32 & 3412 & 39 & 1133 & 9 & 2191 & 24 & 33 \\
\hline 71 & 4 & $\mathrm{~m}$ & ov & osc & 0.9861 & 513 & 0.745 & 1450 & 12.43 & 0.20461 & 0.78 & 16.946 & 2.37 & 0.6006 & 2.21 & 0.93 & 2864 & 14 & 3032 & 54 & 2932 & 23 & 106 \\
\hline 72 & 2 & $\mathrm{~m}$ & ov & $\mathrm{rx}$ & 0.0435 & 33 & 0.575 & 33947 & 33.96 & 0.18743 & 0.41 & 12.953 & 0.83 & 0.5012 & \begin{tabular}{|l|}
0.62 \\
\end{tabular} & \begin{tabular}{|l|}
0.75 \\
\end{tabular} & 2720 & 9 & 2619 & 13 & 2676 & 8 & 96 \\
\hline 73 & 2 & $\mathrm{e}$ & eq & $\mathrm{hb}$ & 0.2529 & 27 & 0.563 & 6021 & 32.07 & 0.14641 & 4.13 & 7.065 & 6.14 & 0.3500 & 4.52 & 0.74 & 2304 & 71 & 1935 & 76 & 2120 & 55 & 84 \\
\hline 74 & 4 & $\mathrm{~m}$ & ov & $\mathrm{rx}$ & 0.2955 & 147 & 0.286 & 4995 & 4.99 & 0.20473 & 0.36 & 14.212 & 0.79 & 0.5034 & \begin{tabular}{|l|}
0.59 \\
\end{tabular} & 0.75 & 2865 & 9 & 2628 & 13 & 2764 & 8 & 92 \\
\hline 75 & 4 & $\mathrm{~m}$ & ov & hd & 4.8360 & 2411 & 2.112 & 312 & 2.24 & 0.23002 & 0.96 & 12.716 & 1.98 & 0.4009 & 1.69 & 0.85 & 3052 & 17 & 2173 & 31 & 2659 & 19 & 71 \\
\hline 76 & 4 & $\mathrm{e}$ & ov & $\mathrm{hb} / \mathrm{osc}$ & 1.3196 & 542 & 0.780 & 1143 & 10.36 & 0.20346 & 0.65 & 11.445 & 1.07 & 0.4080 & 0.77 & 0.72 & 2854 & 12 & 2206 & 14 & 2560 & 10 & 77 \\
\hline 77 & 4 & $\mathrm{e}$ & ov & osc & 7.8278 & 6260 & 1.188 & 197 & 17.46 & 0.40886 & 0.79 & 12.785 & 1.79 & 0.2268 & 1.56 & 0.87 & 3942 & 13 & 1318 & 19 & 2664 & 17 & 33 \\
\hline 78 & 4 & $\mathrm{~m}$ & $\mathrm{fr}$ & $\mathrm{rx}$ & 4.1228 & 20144 & 2.051 & 28 & 3.80 & 0.74150 & 13.73 & 134.388 & 16.17 & 1.3144 & 8.53 & 0.53 & & & & & & & 112 \\
\hline 79 & 2 & $\mathrm{~m}$ & $\mathrm{rd}$ & $\mathrm{hb}$ & 0.0101 & 14 & 0.339 & 145638 & 35.82 & 0.19224 & 0.54 & 13.484 & 0.90 & 0.5087 & 0.63 & \begin{tabular}{|l|}
0.69 \\
\end{tabular} & 2762 & 11 & 2651 & 14 & 2714 & 9 & 96 \\
\hline 80 & 2 & $\mathrm{c}$ & $\mathrm{rd}$ & $\mathrm{rx}$ & 0.0227 & 38 & 4.193 & 64524 & 35.78 & 0.19659 & 0.38 & 14.359 & 0.76 & 0.5297 & \begin{tabular}{|l|}
0.55 \\
\end{tabular} & \begin{tabular}{|l|}
0.72 \\
\end{tabular} & 2798 & 9 & 2740 & 12 & 2774 & 7 & 98 \\
\hline 81 & 4 & $\mathrm{c}$ & ov & osc/ic & 0.0932 & 68 & 0.462 & 15814 & 23.23 & 0.21698 & 0.38 & 15.176 & 0.87 & 0.5072 & 0.68 & 0.79 & 2959 & 8 & 2645 & 15 & 2826 & 8 & 89 \\
\hline 82 & 2 & $\mathrm{e}$ & ov & $\mathrm{hb}$ & 0.0339 & 29 & 0.356 & 43672 & 24.50 & 0.18841 & 0.70 & 12.886 & 1.12 & 0.4960 & 0.79 & 0.70 & 2729 & 13 & 2597 & 17 & 2671 & 11 & 95 \\
\hline 83 & 1 & $\mathrm{e}$ & $\mathrm{fr}$ & $\mathrm{rx}$ & 2.1194 & 1283 & 1.899 & 720 & 16.01 & 0.27655 & 0.88 & 12.687 & 1.34 & 0.3327 & 0.94 & 0.70 & 3344 & 15 & 1852 & 15 & 2657 & 13 & 55 \\
\hline
\end{tabular}


Unidade Serra do Ibituruna: amostra CP-98B (continuação)

\begin{tabular}{|c|c|c|c|c|c|c|c|c|c|c|c|c|c|c|c|c|c|c|c|c|c|c|c|}
\hline spot & pop. & site & habit & CL & $206 *(\%)$ & 204Pb cps & Th/U & $206 \mathrm{~Pb} / 204 \mathrm{~Pb}$ & 10 & $207 \mathrm{~Pb} / 206 \mathrm{~Pb}$ & 10 & $207 \mathrm{~Pb} / 235 \mathrm{U}$ & 10 & $206 \mathrm{~Pb} / 238 \mathrm{U}$ & 10 & Rho & t.76 & $20^{\circ}$ & t.68 & 20 & t.75 & 20 & concordância \\
\hline 84 & 2 & $\mathrm{~m}$ & eq & osc & 0.0088 & 11 & 0.382 & 172812 & 16.86 & 0.13601 & 0.56 & 6.934 & 0.97 & 0.3697 & 0.70 & 0.72 & 2177 & 12 & 2028 & 12 & 2103 & 8 & 93 \\
\hline 85 & 3 & $\mathrm{~m}$ & ov & osc/rx & 0.0137 & 22 & 0.687 & 107074 & 22.90 & 0.20978 & 0.64 & 15.215 & 0.97 & 0.5260 & 0.62 & 0.64 & 2904 & 12 & 2725 & 13 & 2829 & 9 & 94 \\
\hline 86 & 4 & $\mathrm{c}$ & ov & hd & 3.1931 & 1236 & 1.002 & 480 & 2.15 & 0.15793 & 0.86 & 6.463 & 1.36 & 0.2968 & 0.99 & 0.73 & 2434 & 16 & 1675 & 15 & 2041 & 12 & 69 \\
\hline 87 & 2 & $\mathrm{~m}$ & ov & hd & 0.7161 & 156 & 1.070 & 2052 & 6.56 & 0.21837 & 0.79 & 15.661 & 1.15 & 0.5201 & 0.75 & 0.65 & 2969 & 14 & 2700 & 17 & 2856 & 11 & 91 \\
\hline 88 & 1 & $\mathrm{c}$ & $\mathrm{p}$ & osc/ic & 10.1580 & 3030 & 1.557 & 148 & 11.09 & 0.10186 & 14.65 & 6.001 & 14.81 & 0.4273 & 2.17 & 0.15 & & & & & & & 138 \\
\hline 89 & 2 & $\mathrm{c}$ & ov & $\mathrm{rx}$ & 0.0074 & 27 & 0.468 & 198616 & 23.84 & 0.20253 & 0.41 & 14.903 & 0.83 & 0.5337 & 0.62 & 0.74 & 2847 & 9 & 2757 & 14 & 2809 & 8 & 97 \\
\hline 90 & 4 & $\mathrm{c}$ & $\mathrm{rd}$ & ic & 0.6314 & 388 & 0.898 & 2330 & 10.11 & 0.20255 & 0.73 & 14.388 & 1.05 & 0.5151 & 0.65 & 0.62 & 2847 & 13 & 2678 & 14 & 2776 & 10 & 94 \\
\hline 91 & 4 & $\mathrm{~m}$ & ov & $\mathrm{rx} / \mathrm{osc}$ & 12.8551 & 30692 & 1.583 & 37 & 2.36 & 0.61317 & 5.22 & 102.431 & 6.08 & 1.2115 & 3.10 & 0.51 & 4540 & 76 & 5116 & 109 & 4710 & 61 & 113 \\
\hline 92 & 2 & $\mathrm{c}$ & $\mathrm{fr}$ & $\mathrm{hb}$ & 0.1747 & 60 & 0.918 & 8807 & 33.33 & 0.19138 & 2.17 & 6.981 & 4.26 & 0.2645 & 3.65 & 0.86 & 2754 & 36 & 1513 & 49 & 2109 & 38 & 55 \\
\hline 93 & 1 & $\mathrm{~m}$ & fr & hd & 5.1028 & 1088 & 2.082 & 292 & 3.53 & 0.22511 & 1.02 & 14.438 & 1.90 & 0.4651 & 1.56 & 0.82 & 3018 & 18 & 2462 & 32 & 2779 & 18 & 82 \\
\hline 94 & 1 & $\mathrm{c}$ & $\mathrm{p}$ & ic & 0.7776 & 558 & 0.694 & 1922 & 7.45 & 0.22760 & 0.39 & 14.182 & 0.92 & 0.4519 & 0.75 & 0.81 & 3035 & 8 & 2404 & 15 & 2762 & 9 & 79 \\
\hline 95 & 4 & $\mathrm{~m}$ & ov & osc & 2.7761 & 660 & 3.097 & 548 & 2.20 & 0.20177 & 0.81 & 9.718 & 1.28 & 0.3493 & 0.93 & 0.72 & 2841 & 15 & 1931 & 16 & 2408 & 12 & 68 \\
\hline 96 & 4 & $\mathrm{~m}$ & ov & ic & 2.0024 & 7877 & 1.894 & 744 & 23.98 & 0.16887 & 8.62 & 10.899 & 8.68 & 0.4681 & 0.95 & 0.11 & & & & & & & 97 \\
\hline 97 & 3 & $\mathrm{~m}$ & $\mathrm{p}$ & osc/hb & 0.0095 & 35 & 0.426 & 152775 & 25.64 & 0.20728 & 0.47 & 16.303 & 0.85 & 0.5704 & 0.60 & 0.71 & 2885 & 10 & 2910 & 14 & 2895 & 8 & 101 \\
\hline 98 & 4 & $\mathrm{~m}$ & ov & $\mathrm{hb}$ & 0.0367 & 51 & 0.648 & 39663 & 31.70 & 0.19734 & 0.86 & 15.075 & 1.50 & 0.5540 & 1.17 & 0.78 & 2804 & 15 & 2842 & 27 & 2820 & 14 & 101 \\
\hline 99 & 2 & $\mathrm{c}$ & eq & $\mathrm{hb}$ & 0.0841 & 27 & 1.502 & 18049 & 29.72 & 0.16485 & 4.67 & 8.393 & 4.99 & 0.3692 & 1.72 & 0.35 & 2506 & 79 & 2026 & 30 & 2274 & 45 & 81 \\
\hline 100 & 4 & $\mathrm{~m}$ & ov & osc/rx & 0.1544 & 144 & 0.913 & 9668 & 75.02 & 0.18073 & 0.61 & 11.369 & 1.04 & 0.4562 & 0.77 & 0.73 & 2660 & 12 & 2423 & 15 & 2554 & 10 & 91 \\
\hline
\end{tabular}

\section{Unidade Colônia: amostra CP-07}

\begin{tabular}{|c|c|c|c|c|c|c|c|c|c|c|c|c|c|c|c|c|c|c|c|c|c|}
\hline spot & pop. & site & habit & CL & ${ }^{207} \mathrm{~Pb} /{ }^{235} \mathrm{U}$ & 10 & ${ }^{206} \mathrm{~Pb} /{ }^{238} \mathrm{U}$ & 10 & Rho & ${ }^{207} \mathrm{~Pb} /{ }^{206} \mathrm{~Pb}$ & 10 & Pb total & Pb rad & $\mathbf{T h} / \mathrm{U}$ & t.68 & 10 & t.75 & 10 & t.76 & 10 & concordância \\
\hline 1.1 & 2 & $\mathrm{e}$ & p & $\mathrm{r} / \mathrm{hb}$ & 0.8959 & 0.0119 & 0.1089 & 0.0011 & 0.76 & 0.0596 & 0.0008 & 0.05 & 211 & 0.01 & 667 & 12.00 & 650 & 12 & 591 & 54 & 102.6 \\
\hline 2.1 & 1 & $\mathrm{e}$ & $\mathrm{p}$ & $\mathrm{hb}$ & 0.8936 & 0.0135 & 0.1086 & 0.0011 & 0.89 & 0.0597 & 0.0009 & 0.03 & 62 & 0.00 & 665 & 12.00 & 648 & 14 & 592 & 66 & 102.6 \\
\hline 3.1 & 2 & $\mathrm{e}$ & $\mathrm{p}$ & $\mathrm{hb}$ & 0.7756 & 0.0139 & 0.0934 & 0.0010 & 0.72 & 0.0603 & 0.0011 & 0.30 & 39 & 0.00 & 583 & 0.12 & 576 & 0 & 612 & 1 & 101.3 \\
\hline 4.1 & 1 & $\mathrm{e}$ & $\mathrm{p}$ & $\mathrm{hb}$ & 0.8623 & 0.0137 & 0.1048 & 0.0011 & 0.92 & 0.0597 & 0.0009 & 0.23 & 58 & 0.00 & 631 & 0.13 & 642 & 0 & 592 & 1 & 98.3 \\
\hline 5.1 & 2 & $\mathrm{e}$ & $p$ & $\mathrm{r} / \mathrm{hb}$ & 0.8361 & 0.0117 & 0.1017 & 0.0010 & 0.99 & 0.0596 & 0.0009 & 0.97 & 105 & 0.00 & 617 & 0.11 & 624 & 0 & 590 & 0 & 98.8 \\
\hline 6.1 & 3 & $\mathrm{e}$ & ov & $\mathrm{r} / \mathrm{hb}$ & 0.7251 & 0.0108 & 0.0874 & 0.0009 & 0.99 & 0.0602 & 0.0009 & 0.62 & 100 & 0.01 & 540 & 10.00 & 554 & 14 & 610 & 68 & 97.5 \\
\hline 7.1 & 2 & $\mathrm{e}$ & $\mathrm{p}$ & $\mathrm{hb}$ & 0.7711 & 0.0129 & 0.0929 & 0.0010 & 0.76 & 0.0602 & 0.0010 & 0.28 & 47 & 0.00 & 580 & 0.11 & 573 & 0 & 611 & 1 & 101.3 \\
\hline 8.1 & 2 & $\mathrm{e}$ & ov & $\mathrm{r} / \mathrm{hb}$ & 0.9448 & 0.0157 & 0.1154 & 0.0012 & 0.86 & 0.0594 & 0.0010 & 0.04 & 64 & 0.00 & 704 & 14.00 & 675 & 16 & 581 & 74 & 104.3 \\
\hline 9.1 & 1 & $\mathrm{e}$ & $\mathrm{p}$ & $\mathrm{osc} / \mathrm{hb}$ & 0.9048 & 0.0114 & 0.1111 & 0.0010 & 0.99 & 0.0591 & 0.0008 & 0.19 & 171 & 0.00 & 679 & 12.00 & 654 & 12 & 570 & 58 & 103.8 \\
\hline 10.1 & 2 & $\mathrm{e}$ & $\mathrm{p}$ & $\mathrm{r} / \mathrm{hb}$ & 0.9506 & 0.0144 & 0.1124 & 0.0011 & 0.99 & 0.0614 & 0.0010 & 0.47 & 61 & 0.01 & 678 & 0.14 & 687 & 0 & 651 & 1 & 98.8 \\
\hline 11.1 & 1 & $\mathrm{c}$ & $\mathrm{p}$ & ic & 5.4004 & 0.0781 & 0.3382 & 0.0036 & 0.95 & 0.1158 & 0.0017 & 38.98 & 48 & 0.57 & 1878 & 34.00 & 1885 & 26 & 1892 & 54 & 99.3 \\
\hline 12.1 & 1 & $\mathrm{e}$ & $\mathrm{p}$ & $\mathrm{hb}$ & 0.8944 & 0.0128 & 0.1097 & 0.0010 & 0.98 & 0.0592 & 0.0009 & 0.39 & 137 & 0.01 & 671 & 12.00 & 649 & 14 & 573 & 66 & 103.4 \\
\hline 13.1 & 2 & $\mathrm{e}$ & $\mathrm{p}$ & $\mathrm{r} / \mathrm{hb}$ & 0.8698 & 0.0165 & 0.1068 & 0.0008 & 0.75 & 0.0590 & 0.0011 & 0.05 & 109 & 0.00 & 654 & 10.00 & 635 & 18 & 569 & 84 & 103.0 \\
\hline 13.2 & 2 & $\mathrm{c}$ & $\mathrm{p}$ & $\mathrm{ic} / \mathrm{rx}$ & 6.2454 & 0.1566 & 0.3452 & 0.0041 & 0.81 & 0.1312 & 0.0036 & 2.82 & 33 & 0.27 & 2011 & 2.74 & 1912 & 0 & 2114 & 5 & 95.1 \\
\hline 14.1 & 1 & $\mathrm{e}$ & $p$ & $r$ & 0.8830 & 0.0205 & 0.1079 & 0.0009 & 0.84 & 0.0593 & 0.0014 & 0.12 & 66 & 0.00 & 661 & 10.00 & 643 & 22 & 579 & 102 & 102.8 \\
\hline 15.1 & 2 & $\mathrm{e}$ & ov & $\mathrm{r} / \mathrm{hb}$ & 0.9320 & 0.0175 & 0.1132 & 0.0009 & 0.93 & 0.0597 & 0.0011 & 0.07 & 123 & 0.01 & 691 & 10.00 & 669 & 18 & 594 & 82 & 103.3 \\
\hline
\end{tabular}


Unidade Colônia: amostra CP-07 (continuação)

\begin{tabular}{|c|c|c|c|c|c|c|c|c|c|c|c|c|c|c|c|c|c|c|c|c|c|}
\hline spot & pop. & site & habit & $\mathbf{C L}$ & ${ }^{207} \mathrm{~Pb} /{ }^{235} \mathrm{U}$ & 10 & ${ }^{206} \mathrm{~Pb} /{ }^{238} \mathrm{U}$ & 10 & Rho & ${ }^{207} \mathrm{~Pb} /{ }^{206} \mathrm{~Pb}$ & 10 & Pb total & Pb rad & $\mathrm{Th} / \mathrm{U}$ & t.68 & 10 & t.75 & 10 & t.76 & 10 & concordância \\
\hline 16.1 & 2 & $\mathrm{e}$ & ov & $\mathrm{r} / \mathrm{hb}$ & 0.8005 & 0.0128 & 0.0992 & 0.0007 & 0.98 & 0.0585 & 0.0009 & 0.20 & 253 & 0.00 & 597 & 0.12 & 610 & 0 & 550 & 1 & 97.9 \\
\hline 17.1 & 2 & $\mathrm{e}$ & $\mathrm{p}$ & $\mathrm{r} / \mathrm{hb}$ & 1.0018 & 0.0203 & 0.1156 & 0.0009 & 0.93 & 0.0629 & 0.0014 & 0.99 & 88 & 0.05 & 705 & 0.20 & 705 & 0 & 703 & 1 & 99.9 \\
\hline 18.1 & 2 & $\mathrm{e}$ & $\mathrm{p}$ & $\mathrm{r} / \mathrm{hb}$ & 0.8267 & 0.0233 & 0.0988 & 0.0009 & 0.91 & 0.0607 & 0.0018 & 0.56 & 46 & 0.01 & 612 & 0.22 & 607 & 0 & 628 & 1 & 100.7 \\
\hline 18.2 & 2 & $\mathrm{~m}$ & p & $\mathrm{rx}$ & 2.5609 & 0.0580 & 0.1791 & 0.0017 & 0.99 & 0.1037 & 0.0025 & 1.06 & 55 & 0.26 & 1062 & 20.00 & 1290 & 32 & 1691 & 90 & 62.8 \\
\hline 19.1 & 2 & $\mathrm{~m}$ & $p$ & $\mathrm{r}$ & 5.7072 & 0.1331 & 0.3284 & 0.0036 & 0.88 & 0.1260 & 0.0031 & 0.18 & 29 & 0.24 & 1831 & 34.00 & 1932 & 40 & 2043 & 90 & 89.6 \\
\hline 20.1 & 2 & $\mathrm{e}$ & $\mathrm{p}$ & $\mathrm{hb}$ & 0.9105 & 0.0207 & 0.1109 & 0.0009 & 0.96 & 0.0595 & 0.0015 & 0.15 & 87 & 0.00 & 678 & 10.00 & 657 & 22 & 587 & 106 & 103.2 \\
\hline 21.1 & 2 & $\mathrm{~m}$ & $\mathrm{p}$ & $\mathrm{rx} / \mathrm{hb}$ & 0.8309 & 0.0160 & 0.1023 & 0.0008 & 0.99 & 0.0589 & 0.0011 & 0.17 & 168 & 0.00 & 628 & 10.00 & 614 & 18 & 564 & 80 & 102.3 \\
\hline 22.1 & 2 & $\mathrm{e}$ & $p$ & $\mathrm{osc} / \mathrm{hb}$ & 0.9246 & 0.0162 & 0.1144 & 0.0008 & 1.00 & 0.0586 & 0.0011 & 0.00 & 143 & 0.00 & 698 & 10.00 & 665 & 18 & 553 & 84 & 105.0 \\
\hline 23.1 & 2 & $\mathrm{c}$ & $\mathrm{p}$ & ic/rx & 0.7769 & 0.0208 & 0.0870 & 0.0008 & 0.98 & 0.0648 & 0.0016 & 4.49 & 44 & 0.33 & 538 & 10.00 & 584 & 22 & 766 & 106 & 92.1 \\
\hline 23.2 & 2 & $\mathrm{e}$ & $p$ & $\mathrm{hb}$ & 0.8167 & 0.0155 & 0.1015 & 0.0007 & 0.60 & 0.0584 & 0.0010 & 0.08 & 152 & 0.00 & 623 & 8.00 & 606 & 16 & 544 & 78 & 102.8 \\
\hline 24.1 & 2 & $\mathrm{e}$ & $p$ & $\mathrm{r} / \mathrm{hb}$ & 0.8335 & 0.0167 & 0.1030 & 0.0008 & 0.94 & 0.0587 & 0.0011 & 0.64 & 118 & 0.00 & 632 & 10.00 & 616 & 18 & 557 & 86 & 102.6 \\
\hline 25.1 & 2 & $\mathrm{~m}$ & $p$ & $\mathrm{rx}$ & 7.1768 & 0.1661 & 0.3890 & 0.0042 & 0.33 & 0.1338 & 0.0031 & 0.27 & 35 & 0.37 & 2134 & 2.96 & 2118 & 0 & 2149 & 6 & 99.3 \\
\hline 26.1 & 3 & $\mathrm{c}$ & ov & $\mathrm{rx}$ & 13.3440 & 0.5744 & 0.5061 & 0.0143 & 0.60 & 0.1912 & 0.0089 & 0.45 & 11 & 2.76 & 2704 & 10.86 & 2640 & 1 & 2753 & 19 & 98.2 \\
\hline 26.2 & 3 & $\mathrm{e}$ & ov & $\mathrm{r} / \mathrm{hb}$ & 0.9108 & 0.0227 & 0.1059 & 0.0009 & 0.73 & 0.0624 & 0.0016 & 2.73 & 72 & 0.01 & 657 & 0.22 & 649 & 0 & 687 & 1 & 101.3 \\
\hline 27.1 & 1 & $\mathrm{e}$ & $\mathrm{p}$ & $\mathrm{hb}$ & 1.2494 & 0.0270 & 0.1358 & 0.0011 & 0.99 & 0.0667 & 0.0017 & 0.22 & 58 & 0.02 & 823 & 0.30 & 821 & 0 & 829 & 1 & 100.3 \\
\hline 28.1 & 1 & $\mathrm{~m}$ & $p$ & $\mathrm{hb}$ & 0.9039 & 0.0196 & 0.1101 & 0.0009 & 0.91 & 0.0595 & 0.0013 & 0.33 & 73 & 0.01 & 673 & 10.00 & 654 & 22 & 587 & 98 & 102.9 \\
\hline 29.1 & 2 & $\mathrm{e}$ & $\mathrm{p}$ & $\mathrm{r} / \mathrm{hb}$ & 0.8574 & 0.0240 & 0.1041 & 0.0010 & 0.93 & 0.0597 & 0.0017 & 0.31 & 77 & 0.01 & 629 & 0.22 & 638 & 0 & 594 & 1 & 98.5 \\
\hline 30.1 & 2 & $\mathrm{c}$ & $p$ & $\mathrm{rx}$ & 6.9297 & 0.1526 & 0.3753 & 0.0038 & 0.69 & 0.1339 & 0.0029 & 0.12 & 40 & 0.65 & 2102 & 2.70 & 2054 & 0 & 2150 & 5 & 97.8 \\
\hline 31.1 & 3 & $\mathrm{c}$ & ov & $\mathrm{rx}$ & 11.4844 & 0.2677 & 0.4863 & 0.0059 & 0.73 & 0.1713 & 0.0040 & 0.40 & 33 & 1.45 & 2563 & 5.00 & 2555 & 0 & 2570 & 9 & 99.7 \\
\hline 31.2 & 3 & $\mathrm{e}$ & ov & $\mathrm{hb}$ & 0.9344 & 0.0167 & 0.1126 & 0.0008 & 0.90 & 0.0602 & 0.0010 & 0.07 & 154 & 0.00 & 688 & 10.00 & 670 & 18 & 611 & 74 & 102.7 \\
\hline 32.1 & 2 & $\mathrm{~m}$ & $\mathrm{p}$ & $\mathrm{hb}$ & 0.8363 & 0.0231 & 0.1021 & 0.0010 & 0.41 & 0.0594 & 0.0016 & 0.61 & 83 & 0.00 & 617 & 0.22 & 627 & 0 & 582 & 1 & 98.5 \\
\hline 33.1 & 1 & $\mathrm{e}$ & $\mathrm{p}$ & $\mathrm{hb}$ & 0.9173 & 0.0276 & 0.1130 & 0.0012 & 0.97 & 0.0589 & 0.0016 & 0.06 & 166 & 0.00 & 690 & 14.00 & 661 & 28 & 562 & 114 & 104.4 \\
\hline 34.1 & 3 & $\mathrm{c}$ & $\mathrm{p}$ & hd & 20.7921 & 0.5685 & 0.6240 & 0.0094 & 0.40 & 0.2416 & 0.0064 & 0.18 & 30 & 0.65 & 3129 & 11.02 & 3126 & 0 & 3131 & 18 & 99.9 \\
\hline 34.2 & 3 & $\mathrm{e}$ & $p$ & $\mathrm{osc} / \mathrm{hb}$ & 0.8608 & 0.0254 & 0.1039 & 0.0011 & 0.85 & 0.0601 & 0.0017 & 0.65 & 57 & 0.00 & 631 & 0.24 & 637 & 0 & 607 & 1 & 99.0 \\
\hline 35.1 & 2 & $\mathrm{e}$ & $p$ & $\mathrm{osc} / \mathrm{hb}$ & 0.8383 & 0.0246 & 0.1027 & 0.0010 & 0.93 & 0.0592 & 0.0017 & 0.08 & 74 & 0.00 & 618 & 0.22 & 630 & 0 & 574 & 1 & 98.1 \\
\hline 36.1 & 1 & $\mathrm{e}$ & ov & $\mathrm{hb}$ & 0.8149 & 0.0192 & 0.0992 & 0.0009 & 0.84 & 0.0596 & 0.0013 & 0.05 & 138 & 0.00 & 605 & 0.18 & 610 & 0 & 588 & 1 & 99.3 \\
\hline 37.1 & 1 & $\mathrm{e}$ & $\mathrm{p}$ & $\mathrm{hb}$ & 0.8099 & 0.0258 & 0.0995 & 0.0010 & 0.97 & 0.0590 & 0.0019 & 1.17 & 49 & 0.00 & 602 & 0.24 & 611 & 0 & 568 & 1 & 98.5 \\
\hline 38.1 & 1 & $\mathrm{e}$ & $\mathrm{p}$ & $\mathrm{r} / \mathrm{hb}$ & 1.2751 & 0.0353 & 0.1388 & 0.0013 & 0.93 & 0.0666 & 0.0019 & 0.31 & 64 & 0.07 & 835 & 0.40 & 838 & 0 & 826 & 1 & 99.6 \\
\hline 39.1 & 1 & $\mathrm{e}$ & $\mathrm{p}$ & $\mathrm{hb}$ & 0.8489 & 0.0228 & 0.1036 & 0.0010 & 0.79 & 0.0594 & 0.0015 & 1.22 & 97 & 0.00 & 624 & 0.22 & 635 & 0 & 583 & 1 & 98.2 \\
\hline 40.1 & 1 & $\mathrm{e}$ & $\mathrm{p}$ & $\mathrm{hb}$ & 0.8793 & 0.0354 & 0.1083 & 0.0013 & 0.70 & 0.0589 & 0.0023 & 0.77 & 46 & 0.01 & 663 & 16.00 & 641 & 38 & 562 & 170 & 103.4 \\
\hline 41.1 & 1 & $\mathrm{e}$ & $p$ & $\mathrm{hb}$ & 0.8809 & 0.0210 & 0.1054 & 0.0009 & 0.92 & 0.0606 & 0.0014 & 0.00 & 71 & 0.01 & 641 & 0.20 & 646 & 0 & 626 & 1 & 99.3 \\
\hline 42.1 & 1 & $\mathrm{e}$ & $\mathrm{p}$ & $\mathrm{hb}$ & 0.7038 & 0.0266 & 0.0870 & 0.0011 & 0.98 & 0.0587 & 0.0021 & 1.29 & 48 & 0.01 & 541 & 0.22 & 538 & 0 & 555 & 1 & 100.6 \\
\hline 43.1 & 2 & $\mathrm{e}$ & $\mathrm{p}$ & $\mathrm{hb}$ & 0.8315 & 0.0254 & 0.0988 & 0.0010 & 0.81 & 0.0610 & 0.0018 & 0.38 & 82 & 0.01 & 614 & 0.24 & 607 & 0 & 641 & 1 & 101.2 \\
\hline 44.1 & 2 & $\mathrm{e}$ & $p$ & $\mathrm{hb}$ & 0.8122 & 0.0242 & 0.0988 & 0.0010 & 0.89 & 0.0596 & 0.0017 & 0.09 & 76 & 0.00 & 604 & 0.22 & 607 & 0 & 590 & 1 & 99.4 \\
\hline 44.2 & 2 & $\mathrm{c}$ & $\mathrm{p}$ & hd & 7.4339 & 0.3781 & 0.3858 & 0.0085 & 0.33 & 0.1398 & 0.0077 & 0.46 & 12 & 1.08 & 2165 & 6.76 & 2103 & 0 & 2224 & 13 & 97.3 \\
\hline 45.1 & 1 & $\mathrm{e}$ & $\mathrm{p}$ & $\mathrm{hb}$ & 0.9600 & 0.0320 & 0.1153 & 0.0012 & 0.95 & 0.0604 & 0.0021 & 0.11 & 73 & 0.01 & 704 & 14.00 & 683 & 34 & 617 & 158 & 103.1 \\
\hline
\end{tabular}


Unidade Colônia: amostra CP-07 (continuação)

\begin{tabular}{|c|c|c|c|c|c|c|c|c|c|c|c|c|c|c|c|c|c|c|c|c|c|}
\hline spot & pop. & site & habit & CL & ${ }^{207} \mathrm{~Pb} /{ }^{235} \mathrm{U}$ & 10 & ${ }^{206} \mathrm{~Pb} /{ }^{238} \mathrm{U}$ & 10 & Rho & ${ }^{207} \mathrm{~Pb} /{ }^{206} \mathrm{~Pb}$ & 10 & Pb total & Pb rad & $\mathbf{T h} / \mathrm{U}$ & t.68 & 10 & t.75 & 10 & t.76 & 10 & concordância \\
\hline 46.1 & 1 & e & $\mathrm{p}$ & $\mathrm{hb}$ & 0.9774 & 0.0472 & 0.1176 & 0.0016 & 0.88 & 0.0603 & 0.0029 & 0.18 & 31 & 0.01 & 717 & 18.00 & 692 & 46 & 614 & 202 & 103.6 \\
\hline 47.1 & 2 & e & ov & $\mathrm{hb}$ & 0.9351 & 0.0283 & 0.1123 & 0.0012 & 0.97 & 0.0604 & 0.0017 & 0.12 & 89 & 0.00 & 686 & 14.00 & 670 & 30 & 618 & 124 & 102.4 \\
\hline 48.1 & 2 & $\mathrm{e}$ & $\mathrm{p}$ & $\mathrm{hb}$ & 0.8417 & 0.0233 & 0.1026 & 0.0010 & 0.97 & 0.0595 & 0.0016 & 1.36 & 130 & 0.00 & 620 & 0.22 & 630 & 0 & 585 & 1 & 98.5 \\
\hline 48.2 & 2 & $\mathrm{c}$ & $\mathrm{p}$ & hd & 3.8042 & 0.1242 & 0.2372 & 0.0030 & 0.99 & 0.1163 & 0.0034 & 0.77 & 96 & 0.64 & 1372 & 30.00 & 1594 & 46 & 1900 & 96 & 72.2 \\
\hline 49.1 & 2 & $\mathrm{e}$ & $\mathrm{p}$ & $\mathrm{hb}$ & 0.9335 & 0.0379 & 0.1132 & 0.0015 & 0.95 & 0.0598 & 0.0024 & 0.55 & 57 & 0.01 & 692 & 16.00 & 669 & 40 & 596 & 186 & 103.4 \\
\hline 50.1 & 2 & $\mathrm{c}$ & $p$ & hd & 4.5585 & 0.1155 & 0.2812 & 0.0029 & 0.99 & 0.1176 & 0.0031 & 5.66 & 70 & 0.19 & 1598 & 30.00 & 1742 & 46 & 1919 & 96 & 83.3 \\
\hline 50.2 & 2 & $\mathrm{e}$ & $\mathrm{p}$ & $\mathrm{hb}$ & 0.8713 & 0.0270 & 0.1064 & 0.0011 & 0.75 & 0.0594 & 0.0018 & 0.00 & 94 & 0.00 & 652 & 12.00 & 636 & 30 & 581 & 130 & 102.5 \\
\hline 51.1 & 1 & $\mathrm{e}$ & $\mathrm{p}$ & $\mathrm{hb}$ & 0.8858 & 0.0280 & 0.1079 & 0.0011 & 0.60 & 0.0595 & 0.0019 & 0.27 & 64 & 0.00 & 661 & 12.00 & 644 & 30 & 587 & 138 & 102.6 \\
\hline 52.1 & 2 & $\mathrm{e}$ & $p$ & $\mathrm{hb}$ & 0.7597 & 0.0166 & 0.0931 & 0.0011 & 0.99 & 0.0592 & 0.0011 & 0.10 & 146 & 0.00 & 574 & 0.15 & 574 & 0 & 574 & 1 & 100.0 \\
\hline 53.1 & 2 & $\mathrm{e}$ & $\mathrm{p}$ & $\mathrm{hb}$ & 0.9082 & 0.0180 & 0.1114 & 0.0011 & 0.97 & 0.0591 & 0.0012 & 0.52 & 120 & 0.00 & 681 & 12.00 & 656 & 20 & 572 & 88 & 103.8 \\
\hline 53.2 & 2 & $\mathrm{~m}$ & $p$ & hd & 0.8139 & 0.0171 & 0.0937 & 0.0009 & 0.95 & 0.0630 & 0.0013 & 3.00 & 64 & 0.15 & 577 & 10.00 & 605 & 20 & 708 & 88 & 95.4 \\
\hline 54.1 & 2 & $\mathrm{c}$ & $p$ & hd & 4.9107 & 0.1380 & 0.2808 & 0.0037 & 0.98 & 0.1268 & 0.0035 & 0.44 & 16 & 0.43 & 1596 & 36.00 & 1804 & 44 & 2054 & 92 & 77.7 \\
\hline 54.2 & 2 & $\mathrm{e}$ & $\mathrm{p}$ & $\mathrm{hb}$ & 0.6554 & 0.0274 & 0.0753 & 0.0010 & 0.98 & 0.0632 & 0.0026 & 2.45 & 22 & 0.01 & 468 & 12.00 & 512 & 32 & 714 & 182 & 91.4 \\
\hline 55.1 & 2 & $\mathrm{e}$ & $\mathrm{p}$ & $\mathrm{hb}$ & 0.9629 & 0.0227 & 0.1176 & 0.0011 & 0.99 & 0.0594 & 0.0016 & 0.80 & 79 & 0.00 & 717 & 14.00 & 685 & 24 & 581 & 112 & 104.7 \\
\hline 56.1 & 2 & $\mathrm{c}$ & $\mathrm{p}$ & osc & 13.1918 & 0.2455 & 0.4601 & 0.0052 & 0.76 & 0.2080 & 0.0038 & 10.06 & 40 & 0.30 & 2440 & 46.00 & 2693 & 34 & 2890 & 58 & 84.4 \\
\hline 56.2 & 2 & $\mathrm{e}$ & $p$ & osc & 1.6231 & 0.0367 & 0.1194 & 0.0014 & 0.01 & 0.0986 & 0.0022 & 0.95 & 91 & 0.05 & 727 & 16.00 & 979 & 28 & 1598 & 82 & 45.5 \\
\hline 57.1 & 2 & $\mathrm{e}$ & $\mathrm{p}$ & $\mathrm{hb}$ & 0.5417 & 0.0119 & 0.0644 & 0.0007 & 1.00 & 0.0610 & 0.0011 & 0.64 & 127 & 0.01 & 402 & 8.00 & 440 & 14 & 639 & 78 & 91.4 \\
\hline 58.1 & 2 & $\mathrm{~m}$ & ov & hd & 7.0691 & 0.1276 & 0.3924 & 0.0040 & 0.86 & 0.1307 & 0.0023 & 0.17 & 51 & 0.51 & 2120 & 2.28 & 2134 & 0 & 2107 & 4 & 100.6 \\
\hline 59.1 & 2 & $\mathrm{e}$ & $p$ & hd & 0.9816 & 0.0302 & 0.1141 & 0.0013 & 0.74 & 0.0624 & 0.0020 & 0.63 & 33 & 0.01 & 694 & 0.30 & 697 & 0 & 688 & 1 & 99.7 \\
\hline 60.1 & 1 & $\mathrm{c}$ & $\mathrm{p}$ & hd & 0.8691 & 0.0322 & 0.1059 & 0.0013 & 0.51 & 0.0595 & 0.0022 & 1.26 & 20 & 0.01 & 635 & 0.30 & 649 & 0 & 586 & 1 & 97.9 \\
\hline 61.1 & 2 & $\mathrm{c}$ & $\mathrm{p}$ & hd & 6.9084 & 0.1824 & 0.3735 & 0.0043 & 0.98 & 0.1341 & 0.0039 & 0.30 & 30 & 0.37 & 2100 & 3.24 & 2046 & 0 & 2153 & 6 & 97.5 \\
\hline 62.1 & 1 & $\mathrm{e}$ & $p$ & $\mathrm{hb}$ & 0.5686 & 0.0208 & 0.0699 & 0.0008 & 0.96 & 0.0590 & 0.0017 & 1.69 & 34 & 0.01 & 435 & 10.00 & 457 & 22 & 567 & 124 & 95.2 \\
\hline 63.1 & 1 & $\mathrm{e}$ & $p$ & $\mathrm{hb}$ & 0.9746 & 0.0213 & 0.1171 & 0.0009 & 0.97 & 0.0604 & 0.0014 & 0.34 & 96 & 0.01 & 714 & 10.00 & 691 & 22 & 617 & 100 & 103.3 \\
\hline 64.1 & 1 & $\mathrm{e}$ & $p$ & $\mathrm{hb}$ & 0.8833 & 0.0178 & 0.1075 & 0.0008 & 0.97 & 0.0596 & 0.0012 & 0.21 & 90 & 0.00 & 658 & 10.00 & 643 & 20 & 590 & 88 & 102.3 \\
\hline 64.2 & 1 & $\mathrm{~m}$ & $\mathrm{p}$ & $\mathrm{hb}$ & 0.8546 & 0.0153 & 0.1034 & 0.0007 & 0.93 & 0.0599 & 0.0011 & 0.16 & 117 & 0.00 & 627 & 0.14 & 634 & 0 & 602 & 1 & 98.9 \\
\hline 65.1 & 3 & $\mathrm{~m}$ & ov & hd & 6.8405 & 0.1270 & 0.3615 & 0.0030 & 0.82 & 0.1372 & 0.0027 & 0.30 & 51 & 0.30 & 2091 & 2.26 & 1989 & 0 & 2193 & 4 & 95.4 \\
\hline 66.1 & 2 & e & $\mathrm{p}$ & $\mathrm{hb}$ & 1.0579 & 0.0213 & 0.1293 & 0.0010 & 0.96 & 0.0594 & 0.0012 & 0.16 & 138 & 0.00 & 784 & 10.00 & 733 & 20 & 580 & 86 & 107.0 \\
\hline 67.1 & 2 & $\mathrm{~m}$ & $\mathrm{p}$ & hd & 10.2381 & 0.1861 & 0.4460 & 0.0038 & 0.90 & 0.1665 & 0.0031 & 0.22 & 54 & 0.32 & 2457 & 3.44 & 2377 & 0 & 2523 & 6 & 97.4 \\
\hline 68.1 & 1 & $\mathrm{e}$ & $\mathrm{p}$ & $\mathrm{hb}$ & 0.8225 & 0.0180 & 0.0996 & 0.0008 & 0.99 & 0.0599 & 0.0014 & 0.46 & 47 & 0.00 & 609 & 0.16 & 612 & 0 & 600 & 1 & 99.6 \\
\hline 69.1 & 2 & e & $p$ & $\mathrm{hb}$ & 0.9342 & 0.0188 & 0.1138 & 0.0008 & 0.99 & 0.0595 & 0.0013 & 4.05 & 69 & 0.05 & 695 & 10.00 & 670 & 20 & 586 & 96 & 103.7 \\
\hline 70.1 & 2 & $\mathrm{e}$ & $\mathrm{p}$ & $\mathrm{hb}$ & 0.9668 & 0.0299 & 0.1141 & 0.0011 & 0.89 & 0.0614 & 0.0020 & 0.28 & 45 & 0.01 & 687 & 0.30 & 697 & 0 & 655 & 1 & 98.6 \\
\hline 71.1 & 2 & $\mathrm{c}$ & $\mathrm{p}$ & hd & 7.6098 & 0.1757 & 0.3940 & 0.0041 & 0.70 & 0.1401 & 0.0036 & 0.18 & 22 & 0.27 & 2186 & 3.16 & 2141 & 0 & 2228 & 6 & 98.1 \\
\hline 71.2 & 2 & $\mathrm{e}$ & $\mathrm{p}$ & osc & 0.8002 & 0.0216 & 0.0956 & 0.0008 & 0.96 & 0.0607 & 0.0018 & 0.27 & 35 & 0.00 & 597 & 0.19 & 589 & 0 & 629 & 1 & 101.4 \\
\hline 72.1 & 1 & $\mathrm{~m}$ & $\mathrm{p}$ & $\mathrm{hb}$ & 0.9856 & 0.0204 & 0.1194 & 0.0009 & 0.99 & 0.0599 & 0.0014 & 0.59 & 72 & 0.00 & 727 & 10.00 & 696 & 22 & 599 & 102 & 104.5 \\
\hline 73.1 & 2 & $\mathrm{e}$ & ov & $\mathrm{hb}$ & 0.8743 & 0.0175 & 0.1049 & 0.0008 & 0.99 & 0.0604 & 0.0013 & 2.08 & 61 & 0.01 & 638 & 0.17 & 643 & 0 & 620 & 1 & 99.2 \\
\hline 74.1 & 1 & $\mathrm{~m}$ & $\mathrm{p}$ & hd & 0.7703 & 0.0204 & 0.0932 & 0.0008 & 0.97 & 0.0600 & 0.0018 & 1.23 & 45 & 0.00 & 580 & 0.18 & 574 & 0 & 602 & 1 & 101.0 \\
\hline 75.1 & 1 & $\mathrm{e}$ & $p$ & $\mathrm{hb}$ & 0.9325 & 0.0175 & 0.1149 & 0.0008 & 0.98 & 0.0589 & 0.0011 & 0.07 & 119 & 0.00 & 701 & 10.00 & 669 & 18 & 563 & 82 & 104.8 \\
\hline
\end{tabular}


Unidade Colônia: amostra CP-07 (continuação)

\begin{tabular}{|c|c|c|c|c|c|c|c|c|c|c|c|c|c|c|c|c|c|c|c|c|c|c|c|}
\hline spot & pop. & site & habit & CL & $206 *(\%)$ & ${ }^{204} \mathrm{~Pb} \mathrm{cps}$ & $\mathrm{Th} / \mathrm{U}$ & ${ }^{206} \mathrm{~Pb} /{ }^{204} \mathrm{~Pb}$ & 10 & ${ }^{207} \mathrm{~Pb} /{ }^{206} \mathrm{~Pb}$ & 10 & ${ }^{207} \mathbf{P b} /{ }^{235} \mathbf{U}$ & 10 & ${ }^{206} \mathrm{~Pb} /{ }^{238} \mathrm{U}$ & 10 & Rho & t.76 & $20^{\circ}$ & t.68 & $20^{\circ}$ & t.75 & $20^{\circ}$ & concordância \\
\hline 1 & 1 & $\mathrm{c}$ & $\mathrm{p}$ & hd & 0.1088 & 63 & 0.003 & 14319 & 27.74 & 0.06020 & 1.66 & 0.758 & 2.22 & 0.0913 & 1.43 & 0.64 & 573 & 19.44 & 563 & 15 & 611 & 74 & 101.7 \\
\hline 2 & 1 & $\mathrm{~m}$ & $p$ & hd & 0.1756 & 82 & 0.003 & 8869 & 21.39 & 0.05960 & 1.02 & 0.789 & 1.43 & 0.0960 & 0.94 & 0.65 & 591 & 12.80 & 591 & 11 & 589 & 47 & 99.9 \\
\hline 3 & 1 & c & $\mathrm{p}$ & ic/rx & 0.0793 & 100 & 0.003 & 19645 & 40.68 & 0.06063 & 1.40 & 0.717 & 1.82 & 0.0858 & 1.09 & 0.60 & 549 & 15.44 & 531 & 11 & 625 & 63 & 103.4 \\
\hline 4 & 1 & $\mathrm{c}$ & $\mathrm{p}$ & hd & 1.3169 & 278 & 0.006 & 1184 & 19.16 & 0.06709 & 2.79 & 0.598 & 4.04 & 0.0647 & 2.89 & 0.72 & 476 & 30.80 & 404 & 23 & 839 & 117 & 117.8 \\
\hline 5 & 1 & $\mathrm{~m}$ & $p$ & hd/osc & 0.0219 & 73 & 0.002 & 71096 & 70.74 & 0.05943 & 3.25 & 0.730 & 3.68 & 0.0891 & 1.69 & 0.46 & 557 & 31.60 & 550 & 18 & 583 & 142 & 101.2 \\
\hline 6 & 1 & $\mathrm{~m}$ & $p$ & osc & 0.0219 & 58 & 0.002 & 71197 & 49.13 & 0.05944 & 0.41 & 0.741 & 1.32 & 0.0904 & 1.20 & 0.91 & 563 & 11.40 & 558 & 13 & 584 & 24 & 100.9 \\
\hline 7 & 1 & $\mathrm{~m}$ & $\mathrm{p}$ & osc & 0.0280 & 75 & 0.003 & 55603 & 71.92 & 0.05912 & 1.77 & 0.734 & 2.18 & 0.0901 & 1.22 & 0.56 & 559 & 18.74 & 556 & 13 & 570 & 79 & 100.5 \\
\hline 8 & 2 & $\mathrm{~m}$ & $p$ & osc & 0.9542 & 180 & 0.009 & 1635 & 6.78 & 0.06885 & 2.25 & 0.502 & 3.51 & 0.0529 & 2.67 & 0.76 & 413 & 23.80 & 332 & 17 & 894 & 94 & 124.3 \\
\hline 9 & 1 & $\mathrm{~m}$ & $p$ & hd & 0.2963 & 425 & 0.002 & 5256 & 10.93 & 0.06126 & 0.66 & 0.805 & 1.91 & 0.0953 & 1.75 & 0.92 & 600 & 17.30 & 587 & 20 & 649 & 32 & 102.2 \\
\hline 10 & 1 & $\mathrm{~m}$ & $p$ & hd & 0.1598 & 140 & 0.004 & 9751 & 40.16 & 0.06244 & 1.81 & 0.711 & 2.41 & 0.0826 & 1.54 & 0.64 & 545 & 20.40 & 512 & 15 & 689 & 79 & 106.6 \\
\hline 11 & 1 & $\mathrm{~m}$ & $\mathrm{p}$ & osc/rx & 0.0368 & 67 & 0.002 & 42366 & 44.54 & 0.06005 & 0.59 & 0.742 & 1.46 & 0.0896 & 1.28 & \begin{tabular}{|l|}
0.88 \\
\end{tabular} & 564 & 12.62 & 553 & 14 & 606 & 30 & 101.9 \\
\hline 12 & 1 & $\mathrm{~m}$ & $p$ & osc & 0.5118 & 377 & 0.002 & 3044 & 9.76 & 0.06226 & 0.72 & 0.717 & 1.45 & 0.0835 & 1.20 & 0.83 & 549 & 12.30 & 517 & 12 & 684 & 35 & 106.2 \\
\hline 13 & 1 & $\mathrm{~m}$ & $p$ & hd & 0.4931 & 334 & 0.004 & 3160 & 11.26 & 0.06326 & 0.61 & 0.762 & 1.54 & 0.0873 & 1.36 & 0.89 & 575 & 13.52 & 540 & 14 & 719 & 30 & 106.6 \\
\hline 15.1 & 1 & $\mathrm{e}$ & $p$ & osc & 0.7678 & 345 & 0.003 & 2029 & 23.66 & 0.06612 & 2.59 & 0.791 & 3.51 & 0.0868 & 2.34 & 0.67 & 592 & 31.40 & 537 & 24 & 809 & 109 & 110.3 \\
\hline 15.2 & 1 & $\mathrm{c}$ & $p$ & $\mathrm{ic} / \mathrm{rx}$ & 0.1991 & 107 & 0.003 & 7824 & 24.67 & 0.06439 & 2.16 & 0.821 & 3.23 & 0.0925 & 2.37 & 0.74 & 609 & 29.60 & 570 & 26 & 754 & 92 & 106.7 \\
\hline 16 & 1 & $\mathrm{~m}$ & $p$ & osc/ic & 0.0119 & 102 & 0.004 & 130601 & 80.42 & 0.06046 & 0.69 & 0.773 & 1.23 & 0.0927 & 0.95 & 0.77 & 581 & 10.90 & 571 & 10 & 621 & 34 & 101.7 \\
\hline 17 & 1 & $\mathrm{e}$ & $p$ & $\mathrm{hd} / \mathrm{rx}$ & 0.0391 & 65 & 0.001 & 39861 & 25.54 & 0.06034 & 0.86 & 0.771 & 1.54 & 0.0927 & 1.22 & 0.79 & 580 & 13.62 & 571 & 13 & 615 & 41 & 101.5 \\
\hline 18 & 1 & $\mathrm{~m}$ & $p$ & $\mathrm{hd} / \mathrm{rx}$ & 0.3190 & 214 & 0.003 & 4882 & 12.93 & 0.06099 & 0.67 & 0.815 & 1.30 & 0.0969 & 1.05 & 0.81 & 605 & 11.86 & 596 & 12 & 639 & 33 & 101.5 \\
\hline 19 & 1 & $\mathrm{c}$ & $p$ & $\mathrm{ic} / \mathrm{rx}$ & 0.0562 & 191 & 0.002 & 27724 & 77.35 & 0.06657 & 1.52 & 0.682 & 2.97 & 0.0743 & 2.53 & 0.85 & 528 & 24.40 & 462 & 23 & 824 & 65 & 114.3 \\
\hline 20.1 & 1 & $\mathrm{e}$ & $p$ & osc & 0.0570 & 39 & 0.004 & 27341 & 35.79 & 0.06045 & 2.05 & 0.767 & 2.35 & 0.0920 & 1.09 & 0.46 & 578 & 20.80 & 567 & 12 & 620 & 90 & 101.9 \\
\hline 20.2 & 1 & c & $p$ & hd & 0.0100 & 72 & 0.003 & 156172 & 52.04 & 0.06002 & 0.56 & 0.752 & 1.20 & 0.0908 & 1.00 & 0.83 & 569 & 10.46 & 560 & 11 & 606 & 29 & 101.6 \\
\hline 21 & 1 & $\mathrm{~m}$ & $p$ & hd & 0.0307 & 170 & 0.003 & 50781 & 76.13 & 0.05901 & 0.59 & 0.758 & 1.03 & 0.0932 & 0.76 & 0.74 & 573 & 9.02 & 574 & 8 & 567 & 30 & 99.7 \\
\hline 22 & 1 & $\mathrm{e}$ & $p$ & hd & 0.0099 & 39 & 0.002 & 157674 & 43.20 & 0.06003 & 0.53 & 0.774 & 0.99 & 0.0936 & 0.75 & 0.76 & 582 & 8.78 & 577 & 8 & 603 & 28 & 100.9 \\
\hline 23 & 1 & $\mathrm{~m}$ & $p$ & hd & 0.0229 & 62 & 0.002 & 67916 & 70.49 & 0.06042 & 0.60 & 0.778 & 0.97 & 0.0933 & 0.66 & 0.68 & 584 & 8.62 & 575 & 7 & 621 & 31 & 101.6 \\
\hline 24 & 1 & $\mathrm{e}$ & $p$ & osc/rx & 0.0278 & 60 & 0.002 & 56057 & 69.49 & 0.06045 & 0.67 & 0.779 & 1.27 & 0.0935 & 1.01 & 0.80 & 585 & 11.30 & 576 & 11 & 619 & 33 & 101.5 \\
\hline 25 & 1 & $\mathrm{e}$ & $p$ & hd & 0.1698 & 114 & 0.002 & 9177 & 29.36 & 0.06083 & 0.86 & 0.680 & 1.58 & 0.0811 & 1.27 & \begin{tabular}{|l|}
0.81 \\
\end{tabular} & 527 & 12.98 & 503 & 12 & 633 & 40 & 104.8 \\
\hline 26.1 & 1 & $\mathrm{e}$ & $\mathrm{p}$ & hd & 0.0437 & 54 & 0.003 & 35666 & 20.50 & 0.06016 & 0.52 & 0.802 & 1.00 & 0.0967 & 0.78 & \begin{tabular}{|l|}
0.77 \\
\end{tabular} & 598 & 9.04 & 595 & 9 & 609 & 28 & 100.5 \\
\hline 26.2 & 1 & $\mathrm{c}$ & $p$ & $\mathrm{ic} / \mathrm{rx}$ & 0.0606 & 97 & 0.008 & 25711 & 34.97 & 0.07391 & 2.63 & 0.847 & 3.22 & 0.0831 & 1.81 & 0.56 & 623 & 30.00 & 515 & 18 & 1039 & 108 & 59.9 \\
\hline 27 & 1 & $\mathrm{~m}$ & $p$ & osc/rx & 0.0156 & 37 & 0.002 & 99859 & 43.38 & 0.06072 & 0.73 & 0.802 & 1.15 & 0.0958 & 0.80 & 0.70 & 598 & 10.40 & 590 & 9 & 629 & 35 & 101.4 \\
\hline 28 & 1 & $\mathrm{c}$ & $p$ & $\mathrm{ic} / \mathrm{rx}$ & 0.0073 & 39 & 0.007 & 214285 & 32.93 & 0.06540 & 1.09 & 0.845 & 1.48 & 0.0937 & \begin{tabular}{|l|l|}
0.94 \\
\end{tabular} & 0.63 & 622 & 13.76 & 577 & 10 & 787 & 48 & 107.7 \\
\hline 29 & 1 & $\mathrm{~m}$ & $p$ & mix ic & 0.1236 & 156 & 0.006 & 12599 & 36.03 & 0.06300 & 0.59 & 0.815 & 0.94 & 0.0938 & 0.63 & 0.67 & 605 & 8.58 & 578 & 7 & 709 & 30 & 104.7 \\
\hline 30 & 1 & $\mathrm{e}$ & $p$ & osc/rx & 0.0081 & 51 & 0.003 & 191113 & 48.19 & 0.06069 & 0.39 & 0.780 & 0.75 & 0.0932 & 0.51 & 0.69 & 585 & 6.68 & 574 & 6 & 629 & 23 & 101.9 \\
\hline 31 & 1 & $\mathrm{~m}$ & $p$ & $\mathrm{hd} / \mathrm{rx}$ & 0.0434 & 119 & 0.003 & 35852 & 73.38 & 0.05988 & 0.90 & 0.782 & 1.12 & 0.0948 & 0.57 & 0.50 & 587 & 9.98 & 584 & 6 & 597 & 42 & 100.5 \\
\hline 32 & 1 & $\mathrm{e}$ & p & hd/rx & 0.0048 & 18 & 0.002 & 324188 & 21.30 & 0.06028 & 0.51 & 0.753 & 1.10 & 0.0906 & 0.90 & 0.82 & 570 & 9.60 & 559 & 10 & 614 & 27 & 101.9 \\
\hline
\end{tabular}


Unidade Colônia: amostra CP-07 (continuação)

\begin{tabular}{|c|c|c|c|c|c|c|c|c|c|c|c|c|c|c|c|c|c|c|c|c|c|c|c|}
\hline spot & pop. & site & habit & CL & $206 *(\%)$ & \begin{tabular}{|l|}
${ }^{204} \mathrm{~Pb}$ cps \\
\end{tabular} & $\mathbf{T h} / \mathrm{U}$ & ${ }^{206} \mathrm{~Pb} /{ }^{204} \mathrm{~Pb}$ & 10 & ${ }^{207} \mathrm{~Pb} /{ }^{206} \mathrm{~Pb}$ & 10 & ${ }^{207} \mathrm{~Pb} /{ }^{235} \mathrm{U}$ & 10 & ${ }^{206} \mathrm{~Pb} /{ }^{238} \mathrm{U}$ & 10 & Rho & t.76 & $20^{\circ}$ & t.68 & $20^{\circ}$ & t.75 & 20 & concordância \\
\hline 33 & 1 & $\mathrm{c}$ & $\mathrm{p}$ & $\mathrm{ic} / \mathrm{rx}$ & 0.0077 & 34 & 0.002 & 203054 & 41.57 & 0.06045 & 0.63 & 0.743 & 1.10 & 0.0891 & 0.82 & 0.75 & 564 & 9.52 & 550 & 9 & 621 & 31 & 102.5 \\
\hline 34 & 1 & $\mathrm{~m}$ & $\mathrm{p}$ & $\mathrm{hd} / \mathrm{rx}$ & 0.0184 & 163 & 0.003 & 84770 & 52.72 & 0.05894 & 0.86 & 0.757 & 1.19 & 0.0932 & 0.73 & 0.62 & 572 & 10.42 & 574 & 8 & 564 & 41 & 99.6 \\
\hline 35 & 1 & $\mathrm{~m}$ & $\mathrm{p}$ & osc & 0.1035 & 78 & 0.002 & 15052 & 21.62 & 0.06123 & 0.63 & 0.735 & 1.14 & 0.0870 & 0.88 & 0.77 & 559 & 9.80 & 538 & 9 & 649 & 31 & 104.0 \\
\hline 36 & 1 & $\mathrm{e}$ & $\mathrm{p}$ & hd & 0.0144 & 39 & 0.013 & 108005 & 53.08 & 0.07527 & 2.05 & 1.152 & 2.84 & 0.1110 & 1.93 & 0.68 & 778 & 30.80 & 679 & 25 & 1076 & 84 & 72.3 \\
\hline 37 & 1 & $\mathrm{~m}$ & $\mathrm{p}$ & $\mathrm{hd} / \mathrm{rx}$ & 0.0056 & 14 & 0.003 & 276879 & 27.45 & 0.06027 & 0.67 & 0.742 & 1.34 & 0.0892 & 1.09 & 0.82 & 564 & 11.60 & 551 & 12 & 616 & 33 & 102.3 \\
\hline 38.1 & 2 & $\mathrm{e}$ & $\mathrm{p}$ & osc/rx & 0.0060 & 36 & 0.003 & 258225 & 37.62 & 0.06061 & 0.43 & 0.755 & 0.93 & 0.0904 & 0.74 & 0.80 & 571 & 8.12 & 558 & 8 & 624 & 24 & 102.4 \\
\hline 38.2 & 2 & $\mathrm{c}$ & $p$ & $\mathrm{ic} / \mathrm{rx}$ & 0.1045 & 96 & 0.119 & 14752 & 13.35 & 0.15055 & 1.06 & 5.000 & 2.12 & 0.2409 & 1.80 & 0.85 & 1819 & 35.80 & 1391 & 45 & 2352 & 38 & 77.4 \\
\hline 39 & 2 & $\mathrm{~m}$ & $\mathrm{p}$ & $\mathrm{rx}$ & 0.0211 & 68 & 0.002 & 73809 & 79.04 & 0.06219 & 1.29 & 0.731 & 1.62 & 0.0852 & 0.91 & 0.56 & 557 & 13.90 & 527 & 9 & 682 & 57 & 105.7 \\
\hline 40 & 2 & $\mathrm{c}$ & $p$ & osc & 0.0556 & 106 & 0.002 & 28028 & 14.19 & 0.06033 & 0.51 & 0.788 & 1.16 & 0.0947 & \begin{tabular}{|l|}
0.98 \\
\end{tabular} & 0.84 & 590 & 10.38 & 583 & 11 & 616 & 27 & 101.2 \\
\hline 41 & 1 & $\mathrm{e}$ & $p$ & osc/rx & 0.0090 & 28 & 0.002 & 172836 & 35.89 & 0.06007 & 0.46 & 0.769 & 0.81 & 0.0929 & 0.55 & 0.68 & 579 & 7.16 & 573 & 6 & 605 & 26 & 101.1 \\
\hline 42 & 1 & $\mathrm{e}$ & $p$ & hd & 0.0489 & 58 & 0.004 & 31872 & 25.90 & 0.06069 & 0.52 & 0.773 & 1.28 & 0.0924 & 1.11 & 0.87 & 581 & 11.34 & 570 & 12 & 628 & 27 & 102.1 \\
\hline 43 & 3 & $\mathrm{~m}$ & ov & hd & 0.0044 & 13 & 0.276 & 343537 & 14.88 & 0.13502 & 0.56 & 6.603 & 0.86 & 0.3547 & 0.54 & 0.62 & 2060 & 15.16 & 1957 & 18 & 2164 & 24 & 95.2 \\
\hline 44 & 2 & $\mathrm{~m}$ & $\mathrm{p}$ & $\mathrm{hd} / \mathrm{rx}$ & 0.0017 & 33 & 0.001 & 902920 & 31.95 & 0.05974 & 0.39 & 0.793 & 0.74 & 0.0963 & 0.51 & 0.69 & 593 & 6.64 & 593 & 6 & 594 & 23 & 100.0 \\
\hline 45 & 2 & $\mathrm{~m}$ & $\mathrm{p}$ & rx & 0.2423 & 173 & 0.003 & 6428 & 5.30 & 0.06174 & 0.58 & 0.790 & 0.95 & 0.0928 & 0.65 & 0.69 & 591 & 8.52 & 572 & 7 & 665 & 29 & 103.3 \\
\hline 46 & 2 & $\mathrm{~m}$ & $\mathrm{p}$ & $\mathrm{rx}$ & 0.0076 & 31 & 0.029 & 204459 & 23.42 & 0.06524 & 1.13 & 0.856 & 1.31 & 0.0952 & 0.55 & 0.42 & 628 & 12.26 & 586 & 6 & 781 & 50 & 107.1 \\
\hline 47 & 1 & $\mathrm{~m}$ & $\mathrm{p}$ & $\mathrm{hd} / \mathrm{rx}$ & 0.0086 & 40 & 0.003 & 181984 & 36.16 & 0.06083 & 0.33 & 0.785 & 0.79 & 0.0935 & 0.61 & 0.78 & 588 & 7.06 & 576 & 7 & 635 & 21 & 102.1 \\
\hline 48.1 & 2 & $\mathrm{e}$ & $p$ & hd & 0.1094 & 103 & 0.002 & 14246 & 25.46 & 0.06144 & 0.56 & 0.735 & 0.89 & 0.0867 & 0.57 & 0.65 & 559 & 7.66 & 536 & 6 & 656 & 29 & 104.4 \\
\hline 48.2 & 2 & c & $p$ & $\mathrm{ic} / \mathrm{rx}$ & 0.4437 & 1091 & 0.211 & 2898 & 18.53 & 0.40698 & 5.03 & 44.312 & 5.40 & 0.7896 & 1.92 & 0.35 & 3872 & 107.20 & 3752 & 109 & 3935 & 152 & 98.4 \\
\hline 49 & 2 & $\mathrm{~m}$ & $p$ & $\mathrm{hb}$ & 0.0202 & 36 & 0.139 & 77133 & 33.90 & 0.09647 & 0.53 & 1.762 & 0.98 & 0.1324 & 0.73 & 0.75 & 1032 & 12.70 & 802 & 11 & 1558 & 24 & 66.2 \\
\hline 50 & 1 & $\mathrm{e}$ & $p$ & $\mathrm{hd} / \mathrm{rx}$ & 0.0407 & 54 & 0.002 & 38257 & 23.88 & 0.05993 & 0.52 & 0.765 & 0.94 & 0.0926 & 0.69 & 0.73 & 577 & 8.28 & 571 & 8 & 601 & 28 & 101.0 \\
\hline 51 & 3 & $\mathrm{c}$ & ov & ic/rx & 0.1409 & 120 & 0.457 & 10942 & 11.31 & 0.12450 & 0.68 & 4.188 & 1.65 & 0.2439 & 1.46 & 0.88 & 1672 & 27.00 & 1407 & 37 & 2022 & 28 & 82.7 \\
\hline 52 & 2 & $\mathrm{~m}$ & $\mathrm{p}$ & $\mathrm{hd} / \mathrm{rx}$ & 0.0019 & 25 & 0.003 & 813692 & 21.12 & 0.06066 & 0.46 & 0.768 & 0.95 & 0.0918 & 0.75 & \begin{tabular}{|l|}
0.79 \\
\end{tabular} & 579 & 8.38 & 566 & 8 & 628 & 25 & 102.2 \\
\hline 53.1 & 2 & $\mathrm{e}$ & $p$ & $\mathrm{rx}$ & 0.0170 & 64 & 0.001 & 91540 & 69.85 & 0.06061 & 0.52 & 0.781 & 0.93 & 0.0934 & 0.67 & 0.73 & 586 & 8.28 & 576 & 7 & 627 & 27 & 101.8 \\
\hline 53.2 & 2 & $\mathrm{c}$ & $p$ & $\mathrm{rx}$ & 0.0165 & 93 & 0.002 & 94817 & 67.35 & 0.06052 & 0.73 & 0.453 & 3.35 & 0.0542 & 3.25 & 0.97 & 379 & 21.20 & 340 & 22 & 626 & 35 & 111.5 \\
\hline 54 & 2 & $\mathrm{c}$ & $p$ & $\mathrm{rx}$ & 0.0313 & 52 & 0.033 & 49550 & 29.51 & 0.14065 & 1.10 & 3.230 & 1.75 & 0.1665 & 1.31 & \begin{tabular}{|l|}
0.75 \\
\end{tabular} & 1464 & 27.20 & 993 & 24 & 2236 & 40 & 65.5 \\
\hline 55 & 2 & $\mathrm{~m}$ & $\mathrm{p}$ & $\mathrm{hd} / \mathrm{rx}$ & 0.0249 & 46 & 0.002 & 62545 & 28.11 & 0.06129 & 0.41 & 0.778 & 0.88 & 0.0921 & 0.69 & 0.78 & 584 & 7.82 & 568 & 8 & 649 & 24 & 102.9 \\
\hline 56 & 3 & $\mathrm{~m}$ & ov & $\mathrm{rx}$ & 0.0163 & 51 & 0.013 & 95747 & 40.43 & 0.06401 & 3.30 & 0.773 & 3.63 & 0.0876 & 1.46 & 0.40 & 582 & 32.20 & 541 & 15 & 742 & 141 & 107.4 \\
\hline 57 & 2 & $\mathrm{e}$ & $\mathrm{p}$ & $\mathrm{hd} / \mathrm{rx}$ & 0.0027 & 30 & 0.002 & 577292 & 33.66 & 0.06080 & 0.52 & 0.772 & 0.82 & 0.0921 & 0.51 & 0.62 & 581 & 7.26 & 568 & 6 & 632 & 28 & 102.3 \\
\hline 58 & 2 & $\mathrm{~m}$ & $\mathrm{p}$ & osc/rx & 0.0051 & 23 & 0.002 & 302545 & 29.18 & 0.05995 & 0.33 & 0.768 & 0.70 & 0.0929 & 0.50 & 0.71 & 579 & 6.18 & 573 & 5 & 602 & 21 & 101.0 \\
\hline 59 & 1 & $\mathrm{c}$ & $\mathrm{p}$ & $\operatorname{mix}$ ic & 0.0079 & 32 & 0.003 & 197414 & 34.40 & 0.06062 & 0.61 & 0.768 & 1.10 & 0.0918 & 0.83 & 0.76 & 579 & 9.70 & 566 & 9 & 628 & 31 & 102.2 \\
\hline 60 & 1 & $\mathrm{~m}$ & $\mathrm{p}$ & $\mathrm{hd} / \mathrm{rx}$ & 0.0079 & 31 & 0.003 & 198314 & 36.37 & 0.06060 & 0.61 & 0.772 & 0.99 & 0.0924 & 0.69 & 0.69 & 581 & 8.76 & 570 & 8 & 625 & 31 & 102.0 \\
\hline 61 & 2 & $\mathrm{~m}$ & $\mathrm{p}$ & hd & 0.0136 & 32 & 0.002 & 114773 & 28.29 & 0.06116 & 0.37 & 0.776 & 0.71 & 0.0920 & \begin{tabular}{|l|}
0.48 \\
\end{tabular} & 0.68 & 583 & 6.30 & 567 & 5 & 645 & 22 & 102.8 \\
\hline 62 & 2 & $\mathrm{e}$ & $\mathrm{p}$ & hd & 0.0064 & 32 & 0.002 & 241680 & 29.48 & 0.06034 & 0.41 & 0.773 & 0.79 & 0.0929 & 0.57 & 0.72 & 581 & 7.00 & 573 & 6 & 616 & 24 & 101.5 \\
\hline 63 & 3 & $\mathrm{~m}$ & ov & $\mathrm{rx}$ & 0.0241 & 123 & 0.020 & 64661 & 59.79 & 0.05922 & 0.76 & 0.753 & 1.00 & 0.0922 & 0.54 & 0.54 & 570 & 8.72 & 569 & 6 & 576 & 37 & 100.2 \\
\hline 64 & 3 & $\mathrm{~m}$ & ov & osc/rx & 1.1800 & 1756 & 0.018 & 1320 & 13.30 & 0.10427 & 3.78 & 1.201 & 4.56 & 0.0835 & 2.52 & 0.55 & 801 & 50.60 & 517 & 25 & 1702 & 140 & 47.1 \\
\hline 65 & 2 & $\mathrm{c}$ & $\mathrm{p}$ & ic & 0.0224 & 33 & 0.002 & 69469 & 35.42 & 0.06124 & 0.48 & 0.746 & 1.08 & 0.0883 & 0.89 & 0.83 & 566 & 9.38 & 545 & 9 & 649 & 26 & 103.7 \\
\hline 66.1 & 2 & $\mathrm{e}$ & $\mathrm{p}$ & osc & 0.0341 & 64 & 0.003 & 45626 & 11.74 & 0.06044 & 0.36 & 0.787 & 0.74 & 0.0945 & \begin{tabular}{|l|}
0.53 \\
\end{tabular} & \begin{tabular}{|l|}
0.72 \\
\end{tabular} & 589 & 6.62 & 582 & 6 & 618 & 22 & 101.3 \\
\hline
\end{tabular}


Unidade Colônia: amostra CP-07 (continuação)

\begin{tabular}{|c|c|c|c|c|c|c|c|c|c|c|c|c|c|c|c|c|c|c|c|c|c|c|c|}
\hline spot & pop. & site & habit & CL & 206* (\%) & ${ }^{204} \mathrm{~Pb}$ cps & $\mathrm{Th} / \mathrm{U}$ & ${ }^{206} \mathrm{~Pb} /{ }^{204} \mathrm{~Pb}$ & 10 & ${ }^{207} \mathrm{~Pb} /{ }^{206} \mathrm{~Pb}$ & 10 & ${ }^{207} \mathrm{~Pb} /{ }^{235} \mathrm{U}$ & 10 & ${ }^{206} \mathrm{~Pb} /{ }^{238} \mathrm{U}$ & 10 & Rho & t.76 & 20 & t.68 & 20 & t.75 & 20 & concordância \\
\hline 66.2 & 2 & $\mathrm{c}$ & $\mathrm{p}$ & ic & 0.0131 & 52 & 0.359 & 117149 & 46.01 & 0.13185 & 0.48 & 5.482 & 1.37 & 0.3016 & 1.23 & 0.90 & 1898 & 23.60 & 1699 & 37 & 2123 & 21 & 89.4 \\
\hline 67 & 3 & $\mathrm{c}$ & ov & $\mathrm{ic} / \mathrm{rx}$ & 0.3233 & 444 & 0.002 & 4815 & 21.46 & 0.05421 & 1.50 & 0.761 & 1.94 & 0.1018 & 1.17 & 0.60 & 575 & 17.02 & 625 & 14 & 380 & 70 & 91.9 \\
\hline 68 & 1 & $\mathrm{c}$ & $\mathrm{p}$ & $\mathrm{rx}$ & 0.1549 & 145 & 0.244 & 9990 & 19.69 & 0.11741 & 2.36 & 3.252 & 2.65 & 0.2009 & 1.16 & 0.44 & 1470 & 41.20 & 1180 & 25 & 1917 & 85 & 76.7 \\
\hline 69 & 2 & $\mathrm{~m}$ & $\mathrm{p}$ & $\mathrm{rx}$ & 0.0070 & 32 & 0.007 & 221600 & 36.78 & 0.06055 & 0.43 & 0.764 & 0.76 & 0.0916 & 0.50 & 0.66 & 576 & 6.68 & 565 & 5 & 621 & 25 & 102.0 \\
\hline 70 & 1 & $\mathrm{c}$ & $p$ & ic/rx & 0.0074 & 31 & 0.031 & 210727 & 47.61 & 0.07606 & 1.05 & 1.078 & 1.44 & 0.1028 & 0.91 & 0.63 & 743 & 15.18 & 631 & 11 & 1097 & 45 & 67.7 \\
\hline 71 & 2 & $\mathrm{~m}$ & $\mathrm{p}$ & $\mathrm{rx} / \mathrm{hd}$ & 0.0024 & 13 & 0.002 & 656910 & 15.34 & 0.06003 & 0.38 & 0.768 & 0.79 & 0.0928 & 0.59 & 0.74 & 579 & 6.96 & 572 & 6 & 604 & 23 & 101.1 \\
\hline 72.1 & 2 & $\mathrm{e}$ & $\mathrm{p}$ & $\mathrm{rx}$ & 0.0039 & 60 & 0.002 & 402508 & 83.61 & 0.06066 & 0.46 & 0.778 & 0.98 & 0.0931 & 0.78 & 0.80 & 584 & 8.70 & 574 & 9 & 625 & 25 & 101.8 \\
\hline 72.2 & 2 & $\mathrm{c}$ & $p$ & ic/rx & 3.4979 & 3048 & 0.093 & 444 & 14.08 & 0.18898 & 4.50 & 4.129 & 4.96 & 0.1584 & 2.04 & 0.41 & 1660 & 81.00 & 948 & 36 & 2734 & 149 & 60.7 \\
\hline 73 & 1 & $\mathrm{~m}$ & $\mathrm{p}$ & osc/rx & 0.0033 & 28 & 0.003 & 475394 & 28.63 & 0.06093 & 0.42 & 0.784 & 1.35 & 0.0933 & 1.23 & 0.91 & 588 & 12.04 & 575 & 14 & 637 & 24 & 102.2 \\
\hline 74 & 2 & $\mathrm{~m}$ & $\mathrm{p}$ & $\mathrm{sz}$ & 0.1050 & 132 & 0.025 & 14831 & 7.57 & 0.06359 & 1.23 & 0.820 & 1.44 & 0.0935 & 0.64 & 0.45 & 608 & 13.18 & 576 & 7 & 729 & 55 & 105.5 \\
\hline 75 & 1 & $\mathrm{~m}$ & $\mathrm{p}$ & $\mathrm{hd} / \mathrm{rx}$ & 0.0150 & 44 & 0.002 & 103799 & 52.81 & 0.06033 & 0.34 & 0.803 & 0.71 & 0.0965 & 0.50 & 0.71 & 599 & 6.42 & 594 & 6 & 616 & 22 & 100.8 \\
\hline 76 & 2 & $\mathrm{~m}$ & $\mathrm{p}$ & $\mathrm{rx}$ & 0.0050 & 30 & 0.002 & 314602 & 33.47 & 0.06028 & 0.41 & 0.777 & 0.82 & 0.0935 & 0.61 & 0.74 & 584 & 7.28 & 576 & 7 & 613 & 24 & 101.3 \\
\hline 77 & 2 & $\mathrm{~m}$ & $\mathrm{p}$ & $\mathrm{rx}$ & 0.0871 & 126 & 0.011 & 17876 & 10.31 & 0.07895 & 0.88 & 1.133 & 1.24 & 0.1041 & 0.79 & 0.64 & 769 & 13.38 & 638 & 10 & 1171 & 38 & 65.7 \\
\hline 78 & 3 & $\mathrm{~m}$ & ov & $\mathrm{ic} / \mathrm{rx}$ & 0.6249 & 276 & 0.012 & 2493 & 4.61 & 0.06894 & 0.84 & 0.846 & 1.05 & 0.0890 & 0.52 & 0.49 & 622 & 9.78 & 550 & 5 & 897 & 38 & 113.3 \\
\hline 79 & 2 & $\mathrm{~m}$ & $\mathrm{p}$ & $\mathrm{rx}$ & 0.0944 & 113 & 0.002 & 16510 & 4.67 & 0.06133 & 0.44 & 0.738 & 0.92 & 0.0872 & 0.72 & 0.78 & 561 & 7.94 & 539 & 7 & 653 & 25 & 104.1 \\
\hline 80 & 2 & $\mathrm{~m}$ & $\mathrm{p}$ & $\mathrm{rx}$ & 0.0067 & 20 & 0.003 & 233379 & 19.93 & 0.05976 & 0.54 & 0.763 & 0.97 & 0.0926 & 0.72 & 0.74 & 576 & 8.52 & 571 & 8 & 595 & 28 & 100.8 \\
\hline 81 & 3 & c & ov & ic/rx & 0.5533 & 521 & 0.187 & 2810 & 4.49 & 0.10797 & 2.23 & 1.845 & 3.41 & 0.1239 & 2.55 & 0.75 & 1062 & 45.00 & 753 & 36 & 1766 & 82 & 60.1 \\
\hline 82 & 2 & $\mathrm{c}$ & $\mathrm{p}$ & $\mathrm{hd} / \mathrm{rx}$ & 0.0144 & 322 & 0.360 & 104987 & 54.54 & 0.13686 & 0.63 & 7.383 & 1.95 & 0.3912 & 1.81 & 0.93 & 2159 & 34.80 & 2128 & 66 & 2188 & 25 & 98.7 \\
\hline 83 & 2 & $\mathrm{~m}$ & $\mathrm{p}$ & $\mathrm{hb} / \mathrm{rx}$ & 0.0127 & 63 & 0.235 & 119679 & 63.83 & 0.13432 & 0.65 & 6.203 & 1.35 & 0.3349 & 1.12 & 0.83 & 2005 & 23.60 & 1862 & 36 & 2155 & 26 & 93.0 \\
\hline 84 & 1 & $\mathrm{e}$ & $\mathrm{p}$ & $\mathrm{hd} / \mathrm{rx}$ & 0.0043 & 51 & 0.002 & 364829 & 47.62 & 0.05947 & 0.47 & 0.789 & 0.83 & 0.0963 & 0.57 & 0.69 & 591 & 7.44 & 593 & 6 & 583 & 26 & 99.6 \\
\hline 86 & 2 & $\mathrm{e}$ & $\mathrm{p}$ & $\mathrm{hd} / \mathrm{rx}$ & 0.3554 & 426 & 0.201 & 4384 & 17.76 & 0.12142 & 1.16 & 1.418 & 2.63 & 0.0847 & 2.33 & 0.89 & 897 & 31.40 & 524 & 23 & 1977 & 43 & 45.3 \\
\hline 87 & 3 & $\mathrm{~m}$ & ov & ic/osc & 0.0275 & 46 & 0.318 & 55516 & 39.96 & 0.13264 & 0.37 & 5.899 & 1.03 & 0.3226 & 0.89 & 0.86 & 1961 & 17.88 & 1802 & 28 & 2133 & 18 & 91.9 \\
\hline 88 & 3 & $\mathrm{~m}$ & ov & hd/osc & 55 & 0.002 & 70413 & 54.01 & 0.06057 & 0.36 & 0.768 & 0.73 & 0.0919 & 0.52 & 0.71 & 624 & 579 & 6.44 & 567 & 6 & 625 & 22 & 102.1 \\
\hline 89 & 2 & $\mathrm{~m}$ & $\mathrm{p}$ & hd/osc & 80 & 0.007 & 45019 & 22.60 & 0.05659 & 2.22 & 0.716 & 2.40 & 0.0918 & 0.82 & 0.34 & 476 & 548 & 20.40 & 566 & 9 & 475 & 100 & 96.8 \\
\hline 90.1 & 2 & $\mathrm{e}$ & $p$ & hd/osc & 20 & 0.002 & 449647 & 26.15 & 0.05981 & 0.47 & 0.775 & 0.82 & 0.0940 & 0.56 & 0.68 & 597 & 583 & 7.28 & 579 & 6 & 596 & 26 & 100.6 \\
\hline 90.2 & 2 & $\mathrm{c}$ & $\mathrm{p}$ & $\mathrm{hb} / \mathrm{rx}$ & 1.8927 & 786 & 0.636 & 803 & 8.10 & 0.14725 & 1.34 & 7.262 & 1.62 & 0.3577 & 0.84 & 0.52 & 2144 & 29.00 & 1971 & 29 & 2314 & 47 & 92.7 \\
\hline 92.1 & 2 & e & $\mathrm{p}$ & hd/osc & 0.0518 & 80 & 0.017 & 30109 & 10.38 & 0.05531 & 2.33 & 0.606 & 2.50 & 0.0794 & 0.83 & 0.33 & 481 & 19.16 & 493 & 8 & 427 & 105 & 97.7 \\
\hline 92.2 & 2 & $\mathrm{c}$ & $\mathrm{p}$ & $\mathrm{hb} / \mathrm{ic}$ & 0.0335 & 152 & 0.664 & 45515 & 59.68 & 0.13258 & 1.16 & 6.157 & 1.38 & 0.3368 & 0.66 & 0.47 & 1998 & 24.20 & 1871 & 21 & 2133 & 43 & 93.7 \\
\hline 93 & 3 & $\mathrm{c}$ & ov & $\mathrm{rx}$ & 4.9962 & 4048 & 0.530 & 311 & 4.77 & 0.15308 & 3.33 & 3.240 & 3.47 & 0.1535 & 0.91 & 0.26 & 1467 & 53.80 & 921 & 16 & 2381 & 114 & 61.6 \\
\hline 94 & 2 & $\mathrm{c}$ & $\mathrm{p}$ & ic/rx & 0.0095 & 8 & 0.199 & 160577 & 25.62 & 0.13455 & 1.16 & 6.310 & 2.01 & 0.3401 & 1.60 & 0.80 & 2020 & 35.20 & 1887 & 52 & 2158 & 42 & 93.6 \\
\hline 95 & 3 & $\mathrm{~m}$ & ov & $\mathrm{hb} / \mathrm{osc}$ & 0.0086 & 32 & 0.282 & 177252 & 29.11 & 0.13497 & 0.34 & 6.895 & 0.95 & 0.3705 & 0.80 & 0.85 & 2098 & 16.84 & 2032 & 28 & 2164 & 17 & 97.0 \\
\hline 96 & 2 & $\mathrm{~m}$ & $\mathrm{p}$ & hd & 0.0008 & 24 & 0.001 & 1877279 & 83.41 & 0.05985 & 0.36 & 0.781 & 0.74 & 0.0947 & 0.53 & 0.71 & 586 & 6.58 & 583 & 6 & 597 & 23 & 100.5 \\
\hline 97 & 2 & $\mathrm{~m}$ & $\mathrm{p}$ & hd/osc & 0.0046 & 28 & 0.001 & 338801 & 44.19 & 0.06000 & 0.55 & 0.786 & 0.84 & 0.0951 & 0.51 & 0.60 & 589 & 7.50 & 586 & 6 & 602 & 29 & 100.6 \\
\hline 98 & 3 & $\mathrm{~m}$ & ov & $\operatorname{mix}$ ic & 0.0173 & 58 & 0.005 & 89849 & 54.32 & 0.06196 & 0.67 & 0.791 & 1.11 & 0.0926 & 0.80 & 0.72 & 592 & 9.96 & 571 & 9 & 673 & 33 & 103.7 \\
\hline 99 & 2 & $\mathrm{c}$ & $\mathrm{p}$ & ic/rx & 0.0179 & 43 & 0.378 & 85696 & 46.54 & 0.12779 & 0.83 & 5.335 & 1.47 & 0.3028 & 1.16 & 0.79 & 1875 & 25.20 & 1705 & 35 & 2068 & 32 & 90.7 \\
\hline 100 & 2 & $\mathrm{~m}$ & $\mathrm{p}$ & $\mathrm{hd} / \mathrm{rx}$ & 0.0337 & 51 & 0.004 & 46240 & 40.79 & 0.06207 & 0.60 & 0.776 & 0.96 & 0.0907 & 0.65 & 0.68 & 583 & 8.52 & 560 & 7 & 676 & 30 & 104.2 \\
\hline
\end{tabular}


Unidade Serra do Ibituruna: amostra CP-27 (monazita)

\begin{tabular}{|c|c|c|c|c|c|c|c|c|c|c|c|c|c|c|c|c|c|c|c|c|}
\hline spot & ${ }^{207} \mathrm{~Pb} /{ }^{235} \mathrm{U}$ & $10(a b s)$ & ${ }^{206} \mathrm{~Pb} /{ }^{238} \mathrm{U}$ & $10(a b s)$ & Rho & ${ }^{207} \mathrm{~Pb} /{ }^{206} \mathrm{~Pb}$ & $10(a b s)$ & $208 / 206$ & $10(a b s)$ & Pb total & Pb rad & Th ppm & $\mathbf{U}$ ppm & t.68 & $20^{\circ}$ & t.75 & $20^{\circ}$ & t.76 & $20^{\circ}$ & Concordância \\
\hline 1.1 & 0.7702 & 0.0178 & 0.0967 & 0.0015 & 0.59 & 0.0578 & 0.001 & 10.9824 & 1.0322 & 0.23 & 2342.9 & 3656 & 1662 & 595 & 9 & 580 & 10 & 521 & 41 & 102 \\
\hline 2.1 & 0.7587 & 0.0194 & 0.0981 & 0.0016 & 0.08 & 0.0561 & 0.0011 & 14.8107 & 0.5579 & 0.25 & 2455.9 & 3679 & 1756 & 603 & 10 & 573 & 11 & 456 & 65 & 105 \\
\hline 3.1 & 0.7562 & 0.0189 & 0.0952 & 0.0016 & 0.78 & 0.0576 & 0.0011 & 11.2268 & 3.0504 & 0.2 & 2321.7 & 3504 & 1735 & 586 & 10 & 572 & 11 & 515 & 35 & 102 \\
\hline 4.1 & 0.7553 & 0.0194 & 0.097 & 0.0016 & 0.7 & 0.0564 & 0.0011 & 12.1174 & 0.4473 & 0.22 & 2141.7 & 3172 & 1824 & 597 & 9 & 571 & 11 & 471 & 41 & 104 \\
\hline 5.1 & 0.7869 & 0.0175 & 0.0991 & 0.0015 & 0.92 & 0.0576 & 0.0009 & 8.3864 & 1.065 & 0.21 & 2759.9 & 3867 & 3154 & 609 & 9 & 589 & 10 & 514 & 23 & 103 \\
\hline 6.1 & 0.7742 & 0.0191 & 0.0993 & 0.0016 & 0.75 & 0.0566 & 0.0011 & 13.2615 & 0.2566 & 0.25 & 2262.2 & 3199 & 1730 & 610 & 9 & 582 & 11 & 474 & 37 & 104 \\
\hline 7.1 & 0.787 & 0.02 & 0.1031 & 0.0017 & 0.84 & 0.0553 & 0.0011 & 14.5234 & 1.2009 & 0.3 & 2412.9 & 3481 & 2047 & 633 & 10 & 590 & 11 & 427 & 33 & 107 \\
\hline 8.1 & 0.7742 & 0.0182 & 0.0978 & 0.0016 & 0.43 & 0.0574 & 0.001 & 10.5262 & 0.3587 & 0.25 & 2052.3 & 2994 & 1997 & 602 & 9 & 582 & 10 & 507 & 49 & 103 \\
\hline 9.1 & 0.7723 & 0.0189 & 0.0977 & 0.0016 & 0.62 & 0.0573 & 0.0011 & 10.3675 & 0.3335 & 0.26 & 1749.2 & 2601 & 1795 & 601 & 9 & 581 & 11 & 504 & 42 & 103 \\
\hline 10.1 & 0.7605 & 0.0175 & 0.0949 & 0.0015 & 0.83 & 0.0581 & 0.001 & 10.7453 & 3.4494 & 0.28 & 2957.9 & 4347 & 1662 & 584 & 9 & 574 & 10 & 534 & 29 & 101 \\
\hline 11.1 & 0.7392 & 0.0191 & 0.1018 & 0.0016 & 0.01 & 0.0527 & 0.0011 & 19.2993 & 6.5047 & 0.22 & 2157.9 & 2907 & 2997 & 625 & 9 & 562 & 11 & 314 & 68 & 111 \\
\hline 12.1 & 0.7871 & 0.0169 & 0.0983 & 0.0015 & 0.64 & 0.0581 & 0.0009 & 8.6615 & 2.8434 & 0.26 & 2121.6 & 2651 & 3067 & 604 & 9 & 590 & 10 & 533 & 36 & 102 \\
\hline 13.1 & 0.792 & 0.0174 & 0.0995 & 0.0015 & 0.9 & 0.0577 & 0.0009 & 8.6485 & 0.5389 & 0.24 & 2404.9 & 3171 & 2901 & 611 & 9 & 592 & 10 & 520 & 24 & 103 \\
\hline 14.1 & 0.7767 & 0.0139 & 0.0981 & 0.0011 & 0.47 & 0.0574 & 0.0011 & 8.6314 & 0.2151 & 0.25 & 2033.2 & 743.4 & 2397 & 603 & 6 & 584 & 8 & 508 & 35 & 103 \\
\hline 15.1 & 0.7782 & 0.014 & 0.099 & 0.0011 & 0.96 & 0.057 & 0.0011 & 11.9603 & 1.8775 & 0.22 & 2697.1 & 971.2 & 2868 & 609 & 6 & 584 & 8 & 492 & 18 & 104 \\
\hline 16.1 & 0.7384 & 0.014 & 0.0948 & 0.0011 & 0.01 & 0.0565 & 0.0011 & -6372.24 & 27460.7 & 0.22 & 3897.1 & 1581 & 2374 & 584 & 6 & 561 & 8 & 472 & 49 & 103 \\
\hline 17.1 & 0.7767 & 0.0147 & 0.0982 & 0.0011 & 0.8 & 0.0574 & 0.0012 & 11.7416 & 1.059 & 0.22 & 2268.8 & 893.5 & 1696 & 604 & 6 & 584 & 8 & 506 & 27 & 103 \\
\hline 18.1 & 0.7673 & 0.0212 & 0.1056 & 0.0016 & 0.95 & 0.0527 & 0.0015 & 21.4944 & 1.9471 & 0.38 & 1816.2 & 688.9 & 1048 & 647 & 9 & 578 & 12 & 316 & 32 & 111 \\
\hline 19.1 & 0.7812 & 0.0143 & 0.0985 & 0.0011 & 0.04 & 0.0575 & 0.0011 & 9.3647 & 2.1803 & 0.32 & 2318.9 & 844.2 & 2093 & 606 & 6 & 586 & 8 & 512 & 46 & 103 \\
\hline 20.1 & 0.7784 & 0.0157 & 0.0989 & 0.0012 & 0.59 & 0.0571 & 0.0013 & 12.0647 & 0.6287 & 0.27 & 2060.1 & 784.8 & 1688 & 608 & 7 & 585 & 9 & 495 & 36 & 103 \\
\hline 21.1 & 0.7415 & 0.0146 & 0.0936 & 0.0011 & 0.59 & 0.0575 & 0.0012 & 10.8509 & 0.1674 & 0.26 & 1922.7 & 726.2 & 1936 & 577 & 7 & 563 & 9 & 509 & 35 & 102 \\
\hline 22.1 & 0.7763 & 0.0141 & 0.0984 & 0.0011 & 0.77 & 0.0572 & 0.0011 & 11.9643 & 0.8913 & 0.28 & 2410.5 & 893.7 & 2308 & 605 & 6 & 583 & 8 & 500 & 26 & 103 \\
\hline 23.1 & 0.7839 & 0.0164 & 0.0997 & 0.0012 & 0.51 & 0.057 & 0.0013 & 12.2973 & 1.5283 & 0.23 & 1754.8 & 626.3 & 1810 & 613 & 7 & 588 & 9 & 493 & 40 & 104 \\
\hline 24.1 & 0.7653 & 0.0133 & 0.0957 & 0.001 & 0.8 & 0.058 & 0.001 & 7.1382 & 0.4097 & 0.37 & 1982 & 681.6 & 2824 & 589 & 6 & 577 & 8 & 530 & 24 & 102 \\
\hline 25.1 & 0.7411 & 0.0168 & 0.0981 & 0.0013 & 0.34 & 0.0548 & 0.0014 & 17.7835 & 2.7091 & 0.34 & 1993.3 & 716 & 1719 & 603 & 8 & 563 & 10 & 404 & 50 & 107 \\
\hline 26.1 & 0.754 & 0.0145 & 0.0977 & 0.0011 & 0.83 & 0.056 & 0.0011 & 12.5968 & 2.2669 & 0.28 & 2351.2 & 806.9 & 2598 & 601 & 7 & 571 & 8 & 451 & 26 & 105 \\
\hline
\end{tabular}


Unidade Serra do Ibituruna: amostra CP-35 (monazita)

\begin{tabular}{|c|c|c|c|c|c|c|c|c|c|c|c|c|c|c|c|c|c|c|c|c|}
\hline spot & ${ }^{207} \mathrm{~Pb} /{ }^{235} \mathrm{U}$ & 10 (abs) & ${ }^{206} \mathrm{~Pb} /{ }^{238} \mathrm{U}$ & $10(\mathbf{a b s})$ & Rho & ${ }^{207} \mathrm{~Pb} /{ }^{206} \mathrm{~Pb}$ & $10(a b s)$ & $208 / 206$ & 10 (abs) & Pb total & Pb rad & Th ppm & U ppm & t.68 & 20 & t.75 & 20 & t.76 & $20^{\circ}$ & Concordância \\
\hline 1.1 & 0.8211 & 0.019 & 0.0995 & 0.0016 & 0.73 & 0.0599 & 0.0012 & 2.6793 & 0.0947 & 0.09 & 3009.3 & 4796 & 9933 & 611 & 9 & 609 & 11 & 598 & 34 & 100 \\
\hline 2.1 & 0.7779 & 0.0179 & 0.0949 & 0.0015 & 0.9 & 0.0595 & 0.0012 & 2.9937 & 0.0151 & 0.12 & 3311.5 & 5921 & 10293 & 584 & 9 & 584 & 10 & 584 & 24 & 100 \\
\hline 3.1 & 0.777 & 0.0178 & 0.0954 & 0.0015 & 0.83 & 0.0591 & 0.0012 & 4.2978 & 0.3843 & 0.1 & 3797.3 & 6879 & 10023 & 587 & 9 & 584 & 10 & 570 & 29 & 100 \\
\hline 4.1 & 0.7902 & 0.0191 & 0.0957 & 0.0015 & 0.79 & 0.0599 & 0.0013 & 2.035 & 0.2013 & 0.26 & 2036.6 & 2969 & 7994 & 589 & 9 & 591 & 11 & 600 & 33 & 99 \\
\hline 5.1 & 0.7698 & 0.0178 & 0.095 & 0.0015 & 0.87 & 0.0588 & 0.0012 & 5.7819 & 0.4235 & 0.1 & 5384 & 10847 & 9273 & 585 & 9 & 580 & 10 & 559 & 27 & 100 \\
\hline 6.1 & 0.7626 & 0.0191 & 0.0938 & 0.0015 & 0.82 & 0.0589 & 0.0014 & 6.6469 & 0.1497 & 0.1 & 4456 & 9179 & 6843 & 578 & 9 & 576 & 11 & 566 & 33 & 100 \\
\hline 7.1 & 0.7574 & 0.0189 & 0.0934 & 0.0015 & 0.73 & 0.0588 & 0.0013 & 6.1762 & 1.487 & 0.13 & 2478.2 & 4777 & 6349 & 576 & 9 & 573 & 11 & 560 & 38 & 100 \\
\hline 8.1 & 0.7713 & 0.019 & 0.0941 & 0.0015 & 0.49 & 0.0595 & 0.0013 & 4.3327 & 0.2257 & 0.15 & 2748.2 & 5831 & 5506 & 580 & 9 & 581 & 11 & 584 & 47 & 99 \\
\hline 9.1 & 0.7871 & 0.022 & 0.0954 & 0.0016 & 0.6 & 0.0599 & 0.0016 & 4.3538 & 0.128 & 0.23 & 1710.6 & 3408 & 3760 & 587 & 10 & 590 & 13 & 598 & 49 & 99 \\
\hline 10.1 & 0.7713 & 0.0205 & 0.0934 & 0.0016 & 0.51 & 0.0599 & 0.0015 & 3.1381 & 0.5377 & 0.06 & 1630.5 & 3228 & 4414 & 576 & 9 & 581 & 12 & 600 & 50 & 99 \\
\hline 11.1 & 0.7927 & 0.0179 & 0.0957 & 0.0015 & 0.01 & 0.0601 & 0.0012 & 2.5112 & 0.0243 & 0.14 & 3544.8 & 6015 & 11760 & 589 & 9 & 593 & 10 & 606 & 59 & 99 \\
\hline 12.1 & 0.77 & 0.019 & 0.094 & 0.0015 & 0.76 & 0.0594 & 0.0013 & 5.9478 & 0.1497 & 0.07 & 3962.3 & 8400 & 7186 & 579 & 9 & 580 & 11 & 582 & 35 & 99 \\
\hline 13.1 & 0.7631 & 0.019 & 0.0931 & 0.0015 & 0.83 & 0.0594 & 0.0013 & 4.1237 & 0.4752 & 0.13 & 2700 & 4840 & 8283 & 574 & 9 & 576 & 11 & 584 & 32 & 99 \\
\hline 14.1 & 0.7658 & 0.0214 & 0.0943 & 0.0019 & 0.57 & 0.0589 & 0.0011 & 4.4543 & 0.2041 & 0.06 & 3451.5 & 1802 & 7774 & 581 & 11 & 577 & 12 & 563 & 51 & 100 \\
\hline 15.1 & 0.7623 & 0.0215 & 0.0925 & 0.0019 & 0.93 & 0.0598 & 0.0012 & 2.4577 & 0.1408 & 0.08 & 2079.7 & 975.2 & 6613 & 570 & 11 & 575 & 12 & 595 & 26 & 99 \\
\hline 16.1 & 0.7647 & 0.0217 & 0.0927 & 0.0019 & 0.92 & 0.0598 & 0.0012 & 2.215 & 0.086 & 0.12 & 1682 & 679.5 & 6344 & 572 & 11 & 577 & 13 & 597 & 27 & 99 \\
\hline 17.1 & 0.778 & 0.0227 & 0.0969 & 0.002 & 0.01 & 0.0582 & 0.0012 & 9.4338 & 3.3596 & 0.07 & 3279.9 & 1852 & 5194 & 596 & 12 & 584 & 13 & 539 & 78 & 102 \\
\hline 18.1 & 0.7921 & 0.0216 & 0.0959 & 0.0019 & 0.82 & 0.0599 & 0.0011 & 3.3645 & 0.3904 & 0.07 & 2655.4 & 1223 & 7941 & 590 & 11 & 592 & 12 & 600 & 34 & 99 \\
\hline 19.1 & 0.7892 & 0.0217 & 0.095 & 0.0019 & 0.88 & 0.0602 & 0.0011 & 2.7626 & 0.1336 & 0 & 2157.7 & 990.4 & 6790 & 585 & 11 & 591 & 12 & 613 & 30 & 99 \\
\hline 20.1 & 0.7925 & 0.0226 & 0.0959 & 0.002 & 0.87 & 0.0599 & 0.0012 & 3.8092 & 0.9861 & 0.12 & 1652.8 & 786.1 & 4856 & 590 & 12 & 593 & 13 & 601 & 32 & 99 \\
\hline 21.1 & 0.7741 & 0.0217 & 0.0941 & 0.0019 & 0.82 & 0.0596 & 0.0011 & 3.2234 & 0.467 & 0.11 & 2163.1 & 972.8 & 6943 & 580 & 11 & 582 & 12 & 591 & 36 & 99 \\
\hline 22.1 & 0.7827 & 0.0223 & 0.0955 & 0.002 & 0.92 & 0.0595 & 0.0012 & 4.6442 & 0.1316 & 0.1 & 2566.4 & 1316 & 5587 & 588 & 12 & 587 & 13 & 583 & 27 & 100 \\
\hline 23.1 & 0.7778 & 0.0216 & 0.0942 & 0.0019 & 0.25 & 0.0599 & 0.0012 & 3.0676 & 0.2262 & 0.1 & 2152.6 & 966.4 & 6895 & 580 & 11 & 584 & 12 & 599 & 65 & 99 \\
\hline 24.1 & 0.7828 & 0.0223 & 0.0951 & 0.002 & 0.88 & 0.0597 & 0.0012 & 2.8597 & 0.2403 & 0.15 & 2078.5 & 910 & 6338 & 586 & 12 & 587 & 13 & 593 & 31 & 99 \\
\hline 25.1 & 0.771 & 0.0221 & 0.0952 & 0.002 & 0.01 & 0.0587 & 0.0012 & 5.0501 & 3.0618 & 0.16 & 1488.1 & 550.5 & 7118 & 586 & 12 & 580 & 13 & 557 & 77 & 100 \\
\hline 26.1 & 0.784 & 0.0219 & 0.0953 & 0.002 & 0.92 & 0.0596 & 0.0011 & 2.781 & 0.0843 & 0.08 & 2599.1 & 1284 & 7489 & 587 & 12 & 588 & 13 & 592 & 26 & 99 \\
\hline
\end{tabular}


Unidade Colônia: amostra CP-07 (monazita)

\begin{tabular}{|c|c|c|c|c|c|c|c|c|c|c|c|c|c|c|c|c|c|c|c|c|}
\hline spot & ${ }^{207} \mathrm{~Pb} /{ }^{235} \mathrm{U}$ & $10(\mathbf{a b s})$ & ${ }^{206} \mathrm{~Pb} /{ }^{238} \mathrm{U}$ & $10(a b s)$ & Rho & ${ }^{207} \mathrm{~Pb} /{ }^{206} \mathrm{~Pb}$ & $10(\mathbf{a b s})$ & $208 / 206$ & $10(a b s)$ & Pb total & Pb rad & Th ppm & $\mathbf{U}$ ppm & t.68 & $20^{\circ}$ & t.75 & $20^{\circ}$ & t.76 & 20 & Concordância \\
\hline 1.1 & 0.7502 & 0.0577 & 0.0931 & 0.0010 & 0.54 & 0.0585 & 0.0045 & 1.7309 & 0.1412 & 0.08 & 248 & 7937 & 1039 & 574 & 6 & 568 & 34 & 546 & 157 & 100 \\
\hline 2.1 & 0.5607 & 0.0543 & 0.0869 & 0.0011 & 0.79 & 0.0468 & 0.0047 & 0.6693 & 0.0583 & 0.15 & 41 & 1134 & 262 & 537 & 6 & 452 & 35 & 39 & 209 & 118 \\
\hline 3.1 & 0.7910 & 0.0602 & 0.0964 & 0.0010 & 0.62 & 0.0595 & 0.0046 & 2.2652 & 0.3613 & 0.00 & 207 & 6886 & 723 & 593 & 6 & 592 & 34 & 586 & 152 & 100 \\
\hline 4.1 & 0.6879 & 0.0592 & 0.0957 & 0.0011 & 0.83 & 0.0521 & 0.0046 & 1.5113 & 0.0581 & 0.10 & 49 & 1868 & 227 & 589 & 6 & 532 & 36 & 291 & 175 & 110 \\
\hline 5.1 & 0.6804 & 0.0565 & 0.0924 & 0.0010 & 0.64 & 0.0534 & 0.0045 & 1.1584 & 0.0294 & 0.04 & 240 & 6200 & 1142 & 570 & 6 & 527 & 34 & 346 & 173 & 108 \\
\hline 6.1 & 0.7686 & 0.0584 & 0.0940 & 0.0010 & 0.39 & 0.0593 & 0.0046 & 2.3657 & 0.1079 & 0.00 & 115 & 4124 & 345 & 579 & 6 & 579 & 34 & 578 & 158 & 100 \\
\hline 7.1 & 0.7233 & 0.0584 & 0.0949 & 0.0010 & 0.70 & 0.0553 & 0.0047 & 1.1932 & 0.0567 & 0.06 & 103 & 2853 & 501 & 584 & 6 & 553 & 34 & 423 & 164 & 105 \\
\hline 8.1 & 0.7805 & 0.0582 & 0.0957 & 0.0010 & 0.03 & 0.0591 & 0.0046 & 1.5889 & 0.0814 & 0.08 & 219 & 6365 & 877 & 589 & 6 & 586 & 33 & 573 & 163 & 100 \\
\hline 9.1 & 0.7706 & 0.0588 & 0.0950 & 0.0010 & 0.01 & 0.0588 & 0.0046 & 2.3533 & 0.3534 & 0.11 & 279 & 9680 & 868 & 585 & 6 & 580 & 34 & 561 & 168 & 100 \\
\hline 10.1 & 0.8204 & 0.0607 & 0.0978 & 0.0010 & 0.01 & 0.0608 & 0.0046 & 1.5958 & 0.0889 & 0.00 & -95 & -3313 & -301 & 602 & 6 & 608 & 34 & 634 & 161 & 98 \\
\hline 11.1 & 0.7207 & 0.0563 & 0.0936 & 0.0010 & 0.12 & 0.0558 & 0.0045 & 1.2666 & 0.0499 & 0.06 & 115 & 3021 & 555 & 577 & 6 & 551 & 33 & 446 & 172 & 104 \\
\hline 12.1 & 0.6069 & 0.0558 & 0.0888 & 0.0011 & 0.83 & 0.0496 & 0.0046 & 0.9333 & 0.1725 & 0.05 & 73 & 1441 & 528 & 548 & 7 & 482 & 35 & 175 & 191 & 113 \\
\hline 13.1 & 0.7528 & 0.0228 & 0.0927 & 0.0019 & 0.08 & 0.0589 & 0.0013 & 1.3908 & 0.0574 & 0.12 & 203 & 5671 & 923 & 572 & 11 & 570 & 13 & 563 & 77 & 100 \\
\hline 14.1 & 0.8354 & 0.0248 & 0.1031 & 0.0021 & 0.55 & 0.0588 & 0.0013 & 1.3058 & 0.0279 & 0.07 & 240 & 6759 & 965 & 633 & 12 & 617 & 14 & 559 & 55 & 102 \\
\hline 15.1 & 0.7604 & 0.0227 & 0.0933 & 0.0020 & 0.01 & 0.0591 & 0.0013 & 1.7571 & 0.1610 & 0.27 & 672 & 20392 & 2273 & 575 & 12 & 574 & 13 & 571 & 80 & 100 \\
\hline 16.1 & 0.6956 & 0.0236 & 0.0947 & 0.0020 & 0.78 & 0.0533 & 0.0015 & 0.9483 & 0.0970 & 0.04 & 110 & 2513 & 637 & 583 & 12 & 536 & 14 & 340 & 50 & 108 \\
\hline 17.1 & 0.7459 & 0.0227 & 0.0966 & 0.0020 & 0.01 & 0.0560 & 0.0013 & 1.0359 & 0.0760 & 0.17 & 374 & 9040 & 1842 & 595 & 12 & 566 & 13 & 452 & 81 & 105 \\
\hline 18.1 & 0.7906 & 0.0229 & 0.0964 & \begin{tabular}{|l|}
0.0020 \\
\end{tabular} & 0.50 & 0.0595 & 0.0013 & 1.8170 & 0.0270 & 0.00 & 141 & 4163 & 612 & 593 & 12 & 592 & 13 & 585 & 56 & 100 \\
\hline 19.1 & 0.7475 & 0.0225 & 0.0956 & 0.0020 & 0.23 & 0.0567 & 0.0013 & 1.4366 & 0.0476 & 0.12 & 124 & 3693 & 515 & 589 & 12 & 567 & 13 & 480 & 72 & 103 \\
\hline 20.1 & 0.7755 & 0.0233 & 0.0956 & 0.0020 & 0.47 & 0.0588 & 0.0013 & 1.2417 & 0.1083 & 0.07 & 295 & 8049 & 1274 & 589 & 12 & 583 & 13 & 561 & 60 & 100 \\
\hline 21.1 & 0.7683 & 0.0229 & 0.0936 & 0.0020 & 0.29 & 0.0596 & 0.0013 & 1.5488 & 0.1102 & 0.04 & 43 & 1118 & 240 & 577 & 12 & 579 & 13 & 587 & 68 & 99 \\
\hline 22.1 & 0.7482 & 0.0242 & 0.0922 & 0.0020 & 0.34 & 0.0588 & 0.0014 & 1.8964 & 0.0792 & 0.00 & 120 & 3692 & 432 & 569 & 12 & 567 & 14 & 562 & 70 & 100 \\
\hline 23.1 & 0.7867 & 0.0230 & 0.0967 & 0.0020 & 0.74 & 0.0590 & 0.0014 & 1.1206 & 0.0524 & 0.09 & 425 & 10813 & 2008 & 595 & 12 & 589 & 13 & 567 & 43 & 100 \\
\hline 24.1 & 0.7006 & 0.0223 & 0.0970 & 0.0020 & 0.01 & 0.0524 & 0.0013 & 1.7950 & 0.1176 & 0.09 & 284 & 9881 & 1040 & 597 & 12 & 539 & 13 & 302 & 86 & 110 \\
\hline 25.1 & 0.6949 & 0.0234 & 0.0951 & 0.0020 & 0.20 & 0.0530 & 0.0013 & 2.7492 & 0.1153 & 0.09 & 390 & 14987 & 1093 & 586 & 12 & 536 & 14 & 329 & 82 & 109 \\
\hline
\end{tabular}




\section{APÊNDICE I}

Resultados das análises de elementos traço e terras raras via LA-ICP-MS

Observações:

- Todas as concentrações medidas estão reportadas em ppm;

- Razões $\mathrm{Ce} / \mathrm{Ce}^{*}, \mathrm{Eu} / \mathrm{Eu}{ }^{*}$ e $\mathrm{Yb} / \mathrm{Sm}$ foram calculadas com os valores normalizados pelo condrito de acordo com Sun \& McDonough (1989);

- Os valores das concentrações obtidas no padrão Zr-91500 estão de acordo com as medições feitas em cada amostra;

- Dados destacados em cinza não foram utilizados. 
Unidade Serra do Ibituruna: muscovita - quartzo xisto (CP-05)

\begin{tabular}{|c|c|c|c|c|c|c|c|c|c|c|c|c|c|c|c|c|c|c|c|c|c|c|}
\hline zircão & spot & $\mathrm{Zr}$ & $\mathrm{Si}$ & $\mathbf{L i}$ & Mg & Al & $\mathbf{P}$ & Ca & Sc & $\mathrm{Ti}$ & Mn & $\mathrm{Fe}$ & Co & $\mathbf{R b}$ & $\mathrm{Sr}$ & $\mathbf{Y}$ & $\mathrm{Nb}$ & Ta & Mo & Sn & Sb & Ba \\
\hline 2 & $\mathrm{e}$ & 496007 & 91349 & 3.18 & 2.42 & 101.47 & 282.82 & 97.75 & 214.60 & 4.80 & 10.50 & 560.01 & 0.99 & 0.22 & 0.30 & 343.59 & 0.95 & 0.63 & 2.04 & $<0.64$ & $<0.39$ & $<0.60$ \\
\hline 6 & $\mathrm{e}$ & & 3417 & 50 & & 25.25 & & 54.13 & & & & 89.98 & & 0.099 & 0.23 & & 1.08 & 0.46 & 1.62 & 0.33 & & 0.47 \\
\hline 12 & $\mathrm{e}$ & & & 14 & & & & & & 11.24 & & 2298.76 & & & & & 1.10 & 1.21 & 2.26 & & & .36 \\
\hline 17 & $\mathrm{e}$ & 96007 & 7856 & .03 & 3.37 & 254.18 & 07.04 & 99.21 & 157.10 & 11.41 & & 485.16 & & 0.75 & 2.99 & & 0.99 & 0.44 & 1.57 & $<0.40$ & 0.51 & 1.62 \\
\hline 18 & $\mathrm{e}$ & 96007 & 19929 & .48 & 5.81 & 389.43 & 95.91 & 0.00 & 232.28 & 7.87 & 6.90 & 228.78 & 0. & 1.06 & 0.43 & 779.77 & 0.75 & 0.39 & 2.32 & $<0.69$ & 0.41 & 2.92 \\
\hline 25 & $\mathrm{e}$ & & & .63 & 16 & & & & & $<2.52$ & & 84.98 & & & 0.40 & & 0.54 & 0.29 & & & & $<0.76$ \\
\hline 27 & $\mathrm{e}$ & 96007 & 4661 & 3.55 & 5.74 & 360.48 & & & 122.93 & 8.06 & 0.8 & 146.14 & 0.07 & 0.96 & 0.25 & 152.69 & 0.53 & 0.21 & 1.59 & $<0.56$ & 35 & 1.86 \\
\hline 29 & $\mathrm{e}$ & 96007 & 02784 & 4.43 & 3.85 & 342.40 & 5.67 & 0.00 & 142.59 & 10.06 & 2.20 & 285.06 & & 0.75 & 0.36 & & 2.74 & 1.36 & 2.61 & 1.12 & 76 & 1.41 \\
\hline 31 & $\mathrm{e}$ & & & .70 & 28 & & & & & & & 100.65 & & & 0.28 & & 58 & 0.26 & & & & \\
\hline 33 & $\mathrm{e}$ & 6007 & 529 & 0.44 & 3.23 & 86.65 & .57 & & 132.29 & 14.37 & 1.34 & 134.21 & 0.043 & 995 & 0.22 & 90.96 & 0.43 & 0.09 & 2.38 & $<0.36$ & 20 & 0.78 \\
\hline 35 & $\mathrm{e}$ & 96007 & 3281 & .38 & .85 & $<6.46$ & & & 85 & 8.74 & ). & 12.38 & 0.050 & & 0.14 & 0.93 & 1.73 & 0.87 & 1.55 & .89 & 38 & $<0.61$ \\
\hline 36 & $\mathrm{e}$ & 96007 & 5511 & 2.29 & 1.53 & 25.40 & & & 139.65 & 9.22 & & 331.61 & & & 0.29 & & 1.21 & 0.46 & 1.66 & .75 & & 0.99 \\
\hline 39 & $\mathrm{e}$ & 496007 & 115387 & 1.23 & $<0.52$ & 13.68 & & & 142.36 & 8.07 & & 37.97 & & & 0. & & 1.65 & 0.76 & 1.60 & & & $<0.65$ \\
\hline 40 & $\mathrm{~m}$ & 496007 & 3230 & 0.42 & 0.54 & 20.18 & 75.74 & & 123.98 & 3.08 & $<0.38$ & 14.60 & $<0.045$ & & 0.09 & 79.22 & 0.50 & 0.28 & 1.66 & $<0.48$ & $<0$. & 0.54 \\
\hline 47 & $\mathrm{e}$ & 496007 & 52241 & 1.53 & 1.60 & 33.43 & 7.74 & & 151.45 & 13.64 & & 223.95 & $<0.094$ & $<0$. & 0.15 & 134.42 & 1.38 & 0.91 & 1.46 & 1.16 & $<0.60$ & $<0.75$ \\
\hline 48 & $\mathrm{e}$ & 496007 & 116745 & 1.16 & 1.03 & 16.53 & & & 161.11 & 5.90 & & 52.77 & $<0.098$ & & 0.28 & & 1.72 & 1.25 & 2.49 & & $<0.67$ & 0.54 \\
\hline 59 & $\mathrm{e}$ & 496007 & 136592 & 5.22 & 7.91 & 467.08 & & 227.25 & 181.44 & 14.24 & 72.92 & 3839.55 & & $<0.49$ & 1.19 & & 0.85 & 0.79 & 2.67 & & 1.88 & 4.26 \\
\hline 62 & $\mathrm{~m}$ & 496007 & 98019 & 0.78 & 0.78 & & & & 113.61 & 4.39 & & 157.53 & $<0.056$ & & 0.20 & & 0.60 & 0.23 & 1.44 & $<0.60$ & $<0.28$ & $<0.34$ \\
\hline 64 & $\mathrm{~m}$ & 496007 & 102920 & 0.43 & $<0.77$ & & & & 126.91 & & $<0.46$ & $<3.52$ & & $<0.170$ & 0.17 & 1028.26 & 6.19 & 1.36 & 1.51 & & & $<0.70$ \\
\hline 72 & $\mathrm{e}$ & 496007 & 101907 & 0.98 & $<0.57$ & 351.11 & 167.58 & & 133.57 & 4.07 & & 59.19 & 050 & 0.21 & 0.20 & .84 & 0.34 & 0.50 & 1.65 & 0.55 & $<0.30$ & 0.64 \\
\hline 84 & $\mathrm{e}$ & 496007 & 104247 & 1.46 & 7.31 & 109.10 & 263.69 & & 158.95 & 26.16 & & 439.40 & & & 0.55 & 1010.90 & 2.74 & 1.64 & 2.34 & $<0.44$ & $<0.24$ & 0.59 \\
\hline \multicolumn{2}{|c|}{ Zr-91500 } & 490085 & 105402 & 0.97 & $<0.63$ & $<5.89$ & $2 \mathrm{xz}$ & 0.00 & 114.28 & $<1.79$ & $<0.49$ & $<3.81$ & $<0.050$ & $<0.167$ & 0.13 & 70.85 & 0.64 & 0.28 & 2.21 & 1.06 & 0.31 & $<0.67$ \\
\hline
\end{tabular}


Unidade Serra do Ibituruna: muscovita - quartzo xisto (CP-05) (continuação)

\begin{tabular}{|c|c|c|c|c|c|c|c|c|c|c|c|c|c|c|c|c|c|c|c|c|c|c|}
\hline $\mathrm{Zr}$ & spot & $\mathbf{L a}$ & $\mathrm{Ce}$ & Pr & Nd & Sm & Eu & Gd & $\mathbf{T b}$ & Dy & Ho & Er & Tm & Yb & Lu & Hf & $\mathbf{P b}$ & Th & $\mathbf{U}$ & $\mathrm{Ce} / \mathrm{Ce}^{*}$ & $\mathbf{E u} / \mathbf{E u} *$ & $\mathrm{Yb} / \mathrm{Sm}$ \\
\hline 2 & $\mathrm{e}$ & 1.58 & 21.22 & 2.68 & 15.71 & 4.16 & 1.53 & 8.21 & 2.46 & 29.37 & 11.65 & 58.93 & 15.92 & 179.27 & 38.97 & 6459 & 154.85 & 35.19 & 160.40 & 4.54 & 2.63 & 40.11 \\
\hline 6 & $\mathrm{e}$ & 76 & 6.41 & 54 & 2.91 & 71 & .63 & 10.67 & 3.53 & 33.58 & 11.52 & 46.34 & 10.57 & 00.41 & 20.44 & 110 & 48.35 & 62.28 & 211.35 & 2.74 & 1.07 & 34.49 \\
\hline 12 & $\mathrm{e}$ & 2.79 & 60 & 6.81 & 5.64 & 82 & 1.91 & 16.58 & 5.13 & 59.91 & 21.10 & 105.27 & 26.71 & 301.49 & 64.34 & 404 & 275.84 & 7.77 & 324.27 & 13.20 & .34 & 5.89 \\
\hline 17 & $\mathrm{e}$ & 0.69 & 22.55 & 1.70 & 13.37 & 6.50 & 1.45 & 16.42 & 4.21 & 40.77 & 11.31 & 41.63 & 9.30 & 80.38 & 16.01 & 5502 & 350.87 & 85.88 & 190.54 & 6.24 & 1.84 & 11.52 \\
\hline 18 & $\mathrm{e}$ & 0.54 & 25.61 & 1.08 & 10.04 & .65 & 1.20 & 30.57 & 7.70 & 84.39 & 27.21 & 116.33 & 23.10 & 214.34 & 41.18 & 5569 & 226.39 & 54.86 & 127.05 & 8.75 & .20 & 26.10 \\
\hline 25 & $\mathrm{e}$ & 0.33 & .66 & 36 & 1.99 & .66 & .36 & 2.63 & 0.91 & 11.89 & 4.47 & 21.03 & 5.67 & 0.57 & 14.34 & 5363 & 187.32 & 26.12 & 78.86 & .37 & .41 & 9.28 \\
\hline 27 & $\mathrm{e}$ & $<0.072$ & 1.30 & 0.08 & 1.35 & 3.13 & 0.25 & 9.50 & 2.53 & 21.32 & 4.96 & 13.56 & 2.07 & 12.16 & 1.87 & 6470 & 481.78 & 57.12 & 149.81 & 1.79 & 0.43 & 3.62 \\
\hline 29 & $\mathrm{e}$ & $<0.085$ & 16.09 & 0.13 & $<1.01$ & 101 & 0.34 & 9.53 & 3.21 & 41.30 & 16.65 & 75.77 & 17.29 & 163.34 & 33.94 & 6683 & 332.39 & 154.01 & 105.99 & 17.07 & .66 & 151.06 \\
\hline 31 & $\mathrm{e}$ & .17 & 13.60 & & 3.39 & & & 5.48 & 1.61 & 18.41 & 6.01 & 25.16 & 5.26 & .10 & 9.46 & 5383 & & 30.60 & 41.64 & 7.20 & .99 & 2.94 \\
\hline 33 & $\mathrm{e}$ & 0.08 & 7.77 & 0.33 & 1.92 & & 0.29 & 2.71 & 0.96 & 8.60 & 3.01 & 12.33 & 3.21 & 29.99 & 6.28 & 4507 & 24.08 & 5.56 & 7.22 & 5.02 & .90 & 5.20 \\
\hline 35 & $\mathrm{e}$ & 0.06 & 7.48 & $<0.062$ & 0.78 & & 0.24 & 9.18 & 3.66 & 46.23 & 16.49 & 69.23 & 14.11 & 131.50 & 25.67 & 6917 & 180.42 & 34.97 & 49.75 & 20.26 & 0.45 & 72.63 \\
\hline 36 & $\mathrm{e}$ & 35 & 15.83 & 0.65 & 3.67 & & 0.92 & 9.94 & 3.20 & 35.40 & 11.79 & 47.94 & 10.12 & 87.23 & 16.47 & 7737 & 330.98 & 61.53 & 116.69 & 6.94 & .63 & 7.14 \\
\hline 39 & $\mathrm{e}$ & 0.08 & 9.68 & 0.08 & 0.78 & 1.3 & 0.36 & 5.65 & 2.34 & 29.01 & 10.82 & 52.20 & 10.99 & 109.25 & 21.36 & 6606 & 361.23 & 80.81 & 110.16 & 11.28 & .85 & 77.15 \\
\hline 40 & $\mathrm{~m}$ & $<0.053$ & 4.07 & & 0.57 & & 0.39 & 3.84 & 0.86 & 9.82 & 3.14 & 11.51 & 2.45 & 27.21 & 5.01 & 4898 & 68.44 & 20.26 & 27.61 & 4.32 & 1.09 & 24.60 \\
\hline 47 & $\mathrm{e}$ & $<0.104$ & 5.58 & .19 & $<1.10$ & & 0.59 & 6.00 & 1.58 & 13.67 & 4.74 & 25.29 & 4.86 & 50.34 & 11.65 & 7733 & 227.31 & 79.71 & 95.02 & 13.71 & 1.29 & 26.02 \\
\hline 48 & $\mathrm{e}$ & 0.19 & 5.65 & 0.39 & 3.27 & 1.80 & 0.52 & 5.98 & 4.05 & 54.42 & 25.03 & 120.64 & 29.18 & 316.26 & 66.79 & 7117 & 316.12 & 13.57 & 101.98 & 3.22 & 1.15 & 164.12 \\
\hline 59 & $\mathrm{e}$ & 4.91 & 90.64 & 8.35 & 54.20 & 19.36 & 5.66 & 28.90 & 7.03 & 56.97 & 16.79 & 70.86 & 17.21 & 180.81 & 38.64 & 6320 & 429.77 & 58.15 & 367.21 & 10.99 & 4.87 & 8.70 \\
\hline 62 & $\mathrm{~m}$ & $<0.043$ & 5.60 & 0.10 & $<0.46$ & & 0.24 & 3.09 & 1.22 & 14.76 & 5.56 & 27.03 & 6.20 & 60.86 & 12.19 & 4989 & 107.48 & 11.27 & 34.37 & 6.80 & 0.74 & 69.52 \\
\hline 64 & $\mathrm{~m}$ & $<0.068$ & 8.73 & 0.06 & $<0.57$ & 0.78 & 0.52 & 10.96 & 5.43 & 75.79 & 32.78 & 144.99 & 30.51 & 279.63 & 53.28 & 5827 & 159.67 & 21.04 & 47.96 & 14.07 & 0.95 & 333.60 \\
\hline 72 & $\mathrm{e}$ & 0.80 & 28.51 & 2.2 & 13.78 & 5.68 & 1.22 & 6.80 & 2.04 & 21.65 & 7.76 & 34.93 & 8.74 & 90.13 & 18.96 & 6169 & 103.75 & 23.45 & 49.01 & 6.94 & 2.05 & 14.79 \\
\hline 84 & $\mathrm{e}$ & 1.22 & 42.54 & 2.67 & 17.82 & 10.00 & 3.89 & 33.28 & 10.74 & 122.19 & 41.47 & 179.30 & 36.56 & 359.45 & 65.93 & 6719 & 268.52 & 60.00 & 212.40 & 9.31 & 3.63 & 33.47 \\
\hline \multicolumn{2}{|c|}{ Zr-91500 } & $<0.072$ & 1.40 & $<0.061$ & 0.59 & $<0.46$ & $<0.153$ & 1.18 & 0.35 & 5.90 & 2.37 & 12.47 & 3.05 & 36.45 & $\begin{array}{l}\mathbf{7 . 0 7} \\
\end{array}$ & 3605 & 44.67 & 13.88 & 43.20 & & & \\
\hline
\end{tabular}


Unidade Serra do Ibituruna: muscovita - quartzo xisto (CP-27)

\begin{tabular}{|c|c|c|c|c|c|c|c|c|c|c|c|c|c|c|c|c|c|c|c|c|c|c|}
\hline zircão & spot & $\mathrm{Zr}$ & $\mathrm{Si}$ & $\mathbf{L i}$ & Mg & Al & $\mathbf{P}$ & $\mathrm{Ca}$ & Sc & $\mathbf{T i}$ & Mn & $\mathbf{F e}$ & Co & $\mathbf{R b}$ & $\mathbf{S r}$ & $\mathbf{Y}$ & $\mathbf{N b}$ & Ta & Mo & Sn & Sb & $\mathbf{B a}$ \\
\hline 12 & $\mathrm{e}$ & 496007 & 150967 & 2.32 & 9.54 & 362.71 & 206.18 & 0.00 & 247.23 & 6.27 & 4.13 & 131.42 & $<0.081$ & 1.09 & 0.83 & 808.84 & 38.90 & 15.74 & 6.77 & $<0.70$ & $<0.48$ & 2.56 \\
\hline 15 & $\mathrm{e}$ & 496007 & 170402 & 1.68 & 3.93 & 22.41 & 318.79 & 0.00 & 277.57 & $<2.42$ & 14.75 & 398.89 & $<0.080$ & 0.19 & 0.47 & 1044.84 & 2.37 & 1.11 & 7.02 & \begin{tabular}{|l|}
$<0.79$ \\
\end{tabular} & $<0.59$ & 1.19 \\
\hline 18 & $\mathrm{e}$ & 496007 & 163087 & 0.91 & 2.01 & 14.48 & 129.35 & 107.29 & 248.79 & 8.75 & 2.58 & 38.21 & $<0.045$ & $<0.191$ & 0.42 & 519.02 & 1.88 & 1.00 & 7.33 & $<0.77$ & $<0.49$ & $<0.43$ \\
\hline 23 & $\mathrm{e}$ & 496007 & 183630 & 2.74 & 1.47 & 9.72 & 173.08 & 143.30 & 280.20 & 6.91 & $<0.98$ & 8.77 & $<0.096$ & 0.23 & 0.46 & 629.09 & 1.89 & 0.73 & 8.45 & $<0.93$ & 1.05 & $<0.71$ \\
\hline 26 & $\mathrm{e}$ & 496007 & 164002 & 1.28 & 1.45 & 17.75 & 173.43 & 0.00 & 250.81 & 4.81 & $<0.96$ & 10.85 & $<0.077$ & $<0.26$ & 0.41 & 622.85 & 1.90 & 0.69 & 6.27 & 1.59 & $<0.70$ & $<0.54$ \\
\hline 28 & $\mathrm{e}$ & 496007 & 180306 & $<0.61$ & 2.38 & 54.19 & 448.61 & 0.00 & 256.22 & 24.25 & $<1.21$ & $<10.11$ & $<0.109$ & $<0.27$ & 0.21 & 877.35 & 4.11 & 1.87 & 6.92 & 1.72 & $<0.79$ & $<0.83$ \\
\hline 31 & $\mathrm{e}$ & 496007 & 126969 & 1.77 & 1.74 & 15.84 & 670.59 & 2524.46 & 172.78 & 4.03 & 41.11 & 45.00 & $<0.079$ & $<0.20$ & 1.46 & 497.36 & 1.19 & 0.64 & 3.38 & 1.60 & $<0.70$ & $<0.60$ \\
\hline 38 & $\mathrm{e}$ & 496007 & 172796 & 0.83 & 3.24 & 12.43 & 298.48 & 0.00 & 273.22 & 12.20 & $<0.97$ & 18.70 & $<0.130$ & $<0.22$ & 0.38 & 507.20 & 3.32 & 0.92 & 7.33 & 1.21 & $<0.76$ & $<0.75$ \\
\hline 39 & $\mathrm{e}$ & 496007 & 168611 & 1.14 & 2.73 & 100.66 & 844.73 & 0.00 & 295.10 & 6.44 & $<1.34$ & 76.46 & 0.14 & 0.47 & 0.30 & 2008.34 & 2.75 & 1.04 & 8.40 & $<1.51$ & $<0.85$ & 1.12 \\
\hline 40 & $\mathrm{e}$ & 496007 & 122735 & 2.60 & 1.76 & 57.27 & 227.24 & 0.00 & 194.69 & 8.69 & 5.05 & 101.09 & $<0.094$ & $<0.25$ & 0.28 & 562.95 & 2.60 & 1.18 & 3.76 & $<1.32$ & $<0.85$ & $<1.09$ \\
\hline 52 & $\mathrm{~m}$ & 496007 & 171795 & 1.74 & 2.49 & 13.98 & 98.17 & 0.00 & 243.19 & 6.06 & 0.99 & 33.65 & $<0.088$ & $<0.29$ & 0.25 & 187.62 & 1.06 & 0.58 & 5.81 & $<1.20$ & $<0.83$ & $<1.00$ \\
\hline 56 & $\mathrm{~m}$ & 496007 & 199502 & 3.19 & 33.82 & 3105.48 & 386.69 & 0.00 & 247.77 & 22.76 & 4.34 & 375.81 & 0.28 & 6.05 & 0.61 & 605.88 & 2.69 & 1.00 & 6.20 & $<2.08$ & $<1.61$ & 23.28 \\
\hline 58 & $\mathrm{e}$ & 496007 & 151020 & 0.69 & 2.90 & 14.47 & 92.34 & 0.00 & 221.69 & 3.07 & $<0.58$ & $<5.75$ & 0.08 & $<0.165$ & 0.32 & 219.43 & 1.25 & 0.55 & 4.47 & $<0.80$ & $<0.52$ & $<0.63$ \\
\hline 69 & $\mathrm{e}$ & 496007 & & 5.71 & 20.86 & 601.36 & & & & 112.02 & 14.63 & 202.50 & 0.10 & 2.20 & 1.12 & 451.80 & 2.31 & 0.79 & 5.47 & $<1.27$ & 1.66 & 4.56 \\
\hline 71 & $\mathrm{~m}$ & 496007 & 168911 & 1.39 & 5.09 & 97.58 & 265.01 & 0.00 & 254.60 & 28.38 & 4.81 & 2738.25 & $<0.087$ & 0.20 & 0.30 & 389.97 & 2.12 & 0.98 & 5.25 & 1.28 & $<0.72$ & $<0.75$ \\
\hline 85 & $\mathrm{e}$ & 496007 & 164038 & 1.59 & 3.42 & 30.03 & 1507.96 & 5977.52 & 330.57 & 5.82 & 71.96 & 189.54 & $<0.088$ & 0.33 & 3.09 & 762.51 & 2.97 & 1.27 & 5.06 & $<1.10$ & $<0.70$ & $<0.70$ \\
\hline 86 & $\mathrm{e}$ & 496007 & & 7.43 & 22.09 & 1152.79 & & & & & & & 0.39 & 3.29 & 1.56 & & & 2.08 & 5.57 & $<0.82$ & $<0.46$ & 19.29 \\
\hline \multicolumn{2}{|c|}{ Zr-91500 } & 490085 & 170162 & 1.91 & $<0.97$ & 13.79 & $<42.93$ & 0.00 & 172.67 & $<2.67$ & $<0.82$ & 16.21 & $<0.102$ & $<0.29$ & 0.16 & 117.91 & 1.47 & 0.59 & 5.01 & $<1.15$ & $<0.85$ & $<0.74$ \\
\hline
\end{tabular}

\begin{tabular}{|c|c|c|c|c|c|c|c|c|c|c|c|c|c|c|c|c|c|c|c|c|c|c|}
\hline $\mathbf{Z r}$ & spot & La & $\mathrm{Ce}$ & Pr & Nd & Sm & Eu & Gd & $\mathbf{T b}$ & Dy & Ho & Er & Tm & Yb & Lu & Hf & $\mathbf{P b}$ & Th & $\mathbf{U}$ & $\mathrm{Ce} / \mathrm{Ce}^{*}$ & $\mathbf{E u} / \mathbf{E u} *$ & $\mathbf{Y b} / \mathbf{S m}$ \\
\hline 12 & $\mathrm{e}$ & 0.69 & 21.68 & 0.77 & 7.50 & 4.27 & 0.95 & 14.42 & 4.71 & 65.64 & 27.82 & 135.15 & 32.26 & 360.99 & 65.01 & 11450 & 560.53 & 65.70 & 239.75 & 8.29 & 1.35 & \begin{tabular}{|l|}
78.72 \\
\end{tabular} \\
\hline 15 & $\mathrm{e}$ & 0.57 & 20.65 & 0.42 & 4.50 & 5.35 & 1.71 & 26.29 & 10.04 & 99.33 & 38.28 & 162.64 & 32.97 & 312.42 & 56.08 & 9563 & 684.80 & 161.19 & 231.55 & 10.08 & 1.88 & 54.39 \\
\hline 18 & $\mathrm{e}$ & 0.12 & 12.06 & $<0.051$ & $<0.76$ & 2.28 & 1.14 & 11.64 & 3.85 & 41.46 & 17.48 & 82.91 & 18.60 & 209.82 & 42.22 & 9843 & 500.62 & 146.33 & 240.09 & 21.93 & 1.89 & 85.89 \\
\hline 23 & $\mathrm{e}$ & $<0.095$ & 5.38 & 0.18 & 3.34 & 4.78 & 0.67 & 21.72 & 6.32 & 61.93 & 19.92 & 88.14 & 18.43 & 184.80 & 34.76 & 10322 & 786.16 & 150.42 & 420.67 & 4.91 & 0.80 & 36.02 \\
\hline 26 & $\mathrm{e}$ & $<0.091$ & 7.40 & $<0.097$ & 1.00 & 1.78 & 0.22 & 8.69 & 3.44 & 48.20 & 18.75 & 100.24 & 23.64 & 253.96 & 55.14 & 9422 & 537.12 & 65.23 & 167.54 & 0 & 0.43 & 133.17 \\
\hline 28 & $\mathrm{e}$ & $<0.105$ & 22.18 & 0.11 & 1.96 & 2.33 & 0.55 & 15.24 & 6.02 & 81.60 & 32.53 & 153.08 & 32.73 & 319.08 & 62.25 & 11525 & 101.59 & 13.20 & 32.18 & 25.90 & 0.82 & 127.64 \\
\hline 31 & $\mathrm{e}$ & 0.13 & 12.07 & 0.15 & 1.99 & 3.33 & 3.14 & 28.74 & 5.44 & 49.23 & 17.24 & 64.24 & 15.18 & 141.29 & 25.22 & 6921 & 538.66 & 99.96 & 186.46 & 10.55 & 3.47 & 39.48 \\
\hline 38 & $\mathrm{e}$ & $<0.102$ & 27.75 & $<0.086$ & 1.01 & 3.88 & $<0.24$ & 14.73 & 5.15 & 61.41 & 18.81 & 80.98 & 14.66 & 133.58 & 22.90 & 10413 & 355.73 & 222.64 & 95.93 & 0 & 0.00 & 32.06 \\
\hline 39 & $\mathrm{e}$ & 0.17 & 17.08 & 0.42 & 5.55 & 19.01 & 7.92 & 90.28 & 25.56 & 242.79 & 80.92 & 340.29 & 67.03 & 610.95 & 110.50 & 10396 & 450.63 & 142.48 & 194.68 & 9.49 & 4.69 & 29.94 \\
\hline 40 & $\mathrm{e}$ & 0.17 & 19.48 & 0.68 & 5.27 & 3.56 & 1.17 & 12.22 & 4.53 & 47.73 & 18.84 & 83.38 & 16.87 & 168.04 & 30.38 & 7653 & 1016.19 & 182.03 & 353.28 & 8.73 & 1.81 & 44.03 \\
\hline 52 & $\mathrm{~m}$ & $<0.142$ & 1.61 & $<0.105$ & $<1.35$ & $<0.62$ & 0.24 & 2.43 & 1.20 & 15.18 & 6.06 & 30.40 & 6.94 & 80.51 & 17.92 & 9289 & 769.71 & 53.45 & 230.68 & 0 & 0.99 & 0 \\
\hline 56 & $\mathrm{~m}$ & 0.19 & 17.78 & $<0.206$ & 3.07 & 3.77 & 0.93 & 11.34 & 5.26 & 57.56 & 23.99 & 106.64 & 23.00 & 237.73 & 49.37 & 12306 & 399.01 & 81.99 & 108.26 & 26.02 & 1.47 & 58.74 \\
\hline 58 & $\mathrm{e}$ & $<0.089$ & 5.02 & 0.10 & 0.90 & 1.42 & $<0.18$ & 1.84 & 1.61 & 15.59 & 7.45 & 36.52 & 8.22 & 93.13 & 23.27 & 9595 & 82.45 & 23.26 & 40.73 & 6.02 & 0.00 & 60.96 \\
\hline 69 & $\mathrm{e}$ & 0.73 & 23.33 & 1.56 & 13.29 & 7.13 & 2.12 & 13.18 & 3.29 & 34.58 & 15.13 & 71.77 & 20.31 & 238.17 & 44.44 & 11878 & 590.82 & 100.68 & 330.97 & 6.66 & 2.83 & 31.13 \\
\hline 71 & $\mathrm{~m}$ & 0.46 & 13.70 & 0.61 & 5.49 & 3.06 & 0.60 & 10.30 & 3.12 & 35.72 & 13.06 & 56.40 & 12.17 & 113.58 & 21.34 & 11173 & 267.29 & 7.97 & 81.11 & 5.97 & 1.01 & 34.59 \\
\hline 85 & $\mathrm{e}$ & 1.38 & 29.21 & 1.32 & 9.21 & 5.56 & 1.04 & 19.84 & 6.12 & 67.28 & 24.49 & 113.10 & 24.66 & 245.84 & 47.85 & 11016 & 494.26 & 109.03 & 245.71 & 8.33 & 1.27 & 41.17 \\
\hline 86 & $\mathrm{e}$ & 0.11 & 16.32 & 0.22 & 1.70 & 4.88 & 1.35 & 21.62 & 8.15 & 95.54 & 40.36 & 189.17 & 38.56 & 367.49 & 72.93 & 11893 & 1461.09 & 214.44 & 553.17 & 12.27 & 1.62 & 70.23 \\
\hline \multicolumn{2}{|c|}{ Zr-91500 } & 0.08 & 2.17 & $<0.108$ & $<1.10$ & $<0.61$ & $<0.25$ & 1.64 & 0.67 & 8.31 & 4.23 & 19.43 & 5.64 & 58.17 & 11.75 & 5804.50 & 61.37 & 24.69 & \begin{tabular}{|l|}
65.30 \\
\end{tabular} & & & \\
\hline
\end{tabular}


Unidade Serra do Ibituruna: muscovita - quartzo xisto (CP-35)

\begin{tabular}{|c|c|c|c|c|c|c|c|c|c|c|c|c|c|c|c|c|c|c|c|c|c|c|}
\hline zircão & spot & $\mathbf{Z r}$ & $\mathrm{Si}$ & $\mathbf{L i}$ & $\mathrm{Mg}$ & Al & $\mathbf{P}$ & $\mathrm{Ca}$ & Sc & $\mathbf{T i}$ & Mn & $\mathbf{F e}$ & Co & $\mathbf{R b}$ & $\mathbf{S r}$ & $\mathbf{Y}$ & $\mathrm{Nb}$ & Ta & Mo & Sn & $\mathbf{S b}$ & $\mathbf{B a}$ \\
\hline 21 & $\mathrm{e}$ & 496007 & 184270 & 3.84 & 11.37 & 43.39 & 139.94 & 0.00 & 232.91 & 6.00 & $<0.82$ & 523.50 & 0.11 & $<0.27$ & 0.28 & 363 & 1.71 & 0.70 & 6.51 & $<1.36$ & $<0.89$ & $<0.84$ \\
\hline 26 & $\mathrm{~m}$ & 96007 & 3404 & 1.57 & 3.42 & 10.18 & 1059.22 & 0.00 & 76.55 & 23.09 & $<0.54$ & 9.45 & 0.0 & 0.48 & 0.27 & 2409 & 4.71 & 1.69 & 4.23 & $<0.83$ & $<0.56$ & $<0.73$ \\
\hline 32 & $\mathrm{~m}$ & 9600 & & 4.49 & 14.06 & 105.49 & 3.12 & & 52.80 & 9.78 & $<0.52$ & 54.47 & $<0.072$ & 0.43 & 0.46 & 588 & 2.02 & 1.00 & 4.85 & $<0.84$ & 0.58 & $<0.60$ \\
\hline 36 & $\mathrm{e}$ & 496007 & 172243 & 2.99 & 8.63 & 13.93 & 479.53 & 0.00 & 53.83 & 11.80 & 2.53 & 92.83 & 0.12 & 0.23 & 0.27 & 1186 & 13.88 & 6.57 & 5.42 & 2.17 & $<0.63$ & $<0.75$ \\
\hline 41 & $\mathrm{e}$ & 496007 & 177528 & 4.12 & 5.68 & 19.87 & 84.13 & 0.00 & 15.23 & 11.83 & $<0.65$ & 25.57 & 0.068 & 0.20 & 0.24 & 750 & 1.46 & 0.69 & 4.80 & $<1.06$ & $<0.74$ & $<0.83$ \\
\hline 42 & $\mathrm{e}$ & 49600 & & 2.55 & 3.48 & .43 & .60 & & 234 & 5.25 & $<0.78$ & $<8.45$ & $<0.088$ & $<0.23$ & 0.21 & 213 & .40 & 0.78 & 4.91 & $<1.24$ & $<0.85$ & 0.78 \\
\hline 45 & $\mathrm{e}$ & 496007 & 178032 & 0.46 & $<0.98$ & $<8.87$ & 43.09 & 0.00 & 279.56 & 6.87 & 0.79 & 12.68 & 0.09 & $<0.228$ & 0.24 & 586 & 1.36 & 0.66 & 4.92 & $<1.12$ & $<0.75$ & $<0.73$ \\
\hline 48 & $\mathrm{e}$ & 496007 & & 9.91 & 110.45 & 408.43 & 3.11 & 0.00 & 5 & 23.60 & 20.80 & 1350.30 & 0.6 & 0.96 & 1.47 & 1373 & 2 & 1.51 & 4.65 & $<1.17$ & 4.15 & 4.03 \\
\hline 52 & $\mathrm{e}$ & 496007 & & 5.42 & 2.61 & 61.94 & 9.71 & 02.99 & 237.95 & 6.67 & 1.34 & 42.20 & $<0.073$ & $<0.25$ & 0.36 & 413 & .09 & 0.59 & 4.21 & $<1.04$ & $<0.75$ & 1.07 \\
\hline 68 & $\mathrm{e}$ & 496007 & 179345 & 8.03 & 3.49 & 139.55 & 4.27 & 0.00 & 248.67 & 9.08 & 1.50 & 1192.61 & $<0.067$ & $<0.131$ & 0.22 & 555 & 1.99 & 0.60 & 5.92 & 1.20 & 0.63 & $<0.61$ \\
\hline 70 & $\mathrm{e}$ & 496007 & & 2.57 & 4.90 & 90.48 & 3.55 & 0.00 & 31.02 & 14.78 & 1.2 & 34.63 & $<0.128$ & 0.54 & 0.39 & 1209 & 3. & 0.79 & 4.12 & 1.14 & $<0.96$ & $<1.25$ \\
\hline 72 & $\mathrm{~m}$ & 496007 & 161878 & 6.71 & 17.29 & 280.19 & 5.75 & 0.00 & 249.63 & 11.93 & 2.95 & 142.28 & 0.05 & 0.56 & 0.74 & 988 & 3.23 & 1.07 & 3.18 & $<0.66$ & 0.99 & 2.09 \\
\hline 73 & $\mathrm{e}$ & 496007 & 163547 & 4.35 & 4.58 & 14.07 & 118.92 & 0.00 & 29.41 & 25.33 & 0.89 & 28.57 & $<0.075$ & $<0.134$ & 0.11 & 304 & 1. & 0.64 & 3.41 & $<0.82$ & $<0.52$ & $<0.62$ \\
\hline 75 & $\mathrm{c}$ & 496007 & 190462 & 12.80 & 31.88 & 494.45 & 376.96 & & 51.05 & 12.91 & 49.06 & 1632.65 & 0.25 & 0.47 & 2.99 & 686 & 3.3 & 1.46 & 4.41 & $<1.92$ & 4.92 & 9.20 \\
\hline 82 & $\mathrm{~m}$ & 496007 & 163896 & 1.62 & 3.75 & 70.26 & 340.00 & 0.00 & 257.34 & 4.21 & 0.75 & 35.29 & $<0.087$ & 0.27 & 0.37 & 1387 & 4.67 & 1.72 & 4.01 & $<0.86$ & $<0.58$ & 0.85 \\
\hline 90.1 & $\mathrm{e}$ & 496007 & 158807 & 4.31 & 18.49 & 282.31 & 350.74 & 100.98 & 239.74 & 64.42 & 4.76 & 607.59 & $<0.074$ & 0.91 & 1.07 & 1045 & 1.68 & 0.93 & 4.34 & $<0.63$ & 1.47 & 5.72 \\
\hline \multicolumn{2}{|c|}{ Zr-91500 } & 493786 & 178282 & 0.57 & $<1.17$ & $<8.67$ & $<45.52$ & 0 & 195.86 & 6.78 & $<0.71$ & $<7.38$ & $<0.130$ & $<0.23$ & 0.08 & 189.89 & 2.05 & 0.43 & 5.91 & $<1.13$ & $<0.74$ & $<0.73$ \\
\hline
\end{tabular}

\begin{tabular}{|c|c|c|c|c|c|c|c|c|c|c|c|c|c|c|c|c|c|c|c|c|c|c|}
\hline $\mathbf{Z r}$ & spot & La & $\mathrm{Ce}$ & Pr & Nd & Sm & $\mathbf{E u}$ & Gd & $\mathbf{T b}$ & Dy & Ho & Er & Tm & $\mathbf{Y b}$ & $\mathbf{L u}$ & Hf & $\mathbf{P b}$ & Th & $\mathbf{U}$ & $\mathrm{Ce} / \mathrm{Ce}^{*}$ & $\mathbf{E u} / \mathbf{E u} *$ & $\mathbf{Y b} / \mathbf{S m}$ \\
\hline 21 & $\mathrm{e}$ & 0.18 & 8.51 & 0.14 & 1.67 & 2.02 & $<0.30$ & 5.30 & 1.75 & 26.65 & 10.63 & 59.37 & 15.16 & 186.18 & 40.72 & 10369 & 389.96 & 64.25 & 181.14 & 7.28 & 0.00 & 85.70 \\
\hline 26 & $\mathrm{~m}$ & $<0.097$ & 20.74 & 0.09 & 1.14 & 5.66 & 1.24 & 37.98 & 16.56 & 204.06 & 80.47 & 355.93 & 70.99 & 633.18 & 116.66 & 11377 & 149.55 & 51.10 & 44.79 & 26.69 & 1.17 & 104.25 \\
\hline 32 & $\mathrm{~m}$ & 1.98 & 27.72 & 1.00 & 3.97 & 3.52 & 1.23 & 13.84 & 4.82 & 57.42 & 20.02 & 96.93 & 20.00 & 212.21 & 42.03 & 12074 & 310.47 & 74.35 & 131.82 & 8.12 & 1.82 & 56.11 \\
\hline 36 & $\mathrm{e}$ & 0.10 & 23.83 & 0.10 & 1.67 & 4.40 & 0.84 & 32.63 & 12.61 & 135.46 & 41.61 & 150.25 & 28.33 & 238.91 & 40.84 & 12317 & 1004.66 & 39.25 & 347.42 & 25.28 & 0.86 & 50.52 \\
\hline 41 & $\mathrm{e}$ & 0.24 & 6.31 & 0.15 & 2.56 & 4.06 & 0.66 & 16.21 & 6.14 & 70.54 & 28.02 & 129.08 & 25.37 & 246.19 & 49.12 & 8698 & 682.07 & 90.90 & 322.80 & 5.03 & 0.90 & 56.50 \\
\hline 42 & $\mathrm{e}$ & $<0.142$ & 18.84 & $<0.108$ & $<1.27$ & $<0.81$ & 0.31 & 3.84 & 1.48 & 19.58 & 7.68 & 35.14 & 7.88 & 83.60 & 17.94 & 11163 & 248.51 & 63.41 & 65.03 & 0.00 & 1.01 & 0.00 \\
\hline 45 & $\mathrm{e}$ & $<0.115$ & 10.56 & $<0.069$ & $<1.02$ & 1.60 & 0.53 & 7.67 & 3.10 & 42.13 & 19.67 & 102.36 & 24.02 & 274.89 & 61.90 & 10779 & 150.32 & 42.78 & 59.42 & 0.00 & 1.08 & 159.49 \\
\hline 48 & $\mathrm{e}$ & 4.39 & 49.94 & 3.22 & 26.50 & 18.79 & 4.98 & 44.28 & 13.84 & 139.34 & 45.39 & 185.96 & 36.57 & 317.34 & 60.12 & 10147 & 703.83 & 136.63 & 612.31 & 8.76 & 3.81 & 15.73 \\
\hline 52 & $\mathrm{e}$ & 0.24 & 13.78 & 0.23 & 2.29 & 4.91 & 1.52 & 10.97 & 3.64 & 35.96 & 14.07 & 70.23 & 19.33 & 216.69 & 50.85 & 10683 & 413.28 & 66.93 & 212.56 & 9.52 & 2.32 & 41.08 \\
\hline 68 & $\mathrm{e}$ & 0.59 & 26.69 & 0.73 & 4.96 & 4.51 & 1.11 & 13.89 & 4.95 & 58.22 & 19.59 & 87.38 & 18.84 & 171.88 & 33.76 & 11203 & 663.56 & 122.00 & 263.26 & 10.62 & 1.58 & 35.47 \\
\hline 70 & $\mathrm{e}$ & 0.11 & 16.95 & 0.19 & 2.78 & 4.77 & 1.90 & 18.73 & 7.38 & 101.21 & 39.21 & 193.29 & 41.76 & 418.75 & 83.29 & 9095 & 811.81 & 145.52 & 250.75 & 13.62 & 2.42 & 81.81 \\
\hline 72 & $\mathrm{~m}$ & 0.81 & 52.94 & 0.71 & 4.20 & 5.93 & 3.46 & 24.89 & 7.90 & 91.36 & 31.40 & 149.47 & 33.44 & 341.55 & 70.37 & 9829 & 785.28 & 255.75 & 368.48 & 20.38 & 3.85 & 53.63 \\
\hline 73 & $\mathrm{e}$ & 0.10 & 3.90 & 0.08 & $<0.55$ & 0.90 & $<0.170$ & 7.29 & 2.32 & 28.17 & 9.39 & 42.62 & 9.81 & 95.94 & 19.35 & 9956 & 352.74 & 66.10 & 202.87 & 4.39 & 0.00 & 99.45 \\
\hline 75 & $\mathrm{c}$ & 2.75 & 37.79 & 1.36 & 9.98 & 4.95 & 2.49 & 14.45 & 4.92 & 59.03 & 23.66 & 114.56 & 25.85 & 304.15 & 71.35 & 11441 & 657.42 & 436.10 & 509.75 & 9.46 & 3.45 & 57.18 \\
\hline 82 & $\mathrm{~m}$ & $<0.095$ & 47.24 & $<0.097$ & 2.16 & 4.71 & 0.66 & 20.32 & 7.72 & 100.24 & 41.80 & 210.44 & 47.88 & 469.03 & 96.82 & 10133 & 483.02 & 125.08 & 225.84 & 0.00 & 0.81 & 92.71 \\
\hline 90.1 & $\mathrm{e}$ & 7.94 & 78.43 & 5.84 & 33.10 & 24.33 & 6.64 & 44.90 & 13.53 & 127.65 & 36.66 & 131.66 & 25.22 & 223.12 & 37.41 & 11026 & 278.44 & 63.47 & 139.86 & 10.22 & 4.81 & 8.54 \\
\hline 21 & $\mathrm{e}$ & 0.18 & 8.51 & 0.14 & 1.67 & 2.02 & $<0.30$ & 5.30 & 1.75 & 26.65 & 10.63 & 59.37 & 15.16 & 186.18 & 40.72 & 10369 & 389.96 & 64.25 & 181.14 & 7.28 & 0.00 & 85.70 \\
\hline \multicolumn{2}{|c|}{ Zr-91500 } & $<0.136$ & 18.01 & $<0.078$ & $<0.93$ & $<0.74$ & 0.88 & 4.56 & 1.65 & 16.21 & 5.51 & 22.19 & 5.05 & 53.7 & 9.64 & 6310.25 & 113.34 & 14.48 & 232.14 & & & \\
\hline
\end{tabular}


Unidade Serra do Ibituruna: muscovita quartzito (CP-98)

\begin{tabular}{|c|c|c|c|c|c|c|c|c|c|c|c|c|c|c|c|c|c|c|c|c|c|c|}
\hline zircão & spot & $\mathbf{Z r}$ & $\mathbf{S i}$ & $\mathbf{L i}$ & $\mathrm{Mg}$ & $\mathrm{Al}$ & $\mathbf{P}$ & $\mathrm{Ca}$ & Sc & $\mathbf{T i}$ & Mn & $\mathrm{Fe}$ & Co & $\mathbf{R b}$ & Sr & $\mathbf{Y}$ & $\mathrm{Nb}$ & Ta & Mo & Sn & $\mathrm{Sb}$ & $\mathbf{B a}$ \\
\hline 5 & $\mathrm{e}$ & 496007 & 169789 & 6.12 & 2.63 & 59.10 & 176.83 & 0.00 & 255.64 & 25.74 & 3.60 & 29.71 & $<0.146$ & $<0.38$ & 0.57 & 532.87 & 3.14 & 2.17 & 4.54 & $<1.52$ & $<1.12$ & $<1.48$ \\
\hline 7 & $\mathrm{e}$ & 6007 & 3410 & 31 & & & & & 0.34 & 5.19 & & & $<0.21$ & $<0.45$ & 89 & 66.49 & .58 & 35 & 30 & 25 & 1.90 & 1.41 \\
\hline 9 & $\mathrm{e}$ & 6007 & 662 & 4.05 & & & & & 7.64 & 9.41 & & 1.13 & 0.058 & 0.201 & 0.31 & 38.15 & 2.15 & .76 & 08 & 0.85 & 0.61 & 0.73 \\
\hline 15 & $\mathrm{~m}$ & 496007 & 164653 & 2.24 & $<0.60$ & & 235.80 & 0.0 & 272.01 & 13.59 & 3.49 & 48.39 & $<0.107$ & $<0.182$ & 0.27 & 354.61 & 1.40 & 0.49 & 2.74 & $<0.83$ & $<0.70$ & $<0.96$ \\
\hline 16 & $\mathrm{e}$ & 496007 & 156698 & 1.87 & 1.24 & 454 & 10.50 & 0.0 & 232.70 & 11.54 & $<0.74$ & 12.77 & $<0.086$ & $<0.128$ & 0.16 & 41.65 & 0.93 & 0.18 & 42 & 75 & $<0.57$ & $<0.66$ \\
\hline 20 & $\mathrm{~m}$ & 496007 & 155686 & 7.25 & 5.95 & 7.63 & 743.98 & 202.73 & 526.83 & 8.99 & 172.00 & 2129.47 & 0.16 & 0.51 & 2.29 & 1001.56 & 2.47 & 1.58 & .29 & $<0.66$ & 0.90 & 2.53 \\
\hline 27 & $\mathrm{e}$ & 496007 & 161761 & 3.68 & 1.03 & .76 & 426.22 & 608.16 & 288.39 & 8.78 & 1.19 & 97.43 & $<0.093$ & $<0.173$ & 0.17 & 288.56 & 0.98 & 0.34 & 2.77 & $<0.78$ & $<0.59$ & $<0.60$ \\
\hline 30 & $\mathrm{~m}$ & 496007 & 185272 & 1.73 & 1.74 & & 85.44 & 0.00 & 322.95 & 5.29 & $<1$. & $<47.21$ & $<0.134$ & $<0.42$ & 0.19 & 282.79 & 1.27 & 0.35 & 3.48 & $<1.43$ & $<1.21$ & $<0.97$ \\
\hline 31 & $\mathrm{e}$ & 496007 & 203943 & 2.51 & $<1.32$ & 5.49 & 1241.10 & 0.00 & 362.47 & 13.98 & $<1.8$ & $<52.95$ & $<0.21$ & 0.39 & 0.40 & 499.81 & 1.26 & $<0.22$ & .30 & $<1.94$ & $<1.56$ & $<1.30$ \\
\hline 55 & $\mathrm{e}$ & 496007 & 179068 & 3.66 & $<0.99$ & $<11.28$ & $<-65.56$ & 1378.09 & 378.84 & 40.27 & $<1.76$ & -35.65 & $<0.178$ & $<0.34$ & 0.23 & 308.02 & 1.02 & 0.43 & 3.58 & $<1.46$ & $<1.15$ & $<1.17$ \\
\hline 56 & $\mathrm{e}$ & 496007 & 155125 & 3.61 & 1.43 & & $<-42.30$ & 0.00 & 384.01 & 9.23 & $<$ & 80.25 & $<0.118$ & $<0.25$ & 0.22 & 337.91 & 1.35 & 0.28 & 2.78 & $<0.85$ & $<0.78$ & $<0.78$ \\
\hline 57 & $\mathrm{e}$ & 496007 & 192750 & 21.81 & 84.13 & 1628.57 & $<-173.62$ & 853.85 & 626.88 & 58.09 & 120.29 & -407.32 & 7.60 & 5.77 & 20.82 & 5003.83 & 8.64 & 5.79 & 13.44 & $<2.39$ & 18.10 & 35.73 \\
\hline 58 & $\mathrm{e}$ & 496007 & 157157 & 1.13 & $<0.86$ & 15.25 & $<-56.06$ & 2483.74 & 500.94 & 12.54 & .16 & $<-81.29$ & 1.01 & $<0.27$ & 1.47 & 792.86 & 1.63 & 0.52 & 5.17 & $<0.96$ & $<0.74$ & $<1.00$ \\
\hline 63 & $\mathrm{~m}$ & 496007 & 168586 & 4.57 & 6.57 & 192.93 & $<-124.22$ & 1787.58 & 382.91 & 48.34 & 7.30 & $<-3883.12$ & 4.30 & $<0.39$ & 2.15 & 2064.00 & 2.73 & 1.39 & 19.91 & $<1.48$ & $<1.22$ & 2.47 \\
\hline 66 & $\mathrm{~m}$ & 496007 & 141534 & 2.55 & 1.31 & 26.74 & $<-28.03$ & 196.57 & 389.69 & 22.10 & 24.13 & $<-23.72$ & 0.11 & $<0.20$ & 0.59 & 439.31 & 1.67 & 1.42 & 2.78 & $<0.72$ & $<0.49$ & $<0.55$ \\
\hline 84 & $\mathrm{e}$ & 496007 & 154432 & 4.18 & $<1.04$ & $<8.13$ & $<-33.03$ & 0.00 & 430.73 & 15.43 & 1.70 & -24.19 & $<0.178$ & $<0.29$ & 0.25 & 526.41 & 1.35 & 0.37 & 3.14 & $<0.91$ & $<0.87$ & $<0.87$ \\
\hline 97 & $\mathrm{~m}$ & 496007 & 163391 & 10.29 & $<0.93$ & $<11.24$ & & 0.00 & 636.38 & 16.53 & & $<-29.19$ & $<0.22$ & $<0.37$ & 0.30 & 936.90 & 1.35 & 0.34 & 3.38 & $<1.12$ & $<1.23$ & $<0.88$ \\
\hline 98 & $\mathrm{~m}$ & 496007 & 156265 & 4.36 & 0.92 & 51.24 & $<-32.43$ & 0.00 & 411.11 & 52.05 & 3.03 & $<-24.83$ & $<0.178$ & $<0.27$ & $<0.135$ & 74.99 & 0.61 & 0.21 & 2.17 & $<1.09$ & $<0.83$ & $<1.04$ \\
\hline \multicolumn{2}{|c|}{ Zr-91500 } & 490085 & 149985 & 3.55 & $<0.54$ & 7.62 & -15.26 & 0 & 419.6 & 9.43 & $<1.41$ & 10.58 & $<0.162$ & $<0.24$ & $<0.082$ & 117.44 & 1.06 & 0.37 & 3.44 & $<0.86$ & $<0.80$ & $<0.70$ \\
\hline
\end{tabular}

\begin{tabular}{|c|c|c|c|c|c|c|c|c|c|c|c|c|c|c|c|c|c|c|c|c|c|c|}
\hline $\mathrm{Zr}$ & spot & La & $\mathrm{Ce}$ & Pr & Nd & Sm & Eu & Gd & Tb & Dy & Ho & Er & Tm & $\mathbf{Y b}$ & $\mathbf{L u}$ & Hf & $\mathbf{P b}$ & Th & $\mathbf{U}$ & $\mathrm{Ce} / \mathrm{Ce}^{*}$ & $\mathbf{E u} / \mathbf{E u} *$ & $\mathbf{Y b} / \mathbf{S m}$ \\
\hline 5 & $\mathrm{e}$ & 3.17 & 37.02 & 5.27 & 36.45 & 17.29 & 3.08 & 23.45 & 6.14 & 52.11 & 17.24 & 67.74 & 15.10 & 145.01 & 30.79 & 10464 & 183.08 & 71.59 & 126.74 & \begin{tabular}{|l|}
5.6 \\
\end{tabular} & 2.9 & 7.813 \\
\hline 7 & $\mathrm{e}$ & 1 & 79.82 & 2.65 & 18.20 & 13.09 & 2.16 & 18.96 & 4.73 & 36.48 & 15.17 & 68.84 & 6.57 & 175.37 & 5.37 & 10447 & 611.18 & 149.57 & 225.12 & 16.9 & 2.3 & 12.478 \\
\hline 9 & $\mathrm{e}$ & 0.28 & 56.85 & 0.78 & 6.79 & 6.76 & 1.14 & 20.46 & 6.83 & 67.78 & 24.63 & 97.78 & 18.49 & 175.91 & 31.81 & 8362 & 342.41 & 155.27 & 166.07 & 23.3 & 1.3 & 24.251 \\
\hline 15 & $\mathrm{~m}$ & 0.89 & 26.16 & 1.4 & 10.10 & 4.0 & 0.55 & 6.36 & 2.45 & 26.78 & 10.21 & 41.12 & 8.73 & 84.17 & 15.40 & 8772 & 81.48 & 54.58 & 24.74 & 7.7 & 1.0 & 19.550 \\
\hline 16 & $\mathrm{e}$ & $<0.079$ & 26.39 & 0.09 & & 1.00 & 0.40 & 2.41 & 0.36 & 4.37 & 1.29 & 4.77 & 1.10 & 10.41 & 1.51 & 10404 & 74.70 & 54.60 & 22.58 & 34.2 & 1.3 & 9.693 \\
\hline 20 & $\mathrm{~m}$ & 4.93 & 148.70 & 7.15 & 39.85 & 33.16 & 7.66 & 45.11 & 9.81 & 78.39 & 26.65 & 118.42 & 25.16 & 251.17 & 52.40 & 10077 & 763.66 & 337.36 & 222.53 & 19.2 & 5.2 & 7.055 \\
\hline 27 & $\mathrm{e}$ & $<0.070$ & 6.73 & 0.24 & 1.93 & 0.97 & 0.53 & 6.93 & 1.76 & 18.91 & 7.42 & 31.94 & 7.11 & 69.25 & 13.56 & 6018 & 162.70 & 29.53 & 59.50 & 5.4 & 1.2 & 66.166 \\
\hline 30 & $\mathrm{~m}$ & 0.30 & 29.98 & 1.06 & 7.07 & 7.39 & 1.82 & 20.19 & 4.48 & 35.69 & 8.70 & 26.59 & 3.87 & 23.60 & 4.44 & 7596 & 84.44 & 85.23 & 18.82 & 10.7 & 2.1 & 2.974 \\
\hline 31 & $\mathrm{e}$ & $<0.191$ & 24.36 & $<0.167$ & 2.44 & 4.51 & 1.31 & 11.82 & 4.49 & 41.34 & 14.81 & 62.40 & 12.27 & 115.81 & 22.48 & 7378 & 333.26 & 98.50 & 76.80 & 0.0 & 2.0 & 23.935 \\
\hline 55 & $\mathrm{e}$ & $<0.127$ & 5.65 & $<0.077$ & $<1.05$ & 0.91 & $<0.26$ & 4.23 & 1.55 & 19.24 & 7.28 & 31.84 & 6.45 & 62.85 & 12.65 & 6078 & 159.85 & 16.27 & 39.01 & 0.0 & 0.0 & 64.489 \\
\hline 56 & $\mathrm{e}$ & 0.09 & 17.91 & $<0.091$ & $<0.72$ & 1.54 & 0.49 & 7.32 & 2.05 & 21.81 & 8.17 & 34.48 & 7.71 & 79.27 & 16.15 & 6495 & 104.19 & 27.07 & 41.46 & 38.2 & 1.0 & 48.063 \\
\hline 57 & $\mathrm{e}$ & 59.23 & 741.83 & 53.99 & 304.00 & 260.15 & 82.35 & 401.54 & 77.79 & 494.27 & 118.95 & 386.02 & 79.37 & 641.34 & 116.15 & 6504 & 1491.56 & 858.42 & 495.24 & 32.9 & 19.2 & 2.296 \\
\hline 58 & $\mathrm{e}$ & 1.35 & 21.11 & 0.94 & 4.75 & 4.57 & 1.52 & 12.40 & 4.25 & 49.52 & 18.42 & 90.27 & 20.68 & 209.62 & 45.23 & 6129 & 70.11 & 24.97 & 33.93 & 6.8 & 2.3 & 42.690 \\
\hline 63 & $\mathrm{~m}$ & 10.38 & 189.30 & 15.60 & 97.51 & 85.00 & 23.50 & 123.41 & 31.39 & 202.73 & 53.03 & 186.39 & 32.58 & 257.52 & 43.76 & 7966 & 118.67 & 634.87 & 173.27 & 16.6 & 9.7 & 2.822 \\
\hline 66 & $\mathrm{~m}$ & 1.15 & 28.41 & 2.11 & 14.51 & 5.44 & 1.49 & 10.27 & 2.26 & 25.57 & 9.02 & 40.76 & 8.32 & 80.62 & 14.92 & 6227 & 62.00 & 5.78 & 30.39 & 6.9 & 2.3 & 13.804 \\
\hline 84 & $\mathrm{e}$ & $<0.107$ & 7.05 & 0.13 & 1.85 & 1.50 & 0.35 & 7.48 & 2.71 & 30.92 & 10.98 & 49.40 & 10.32 & 102.41 & 21.03 & 4889 & 139.13 & 27.98 & 61.41 & 7.6 & 0.7 & 63.433 \\
\hline 97 & $\mathrm{~m}$ & $<0.136$ & 8.61 & 0.08 & 1.52 & 2.90 & 1.22 & 12.43 & 4.54 & 53.47 & 21.91 & 97.26 & 21.84 & 217.06 & 45.01 & 6008 & 333.38 & $\begin{array}{l}51.82 \\
\end{array}$ & 82.63 & 11.5 & 1.9 & 69.739 \\
\hline 98 & $\mathrm{~m}$ & 0.33 & 19.42 & 0.72 & 6.51 & 5.10 & 1.67 & 7.58 & 1.34 & 8.53 & 1.65 & 4.53 & 0.79 & 5.71 & 1.05 & 6824 & 92.89 & 39.00 & 29.85 & 8.2 & 2.8 & 1.042 \\
\hline \multicolumn{2}{|c|}{ Zr-91500 } & $<0.065$ & 1.58 & $<0.063$ & $<0.70$ & 0.72 & $<0.100$ & 0.91 & 0.48 & 6.57 & 2.37 & 13.75 & 3.24 & 35.53 & 6.83 & 3429 & 36.14 & 12.74 & 38.98 & & & \\
\hline
\end{tabular}


Unidade Colônia: Cianita - estaurolita - muscovita - granada - quartzo - biotita xisto (CP-07)

\begin{tabular}{|c|c|c|c|c|c|c|c|c|c|c|c|c|c|c|c|c|c|c|c|c|c|c|}
\hline zircão & spot & $\mathbf{Z r}$ & $\mathbf{S i}$ & $\mathbf{L i}$ & Mg & Al & $\mathbf{P}$ & Ca & Sc & $\mathbf{T i}$ & Mn & $\mathbf{F e}$ & Co & $\mathbf{R b}$ & $\mathrm{Sr}$ & $\mathbf{Y}$ & Nb & $\mathbf{T a}$ & Mo & Sn & $\mathbf{S b}$ & Ba \\
\hline 7.1 & $\mathrm{rx}$ & 496007 & 188525 & 16.0 & 78.9 & 556.8 & 267.0 & 0.00 & 316.2 & 11.4 & 15.2 & 3460.4 & 0.4 & 1.0 & 1.2 & 394.3 & 0.4 & $<0.28$ & 3.0 & $<2.69$ & $<1.69$ & 2.0 \\
\hline 7.2 & mix-c & 496007 & 174510 & 8.6 & 31.0 & 686.6 & 347.4 & 598.53 & 301.2 & 19.2 & 23.9 & 3018.6 & 0.1 & $<0.27$ & 3.2 & 1100.2 & 6.4 & 6.2 & 2.7 & 1.9 & $<0.69$ & 8.6 \\
\hline 10.1 & mix-e & 496007 & 139062 & 19.6 & 5.0 & 272.6 & 309.6 & 81.7 & 289.8 & 15.9 & 21.9 & 225.4 & $<0.066$ & $<0.15$ & 2.2 & 868.1 & 0.9 & 1.9 & 1.8 & 1.4 & $<0.38$ & 3.8 \\
\hline 10.2 & $\mathrm{p}$ & 496007 & 125896 & 3.3 & 5.4 & 471.0 & 315.2 & 96.9 & 175.8 & 25.6 & 18.6 & 578.3 & $<0.040$ & 0.2 & 2.2 & 1713.6 & 5.4 & 3.2 & 2.0 & 0.8 & $<0.26$ & 5.7 \\
\hline 11 & $\mathrm{rx}$ & 496007 & 140506 & 11.9 & 76.9 & 5515.6 & 1995.2 & 2211.23 & 367.8 & 151.2 & 257.1 & 6598.4 & 0.2 & 0.9 & 10.0 & 1997.3 & 1.0 & 0.8 & 2.5 & $<2.06$ & $<1.02$ & 31.7 \\
\hline 13.1 & mix-e & 496007 & 168605 & 23.4 & 7.8 & 159.4 & 339.5 & 550.82 & 352.3 & 11.1 & 21.2 & 357.6 & $<0.083$ & $<0.29$ & 2.9 & 476.5 & 1.0 & 0.6 & 2.8 & 1.5 & $<0.60$ & 5.6 \\
\hline 13.2 & $\mathrm{p}$ & 496007 & 159452 & 4.1 & 34.8 & 372.5 & 302.2 & 184.5 & 276.2 & 18.1 & 33.9 & 762.3 & 0.1 & 0.7 & 3.9 & 1656.1 & 2.8 & 0.9 & 2.6 & $<0.91$ & $<0.54$ & 10.0 \\
\hline 26.1 & mix-c & 496007 & 122367 & 2.8 & 44.0 & 1069.4 & 148.7 & 0.00 & 167.1 & 19.7 & 2.5 & 561.0 & 0.2 & 0.2 & 0.8 & 215.5 & 0.5 & 0.3 & 2.0 & $<0.72$ & 0.4 & 10.8 \\
\hline 26.2 & mix-e & 496007 & 122584 & 15.4 & 7.1 & 449.2 & 344.8 & 306.9 & 307.7 & 31.6 & 25.7 & 814.6 & $<0.168$ & 0.4 & 3.4 & 802.6 & 0.6 & $<0.22$ & 1.3 & $<1.33$ & $<0.74$ & 6.3 \\
\hline 31.1 & $\mathrm{p}$ & 496007 & 121500 & 0.5 & 4.1 & 99.5 & 248.9 & 0.00 & 207.1 & 25.4 & 4.5 & 47.4 & $<0.072$ & $<0.15$ & 0.7 & 771.0 & 1.5 & 0.5 & 2.1 & $<0.65$ & $<0.35$ & 1.7 \\
\hline 31.2 & mix-e & 496007 & 160427 & 14.4 & 93.4 & 1232.7 & 857.6 & 3719.46 & 348.8 & 61.6 & 492.7 & 1676.1 & $<0.170$ & $<0.44$ & 128.9 & 2307.4 & 2.1 & 2.6 & 1.9 & 1.5 & $<0.76$ & 161.0 \\
\hline 34.1 & $\mathrm{p}$ & 496007 & 100719 & 24.7 & 51.5 & 887.5 & $<277.66$ & 1343.9 & 308.6 & $<17.36$ & 57.5 & 334.5 & $<0.74$ & $<1.96$ & 9.0 & 917.7 & 4.4 & 4.9 & $<4.27$ & $<6.85$ & $<4.71$ & $<6.71$ \\
\hline 34.2 & $\mathrm{rx}$ & 496007 & 133270 & 9.8 & 1.2 & 27.0 & 301.6 & 0.00 & 297.5 & $<2.51$ & 1.7 & 18.9 & 0.1 & $<0.28$ & 0.3 & 568.9 & 0.4 & 0.4 & 1.5 & $<1.19$ & $<0.59$ & $<0.90$ \\
\hline 35.1 & mix-e & 496007 & 177227 & 29.3 & 227.1 & 1153.1 & 366.1 & 0.00 & 312.7 & 24.1 & 19.2 & 506.2 & 0.3 & $<0.30$ & 3.4 & 460.7 & 0.6 & 0.4 & 2.3 & $<1.37$ & $<0.87$ & 2.3 \\
\hline 35.2 & mix-c & 496007 & 192361 & 59.0 & 204.3 & 2168.9 & $<330.35$ & 1125.4 & 497.3 & 38.2 & 105.2 & 4752.6 & 19.5 & $<2.60$ & 28.9 & 815.2 & 5.4 & 2.6 & 25.9 & $<9.90$ & $<6.01$ & 418.0 \\
\hline 37.1 & $\mathrm{rx}$ & 496007 & 540713 & $<56.75$ & 854.3 & 10762.0 & $<6024.28$ & 0.00 & 466.7 & 539.1 & 498.6 & 10918.4 & $<13.26$ & $<37.27$ & 23.9 & 2730.1 & $<11.88$ & $<17.70$ & $<66.56$ & $<142.85$ & $<85.55$ & $<154.16$ \\
\hline 44.1 & $\mathrm{rx}$ & 496007 & 148873 & 34.9 & 120.1 & 468.2 & 435.8 & 0.00 & 325.3 & 11.4 & 6.0 & 618.5 & 0.3 & $<0.50$ & 0.6 & 701.4 & 1.0 & 0.8 & 2.2 & $<1.76$ & $<1.16$ & 1.8 \\
\hline 44.2 & $\mathrm{p}$ & 496007 & 164319 & 6.5 & 208.8 & 1266.1 & 342.1 & 496.41 & 307.8 & 14.1 & 6.5 & 2043.7 & 0.7 & 0.9 & 1.5 & 599.5 & 1.7 & 0.9 & 2.5 & $<0.70$ & $<0.43$ & 3.9 \\
\hline 48.1 & $\mathrm{rx}$ & 496007 & 155988 & 9.8 & 20.7 & 482.7 & 220.3 & 0.00 & 192.0 & 11.2 & 33.3 & 643.4 & 0.2 & $<0.20$ & 3.0 & 647.8 & 1.2 & 0.6 & 3.2 & $<0.86$ & $<0.48$ & 6.8 \\
\hline 48.2 & mix-c & 496007 & 145089 & 13.7 & 52.2 & 1789.3 & 425.9 & 573.95 & 214.9 & 30.3 & 47.6 & 911.0 & 0.1 & 0.6 & 6.7 & 1489.7 & 6.9 & 9.8 & 1.4 & $<0.66$ & 0.5 & 19.1 \\
\hline 52.1 & mix-e & 496007 & 170005 & 44.2 & 31.9 & 1382.6 & 897.6 & 292.7 & 444.1 & 67.6 & 126.9 & 1020.1 & $<0.21$ & $<0.64$ & 19.6 & 2259.4 & 1.9 & 1.5 & 5.6 & $<2.31$ & $<1.38$ & 31.1 \\
\hline 52.2 & mix-c & 496007 & 172551 & 38.1 & 52.5 & 3003.6 & $<943.76$ & 0.00 & 360.1 & 74.4 & 110.6 & 3070.2 & $<2.21$ & $<6.10$ & 14.1 & 2321.5 & 3.9 & $<3.73$ & $<10.71$ & $<21.60$ & $<13.05$ & $<22.16$ \\
\hline 59.1 & $\mathrm{p}$ & 496007 & & 13.5 & 28.5 & 526.9 & 263.2 & 158.0 & 234.1 & 25.5 & 25.8 & 613.0 & 0.0 & $<0.15$ & 3.1 & 979.9 & 4.8 & 2.3 & 2.5 & $<0.62$ & 3.2 & 13.3 \\
\hline 59.2 & mix-e & 496007 & 158647 & 41.2 & 114.6 & 1888.7 & 659.2 & 311.9 & 383.6 & 45.2 & 33.7 & 4305.5 & $<0.152$ & 1.5 & 3.3 & 1069.4 & 1.1 & 0.5 & 3.8 & 2.2 & $<1.16$ & 13.8 \\
\hline 60.1 & mix-c & 496007 & 193473 & 22.3 & 183.8 & 2449.8 & 674.6 & 3195.56 & 500.7 & 93.1 & 115.2 & 3012.5 & $<0.41$ & 3.6 & 5.5 & 1194.1 & 3.6 & 4.2 & 3.1 & $<4.84$ & 2.3 & 24.1 \\
\hline 64.1 & $\mathrm{rx}$ & 496007 & 169913 & 24.3 & 19.5 & 1174.5 & 1028.9 & 0.00 & 484.9 & 66.0 & 54.2 & 1083.3 & $<0.35$ & $<0.87$ & 4.5 & 1584.2 & 1.0 & 0.8 & $<1.96$ & $<2.90$ & $<1.95$ & 13.9 \\
\hline 65.1 & $\mathrm{p}$ & 496007 & 173594 & 3.3 & 11.5 & 203.7 & 240.5 & 0.00 & 246.5 & 9.0 & 4.3 & 73.6 & $<0.090$ & 0.3 & 0.6 & 674.2 & 1.8 & 0.9 & 2.8 & $<0.99$ & $<0.48$ & 3.8 \\
\hline 67.1 & $\mathrm{p}$ & 496007 & 169583 & 14.0 & 146.2 & 6789.6 & 3107.3 & 5038.09 & 410.8 & 74.3 & 443.3 & 8589.9 & $<0.202$ & $<0.65$ & 21.0 & 3184.1 & 1.2 & 0.7 & 2.9 & $<2.55$ & $<1.48$ & 108.2 \\
\hline 68.1 & $\mathrm{rx}$ & 496007 & 181102 & 28.8 & 55.6 & 900.0 & $<538.37$ & 0.00 & 651.5 & 57.7 & 83.8 & 593.7 & $<1.28$ & $<3.52$ & 12.7 & 1647.3 & 1.6 & $<1.49$ & $<7.07$ & $<13.56$ & 6.1 & 41.5 \\
\hline 68.2 & mix-c & 496007 & 212646 & 37.9 & 87.4 & 1154.5 & 794.4 & 1470.3 & 484.5 & 57.4 & 139.0 & 1771.5 & 0.7 & $<2.39$ & 17.9 & 1295.4 & 2.1 & $<0.96$ & 9.3 & $<10.50$ & $<5.92$ & 41.1 \\
\hline 70.1 & mix-c & 496007 & 170905 & 16.9 & 24.9 & 1675.2 & 650.7 & 329.0 & 289.0 & 16.7 & 41.9 & 2933.1 & 4.2 & 0.6 & 14.2 & 1254.8 & 6.5 & 2.9 & 20.5 & $<1.60$ & $<1.01$ & 70.5 \\
\hline 70.2 & $\mathrm{rx}$ & 496007 & 179266 & 24.2 & 22.9 & 298.2 & 436.6 & 0.00 & 413.6 & 6.7 & 3.7 & 410.7 & $<0.152$ & $<0.68$ & 0.4 & 766.0 & 0.5 & 0.6 & 1.9 & $<2.42$ & $<1.23$ & $<2.36$ \\
\hline \multicolumn{2}{|c|}{ Zr-91500 } & & & & & & & & & & & & & & & & & & & & & \\
\hline
\end{tabular}


Unidade Colônia: Cianita - estaurolita - muscovita - granada - quartzo - biotita xisto (CP-07), continuação

\begin{tabular}{|c|c|c|c|c|c|c|c|c|c|c|c|c|c|c|c|c|c|c|c|c|c|c|}
\hline zircão & spot & $\mathbf{Z r}$ & $\mathbf{S i}$ & $\mathbf{L i}$ & Mg & Al & $\mathbf{P}$ & $\mathbf{C a}$ & Sc & $\mathbf{T i}$ & Mn & $\mathrm{Fe}$ & Co & $\mathbf{R b}$ & $\mathrm{Sr}$ & $\mathbf{Y}$ & $\mathbf{N b}$ & Ta & Mo & Sn & Sb & $\mathbf{B a}$ \\
\hline 71.1 & $\mathrm{p}$ & 496007 & 165375 & 10.0 & 246.0 & 3121.7 & 487.5 & 147.5 & 233.8 & 20.4 & 7.3 & 9092.5 & 0.6 & 0.5 & 33.8 & 869.3 & 0.8 & 0.5 & 4.7 & $<0.71$ & $<0.36$ & 144.5 \\
\hline 71.2 & $\mathrm{rx}$ & 6007 & 162199 & 12.9 & 22.7 & 3979.6 & 2010.0 & 1905.10 & 374.4 & 111.9 & 225.5 & 6110.4 & $<0.121$ & $<0.47$ & 6.4 & 901.2 & 0.9 & 0.5 & 2.5 & $<1.57$ & $<0.90$ & 26.0 \\
\hline 96.2 & mix-c & 496007 & 145665 & 25.8 & 16.7 & 1144.1 & 478.4 & 279.0 & 419.9 & 18.5 & 27.1 & 2542.7 & 0.2 & 0.7 & 2.8 & 1016.3 & 1.1 & 0.7 & 2.1 & $<1.09$ & $<0.84$ & 4.5 \\
\hline 97 & $\mathrm{rx}$ & 496007 & 189226 & 28.9 & 2.5 & 214.4 & 533.1 & 0.00 & 432.6 & 5.7 & 15.6 & 199.1 & $<0.080$ & 0.4 & 1.0 & 646.2 & 0.8 & 0.5 & 2.7 & $<0.68$ & $<0.50$ & 1.3 \\
\hline 98 & mix-c & 496007 & 209990 & 57.8 & 62.9 & 1953.2 & 1172.7 & 0.00 & 474.6 & 66.8 & 69.0 & 1278.8 & $<1.00$ & $<3.60$ & 6.7 & 1287.0 & 1.7 & $<2.36$ & $<8.31$ & $<16.29$ & $<11.44$ & $<12.40$ \\
\hline 99 & $\mathrm{rx}$ & 496007 & 182160 & 37.4 & 55.1 & 925.2 & 410.0 & 1427.32 & 457.1 & 43.6 & 54.3 & 436.3 & 0.3 & $<0.50$ & 11.4 & 870.6 & 1.4 & $<0.38$ & 2.9 & $<2.18$ & $<1.62$ & 14.4 \\
\hline 100.1 & $\mathrm{rx}$ & 496007 & 380719 & 29.2 & 112.4 & 656.2 & $<2368.30$ & 7849.3 & 561.5 & 146.8 & 97.6 & 918.9 & $<5.91$ & $<11.14$ & 9.0 & 1991.6 & $<3.62$ & $<7.17$ & $<33.60$ & $<53.15$ & 45.4 & $<45.74$ \\
\hline 100.2 & nix-c & 496007 & 318512 & 76.5 & 95.1 & 1468.5 & $<2163.08$ & 0.00 & 520.6 & $<111.37$ & 35.8 & 1683.7 & $<3.02$ & $<9.92$ & 4.7 & 970.7 & $<3.84$ & $<7.58$ & $<25.23$ & $<49.40$ & $<30.00$ & $<48.57$ \\
\hline 102.1 & $\mathrm{rx}$ & 496007 & 232976 & 18.6 & 20.5 & 274.1 & 594.8 & 0.00 & 451.4 & $<10.41$ & 8.8 & 533.5 & $<0.36$ & $<0.75$ & 1.2 & 628.0 & 1.1 & $<0.65$ & 2.8 & $<4.24$ & $<3.01$ & $<3.45$ \\
\hline 108 & mix-e & 496007 & 194473 & 26.1 & 24.8 & 307.0 & 583.8 & 0.00 & 454.0 & 18.6 & 8.6 & 1318.3 & $<0.22$ & 0.7 & 0.5 & 550.3 & 1.0 & 0.6 & 10.0 & $<2.69$ & 1.8 & $<2.24$ \\
\hline 118.1 & mix-e & 496007 & 160532 & 41.4 & 40.5 & 689.4 & $<738.96$ & 1619.3 & 477.4 & $<33.08$ & 59.8 & 748.4 & $<1.06$ & $<2.34$ & 4.4 & 1111.6 & 1.2 & $<1.87$ & $<8.59$ & $<14.42$ & $<8.88$ & $<12.82$ \\
\hline 119.1 & $\mathrm{p}$ & 496007 & 168115 & 2.4 & 7.7 & 266.8 & 487.4 & 0.00 & 298.1 & 14.2 & 4.3 & 318.6 & $<0.089$ & $<0.20$ & 1.2 & 1527.3 & 2.3 & 0.7 & 2.3 & 0.9 & $<0.64$ & 2.8 \\
\hline 119.2 & mix-e & 496007 & 164379 & 51.7 & 73.8 & 482.9 & 633.2 & 145.4 & 425.3 & 27.1 & 31.0 & 830.1 & 0.1 & 0.5 & 2.2 & 964.2 & 1.4 & 0.7 & 3.8 & $<1.03$ & $<0.64$ & 4.3 \\
\hline 120.1 & $\mathrm{rx}$ & 496007 & 181977 & 43.8 & 12.3 & 252.8 & 1567.6 & 193.7 & 592.6 & 14.7 & 92.2 & 417.1 & $<0.098$ & 0.3 & 21.5 & 2046.4 & & 1.4 & 2.8 & $<1.08$ & $<0.78$ & 31.4 \\
\hline 120.2 & iix-c & 496007 & 176748 & 53.3 & 353.8 & 2841.1 & 1737.2 & 395.92 & 684.2 & 67.4 & 190.7 & 5408.2 & 0.8 & 0.7 & 69.8 & 2348.7 & 19.2 & 9.0 & 5.5 & 4.2 & 17.7 & 392.7 \\
\hline 123.1 & mix-e & 496007 & 190935 & 62.5 & 16.3 & 424.8 & 824.4 & 3127.7 & 548.7 & 8.9 & 20.4 & 773.2 & $<0.30$ & $<0.66$ & 2.4 & 1169.8 & 1.5 & $<0.46$ & 1.8 & $<3.52$ & $<2.41$ & $<3.77$ \\
\hline 128.1 & mix-e & 496007 & 168133 & 42.0 & 45.8 & 402.4 & 526.5 & 208.1 & 398.4 & 23.7 & 63.0 & 520.6 & 0.1 & 0.5 & 9.9 & 981.1 & 1.9 & 1.4 & 2.5 & 1.3 & $<0.48$ & 20.5 \\
\hline 128.2 & $\mathrm{p}$ & 496007 & 187729 & 5.7 & $<1.15$ & 21.7 & 326.6 & 0.00 & 249.9 & 12.4 & 1.0 & 84.5 & $<0.163$ & $<0.29$ & 0.4 & 760.5 & 1.9 & 0.6 & 2.4 & $<1.61$ & $<1.04$ & $<1.34$ \\
\hline 139.1 & iix-e & 496007 & 168668 & 66.2 & 31.9 & 1270.7 & 1343.2 & 386.9 & 438.1 & 58.1 & 72.6 & 956.4 & 0.1 & 0.5 & 9.1 & 1869.4 & 4.4 & 5.3 & 2.8 & 1.1 & $<0.47$ & 12.8 \\
\hline 139.2 & mix-c & 496007 & 190277 & 55.5 & 185.8 & 1392.4 & 928.1 & 2393.39 & 309.1 & 53.6 & 91.7 & 2429.9 & 0.6 & 0.8 & 47.2 & 1778.5 & 22.2 & 10.0 & 23.7 & 3.5 & 17.6 & 119.1 \\
\hline 142.1 & mix-e & 496007 & 182894 & 59.6 & 215.6 & 2606.8 & 649.2 & 0.00 & 413.8 & 59.8 & 81.7 & 1584.1 & 0.7 & 2.4 & 10.5 & 1556.7 & 3.0 & 2.5 & 5.9 & $<3.79$ & 5.5 & 22.6 \\
\hline 142.2 & $\mathrm{p}$ & 496007 & 201288 & 22.9 & 308.7 & 1203.0 & 540.6 & 669.2 & 320.2 & 74.3 & 9.2 & 2003.4 & 0.6 & 0.8 & 2.5 & 1852.9 & 8.0 & 2.9 & 2.6 & $<1.35$ & 1.7 & 11.4 \\
\hline 148.1 & mix-e & 496007 & 167493 & 54.7 & 21.3 & 544.9 & 518.6 & 201.2 & 376.9 & 23.4 & 18.1 & 759.3 & $<0.062$ & 0.4 & 1.9 & 642.0 & 0.9 & 0.4 & 3.0 & $<1.02$ & $<0.65$ & 3.8 \\
\hline 148.2 & mix-c & 496007 & 200775 & 35.8 & 476.3 & 5114.4 & $<1234.93$ & 0.00 & 518.3 & 161.6 & 50.9 & 2722.1 & $<2.83$ & $<5.40$ & 26.6 & 2872.1 & 7.0 & $<3.63$ & $<14.64$ & $<28.55$ & 16.2 & 68.2 \\
\hline 158.1 & mix-c & 496007 & 173406 & 25.7 & 479.5 & 2807.2 & 1831.2 & 1900.39 & 393.3 & 60.1 & 170.8 & 6275.5 & 1.2 & 3.7 & 14.6 & 2321.9 & 5.2 & 1.5 & 4.1 & 1.5 & 1.9 & 61.1 \\
\hline 158.2 & mix-e & 496007 & 168310 & 17.0 & 622.4 & 2690.8 & 1145.4 & 151.1 & 394.9 & 40.7 & 26.6 & 12133.8 & 1.7 & 3.5 & 5.5 & 1759.5 & 6.4 & 1.9 & 6.0 & 1.2 & 2.6 & 25.4 \\
\hline 160.1 & mix-e & 496007 & 188116 & 80.4 & 18.4 & 415.9 & 756.4 & 0.00 & 362.1 & 15.2 & 56.2 & 339.5 & $<0.40$ & $<0.79$ & 9.0 & 1153.8 & 3.4 & 4.0 & 2.5 & $<3.93$ & $<2.65$ & 14.3 \\
\hline 160.2 & mix-c & 496007 & 185742 & 71.5 & 39.9 & 883.2 & $<1030.43$ & 0.00 & 353.8 & 122.7 & 102.7 & 1607.1 & $<1.56$ & $<3.64$ & 17.8 & 1405.8 & 8.9 & 4.8 & 14.3 & $<15.48$ & $<9.71$ & 105.1 \\
\hline 166.1 & mix-e & 496007 & 164585 & 33.6 & 9.0 & 453.9 & 1010.2 & 0.00 & 414.9 & 16.7 & 53.0 & 454.1 & $<0.095$ & $<0.24$ & 8.0 & 1209.8 & 1.7 & 1.5 & 2.7 & $<1.11$ & $<0.85$ & 9.0 \\
\hline 166.2 & $\mathrm{p}$ & 496007 & 174802 & 7.4 & 81.7 & 5100.8 & 3941.4 & 391.1 & 260.7 & 31.4 & 15.4 & 45646.8 & 1.8 & 1.7 & 739.7 & 888.5 & 2.1 & 1.2 & 3.4 & $<1.48$ & $<1.14$ & 1944.5 \\
\hline 171.1 & mix-c & 496007 & 189115 & 17.4 & 343.1 & 2365.1 & 889.5 & 385.5 & 322.4 & 46.8 & 64.9 & 4041.2 & 0.6 & 0.6 & 2.9 & 1440.2 & 1.6 & 0.7 & 2.7 & $<1.71$ & $<1.17$ & 9.2 \\
\hline 171.2 & mix-e & 496007 & 169078 & 23.5 & 111.7 & 3748.8 & 2896.9 & 4195.41 & 426.6 & 111.3 & 281.8 & 6368.2 & $<0.231$ & 0.4 & 9.6 & 1484.2 & 1.0 & 0.5 & 3.9 & $<1.88$ & $<1.34$ & 31.9 \\
\hline Zr-9 & 1500 & & & & & & & & & & & & & & & & & & & & & \\
\hline
\end{tabular}


Unidade Colônia: Cianita - estaurolita - muscovita - granada - quartzo - biotita xisto (CP-07), continuação

\begin{tabular}{|c|c|c|c|c|c|c|c|c|c|c|c|c|c|c|c|c|c|c|c|c|c|c|}
\hline zircão & spot & La & $\mathrm{Ce}$ & Pr & Nd & $\mathrm{Sm}$ & Eu & Gd & $\mathbf{T b}$ & Dy & Ho & Er & Tm & $\mathbf{Y b}$ & Lu & Hf & $\mathbf{P b}$ & Th & $\mathbf{U}$ & $\mathrm{Ce} / \mathrm{Ce}^{*}$ & $\mathbf{E u} / \mathbf{E u} *$ & $\mathbf{Y b} / \mathbf{S m}$ \\
\hline 7.1 & $\mathrm{rx}$ & 1.2 & 5.1 & 1.3 & 6.3 & 3.7 & $<0.77$ & 7.1 & 2.8 & 40.2 & 13.7 & 61.0 & 11.9 & 104.1 & 18.5 & 14621 & 467.79 & 2.0 & 823.0 & 1.51 & 0.00 & 26.12 \\
\hline 7.2 & mix-c & 9.8 & 95.2 & 13.9 & 78.0 & 28.1 & 7.5 & 49.7 & 13.7 & 120.5 & 38.0 & 174.5 & 44.7 & 488.5 & 98.9 & 11290 & 357.07 & 75.4 & 323.5 & 8.80 & 5.13 & 16.17 \\
\hline 10.1 & mix-e & 9.7 & 84.0 & 13.2 & 75.1 & 23.4 & 7.8 & 41.0 & 11.5 & 122.8 & 34.8 & 130.9 & 22.9 & 194.1 & 29.1 & 16066 & 612.71 & 4.1 & 1289.8 & 7.92 & 5.88 & 7.73 \\
\hline 10.2 & $\mathrm{p}$ & 12.1 & 94.9 & 15.7 & 90.6 & 42.6 & 9.9 & 71.1 & 22.0 & 206.1 & 67.6 & 251.4 & 42.4 & 391.4 & 66.3 & 8622 & 257.07 & 51.7 & 217.3 & 8.17 & 5.55 & 8.56 \\
\hline 11 & $\mathrm{rx}$ & 198.0 & 1382.8 & 183.9 & 798.7 & 109.5 & 38.8 & 140.3 & 28.6 & 220.5 & 60.3 & 208.7 & 37.3 & 285.1 & 48.1 & 13745 & 403.47 & 3.8 & 1550.4 & 33.31 & 14.61 & 2.42 \\
\hline 13.1 & mix-e & 7.9 & 48.7 & 6.2 & 26.1 & 9.0 & 4.5 & 18.1 & 5.6 & 55.5 & 16.8 & 66.7 & 11.7 & 114.9 & 19.1 & 14320 & 475.49 & 4.3 & 1039.7 & 6.24 & 5.18 & 11.88 \\
\hline 13.2 & $\mathrm{p}$ & 19.7 & 104.7 & 15.0 & 67.0 & 26.1 & 5.8 & 54.0 & 16.5 & 165.6 & 59.5 & 248.7 & 50.8 & 470.3 & 90.0 & 9242 & 291.55 & 51.4 & 296.1 & 8.56 & 3.90 & 16.80 \\
\hline 26.1 & mix-c & 1.1 & 15.3 & 1.8 & 13.3 & 6.4 & 1.6 & 16.2 & 3.3 & 28.5 & 7.7 & 23.7 & 3.7 & 30.1 & 5.0 & 7539 & 57.90 & 37.9 & 26.6 & 4.01 & 1.98 & 4.39 \\
\hline 26.2 & mix-e & 9.9 & 66.7 & 11.9 & 67.5 & 22.3 & 5.9 & 35.9 & 8.9 & 85.7 & 26.9 & 98.6 & 19.6 & 145.8 & 24.2 & 10318 & 355.53 & 3.5 & 776.4 & 6.54 & 4.62 & 6.08 \\
\hline 31.1 & $\mathrm{p}$ & 3.6 & 62.2 & 4.9 & 23.6 & 11.6 & 3.4 & 29.6 & 8.8 & 87.0 & 27.1 & 101.9 & 18.3 & 169.6 & 30.9 & 7501 & 165.74 & 88.4 & 74.7 & 9.63 & 3.26 & 13.67 \\
\hline 31.2 & mix-e & 45.7 & 256.8 & 39.7 & 206.5 & 86.5 & 33.0 & 153.1 & 37.4 & 310.0 & 80.7 & 253.4 & 42.1 & 316.4 & 45.5 & 14800 & 1281.31 & 14.4 & 3167.0 & 13.18 & 12.81 & 3.41 \\
\hline 34.1 & $\mathrm{p}$ & 36.4 & 139.5 & 17.0 & 81.7 & 46.0 & 4.6 & 27.2 & 10.9 & 61.4 & 33.7 & 146.7 & 34.4 & 375.0 & 73.2 & 11039 & 207.26 & 22.1 & 689.8 & 9.75 & 3.13 & 7.59 \\
\hline 34.2 & $\mathrm{rx}$ & 0.6 & 3.9 & 0.6 & 2.9 & 1.4 & 0.6 & 4.8 & 2.7 & 46.5 & 18.7 & 85.9 & 16.7 & 138.3 & 23.0 & 10009 & 423.84 & 1.8 & 900.4 & 1.65 & 1.37 & 94.17 \\
\hline 35.1 & mix-e & 17.5 & 113.5 & 18.1 & 89.1 & 23.9 & 9.5 & 35.1 & 8.7 & 65.9 & 16.7 & 60.1 & 10.9 & 95.3 & 18.1 & 13647 & 424.97 & 2.8 & 848.6 & 8.85 & 7.35 & 3.71 \\
\hline 35.2 & mix-c & 17.0 & 111.5 & 19.8 & 89.2 & 28.0 & 40.0 & 48.3 & 8.3 & 106.8 & 30.8 & 127.4 & 20.7 & 228.7 & 37.0 & 13443 & 285.69 & 17.7 & 1012.8 & 8.44 & 27.57 & 7.62 \\
\hline 37.1 & $\mathrm{rx}$ & 249.2 & 1615.8 & 247.2 & 1237.8 & 233.1 & 62.8 & 151.9 & 35.7 & 222.6 & 72.4 & 211.8 & 40.1 & 437.3 & 64.9 & 11134 & 204.72 & 4.5 & 1324.8 & 33.88 & 18.61 & 1.75 \\
\hline 44.1 & $\mathrm{rx}$ & 1.1 & 4.3 & 1.0 & 5.5 & 3.0 & 1.5 & 9.2 & 4.1 & 51.5 & 21.0 & 101.0 & 20.3 & 175.1 & 29.5 & 11491 & 612.30 & 2.8 & 1202.5 & 1.41 & 2.63 & 53.64 \\
\hline 44.2 & $\mathrm{p}$ & 2.4 & 27.3 & 3.6 & 22.1 & 11.1 & 4.3 & 21.6 & 5.9 & 58.0 & 19.5 & 75.8 & 15.3 & 145.3 & 27.9 & 10659 & 74.84 & 21.0 & 71.1 & 4.99 & 4.50 & 12.23 \\
\hline 48.1 & $\mathrm{rx}$ & 12.8 & 69.3 & 9.3 & 43.3 & 12.5 & 3.6 & 27.2 & 8.1 & 76.2 & 20.8 & 81.0 & 15.2 & 155.4 & 30.6 & 10366 & 376.21 & 52.5 & 248.3 & 7.15 & 3.45 & 11.62 \\
\hline 48.2 & mix-c & 15.8 & 133.3 & 22.4 & 130.6 & 49.6 & 14.5 & 85.1 & 20.2 & 171.3 & 51.7 & 197.1 & 42.3 & 408.5 & 79.9 & 10125 & 476.26 & 125.6 & 584.4 & 9.68 & 7.50 & 7.67 \\
\hline 52.1 & mix-e & 29.4 & 202.3 & 39.1 & 217.2 & 82.9 & 27.5 & 129.1 & 33.7 & 303.4 & 79.9 & 288.8 & 48.3 & 334.5 & 55.6 & 14405 & 995.62 & 7.3 & 2294.9 & 11.06 & 11.33 & 3.76 \\
\hline 52.2 & mix-c & 28.7 & 155.2 & 25.8 & 188.3 & 99.4 & 30.1 & 81.4 & 23.4 & 236.2 & 62.0 & 338.0 & 38.3 & 325.4 & 48.3 & 13277 & 961.12 & 57.6 & 3525.7 & 9.93 & 13.12 & 3.05 \\
\hline 59.1 & $\mathrm{p}$ & 9.9 & 75.3 & 12.5 & 65.9 & 25.5 & 8.3 & 43.6 & 12.3 & 109.9 & 35.2 & 135.1 & 29.3 & 288.2 & 62.8 & 11307 & 679.10 & 94.2 & 425.4 & 7.25 & 5.97 & 10.52 \\
\hline 59.2 & mix-e & 11.3 & 76.7 & 14.3 & 83.8 & 30.5 & 11.0 & 51.9 & 14.1 & 122.2 & 36.0 & 141.0 & 25.5 & 206.3 & 32.8 & 11499 & 360.56 & 5.0 & 964.0 & 6.90 & 7.26 & 6.29 \\
\hline 60.1 & mix-c & 47.2 & 306.8 & 46.1 & 220.1 & 47.0 & 15.2 & 68.9 & 15.7 & 123.6 & 35.6 & 146.9 & 34.5 & 370.7 & 64.3 & 13822 & 240.20 & 11.6 & 820.9 & 14.87 & 8.43 & 7.34 \\
\hline 64.1 & $\mathrm{rx}$ & 35.5 & 248.6 & 35.9 & 188.5 & 45.0 & 18.1 & 75.9 & 20.8 & 193.1 & 60.9 & 232.3 & 44.0 & 356.0 & 57.1 & 14759 & 723.11 & 5.3 & 1901.9 & 13.72 & 9.87 & 7.37 \\
\hline 65.1 & $\mathrm{p}$ & 1.1 & 12.3 & 1.0 & 6.3 & 4.1 & 1.2 & 14.1 & 5.2 & 65.3 & 25.1 & 120.5 & 26.3 & 260.3 & 54.2 & 9912 & 263.96 & 43.0 & 171.1 & 3.94 & 1.68 & 59.37 \\
\hline 67.1 & $\mathrm{p}$ & 326.7 & 1818.8 & 229.1 & 1141.9 & 289.9 & 95.4 & 337.5 & 60.2 & 413.4 & 100.2 & 268.2 & 38.1 & 238.4 & 36.0 & 14846 & 515.59 & 4.4 & 2526.7 & 37.54 & 22.58 & 0.77 \\
\hline 68.1 & $\mathrm{rx}$ & 26.8 & 123.1 & 19.9 & 85.4 & 45.2 & 13.8 & 99.1 & 22.6 & 221.7 & 50.2 & 185.0 & 37.4 & 343.2 & 50.7 & 13031 & 451.06 & 2.9 & 1278.4 & 8.72 & 6.96 & 7.07 \\
\hline 68.2 & mix-c & 17.5 & 126.8 & 21.7 & 113.9 & 53.3 & 20.8 & 89.3 & 22.4 & 192.1 & 48.7 & 147.9 & 24.7 & 210.7 & 36.9 & 11229 & 312.58 & 1.5 & 755.6 & 9.23 & 10.45 & 3.68 \\
\hline 70.1 & mix-c & 10.0 & 55.9 & 9.1 & 48.5 & 16.2 & 5.5 & 42.0 & 12.4 & 128.3 & 42.4 & 177.2 & 36.9 & 346.6 & 64.7 & 11811 & 794.47 & 50.3 & 521.8 & 6.03 & 4.40 & 19.95 \\
\hline 70.2 & rx & 0.8 & 3.2 & 0.8 & 3.0 & 2.4 & 0.6 & 7.8 & 3.8 & 61.0 & 26.0 & 121.2 & 25.4 & 234.6 & 38.8 & 14124 & 485.62 & 3.4 & 1172.0 & 1.18 & 1.07 & 89.66 \\
\hline
\end{tabular}


Unidade Colônia: Cianita - estaurolita - muscovita - granada - quartzo - biotita xisto (CP-07), continuação

\begin{tabular}{|c|c|c|c|c|c|c|c|c|c|c|c|c|c|c|c|c|c|c|c|c|c|c|}
\hline zircão & spot & La & $\mathrm{Ce}$ & Pr & Nd & Sm & $\mathbf{E u}$ & Gd & $\mathbf{T b}$ & Dy & Ho & Er & $\mathbf{T m}$ & $\mathbf{Y b}$ & $\mathbf{L u}$ & Hf & $\mathbf{P b}$ & Th & $\mathbf{U}$ & $\mathrm{Ce} / \mathrm{Ce}^{*}$ & $\mathbf{E u} / \mathbf{E u} *$ & $\mathrm{Yb} / \mathrm{Sm}$ \\
\hline 71.1 & $\mathrm{p}$ & 8.7 & 28.5 & 3.8 & 17.5 & 7.5 & 1.9 & 19.0 & 6.2 & 71.1 & 26.3 & 118.7 & 25.2 & 216.4 & 45.6 & 8111 & 239.90 & 26.8 & 90.8 & 4.16 & 2.24 & 27.02 \\
\hline 71.2 & $\mathrm{rx}$ & 195.4 & 1193.9 & 145.4 & 533.3 & 47.1 & 12.8 & 51.1 & 10.5 & 89.4 & 29.5 & 115.0 & 21.4 & 180.0 & 29.9 & 12819 & 325.79 & 8.2 & 1530.9 & 31.25 & 7.66 & 3.56 \\
\hline 96.2 & mix-c & 5.5 & 38.6 & 7.7 & 38.8 & 18.1 & 7.4 & 29.7 & 10.3 & 92.6 & 26.3 & 124.1 & 26.1 & 206.3 & 31.8 & 12312 & 484.91 & 6.6 & 1233.8 & 4.78 & 6.39 & 10.60 \\
\hline 97 & rx & 5.1 & 26.4 & 4.4 & 24.0 & 8.0 & 3.2 & 21.3 & 6.9 & 69.9 & 23.6 & 94.0 & 18.9 & 175.5 & 29.0 & 14154 & 579.05 & 4.2 & 1329.9 & 4.06 & 3.63 & 20.47 \\
\hline 98 & mix-c & 32.4 & 202.3 & 30.8 & 131.3 & 43.3 & 17.8 & 54.5 & 14.5 & 160.6 & 40.7 & 176.6 & 31.0 & 337.3 & 59.0 & 16057 & 515.70 & 10.5 & 1351.3 & 11.94 & 10.67 & 7.25 \\
\hline 99 & rx & 12.6 & 73.6 & 13.9 & 68.0 & 28.6 & 6.0 & 39.8 & 14.2 & 100.6 & 32.1 & 112.8 & 20.4 & 198.0 & 36.7 & 13204 & 528.13 & 4.4 & 2109.5 & 6.60 & 4.29 & 6.45 \\
\hline 100.1 & $\mathrm{rx}$ & 17.4 & 48.3 & $<6.97$ & $<42.74$ & $<40.17$ & $<11.57$ & 47.8 & 9.3 & 76.7 & 18.4 & 168.9 & 38.5 & 388.3 & 50.4 & 12539 & 363.65 & 5.5 & 1148.2 & 7.34 & 0.00 & 0.00 \\
\hline 100.2 & mix-c & 14.1 & 54.3 & 9.6 & 80.2 & $<34.69$ & $<12.25$ & $<37.82$ & 10.8 & 94.3 & 17.7 & 102.4 & 16.0 & 244.4 & 28.6 & 11013 & 386.23 & 10.2 & 811.7 & 5.45 & 0.00 & 0.00 \\
\hline 102.1 & $\mathrm{rx}$ & 1.6 & 10.3 & 1.5 & 15.4 & 9.3 & 1.3 & 10.8 & 5.1 & 46.4 & 22.7 & 98.3 & 19.0 & 177.8 & 33.0 & 13905 & 492.39 & 3.6 & 1068.4 & 2.76 & 1.65 & 17.81 \\
\hline 108 & mix-e & 1.9 & 14.1 & 1.8 & 11.2 & 3.4 & 2.3 & 14.2 & 5.2 & 54.4 & 19.2 & 85.8 & 19.5 & 224.7 & 35.6 & 14350 & 410.58 & 3.4 & 920.4 & 3.43 & 3.44 & 61.48 \\
\hline 118.1 & mix-e & 32.9 & 154.4 & 17.6 & 122.6 & 37.2 & 8.9 & 45.7 & 15.2 & 131.1 & 36.7 & 130.4 & 20.5 & 153.6 & 29.6 & 13615 & 531.33 & 5.7 & 1575.8 & 10.92 & 5.82 & 3.85 \\
\hline 119.1 & $\mathrm{p}$ & 4.3 & 41.6 & 7.6 & 43.8 & 20.6 & 6.2 & 49.8 & 15.7 & 149.7 & 52.5 & 243.7 & 50.7 & 497.3 & 106.8 & 10472 & 392.98 & 94.5 & 208.2 & 5.30 & 4.46 & 22.45 \\
\hline 119.2 & mix-e & 4.4 & 33.6 & 6.1 & 36.4 & 15.0 & 4.3 & 27.8 & 9.1 & 104.2 & 33.6 & 143.1 & 28.8 & 235.5 & 40.3 & 14042 & 625.41 & 4.1 & 1453.5 & 4.68 & 3.96 & 14.66 \\
\hline 120.1 & $\mathrm{rx}$ & 6.0 & 40.2 & 8.4 & 47.6 & 28.2 & 6.6 & 48.7 & 18.1 & 192.2 & 65.7 & 282.8 & 51.4 & 403.7 & 67.4 & 14758 & 2047.81 & 9.1 & 4568.4 & 4.78 & 4.53 & 13.33 \\
\hline 120.2 & mix-c & 22.7 & 165.1 & 31.4 & 175.1 & 71.6 & 44.1 & 118.3 & 29.8 & 255.3 & 73.2 & 282.2 & 57.1 & 512.9 & 95.5 & 10863 & 830.83 & 207.6 & 1468.0 & 10.11 & 19.19 & 6.68 \\
\hline 123.1 & mix-e & 6.1 & 44.0 & 7.4 & 52.0 & 20.1 & 6.1 & 38.7 & 11.5 & 107.4 & 38.7 & 164.3 & 33.4 & 258.4 & 46.2 & 14029 & 639.95 & 9.4 & 1439.6 & 5.48 & 4.83 & 11.97 \\
\hline 128.1 & mix-e & 8.6 & 70.1 & 14.5 & 81.3 & 35.6 & 12.4 & 56.6 & 13.3 & 117.2 & 34.8 & 121.4 & 22.0 & 188.7 & 32.2 & 15376 & 686.06 & 13.2 & 1674.2 & 6.45 & 7.71 & 4.93 \\
\hline 128.2 & $\mathrm{p}$ & 0.2 & 27.2 & 0.6 & 4.9 & 4.7 & 2.2 & 17.4 & 6.6 & 68.5 & 22.4 & 114.5 & 25.9 & 283.9 & 62.2 & 10593 & 388.00 & 121.1 & 188.6 & 12.73 & 2.87 & 56.23 \\
\hline 139.1 & mix-e & 21.4 & 159.7 & 27.7 & 137.1 & 56.0 & 26.3 & 83.6 & 25.3 & 217.7 & 68.1 & 255.3 & 47.5 & 410.8 & 66.9 & 17192 & 912.83 & 15.4 & 2202.8 & 10.34 & 13.31 & 6.83 \\
\hline 139.2 & mix-c & 9.0 & 55.9 & 9.1 & 46.8 & 24.6 & 22.4 & 51.6 & 16.1 & 182.6 & 65.3 & 285.4 & 62.5 & 616.5 & 113.0 & 12246 & 614.08 & 315.8 & 1151.6 & 6.14 & 15.56 & 23.34 \\
\hline 142.1 & mix-e & 13.5 & 98.8 & 18.3 & 108.8 & 39.3 & 14.4 & 73.1 & 20.4 & 163.5 & 50.8 & 193.0 & 38.7 & 243.3 & 45.3 & 14508 & 739.80 & 8.3 & 2181.8 & 7.92 & 8.18 & 5.77 \\
\hline 142.2 & $\mathrm{p}$ & 1.7 & 25.8 & 2.1 & 13.8 & 8.7 & 3.0 & 35.8 & 14.4 & 175.3 & 69.2 & 317.4 & 71.6 & 686.1 & 131.7 & 11700 & 726.90 & 323.0 & 616.4 & 6.07 & 2.79 & 73.21 \\
\hline 148.1 & mix-e & 6.5 & 36.1 & 6.8 & 34.4 & 11.0 & 3.4 & 21.6 & 5.4 & 63.0 & 21.1 & 82.4 & 16.0 & 136.0 & 22.6 & 13705 & 601.36 & 3.3 & 1284.6 & 4.61 & 3.57 & 11.49 \\
\hline 148.2 & mix-c & 9.7 & 118.1 & 12.4 & 63.1 & 29.3 & 21.3 & 101.9 & 26.5 & 270.2 & 100.8 & 504.3 & 83.8 & 946.5 & 150.1 & 11370 & 260.14 & 233.6 & 809.9 & 11.43 & 11.43 & 30.12 \\
\hline 158.1 & mix-c & 75.1 & 448.5 & 59.4 & 271.1 & 69.9 & 21.3 & 111.4 & 27.9 & 236.3 & 67.7 & 262.8 & 50.6 & 445.5 & 87.1 & 9230 & 536.54 & 227.2 & 847.8 & 18.55 & 9.47 & 5.94 \\
\hline 158.2 & mix-e & 6.7 & 92.9 & 7.8 & 42.6 & 21.6 & 6.1 & 55.0 & 17.6 & 172.1 & 57.2 & 254.4 & 53.6 & 520.2 & 101.1 & 10430 & 674.40 & 195.0 & 443.6 & 11.19 & 4.24 & 22.43 \\
\hline 160.1 & mix-e & 12.6 & 74.8 & 11.0 & 49.5 & 25.1 & 5.5 & 36.4 & 10.0 & 115.9 & 37.0 & 147.1 & 26.4 & 228.8 & 36.2 & 15519 & 1310.36 & 11.8 & 2599.5 & 7.32 & 4.18 & 8.49 \\
\hline 160.2 & mix-c & 18.2 & 107.2 & 18.6 & 91.0 & 36.0 & 12.0 & 56.7 & 15.0 & 140.2 & 45.8 & 164.1 & 27.9 & 256.1 & 46.6 & 12750 & 681.99 & 51.0 & 1535.1 & 8.22 & 7.45 & 6.63 \\
\hline 166.1 & mix-e & 13.3 & 105.0 & 19.2 & 101.4 & 36.0 & 15.7 & 50.7 & 12.9 & 125.5 & 39.9 & 154.3 & 31.0 & 254.7 & 43.2 & 13707 & 912.33 & 10.8 & 1998.3 & 8.26 & 10.07 & 6.60 \\
\hline 166.2 & $\mathrm{p}$ & 316.9 & 601.0 & 65.7 & 249.8 & 50.1 & 8.1 & 60.6 & 12.8 & 104.5 & 29.5 & 105.4 & 20.5 & 194.8 & 37.3 & 10858 & 10778.19 & 107.3 & 185.0 & 17.14 & 4.57 & 3.62 \\
\hline 171.1 & mix-c & 16.3 & 124.5 & 18.0 & 93.9 & 25.4 & 9.2 & 48.9 & 15.1 & 138.2 & 47.8 & 203.4 & 42.6 & 378.3 & 75.4 & 10143 & 501.13 & 101.8 & 473.6 & 9.82 & 6.44 & 13.89 \\
\hline 171.2 & mix-e & 118.6 & 831.5 & 115.0 & 538.9 & 106.0 & 37.8 & 129.1 & 23.1 & 155.8 & 44.8 & 146.5 & 24.2 & 199.9 & 32.7 & 14137 & 424.71 & 3.3 & 1629.8 & 25.49 & 14.65 & 1.76 \\
\hline & & & & & & & & & & & & & & & & & & & & & & \\
\hline
\end{tabular}


